
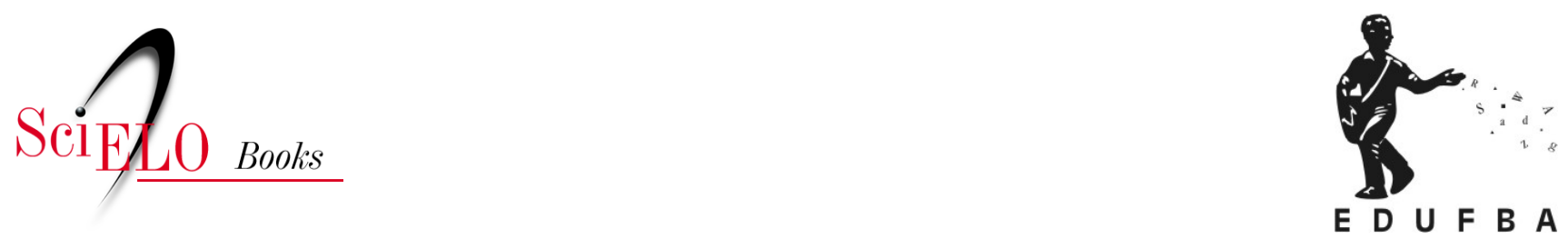

\title{
A Cidade barroca na Europa e América Ibérica
}

\author{
Rodrigo Espinha Baeta
}

BAETA, R.E. A Cidade barroca na Europa e América Ibérica [online]. Salvador: EDUFBA, PPGAU, 2017, 495 p. ISBN 978-85-232-1997-0. https://doi.org/10.7476/9788523219970.

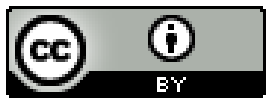

All the contents of this work, except where otherwise noted, is licensed under a Creative Commons Attribution 4.0 International license.

Todo o conteúdo deste trabalho, exceto quando houver ressalva, é publicado sob a licença Creative Commons Atribição 4.0. 
Rodrigo Espinha Baeta

A CIDADE BARROCA NA EUROPA E NA AMÉRICA IBÉRICA 
Universidade Federal da Bahia

REITOR

João Carlos Salles Pires da Silva

VICE-REITOR

Paulo Cesar Miguez de Oliveira

ASSESSOR DO REITOR

Paulo Costa Lima

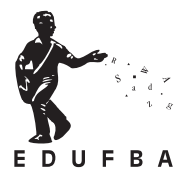

Editora da Universidade Federal da Bahia

DIRETORA

Flávia Goulart Mota Garcia Rosa

CONSELHO EDITORIAL

Alberto Brum Novaes

Angelo Szaniecki Perret Serpa

Caiuby Alves da Costa

Charbel Ninõ El-Hani

Cleise Furtado Mendes

Evelina de Carvalho Sá Hoisel

José Teixeira Cavalcante Filho

Maria do Carmo Soares de Freitas

Maria Vidal de Negreiros Camargo

\section{fapesb}

Fundação de Amparo

à Pesquisa do Estado da Bahia 


\section{Rodrigo Espinha Baeta}

\section{A CIDADE BARROCA NA EUROPA E NA AMÉRICA IBÉRICA}

SALVADOR

EDUFBA PPGAU

2017 
2017, Rodrigo Espinha Baeta.

Direitos para esta edição cedidos à Edufba.

Feito o Depósito Legal.

Grafia atualizada conforme o Acordo Ortográfico da Língua Portuguesa de I990, em vigor no Brasil desde 2009.

CAPA E PROJETO GRÁFICO

Gabriela Nascimento

REVISÃO

Eduardo Ross

Sistema de Bibliotecas - UFBA

Bi4I Baeta, Rodrigo Espinha

A Cidade barroca na Europa e América Ibérica. Rodrigo

Espinha Baeta. - Salvador : Edufba, PPGAU, 2017.

496 p. il. $24 \mathrm{~cm}$.

ISBN 978-85-232-I648-I

I. Arquitetura Barroca - Europa. 2. Arquitetura Barroca - América Ibérica. 3. Arquitetura Religiosa. 4. Arte barroca. 5. Cidades e vilas. I. Título.

CDU 72.03

Editora filiada à

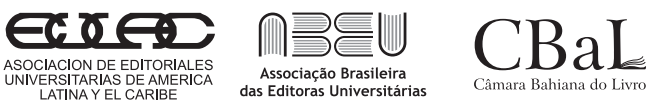

Editora da UFBA

Rua Barão de Jeremoabo

$\mathrm{s} / \mathrm{n}$ - Campus de Ondina

40170-II5 - Salvador - Bahia

Tel.: +55 7I 3283-6164

Fax: +55 7I 3283-6160

www.edufba.ufba.br

edufba@ufba.br 


\section{AGRADECIMENTOS}

Em primeiro lugar, é necessário salientar a importância que a Universidade Federal da Bahia, a Faculdade de Arquitetura e o Programa de Pós-Graduação em Arquitetura e Urbanismo tiveram para o desenvolvimento deste trabalho, já que vêm impulsionando, há mais de 20 anos, minhas investigações e minhas publicações - particularmente as pesquisas que desenvolvo sobre a temática do Barroco.

Ainda sou grato ao PPGAU por ter editado este livro em parceria com a Edufba. Agradeço, especialmente, seu atual Coordenador, o Professor Lula Cardoso por todo apoio dado a esse livro - direta ou indiretamente.

Devo dizer que o pessoal da Edufba contribuiu, como sempre, imensamente para a elaboração do livro: sobretudo agradeço à sua Diretora, professora Flávia Garcia Rosa e à Susane Barros, Coordenadora Editorial, pela paciência, presteza e pelo esforço despendido para a publicação - assim como para o seu lançamento. Também agradeço, novamente (pela terceira vez, e espero que não seja a última!), a Gabriela Nascimento pelo belíssimo trabalho na elaboração do projeto gráfico.

Também especial é a gratidão à FAPESB (Fundação de Amparo à Pesquisa do Estado da Bahia) por ter aprovado integralmente os recursos relativos à publicação deste livro, benefício concedido após o texto passar por seleção na modalidade Chamada Pública para Publicação Científica, por meio do Programa de Apoio Regular.

Dando continuidade aos agradecimentos conferidos a pessoas que contribuiriam para o desenvolvimento desta publicação, devo distinguir meu querido amigo, irmão de coração, Professor André Dangelo - por mais de 25 anos de debates e conversas sobre o Barroco e por ter, gentilmente, elaborado o comovente prefácio desse livro.

O livro não existiria sem a preciosa contribuição da Professora Eloísa Petti Pinheiro. Na verdade, a primeira parte deste texto é uma revisão de dois capítulos da tese que defendi no ano de 2oII, e que foi orientada com muita paciência e compreensão por Elô.

Também sou profundamente grato à minha mãe, por sempre ter acreditado e apoiado meus projetos acadêmicos e meus projetos de vida.

Eu não teria conseguido escrever este livro com tanto prazer sem o amor que sinto pela minha esposa, amada, amiga, companheira, colega de trabalho, 
e parceira intelectual, Juliana Cardoso Nery. Também devo agradecer ao nosso filho Artur, menino brilhante, amigão e outro grande amor de minha vida. E sem esquecer, é claro, a mais nova integrante da família: a nossa princesinha Ana Luiza, bebezinha de um ano de vida, tão amada e querida por nós três. É uma imensa felicidade ter uma família como esta.

Finalmente, dedico este livro a meu pai, Benjamim Baeta, que infelizmente nos deixou no ano passado; uma das pessoas mais cultas que conheci, e a minha maior referência de conduta intelectual. 


\section{SUMÁRIO}

PREFÁCIO ... II

INTRODUÇÃO ... I5

\section{PRIMEIRA PARTE • A CIDADE BARROCA NA EUROPA}

I URBANÍSTICA BARROCA ... 3I

A Cidade Capital ... 4I

As origens da urbanística barroca nos séculos XV e XVI ... 50

Urbanística clássica ou barroca? ... 77

Considerações sobre os principais artifícios da urbanística barroca ... 88

Urbanística barroca na França dos séculos XVII e XVIII ... IIo

As praças reais parisienses • Outras intervenções significativas na Paris do Ancien Régime - espaços para a contemplação e para o passeio - Urbanística regular e paisagismo: Vaux-le-Vicomte e Versailles

A influência da urbanística regular da corte francesa para as províncias e para outros Estados europeus ... I7I

2 URBANÍSTICA X CENOGRAFIA: A CONSTITUIÇÃO DA ROMA BARROCA ... I 89

Urbanística romana no Cinquecento ... I94

Piazza del Popolo: a abertura do drama barroco romano ... 218

Para além da urbanística: os acontecimentos cenográficos dispersos no âmago da Roma barroca ... 234

A expressão do Barroco no denso emaranhado que comporia o tecido urbano da capital pontifícia - Os persuasivos cenários fixos compostos pelas fachadas dos monumentos espalhadas por toda extensão da Roma barroca • Piazza Navona e imediações - Escadarias romanas no Settecento: dois eventos dramáticos no Campo Marzio - A área dos antigos Fóruns: o trágico cenário da Roma antiga e o Barroco

O grande teatro do mundo: a Piazza di San Pietro, em Roma ... 305 
3 A CIDADE BARROCA SEM QUALQUER PLANIFICAÇÃO:

O EXEMPLO DE OURO PRETO ... 33I

O sítio natural no qual se assentaria a antiga Vila Rica ... 336

Considerações sobre a formação viária de Ouro Preto ... 338

A arquitetura religiosa e a paisagem urbana de Ouro Preto ... 345

A Igreja de Nossa Senhora do Rosário dos Pretos e sua contribuição para a constituição do cenário barroco de Ouro Preto • Espaço exterior x espaço interior: a Matriz de Nossa Senhora do Pilar de Ouro Preto • A Igreja da Ordem Terceira de Nossa Senhora do Carmo e a sua relação com a trama barroca de Ouro Preto • A Igreja da Ordem Terceira de São Francisco de Assis de Ouro Preto

A Praça Tiradentes ... 38I

A Ouro Preto barroca ... 384

4 ARQUITETURA E CIDADE NA AMÉRICA HISPÂNICA: A CONFIGURAÇÃO DO CENÁRIO BARROCO DA CUSCO COLONIAL ... 387

A Cusco Inca ... 409

A fundação da Cusco espanhola sobre os alicerces do núcleo pré-hispânico ... 4IO

A Plaza de Armas como estrutura cenográfica barroca ... 415

A "Via Sacra" como eixo dominante da Cusco barroca ... 426

O papel da arquitetura religiosa como elemento estruturador da cenografia barroca na cidade de Cusco ... 442

A arquitetura religiosa e as vistas panorâmicas da cidade de Cusco ... 446

Contra a quadrícula: a arquitetura como artifício de dramatização da rígida grelha hispano-americana ... 452

CONSIDERAÇÕES FINAIS ... 465

FONTES ... 48I

REFERÊNCIAS ... 489 


\section{PREFÁCIO}

Na última década, dentro da cena acadêmica, muito tem-se discutido sobre o sentido e o valor do estudo da História da Arquitetura na formação do arquiteto e do urbanista contemporâneo. Poderíamos mesmo nos perguntar, e muitos acadêmicos se perguntam, qual o sentido de se continuar estudando o fenômeno da arte, da arquitetura, do urbanismo e, particularmente, da cidade barroca - de que trata essa obra -, depois de quase 200 anos que esse fenômeno artístico se concluiu nas suas manifestações mais tardias das Américas.

Respondo por mim, com uma série de certezas amadurecidas após ler com grande atenção, cuidado e, por que não dizer também, com grande prazer, a belíssima narrativa que o autor dessa obra, o Prof. Rodrigo Baeta, nos propõe para esse fenômeno, agora abordado através da produção da cidade barroca na Europa e nas Américas.

A obra aqui apresentada nos pontua, primeiramente, uma reflexão básica: se a história pura nos serve, principalmente, como suporte de análise dos fenômenos do passado sob uma ótica crítica, dentro de um contexto sociopolítico, econômico e cultural, o estudo da História da Arquitetura (seja na produção de edifícios ou cidades) se estrutura sob uma natureza diferente que reside em sua "dimensão intelectual" e retrata o processo de materialização de uma ideia, dimensão essa que se revela elemento constante na atividade do arquiteto, e que a obra aqui apresentada destaca, e nos dá tantas mostras da sua aplicação na dimensão projetual. Só isso, penso eu, já bastaria para justificar a importância e a pertinência de se continuar o estudo da História da Arquitetura e das cidades como objeto de investigação historiográfica, tema que essa obra tão bem aborda.

Nos parece importante ressaltar o ineditismo do trabalho aqui apresentado, que aponta para a atualidade da investigação bem como para a do estudo crítico da História da Arquitetura, sempre essenciais, ao contrário do que muitos pensam, pois é de sua natureza permitir novas e constantes reflexões, como aqui nos mostra Baeta em muitas das suas observações sobre a cidade barroca, e que certamente também não tem como objetivo encerrar a questão colocada. Neste sentido, seria oportuno lembrar que essa característica, longe de ser um fato 
novo, faz parte da dinâmica da historiografia e da construção da narrativa histórica, e mesmo do próprio estudo do fenômeno Barroco mundial, se lembrarmos pioneiros como Jacob Burckhardt e Heinrich Wölffin no século XIX, que tinham visões tão diversas e contrastantes, em muitos aspectos, de críticos modernos como Benedetto Croce e Giulio Carlo Argan, e mais recentemente Jose Antônio Maravall, autores muito bem demarcados, analisados e delineados pelo próprio Prof. Rodrigo Baeta em sua segunda obra, que trata da Teoria do Barroco.

Logicamente, essa multiplicidade de abordagens não está imune aos perigos e armadilhas historiográficas, como nos previne a boa teoria da História Cultural. Neste aspecto, penso eu que é na qualidade da abordagem, nos cuidados com o trato das fontes escolhidas (primárias e secundárias) e principalmente na seriedade e criatividade intelectual, além do critério objetivo e crítico da narrativa, que se selecionam as boas obras de releitura que se apresentam sobre determinadas temáticas de investigação que, pela sua universalidade, já são consagradas por estudos de grandes autores. Sob este ponto de vista, estou certo de que a obra aqui apresentada pelo Prof. Rodrigo Baeta responde positivamente a todos os quesitos e critérios supracitados, dando forma a um trabalho de fôlego, que envolve duas décadas de estudos dedicados ao tema de forma completa e inédita no Brasil, dialogando com a produção mais atualizada sobre o tema no Brasil, na América Hispânica e na Europa.

O autor, na construção da sua narrativa, passa inicialmente pelo sentido da "Urbanística Barroca" tanto na França absolutista, sob os reinados de Luís XIV e Luís XV, como na sua vertente italiana na cidade de Roma, sob o Papa Sisto V, e, posteriormente, frente às grandes contribuições dos mestres do Barroco italiano, com ênfase no projeto da Piazza di San Pietro. O trabalho ainda tem fôlego para atravessar o Atlântico e discutir o fenômeno da cidade barroca, interpretada pelo autor de uma maneira nova, ou seja, a partir da dinâmica da leitura do espaço e suas relações com os monumentos que compõem o drama barroco, e não se limitando a uma visão corrente e tradicional, que procura características morfológicas ou categorias de tipos de traçado para definir a cidade barroca. O trabalho também inova na maneira e no método de abordar como o fenômeno da cidade barroca se manifestou na produção da cidade brasileira setecentista, analisando particularmente Ouro Preto e, na América Hispânica, a cidade de Cusco, com todas as suas similaridades e diversidades, conseguindo de forma rigorosa e com 
grande talento o difícil trabalho de construção e tessitura desses diálogos formais, ora tão distantes e ora tão próximos e vigorosos.

Gostaria ainda de enfatizar aqui a leveza, a perfeição de estilo e a paixão da narrativa. O prof. Rodrigo Baeta, mais que um especialista, é um apaixonado pelo fenômeno do Barroco, já descrito poeticamente por ele em obra anterior como: "[...] algo oriundo da instauração da experiência infinita da imaginação - da abertura da experiência do real para o alcance ilimitado da ficção - como o objetivo essencial a ser alcançado."

Concluindo, agradeço o apreço e a confiança do Prof. Rodrigo Baeta e reafirmo mais uma vez o prazer de apresentar esse trabalho, na certeza de que esta obra, além de ser mais uma contribuição referencial à área de estudo e pesquisa do Barroco, permitirá, não apenas a docentes, pesquisadores, estudantes de arquitetura e urbanismo e áreas afins, de graduação e pós-graduação, mas também a mais tantos leitores apaixonados pela cultura do mundo do Barroco, de se "inebriarem", como ele mesmo gosta de dizer, por mais esse mergulho que o autor nos propõe nesse universo artístico e cultural, gestados em matrizes tão diversas e ao mesmo tempo tão próximas.

André Guilherme Dornelles Dangelo

Professor da Escola de Arquitetura da UFMG 


\section{INTRODUÇ, ĨO}

Fruto de uma investigação que trata, especificamente, da configuração artística de diversos organismos urbanos que sofreriam intervenção, ou que seriam efetivamente criados, em um recorte temporal que se estenderia do século XVI até finais do século XVIII, A cidade barroca na Europa e na América Ibérica apresenta-se como um estudo locado na grande área da crítica da arte, da arquitetura e do espaço urbano - voltado para a apreciação estética da paisagem citadina remodelada no período que coincidira com a eclosão e desenvolvimento da poética barroca. Assim, o livro aqui apresentado não tem a pretensão de alargar as interpretações historiográficas sobre as cidades do período barroco, e sim almeja alcançar um pertinente juízo acerca da qualidade artística de algumas importantes cidades que receberiam massivas intervenções relacionadas a uma prática contemporânea de transfiguração cenográfica do ambiente - fruto de ações atreladas aos fundamentos da estética barroca: fantasia, ebriedade, persuasão, maravilha. Falando de modo mais claro, o anseio do autor é o de conseguir provar que o espírito arrebatador que invadiria o velho continente e o Novo Mundo - a chamada cultura barroca - teria alcançado fatalmente as intervenções que o espaço urbano sofreria: e não só contaminaria a imagem emanada por trechos de cidades, áreas que viriam a ser recompostas em nome da teatralização de seu contexto imediato, mas chegaria a "corromper" cidades inteiras com seu impulso à imaginação, ao encanto dos olhos, à sedução, à propaganda - núcleos que se tornariam verdadeiros palcos nos quais seria encenado, genericamente, o drama retórico e persuasivo do Barroco.

Contudo, por diversas vezes, seria possível se deparar com juízos consistentes, elaborados por consagrados teóricos da urbanização que impulsionariam interessantes análises das cidades humanistas - aqueles núcleos urbanos que passariam por processos de planificação em prol de sua modernização, ou que seriam fatalmente criados nos séculos que coincidiriam com a eclosão e desenvolvimento da cultura artística da Renascença, do Maneirismo e do Barroco -, pesquisadores que assegurariam, categoricamente, a incompatibilidade, a incoerência, o equívoco derivado do conceito, muitas vezes celebrado, de "cidade barroca". 
Uma das teorizações mais taxativas seria difundida pelo historiador da arte, da arquitetura e da cidade Cesare de Seta (nascido em I94I), no ensaio intitulado Sulla presunta "città barocca", texto publicado em I973 no livro, assinado em parceria com o historiador da arte inglês Anthony Blunt (I907-I983), denominado Architettura e città barocca. No polêmico artigo, síntese da conferência proferida no Courltauld Institute of Art de Londres, em 1972, o crítico italiano afirmaria que o termo "Barroco" - cunhado para designar o conjunto das manifestações artísticas vinculadas aos séculos XVII e XVIII, especialmente aquelas iniciativas faustosas que teriam como promotoras o poder teocrático da lgreja e as monarquias absolutistas em formação - seria frequentemente apropriado de forma inadequada por autores consagrados, como Giulio Carlo Argan (I909I992), Pierre Lavedan (I885-I982), Sigfried Giedion (I888-I968), Rudolf Wittkower (I90I-I97I), ${ }^{\text {I }}$ ao empregarem a alcunha de "cidade barroca" para caracterizarem, integralmente, alguns contextos urbanos supostamente transfigurados no Seicento e no Settecento: ações orientadas no sentido da implosão da estrutura urbana preexistente, em prol da exaltação do inovador espírito barroco. Para o autor, não existiria esta "suposta" "cidade barroca", pois, mesmo acreditando que alguns empreendimentos voltados às transformações dos núcleos preexistentes poderiam estar enquadrados naquele espírito persuasivo que viria a contaminar a arte patrocinada pelas grandes estruturas de poder das nações do Ancien Régime - investimentos que acometeriam especialmente as Cidades Capitais dos poderosos Estados totalitários que se desenvolveriam a partir de finais do Cinquecento -, jamais as intervenções quinhentistas, seiscentistas e setecentistas teriam conseguido transformar o caráter e a identidade do tecido urbano em sua totalidade.

O caso mais discutido seria o da consagrada "Roma barroca" - capital dos Estados pontifícios -, já que seu exemplo seria aproveitado por tantos autores como paradigma da urbanística dita barroca. Cesare de Seta compreenderia que as iniciativas de renovação urbanística da cidade, implantadas entre os séculos XVI e o XVIII, compreenderiam intervenções que afetariam apenas pequenos trechos da cidade, não autorizando, em termos quantitativos, a compreensão

1 Aqui segue uma lista com algumas das principais obras destes autores a discorrerem sobre a "cidade barroca”: de Giulio Carlo Argan, L'Europa delle capitali, publicada pela primeira vez em 1964 (ARGAN, 2004); de Sigfried Giedion, o clássico estudo Raum, zeit, architektur, lançado em 1941 (GIEDION, 2004); de Pierre Lavedan, o volume Histoire de l'urbanisme. Renaissance et temps moderns, também publicado em 1941 (LAVEDAN, 1941); e de Rudolf Wittkower, Art and architecture in Italy: 1600 to 1750, cuja primeira edição sairia em 1958. (WITTKOWER, 1993) 
de uma alteração morfológica substancial do núcleo urbano - particularmente a declaração do surgimento de uma "cidade barroca" ou de uma trama urbanística de filiação barroca. Mesmo as iniciativas cenográficas pontuais dos mestres Gian Lorenzo Bernini (1598-I680), Francesco Borromini (I599-I667), Pietro da Cortona (I596-I669), Carlo Rainaldi (I6II-I69I), e de seus seguidores do século XVIII, Alessandro Specchi (I668-I729), Francesco de Sanctis (I695-I740), Filippo Raguzzini (I680-I77I), com a indiscutível - complexa e plural - qualidade expressiva de suas obras, teriam sido capazes de mudar o rosto da capital pontífice:

\begin{abstract}
Mas, para seguir o fio que traçamos, resta o fato de que Roma, cidade barroca, não existe, se queremos indicar com esta afirmação um organismo onde as intervenções que podemos referenciar ao Barroco alcançam uma vastidão e uma densidade tal a transformar quantitativamente e, portanto, qualitativamente as coordenadas interpretativas deste complexo urbanístico na sua inteireza. E impõe-se, necessariamente, a introdução de um conceito que é bem relevante em uma diagnose paralela arquitetura-cidade: aqueles princípios que na arte barroca são genialmente enunciados e aplicados, se tornarão operantes no desenho urbano com enorme atraso: a cidade possui um instinto de conservação que a consente de absorver traumas violentos, como as intervenções de Bernini e Borromini, e de preservar a sua identidade geral. A promenade que liga Trinatà dei Monti à Piazza di Spagna, o demolido Porto di Ripetta, até mesmo a sistematização da Piazza del Popolo pelo neoclássico Valadier poderiam considerar-se alguns pedaços que se reconectam ao desenho incompleto da Roma 'barroca'. (DE SETA, 1978, p. 56-57, tradução nossa)
\end{abstract}

Portanto, o autor defenderia que, mesmo quando as intervenções em trechos da cidade influenciassem a conformação do caráter local oriundas da imponência das iniciativas ou da alta qualidade que estas assumiriam frente ao tecido urbano, a cidade preexistente, apertada, densa e confusa - ainda de caráter medieval - não absorveria de imediato o trauma sofrido, preservando por muito tempo, quantitativamente, uma hegemonia da urbanística tradicional frente às ações revolucionárias. Por outro lado, o fato de que na Roma papal as intervenções viárias mais importantes, praticamente todas implantadas no século XVI, aconteceriam em áreas adjacentes ao núcleo central da cidade, e que muitas vezes estes bairros demorariam a ser habitados e densificados, contribuiria para a inconsistência da denominação que nos últimos anos, frequentemente, seria 
oferecida à Cidade Eterna - o título de "cidade barroca". Só mesmo com a declaração de Roma como capital do reino da Itália, em I870, a cidade viria a sofrer, desgraçadamente, uma transformação quantitativa radical, não vinculada ao espírito barroco, mas a uma ação destrutiva oriunda dos empreendimentos ligados aos princípios do urbanismo moderno.

Ao prosseguir a análise, o autor chegaria a debater iniciativas urbanísticas que outros núcleos vinculados ao Ancien Régime viriam a acolher - como Paris, Turim, Viena -, intervenções que seriam, mais uma vez, estéreis no que tange à alteração incondicional da estrutura urbana das cidades, levando-o à conclusão de que não seria legítimo atribuir o epíteto de "barroca" para nenhuma destas importantes Cidades Capitais. Seriam, indubitavelmente, cidades do Barroco, espaços urbanos onde o espírito do Grand Siècle ${ }^{2}$ triunfaria radicalmente - mas apenas pontualmente, em pequenos segmentos do tecido urbano.

Este juízo sobre a inexistência da cidade barroca não seria privilégio de Cesare de Seta, mas seria declarado, de modo semelhante, por outros tantos críticos, como o professor italiano de história da cidade e da urbanística, Enrico Guidoni (1939-2007), no detalhado estudo de 1979, Storia dell'urbanistica: il Seicento, escrito em parceria com a professora Angela Marino:

\begin{abstract}
Mas se trata sempre de uma caracterização que não pode ser considerada aplicável à cidade em seu conjunto, nem mesmo às suas partes bem definidas; mais que nunca, se pode reconhecer uma qualidade barroca em determinados espaços, em direta relação com edifícios públicos de particular significado, em detalhes decorativos que, contudo, adquirem outro significado na escala urbana, e em pequenos espaços como praças, pórticos de igrejas, escadarias - nos quais é sempre o detalhe, o paramento, a ornamentação estatuária ou o entrelaçamento dos temas decorativos que complicam e empalidecem a recíproca relação entre o construído e o espaço vazio. (GUIDONI; MARINO, I979, p. I4, tradução nossa)
\end{abstract}

Ou seja, para Guidoni seria incontestável a existência de monumentos barrocos - como igrejas, catedrais, conventos, palácios - espalhados pelas cidades seiscentistas e setecentistas; bem como seria fatal a abertura de espaços urbanos tratados através de uma configuração vinculada ao seu espírito inebriante

O século XVII. 
- ou mesmo dever-se-ia admitir que alguns cenários urbanos seriam tocados pela presença de imponentes edifícios, frontarias, estátuas, fontes, escadarias, jardins barrocos. Mas, todas estas ações acabariam se apresentando como acontecimentos singulares e isolados, não autorizando a construção de um juízo que assegurasse a possibilidade da existência de uma cidade que teria toda sua extensão restabelecida como um organismo urbano definitivamente barroco.

Além disso, voltando-se ao discurso de Cesare de Seta, a noção de "cidade barroca" - assim como a de cidade renascentista, cidade iluminista - estaria comprometida pelo fato de reduzir o desenvolvimento e o caráter do ambiente urbano à simples questão de uma poética, ignorando variáveis muito mais significativas, como os problemas demográficos, de segurança, os ciclos econômicos. A estrutura urbana da cidade seria, indubitavelmente, comandada por fatores mais complexos, sendo uma tolice avaliá-la apenas pelo lado da estética. Em resumo:

Se de tudo o que foi dito aqui tentarmos tirar as somas - somas provisórias e parciais -, resulta claro que nenhuma das cidades mencionadas, de Roma a Paris, de Turim a Viena, chegou a se tornar uma cidade barroca, mas cada uma delas foi uma cidade do Barroco: isto é, lugar e espaço urbano onde os princípios de uma múltipla, complexa e contraditória poética barroca tiveram possibilidade de germinar, afirmando-se e expandindo-se; todavia nunca na medida tal a transformar a identidade geral do corpo urbano: que, em todos os casos, foi expandido e radicalmente transformado, mas seguindo leis de alteração que não estão relacionadas a uma poética artística, mesmo que seja uma poética extensiva como aquela que se diz ser a do Barroco. Propriamente porque no conceito de mudança da cidade, as variáveis são tais e tantas e tão diversas que seria um grave erro de método reduzi-las ao sistema de uma poética. A evolução demográfica, razões militares e estratégicas, os ciclos econômicos que regulam os regimes fundiários são estruturas que frequentemente, de caso em caso, contribuíram para transformar a cidade; mas elas são reguladas por uma dinâmica interna que é totalmente estranha ao sistema de alterações que se vincula a uma poética artística. (DE SETA, I978, p. 8I-82, tradução nossa)

Para além do fato de que, para grande parte da crítica moderna, a ideia de Barroco extrapolaria a esfera da história da arte e alcançaria a dimensão, incontestavelmente mais vasta, fundada no conceito de cultura barroca, envolvendo 
os domínios da economia, da sociedade, das nações, das guerras, da religião, do comportamento, as colocações do crítico italiano abririam a possibilidade de se formular questões essenciais para se compreender o fenômeno da cidade barroca - ou de sua inexistência. Será que não haveria uma distinção entre os mecanismos de intervenção propriamente urbanísticos e os meios de contaminação cenográfica do ambiente? Será que não seriam dois processos diferentes, especialmente para o caso do Barroco? De uma parte, intervenções em grande escala, com uma necessária coordenação institucional; iniciativas que frequentemente seriam concebidas para servir à celebração da autoridade dos governantes absolutistas; mas também ações que objetivariam alcançar não só um novo e imponente desenho para amplos setores do tecido urbano, mas também orientar seu desenvolvimento posterior - operações de reformulação do sistema viário, de confecção e organização de espaços públicos, implantação de infraestrutura urbana -, artifícios ligados a uma busca por melhorias no funcionamento propriamente dito das cidades. Da outra parte, ações individuais de transformação do caráter artístico dos ambientes preexistentes, perseguidas, sequencialmente, através da inclusão de inúmeros eventos pontuais, mas que, em sua "costura" com outros tantos acontecimentos atraentes, alterariam radicalmente a experiência de se vivenciar o espaço da cidade, introduzindo de forma global aqueles princípios caros à força imaginativa barroca. Ou seja, será que não seriam categorias diversas, apesar de essenciais e muitas vezes complementárias: planificação barroca e cenografia barroca; ou melhor dizendo - urbanística barroca e cidade barroca?

De fato, ao contrário do pensamento do crítico italiano, uma das questões levantadas nesta investigação asseguraria que não seria possível avaliar esteticamente a cidade partindo-se exclusivamente de iniciativas ligadas à esfera da urbanística: compreendendo a urbanística como a disciplina que coordenaria os empreendimentos que afetariam a estrutura das cidades - sejam núcleos urbanos de nova fundação ou aqueles preexistentes; ações que iriam muito além da escala arquitetônica propriamente dita, alcançando uma dimensão que envolveria, genericamente, a armação urbana, o sistema viário, o desenho da cidade, ou que comprometeriam trechos significativos da massa edificada ou dos vazios residuais internos e externos ao núcleo citadino. ${ }^{3}$

3 Neste livro, preferiu-se usar o termo "urbanística” por entender que a palavra "urbanismo" estaria muito vinculada ao surgimento da disciplina que viria problematizar a cidade no século XIX - situação posterior 
Na mesma direção, acredita-se que não faria sentido a avaliação quantitativa das intervenções pontuais que o núcleo urbano sofreria como única forma de determinação das possibilidades de alteração figurativa do organismo preexistente - frente a toda extensão da cidade. Na verdade, a interpretação artística de seguimentos do espaço urbano, ou mesmo de cidades inteiras - assim como a apreciação das obras de arquitetura ou das outras manifestações das artes plásticas -, passaria, quase sempre, por um sentido de hierarquia compositiva no qual a conjunção entre poucos elementos de destaque, ou mesmo a presença massiva de um único acontecimento especial, poderia coordenar, genericamente, a descoberta, fruição e encantamento do espectador diante da obra de arte. Assim, uma cidade poderia ter sua paisagem gravemente afetada por intervenções barrocas, independentemente da dimensão e da quantidade de empreendimentos que o organismo urbano receberia - tanto aquelas ações filiadas à escala urbanística quanto aquelas atreladas à esfera arquitetônica propriamente dita. Ou seja, mesmo um número ínfimo de edifícios, monumentos e espaços vazios de alto teor expressivo poderia transfigurar ou reorientar a experimentação estética e visibilística da cidade.

Logo, a paisagem urbana revelaria seu caráter artístico pelo cenário que seria oferecido ao transeunte, e não exclusivamente pela estrutura bidimensional do plano; e este espetáculo seria absorvido através da interação entre todos os fatores que comporiam os panoramas emanados na imagem da cidade: a paisagem natural, o traçado, mas principalmente o intercâmbio destes elementos com a arquitetura. Por um lado, os eventos monumentais surgiriam para dar forma e expressão ao núcleo urbano; a arquitetura ordinária, por outro lado, promoveria uma amarração entre os grandes episódios dramáticos dispersos pela cidade. Deste modo, poderiam até existir núcleos urbanos que não teriam so-

\footnotetext{
ao recorte temporal que interessa ao livro. A princípio, também seria pertinente o emprego da expressão "Arte Urbana”, utilizada por Gaston Bardet para designar as grandes intervenções que as cidades ocidentais sofreriam antes do surgimento da "ciência" do urbanismo. Segundo Bardet (1967, p. 6-7, tradução nossa): "O aparecimento do urbanismo entre as ciências, e dos urbanistas entre os pesquisadores, foi, portanto, a consequência de novos problemas colocados por fenômenos cuja amplitude quase não conhecíamos exemplo na história. É preciso não confundir as grandes realizações da Arte Urbana, que magistralmente resolveu problemas que não eram nem da mesma escala, nem da mesma complexidade, nem da mesma substância que os nossos, com as soluções do Urbanismo, hoje necessárias." Contudo, esta denominação poderia entrar em grave conflito com a ideia da remodelação cenográfica e artística do ambiente urbano conseguido, primordialmente, através da presença arquitetônica, procedimento diverso da urbanística e da "Arte Urbana" de Bardet, e que será de primeira ordem para a avaliação do processo de confecção das cidades ditas barrocas - logo, para a construção da abordagem crítica da investigação e de suas hipóteses.
} 
frido nenhuma modificação em sua estrutura viária, nenhum plano urbanístico de modernização, mas que teriam passado por verdadeiras renovações artísticas, irrompendo no Seicento e no Settecento como representantes legítimos das manifestações barrocas. Isto porque um dos grandes fatores de apelo persuasivo para a cidade seria, efetivamente, a arquitetura - o inevitável processo de interconexão de sua imagem com o organismo urbano.

Ou seja, fica claro que a pesquisa se funda em um princípio que aceita a ideia de que a cidade possa se configurar como uma obra de arte e, consequentemente, seja capaz de alcançar uma categorização estética que se fundamente na atribuição de uma condição barroca ao seu espaço urbano componente - e mais precisamente ao cenário desvelado pela trama paisagística capturada por quem a vivencia. Mesmo admitindo que a cidade seja, invariavelmente, fruto de vários e complexos fatores, condicionantes que ultrapassariam, enormemente, a "elementar" questão da atribuição de um valor artístico ao artefato componente, seria na sua materialidade física que ganharia forma e expressão visibilísticas. E, enquanto forma, a configuração do ambiente urbano poderia comportar diversas avaliações estéticas daqueles indivíduos que a experimentassem visualmente - avaliações que jamais se furtariam dos demais condicionantes que contribuiriam para edificá-la, mas que se fundamentaria em um juízo específico sobre a sua percepção visual.

Assim, o problema inicial que afetaria todas as discussões que apoiariam o desenvolvimento deste livro seria a existência da cidade barroca. Seria coerente acreditar que a expressão da cidade como obra de arte poderia exaltar, massivamente, uma poética barroca? No desenvolvimento de seu impulso à teatralidade, os núcleos urbanos que receberiam intervenção desde finais do século XVI até o século XVIII, ou que seriam fundados durante este período, poderiam revelar uma condição artística filiada ao espírito barroco?

Portanto, a averiguação da hipótese que asseguraria a pertinência da constituição, nos séculos XVII e XVIIl, de cenários urbanos que se configurariam como verdadeiras cidades barrocas comandaria o desenvolvimento da narrativa da pesquisa aqui apresentada. Para isso, a investigação foi dividida em duas partes: A cidade barroca na Europa e A cidade barroca na América Ibérica; a primeira parte organizada através dos dois primeiros capítulos, e a segunda parte - que versa sobre as cidades coloniais ibero-americanas - desenvolvida em outras duas unidades. 
Abrindo a parte inicial do livro (A cidade barroca na Europa), o primeiro capítulo, denominado A urbanística barroca, se balizaria na apreciação do que normalmente se entenderia por esta expressão: como surgiria a urbanística barroca, e como a prática da intervenção urbana em grande escala poderia ser avaliada naquele país que mais a teria praticado: a França do Ancien Régime. A unidade abriria um fórum de discussão que passaria pelo problema da Cidade Capital; pelas origens quinhentistas da urbanística barroca; pelas coincidências existentes entre a chamada urbanística clássica e aquela barroca; pelos artifícios mais significativos praticados na urbanística do período; finalmente, alcançando a análise de algumas de suas principais iniciativas constituídas na França imperial dos séculos XVII e XVIII (mais especificamente em sua capital, Paris) - bem como promovendo o exame de outras manifestações da urbanística barroca: como algumas residências de campo da realeza francesa, além de cidades criadas, ou remodeladas, em reinos periféricos e províncias.

Nesta direção, se abriria espaço para a formulação das seguintes perguntas, essenciais para o encaminhamento do estudo: Seriam mesmo as intervenções urbanísticas dos séculos XVII e XVIII que dariam o aspecto barroco às cidades? Se a urbanística isolada, raramente, seria capaz de promover a construção do caráter estético-paisagístico dos núcleos urbanos seiscentistas e setecentistas, qual seria o procedimento que permitiria a transfiguração dramática de sua paisagem? Ou será que não existiria a suposta "cidade barroca”?

$\mathrm{Na}$ verdade, acredita-se que a ação de remodelamento do ambiente urbano poderia partir tanto da urbanística como da "arquitetura da cidade" (ROSSI, 2006), ou mesmo de uma correlação entre os dois fatores (o que seria mais comum). O cenário urbano barroco não traria como pressuposto a existência de uma urbanística barroca. A apreciação da cidade dever-se-ia efetivar através da sua apreensão como um grande teatro da "fantasia", da "maravilha", da "imaginação".

Portanto, o segundo capítulo, Urbanística x Cenografia: a constituição da Roma barroca, capítulo que encerraria a primeira parte do livro, avaliaria as intervenções que a cidade de Roma receberia desde o século XVI até o século XVIII - empreendimentos vinculados tanto à massiva reorientação urbanística pela qual a cidade passaria no Cinquecento quanto atrelados ao povoamento obsessivo da cidade por eventos arquitetônicos sucessivos, e de alta expressão cenográfica, levantados por todo o núcleo urbano no Seicento e no Settecento. 
A escolha da cidade de Roma para esta análise seria óbvia, em função dela servir, já há algum tempo, como paradigma da existência da cidade barroca - atribuição contestada por alguns autores, como foi visto. No entanto, as visões críticas positivas que confirmariam a tese defendida seriam quase que invariavelmente fundadas na apreciação das precoces intervenções viárias que a capital pontifícia sofreria no século XVI, especialmente aquelas patrocinadas pelo Papa Sisto V (I52I-I607) - empreendimentos que teriam inaugurado a urbanística barroca.

Para além do fato do debate promovido na segunda unidade procurar demonstrar que não seriam estas intervenções viárias quinhentistas que definiram a alteração da paisagem urbana da cidade em prol da exaltação da poética barroca, e sim sua conjunção com a grande massa de eventos arquitetônicos singulares e expressivos que a cidade acolheria nos próximos dois séculos, é preciso esclarecer que, mesmo reconhecendo a indiscutível conjuntura histórica que colocaria as iniciativas da urbanística papal em datas anteriores às intervenções barrocas francesas dos séculos XVII e XVIII, elas serão analisadas a posteriori. Na verdade, o que se persegue não é, definitivamente, uma avaliação dos fatos que se sucederiam sequencialmente; a investigação não objetiva atingir uma análise puramente cronológica que revele a "evolução" da urbanística ou da cidade barroca. A armação do texto, pelo contrário, perseguirá sempre um sentido de encaminhamento didático em prol da resolução dos problemas apresentados e das hipóteses formuladas. Assim, almeja-se, no encerramento do capítulo, provar, a partir da análise da Roma barroca, que o fator principal de constituição do caráter persuasivo e inebriante da cidade barroca seria a interface da arquitetura com o espaço urbano.

$\mathrm{Na}$ verdade, nem sempre existiria uma conexão direta entre a urbanística praticada na época e a construção do ambiente cenográfico que caracterizaria a paisagem urbana barroca; o espetáculo dramático encenado na cidade se daria através da "amarração" dos acontecimentos teatrais que transformariam o núcleo urbano em uma total e dramática experiência artística; e isto se daria, muitas vezes, à revelia de qualquer processo de planificação, dependendo exclusivamente das intervenções pontuais que o núcleo estaria recebendo gradativamente - e, particularmente, da "costura" destes "eventos" no espaço e no tempo da apreciação da cidade pelo fruidor, pelo transeunte, pelo espectador.

Neste sentido, após a avaliação de cidades europeias que passariam por grandes transformações no plano urbanístico - mesmo admitindo que no caso 
de Roma não seriam as intervenções urbanísticas em grande escala que mais contribuiriam para a sua transfiguração no grande baluarte da propaganda barroca católica -, os debates sobre o desenvolvimento da cidade barroca prosseguirão a partir da análise de organismos urbanos que não passariam, minimamente, por qualquer ação que poder-se-ia vincular à chamada urbanística barroca. Logo, na segunda parte do livro a análise se volta à apreciação de organismos urbanos cuja eloquência barroca seria oferecida exclusivamente pela relação entre a arquitetura componente, o traçado viário espontâneo ou regular (de caráter quinhentista), e a paisagem urbana e natural circundante. Ou seja, serão avaliados exemplos de cidades - no vasto cenário da América de colonização portuguesa e espanhola cuja condição barroca prescindiria totalmente da urbanística dita barroca.

Logo, no terceiro capítulo, denominado A cidade barroca sem qualquer planificação: o exemplo de Ouro Preto, a conformação do cenário urbano da antiga Vila Rica - capital da Capitania das Minas Gerais durante o período de colonização portuguesa no Brasil - é avaliada para se buscar respostas às seguintes perguntas: Seria possível afirmar que durante o período colonial o processo de desenvolvimento urbano de Ouro Preto revelaria o surgimento de um núcleo que, em sua conformação paisagística, assumira uma configuração cenográfica que poderia ser interpretada como barroca? Como a trama urbana da capital das Minas Gerais colonial poder-se-ia configurar como uma cidade barroca se seu plano urbanístico nasceria de processos espontâneos de crescimento e desenvolvimento urbano? Como seria possível a poética barroca comandar a conformação paisagística e cenográfica da antiga Vila Rica se seu desenho viário não se aproximaria minimante da própria urbanística praticada no período?

$\mathrm{Na}$ verdade, poder-se-ia dizer que as ações que transfigurariam Ouro Preto em um organismo urbano no qual seria encenado o drama barroco não se fundariam em intervenções propriamente urbanísticas. O espetáculo dramático da cidade se daria através da "amarração" dos acontecimentos cenográficos dispersos na cidade, e estes eventos teatrais estariam quase sempre vinculados à massiva presença da arquitetura religiosa. Seria claramente perceptível como as igrejas dominariam a paisagem citadina: tanto no que se refere à sua inserção majestosa no sítio, como em relação à expressividade, muitas vezes fatal, de sua articulação formal.

Em outra direção, o último capítulo do livro, intitulado Arquitetura e cidade hispano-americanas: a configuração do cenário barroco da Cusco colonial, tratará 
das possibilidades de uma cidade de trama regular ou semirregular, fundada pelos espanhóis no Novo Mundo, ou reordenada no século XVI acima de um plano consolidado pré-colombiano, alcançar - com sua trama visibilística - uma condição barroca. Voltando-se à centúria que precederia a eclosão da poética barroca, uma tipologia consagrada da cidade regular seria constituída na América hispânica, padrão urbanístico vastamente praticado através da fundação de mais de 200 cidades, nas Î́ndias Ocidentais, até I573 (ano da promulgação das leis Filipinas).

Neste sentido, é revelado o último problema a ser resolvido na investigação apresentada neste livro: questão conectada ao fato da tipologia de cidade hispano-americana - de configuração tanto mais engessada quanto mais regular - estar muito distante daquela urbanística (investigada no primeiro capítulo) que seria reconhecida como derivada do período barroco. Para além disso, a aparente monotonia do traçado em forma de grelha tenderia a coibir a expressão da "maravilha" barroca, ação atrelada à presença de eventos dramáticos monumentais disseminados pelo cerne da cidade, muitas vezes descobertos de forma surpreendente devido às irregularidades do tecido urbano - situação impossível de ser estabelecida na cidade regular virreinal.

Em função destas constatações e destes problemas apresentados, seria possível formular uma pergunta-chave para a resolução da hipótese que assegura a existência de cidades barrocas na América hispânica: Como seria possível a urbanística praticada pelo projeto de colonização espanhol ter contribuído para a construção do espaço urbano barroco, já que os planos regulares seriam iniciativas que estariam muito apartadas dos princípios essenciais da sua poética, assim como não se aproximariam da própria urbanística praticada no período - além de terem-se estabelecido em precedência à eclosão do espírito barroco?

A resposta a este último questionamento será buscada na avaliação da trama urbana barroca da cidade de Cusco. A hipótese final alega que a cidade hispano -americana poderia alcançar, eventualmente, uma condição barroca "apesar" da urbanística - apesar da presença tirânica de sua grelha regular e obsessiva. Ou seja, as cidades ordenadas, fundadas no século XVI, deveriam contar, nas próximas duas centúrias, com intervenções - de teor urbanístico, mas especialmente de escala arquitetônica - que atuassem "contra" a quadrícula, contra o esquema rígido e estacionado do traçado típico hispano-americano.

Já que a estrutura urbanística das cidades seria extremamente engessada e inflexível, não seria fácil transfigurá-la a partir de intervenções em sua armação 
viária. Logo, os assentamentos poderiam se conformar como cenários barrocos, especialmente devido à contaminação do seu ambiente por "eventos" profundamente expressivos, acontecimentos dramáticos gerados pela influência que a arquitetura exerceria nas imagens capturadas no núcleo urbano, "costuradas" na dimensão espaço-temporal da apreensão da cidade - aliás, como aconteceria na Roma barroca, em Ouro Preto e, quase que genericamente, em todas as cidades barrocas. 


\section{A cidade barroca na Europa}

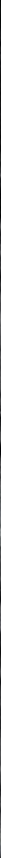




\section{A URBANÍSTICA BARROCA}

Poderíamos introduzir a seguinte distinção: se a cultura dos séculos $\mathrm{XV}$ e XVI é fundamentalmente citadina - e a este conceito se liga certo grau de liberdade municipal e de relação pessoal entre seus habitantes -, o Barroco é mais propriamente urbano - atribuindo-se a esta palavra, como vamos ver, um matiz de vida administrativa e anônima.

Comecemos por fazer algumas comprovações iniciais que logo complementaremos e desenvolveremos. Durante a etapa do Barroco, seus governantes e, em geral, os indivíduos das classes dominantes não são senhores que vivem no campo [...]: são ricos que habitam a cidade e burocratas que ali administram e enriquecem. Ao mesmo tempo, ainda que haja um mal-estar camponês que por todos os lados estoura em revoltas ocasionais, no século XVII são as populações urbanas as que inquietam o poder e às quais se dirige normalmente a política de sujeição, que se traduz, inclusive, nas mudanças topográficas da cidade barroca.

É também nela onde se levantam os monumentos históricos: Roma, Viena, Praga, Paris, Madrid, Sevilha e Valência concentram, junto com muitas outras, as criações de pintores, arquitetos, escultores etc. [...] O drama da cultura barroca é um drama caracteristicamente urbano. (MARAVALL, 2007, p. 227-228, tradução nossa) 
Seria possível, partindo das palavras do historiador espanhol José Antonio Maravall (I9II-I986), retiradas de seu consagrado livro, La cultura del Barroco (primeira edição de I975) - provavelmente a mais completa investigação conduzida sobre o universo cultural do período -, dar início a uma discussão absolutamente pertinente ao desenvolvimento deste trabalho. O Barroco foi um fenômeno cultural genérico que, apesar de ter-se apresentado mais explicitamente nas artes, na arquitetura, literatura, poesia, teatro, se estenderia para muito além destas expressões, alcançando todas as esferas culturais que caracterizariam o século XVII e parte do século XVIII - principalmente nos domínios do que poderia ser entendido como mundo ocidental. Deste modo, as conturbadas manifestações estéticas do período estariam vinculadas, indissociavelmente, às condições econômicas e sociais da época, sendo, na verdade, uma das muitas possibilidades de respostas à crise geral que estaria abalando, categoricamente, as nações. Mas toda esta conjunção de fatores culturais - de cunho artístico, ou ligados às circunstâncias políticas e sociais coetâneas - teria como principal palco dos seus acontecimentos e de suas manifestações mais significativas o cenário urbano como afirmaria Maravall.

Esta constatação não era de forma alguma direta, imediata ou óbvia, já que, reconhecidamente, era o campo que ditava a vida econômica durante o Seicento e parte do Settecento. O período barroco marcou, no contexto europeu, uma revalorização da aristocracia rural como uma das classes mais importantes e de maiores riquezas, "casta" estacionada logo abaixo da realeza na pirâmide estamental do Grand Siècle: promovendo um retrocesso frente aos avanços das cidades-estados independentes do Quattrocento e do Cinquecento - com sua vida comunal de direitos civis e liberdade dos cidadãos -, a estrutura econômica barroca voltarse-ia novamente para a nobreza e para as suas grandes propriedades campestres, núcleos de geração de renda afastados dos centros urbanos. E o meio rural não acolheria somente aqueles processos econômicos que estariam relacionados à agricultura e à pecuária, vinculados à produção de gêneros alimentícios para abastecer as populações mais favorecidas e a grande massa de miseráveis e indigentes; mas também abrigaria a maior parte das atividades que diziam respeito à fabricação de objetos provenientes da incipiente indústria da manufatura o que levaria o crítico de arte Victor-Lucien Tapié (I900-I974) a assegurar:

Os progressos econômicos e técnicos do século XVII, nos quais o pensamento científico teve um desenvolvimento considerável, não 
prepararam, a não ser de longe, a civilização industrial que viria transformar a Europa e o mundo. Enquanto o maquinismo não se desenvolveu e não provocou a concentração dos operários em volta da fábrica, a produção industrial continuou ligada ao ateliê rural. As mercadorias postas em circulação pelo capitalismo comercial provinham direta ou indiretamente da agricultura: cereais e produtos alimentícios de toda a espécie, produtos têxteis fabricados com linho, cânhamo ou com lã dos rebanhos. Quanto à estrutura econômica profunda, a Europa continuava a ser camponesa e rural. (TAPIÉ, I980, p. I74-I75, tradução nossa)

Dando prosseguimento a estas verificações, e buscando uma coerência entre a realidade econômica seiscentista e setecentista e a arte praticada contemporaneamente, o crítico francês viria a afirmar - no ensaio Baroque et Classicisme, escrito duas décadas antes do livro de Maravall (em i957) - que o Barroco seria potencialmente uma invenção do campo; ou seja, que a cultura barroca era, eminentemente, uma cultura derivada do meio rural e dirigida ao enorme contingente de camponeses que viviam em uma condição subumana, assentados nos isolados interiores das grandes nações absolutistas do Grand Siècle. Assim, paradoxalmente, os iletrados, ignorantes, desfavorecidos e absolutamente miseráveis aldeões, os humildes roceiros, as paupérrimas famílias que habitavam os recônditos confins do mundo rural - homens de pouca ambição, cuja expectativa de vida era mínima, envolvidos por um cenário no qual o tédio era uma das únicas e indiscutíveis certezas - abrigariam de maneira inteiramente apaixonada, essencial e natural a inebriante experiência da arte barroca.

Segundo Tapié, os santuários barrocos dispersos em algumas das mais bucólicas e sublimes paisagens rurais europeias, especialmente os inúmeros complexos religiosos que ainda hoje povoariam o coração das antigas regiões da Baviera e da Francônia no sul da Alemanha (Figura I) impressionariam abertamente os camponeses: conjuntos sacros que se distinguiriam pela inovadora e dinâmica arquitetura na qual uma rica decoração teatral formada por efusivas tramas de pinturas, afrescos, esculturas e ornamentos derivados do repertório rococó emergiria das abóbadas e das cúpulas que se confrontavam em seus fechamentos superiores, se interpenetrando mutuamente em complicados mecanismos de contração e dilatação espacial. Todos estes espetáculos do Barroco Tardio, cuja cavidade interior guardaria a ostentação de uma absoluta riqueza impressa na miragem do ouro, dos mármores, dos granitos e das cores claras dos 
afrescos que desvelariam o poder da Igreja na Europa Central (Figuras 2-4), seriam apresentados àqueles seres brutos - àqueles homens ignorantes e limitados - como a sua revanche de lumière, a sua vingança hipnótica de luz às privações, à pobreza, à monotonia da vida rural. Portanto, segundo Tapié, para o camponês europeu, não só o do sul da Alemanha, mas também aquele da área rural da França, da Península Ibérica, da Itália, Áustria, Boêmia, Polônia, Rússia, o Barroco seria uma fuga para o maravilhoso (Figuras 5-7):

\begin{abstract}
Aberto ao maravilhoso, espera o que possa iluminar a sua vida, ordinariamente dura e monótona, marcar com uma esperança ou com uma alegria as etapas do ano, lhe proporcionar uma espécie de fuga que o encante e o tranquilize. Ora, a maior parte das vezes, a alegria, e a fuga para o maravilhoso só poderiam ser encontradas nas festas de igreja em que participava, ou daquelas do castelo, cujos reflexos chegavam até ele. Uma vida quotidiana dura, uma profissão que a mediocridade das técnicas, a submissão quase total ao clima, rendiam na maior parte do tempo desencorajante, ausência de leitura, nenhuma novidade vinda de fora, tal era o destino deste camponês. Era a igreja paroquial ou abacial vizinha, que lhe permitia conhecer os metais preciosos, o brilho dos mármores e das cores. Em todo o Oriente cristão até as planícies da Rússia, o povo recebia da liturgia e da arquitetura religiosa a única iniciação à riqueza e à beleza ao seu alcance. Na Europa Central e Oriental, na Alemanha do Sul, as populações rurais, profundamente pobres e habituadas à miséria, longe de recusarem a arte barroca por ser suntuosa e ostentatória, aceitaram-na exatamente por isso e, na maioria das vezes, com grande entusiasmo, porque ela trazia a sua revanche de luz à monotonia das suas existências. Elas encontravam motivo de orgulho na beleza do santuário local, seja essa beleza a mesma dos apreciadores mais requintados ou, na falta de qualidade das miniaturas, um reflexo distorcido da verdadeira arte. (TAPIÉ, I980, p. I77, tradução nossa)
\end{abstract}

Contudo, por mais que seja incontestável o fato de ter sido o campo, no Ancien Régime, o espaço prioritário da produção, e de existirem inúmeros exemplos de grandes estruturas arquitetônicas barrocas imersas na zona rural - não só da Europa, mas também da América hispânica e lusitana -, no contexto da sociedade absolutista, no qual a aristocracia agrária era completamente servil às poderosas monarquias, as cidades acabariam absorvendo quase todo o montante 


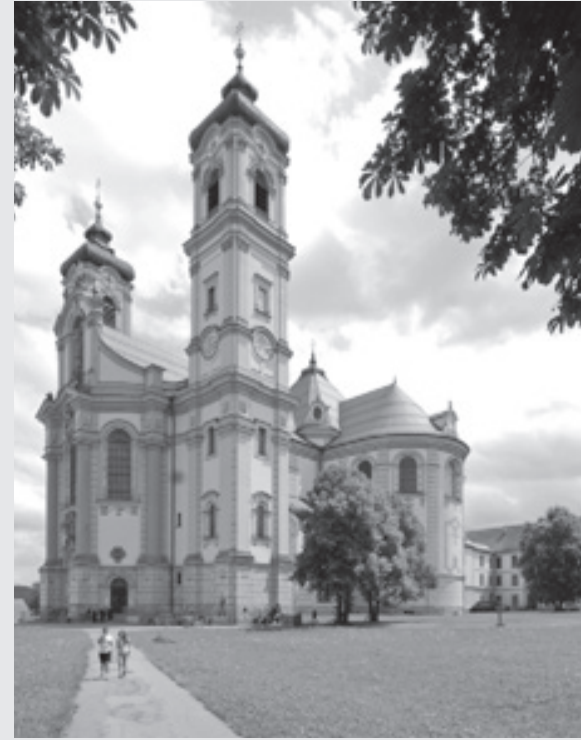

1. Exterior da Igreja da Abadia Beneditina de Ottobeuren, na Baviera, projetada e construída, de 1747 a 1766, pelo arquiteto alemão Johann Michael Fischer (1692-1766). Fonte: Fotografia elaborada pelo autor (2012).

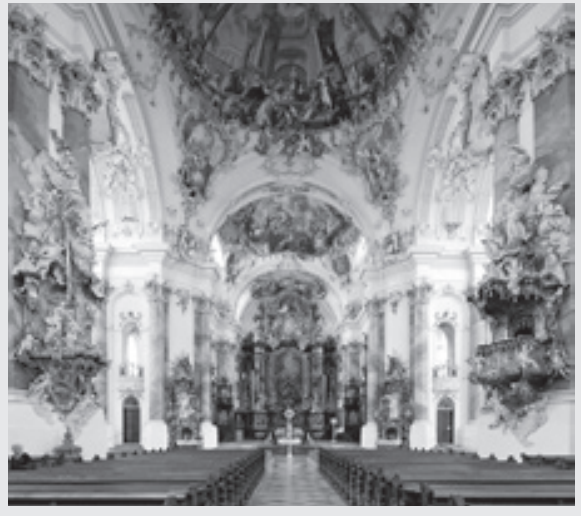

2. Quando, a partir de 1747 , o arquiteto alemão Johann Michael Fischer assumiu a obra Igreja da Abadia Beneditina de Ottobeuren, grande parte do rígido envoltório em cruz latina já havia sido concluído; mesmo assim, o arquiteto transformaria a experiência do ambiente interior do edifício em um dos melhores exemplos do espírito de síntese da época: a fusão dos espaços pulsantes e dinâmicos do Barroco Tardio, com a elegância e luminosidade do Rococó e a verticalidade e o encaminhamento longitudinal do Gótico - recursos arquitetônicos conflitantes, unidos pelo impulso imaginativo e pela retórica dramática do Barroco. Fonte: Fotografia elaborada pelo autor (2012)

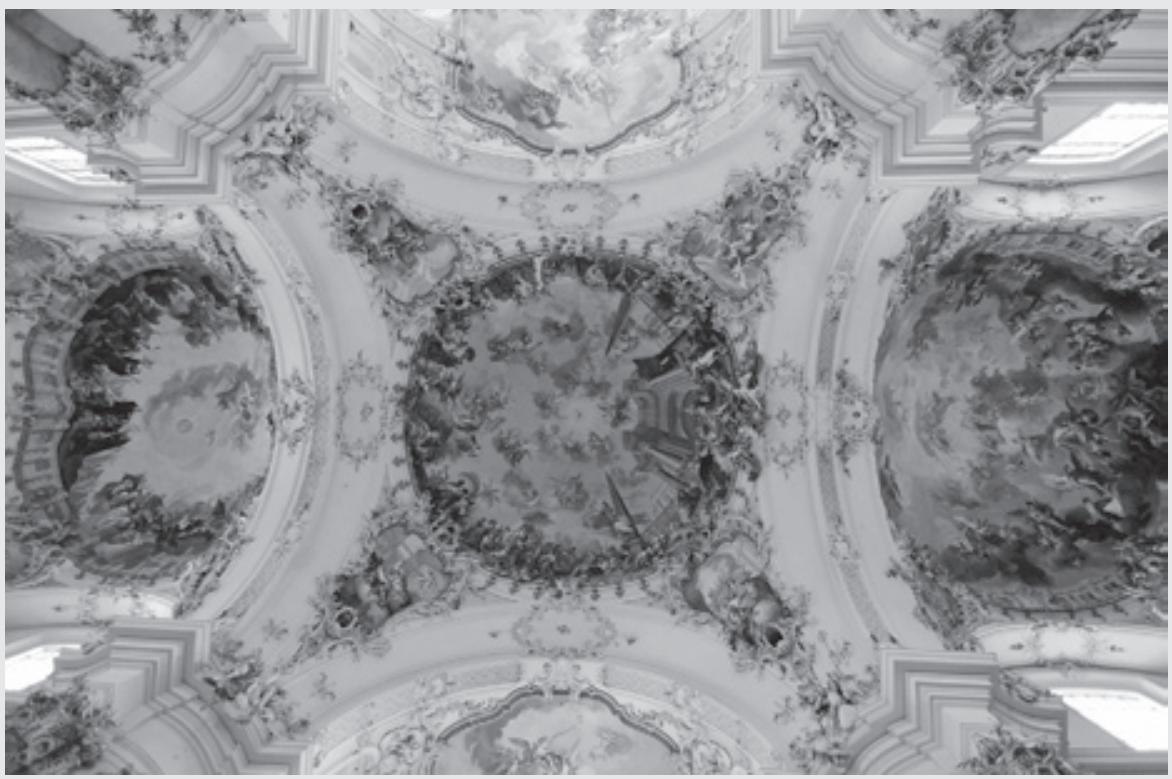

3. Detalhe das abóbadas que comporiam o Cruzeiro da Igreja da Abadia Beneditina de Ottobeuren. Os afrescos seriam realizados pelo pintor austríaco Franz Anton Zeiller (1716-1794), entre outros artistas. Fonte: Fotografia elaborada pelo autor (2012). 


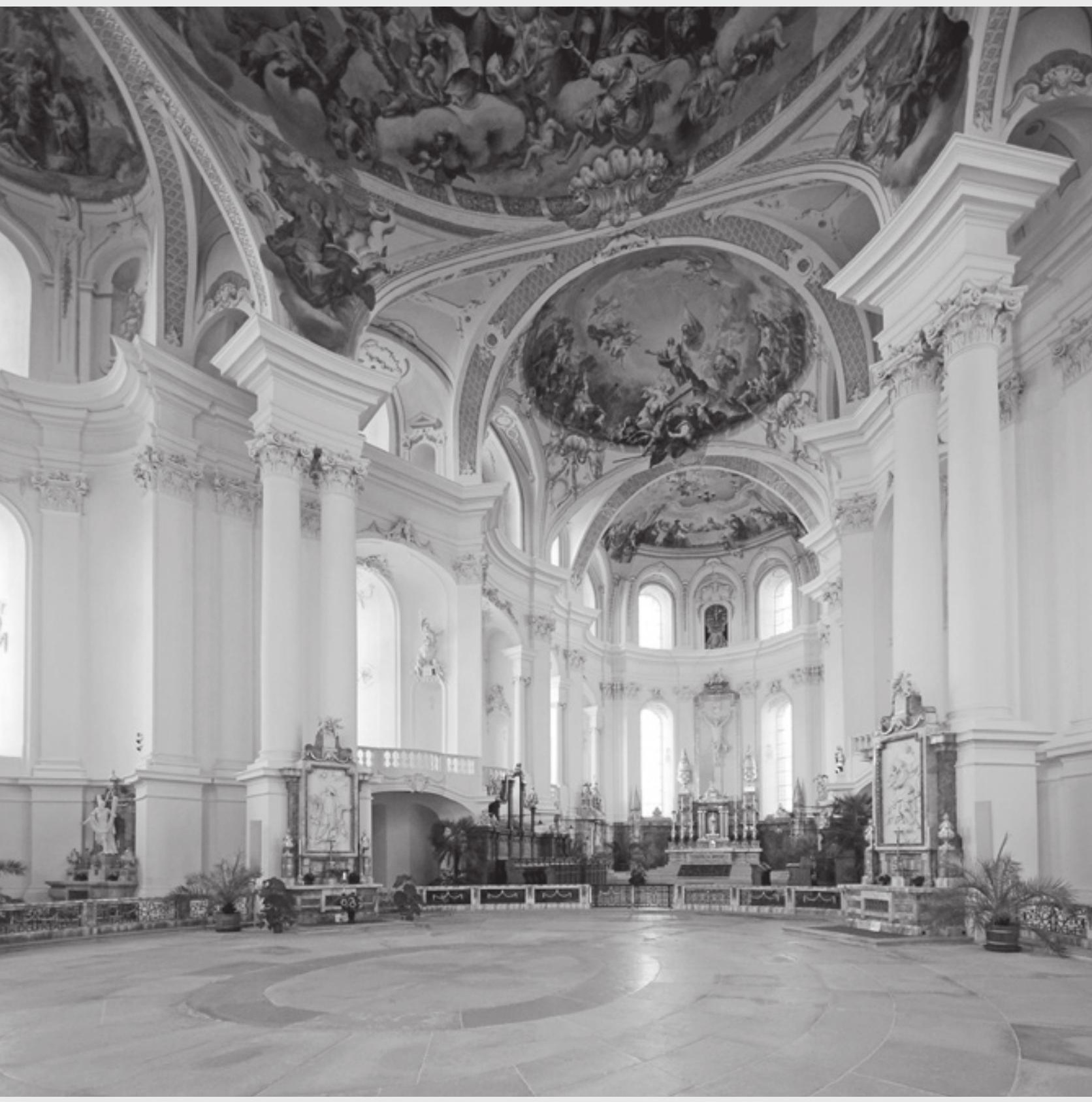

4. Hipnótico interior da Igreja da Abadia Beneditina de Neresheim, em Baden-Württemberg, Alemanha. Templo construído a partir de 1747 - projetado pelo mestre Balthasar Neumann (1687-1753), arquiteto nascido na Boêmia, mas atuante principalmente na Alemanha a partir do segundo quartel do século XVIII. Fonte: Fotografia elaborada pelo autor (2012). 


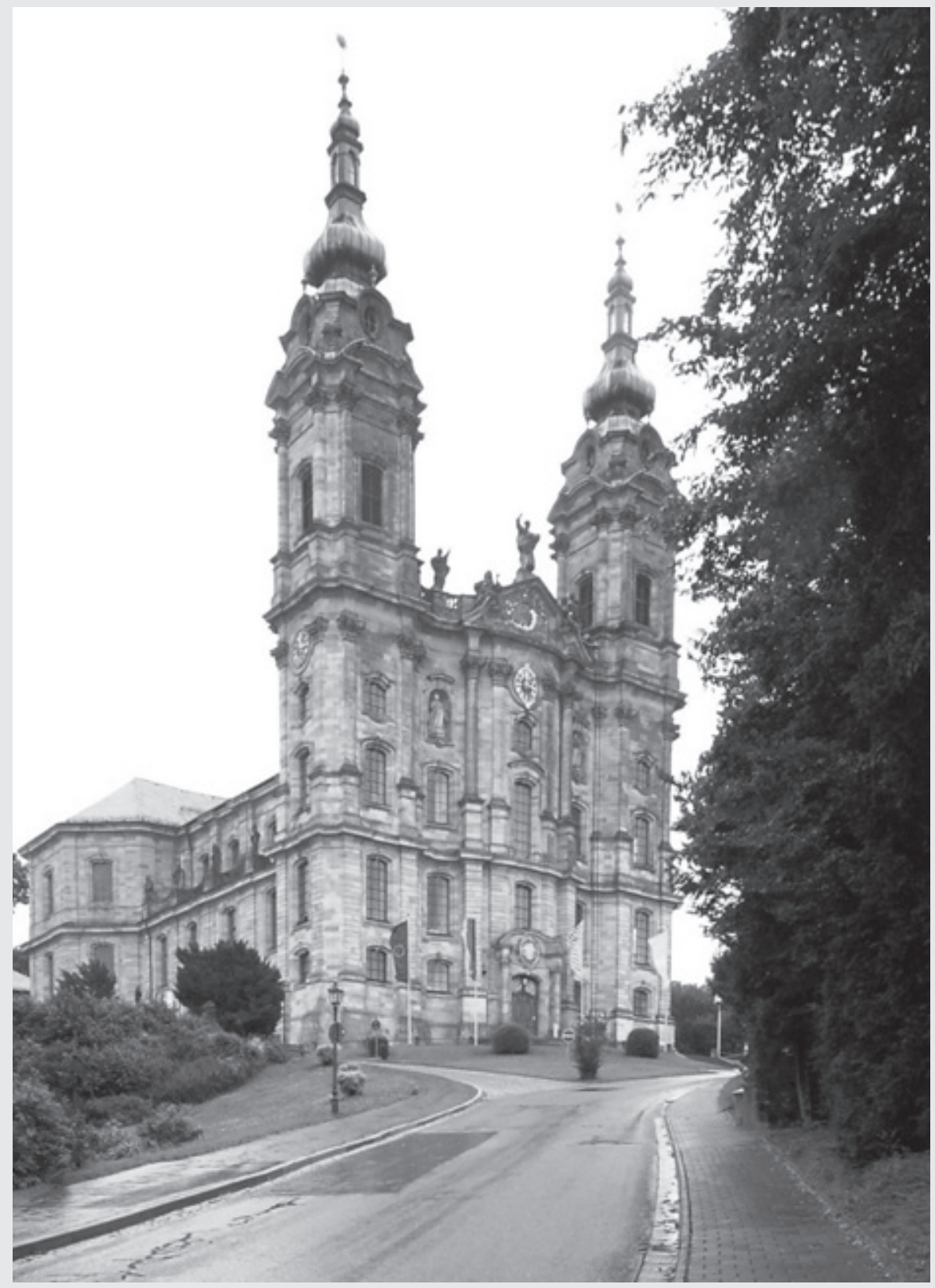

5. O Santuário dos Catorze Santos (Vierzehnheiligen), projetado por Balthasar Neumann, apareceria isolado, no vale do Rio Main, como uma estrutura justaposta à paisagem bucólica adjacente. Fonte: Fotografia elaborada pelo autor (2012). 


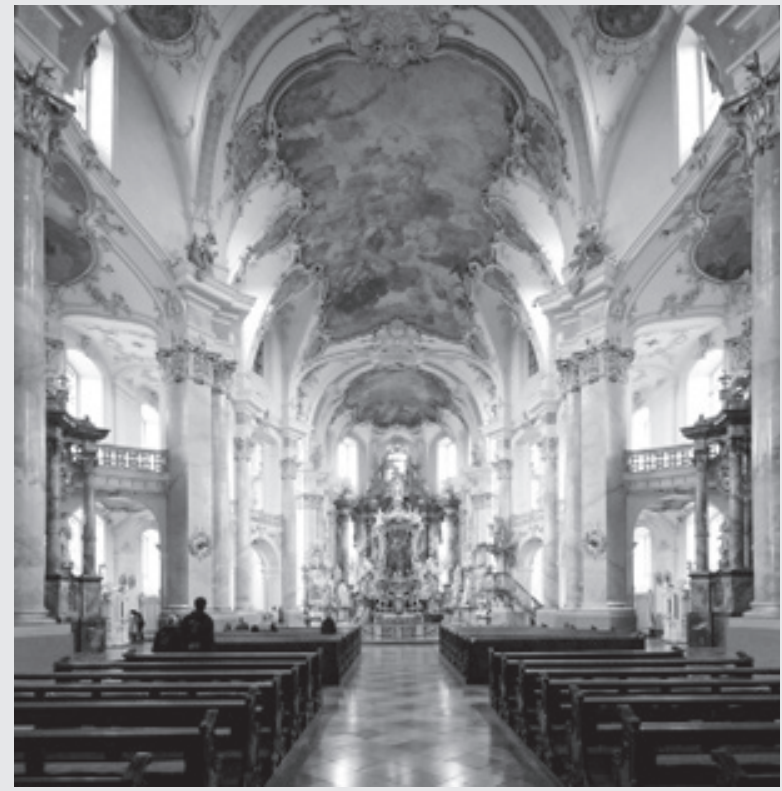

6. Interior da Igreja de

Vierzehnheiligen. A arquitetura religiosa da Europa Central

ampliaria ainda mais a ideia de síntese entre as experiências da arte contemporânea e as tradições edilícias locais. De uma maneira mais explícita, o esforço de interpenetração espacial viria a aliarse à tradição gótica, que, por sua vez, abriria caminho para a radiante proposta rococó, que emergiria através da luminosidade excessiva e da decoração exuberante dos interiores dos grandes santuários e igrejas monásticas da Francônia e da Baviera. Fonte: Fotografia elaborada pelo autor (2012).

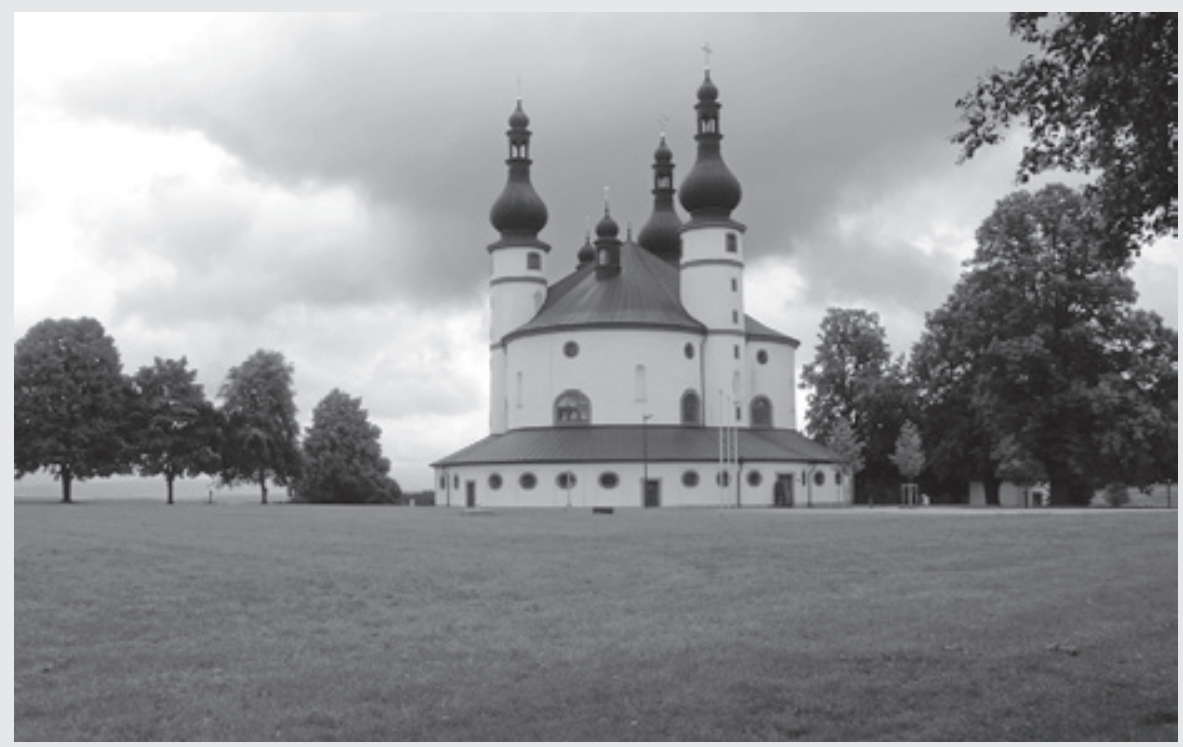

7. Lançada no ambiente rural de Waldassen, na Alemanha, surge a Igreja da Santíssima Trindade - construída a partir de 1684. Conhecida como Kappel, foi projetada pelo arquiteto alemão, Georg Dientzenhofer (1643-1689). Fonte: Fotografia elaborada pelo autor (2012). 
econômico que era produzido no campo, capital que alcançava as cidades sob a forma de impostos. ${ }^{4}$

O preço da máquina do Estado era enorme, e não só devido ao alto custo da complexa burocracia necessária para viabilizar o funcionamento adequado do governo que tudo centralizava, e do imenso capital destinado a manter a corte satisfeita e, consequentemente, obediente ao imperador, ao governante. O Estado, que absorvia o dinheiro da nobreza em forma de tributos, também o usava com a finalidade de contribuir para o financiamento dos intermináveis conflitos bélicos a que estavam sempre submetidas as nações, bem como para implementar mecanismos de coerção das revoltas internas que explodiam por todos os lados - insurreições derivadas, especialmente, do desespero geral devido à fome que assolou o Ocidente no século XVII, e também oriundas da alta mortalidade originária da peste, que a falta de alimentos só fazia agravar. Estas tragédias eram sentidas de modo muito mais intenso nas cidades do que no campo, em função da própria realidade que caracterizava, e ainda caracteriza, o ambiente urbano: a dura concentração de milhares de indivíduos vivendo conjuntamente, com a consequente multiplicação exponencial dos problemas provenientes da insalubridade, das doenças, da dificuldade de abastecimento, da falta de alimentos. Por isso, apesar dos constantes levantes que aconteciam no meio rural, o ambiente urbano apresentaria uma frequência mais significativa de perigosíssimas rebeliões populares, sublevações que ameaçavam a estabilidade dos governos autoritários do Ancien Régime. ${ }^{5}$

4 "Na fase histórica do século XVII, é o campo que produz. Dele procedem a totalidade dos produtos de alimentação e boa parte da indústria artesanal. Contudo, a cidade drena a quase totalidade dos rendimentos, porque, transformados em dinheiro - pelo menos em considerável proporção -, a cidade o absorve, sob a forma de impostos - inclusive ainda pagos em espécie-, com os quais se retribuem burocratas, militares, servidores da Corte, profissionais liberais etc.; ou o recebem a título de direitos senhoriais, laicos ou eclesiásticos, e outros encargos que se administram fora do meio rural. As riquezas produzidas se concentram, em uma proporção muito elevada, no âmbito urbano. Isso produz uma drenagem do dinheiro que se acumula no âmbito da cidade e desaparece da aldeia, dificultando seu comércio, em um momento no qual a redução da sua capacidade de autossuficiência tornaria necessário um maior volume de transações comerciais de sua parte." (MARAVALL, 2007, p. 233, tradução nossa)

5 Para Maravall (2007, p. 264, tradução nossa): “A cidade é, por antonomásia, o meio conflitivo do século $\mathrm{XVII}$, ainda que as dificuldades de abastecimento, os excedentes demográficos etc. cheguem do campo. Se o século XVI, apesar da repentina extensão do mercado, havia podido fazer frente às novas necessidades, melhorando a alimentação das populações, ao terminar a centúria o fato se inverte e a situação alimentícia piora, a ponto da fome, aliada da peste e da morte, dizimar os países do Ocidente europeu e arruinar as populações, que não podiam dispor nem empregar a força de seus braços, nem sequer se manter com seus já escassos produtos. A falta de cereal e a elevação de seu preço - em proporção muito superior à própria escassez [...] - castigou especialmente as cidades. Por esse aspecto econômico, ao que se acrescentam outros não menos graves - e de modo muito dramaticamente espetacular o das pestes 
A cultura barroca, desta forma, surgiria como um instrumento essencial para o arrefecimento das massas urbanas, em função de sua verve persuasória, de seu apelo à maravilha, à imaginação, à fantasia. Portanto, deveria ser a cidade, e não o meio rural, a se oferecer prioritariamente como um grande teatro, espetáculo do poder sobrenatural do monarca e da Igreja. O espaço urbano seria o lugar da grave contestação - por incitativa da descontrolada turba - do status quo que subjugava e esmagava o povo, mas também se apresentaria como o cenário da imediata reação da máquina governamental que - para além de pagar o funcionalismo, bajular os importantes componentes da corte e financiar o exército, para além de promover a repressão física das revoltas - despenderia espantosas quantias daquele capital concentrado nas cidades para oferecer ao público distrações intermináveis: grandes intervenções urbanas, belos e dinâmicos monumentos, a arte espalhada por todos os lados, espetáculos teatrais, poesia, literatura, celebrações religiosas, festejos em honra da realeza. Ou seja, contrariando a tese de Tapié, e voltando-se ao início desta unidade, a cidade seria o verdadeiro palco da exuberante cultura do Barroco (Figuras 8-10).

$\mathrm{Na}$ cidade barroca, levantam-se templos e palácios, organizam-se festas e se montam deslumbrantes fogos de artifícios. Onde mais poderiam ser contemplados os arcos de triunfo, os cadafalsos para as honras fúnebres, os cortejos espetaculares, senão na grande cidade? Nela, existem academias, celebram-se certames, circulam folhetos, pasquins, panfletos, que são escritos contra o poder ou que o poder inspira. Nela se constroem - uma grande novidade para aqueles tempos - locais para teatros e aglomeram-se as pessoas nas representações cênicas que encerram a mais enérgica ação configuradora da cultura barroca. (MARAVALL, 2007, p. 267, tradução nossa)

\section{A Cidade Capital}

Outro aspecto de primeira relevância marcaria abertamente a estrutura urbana europeia já em meados do Cinquecento. Existiriam cidades que desvelariam de modo muito mais intenso e explícito aquele panorama político, social e

ligadas à fome - a cidade é, por antonomásia, o lugar problemático da época barroca. O problema da falta de trigo, da carestia e escassez de alimentos não é no campo onde mais agudamente se observa, mas tem na cidade seu reflexo mais perceptível." 


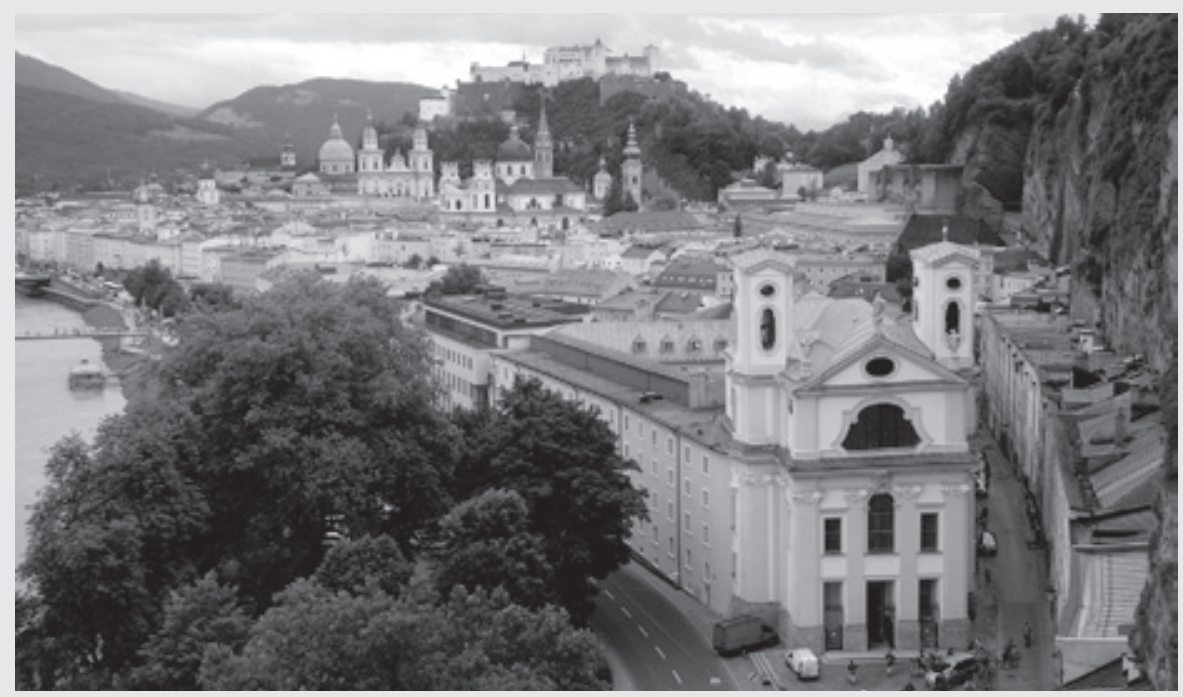

8. Imagem panorâmica da cidade de Salzburg, nos Alpes Austríacos, feita de uma das colinas que envolvem a cidade. É possível perceber como os edifícios religiosos transfiguram a estrutura medieval da cidade, promovendo um espetáculo em tom profundamente dramático para aquele que vivencia o núcleo urbano. Em primeiro plano destaca-se a Igreja das Ursulinas (Ursulinenkirche und kloster), projetada pelo arquiteto austríaco Johann Bernhard Fischer von Erlach (1656-1723) e construída entre 1699 e 1705. Para além da igreja, que marca um dos acessos ao centro urbano, outras torres e cúpulas religiosas despontam na paisagem citadina. Fonte: Fotografia elaborada pelo autor (2012).

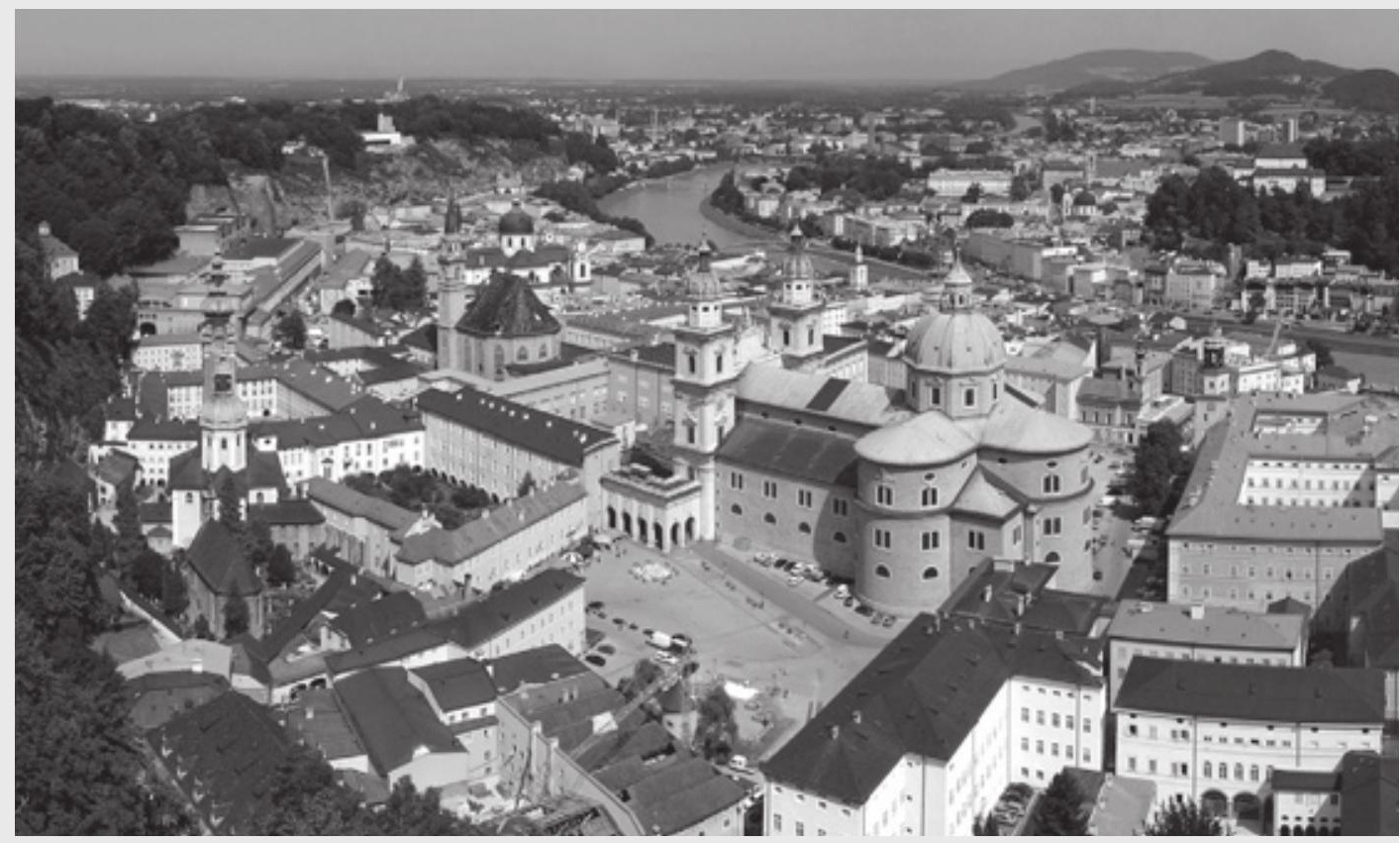




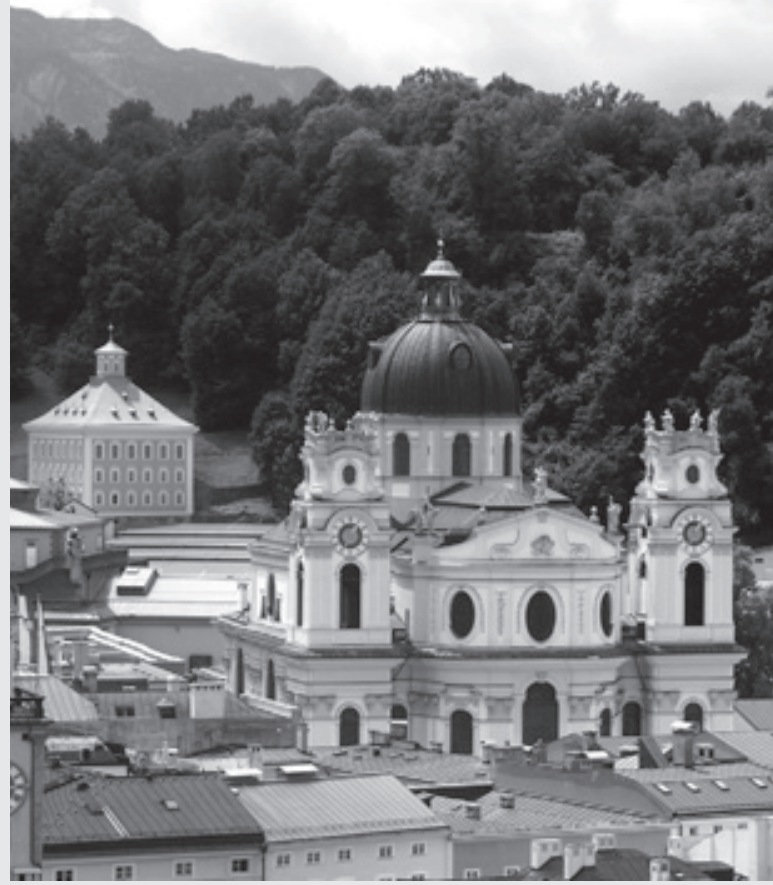

9. Panorama da cidade de Salzburg (retirado de outra colina que cerca o núcleo urbano), com destaque para a Kollegienkirche, igreja projetada por Fischer von Erlach e construída entre 1696 e 1707 . Fonte: Fotografia elaborada pelo autor (2012)
10. Panorama formado pela junção de quatro imagens, retirado do outeiro da Fortaleza e do Castelo de Salzburg. Destaque para a Catedral (Salzburger Dom), igreja seiscentista projetada pelo arquiteto italiano Santino Solari (1576-1646) - após ter modificado os planos originais de Vincenzo Scamozzi (1548-1616). Fonte: Fotografia elaborada por David Iliff (2004) Licença: CC-BY-SA 3.0 / Wikimedia Commons contributors. 
econômico que caracterizaria a realidade histórica do século XVIl e de parte do XVIII; que receberiam, por conseguinte, uma atenção bem maior no que se refere à manifestação da cultura barroca se comparadas a outros núcleos do período: as chamadas "Cidades Capitais". Se a Idade Média e o Renascimento distinguiram-se pela presença das cidades dominantes - aquelas que não teriam ainda alcançado (e a maioria nunca alcançaria) a condição de sedes de um poder político que chegasse a abranger geograficamente uma jurisdição significativa, mas que por diversos motivos, especialmente razões de ordem econômica ou estratégica, sempre se apresentariam como polos de aglomeração e de influência sobre os núcleos vizinhos, envolvendo constantemente territórios mais abrangentes do que seus próprios domínios municipais -, nos séculos barrocos imperariam as Cidades Capitais, centros absolutos do poder totalitário do Estado e da lgreja. (DE SETA, 2010, p. I62)

Mas, quando, como e por que teriam surgido as modernas Cidades Capitais? Um esclarecimento da gênese destes organismos essenciais para a cultura barroca seria possível através da análise do conteúdo de um dos mais conhecidos trabalhos do historiador americano Lewis Mumford (1895-1990) - o livro The city in history, cuja primeira edição foi lançada em 196r. Para o autor, levando em conta o período que se desenrola para além da queda do Império Romano, o primeiro grande impulso dado no continente europeu que viria a incrementar um mais genérico aparecimento de cidades caracterizadas como capitais de nações independentes aconteceria algum tempo antes do período barroco, mais especificamente no século XIV. Até então, os pequenos reinos que lentamente se conformavam na conjuntura da Alta Idade Média - aglomerados de feudos sob o comando de um senhor, de um príncipe - necessitavam, para a sua gerência, de um soberano que amiúde acorresse às diversas regiões em seus domínios, seja para coletar impostos, seja para ouvir os nobres, os súditos e resolver os problemas ligados à sua administração. E não só o rei deveria estar sempre em trânsito, em contínuo movimento; toda a corte acabaria, inevitavelmente, assumindo uma condição itinerante, acompanhando o governante em suas incursões pelos confins da acanhada nação. Logo, a corte era substancialmente um acampamento móvel. (MUMFORD, 1989, p. 353)

No século XIV, entretanto, este quadro começaria a se alterar na medida em que muitos dos mais poderosos Estados em formação iriam sendo acometidos por um substantivo aumento em sua área territorial. Esta ampliação se daria 
através da incorporação de reinos vizinhos e principados de menor importância, ou mesmo por meio de alianças de sangue que promoveriam a anexação de grandes regiões, ou a simples junção dos domínios de poderosas nações em ascensão, reinos, às vezes, muito distantes entre si, que passariam a fazer parte de um único Estado. A consequência desta nova realidade foi o aumento vertiginoso do aparelho burocrático da administração pública, assim como o crescimento do corpo de funcionários que apoiava a máquina do Estado. Ao tornar-se incrivelmente volumosa, a complexa estrutura que compunha a corte, tanto em sua componente material como humana, deixaria de ser passível de condução, uma vez que sua transposição se tornaria praticamente inviável - logo, a prática frequente do assentamento provisório do monarca e de sua corte nas diversas paradas do reino viria a ser, aos poucos, inevitavelmente abandonada. Para Mumford, seria este acontecimento histórico que impulsionaria, ao final da Idade Média, o ressurgimento da Cidade Capital, organismo que praticamente desaparecera da estrutura urbana europeia após o colapso das grandes civilizações da Antiguidade. ${ }^{6}$

Não obstante, pelo menos dois séculos se passariam até a Cidade Capital assumir a hegemonia e a grandiosidade que absorveria como centro cultural do período barroco. Do século XIV a meados do século XVI, quando as grandes nações modernas tomavam forma e aos poucos se consolidavam, as sedes das cortes - mesmo perdendo o caráter de acampamento provisório - continuavam, com frequência, itinerantes; o soberano alterava, invariavelmente, o centro de seu rei-

6 "Na Alta da Idade Média, os grandes senhores feudais tinham conseguido alimentar seus vassalos, coletando seus impostos, e assegurando um nível módico de paz e ordem em seus domínios, apenas por estarem em contínuo movimento de um feudo a outro. A corte era um acampamento móvel: a vigilância e o movimento eram o preço do poder. Isto se aplicava tanto aos reis quanto aos nobres menores. Os ministros reais, os juízes reais, todo o aparato do governo e o controle fiscal eram, essencialmente, uma aparelhagem móvel: a autoridade era mantida através da supervisão pessoal. Durante o século XIV nas grandes monarquias da Inglaterra e da França, esse processo chegou a uma interrupção efetiva. Os documentos das cortes, as listas, os registros, os arquivos, a correspondência, para não mencionar os próprios funcionários, tinham-se tornado demasiado numerosos e volumosos para se moverem. À medida que a população e o território cresciam em tamanho, a supervisão pessoal direta tornava-se impossível: a administração impessoal e a autoridade delegada tornavam-se necessárias. Embora o movimento popular pelo controle parlamentar não se mantivesse propriamente com grande sucesso, exceto na Inglaterra, o Estado moderno começou a se moldar no século XIV. Suas marcas distintivas são: uma burocracia permanente, permanentes tribunais de justiça, arquivos e documentos permanentes, e edifícios permanentes, mais ou menos centralizados, para a condução dos negócios oficiais. [...] E o próprio processo era de natureza recíproca: a centralização da autoridade exigia a criação de uma cidade capital, ao passo que a cidade capital, comandando as principais rotas de comércio e movimento militar, era uma poderosa contribuição à unificação do Estado. Essa transferência de poder foi acompanhada pelo surgimento de uma burocracia oficial. O soberano andarilho da Alta Idade Média, muitas vezes ausente de seu castelo ou de sua capital, lutando ou tomando parte em cruzadas, estava, agora, fixo: era suficientemente forte para compelir seus mais poderosos vassalos a irem procurá-lo." (MUMFORD, 1989, p. 353-354, tradução nossa) 
nado de acordo com as necessidades cambiantes do Estado. A capital provisória era fundada quase sempre em cidades dominantes de grande relevância política e econômica para a nação, mas sem o caráter de estabilidade e eternidade das estruturas urbanas que viriam a caracterizar as imponentes capitais barrocas dos séculos XVII e XVIII. Segundo o juízo do historiador italiano da arte, da arquitetura e da cidade, Cesare de Seta, juízo proferido no ensaio escrito em I986 e intitulado Città capitali e città dominanti, a única exceção seria Roma, que nunca teria deixado de ser a capital dos Estados Pontifícios e de todo o mundo católico, a não ser no lapso de tempo que se estendeu entre os anos I309 e 1377, durante o exílio dos papas em Avignon, na França.

Ou seja, para De Seta, durante toda a Idade Média, e em grande parte do Período Humanista, por mais que importantes núcleos urbanos viessem a alcançar a condição de centros do poder ao receberem a máquina do Estado, a corte inevitavelmente partiria depois de alguns anos para outro significativo núcleo urbano. Mesmo Paris, considerada, além de Roma, a mais antiga das capitais medievais - reconhecida como capital em 987, quando Hugues Capet (940-996) tornou-se rei dos francos -, por diversas ocasiões acabaria perdendo sua condição de sede do império francês para outros núcleos espalhadas pelos domínios da antiga nação. (DE SETA, 20ıo, p. I79) Assim sendo, a moderna Cidade Capital, o monumental espaço de exposição da força dos impérios absolutos, só despontaria mesmo no século XVII, quando os Estados nacionais tomariam sua forma definitiva, sua extensão, sua força política, sua concentração econômica. O historiador e crítico de arte italiano, Giulio Carlo Argan (2004, p. 59, tradução nossa), afirmaria, em seu conhecido estudo de i964, L’Europa delle Capitali:

A grande criação política do Seicento é o Estado nacional, e a sua forma típica é a monarquia absoluta. A Europa moderna é um sistema de Estados à procura de um equilíbrio de forças políticas e econômicas. O Renascimento tinha dado vida a uma civilização urbana em que cada cidade se apresentava, não mais como um município livre, mas como um pequeno Estado soberano: a cidade não era exclusivamente a sede do príncipe ou o instrumento de sua política pessoal, mas a herdeira de uma tradição histórica própria e o centro de uma cultura. No século XVII a centralização dos poderes determina a prevalência de uma cidade, que se torna a sede da autoridade do Estado, dos órgãos de governo e da administração pública, das representações diplomáticas que regulam as relações entre os Estados. A formação da 
Cidade-Capital determina, obviamente, a regressão das outras cidades do Estado à categoria subalterna de sedes de província: de agora em diante, teremos uma cultura e uma arte da capital, abertas a todas as trocas internacionais, e uma cultura e arte de província, às vezes de nível elevado, mas em posição periférica em relação às grandes correntes da metrópole. A Cidade-Capital possui também uma função representativa e tende, por isso mesmo, a perder o tradicional caráter municipal, seja na sua estrutura social, seja na configuração planimétrica e edilícia. [...] Além disso as transformações internas da cidade não ocorrem mais por iniciativa dos cidadãos ou da municipalidade, mas pela autoridade política; mais do que a pressão que vem de baixo, que fizera das cidades comunais a imagem da comunidade urbana, prevalece a vontade do soberano e do governo, que querem fazer da Cidade-Capital a imagem do Estado e do poder.

Consequentemente, para Argan, a capital moderna é uma criação definitivamente barroca. Se na Idade Média e no Renascimento, mesmo depois da formação das primeiras capitais, as cidades dominantes - as cidades-estados, os núcleos urbanos mais significativos dos pequenos reinos e das inúmeras províncias das nações mais extensas - absorveriam a hegemonia cultural no cenário europeu, no Seicento e no Settecento a Cidade Capital, base política dos consolidados Estados nacionais, centralizaria a alta cultura literária e artística do continente.

Da mesma forma, as sedes dos vice-reinados e das audiências hispanoamericanas, núcleos urbanos idealizados e constituídos para serem polos de representação da autoridade da coroa nas mais importantes regiões conquistadas pelo império espanhol nas Américas, bem como as capitais portuguesas na América lusitana, fundadas para ordenar e proteger os territórios ocupados além -mar, e ainda alguns centros regionais dispersos nas vastíssimas extensões das colônias ibéricas das Índias Ocidentais, assumiriam uma condição de domínio e de concentração de poder semelhantes às das capitais soberanas da Europa. Estes centros de civilidade, assentados naquelas longínquas paradas, contrairiam um papel equivalente ao das capitais europeias ao acolherem os emissários do rei e de sua corte, já que o soberano estava impossibilitado de acudir a tão distantes e inóspitos territórios. Os vice-reis e os governadores, com toda a aparelhagem necessária para o comando das novas possessões hispânicas e lusitanas, iriam assumir a regência das colônias no lugar do imperador, e teriam como tarefa garantir, a partir da sede do governo, a estabilidade e a autoridade do monarca. 
Desta forma, seria possível dizer que as capitais coloniais, a partir de finais do século XVI, em consonância com as europeias, também assumiriam um importante papel na era das capitais barrocas. (MÍNGUEZ, RODRÍGUEZ, 2006, p. 2I)

E é claro que, no contexto da cultura barroca, estes núcleos urbanos deveriam apresentar-se como o ambiente adequado para a exposição do poder infinito do soberano - e este processo, muitas vezes, culminaria em extensas e complexas intervenções. Como pequena amostragem, entre os séculos XVI e XVIII - além do próprio século XIX, que acabaria elevando a prática de renovação urbanística a extremos -, seria possível apontar grandes operações urbanas em capitais como Roma, Paris, Londres, Turim e Lisboa; da mesma forma poder-se -ia assinalar a construção de cidades novas, totalmente planificadas, na Europa, como Versailles, Karlsruhe, São Petersburgo (Figuras II-I2). Nas Américas, não seria preciso citar as centenas de cidades que seriam fundadas em seu vasto território já no século XVI, sendo que algumas capitais, como a Cidade do México, Lima, Salvador, e mesmo centros regionais como Cusco ou a antiga Vila Rica, passariam por um desenvolvimento cenográfico em muitos aspectos equivalente às monumentais capitais europeias. E não deveria ser esquecida a planificação da capital do primeiro país soberano das Américas - a cidade de Washington, nos Estados Unidos, ao final do século XVIIl.

A imensa concentração de poder político que estes núcleos retinham, derivada da administração quase sempre absolutista dos Estados e das colônias, viria a contribuir para a viabilização econômica destas ações projetuais. Os assentamentos que não conseguiriam alcançar o status de uma Cidade Capital não ficariam totalmente à margem. Algumas vezes sofreriam intervenções de renovação mais modestas, mas não raramente inspiradas naquelas oriundas da teoria e da prática urbanísticas experimentadas nas sedes das grandes nações. Não obstante, os empreendimentos realizados nas capitais - ou sob sua influência - se caracterizariam constantemente por um desejo de organização global do espaço, uma busca por uma estrutura urbana e uma imagem persuasiva que revelasse a disciplina e o poder excessivo dos governos barrocos.

Em vista disso, nos próximos itens será feita uma avaliação crítica daqueles aspectos que, usualmente, seriam pontuados pelos historiadores da arquitetura e da cidade, como os mais comuns da chamada urbanística barroca - compreendendo a urbanística como os processos de intervenção na cidade que chegariam a ultrapassar, substancialmente, a escala do edifício, atingindo uma dimensão 


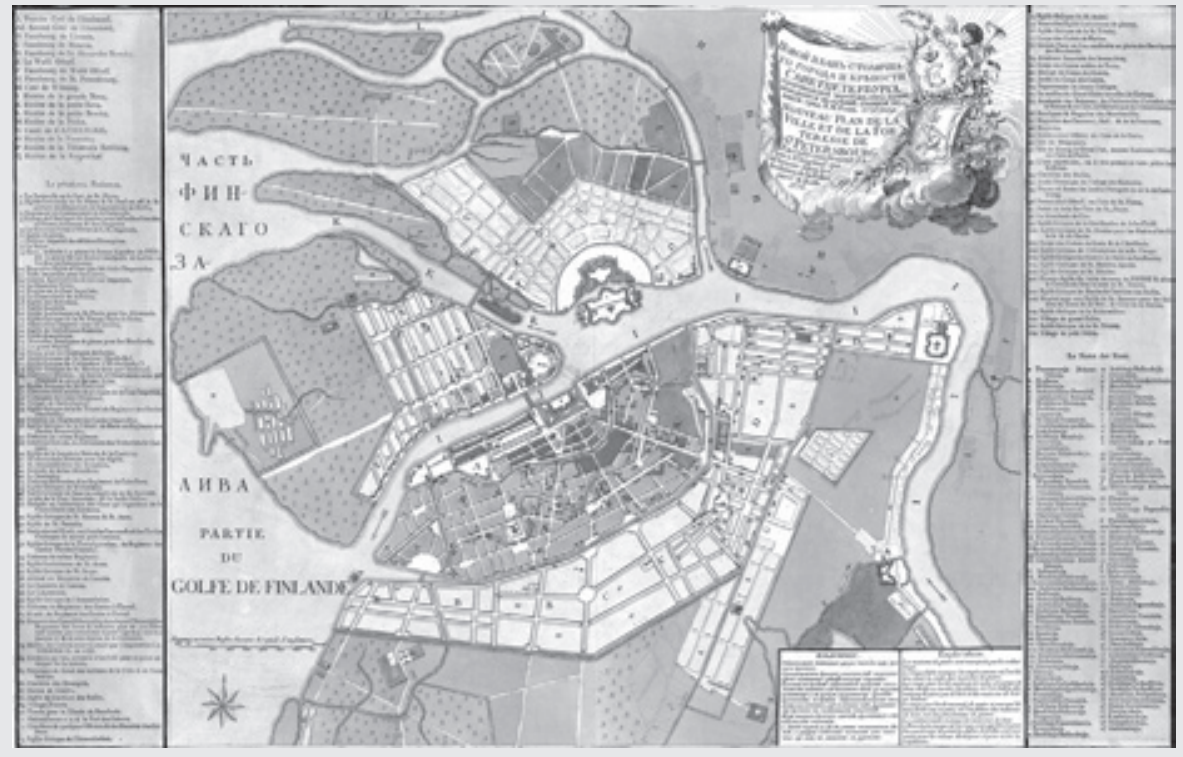

11. Novo plano da cidade e da fortaleza de São Petersburgo, 1776. A cidade foi construída por Pedro I, o Grande (1672-1725), a partir de 1703. A capital da Rússia foi transferida de Moscou para lá em 1712. Fonte: Wikimedia Commons contributors.

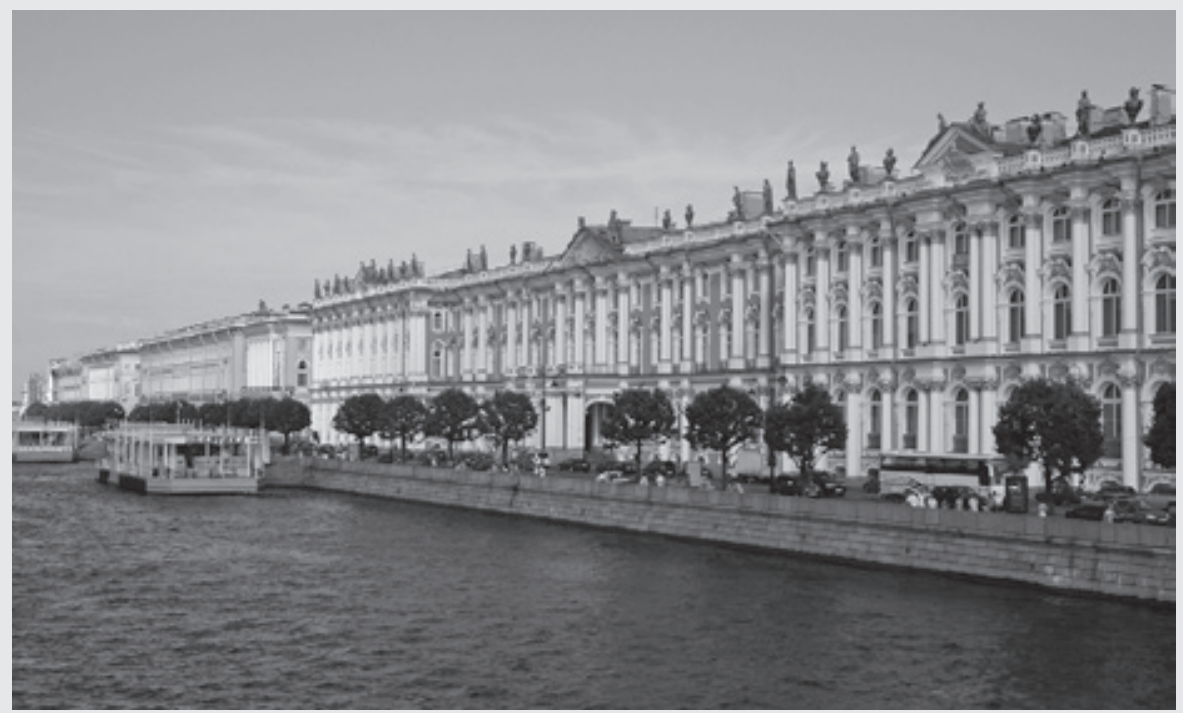

12. São Petersburgo, vista do Rio Neva. Destaque para o Palácio de Inverno, projetado pelo arquiteto italiano, a serviço do império russo, Bartolomeo Rastrelli (1700-1771) - construído entre 1754 e 1762. Fonte: Fotografia elaborada pelo autor (2007). 
maior que envolveria genericamente a estrutura urbana e o desenho da cidade, ou que comprometeria grandes trechos da massa edificada ou dos vazios residuais internos e externos ao núcleo citadino.

Logo, para a urbanística do Ancien Régime serão rapidamente analisados, de forma difusa, nos próximos itens, os mais significativos mecanismos de ação projetual e de intervenção no ambiente da cidade ligados às iniciativas do poder totalitário dos governos absolutistas: abertura de ruas diretas, avenidas retilíneas e bulevares nos limites externos ao núcleo citadino; organização de sistemas de vias que se encontravam em um ponto nodal importante; constituição de monumentais praças regulares; assentamento de novos bairros planificados; inserção de jardins e parques no tecido urbano preexistente; ampliação da cinta fortificada e construção de cidadelas; paradoxalmente, vencimento dos limites impostos ao núcleo preexistente através da derrubada das antigas e obsoletas muralhas, não mais eficientes. Estas ações acometeriam tanto a esfera do já construído, ou seja, a cidade preexistente, como os poucos centros urbanos novos que seriam planificados e assentados - comumente espaços de recreio ou de simples ostentação da corte e da nobreza que, por conseguinte, frequentemente se confundiriam com a própria estrutura de um palácio real e seu monumental jardim.

\section{As origens da urbanística barroca nos séculos XV e XVI}

A engenharia militar torna-se, assim, em poucos anos, o setor que viria a rebocar a atividade edilícia e urbanística, primeiramente na Itália e na França, e depois nos outros países europeus e mediterrâneos, bem como além-mar. Nenhum outro campo de atividade projetual possui um comparável impulso inovador, uma tão alta densidade de conexões com outras disciplinas e com outros fenômenos econômicos, políticos e sociais, um custo tão significativo de programações e de intervenções. A este fato se deve acrescentar que os tempos de realização são, com muita frequência, extremamente restritos; e que a rápida superação das técnicas e dos sistemas de defesa leva, ao mesmo tempo, a um rápido consumo das soluções adotadas poucos anos antes, com grande desperdício de recursos econômicos e também com um grande empenho de recursos intelectuais. (GUIDONI; MARINO, I982, p. Io, tradução nossa) 
Até pouco tempo, quando se argumentava sobre as origens da urbanística moderna, origem que estaria fundada nos acontecimentos que se desenvolveram no cenário europeu a partir da gênese da cultura do Renascimento italiano, um dos temas mais recorrentes que se abria para o universo das discussões sobre o cenário urbano dos primórdios da cultura humanista seria a ideia da hegemonia das reflexões sobre a cidade ideal frente à prática de reordenação urbanística da cidade real. Este juízo, que versava sobre a preeminência da construção utópica virtual do ambiente que deveria acolher a nova civilização, em oposição ao esforço de transformação efetiva dos núcleos urbanos, revelaria que durante todo o Quattrocento, e pelo menos a primeira metade do Cinquecento, os avanços derivados do campo da urbanística estariam mais vinculados ao plano teórico do que à dimensão prática. Ou seja, para além da revolução que teria se estabelecido através do debate sobre os modelos inovadores, mas inexequíveis, idealizados para o desenho da cidade perfeita, pouco se teria feito de significativo e de inédito no que se referiria às intervenções empreendidas nos núcleos urbanos importantes; poucas iniciativas de remodelamento das cidades preexistentes teriam contribuído para ultrapassar significativamente a tradicional configuração urbana medieval.

No entanto, já há muitos anos, vem-se contestando este valor incondicional atribuído às discussões sobre o modelo da cidade ideal para o desenvolvimento da urbanística no período humanista, e a consequente influência que haveria de exercer para a configuração da cidade barroca. Atualmente, o interesse acabaria se voltando para a investigação dos fatores que teriam efetivamente colaborado para agenciar um movimento mais generalizado de transformação dos núcleos preexistentes e de fundação de novos organismos urbanos no velho continente, e nas colônias conquistadas além-mar pelos europeus desde o século XV. ${ }^{7}$

Neste sentido, seria possível vislumbrar que exigências objetivas imediatas, sejam de cunho prático-utilitário, mas também de inspiração estético-formal, viriam a exercer um papel muito mais relevante para o desenvolvimento posterior da cidade moderna (a cidade barroca, iluminista, industrial) do que as tipologias ideais de núcleos desenhados pelos tratadistas. Logo, as peculiaridades da urba-

7 Especial destaque poderia ser dado ao processo de fundação de cidades pelos espanhóis e portugueses em suas incursões imperialistas além-mar, particularmente na Ásia, África e na América Ibérica. Mais organizado e influente teria sido o monumental projeto encaminhado pela coroa espanhola para o povoamento do Novo Mundo, que já no século XVI contaria com cidades absolutamente ordenadas em grandes extensões de seu território. Contudo, apesar de precoces e profundamente relevantes, a análise do caráter das cidades coloniais hispano-americanas, por ser conteúdo exclusivo do último capítulo, ficará ausente desta unidade para evitar que a avaliação crítica se torne redundante. 
nística do século XV, e principalmente aquela da primeira metade do século XVI, seriam oriundas das novas demandas exigidas para os assentamentos urbanos, uma realidade que ultrapassaria em muito as discussões sobre os modelos formais de caráter meramente utópico; ou seja, as reais condições para a conformação de soluções inovadoras para a ordenação do ambiente urbano teriam sido edificadas, justamente, como resposta a algumas necessidades práticas emergentes.

Como foi visto na citação que abriu este item, os mais significativos problemas a serem resolvidos pela configuração e pelos novos equipamentos projetados e construídos para a cidade humanista estariam quase sempre ligados às exigências de defesa do núcleo citadino, problemas agravados no Cinquecento pela difícil realidade política dos Estados, pelos inúmeros conflitos a que estavam submetidas as nações em formação, guerras que afetavam diretamente a segurança dos principais assentamentos urbanos europeus - especialmente devido ao desenvolvimento de novas e poderosas técnicas de combate e de assalto. Entretanto, em consonância com o campo da engenharia militar, a ser detalhado mais à frente, outros fatores vinculados a demandas utilitárias, mas também a resoluções de caráter artístico, contribuiriam para superar a prática urbanística medieval e antecipar o amadurecimento da cidade humanista que aconteceria no século XVII, em pleno período barroco. Muitos destes fatores já se apresentavam claramente nos primórdios do Renascimento, no Quattrocento, sendo debatidos pelo primeiro e mais importante teórico humanista: o arquiteto, matemático, poeta, filósofo, linguista, arqueólogo, Leon Battista Alberti (I404-I472).

Em um texto publicado em i986 e denominado Ideologia e immagine della città nel Rinascimento, o crítico de arquitetura Cesare de Seta viria, justamente, contestar o juízo comum que afirmava o caráter simplesmente ideal - não aplicável objetivamente para a conformação da arquitetura e da cidade real - contido no discurso de Alberti. Apenas uma breve análise do tratado sobre arquitetura e construção escrito pelo grande teórico humanista entre I443 e I452, o De Re Aedificatoria, ${ }^{8}$ já seria suficiente para perceber que o discurso do arquiteto de origem toscana (mas nascido em Genova) apontaria para um caminho diverso daquela construção meramente utópica constantemente celebrada pela crítica - especialmente no que tange à visão do autor sobre a configuração do espaço urbano.

8 Aqui foi contemplada a versão do texto latino original cotejado com a tradução para o italiano de Giovanni Orlandi, intitulada L'architettura (De Re Aedificatoria), com introdução e notas de Paolo Portoghesi. (ALBERTI, 1966) 
No livro IV do De Re Aedificatoria, denominado Leonis Baptistae Alberti de Universorum Opere, o capítulo no qual o autor mais debateria o problema das cidades, Alberti reconheceria, por exemplo, as dificuldades provenientes do assentamento dos núcleos urbanos nos diferentes sítios. Por conseguinte, as muralhas deveriam se conformar à diversidade dos terrenos e às peculiaridades da topografia local - apesar de que, reconhecidamente, o melhor contorno para a cidade deveria ser o círculo perfeito, seja por uma questão prático-utilitária ligada especialmente à defesa, mas principalmente por simples decoro. (ALBERTI, I966, t. I, p. 294) Da mesma forma, não deveriam ser concebidas, exclusivamente, vias retilíneas e diretas para os diferentes tipos de assentamentos, mas também ruas estreitas e tortuosas:

Se, ao contrário, se trata ou de uma colônia ou de uma simples praça forte, as vias de ingresso mais seguras não são aquelas que conduzem diretamente à porta, porém aquelas que se desviam para a direita ou para a esquerda ao longo dos muros - melhor ainda se elas passarem sob as ameias; e dentro da cidade as vias não devem se configurar em linha reta, mas sim se dobrar em amplas curvas, como os meandros de rios, muitas vezes de um lado a outro. Isso porque, em primeiro lugar, a rua, ao parecer mais longa, dará a impressão que a cidade é maior; além do mais, é um fato que traz grande benefício, seja à beleza, seja à conveniência prática, seja às necessidades de determinados momentos. E é nada desprezível que aqueles que caminham venham a descobrir aos poucos, quase a cada passo, novas perspectivas dos edifícios; que a entrada e a fachada de cada habitação se mostrem diretamente ao centro da via; e que a mesma amplitude seja aqui favorável, enquanto alhures um excessivo alargamento resulta desagradável e insalubre. [...] Ademais, a rua curva estará sempre sombreada, mesmo no verão; e por outro lado não existirá casa aonde não chegue a luz durante o dia. Nunca faltarão as brisas, as quais, de qualquer parte que venham, encontrarão sempre uma passagem direta e ágil. Nem existirá o perigo dos ventos nocivos, que seriam subitamente repelidos pelos muros sobrepostos. Enfim, se o inimigo penetrasse na cidade, se encontraria em grande apuro, podendo ser atacado pela frente, pelos flancos, e pela sua retaguarda. (ALBERTI, I966, t. I, p. 306, tradução nossa)

Esta passagem do livro IV de Alberti não deixaria dúvidas sobre como, frequentemente, o arquiteto italiano se afastava dos pressupostos do novo método perspectivo e da geometria euclidiana em nome da absorção e da reformulação 
moderna de sistemas de ordenação tradicionais (leia-se, medievais) do espaço urbano, quanto mais adequados fossem à situação objetiva, ao problema real que se colocava à frente. As ruas tortuosas contribuíam para a defesa, para a climatização no interior de certos núcleos urbanos; mas também os valorizavam esteticamente, aumentando virtualmente o tamanho das vias nos aglomerados de menor importância, além de oferecerem uma gama infindável de visadas inesperadas e de surpresas fascinantes, situação em que Alberti teria tido, constantemente, a oportunidade de experimentar nas suas incursões pelos assentamentos de seu tempo - artifício que viria a ser utilizado, largamente, nas posteriores intervenções barrocas nas cidades preexistentes: particularmente a ideia de incrementar as tensões capturadas pelo transeunte através da confusão que as ruas irregulares causariam no espectador, antes dele se deparar, surpreendentemente, com inovadoras estruturas arquitetônicas barrocas dispersas cenograficamente no seio dos bairros medievais (com uma fonte, com uma igreja, um palácio, uma praça, um obelisco, uma grande escadaria). Ou seja, mesmo privilegiando, abertamente, os princípios que viriam a dominar o discurso sobre a arquitetura, e consequentemente a cidade do Quattrocento - notadamente a ideia da perspectiva como procedimento determinante para a configuração do novo espaço urbano -, a inclusão de pressupostos da urbanística medieval na divagação sobre a configuração da cidade revelaria que o pensamento do arquiteto não perseguia, simplesmente, a utopia, a cidade ideal, e sim almejava a reformulação objetiva da cidade real, a reordenação dos núcleos preexistentes a partir do próprio reconhecimento das qualidades que poderiam ser retiradas das cidades medievais. Assim:

Livremo-nos do equívoco que às suas formulações - propriamente práticas - se possa atribuir o abusado adjetivo de ideal. Não existe nada de ideal na cidade albertiana; pelo contrário, todo o seu tratado é um repertório muito denso de normas, preceitos e regras para tornar mais habitável, melhor organizado funcionalmente e mais harmonioso - se se pode dizer assim - o mundo urbano de seu tempo. (DE SETA, 20Io, p. 32, tradução nossa)

O arquiteto e crítico italiano, Leonardo Benevolo (I923-20I7), revelaria um juízo semelhante ao de Cesare de Seta em seu vasto estudo sobre a Renascença, Storia dell'architettura del Rinascimento, cuja primeira edição seria lançada em I968. Benevolo (2008, p. II9-I20) demonstraria como as concessões feitas por Alberti frente à cidade medieval teriam contribuído para as poucas intervenções 
de caráter moderno que núcleos urbanos italianos de pequeno e médio porte viriam a sofrer ao longo do século XV - especialmente as cidades de, Urbino e Ferrara -, assim como se relacionariam com algumas iniciativas de reordenação pontual de partes isoladas de cidades preexistentes - como, por exemplo, a inclusão de arcadas em três dos quatro lados da Piazza della Santissima Annunziata, em Florença (Figura 13), a partir da construção do Spedale degli Innocenti, iniciado em I4I9 por Filippo Brunelleschi (I377-I446), bem como o envolvimento da Piazza Ducale de Vigevano (Figura I4) por uma grande loggia regular, supostamente projetada pelo arquiteto Donato Bramante (I444-I5I4) por volta de I490.

$\mathrm{Na}$ verdade, Alberti teria absoluta consciência da necessidade da inserção coerente da arquitetura moderna - que deveria seguir os revolucionários padrões de harmonia e beleza do Classicismo reinventado - no espaço urbano real. Os novos edifícios e monumentos assentados no tecido medieval preexistente deveriam ser admirados como eram apreciados os ornamentos na estrutura mural dos edifícios: ou seja, elementos de destaque frente à monotonia dominante. Desta forma, o mestre humanista desvelaria um dos procedimentos mais eficientes de intervenção pontual na cidade real, principalmente quando se considerava o desejo de renovação cenográfica do ambiente citadino, que aspirava a uma transformação visibilística da paisagem urbana. Sem dúvida, era uma solução que se afastaria daquilo que poderia ser compreendido, grosso modo, como um procedimento vinculado aos métodos de intervenção propriamente urbanísticos, e que viria a ser uma das bases para a reconfiguração cenográfica das cidades no período barroco (Figura I5).

Um dos maiores exemplos deste tipo de empreendimento, efetivado ainda nos primórdios da Renascença, antes mesmo da formulação teórica de Alberti, foi a edificação da primeira obra monumental da arquitetura renascentista - a cúpula da Catedral de Santa Maria del Fiore, em Florença, projetada pelo arquiteto florentino Filippo Brunelleschi para o concurso estabelecido em I4I8.9 A grande cúpula do Duomo se sobreporia à nave da igreja, ${ }^{\text {Io }}$ propondo uma revolução no desenho da cidade adjacente, passando a compor com toda a preexistência

9 A obra foi iniciada em 1423.

10 A nave da Catedral de Florença foi iniciada em 1296 e construída pelo arquiteto e escultor Arnolfo de Cambio (1240-1302), assim como pelo conhecido pintor medieval Giotto di Bondone (1267-1337), pelo arquiteto e escultor Francesco Talenti (1300-1369), entre outras importantes personalidades da arte medieval. 


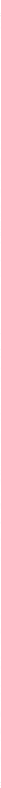

13. Piazza della Santissima Annunziata, em Florença. A direita, o hospital projetado por Filippo Brunelleschi (13771446) e iniciado em 1419. As outras duas galerias, construídas posteriormente, seguiriam o modelo do Spedale degli Innocenti - inclusive, as arcadas diante da igreja que daria nome à praça. Fonte: Fotografia elaborada por Gryffindor (2008) - Licença: CC-BY-SA 3.0 / Wikimedia Commons contributors.

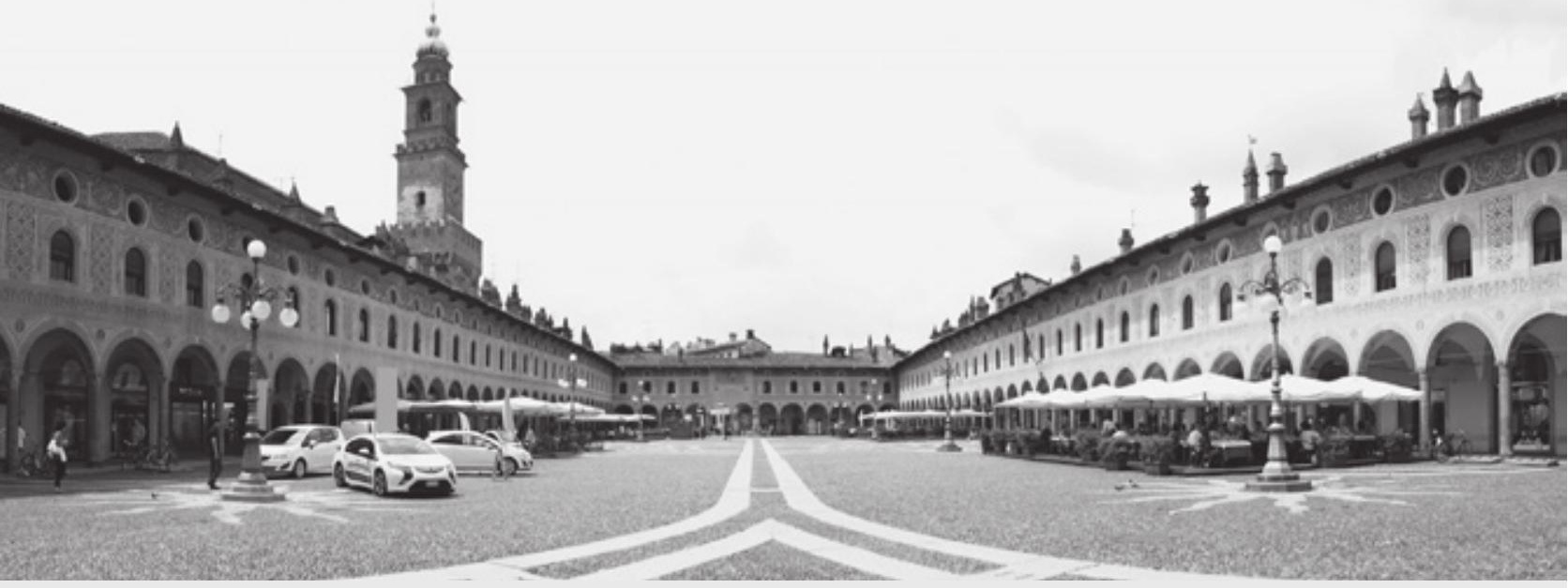

14. Piazza Ducale de Vigevano, construída entre 1492 e 1494. Fonte: Fotografia elaborada por Alien66 (2012) Licença: CC-BY-SA 3.0 / Wikimedia Commons contributors. 

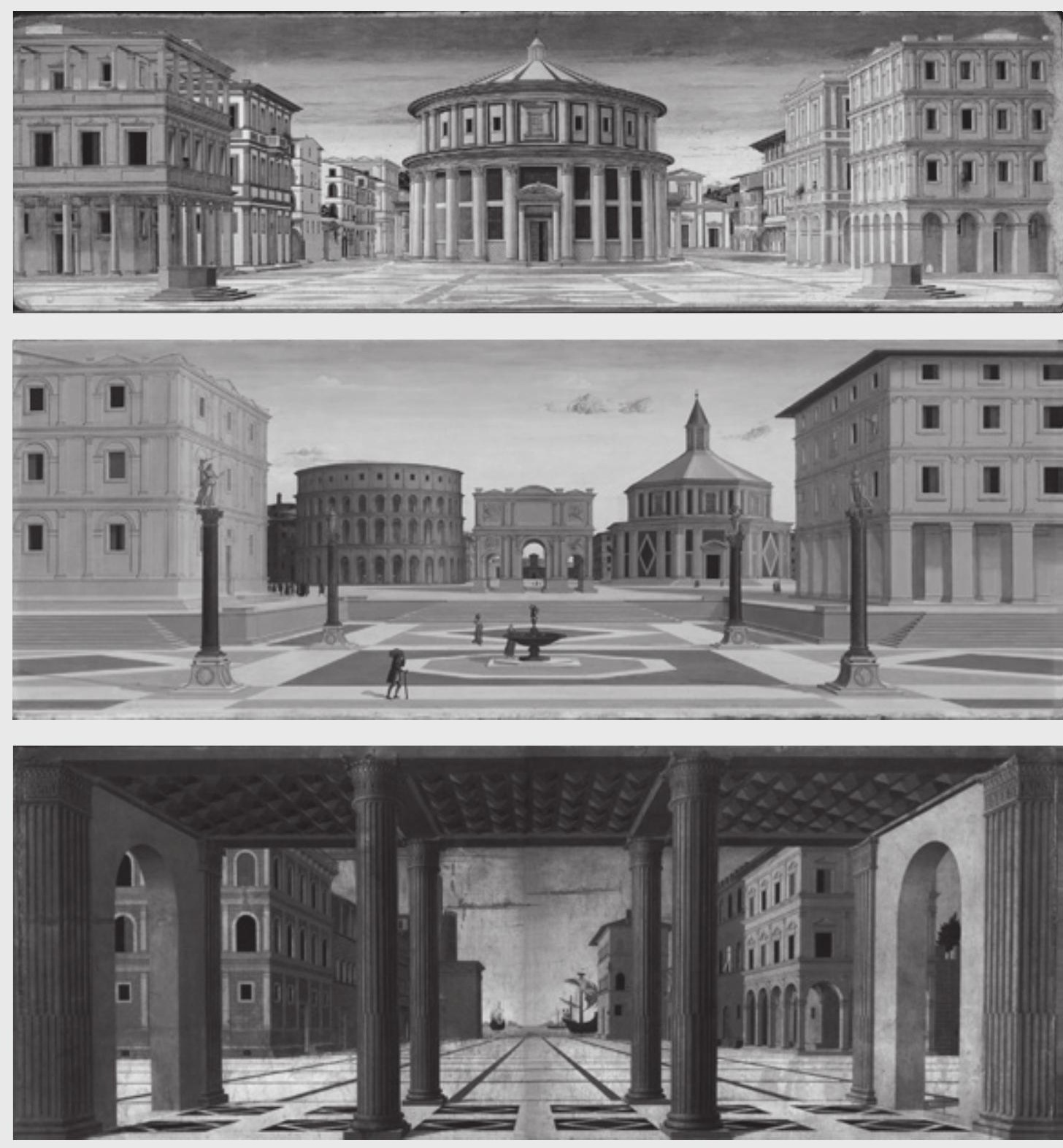

15. Três Pinturas (têmpera sobre madeira) de cidades ideais renascentistas (de autor incerto), datadas de finais do século XV, claramente influenciadas pelo discurso do grande arquiteto e teórico humanista Leon Battista Alberti (1404-1472). A primeira se encontra na Galleria Nazionale delle Marche, em Urbino; a segunda, no Walters Art Museum, em Baltimore; e a terceira, Gemäldegalerie, de Berlim. Fonte: Wikimedia Commons contributors. 
urbana da Florença medieval a partir da sua admissão como elemento visibilisticamente prioritário na estrutura hierárquica do espaço.

A forma de ogiva inchada da cúpula sugeriria a ideia de que ela flutuava no horizonte da cidade (Figura I6). A convergência de seus imensos elementos estruturais - os espigões de pedra que sustentavam as calotas de tijolo - ao ponto mais alto do edifício aludiria a um movimento rotatório em torno do próprio eixo, ponto central marcado pela lanterna clássica que coroava toda a composição. Deste modo, a cúpula não só ofereceria uma terminação coerente em relação ao edifício preexistente, colocando-se prioritariamente à frente do organismo plástico, como apresentaria um direcionamento perspectivo voltado para toda a cidade e para todo ambiente circundante, fazendo as visadas convergirem, necessariamente, para as linhas definidas pelos espigões de pedra e para a lanterna que marcaria o fechamento do organismo inchado (Figura I7).

Esta relação explícita com a cidade e com o próprio sítio natural circundante já seria reconhecida, em meados do século XV, pelo próprio Alberti (em sua Dedica a Filippo Brunelleschi), que diria que a estrutura inovadora superava tecnicamente até aos Antigos, definindo um organismo que se erguia ao céu cobrindo com sua sombra todos os povos da Toscana. ${ }^{\mathrm{II}}$ Da mesma forma, no século XVI, o historiador da arte, pintor e arquiteto Giorgio Vasari (I5II-I574) diria - em seu livro de 1550, Le vite de' piú eccellenti architetti, pittori et scultori italiani, da Cimabue, insino a' tempi nostri - que, de tão grandiosa e perfeita que era, o céu tinha inveja da cúpula:

E se pode dizer, ao certo, que os antigos não chegaram nunca tão longe com as suas obras, nunca se colocaram à frente de um risco tão grande como se quisessem combater o céu, como na realidade a cúpula de Brunelleschi combate: vendo ela se elevar a tamanha altura, que os montes entorno de Florença parecem similar a ela. E, na verdade, parece que o céu tem inveja da cúpula, que ele sempre fica atormentado com a sua repercussão, parecendo que a sua fama tenha quase vencido a nobreza do ar. (VASARI, I986, v. I, p. 300-30I, tradução nossa)

11 "Quem nunca louvou Filippo, arquiteto, vendo a estrutura tão grande, erguida sobre os céus, tão ampla que cobre com a sua sombra todos os povos da Toscana, feita sem a ajuda de nenhum travamento ou par de andaimes, um artifício certo, se eu bem julgo, neste tempo que era incrível conseguir, e que talvez nem os Antigos conhecessem.” (ALBERTI, 1994, v. 2, p. 343, tradução nossa) 
Para esta verdadeira renovação do espaço urbano, não houve necessidade de se investir em nenhuma mudança material na preexistência da cidade; nenhum redesenho da trama viária; nenhuma mutilação em seu tecido original; nenhuma iniciativa que poder-se-ia enquadrar naquilo que usualmente seria compreendido como um método de intervenção urbanística. A cúpula passaria a ser parte inevitável da nova Florença - e a cidade, elemento necessário para a composição correta da cúpula; verdadeira aliança entre o desenho e a realidade. Ela, por si só, com sua grandiosidade, sua relação com a paisagem natural e com a abóbada celeste, sua composição pura e equilibrada, dominaria visualmente todo o ambiente medieval, tornando-o moderno (Figura I8).

A cúpula monumental imporia para Florença uma estrutura que se tornaria o eixo mais importante de toda a polis, realizando para o espaço urbano o conceito de centralidade, um dos ideais mais significativos da Renascença ideal vinculado ao princípio de mimesis e derivado do desejo de imitar, através da arte, da arquitetura, da cidade, as formas mais perfeitas da natureza (o círculo e a esfera), bem como representar a condição do homem como a figura central do projeto de criação, figura que habitava a Terra, que até então se acreditava o centro do universo. Todas as outras estruturas viárias, edilícias ou naturais da Florença quatrocentista passariam à condição de submissão simbólica ao ponto médio da urbis - organismos voltados para a cúpula, para suas linhas perspectivas que corriam para o lanternim que coroava toda a composição (Figura I9).

Benevolo reconheceria, em um estudo recente datado de 1993 e intitulado La città nella storia d'Europa, que esta aliança entre teoria e prática característica do discurso de Alberti, e perceptível em algumas intervenções em espaços urbanos no Quattrocento, começaria a se deteriorar a partir da segunda metade do século XV através das formulações teóricas utópicas que ocupariam o debate sobre a cidade - particularmente após a elaboração do tratado do arquiteto florentino Antonio di Pietro Averlino, dito Filarete (I400-I469):

O prudente equilíbrio entre teoria e prática que por volta da metade do Quattrocento domina o tratado de Alberti, já se perde nas décadas sucessivas. O tratado de Filarete - escrito em Milão entre I460 e I465 - descreve uma cidade imaginária, Sforzinda; aquele de Francesco di Giorgio - escrito entre 1470 e I480, e dedicado ao duque de Urbino - persegue uma casuística de cidade ideal de várias formas. Os desenhos incluídos nos tratados assumem uma supremacia sobre os textos 


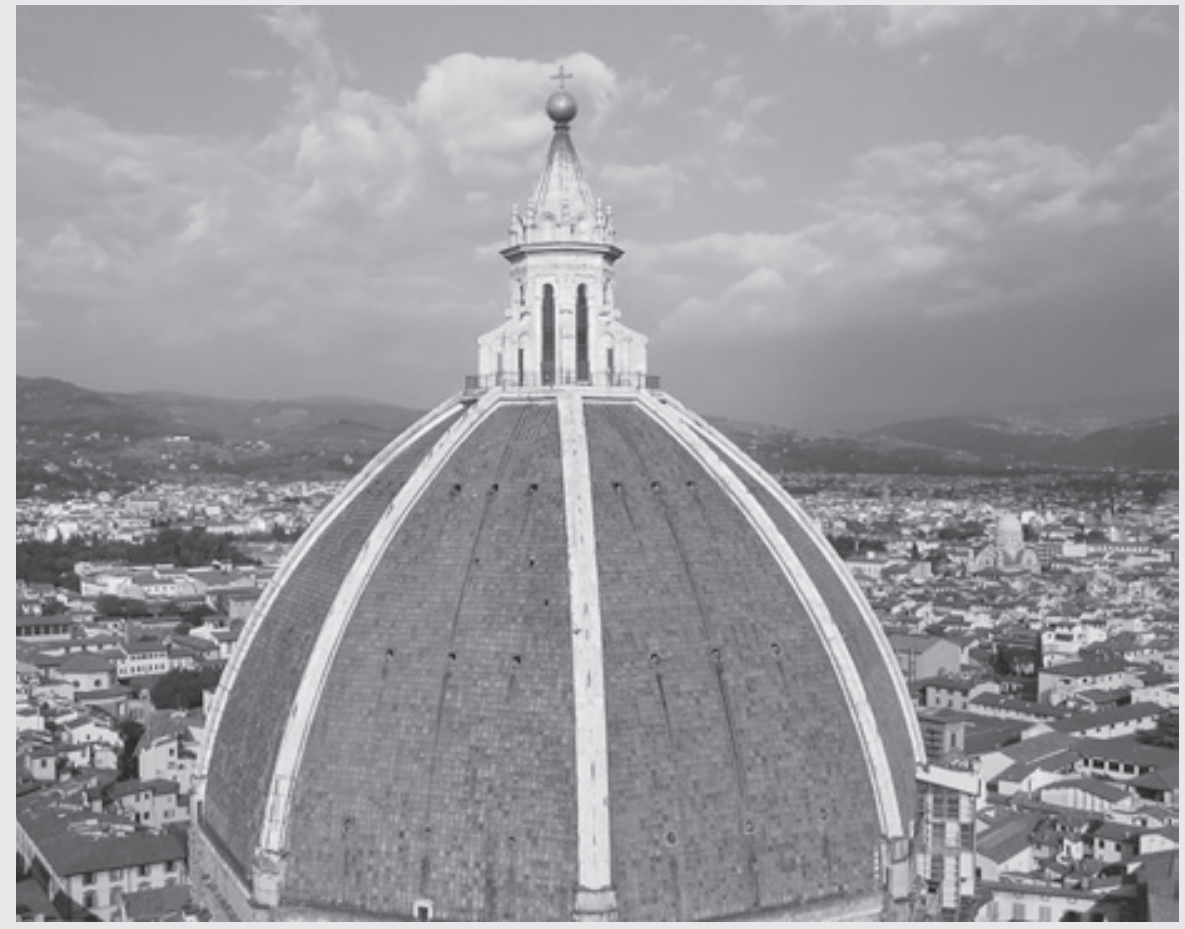

16. Cúpula da Catedral de Santa Maria del Fiore, projetada pelo arquiteto florentino Filippo Brunelleschi para o concurso de 1418. Fonte: Fotografia elaborada por S. Scheele, Essen (2003) - Licença: CC BY-SA 3.0 / Wikimedia Commons contributors.

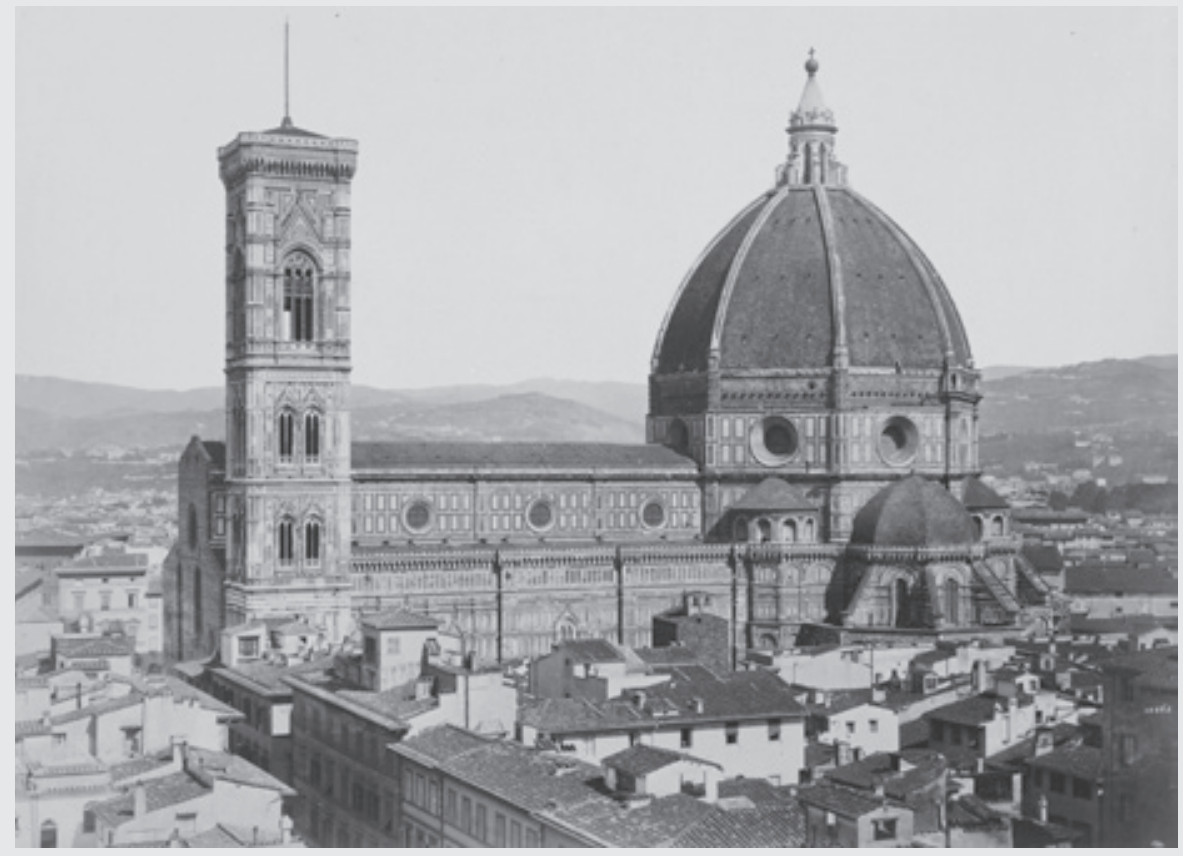

17. Catedral de Santa Maria del Fiore em 1860, por Fratelli Alinari - estúdio fotográfico fundado em 1852. Fonte: Wikimedia Commons contributors. 


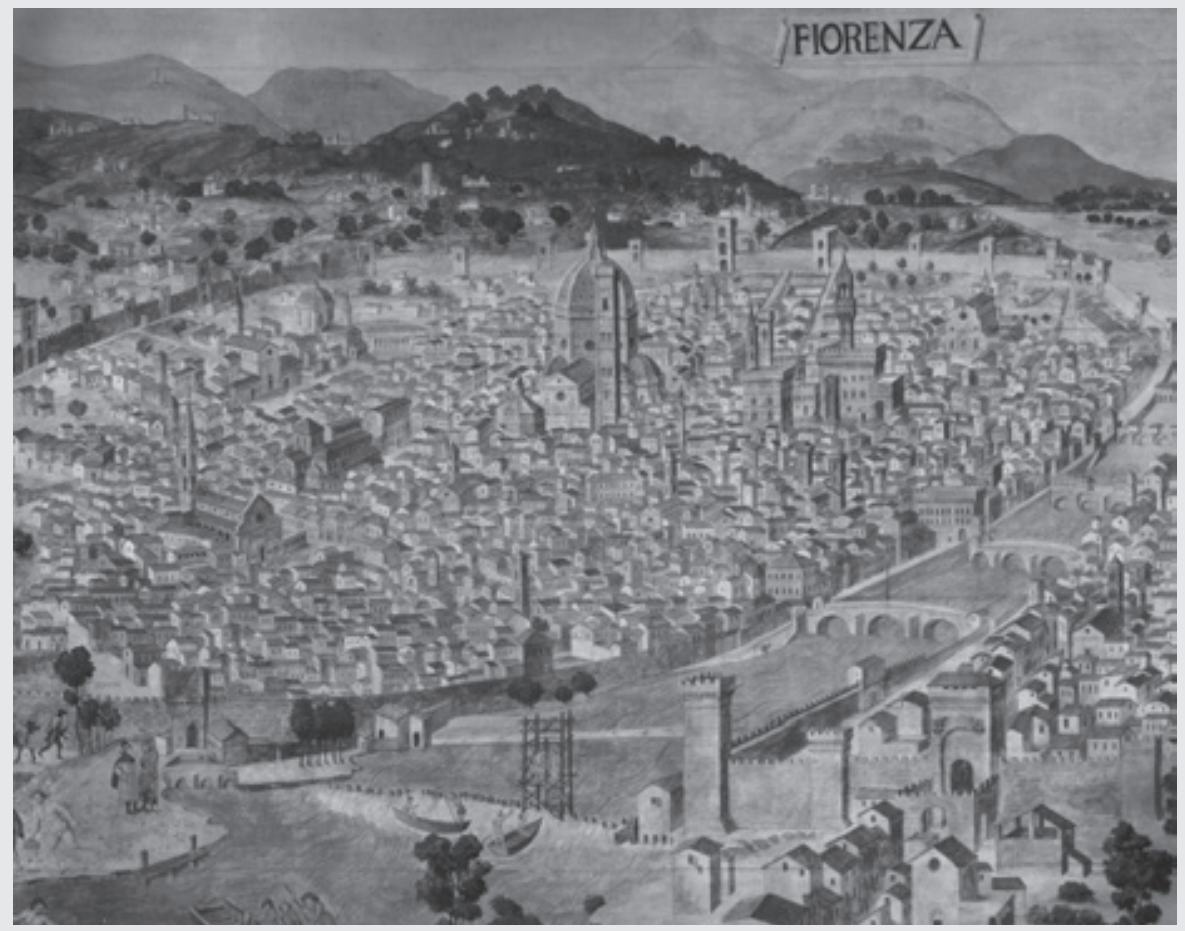

18. Detalhe da pintura de Francesco Rosselli (1445-1513) com imagem panorâmica de Florença no século XV baseada na vista conhecida como Catena, gravada entre 1472 e 1482. Fonte: Wikimedia Commons contributors.

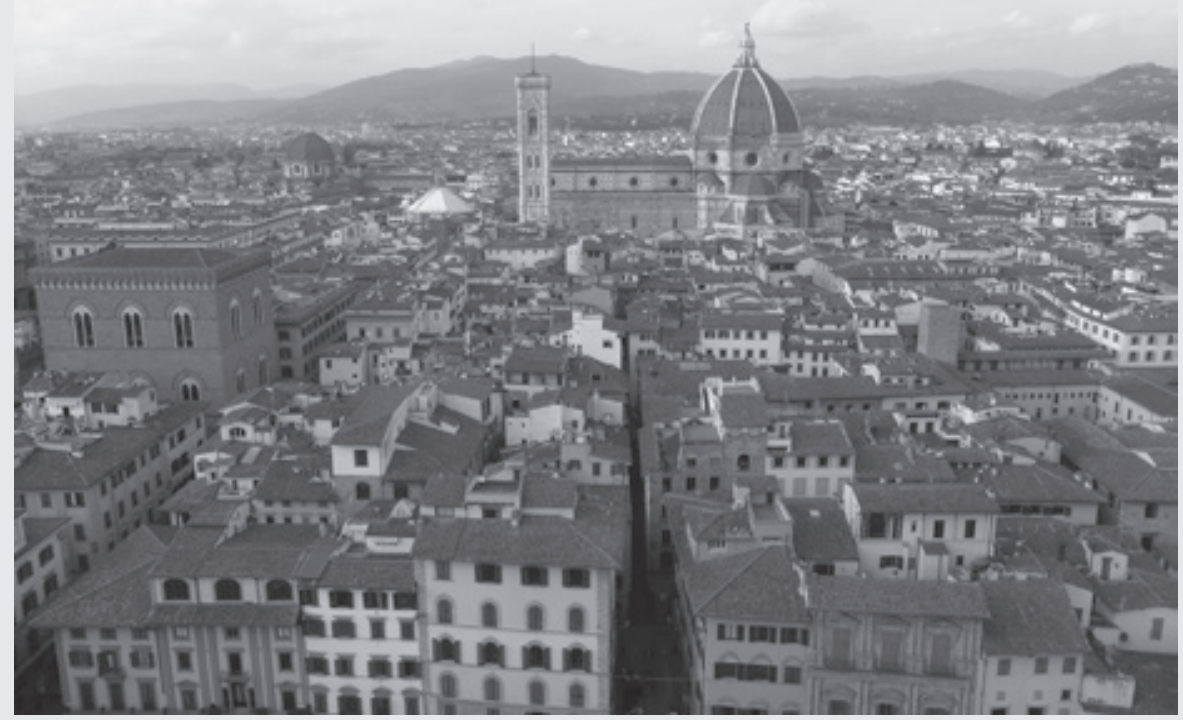

19. A Catedral de Santa Maria del Fiore e a cúpula projetada por Filippo Brunelleschi vistas a partir do Palazzo Vecchio de Florença. Fonte: Fotografia elaborada por Giulio1996Cordignano (2014) - Licença: CC BY-SA $4.0 /$ Wikimedia Commons contributors. 
escritos. Modelos de cidades perspecticamente regulares encontram lugar nas edições ilustradas do tratado de Vitruvio: Fra' Giocondo, I5II; Cesariano, I52I; Caporali, I536; Martin, I547; Barbaro e Palladio, I556. Mas é na pintura que tomam forma os ambientes e as paisagens irrealizáveis na dimensão real, nos fundos das 'histórias' ou ainda nas oportunas imagens de grupos de edifícios em perspectiva, como o quadro de Urbino, aquele de Baltimore e aquele de Berlim. A idealização perde contato com as circunstâncias concretas da realização e as figuras produzidas pela pesquisa teórica encontraram aplicação - após a metade do Cinquecento - apenas no campo da arquitetura militar, quando, ao longo das fronteiras de toda a Europa, serão realizadas novas cidades fortificadas. (BENEVOLO, 2007, p. Io6-I07, tradução nossa)

Ao contrário do debate promovido por Leon Battista Alberti, os tratadistas que discorreram sobre a cidade, a posteriori, especialmente aqueles que escreveram seus tratados na segunda metade do Quattrocento e durante todo o Cinquecento, fugiriam completamente da flexibilidade do mestre humanista. Em nome da perseguição do desenho perfeito, organizado e fechado para a cidade ideal, estes teóricos da arquitetura acabariam se afastando da busca pela adaptabilidade das intervenções modernas aos cenários urbanos medievais - concessões vislumbradas nos princípios desenvolvidos por Alberti -, se distanciando, implacavelmente, do problema de reordenação da cidade real em prol de um discurso utópico que teria gerado poucos resultados práticos. Em seu discurso teórico, Alberti recusaria qualquer imposição a um modelo definitivo para a concepção da arquitetura e para o desenho do espaço urbano, abdicando, decisivamente, da possibilidade de expor ilustrações para seus dez livros sobre arquitetura e construção; na direção oposta, como atestou Benevolo, para os teóricos que viriam a sucedê-lo, a formulação gráfica de seus ideais absorveria um caráter mais significativo, nos estudos apresentados nas décadas sucessivas, do que o próprio texto que deveria versar sobre a arquitetura e sobre a cidade.

Para o desenho dos assentamentos urbanos seriam desenvolvidos aqueles conhecidos modelos concêntricos, os notórios planos de cidades regulares radiais com contornos externos amuralhados de formas circulares ou poligonais - principalmente a tipologia da cidade de oito lados baseada na reinterpretação dos conceitos proferidos no primeiro século antes de Cristo pelo arquiteto romano Marcus Vitruvius Pollio (nascido entre 80 e 70 a.C., e morto antes de 15 a.C.) em seu tratado De Architectura, única referência teórica a abordar a arquitetura e a 
urbanística no mundo clássico a sobreviver até os tempos modernos. Na verdade, os modelos das cidades ideais revelariam o desejo característico da época pela disciplina, simetria, harmonia e centralidade. As vias radiais que nasciam, muitas vezes, nos vértices ou nos pontos médios dos lados das muralhas poligonais acorriam à principal praça localizada no ponto médio do assentamento, tendo quase sempre o edifício mais importante do núcleo urbano - a catedral, o palácio do governante, a comuna - como ponto focal das perspectivas retiradas dos eixos retilíneos. Nenhuma concessão à topografia ou às características morfológicas do sítio era tolerada; nenhuma solução que não estivesse de acordo com a mais perfeita simetria e o mais rígido esquema distributivo era possível (Figuras 20-2I).

Para além do debate sobre o modelo ideal para a cidade humanista, segundo o juízo proferido pelo professor italiano de história da cidade Enrico Guidoni, juízo exposto no livro, escrito em parceria com a professora Angela Marino, intitulado Storia dell'Urbanistica: il Cinquecento (primeira edição de I982), o século XVI marcaria uma reviravolta em relação ao problema objetivo da renovação do espaço urbano preexistente; seria agenciada uma mudança de atitude frente à necessidade de promover a adaptação dos antigos e dos modernos assentamentos às novas demandas que vinham se constituindo desde o início do período humanista - fatores que ultrapassariam em muito as teorias da cidade ideal. Seria um importante passo que teria contribuído para dar início à caracterização da urbanística como um método autônomo e organizado de intervenção no espaço urbano, através de ações, mecanismos, tecnologias, artifícios próprios - um ensaio inicial daquela disciplina que viria a se consolidar, definitivamente, somente no século XIX. ${ }^{\text {I2 }}$

Como foi visto na citação que abre este item, a principal motivação de cunho utilitário que viria a incentivar, através do desenvolvimento de novos procedimentos de intervenção no ambiente citadino, a concepção de inúmeros planos e a realização de centenas de operações urbanísticas de porte considerável, seria a reconstrução integral dos sistemas defensivos das cidades preexistentes,

12 "A centralização do poder, o crescimento das tensões e das guerras entre os Estados, a abertura de uma grande parte do mundo ao comércio e à conquista europeia, favoreceram o nascimento e a consolidação de técnicas de intervenção sobre o território, sobre a cidade e sobre suas partes sempre mais 'cientificamente' programadas e eficazes. A própria urbanística - entendida, neste período e no âmbito que aqui nos interessa, como o setor que envolve intervenções programadas em escala média e grande - começa a delinear-se como uma reunião de regras e de comportamentos práticos mesmo antes de se tornar (mas serão precisos três séculos para que o processo possa se dizer concluído) um setor autônomo e reconhecível das atividades projetuais." (GUIDONI; MARINO, 1982, p. 9, tradução nossa) 


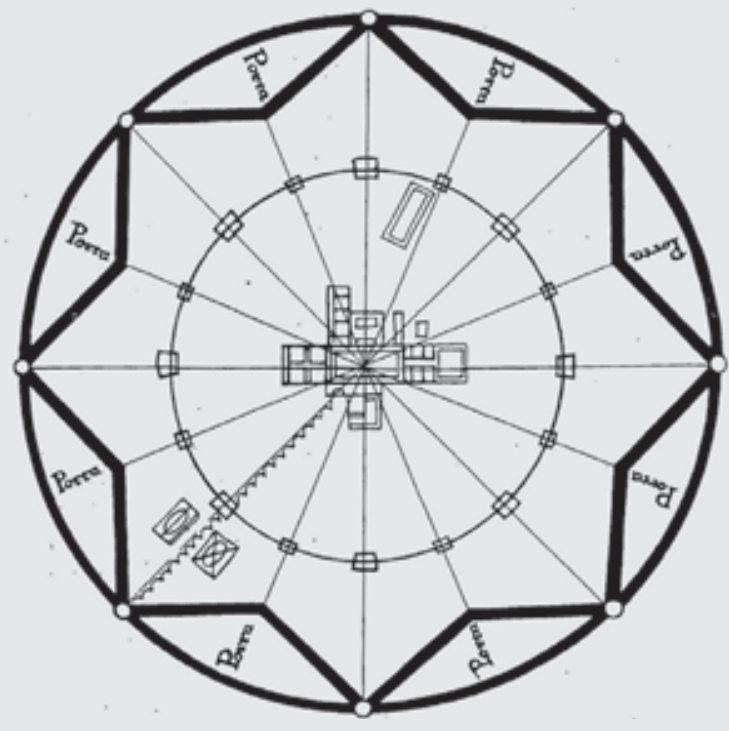

20. Planta da cidade ideal de Sforzinda. Por Filarete (1400-1469), desenho elaborado entre 1460-1464. Fonte: Kostof (1991, p. 381)

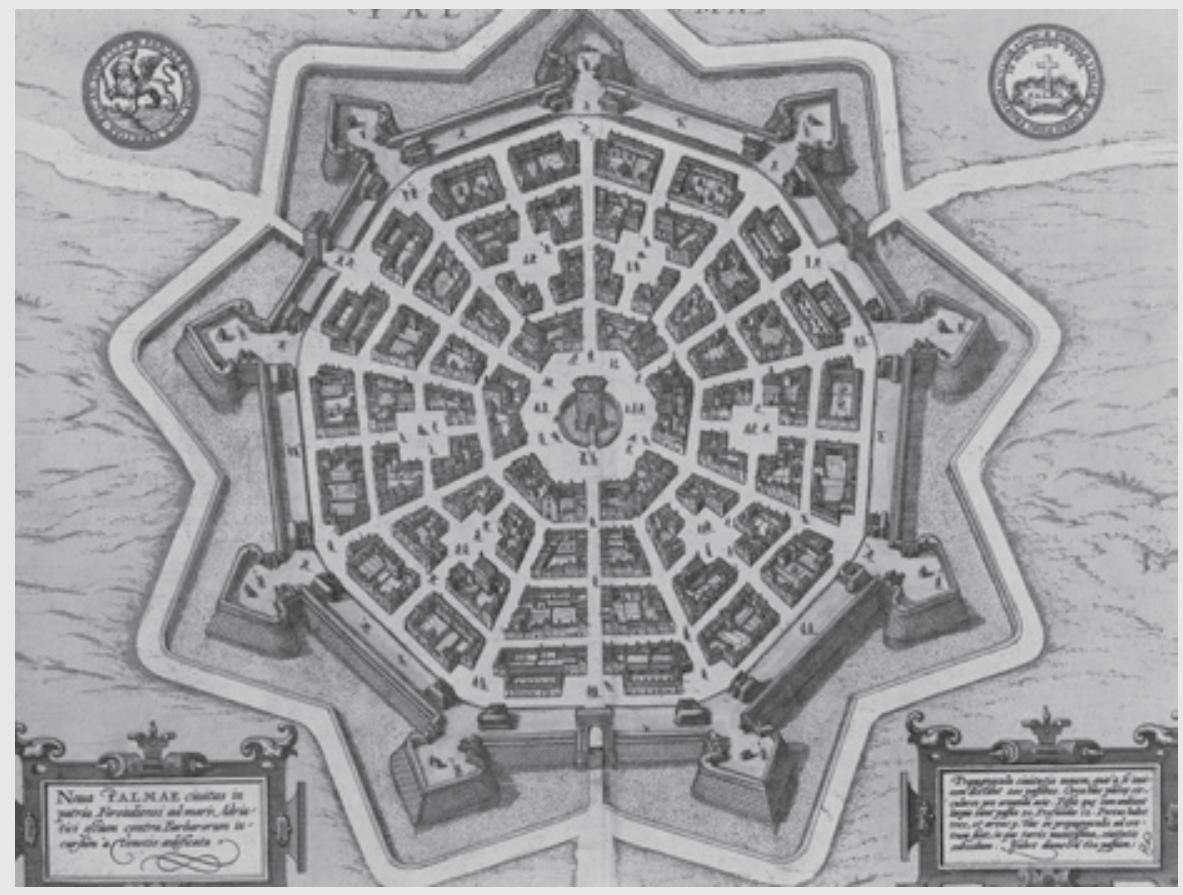

21. Planimetria de Palmanova, núcleo urbano projetado pelo arquiteto e engenheiro militar italiano Giulio Savorgnan (1510-1595). Cidade fortaleza construída a partir de 1593. Fonte: Wikimedia Commons contributors. 
bem como, em número muito menos abundante, o design e a edificação de novos assentamentos urbanos de cunho militar, pequenas cidades levantadas para proteger as fronteiras distantes dos Estados nacionais - iniciativas que, como Benevolo havia afirmado, alcançariam uma certa proximidade com as formulações gráficas das cidades ideais. Ou seja, as cintas fortificadas bastionadas que estavam sempre presentes nos desenhos dos assentamentos utópicos devidos aos teóricos dos séculos XV e XVI (com exceção de Alberti), para além da influência do tratado de Vitruvio, eram provenientes das novas tecnologias de edificação de muralhas e de fortificação de cidades que se desenvolviam desde primórdios do Quattrocento.

Seria a difícil situação política da Europa da primeira metade do século $\mathrm{XVI}$ - na qual a instabilidade dos governos e os conflitos entre as nações explodiam por todas as regiões, culminando, cem anos depois, no problemático século barroco - que teria imposto a necessidade de proceder às autoritárias desapropriações e às demolições necessárias ao reforço das fortificações que protegiam as cidades. Naquela Europa em que as guerras e os assaltos ainda aconteciam nas proximidades das principais cidades, mas na qual os núcleos urbanos vinham gradativamente perdendo sua autonomia municipal em nome da instauração de um despótico governo central absolutista, as onerosas intervenções, conduzidas por exigência das autoridades militares, seriam assumidas como o investimento urbanístico prioritário. Segundo Guidoni e Marino (1982, p. 9, tradução nossa):

É com a tecnologia e com o poder decisório dos militares - inspirado pela ideologia da necessidade superior, imediata e absoluta - que se deve relacionar qualquer intervenção urbanística significativa, pelo menos na primeira metade do século $\mathrm{XVl}$, que apresente os caracteres de 'modernidade'.

Na realidade, a arquitetura militar seria obrigada a passar por um grande processo de reformulação após serem introduzidos, no mundo ocidental, novos armamentos que acabariam provocando uma verdadeira revolução na arte da guerra - especialmente o aperfeiçoamento da balística, e particularmente o uso da pólvora e do canhão. No livro de 1974, History of Urban Form: Before the Industrial Revolution, o pesquisador britânico Anthony Morris iria assegurar que, para evitar os assaltos às cidades e aos castelos na Idade Média, as muralhas de contenção deveriam assumir uma dimensão significativa em relação ao seu 
direcionamento vertical, além de apresentarem um grande fosso. Da Renascença em diante a situação se configuraria de modo bastante diverso:

O canhão alterou tudo isso. Sua utilização pelos turcos, quando devastaram a cidade de Constantinopla em I453, abriria uma nova era na história da fortificação militar. Depois de resistir ao poderio do Islã por mais de setecentos anos, o sistema defensivo da cidade constituído por um tríplice cerco de muralhas, sucumbiria ante um monstruoso canhão capaz de disparar projéteis de mais de 550 quilogramas de peso. A partir desta data a criação de defesas adequadas iria requerer um progressivo aumento da distância horizontal que deveria deixar-se entre o perímetro da cidade e o limite exterior das fortificações. Além da necessidade deste espaço suplementar, as próprias fortificações tornaram-se cada vez mais complexas, incluindo intrincados sistemas de fortins e baluartes interdependentes. Uma vez levadas a cabo, estas defesas bidimensionais em profundidade poderiam ampliar-se tão só a expensas de enorme custo, impondo, por esta razão, densidades sempre crescentes à cidade. (MORRIS, I979, p. I30, tradução nossa)

Não seria o caso de se debater, especificamente, as grandes transformações na engenharia militar derivadas do desenvolvimento da pólvora e do canhão, mas sim suas consequências para a nova conformação do espaço urbano proposta principalmente no final do século XV e na primeira metade do XVI. Para Giudoni e Marino, a urbanística deste período pouco contemplou os problemas e os anseios da sociedade civil para se aperfeiçoar, quase que exclusivamente, nas exigências da defesa aos ataques inimigos, na adequação das cintas fortificadas aos novos métodos de artilharia. Em oposição à preexistente cidade medieval, na qual as iniciativas de reordenação do ambiente citadino que acarretassem em demolições e expropriações - mesmo aquelas de cunho militar - aconteciam em prol do benefício de todos os cidadãos e com o apoio direto da comunidade através dos instrumentos adotados pelos organismos de controle municipal, as intervenções urbanas no Cinquecento partiriam diretamente da tirania do governo das nações, passando por cima dos antigos mecanismos comandados pelas autoridades municipais com a justificativa de oferecer a proteção adequada às cidades e regiões componentes do novo Estado.

E não era uma simples questão de substituição dos antigos sistemas de muralhas elevadas pelos esquemas estelares formados por bastiões, baluartes, fortins, 
terraplenos, fossos. Os novos muros deveriam ser rasantes, inclinados, muito espessos, e precedidos por grandes aterros para poderem suportar os poderosos tiros de canhão, fato que, ao lado da extensão radial do desenho das muralhas condicionado pelos bastiões e baluartes, exigiria grandes áreas para sua construção e enormes custos em seu projeto e execução. Por outro lado, a cidade deveria estar afastada o máximo possível das muralhas para, mesmo na possibilidade dos projéteis passarem por cima das rasantes defesas, não conseguirem alcançar o núcleo urbano. Não obstante, para se apartar ainda mais as bocas de fogo inimigas do núcleo urbano, a área imediatamente exterior às muralhas necessitaria estar totalmente vazia de construções e vegetações. Desta forma, o acostamento do inimigo e o seu abrigo seriam enormemente dificultados - em um eventual assalto, o exército oponente teria de assumir uma posição extremamente vulnerável, isolado na grande esplanada desolada, alvejado por todos os lados pela artilharia, pelos canhões locados nos terraplenos acima dos baluartes (Figura 22).

A abertura dos vazios internos, e principalmente daqueles externos às novas cintas fortificadas, derrocaria, provavelmente, nas mais significativas e fatais intervenções urbanas do Cinquecento: acarretaria em processos de desapropriação e demolição não antes vistos no mundo medieval, jamais executados de forma tão intensa e autoritária desde o ressurgimento das cidades na Baixa Idade Média. Esta aniquilação de inteiros bairros periféricos, internos e externos às antigas muralhas, só seria viabilizada através da força adquirida pelos Estados absolutistas, através do controle autoritário que, como já foi insistentemente discutido, as nações europeias em formação passariam a ter frente às suas possessões e frente aos seus súditos.

Por outro lado, ao contrário das muralhas medievais, mais susceptíveis de serem ampliadas, reconstruídas além do núcleo urbano, permitindo o crescimento concêntrico das cidades, as custosas fortificações humanistas acabariam, em um primeiro momento, barrando a expansão de diversos núcleos urbanos, assentamentos que se tornariam verdadeiras praças fortes. Para reforçar esta disposição militar que inúmeras cidades estariam adquirindo no século XVI, em muitas delas seriam construídas, adjacentes às novas cintas fortificadas, complexas cidadelas, organismos militares que tinham o objetivo de proteger os centros urbanos deles mesmos; ou seja, assumiam o escopo primordial de coibir prováveis revoltas populares internas aos muros da cidade, bem como servir de último baluarte à proteção contra exércitos inimigos que conseguissem, eventualmente, 


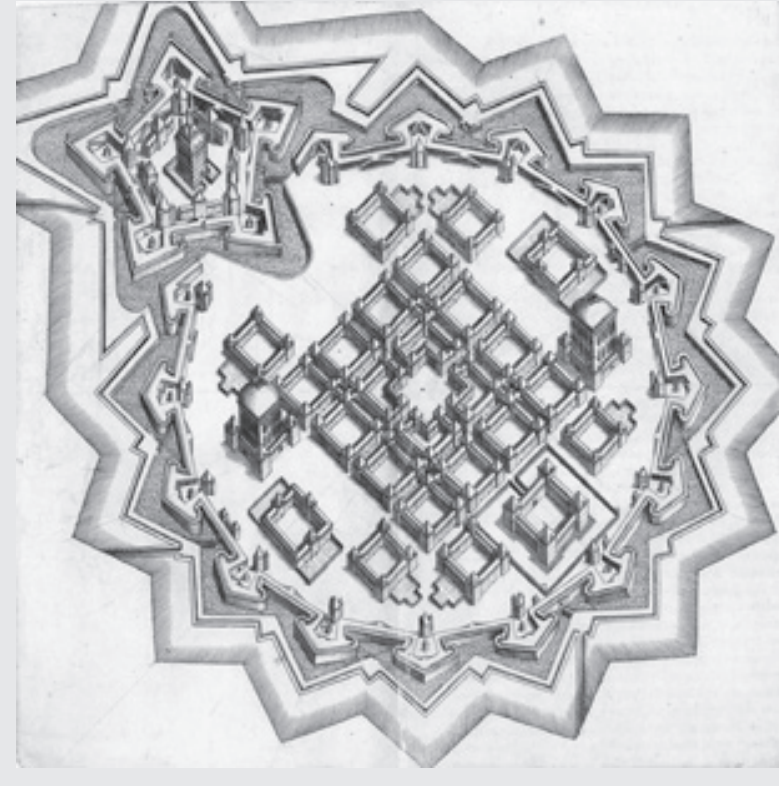

22. Des fortifications et artifices d'architecture et perspective. Tratado de arquitetura militar de Jacques Perret (1545-1619), publicado pela primeira vez em 1601 . Visão axonométrica de uma cidade ideal com cidadela. Fonte: Giudoni e Marino (1982, p. 23).

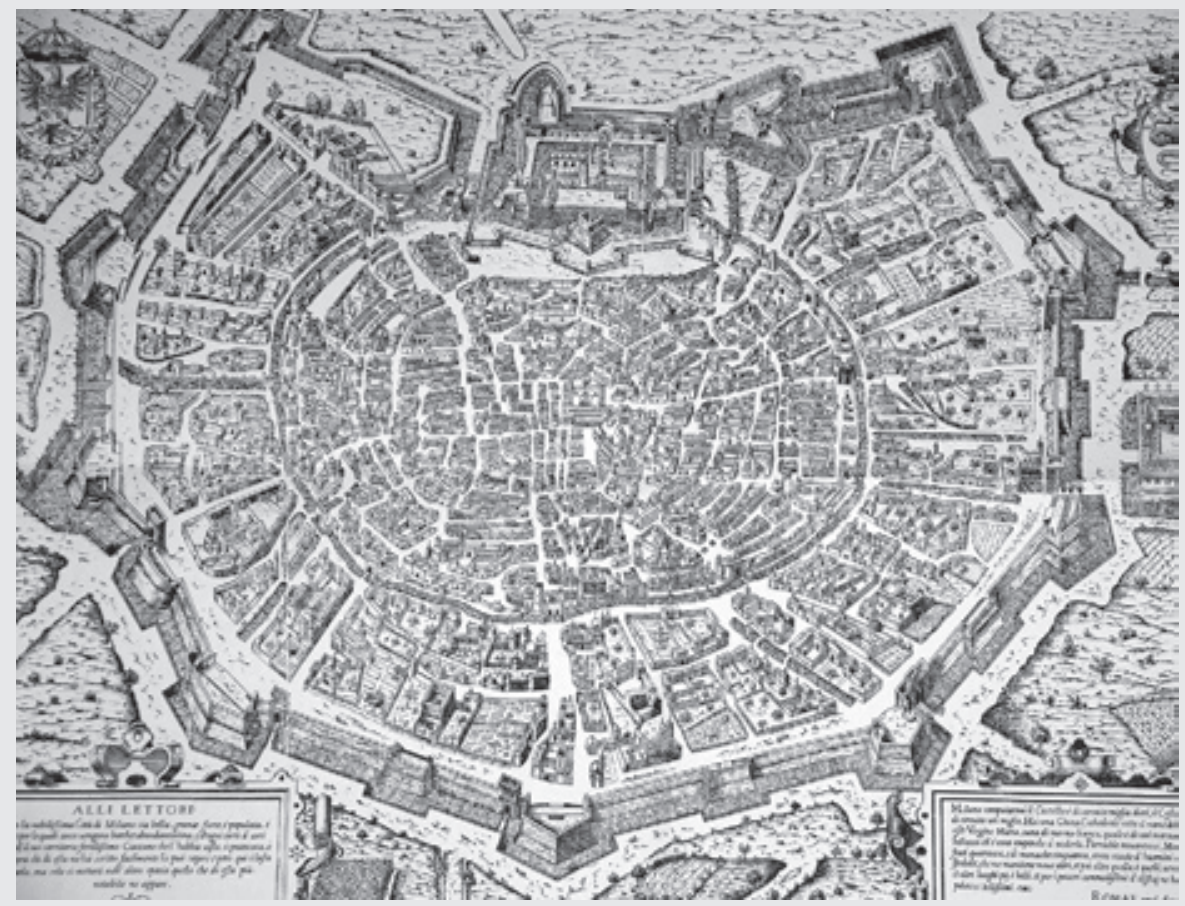

23. Planta da cidade de Milão e de suas cintas fortificadas em 1573. Fonte: Benevolo (2008, p. 135). 
vencer os sistemas defensivos e invadir o núcleo urbano (Figura 23). Para Guidoni e Marino (I982, p. I4, tradução nossa):

\begin{abstract}
A tragédia da 'tábula rasa', efetivada, onde quer que seja, com impiedoso rigor, foi conhecida através de escassos e alarmantes testemunhos da época, mas deve ser ainda valorada na sua real condição política e cultural. Sobre o plano econômico é evidente que se trata de um dos mais radicais momentos de desperdício e de destruição na história da cidade; partes inteiras de tecido urbano com igrejas, conventos, hospitais, indústrias, residências são inteiramente perdidas, e se produz, na melhor das hipóteses, apenas entulho para a construção dos terraplenos. Mas é sobre o plano político que este tipo de operação se revela como a mais eficaz, didascálica representação do poder absoluto do Estado nos confrontos com a comunidade citadina, com as suas instituições e com o indivíduo. Não existe de fato possibilidade de resistência ou de violação à execução das demolições; na verdade, estas operações são frequentemente programadas propriamente para danificar a cidade, para golpeá-la na sua estrutura física e, portanto, política.
\end{abstract}

Logo, a armação da cidade que se configurava no século XVI também deveria assumir um compromisso com o desejo dos gestores de demonstrar, através das obras ligadas à engenharia militar e à infraestrutura, a superação da polis medieval, o abandono de tudo o que a forma e a organização das cidades na Baixa Idade Média representavam enquanto conformação de um organismo democrático. Por isso, mesmo aquelas soluções da nova urbanística que chegariam a ultrapassar o aporte militar, que conseguiriam extrapolar a simples implantação das cintas fortificadas, esplanadas e cidadelas, teriam seu desenvolvimento inicial derivado de preocupações de ordem bélica.

Assim, as tão celebradas vias retilíneas, os amplos eixos perspectivos que seriam rasgados na primeira metade do Cinquecento em tantas operações em núcleos urbanos importantes, intervenções que acabariam se tornando paradigmáticas, especialmente para a cidade barroca, surgiriam, frequentemente, de uma clara necessidade defensiva: as largas estradas diretas eram mais susceptíveis de serem percorridas pelos batalhões com seus novos e pesados canhões; eram mais aptas à rápida passagem das tropas aliadas, bem como evitavam o abrigo do exército inimigo ou as barricadas dos revoltosos, situações comuns nas incursões nas tortuosas ruas medievais. Da mesma forma, outra solução definitivamente 
moderna, praticada principalmente na França do século XVI, mas muito repetida pela urbanística barroca, também seria oriunda de uma inspiração militar:

\begin{abstract}
Análogas considerações nos poderiam levar, enfim, a considerar também a fachada contínua como um precioso resultado da urbanística militar: as casas 'uniformes' - quase que a repetição igual e serial, como uma divisa militar - continham em si mesmas um positivo elemento ordenador dos espaços e da sociedade que lhes habitava, experimentados propriamente a partir do início do século em organismos viários altamente especializados. (GUIDONI; MARINO, I982, p. I7, tradução nossa)
\end{abstract}

Finalmente, poder-se-ia dizer que mesmo o modelo da cidade radial e poligonal, tão comum nos tratados de arquitetura, desde os textos de Filarete e de Francesco di Giorgio Martini (I439-I5OI) do século XV, também seria derivado, ou pelo menos bastante influenciado, por preocupações de cunho militar. Na verdade, a arquitetura e as intervenções urbanas levadas a cabo pelas necessidades de defesa acabariam promovendo a aliança entre as discussões teóricas e as ações urbanísticas praticadas no plano real; trariam, para aqueles modelos desenhados pelos tratadistas, a fusão entre a visão utópica das cidades ideais e a tecnologia de intervenção na cidade real - a união entre os planos perfeitos e inflexíveis presentes nos "manuais" e aqueles artifícios de inspiração belicosa que viriam a dominar as intervenções urbanas. A cidade ideal se tornaria, assim, uma realidade possível: inviável de ser implantada em um ambiente urbano consolidado, por meio de intervenções em sólidos e importantes núcleos preexistentes, pois seria uma ação que exigiria a eliminação completa de toda a antiga cidade para o assentamento do rígido esquema radiocêntrico; contudo, factível para cidades construídas de um só lance, empresa que seria exequível apenas para organismos concebidos como núcleos urbanos militares, projetados e fundados ex novo por motivações ligadas à proteção de partes do território; ${ }^{13}$ ou seja, cidades de menor relevância

13 Leonardo Benevolo (2008, p. 172, tradução nossa) confirma esta afirmação: “A técnica da fortificação exerce influência sobre o discurso da forma da cidade, porque uma das exigências desta técnica - o traçado poligonal das muralhas, com os baluartes situados nos ângulos - coincide com o desenvolvimento do esquema radiocêntrico. Começa assim a combinação dos dois motivos (aquele técnico e aquele teórico) que caracterizam toda tratadística posterior, por pelo menos dois séculos, como veremos em seguida. A inserção do fator defensivo transporta a casuística dos traçados para um terreno realístico, mas faz a cidade perder seu caráter de modelo global: a cidade se torna uma praça-forte; o centro cívico se torna o lugar da concentração de tropas; a rede viária serve para facilitar o fluxo e o refluxo dos defensores, ou para obstacularizar o ingresso dos inimigos. A cidade ideal é finalmente projetável, mas se converte em um assentamento especializado, e deixa de funcionar como mito cultural." 
e dimensão, criadas excepcionalmente para exercerem o papel de praças fortes avançadas. Assim:

Que o ponto de partida da estrutura radiocêntrica vem mesmo indagado nesta dimensão de prática militar é demonstrado propriamente pela estreita correlação entre a implantação viária e o recinto fortificado: como veremos, tratadistas e intervenções em torno da metade do século convergem para o ajuste de um 'tipo' completamente novo de implantação. Não existe mais qualquer preexistência cultural da cidade 'civil' a qual se poderia fazer referência, senão como vínculo projetual: divide-se sobre bases exclusivamente tecnológicas, inventando organismos de pequena dimensão, metade cidade e metade cidadelas, nos quais a praça central é uma praça de armas, e as estradas radiais, que conduzem às portas, mas também aos bastiões, aparecem condicionadas pela exigência prioritária de golpear, com peças de fogo situadas ao centro, as vias de acesso ocupadas por eventuais infiltrações inimigas, e de favorecer a rápida subdivisão das artilharias de um ponto ao outro da cinta defensiva. Radial é, enfim, e antes de tudo, o critério balístico do controle de todas as direções do espaço. (GUIDONI; MARINO, I982, p. I6, tradução nossa)

Se na primeira metade do Cinquecento poder-se-ia dizer que a urbanística europeia (excluindo desta análise as tipologias urbanas hispano-americanas) se confundiria, em grande parte, com a engenharia militar, que mesmos as soluções internas que extrapolavam a fortificação dos núcleos citadinos inevitavelmente andariam a reboque das preocupações defensivas, na segunda metade do século outros fatores profundamente significativos viriam a contribuir para revolucionar a prática de reordenação das cidades. Na medida em que as tensões nas proximidades dos principais núcleos urbanos dos mais poderosos reinos vinham diminuindo - abrandamento devido à consolidação dos sistemas defensivos nas fronteiras distantes dos Estados nacionais, fato essencial para o progressivo império das capitais que culminaria no século barroco -, no instante em que as guerras iam se distanciando das cidades dominantes, eram abertas possibilidades de experimentação, para a urbanística moderna, de alternativas que transpunham a contribuição militar.

O interessante é que, mais uma vez, os principais caminhos que a urbanística viria a tomar estariam ligados a universos de natureza incomum à prática de intervenção no espaço urbano; encontrar-se-iam conectados a disciplinas que 
estavam se desenvolvendo e se inovando no final do Quattrocento e na primeira metade do Cinquecento - manifestações de cunho artístico que acabariam influenciando, fatalmente, a urbanística da segunda metade do século XVI, bem como aquela de configuração barroca das duas próximas centúrias.

Para o historiador francês da arte e da cidade Pierre Lavedan (I885-I982), mais ainda que a engenharia militar, a urbanística do período devia suas características mais originais ao teatro e à arte dos jardins. (LAVEDAN, I94I, p. 27-28) Mesmo antes da utilização direta, nas cidades, das novas soluções professadas por estas duas manifestações das artes e da cultura, a cenografia e o paisagismo serviriam como meios implícitos de experimentação a um renovador desenho para os núcleos urbanos, já que seus procedimentos eram sempre viáveis economicamente.

Na verdade, esta viabilidade se daria em função das dimensões reduzidas que ganhariam as cenas fixas ou móveis dos teatros, elaborações da arte da cenografia que não demandariam mais que modestos investimentos para a promoção, sem embargo, de infinitas possibilidades de representação através da nascente técnica do trompe-l'œil. Igualmente, a implantação dos jardins principescos e dos jardins da nobreza do século XVI, ambientes que facilmente poderiam ser configurados espacialmente através dos preceitos da simetria, ordem e por meio de uma rígida geometrização, mesmo exigindo investimentos significativos, nunca imporiam gastos comparáveis ao montante necessário para uma intervenção urbanística de grande porte - exatamente em função da pequena escala que estes procedimentos ainda absorveriam no período imediatamente anterior à grande empresa do Barroco.

Por isso, no teatro, nas vilas e nos jardins quinhentistas, não seria difícil revelar, francamente, as mais diversas categorias de cidades perfeitamente ordenadas, ou mesmo representar as mais variadas conformações de assentamentos urbanos ideais: por meio das técnicas cenográficas de exposição virtual das imagens, ou por intermédio do universo ideal que os espaços ajardinados desvelariam, tudo era possível - ao contrário do alto custo social, tecnológico, político e econômico que se pressupunha qualquer intervenção de certo porte nas cidades preexistentes, bem como em oposição à enorme dificuldade de se desenhar, construir, e fundar qualquer núcleo urbano ex novo, empresa viável apenas quando se impunha a necessidade imperiosa de se levantar eficientes praças-fortes para a proteção das bordas fronteiriças dos Estados. Lavedan (I94I, p. 27-28, tradução 
nossa), ao discutir o problema da conexão entre a urbanística e o teatro no século XVI, faria a seguinte colocação:

O teatro une a geometria ao urbanismo. É o cenário do teatro que vai agir sobre o cenário urbano; mas a cenografia nasce dos tratados de perspectiva: enquanto que as representações da Idade Média se dão ao ar livre e a própria cidade forma o cenário, o teatro moderno está confinado ao interior de um edifício e são as telas pintadas de modestas dimensões que devem dar a ilusão da cidade. A ligação desses elementos aparece muito numa obra célebre: o Premier Livre d'Architecture de Serlio, o qual Jean Martin publica uma tradução francesa em Paris em I545. Depois do estudo, constantemente mencionado, da geometria plana, Serlio se prende à perspectiva, considerando alternadamente figuras abstratas: os arcos, as colunas, os pórticos, as escadarias, para chegar enfim à cena do teatro. Ele declara ser a cena do teatro uma das obras-primas do espírito humano, porque ali 'se vê em pouco espaço alguns palácios erguidos pela arte da perspectiva, com grandes templos e diversos palácios próximos e afastados da vista, praças belas e espaçosas, ruas longas e retilíneas.... Ele prevê modelos de cenário para os três tipos de obras teatrais: comédia, tragédia, drama satírico; mas, somente nos interessam os dois primeiros, já que o último não conheceu senão uma existência teórica. A cena cômica de Serlio é representada por uma rua com arcadas, pórticos e ao fundo uma igreja; a cena trágica é igualmente uma rua de cidade guarnecida por palácios e encerrada por um arco do triunfo; é o tipo da perspectiva urbana limitada, tal como os arquitetos dos séculos clássicos a realizaram em inúmeros exemplares. Os cenógrafos se aperfeiçoam no teatro antes de trabalharem na realidade

Mas a representação virtual das cidades não apareceria apenas naquela cenografia efêmera constituída pelas placas de madeira pintadas com cenas em perspectiva simulando a arquitetura, o espaço urbano, ou o ambiente natural, solução comum, desde meados do Quattrocento, nos espetáculos humanistas italianos encenados no ambiente cortesão das antigas salas especiais dos palácios da nobreza - espaços destinados propriamente ao teatro (Figuras 24-25). Para além destes mecanismos debatidos pelo teórico da arquitetura bolonhês Sebastiano Serlio (I475-I554), na segunda metade do século XVI alguns edifícios seriam construídos especialmente para abrigar organismos teatrais, apresentando, frequentemente, em seus cenários fixos tridimensionais, impressionantes representações de 

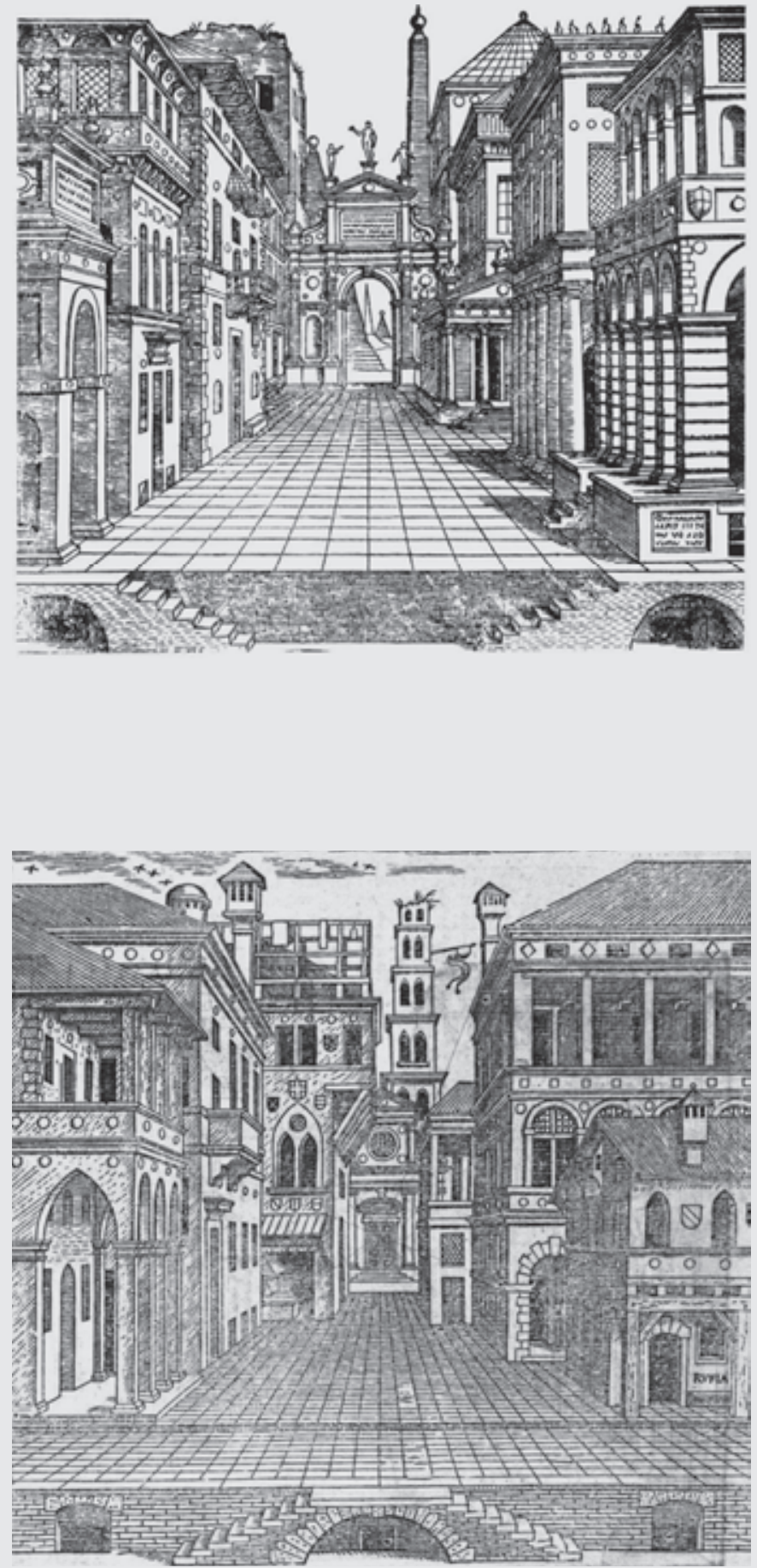

24. Cena Trágica: vista em perspectiva de uma via, com um arco do triunfo ao fundo. Retirada do Premier Livre d'Architecture de Serlio, 1537. Fonte: Kostof (1991, p. 223).
25. Cena Cômica: vista em perspectiva de uma via. Retirada do Premier Livre d'Architecture de Serlio, 1537. Fonte: Kostof (1991, p. 223). 
núcleos urbanos ideais - como viria a ser o caso do Teatro Olimpico de Vicenza, projetado pelo arquiteto vêneto Andrea Palladio (I508-I580) e construído entre I580 e I584, assim como o pequeno Teatro Olimpico de Sabbioneta, projetado pelo também arquiteto vêneto Vicenzo Scamozzi (I548-I6r6), e construído em 588.

O teatro projetado por Palladio, por exemplo, apresentava uma grande cena fixa por trás do palco, uma scaenae frons que seguia o modelo do teatro clássico romano. Mas, ao contrário das tão conhecidas estruturas romanas, por trás da monumental parede cenográfica - tratada para parecer supostamente feita de mármore, e composta por ordens sobrepostas, áticos, entablamentos (arquitraves, frisos, cornijas), frontões, tímpanos, esculturas clássicas -, para além da abertura central do arco triunfal e dos quatro vãos inferiores dispostos aos dois lados do fórnice, seria possível vislumbrar, em profundidade, vias regulares com fachadas contínuas, ortogonais à parede cênica ou diagonais a ela: a partir do arco triunfal era possível capturar o panorama de um poderoso tridente de vias se desenvolvendo perspecticamente; das outras quatro aberturas eram apreciadas diversas ruas que se abriam ao eixo central do palco (Figura 26).

Ou seja, nos teatros com cenas fixas tridimensionais de Palladio, mas também no Teatro Olimpico de Sacamozzi em Sabbioneta, a cidade que se apresentava por trás do palco se constituía por técnicas de representação trompe-l'œil, pelas técnicas do "engano dos olhos" - do mesmo modo que acontecia nos cenários pictóricos planos constituídos pelas perspectivas da cenografia pregada por Serlio. Nestas cidades virtuais imperavam as vias perspectivas com edifícios monumentais ao fundo, emoldurando o foco do eixo retilíneo; também reinavam os encontros regulares e angulosos de duas avenidas, ou de três (o tridente); também constante era o aparecimento de grandiosas praças regulares com poderosos edifícios em destaque. Ou seja, as possibilidades de representação oferecidas pela cenografia eram infinitas.

No entanto, estes procedimentos não deveriam ser confundidos com o esforço, que culminaria no século XVII, e será discutido mais adiante, de transformar o espaço urbano em um espetáculo teatral propriamente dito. As experimentações da cenografia "confinada" do século XVI abririam o caminho para a elaboração de intervenções que viriam a tratar a cidade, a posteriori, como ambiente teatral, principalmente no que se refere à configuração de praças de caráter monumental. 


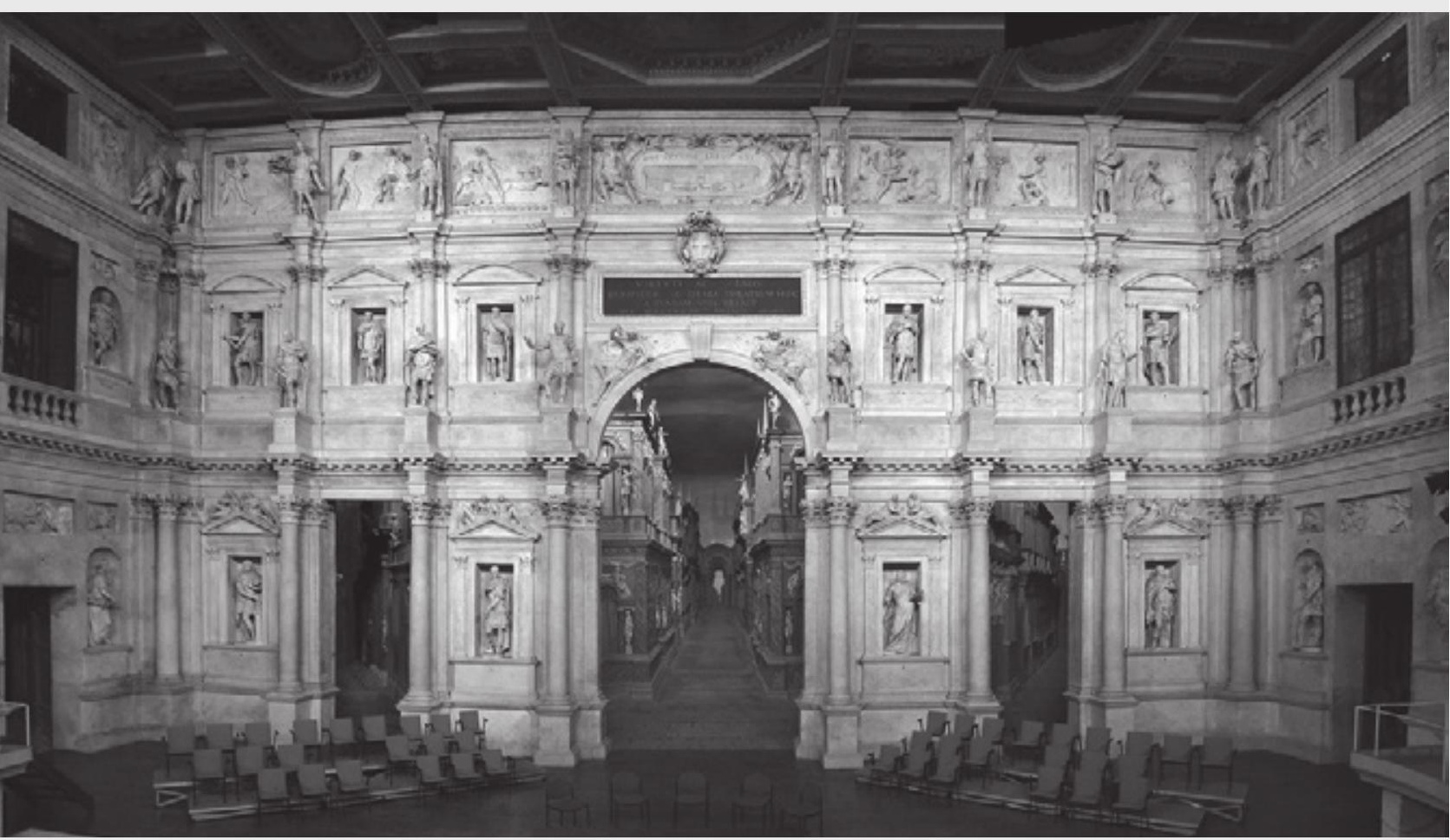

26. Scaenae frons do Teatro Olimpico de Andrea Palladio (1508-1580), em Vicenza, com destaque para as vias falsas em perspectiva se abrindo para as duas passagens visíveis do cenário. Fonte: Fotografia elaborada por Sailko (2012) - Licença: CC BY-SA 3.0 / Wikimedia Commons contributors. 
Da mesma forma, os jardins das residências principescas, principalmente das propriedades e vilas extramuros ou locadas na periferia interna das grandes cidades - como, por exemplo, as inúmeras vilas que se assentavam dentro e fora dos muros, na área idílica das colinas que envolviam o centro da Roma quinhentista -, eram espaços de experimentação dos novos preceitos que ganhariam força na urbanística do século seguinte. No caso dos jardins, as experimentações envolveriam, particularmente, a ideia de se conceber uma conformação espacial de filiação puramente clássica, situação difícil de ser reproduzida nas cidades preexistentes que ainda apresentavam, em sua maioria, uma configuração apertada e confusa, oriunda da estrutura do mundo urbano medieval (Figuras 27-32). Victor Minguéz e Inmaculada Rodriguéz (2006, p. 6I, tradução nossa), em seu estudo de 2006, Las ciudades del absolutismo, concluiriam:

Nas residências dos príncipes e na hora de refletir a grandeza de seu proprietário, tão importante ou mais ainda que a edificação arquitetônica foram os jardins que a completavam. Pequenos e ocultos a princípio, imensos e deslumbrantes depois, os jardins refletiram melhor que nenhum outro elemento urbano a presença simbólica do príncipe entre seus súditos durante o século XVI. Porém, ademais, os jardins permitiram explorar e investigar as possibilidades do urbanismo moderno de inspiração clássica, muito difícil de projetar nas tramas urbanas medievais nas quais transcorria a vida no Renascimento.

\section{Urbanística clássica ou barroca?}

O urbanismo antigo foi, em grande parte, comandado pela religião. O urbanismo presente é comandado pelas preocupações práticas, tais como higiene e circulação. No período em que estudamos aqui não se procurou construir a cidade dos homens sobre o modelo da cidade de Deus. Neste período não se conseguiu mais esquecer que o homem era um corpo: um estômago, uma vez que o fornecimento de água em Roma permanece para nós um modelo; pulmões, visto que, se os jardins de Paris não tivessem sido construídos nos séculos XVII e XVIII, nossa capital seria hoje em dia muito sufocante. Contudo, lhe foi também revelado que o homem era um espírito e que não valia a pena viver a vida sem o prazer intelectual; que as cidades não deviam 


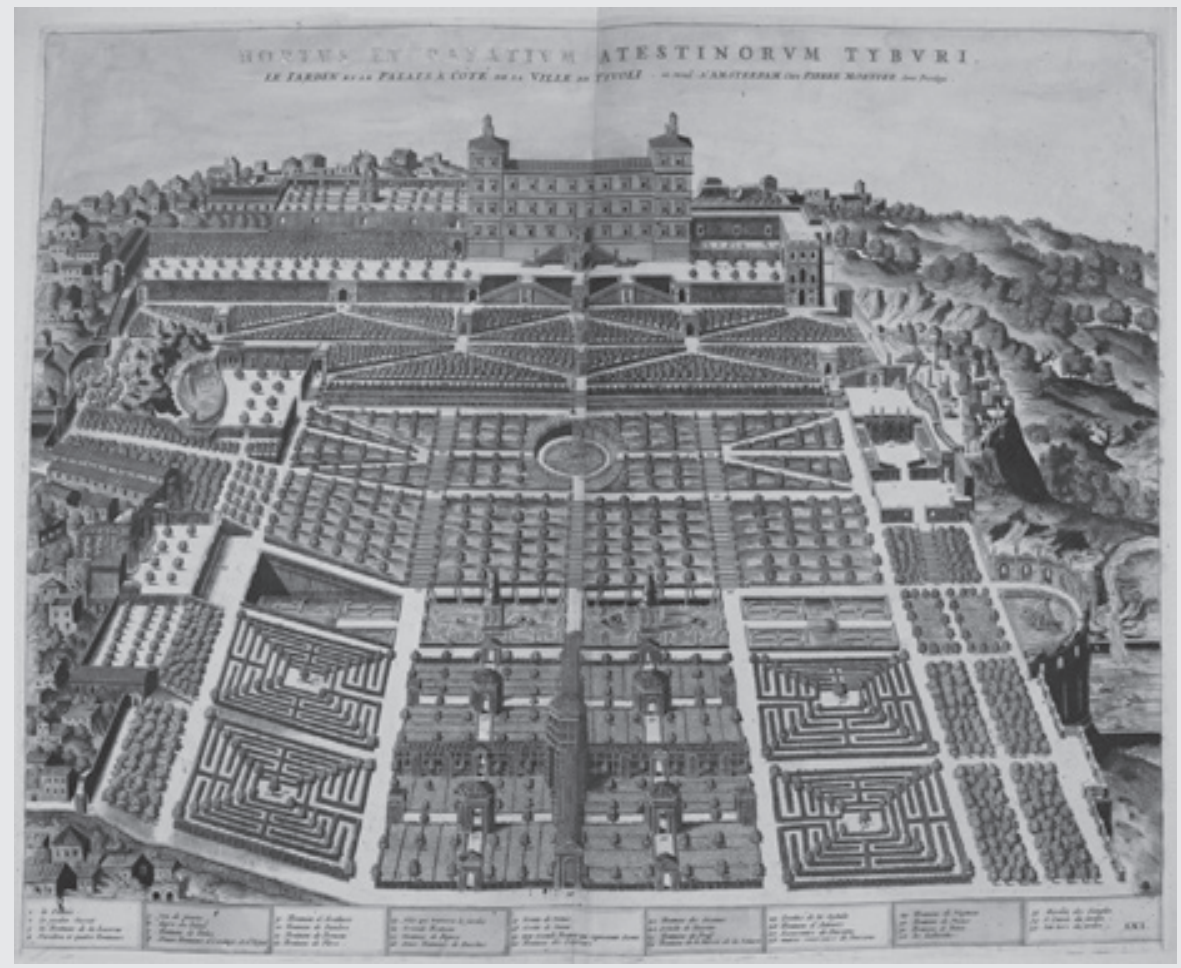

27. Vista perspectiva da Villa d'Este, em Tivoli, e de seus jardins, desenhados por Pirro Ligorio (1500-1583), em 1550. Notar a regularidade geométrica do design, as perspectivas e o uso dos tridentes. Fonte: Wikimedia Commons contributors.

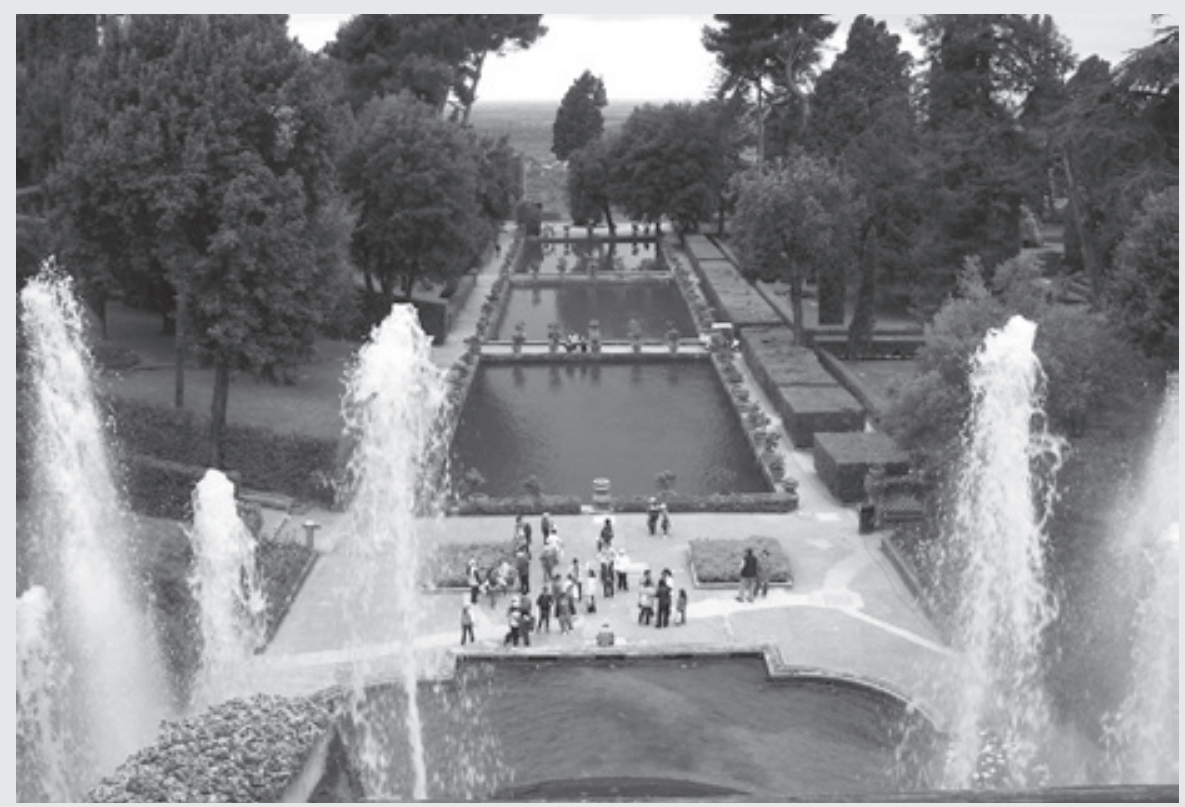

28. Fontes e espelhos d'água na Villa d'Este, em Tivoli. Fonte: Fotografia elaborada por Wknight94 - Licença: CC BY-SA 3.0 / Wikimedia Commons contributors. 


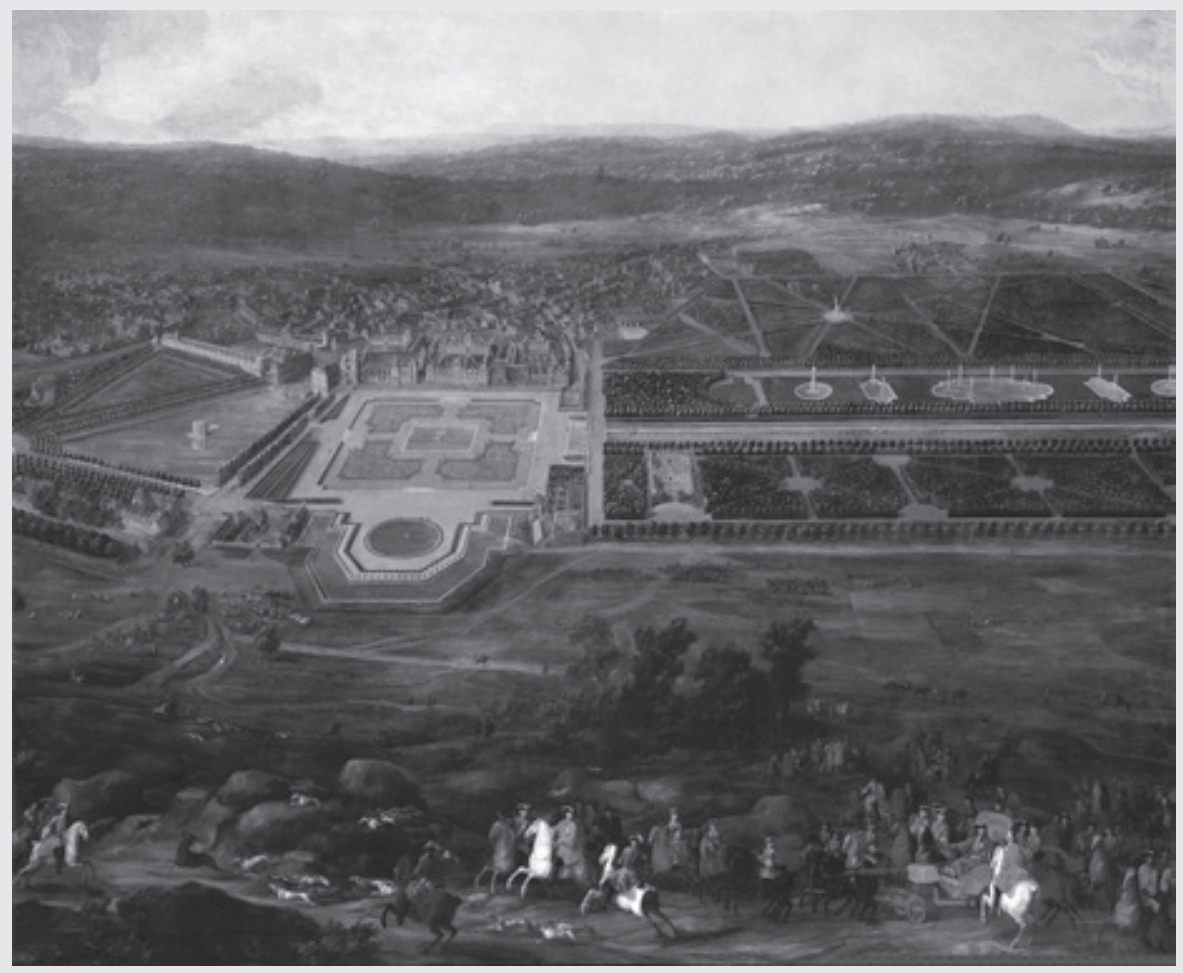

29. Vue du Château de Fontainebleau (1718-1723), pelo pintor francês Pierre-Denis Martin (1663-1742). O Castelo Real de Fontainebleau foi uma das moradas dos soberanos franceses do século XII (com Francisco I) até o século XIX (com Napoleão III), mas passou por grandes remodelações comandadas por importantes arquitetos, a partir do século XVI. Seus jardins quinhentistas e seiscentistas influenciaram profundamente o paisagismo barroco - e, consequentemente, as experiências da urbanística praticadas no período. Fonte: Wikimedia Commons contributors.

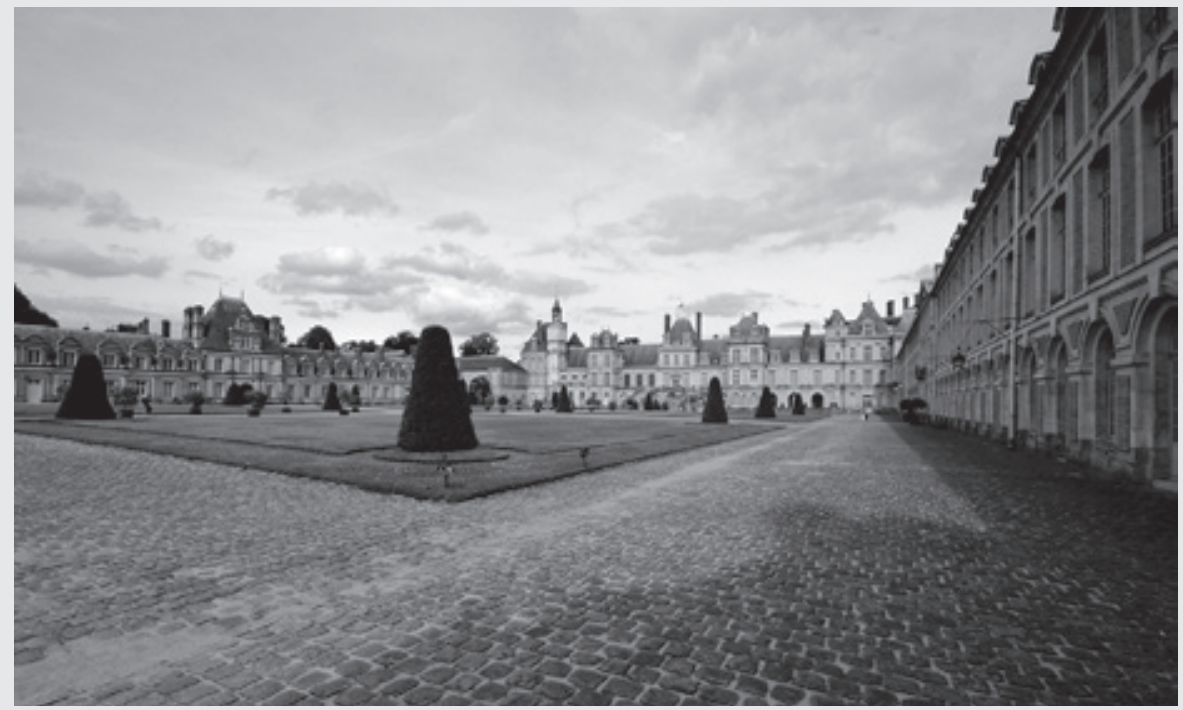

30. Pátio de honra (cour d'honneur) que dá acesso ao Château de Fontainebleau. Fonte: Fotografia elaborada pelo autor (2007). 


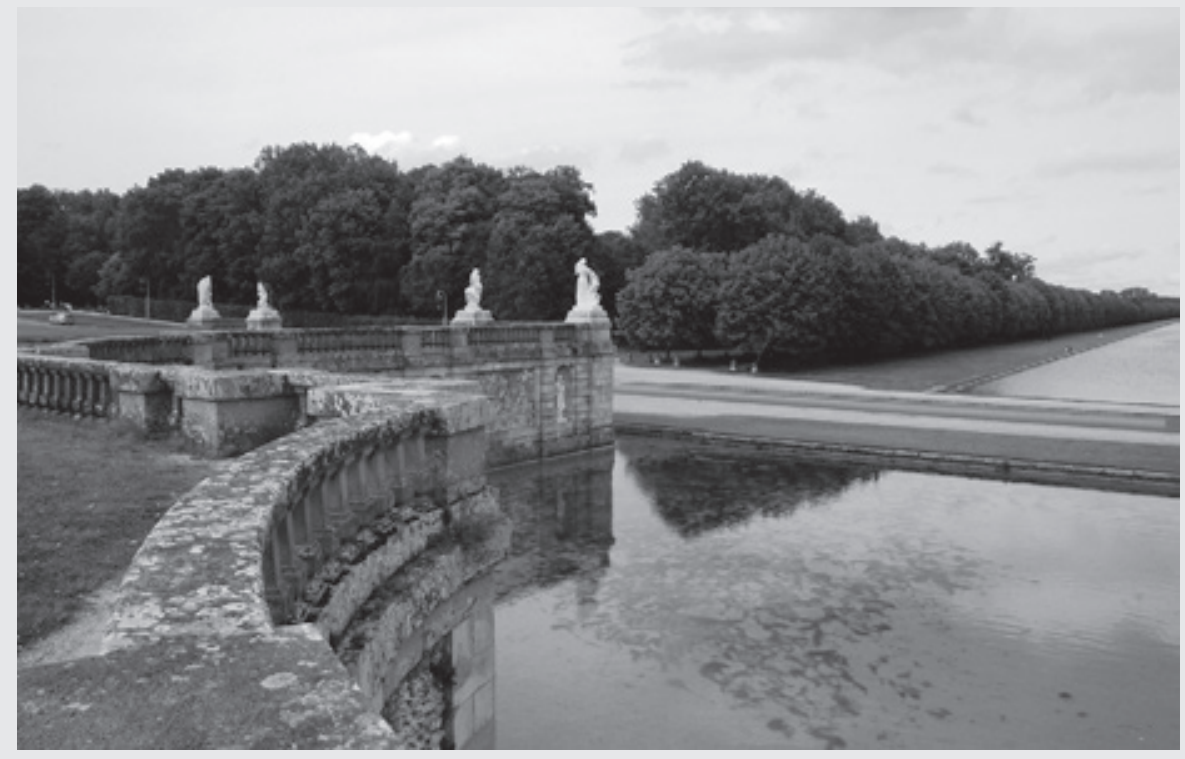

31. Detalhe do grande canal dos jardins do Château de Fontainebleau, remodelado entre 1661 e 1664 pelo criador dos jardins de Versailles, André Le Nôtre (1613-1700). Fonte: Fotografia elaborada pelo autor (2007).

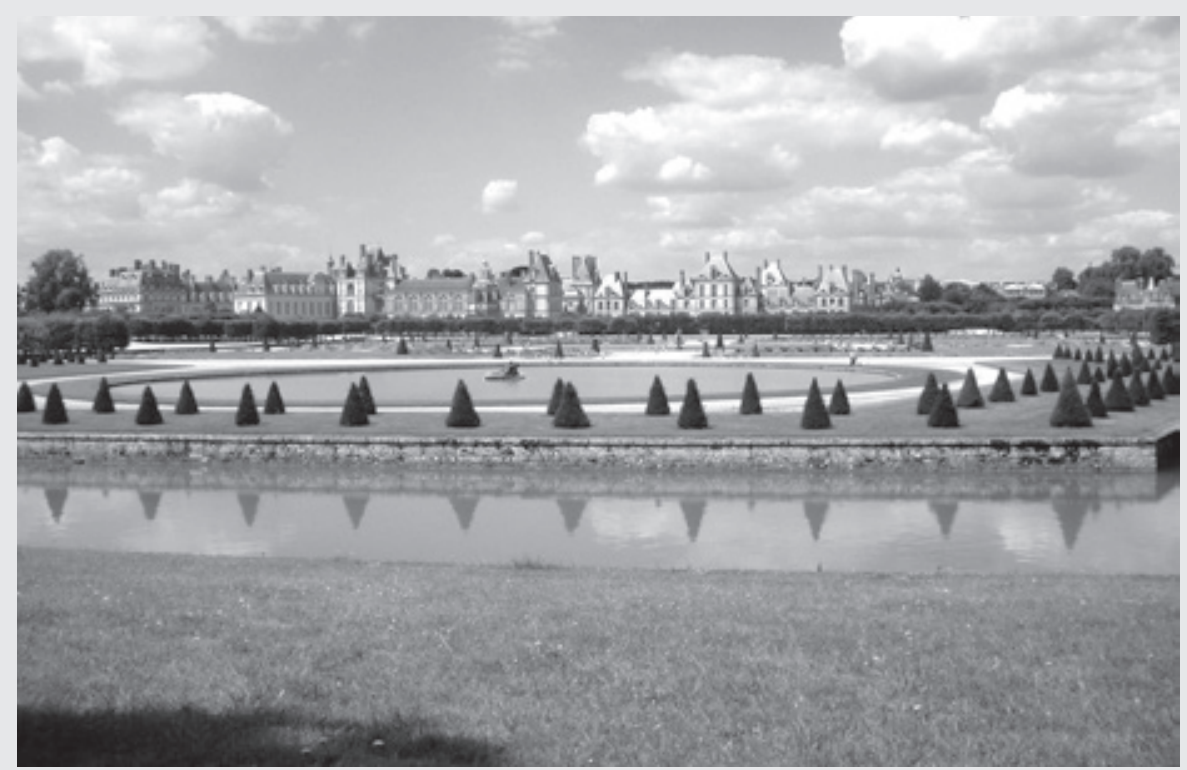

32. Jardins do Château de Fontainebleau. Fonte: Fotografia elaborada por Nemanja Stijak (2005) - Licença: CC BYSA 3.0 / Wikimedia Commons contributors. 
ser, portanto, somente sãs e cômodas, mas também belas; que em um período normal, o primeiro dever era o de agradar. Entre o urbanismo religioso dos antigos e o urbanismo prático dos modernos, aquele da idade clássica poderia se dizer estético. Durante esses três séculos aplicaram-se a defender ou a criar a beleza das cidades como tesouros da paciência e da engenhosidade, uma sutileza que temos dificuldade hoje de imaginar. Portanto, se nós queremos permanecer fiéis à noção de harmonia urbana, ou seja, fazer obras como artistas e não somente como agrimensores ou como pedreiros, vale a pena ouvir esta lição. (LAVEDAN, I94I, p. 6, tradução nossa)

Ao abrir este item apresentando um dos juízos sobre a urbanística do período humanista proferido pelo já citado historiador da cidade Pierre Lavedan, uma série de questões essenciais para a compreensão da temática é automaticamente revelada. Na introdução do segundo volume de sua obra clássica, Histoire de l'Urbanisme ${ }^{\mathrm{I4}} \mathrm{o}$ autor viria a declarar, explicitamente, diferenças fatais entre a urbanística praticada no período humanista (Renascimento ao Barroco) e iluminista (Neoclassicismo), frente à anterior realidade medieval, bem como em relação à urbanística cometida posteriormente, no mundo contemporâneo.

Nesta consagrada investigação, um dos primeiros esforços sistemáticos de construção de uma história organizada da urbanística no mundo ocidental, que celebraria, precocemente, como metodologia essencial para a investigação das cidades, o caráter morfológico do espaço urbano, ${ }^{15}$ Lavedan destacaria, antes de tudo, que não seria possível, no campo da urbanística, apontar qualquer diferença entre as ações empreendidas no Renascimento Clássico, se comparadas àquelas que foram desenvolvidas no Barroco ou na idade do lluminismo. Na verdade, a prática da urbanística nos séculos XVII e XVIII deveria ser compreendida como uma extensão e um amadurecimento das iniciativas e dos ideais primitivamente inaugurados no contexto da cultura urbanística da Renascença. Por isso, não faria sentido falar em urbanística renascentista ou barroca, mas simplesmente

14 Pesquisa desenvolvida durante quase três décadas, cujo primeiro volume, lançado em 1926, apresentaria o título Histoire de l'Urbanisme: Antiquité - Moyen Âge; o segundo volume, publicado pela primeira vez em 1941, e aqui avaliado, seria denominado Histoire de l'Urbanisme: Renaissance et Temps Moderns; e o terceiro volume, que sairia em 1952, se chamaria Histoire de l'Urbanisme: Époque Contemporaine.

15 Não esquecendo a obra pioneira do arquiteto e crítico austríaco Camillo Sitte (1843-1903), particularmente seu ensaio de 1889, Der Städtebau nach seinen kunstlerischen Grundsätzen, versão para o português denominada A Construção das cidades segundo seus princípios artísticos, tradução de Ricardo Ferreira Henrique. (SITTE, 1992) 
em urbanística clássica, já que a coerente continuidade dos padrões inicialmente estabelecidos no Quattrocento e maturados até o adentrar do século XVIII revelaria um senso utilitário, mas principalmente um envolvimento estético que se aproximaria da busca pela clareza, pureza, regularidade, simetria e magnificência típicas daquilo que poderia ser denominado de Classicismo.

Contudo, seria prudente afirmar que no contexto histórico em que Lavedan desenvolvia sua pesquisa, décadas de I920, I930 e I940, a crítica da arte ainda não reconhecia possibilidades de conexões entre a estética do Barroco e aquela do Classicismo, entendendo os dois momentos da história da arte como antagôni$\cos ^{16}{ }^{16} \mathrm{Na}$ verdade, a cultura barroca não descartaria a estética do Classicismo; ao contrário, muitas das suas manifestações mais significativas apresentariam uma filiação clara e aberta aos mecanismos de produção da arte e da arquitetura derivados da maneira clássica - especialmente as manifestações imperiais do Barroco francês, nação que foi a maior referência para a construção do discurso sobre a história da urbanística elaborado por Pierre Lavedan, principalmente quando o autor avaliava o período que se estendia de finais do século XVI a finais do século XVIII. Seria muito difícil para o historiador francês identificar, antes de I94I, ano da publicação do volume da Histoire de l'Urbanisme dedicado aos séculos renascentistas, barrocos e iluministas, aquela simbiose entre Classicismo e Barroco que se desenhava no Seicento e no Settecento. O caráter de regularidade e rigidez das intervenções propostas e realizadas parecia incompatível com o juízo, ainda hegemônico, sobre a suposta anarquia da arte barroca.

Não obstante, seria possível identificar, já em finais do Cinquecento, uma urbanística autenticamente barroca. Mas uma urbanística que, pelas próprias características de necessária sistematização e ordenação típicas das ações de intervenção em espaços urbanos, não deixaria de ser também definitivamente clássica - circunstância completamente aceitável para a crítica atual. Mas Lavedan estava certo quando apontava os mecanismos de intervenção na cidade acionados a partir do Grand Siècle como um desenvolvimento do que fora praticado nos dois séculos anteriores - mas que se diferenciariam das ações de redesenho dos ambientes urbanos no Quattrocento e no Cinquecento pelo seu caráter eloquente, persuasivo, magnificente, mecanismos típicos das ações barrocas.

16 Ver nosso livro, lançado em 2012, Teoria do Barroco, especialmente o capítulo intitulado As primeiras teorias e discursos sobre o Barroco. (BAETA, 2012, p. 31-86) 
Assim, a preocupação maior dos profissionais que viriam a promover as ações de remodelamento urbano que assaltariam o espaço das cidades preexistentes, ou mesmo a idealização de novos núcleos estratégicos, não seria a edificação da cidade de Deus, como era o caso da planificação medieval. Também a urbanística do período humanista não apresentaria o caráter absolutamente utilitário que distinguiria o urbanismo praticado de finais do século XIX em diante - apesar da reconhecida influência exercida pela engenharia militar nas intervenções urbanas praticadas, principalmente, na primeira metade do século XVI. Para o historiador francês, a urbanística clássica estaria fundada, pela primeira vez, em uma preocupação necessariamente estética, fato que deveria acarretar, grosso modo, estratégias globais de redefinição morfológica de todo o ambiente da cidade - obviamente, na medida em que as intervenções fossem viáveis politicamente, economicamente, tecnicamente.

Também não deixaria de ser perceptível, ao se analisar o planejamento e o desenho da cidade contemporânea, especialmente aquela do século XIX, como a questão estética se manteria como uma das motivações mais significativas para a nova ciência do urbanismo. Particularmente, os procedimentos da urbanística barroca não se esgotariam na configuração das cidades dos séculos XVII e XVIII, mas serviriam de modelo para as grandes transformações urbanas oriundas da nova realidade ocidental introduzida pela cultura do lluminismo e estabelecida pelas mudanças econômicas e sociais promovidas pela Revolução Industrial. A relação com a estética barroca se daria através de uma apropriação direta de suas formas e soluções mais consagradas, situação que deflagraria a filiação das intervenções ao espírito do Ecletismo, em ascensão nos oitocentos. Para Mumford (I989, p. 40I, tradução nossa):

\footnotetext{
Alguns dos grandes sucessos do planejamento barroco estavam reservados, na realidade, à Paris do século XIX: prova, aliás, de que a fase histórica da cultura urbana cria um arquétipo durável que não pode ser corretamente colocado dentro das fronteiras do tempo de qualquer período único.
}

É claro que o plano concebido pelo Barão de Haussmann (I809-I89I) para a Paris da segunda metade do século XIX, mesmo contemplando soluções de cunho artístico que se referiam à urbanística barroca - criação de eixos viários imensos e retilíneos com importantes monumentos emoldurando o encerramento dos 
direcionamentos perspectivos; regularização da arquitetura levantada em algumas vias de circulação; abertura de bulevares; organização de parques; estabelecimento de rond points para o tráfego; sistematização de áreas estratégicas nas quais eram promovidos encontros radiais de avenidas direcionadas muitas vezes a importantes monumentos -, não apresentaria como a sua principal motivação a reformulação estética da cidade, e sim aqueles diversos mecanismos de caráter utilitário que viriam a ser a base para a concepção da nascente disciplina do urbanismo. Da mesma forma, como foi debatido no item anterior, a urbanística dita clássica, ou mesmo barroca, também não viria a ignorar as necessidades práticas - mesmo sendo reconhecível a diferença entre os mecanismos utilitários que preocupavam os arquitetos dos séculos humanistas em relação àquelas ações que viriam a ser consagradas pelo urbanismo contemporâneo.

Contudo, uma grande peculiaridade marcaria o caráter barroco da urbanística clássica dos séculos XVII e XVIII, identificando-a em relação àquela renascentista e maneirista, mesmo reconhecendo que suas bases foram estabelecidas no século XVI: a conformação de um espaço de alto teor cenográfico. Esta tese é tratada de modo informal, mas muito convincente e consistente, em um dos livros menos conhecidos da professora de arquitetura e urbanismo Françoise Choay (nascida em I925), estudo lançado em I969: Espacements. Essai sur l'évolution de l'espace urbain en France. O cuidadoso ensaio foi concebido originalmente como o texto que deveria acompanhar um conjunto de imagens que o fotógrafo Jean-Louis Bloch-Lainé deveria fazer sobre a arquitetura e as cidades francesas no tempo, fotos que seriam confeccionadas na década de i960, sempre com a presença da autora. Na verdade, as imagens, conjuntamente ao texto, teriam como escopo pôr em discussão a qualidade das novas cidades e do novo urbanismo frente ao espaço urbano preexistente. ${ }^{17}$

A autora identificaria em seu ensaio quatro momentos característicos da configuração da imagem do ambiente urbano no tempo: o que ela chamaria de "espaço de contato", no Medievo; "espaço cênico”, na época clássica - o que para um francês, segundo suas próprias palavras, equivaleria e se confundiria, decisivamente, com o período barroco; "espaço de circulação", nos séculos XIX e XX; e "espaço de conexão", no mundo contemporâneo. Apesar de uma clara preferência pelo espaço urbano medieval, que para a autora era, enquanto lugar do contato,

17 A primeira edição, de apenas 500 exemplares, seria destinada exclusivamente a clientes de uma imobiliária de Paris. Mas, devido ao seu sucesso, o livro foi reeditado algumas vezes. 
também o ambiente da informação - na medida das possibilidades oferecidas pela Baixa Idade Média -, sua análise da cidade clássica (barroca) seria profundamente sólida, particularmente em relação à hegemonia que seria perseguida no período em direção ao império do visivo, ao universo da cenografia:

Enquanto sistema de circulação, a cidade clássica se opõe, portanto, à cidade medieval através de uma rede mais aberta ao exterior (supressão das muralhas, criação de perspectivas), mais ampla e na qual a noção de circulação adquire autonomia. O lugar da passagem é dissociado dos elementos permanentes que o margeiam. Todavia, o significado deste sistema é antes de tudo estético e político, e se trata de satisfazer o olho ou o exercício da parada. [...] Ao nível daquilo que chamamos informação direta, o espaço urbano clássico é menos favorável ao contato humano em relação ao medieval. Não obstante, por causa de sua função cenográfica, conserva as duas qualidades chaves de fechamento e contiguidade.

Contudo, em função da mudança de escala e sobretudo do momento que é 'composto' para o olho - não mais destinado ao corpo e à reunião dos sentidos, mas consagrado à hegemonia do olhar - enquanto assume um valor de imagem, perde a sua antiga intimidade e não mais pode ser vivido subitamente. Enfim, no que concerne ao seu próprio valor informativo, o espaço urbano clássico cessa de estar ligado à totalidade das necessidades e dos comportamentos cotidianos. Por outro lado, é possível ler nas suas perspectivas e nos seus ordenamentos, escritos com a 'clareza e distinção' características destes séculos, aquilo que Mumford justamente chamou 'a ideologia do poder', bem como a ambição de uma cultura que pela primeira vez se propôs, como objetivo explícito, ao controle do mundo e das suas leis. (CHOAY, 2003, p. 70-72, tradução nossa)

Portanto, é possível perceber a absoluta coerência deste juízo de Choay frente aos valores essenciais do Barroco. (BAETA, 20I2) A cidade clássica apreciada pela autora francesa se resumiria àquela edificada nos séculos XVII e XVIII e se caracterizaria, mais do que pela eficiência do tráfego, pelo apelo cenográfico ao olhar; pelo desenvolvimento de uma paisagem urbana que sensibilizaria o transeunte através do império do sentido da visão, através da comoção que as imagens teatrais atiradas por todos os lados provocariam no espectador. Como diria a autora, o objetivo último seria plenamente político: a direção das massas através do 
envolvimento pelas imagens - nada poderia ser mais Barroco. Ou seja, a urbanística do Seicento e do Settecento tenderia a ser, ao mesmo tempo, clássica e barroca.

Neste sentido, as cidades, principalmente as capitais barrocas, acabariam se transformando no baluarte do projeto de propagação deste Classicismo retórico e envolvente, reinterpretado e alargado em suas possibilidades de expressão, sempre a serviço dos governos. Para isso seus espaços urbanos contínuos, gerados muitas vezes por processos globais de planificação, apresentariam, frequentemente, um atributo comum: a representação da magnificência das estruturas de poder a que a cidade estava submetida, conseguida através da monumentalização do ambiente urbano.

Logo, a herança clássica se encontraria simulada justamente na imponência e na regularidade que os vazios urbanos passariam a expor (Figuras 33-34). Além disso, a figura da Antiguidade seria usada em nome da pompa, do fausto, do luxo a serem encenados no seio da Cidade Capital - o ambiente de circulação e de convívio social se tornaria majestoso e eloquente, perfeito para acolher a passagem de um exército em triunfo ou o andamento ritmado de uma procissão. Esta prática de organização da cidade em busca da ostentação e da magnificência herdeira direta da ideia de um Classicismo barroco revisitado - seria reconhecida como a Grand Manner pelo historiador da arquitetura turco, mas radicado nos Estados Unidos, Spiro Kostof (I936-I99I). Em seu livro de I991, The City Shaped:

A Grand Manner não é recorrente em pequenas cidades. Não é prática nem modesta. Percebida como um modelo expansivo de largas vistas, sua relação com a topografia e com os arranjos urbanos preexistentes é caprichosa, seus efeitos frequentemente grandiloquentes. Usualmente, por trás dos projetos na Grand Manner reside um Estado poderoso e centralizador, cujos recursos e indiscutível autoridade tornam possível a extravagante visão urbana de avenidas diretas, vastas praças com limites uniformes, e a conveniente presença de prédios públicos monumentais. Isto é, de fato, urbanismo público. Fala de cerimônia, cortejos intencionais, uma vida pública regularizada. A rua contém uma promessa de pompa: ela atravessa a cidade com este único propósito, utilizando-se de acessórios ostentatórios como arcos triunfais, obeliscos e fontes permanentes. (KOSTOF, I99I, p. 240, tradução nossa)

Assim, a Grand Manner se apropriaria abertamente de um dos princípios mais caros à estética barroca: a retórica persuasiva. O espaço urbano barroco iria se 


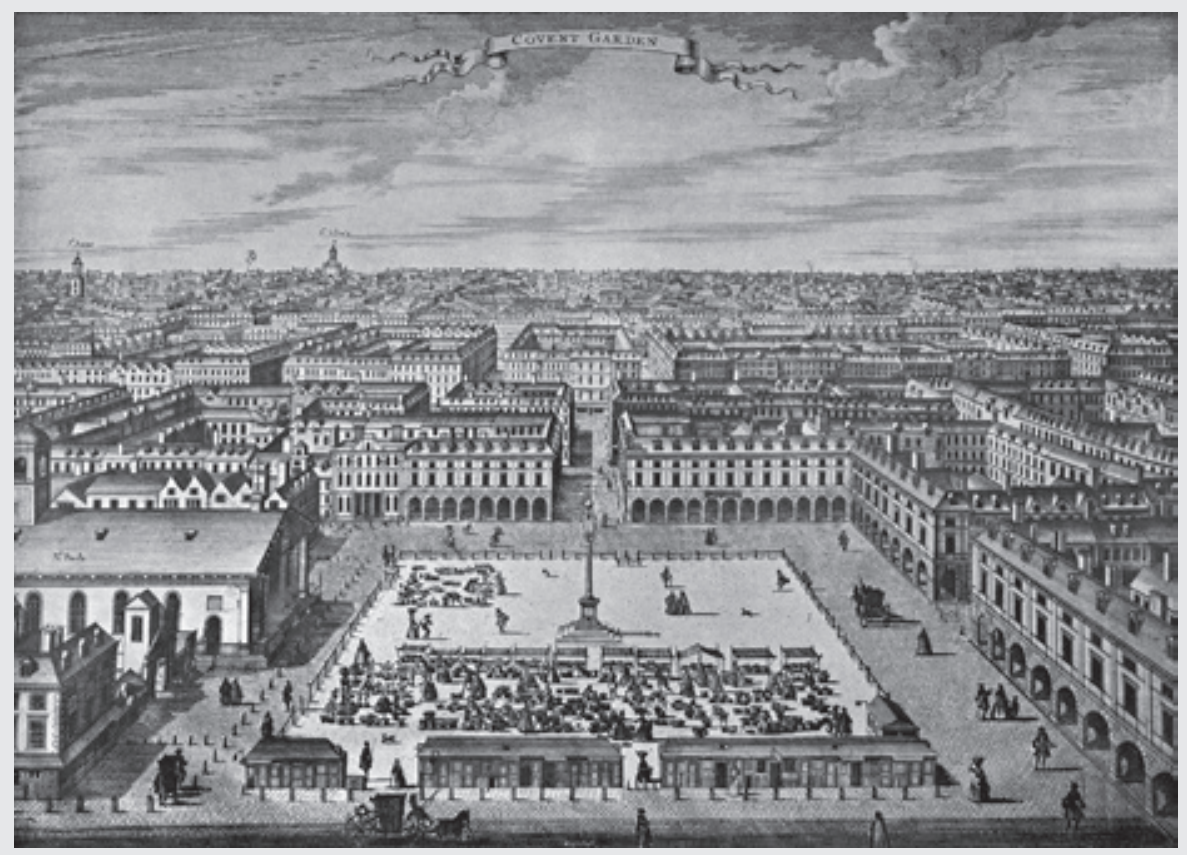

33. General view of Covent Garden looking north (cerca de 1720), gravura feita por Sutton Nicholls (1680-1740) e publicada pela primeira vez no London Described or the most noted Regular Buildings both Public and Private, with the Views of several squares in the Liberties of London and Westminster (1731). Praça do Covent Garden, em Londres, iniciada por Iñigo Jones (1573-1652), em 1631. Fonte: Wikimedia Commons contributors.

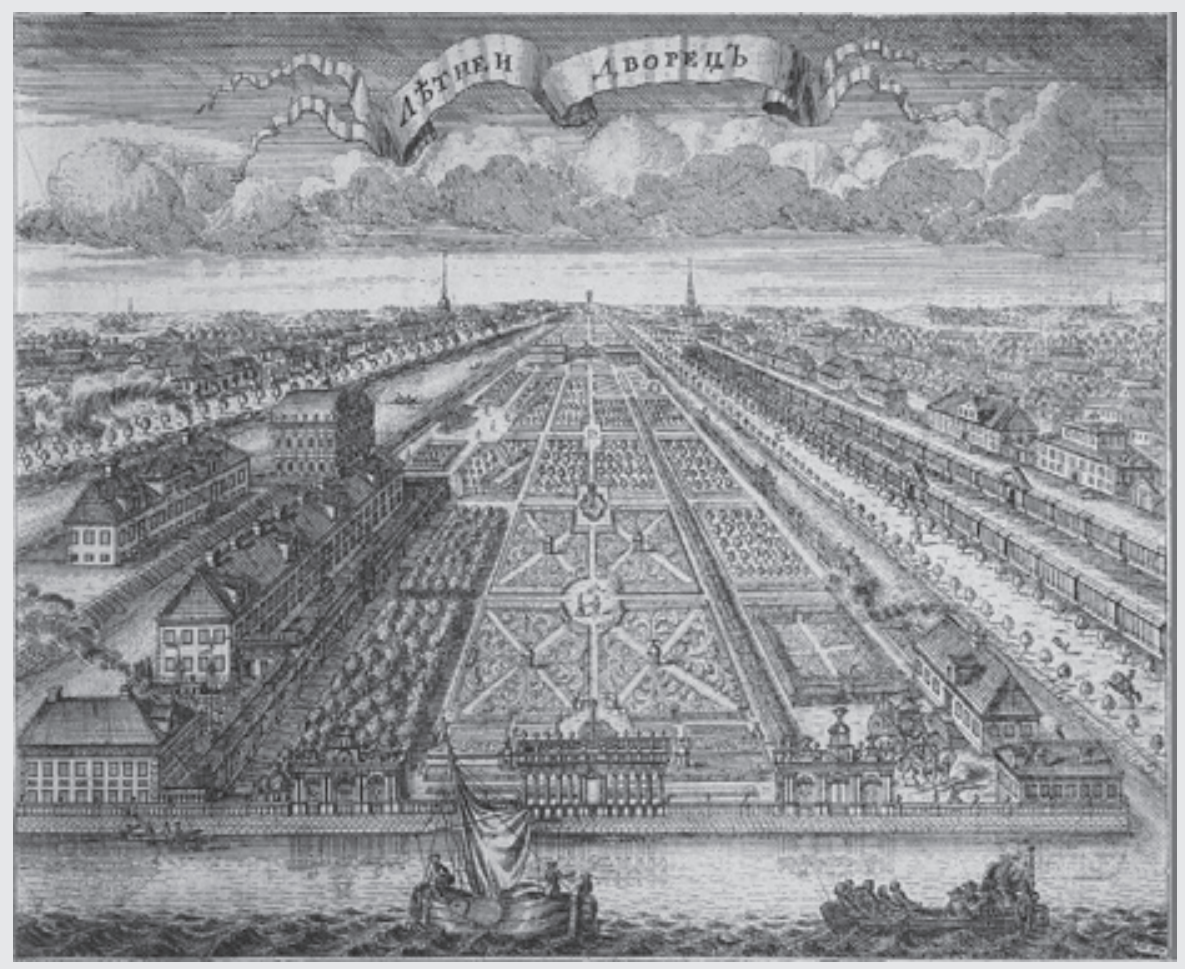

34. Vista dos Jardins de Verão, a partir do Rio Neva, em São Petersburgo (1717) - por Alexey Zubov (1682-1741). O jardim teria sido pessoalmente projetado, em 1704, pelo Czar, Pedro, o Grande, fundador da nova capital russa. Fonte: Wikimedia Commons contributors. 
desenvolver como uma grande encenação dramática, onde todos eram protagonistas de uma experiência inebriante, inusitada. Por isso, o exercício da imponente urbanística clássica buscaria produzir a cidade como uma cativante encenação teatral.

\section{Considerações sobre os principais artifícios}

\section{da urbanística barroca}

Após a avaliação do caráter clássico que a urbanística barroca normalmente absorveria nas iniciativas de reformulação da estrutura das mais importantes cidades preexistentes, bem como na fundação de novos núcleos planificados, seria pertinente promover um debate sobre os principais artifícios urbanísticos acolhidos especificamente pela Grand Manner: procedimentos que seriam vastamente experimentados nos séculos XVII e XVIII, mas que teriam sua origem vinculada aos primeiros dois séculos da cultura humanista - se expressando, sobretudo, através da abertura de vias retilíneas e praças regulares no seio das cidades absolutistas, bem como trazendo o verde para o seio do núcleo urbano, através da inclusão de parques, jardins, passeios, alamedas, bulevares.

Prioritariamente, para se alcançar o fim da persuasão, muitas das mais importantes cidades europeias, especialmente as capitais e sedes das cortes, passariam por vastos processos de renovação urbanística ditados, constantemente, por intervenções baseadas em reformulações viárias - novas ruas e avenidas que cortariam os núcleos urbanos preexistentes, ou seriam a base para o desenho dos aglomerados de nova fundação. Das diversas possibilidades de abertura de artérias de circulação no ambiente da cidade, os planejadores barrocos acabariam privilegiando a construção de ruas mais largas, diretas e retilíneas, principalmente aquelas que se caracterizariam como amplas avenidas. Na Grand Manner, as avenidas serviriam para inúmeras ações ligadas, ao mesmo tempo, ao uso do espaço urbano e à sua conformação estética: intervenções derivadas tanto da busca por um funcionamento mais adequado do organismo urbano - contribuindo para assegurar o caráter de modernidade das cidades que se afirmavam como importantes sedes de poder - quanto para o seu aformoseamento, através da organização dramática do ambiente, da transformação cenográfica do núcleo citadino.

Para Mumford, rasgar a cidade com longas e largas avenidas seria a forma mais prática, econômica e rápida de promover uma radical mudança em seu 
aspecto geral, já que - salvo situações especiais de planificação global de uma nova cidade - para as intervenções em núcleos preexistentes seria inviável a reestruturação física integral de seu tecido urbano. Contudo, segundo o mesmo autor, o primeiro incentivo para a formulação destes planos - que contemplavam a criação de um sistema de eixos que dilacerariam partes das cidades antigas não estaria vinculado à estética, mas ao aparelhamento do sistema de circulação de veículos de roda:

A avenida é o mais importante símbolo e o fato principal no que diz respeito à cidade barroca. Nem sempre era possível planejar toda uma nova cidade no estilo barroco; mas, no layout de meia dúzia de novas avenidas, ou em um bairro novo, seu caráter podia ser redefinido. $\mathrm{Na}$ evolução linear da planta da cidade, o movimento de veículos de roda desempenhou um papel crítico; e a generalizada geometrização do espaço, tão característica do período, teria sido inteiramente sem função, não houvesse facilitado o movimento do tráfego e dos transportes, ao mesmo tempo em que servia como manifestação do sentido dominante da vida. (MUMFORD, I989, p. 367-368, tradução nossa)

Contrariando a tese defendida por Argan (1994, v. 3, p. 222), no terceiro volume de sua importante publicação de I968, Storia dell'arte Italiana, tese que declarava o aspecto democrático das intervenções barrocas, para Mumford (I99I, p. 402) as avenidas surgiriam no âmago das cidades como o mais significativo representante do afastamento entre as classes sociais. Era para as camadas dominantes, para a realeza, a nobreza, a burguesia, que as vias eram abertas; era para tornar mais rápido e agradável o tráfico nos veículos de roda que as avenidas foram traçadas e pavimentadas (Figuras 35-38). Neste sentido, as modificações que as carroças e carruagens viriam a sofrer a partir do século XVI contribuíram francamente para a nova experiência de cruzar a cidade instantaneamente. ${ }^{18}$

$\mathrm{Na}$ mesma direção, o reaparecimento das calçadas mostraria para as classes baixas qual era o seu verdadeiro lugar: relegadas ao segundo plano, nos cantos, à margem do rápido tráfego de veículos que acontecia no cerne da rua, onde os ricos apontavam como os protagonistas, com seus vistosos coches. Este fato

18 "Foi durante o século XVI que os carros e carroças tiveram uso mais generalizado nas cidades. Isso foi parcialmente o resultado de melhoramentos técnicos que substituíram a antiga roda sólida por aquela construída de partes separadas: cubo, raio, arco, e o acréscimo de uma quinta roda para facilitar as voltas." (MUMFORD, 1989, p. 368, tradução nossa) 


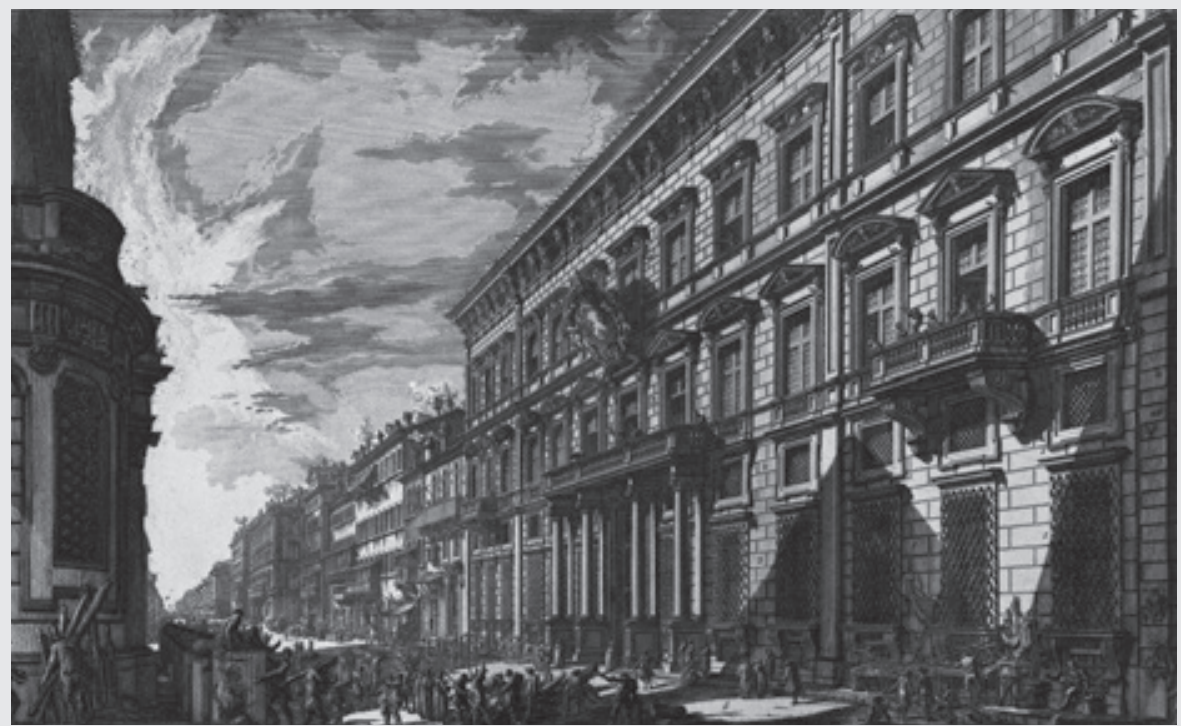

35. Veduta nella Via del Corso, del Palazzo dell'Accademia. Pelo arquiteto e gravurista italiano, Giambattista Piranesi (1720-1778). Da Série Vedute di Roma, publicadas em 1798 - as gravuras foram iniciadas em 1748. A Via del Corso foi originalmente aberta em 220 antes de Cristo como um grande eixo retilíneo, então denominado Via Flaminia - mas que também seria conhecido, na Antiguidade e no Medievo, como Via Lata. É a grande artéria perspectiva que até hoje corta o núcleo urbano da cidade de Roma. Contudo, sua atual aparência monumental é derivada das diversas intervenções urbanísticas e sistematizações que sofreria nos séculos XVI, XVII e XVIII. Fonte: Ficacci (2000, p. 710).

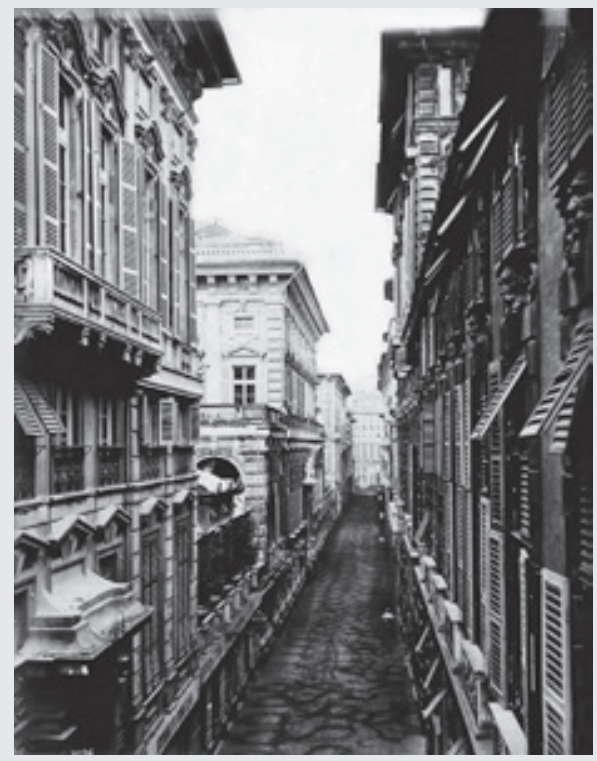

36. Via Nuova, em Genova, em fotografia do século XIX. Imagem elaborada por Alfred Noack (1833-1895). $A$ via foi aberta na segunda metade do século XVI e poderia ser considerada como uma das primeiras intervenções que antecipariam a urbanística barroca. Fonte: Wikimedia Commons contributors. 


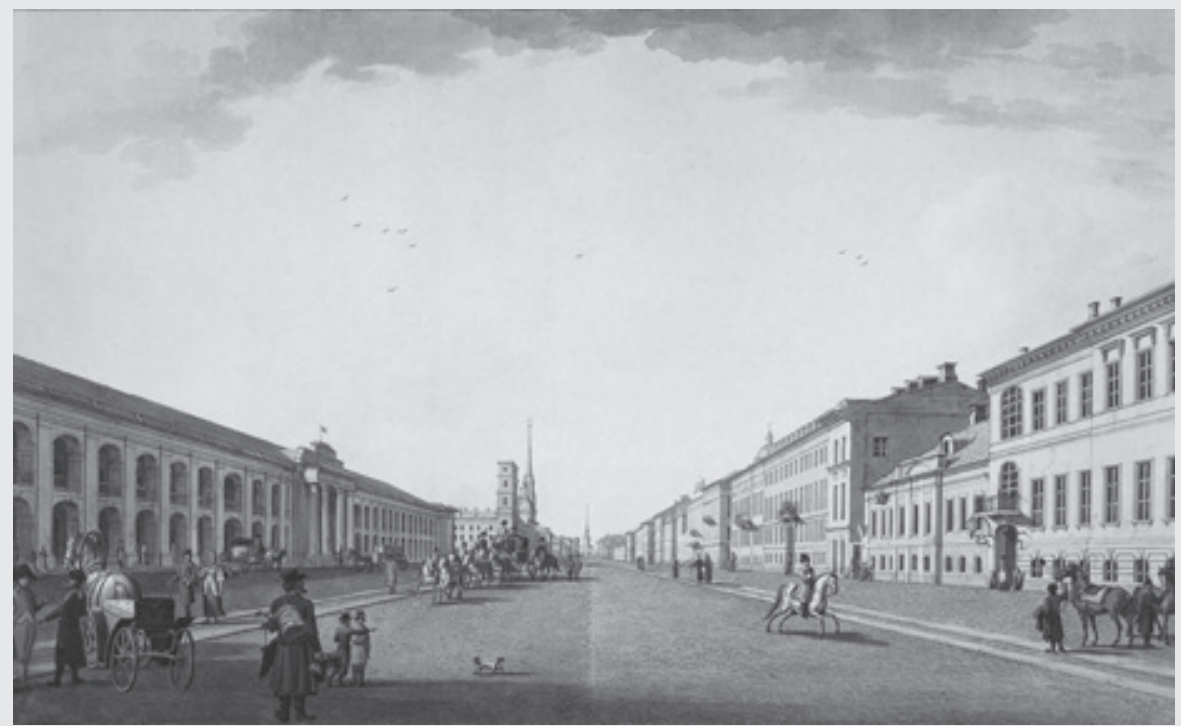

37. Perspectiva Nevsky, em São Petersburgo (1799), por Benjamin Patersen (1750-1815). A grande avenida retilínea foi planejada já na fundação da cidade, no início do século XVIII. Fonte: Wikimedia Commons contributors.

38. Perspective de Newski. Desenho retirado do álbum Voyage pittoresque et archéologique en Russie, 1839.

André Durand (1807-1867). Fonte: Wikimedia Commons contributors.

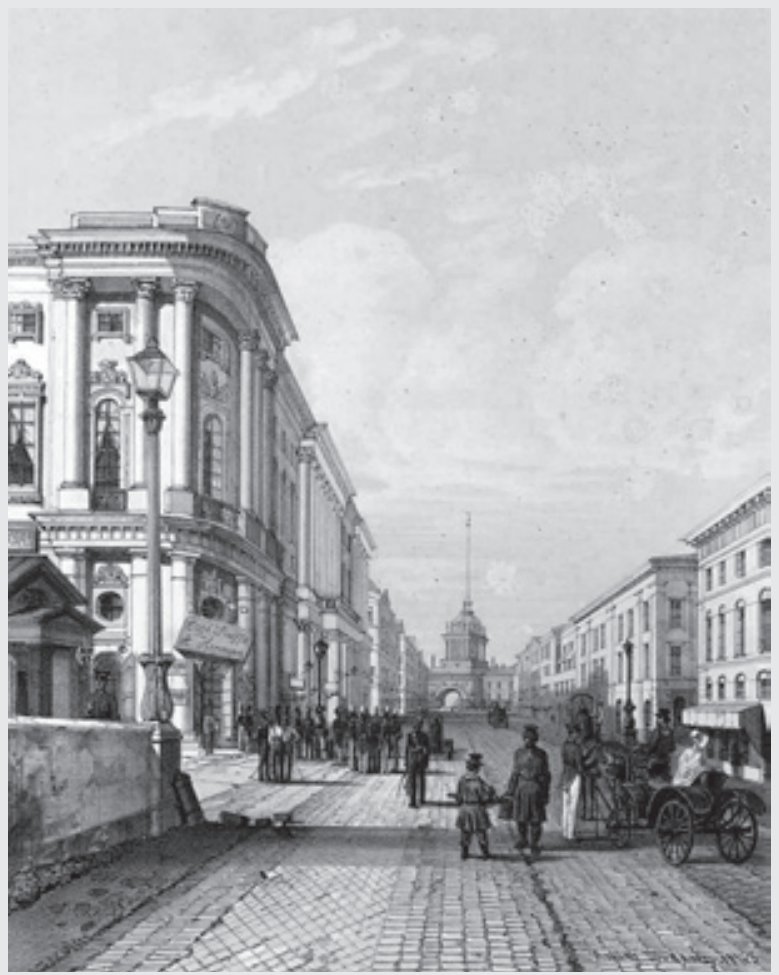


poderia ser confirmado pela análise que Choay faria, no livro já citado, sobre as diferenças entre o espaço de contato e o da comunicação direta oriundos da cidade medieval, e o espaço cenográfico e o da cultura puramente visiva, comuns à urbis barroca. Mumford (1989, p. 370-371, tradução nossa) resume:

$\mathrm{Na}$ cidade medieval as classes altas e as classes baixas amontoavam-se juntas na rua, no mercado, tal como na catedral: os ricos podiam montar em seus cavalos, mas tinham que esperar que o homem pobre com a sua trouxa, ou o mendigo cego, arrastando-se com a sua bengala, saíssem do caminho. Agora, com o desenvolvimento da larga avenida, a dissociação entre as classes superiores e inferiores toma forma na cidade mesma. Os ricos conduzem; os pobres caminham. Os ricos rolam pelo eixo da grande avenida; os pobres estão afastados do centro, na sarjeta; e eventualmente uma faixa especial é destinada ao pedestre comum, a calçada. Os ricos olham; os pobres admiram: a insolência esmaga o servilismo. [...] Havia apenas um estado desejável nesse despotismo; era o dos ricos. Foi para eles que a avenida foi feita e foi aplainado o calçamento; foi para eles que se acrescentaram molas e almofadas ao veículo de rodas: era para protegê-los que os soldados se punham em marcha.

Por outro lado, a tendência à regularidade absorvida no tratamento das avenidas, que foi perseguida não só na sua forma direta e retilínea, mas também na composição da arquitetura que margeava a calha da rua, também seria, em grande parte, derivada da circulação dos veículos velozes. A cidade feita não mais para ser apreendida pelo transeunte que percorria lentamente seus caminhos, mas para ser fruída pelo passageiro das carruagens que capturava o cenário urbano subitamente, através da sequência de panoramas que se sucediam pelo olhar, poderia desprezar a rica variedade das imagens delicadas e inesperadas que os núcleos medievais ofereciam. Na verdade, a homogeneidade era desejável, pois quem "navegava" pelos veículos de roda não tinha tempo para se deter em um ornato atraente, em um edifício destacado, a não ser que este organismo arquitetônico se apresentasse como um poderoso monumento emoldurado pela projeção perspéctica. Independente disso, a presença de edifícios idênticos ou semelhantes, alinhados gregariamente aos dois lados da via, ajudava a valorizar as linhas horizontais de fuga, bem como o ritmo regular da modenatura arquitetônica, 
favorecendo a percepção do espaço urbano para quem o mirava de dentro dos velozes coches (Figuras 39-4I). Assim:

O movimento em linha reta ao longo de uma avenida não era meramente uma economia, mas um prazer especial: trazia para dentro da cidade o estímulo e a animação do movimento rápido, que até então só o cavaleiro tinha conhecido galopando pelos campos ou através da floresta de caça. Era possível aumentar esteticamente esse prazer por meio da disposição regular de edifícios, com fachadas simétricas e até mesmo as cornijas, cujas linhas horizontais tendiam para o mesmo ponto distante como aquele para o qual a carruagem mesma estava se dirigindo. Na caminhada, o olhar corteja a variedade, mas, em ritmo mais acelerado, o movimento exige repetição das unidades que devem ser vistas: é somente assim que a parte individual, à medida que se desloca velozmente, pode ser recuperada e reconstituída conjuntamente. O que seria monotonia para uma posição fixa ou mesmo numa procissão torna-se um correspondente necessário ao ritmo de andar dos cavalos rápidos. (MUMFORD, I989, p. 368, tradução nossa)

Muitas vezes, esta regularidade era alcançada através do uso de artifícios claramente cenográficos, não só nas vias de circulação, mas também nas praças ordenadas e homogêneas que frequentemente se apresentariam como elementos essenciais na urbanística barroca - principalmente no caso francês. Por meio de investimentos públicos, os governos levantavam o encadeamento ritmado de fachadas idênticas que encerrariam as imponentes ruas e praças:

Como as autoridades planejadoras se asseguram da execução de ruas e praças uniformes? A maneira mais comum foi construírem, elas mesmas, as edificações reais. Estados totalitários onde a indústria de construção é centralizada não têm outra alternativa. Um método mais barato para o Estado, e os séculos barrocos dispuseram dele, foi construir somente as partes externas, as fachadas contínuas, deixando a construção das casas para os indivíduos que possuíam os terrenos. (KOSTOF, I99I, p. 260, tradução nossa)

Ou seja, o que se construía era um cenário bidimensional que aos poucos ia recebendo edifícios em sua parte posterior, erguidos agora pela iniciativa privada. Por detrás do "cenário", as habitações não eram sequer semelhantes: variavam 


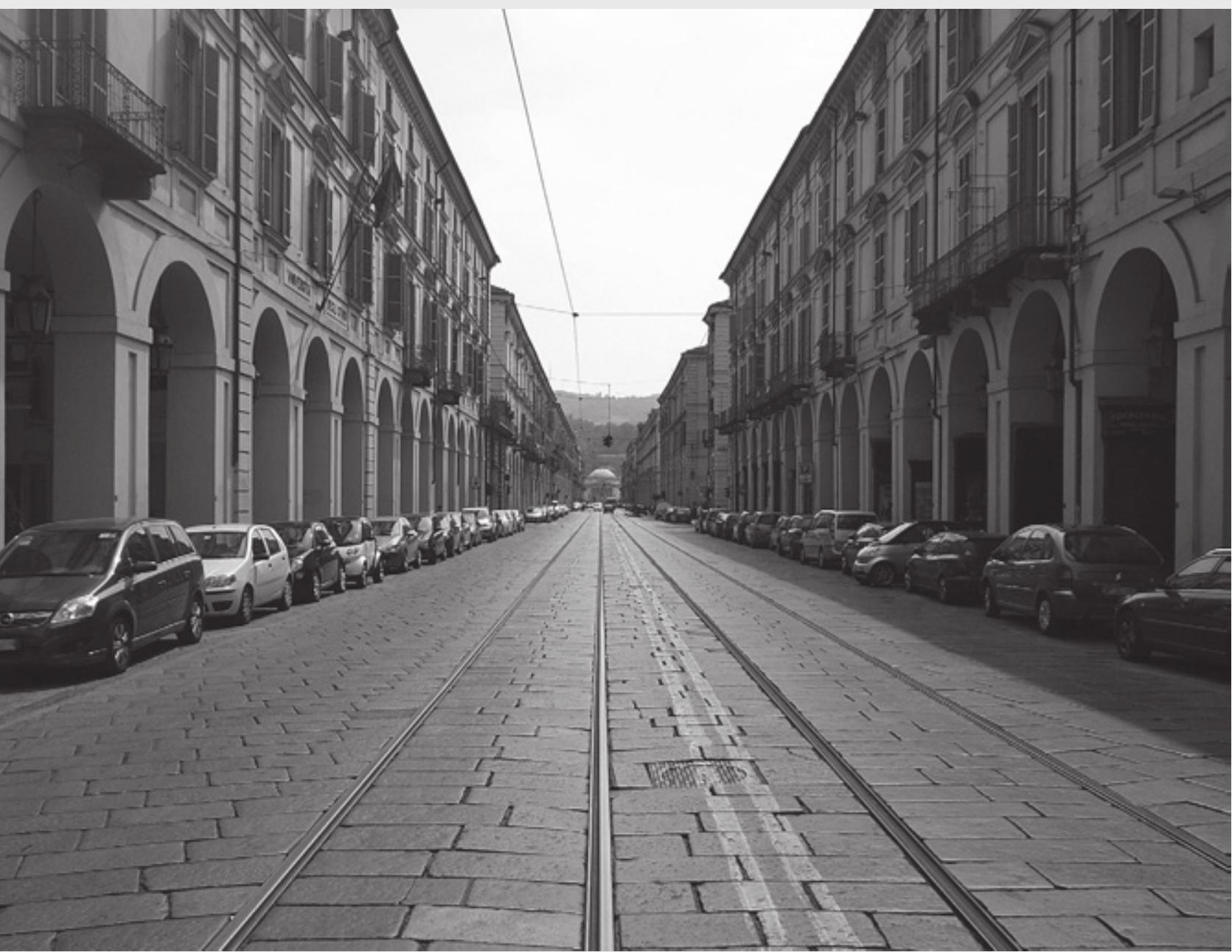

39. Via Po, em Turim, projetada pelo arquiteto e engenheiro militar Amedeo Cognengo di Castellamonte (16131683) e inaugurada em 1674. Fonte: Fotografia elaborada por Alessandro Ricci (2012) - Licença CC BY-SA 3.0 / Wikimedia Commons contributors. 


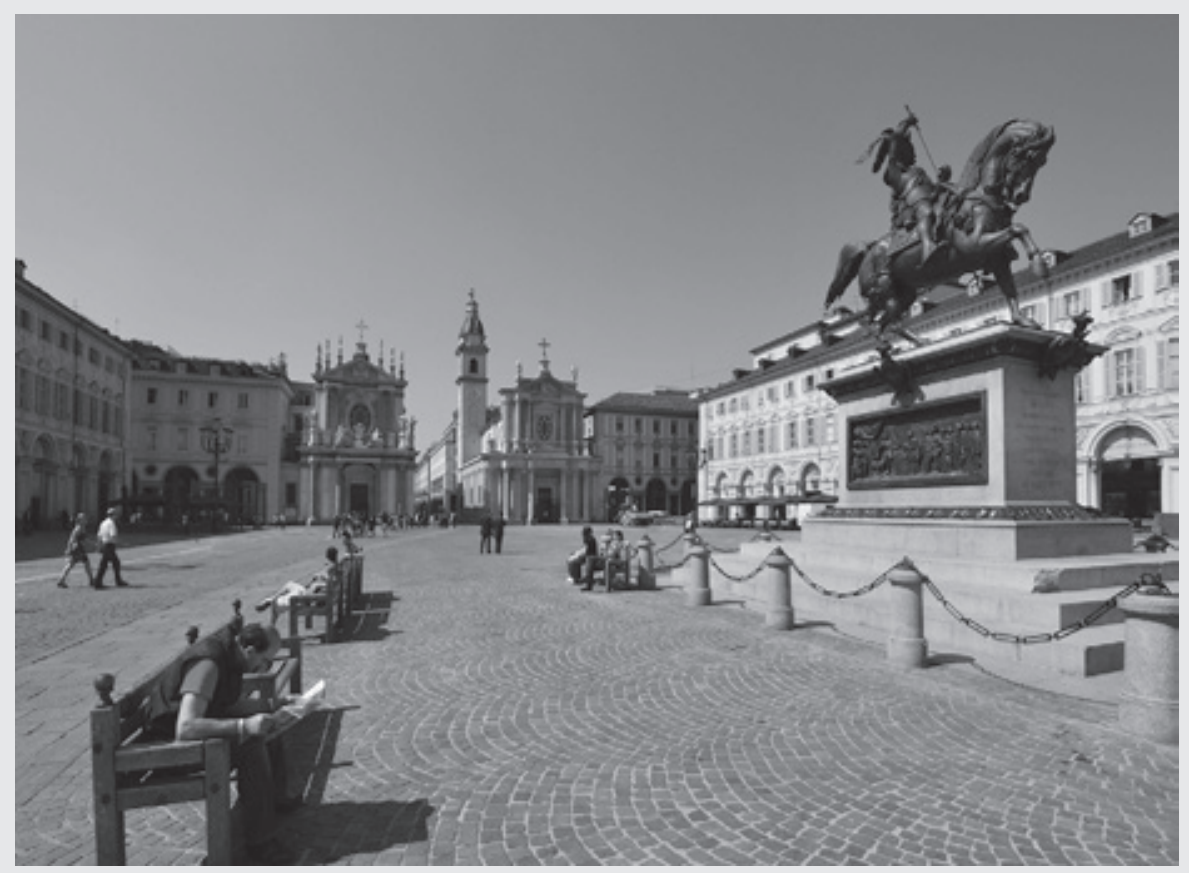

40. Piazza San Carlo, em Turim, projetada em 1721 pelo arquiteto Filippo Juvarra (1676-1736). Fonte: Fotografia elaborada por Chensiyuan - Licença CC BY-SA 4.0 / Wikimedia Commons contributors.

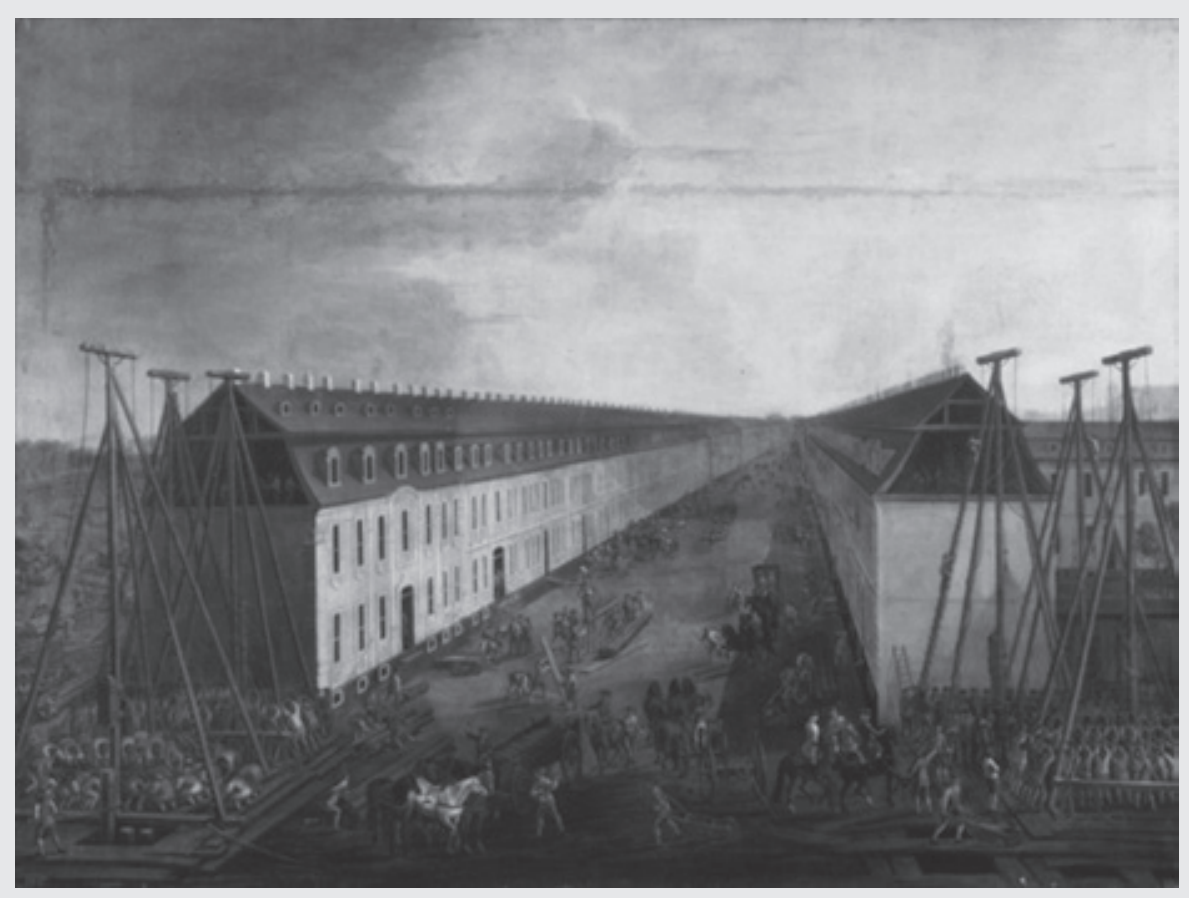

41. Pintura de 1732 atribuída a Dismar Dägen (1700-1753) mostrando casas alinhadas e idênticas sendo construídas na perspectiva infinita da Friedrichstrasse, em Berlim. Fonte: Kostof (1991, p. 257). 
a largura, a cobertura, o tratamento exterior. Mas nada disso era visível nos panoramas retirados do espaço urbano: apesar da diversidade plástica encontrada no fundo das residências, a integridade do "teatro" encenado na cidade era preservada, pois as elevações voltadas para os logradouros eram protegidas por legislação urbana e permaneciam homogêneas (Figuras 42-45).

Logo, as praças urbanas, com suas formas geométricas regulares, valorizadas pela estátua do soberano em seu centro geométrico, sugeriam a ideia ilusionística de estarem conformando pátios internos de imensos palácios reais - bem diferente da sua condição real de acolhimento de inúmeras casas independentes, ou mesmo da presença de simples fachadas cenográficas ainda não "preenchidas", em sua parte posterior, por edifícios de especulação. Já as grandes avenidas - através da ordenação regular das fachadas ritmadas por suas elegantes marcações - aludiam a presença de residências aristocráticas que se estendiam infinitamente na fuga perspectiva. Em ambos os casos, o resultado era puro teatro e fantasia: um ambiente monumental, marcial, e hipnótico, que exaltava vastamente o poder da figura do soberano, do governante - e que ultrapassava em muito a simples necessidade de eixos viários adequados ao tráfego das carroças.

Além do problema do tráfego e da busca compositiva por um eixo viário contínuo e regular, as ruas diretas também seriam convenientes às classes dominantes para aumentar o sentimento de segurança frente aos perigos derivados da situação social dos núcleos centrais preexistentes, constantemente afeitos a revoltas, rebeliões - situação herdada das práticas de intervenção do século XVI. O tecido urbano medieval, com seus becos escuros e irregulares, suas travessas íngremes, sua conformação labiríntica, seu calçamento defeituoso, sua arquitetura "sombria" e "desordenada", favorecia o surgimento de levantes por parte da população miserável, cada vez mais oprimida - situação já comum na cidade quinhentista e que continuará crítica após o período barroco, culminando nas revoluções de i848. Nos núcleos densos e confusos era fácil se esconder, seja nas imprevisíveis vielas ou nas habitações, amontoadas umas sobre as outras. No centro apertado se constituíam barricadas, trincheiras de difícil combate por parte do exército. Dentro do emaranhado confuso de caminhos sinuosos e estreitos os carros de guerra não podiam passar. Também era quase impossível para os soldados manterem a formação em um cenário tão errático. Por outro lado, nas largas avenidas os esquadrões conseguiriam marchar sem perder o passo; as máquinas bélicas dificilmente poderiam ser obstruídas; os quarteirões densos e estrangula- 
dos, proteções naturais para os revoltosos, desapareceriam, cedendo lugar a um organismo urbano desafogado e de fácil inspeção; os pelotões teriam áreas de sobra para fazer manobras. ${ }^{19}$

Igualmente, a organização do espaço das avenidas viria a privilegiar a apresentação triunfal do exército, utilizada como espetáculo de poder, representando a força e a disciplina do Estado. A própria cadência contínua dos elementos plásticos componentes do tratamento arquitetônico dos palacetes que ladeavam as vias - a eloquente modenatura, muitas vezes derivada da linguagem áulica do Classicismo - entraria em absoluta sintonia com a marcha ritmada e forte dos soldados:

O efeito estético das filas regulares e da linha reta de soldados é realçado pela regularidade da avenida: a linha de marcha ininterrupta contribui enormemente para a demonstração de poder, e um regimento que assim se movimenta dá a impressão que irromperá através da sólida muralha sem perder o passo. Isto, é claro, é exatamente a crença que o soldado e o Príncipe desejam transmitir para a população: ajuda-os a mantê-la em ordem sem chegar a uma demonstração verdadeira de força, que sempre carrega a clara possibilidade que o exército possa ser vencido. Mais ainda, em ruas irregulares, mal pavimentadas, com grande número de pedras soltas e lugares para se esconder, as formações espontâneas de indivíduos não treinados possuem uma vantagem sobre os soldados bem adestrados: os soldados não podem atirar pelas esquinas, como não podem proteger-se dos tijolos lançados do alto das chaminés imediatamente em cima das suas cabeças: eles precisam de espaço para fazer manobras. [...] Na cidade nova ou nos acréscimos regulares feitos aos centros antigos, o edifício serve de cenário para a avenida, e a avenida é essencialmente um campo para as paradas: um lugar onde pode-se reunir espectadores, nas calçadas ou nas janelas, para assistirem às evoluções e exercícios e marchas triunfais do exército - e ficarem devidamente atemorizadas e intimidadas. As construções levantam-se de ambos os lados, rígidas e uniformes,

19 "As ruas diretas promoviam a ordem pública desfazendo-se de cantos e frestas dos arrabaldes irregulares, e frustrando a tentação de obstruir passagens ou de proteger insurreições por meio de barricadas. O Rei Ferdinando, de Nápoles, gostava de dizer que 'ruas estreitas são um perigo para o Estado'. Sobre a Via Alessandrina, aberta em 1499 no lado do Burgo de Roma, uma fonte contemporânea escreveu: 'Os arquitetos decidiram construir uma rua diretamente da ponte (do Castelo S. Ângelo) ao portão do palácio (do Vaticano) para dar ao palácio uma perspectiva aberta, livre de obstáculos, e em casos de tumultos - que sempre acontecem nesta turbulenta Roma -, qualquer um poder rapidamente obter ajuda e defender-se de atacantes urbanos'." (KOSTOF, 1991, p. 230, tradução nossa) 


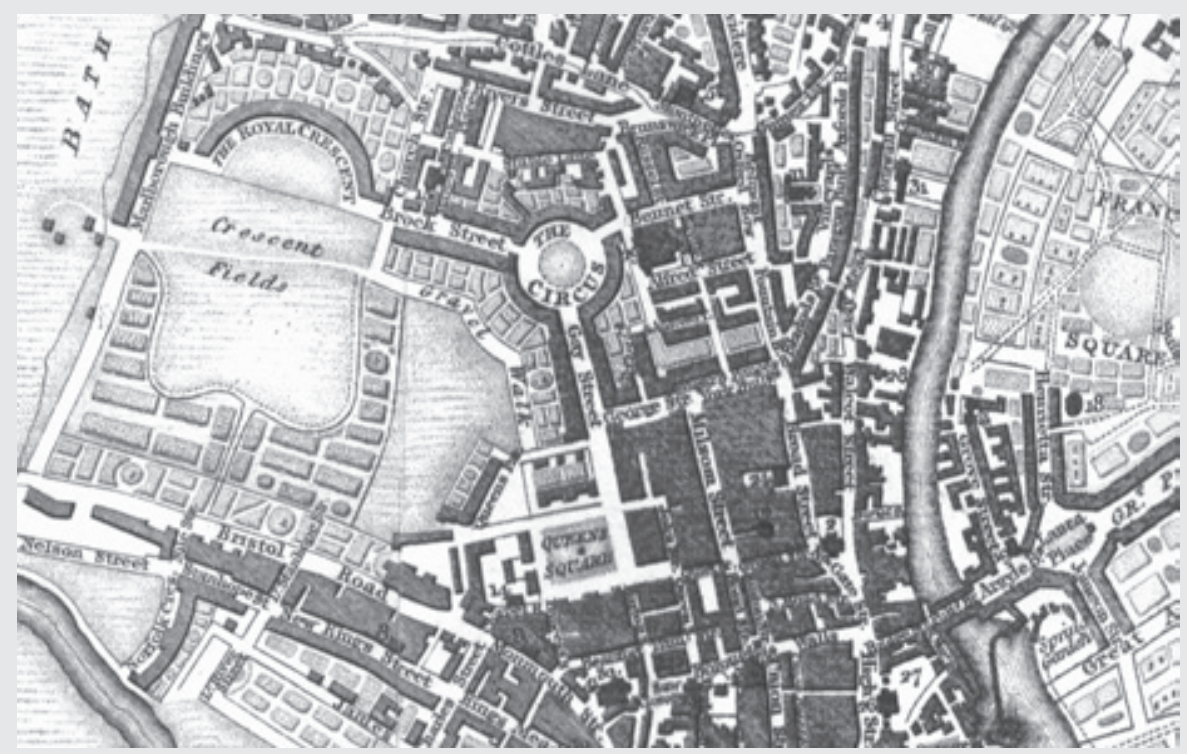

42. Pormenor do plano da cidade de Bath - intitulado A new and correct plan of the city of Bath (1818) -, com destaque para o Royal Circus e para o Royal Crescent, dois conjuntos de casas residenciais construídos na segunda metade do século XVIII. Plano retirado do livro The Historical and local new Bath guide, containing an accurate description of the public buildings, institutions, and amusements of the city; with observations on the medicinal virtues, and directions for the use of the hot waters. Fonte: Yale University, Cushing/Whitney Medical Library.

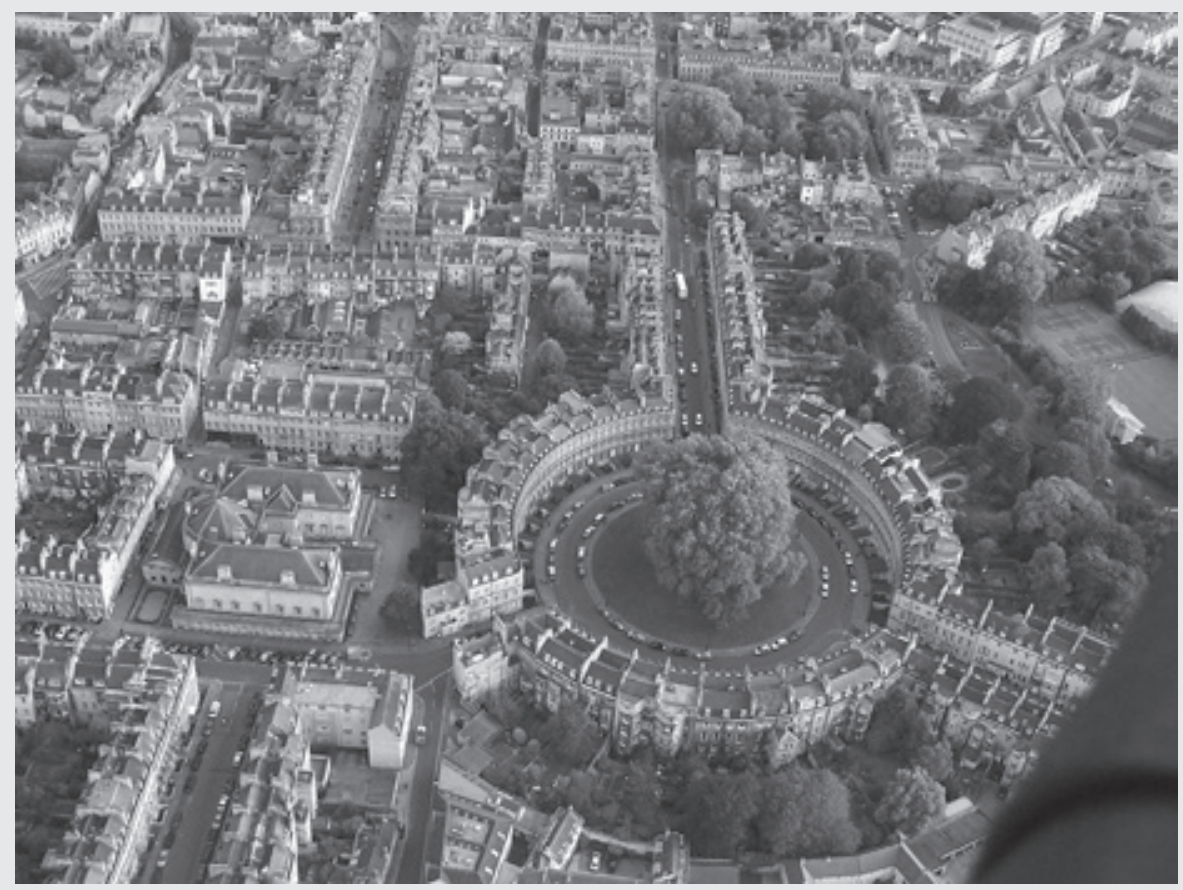

43. O Royal Circus, em Bath, Inglaterra, visto de um balão aerostático. O conjunto de casas residenciais de estilo georgiano foi levantado entre 1754 e 1768 por John Wood, the Elder (1704-1754), e por seu filho John Wood, the Younger (1728-1782), que assumiu os trabalhos em 1764. Fonte: Fotografia elaborada por Roger Beale - Licença CC BY-SA 2.0 / Wikimedia Commons contributors. 


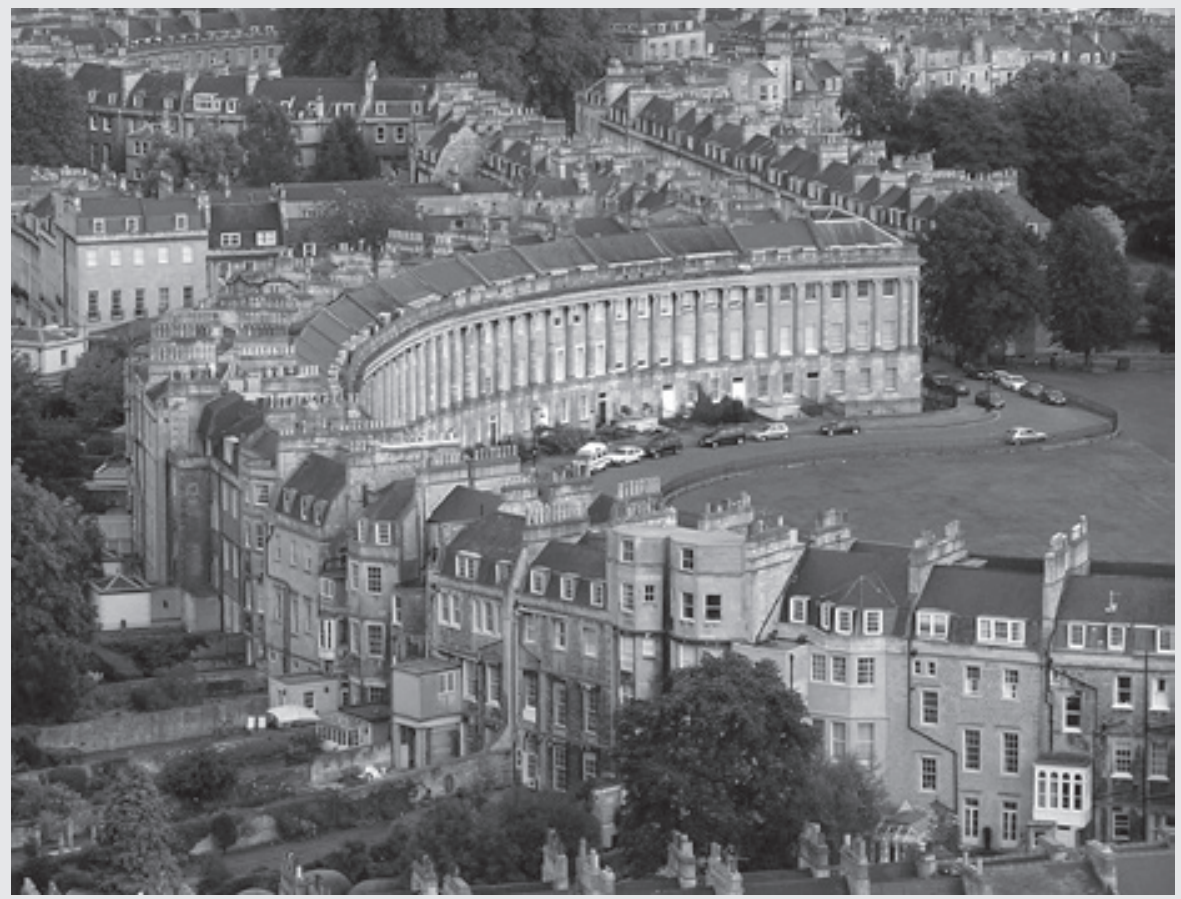

44. Royal Crescent, em Bath, Inglaterra, visto de um balão aerostático. O conjunto de 30 terraced houses em estilo georgiano foi desenhado por John Wood, the Younger, e levantado entre 1767 e 1774. Fonte: Fotografia elaborada por Adrian Pingstone (2005). Este trabalho foi declarado de domínio público pelo seu autor / Wikimedia Commons contributors.

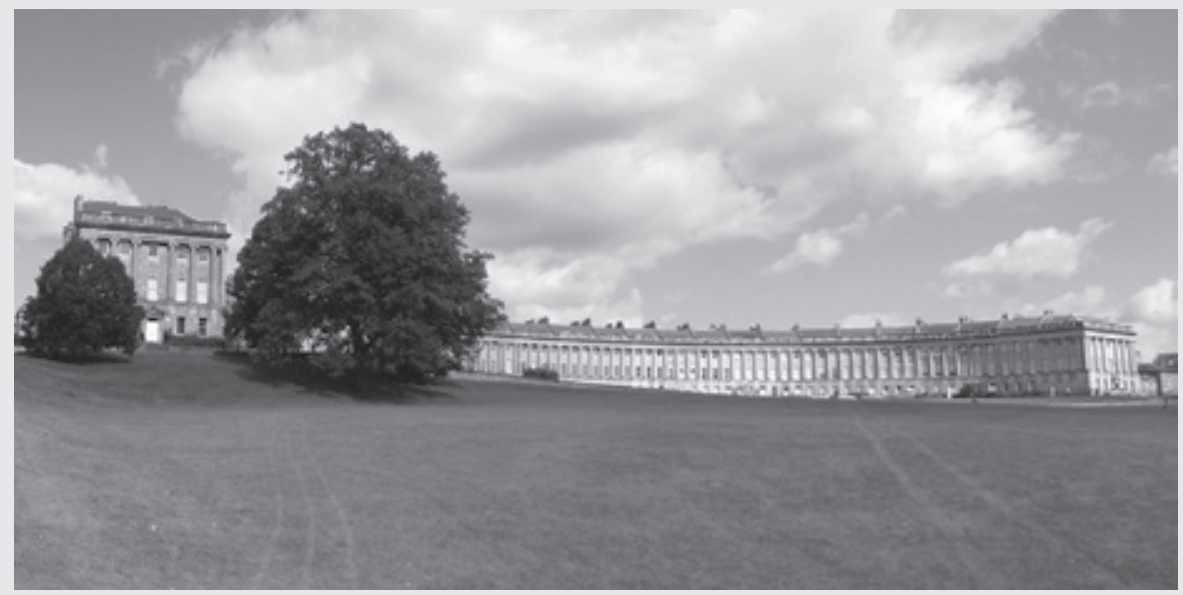

45. Royal Crescent, em Bath. Fonte: Fotografia elaborada por Oast House Archive (2007) - Licença CC BY-SA 2.0/ Wikimedia Commons contributors. 
como soldados em sentido: os soldados uniformizados marcham pela avenida, eretos, regulares, repetitivos: um edifício clássico em movimento. (MUMFORD, I989, p. 369-370, tradução nossa)

Além das avenidas encerradas por edifícios rigorosamente alinhados, foi também recorrente a abertura de vias longas e largas flanqueadas por árvores, principalmente em áreas mais afastadas ou adjacentes ao centro. Durante o período barroco, foi rara sua presença em logradouros que também apresentassem construções, sendo comum sua abertura em parques retilíneos e passeios públicos (as alamedas), mas também em vias de circulação que envolviam o centro (os bulevares), rasgadas nas imensas áreas vazias derivadas das demolições dos antigos sistemas defensivos de muralhas que protegiam as cidades, estruturas que já estavam obsoletas no século XVII. Assim, ou funcionavam como um eixo em poderosa fuga perspectiva provocada pela presença dos álamos sequencialmente distribuídos aos dois lados, ou como um cinturão verde que acolhia o antigo núcleo e o isolava das novas ocupações que se materializavam fora dos muros.

Logo, a projeção perspéctica que era conseguida pelo encadeamento sucessivo de edifícios alinhados agora poderia ser alcançada na sequência rítmica das árvores que, sempre com uma poda cuidadosa, marcavam o compasso ininterrupto e célere que buscava a fuga perspectiva. Desta forma, a visão idílica do campo e da natureza era trazida para o ambiente das grandes capitais, proporcionando mais um elemento para a trama cenográfica que caracterizaria a cidade barroca. ${ }^{20}$

Neste ponto, outro aspecto essencial da urbanística barroca, também vinculado às intervenções viárias que cidades preexistentes ou novos assentamentos viriam a sofrer, despontaria no cenário desde finais do século XVI: o uso revolucionário das técnicas da perspectiva - inovador se comparado àquele praticado especialmente nos períodos renascentista e maneirista. Em um ensaio de i99I, intitulado La cattura dell'infinito, o historiador da arquitetura e da cidade Leonardo Benevolo revelaria como, a partir da mudança no Seicento e no Settecento da ideia que se tinha do mundo, o sentido da palavra "infinito" também se alteraria radicalmente. Até o século XVI a noção de infinito estaria ligada à imagem construída mentalmente, e repassada para as artes, dos limites metafísicos ou religiosos do cosmos; no período barroco, com todas as transformações a que o homem esta-

20 A partir do século XIX se consolida o uso das alamedas e dos bulevares como vias margeadas por palacetes e, ao mesmo tempo, por árvores. O modelo seria a cidade de Paris. 
va submetido - alterações nas ciências, na filosofia, na religião, na política, na economia, nas sociedades, enfim, aquela revolução cultural que teria absoluta continuidade e rebatimento nas artes, na arquitetura e na urbanística -, o conceito de infinito se libertaria dos limites impostos pela sua herança renascentista: acolheria a ideia de se vencer o mundo fechado preexistente em prol da busca ao universo sem fim, situação que estaria em consonância com os termos perturbadores que a nova ciência deflagrava. (BENEVOLO, I99I, p. 5)

Nesta direção, seria despertado um desejo de se representar a noção inédita da dimensão ilimitada do cosmos através dos meios físicos tradicionais da arte e da arquitetura, ação que na urbanística recairia na ampliação desmesurada dos eixos retilíneos que já rasgavam o espaço urbano desde finais do século XV. As grandes vias diretas abertas no ambiente da cidade não serviriam mais apenas a motivos utilitários; não seriam coordenadas simplesmente por razões militares, de tráfego, de organização e legibilidade do espaço urbano; o uso simbólico e estético dos grandes eixos superaria o objetivo da dramática antecipação visual, em profundidade, de importantes estruturas monumentais; não se prestaria, exclusivamente, a exercer o papel de enquadramento perspectivo de um organismo representativo do poder vigente. Para a urbanística barroca também despontaria o intento de romper os limites tradicionais da perspectiva viária urbana em vários quilômetros, ampliando-a para o máximo alcance do que poderia ser percebido pelo olhar (algumas vezes indo além do que seria viável capturar com a visão), promovendo um sentido de representação que entraria em consonância simbólica com a ideia de um universo de extensão ilimitada (Figuras 46-49). Benevolo (I991, p. 69, tradução nossa) resume:

A ampliação de extensão de uma perspectiva até o limite da percepção visual nasce de uma situação característica da cultura barroca: a expectativa da confirmação das regras da perspectiva com a nova escala se entrelaça com o temor e a emoção de que essas regras percam sua vigência. Esta aventura vive à sombra do poder absoluto, que dispõe da autoridade e dos meios econômicos necessários. A ampliação das dimensões se converte, por sua vez, em um dos temas preferidos da arquitetura áulica, onde o absolutismo expressa ao mesmo tempo sua componente emotiva - a exaltação hiperbólica do governo -, e a organizativa - a concentração dos recursos disponíveis. A combinação de ambas as coisas faz que os projetos abandonem a cidade e se apoderem da paisagem extraurbana. 
46. Schloss und Park Nymphenburg. Miniatura do Palácio e do Parque de Nymphenburg, em Munique (1730), elaborada por Maximilian von Geer (1680-1768). A grande estrutura foi, em sua maior parte, edificada no século XVIII. Fonte: Wikimedia Commons contributors.

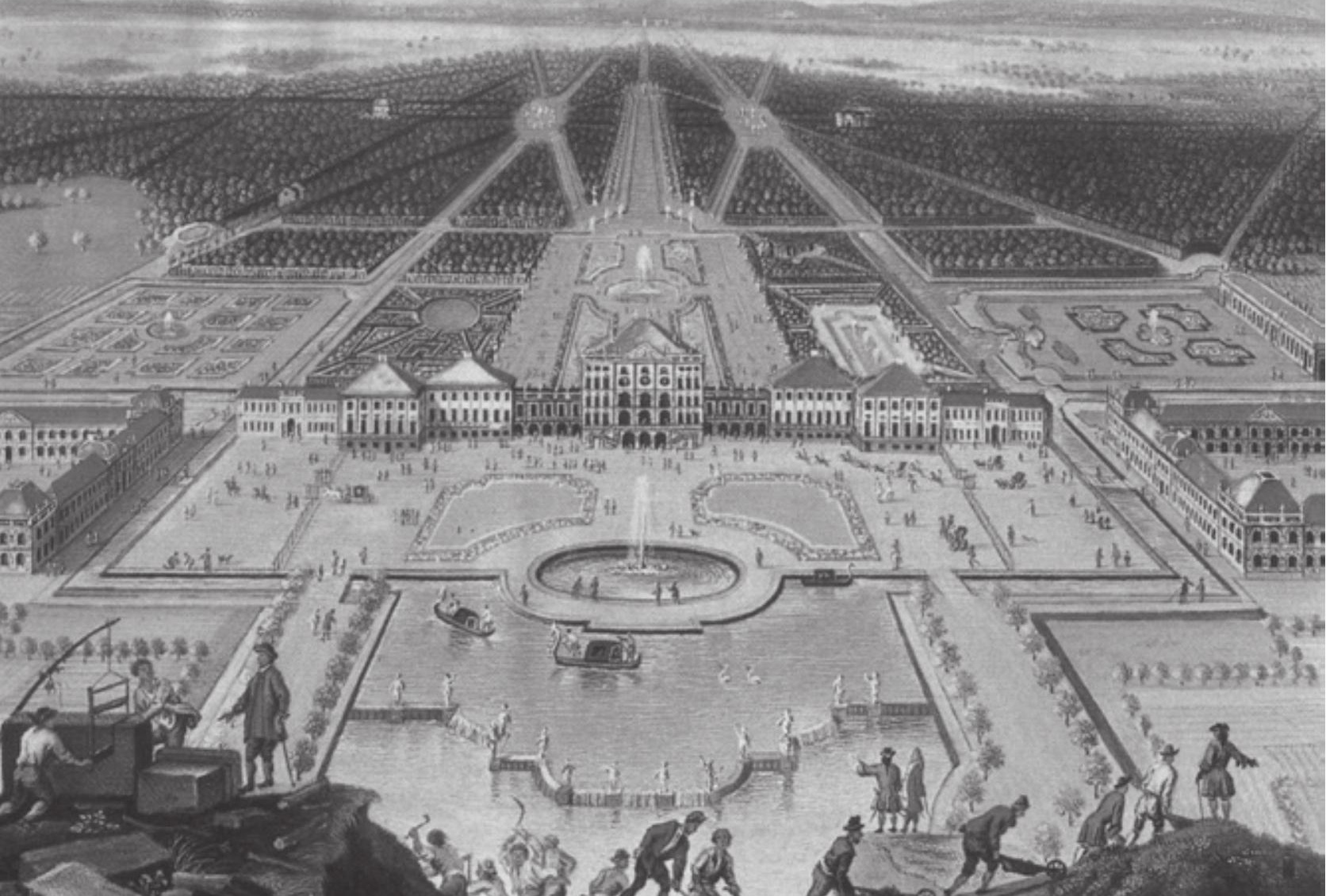




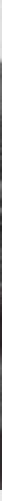

47. A perspectiva infinita do grande canal que dá acesso ao Palácio e ao Parque de Nymphenburg, em Munique. Fonte: Fotografia elaborada pelo autor (2012).

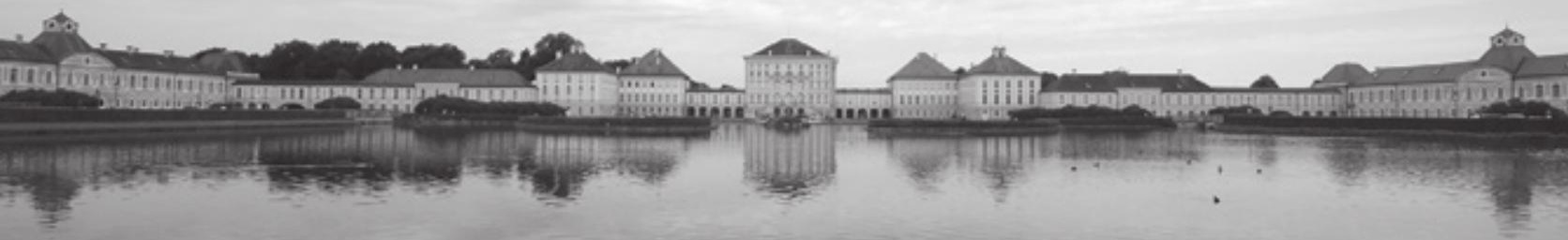

48. Palácio de Nymphenburg. Fonte: Fotografia elaborada pelo autor (2012)

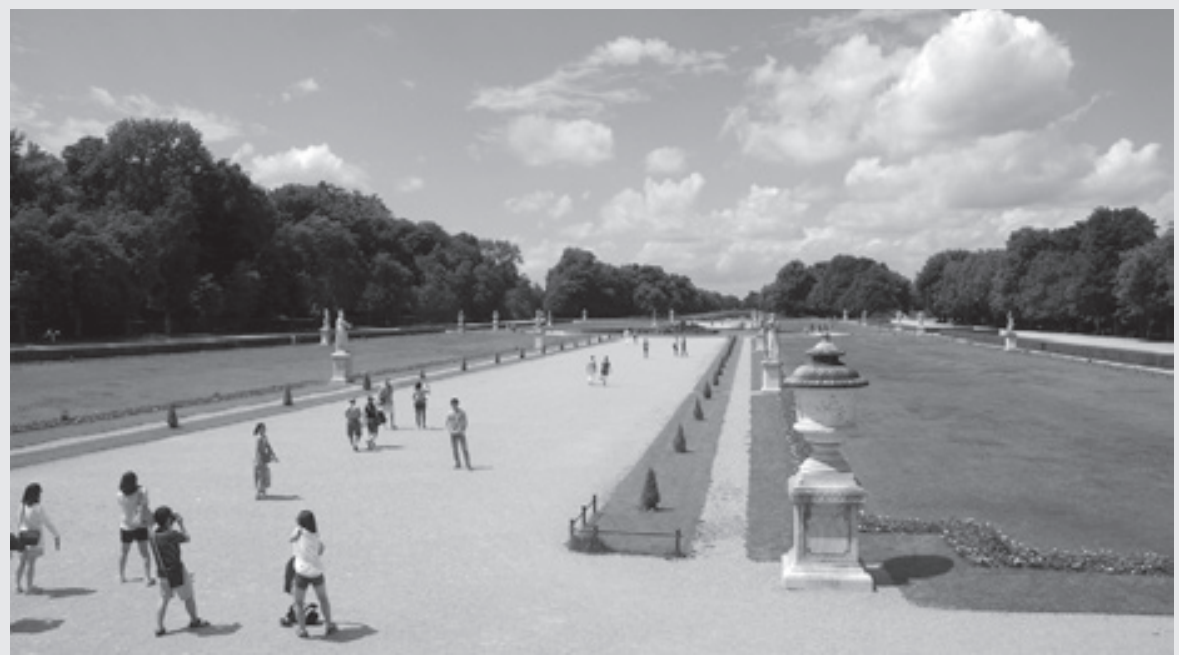

49. Jardins à francesa do Palácio de Nymphenburg, em Munique. Fonte: Fotografia elaborada pelo autor (2012). 
As palavras de Benevolo revelariam outro aspecto profundamente significativo da urbanística do período: o enorme apreço que os governantes barrocos nutriam por exportar as experiências urbanísticas mais relevantes para além dos limites citadinos, para o espaço natural do campo - ambientes distantes dos centros urbanos congestionados. A realeza e sua corte dedicariam somas inimagináveis para a construção das residências reais, dos monumentais châteaux com seus grandes jardins contíguos e com sua completa infraestrutura de apoio ao pomposo funcionamento exigido ao ambiente real. Estes imensos palácios chegariam, algumas vezes, a substituir a própria capital monárquica como o lugar efetivo de moradia do governante absoluto:

O culto à autoridade monárquica tem seu reflexo na grandiosidade dos cenários edificados e exige da arquitetura construções físicas, fixas e temporárias, em consonância com o tom hiperbólico da literatura de corte, e, portanto, não só magníficas, mas também surpreendentes e dramáticas. Não obstante, existe uma desproporção insuperável entre os recursos e as ambições; especialmente, os recursos financeiros concentrados na corte são absolutamente inadequados às obras das cidades, nas quais os custos das modificações são muito elevados e falta em grande medida o multiplicador dos encargos privados para completar os espaços construídos. Os governos absolutistas acrescentam às cidades algumas ordenações visualmente importantes, porém estruturalmente secundárias, e as grandes ordenações unitárias das cidades se transferem aos espaços abertos do território vizinho: produzem castelos e jardins, ao invés de palácios, bairros ou cidades. (BENEVOLO, I99I, p. 37, tradução nossa)

Fica claro que o característico anseio por uma planificação global, pela absoluta transformação do cenário das capitais por meio dos instrumentos reguladores da urbanística clássico-barroca, não poderia ser satisfeito plenamente nos densos cenários preexistentes de centros urbanos como Paris, Londres, Viena, Praga, Madri, Roma, Nápoles. Mesmo com os colossais recursos que o imperador e sua corte poderiam armazenar em privilégio das intervenções na sede do governo, não era executável em termos econômicos, técnicos e políticos a prática da tabula rasa, a total aniquilação do ambiente preexistente para a reconfiguração irrestrita do núcleo citadino segundo os novos preceitos da urbanística moderna. Por isso, reis, imperadores, príncipes, enfim, os governantes absolutistas se dedicariam tão obcecadamente a construir suas residências no campo, já que no 
espaço natural e vazio extraurbano seria possível a implantação de estruturas palacianas que dominassem gigantescas áreas ajardinadas - muitas vezes aparelhadas com verdadeiras cidades concebidas apenas para servir a realeza e sua corte -, estruturas que, frequentemente, chegariam a ultrapassar, em dimensão, a própria extensão da capital.

Os eixos perspectivos ilimitados, estendidos a muitos quilômetros, bem como qualquer preceito de ordem, simetria, cenografia e drama comuns à urbanística barroca, seriam perfeitamente aplicáveis nestas áreas virgens e bucólicas. Por isso, os pressupostos da perspectiva barroca com o ponto de fuga disposto no enquadramento infinito, aqueles princípios celebrados por Leonardo Benevolo, seriam preferencialmente praticados na planificação dos territórios naturais em ocasião do assentamento destas grandiosas estruturas de poder que foram as residências da realeza e seus monumentais jardins. Ou seja, confirmariam e ampliariam os preceitos trabalhados anteriormente e que colocavam a arte dos jardins como um dos artifícios que maior influência teria exercido para a urbanística do período humanista - com a única diferença que, nos châteaux barrocos, o conjunto palácio-jardim não era apenas um elemento de experimentação dos princípios que seriam acionados nas cidades a posteriori, mas sim formava, definitivamente, uma estrutura urbanística completa. As palavras do arquiteto e historiador espanhol Fernando Chueca Goitia (I9II-2004), proferidas no sintético livro Breve historia del urbanismo, confirmam esta afirmativa:

O Barroco constitui, ordena o mundo como panorama. É por esta simples razão que devia fatalmente descobrir o urbanismo como arte, e encontrar um instrumento que facilitasse a possibilidade de criar o panorama onde ele ainda não existia. Daqui que o urbanismo se ensaiasse primeiro nos jardins, cujos traçados influíram tão decisivamente nos das cidades e conjuntos urbanos. (CHUECA GOITIA, I986, p. I46, tradução nossa)

Não obstante, em um aspecto a tese de Benevolo deveria ser avaliada com atenção. A monumental empresa barroca se consolidou quando a arte superou radicalmente a experiência da realidade e rompeu as amarras do conhecimento objetivo para abrir caminho ao domínio humano da imaginação - compreendida como um dos princípios essenciais da cultura seiscentista e setecentista. Por isso, não seriam exatamente as imagens que derivavam do mundo sensível ou do mundo dos conceitos que se afirmariam como o tema básico para a arte, mas 
aquelas que nasciam da habilidade criativa da mente humana, da capacidade de interpretação ilimitada contida na apreensão dos fenômenos pelos espectadores. Logo, a arte barroca se afastaria decididamente do desejo de representação da natureza em prol da busca pelos artifícios da fantasia; do ilusionismo óptico; da maravilha; da imaginação. (BAETA, 2012, p. 138)

Nesta direção, a tese de Benevolo sobre a "captura do infinito" se revelaria polêmica se confrontada àquela debatida por Argan (2004, p. 46), já que colocaria, como elemento de inspiração máxima para a abertura dos grandes eixos perspectivos rasgados nos territórios naturais das nações europeias, um fenômeno derivado diretamente dos novos preceitos cogitados pela ciência moderna. De certo modo, Benevolo estaria negando a ideia de que a arte barroca perseguiria, primordialmente, o exercício da maravilha, da fantasia, da hipnose como meio para a superação do naturalismo herdado da Renascença - como caminho para o abandono das verdades da ciência em nome da elevação da experiência artística a níveis superiores, a patamares só possíveis de serem alcançados através das possibilidades infinitas oferecidas pelos domínios da imaginação humana.

Contudo, independente dos princípios declarados pela nova ciência, a projeção ao infinito se adequaria, perfeitamente, tanto à busca da poética barroca ao apelo persuasivo e propagandístico através da arte, como ao seu interesse obcecado pela imaginação. As grandes vias retilíneas abertas nos centros do poder barroco, bem como os caminhos imensuráveis rasgados nos jardins dos châteaux da realeza, usualmente teriam, como elemento de origem da perspectiva infinita, uma estrutura representativa dos grandes organismos do poder absolutista - um obelisco egípcio coroado por um crucifixo; a dinâmica fonte barroca; a estátua equestre de um importante monarca; o palácio do imperador; a sede administrativa da nação; a imponente basílica; uma grandiosa estrutura conventual; o volumoso châteaux das residências reais. Quando o transeunte olhava na direção oposta ao monumento dedicado ao governante ou à Igreja, a perspectiva se perderia na dimensão ilimitada do ponto de fuga aberto ao vazio, artifício da imaginação ilusionista que contribuiria para a representação simbólica do poder infinito do monarca ou do próprio Deus católico; ao percorrer a estrada, a avenida, a rua na outra direção, o enquadramento perspectivo revelaria, em profundidade, o ser supremo, político ou religioso, representado pelo monumento assentado no ponto de fuga. Ou seja, o apelo ilusionístico à imaginação provocado pelo sistema 
composto pelo monumento e pelo eixo perspectivo disposto à frente deflagraria um poderoso engenho da retórica e da imaginação barrocas.

Por outro lado, este interessante e eficiente mecanismo de persuasão barroca poderia ser vastamente multiplicado através de um mecanismo profundamente hábil: sejam ruas, avenidas, caminhos ajardinados, alamedas, as vias retilíneas da urbanística barroca frequentemente conformariam sistemas radiais de organização espacial, herança das experimentações que aconteceram no teatro e na arte dos jardins durante o Cinquecento. A ideia seria criar um encontro de artérias de tráfego em um largo ou praça onde, nas proximidades de seu ponto focal, ou coincidindo com ele, se desvelaria a imagem daquele monumento escultórico ou daquele organismo arquitetônico (às vezes, ambos) representativo do poder do Estado ou da Igreja. A configuração mais típica seria o trivium, ou o sistema urbano onde três vias desenhariam uma espécie de tridente. ${ }^{21}$ Outra opção seria o polivium, a multiplicação destes eixos viários que continuariam convergindo a um grande espaço central (Figura 50).

Independentemente do uso de três ou mais artérias radiais, a imagem oferecida teria profundo sentido retórico: mais uma vez, do ponto onde os eixos imaginários das vias se encontravam, seria oferecida a dramática visão perspectiva dos caminhos possíveis a percorrer - panoramas abertos que se perdiam no infinito. Ou seja, do ambiente da praça, mirando na direção oposta ao monumento representativo do poder local, a vista se dissipava no ponto de fuga enquadrado pela extensão perspectiva ilimitada - o vazio não apreensível pelo olhar, a única dimensão capaz de simular a faculdade sobrenatural da religião católica ou dos governos absolutistas barrocos. Por outro lado, alcançando a praça por qualquer uma das vias radiais, a imagem do artefato representativo da Igreja ou do Estado estaria coincidindo com o distante ponto focal - por qualquer dos percursos escolhidos o passante veria, perdido na fuga distante, o edifício, a estátua, o monumento. Logo, todos os caminhos levariam ao monarca ou a Deus, entidades que se encontravam no centro ideal do universo. Christian Norberg-Schulz (19262000), arquiteto e crítico norueguês, concluiria, em seu estudo de i974, publicado originalmente em italiano e intitulado Significato nell'architettura occidentale:

21 "O trivium, o encontro de três ruas radiais, chegando ou saindo de uma piazza, está seguramente ligado a experiências da Renascença com esquemas radiais de urbanismo; mas é menos totalitária e muito mais flexível. Há um enorme potencial para uma área urbana de tamanho variável tornar-se um ponto de encontro crucial para o qual todo o movimento irá fluir, ou ao contrário, da qual todo o movimento irá escoar, eventualmente." (KOSTOF, 1991, p. 235, tradução nossa) 


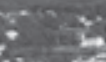

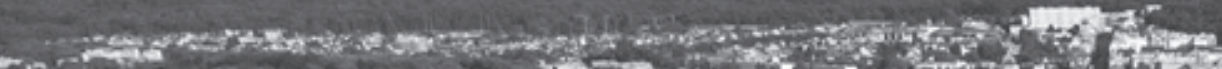

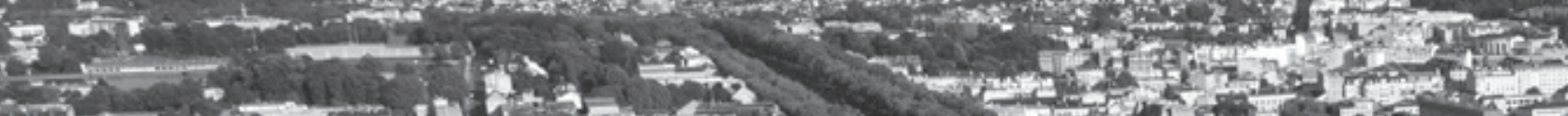

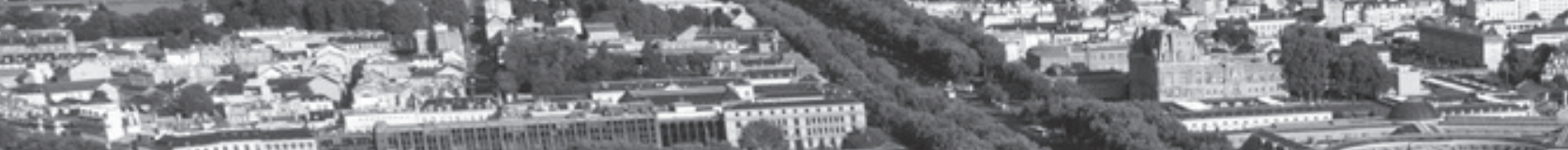

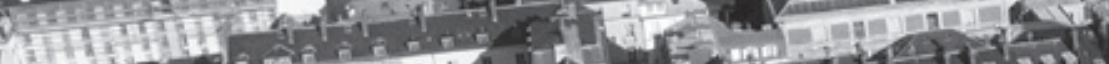
7.4
17 17

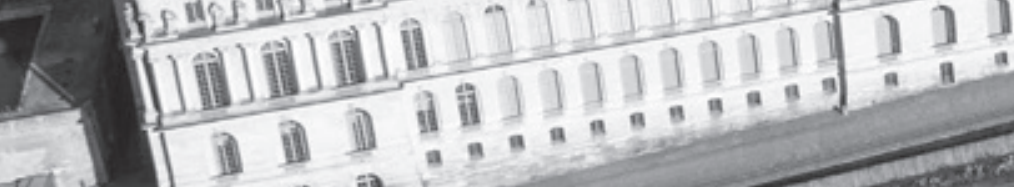
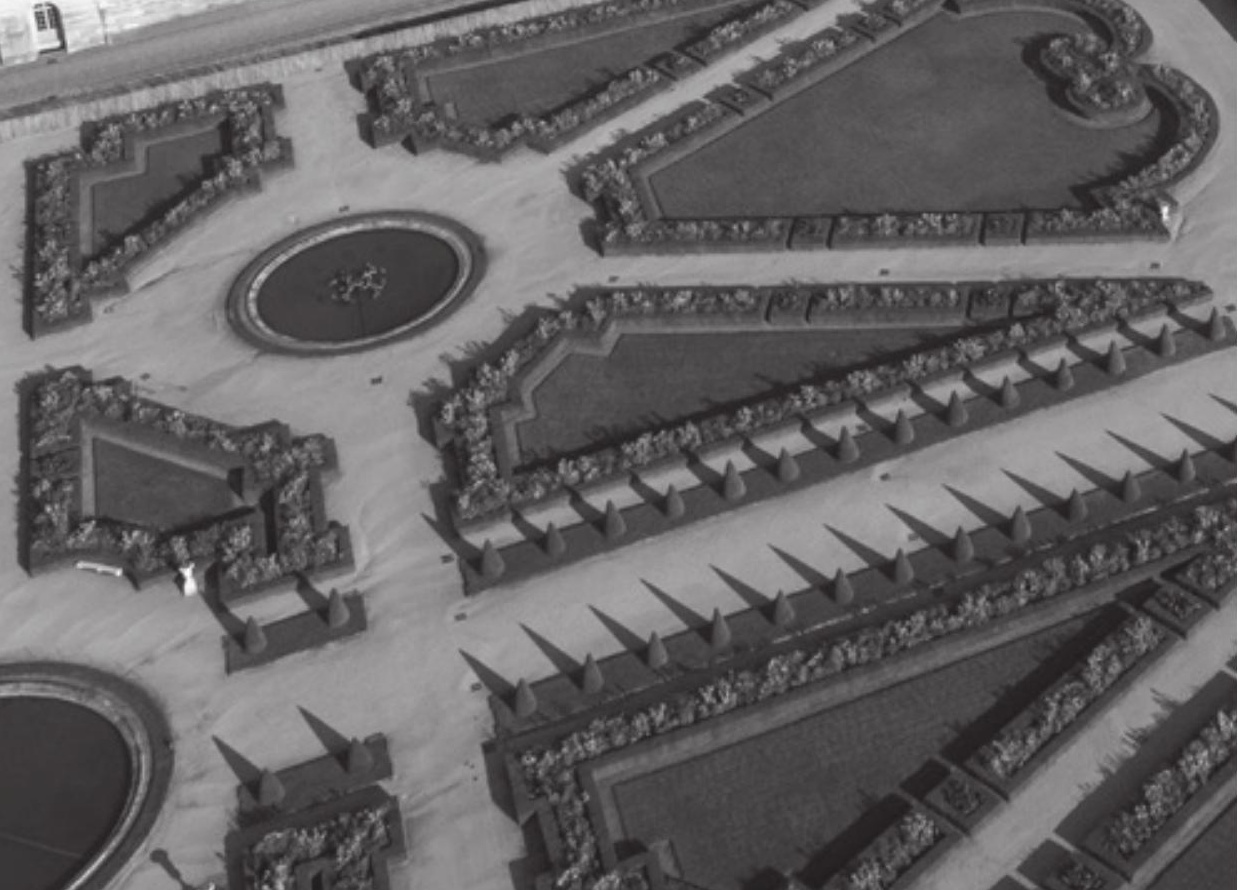
50. Vista aérea de Versailles: os jardins, o palácio e a cidade. Fonte: Fotografia elaborada por Toucan Wings (2013)

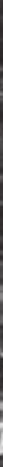

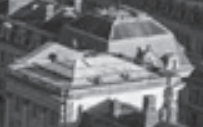
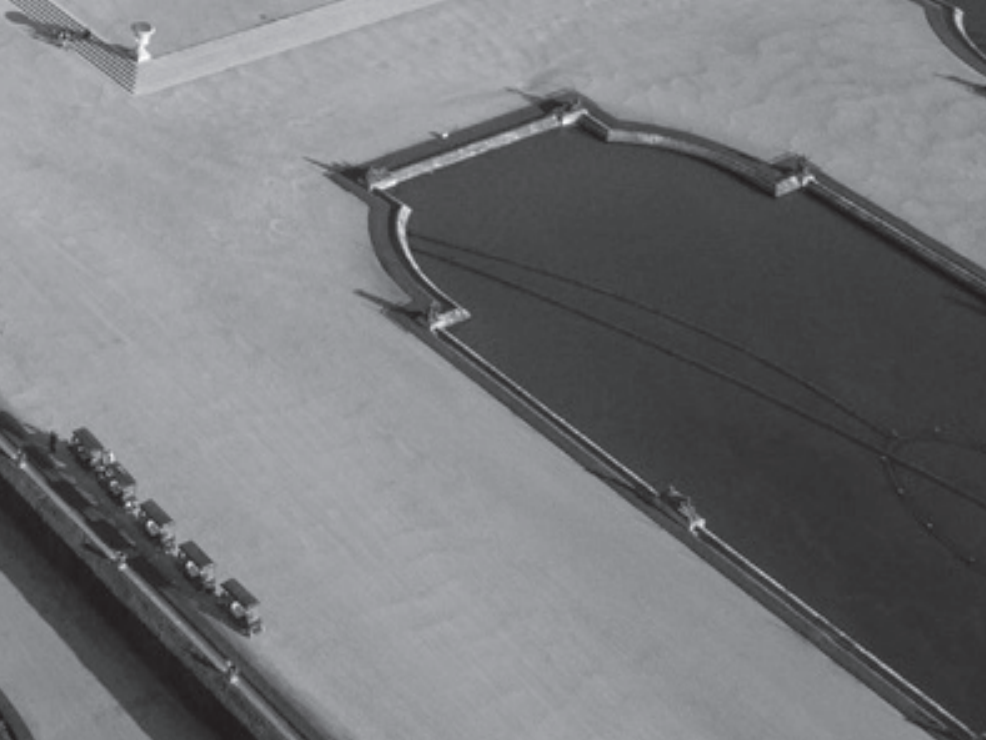
Persuasão e propaganda adquirem significado quando se referem a um centro, que representa os axiomas básicos do sistema. Os centros religiosos, científicos, econômicos e políticos do século XVII eram focos de forças radiantes que, vistas a partir do centro, não teriam limites espaciais. Portanto os sistemas da época possuíam um caráter aberto e dinâmico, e partindo de um ponto fixo, podiam prolongar-se ao infinito. (NORBERG-SCHULZ, I974, p. 287, tradução nossa)

\section{Urbanística barroca na França dos séculos XVII e XVIII}

A unidade a que tende a urbanística europeia depois de 1648 pode em grande parte reconduzir-se à sempre mais forte influência determinada pela França de Luís XIV. Esta influência se estende naturalmente a outras manifestações - à arte, à moda -, mas se pode dizer que a qualidade alcançada na projetação de cidades, de jardins, de grandes conjuntos arquitetônicos, de sistemas de fortificação, representa verdadeiramente a contribuição mais duradoura e característica da França à urbanística europeia, afetando praticamente todo o continente e suas ramificações coloniais.

Os ingredientes da planificação 'à francesa' amadurecem já na primeira metade do Seicento, mas representam, como já se viu, nada mais que uma das tantas variantes nacionais, em um período condicionado por um 'particularismo' nacionalista, municipalista, religioso e econômico; todavia, depois de 1648 , a tendência à confluência em uma forma unitária das várias experiências leva rapidamente à superação dos resíduos ecléticos da primeira metade do século, para alcançar um sistema cultural geral que se faz, ele mesmo, modelo e estímulo para outros países. A urbanística francesa, da arte dos jardins e dos parques até as promenades urbanas, das inovações da engenharia, da arte das fortificações de Vauban até as inéditas soluções arquitetônicas à escala urbana - como o Louvre ou Les Invalides, em Paris -, se impõe penetrando profundamente nos países centro-europeus, e desenvolvendo plenamente a própria influência no século XVIII. [...] Aquilo que se faz em Paris e na França vem rapidamente imitado, e é imitável na medida em que está inserido em um sistema completo de organismos burocráticos e técnicos como o que dispõe o Estado mais forte e mais organizado da Europa. (GUIDONI; MARINO, I979, p. 473, tradução nossa) 
As palavras proferidas por Angela Marino - em seu já citado livro de I979 que versa sobre a cidade do século XVII, escrito em parceria com Enrico Guidoni - apresentam uma boa introdução para este item que vem a propor um necessário aprofundamento na busca pelas características das soluções adotadas pela urbanística no período barroco e discutidas anteriormente. Para isso, serão analisadas, com brevidade, algumas iniciativas urbanísticas praticadas na França dos séculos XVII e XVIII, em nome da promoção de um juízo pessoal sobre o poder que estas intervenções deteriam de alterar plenamente o caráter da paisagem e do cenário das cidades - particularmente a avaliação das transformações que diriam respeito à remodelação dos espaços urbanos na direção dos princípios da retórica, da persuasão e da imaginação barrocas, diretrizes caras aos governantes da época.

Neste sentido, não há dúvidas de que a nação francesa tomaria a frente das iniciativas mais maduras em relação à urbanística no cenário europeu, principalmente no reinado de Luís XIV (I638-I7I5), rei que subiria ao trono em I643, mas que só governaria efetivamente após a morte, em I66I, de seu primeiro ministro, Jules Mazarin (I602-I66I). ${ }^{22}$ Nos tempos do Rei Sol, o império se consolidaria e despontaria como o mais poderoso e influente Estado do mundo ocidental, ultrapassando enormemente a supremacia da nação espanhola que teria marcado parte do século XVI. Não obstante, como diria Marino, os empreendimentos em grande escala aplicados no seio das mais importantes cidades preexistentes, bem como aquelas iniciativas de fundação de residências reais fora dos limites edificados, ou de criação de núcleos urbanos constituídos ex novo com objetivos militares ou políticos, se fundamentariam, coerentemente, nas intervenções que vários assentamentos urbanos sofreriam na primeira metade do século, particularmente nos reinados de Henrique IV de Bourbon (I553-16Io), que governaria de 1589 até a sua morte, e de seu filho Luís XIII (I60I-I643), que reinaria a partir de i6ro. Além disso, as ações urbanísticas praticadas durante o Ancien Régime teriam como base de influência as já comentadas tendências explicitadas no Cinquecento, particularmente a interface com os campos da engenharia militar, da arte dos jardins e da cenografia. 


\section{As praças reais parisienses}

O urbanismo francês do grande século compraz-se com um tema que o Barroco adotará com entusiasmo: a praça monumental construída para servir de quadro à estátua de um rei. A preocupação da magnificência própria do urbanismo barroco e o desejo de exaltar a monarquia centralista, vértice de todo o sistema político preponderante, conjugam-se neste tema. (CHUECA GOITIA, I986, p. I53, tradução nossa)

As praças reais viriam a ser as estruturas mais marcantes do projeto de remodelação visibilística que a cidade de Paris sofreria a partir de finais do século XVI, na época do reinado de Henrique IV, le Grand - quando foram construídas a Place Dauphine e a Place Royale (posteriormente Place des Vosges), e projetada, mas não edificada, a Place de France. O ápice desta nova tradição aconteceria com a abertura, no final do século XVII, na época do Roi-Soleil, da Place des Victoires e da Place Vendôme (originalmente Louis le Grand). Não obstante, esta prática se estenderia até meados do século XVIII, quando o Rei Luís XV (I7IO-I774) viria a patrocinar a abertura da Place de la Concorde, originalmente batizada Place Louis XV.

Como diria Fernando Chueca Goitia, a principal característica destes ambientes era a presença em posição surpreendente da estátua do rei, bem como a regularidade das edificações ou das fachadas que compunham a praça. Ao contrário das praças barrocas romanas, que serão analisadas no próximo capítulo, nas quais, frequentemente, um ou mais edifícios se destacavam de forma imponente - organismos civis ou religiosos que se tornavam os protagonistas da percepção cenográfica do espaço -, nas places royales francesas nenhuma construção isolada era ressaltada. O que sempre se buscava era a produção de um vigoroso conjunto de idênticas frontarias contíguas de casas de habitação, comércio ou negócios, panos cenográficos que envolveriam os limites construídos da praça e que adquiririam monumentalidade pela repetição obstinada do mesmo motivo tipológico. Uma grandiloquência que pela sua monotonia não chegaria a ameaçar o papel primordial e centralizador que a majestosa estátua do monarca exerceria para o inovador contexto - a verdadeira protagonista da experiência dramática das praças.

A primeira das praças reais construídas em Paris por iniciativa do Rei Henrique IV foi a Place Dauphine. Sua abertura está condicionada à edificação, a partir de I578, por iniciativa do Rei Henrique Ill de Valois (I55I-I589) - que reinou entre 1574 e 1589 -, de uma nova ponte que atravessaria o Rio Sena, passando 
por cima da área pantanosa na ponta oeste da Île de la Cité, uma alternativa ao tráfego congestionado que cruzava os conjuntos de pontes que venciam o rio desde o período medieval, passagens que atravessavam as distâncias menores que se estendiam da margem esquerda do Sena até a ilha onde se assentava a catedral de Notre-Dame, e da ilha até o aglomerado urbano da margem direita do rio. Apesar de os dois braços da Pont Neuf terem sido projetados e iniciados como as outras pontes parisienses, com a presença de edificações regulares dispostas aos lados da pista, dando continuidade ao conjunto de casas que preenchiam as ruas que desembocavam no Sena (fato que impedia a efetiva percepção, por parte do transeunte, de que estava atravessando o rio), em I6o2, após várias interrupções nos trabalhos (MORRIS, I979), Henrique IV aprovaria o projeto definitivo, prevendo a retirada das edificações da ponte com o objetivo de liberar mais espaço para o trânsito e oferecer uma inédita amplitude visual e elegância ao organismo proposto. Desta forma, a ponte abriria o visual para o rio a quem chegava à margem direita, pelo norte: vindo do subúrbio de Saint-Honoré, descendo a Rue de la Monnaie, tangenciava o vértice formado pela área em forma de triângulo, oriundo da retificação dos pântanos da ponta oeste da ilha de Notre-Dame, e prosseguia até a margem esquerda, na direção meridional, no bairro de Saint-Germain, onde encontraria a pequena e retilínea Rue Dauphine - que estava sendo aberta pelo imperador com muitas dificuldades e conflitos por desapropriar diversas áreas pertencentes a ordens religiosas. Deste modo, o conjunto constituído pela Rue de La Monnaie, que cruzava o lado norte da cidade (conhecido na Idade Média como la ville), a ponte nova que cortava o vértice da principal ilha sobre o Sena (área conhecida como la cité) e a recém-traçada Rue Dauphine, que rasgava parte do setor sul da cidade (conhecido no Medievo como la université) (MíNGUEZ; RODRÍGUEZ, 2006, p. 177), formaria o primeiro eixo moderno de consolidação e de união da cidade, conectando os dois lados e os aproximando da região do palácio do Louvre, na margem norte (direita).

Para enfatizar esta importante incitativa amadurecida por Henrique IV e por seu ministro de finanças, Maximilien de Béthume, duque de Sully (1560I64I), foi iniciada, em I607, a primeira praça real da cidade de Paris, aberta em homenagem ao delfim - o jovem filho do imperador: recinto que seria denominado, justamente, Place Dauphine. Com sua forma triangular, a praça ocuparia, adequadamente, o terreno pantanoso, fruto dos aterros praticados na face oeste da Île de la Cité, tendo como limite oriental o palácio real, que seria parcialmente 
oculto pela base do triângulo que formaria a praça; do outro lado, teria seu vértice se abrindo, inusitadamente, à estátua equestre de Henrique IV, organismo colocado acima de uma plataforma, um pouco à frente da área onde se dava o encontro, na ponta da ilha, dos dois braços que recentemente tinham passado a formar a armação da Pont Neuf. Neste sentido, mesmo estando assentada para além dos domínios físicos da praça, a escultura que retratava o imperador não poderia estar mais conectada à Place Dauphine, enquadrada em profundidade pela perspectiva forçada que se desenvolvia através do eixo formado pela abertura no conjunto de edificações regulares na base do triângulo da praça - à frente do Palais Royale - até o vão exposto na fresta de seu vértice, vão que emoldurava, em perspectiva ilusionística, o panorama da estátua do rei em seu cavalo. Este efeito dramático era enfatizado pelo ritmo inabalável da modenatura presente nas fachadas homogêneas de casas com telhados coincidentes que compunham todos os lados da praça - edificações que foram, infelizmente, alteradas, só restando as duas que emolduram a abertura do vértice do triângulo.

Para além deste fato, a estátua que figurava na plataforma mais a oeste da ponte não interrompia o percurso de quem transpunha o rio, e ainda oferecia vistas fascinantes retiradas dos dois segmentos da travessa - a imagem da escultura em generoso contraponto sob o fundo de uma das margens edificadas do rio (Figuras 5I-56). Quando o transeunte alcançava a metade do caminho, acima da ponta da ilha, poderia apreciar, a oeste, a imagem imediata da grande escultura; mas, se olhasse para a direção oposta, apreenderia tanto o contorno externo como a cavidade interna da marcial e regular Place Dauphine - uma perspectiva monumental semelhante àquela promovida por Michelangelo Buonarroti (I4751564) na Piazza del Campidoglio, em Roma. Em seu livro de I979, Arquitettura barocca, Norberg-Schulz (I979, p. 37-38, tradução nossa) resume:

Entre a ponte e a antiga Île de la Cité, foi criada uma nova praça de forma triangular, a Place Dauphine. Onde o eixo da praça cruza com a ponte, é colocada uma estátua equestre do soberano. A ponte era coligada por ambos os lados com estradas retilíneas que levavam, ao norte, à igreja de Saint-Eustache, e, ao sul, à Ponte Saint-Germain. Paris ganhou, deste modo, o seu primeiro eixo urbano. Este traçado transversal cruza em ângulo reto o eixo principal do plano, constituído pelo Rio Sena. A Place Dauphine rende evidente, de um ponto de vista arquitetônico, o eixo constituído pelo rio; e este foi o primeiro de 
uma série de projetos que deram ao Sena uma importância superior àquela dos rios de qualquer outra capital. A praça consistia em dois longos edifícios, cujas alas convergiam formando um triângulo. As estradas traçadas ao exterior sobre os dois lados formam, em conjunto com o eixo principal, um tridente que parte da estátua. Os edifícios contêm uma série uniforme de apartamentos relativamente pequenos, com lojas no pavimento térreo. A articulação demonstra uma acentuação, não privada de incertezas, das superfícies e dos volumes (definidos pelos tetos altos e íngremes), antes que um uso do tipo 'italiano' das massas e dos elementos plásticos. Sobre a praça não existem monumentos; a estátua de Henrique IV estava situada de modo a servir como 'foco perspectivo' para toda a cidade.

Na mesma década da abertura da Place Dauphine, se daria a construção daquela que marcaria, possivelmente, o modelo mais celebrado e clássico de praças reais francesas - a Place Royale, conhecida posteriormente como Place des Vosges, edificada no lugar no qual se assentava o Hôtel des Tournelles, residência real que seria demolida por Catherine de Médicis (I5I9-I589) após a morte acidental de seu marido, o Rei Henrique Il (I5I9-I559), em um torneio, como era de praxe acontecer naquela área. Concluída em I6ı2, a Place des Vosges não foi projetada para ter em seu centro a estátua equestre de um rei; da mesma forma, não seria completamente revolucionária e original, já que foi precedida, ou pelo menos contemporânea, da Place Ducale, que estava sendo edificada durante a construção, no nordeste da França, da cidade fortificada de Charleville - por isso o projeto da Place Royale de Paris é comumente atribuído a Louis Métezeau (I559-I6I5), cujo irmão Clément (I58I-I652) construira a Praça de Charleville.

$\mathrm{Na}$ verdade, a história da abertura da Place des Vosges demonstra uma conjunção de fatos e acontecimentos díspares e incoerentes, fatos que, a princípio, não pareceriam condizer com a forma homogênea, rígida e fechada que a praça acabaria guardando - a real consolidação do modelo de Classicismo cenográfico de teor barroco que Choay tanto enfatizaria em seu livro Espacements. A primeira ideia do Rei Henrique IV para uma praça quadrada e simétrica na área que valorizaria imensamente o Bairro de Marais, na margem direita do Sena, se baseava em uma solução de caráter absolutamente utilitário e popular: um largo fechado que acolheria um edifício de uma manufatura têxtil em uma das faces e, nos outros três lados, as casas para servir de moradia aos operários. (BENEVOLO, 20o8, 


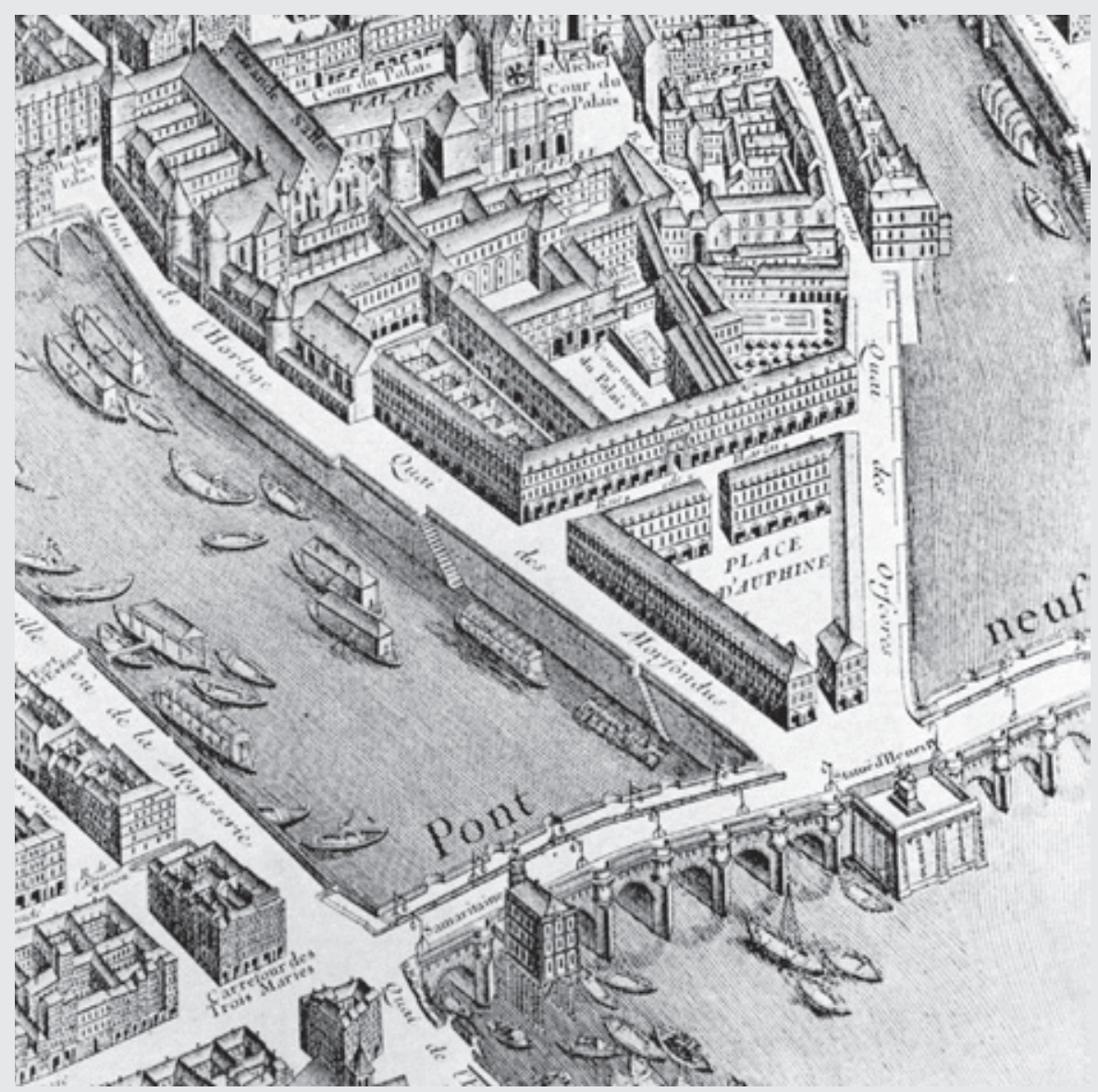

51. Imagem perspectiva da Place Dauphine, na Île de la Cité, e da Pont Neuf, vistas no Plan de Turgot, publicado em 1739. O Plano de Turgot foi concebido pelo Chefe da Municipalidade de Paris, Michel-Étienne Turgot (1690-1751) e desenhado entre 1734-1739 pelo arquiteto e cartógrafo francês Louis Bretez (morto em 1736). Em destaque, os dois braços da Pont Neuf. Fonte: Wikimedia Commons contributors.

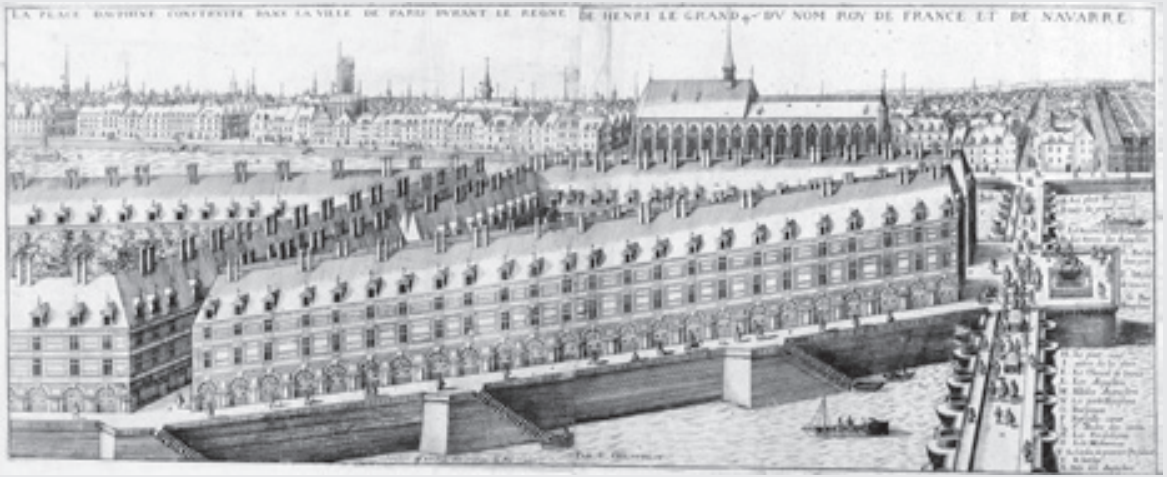

52. La place Dauphine construite dans la ville de Paris durant le règne d'Henri le Grand. Gravura pelo arquiteto, engenheiro e topógrafo francês Claude Chastillon (1560-1616). Fonte: Musée National du Château de Pau / JeanYves Chermeux. 


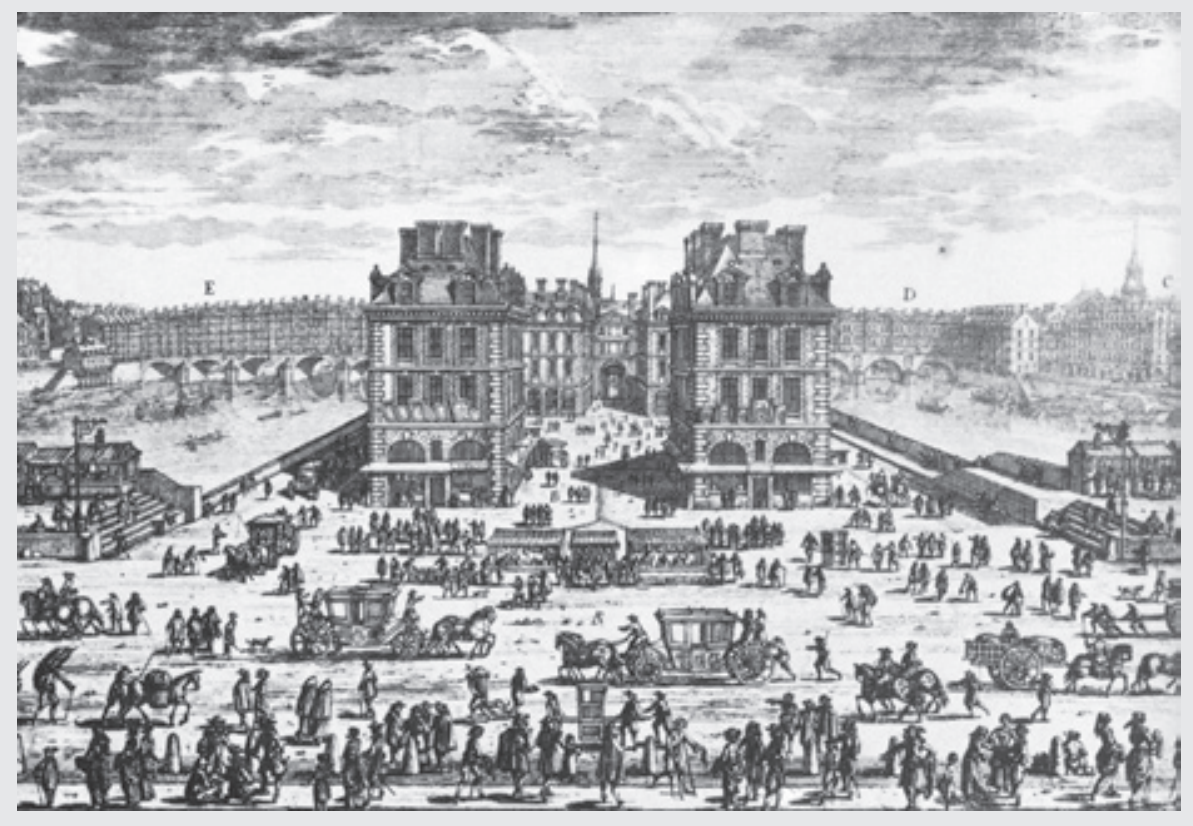

53. Gravura de Adam Perelle (1638-1695) mostrando a entrada da Place Dauphine vista desde a estátua equestre de Henrique IV, em finais do século XVII. Notar a presença, ao fundo, das antigas pontes - que atravessavam o rio em direção à ilha - ocupadas por edifícios, ao contrário do que aconteceria na Pont Neuf. Fonte: Norberg-Schulz (1979, p. 31).

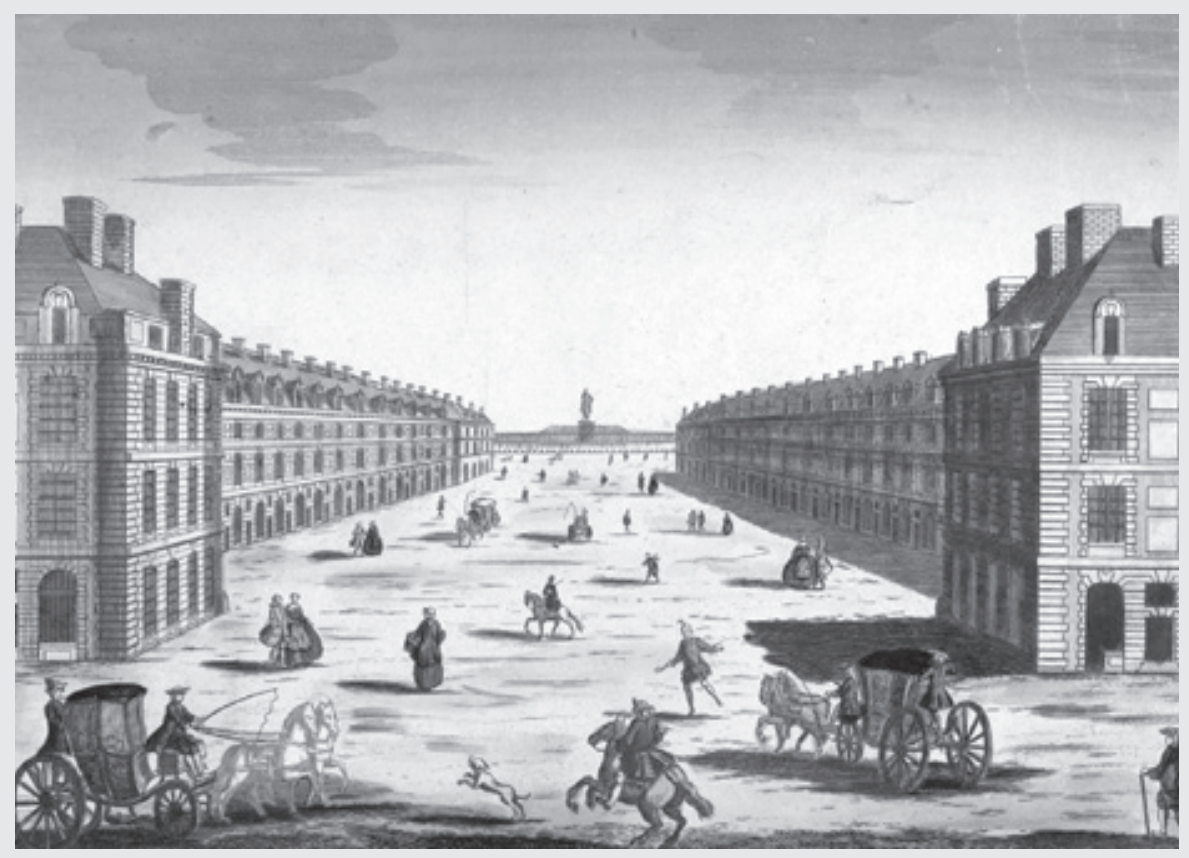

54. Vue perspective de la Place Dauphine de Paris (du côté de la Rue de Harlay). Gravura por Jacques Chereau (16881766). Fonte: Site Nicolas Le Floch. 


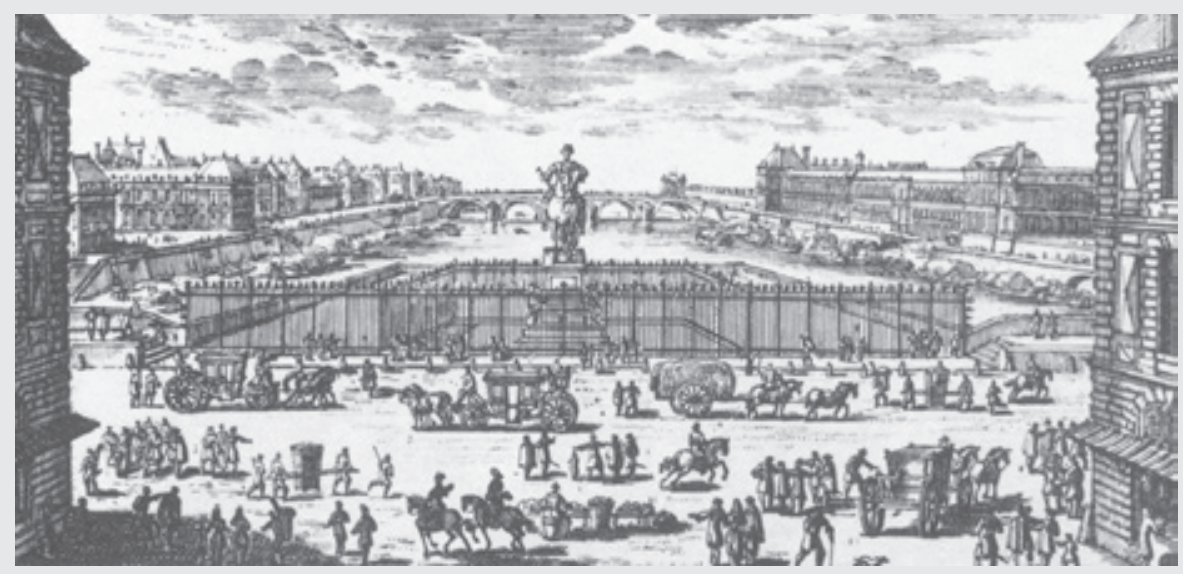

55. Vista axial retirada da Place Dauphine, direcionada à estátua de Henrique IV, monumento disposto entre as duas travessas da Pont Neuf. Gravura de Perelle de cerca de 1670. Fonte: Guidoni e Marino (1979, p. 293).

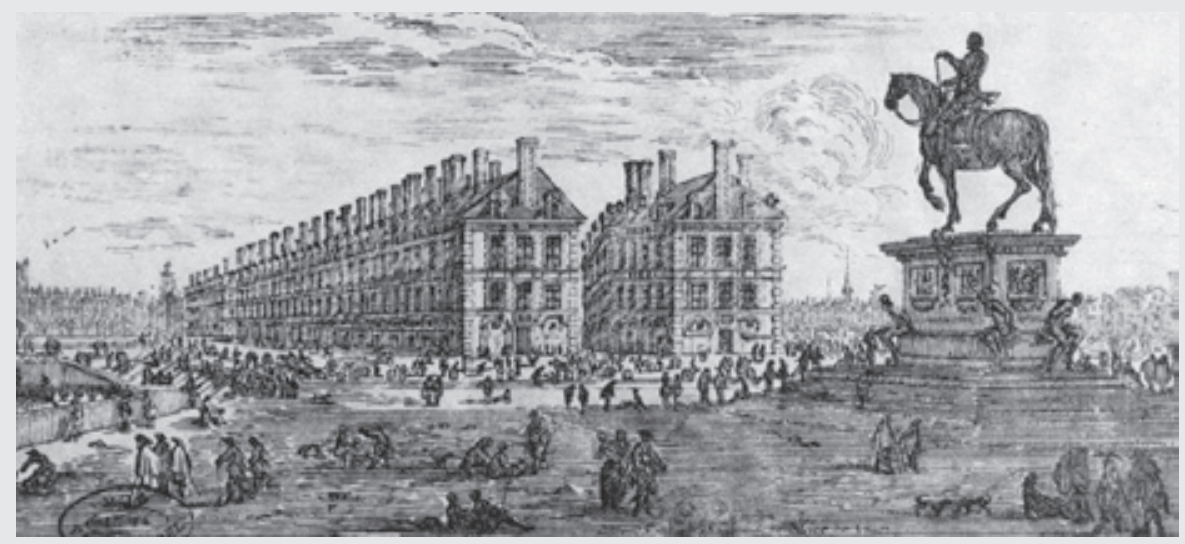

56. Gravura de Israël Silvestre (1621-1691) mostrando a entrada da Place Dauphine no século XVII. Fonte: Lavedan (1975, p. 242). 
p. 623) Porém, logo o imperador deixou esta ideia de lado por influência do Duque de Sully:

Mas, o Duque de Sully tenta já em I603 dissuadir o rei a fazer nos Tournelles casas operárias, e se declara pelo contrário, disposto a desenhar um ambiente urbano unitário, mas de alto prestígio e, portanto, competitivo, capaz de se tornar 'um dos mais magníficos de Paris e quiçá da Europa'. Provavelmente é construído inicialmente o pavilhão do rei, um edifício com três arcadas, o mais alto daqueles que seriam edificados em seguida; nas 'cartas credenciais' de julho de I605 se estabelece que para os outros três lados da praça os eventuais compradores podem adquirir os lotes e construir casas privadas com a obrigação de atender a um projeto já predisposto, cuja tipologia arquitetônica faz referência ao pavilhão real.

A exigência de simetria é primária e absoluta, diretamente imposta pelo rei; além de ter que seguir o desenho geral, é tornado obrigatório o uso dos mesmos materiais para as fachadas, que deveriam ser em pedra e tijolo. Os proprietários dos parcelamentos são nobres, altos funcionários, muitos colaboradores de Sully, e o próprio duque-arquiteto. Começa-se a construir e, por volta de I6o8, a ideia 'popular' que havia guiado os propósitos do rei seria completamente abandonada; sobre o lado norte se jogam abaixo as habitações operárias já edificadas e se uniformiza a fachada contínua segundo o modelo daquelas em construção dos outros lados, oferecendo à praça urbana um destino completamente diverso. (GUIDONI; MARINO, I979, p. 29I-I97, tradução nossa)

Na cidade cartesiana de Charleville, a Place Ducale ocuparia uma área em forma de retângulo regular, cujos lados maiores e menores eram interrompidos, em seus centros geométricos, por acessos formados por ruas retilíneas com ocupação edilícia regular de pequeno porte - com exceção do lado menor, no qual se assentava o Palais Ducal (Figuras 57-58). Esta configuração atribuía à praça uma configuração dinâmica de passagem de tráfego, caráter que não seria encontrado na quadrada Place Royale de Paris, já que a praça parisiense se apresentaria como um espaço mais fechado e acolhido. No Marais, o acesso de pedestres era possível por aberturas centrais que passavam abaixo dos pavilhões do rei e da rainha, organismos mais altos e imponentes dispostos frente a frente, respectivamente no eixo do lado sul e do lado norte do ambiente da praça. Mas, adjacente ao lado norte, uma rua se desenvolvia permitindo a circulação de veículos, fato que ainda 
hoje fica restrito a esta face da praça, não retirando, porém, a sensação de clausura adquirida pelo espaço.

A arquitetura regular, com suas 38 casas de dois pavimentos, dispostos acima de uma loggia contínua de arcadas e galerias que envolviam todos os quatro lados da praça, lembra muito as soluções adotadas em Charleville. Os telhados de ardósia independentes e de alta pendência das edificações humanizam o ambiente, retirando um pouco da monumentalidade que seria conseguida se as linhas das coberturas coincidissem em todos os grandes panos de frontarias cenográficas. Desta forma, a estátua do Rei Luís XIII - que só foi transposta para o centro geométrico da praça em I639 pelo então primeiro ministro do rei, Cardeal Richelieu (I585-I642), ocasião em que o espaço central da praça seria efetivamente aberto ao público, já que antes era restrito aos seus moradores ricos - estaria muito mais realçada em função da escala reduzida que acabaria conformando o conjunto de edificações independentes (Figuras 59-62).

Henrique IV de Bourbon também chegaria a incentivar a concepção de outra praça, ao norte da Place des Vosges, projetada com o objetivo de ser um importante polo de expansão da cidade na margem direita do rio: a Place de France. O espaço foi concebido, pouco antes da morte do rei, como um ambiente monumental de distribuição do fluxo de tráfego que acorreria à cidade por uma das portas abertas na muralha do setor oriental do lado norte da cidade. A praça se desenvolveria em forma de semicírculo, cujo centro coincidiria com o acesso à cidade, e o arco se estenderia para dentro do núcleo urbano. Um pouco à frente do eixo da porta, um polivium de oito vias se desdobraria regularmente para dentro da cidade, vias que receberiam os nomes das províncias da França, acordando perfeitamente com a denominação de Place de France que receberia. Entre cada encontro de vias, pavilhões idênticos seriam construídos, formando o arco do círculo que acolheria a forma interna da grande praça. Um pouco mais à frente, em direção radial ao centro da cidade, mais uma rua em arco de círculo apareceria, e assim sucessivamente. A professora Donatella Calabi (200I, p. I74, tradução nossa) acrescenta, no livro publicado em 200I, Storia della città: l'età moderna:

Depois do complexo da Place Dauphine e aquele da Place des Vosges, um terceiro modelo é projetado - mesmo não chegando a ser realizado - sob o reinado de Henrique IV: a Place de France nasce para fornecer um plano de desenvolvimento às áreas ocupadas das propriedades do Templo, que os religiosos queriam lotear e urbanizar. Em I608, 


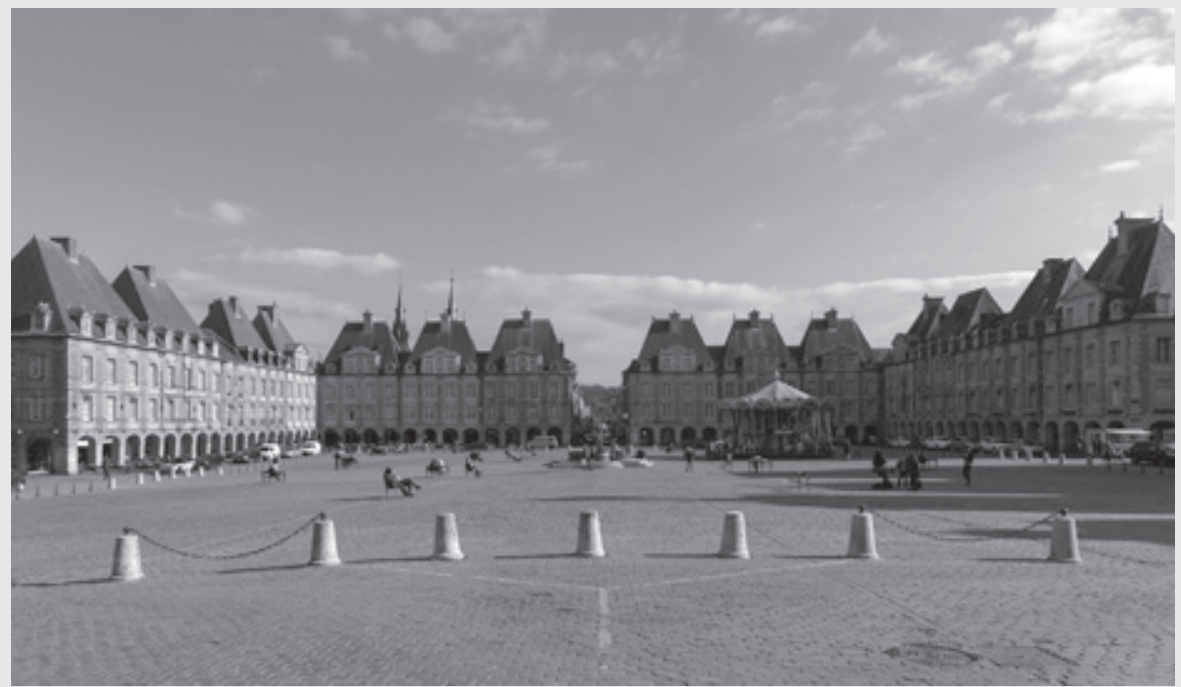

57. Place Ducale de Charleville. Fonte: Fotografia elaborada por Dietmar Rabich (2017) - Licença CC BY-SA 4.0 / Wikimedia Commons contributors.

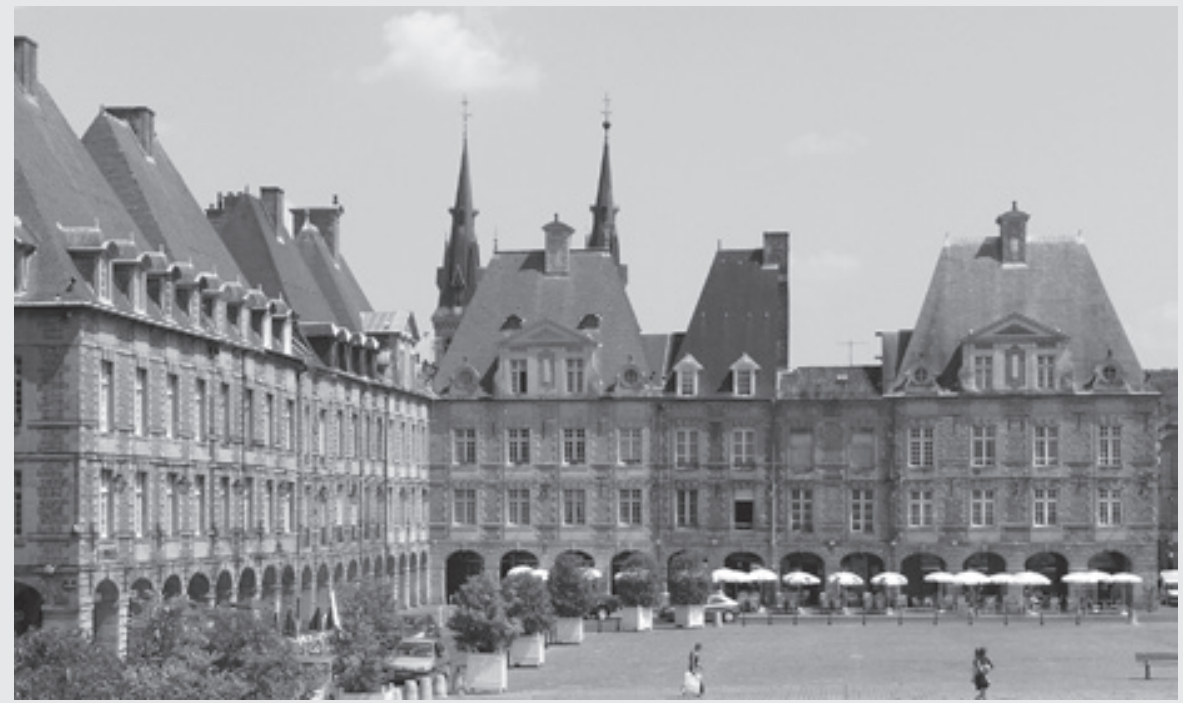

58. Detalhe da Place Ducale de Charleville. Fonte: Fotografia elaborada por Ad Meskens (2009) - Licença CC BY-SA 3.0 / Wikimedia Commons contributors. 


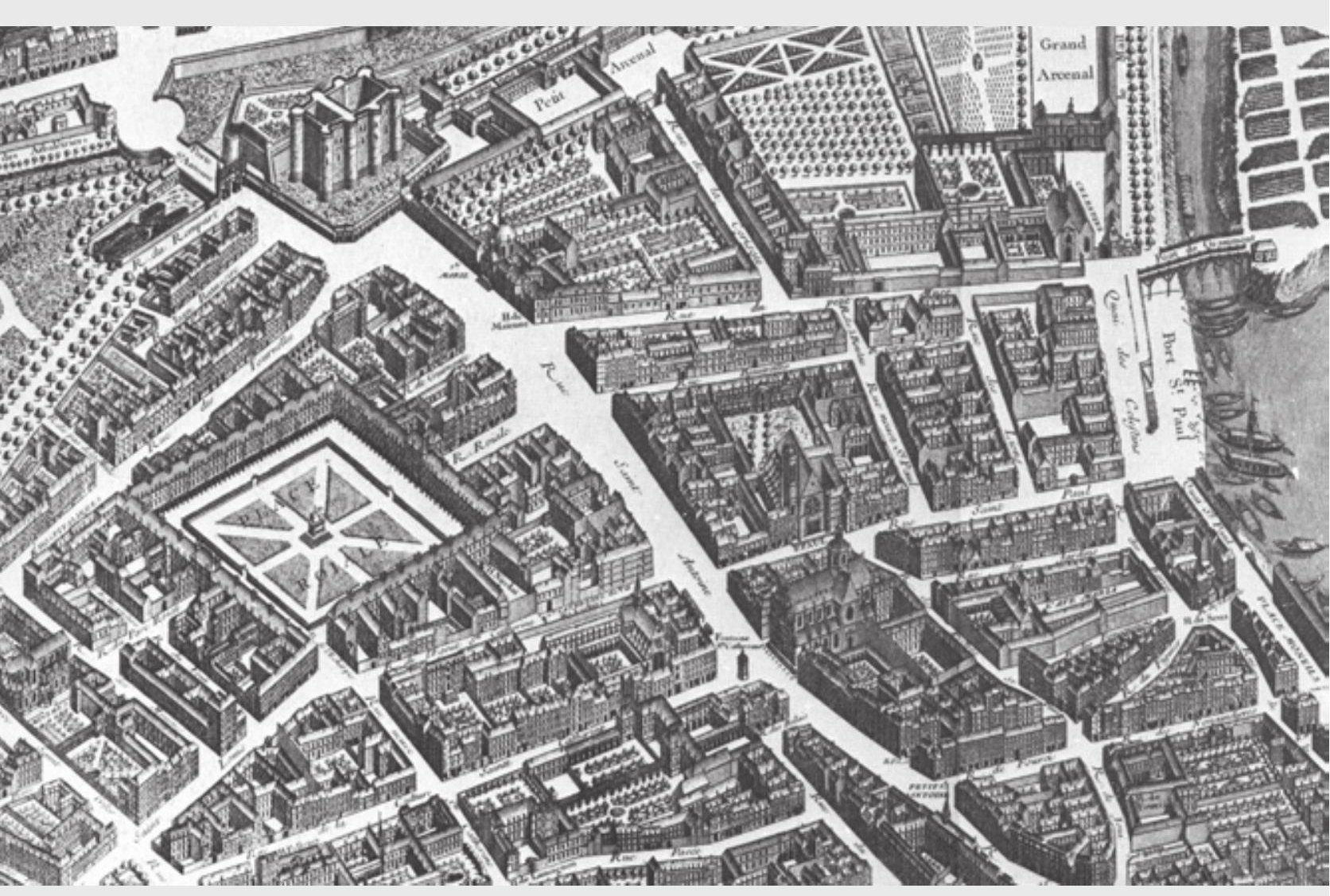

59. Detalhe do plano de Michel-Étienne Turgot (1690-1751) mostrando a Place Royale. Fonte: Wikimedia Commons contributors. 


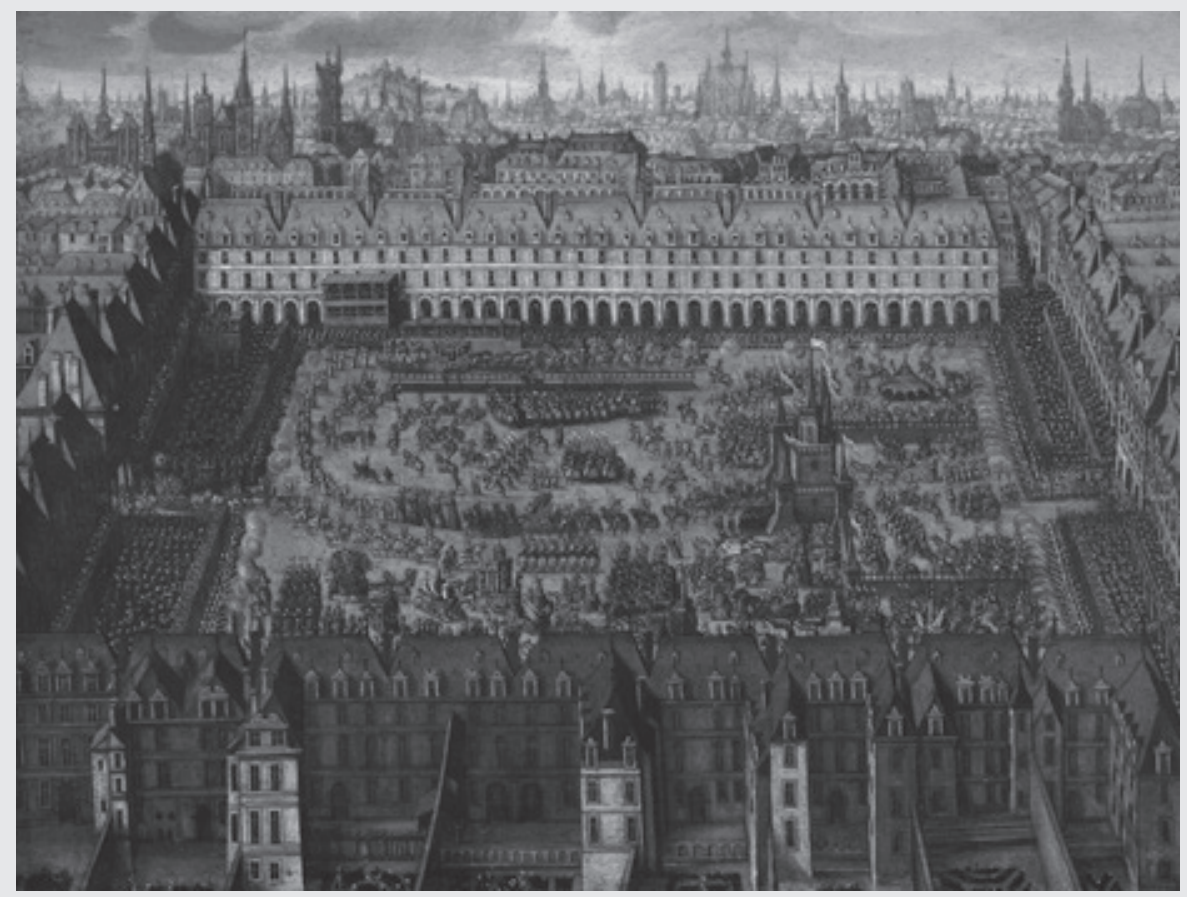

6o. Dessin des pompes et magnificences du Carousel faict en la place royalle à Paris le V. VI. VII. d'Aprvil 1612. Festa de inauguração da antiga Place Royale (atual Place des Vosges). Pintura de Claude Chastillon, retratando a comemoração no ano de 1612. Fonte: Musée National du Château de Pau / Jean-Yves Chermeux.

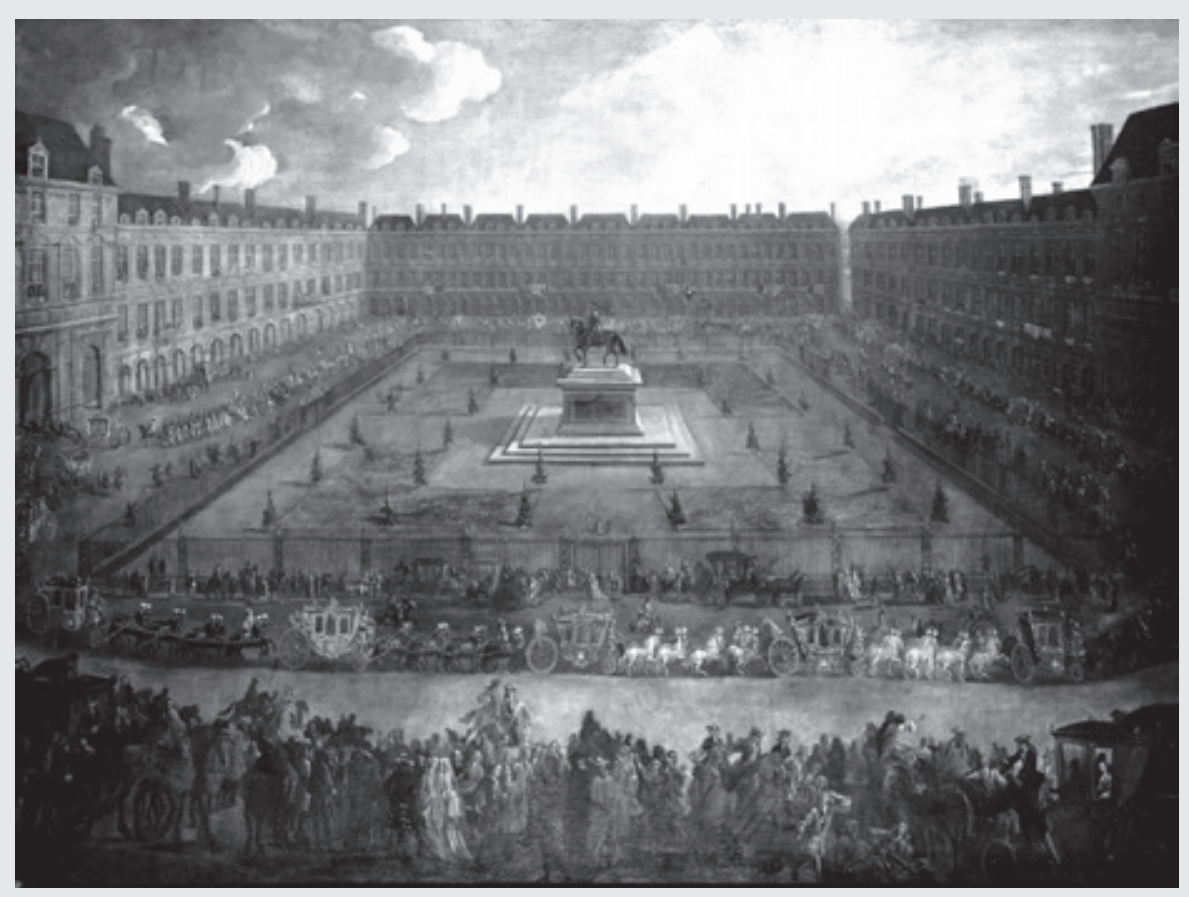

61. Tela mostrando a Place des Vosges (antiga Place Royale) em 1709-com destaque para a estátua equestre de Luís XIII, transferida para o centro da praça em 1639. Fonte: Wikimedia Commons contributors. 


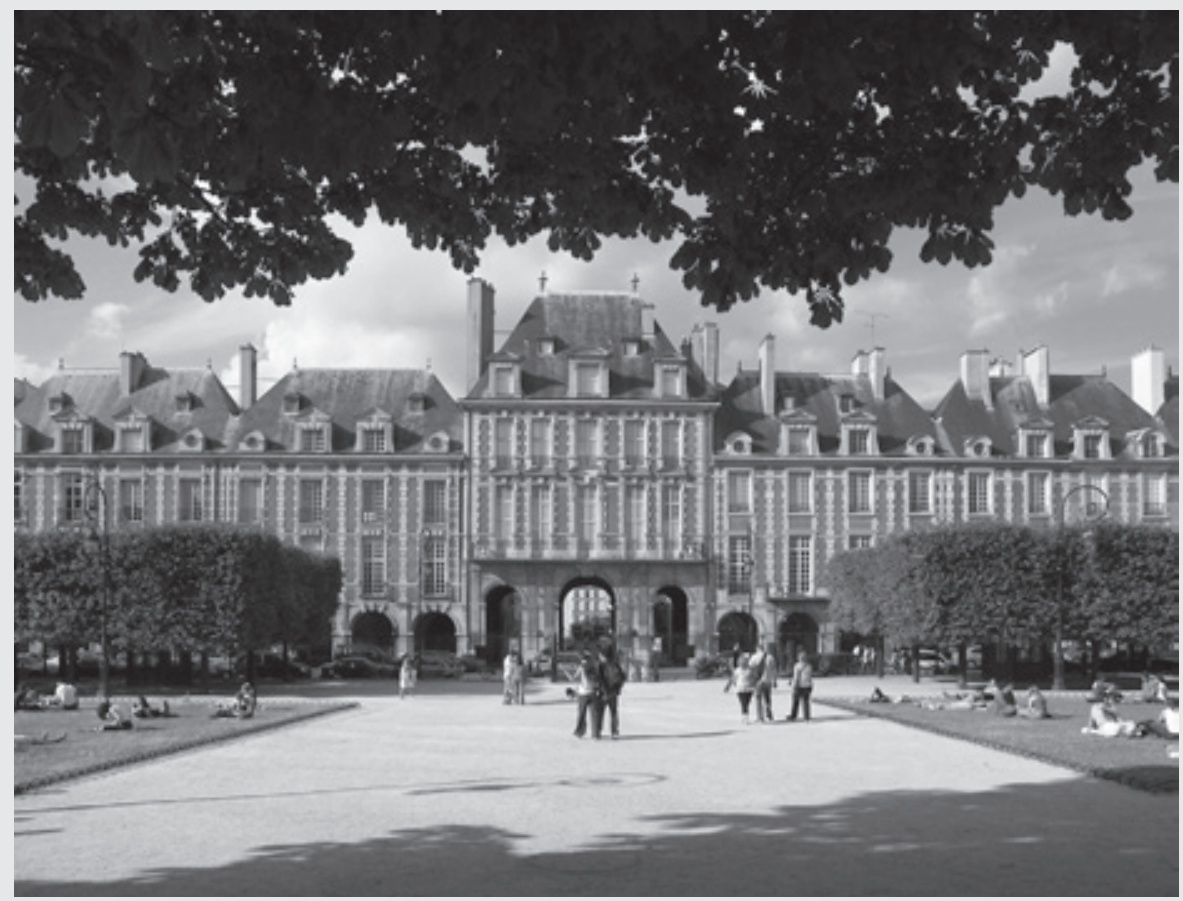

62. Detalhe da atual da Place des Vosges, em Paris. Fonte: Fotografia elaborada pelo autor (2006).

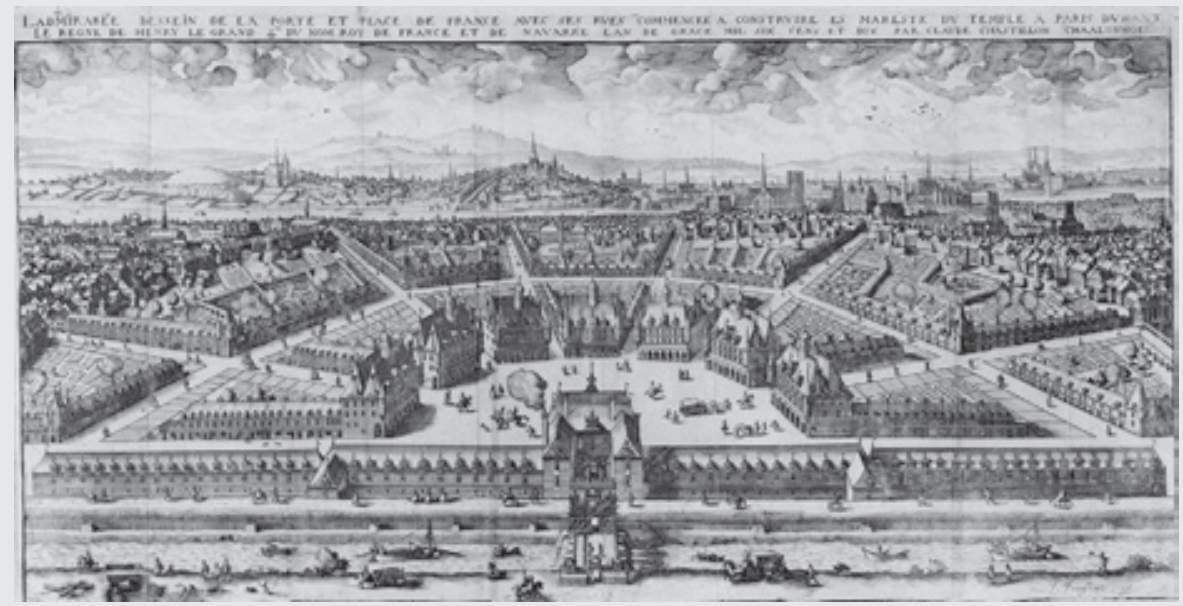

63. Desenho de Claude Chastillon (1560-1616) da Place de France, projetada por ele e por Jacques Allaume (15621627). Retirado da Topographie francoise ou representations de plusieurs villes, bourgs, chasteaux, plans, forteresses, vestiges d'antiquité, maisons modernes et autres du royaume de France, publicada em 1655. Fonte: Wikimedia Commons contributors. 
o empreendedor Claude Charlot é autorizado a adquirir os terrenos e a erigir as casas, a suas custas e dos futuros proprietários dos lotes, segundo o projeto do rei: uma grande praça que se abre em semicírculo diante de uma porta monumental, no setor oriental das muralhas bastionadas reforçadas por Henrique II. O desenho é de Jacques Allaume (engenheiro real e matemático) e de Claude Chastillon (também autor de uma topografia parisiense na qual foi inserida a imagem perspectiva da praça); sobre o perímetro do semicírculo convergem oito avenidas radiais (simbolicamente denominadas como as províncias de Estado), separadas entre si por pavilhões de implantação uniforme e conectadas por segmentos anulares de uma via semicircular mais externa. Não realizado, o modelo desta praça voltaria frequentemente na história da cidade francesa e europeia.

Logo, como diria Calabi, a não edificada Place de France acolheria grande relevância para a urbanística praticada a posteriori na França, e especialmente em outras nações europeias: a popularização do motivo do polivium como elemento de distribuição de tráfego ou modelo de ordenação monumental do espaço de largos, praças, e até mesmo de cidades inteiras, seria particularmente influenciada pelo projeto não executado da praça (Figura 63).

$\mathrm{O}$ amadurecimento da concepção projetual e do assentamento das praças regulares se daria na fase de maior prosperidade e de poder do Estado francês na era barroca: durante os anos de governo do Rei Luís XIV. Em seus mais de 70 anos de reinado, o Rei Sol viria a construir em Paris pelo menos duas importantes praças reais - a Place des Victoires e a Place Vendôme, organismos que também viriam a influenciar decisivamente, e por motivos diversos, a urbanística praticada na Europa e no resto do mundo. Segundo Benevolo (2008, p. 703, tradução nossa):

As duas praças reais parisienses - Place des Victoires e Place Vendôme - nascem a partir de uma combinação de impulsos especulativos e celebrativos. A primeira é uma iniciativa do marechal francês La Feuillade, que adquire certo número de terrenos no bairro vizinho ao Palais Royal e se empenha em construir uma praça, com uma estátua equestre de Luís XIV, loteando novamente e vendendo os terrenos adjacentes; a municipalidade contribui com esta iniciativa, encarregando, em I685, Hardouin-Mansart de fazer o projeto; em I686 é inaugurada a parte compreendida como a mais importante do complexo, isto é, a estátua, mas as cases estavam apenas projetadas, e são completadas 
lentamente nos decênios sucessivos. $\mathrm{O}$ arquiteto escolhe - talvez por sugestão da academia - um perímetro redondo, regularizando o mais possível as saídas das ruas existentes, e fixa um desenho uniforme para as fachadas das casas.

A configuração da Place des Victoires (originalmente Place Louis XIV) estaria baseada em alguns artifícios que já eram comuns nas praças abertas na época de Henrique IV. Não obstante, para além da arquitetura regular que circundaria a cavidade interior do ambiente, e da forma geométrica pura que comporia o desenho do espaço - a circunferência de 39 metros de raio que conformaria o perímetro da praça (GUIDONI; MARINO, I979, p. 484) -, o grande arquiteto francês Jules Hardouin-Mansart (I646-I708) não deixaria de apresentar novas soluções para a primeira praça real que projetava. Mais do que qualquer outro empreendimento urbanístico semelhante praticado na capital francesa, pelo menos durante os períodos barroco e iluminista, a antiga Place Louis XIV seria pensada como um relevante organismo de distribuição e controle do tráfego que se desenvolvia na grande região à margem direita do Rio Sena, pouco acima do complexo do Louvre, que então sofria significativas alterações. Apresentar-se-ia como uma eficiente rotunda que receberia o fluxo de carroças, coches, carruagens, enfim, todo tipo de veículos de roda que acorreria à praça pelos quatro lados, veículos que buscariam a próxima saída desejada, circundando o ambiente em volta da monumental estátua equestre de Luís XIV. Deste modo, a Place des Victoires tomaria a forma de um típico rond-point, um importante ponto de direcionamento do trânsito das áreas mais afastadas para o centro da cidade.

Hardouin-Mansart, entretanto, esbarraria com uma série de obstáculos no processo de projetação e de edificação da praça, entraves que, pelo menos no que tange à questão do design do ambiente, o arquiteto teria conseguido resolver. Entre os graves problemas que precederiam a concepção do espaço poderia ser destacada a situação do tecido urbano adjacente, que era absolutamente irregular: das seis vias que alcançariam a praça, pelo menos metade não se apresentaria através de um direcionamento axial radial em relação à estátua equestre do rei, que se postava ao centro do largo. Irrompiam na cavidade circular de forma aleatória e casual - como a Rua Vide-Gousset, uma via que cruzava a rotunda como um seguimento de reta secante à circunferência da praça. Consequentemente, a sugestão da regularidade do espaço teve de ser perseguida através do caráter hegemônico oferecido pela composição das fachadas regulares e alinhadas com 
a linha da circunferência, frontarias presentes em grande parte do contorno da praça, assentadas em lados opostos, encerrando a maior extensão do rond-point conformado pela Place des Victoires.

Assim, os dois seguimentos de circunferência desvelariam interessantes panoramas formados pelas imponentes frontarias côncavas, vastas fachadas de pavimento térreo rústico e com pisos superiores ritmados por vigorosas ordens colossais jônicas. Os acolhedores organismos acabariam funcionando como panos de fundo cenográficos para a estátua do rei - êxedras que se contrapunham à imagem em escorço da escultura de Luís XIV. Nas duas áreas mais abertas da praça, setores de onde, em lados opostos, despontariam as seis vias que invadiam o ambiente, engenhosos artifícios de desenho foram pensados para ocultar o máximo possível o caráter aberto destas áreas - exceção feita ao eixo perspectivo da Rue Fossés Montmartre, que emoldurava, para além da praça, a visão frontal em profundidade da estátua de Luís XIV - artifício típico da época (Figuras 64-66).

Curiosamente, como fica claro nas palavras de Benevolo citadas mais acima, a ocupação dos edifícios regulares da praça se daria lentamente, e por conta da iniciativa privada. Não obstante, os proprietários e seus construtores tiveram que seguir fielmente o desenho exigido no projeto original para as fachadas, mecanismo que se tornaria viável através do grave controle acionado por parte Estado. No caso da outra praça projetada por Hardouin-Mansart, a Place Vendôme (originalmente conhecida como Place Louis Le Grand), o mais imponente e áulico dos espaços públicos abertos desde o início do século XVII por iniciativa real, o estratagema utilizado pelo arquiteto para garantir a essencial homogeneidade das frontarias que comporiam o contorno interno do perímetro do largo seria ainda mais eficiente - se comparado às outras intervenções públicas de Henrique IV, Luís XIII e do próprio Roi-Soleil. O rei garantiria a regularidade e a celeridade do investimento construindo, por iniciativa própria, as fachadas que comporiam o ambiente e vendendo os terrenos em volta da praça para particulares ricos, que aos poucos iriam levantando, por detrás dos epidérmicos e teatrais cenários de pedra, domicílios, estabelecimentos comerciais, negócios, empresas. O contorno edificado da praça se configuraria, deste modo, como um pano de fundo cênico para mais uma estátua equestre de Luís XIV (desta vez vestido em trajes romanos), monumento que seria assentado em I699, bem no centro do recinto - aliás, como era de praxe. Em um primeiro momento, nada haveria para além do dorso da armação teatral, mas o espaço cumpriria, desde já, seu papel de organismo 

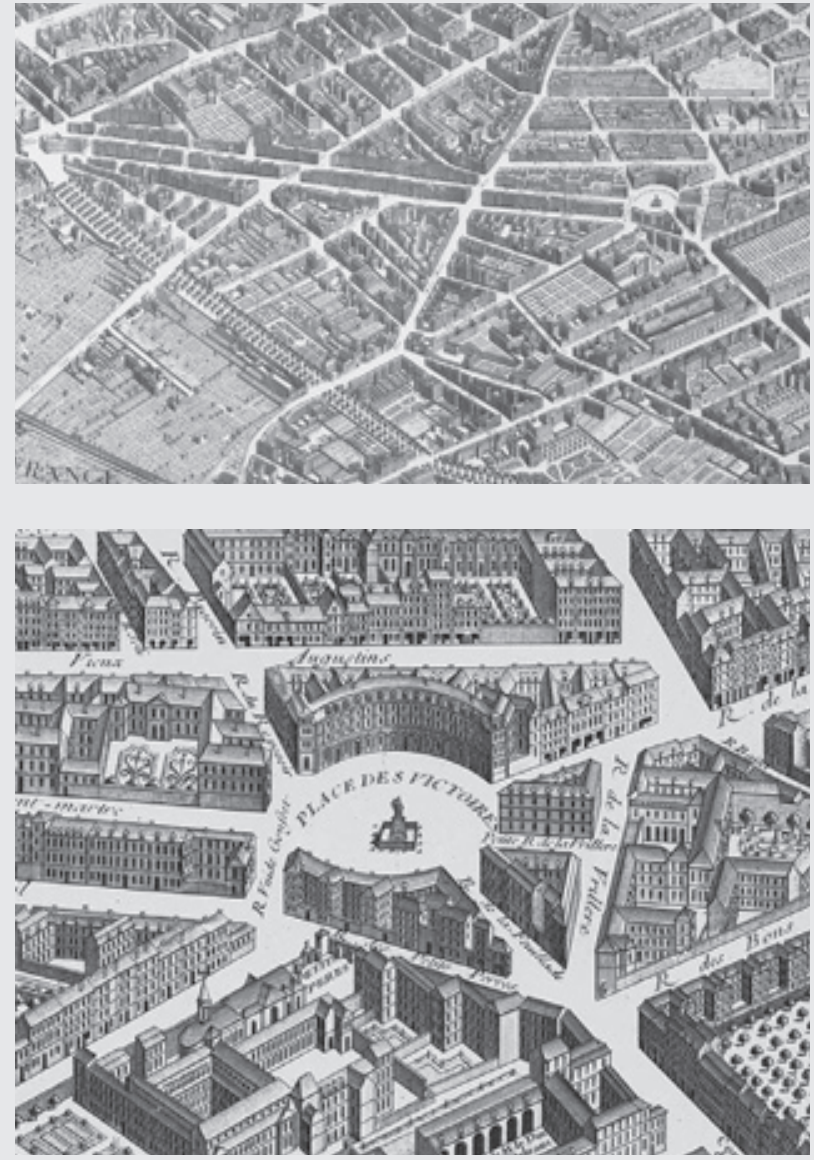

64. Detalhe do Plan de Turgot mostrando a cidade de

Paris - com destaque para a Place des Victoires, à direita. Fonte: Wikimedia Commons contributors.

65. Place des Victoires, em detalhe aproximado no Plan de Turgot. Fonte: Wikimedia Commons contributors.

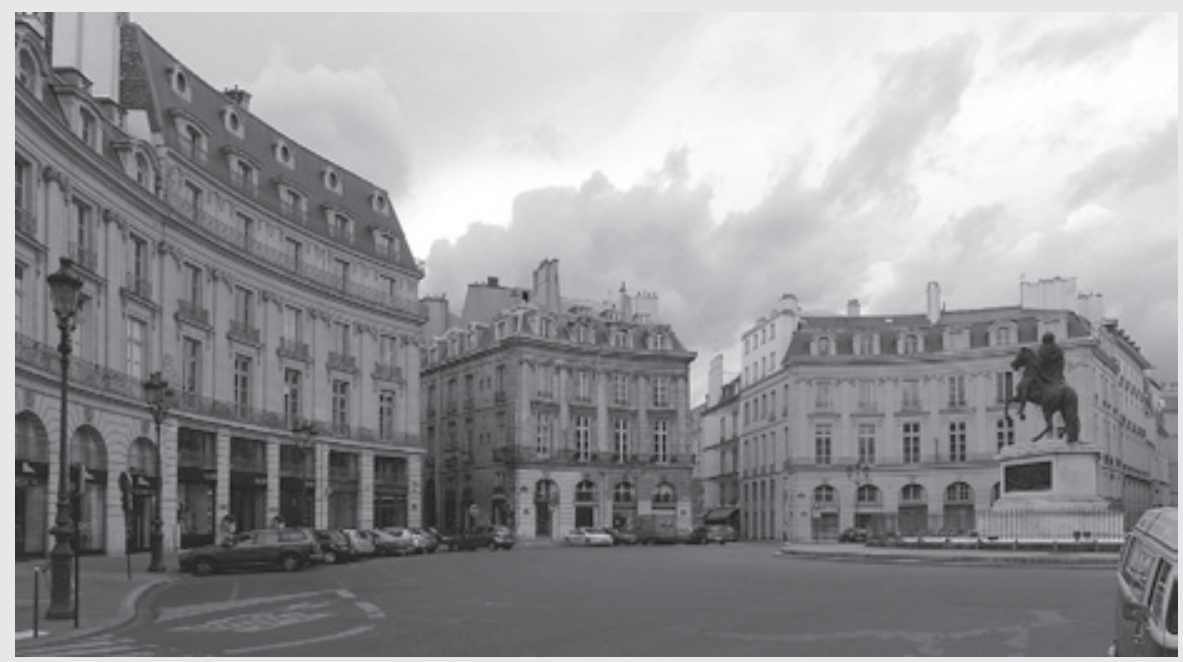

66. Imagem atual da Place des Victoires.Fonte: Fotografia elaborada por Mbzt (2012) - Licença CC BY 3.0 / Wikimedia Commons contributors. 
áulico de representação da força e do poder infinitos do rei - nada poderia ser mais barroco. No entanto, para alcançar esta última concepção e o design final da praça, Mansart teria de reformular algumas vezes a tática de ocupação e a projetação do espaço:

Um primeiro projeto foi feito por Mansart em I685, e parte das fachadas foram construídas sem que por detrás existissem edifícios. Originalmente estava projetada uma série de edifícios públicos (ou reais): academias, uma biblioteca, a Real Casa da Moeda e embaixadas, mas em 1698 o plano foi abandonado e as fachadas demolidas. Mansart apresentou um novo projeto menor, que consistia em um espaço retangular com ângulos cortados, isto é, um octógono com lados desiguais. As fachadas foram novamente construídas e os lotes dos terrenos posteriores às fachadas foram vendidos a proprietários privados. A Place Vendôme repete, assim, em certos aspectos, a solução geral da Place des Vosges. O fechamento do espaço é sublinhado pela quebra dos ângulos e pelo ritmo forte e regular do desenvolvimento dos muros das fachadas. Ao mesmo tempo, a forma se estende longitudinalmente em correspondência com o seu eixo norte-sul, que originalmente ligava a praça com a igreja vizinha dos Capuchinhos e dos Feuillants. A solução representa uma característica síntese barroca de organização centralizada e longitudinal, de fechamento e integração com o ambiente circundante. A articulação das fachadas repete o sistema geral da Place des Victoires, mas a modenatura apresenta uma proporção mais alongada e os detalhes são mais ricos. O centro á assinalado por uma estátua equestre em bronze de Luís XIV em vestes de um imperador romano. (NORBERG-SCHULZ, I979, p. 44, tradução nossa)

$\mathrm{Na}$ verdade, segundo Morris (I979, p. I62), a iniciativa radical de se construir, imediatamente, os dois panos de fachadas que se oporiam frente a frente na futura Place Vendôme surgiria como uma estratégia desesperada, idealizada por Mansart e pelo Rei Sol, em prol do incentivo à ocupação edilícia da praça que ainda não contaria com nenhuma habitação por ocasião da inauguração do monumento equestre a Luís XIV. Com o tempo, os lotes parcelados na parte posterior dos tramos sucessivos das frontarias foram sendo ocupados por edifícios de extensão e formatos variáveis, diversidade que não afetaria, em nada, o caráter regular e cortesão da praça. A sua configuração homogênea - que sugeriria a presença de dois imponentes palácios gêmeos que se confrontavam nas faces leste e 
oeste da praça, se desdobrando para os lados menores em ângulos de $45^{\circ}$ - estava garantida pela cenografia barroca imposta no empreendimento real. O caráter fechado do espaço, situação que reforçava o sentido de monumentalidade retirado pelo transeunte que se postava em sua cavidade interna, era favorecido pela pequena dimensão das vielas que chegavam pelos acessos alinhados ao eixo norte-sul da praça: de dentro do largo, as perspectivas geradas pelas duas travessas regulares (que apresentavam o mesmo tratamento das fachadas da praça) logo se encerrariam em edifícios assentados nas ruas paralelas aos seus lados menores, enfatizando, enormemente, a noção da clausura do espaço - enquadrando, na direção norte do eixo dominante, a mole da Igreja dos Capuchinhos, e em seu lado sul, as fachadas alinhadas da Rue Saint Honoré. ${ }^{23} \mathrm{O}$ sentido grandiloquente das frontarias não ameaçava, contudo, o caráter hegemônico da estátua equestre de Luís XIV, já que sua altura de I8 metros não seria ultrapassada pelas fachadas cenográficas regulares ${ }^{24}$ (Figuras 67-70).

A última praça significativa edificada para abrigar a estátua de um rei em Paris seria aberta mais de cinco décadas após o desenvolvimento dos projetos que definiram a construção da Place Vendôme, em um contexto ideológico bastante diverso daquele da época do Rei Sol, e que se aproximaria mais do pensamento iluminista do que da cultura barroca. Não obstante o sentido original que levou à construção da Place de la Concorde, a ideia de organizar um espaço urbano monumental que deveria servir como cenário para a inclusão de uma grande estátua do Rei Luís $\mathrm{XV}^{25}$, se aproximaria, abertamente, dos outros empreendimentos realizados no período barroco. Além disso, inspiradas nos modelos barrocos precedentes - particularmente nas ações especulativas promovidas em nome do incentivo à construção dos edifícios que deveriam envolver os espaços abertos -, as fachadas regulares dos monumentais palácios, que viriam compor a nova place royale, também seriam edificadas antes da ocupação efetiva dos lotes que seriam parcelados por detrás das frontarias cenográficas. Ou seja, mais uma vez

23 Esta relevante sensação de clausura está perdida atualmente devido à substituição das pequenas travessas que irrompiam na praça por duas grandes avenidas, eixos perspectivos que se perdem para muito além do espaço interno da praça.

24 Infelizmente, desde 1810, o centro da praça está ocupado pela Colonne d’Austerlitz, de 44 metros de altura. Substituindo a estátua de Luís XIV, destruída na revolução, a coluna altera radicalmente as relações de proporção que se guardavam entre os edifícios que ocupavam a praça e seu monumento central. (MORRIS, 1979, p. 162) 
67. Place Vendôme, em um detalhe do Plan de Turgot. Notar o cenário teatral formado pelas fachadas puramente epidérmicas que envolveriam o espaço onde se assentaria a estátua equestre do rei. Fonte: Wikimedia Commons contributors.

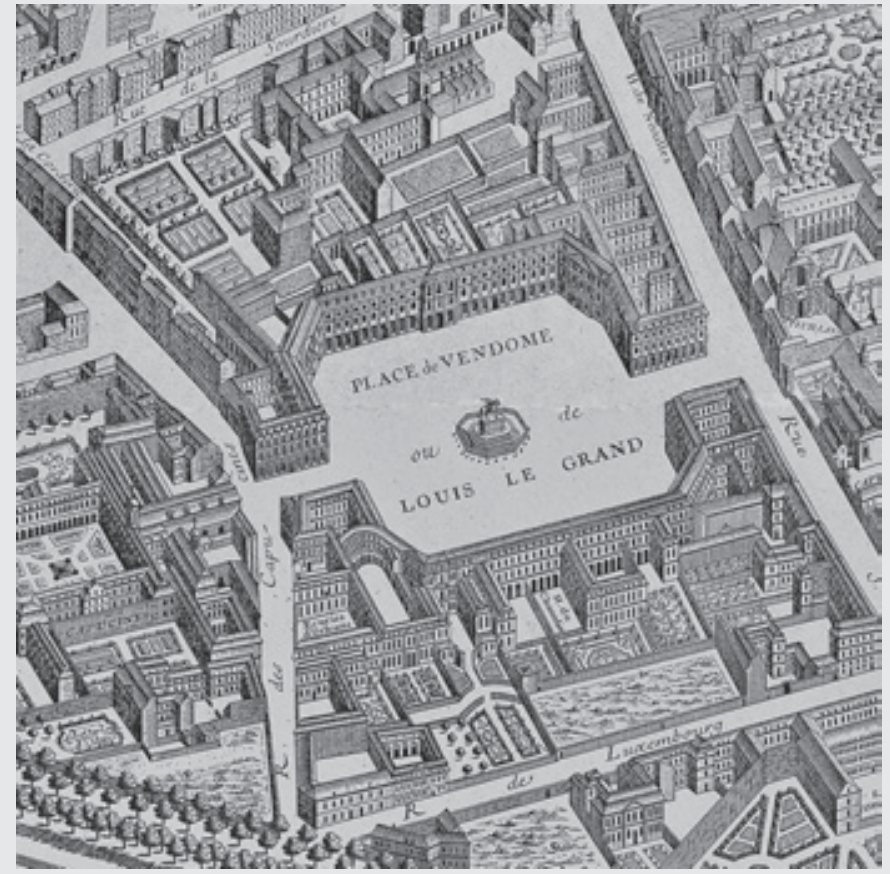

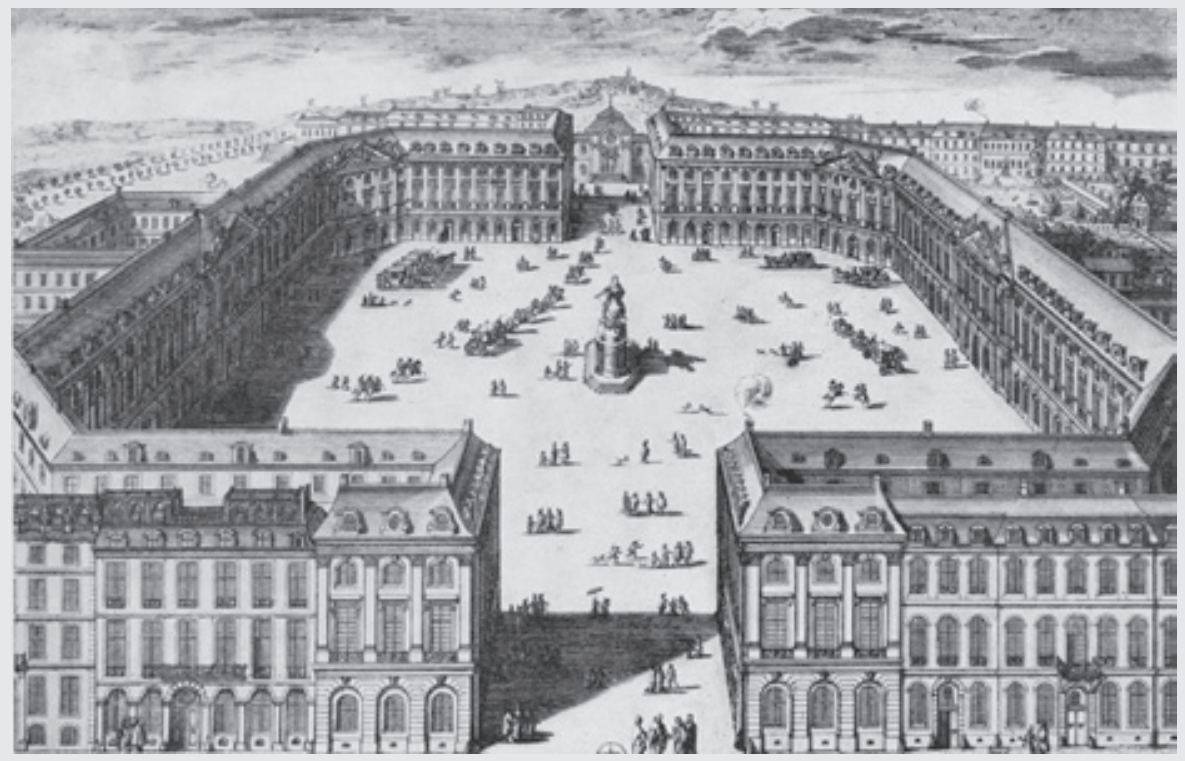

68. Place Vendôme, ao final do século XVII, em uma gravura de Perelle. Notar a Igreja dos Capuchinhos enquadrada perspectivamente, ao fundo. Fonte: Lavedan (1975, p. 255). 


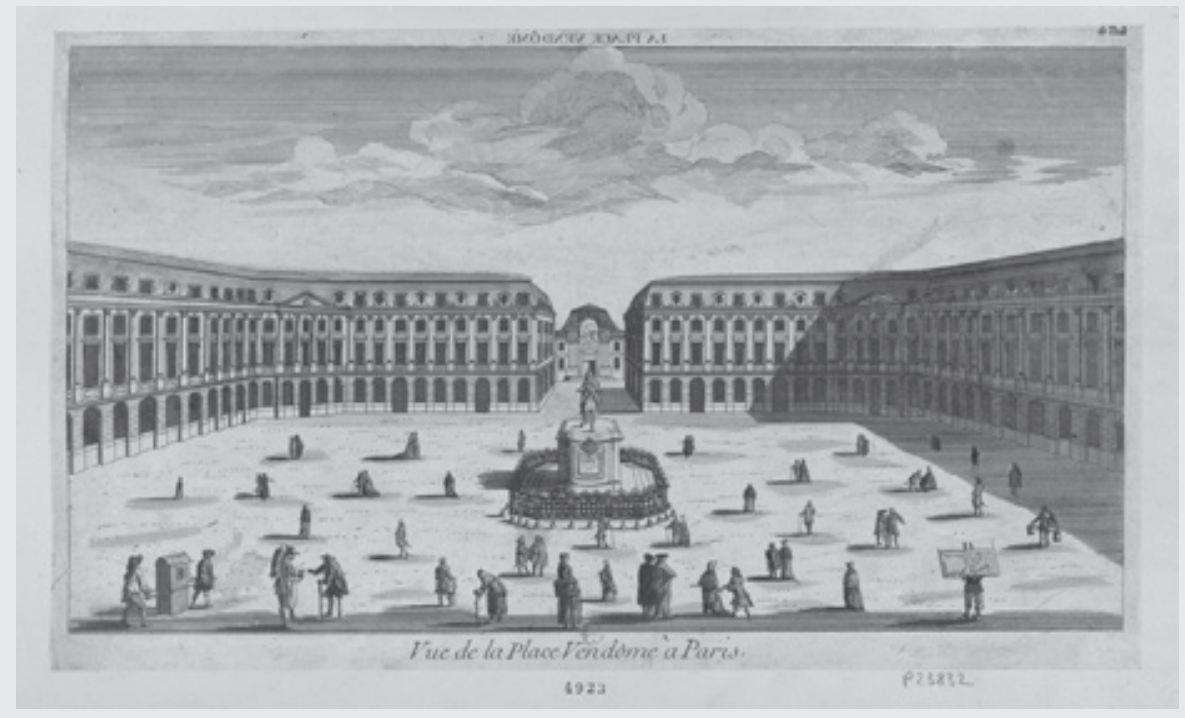

69. Vue de la Place Vendôme à Paris - autor desconhecido. Fonte: Biblioteca Nacional da França.

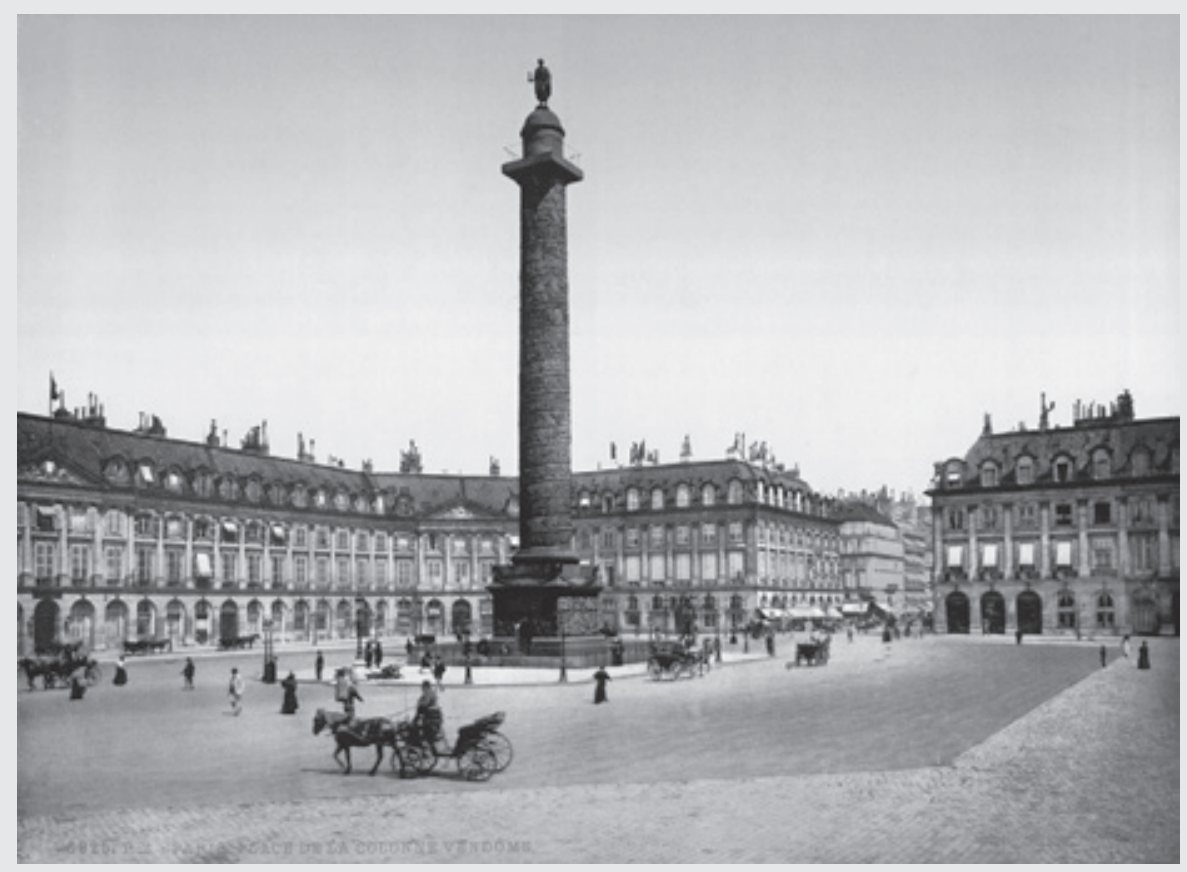

70. Place Vendôme, em Paris, entre 1890 e 1900. Destaque para a Colonne d'Austerlitz, colocada em 1810, no centro da praça, substituindo a estátua de Luís XIV, destruída na revolução. Fonte: Wikimedia Commons contributors. 
um artifício da teatralidade barroca era utilizado para garantir a homogeneidade do imponente cenário retirado das testadas dos falsos palácios.

Independente destes fatos, o desenvolvimento da antiga Place Louis XV teria sido bastante tumultuado. Segundo relata o historiador das cidades, Paolo Sica (I935-I988), em seu estudo publicado em I976 e intitulado Storia dell'urbanística: Il Settecento, a história da praça se iniciaria com a abertura de um concurso dirigido para arquitetos que deveriam propor um espaço adequado para acolher a estátua do imperador Luís XV - que seria comissionada, em I748, pela municipalidade de Paris, ao escultor francês Edmé Bourchardon (I698-I762). Na verdade, o proponente precisaria não só desenvolver superficialmente a sistematização de um espaço para abrigar o monumento, como especialmente indicar o lugar da cidade onde seria pertinente a abertura do recinto que serviria como moldura cênica para a escultura - organismo que não precisaria, necessariamente, configurar-se como uma praça. Inúmeros projetos foram apresentados (cerca de 50), mas todos foram considerados muito onerosos e impopulares, pois, frequentemente, exigiam altos investimentos derivados da desapropriação de bairros inteiros e consequentes demolições. Neste sentido, o rei acabaria tomando a iniciativa pessoal de escolher uma área específica da cidade para acolher sua estátua, uma área cujos terrenos já eram de propriedade real. Outro concurso seria estabelecido, desta vez reservado aos acadêmicos, com o objetivo de escolher o melhor projeto para a sistematização do sítio predefinido. Mais uma vez, Luís XV não ficaria satisfeito com os resultados, o que o levaria a confiar o empreendimento diretamente ao arquiteto Ange-Jacques Gabriel (I698-I782), filho do autor da Place Royale de Bourdeaux, intervenção que o havia impressionado. (SICA, I992, p. 37-39)

A praça projetada por Gabriel, mesmo se aproximando de muitos princípios e soluções que caracterizavam as iniciativas anteriores, apresentaria pelo menos um aspecto muito diverso no que se referia ao planejamento das praças reais: inovação que poderia ser resumida na configuração aberta e permeável que o largo assumiria e na interface que o recinto guardaria com o ambiente natural. As escolhas projetuais que levariam o arquiteto a conceber sua obra de forma tão singular teriam conexões diretas com a situação urbanística da área escolhida:

As praças reais do século XVII eram essencialmente espaços fechados: muito raramente se empregavam elementos paisagísticos, e, em tal caso, era concedido a eles um papel secundário, estando sempre subordinados à configuração arquitetônica. Durante o século XVIII [...] 
os espaços abertos, como contraposição aos espaços fechados, constituíam o novo ideal e sua materialização esteve assegurada pela inclusão da natureza; independentemente destes sentimentos o rei cedeu à cidade de Paris os terrenos livres delimitados pelo Jardin des Tuileries, o Rio Sena, os Champs Elysées e o bairro situado ao redor da igreja projetada da Madeleine. Assim, a nova praça podia dilatar-se em três direções para espaços abertos.

O primeiro problema que enfrentou Gabriel foi o de definir a place sem separá-la dos espaços ajardinados existentes situados a leste. O segundo problema consistiu em organizar algumas conexões planificadas entre os quatro eixos preexistentes que atravessavam os terrenos: o definido pelo Jardin des Tuileries e os Champs Elysées, a Rue Royale (aberta em I732), o Cours-la-Reine e seu equivalente ao norte dos Champs-Elysées. Suas obras começaram em I755, com a colocação da estátua de Luís XV no ponto de interseção dos primeiros eixos citados. (MORRIS, I979, p. I67, tradução nossa)

Como relata Morris, os terrenos reais localizados ao norte do Rio Sena e envolvidos por jardins e passeios - a leste, o Jardin des Tuileries, e na direção oeste, o eixo dos Champs-Elysées e o passeio formado pelo Cours-la-Reine (organismos abertos nos séculos XVI e XVII) - exigiram do projetista um cuidado especial no que concerne à busca por uma continuidade frente a estes sítios naturais preexistentes, ambientes que haviam assumido a condição de equipamentos voltados ao público comum. A solução adotada foi extremamente satisfatória, pois os três lados da praça que se abriam para as áreas adjacentes formadas pelo Rio Sena, pelas Tuileries, pelos Champs-Elysées e pelo Cours-la-Reine foram deixados livres de edificações e tratados apenas paisagisticamente. O projeto foi baseado na inclusão de fossos de 5 metros de profundidade e i8 metros de largura, envolvidos por balaustradas de mármore, organismos interrompidos apenas nos quatro vértices que configuravam o ambiente, bem como nas passagens abertas para celebrar os direcionamentos pertinentes aos eixos principais do largo: no sentido leste-oeste, o eixo marcado pelo Jardin des Tuileries e pelos Champs-Elysées; no sentido norte-sul, o eixo comandado pela recém-aberta Rue Royale e pelo Rio Sena. ${ }^{26} \mathrm{O}$ desenho adotado em forma de octógono irregular alongado, ou seja, de retângulo com os vértices chanfrados - à semelhança da Place Vendôme -, se justificava em

26 Os fossos foram cobertos em 1854. A atual Pont de la Concorde, que complementa o eixo norte-sul, foi terminada em 1790. (MORRIS, 1979, p. 166-168) 
nome da adaptação às direções diagonais dos eixos do Cours-la-Reine e da outra alameda simétrica, passeios que acorriam à praça pelo lado ocidental. A única barreira de edifícios concebida encerraria o recinto em sua face norte, justamente aquela que apresentava um confuso e tradicional emaranhado urbano: os dois imponentes palácios, já citados, tratados com uma arquitetura áulica que lembrava o projeto de Perrault para a fachada leste do Louvre, ocultariam o tecido construído que se escondia por detrás da praça, se abrindo exclusivamente para o eixo da Rue Royale que os separava. A via, por sua vez, ofereceria uma vigorosa perspectiva em profundidade que enquadraria a idealizada Igreja da Madeleine, que pela ocasião constava apenas em projeto. ${ }^{27} \mathrm{~A}$ estátua de Luís XV, naturalmente, apareceria no centro do largo, tendo como pano de fundo cenográfico todo o imponente conjunto ${ }^{28}$ (Figuras 7I-73).

\section{Outras intervenções significativas na Paris do Ancien Régime - espaços para a contemplação e para o passeio}

É provável que as places royales tenham sido os elementos mais característicos da urbanística barroca parisiense e, por extensão, a tipologia de espaço público mais simbolicamente vinculada à França do Ancien Régime. Reproduzidas inúmeras vezes em distintas capitais de província, em núcleos urbanos de certa importância, ou mesmo em cidades fundadas ex novo, despontariam no contexto do absolutismo ocidental dos séculos XVII e XVIII como uma das soluções mais engenhosas no que diz respeito ao exercício dos princípios da retórica e da persuasão - além de estarem calcadas na prática barroca da imaginação teatral e da fantasia, particularmente devido à contrafação exposta em suas estruturas urbanas ilusionísticas - o imponente biombo cenográfico composto pelas longas e contínuas fachadas epidêmicas. Não obstante, a capacidade de alterar o caráter cenográfico dos organismos urbanos ficaria muito restrita ao entorno imediato em que seriam levantados os recintos para acolher as estátuas dos reis. Mesmo Paris, que antes da revolução revelaria gradativamente o vigoroso conjunto das

27 O primeiro projeto para a igreja foi desenvolvido pelo arquiteto Pierre Constant d'Ivry (1698-1777), mas sua atual feição neoclássica oitocentista se deve a Pierre-Alexandre Barthélemy Vignon (1763-1828).

28 Em 1836, foi colocado o obelisco egípcio, retirado do templo de Luxor, no centro da praça, no lugar da antiga estátua de Luís XV. (MORRIS, 1979, p. 168) 


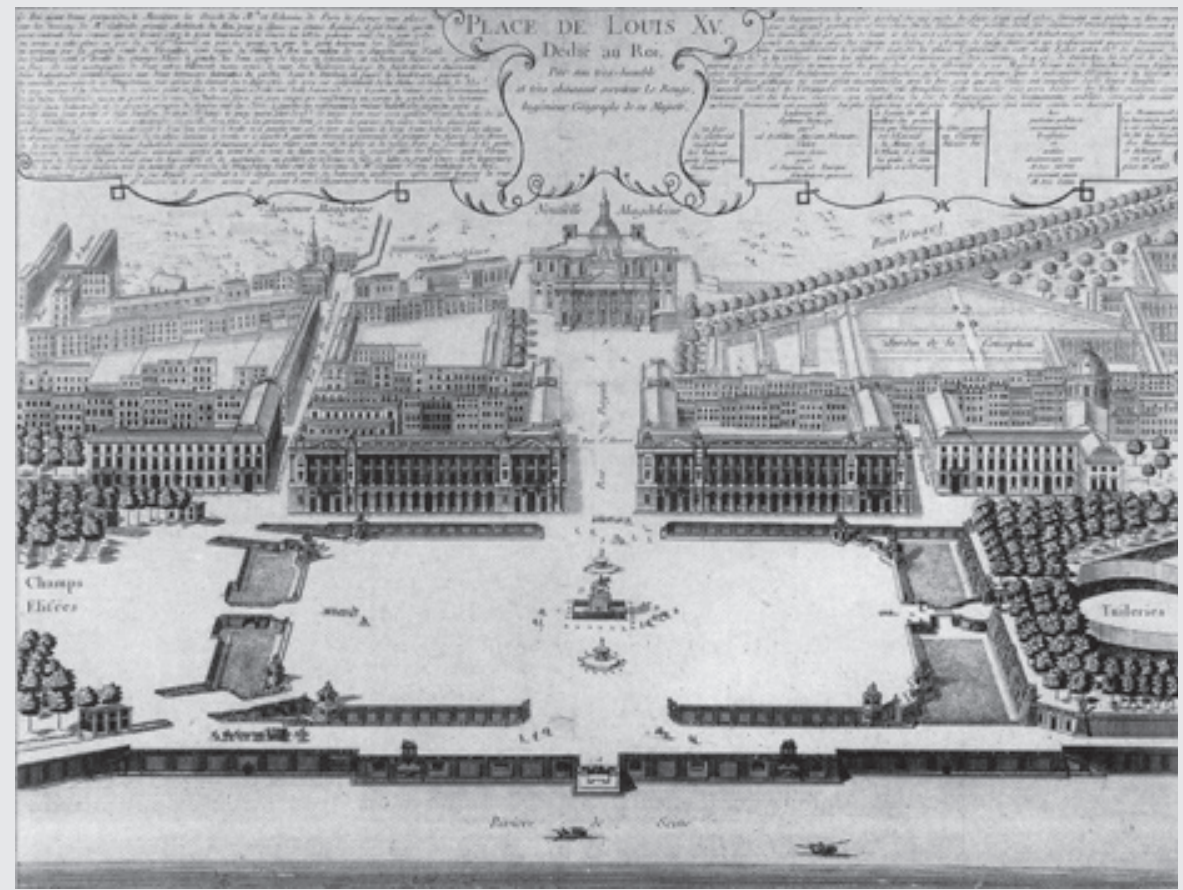

71. Projeto de Ange-Jacques Gabriel (1698-1782) para a Place Louis XV. Fonte: Wikimedia Commons contributors.

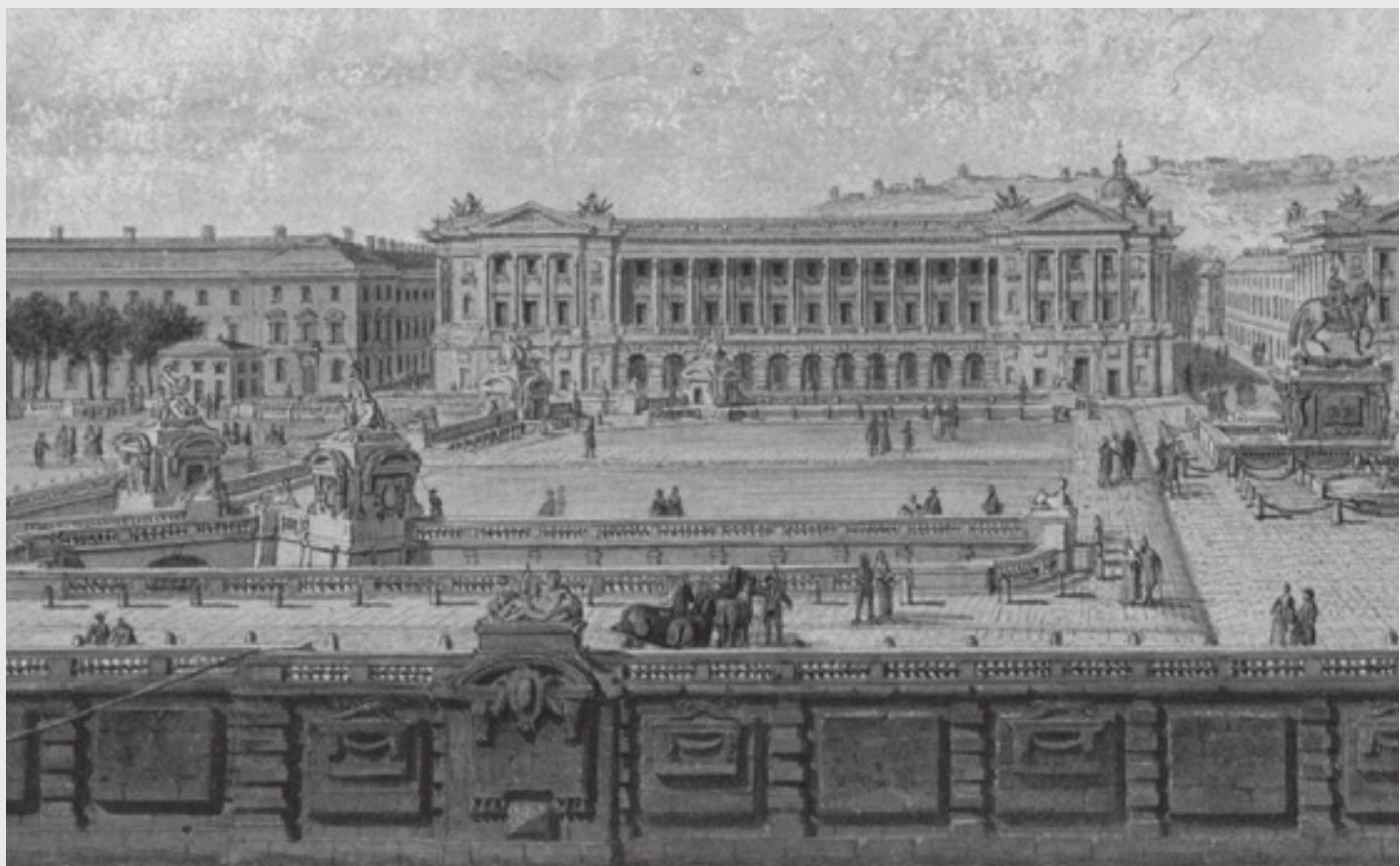

72. Vue de la place Louis XV, avant la construction du Pont, plume, aquarelle et gouache, vers 1780 . Aquarela de Alexis-Nicolas Perignon (1726-1782). Fonte: Blog English 18th century portrait sculpture. 
cinco praças reais, abertas em homenagem aos imperadores seiscentistas e setecentistas, não absorveria uma transformação significativa no que tange à sua conformação visibilística medieval: a enorme dimensão que teria alcançado a apertada massa edificada do núcleo preexistente por ocasião da construção das places royales inibiria uma contaminação mais efetiva da sua experiência cenográfica, de seus espaços regulares e cortesãos, frente à extensão da cidade - que já contava, no século XVII, com mais de 600.000 habitantes, sendo o maior aglomerado urbano do mundo. (BENEVOLO, 2008, p. 680) Na mesma direção, em função do caráter reduzido e fechado de seus ambientes, as praças reais teriam exercido pouca influência no posterior crescimento da cidade.

Em oposição, os espaços verdes, os jardins públicos, as promenades, os passeios e boulevards, ambientes idílicos que se tornariam os outros protagonistas da urbanística barroca francesa - soluções particularmente revolucionárias, experimentadas inicialmente em intervenções na cidade de Paris -, influenciariam, decisivamente, o processo de expansão da cidade, especialmente sua ampliação setentrional a partir do traçado dos Grand Boulevards, bem como seu crescimento para além das antigas muralhas, na direção ocidental, devido à abertura do eixo perspectivo dos Champs-Elysées.

$\mathrm{Na}$ verdade, o Grand Siècle francês traria pela primeira vez na história da urbanística ocidental o verde para dentro das cidades; ou seja, apresentaria a natureza - domesticada obcecadamente pelos paisagistas e arquitetos - como elemento compositivo essencial para a estrutura dos principais aglomerados urbanos. Deste modo, o verde não ficaria mais relegado aos quintais das casas; aos ocultos jardins e hortas dos conventos e monastérios; aos delicados jardins particulares, fechados ao público, da nobreza e da realeza. A natureza não se faria mais presente, exclusivamente, para além dos muros das cidades; nas florestas, nos bosques, nos châteaux da aristocracia. Já em princípios do século XVII seriam oferecidos ao público em geral - aos transeuntes, aos súditos do imperador -, espaços verdes para a contemplação, para o recreio, passeio, lazer, ou pensados simplesmente para servirem de passagem - caminhos que acolheriam o tráfego de pedestres, ou que se adequariam satisfatoriamente ao célere fluxo dos veículos de roda.

Um dos mais significativos empreendimentos na Paris do Ancien Régime, a concepção da ampla avenida perspectiva dos Champs-Elysées, marco para o desenho urbano de áreas verdes nos períodos barroco e iluminista, contribuiria decisivamente para a expansão linear da cidade para o poente, a partir do palácio 
do Louvre. Contudo, a abertura da grande alameda só poderia ser compreendida como uma ação incluída em um intricado processo de planejamento e constituição de jardins e passeios que começariam a ser ordenados na segunda metade do século XVI.

A primeira iniciativa que decretaria este crescimento para além dos muros da cidade, que então estavam sendo reedificados, foi a construção, na década de I550, por iniciativa da Rainha Catherine de Médicis, de um novo palácio para sua moradia: o Palais des Tuileries, que seria projetado pelo arquiteto Philibert de l'Orme (I5IO-I570) logo à frente da antiga residência real do Louvre. ${ }^{29}$ Como elemento essencial componente do novo edifício, o amplo Jardin des Tuileries, inicialmente desenhado em estilo italiano, se estenderia a oeste da mole do palácio de Catherine, até alcançar o sítio onde posteriormente seria aberta a Place Louis XV (hoje Place de la Concorde). O mais conhecido jardim parisiense teria seu desenho completamente reformulado mais de cem anos depois, em I666, pelo célebre paisagista francês André Le Nôtre (I6I3-I700) - jardineiro oficial do Rei Sol de I645 até a sua morte. Após o traslado de Luís XIV e sua corte para o Château de Versailles, o jardim seria definitivamente aberto ao público, iniciativa justificada em nome da reconhecida condição do recinto como espaço para contemplação e lazer; um respiro de ar e luz frente ao apertado e insalubre núcleo urbano - que guardaria sua emaranhada e densa configuração medieval, pelo menos até meados do século XIX, quando as intervenções do Barão de Haussmann viriam alterar, radicalmente, o tecido urbano da antiga cidade de Paris. Porém, o complexo das Tuileries não seria o primeiro jardim público oferecido à cidade:

O primeiro verdadeiro jardim público é, todavia, o Jardin des Plantes (chamado também de 'Jardin Royal' para as plantas medicinais); Luís XIV comprou em I635 um terreno não cultivado no bairro de SaintVictor e mandou construir um jardim que possuía mais as características de um horto botânico; o médico Gui de la Brosse se encarrega da escolha das plantas, que devem ainda servir a objetivos didáticos e experimentais.

29 O palácio, que foi ampliado e reformado várias vezes, seria incendiado em 1871, e finalmente suas ruínas seriam derrubadas em 1882. (MORRIS, 179, p. 163) Estava assentado entre os atuais Jardins du Carrousel e des Tuileries, pouco à frente do oitocentista Arc de Triomphe du Carrousel - que originalmente ficava oculto entre a esplanada do Louvre e o Palais des Tuileries. 
As Tuileries serão transformadas em I666 por Le Nôtre, que cria uma imensa avenida arborizada com bacias e fontes. Colbert manifesta a intenção de fechar o jardim ao público para evitar que seja degradado; mas Perrault insiste para que isto não aconteça: o jardim público é um lugar socialmente importante; os convalescentes vêm tomar o ar mais saudável, 'lá se fala de negócios e de matrimônios e de todas aquelas coisas que se tratam melhor em um jardim do que em uma igreja'. (GUIDONI; MARINO, I979, p. 308, tradução nossa) 30

O comentário do escritor e poeta Charles Perrault (I628-I703) demonstra como, tanto o Jardin Royal des Plantes Médicinales (depois Jardin du Roi) - levantado a sudeste, na margem esquerda do Rio Sena, próximo aos limites orientais das muralhas da cidade - como o reformado Jardin des Tuileries - na direção oposta, na margem direita do rio -, proporiam uma nova relação entre as áreas públicas do núcleo urbano e a apropriação, por parte dos cidadãos, dos benefícios para a saúde física e mental trazidos pelos ambientes naturais (Figuras 74-76).

Com os mesmos objetivos, outro tipo de organismo verde despontaria na cidade de Paris pouco antes da constituição destes dois jardins: seriam os chamados passeios, vias arborizadas, abertas muitas vezes para além dos contornos da cidade, e que possuiriam a função de permitir a agradável passagem de pedestres, carroças e carruagens por artérias flanqueadas por barreiras vegetais ordenadas por fileiras de frondosas árvores de poda cuidadosa. Guidoni descreveria os dois principais passeios fundados em Paris ao início do século XVII:

Sully, quando reconstruiu bem no início do século o palácio do Arsenal, na extremidade oriental da cidade, cuida também da sistematização de uma grande avenida arborizada ao longo do Sena, o passeio do Arsenal, em grande voga durante o reino de Henrique IV, cuja mulher, Marie de Médicis, mandou construir em i6ı6, no lado oposto da cidade, o Cours-la-Reine. Estas avenidas (munidas de cancelas) são destinadas não só ao passeio a pé, como também ao passeio em carroça que, segundo Sauval, é uma inovação introduzida pela rainha italiana, assim como a denominação de 'corso', nova para a toponomástica

30 Gui de la Brosse (1586-1641) foi um importante médico, botânico e farmacologista francês ligado ao Rei Luís XIII.

31 Charles Perrault era irmão do renomado arquiteto Claude Perrault (1613-1688). Foi assistente de Colbert e superintendente das obras públicas do reino de Luís XIV. 
74. Le Jardin des Plantes. Por Paul Legrand (1842). Fonte: Wikimedia Commons contributors.

75. Jardin des Tuileries, visto do Plan de Turgot (1739). Fonte: Wikimedia Commons contributors.
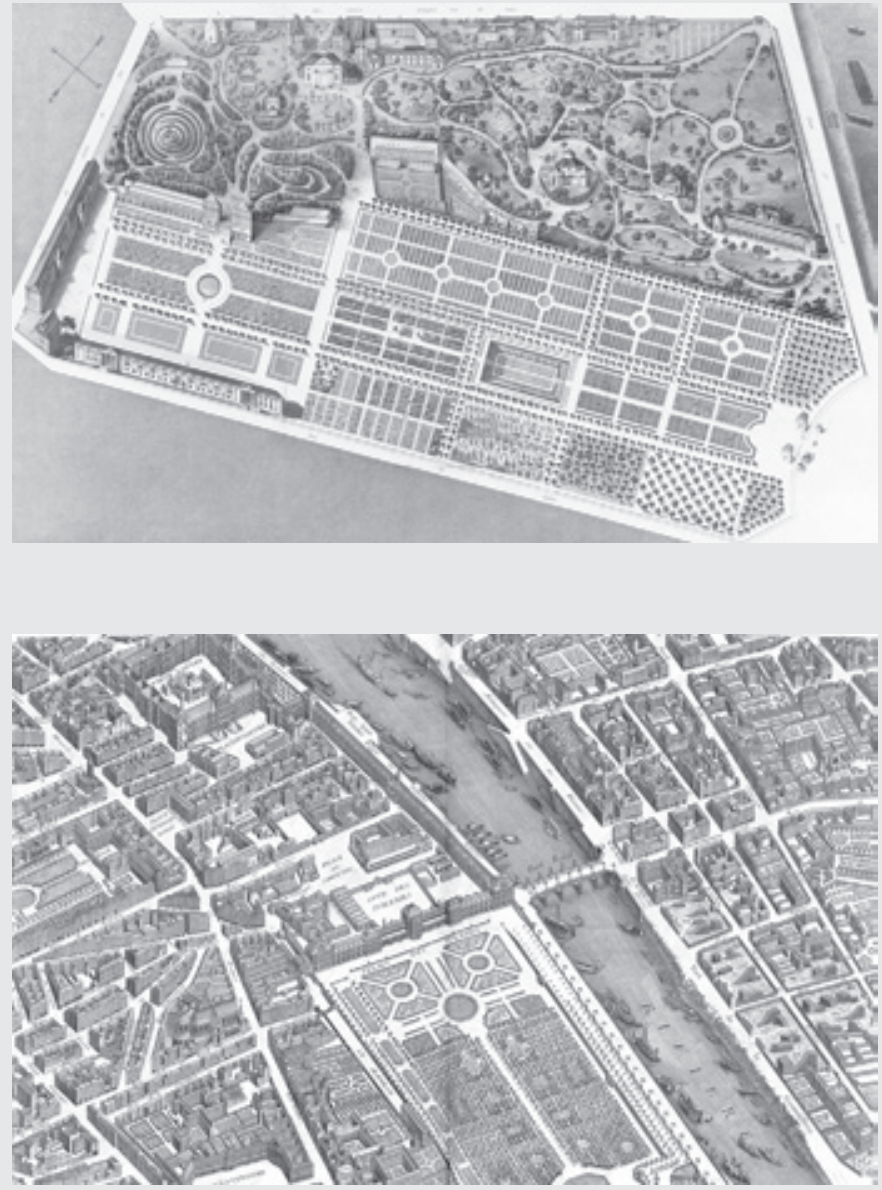

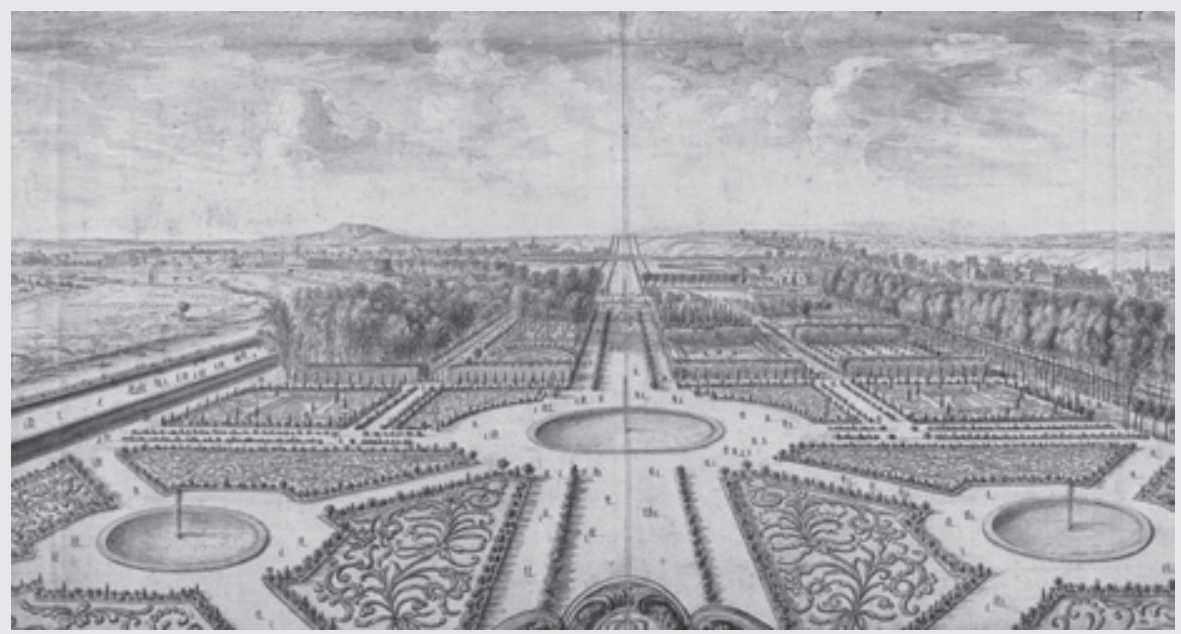

76. Vista do Jardin des Tuileries. Gravura de Israël Silvestre, segunda metade do século XVII. Fonte: Lavedan (1975, p. 293). 
parisiense; o modelo inspirador seria a Cascine florentina. (GUIDONI;

MARINO, I979, p. 289, tradução nossa) ${ }^{32}$

Um ano antes da construção do Cours-la-Reine, em uma área não muito distante do Jardin des Plantes, no lado esquerdo do Sena, Marie de Médicis (1575I6642) patrocinaria a edificação do Palais e do Jardin du Luxembourg - projetados pelo arquiteto Salomon de Brosse (I57I-I626) e inspirados no Palazzo Pitti, de Florença. Logo, a abertura do "Corso da Rainha" acompanharia, coerentemente, o gosto da imperatriz pelos espaços verdes e o apreço demonstrado por sua terra natal, já que a concepção da alameda seria baseada no Parco delle Cascine, levantado em Florença na década de 1560. O agradável passeio arborizado seria traçado pouco à frente do limite ocidental das Tuileries, em um direcionamento axial diverso dos jardins de Catherine de Médicis, buscando um sentido diagonal em relação àquela área. Seguiria, na realidade, de forma direta e retilínea, a margem setentrional do Sena - dando prosseguimento ao processo de expansão da cidade para o oeste, iniciado pela construção do complexo das Tuileries.

Décadas mais tarde, já na época de Luís XIV, André Le Nôtre, a pedido do Ministro de Estado e da Economia do monarca, Jean-Baptiste Colbert (I6I9-1683), projetaria, finalmente, o organismo paisagístico que viria a se tornar a mais famosa avenida de Paris - a já citada alameda dos Champs-Elysées. O jardineiro do rei entenderia o empreendimento como a abertura de uma larga estrada que extrapolaria enormemente os limites ocidentais do antigo núcleo urbano, distendendo profusamente o eixo perspectivo que acabara de projetar e que estava sendo rasgado no meio do Jardin des Tuileries - cujo desenho o próprio paisagista reordenava radicalmente. A grande extensão da perspectiva gerada pelo encaminhamento axial dos jardins e seu prolongamento nos Champs-Elysées é ainda mais apreensível hoje em dia, especialmente devido à destruição, em I882, das ruínas do Palais des Tuileries: atualmente, quando se olha para o ocidente a partir da esplanada do Museu do Louvre - por baixo, ou logo após o Arc de Triomphe du Carrousel - é possível apreciar a conformação dramática da imagem em profundidade do longo caminho linear que alcança o outro monumental arco do triunfo oitocentista assentado na Place de l'Etoile.

Mas, a longa avenida não seria traçada de um único relance, mas seria ampliada com o decorrer do tempo. Após I667, um pequeno trecho inicial passaria a

Henri Saulval (1623-1676) foi um importante historiador francês. 
figurar na mesma área onde partiria o Cours-la-Reine (Figura 77), em seguida ao sítio que receberia, em meados do século XVIII, a Place de la Concorde - a praça que proporcionaria a conexão perfeita entre o complexo das Tuileries, o "Corso da Rainha”, e os Champs-Elysées. Aos poucos, com a entrada do século XVIII, a alameda se prolongaria para o ocidente, transformando-se na maior via linear de Paris - revelando aquele gosto, típico da época barroca, pelas perspectivas que se perdiam no ponto de fuga postado no infinito (Figura 78 ).

Contudo, a paisagem apreendida no grande eixo perspectivo seria, até o século XIX, bastante diferente daquela apreciada hoje. Por um lado, o panorama que se mirava seria constituído por uma idílica alameda frondosa, sem a presença de construções em nenhum dos dois lados da via - daí a denominação mitológica de "Campos Elíseos"; por outro lado, a topografia, bastante diversa da situação atual, favoreceria o encaminhamento dramático da perspectiva, já que a prolongação em profundidade da alameda na direção oeste, até o alcance da Place de l'Étoile, se faria através de um suave aclive, e sua ampliação, até a distante ponte Neuilly, ofereceria a imagem de um equivalente declive. É bom dizer que estes dois trechos mais remotos da avenida só seriam abertos no século XVIII, e que, em I774, o arquiteto Jacques-Germain Soufflot (I713-1780) rebaixaria em cinco metros a Butte de Chaillot - o morro cujo cume coincidiria com a área na qual, desde a primeira metade do século XIX, estaria implantado o grande Arc de Triomphe - diminuindo, sobremaneira, a apreensão cenográfica da perspectiva que galgava suavemente a pequena elevação da colina. (MORRIS, I979, p. I65)

Analisando o desenvolvimento dos Champs-Elysées e dos passeios edificados na capital francesa durante o Ancien Régime, não deixa de ser significativo o fato de todas as vias lineares de dimensões significativas traçadas na cidade terem sido abertas para além dos limites do ambiente construído - ao contrário do que aconteceria na Roma quinhentista, onde inúmeros eixos perspectivos seriam rasgados em áreas contidas dentro de suas antigas fortificações. Ao mesmo tempo, é profundamente relevante a forma como estas avenidas eram tratadas: pensadas e levantadas antes como alamedas e passeios arborizados, ao invés de serem vias tradicionais de ocupação urbana; vias cujo caráter seria dado pela presença maciça do verde, e não pela densa massa de edifícios alinhados e agregados aos dois lados - situação que também contrastava com a realidade da capital pontifícia. Este fato revelaria a cautela que era assumida pelos imperadores franceses do Ancien Régime na proposição e na execução de intervenções viárias nas áreas mais 


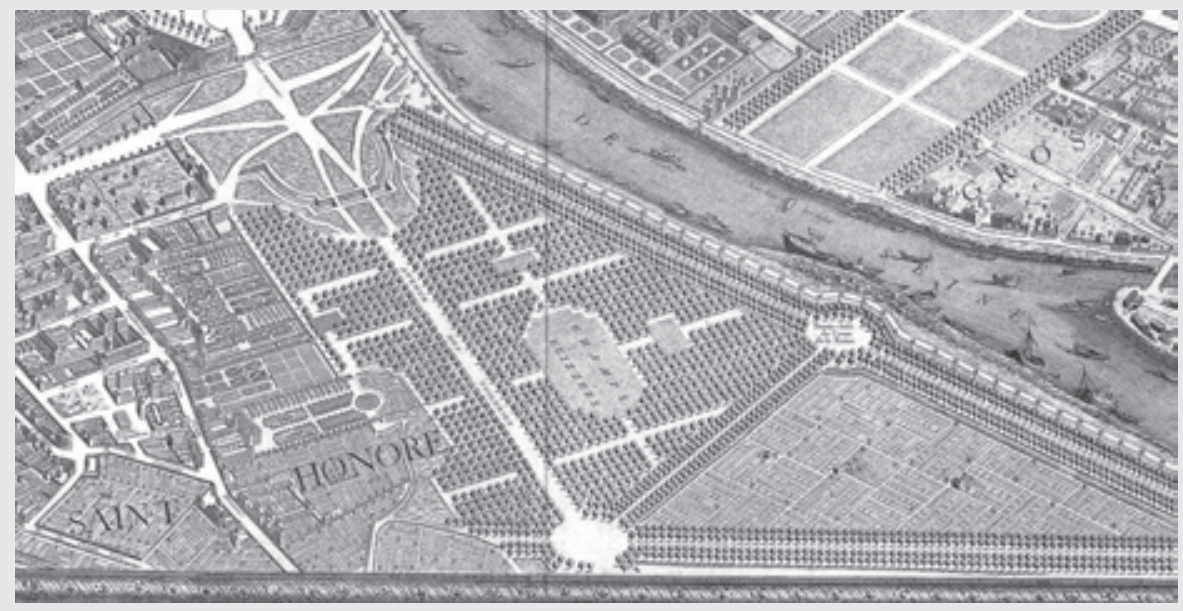

77. Cours-la-Reine (canto direito, em diagonal) e Avenida des Tuileries (no centro, no eixo do jardim) o primeiro ramal do que viria a ser a Champs-Élysées - vistos em detalhe do Plano de Turgot (1739). Os dois passeios arborizados são vistos surgindo na área que viria a acolher a futura Place Louis XV, depois Place de la Concorde. Fonte: Wikimedia Commons contributors.

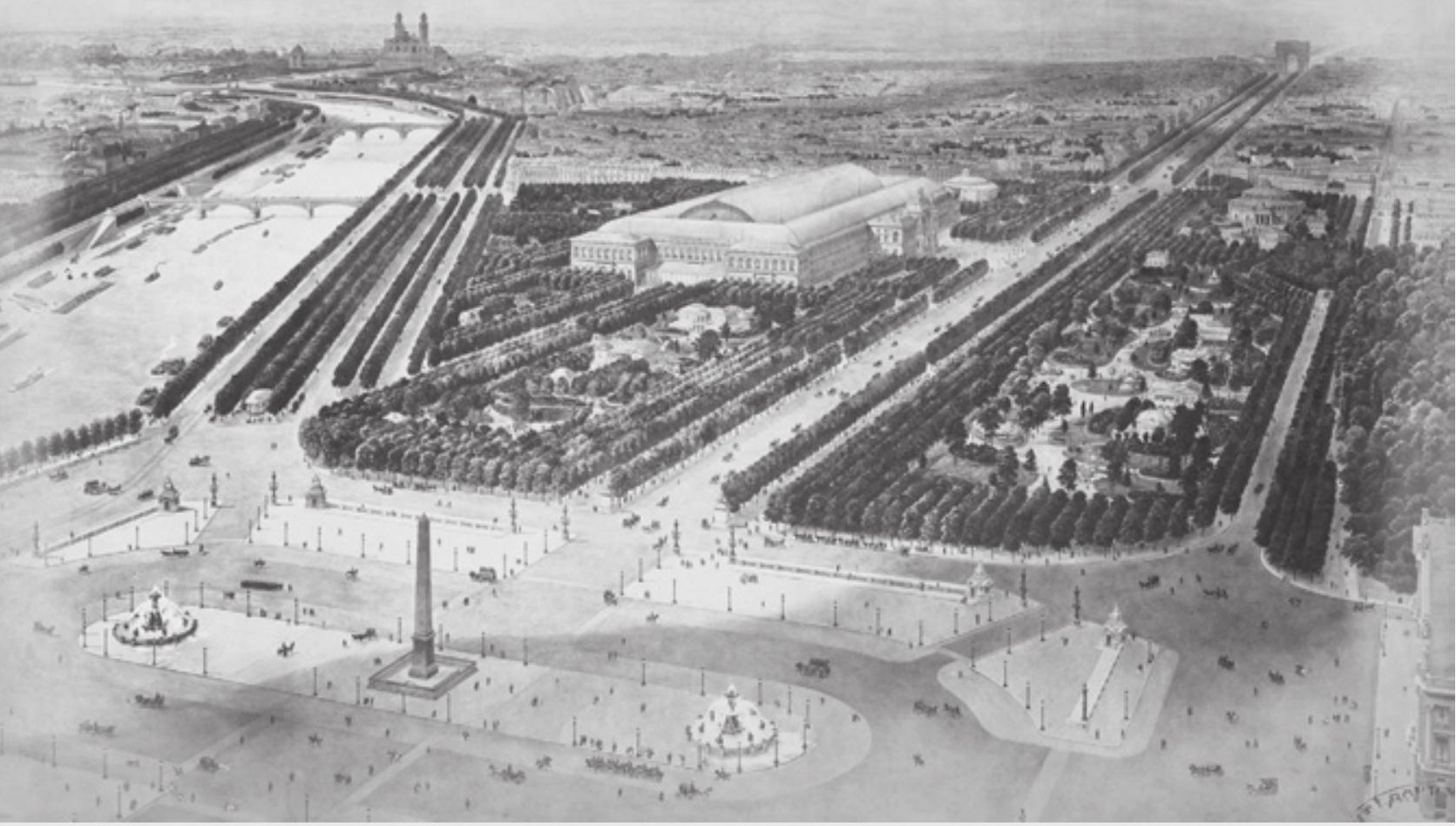

78. Vue des Champs Élysées (après dessin prise de la place de la Concorde). Artista desconhecido, 1880. A esquerda aparece o Cours-la-Reine. Fonte: Wikimedia Commons contributors. 
densas do tecido urbano - prudência derivada do alto custo social e econômico das desapropriações. Também exporia o já comentado apreço que os governantes viriam a nutrir pelos espaços urbanos ajardinados e pelas áreas verdes, que acabariam povoando os setores limítrofes do núcleo urbano.

Neste sentido, a Rue de Rivoli, extensa artéria linear de tráfego aberta para servir como eixo viário de ligação entre o Louvre, as Tuileries e a Place de la Concorde, não poderia ser encarada como uma exceção à tradição barroca de abrir alamedas retilíneas arborizadas. Na verdade, esta importante avenida, flanqueada por edificações gregárias em pelo menos um de seus lados, e rasgada em meio ao denso tecido urbano preexistente do bairro do Louvre, seria projetada e iniciada nos tempos do império napoleônico, em seguida à queda da monarquia francesa - em uma situação política e ideológica muito distinta daquela oriunda da cultura barroca do absolutismo, ligada diretamente ao contexto iluminista pós -revolucionário. Não obstante, o projeto de ocupação da avenida, desenvolvido pelos arquitetos Charles Percier (I764-I838) e Pierre François Léonard Fontaine (I762-I853), absorveria inúmeras semelhanças com a urbanística barroca do Grand Siècle, principalmente o caráter áulico e grandiloquente alcançado na repetição interminável das mesmas frontarias regulares em toda extensão da via - artifício cenográfico conseguido através da construção, por parte do governo napoleônico, das arcadas inferiores dos edifícios e da imposição aos proprietários de um desenho regular para as fachadas. $\mathrm{O}$ panorama em profundidade, composto pelo conjunto de frontarias regulares e contíguas, de um lado, e a massa verde do Jardin des Tuileries, do outro, definiria um encaminhamento dramático impressionante, pois viria a destacar enormemente a poderosa imagem da fuga perspéctica dos edifícios sequencialmente distribuídos na face norte da via (Figura 79). Por isso, a abertura da Rue de Rivoli poderia ser facilmente incluída no processo de sistematização, iniciado no século XVI, da área a oeste do palácio do Louvre - do somatório coerente de ações que viriam a conectar o Palais e o Jardin des Tuileries, a Place de la Concorde, o Cours-la-Reine, e os Champs-Elysées. Paolo Sica resume os mecanismos utilizados para garantir o caráter monumental da via:

O nó a desatar para definir a estrutura interna de Paris tinha sido há muito tempo indicado no reforço e na realização do complexo LouvreTuileries-Concorde, na direção leste-oeste, no lado direito do Sena. O primeiro elemento deste sistema é o tramo inicial da Rue de Rivoli, cuja construção se iniciou em I8oı, já em si um exemplo extremamente 


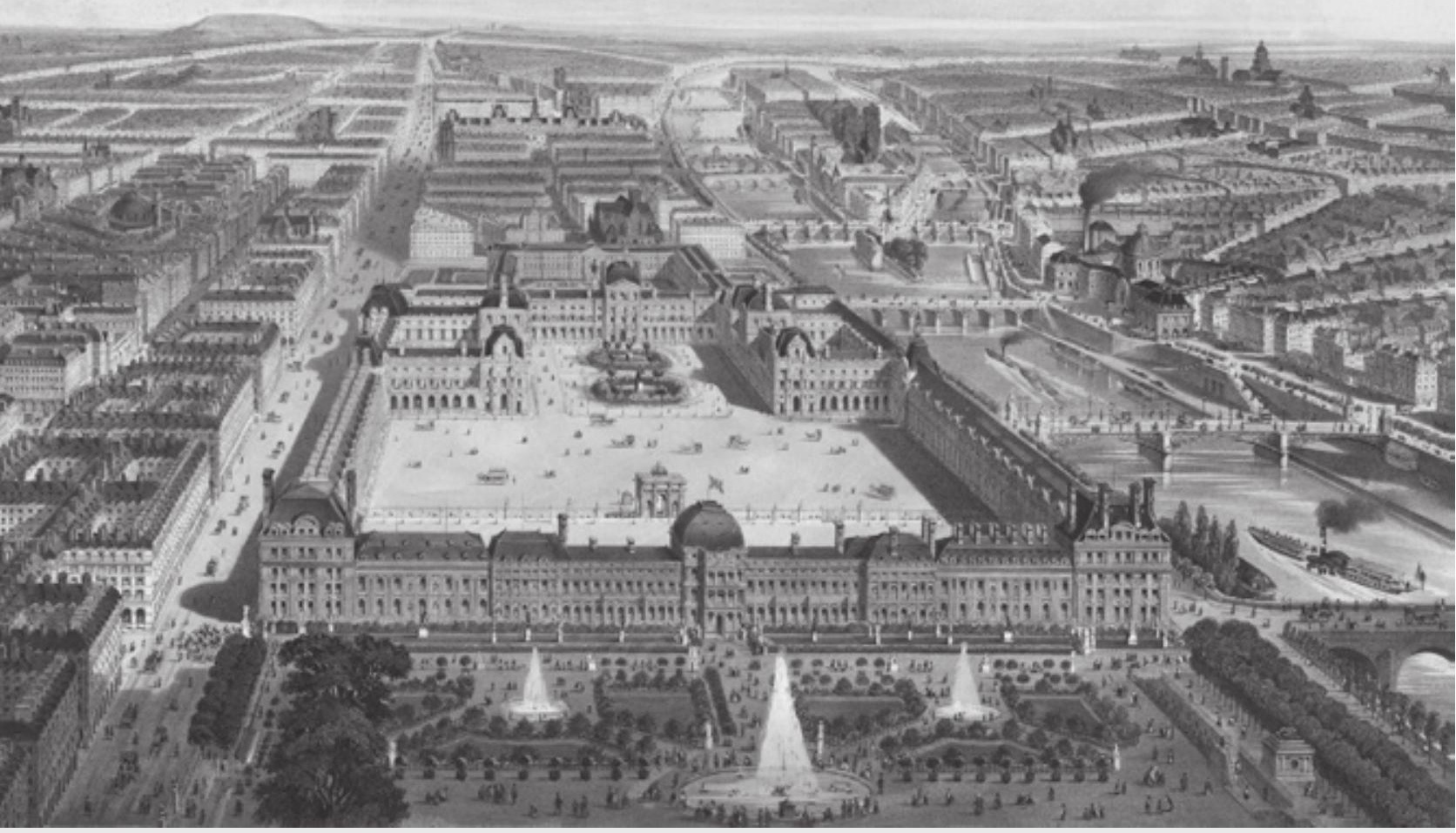

79. Paris moderne. Les Tuileries, le Louvre, et la rue de Rivoli, vue prise du Jardin des Tuileries (1850). Por Charles Fichot (1817-1903). Grande destaque para a Rue de Rivoli - que corre à esquerda, adjacente aos Jardin et Palais des Tuileries e ao Louvre. Fonte: Wikimedia Commons contributors. 
significativo de um mecanismo de construção de um setor urbano que, enquanto se propõe a salvaguardar as exigências de requalificação áulica e monumental, tende contemporaneamente a envolver a vontade e as iniciativas do capital, com funções de estímulo e de incentivo concreto. Da Rue de Rivoli, que se apresenta sobre os jardins reais das Tuileries em um tema contínuo de arcadas que encadeiam habitações e negócios, Percier e Fontaine desenham as fachadas e prescrevem os termos da unificação estilística e perspectiva da arquitetura. Depois, aos cuidados da iniciativa pública, se constroem as arcadas de suporte dos edifícios, deixando aos proprietários privados as intervenções de completamento da obra. A infraestrutura deve agir - mesmo que materialmente - como suporte direto geral para as intervenções singulares dos proprietários: o capital público é usado com valor promocional, mas as premissas e os fins da operação implicam ainda uma 'figura' da arquitetura tipologicamente preordenada. (SICA, I992, p. 297-299, tradução nossa)

A última das ações relevantes de inclusão de organismos verdes na Paris seiscentista acabaria se transformando na mais vasta das intervenções viárias dos séculos XVII e XVIII: os Grands Boulevards, dilatadas alamedas com cerca de 40 metros de largura e que, em comprimento, chegariam a contar com mais de cinco quilômetros de perímetro. A abertura dos bucólicos bulevares, fruto da iniciativa do Roi-Soleil e dos esforços de seu primeiro ministro, Jean-Baptiste Colbert, ofereceria, para a cidade, uma larga avenida com quatro pistas para o tráfego de carroças, todas separadas por fileiras de árvores dispostas de forma regular, que sequencialmente flanqueavam os dois lados de cada caminho. A monumental artéria verde envolveria, em um primeiro momento, toda a área edificada que se estendia para além da margem direita do Rio Sena (Figuras 80-8I); em um segundo momento, já no século XVIII, alcançaria os contornos da área habitada no lado meridional do rio.

$\mathrm{Na}$ verdade, com a abertura dos grandes bulevares o governo da cidade de Paris inauguraria uma prática de planejamento e desenho urbano que algumas décadas depois seria frequentemente reproduzida nos mais diversos contextos do continente europeu: a derrubada das antigas muralhas e a criação, na consequente área desolada que envolveria a cidade, de parques públicos ou vias arborizadas de contorno. Se a urbanística do século XVI se caracterizaria, primordialmente, pelas graves preocupações com a defesa - com a onerosa reconstrução das cintas 


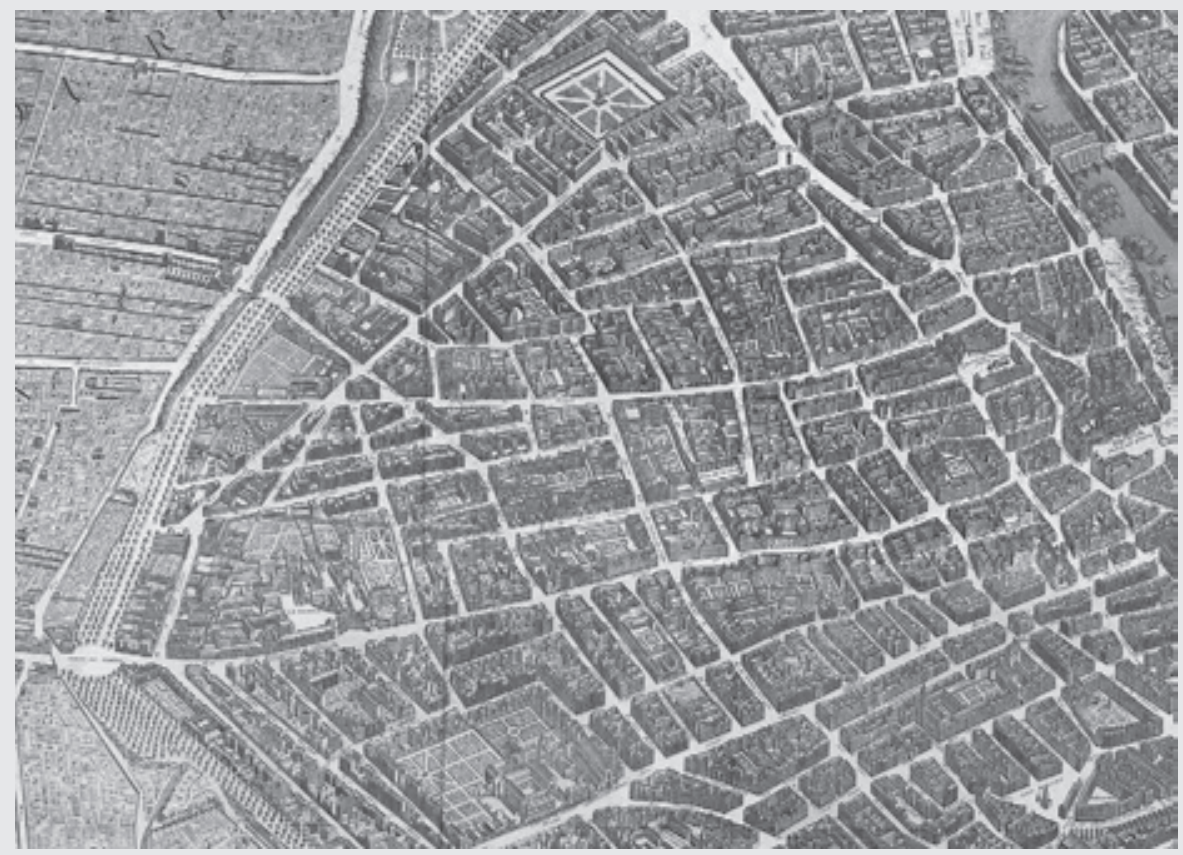

8o. Les Grands Boulevards, em um detalhe do Plan de Turgot (1739). Fonte: Wikimedia Commons contributors.

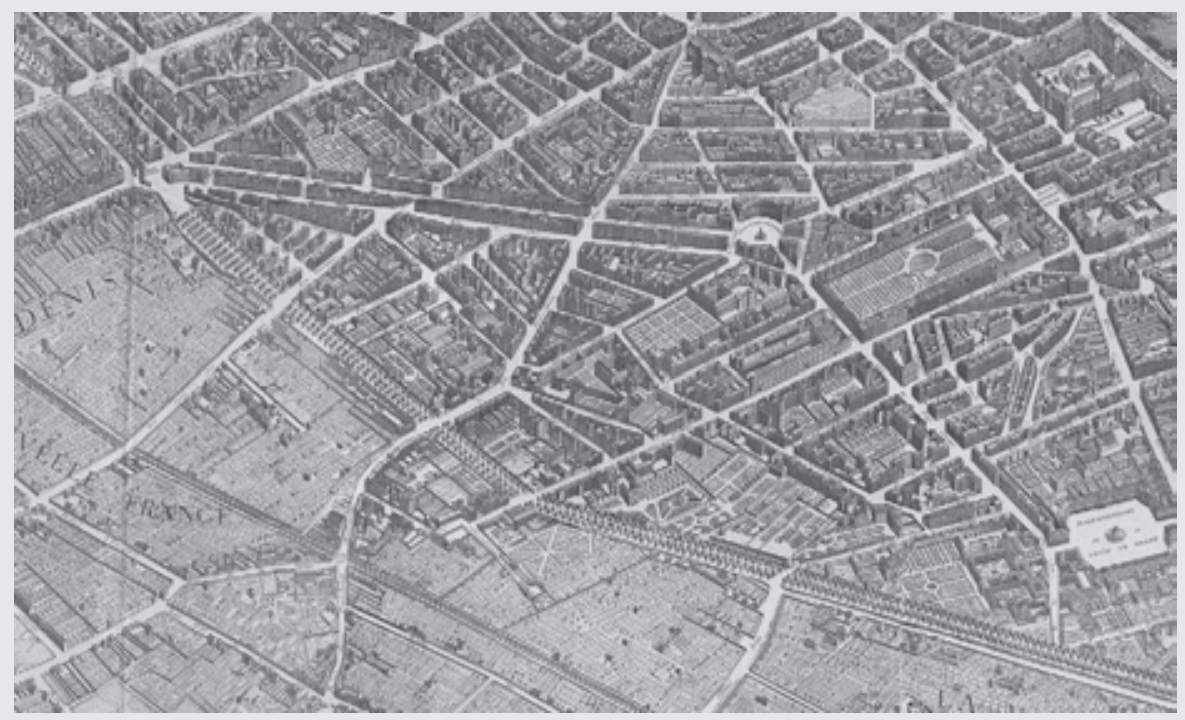

81. Les Grands Boulevards, próximo a Place des Victoires, em um detalhe do Plan de Turgot. Fonte: Wikimedia Commons contributors. 
fortificadas que protegiam as mais importantes cidades do continente, inibindo, fatalmente, o crescimento de muitos dos núcleos urbanos, em função da grande extensão radial necessária para o funcionamento adequado dos modernos sistemas defensivos (para que pudessem resguardar as cidades das incursões da artilharia pesada dos inimigos) -, a capital francesa (que também teria seus muros refeitos e ampliados) daria início à fase de destruição das muralhas e à natural expansão radial de seu centro urbano.

Não que o governo da mais poderosa nação do Grand Siècle tenha se descuidado dos problemas de defesa. Pelo contrário: da mesma forma que Luís XIV traria Jules Hardouin-Mansart como seu arquiteto de confiança, e André Le Nôtre como seu paisagista oficial, também contaria com os serviços daquele que viria a ser o maior engenheiro militar da história: o Marechal Sébastien Le Prestre, Marquês de Vauban (I633-I707). Vauban revolucionaria a arte das fortificações de núcleos urbanos e de construção de cidadelas, fundando diversas praças fortes para a proteção das fronteiras da nação francesa, principalmente no último quartel do século XVII - com destaque à conhecida cidade de Neuf Brisach, projetada ao final dos seiscentos e construída entre I698 e I707 nas proximidades de Estrasburgo, na fronteira nordeste da França, próximo às atuais Suíça e Alemanha. Contudo, já na década de I660, mesmo antes de Vauban organizar definitivamente o sistema defensivo que tornaria as bordas do império do Rei Sol quase inexpugnáveis, o país já estaria muito bem defendido e a cidade de Paris não estaria correndo riscos eminentes de ser tomada, nem sequer de sofrer qualquer aproximação por parte de seus inimigos - fato também favorecido pela paz interna que reinava nas províncias. (MORRIS, 1979, p. 165) A consequência desta situação de estabilidade política para a capital francesa é sintetizada por Cesare de Seta (1978, p. 65-66, tradução nossa) no já debatido ensaio Sulla presunta "città barocca":

Colbert possui a consciência histórica de que Paris não é mais a cidade a se defender dos assédios - o sistema defensivo está, de agora em diante, organizado nos confins do Estado, concentrado sobre Vauban -, e sim a capital de um reino de limites extensíssimos e fronteiras seguras: caracteriza, deste modo, o novo papel de Paris como sistema metropolitano aberto, e não mais fechado sobre seus muros. [...] A cidade de Colbert é a capital do reino; por isso seus muros devem ser substituídos pela circunvalação dos grandes boulevards, coligados com um sistema radial que se irradia no campo. 
Portanto, Colbert proporcionaria a Paris o sentido de abertura que passaria a caracterizar as cidades barrocas e iluministas europeias, núcleos urbanos que aos poucos também viriam a se libertar das muralhas e, na ausência dos limites impostos pelos sistemas defensivos, se expandiriam enormemente para além dos burgos medievais que formavam o centro urbano. Este caráter acessível e dinâmico estaria em total congruência com o espírito barroco, mais especificamente com a influente cultura absolutista: da capital aberta e expansiva, disposta geográfica ou simbolicamente no centro da nação, um sistema irradiante de caminhos deveria alcançar os confins do império, contribuindo para o controle absoluto que o monarca deveria guardar frente aos seus súditos, frente às províncias e mesmo às mais remotas aldeias.

Certamente, uma grande sensação de alívio deve ter sido gradualmente assimilada pela população na medida em que as pesadas, onerosas, agressivas e desagradáveis fortificações vinham sendo substituídas pelos idílicos passeios dos bulevares, artérias verdes que tomariam o lugar dos muros, baluartes e fossos, nos antigos confins da cidade. Em consonância com esta situação histórica, o próprio termo boulevard, assintomaticamente adotado após as intervenções em Paris para denominar qualquer avenida flanqueada por fileiras de árvores, seria inequivocamente derivado do processo que marcou a abertura dos Grands Boulevards parisienses: etimologicamente teria sua origem na corruptela da palavra nórdica equivalente a "baluarte", "bulvirke". (MORRIS, I979, p. I65) Benevolo (2008, p. 68o, tradução nossa) acrescenta:

Mas as medidas mais importantes referem-se à nova periferia. A cidade, que atinge os 600.000 habitantes, já havia crescido muito além dos limites impostos por Luís XIII, e a cinta fortificada, embora completada pouco a pouco nas imediações do bairro do Louvre, perdeu todo o significado militar. Colbert, em i662, fixa um novo perímetro além do qual é vetado construir (mais ou menos correspondente ao contorno tributário dos fermiers généraux, constituído por Luís XVI entre I785-87), mas abandona a ideia de fortificar a capital e começa a transformar a antiga cidade fechada em uma cidade aberta. Manda demolir, entre i67o e I676, as fortificações do lado direito do Sena, e sistematiza em seu lugar uma avenida arborizada larga I8 toesas 'para um maior decoro da cidade e para servir de passeio aos habitantes'; projeta uma análoga cinta de avenidas em torno da área habitada ao lado esquerdo do rio, mas desta vez, não podendo utilizar uma faixa de terreno de propriedade pública, 
não é capaz de iniciar os trabalhos (esta cinta será executada aos poucos no curso do século XVIII). Nascem assim os Grands Boulevards: não uma série de ramais de estrada isolados, como os passeios da primeira metade do século XVII, mas uma nova rede viária que envolve aquela precedente traçada no Medievo e libera o campo em volta da cidade.

\section{Urbanística regular e paisagismo: Vaux-le-Vicomte e Versailles}

A análise das intervenções urbanísticas mais significativas que Paris sofreria nos seiscentos e nos setecentos abre caminho para uma discussão essencial: se a inclusão do verde na cidade - na composição de jardins púbicos e privados, passeios, alamedas, bulevares -, em conexão com a abertura das praças reais, durante o Ancien Régime, teria conseguido alterar, significativamente, a densa paisagem medieval preexistente; se o caráter visibilístico e cenográfico do núcleo urbano teria assumido genericamente uma condição barroca, desvelando uma transformação sistemática da paisagem da grande cidade em nome da exaltação retórica e persuasiva da monarquia governante.

Já se debateu a incapacidade das praças construídas em homenagem aos monarcas Henrique IV, Luís XIII, Luís XIV e Luís XV33 em modificar, de forma relevante, a paisagem urbana da Paris medieval. Em relação às intervenções verdes que a capital francesa viria a sofrer, a situação não seria diferente: por mais extensas e expressivas tenham sido, por mais influência que tenham exercido para o posterior crescimento da cidade e para a atribuição de um caráter aberto e dinâmico a uma parte do organismo preexistente, elas ficariam quase que invariavelmente restritas a algumas áreas limítrofes da cidade, ou mesmo fundadas para além do ambiente construído. Era como se um novo sistema, que aliasse a proximidade entre a cidade e o campo, fosse edificado, independe do núcleo urbano. Uma cidade para os ricos - confirmando o que diria Mumford (I989, p. 370-37I); um organismo que, apesar de estar conectado indissociavelmente ao ambiente preexistente, se desenvolvia alheio a ele. Logo, o conjunto dos espaços verdes destinados à contemplação, lazer, passeio ou tráfego não teria conseguido gerar, efetivamente, uma Paris barroca - mesmo com a inclusão de refinados monumentos de inspiração militar: como arcos do triunfo, por exemplo, equipa-

33 Pegando o recorte dos século XVII e XVIII, apenas o último dos reis franceses do antigo regime, Luís XVI (1754-1793), que seria guilhotinado na Place de la Concorde, não edificaria uma imponente praça real. 
mentos ornamentais levantados em pontos estratégicos das avenidas, passeios e bulevares, nas localidades que coincidiriam com os antigos acessos à cidade; monumentos justapostos às ancestrais portas que permitiriam, antes da derrubada das muralhas, o ingresso ao núcleo urbano (Figura 82).

É certo que a cidade receberia e celebraria pontualmente uma série de episódios dramáticos ligados à Grand Manner; mas seriam eventos incapazes de contaminar, com sua carga teatral, todo o imenso núcleo urbano preexistente. Da mesma forma, seria possível testemunhar a alteração substancial da dinâmica de crescimento da capital ao serem rompidos os limites que até então o cinturão fortificado impunha - mas esta moderna cidade, aberta e expansiva, não afetaria, de forma significativa, o apertado núcleo urbano original; não tocaria expressivamente o antigo burgo remanescente dos tempos medievais.

O fato é que, a partir da década de I660, o Rei Sol passaria a revelar certo desinteresse em relação à planificação e à monumentalização de Paris. O monarca se afastaria substancialmente dos problemas que apontavam à remodelação da capital segundo os novos preceitos expostos pela cultura barroca seiscentista, pois estaria dirigindo seus esforços para a edificação de outro conjunto que se tornaria, súbita e inesperadamente, a sede oficial da corte francesa em substituição à antiga capital: o Château de Versailles - um extraordinário complexo arquitetônico concebido para a realeza; um núcleo urbano e paisagístico, minuciosamente planificado, que alcançaria a realização global dos objetivos cenográficos e persuasivos da Grand Manner; um recinto monumental que apresentaria uma coerente interface entre o ambiente natural artificialmente composto, a gigantesca mole da residência palaciana e a cidade desenhada à frente do castelo.

Colbert acreditava que o rei deveria voltar suas energias ao embelezamento da histórica capital, aproveitando os fartos recursos que abundavam por estarem sendo pouco direcionados às onerosas campanhas militares - já que a paz reinante diminuíra o empenho para a conquista de territórios e a necessidade do Estado em contrair gastos exorbitantes em nome da proteção das fronteiras da nação. Neste sentido, o primeiro ministro diria:

$\mathrm{Na}$ falta de ações de guerra exaltantes, nada mais assinala o espírito de grandeza dos príncipes que as construções que atraem com estupor os olhos do povo, e toda a posteridade os vangloriará por estes soberbos edifícios que levantaram durante as suas vidas" (COLBERT apud GUIDONI; MARINO, I979, p. 492, tradução nossa) 

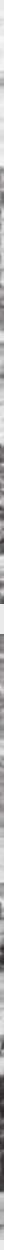

82. Arcos do triunfo levantados, no século XVII, em pontos estratégicos das avenidas, passeios e bulevares de Paris, nas localidades que coincidiriam com os antigos acessos à cidade. Nessa ordem: a Porta de Saint-Denis, ornando uma das antigas entradas nos limites da cidade; a Porta Saint-Bernard; o Arco do Triunfo da Place du Trône; a Porta Saint-Antoine. Gravuras de Perelle. Fonte: Lavedan (1975, p. 190-195). 
Palavras perfeitamente adequadas à busca barroca pelo estupor; à procura desenfreada pelos mecanismos de sedução, direção e conquista que provocassem a paralisia do espectador, que impressionassem os súditos com as imagens capturadas, levando-os a apoiarem obtusamente o governo que os subjugava. (MARAVALL, 2007, p. 88-89) Nesta direção, o primeiro ministro se empenharia efusivamente em patrocinar as já discutidas intervenções urbanísticas que a Paris dos tempos barrocos viria a sofrer, bem como a construção ou restauração de grandes estruturas arquitetônicas, edificações monumentais que chegariam a atingir uma escala propriamente urbanística: como as gigantescas estruturas do Dôme e do Hôtel des Invalides - primeiro hospital militar construído em Paris (Figuras 83-85) -, o Collège des Quatre-Nations, ou a fachada leste do Palácio do Louvre.

No entanto, apesar das fortes pressões do primeiro ministro Colbert, Luís XIV concentraria os fundos do Estado na construção de Versailles - fato que seria, décadas mais tarde, condenado abertamente pelo filósofo iluminista FrançoisMarie Arouet (I694-I778), mais conhecido como Voltaire:

Se Luís XIV tivesse gasto em Paris a quinta parte daquilo que desembolsou em Versailles para forçar a natureza, Paris seria em toda a sua extensão tão bela como entre as Tuileries e o Palais Royale, e teria se tornado a cidade mais magnífica do universo." (VOLTAIRE, I74I apud BENEVOLO, 2008, p. 68I, tradução nossa)

Ou seja, já se tinha absoluta consciência, no século XVIII, de que o projeto seiscentista de transformar Paris em uma cidade cenograficamente tão impecável e expressiva como a Roma barroca falharia por conta do desejo pessoal do Rei Sol em converter sua residência de verão no mais suntuoso e monumental palácio jamais visto - em uma morada que representasse a pompa ritualística de sua corte. $E$ a rígida etiqueta que a realeza francesa, na época do Rei Sol, deveria seguir em prol do espetáculo teatral da persuasão barroca teria contribuído decisivamente para a escolha de Versailles como sede oficial da corte, como apontaria o professor de história francesa Alfred Cobban (I9OI-I968), em seu livro de I957 intitulado A history of modern France:

A rígida etiqueta que Luís impunha para sua corte não deve ser julgada como expressão da frivolidade do espírito, mas como astúcia política. O propósito perseguido consistia em proporcionar o cenário adequado ao monarca que iria converter-se no centro da vida da nação 
e sobre o qual estavam dirigidos todos os olhares. A corte constituía um espetáculo permanente para o povo: a vida do rei transcorria em público, desde o nascimento até a morte. [...] Com tudo isso e com um rei como Luís XIV desempenhando o papel principal, a corte se converteu em um cenário de um ballet contínuo representado perante um auditório de vinte milhões de espectadores. Para isso se requeria um fundo mais clássico que as desarticuladas estâncias reais de Paris. Pese o fato de se ter argumentado outros motivos sobre a razão que impulsionou Luís XIV a abandonar Paris por Versailles - a aversão pela sua capital induzida pelos problemas trazidos pela Fronde, ${ }^{34}$ seu amor por caminhar e caçar, o desejo de aliviar sua amante da dificuldade de viver em uma grande cidade -, a necessidade de prover um glorioso marco para a corte não foi o menos importante. (COBBAN, I99o, p. II, tradução nossa)

Portando, o irredutível monarca não estaria agindo por simples capricho: o Rei Sol tinha absoluta consciência da necessidade da sede da corte de se apresentar aos súditos e às outras nações como um cenário digno e pertinente à expressão do mais prestigioso e próspero Estado da época. Contudo, a tarefa de transformar Paris em uma cidade modelo para a representação da poderosa monarquia de Luís XIV - em um núcleo urbano organizado segundo os princípios franceses do Classicismo barroco e adornado com o que poderia haver de mais suntuoso e monumental para a arquitetura e a arte do Grand Siècle -, seria uma tarefa quase impossível. Exigiria a aniquilação de praticamente todo o ambiente preexistente, especialmente em sua área mais central, mais densamente habitada - o antigo burgo que deu origem à cidade. Depois de pulverizado, o núcleo urbano deveria ser amplamente redelineado em seu traçado e depois reconstruído através daqueles instrumentos de controle satisfatoriamente utilizados, em uma escala muito reduzida, nas places royales. Para a cidade inteira, estes artifícios se fariam inviáveis, pois seria imperativo o uso de mecanismos tirânicos de desapropriação em uma escala nunca antes vista, incursões que fatalmente atingiriam a totalidade da massa edificada, promovendo ações bastante impopulares e incrivelmente onerosas - e, na verdade, inexequíveis economicamente, mesmo levando-se em conta os fartos recursos disponíveis na segunda metade do século XVII. Muito mais fácil e imediato seria a criação de uma estrutura urbanística e paisagísti- 


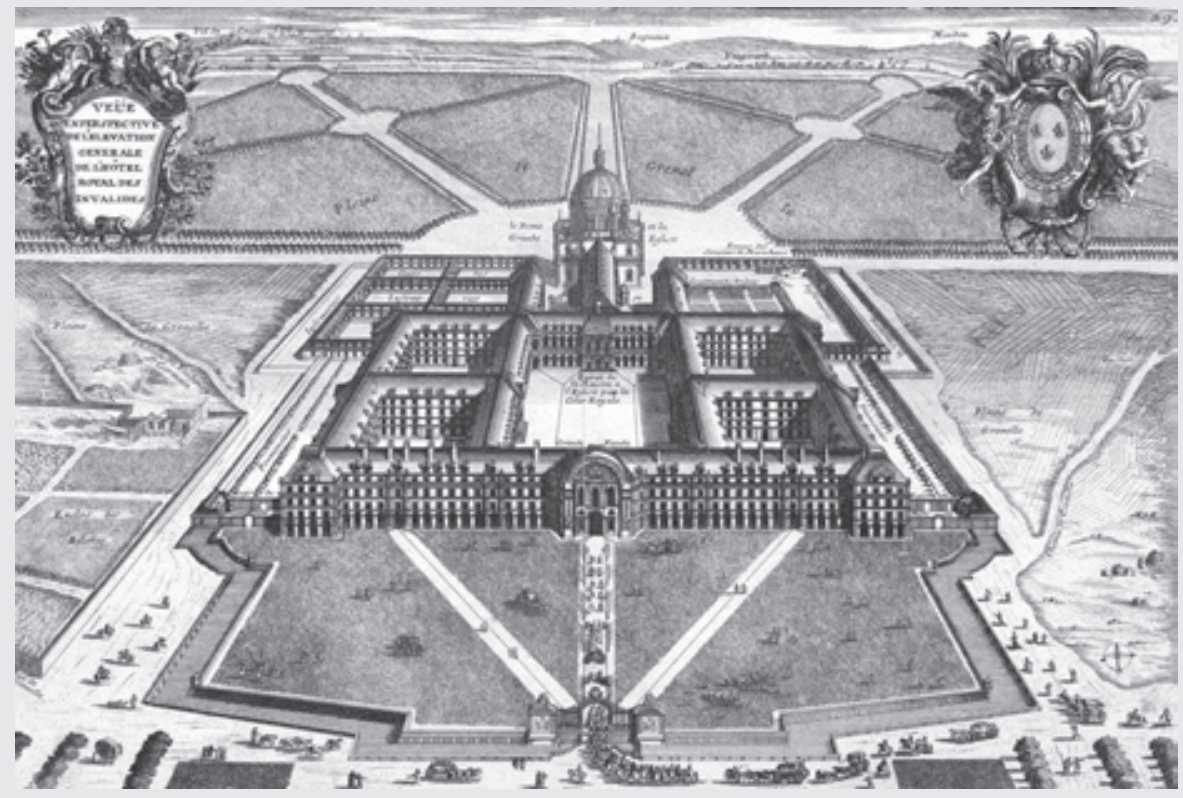

83. Veue en Perspective de l'Elevation Generale de Hotel Royal des Invalides. Vista feita, em 1714, por Nicolas de Fer (1646-1720), do complexo arquitetônico dos Inválidos. Percebe-se o tridente que marca a entrada do complexo e o polivium de cinco vias que se dirige à Catedral de Saint-Loius-des-Invalides. Fonte: David Rumsey Historical Map Collection.

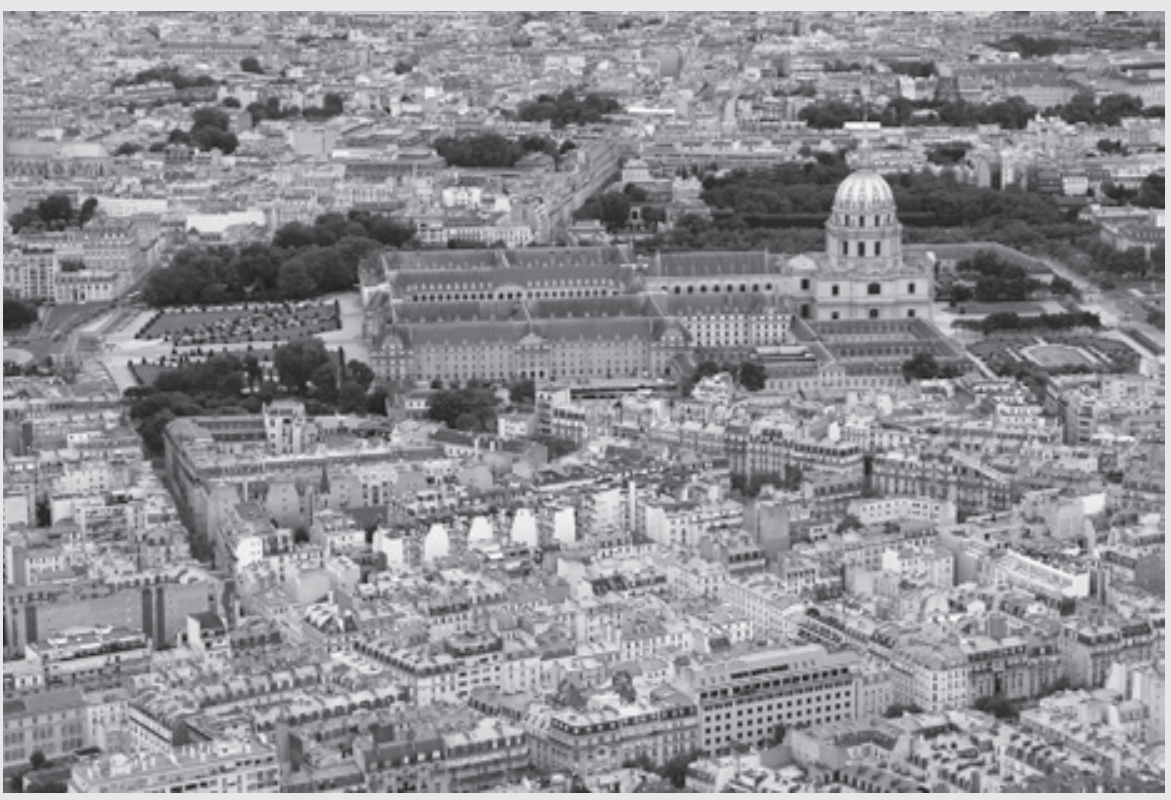

84. Fotografia aérea do Hôtel des Invalides em Paris, projetado pelo arquiteto Libéral Bruant (1636-1697) entre 1671-1677. Destaque para a Catedral de Saint-Loius-des-Invalides, igreja projetada por Jules Hardouin-Mansart. Fonte: Fotografia elaborada por Walter Gustavo Mera Melo (2013) - Licença: CC BY 2.0/ Wikimedia Commons contributors. 


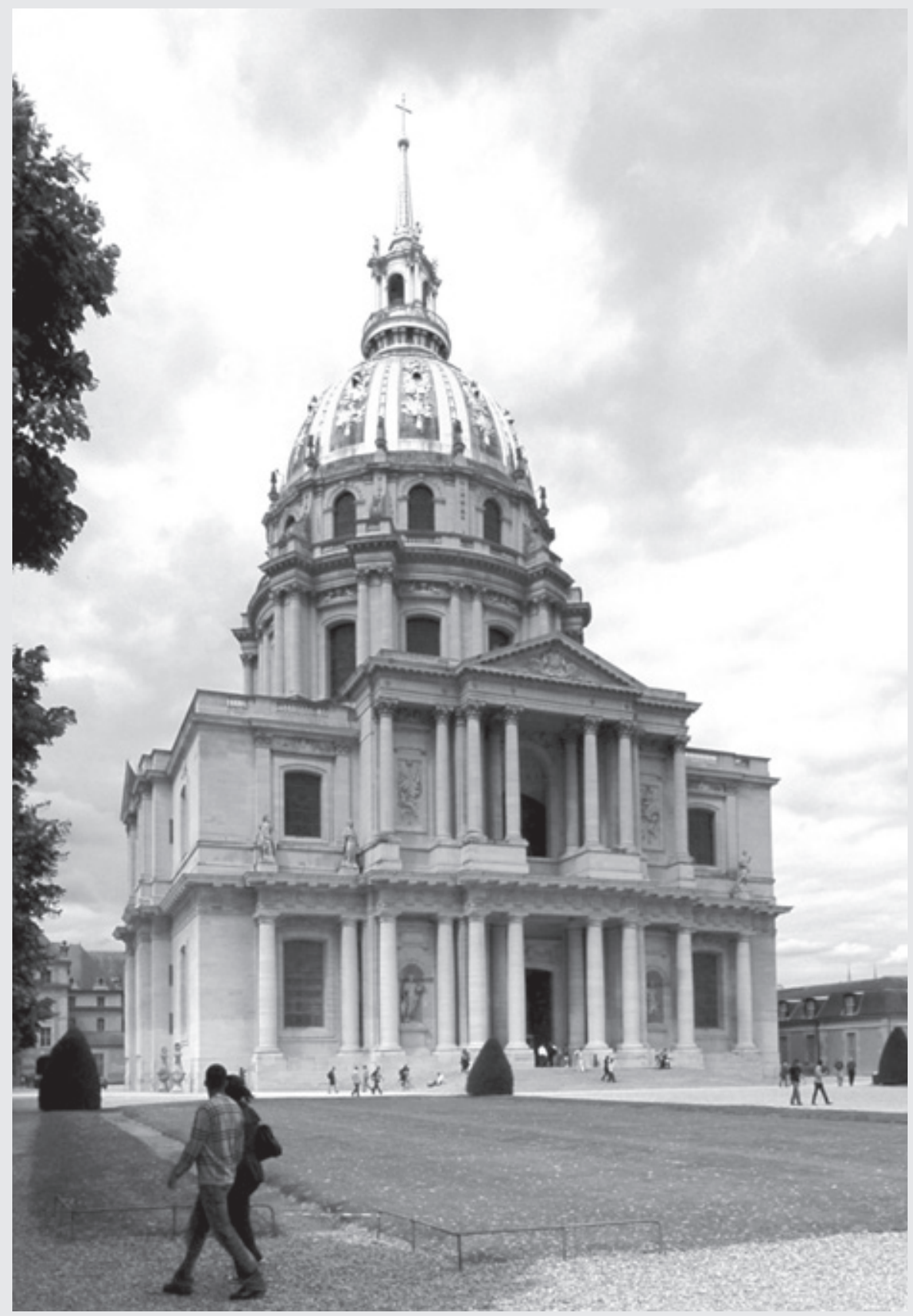

85. A retórica barroca seiscentista, na França, seria exposta através do desenvolvimento de um Classicismo monumental, aristocrático e profundamente sóbrio - como seria possível visualizar na Catedral de Saint-Loiusdes-Invalides, em Paris - igreja projetada por Jules Hardouin-Mansart (1646-1708) e construída entre 1676 e 1706. Fonte: Fotografia elaborada pelo autor (2007). 
ca em território virgem; um complexo urbano desenhado segundo os preceitos retóricos e teatrais caros à época, princípios oriundos da cultura barroca e que comandariam a concepção da cidade, do palácio e dos jardins. O ambiente escolhido, o antigo pavilhão de caça de Luís XIII em Versailles, era, em sua maior parte, pantanoso e insalubre, mas estes problemas seriam facilmente solucionáveis se comparados à grande empresa de reordenar a cidade de Paris.

Historicamente, o interesse do Rei Sol pela remodelação de Versailles seria despertado em I66I quando o monarca compareceu, a convite de seu superintendente das finanças, Nicholas Fouquet (1615-I680), à aparatosa festa de inauguração de seu château (Figura 86), construído na área rural, nas imediações de Paris: o palácio e os jardins de Vaux-le-Vicomte. O imperador teria ficado comovido - para além da espantosa e soberba celebração que envolveria os maiores artistas da época - com o conjunto arquitetônico-paisagístico projetado pelo arquiteto Louis-Le-Vau (I6I2-I670), que conceberia o palácio, pelo pintor Charles Le Brun (I6I9-I690), que projetaria a rica decoração da residência, e especialmente pelos trabalhos desenvolvidos por André Le Nôtre, que idealizaria o impressionante jardim, modelo para as próximas realizações que viriam a sublinhar o tipo de composição paisagística, profundamente barroca, que ficaria conhecida como "jardim à francesa". NorbergSchulz (1974, p. I50, tradução nossa) sintetizaria as inovações promovidas por Le Nôtre - cujo pioneiro ensaio aconteceria nos vastos jardins de Vaux-le-Vicomte:

[...] os pressupostos de tais inovações derivam da arquitetura dos jardins. O grande inovador, neste campo, foi André Le Nôtre (I6I3-I70o). Apesar da sua infinita variedade, os seus jardins se baseiam sobre poucos princípios elementares. $\mathrm{O}$ artifício principal é naturalmente o eixo longitudinal, que constitui o 'percurso' que conduz o visitante até a sua meta: o palácio divide o percurso em duas metades diferentes; a chegada ao mundo urbano através o pátio 'aberto'; a imersão no infinito, definida como uma gradual passagem através do ambiente ainda 'civilizado' dos 'parterres', a natureza domesticada do 'bosquet', e a natureza 'natural' do 'selvatico'. Eixos transversais e esquemas radiais são introduzidos para dar a sensação do caráter aberto do sistema.

Logo, a ordenação do ambiente pressupôs a presença do organismo plástico-volumétrico do castelo como "divisor de águas" entre a chegada ao pátio para quem vinha do ambiente rural - espaço que receberia o visitante e lhe apresentaria o château -, e o imenso jardim que se desenvolveria ao fundo, recinto aberto 


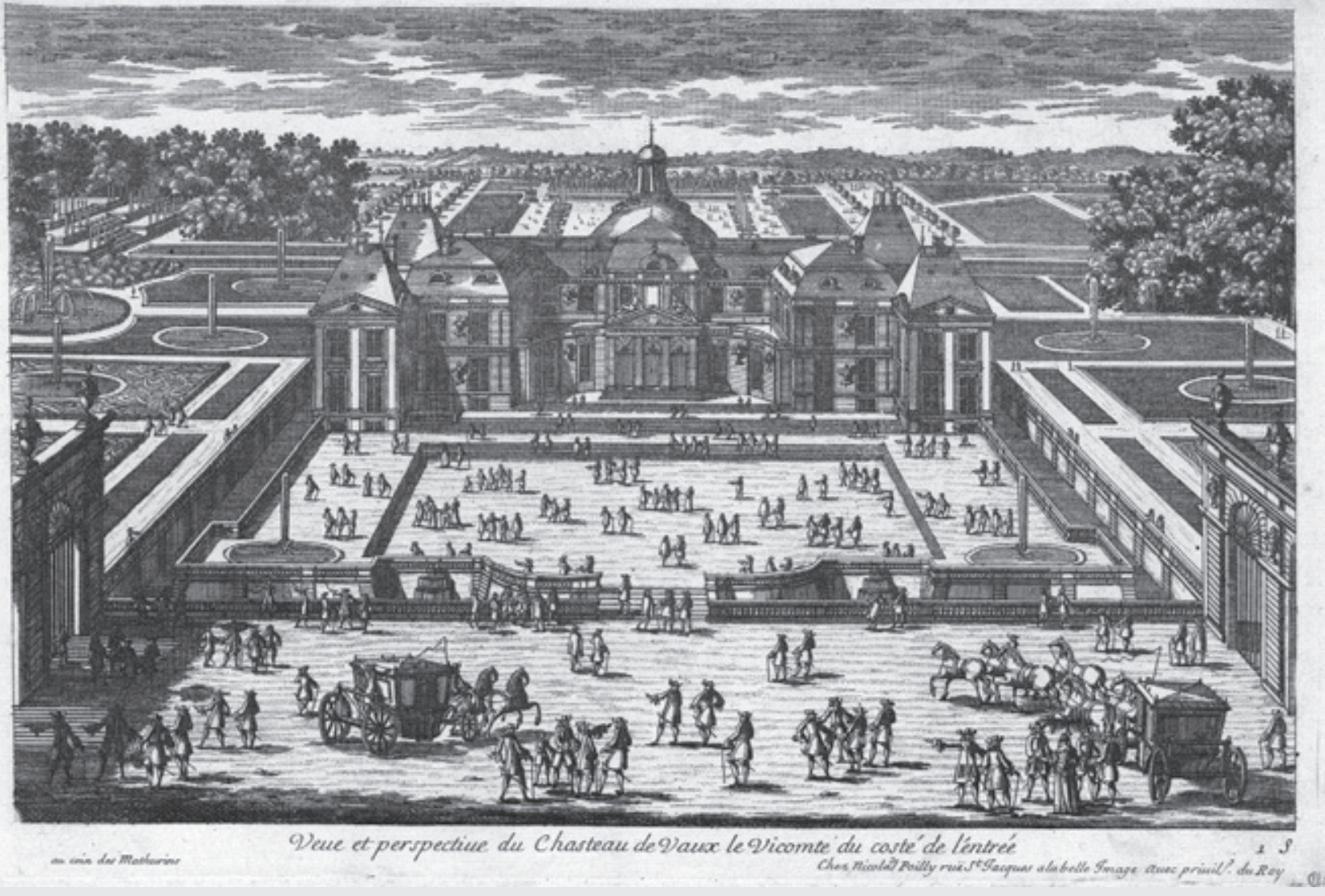

86. Veue et perspective du Chasteau de Vaux-le-Vicomte du costé de l'entrée. Autor desconhecido. Panorama do palácio desde seu acesso principal. Segunda metade do século XVII. Fonte: Wikimedia Commons contributors. 
no qual o espectador se sentiria perdido na miragem perspectiva que se abria para além da distante colina que marcava a conclusão do eixo dominante que orientava o conjunto. Para conseguir este encaminhamento da vista concentrada em profundidade, Le Nôtre forçaria a apreensão de um panorama desenvolvido através de um direcionamento axial centralizado, orientado no sentido norte-sul, se expandindo longitudinalmente. $\mathrm{O}$ artifício imediato para se alcançar este objetivo estaria fundado na concepção de uma forma relativamente estreita para o jardim, que se distenderia linearmente através do eixo dominante, sendo estrangulada nas proximidades da colina para compelir o enquadramento do ponto de fuga. Logo, mirando para o sul, dos fundos da nobre residência de Fouquet, cercas vivas regulares, formadas por arbustos de poda precisa e dispostos nos lados maiores das plataformas, separariam os jardins artificiais dos frondosos e densos bosques que flanqueavam os parterres; mais distante, quase no limite do olhar, o gramado transporia a suave colina e os alinhamentos dos bosques se fechariam até emoldurar, no ponto de fuga, uma enorme cópia da estátua de Hércules Farnesio, ${ }^{35}$ representando, simbolicamente, o poderoso Fouquet. Para além da colina, o projeto previa a abertura de um tridente que se irradiaria desde o colosso disposto em uma praça circular, dando prosseguimento, em sua alameda central, ao eixo dominante e ao encaminhamento perspectivo que caracterizava a concepção de Le Nôtre - hoje em dia só se preserva esta alameda axial (Figuras 87-88).

Não obstante, antes de o transeunte alcançar o colosso, a meio caminho entre o château e o outeiro, seria possível vislumbrar a abertura gradual de um extenso espelho d'água que longamente se dissiparia no sentido transversal ao eixo principal do jardim, decompondo a "captura do infinito", ao forçá-la também para o direcionamento leste-oeste. Tanto a linha dominante do complexo como o encaminhamento transversal marcado pela fuga perspectiva comandada pelo espelho d'água - o canal disposto no vale imediatamente anterior ao início do aclive da colina - apresentariam uma dimensão linear incomum (além de mil e duzentos metros de extensão), sendo que o direcionamento axial norte-sul se estenderia por mais de três quilômetros, compelindo a profundidade perspectiva a pontos de fugas aparelhados na ilusão do infinito (Figuras 89-94). Segundo Benevolo (I99I, p. 4I, tradução nossa), desde a praça da estátua de Hércules, no cume do morro, a apreensão do palácio seria substancialmente alterada, tanto em forma como em escala:

35 "Hércules em Repouso", escultura grega de mais ou menos 350 a.C., conhecida através de cópias romanas. 
O castelo, com a cúpula idealizada por Le Vau, domina seus arredores imediatos, mas a uma maior distância perde sua notoriedade volumétrica e se transforma em uma mancha mais fortemente cromatizada; a semiesfera da cúpula se transforma em um ponto de luz, como a fonte que $o$ antecede.

Após a festa de inauguração do château, o rei teria ficado tão impressionado com a suntuosidade e a beleza do conjunto e com a magnificência da festa oferecida pelo seu proprietário que, enciumado, mandaria prender Fouquet sob a acusação de prevaricação, de uso inescrupuloso do dinheiro público - o que não deixaria de ser verdade, visto os gastos exorbitantes contraídos pelo superintendente de finanças do monarca para construir Vaux-Le-Vicomte. Imediatamente confiscaria todo o complexo e acolheria em sua corte os três responsáveis pelo projeto, encaminhando-os para os trabalhos de remodelação do antigo palácio, da cidade e do jardim de Versailles. Mínguez e Rodriguéz (2006, p. I9I-I92, tradução nossa) resumiriam a história da construção do conjunto:

A origem deste palácio se situa no ano de 1624, quando Luís XIII ordena construir um pavilhão de caça na colina de Versailles, que sete anos depois será ampliado por Philibert Le Roy. Quase trinta anos mais tarde, em I66o, e poucos meses depois de sua boda, Luís XIV e Maria Teresa, infanta da Espanha, visitam Versailles, que ainda seguia sendo um lugar de vegetação escassa, pantanoso e desnivelado. No ano seguinte, e após assistir a festa de inauguração do palácio de Nicholas Fouquet, Vaux-Le-Vicomte, Luís XIV contrata a equipe responsável por este conjunto para encarregá-la da realização do novo Versailles. A equipe está formada pelo arquiteto Louis Le Vau, o pintor Charles Le Brun e o jardineiro André Le Nôtre. O palácio e seus jardins serão ampliados progressivamente até alcançar proporções desconhecidas até o momento. Em I678, Jules Hardouin-Mansart assume a direção das obras do palácio, modificando-o consideravelmente. É então que se constrói a grande fachada aberta ao jardim, assim como os salões mais suntuosos e esplêndidos, como a Galeria dos Espelhos, o Salão da Guerra e o Salão da Paz, além da capela palatina. Em seis de maio de I682 Luís XIV decretou que daquela data em diante Versailles fosse a residência oficial da corte e sede do governo, condição que manteria até I789.

Três amplas avenidas em forma de tridente cruzam o aglomerado urbano de Versailles e convergem à praça de armas e ao pátio de honra do palácio. Entre elas se situam as cavalariças reais, construídas por 


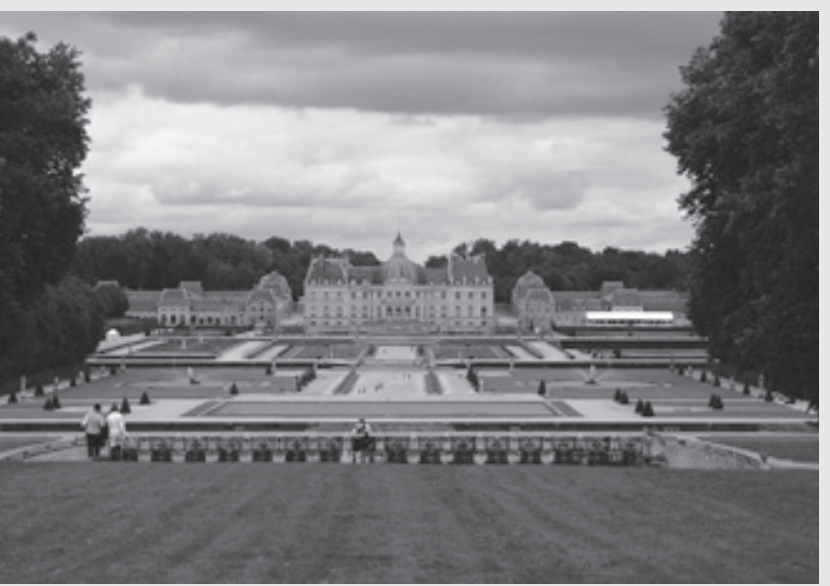

87. Panorama retirado na direção contrária e no lado oposto da imagem anterior - para a direção norte, enquadrando o Château e os Jardins de Vaux-leVicomte, vistos da colina disposta ao sul. Fonte: Fotografia elaborada pelo autor (2007)

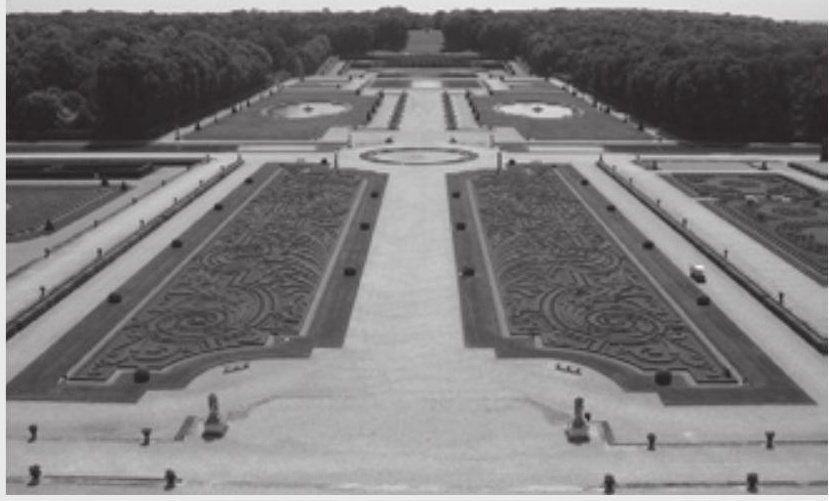

88. Jardim do Palácio de Vaux-le-Vicomte. Fonte: Fotografia elaborada por Esther Westerveld - Licença CC BY 2.0/ Wikimedia Commons contributors.

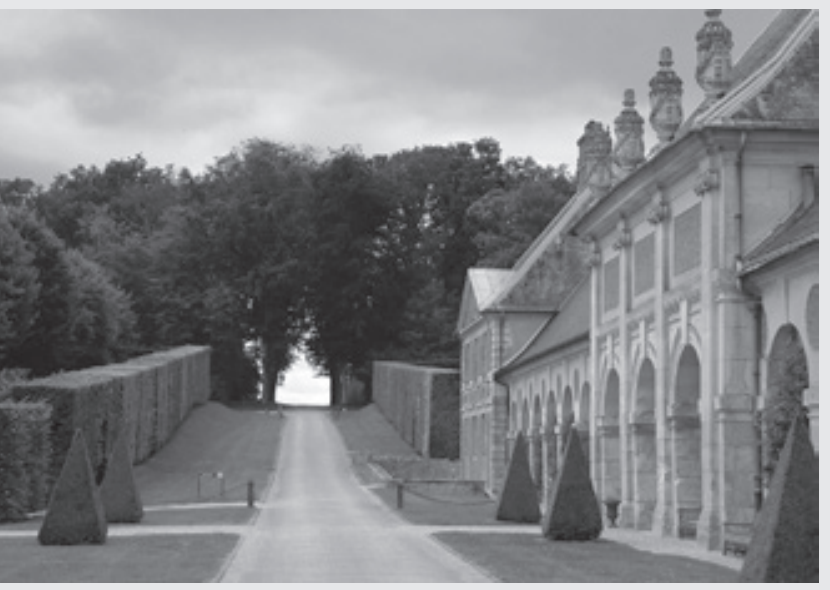

89. Unidades de serviço do Château de Vaux-leVicomte. Fonte: Fotografia elaborada pelo autor (2007).

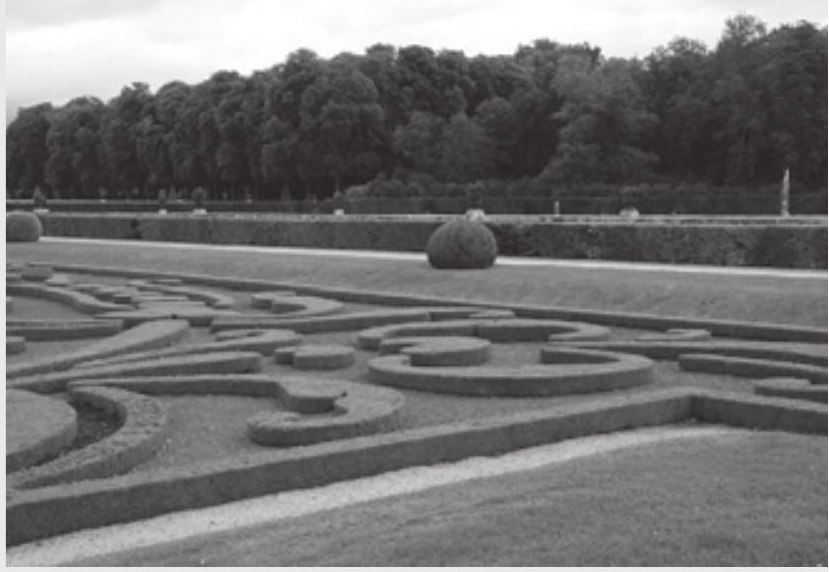

90. Detalhes dos jardins do Château de Vaux-leVicomte. Fonte: Fotografia elaborada pelo autor (2007). 


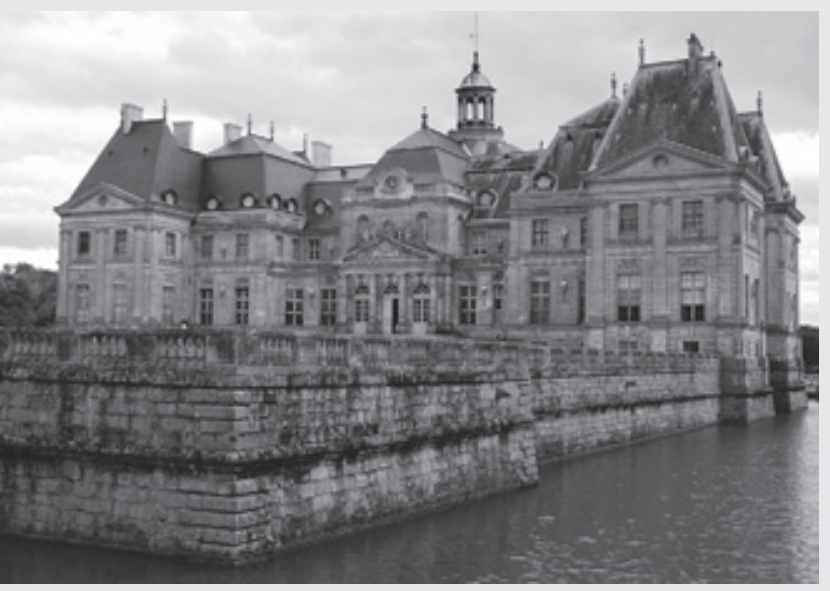

91. Château de Vaux-le-Vicomte. Fonte: Fotografia elaborada pelo autor (2007).

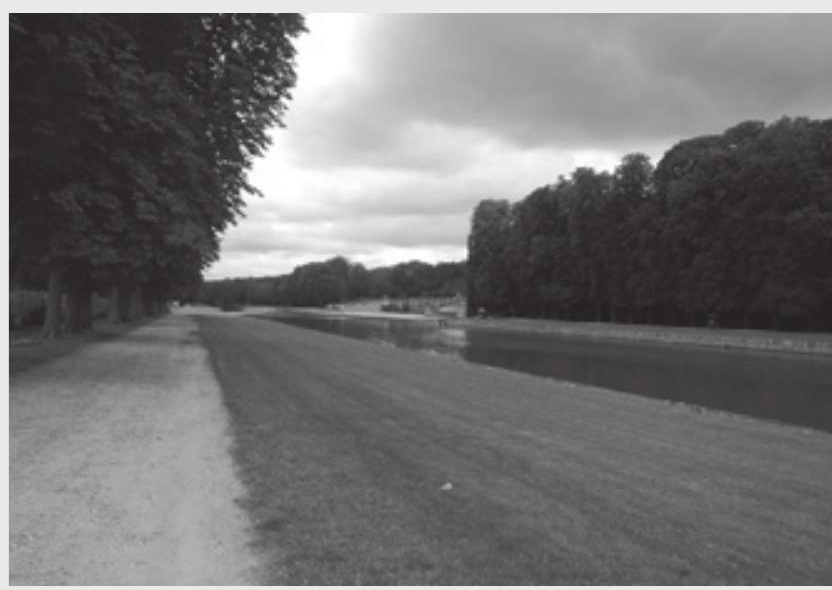

92. Grande canal dos Jardins do Château de Vauxle-Vicomte. Fonte: Fotografia elaborada pelo autor (2007).

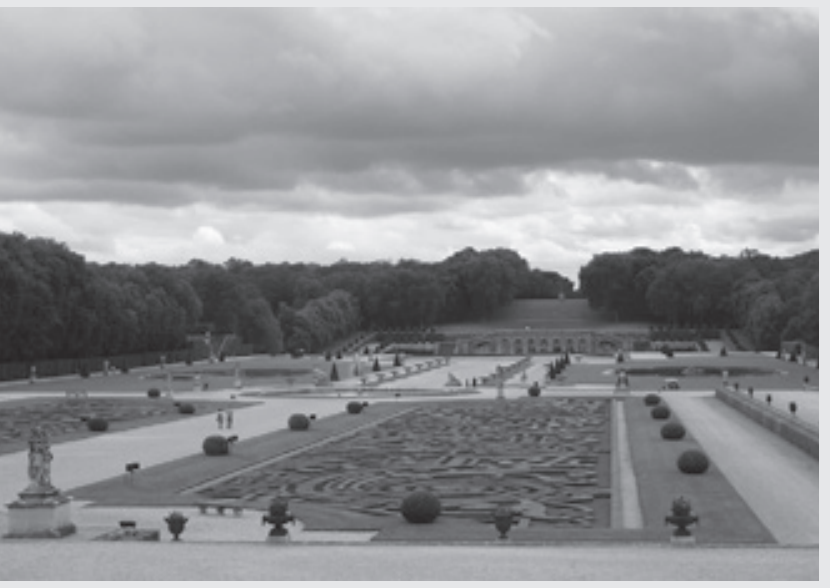

93. Panorama retirado para a direção sul, revelando a colina dos Jardins Vaux-le-Vicomte, ao fundo Fonte: Fotografia elaborada pelo autor (2007).

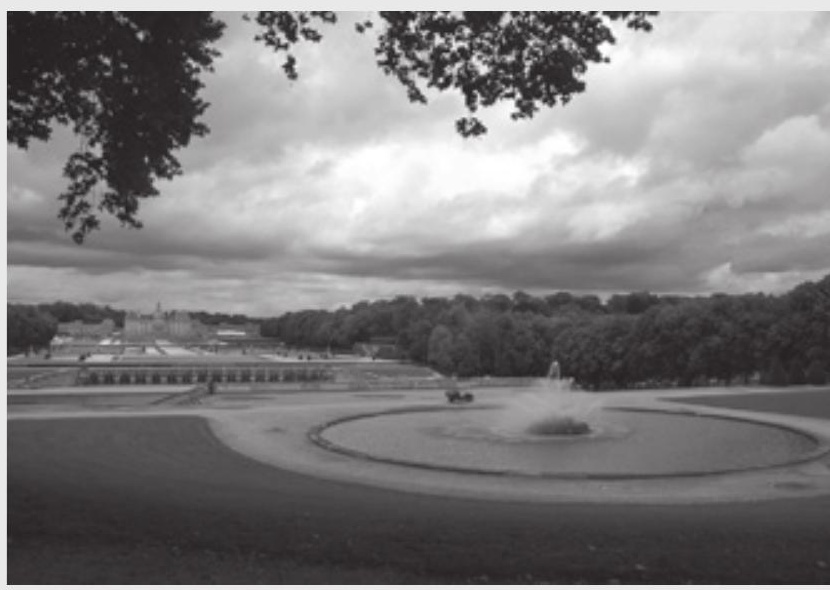

94. Panorama do Palácio de Vaux-le-Vicomte retirada da colina, ao sul. Fonte: Fotografia elaborada pelo autor (2007). 
Mansart entre i679 e i685. Em torno ao pátio de honra se distribuíam os edifícios nucleares construídos por Le Vau. Estes foram posteriormente modificados pela grande ampliação do edifício que executou Mansart depois da morte de Le Vau. O resultado final é um palácio de grande desenvolvimento horizontal e cuja fachada principal - de 680 metros - é o elemento arquitetônico frente ao qual se dispõe o parque, duas características afastadas do modelo italiano, e que representam a nova concepção do jardim como espaço privado e privilegiado do monarca absoluto e sua corte.

Em Versailles, de maneira muito mais expressiva do que em Vaux-leVicomte, o château viria a funcionar como um elemento coerente de separação entre o "mundo dos homens", marcado pela presença do burgo - redelineado a partir da década de I660 e disposto do lado sudeste em relação ao palácio -, e o ambiente natural - caracterizado pela presença do gigantesco jardim de Le Nôtre que se distenderia, a noroeste, em torno do longo eixo que passaria pelo ponto médio da fachada posterior da residência do Roi-Soleil (Figura 95). Assim, o castelo - que atingiria uma dimensão incomensurável, tanto no que se refere ao seu desenvolvimento longitudinal, mas principalmente ao comprimento transversal da frontaria voltada aos jardins - se tornaria o monumento que constituiria a barreira física e visual na qual as principais linhas perspectivas dos dois organismos se dirigiriam. No caso da cidade, três grandes avenidas formariam um clássico tridente barroco e acorreriam ao palácio, se abrindo para a desmesurada Place d'Armes - sendo que a continuação virtual de seus eixos se concluiria em um ponto de distribuição radial, locado na imensa cour d'honneur, especificamente na entrada da Cour de Marbre, o pátio conclusivo envolvido pelas mais antigas dependências do palácio construídas por Luís XIII. ${ }^{36}$ Do lado dos jardins de Le Nôtre, o vasto direcionamento axial teria como limite perspectivo, mirando a noroeste, a grandiosa fachada posterior do palácio.

Abstraindo sua escala mais grandiosa, os jardins possuiriam uma ordenação longitudinal muito semelhante àquela de Vaux - com destaque para o grande canal em cruz, cujo eixo principal, coincidente com o desenvolvimento longitudinal do parque, apresentaria mais de mil e oitocentos metros de extensão linear (Figuras 96-100).

36 Desde 1829 o ponto de intersecção dos eixos do trivium é marcado pela presença de uma estátua em homenagem ao Rei Luís XIV. 
Por outro lado, vislumbrando quaisquer das três avenidas que cortavam a cidade a partir do ponto de interseção do tridente, locado no pátio de honra do château, o panorama forçado pela fuga perspectiva, orientada pelas árvores sequencialmente dispostas flanqueando as alamedas, se perderia na ilusão do infinito (Figura IoI); igualmente, capturando em profundidade a fuga perspéctica que se abria para o jardim, no lado oposto do palácio, o olhar não conseguiria alcançar um limite apreensivo - confirmando a teoria da "captura do infinito" desenvolvida por Leonardo Benevolo (Figuras I02-I03). Para todo este sistema aberto e expansivo, centralizado na imensa estrutura do palácio, a mensagem era clara: o poder do monarca francês em relação ao mundo dos homens (representado pela cidade minuciosamente ordenada e voltada ao castelo) e em relação à própria natureza (expressada pela estrutura paisagística artificialmente composta dos jardins) era infinito e sobrenatural - todos os caminhos levavam ao rei; se direcionavam ao conquistador do universo (Figuras I04-I05). ${ }^{37}$ Norberg-Schulz (I974, p. 305, tradução nossa) concluiria:

O palácio está no centro, e as suas longas alas dividem a área em duas partes: os jardins de um lado e a cidade do outro. Esta última é estruturada por três artérias principais, que se irradiam do centro: a Avenue de Paris, a Avenue de Saint-Cloud e a Avenue de Sceaux. Vias e praças secundárias são projetadas em base a uma retícula ortogonal. A trama dos jardins apresenta um sistema de percursos radiais e rond points, da forma que ambas as partes são caracterizadas pela perspectiva infinita

37 Sobre as extensões perspectivas do complexo de Versailles, diria Benevolo: “O castelo, existente já nos tempos de Luís XIII, ocupa uma pequena elevação de frente a um vale pantanoso. Os artistas de Luís XIV o transformam em um colossal espetáculo arquitetônico, que começa com a curva do caminho proveniente de Paris, a 125 metros, onde nasce um eixo retilíneo que mede no total uns nove quilômetros. Um primeiro tramo de 1,8 quilômetros ascende até a altura do castelo (142 metros), que bloqueia a vista com a sua fachada de 500 metros, e enquadra, no ponto de fuga, o antigo pátio com as janelas das dependências reais. Mais além do castelo, o eixo prossegue em direção ao noroeste, atravessa o enorme parterre decorado com arbustos em broderie, e a partir das fontes desce até os 108 metros do canal em cruz, de 1,8 por 1,2 quilômetros, que ocupa o fundo do vale. O canal termina em um grande espelho d'água, destinado a refletir os pores do sol no verão; a vista se detém, imediatamente depois, em uma pequena colina de 116 metros, a 3 quilômetros de distância, de onde se abre a habitual estrela de ruas cortadas no bosque (a via axial percorre outros 4 quilômetros). Uma rua diagonal de 4,5 quilômetros conduz desde o limite setentrional do parque até o Castelo de Marly, de onde uma cena em perspectiva mais modesta, a 134 metros, termina em uma cascata que alcança os 171 metros. O parque real se estende ainda ao largo de muitos quilômetros; nele, Le Nôtre e seus colaboradores encontram um espaço alcançável pela vista e controlado em todas as direções, que tem por limite só a capacidade resolutiva do olho humano. Os dois limiares, o da visão em relevo e o da visão plana - 300 e 3000 metros, respectivamente -, jogam entre si para criar um universo de múltiplas sugestões, previsíveis ou inesperadas, nas quais intervêm a planificação da paisagem, a arquitetura, a escultura, as artes decorativas e até os autômatos que se movem representando as fábulas de La Fontaine." (BENEVOLO, 1991, p. 42-44, tradução nossa) 


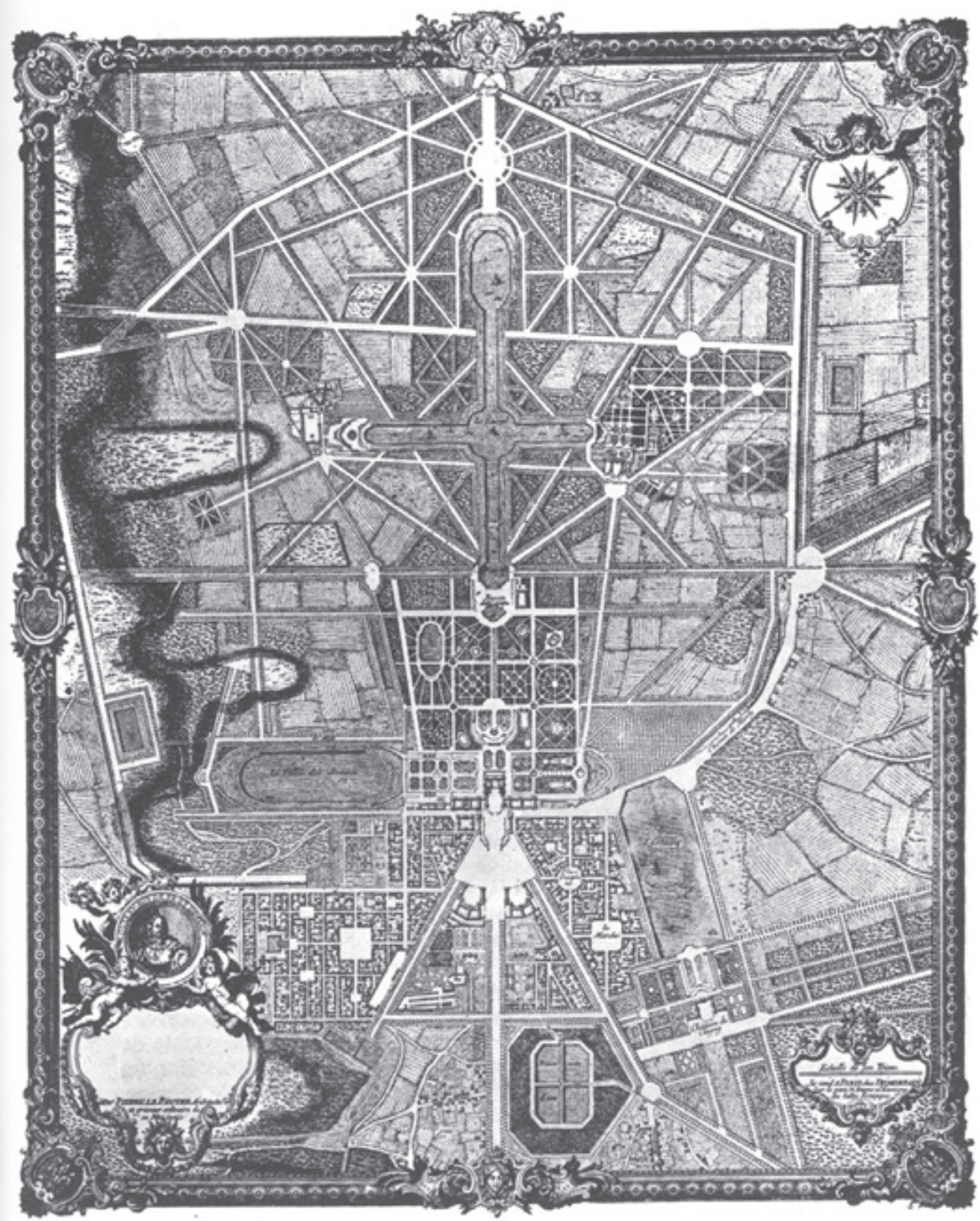

95. Plano da Cidade, do Palácio e dos Jardins de Versailles, confeccionado por Jean Le Pautre (1618-1682). Fonte: Benevolo (2008, p. 691). 


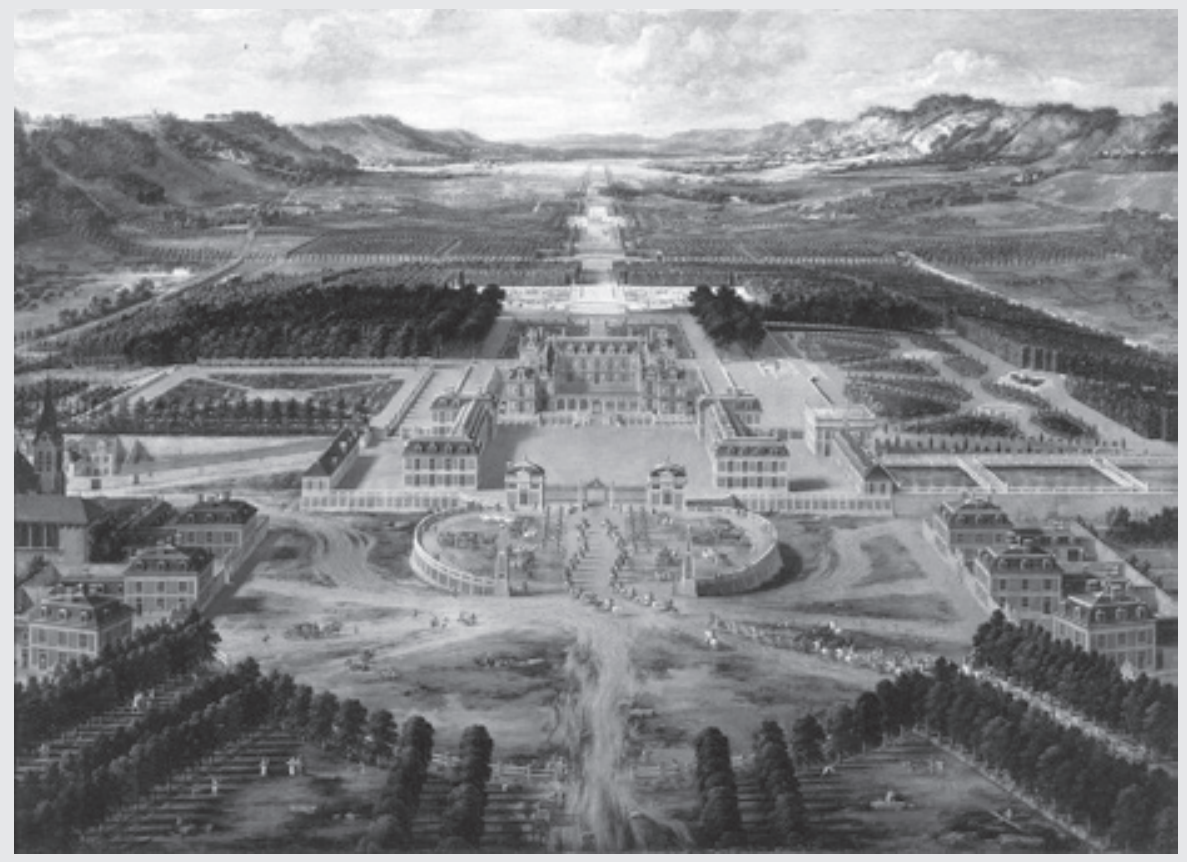

96. O Château de Versailles antes das ampliações, em 1668, pelo pintor paisagista francês Pierre Patel (1605-1676). Fonte: Wikimedia Commons contributors.

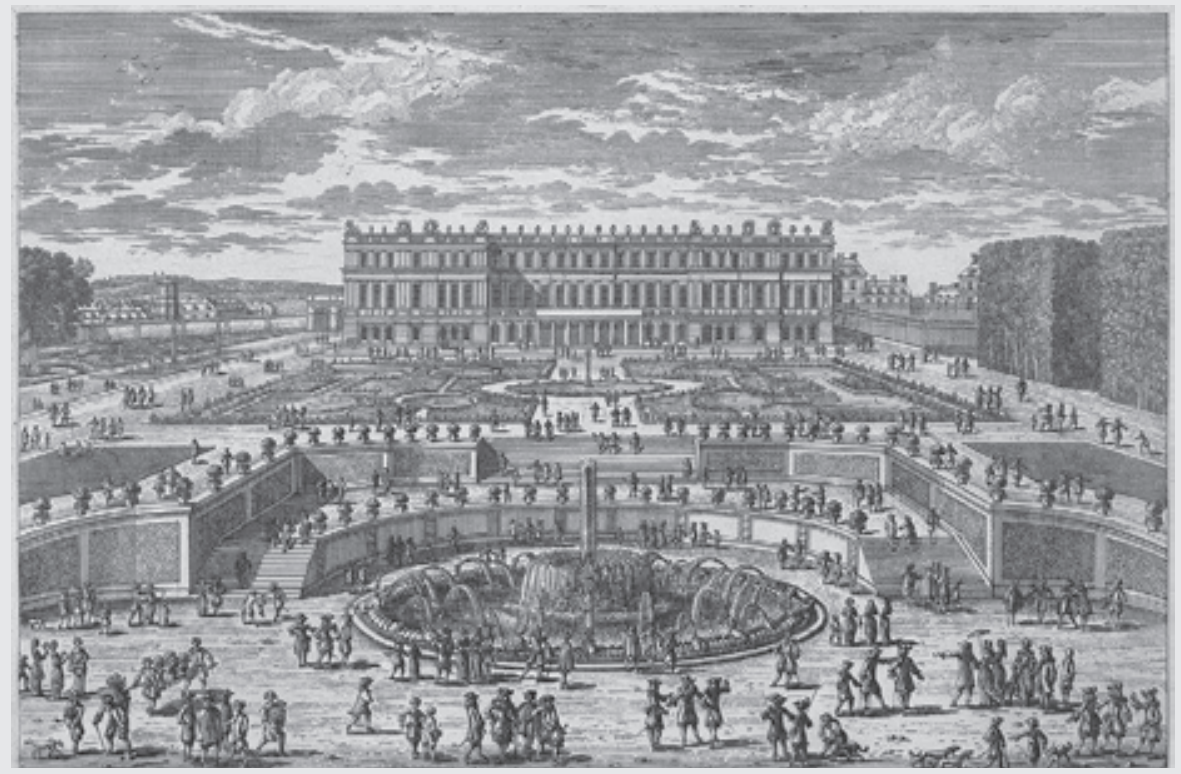

97. Veuë du Chasteau de Versaille du côté du Parterre d'Eau. Imagem posterior do palácio - da área dos jardins antes das ampliações concebidas pelo arquiteto francês Jules Hardouin-Mansart (1646-1708). Por Adam Perelle, 1680. Fonte: Wikimedia Commons contributors. 


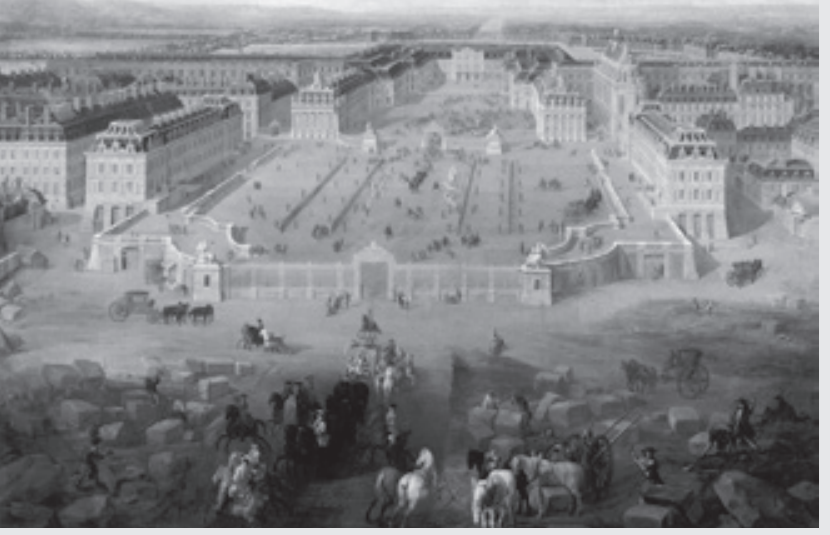

98. Vue du château de Versailles prise de la place d'Armes (1722). Imagem do complexo arquitetônico após as ampliações promovidas em finais do século XVII. Pelo pintor francês Pierre-Denis Martin (1663-1742). Fonte: Wikipedia, the free encyclopedia.

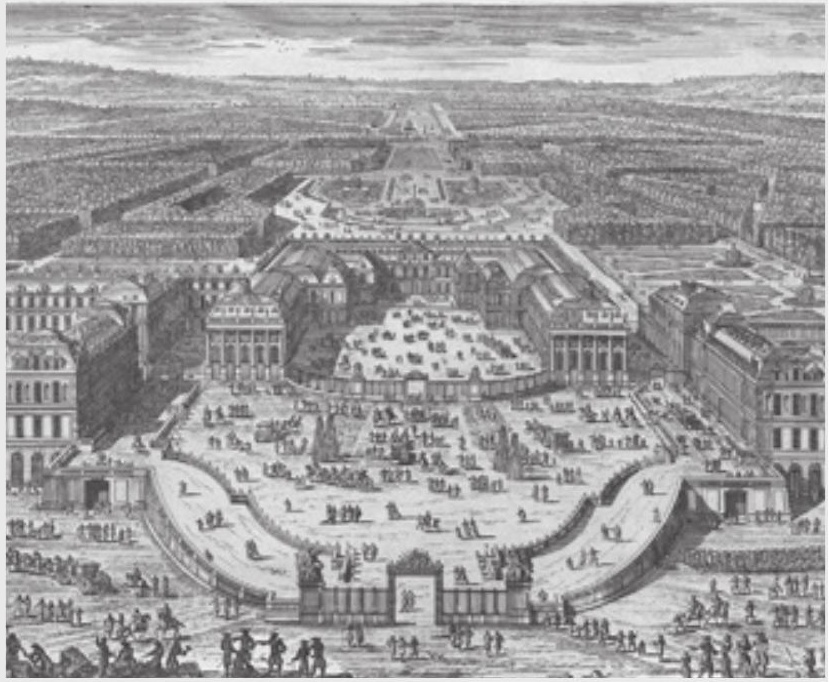

99. Veuë generale du Château de Versailles. Por Perelle, nos anos 1680, durante o processo de ampliação das estruturas do palácio. Fonte: Benevolo (2008, p. 698).

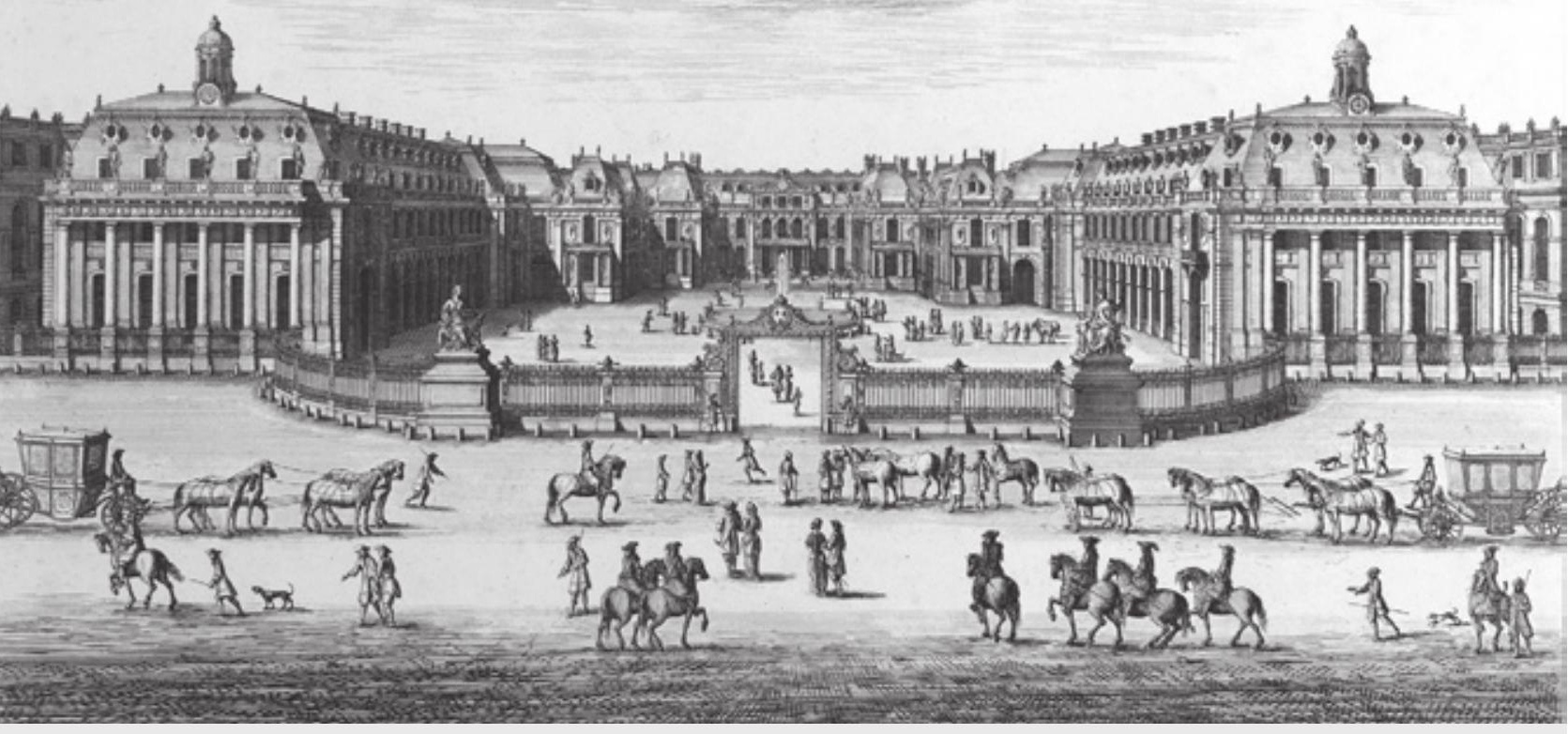

100. Chasteau de Varsailles, veu de l'Avantcour. Gravura de Israël Silvestre, 1682. Fonte: Wikimedia Commons contributors. 


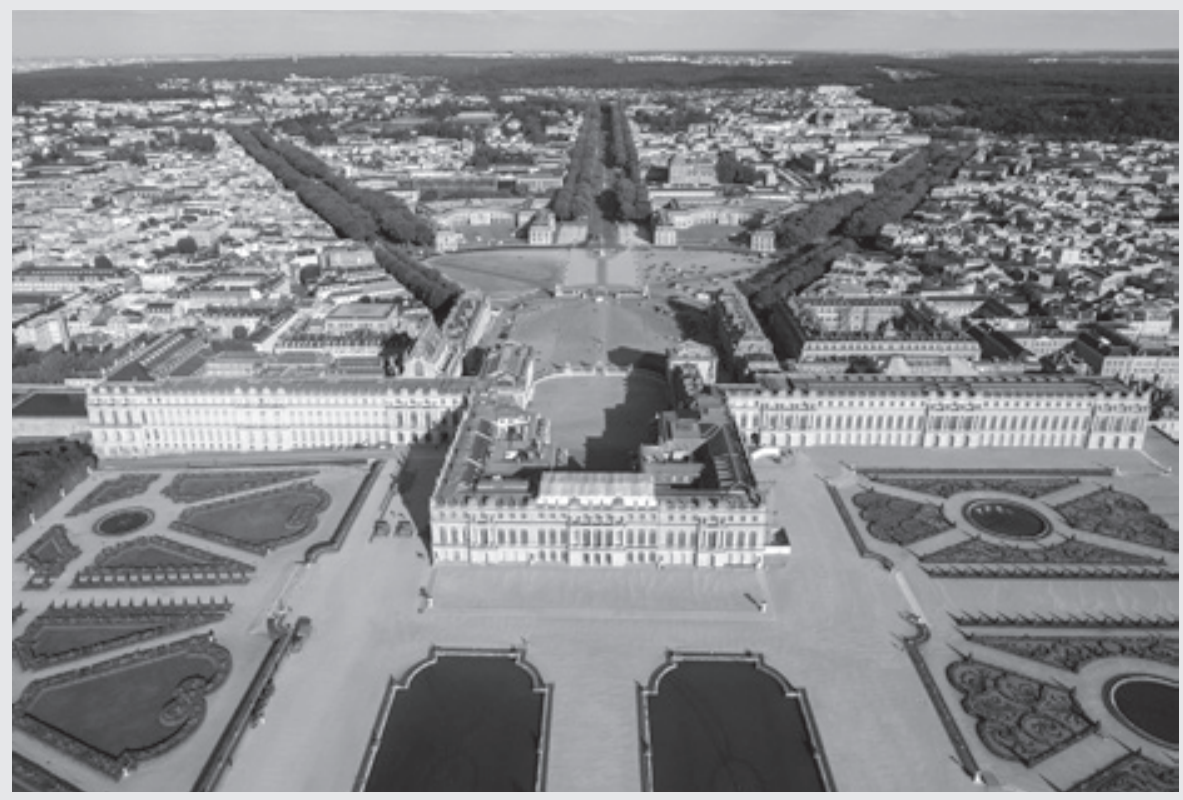

101. Vista aérea de Versailles: os jardins, o palácio e a cidade. Fonte: Fotografia elaborada por Toucan Wings (2013) - Licença CC BY 3.0 / Wikimedia Commons contributors.

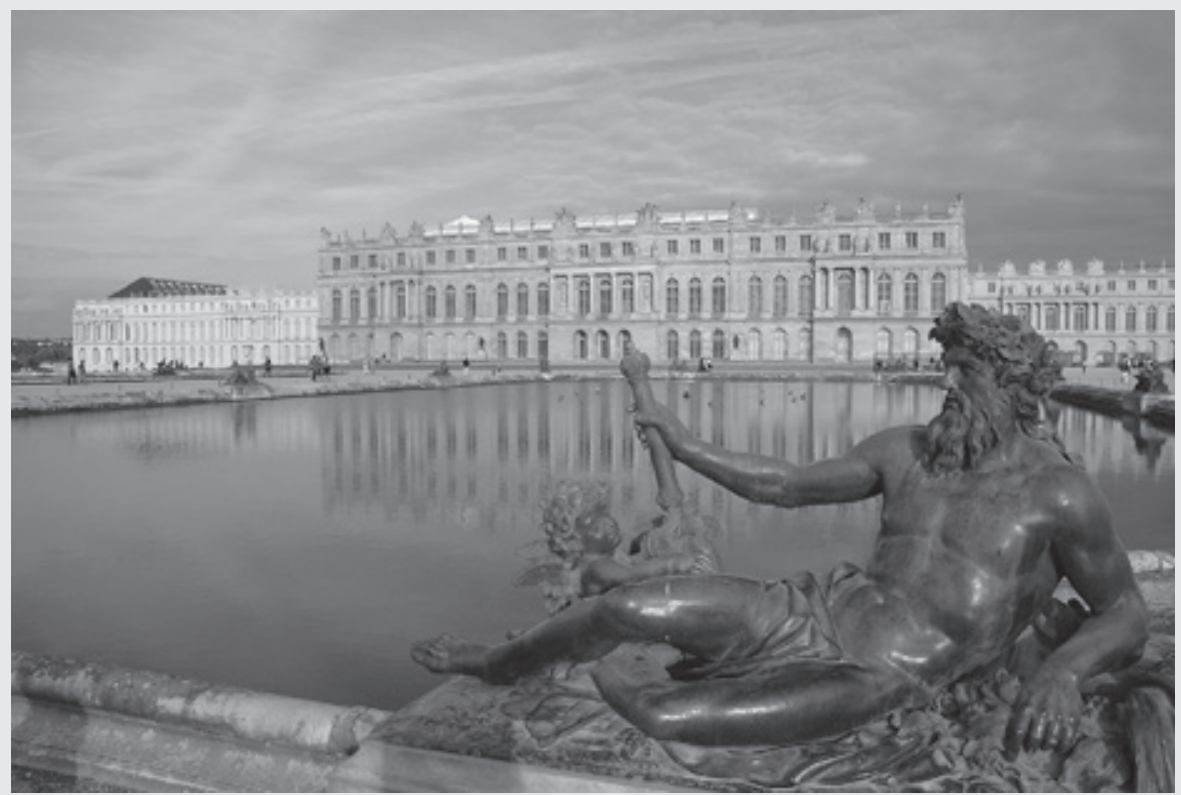

102. Château de Versailles visto do jardim. Fonte: Fotografia elaborada por Marc Vassal (2007) - Licença CC BY-SA 3.0 / Wikimedia Commons contributors. 


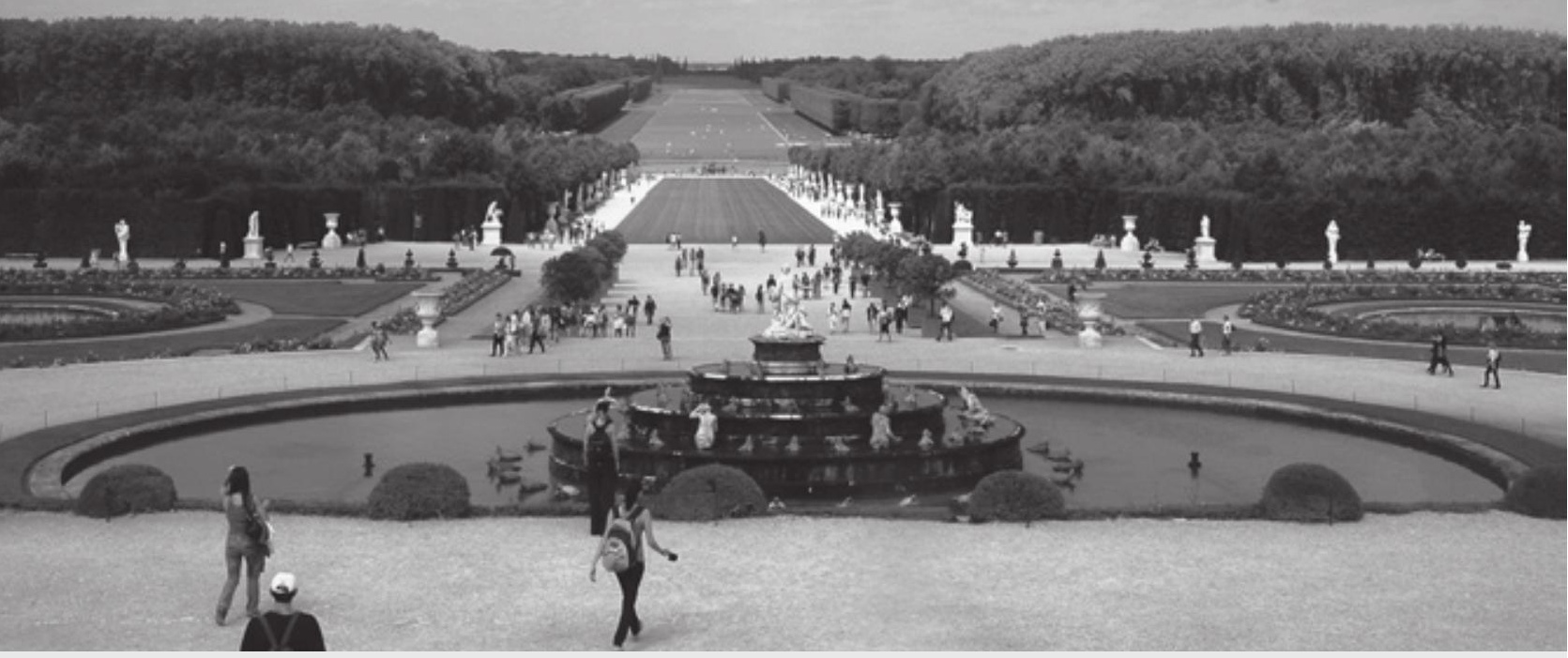

103. Perspectiva do jardim à frente da fachada posterior do Palácio de Versailles, direcionada ao panorama infinito do jardim e de seu canal. Fonte: Fotografia elaborada pelo autor (2007).

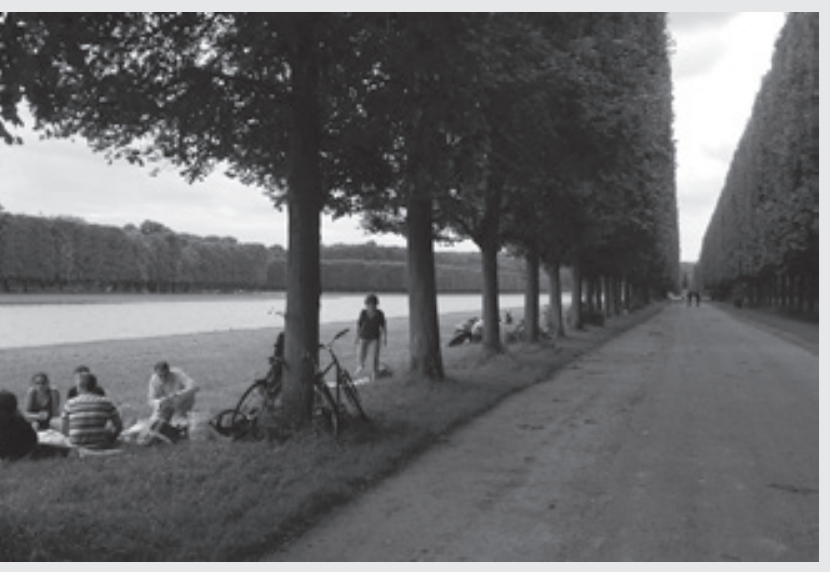

104. Fuga perspéctica flanqueada por árvores em um dos lados do canal dos Jardins de Versailles. Fonte: Fotografia elaborada pelo autor (2007)

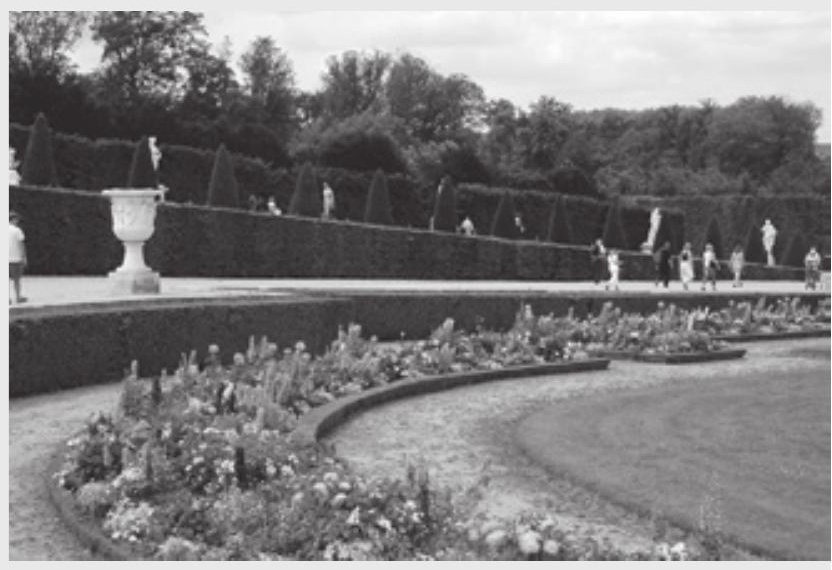

105. Detalhe dos Jardins de Palácio de Versailles. Fonte: Fotografia elaborada pelo autor (2007). 
que tem como centro o palácio. A inteira paisagem circundante torna-se parte deste sistema aparentemente sem limite. Com o objetivo de acentuar-lhe a extensão, a topografia natural é transformada em uma série de terraços planos e de grandes espelhos d'água, que refletem o espaço. [...] Versailles representa a essência mesma da cidade do século XVII: autoridade e definição, mas também dinamismo e abertura.

\section{A influência da urbanística regular da corte francesa para as províncias e para outros Estados europeus}

A concepção e a edificação do complexo urbano protagonizado pelo Château de Versailles - ação projetual e construtiva que seria fruto do esforço dos mais renomados artistas do Grand Siècle francês (Le Vau, Le Brun, e especialmente Le Nôtre e Hardouin-Mansart) - mesmo com toda a diversidade de intenções e atitudes revelada entre seus designers, mesmo com seu desenvolvimento temporal gradativo, marcado por ampliações e reordenações não previstas inicialmente, conquistaria uma coerente unidade compositiva na junção do trinômio cidade-palácio-jardim: um sistema barroco integrado que conseguiria expressar o escopo da cultura seiscentista - a prioridade dada aos mecanismos de ativação da imaginação através de uma rica e cenográfica experiência visual, artifício retórico essencial para o necessário objetivo absolutista de atração e direção das massas. $\mathrm{O}$ afastamento em relação aos graves problemas que acometeriam a intervenção em grande escala em uma metrópole consolidada definiriam a escolha do Rei Sol por trasladar a corte para um ambiente de pura fantasia e teatro, um núcleo no qual uma atmosfera áulica e cortesã poderia ser perpetrada sem empecilhos, sem os vícios e os entraves da capital Paris. Para Mínguez e Rodriguez (2006, p. 196, tradução nossa), Versailles chegaria a ser a mais coerente realização urbana do Ancien Régime - a pura expressão do absolutismo barroco:

Versailles representa a vontade despótica do monarca mais poderoso do mundo, desejoso de construir um espaço adequado para ele, distante da tumultuada Paris, desde onde poderia governar de maneira absoluta. Não esqueçamos que Colbert e outros cortesãos se opuseram inicialmente à desmesura do projeto, para não falar dos inconvenientes naturais do lugar escolhido - pântanos, carência de água, etc. Porém, Luís XIV superou todas as dificuldades e conseguiu criar uma 
cidade palatina como não se havia visto nem se veria igual em toda Europa. Pela primeira vez o jardim não era desenhado em função do terreno, mas sim se modificou o terreno em função do imenso jardim. A magnificência do conjunto, a grandeza e a suntuosidade do palácio e dos jardins, são o melhor reflexo artístico e urbanístico do absolutismo do Antigo Regime.

O modelo aparentemente bem-sucedido de Versailles viria a ser repetido inúmeras vezes em outras nações europeias: seja parcialmente, na edificação de uma residência real com grandioso jardim adjacente, organismo normalmente levantado nas imediações da Cidade Capital, mas sem a presença de um regular burgo de apoio; seja na idealização de um novo núcleo urbano de caráter rigorosamente planificado, sistema formado, invariavelmente, pela presença da monumental residência palaciana que separaria o centro urbano do extenso organismo paisagístico que se expandiria por detrás do castelo - situação menos comum, mas com significativas experiências realizadas.

Indubitavelmente, o mais impressionante exemplo de planejamento global de uma cidade principesca, na Europa barroca, se daria com a concepção - por parte do Margrave de Baden-Durlach, ${ }^{38}$ Karl III Wilhelm (I679-I738) - da cidade que ficaria conhecida como Karslruhe, localizada no centro de uma floresta, próxima à margem oriental do Rio Reno, bem na região sul do território da atual Alemanha. Da mesma forma que aconteceria em Versailles, a cidade, cujo nome significava "o descanso de Carlos", seria desenhada em I715, originalmente pelo arquiteto e engenheiro germânico, Jakob Friedrich von Batzendorf, ${ }^{39}$ para dar suporte a uma pequena residência, construída no local onde o Margrave apreciava caçar. O complexo, que buscaria a interação entre a residência principesca, o moderno núcleo urbano planificado, os jardins geometrizados e a floresta preexistente, seria traçado com a finalidade de atingir a máxima expressão da tradição barroca do polivium: um conjunto de 32 vias irradiaria por todos os $360^{\circ}$ de uma circunferência com cerca de 450 metros de raio, circunferência na qual a linha que marcaria seu perímetro cortaria o burgo - que estaria assentado na direção sul -, bem como cruzaria o bosque que se formava no sentido norte. Assim, os

38 Margrave: "Título que outrora se dava aos príncipes soberanos de certos estados fronteiriços da Alemanha". (HOLANDA, 2004)

Não se sabe o ano de seu nascimento nem o de sua morte. 
eixos das estradas partiriam radialmente do centro do círculo que, por sua vez, coincidiria com a torre de apoio à caça construída nas imediações da floresta, pouco atrás da estrutura da casa principesca à qual estava conectada.

Em meados do século XVIII, a residência seria transformada em um grande palácio, monumento projetado e edificado por algumas das mais renomadas personalidades da arquitetura setecentista, como o arquiteto, nascido na Boêmia, Johann Balthasar Neumann (I687-I753). O enorme castelo, que ocuparia uma extensão linear de quase 200 metros, apresentaria uma espécie de pátio de honra voltado para a cidade. Contudo, este pátio não seria desenhado segundo a forma usual de uma cour d'honneur, conforme aquela tradicional estrutura acolhedora e envolvente em forma de "u". A composição do vácuo que avançava à frente do palácio seria definida pelos contornos da fachada chanfrada da mansão: uma frontaria marcada por três blocos edilícios de mesmo comprimento, organizados como três lados contíguos de um octógono regular, interrompido e aberto à cidade - forma geométrica que "abraçaria" perspectivamente o núcleo urbano disposto à frente. Por trás do bloco intermediário do castelo, coroando o eixo central da composição, seria possível apreciar a cúpula delgada do torreão de caça, locado no eixo que passava pelo ponto médio da grandiosa fachada (Figuras Io6-I07).

A cidade, por sua vez, estaria limitada pelas linhas que irradiariam desde os blocos laterais do castelo - linhas virtuais que, no sentido oposto, por trás da residência principesca e em direção à floresta, se encontrariam, formando um ângulo reto no ponto nodal da torre de caça. Assim, a cidade ocuparia, originalmente, apenas a quarta parte da circunferência supracitada; em um segundo momento, se distenderia para além do primitivo arco, permanecendo, porém, dentro dos limites radiais impostos pela angulação de $90^{\circ}$. Neste quarto de círculo, nove vias radiais formariam as artérias principais do burgo que acorreriam em direção ao palácio. Estas ruas, entretanto, só nasceriam há cerca de 400 metros do torreão de caça, a uma distância razoável do castelo, bem à frente de seu pátio de honra, no limite meridional da imensa Schlossplatz. A praça do castelo, a principal de Karlsruhe - largo que abrigaria, em seu vazio, jardins geométricos de inspiração francesa, formados por rasantes estruturas ortogonais de canteiros não coincidentes com a organização radial do ambiente -, estaria limitada, ao norte, pela mole do palácio, e, ao sul, por uma extensa parede cenográfica côncava formada por um conjunto de edificações residenciais contíguas com tramas de arcadas sucessivas que se abririam para o pavimento inferior dos prédios. Este conjunto de fachadas regulares 


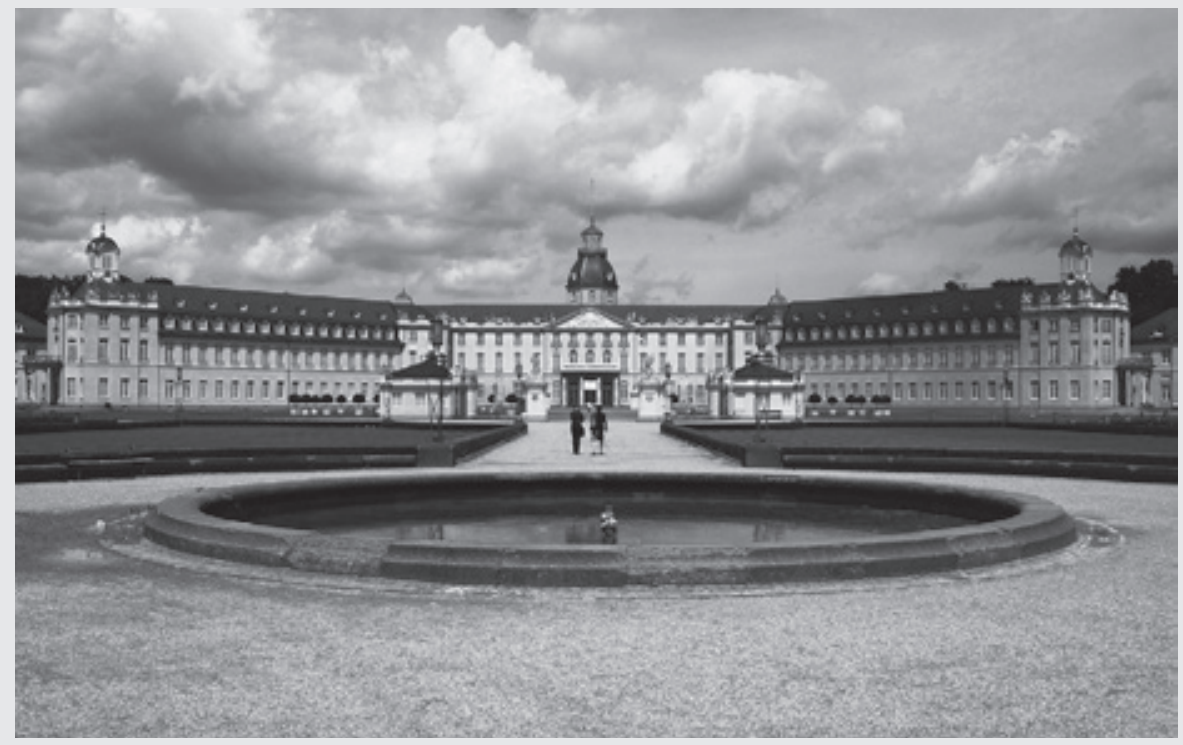

106. O Palácio de Karlsruhe visto da Schlossplatz. Fonte: Fotografia elaborada pelo autor (2007).

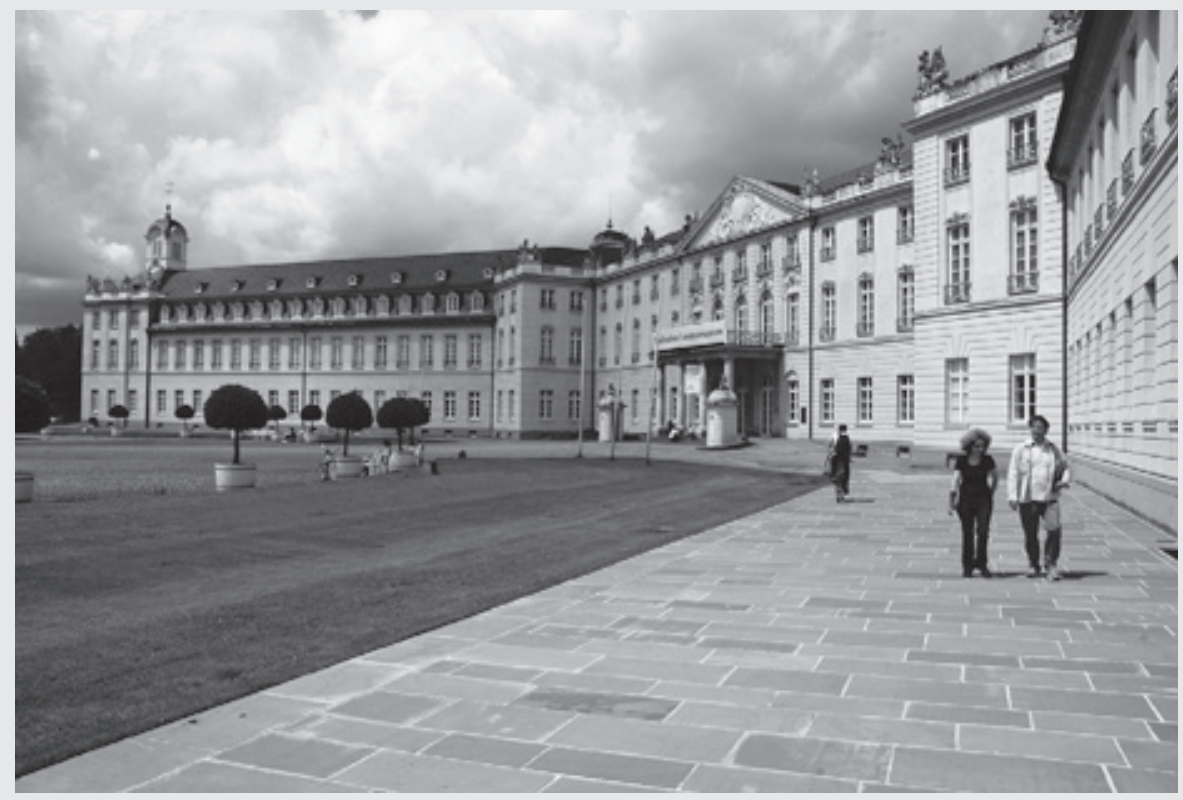

107. Detalhe do Palácio de Karlsruhe. Fonte: Fotografia elaborada pelo autor (2007). 


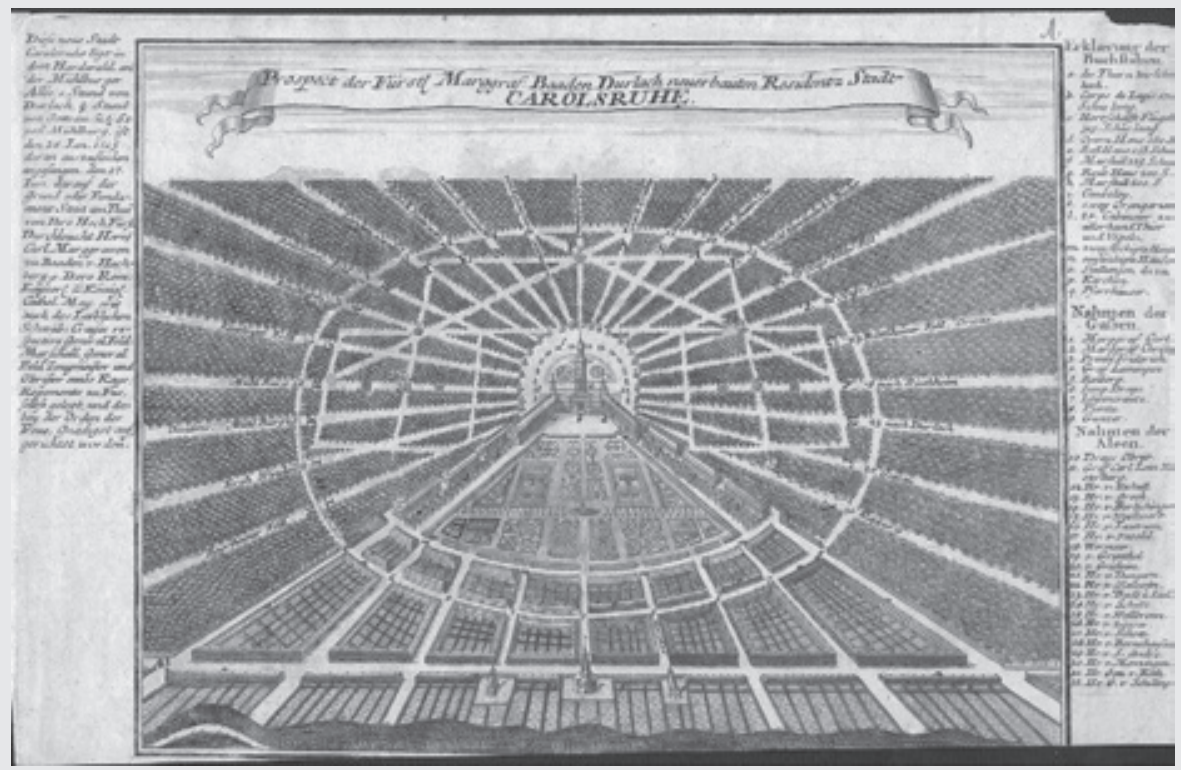

108. Mapa da recém-construída cidade de Karlsruhe, em 1722. Por Gabriel Bodenehr (1664-1758). Fonte: Wikimedia Commons contributors.

109. Karlsruhe. Vista perspectiva do castelo e da cidade (na direção contrária da imagem anterior), de uma gravura de 1739. Por Christian Thran (1701-1778). Fonte: Norberg-Schulz (2000, p. 13).

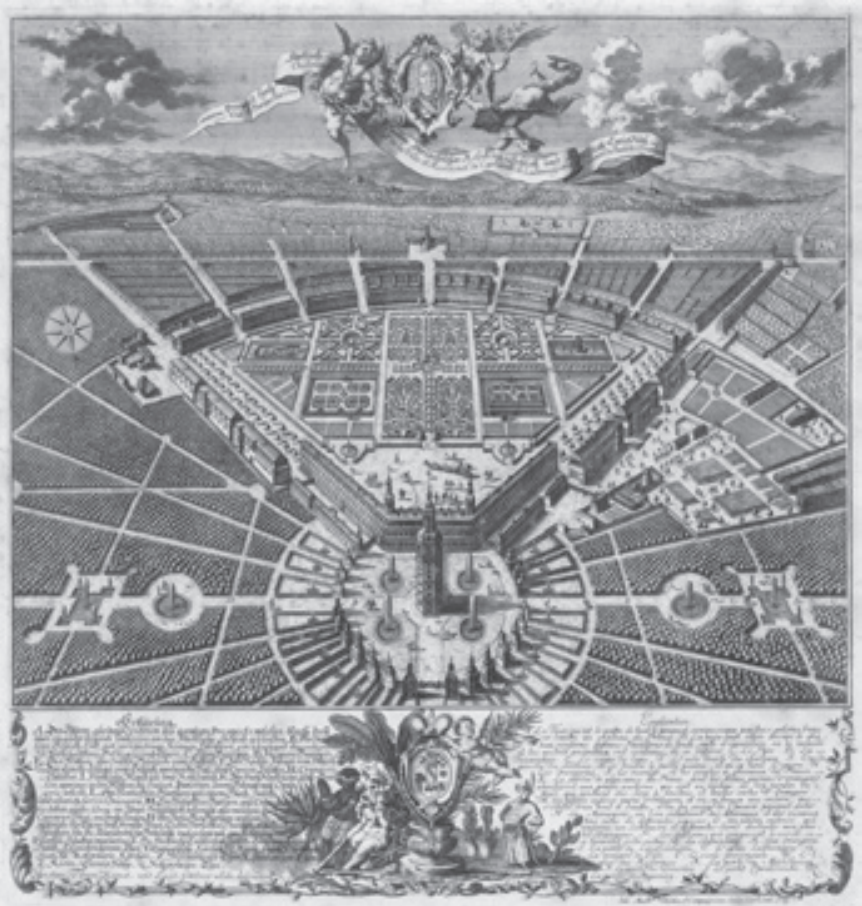


seria interrompido apenas pelo nascimento das nove vias radiais que adentravam a cidade desde o limite arqueado dos alinhamentos das edificações postadas à frente do distante palácio. Por outro lado, o perímetro de 450 metros do círculo, que envolveria o plano original do complexo, cortaria as vias radiais da cidade na primeira rua concêntrica à Schlossplatz, disposta no sentido sul - rua que, originalmente, também apresentaria uma disposição regular para seus edifícios (Figuras Io8-Iog).

Para além do quarto de círculo voltado para o aglomerado urbano, as outras 23 vias se espalhariam radialmente no bosque a partir da estrutura, desta vez claramente apreensível, da torre de caça - em uma área três vezes maior que aquela destinada ao aglomerado urbano, confirmando a tendência contemporânea de planificação de residências para a nobreza e para a realeza, tendência que atribuiria um espaço significativamente maior para o complexo paisagístico que para aquele ocupado pela própria cidade. Diversamente de Versailles e Vauxle-Vicomte, em Karlsruhe o jardim regular estaria assentado à frente do castelo, voltado para a cidade; por trás se abriria a floresta nativa que seria rasgada, ordenadamente, pelos eixos radiais que partiam da torre (Figura IIo).

A revisão da experiência de Versailles para a concepção, por parte do arquiteto Jakob Friedrich von Batzendorf, do palácio de caça e do burgo, construídos para satisfazer os desejos cortesãos do Margrave Karl Wilhelm, foi tão bem-sucedida que logo, em I77I, a cidade de Karlsruhe se tornaria a capital da região de Baden-Durlach - e seguiria sendo a sede do governo de Baden por muito tempo.

Não obstante, a influência da urbanística regular da corte francesa não seria sentida apenas na fundação de novas cidades ou châteaux principescos para a realeza, mas também em intervenções de certo porte em grandes capitais nacionais ou de províncias, assim como em cidades dominantes preexistentes. Inúmeros núcleos urbanos europeus, especialmente as sedes das nações modernas, teriam seus cinturões fortificados substituídos por parques e bulevares; outras cidades viriam abrigar a confecção de parques ou passeios públicos formados por longas alamedas, organismos verdes traçados em pleno núcleo urbano. Muitas vezes, os Estados patrocinariam a abertura de vias de ocupação edilícia regular nas áreas centrais das cidades mais importantes.

Mas, voltando-se ao caso francês e mirando para além das intervenções urbanísticas sofridas pela grande capital, ou da implantação da suntuosa sede da corte em Versailles, particularmente importante seria a assimilação da prática parisiense de abertura de places royales em significativas cidades de província, fato 
que se daria principalmente no século XVIII. A mais interessante e bem sucedida iniciativa de construção de praças regulares aconteceria em meados do século XVIII, na cidade de Nancy, que então era a capital do ducado de Lorena, região que somente em 1766 perderia sua autonomia política e se tornaria uma província do poderoso Estado de Luís XV - apesar de que, por ocasião das intervenções urbanísticas que o núcleo urbano receberia, o ducado já absorvia influência direta da coroa, sendo praticamente uma cidade francesa.

A iniciativa de abertura do complexo monumental, formado por três praças sucessivamente dispostas no sentido longitudinal, bem como pela sistematização de duas grandes avenidas paralelas transversais ao conjunto, seguidas pela presença de duas praças, construídas nas imediações da supracitada sequência monumental de espaços públicos, partiria do monarca Stanislas Leszczynski (I677-I766) - ex-rei da Polônia, exilado na região de Lorena, onde obteria proteção de seu genro, o Rei Luís XV, e seria nomeado duque em I737. Para a concepção das intervenções arquitetônicas e urbanísticas que a cidade de Nancy viria a sofrer, Stanislas confiaria o plano ao arquiteto Emmanuel Héré de Corny (1705I763), que teria como principal tarefa promover a união compositiva e simbólica entre as duas metades, historicamente separadas, do núcleo urbano: a cidadela, antigo burgo medieval que densamente ocupava o lado norte da cidade, área que seria ampliada em 1552 por ocasião da abertura de uma praça conhecida como Carrière; e, na direção meridional, a Ville Neuve, aglomerado urbano edificado contíguo ao antigo núcleo, levantado desde o último quartel do século XVI, seguindo um traçado ortogonal semirregular. Até finais do século XVII os dois lados da cidade estariam isolados entre si pela presença das muralhas que encerravam individualmente os burgos (Figura III). Em I697, Luís XIV mandaria derrubar as cintas fortificadas que encerravam a cidade nova (MORRIS, I979, p. I70), sendo substituídas por uma área livre que preservaria, em consonância com os persistentes muros da cidadela, as duas metades da capital de Lorena, isoladas e independentes.

Baseando-se nesta inadequada realidade, Héré de Corny desenharia, em I75I, a celebrada sucessão de três praças: recintos que em parte ocupariam uma área limítrofe da Ville Neuve e, na sequência, penetrariam os cinturões e o tecido urbano da cidade medieval preexistente (Figura II2). A praça, que marcaria o despertar do persuasivo encaminhamento serial de união das duas metades do núcleo citadino - ambiente que viria a ser o mais importante dos espaços 


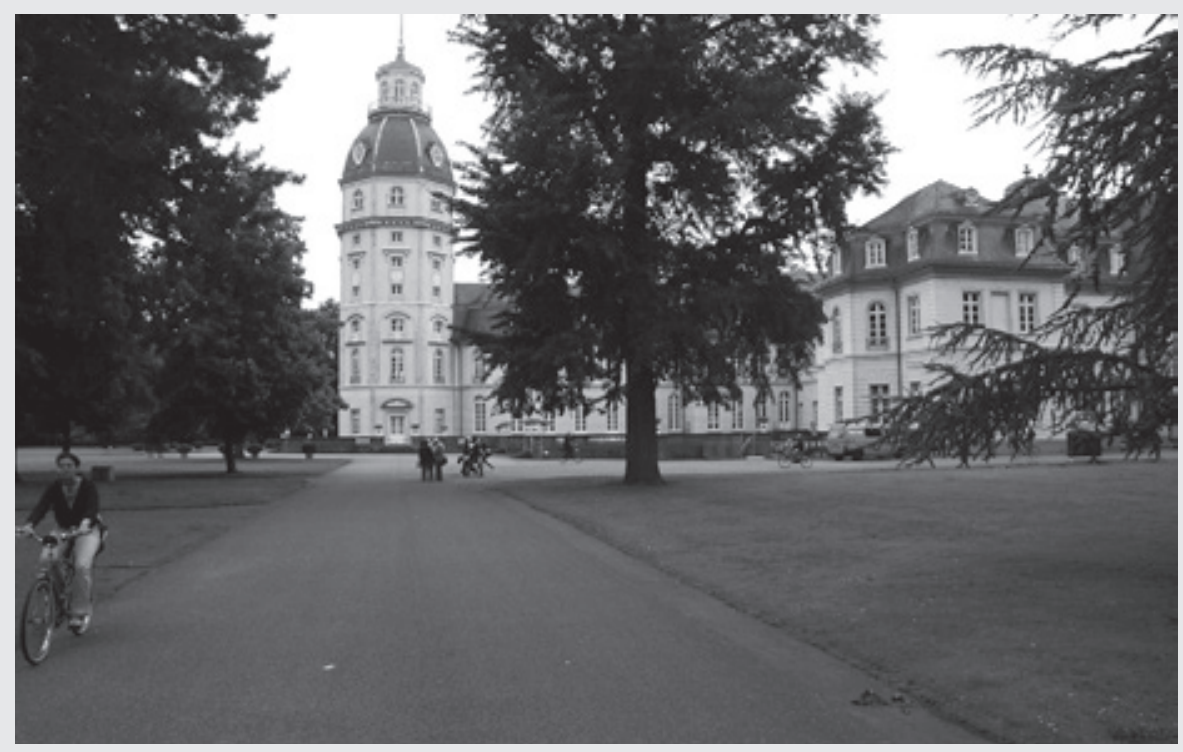

110. Uma das alamedas radiais direcionadas ao torreão de caça disposto no bosque que se abre por detrás do Palácio de Karlsruhe. Fonte: Fotografia elaborada pelo autor (2007).

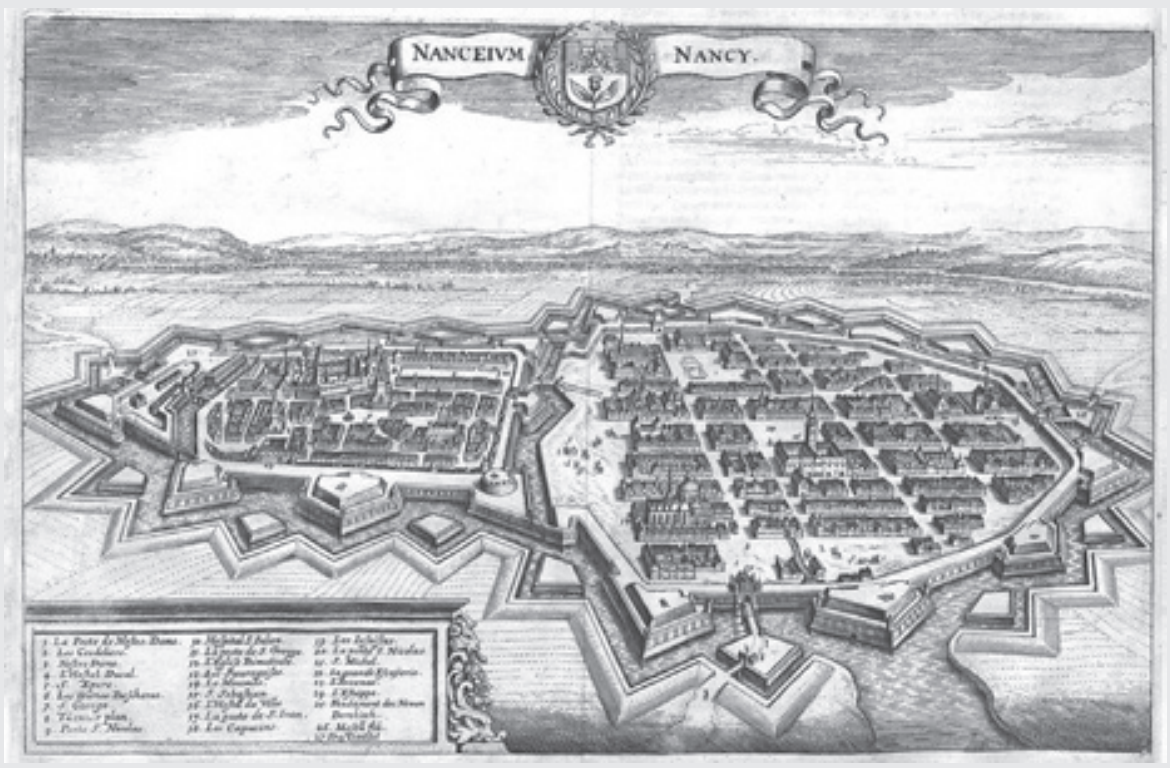

111. Plano de Nancy em 1645, com destaque para a cidade medieval à esquerda (norte) e a cidade quinhentista à direita (sul) - as duas separadas por fortificações modernas, que as envolveram totalmente. Pelo gravurista suíço Matthäus Merian (1593-1650). Fonte: Vikidia contributors. 


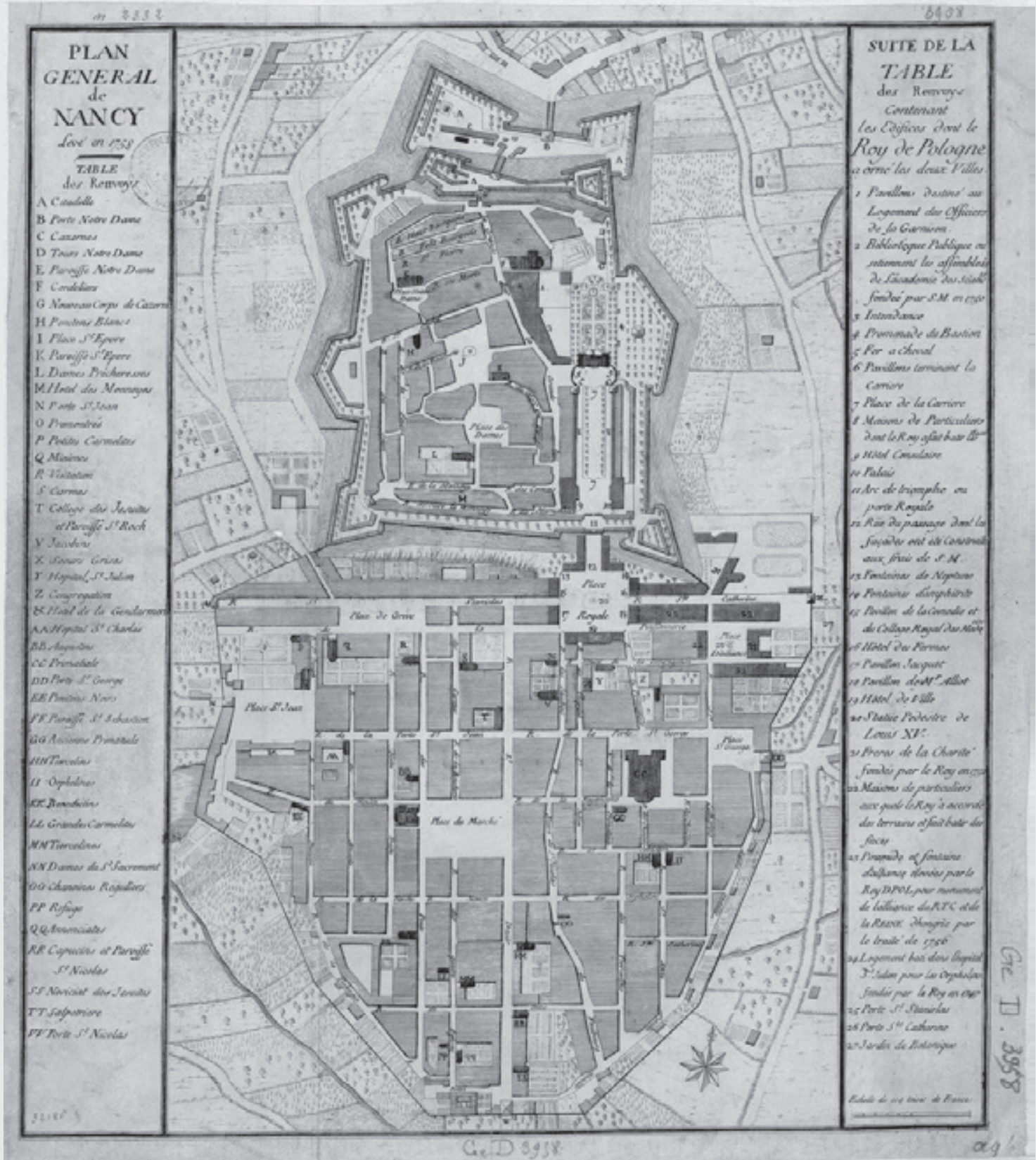

112. Plan général de Nancy, levé en 1758. Notar a presença das cinco praças na parte central (um pouco à direita) do desenho. Fonte: Biblioteca Nacional da França. 
públicos projetados, assentado no contorno nordeste da área compreendida como "cidade nova" -, seria a Place Royale (hoje conhecida como Place Stanislas): um ambiente idealizado pelo Duque de Lorena para acolher, no centro geométrico, uma monumental estátua em homenagem ao Rei Luís XV (Figuras II3-II4). No encadeamento sucessivo das praças, após a travessia do imponente arco do triunfo - monumento postado em uma abertura produzida nas antigas muralhas da cidadela e concebido para representar a passagem, bem como o ponto de união entre as duas áreas do núcleo urbano -, o espectador adentraria o antigo burgo e seria capturado por um vasto direcionamento perspectivo longitudinal, constituído pela Place de la Carrière, espaço remanescente da intervenção que a cidade sofreria em meados do século XVI (Figura II5), mas que viria a ser totalmente redelineado - regularizado por meio da sucessão, aos dois lados maiores da place, de casas gregárias de idênticas elevações (Figura II6), bem como pela presença, no eixo do vazio longitudinal, de fileiras de árvores que flanqueariam a canalização da perspectiva que buscaria o Palácio do Governador, disposto na última praça. Este derradeiro espaço público, denominado Fer de Cheval - para além da imagem frontal do Palácio do Governador, enquadrada pela fuga perspectiva produzida pela arborização que ladeava o eixo central da Place de la Carrière -, seria ornado por pórticos semicirculares abertos à cidade medieval e às antigas muralhas: permeáveis êxedras teatrais que conectariam, lateralmente, a fachada do palácio de governo com a terminação das frontarias da praça que as antecedia. A boa descrição de Paolo Sica (I992, p. 23-25, tradução nossa) sublinharia o efeito que as intervenções de Héré tiveram para unificar as duas áreas urbanas e para oferecer um novo caráter monumental, retórico e persuasivo para o centro da nova cidade de Nancy (Figuras II7-I22):

Partindo da cidade amuralhada, a sequência se inicia na Place Royale, onde as harmoniosas grades desenhadas por Lamour fecham os ângulos um pouco além do fosso de proteção da cidadela: do lado da cidadela, o eixo norte-sul da Place Royale se enxerta telescopicamente na alongada Place de la Carrière, introduzida por um arco triunfal de três fórnices de medidas clássicas. O primeiro seguimento do espaço alongado da Carrière forma uma espécie de praça na praça, assinalada pelas variações arquitetônicas do Hôtel de Craon projetado por Boffrand sobre o lado leste (de frente Héré construiu um edifício que lhe corresponde, o Tribunal de Commerce), mas é netamente dominado pelo cone óptico maior que desenha a conformação perspéctica e 


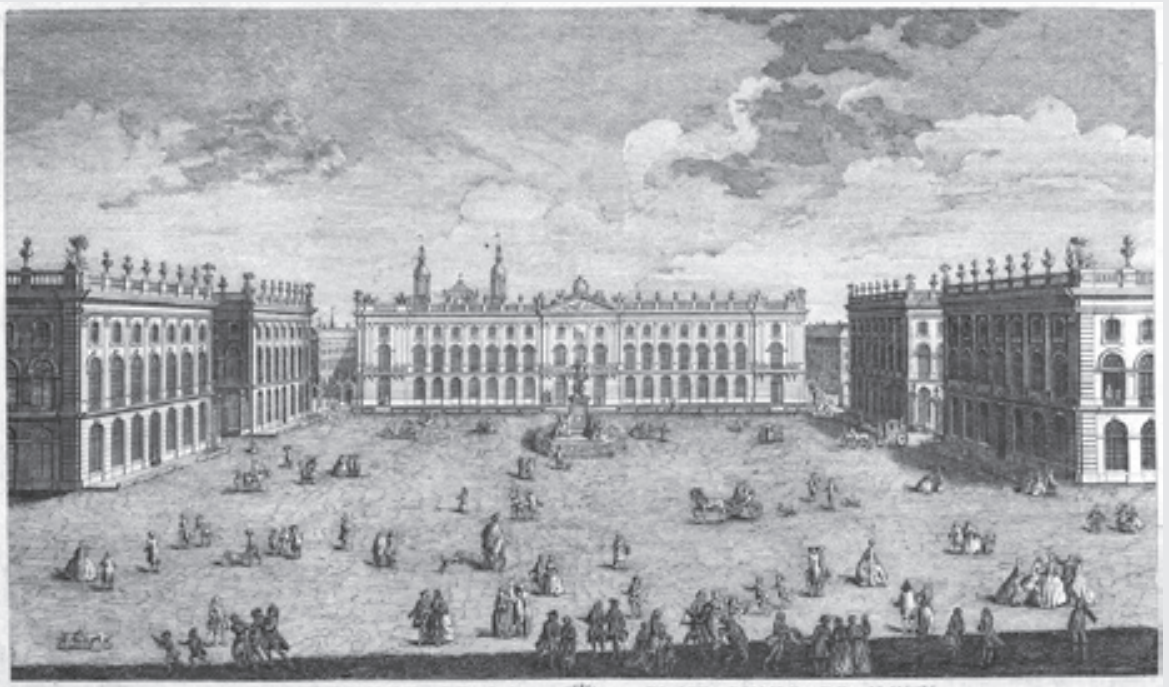

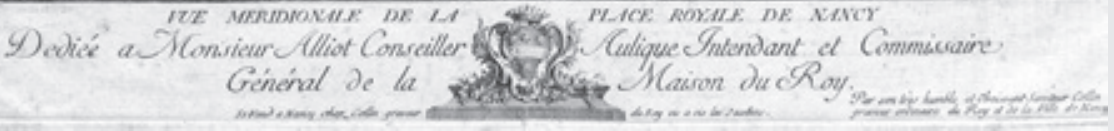

113. Vue meridionale de la Place Royale de Nancy. À frente é possível perceber o Hotel de Ville (prefeitura) de Nancy. Dominique Collin (1725-1781). Fonte: Le Journal de Durival, Biblioteca de Nancy.

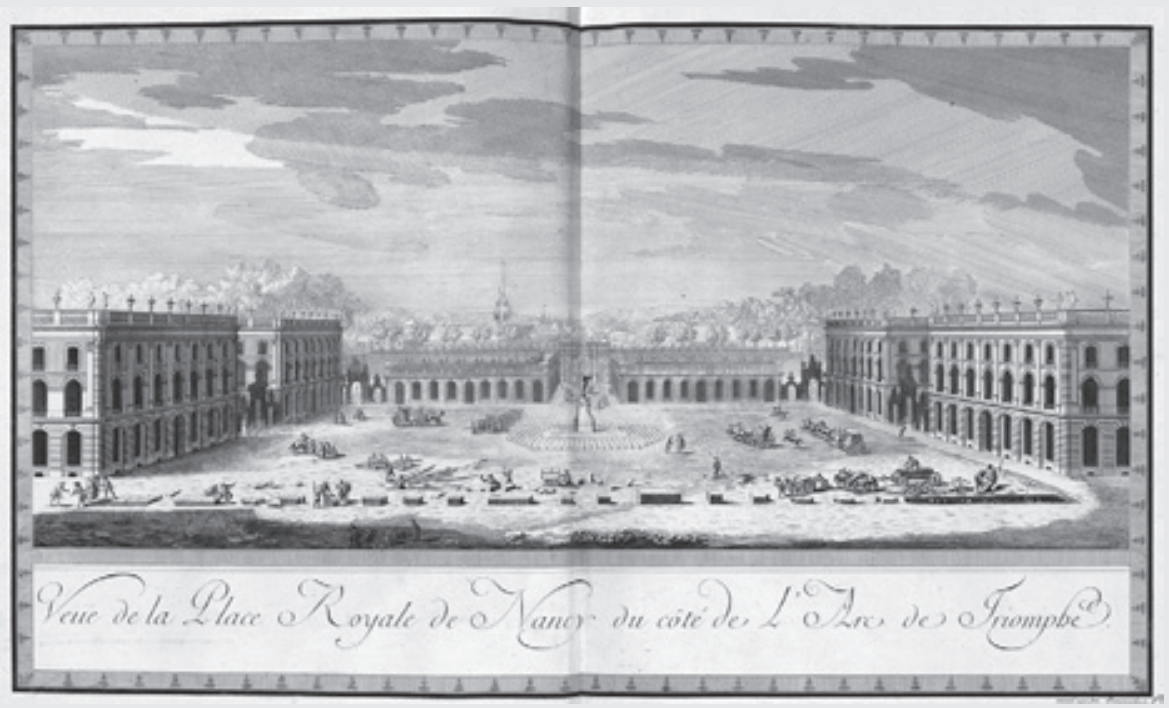

114. Veue de la Place Royale de Nancy du côté du l'Arc de Triumphe. Por Emmanuel Héré de Corny (1705-1763), o arquiteto que projetou o complexo das três praças. Fonte: Getty Search Gateway / GRI Digital Colletions. 


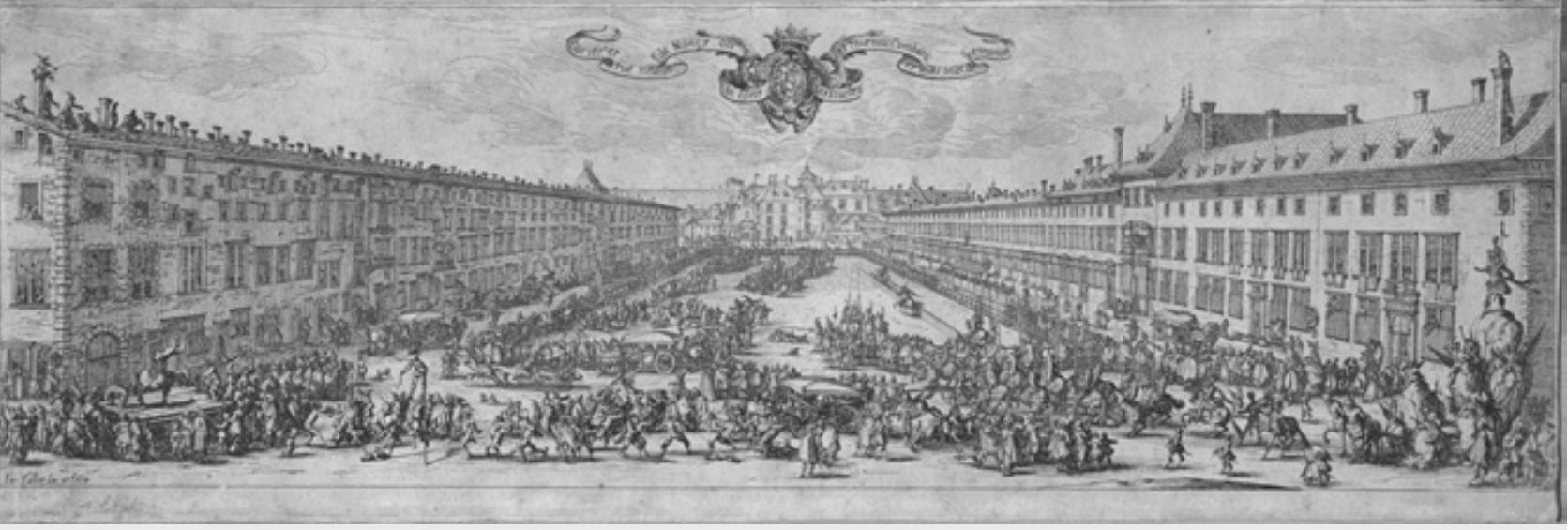

115. La Place de la Carrière antes das intervenções setecentistas, em gravura de Jacques Calot (1592-1635).

Fonte: Académie de Nancy-Metz.

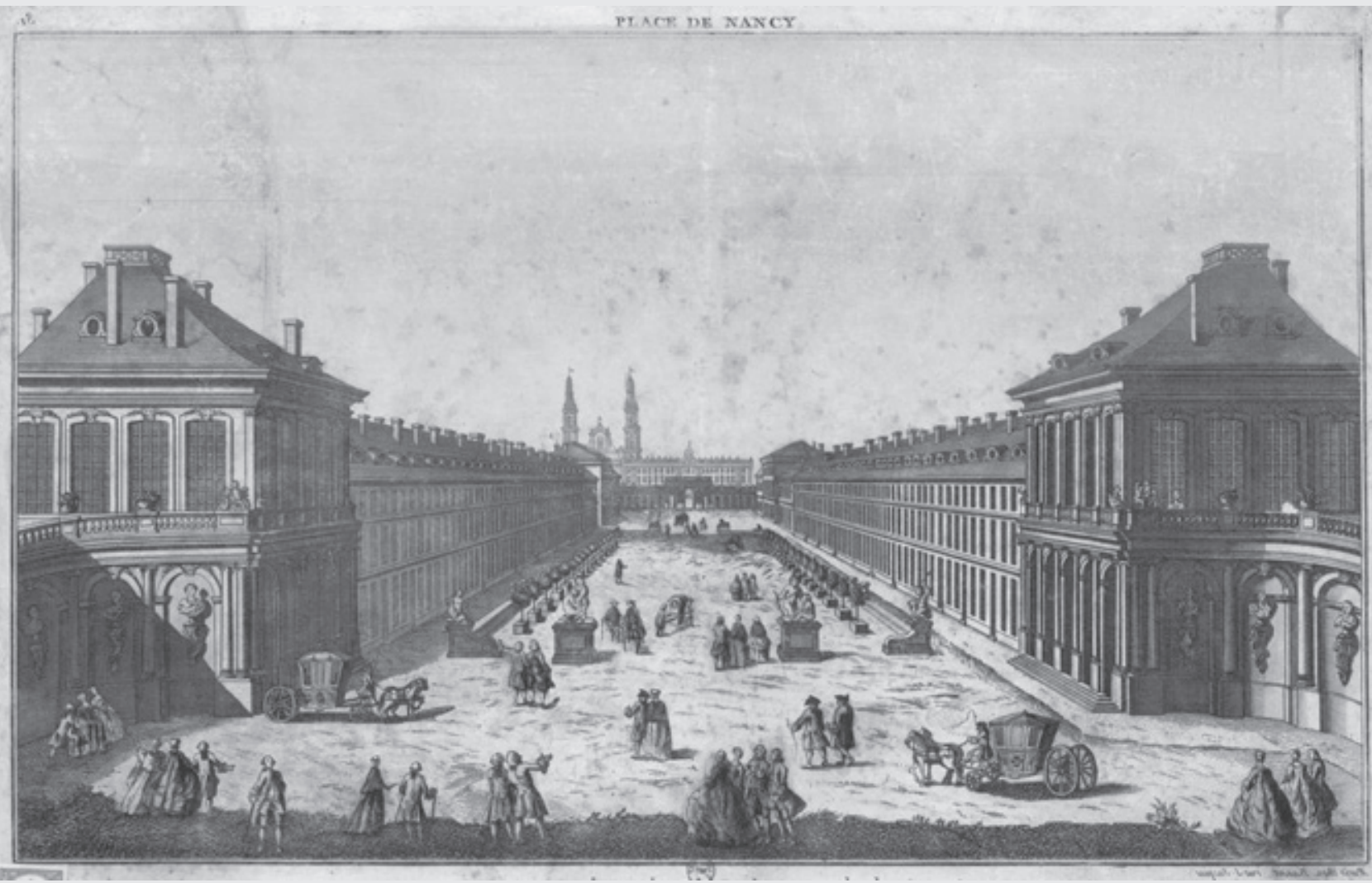

116. Vue Meridionale de la grande Place ditte la Carriere a Nancy. Após as intervenções de abertura e remodelamento das praças. Estampa de 1785 . Fonte: Biblioteca Nacional da França. 
117. Place Royale (atual Praça Stanislas), Nancy. A frente, o Hotel de Ville (prefeitura) com a estátua do Duque de Stanislas no eixo de simetria - ao centro da praça. Fonte: Fotografia elaborada pelo autor (2007)

118. Place Royale (atual Praça Stanislas), Nancy. A esquerda aparece uma das torres da catedral. Fonte: Fotografia elaborada pelo autor (2007).

119. A catedral de Nancy vista da antiga Place Royale. Fonte: Fotografia elaborada pelo autor (2007).
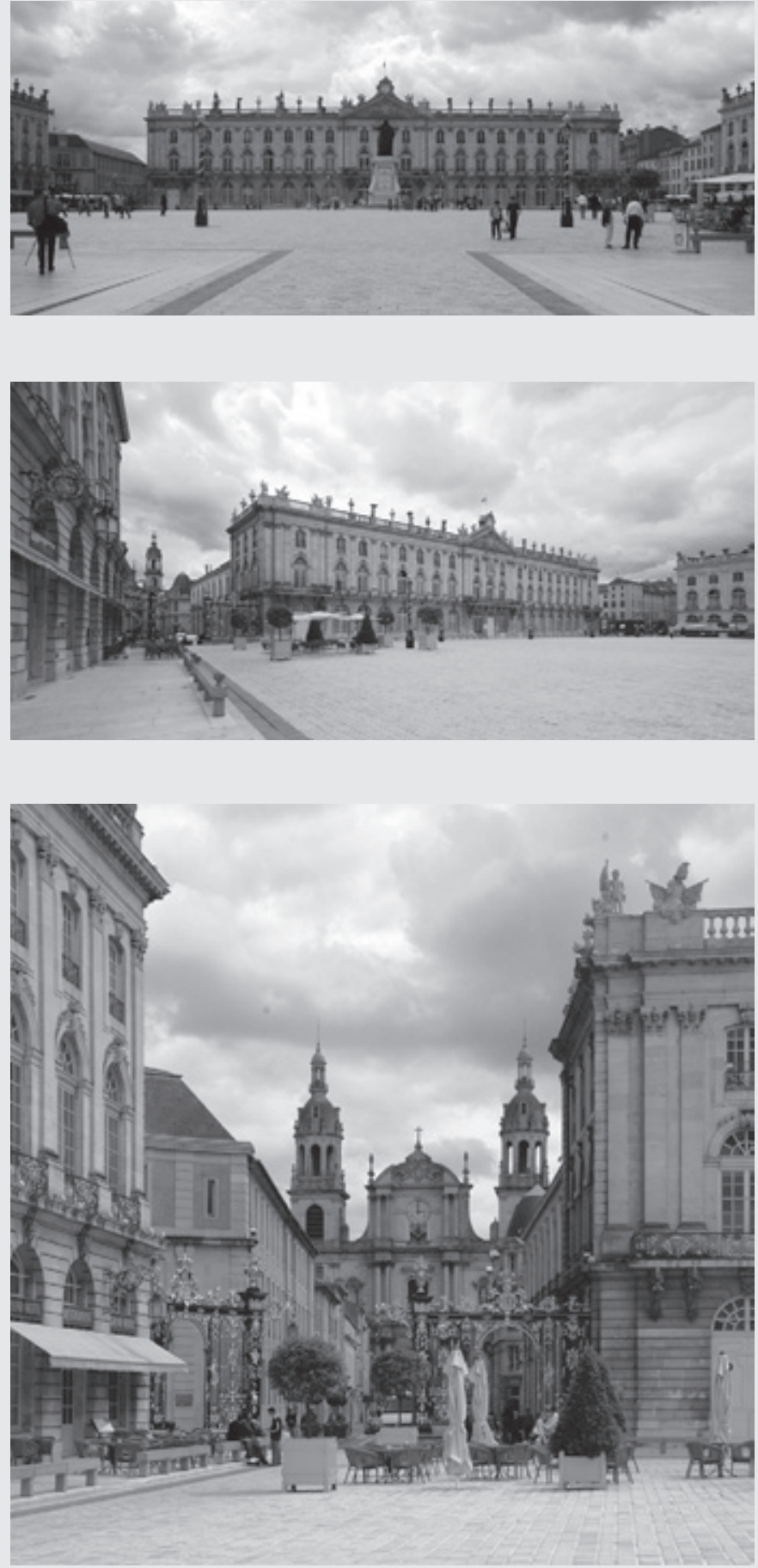


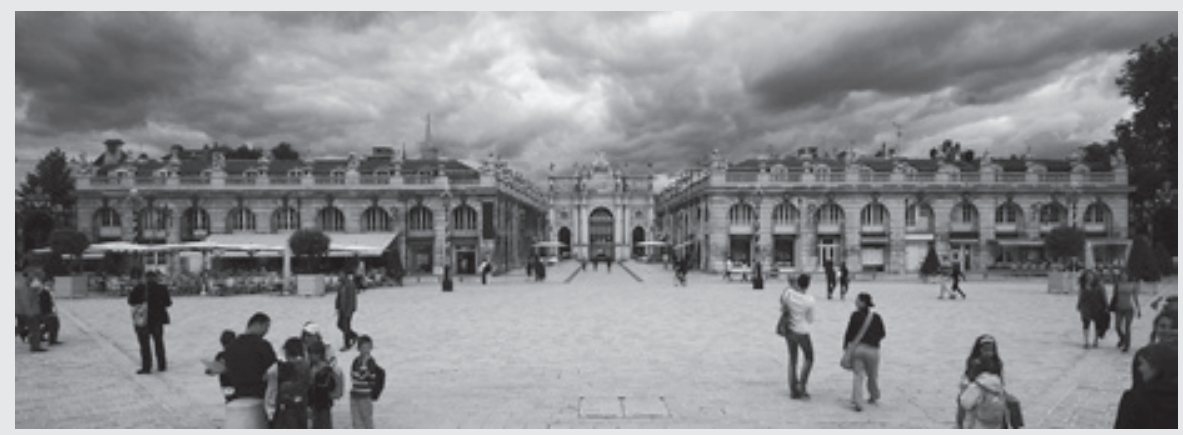

120. A face do arco do triunfo que separa a Place Royale da Place de la Carrière, em Nancy, e marca a transição da cidade nova para a cidade velha. Fonte: Fotografia elaborada pelo autor (2007).

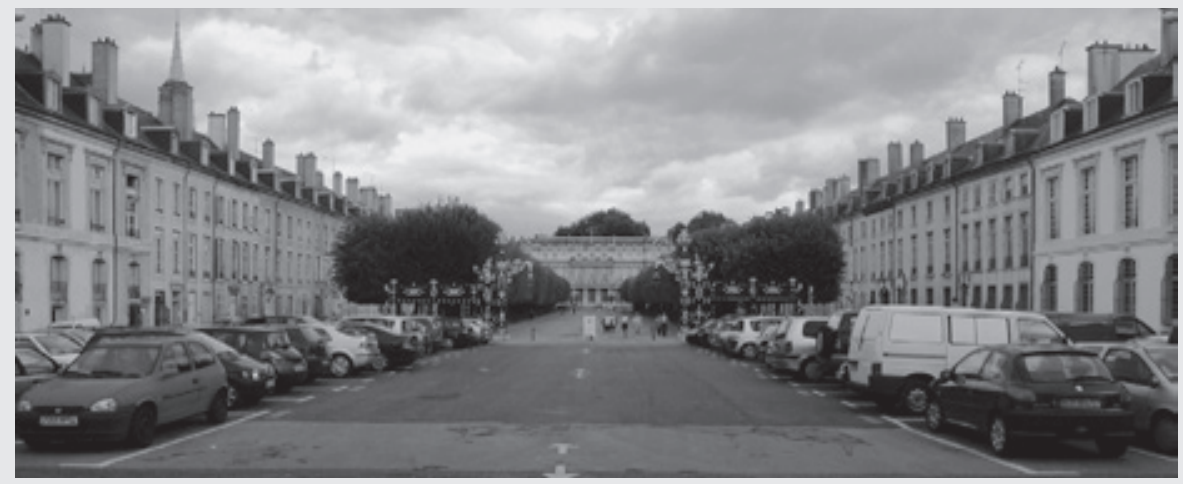

121. Place de la Carrière, em Nancy. Fonte: Fotografia elaborada pelo autor (2007).

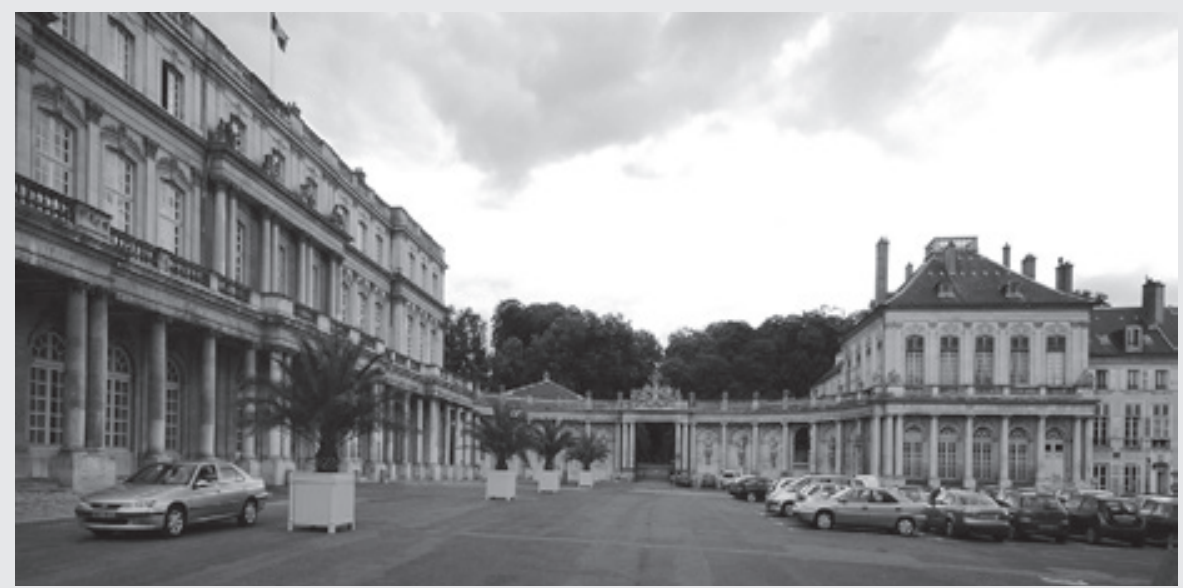

122. Fer de Cheval, Praça do Hemicírculo, Nancy. Fonte: Fotografia elaborada pelo autor (2007). 
geométrica das fachadas unificadas dos longos blocos edilícios contrapostos e das fileiras maciças de arborização; ao término, a sequência se conclui à frente da fachada do Palácio do Intendente como uma praça-peristilo transversal, o Fer de Cheval, circundada por pórticos abertos. É uma articulação global feita em setores espaciais identificados pela altura e pelas características dos edifícios, mas ligados em uma sequência fechada.

Superando os rígidos vínculos impostos pelas preexistências militares, o novo sistema se insere satisfatoriamente como órgão vivo nas estruturas preexistentes, sobretudo pela função de filtro e conexão das duas praças terminais. De fato, ao norte, o Fer de Cheval - com as colunatas em forma de êxedra que prosseguem à frente do Palácio da Intendência (construído entre I75I e I753, idealmente contraposto ao Hôtel de Ville, no outro extremo da sequência) - penetra de um lado no tecido medieval da cidade antiga, e da parte oposta deixa entrever os bastiões fortificados (e, nas sucessivas transformações, o grande parque retangular); ao sul, a Place Royale se coliga à Ville Neuve com os braços viários transversais e com as conexões que partem das interrupções nos ângulos dos blocos edificados, e se fixam no tecido preexistente mediante a previsão de duas novas praças, a Place d'Alliance, e a Place de Grève, tipologicamente afins aos vazios preexistentes e organicamente distribuídas na cidade nova. Em particular, a Place Royale é o nó central do sistema urbano e territorial unificado, nó que dá origem a duas direções perpendiculares entre si: uma, que funciona como elo de união das duas cidades; a outra, no sentido leste-oeste, que une todo o conjunto ao território - a artéria da Esplanade, primeira estrada periférica da Ville Neuve, torna-se um elemento do novo sistema, no paralelismo com a existente diretriz leste-oeste.

Ou seja, para além da estratégia adotada por Héré de Corny para provocar a definitiva junção compositiva e simbólica dos dois lados historicamente separados da cidade através da sobreposição da sequência longitudinal de praças interpenetrantes formada pela Place Royale, pela Place de la Carrière e pelo Fer de Cheval, o arquiteto também se preocuparia com a direção de mecanismos urbanísticos que promovessem a expansão transversal do núcleo urbano: aproveitando o espaço vazio entre as duas metades preexistentes do organismo citadino, Héré de Corny sistematizaria um par de avenidas paralelas que atravessariam a Place Royale por aberturas nos ângulos e no eixo que cortava transversalmente a praça, vãos encerrados pelas espetaculares grades (Figura I23) concebidas por Jean 
Lamour (I698-I7I). À frente, nas direções leste e oeste, outras duas praças regulares, excêntricas ao complexo monumental, contrabalanceariam transversalmente a composição longitudinal dos outros ambientes sequencialmente distribuídos.

Não obstante as intervenções patrocinadas pelo duque de Lorena não terem chegado a atingir a totalidade do núcleo edificado, os trabalhos realizados em meados do século XVIII teriam obtido um êxito muito maior, no que tange à alteração do caráter estético do núcleo preexistente, se comparados às ações urbanísticas que Paris estaria sofrendo desde inícios dos seiscentos, há mais de 150 anos. Este fato poderia ser justificado em função da escala relativamente pequena que a cidade de Nancy teria naquela ocasião, e também devido ao sucesso absoluto que o plano alcançaria por cumprir satisfatoriamente o objetivo de provocar um senso de unidade em um núcleo urbano que era tradicionalmente fragmentado, claramente dividido em duas metades. Por outro lado, poder-se-ia dizer que, ao contrário do plano urbanístico da nova cidade de Karlsruhe, em grande parte uma planificação bidimensional, a concepção das cinco praças de Nancy, bem como a das novas artérias de orientação do crescimento da cidade, extrapolaria o universo da urbanística propriamente dita, e alcançaria uma estratégia mais preocupada com a alteração cenográfica do ambiente - como era comum, aliás, nas constituições das praças reais.

Neste sentido, as places contíguas de Nancy constituíram um evento de dramatização barroca inigualável, fundado no percurso do transeunte que iria gradativamente descobrindo as inebriantes imagens teatrais oferecidas na incrível diversidade dos espaços: desde a surpresa adquirida ao atravessar uma das grades de ferro batido de Lamour e ingressar na monumental Place Royale, passando pela descoberta do cone perspectivo da Carrière após a transposição do arco do triunfo postado no eixo longitudinal do complexo, até a chegada no cenário teatral fundado no Fer de Cheval, de onde o transeunte poderia se surpreender ao atravessar uma das êxedras e alcançar o ambiente pitoresco do burgo medieval, plenamente conectado a toda a composição - uma perfeita aliança entre a urbanística e a cenografia. Nenhuma praça real parisiense teria oferecido, de forma tão expressiva, a experiência barroca calcada na ativação da imaginação, no despertar da fantasia, na apreciação do que acontecia à frente do espectador, mas especialmente na expectativa do que estaria por vir. 


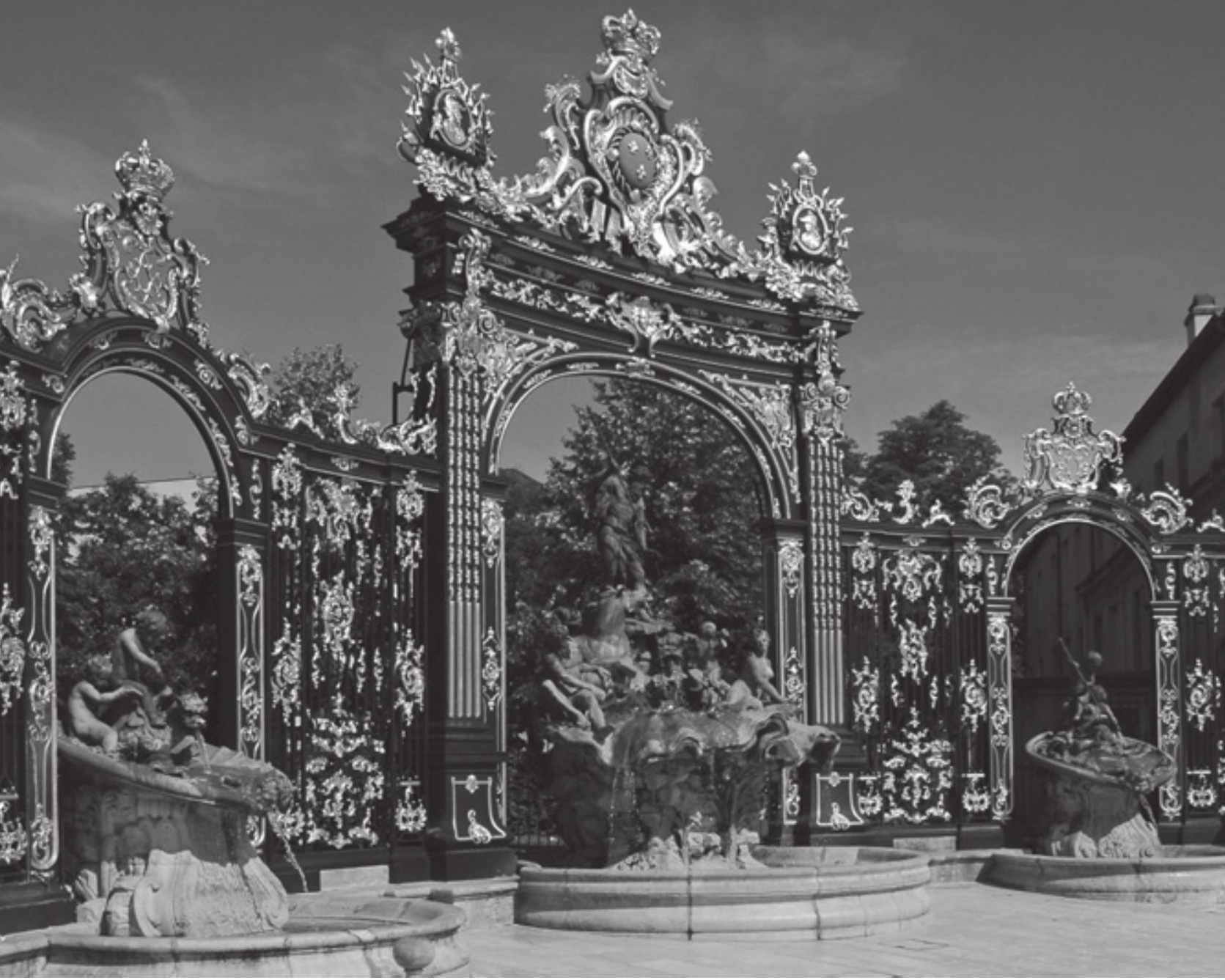

123. Grades de ferro batido de Lamour (1698-1771) que encerram a Place Royale, em Nancy.

Fonte: Fotografia elaborada pelo autor (2007). 


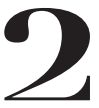

\section{URBANÍSTICA X CENOGRAFIA: A CONSTITUIÇÃO DA ROMA BARROCA}

A cidade pretendia impressionar, em primeiro lugar, por seu traçado, no qual suas distintas partes e seus centros secundários deveriam estar amarrados por avenidas retilíneas, mais ou menos do mesmo modo que os cerimoniosos jardins italianos, que precisamente naquela época começavam a ser imitados mais além dos Alpes. Em segundo lugar, a cidade pretendia impressionar mediante as magníficas fachadas de suas igrejas e palácios, e mediante suas elaboradas fontes. Em terceiro lugar, e talvez seja este ponto o mais importante, pretendia impressionar mediante suas perspectivas monumentais. Os arquitetos e urbanistas tomaram esta ideia dos pintores renascentistas e maneiristas cujas composições arquitetônicas idealizadas começavam a ser transladadas da tela à pedra. [...] As cidades barrocas, tal como começaram a ser planejadas na Itália durante o século XVI e urbanizadas em grande parte da Europa nos séculos XVII e XVIII, se converteram em parte dos atrativos com intenções teatrais e dramáticas da monarquia absolutista. Do mesmo modo que o novo estilo barroco de ornamentação de igrejas fomentava um interesse popular premeditado ao transformar o interior da igreja, e, em especial, o altar-mor, em algo parecido com um cenário onde a missa se celebrava quase como uma representação teatral para uma congregação de fiéis a modo do público, assim a cidade barroca se converteu em uma enorme montagem cenográfica para a exibição da corte, da nobreza e de outros personagens ricos e poderosos. Tratava-se do aspecto visível da mudança política e social que transformou a cidade-estado, com seus cidadãos livres, na capital da monarquia absolutista, com sua corte e seus habitantes subjugados. (KOENIGSBERGER; MOSSE, 1975, p. 82-83, tradução nossa) 
A urbanística barroca dos séculos XVII e XVIII - constituída por iniciativas de grande escala vinculadas à remodelação parcial de importantes Cidades Capitais, bem como conectada às intervenções modernizadoras que núcleos urbanos de província receberiam, mas também atrelada ao design regulador que poucos assentamentos planificados, criados nestas duas centúrias, acolheriam - contribuiria, em muitas nações europeias, para o surgimento de uma nova dinâmica urbana. Porém, seria improvável que estas ações, isoladamente, pudessem alterar o caráter cenográfico dos organismos urbanos preexistentes, oferecendo, para a estrutura visibilística da cidade, uma nova configuração paisagística, herdeira da poética barroca. Sem a conjugação destas iniciativas com os outros elementos que comporiam a unidade artística indivisível que os núcleos poderiam conformar, existiriam poucos eventos significativos; episódios urbanísticos incapazes de garantir a transmutação da imagem preexistente das cidades; intervenções setorizadas baseadas em um desenho regular; empreendimentos fundados pelos expressivos eventos patrocinados pelos governos e exaltados nos grandes eixos perspectivos, nos triviuns e poliviuns, nas praças regulares, jardins, passeios e bulevares - contudo, acontecimentos insuficientes para promover a reorientação dramática do ambiente.

De fato, o que poderia dar o tom da modernização destes organismos seria a filiação do espaço resultante aos princípios essenciais do Barroco: o apelo persuasivo e o uso do poder ilimitado da imaginação. (BAETA, 20I2) A persuasão seria derivada da necessidade de desenvolvimento de um enérgico mecanismo de divulgação e de exposição do imenso poder das estruturas políticas e religiosas que povoariam o cenário seiscentista: uma estratégia de representação que fosse acessível a todos, desde os mais humildes aos mais doutos. A imaginação, por sua vez, estaria relacionada ao desinteresse que o artista barroco demonstraria pelo conhecimento e representação da natureza. Assim, a arte possibilitaria a substituição do real pelo fantástico, transformando o que estaria além da razão objetiva em realidade visível.

O ilusionismo ótico, a "maravilha", permitiriam o esclarecimento da prodigiosa organização da Igreja Católica Romana e dos Estados autoritários seiscentistas. As paixões que o poder das imagens emanadas pela arte despertariam nos homens promoveriam a compreensão da mensagem sobrenatural que as grandes estruturas de poder transmitiriam aos seus seguidores, tornando realidade o que era antes alcançado apenas pela imaginação. A arte cumpriria, enfim, seu papel de agente da persuasão. 
E assim a cidade tornar-se-ia um dos maiores agentes da propaganda barroca: processo alcançado, para além da urbanística, pela presença marcante da arquitetura como instrumento retórico essencial - como ficaria claro na citação que abriria este capítulo, fruto do juízo proferido pelos historiadores Helmut Georg Koenigsberger (I9I8-20I4) e George Lachmann Mosse (I9I8-I999), no livro Europe in the sixteenth century, ensaio publicado pela primeira vez em I968. $\mathrm{Na}$ realidade, a arquitetura contaminaria toda a cidade - tanto os grandes monumentos quanto as construções ordinárias que preparariam o percurso e se abririam às visadas generosas. Cada intervenção promoveria, ativamente, uma relação com o espaço preexistente, seja na conformação de um cenário regular de preparação, seja em um grande acontecimento cenográfico - uma igreja, um palácio, uma praça - que se apresentaria no espaço urbano como uma das destinações dramáticas do universo citadino.

Esta relação inevitável da arquitetura com seu contexto e a forma como esta interação poderia alterar, mutuamente, o caráter do monumento e de seu entorno, ou seja, do sítio no qual estaria inserido, já era reconhecida pelo próprio Gian Lorenzo Bernini (I598-I680), o mais influente escultor e arquiteto do período barroco: Paul Fréart de Chantelou (I609-I694), personagem responsável por ciceronear o grande mestre em sua viajem à França, de junho a outubro de I665, a convite do Rei Sol, relataria uma conversa muito interessante entre o mestre da arte romana e o cenógrafo de Modena, Carlo Vigarani (I637-I7I3), acontecida no dia 23 de agosto de 1665 , enquanto Bernini esperava uma audiência com o monarca na antecâmara de seus aposentos - diálogo citado no Journal du voyage en France du Cavalier Bernin, o testemunho diário da viagem do artista italiano à Paris, escrito por Chantelou (I972, p. I29, tradução nossa), e publicado em I67I:

$\mathrm{Na}$ espera, começaram a discorrer sobre algumas coisas e, entre elas, sobre arquitetura, da qual foi dito que é uma arte difícil e para poder exercê-la é necessário associar a teoria e a prática. Vigarani observou que era necessário para um arquiteto ser especialista na geometria e principalmente na perspectiva. O Cavaliere acrescentou que um dos pontos mais importantes é possuir um bom olho para bem julgar os contrapostos, porque as coisas não aparecem somente como são, mas também em relação a aquilo que é seu vizinho, relação que muda a sua aparência. 
Deste modo, Bernini anteciparia alguns princípios que seriam aprofundados somente no início do século XX pela Psicologia da Forma, particularmente a impossibilidade de se apreciar a imagem de um objeto fora do contexto que inevitavelmente deveria habitar.

Estendendo o conceito do mestre da arte romana para a dimensão urbana, o artista barroco trabalharia as potencialidades da paisagem edificada em função da sensibilização da mente do fruidor - em nome da direção de seu comportamento, em prol da persuasão -, tirando proveito das preexistências naturais e arquitetônicas para utilizá-las em função da elevação dos efeitos cênicos, para a criação do grande teatro que deveria ser revelado pela trama urbana do ambiente citadino. Nenhum elemento possuiria qualquer significação fora de seu contexto e mesmo a preexistência passaria a prescindir das novas intervenções. Assim, os próprios eixos perspectivos que viriam a ser tão comuns nas cidades seiscentistas e setecentistas, mesmo quando se prestavam à definição de episódios monumentais, normalmente adquiririam uma importância maior na comunicação, nem sempre direta, entre os espaços onde se desenvolveriam as cenas mais significativas. Desta forma contribuiriam, juntamente com outros elementos urbanos - construídos, preexistentes ou naturais -, para a amarração destas imagens poderosas, transformando todo o ambiente em uma experiência barroca superior assimilada no processo gradativo de descoberta da cidade.

Assim, a cidade barroca não fugiria ao desenvolvimento típico de toda arte do período baseado na imaginação e na persuasão. Sua percepção se faria na experimentação direta do ambiente urbano; nas preparações, tensões, surpresas presentes para quem o explorava. As preexistências edificadas ou naturais serviriam à elevação do jogo cenográfico a ser exposto, sendo utilizadas sistematicamente para a orientação do enredo dramático que se encenava - na descoberta gradativa da trama barroca que se desenrolava no núcleo urbano. Segundo as palavras de Argan (I986, p. 349, tradução nossa), proferidas no ensaio Bernini e Roma,$^{40}$ escrito em I980, este processo estaria plenamente desenvolvido na obra de Bernini: "Aquilo de que mais se preocupa é a condição de perceptibilidade das próprias obras: como no teatro, predispõe cuidadosamente as sugestões, as surpresas, os retardamentos e as acelerações do processo perceptivo dos espectadores."

40 Artigo retirado da coletânea de 1986 de textos do historiador da arte italiano: Immagine e persuasione. Saggi sul barocco. 
Portanto, este capítulo objetiva debater alguns processos de contaminação cenográfica do ambiente urbano em prol da compreensão de mecanismos - que extrapolem a esfera urbanística - que poderiam fomentar a transfiguração barroca de núcleos preexistentes, bem como a construção de uma cenografia barroca para aglomerados urbanos de nova formação. Para se alcançar esta finalidade, será promovida uma análise específica de muitas das principais intervenções urbanas e arquitetônicas que a cidade de Roma, capital dos Estados Pontifícios, teria sofrido entre o final do século XVI e a segunda metade do século XVIII (Figura I24), e particularmente como estes acontecimentos pontuais, em sua contínua amarração, em sua "costura", poderiam efetivamente autorizar a atribuição da alcunha de "cidade barroca" - pelo menos até o ano de i870, quando Roma seria declarada capital da nova nação italiana e acabaria passando por operações urbanísticas que fragmentariam tragicamente seu tecido urbano preexistente.

\section{Urbanística romana no Cinquecento}

Há outras razões pelas quais Roma é singular entre as cidades - razões que talvez não sejam tão facilmente apreendidas. A Santa Sé não é apoiada por nenhum império mundial. O papado é um poder religioso internacional. Os cidadãos de Roma, sujeitos à autoridade papal, têm pouca voz no que diz respeito ao desenvolvimento de sua cidade. Não obstante, ali foi gerada uma das realizações mais suntuosas de desenho cívico: a Roma barroca, que ainda hoje domina completamente a feição da cidade. (GIEDION, 2004, p. I02)

Poder-se-ia abrir a análise das transformações que a Cidade Eterna viria a sofrer em prol da exaltação, após a Contrarreforma católica, da autoridade da Igreja Romana com as palavras sintéticas proferidas pelo consagrado historiador da arquitetura Sigfried Giedion (I888-I968), juízo revelado em seu conhecido estudo lançado em I94I e intitulado Raum, zeit, architektur. ${ }^{4 \mathrm{I}}$ Como afirmaria o crítico suíço (nascido em Praga), Roma nunca chegaria a ser, após a queda do mo-

41 Aqui foi contemplada a versão em português de 2004, Espaço, tempo e arquitetura. O desenvolvimento de uma nova tradição. A tradução foi empreendida por Alymar Lamparelli a partir do texto em inglês lançado em 1941, o mesmo ano da publicação da versão original em alemão. 


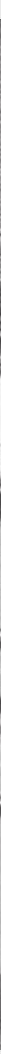

124. Roma - Igreja de Santa Maria in Campitelli e praça homônima. Imagem retirada de uma gravura do arquiteto siciliano, Giuseppe Vasi (1710-1782), da série Le Magneficenze di Roma, elaborada em 1747. Fonte: Coen (1996, p. 175). 
numental império latino, uma cidade economicamente importante, nem sequer a sede de uma grande nação em extensão territorial; pelo contrário, os domínios do Estado pontifício seriam sempre relativamente modestos, principalmente se comparados à imensa influência religiosa, e consequentemente política, que a capital católica do mundo absorveria em todo o contexto mundial - um alcance político sentido especialmente no ocidente, mas que também se estenderia para os distantes confins do oriente; um poder espiritual que comandaria todas as nações católicas, mas que não deixaria de se fazer presente nas regiões que professavam as crenças protestantes no continente europeu; um controle religioso que marcaria em definitivo a história do Novo Mundo, principalmente as colônias hispânicas e lusitanas das Américas.

Logo, a suntuosa feição que a cidade, gradativamente, viria a adquirir nos séculos XVI, XVII e XVIII, poderia não condizer com a sua fragilidade econômica, nem com seu parco poderio militar, bem como com a pequena extensão territorial dos seus domínios, mas estaria plenamente de acordo com a qualidade de sede legítima, espiritual e política da grande comunidade católica - atribuição que aos poucos seria recuperada após o retorno dos papas do exílio de Avignon, em I377.

Por isso, a Roma barroca viria a ser o modelo de cidade a constituir, em todo o seu tecido urbano, um verdadeiro palco para a exaltação da autoridade histórica da Igreja Católica, emanando um decisivo cenário persuasivo em nome da celebração da mais antiga instituição do poder temporal e do poder religioso ainda em vigor na Europa humanista. Após as diversas iniciativas de reformulação viária efetivadas no Cinquecento, empreendimentos urbanísticos que decretariam a abertura de avenidas diretas em diferentes áreas da Cidade Eterna, o núcleo urbano passaria a receber inúmeras intervenções pontuais, principalmente no século XVII, obras que alterariam dramaticamente sua paisagem: construção e restauração de palácios, igrejas, fontes; abertura de ruas e praças; ereção de obeliscos inseridos em áreas estratégicas do espaço urbano; obras de infraestrutura e defesa; reocupação da área desolada em volta do tecido edificado, principalmente em cima das colinas, com o surgimento de imponentes vilas de propriedade de cardeais, papas, príncipes e famílias nobres - espaços verdes onde se destacariam os jardins paradisíacos e que serviriam como contraponto ao cada vez mais denso núcleo central. Estas ações, concebidas e realizadas pelos grandes mestres da arquitetura e da arte barrocas, contribuiriam para definir uma amarração entre 
muitas das partes irregulares do tecido urbano, seja nos bairros mais densos, seja nas áreas mais dispersas dentro do perímetro das muralhas de Aureliano. ${ }^{42}$

Até meados do Settecento, a Roma papal continuaria afirmando, sucessivamente, o seu dinâmico equilíbrio barroco através da inclusão, em seu sítio, de outros tantos eventos de forte apelo persuasivo. A cidade consolidada, mas demográfica e economicamente estacionada, manteria seu caráter até o último quartel da próxima centúria. Mas as intervenções pontuais dos grandes mestres da arquitetura e da arte do Seicento e do Settecento só poderiam ser apreciadas, em toda a sua expressão, se confrontadas, mesmo que minimamente, com a estrutura urbana que a cidade teria adquirido nas últimas décadas do século XVI. Por isso, apesar do objetivo desta unidade ser o de alcançar um juízo sobre a construção cenográfica da cidade barroca através da avaliação de algumas das mais importantes obras da arquitetura romana, seria imperativo - para a apreensão dos artifícios visibilísticos que comandariam a costura destes eventos dramáticos dispersos na urbe em prol da transfiguração do tecido urbano preexistente o desenvolvimento de uma prévia e sintética análise dos empreendimentos propriamente urbanísticos que a cidade amplamente sofreria durante o século que antecederia a grandiloquente experimentação barroca - as ações de grande escala promovidas pelos papas que governariam a Cidade Eterna no Cinquecento.

E parece consenso que o fenômeno do espaço urbano barroco seria, em grande parte, definido por uma política urbanística que alcançaria a Europa Ocidental através da Itália já no século XVI. O plano do pontífice Sisto V (Felice Peretti, nascido em I52 I e morto em I590) para a renovação de Roma - desenhado pelo arquiteto Domenico Fontana (I543-I607) - apareceria como uma espécie de síntese conclusiva das diversas iniciativas de ressistematização do sistema viário que a cidade de Roma acolheria, iniciativas agenciadas por outros papas que o antecederiam. Além disso, o projeto - só em parte realizado - teria servido de base tipológica para as posteriores iniciativas de reformulação de diversos núcleos urbanos europeus desde inícios do século XVII.

42 O Imperador Aureliano começou a levantar, em 272 d. C., o sistema defensivo que iria proteger Roma até os tempos modernos. As muralhas, com um perímetro de aproximadamente $18 \mathrm{~km}$, foram restauradas e elevadas em quase duas vezes por Massenzio, entre os anos 309 e 312, e foram reforçadas por Onorio entre 402 e 403 . Após a queda do império, a parte ocupada da cidade dentro das fortificações passaria a ser mínima, e mesmo no auge da Roma barroca o tecido urbano não preencheria nem metade do ambiente envolvido pelos muros. No final do século XIX as fortificações de Aureliano seriam finalmente vencidas pela ampliação da cidade. Não obstante, ainda hoje estão em sua maior parte preservadas, acolhendo o núcleo mais antigo. (SANFILIPPO, 2004, p. 8) 
Porém, seria importante assegurar que muitas das intervenções e dos procedimentos de ordenação urbanística que frequentemente acabariam sendo atribuídos ao Papa Felice Peretti, na verdade teriam acontecido em uma fase anterior ao governo do pontífice, ou mesmo seriam iniciativas que só viriam a ser concebidas após sua morte. Segundo a afirmação do arquiteto e historiador italiano Italo Insolera (1929-20I2), proferida em seu importante estudo - cuja primeira edição sairia em I980 - Roma: Immagine e realtà dal $X$ al XX secolo, publicação que faria parte da coleção Le cità nella storia d'Italia, coordenada por Cesare de Seta, o pontífice não teria sido apenas um mestre como gestor de grandes obras públicas, mas também como propagandista e promotor de sua própria figura:

Sisto $\mathrm{V}$ foi uma daquelas pessoas que não apenas se preocupava em fazer, mas também - pelo menos tanto quanto - em dizer e em fazer dizer aquilo que fazia e aquilo que teria feito. Em função disso os historiadores sempre o amaram - parece que os contemporâneos um pouco menos -, assim como sempre amaram aqueles outros papas e personagens que contribuíram para poupar o trabalho fatigoso das longas pesquisas, oferecendo a eles tudo já escrito sobre o capítulo que lhe dizia respeito. Mas é supérfluo observar que, se estes capítulos são extremamente interessantes para se conhecer como Nicolò V, Sisto V, Luís XIV, Haussmann gostariam que os outros pensassem sobre sua política para Roma ou Paris, estes relatos não poderiam ser assumidos como descrições fidedignas desta mesma política. O elogio fúnebre de Giannozzo Manetti, as descrições de Domenico Fontana, os projetos de Hardouin-Mansart, as Memóires de Haussmann são alguns documentos políticos partidários, e só como tais são um capítulo da história de Roma ou de Paris.

Talvez para nenhum papa como para Sisto $V$ a distância entre as tantas coisas declaradas nas intenções e aquelas realizadas aparece mais ampla. Não porque ele tenha realizado pouco, pelo contrário; mas porque gravuras, afrescos, biografias engrandeceram a sua obra provavelmente com zelo exagerado e contraproducente. E o fenômeno não se limitou aos seus tempos, mas também foi sendo cada vez mais ampliado, com o resultado de acumular em torno do seu nome obras realizadas antes e depois, em situações e com intenções - urbanísticas, arquitetônicas, monumentais - totalmente diferentes. (INSOLERA, I996, p. I65, tradução nossa) 
Com a finalidade de explorar a imagem de um estadista que estaria promovendo um plano geral de renovação urbanística, e particularmente de redelineamento viário, para a cidade de Roma, Sisto V - que teria um breve pontificado, que se estenderia entre 1585 e 1590 - usualmente incorporaria, nas imagens que eram produzidas para celebrar seus grandes feitos, intervenções devidas a outros pontífices que o antecederam: como, por exemplo, o famoso tridente da Piazza del Popolo, um dos mais importantes organismos urbanísticos da Cidade Eterna, fruto de uma complexa sistematização realizada na primeira metade do século XVI, na qual longas avenidas, novas e preexistentes, seriam ordenadas linearmente em prol da geração de um trivium regular disposto à frente do antigo acesso norte da cidade. Não obstante a antecedência de décadas da intervenção em relação à época do Papa Felice Peretti, o tridente viria figurar, em primeiro plano, em um afresco encomendado pelo pontífice para ornar uma parede da Biblioteca Vaticana (edifício construído por ele), afresco pintado na década de 1580 para exaltar o plano viário concebido por Domenico Fontana que ligaria muitas das basílicas e dos lugares mais sagrados da cidade ${ }^{43}$ - um dos fatores que certamente teriam colaborado para a constituição do juízo equivocado presente em algumas afirmações do emérito historiador das cidades, Lewis Mumford, quando assegurava a autoria de Sisto V para o tridente. ${ }^{44}$

Logo, seria importante lembrar que antes do governo de Sisto V diante da Santa Sé a cidade já estaria passando por uma série de intervenções que colaborariam para transformar a antiga urbe medieval em uma cidade moderna: um núcleo urbano dinâmico, que - apesar de sua dimensão extremamente reduzida em relação àquela que guardaria no auge do período imperial, quando chegaria a contar com mais de um milhão e duzentos mil habitantes (MORRIS, I979, p. 39) - escaparia totalmente à imagem desolada que o marcaria durante toda a ldade Média, despontando no início do século XVII como uma das mais modernas

43 Este afresco faria parte de um conjunto de outros afrescos confeccionados para a Sala Sistina da Biblioteca Vaticana, imagens realizadas por vários pintores entre 1588 e 1590, com a coordenação de Giovanni Guerra (1540-1618) e de Cesare Nebbia (1536-1614). (INSOLERA, 1996, p. 165)

44 "As três grandes avenidas que irradiam da Piazza del Popolo, em Roma, concepção do Papa Sisto V, foram desenhadas para tornar mais fácil ao peregrino encontrar seu caminho para as inúmeras igrejas e locais sagrados; contudo, foram inventadas dentro da mesma inflexível maneira militar, e não é por acidente que uma delas, o Corso, tornou-se a principal rua de comércio de Roma, aberta ao 'comércio de carruagem'." (MUMFORD, 1989, p. 389, tradução nossa) 
cidades europeias - senão mesmo, pelo menos por algumas décadas, como a mais inovadora metrópole do ocidente.

Para isso, o artifício mais proeminente presente nas intervenções na "cidade santa" durante o Cinquecento seria, indubitavelmente, a abertura de novas vias retilíneas e diretas, assim como a recuperação de antigas e longas artérias rasgadas no período imperial. As extensas avenidas, que passariam a cortar a preexistência medieval, os sítios arqueológicos, as áreas desabitadas internas às muralhas aurelianas, formariam eixos perspectivos que uniriam muitas das principais áreas da cidade, dando uma nova legibilidade ao espaço urbano. ${ }^{45}$ Benevolo (2008, p. 518, tradução nossa) resumiria as principais ruas traçadas e efetivamente rasgadas antes dos pontificados de Pio IV (que coordenaria a Igreja entre I559 a I565), e Gregório XIII (que dirigiria o Vaticano de I572 a I585), bem como em antecedência ao plano de reestruturação urbanística concebido por Fontana para Sisto $V{ }^{46}$ pois, para o crítico italiano, o projeto de Felice Peretti:

É a lógica continuação das sistematizações parciais promovidas pelos papas precedentes: Sisto IV (os Borghi e o tridente da ponte Sant'Angelo), Alessandro VI (Via Alessandrina), Giulio Il (Via Giulia e Via della Lungara), Leone X (Via Ripetta), Paolo Ill (o tridente da Piazza del Popolo, Via Condotti, Via dei Baullari; já neste ponto as intervenções urbanísticas aparecem coordenadas em um programa unitário, devido à Giovenale Manetti, enquanto as intervenções edilícias monumentais - San Pietro, o Campidoglio, Palazzo Farnese - são dirigidas por Michelangelo); as novas vias são articuladas com os traçados retilíneos da Antiguidade (Via Lata, Via Flaminia, Via Nomentana, Via dei Coronari) e entrelaçam a cidade medieval com uma rede viária 'moderna', se bem que de forma parcial e descontinua. ${ }^{47}$

45 É bom lembrar que, mesmo nos séculos XVII e XVIII, a cidade de Paris não sofreria intervenções semeIhantes. O grande eixo perspectivo da Champs-Elysées não ligaria nenhuma parte importante da cidade e não seria concebido como uma avenida que deveria acolher construções em seus lados, mas como um passeio público diluído no verde.

46 Giovanni Angelo de Medici (1499-1565), o Papa Pio IV; Ugo Boncompagni (1502-1585), o Papa Gregório XIII.

47 Francesco della Rovere (1414-1484) foi o Papa Sisto IV, que dirigiu a Igreja desde 1471 até sua morte; Roderic de Borja i Borja (1431-1503) foi o Papa Alessandro VI, dirigindo a Santa Sé a partir de 1492; Giuliano della Rovere (1443-1513) foi o Papa Giulio II, que dirigiu a Igreja de 1503 até sua morte; Giovanni di Lorenzo de' Medici (1475-1521) foi o Papa Leone X, dirigindo a Igreja a partir de 1513; finalmente, Alessandro Farnese (1468-1549), o Papa Paolo III, foi pontífice máximo de 1534 até sua morte. Alessandro Farnese, em seu pontificado, foi auxiliado, no que se refere aos problemas de planejamento urbano, por Giovenale Manetti (1485-1553), diplomata humanista que receberia o título de curatores viarum. 
Deste modo, não seria nada leviano afirmar que em Roma, muito precocemente, a tradição humanista da abertura de grandes avenidas retilíneas, discutida no capítulo precedente, alcançaria o auge da expressão ainda no Cinquecento (Figuras I25-I29), antes mesmo do pontificado de Sisto V, levando-se em consideração que, para além das vias citadas por Benevolo, outros grandes eixos perspectivos seriam abertos pelos pontífices quinhentistas que sucederiam Paolo III: por iniciativa de Pio IV seria traçada a imensa Strada Pia (Figura I30), que se distenderia para o limite nordeste da cidade, ligando o palácio papal do Quirinale à distante Porta Pia projetada por Michelangelo, permitindo o tráfego direto para fora dos muros, se conectando à antiga estrada romana conhecida como Via Nomentana; já Gregório XIII conceberia a Via Gregoriana, aberta desde a Igreja Trinità dei Monti, descendo para as proximidades de Sant'Andrea della Fratte, bem como traçaria a longa Via Merulana, que ligaria a Basílica de Santa Maria Maggiore à Catedral de Roma, a Igreja de San Giovanni in Laterano. Mas, é certo que o auge das intervenções coordenadas em prol da remodelação do ambiente citadino da Cidade Eterna recairia na figura de Sisto V - mesmo reconhecendo a distância entre o que viria a ser declarado como realização do papa e o que seria efetivamente consumado por ele, bem como assegurando que mais da metade de seu plano não chegaria a ser realizado.

Certamente, o mérito de Felice Peretti incidiria no fato do pontífice ter sido o primeiro governante a pensar, ainda no século XVI, a planificação em uma dimensão global; ou seja, Sisto V, por meio de seu técnico Domenico Fontana, teria realmente antecipado alguns princípios que só viriam a se consolidar bem mais tarde, com o advento da moderna disciplina do urbanismo - e por isso seria exaltado por diversos teóricos e críticos contemporâneos da arquitetura. (ROSSI, 2006, p. 169) Ao conceber o seu grande plano urbanístico para a Roma quinhentista, Fontana levaria em consideração não somente a reordenação da estrutura urbanística da Cidade Eterna através de intervenções coordenadas que contemplassem toda a extensão do núcleo habitado, mas também outras preocupações essenciais: o bom funcionamento da urbe, perseguido através da inclusão de diversas obras de infraestrutura urbana, com especial atenção à restauração de aquedutos em prol da recuperação do sistema de fornecimento de água para os antigos bairros dispostos nos sítios mais salubres, localizados no alto das colinas - áreas abandonadas desde a interrupção dos aquedutos pelos invasores da Idade Média; consequentemente, promoção do crescimento do núcleo habitado para 


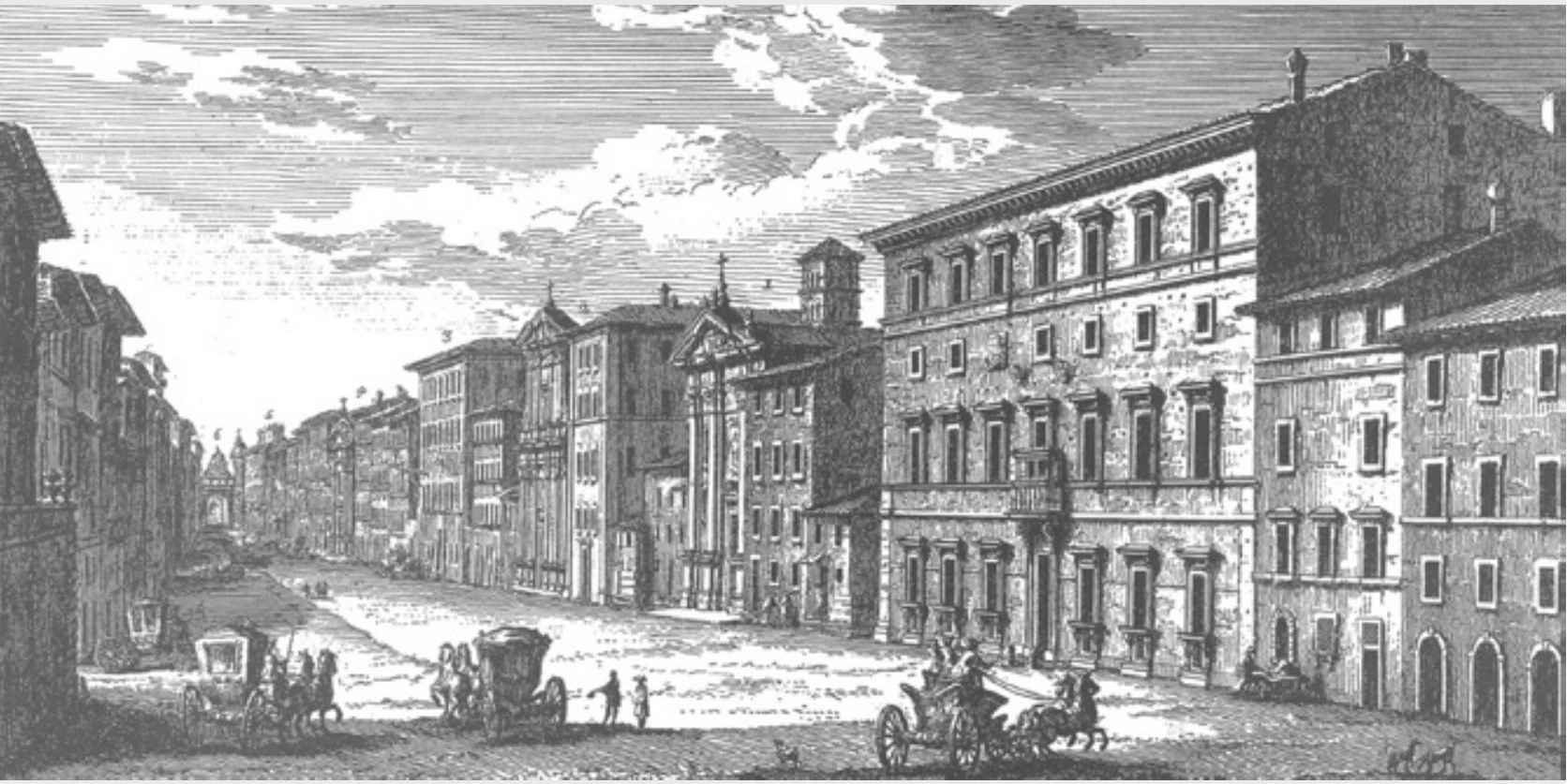

125. Panorama da Via Giulia - aberta pelo papa Giulio II no começo do século XVI - em uma gravura de Giuseppe

Vasi, da série Le Magneficenze di Roma, 1747. Destaque para o Palazzo Sacchetti. Fonte: Coen (1996, p. 175).

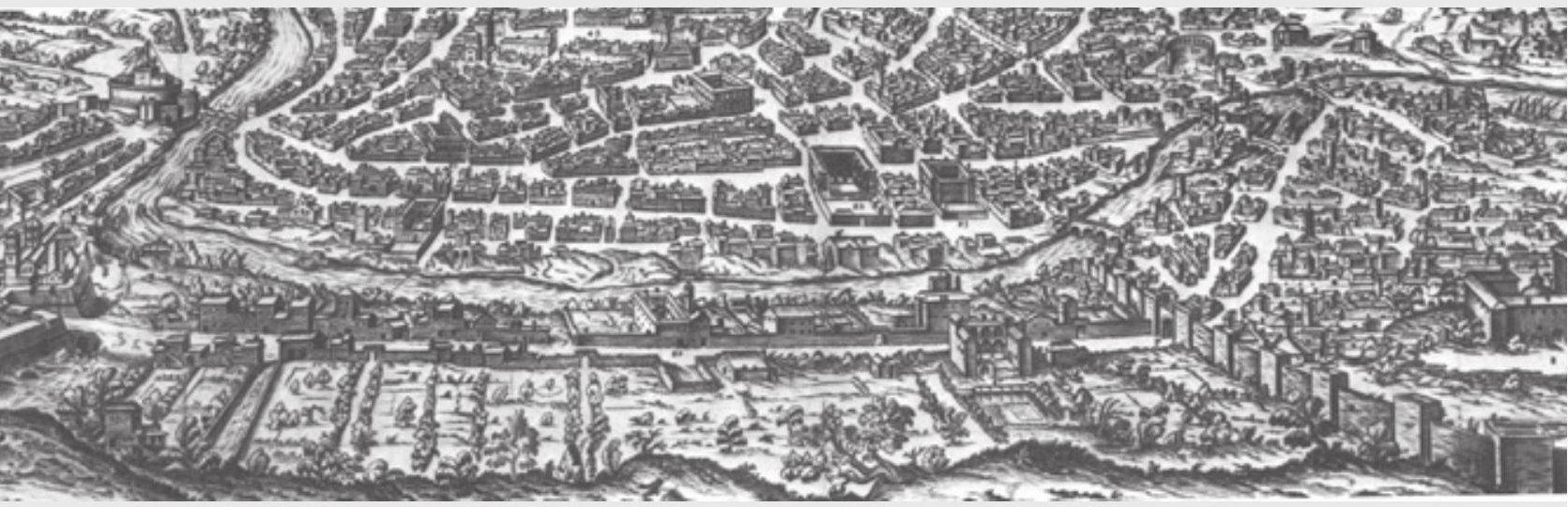

126. Detalhe da planta de Roma confeccionada, em 1555, por Ugo Pinard. Percebe-se a retilínea Via della Lungara, abaixo, na margem direita do Rio Tevere, e a Via Giulia, acima, rente à sua margem esquerda. As duas ruas foram abertas por Giulio II. Fonte: Frutaz (1962, v. 2, p. 123). 


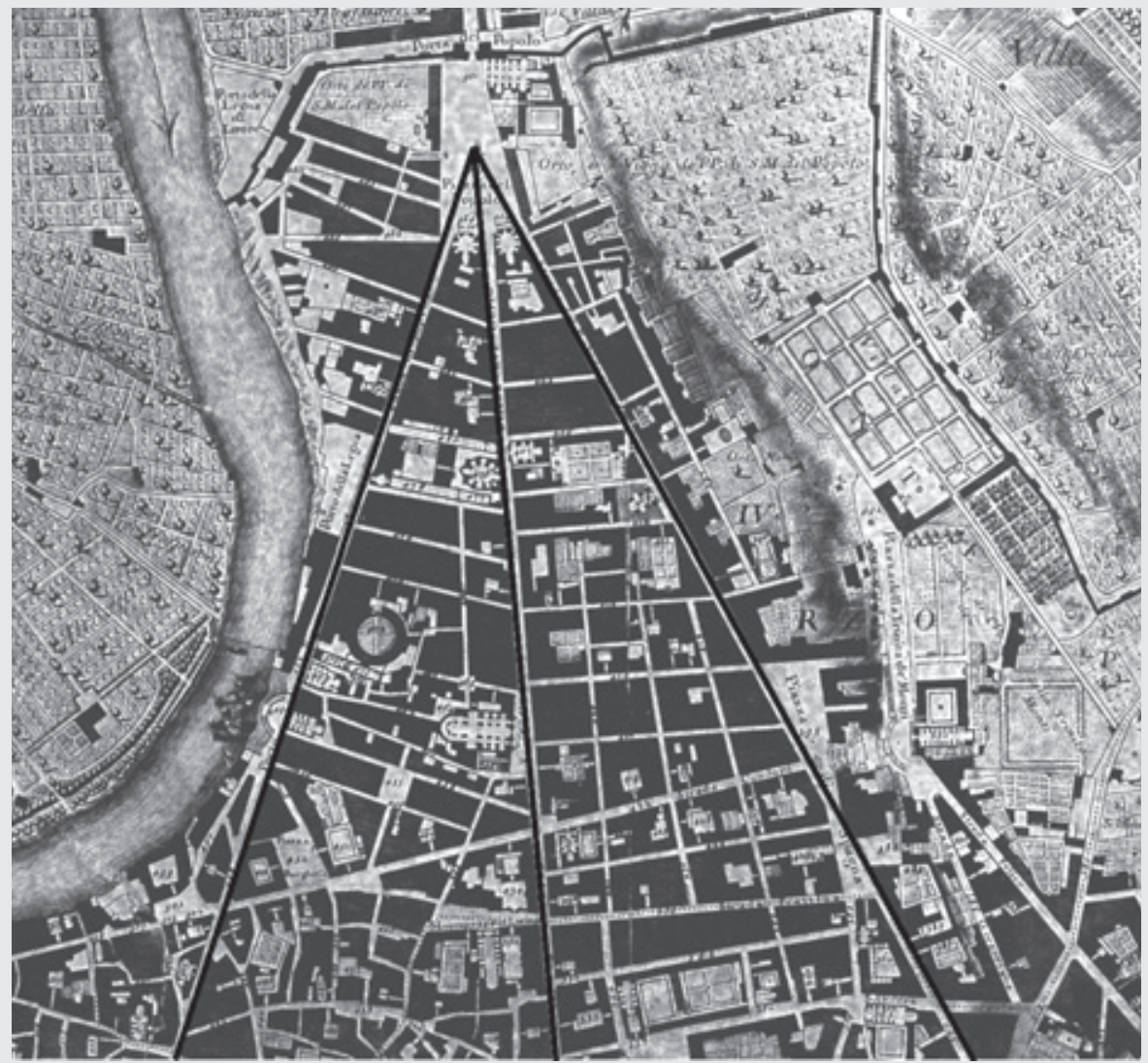

127. Detalhe da célebre planta de Roma que Giambattista Nolli (1701-1756) - engenheiro, arquiteto, gravurista e cartógrafo italiano - elaborou e publicou em 1748 (a versão grande da Nuova Topografia di Roma). Detalhe da área plana do tridente do Campo Marzio formado pela Via di Ripetta, Via del Corso e Via Babuino - marcadas pelas linhas pretas. Fonte: Elaboração do autor a partir da planta de Nolli. Frutaz (1962, v. 3, p. 396).

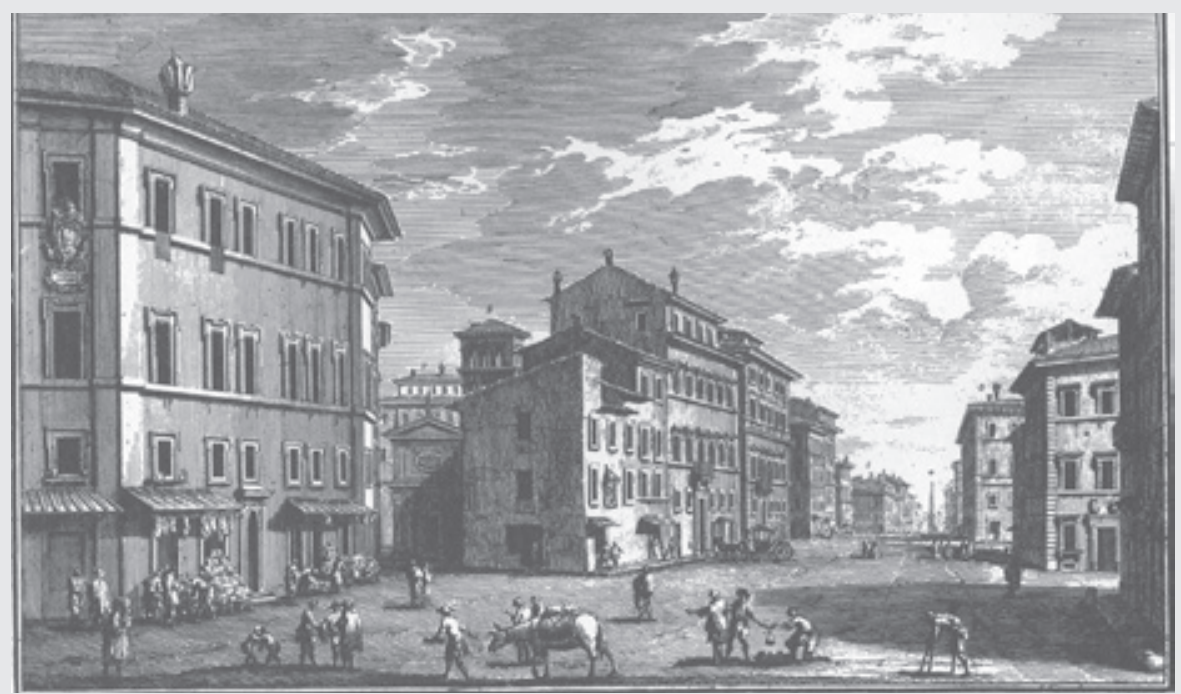

128. Via di Ripetta, em uma gravura de Giuseppe Vasi. Fonte: Coen (1996, p. 165). 


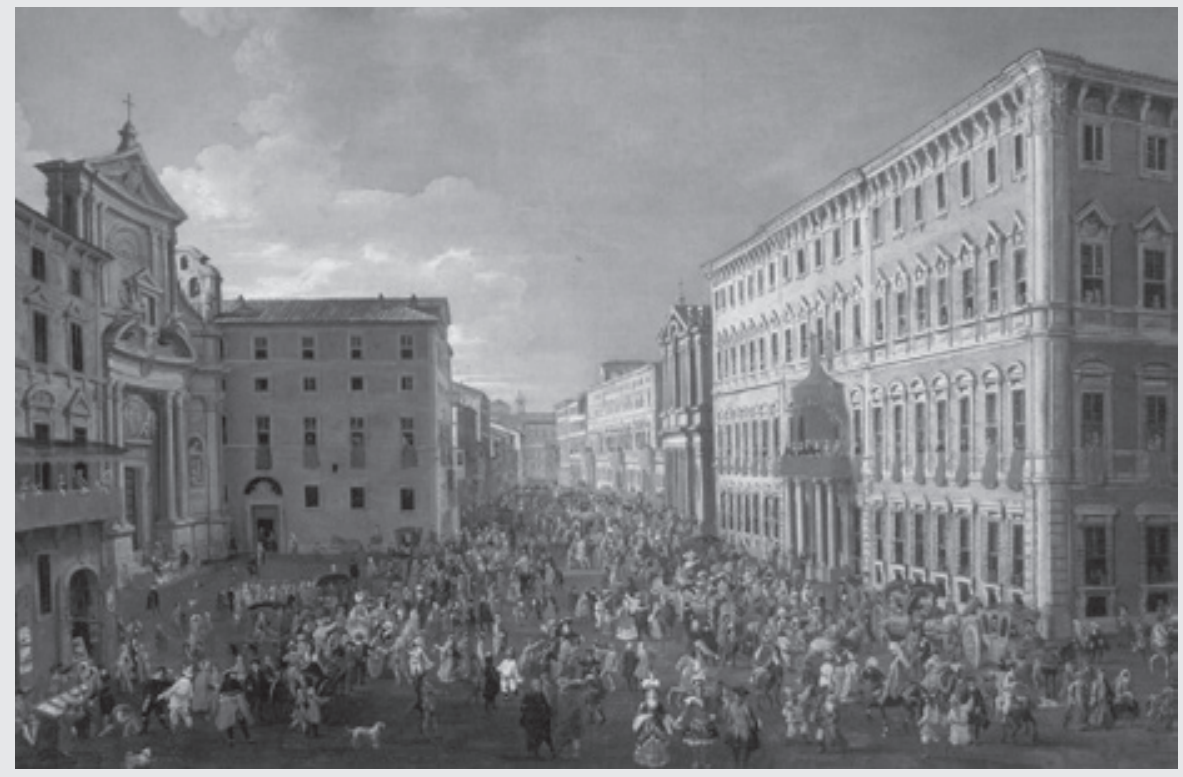

129. II Carnevale al Corso - 1740. Óleo sobre tela de Hendrik Frans van Lint (1684-1763). Destaque, à esquerda, para a Igreja de San Marcello al Corso (1682-1683) - projeta por Carlo Fontana (1634-1714) - e, à direita, para a Igreja de Santa Maria in Via Lata - restaurada por Pietro da Cortona (1596-1669) entre 1658 e 166o. Fonte: Fagiolo (1997, p. 173).

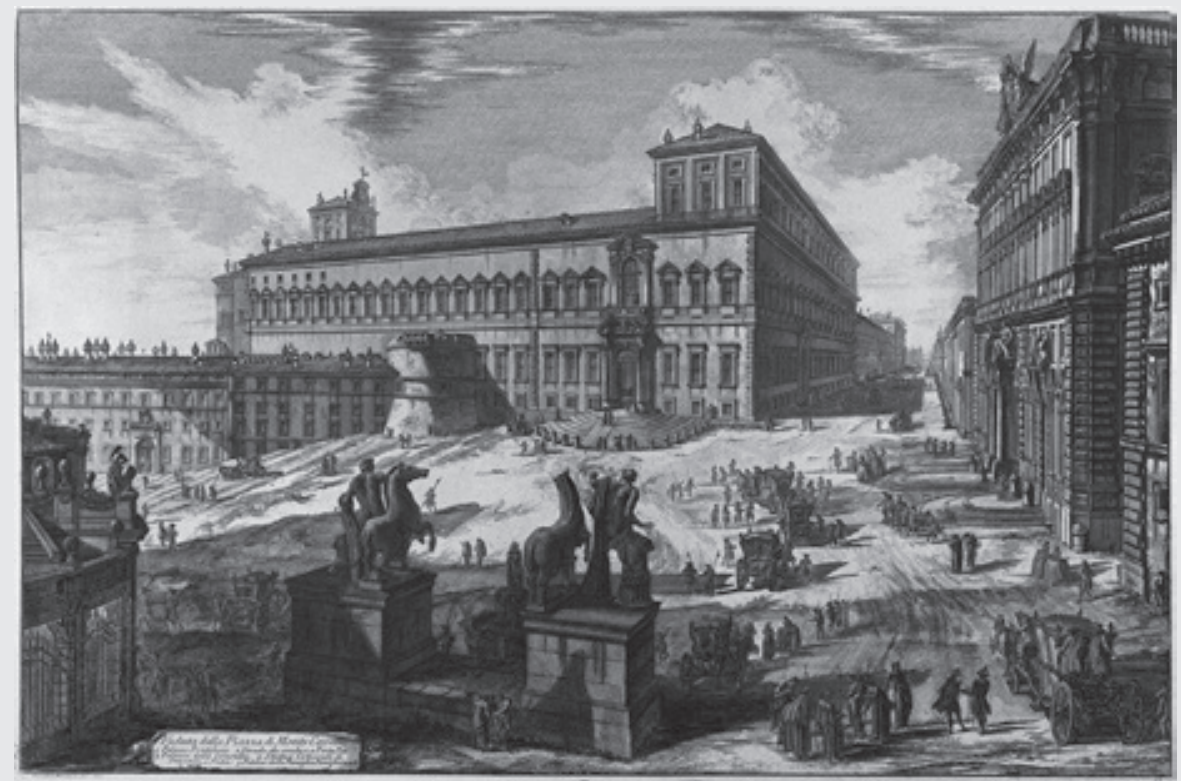

130. Veduta della Piazza di Monte Cavallo, pelo arquiteto e gravurista italiano, Giambattista Piranesi (1720-1778), da série Vedute di Roma. Imagens publicadas em 1798 - as vistas, porém, foram iniciadas em 1748. Em primeiro plano, o Palazzo del Quirinale, palácio pontifício iniciado no século XVI. À direita se percebe a abertura da Strada Pia, via rasgada por Pio IV. Fonte: Ficacci (2000, p. 740). 
além das planícies próximas ao Rio Tevere, através do incentivo ao repovoamento das regiões mais altas da urbe - internas e externas aos muros de Aureliano; organização de critérios legais para a orientação da ocupação edilícia em áreas importantes da cidade preexistente ou para além dela, nos sítios que então estariam recebendo infraestrutura viária e de fornecimento de água para viabilizar sua posterior ocupação; preocupações estéticas e simbólicas em atribuir uma nova identidade ao núcleo urbano, oferecendo um largo senso de legibilidade por meio da enfática marcação de suas intervenções, ou mesmo da evidência dada a outras áreas significativas da cidade. Morris (I979, p. I43, tradução nossa) sintetizaria o plano de Peretti e Fontana em três objetivos prioritários:

Primeiro, repovoar as colinas de Roma proporcionando o fornecimento contínuo de água que carecia desde que foram cortados os antigos aquedutos; segundo, integrar em um único sistema de vias principais as diversas obras realizadas por seus predecessores enlaçando as igrejas mais importantes e outros pontos-chaves da cidade; por último, criar uma cidade estética que supusesse a superação da frequente configuração de ruas e espaços públicos como resultado da agregação de edifícios díspares.

Não obstante, todos estes princípios declarados por Morris se conectariam em nome de uma finalidade específica maior: coligar as principais basílicas e os lugares mais sagrados da "cidade santa" através de uma rede viária direta e eficiente, permitindo o fluxo mais rápido dos peregrinos que visitassem a urbe e dando uma maior nitidez ao confuso burgo composto pelo tecido medieval e renascentista e pelas ruínas preexistentes da Roma imperial. Na verdade, a ideia de privilegiar a ligação dos locais pios da Cidade Eterna, e particularmente os acessos mais diretos às principais igrejas medievais, remontaria ao ano de 1300 , quando o Papa Bonifácio VIII ${ }^{48}$ (I235-I303) instituiria o primeiro jubileu da lgreja Católica, prometendo indulgência plenária a quem fosse à cidade de Roma nestas ocasiões e visitasse pelo menos as tumbas de São Pedro e de São Paulo; ou seja, estaria garantido, ao peregrino que acorresse aos lugares santos de Roma na época dos jubileus, o perdão de todos os seus pecados. ${ }^{49}$ No entanto, apenas na segunda metade do século XVI - devido aos esforços do sacerdote, depois elevado

48 Nascido Benedicto Gaetane, foi papa entre 1294 e 1303.

Os jubileus viriam a acontecer, mais tarde, a cada 25 anos. 
a santo, Filippo Neri (15I5-I595) - as peregrinações aos lugares sagrados de Roma se popularizariam em definitivo. Também seria por esta ocasião que se estabeleceria - para o agraciamento da indulgência ao fiel - a necessidade imposta ao peregrino de visitar as sete basílicas que conservariam as principais relíquias do cristianismo encontradas na cidade (Figuras I3I-I32). O historiador da arte Paolo Coen (nascido em I967), em seu livro de 1994 intitulado Le sette chiese: le basiliche giubilari romane, esclarece:

A peregrinação, iniciada por Neri nos anos quarenta em perfeita solidão ou, na melhor das hipóteses, junto a algum discípulo íntimo, somente em 559 torna-se uma prática estável e organizada: ao longo de dezesseis milhas e dividida em duas jornadas, a peregrinação compreendia, em geral, as igrejas de San Pietro, San Paolo, San Sebastiano, San Giovanni, Santa Croce in Gerusalemme, San Lorenzo e Santa Maria Maggiore. Em algumas circunstâncias, todavia, o itinerário poderia sofrer leves modificações: quando os trabalhos de restauro tornavam impraticáveis algumas paradas habituais, estas eram substituídas por uma parada alternativa, quase sempre representada pela basílica menor de Santa Maria in Trastevere. (COEN, I999, p. I4, tradução nossa)

Os papas humanistas que antecederam Sisto $\mathrm{V}$ já teriam rasgado diversas artérias que contribuiriam para melhorar o tráfego nas áreas mais densas e para facilitar o ingresso a alguns dos locais recomendados por San Filippo Neri para a purificação do fiel: no lado ocidental do Rio Tevere, na região conhecida como os Borghi, destacar-se-iam a Via del Borgo Vecchio e a Via Alessandrina, logradouros que ligariam a ponte Sant'Angelo à Igreja de San Pietro e ao palácio Vaticano, respectivamente; no rione ${ }^{50}$ medieval de Trastevere, também localizado na face oeste do rio, seriam traçadas a Via della Lungara e a Via della Lungaretta, artérias que alcançariam a igreja de Santa Maria in Trastevere; nas extensões planas do Campo Marzio, as vias que sairiam do tridente da Piazza del Popolo (Via di Ripetta, Via del Corso, e Via Babuino) se irradiariam na direção sul, invadindo a face oriental da cidade - mas também a Via Trinitatis (atual Via dei Condotti), eixo perspectivo que alcançaria o pé da colina abaixo da Igreja Trinità dei Monti, na atual Piazza di

50 Rione é uma antiga denominação derivada da palavra regione, que era usada para definir as principais áreas que dividiam Roma, desde a época de Augusto - apesar de que os rioni da cidade dos papas não coincidiam necessariamente com os imperiais. Até o século XV estas regiões possuíam uma certa autonomia administrativa, liberdade sobrepujada, posteriormente, pela política centralizadora de domínio dos papas frente a toda a cidade. (SANFILIPPO, 2004) 


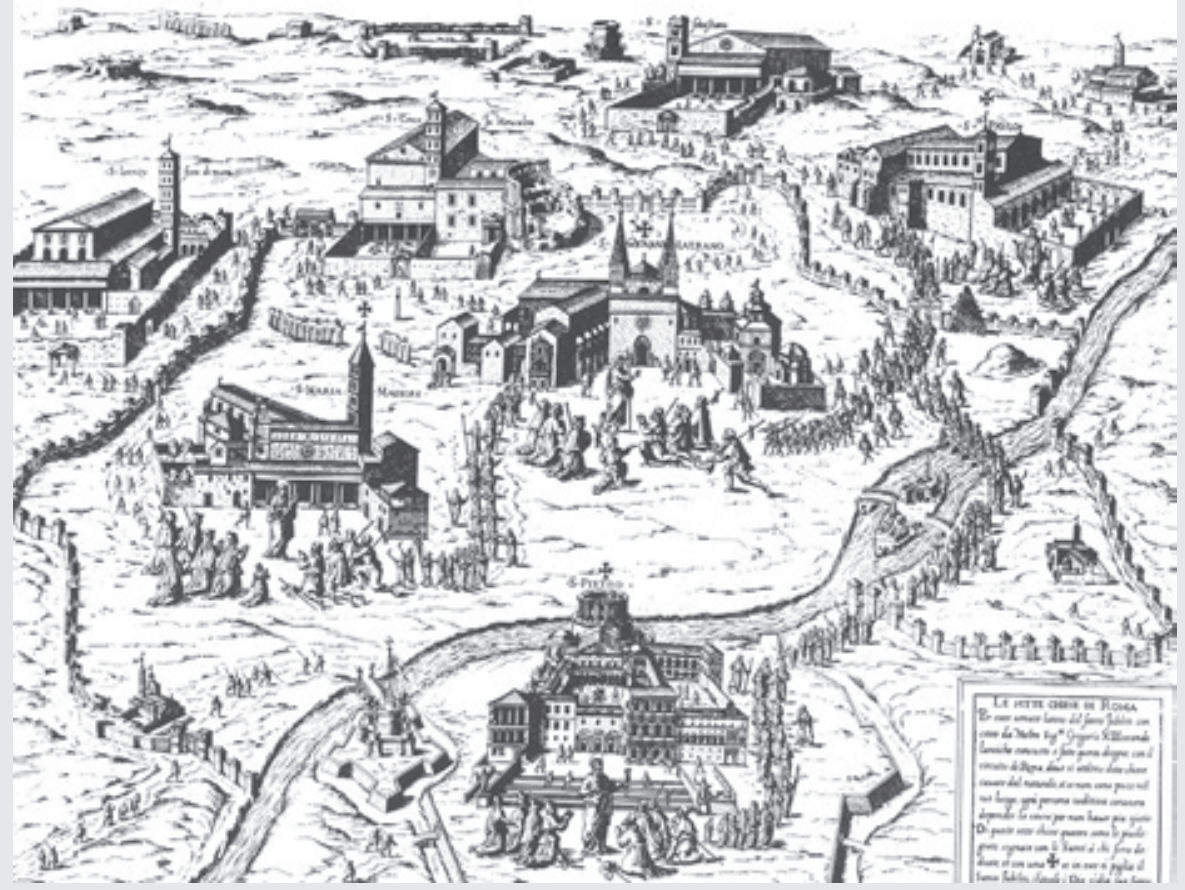

131. Le sette chiese di Roma, representação do gravurista francês Antoine du Pérac Lafréry (1512-1577) para o jubileu de 1575 . Todas as sete basílicas ainda possuíam as suas feições primitivas que seriam radicalmente alteradas nos dois séculos seguintes. Fonte: Insolera (1996, p. 163).

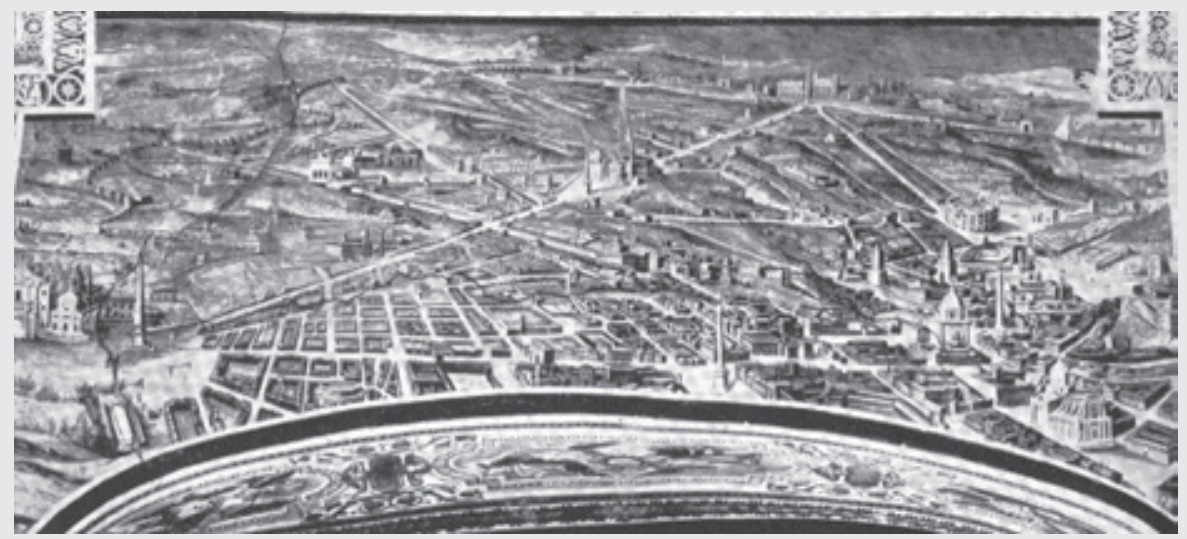

132. Veduta di Roma con le strade progettate da Sisto V. Afresco pintado entre 1587 e 1589 no Salão Sistino - na luneta sobre a porta da Biblioteca Vaticana -, mostrando o plano de Sisto V e Domenico Fontana para Roma. Por Giovanni Guerra (1544-1618) e Cesare Nebbia (1536-1614). Fonte: Benevolo (2008, p. 522). 
Spagna, após nascer na margem esquerda do Tevere e cortar as três artérias supracitadas; também ao leste do rio, e nas proximidades de sua margem, a Via Giulia cruzaria parte dos rioni medievais estabelecidos na acentuada curva do Tevere; outras pequenas vias retilíneas, como a Via Baullari, que ligava o Palazzo Farnese às proximidades da Piazza Navona, também seriam traçadas, rasgando os bairros medievais e renascentistas para além da margem esquerda do rio.

Entretanto, considerando que pelo menos quatro das basílicas jubilares estariam espalhadas a oriente, nas partes mais altas da urbe (Santa Maria Maggiore, San Giovanni in Laterano, Santa Croce in Gerusalemme e San Lorenzo fuori le Mura), considerando também que outras duas (San Sebastiano e San Paolo fuori le Mura) estariam dispostas em sítios muito distantes do núcleo habitado, e que mesmo a mais importante das igrejas (San Pietro) estaria assentada nos limites ocidentais da cidade, ainda atentando ao fato de que seria muito difícil e custoso patrocinar intervenções viárias em grande escala na povoada área espalhada pelos terrenos baixos aos dois lados do núcleo urbano - e que estas regiões estariam recebendo, pontualmente, uma nova rede de tráfego desde finais do século XV -, Sisto $\mathrm{V}$ concentraria suas ações de reorientação do traçado da cidade nos sítios adjacentes aos centros imperiais, medievais e ao Campo Marzio, especialmente nas linhas de cumeada. Dando continuidade e se entrelaçando com os empreendimentos promovidos por Pio IV e Gregório XIII, o pontífice privilegiaria a abertura de vastos eixos perspectivos nas elevações do Quirinale, do Viminale, do Esquilino, largas e extensas avenidas que conectariam as colinas e promoveriam a junção delas com os rioni medievais e renascentistas. Não obstante, as novas avenidas abertas por Domenico Fontana seriam incorporadas à estrutura viária moderna que se desenhava, há pelo menos cem anos, no núcleo edificado preexistente - agenciando uma interface entre as partes altas e baixas da cidade, agora atreladas definitivamente, alcançando uma considerável reordenação das linhas de circulação para toda a cidade.

Para além deste desígnio, os eixos perspectivos formados pelas Vias Pia, Merulana e Gregoriana, abertas por Pio IV e Gregório XIll, bem como aquelas avenidas traçadas por Sisto V - a Strada Felice, que conectaria a Basílica de Santa Croce in Gerusalemme à Igreja Trinità dei Monti; a Via Panisperna, que uniria a basílica de Santa Maria Maggiore às proximidades da Coluna de Trajano (Figuras I33-I34); e a Via di San Giovanni, que se estenderia da Catedral de San Giovanni in Laterano ao Colosseo (outro importante ponto de peregrinação nos anos de 


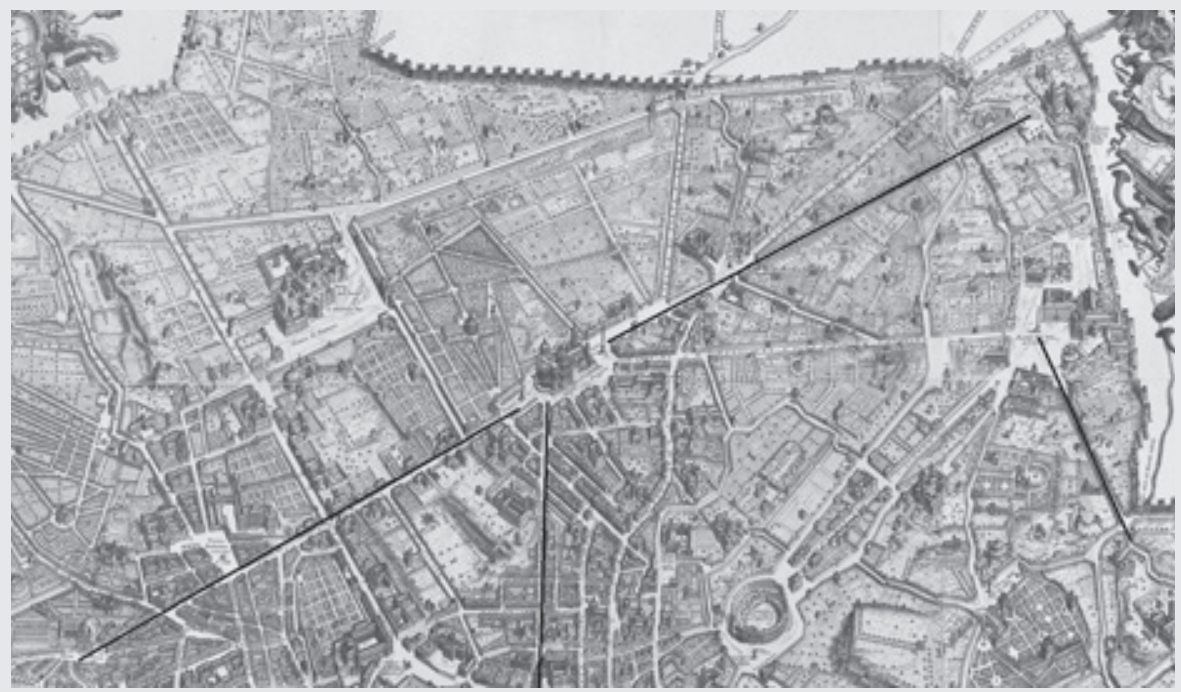

133. Detalhe da planta elaborada, em 1676, pelo arquiteto e gravurista italiano, Giovanni Battista Falda (1643-1678), mostrando a região das colinas a leste do núcleo central de Roma, com destaque para a imensa e direta Via Felice - passando pela Igreja de Santa Maria Maggiore. Também em evidência a igualmente retilínea Via Panisperna, descendo em diagonal para o centro - desde a mesma basílica e a Via di San Giovanni, que ligava a Basílica de San Giovanni in Laterano ao Colosseo. As três estão marcadas com traços escuros. Fonte: Elaboração do autor a partir da planta de Falda. Frutaz (v. 3, p. 349).

134. Fotografia atual da Via Panisperna. Fonte: Fotografia elaborada pelo autor (2011).

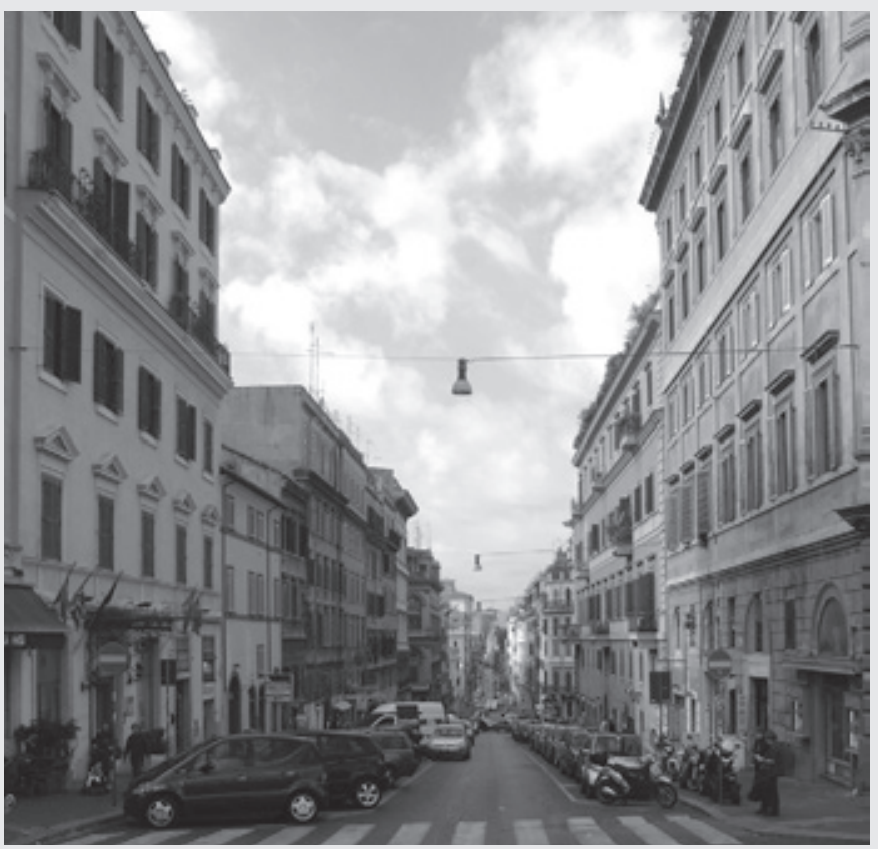


jubileu) -, serviriam como um impulso para o rápido povoamento das colinas após a construção do aqueduto Acqua Felice, grande empreendimento sistino que incorporaria parte dos antigos aquedutos romanos de Acqua Marcia e Acqua Claudia, e forneceria água abundante para os outeiros, viabilizando sua reocupação após séculos de abandono. Estas finalidades práticas, bem como os objetivos simbólicos e estéticos provenientes da idealização do novo conjunto de vias retilíneas que Felice Peretti estaria oferecendo para a cidade, seriam relatadas, em I590, por Domenico Fontana (I590, p. IOo-IOI, tradução nossa) ao publicar o livro Della trasportatione dell'obelisco vaticano et delle fabriche di nostro signore Papa Sisto V fatte dal Cavallier Domenico Fontana architetto di Sua Santità, livro em que o arquiteto descreve as obras realizadas para o seu senhor, Papa Sisto V. É impressionante a clareza e a consciência presentes em seu depoimento:

Desejando ainda, Nosso Senhor, facilitar o caminho para aqueles que, movidos pela devoção ou por promessa, estão acostumados a visitar com frequência os mais santos lugares da cidade de Roma, e em particular as sete igrejas tão celebradas por grandes indulgências e relíquias que possuem, abriu em muitas áreas vias amplíssimas e profundamente diretas: de modo que é possível iniciar o percurso a pé, a cavalo ou de carruagem a partir de qualquer ponto de Roma, e prosseguir praticamente em linha reta em direção às mais famosas devoções, que acabam prestando a povoar a cidade: porque a partir do momento que estas ruas são frequentadas pelo povo, vão sendo construídas casas e lojas em grande quantidade, em um lugar que anteriormente era comum as pessoas se deslocarem com grande desconforto e lentamente em função do grande número de curvas que existiam, e que em alguns sítios, devido às irregularidades das vias, ninguém poderia alcançar os lugares desejados. E a um custo verdadeiramente incrível, e em conformidade com o ânimo de um tal Príncipe grandioso, estendeu estas ruas de uma extremidade a outra da cidade, não considerando os montes ou os vales que atravessavam: mas, fazendo com que as colinas fossem niveladas e os vales aterrados, reduziu-os às mais suaves planícies e aos locais mais encantadores, revelando, nos lugares onde se passa, as mais baixas partes da cidade, com suas mais diversas perspectivas; de modo que, além das devoções, também sustentavam com seu encanto os sentidos do corpo. 
A maior e mais importante avenida perspectiva rasgada por Sisto V seria a afamada Strada Felice (Figuras I35-I36). Após brotar diante da praça que se abria para a Igreja de Santa Croce in Gerusalemme - uma das basílicas jubilares, assentadas a sudeste, nas adjacências da ancestral muralha da cidade - e percorrer linearmente mil e novecentos metros, a via seria obstruída a meio caminho pela grande mole da Basílica de Santa Maria Maggiore, tendo que contorná-la pelos dois lados; em um segundo momento, vencendo por um quilômetro e meio a difícil topografia das colinas, ao subir e descer as cristas dos morros do Esquilino, do Viminale e do Quirinale, circunstância que serviria para enriquecer e dinamizar o efeito da fuga perspéctica que acompanharia grande parte do percurso, a longa estrada terminaria à frente da Igreja de Trinità dei Monti, próximo ao limite norte da cidade. Para além deste imenso trecho linear, o projeto de Fontana também previa uma distensão de mais seiscentos metros para o eixo perspectivo, ampliação que buscaria o direcionamento norte: a avenida deveria atravessar a acidentada colina do Pincio, e descê-la para alcançar a Piazza e a Porta del Popolo, empresa que não seria viabilizada pelas grandes dificuldades técnicas exigidas pela complexa e onerosa terraplanagem imposta à iniciativa. $O$ próprio arquiteto comentaria, no livro supracitado, o grande esforço despendido para a concepção e edificação da avenida, que ainda hoje se apresenta como uma das mais bem-traçadas de Roma, com nada menos que três mil e quatrocentos metros de extensão (sem contar o trecho não construído):

A mais célebre é a via denominada Felice, que parte da Igreja de Santa Croce in Gerusalemme, e chega à Igreja de Santa Maria Maggiore e depois prossegue até a Trinità dei Monti, de onde deve descer até a Porta del Popolo, que em toda sua extensão transcorre duas milhas e meia de distância, ao longo das quais permanece reta como o fio de um prumo e larga o suficiente para dar lugar a cinco carruagens emparelhadas. (FONTANA, I590, p. IoI, tradução nossa)

Para celebrar o novo rosto moderno que se propunha para a capital do mundo católico (Figura 137), Fontana ainda conceberia a relocação de quatro obeliscos para ambientes estratégicos da malha urbana. Estes monumentos, espoliados do Egito antigo por iniciativa dos governantes da Roma imperial, seriam restaurados, recompostos e reerguidos com grande perícia técnica nestas importantes áreas sagradas da Cidade Eterna. Marcariam, respectivamente: o largo que se encontrava à frente da Igreja de San Pietro, que na época estava em obras com a 


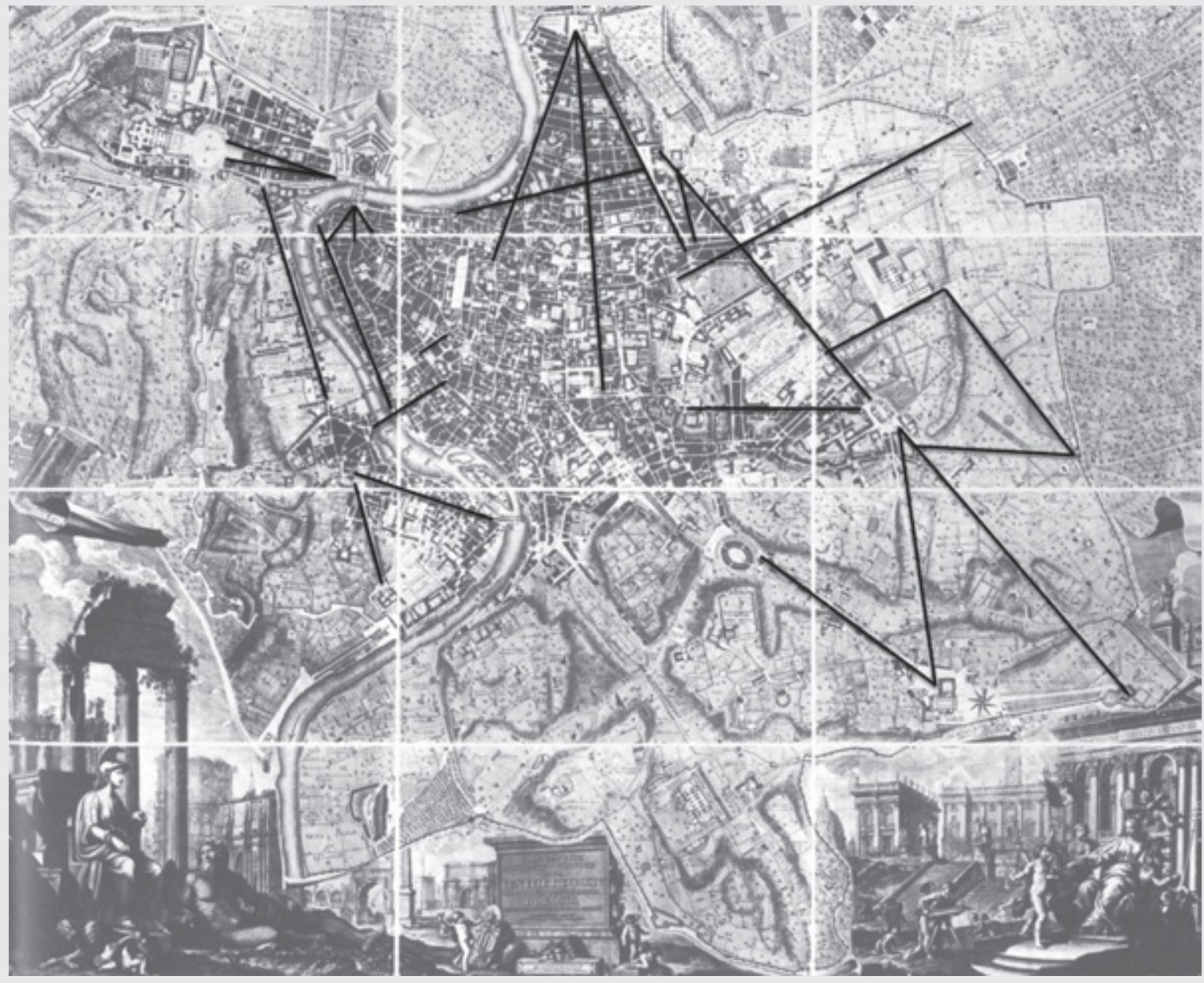

137. Esquema montado pelo autor, usando como base a Pianta Grande di Roma, de 1748 - elaborada por Giambattista Nolli (1692-1756), com a inclusão de vistas da cidade confeccionadas por Stefano Pozzi (1707-1768) -, expondo os principais eixos perspectivos abertos na cidade de Roma desde finais do século XV até o período barroco - quase todos rasgados no Cinquecento. As vias em destaque estão marcadas com traços escuros. Fonte: elaboração do autor a partir da planta de Nolli. Frutaz (1962, v. 3, p. 396). 
construção da cúpula; a praça que se abria para a abside da Basílica de Santa Maria Maggiore, na qual o monumento (feito na época romana imperial imitando antigos obeliscos egípcios) serviria de ponto focal para a chegada de um dos trechos da Strada Felice, o seguimento da via que partiria da Igreja de Trinità dei Monti e se encaminharia na direção sudeste até a praça - praça que também receberia a Via Panisperna rasgada por Sisto V, avenida que alcançaria a abside da basílica de Santa Maria desde os sítios mais baixos da cidade, nas proximidades de San Marco (Figura I38); o ambiente que precederia o transepto norte da Basílica de San Giovanni in Laterano, no qual o obelisco seria erguido em uma posição que serviria de moldura perspectiva para outras avenidas diretas abertas pelo Papa Felice Peretti e pelo seu antecessor, Gregório XIII -, respectivamente, a atual Via di San Giovanni, eixo que uniria imediatamente as ruínas do Colosseo à antiga catedral de Roma, e a Via Merulana, que coligaria Santa Maria Maggiore à catedral (Figura I39); e, finalmente, o obelisco transferido para a Piazza del Popolo, situação que será analisada no próximo item. Segundo o historiador e crítico da arquitetura Sigfried Giedion (2004, p. I24), "Como se tivesse em mãos uma vara de condão divina, Sisto V implantou seus obeliscos em pontos nos quais, durante os séculos subsequentes, as mais esplêndidas praças se desenvolveriam.”

Estes marcos verticais não seriam apropriados pelo papa e pelo seu arquiteto para serem utilizados como simples monumentos independentes espalhados pela cidade. Na verdade, passariam a fazer parte de uma unidade plástico-compositiva maior que envolveria todos os artefatos expostos ao limite visual do cenário revelado nos recintos onde os obeliscos viriam a ser levantados. Constituiriam um organismo coeso formado pelas vias que alcançariam as praças, pela arquitetura ordinária que as conformaria, pelos monumentos preexistentes - ou por aqueles que ainda viriam a ser edificados - que as comporiam, pela paisagem natural que as envolveria. Além disso, estes poderosos marcos verticais contribuiriam para oferecer uma nova identidade para a Cidade Eterna, já que a prática de ornar alguns dos mais importantes ambientes da Roma católica com antigos obeliscos egípcios (ou cópias romanas imperiais) seria logo retomada. Após a experiência de Sisto V e de seu arquiteto, também seriam erigidos obeliscos na Piazza della Rotonda, na Piazza Navona, em frente à igreja Trinità dei Monti, diante do Palazzo Montecitorio, na Praça da Igreja de Santa Maria sopra Minerva, em frente ao Palazzo del Quirinale. Os panoramas oferecidos nestes ambientes, espaços absorvidos pelos impulsos verticais oriundos da presença dominante das 
138. Veduta della facciata di dietro della Basilica di Santa Maria

Maggiore. Por Giambattista Piranesi, Vedute di Roma. Nota-se a presença de um dos obeliscos transferidos por Sisto V, no caso, para marcar a chegada de um dos ramais da Via Felice. A fachada posterior da igreja é do século XVII, obra de Carlo Rainaldi (1611-1691). Fonte: Ficacci (2000, p. 707).

139. Veduta della Piazza e Basilica di San Giovanni in Laterano, por Giambattista Piranesi, da série Vedute di Roma. Nota-se a presença do Obelisco Laterano enquadrando a perspectiva da Via di San Giovanni, bem como a saída da Via Merulana - acima, à esquerda. Logo à frente, o Palácio Laterano $\mathrm{e}$ a nova fachada do transepto norte da Catedral de Roma - projetos de Domenico Fontana (1543-1607) elaborados para o Papa Sisto V (1521-1590). Fonte: Ficacci (2000, p. 749).

140. Vedute delle due chiese, I'una detta della Madonna di Loreto l'altra del Nome di Maria. Giambattista Piranesi, década de 1740. As duas igrejas centralizadas estão dispostas nas proximidades da Coluna de Trajano e compõem com seu trágico cenário. Fonte: Ficacci (2000, p. 722).
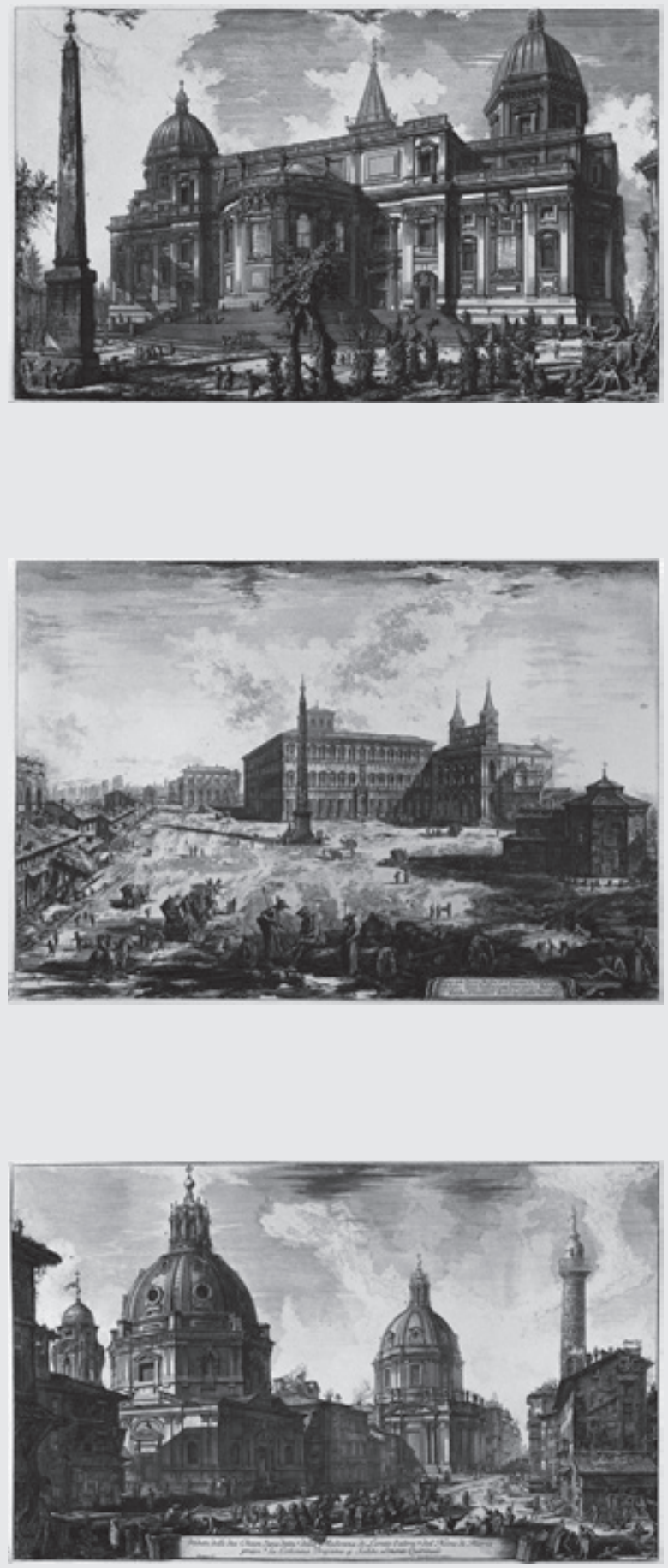
altas balizas de pedra, impregnariam a memória do transeunte: uma amarração entre todos os cenários seria promovida na mente do fruidor - passaria naturalmente a povoar a imaginação do peregrino -, já que estas estruturas colossais se tornariam, inevitavelmente, marcos referenciais para a cidade - como também viriam a ser as altas cúpulas maneiristas e barrocas. Assim, as estruturas verticais se prestariam como metas visibilísticas capturadas desde os eixos perspectivos que irrompiam em muitos destes importantes ambientes sagrados, contribuindo para dar legibilidade à cidade, ainda confusa e irregular.

Estes expressivos pontos focais se apresentariam como poderosos símbolos da afirmação da cidade de Roma como capital espiritual e política do mundo católico: monumentos extorquidos do Egito antigo (ou imitados pelos seus conquistadores romanos) pelo menos mil e quinhentos anos antes do pontificado de Sisto $\mathrm{V}$, e que chegariam ao período barroco para indicar o resgate da noção da cultura clássica como uma entidade superior; consequentemente, o rebatimento, para a moderna capital pontifícia da força contida neste emblema ancestral da herança das conquistas e do poder da Roma imperial. Assim sendo, a cidade antiga e a moderna, em total congruência, seriam fatalmente apreendidas como um unitário organismo civilizador do mundo.

Para além destes fatos, com a prática obrigatória de coroar os obeliscos com o símbolo máximo do cristianismo (a cruz latina), um dos aspectos negativos oriundos da celebração dos monumentos da Antiguidade - sua origem inevitavelmente pagã - seria eliminado: o obelisco era sacralizado, revelando o triunfo da fé tridentina sobre o paganismo egípcio e romano, podendo, desta forma, habitar, sem nenhuma contradição ideológica, o cenário espiritualizado que se desenhava na praça que acolhia a Igreja de Santa Maria del Popolo, na Piazza di San Pietro, em frente às Igrejas de Santa Maria Maggiore e San Giovanni in Laterano e nos outros locais que receberiam obeliscos nos séculos XVII e XVIII. Segundo asseguraria o influente arquiteto, crítico e acadêmico italiano, Paolo Portoghesi (nascido em I93I), em seu estudo Roma Barocca, publicado originalmente em ig66:

Outro aspecto original do plano sistino é a identificação do problema funcional da viabilidade com aquele ótico da percepção direta e imediata da meta. Vias diretas e lineares como a Lungara, a Via Giulia, e a Via dei Coronari, não são comparáveis com aquelas sistinas porque carecem de uma clara terminação visiva e porque se desenvolvem sobre terrenos 
planos. A própria Via Merulana iniciada por Gregório XIIl, mesmo interligando dois monumentos como San Giovanni e Santa Maria Maggiore, conquistou um caráter de união ótica apenas após a ereção do Obelisco Lateranense, operada por Domenico Fontana em 1587.

A ereção dos obeliscos, sugerida provavelmente ao Pontífice por uma vontade de afirmação da potência e da ocasião oferecida a ele de reafirmar o triunfo da fé cristã sobre o paganismo, torna-se, na realidade, um instrumento compositivo essencial, a ponto de transformar a finalidade prática das interligações viárias em um resultado estético destinado a influenciar profundamente a cultura dos artífices barrocos. A presença do obelisco como fundo de um telescópio óptico constituído pelas coxias viárias e como elemento de mediação e de fechamento entre a diretriz sugerida da estrada e aquela determinada pelo volume do monumento posterior é, na realidade, a genial solução de um problema perspectivo. (PORTOGHESI, I997, p. 43, tradução nossa)

Com o mesmo sentido de promover a sacralização de monumentos pagãos, Sisto $\mathrm{V}$ patrocinaria a restauração das colunas comemorativas de Trajano e Marco Aurélio, além da reordenação urbana das áreas onde as mesmas se encontravam, já que a ação de transportá-las para outros setores seria extremamente complicada. E da mesma forma como teria feito com os obeliscos, o pontífice coroaria os monumentos com símbolos que representavam o triunfo da fé católica, substituindo a estátua de Trajano, que laureava sua coluna, pela de São Pedro (Figura I40), e a de Marco Aurélio, pela de São Paulo.

Como conclusão, poder-se-ia afirmar que o plano que Domenico Fontana elaboraria para o Papa Sisto V, em conexão com os outros empreendimentos urbanísticos devidos aos pontífices que o antecederam, fundaria as bases para o renascimento da cidade de Roma no contexto da cultura moderna. Inauguraria, segundo Argan, um dos princípios essenciais derivados do espírito barroco: a construção de um espaço urbano destinado a servir ao exercício da retórica espiritual e da devoção através da consagração de um ambiente de alto teor persuasivo - artifício essencial para a necessária propagação da fé católica naquela cidade que seria considerada a sua sede universal, ação vinculada ao contexto da Contrarreforma, então em pleno andamento. Sisto V construiria, deste modo, os alicerces para que, nos séculos XVII e XVIII, a Cidade Eterna fosse povoada com as mais diversas e expressivas experiências da cenografia barroca, situação que decretaria sua completa renovação artística. Logo, mais do que a sede do governo 
dos Estados Pontifícios, a cidade se consolidaria, na Europa das capitais, como a legítima caput mundi, a capital do mundo católico. Argan (2004, p. 60-6I, tradução nossa) finalizaria:

A verdadeira e própria reforma urbanística vem empreendida nos últimos anos do século XVI por iniciativa de Sisto V, que tem como técnico projetista Domenico Fontana. Superada a fase mais perigosa, de franca revolta, da Reforma, o papa sente que, em uma Europa desde já prestes a tornar-se um sistema de Estados nacionais, o poder espiritual e supranacional da Igreja exige o suporte de um Estado temporal. Deste Estado, economicamente e militarmente débil, Roma é a capital: o seu prestígio histórico e moral é o fundamento da nova política de equilíbrio entre os Estados - que a Igreja adota por princípio. É também a meta da peregrinação proveniente de todos os países católicos: e esta centralidade possui uma função política, não menos que religiosa. Se a figura da capital espiritual do catolicismo é também um meio de propaganda política e religiosa, a forma urbis estudada por Sisto $\mathrm{V}$ e por Domenico Fontana regressa à esfera das formas destinadas à persuasão ou das formas 'retóricas'. As novas estradas traçadas pelo plano ligam entre si as antigas basílicas cristãs e servem, portanto, à função devocional: mas, se todas as antigas basílicas se tomam objeto de devoção e meta de peregrinação, toda a área da cidade vem a ser reconsagrada, isto é, investida de valor ideológico. Em uma cidade 'santa', a função devocional é dominante, assim como hoje, na cidade industrial, o é a função produtiva. A cidade não é mais apenas a morada de uma comunidade tradicional: é a meta de visitantes de todos os países, e por isso deve impor-se pela grandiosidade dos seus monumentos, deve orientar as próprias estruturas viárias em conexão com as grandes estradas de acesso pelo exterior.

\section{Piazza del Popolo: a abertura do drama barroco romano}

Sisto $\mathrm{V}$ e seu arquiteto Domenico Fontana, bem como os outros pontífices que precederam o Papa Felice Peretti na monumental empresa fundada na reconfiguração viária da cidade de Roma no século XVI, edificaram o novo esqueleto urbanístico que se sobreporia aos antigos núcleos clássicos, medievais e renascentistas preexistentes, danificando-os, todavia, minimamente - principalmente se for levada em consideração a grande extensão preservada dos bairros antigos 
-, apesar das apreciáveis transformações estruturais que a cidade estaria sofrendo. Os pontífices humanistas também procurariam justapor suas longas avenidas retilíneas às desoladas colinas que cercavam a cidade - sítios em que, outrora, na época dos césares, termas, palácios, vilas, teatros despontavam por todos os cantos. Esta moderna armação viária proveniente da Roma quinhentista ofereceria, em consonância absoluta com a antiga massa edificada da cidade, a estrutura necessária para que a paisagem urbana remanescente fosse posteriormente invadida e contaminada pelos incontáveis empreendimentos cenográficos derivados da espetaculosa exaltação da nascente cultura barroca - em prol da reconfiguração da imagem urbana através do exercício da imaginação e da persuasão no seio da cidade.

Neste sentido, seria sugestivo que, nos séculos XVII e XVIII, nenhum empreendimento viário alcançaria, no que tange à sua importância estratégica, ou mesmo no que se refere à própria escala, uma pequena fração daqueles mais significativos praticados na centúria precedente - com exceção de algumas ruas diretas (entre elas a Via de San Francesco a Ripa, em Trastevere), que seriam traçadas por Camillo Borghese (I552-I62I), o Papa Paolo V.5 Efetivamente, os grandes pontífices seiscentistas, bem como aqueles da primeira metade do século XVIII - com destaque para Urbano VIII (I568-I644), ${ }^{52}$ Innocenzo X (I574-I665), ${ }^{53}$ Alessandro VII (I599-I667) ${ }^{54}$-, não se preocupariam em investir em transformações propriamente urbanísticas da Cidade Eterna. Não obstante, se dedicariam, obcecadamente, em deixar sua marca indelével na paisagem citadina, promovendo verdadeiras revoluções na percepção visual dos antigos e dos novos rioni romanos, através da edificação de expressivos monumentos espalhados em toda extensão da urbe. Para além das intervenções arquitetônicas financiadas pelos governos pontifícios, o núcleo urbano também seria povoado por persuasivas obras acionadas por entidades independentes que representavam os poderes não institucionais arraigados há tempos na capital, organizações muito relevantes e que historicamente jaziam no âmago dos antigos burgos internos à cidade: ordens religiosas e irmandades que se amontoavam na Roma barroca; famílias nobres que ali residiam

51 Paolo V teria um longo pontificado, de 1605 até sua morte.

Maffeo Barberini, dirigiu a Igreja de 1623 até 1644 .

Giovanni Battista Pamphilj, papa de 1644 a 1655 
há séculos e que comandavam, algumas vezes, inteiros rioni; representações dos governos de inúmeras nações ocidentais, particularmente dos Estados católicos, cujos súditos que habitavam a capital costumavam ocupar áreas significativas, ou mesmo bairros inteiros da cidade. 55

Logo, seria pertinente avaliar algumas das mais importantes operações não urbanísticas que a cidade sofreria no decorrer dos anos - uma amostragem muito pequena se confrontada à infinidade dos edifícios barrocos levantados no Seicento e no Settecento, construções que preencheriam os panoramas da cidade com sua carga retórica e persuasiva e com seu apelo à imaginação. Esta análise poderia ser justificada como uma busca pelo caráter estético e paisagístico (pessoal e intransferível) da Roma do Ancien Régime, em prol de se alcançar um juízo final sobre o debate aberto através da exposição do tema levantado por Cesare de Seta (1978) e exposto na introdução deste livro: se a capital do mundo católico teria alcançado uma condição barroca - se Roma seria ou não uma cidade barroca, e, por extensão, se seria possível existir uma cidade barroca.

Assim, seria interessante que a experimentação dos eventos cenográficos que despontariam na "cidade santa" começasse, efetivamente, pela abertura do drama barroco; a praça que marcaria o ingresso à cidade por uma de suas portas mais antigas: a Piazza del Popolo, espaço caracterizado pela presença do famoso tridente das Vias Babuino, Corso e di Ripetta - provavelmente o mais conhecido trivium atribuído à urbanística barroca. Antes de tudo, é importante dizer que apesar da Piazza del Popolo oferecer ao espectador panoramas coerentes e articulados, a conformação de seu ambiente não nasceria de um plano único nem de um desejo consciente de criar o encontro radial destas avenidas na porta norte da Cidade Eterna. Na verdade, a ordenação do espaço seria definida gradativamente e absorveria proeminência somente após a inserção de determinados monumentos e edifícios significativos em seu ambiente grandioso.

Já, há muitos séculos, a praça se caracterizaria como o principal acesso à cidade: na Roma imperial, a longa e retilínea Via Flaminia adentrava o núcleo

55 Sobre o poder paralelo ligado à presença estrangeira na Roma barroca, afirmaria Joseph Connors (2005, p. XX, tradução nossa): "Em torno das residências dos embaixadores estrangeiros existia uma espécie de campo de forças. Os embaixadores sustentavam a existência de um direito de 'bairro' que estendia o conceito de extraterritorialidade do contexto imediato da sua residência aos edifícios vizinhos nos quais viviam o seu entourage e até as moradias dos artesãos que trabalhavam para eles. As estradas dos bairros eram patrulhadas por bandos armados ao serviço dos embaixadores e a justiça era administrada por tribunais privados. Aquela zona era praticamente interditada ao governante e à sua força de polícia, até o ponto de, nos anos sessenta e oitenta do século XVII, se dizer que meia Roma se subtraía ao controle do papa." 
urbano pelo norte, recebendo então o nome de Via Lata, e continuava inflexível, direta e unidirecional, rasgando por mais de um quilômetro e meio o centro urbano intramuros - particularmente a planície conhecida como Campo Marzio. O grande eixo perspectivo da Via Lata passaria por um processo de decadência e abandono com a queda do Império Romano, mas ressurgiria sistematizado e reordenado no Cinquecento, já com a sua atual denominação de Via del Corso..$^{56}$ Assim, viria a contribuir decisivamente, junto às outras intervenções viárias quinhentistas, a dar impulso significativo para a mudança, nos séculos barrocos, do funcionamento e da feição da capital, tornando-se a mais importante avenida comercial, bem como a mais movimenta artéria retilínea da Cidade Eterna.

Além da Via del Corso, outros empreendimentos viários destacar-se-iam em prol da orientação do tráfego e da legibilidade no Campo Marzio: a ampliação e realinhamento da antiga Via Leonina, atual Via di Ripetta, edificada por volta de I5I8 pelo Papa Leone X; bem como a abertura da Via Babuino, traçada em I525 por Clemente VIl e aprimorada por Paolo III a partir de I540. (INSOLERA, I996) Somadas à Via del Corso, as três avenidas passariam a compor o tridente, ordenado em definitivo por Paolo IIl, que derrocaria na praça homônima à lgreja de Santa Maria del Popolo - basílica edificada na Idade Média adjacente ao acesso norte e profundamente restaurada no Quattrocento.

Em 1589, a importância da Piazza del Popolo seria percebida por Domenico Fontana no projeto de renovação da cidade elaborado para Sisto V, quando o arquiteto viria a transferir um obelisco para o centro da praça (Figuras I4I-I42).57 O monumento vertical proveniente do Egito antigo, assentado no ponto de encontro do prolongamento dos eixos das vias que alcançariam a praça, celebraria o mecanismo de ordenação dos aparatos urbanísticos da Grand Manner - a prática eloquente de lidar com o espaço urbano na época barroca. (KOSTOF, I99I, p. 240) Segundo Giedion (2004, p. I26), de todos os obeliscos levantados na Roma sistina, o da Piazza del Popolo apresentaria a mais sutil locação:

Ao último dos quatro obeliscos implantados por Sisto coube, talvez, a posição mais sutil de todas. Situado na entrada norte da cidade,

56 Corso era um tipo de via, comum na Itália, destinada a ser percorrida velozmente a cavalo ou carruagem. O nome vem da palavra italiana "corsa" (corrida).

57 Proveniente de Heliópolis, o Obelisco Flaminio foi o primeiro a ser trazido a Roma, iniciativa do Imperador Augusto (63 a.C.-14 d.C), em 10 d.C. É o segundo mais antigo da cidade, remontando ao décimo terceiro século a.C. 


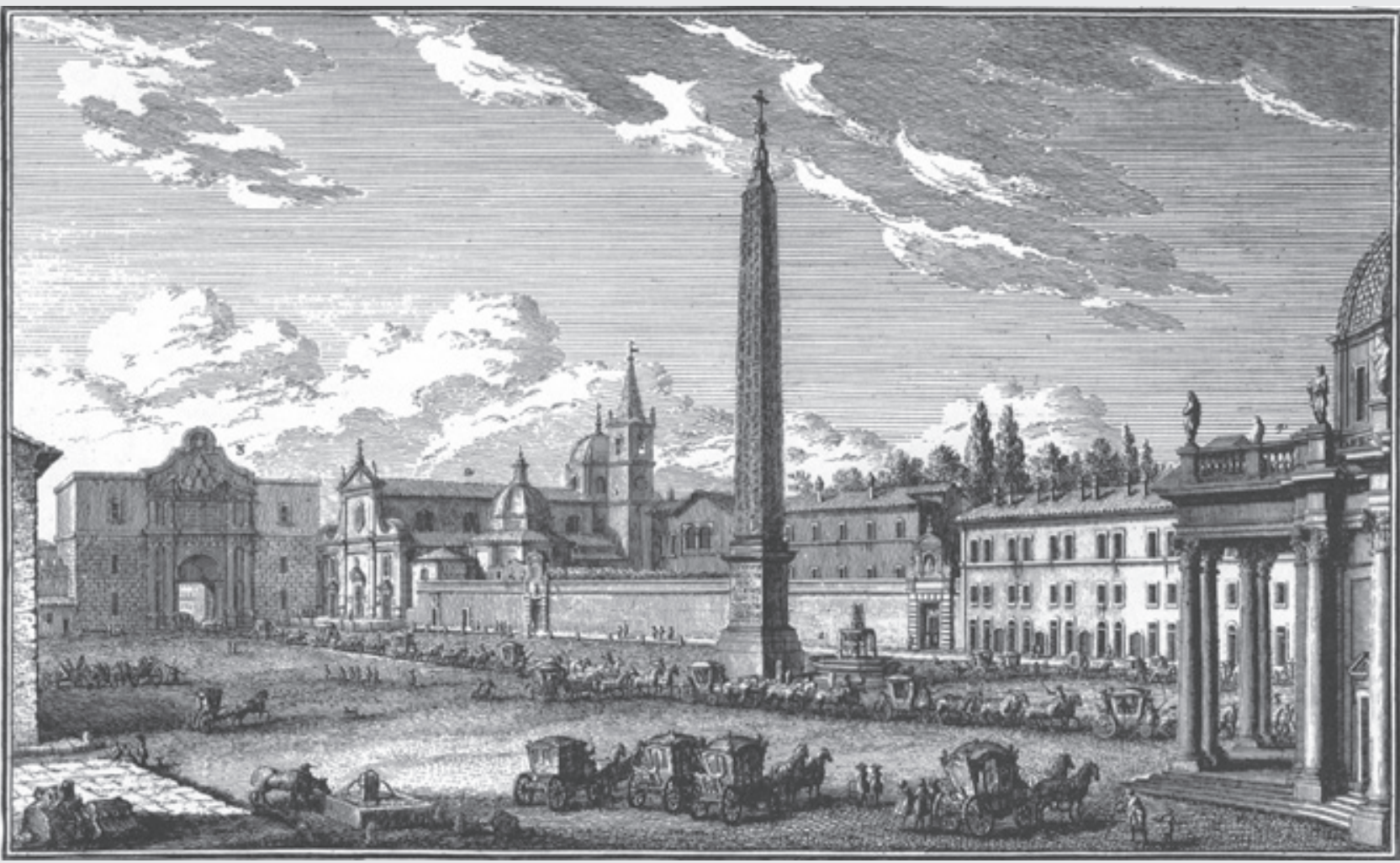

141. Giuseppe Vasi, 1747. Vista da Piazza del Popolo, tomada desde seu lado sul. Em destaque, a Porta e a Igreja de Santa Maria del Popolo (basílica medieval amplamente restaurada no Quattrocento), além do Obelisco Flaminio. Fonte: Coen $(2003$, p. 63$)$ 
marcava a confluência de três vias principais (assim como a extensão final da Strada Felice, muitas vezes projetada, porém nunca executada). Dois séculos depois, a Piazza del Popolo se cristalizou ao redor deste ponto.

Não obstante, cerca de 80 anos depois, no pontificado de Alessandro VII, estes empreendimentos já não bastariam para expressar a condição que o ambiente, contíguo à porta principal da cidade, deveria revelar: seria imperativo que os panoramas retirados da praça antecipassem a intensidade dramática dos acontecimentos que se desvelariam, gradativamente, no âmago da cidade. Logo, a partir da década de I660, uma nova intervenção acabaria mudando todo caráter da piazza e da apresentação do tridente marcado pelas Vias Babuino, Corso e di Ripetta: seriam edificados os templos gêmeos que iriam enquadrar o acesso às três avenidas: as Igrejas de Santa Maria di Montesanto e Santa Maria dei Miracoli (Figura I43). Mais do que uma obra de arquitetura isolada, os dois edifícios, projetados inicialmente por Carlo Rainaldi (I6II-I69I), se destacariam por definir uma nova configuração cenográfica para o ingresso à cidade. Gian Lorenzo Bernini e seu ajudante Carlo Fontana (I634-I7I4) sucederiam Rainaldi na obra que seria concluída após o pontificado do Papa Fabio Chigi, sendo muitas das intervenções dignas de infindáveis discussões sobre a autoria no processo de concepção e construção dos templos.

Estes arquitetos assumiriam como objetivo principal a monumentalização da área à frente da porta norte, através da construção de dois organismos arquitetônicos que emoldurassem a entrada das três vias, situando-os nos ângulos de encontro do tridente. Rainaldi pensou em duas igrejas gêmeas que funcionassem como um segundo portal, mostrando os três caminhos possíveis para se percorrer a cidade santa. De início, projetou templos em cruz grega, com cúpula sobre pendentes no cruzeiro e fachada plana com relevos de colunas e pilastras sustentando o entablamento e o frontão. Porém, a ideia da cruz grega acabaria sendo rejeitada, sendo concebida a edificação de duas rotundas com imponentes calotas hemisféricas, cada uma com um pórtico clássico à frente e uma pequena torre assentada do lado adjacente à outra igreja, marcando, deste modo, um portal simbólico para o Corso. O motivo da modificação do projeto inicial e da construção dos edifícios em plantas curvilíneas, com as calotas preenchendo todo o espaço das naves, viria decorrente do fato de que as cúpulas, que coroariam os cruzeiros no projeto anterior, seriam por demasiado pequenas, não conseguindo o efeito cênico necessário 
para tal empreendimento, já que seriam pouco visíveis desde o ingresso ao núcleo urbano, há uma distância considerável..$^{8}$ Por outro lado, a imagem em conjunto das duas grandes rotundas e suas pronaos clássicas contíguas, em sua interface com o Obelisco Flaminio disposto à frente, ofereceria o ardor e a suntuosidade que se impunha à iniciativa.

Para o sucesso da intervenção, consequentemente, seria imperativo que os dois templos fossem idênticos, absolutamente simétricos. Mas, os apertados lotes triangulares destinados às construções, espaços formados pelo encontro da Via Babuino com a Via del Corso, e do Corso com a Via di Ripetta, possuíam larguras diferentes provenientes da angulação diversa da interseção das avenidas (Figura I44). Em decorrência desta situação de irregularidade dos terrenos, foram concebidas igrejas com formas inevitavelmente desiguais, fato confirmado facilmente pela comparação entre as plantas baixas dos edifícios: a Igreja de Santa Maria dei Miracoli assumiria a condição de uma perfeita rotunda, mas Santa Maria di Montesanto, cujo lote possuía uma angulação mais aguda que o da igreja contígua, seria idealizada como uma rotunda elíptica, com seu eixo maior desenvolvido no sentido longitudinal do templo (Figura I45).

Não obstante, apesar de possuírem uma conformação absolutamente distinta, os dois templos se mostrariam, na imagem que se capturaria ao entrar na cidade, como duas rotundas gêmeas: o diâmetro transversal da cúpula elíptica de Santa Maria di Montesanto e o diâmetro da rotunda di Santa Maria dei Miracoli seriam idênticos; logo, na visão frontal os edifícios apresentariam, definitivamente, a mesma largura, fato que ofereceria, sugestivamente, a ilusão de que os dois templos eram iguais. Seu valor de conjunto como portais ideais para uma entrada triunfante na Roma barroca seria, desta forma, mantido, pois só poderia ser percebida a diferença entre os edifícios em alguns pontos da praça, na visão descontínua e em escorço do complexo (Figuras I46-I47). Norberg-Schulz (I979, p. I9-20, tradução nossa) sintetizaria:

As igrejas de Rainaldi representam um interessante exemplo de edifícios funcionais organizados para o espaço urbano, e merecem por isso

58 Existe uma grande polêmica acerca de quem teria concebido tais modificações. Wittkower (1993), bem como Norberg-Schulz (1979), entenderam que o próprio Rainaldi teria efetuado as transformações no projeto das duas igrejas. Mais pertinente parece a visão de Argan (1973) e Portoghesi (1997), que compreenderam a atual conformação dos templos gêmeos como obra vinculada à poética de Bernini, que efetivamente assumiria as obras de sua construção na década de 1670. 
um estudo mais detalhado. As avenidas radiais da Piazza del Popolo favoreciam o desenvolvimento de uma simetria monumental cara à idade barroca, e nada seria mais apropriado para a cidade sacra que a ereção das duas igrejas. Mas, era necessário superar uma dificuldade aparentemente insolúvel: as duas áreas possuíam tamanhos diversos; mesmo se Rainaldi tivesse realinhado as fachadas sobre os dois lados, o espaço entre a Via di Ripetta e a Via del Corso seguiria sendo maior do que aquele limitado pela via del Babuino. Em outras palavras, as duas igrejas teriam cúpulas de diâmetros diversos e não apareceriam como organismos simétricos, e sim diferentes. Rainaldi resolve o problema de modo engenhoso: construindo a igreja sobre o terreno mais estreito com uma forma elíptica, pôde recuar o seu diâmetro até fazê-lo ficar igual ao de sua 'gêmea'. Vistas da porta da cidade, as igrejas parecem similares, não obstante as suas diferenças. Compreendemos deste modo como equivalência arquitetônica não significa necessariamente semelhança física. As igrejas de Rainaldi criam também um momento de feliz sutura entre os quarteirões agregados às igrejas e à praça, através de um profundo pórtico que invade o espaço urbano à frente; as colunas do pórtico continuam ao longo dos muros laterais das igrejas, unidos, sem interrupção, com as fachadas dos quarteirões posteriores. Os pórticos, desta maneira, não se configuram como volumes 'justapostos' às igrejas, mas formam um elemento orgânico de conjunto. Por isso as igrejas aparecem como uma frontaria monumental da massa de casas que estão atrás, e também, na realidade, da cidade inteira. Assim Rainaldi alcança uma convincente síntese de definição espacial e movimento em profundidade.

A Piazza del Popolo demonstraria como, no século XVII, o objetivo da arte viria a ser o de produzir sensações no indivíduo que não estariam relacionadas com a pureza de seu desenho, mas que se fundariam no efeito visual que a imagem da obra terminada suscitaria. Não importava o fato das duas rotundas serem edifícios volumetricamente diferentes; não interessava se a sua concepção projetual deflagre um confronto com as leis mais primárias da simetria. A experiência do ingresso em Roma pela porta norte ofereceria a imagem de duas igrejas idênticas guardando os três caminhos que se abririam para o interior do núcleo urbano. Esta imagem racionalmente inverossímil, produzida pela ilusão de se estar contemplando, oticamente, dois edifícios iguais e simétricos - situação que, como diria Norberg-Schulz, revelaria que equivalência arquitetônica não significaria, necessariamente, semelhança física -, não furtaria em nada a imponência da 


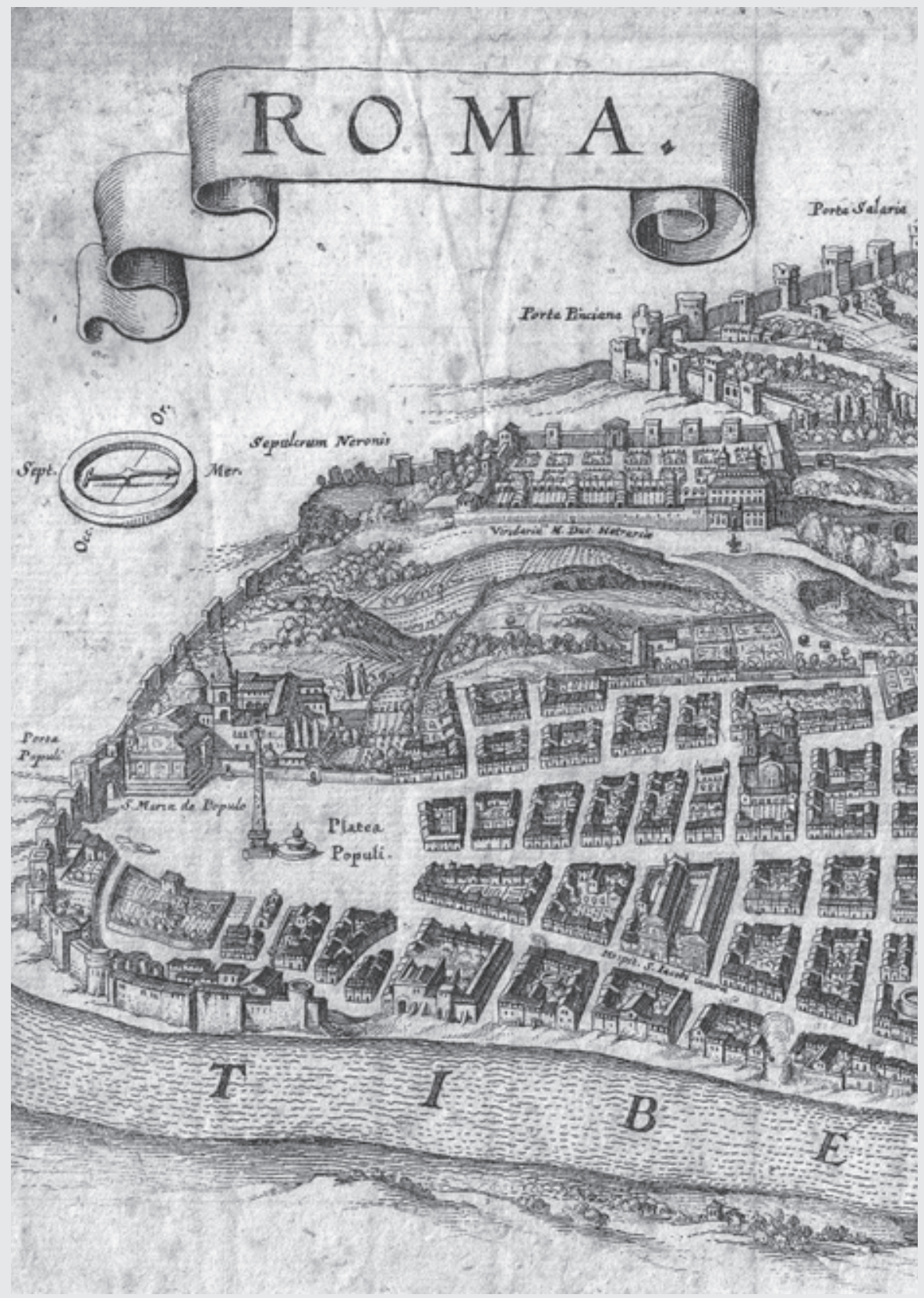

142. Pormenor do Mappa di Roma, confeccionado (em 1593) pelo pintor e gravurista italiano, Antonio Tempesta (1555-1630) - com destaque à Piazza del Popolo. É possível notar a presença do Obelisco Flaminio, recémtrasladado para o local por Domenico Fontana a pedido do Papa Sisto V. Também se percebe o tridente de vias que alcançam a praça após atravessarem o Campo Marzio. Fonte: Wikimedia Commons contributors. 


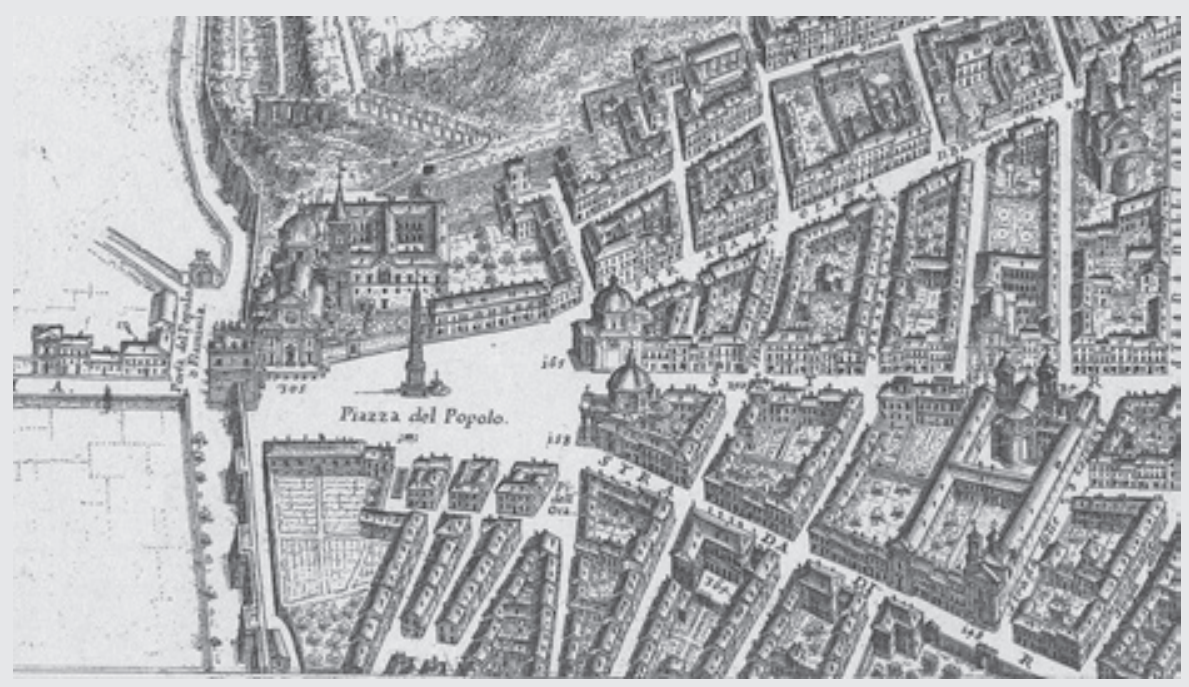

143. Pormenor do Mappa della città di Roma, confeccionado (em 1676) pelo gravurista italiano, Giovanni Battista Falda (1643-1678), com destaque à Piazza del Popolo - no mesmo ângulo de visão da anterior. É possível notar a presença das duas igrejas gêmeas que viriam marcar a abertura do tridente após o acesso à porta norte da cidade, edifícios religiosos construídos a partir da década de 1660 e projetados por Carlo Fontana. Fonte: Site Roma ieri oggi.

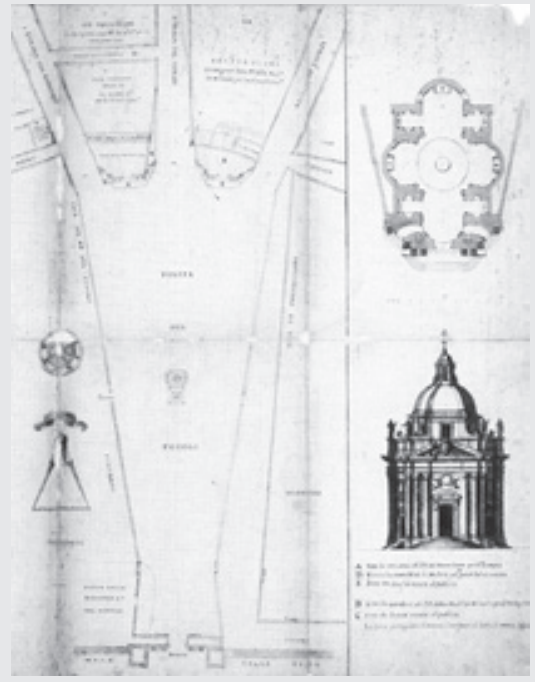

144. Plano de Carlo Rainaldi para a Piazza del Popolo. Percebe-se como o ângulo superior do encontro da Via Baubuino com a Via del Corso é mais agudo que o inferior. Fonte: Marder (1998, p. 153).

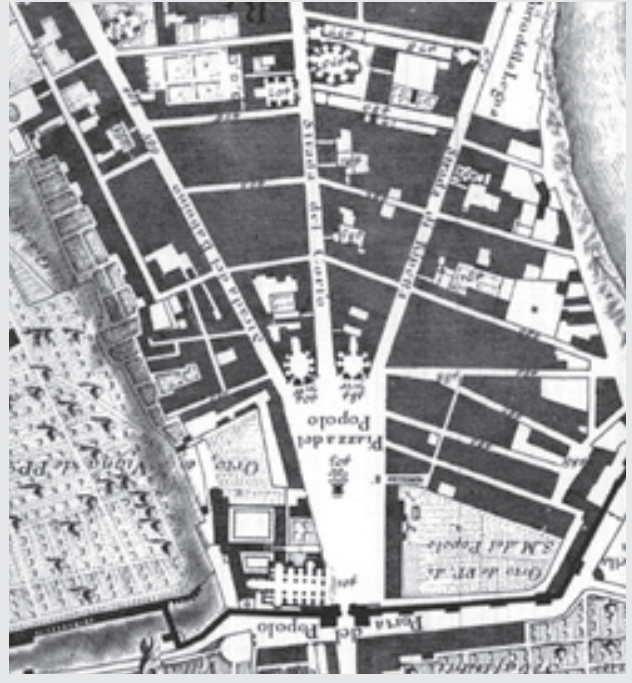

145. Pormenor da Piazza del Popolo e do tridente a partir da planta elaborada por Nolli e publicada em 1748. Em destaque, as duas igrejas de Santa Maria de' Miracoli (circular - à direita) e Santa Maria di Montesanto (elíptica à esquerda). Fonte: Frutaz (1962, p. 296). 


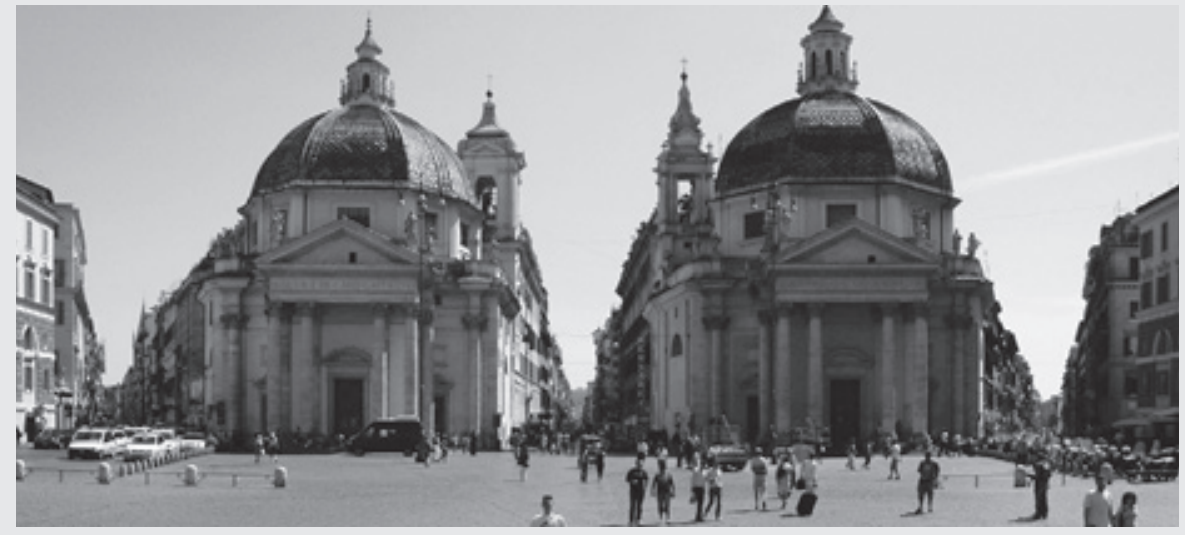

146. Piazza del Popolo. À direita, a Igreja de Santa Maria de' Miracoli e, à esquerda, a Igreja de Santa Maria di Montesanto. Fonte: Fotografia elaborada pelo autor (2007).

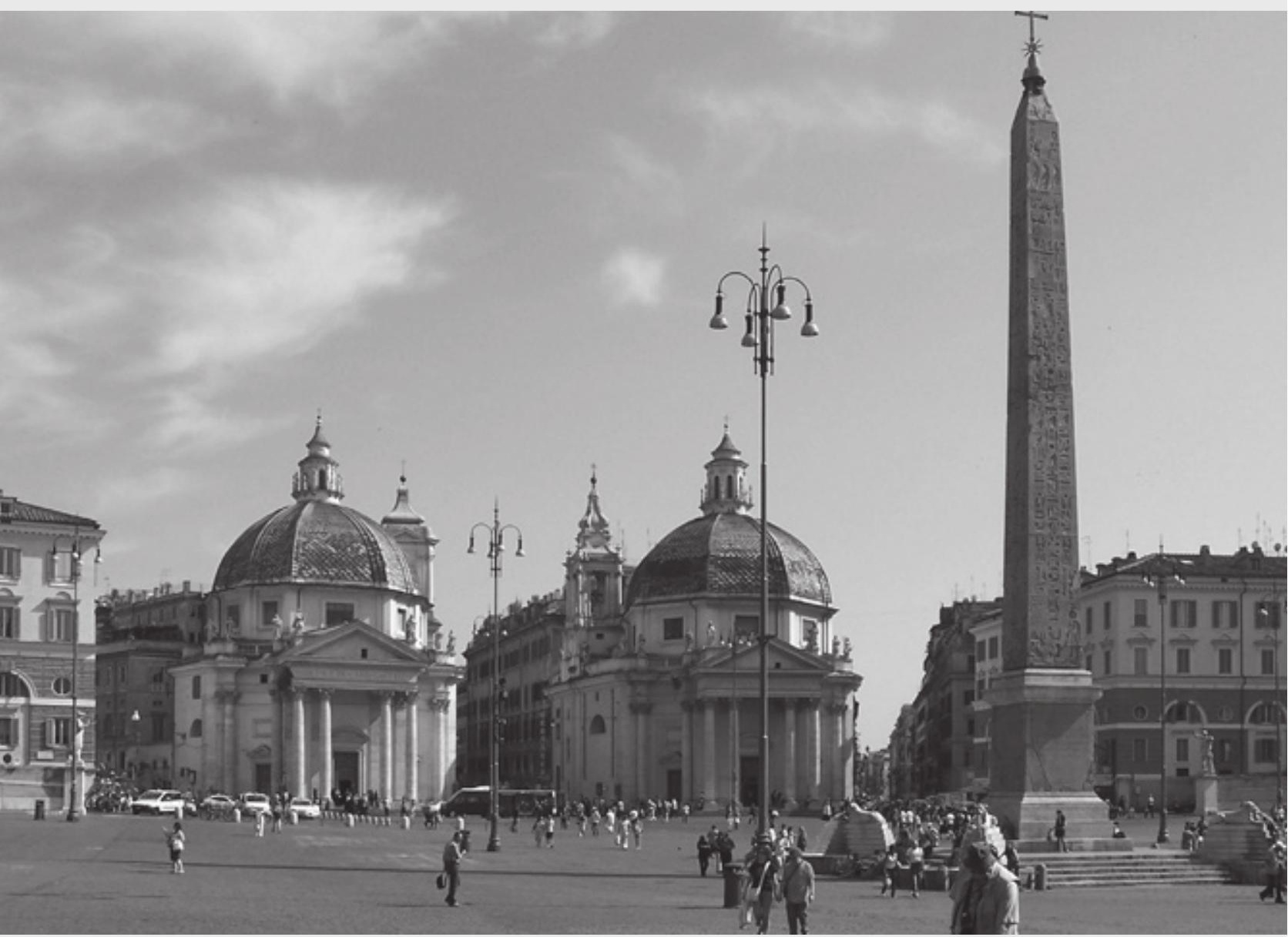

147. Igrejas da Piazza del Popolo e Obelisco Flaminio. Fonte: Fotografia elaborada por Berthold Werner. Este trabalho foi declarado de domínio público pelo seu autor / Wikimedia Commons contributors. 
obra, pois para o Barroco o importante era o que se via e não a realidade objetiva dos fatos.

Esta situação paradigmática deflagraria mais um importante mecanismo utilizado pela arte do período e que estaria relacionado diretamente ao grande valor atribuído à imagem e à imaginação: segundo o juízo proferido por Giulio Carlo Argan (1973, p. 79) - no livro editado, originalmente em espanhol, no ano de 1973 e intitulado El concepto del espacio arquitectónico, desde el barroco a nuestros días ${ }^{59}$ - o que os artistas barrocos desenvolveram como ninguém foi o conhecimento dos "modos de visão". A arte não se contemplaria a priori, como objeto de fruição lógica e imediata. Seria construída com o rigor de uma pesquisa visual sistemática - a criação a serviço da percepção subjetiva, para ser fruída pela mente como obra aberta.

Veja então o espaço; não é que exista um espaço com sua estrutura, com suas leis interiores; este espaço é um dado de visão, é uma imagem; o que interessa é que vós estudeis qual é a estrutura desta imagem, quais são as leis interiores desta visão; o que importa não é saber como estão realizadas objetivamente as coisas que nós vemos, o que importa é conhecer as leis segundo as quais nós vemos as coisas. (ARGAN, I973, p. 79, tradução nossa)

Assim, na cidade, as imagens elaboradas pelos artistas barrocos - muitas vezes artifícios inverossímeis concebidos para a sedução e o convencimento - deveriam jorrar à frente do passante que as capturaria inevitavelmente com o olhar. As infindáveis cenas oferecidas aos espectadores acabariam atuando, prontamente, como elementos essenciais da propaganda ideológica do Barroco através do apelo teatral à maravilha, à fantasia, à hipnose, à imaginação - mecanismos persuasórios empregados, invariavelmente, a serviço da estrutura grandiosa da lgreja e dos Estados vinculados ao Ancien Régime. O espaço urbano se transformaria, consequentemente, numa encenação dramática onde o transeunte comandaria, ao escolher seu percurso, o andamento da peça, e na qual a arquitetura ordinária e os monumentos seriam, respectivamente, moldura cenográfica e protagonista do grande teatro.

59 O livro é fruto de um curso ministrado por Argan em 1961 para o Instituto Universitario de Historia de la Arquitectura de Tucumán (Argentina). 
Neste sentido, antes da ereção do obelisco no centro da Piazza del Popolo em 1589, mas, sobretudo, antes da construção das duas igrejas gêmeas que convidariam o transeunte a escolher um dos três caminhos para descobrir e experimentar o núcleo urbano, não se poderia atribuir, definitivamente, um caráter barroco a este espaço. Sem a montagem desta extraordinária cenografia ilusionística formada pelas igrejas projetadas por Rainaldi, Bernini e Fontana - aparato teatral que caracterizaria a abertura da grande peça a ser encenada no âmago da cidade e que seria revelada lentamente ao espectador -, a energia dramática típica do dinâmico espírito barroco não poderia ser ainda capturada (Figuras I48-I49):

Até a época de Sisto V, a Piazza del Popolo era simplesmente o ponto de partida das três estradas, mas o obelisco ereto em 1589 a converteu em um verdadeiro nó urbano, e em meados do século XVII foi transformada em uma praça barroca. Em I5 de março de 1662 foram postas as fundações das igrejas gêmeas de Carlo Rainaldi. As duas igrejas ocupam simetricamente as áreas compreendidas entre as três estradas radiais e deste modo aparecem como a entrada monumental à cidade, com a avenida principal, o Corso, em condição de ingresso principal. $\mathrm{O}$ visitante que entrava na cidade encontrava à frente as igrejas com as cúpulas, e assim era 'introduzido nos ocultos tesouros da famosa cidade', como escreve Titi no seu guia de I686. ${ }^{60}$ (NORBERG-SCHULZ, I979, p. I9, tradução nossa)

Mas, para a plena apreensão das igrejas gêmeas como um segundo portal para a "cidade santa", cenário que introduziria o transeunte - segundo o cronista contemporâneo Filippo Titi (I763) - nos "ocultos tesouros da famosa cidade" que logo se desvelariam, era essencial que houvesse uma concentração perspectiva que direcionasse o olhar diretamente para os templos e para o tridente. Esta concentração seria fruto natural da forma preexistente da praça: vencendo o acesso pela Porta del Popolo, o ambiente se desenvolveria através de um extenso eixo longitudinal que passaria pelo obelisco e alcançaria a Via del Corso; este direcionamento axial era derivado do desenho em trapézio alongado que a praça absorveria, trapézio que se abria suavemente para o quadro que se constituía à frente, composto pela imagem contígua das igrejas virtualmente gêmeas de Santa Maria dei Miracoli e di Montesanto. O destaque que o eixo longitudinal

6 Norberg-Schulz se refere ao abade Filippo Titi (1639-1702), escritor do importante guia Descrizione delle pitture, sculture e architetture esposte al pubblico in Roma, cuja edição de 1686 seria a terceira lançada. 
dominante ofereceria ao portal sagrado da cidade era ainda sublinhado pelo fato de que os limites laterais do espaço - definidos pela presença da lgreja de Santa Maria del Popolo e os muros de seu horto (ao lado leste) e pelo casario simples e gregário (ao lado oeste) - promoveriam uma solução de orgânica continuidade em relação à abertura do tridente, não apresentando nenhuma interrupção na quebra de angulação do trapézio no início das Vias del Babuino e di Ripetta (Figuras I50-15I).

Infelizmente, toda esta trama cenográfica seria imensamente prejudicada quando, ao início do século XIX, o arquiteto neoclássico Giuseppe Valadier (I762-I839) viria a propor uma nova sistematização para a Piazza del Popolo. Na verdade, Valadier já havia desenvolvido outros estudos para o "embelezamento" da praça, com destaque a um projeto apresentado em $1793 \mathrm{em}$ que o construtor sugeria a organização das faces oriental e ocidental do ambiente através da inclusão de um grande porticado regular, com duas ordens de colunas sobrepostas. As galerias começariam alinhadas logo após a fachada de Santa Maria del Popolo e dariam continuidade à abertura do trapézio em direção às igrejas gêmeas, sendo concluídas no início das Vias di Ripetta e del Babuino. A empresa acarretaria em inúmeras demolições, já que os pórticos coincidiriam em parte com os antigos alinhamentos das construções que se apresentavam, sequencialmente, nos lados não paralelos do trapézio. Não obstante, a ação teria mantido a concentração perspectiva frente ao eixo dominante e à forma longitudinal da praça, só prejudicando o ambiente barroco ao diminuir a importância hierárquica dos organismos religiosos em relação aos monumentais pórticos.

Mas, o projeto que foi executado não apresentaria mais qualquer semelhança com a proposta anterior e pouco compromisso com a estrutura cenográfica desenvolvida no Barroco. Valadier o desenvolveria durante o período napoleônico e seu estudo seria aprovado em I8I6 e logo realizado. Seria uma proposta ligada a outro empreendimento: a organização dos jardins da colina do Pincio, que alcançariam, em grande declive, a área da Piazza del Popolo. Segundo Norberg-Schulz (I979, p. 20, tradução nossa):

Hoje a Piazza del Popolo se apresenta fundamentalmente alterada, depois que, em I8I6, Giuseppe Valadier deu início a uma transformação que introduziu um eixo transversal definido por imensas êxedras em ambos os lados. A intenção era coligar a praça com o declive do Pincio, de um lado, e com o Tevere, do outro. Valadier assinalou os quatro 


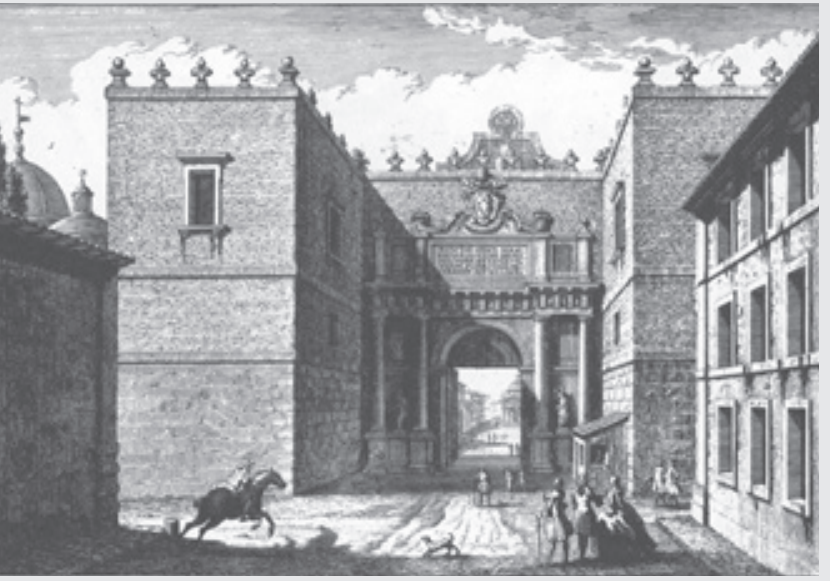

148. A Porta del Popolo, ou Porta Flaminia, em uma gravura de Giuseppe Vasi - 1747. A fachada externa foi comissionada pelo Papa Pio IV a Michelangelo Buonarroti (1475-1564), mas ele transferiu o encargo a Nanni di Baccio Bigio (morto em 1568), que realizou a obra entre 1562 e 1565 . A gravura mostra a porta marcando o acesso norte à cidade de Roma e revelando, para além de seu vão, um fragmento da visão distante da Igreja de Santa Maria de' Miracoli - anunciando a abertura do drama barroco a ser encenado dentro dos muros da cidade eterna. Fonte: Coen (1996, p. 39).

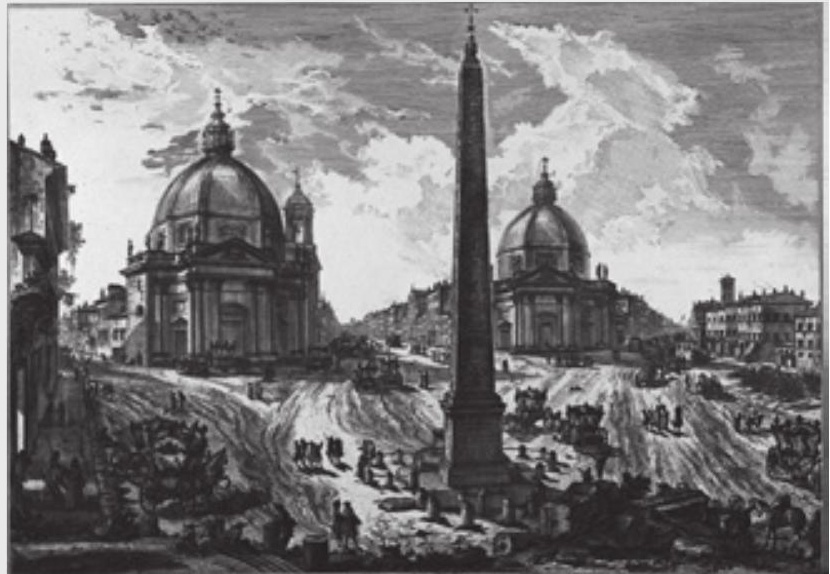

149. Veduta della Piazza del Popolo. Por Giambattista Piranesi, Vedute di Roma, publicadas em 1798 - as vistas, porém, foram iniciadas em 1748. Destaque para o Obelisco Flaminio e para as duas igrejas supostamente gêmeas. Fonte: Ficacci (2000, p. 689).

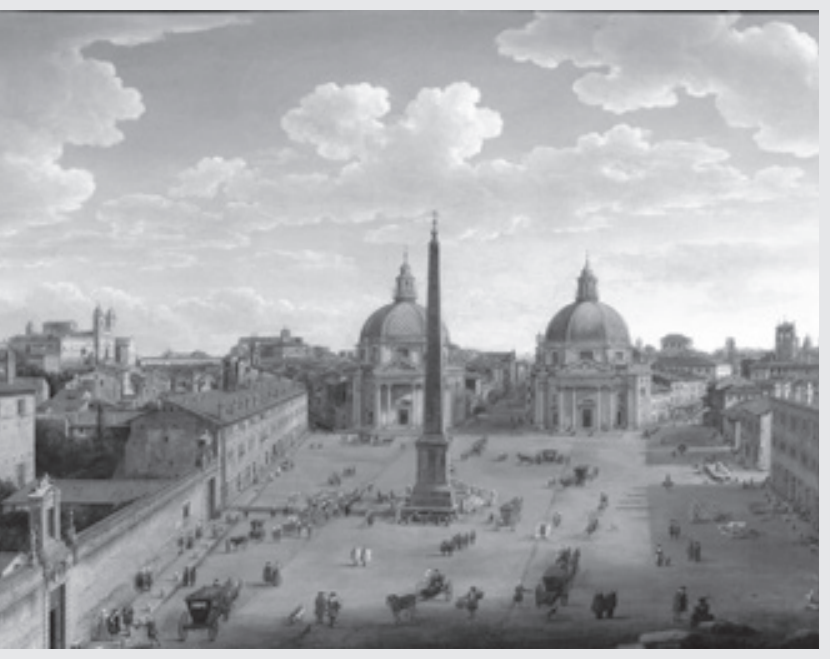

150. Piazza del Popolo, em óleo sobre tela de Hendrik Frans van Lint (1684-1763). Notar a trama perspectiva da praça, com os braços do trapézio que configurava o espaço se abrindo para o tridente - solução desfigurada pela intervenção oitocentista de Giuseppe Valadier (1762-1839). Fonte: Wikimedia Commons contributors.

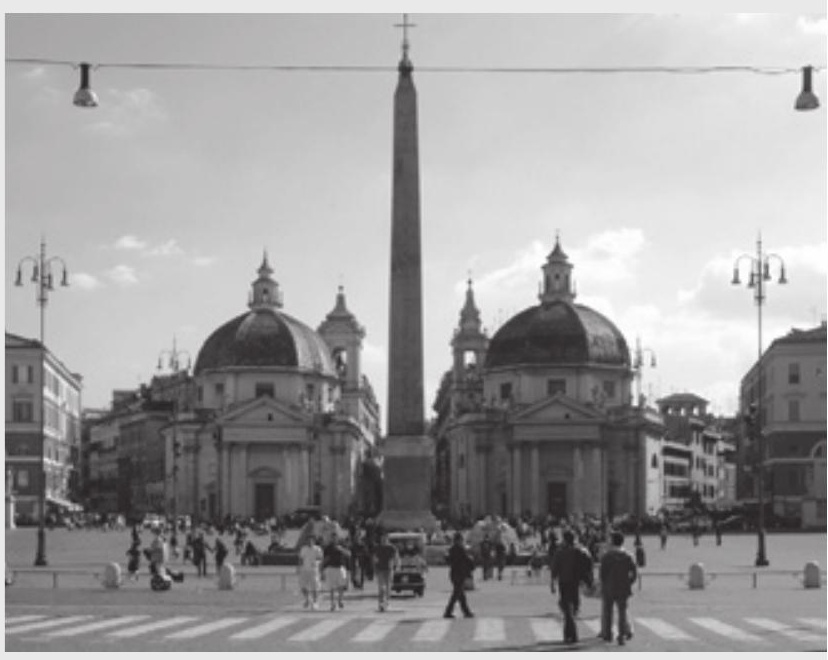

151. Igrejas da Piazza del Popolo e Obelisco Flaminio, em fotografia retirada após a travessia da Porta del Popolo. Fonte: Fotografia elaborada pelo autor (2007). 
ângulos do novo espaço que se formava com palácios semelhantes, e suas alterações reduziram o efeito do tridente barroco. A praça, ao invés de formar um nó entre via Flaminia e as três estradas radiais, tornou-se um amplo organismo de definição menos precisa. De fato, nada poderia danificar mais a estrutura urbana que a introdução de um eixo transversal 'verde' no ponto em que se entra na cidade. A ideia era derivada da Piazza di San Pietro, de Bernini, na qual, porém, este eixo tem um significado diverso. A conhecida vista de Piranesi (cerca de I750) nos mostra como se apresentava ao espectador a Piazza del Popolo antes da intervenção de Valadier: uma integração de massa e espaço, que tinha como qualidade predominante o movimento em profundidade e o obelisco como ponto de referência necessário para todo o conjunto.

É este movimento em profundidade que em grande parte iria se perder quando o novo desenho elíptico do ambiente iria abrir desmesuradamente o espaço na direção oposta ao do portal arquitetônico formado pelas igrejas gêmeas. O ambiente expansivo derivado da eliminação do horto e dos jardins do convento agostiniano e da demolição dos quarteirões assentados à oeste da praça - para a posterior construção das êxedras semicirculares que fariam parte da composição da praça elíptica - apresentaria uma dimensão não compatível com a escala das igrejas gêmeas e da própria Basílica de Santa Maria del Popolo. O imenso vácuo eliminaria dos templos aquela continuidade orgânica em relação ao sítio preexistente, fazendo os monumentos flutuarem em um espaço vazio. (MONCLÚS; OYÓN, I998, p. 22) ${ }^{6}$ Desta forma, o eixo dominante naturalmente se redirecionaria ao sentido Tevere-Pincio, celebrando o acesso à colina com os novos jardins, implodindo de vez a concepção barroca preexistente. ${ }^{62}$

61 "A nova praça, definitivamente aprovada em 1816, abre o espaço. Desde o panorama da entrada, é totalmente alterada a função de fundo de um espaço unitário das igrejas, que passam a flutuar em um grande vazio, sem nenhum tipo de contenção visual." (MONCLÚS; OYÓN, 1998, p. 22, tradução nossa)

62 "E mesmo na Piazza del Popolo, (Valadier) estuda, desenha, faz e desfaz, mas não satisfaz (talvez nem a si próprio); continua a considerar a praça como um fato em si e o arrimo do Pincio como seu fundo cenográfico, e se coloca continuamente em crise em função da exigência de subir da praça à colina, da impossibilidade de reduzir a natureza à simetria." (INSOLERA, 1996, p. 332, tradução nossa) 


\section{Para além da urbanística: os acontecimentos cenográficos dispersos no âmago da Roma barroca}

Após a inebriante experiência dramática vivenciada pelo espectador que alcançaria o interior da Cidade Eterna ao cruzar seu acesso norte e ingressar na Piazza del Popolo, seria possível promover uma apreciação genérica de alguns eventos dramáticos que estariam dispersos pela urbe. No entanto, antes de tudo seria interessante perseguir uma apreensão global da estrutura cenográfica e paisagística que compunha a capital pontifícia através de um reconhecimento sintético das duas metades do núcleo citadino separadas pelo Rio Tevere, o curso d'água que cortaria sinuosamente Roma desde sua fundação; ou seja, em linhas gerais, investigar, para além das artérias de tráfego abertas no Cinquecento, como se configuraria o apertado centro urbano no período barroco em sua relação com o cenário adjacente - cenário formado pelas áreas desoladas cheias de ruínas da Roma imperial, pelas colinas verdes que envolveriam a massa edificada, e pela expressiva presença do rio (Figura I52).

Ao lado ocidental do Tevere, para além de sua margem direita, estaria assentado o denso e tradicional rione medieval de Trastevere; mais ao norte se destacariam os Borghi - núcleos fortificados medievais e renascentistas compostos por um aglomerado de quarteirões relativamente regulares, bem como por uma espécie de cidadela constituída pelo Castel Sant'Angelo e pelos baluartes que o contornavam. Os muros dos Borghi ainda conteriam o conjunto do Vaticano, o mais importante complexo religioso do ocidente, formado pela lgreja de San Pietro, pela atual piazza homônima projetada por Bernini, pelos palácios pontifícios, e pelos seus suntuosos jardins. A oeste de Trastevere, em uma cota mais elevada, poderia ser vislumbrada a colina do Gianicolo, com seus belvederes que se abririam para inebriantes panoramas da Cidade Eterna; a colina seria abastecida pelo aqueduto Acqua Paola e pela cenográfica fontana de mesmo nome, estruturas inauguradas pelo Papa Paolo V em I6ı⿰ para fornecer água pura às partes altas da face oeste da cidade - fato que viabilizaria a sua ascensão como uma das regiões mais privilegiadas de Roma, vindo a acolher imponentes vilas patrícias.

$\mathrm{Na}$ direção oriental, na margem esquerda do rio, se alastraria a face mais importante e povoada da cidade. Lá estariam locados os centros da Roma republicana e imperial, com suas ruínas dispersas por ambientes que guardariam vestígios da trágica herança do pujante Império Romano: o Monte Palatino, 


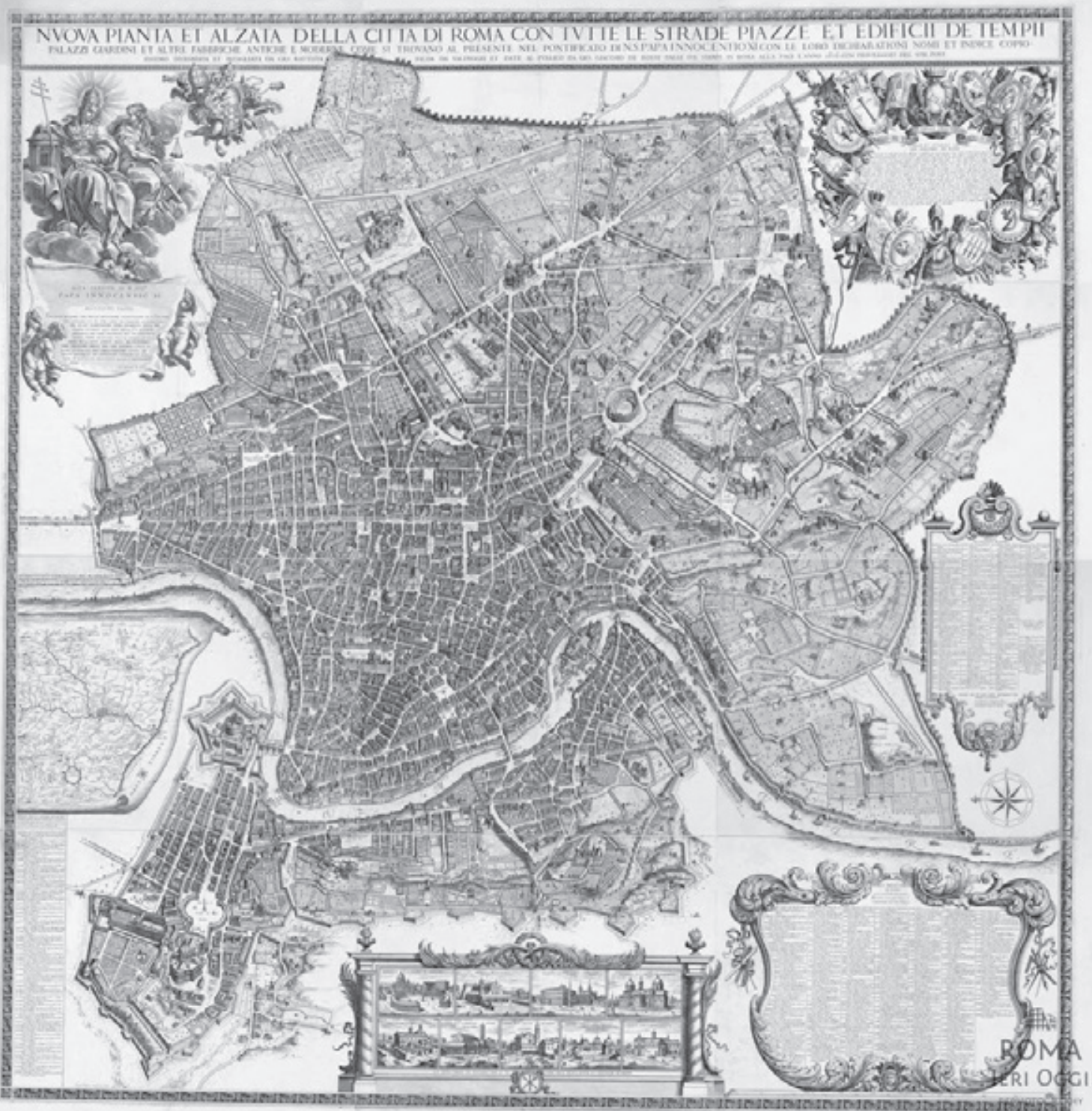

152. Planta de Roma, por Giovanni Battista Falda, elaborada em 1676. Notar a presença do Rio Tevere dividindo a cidade. A área central era bastante densa, principalmente a curva mais acentuada do rio, assim como também o tridente do Campo Marzio - enquanto as áreas das colinas eram pouco habitadas. Fonte: Site Roma ieri oggi. 
recém-povoado pelos paradisíacos jardins aristocráticos dos Orti Farnesiani, esquematizados, no século XVI, acima da colina que testemunharia - há mais de dois mil e quinhentos anos - o nascimento da cidade; alguns bairros populares como os Pantani, também traçados nas últimas décadas do Cinquecento, invadindo a região na qual antes se assentavam os Fóruns Imperiais; a praça conhecida como Campo Vacino, que se abriria para o vazio, repleto de destroços dos grandes monumentos que compunham, em tempos ancestrais, o Fórum Romano; mais distante, na direção meridional, a grande estrutura arruinada do Colosseo, o recinto abandonado do Circo Massimo, a Colina do Aventino, o Monte Celio, as Termas de Caracala. De núcleos centrais na Roma clássica, estes ambientes se converteriam em áreas periféricas da cidade, especialmente se confrontadas aos populosos rioni ocupados durante o Medievo e o Renascimento - os inúmeros bairros que constituiriam a massa edificada da Roma seiscentista e setecentista. Estes antigos centros políticos, civis e religiosos - áreas que se espraiavam ao sul do denso núcleo moderno, despovoadas após o grave processo de decadência da gigantesca metrópole imperial -, mesmo no decorrer do período barroco, quando os sítios arqueológicos seriam, em grande parte, reincorporados à dinâmica da urbe, continuariam a ser apreendidos como espaços limítrofes do aglomerado urbano (Figuras I53-I54).

Logo, a pulsante cidade barroca despontaria, notadamente, na direção setentrional aos antigos Fóruns: os profusos emaranhados de vielas e becos do centro medieval da urbe ocupariam especificamente os rioni contidos na acentuada curva do Tevere, no extremo ocidental da margem esquerda do rio - talvez a área mais densa e menos salubre da cidade; um pouco mais a leste se configuraria a vasta planície contígua aos burgos medievais, área em grande parte recuperada no século XV e que se dilatava para além das locações da Piazza Navona e do Pantheon; bem ao norte se destacaria a região na qual se abriria o tridente do Campo Marzio, núcleo que ganharia um traçado mais regular, e se adensaria principalmente no período barroco, nos séculos XVII e XVIII. Encerrando as planícies espraiadas pela face oriental do rio, brotariam as inúmeras colinas que envolveriam o tecido edificado - Pincio, Quirinale, Viminale, Esquilino -, recintos idílicos favorecidos pela construção do aqueduto Acqua Felice, pela restauração de outros tantos aquedutos de origem romana republicana ou imperial (Figuras I55-I56) e pelo novo sistema viário implantado pelos papas na segunda metade do Cinquecento. 


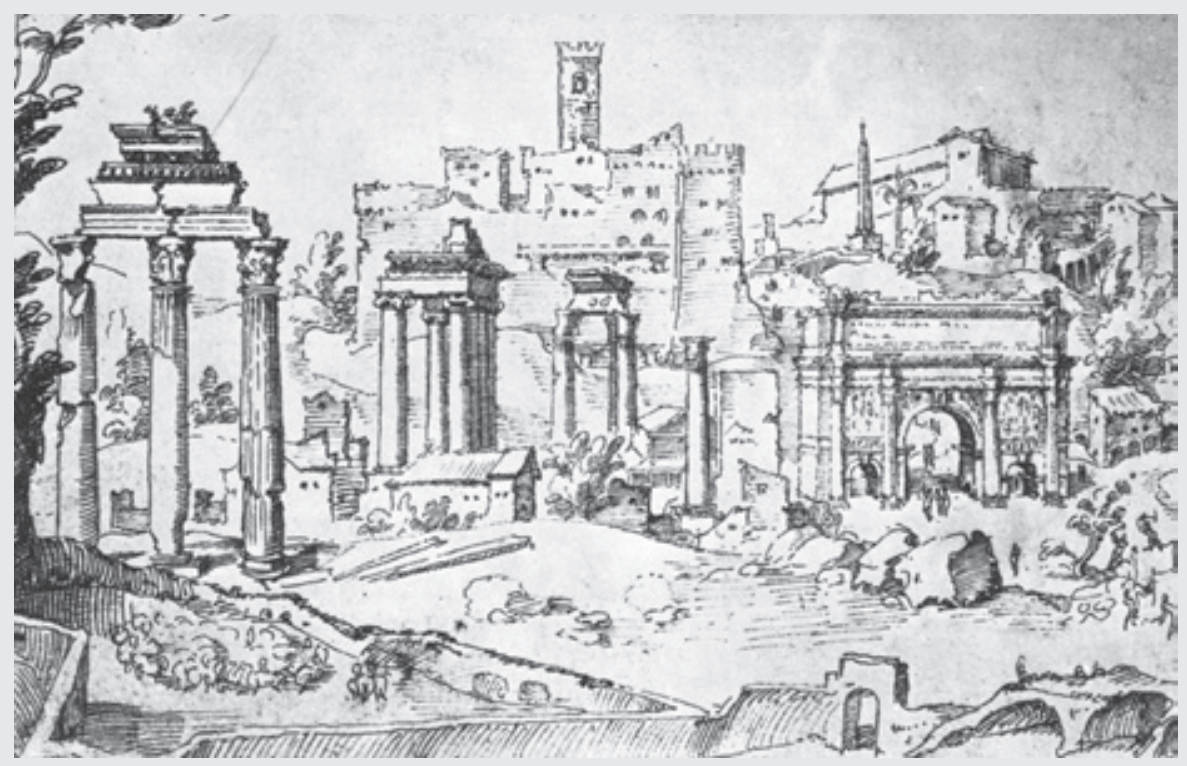

153. Vista do pintor holandês Maarten van Heemskerck (1498-1574) do Campo Vacino (Fórum Romano), 1532-1536. $\mathrm{Na}$ época, uma área ainda desolada. Fonte: Insolera (1999, p. 4).

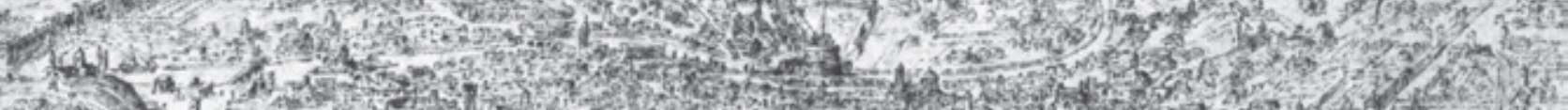

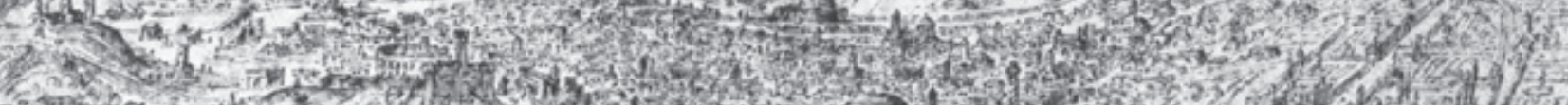

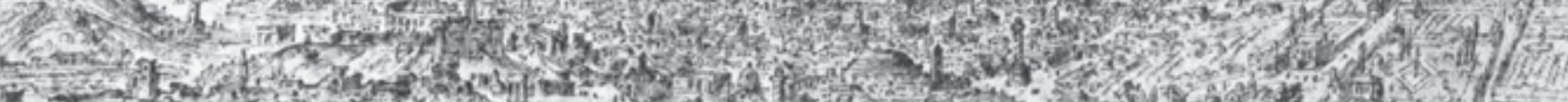

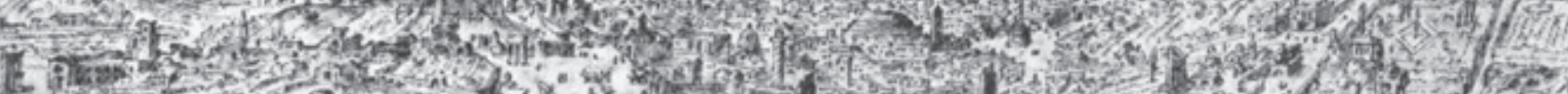

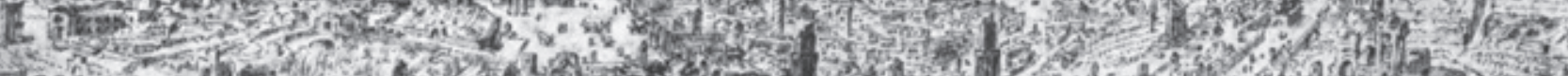

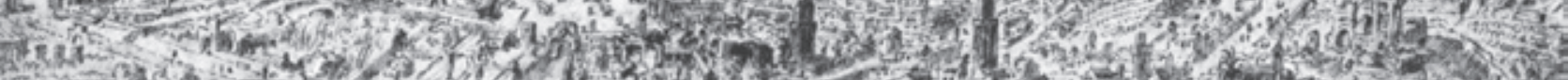

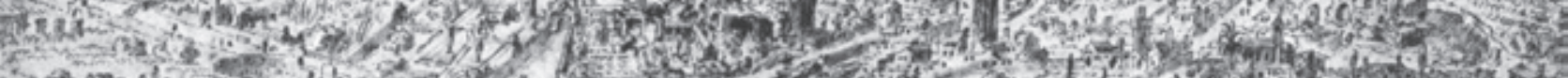

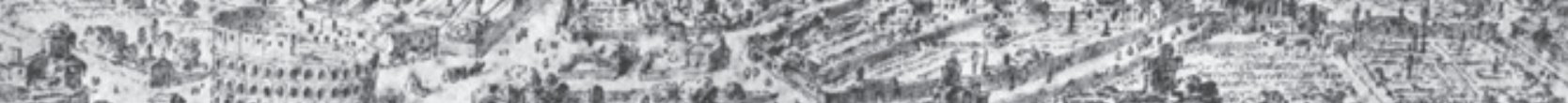

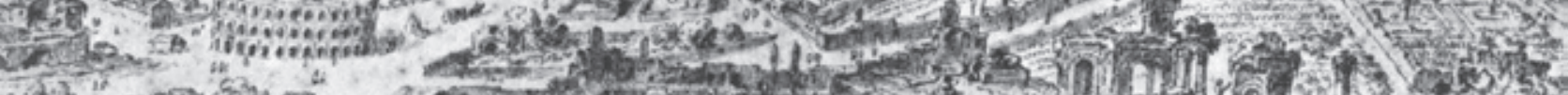

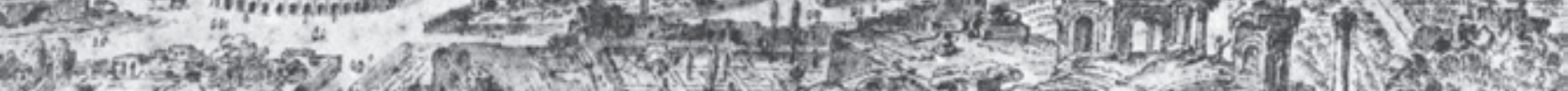

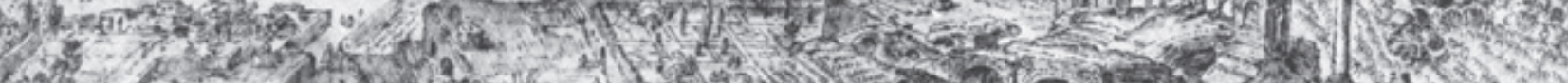

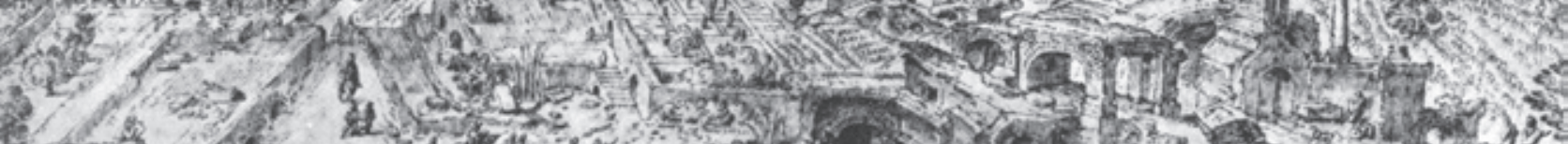

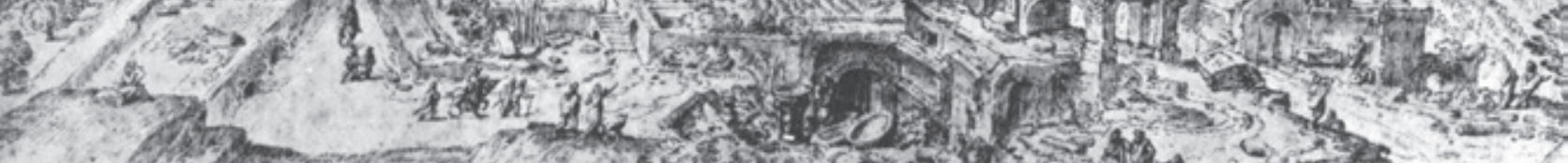

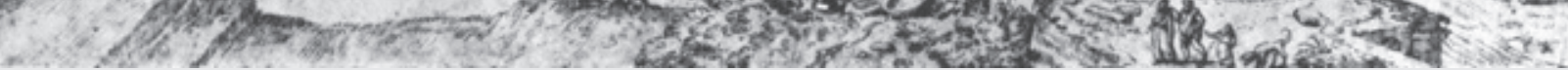

154. Veduta del Colle Oppio, 1550. Por Hendrik van Cleve (1525-1589). Percebe-se, na vista do pintor e gravurista flamengo, a área desolada, pontuada por campos e ruínas, que antes marcava o coração da Roma republicana e imperial - com destaque para o Colosseo. Fonte: Insolera (1996, p. 125). 


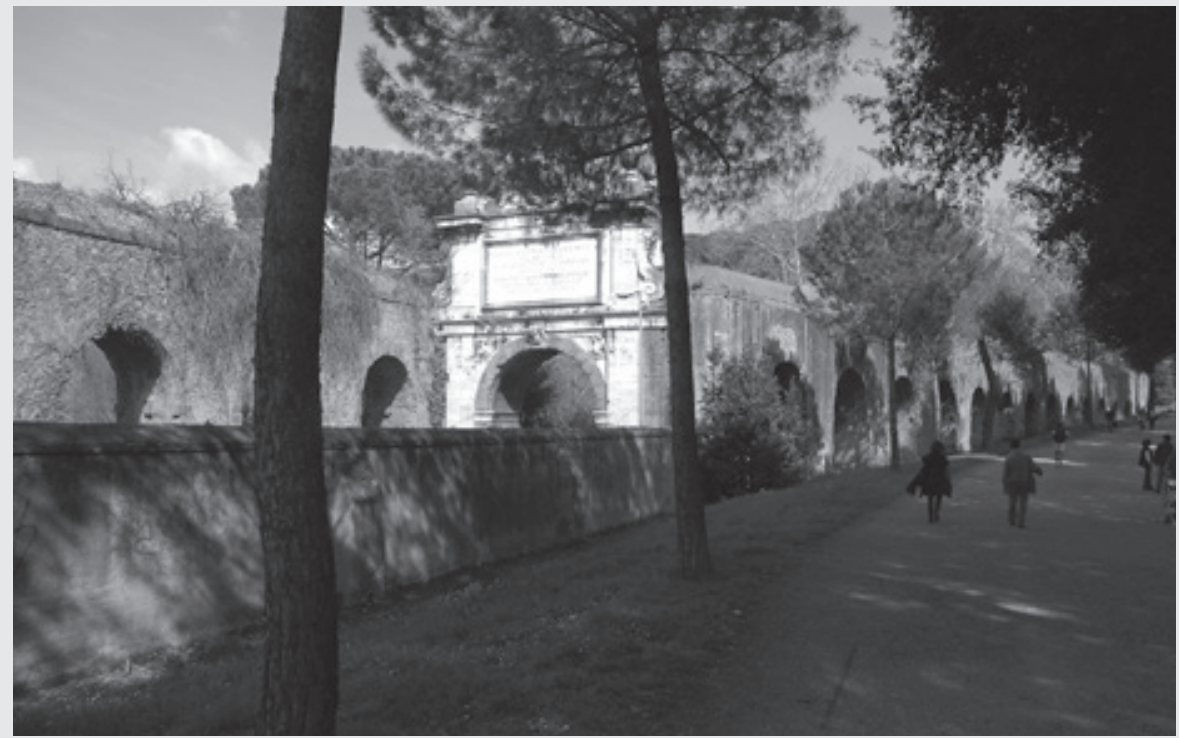

155. Acquedotto dell'Acqua Paola e Arco di Tiradiavoli percorrendo a área verde da colina do Gianicolo, em Roma. $\mathrm{O}$ aqueduto foi fruto da restauração do antigo Acquedotto Traiano pelo Papa Paolo V (1552-1621), no início do século XVII. O papa também construiu, em 1612, o Arco di Tiradiavoli para permitir que a Via Aurelia Antica passasse abaixo de seu aqueduto. Fonte: Fotografia elaborada pelo autor (2007).

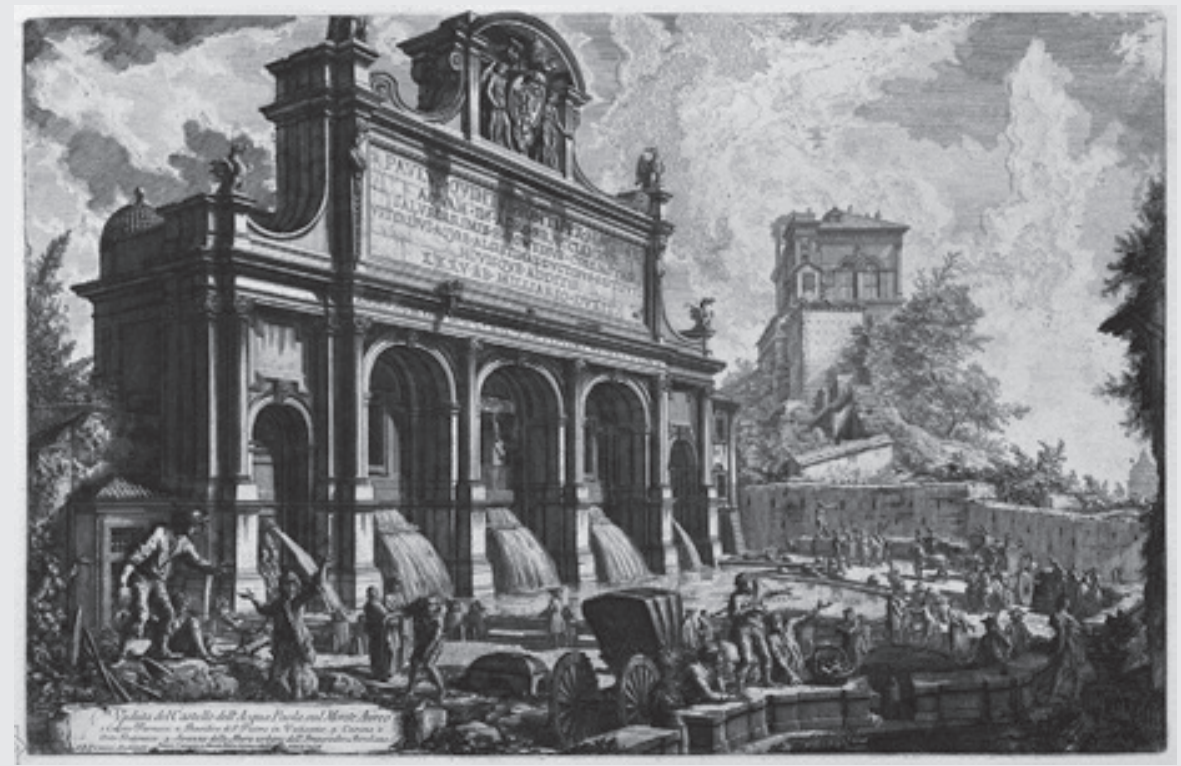

156. Giambattista Piranesi. Veduta del Castello dell'Acqua Paola sul Monte Aureo. Vedute di Roma. A fonte que fornece água para a colina do Gianicolo foi projetada por Flaminio Ponzio (1590-1613) e marca o final do Acquedotto Paolo. Fonte: Ficacci (2000, p. 708). 
E justamente a relação que o centro urbano guardaria frente às colinas que o envolveriam despertaria um aspecto bastante singular no que concerne à construção, em escala global, da estrutura paisagística da cidade barroca. Ao contrário da Roma imperial - que chegaria a abranger, com seus mais de um milhão de habitantes, não só toda a extensão do espaço acolhido pelos i8 quilômetros do perímetro das muralhas construídas pelo Imperador Aureliano, mas se expandiria para além das cintas fortificadas, a Roma barroca contaria com pouco mais de duzentas mil pessoas, não ocupando nem a metade do espaço intramuros. Esta realidade seria claramente perceptível na Nuova Pianta di Roma, confeccionada em 1748 pelo engenheiro, arquiteto, gravurista e cartógrafo italiano Giovanni Battista Nolli (I692-1756), planta cadastral que apresentaria a Cidade Eterna no auge de sua configuração barroca. Uma análise superficial do desenho - incrivelmente preciso e detalhado - revelaria como o vasto ambiente que se estenderia nas cotas mais elevadas da urbe, espalhando-se entre o perímetro do sistema defensivo e o denso núcleo habitado, estaria ocupado, de forma dispersa, por vinhas, campos e, de maneira especial, por vilas - ainda em meados do século XVIII (Figura 157).

Assim, na cidade dos papas, o trecho residual entre a massa edificada e seus antigos muros, principalmente as áreas das colinas que cercariam o núcleo urbano aos dois lados do rio, seria, gradativamente, apropriado pelas famílias ricas que ali construiriam suas paradisíacas vilas ajardinadas - nobres residências e parques patrícios diluídos na massa verde de extensos e espetaculares jardins, distantes da trama edificada compacta e insalubre do vale do Tevere, distantes das doenças, da malária. Herman Grimm (I828-I90I), professor de história da arte da Universidade de Berlim, escreveria, em I886, sobre uma das mais belas vilas romanas: a Villa Ludovisi - citação retirada do livro de Italo Insolera, Roma Moderna, cuja primeira edição sairia em I993:

Belíssimas avenidas sombreadas de carvalhos e louros, aqui e ali permeadas por altos e volumosos pinheiros, tranquilidade e ar balsâmico faziam da Villa Ludovisi um dos lugares de Roma que eram primeiramente nomeados quando se discorria sobre os encantos da Cidade Eterna. Sim, eu acredito, se perguntasse qual era o mais belo jardim do mundo, aqueles que conheciam Roma teriam respondido sem hesitar: Villa Ludovisi. (GRIMM, I886 apud INSOLERA, 200I, p. 52-53, tradução nossa) 


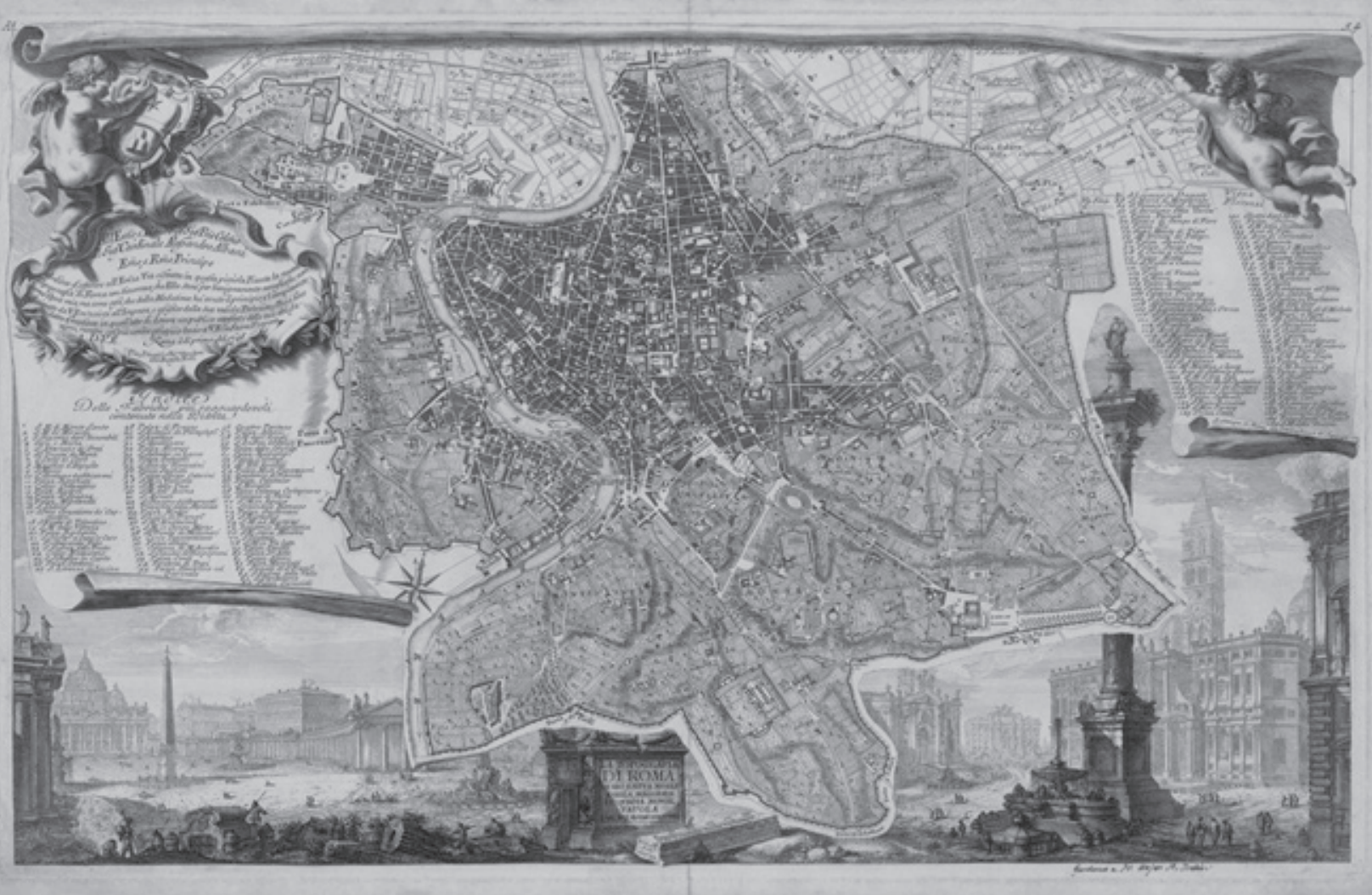

157: Nuova Topografia di Roma, de Giovanni Battista Nolli (1701-1756), versão reduzida publicada em 1748, ornada com imagens de monumentos romanos feitas por Giambattista Piranesi. Notar que a mancha edificada da cidade não ocupa metade da área dentro do contorno das muralhas. $\mathrm{O}$ ambiente entre o perímetro do sistema defensivo e a cidade é ocupado por vilas, vinhas e campos. Fonte: Insolera (1996, p. 307).

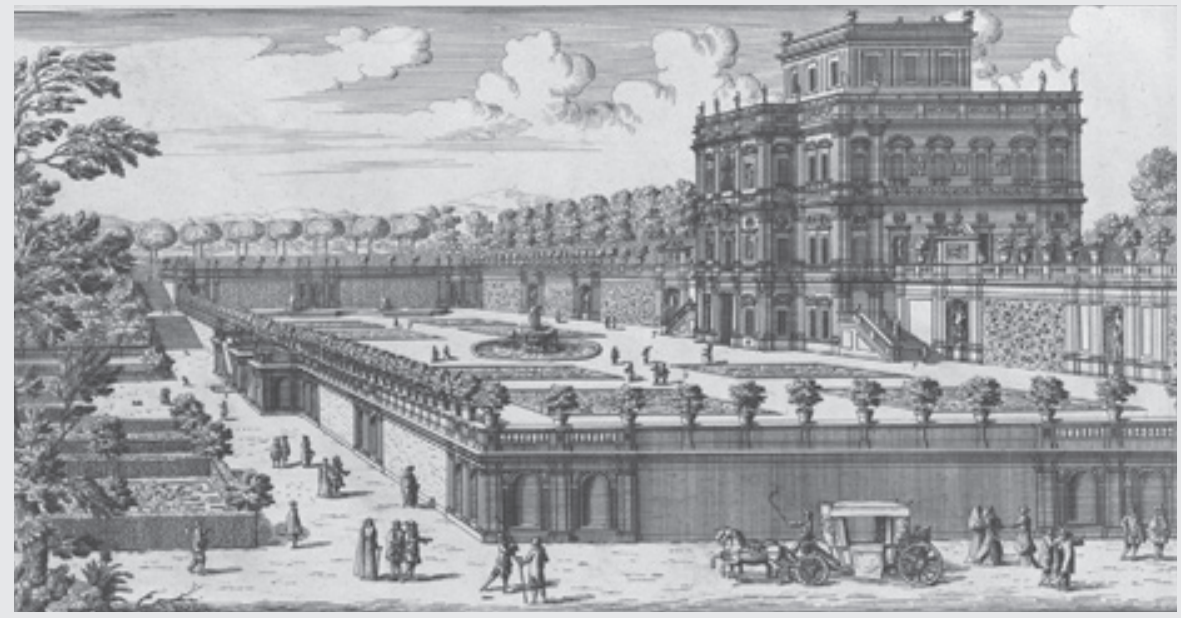

158: Perspectiva, elaborada por Giovanni Battista Falda, da Villa Doria Pamphilj - da série Li giardini di Roma con le loro piante alzate e vedute in prospettiva -, editada postumamente em $1683 \mathrm{com}$ o nome Ville e giardini di Roma nelle incisioni di Giovanbattista Falda. A vila foi construída por Alessandro Algardi (1595-1654) e se ergue na colina do Gianicolo. Fonte: Falda (1980, p. 74). 
Para a Roma barroca, este cinturão de vilas e parques assumiria a qualidade essencial de moldura verde que envolveria a compacta mancha construída, situação que poderia ser desvelada através dos panoramas capturados do alto das colinas do Gianicolo, do Pincio, do Aventino. Seria também o ambiente adequado para a evasão em relação ao tecido denso e apertado do núcleo citadino, um mergulho na ordenada natureza barroca através do respiro que seria imediatamente sentido por quem se aventurasse além das planícies. Portanto, propiciaria experiências dramáticas diametralmente opostas àquelas derivadas do congestionamento de informações gradativamente sobrepostas e oferecidas ao passante no âmago dos rioni mais centralizados. Contudo, esta oposição cidade-natureza seria absolutamente necessária para reforçar ainda mais, por contraste, o "efeito surpresa”, tão característico do Barroco - e tão explícito na configuração da trama cenográfica da Roma papal (Figuras I58-I6I). ${ }^{63}$

Para além do cinturão verde formado pelas colinas ocupadas pelas idílicas vilas, o próprio rio se prestaria como um artifício significativo que contribuiria para a elevação da cenografia dramática que se dispunha na cidade. Na verdade, o casario gregário, constituído por construções enfileiradas e irregulares que se amontoariam na maior extensão do tecido edificado, particularmente nas áreas planas e densamente habitadas aos dois lados do núcleo urbano, alcançaria o curso d'água e se apoiaria no rio, permanecendo diretamente engastado nas praias, nos taludes ou nos restos das antigas muralhas às margens do Tevere - principalmente em seu lado oriental, mais populoso. Não existiriam ruas ou avenidas em suas bordas, o que só permitiria a visão do curso d'água em poucas ocasiões: para quem alcançava os panoramas que se abriam do alto das colinas que envolviam o centro; para aqueles que se colocavam às margens do rio em uma das áreas desabitadas adjacentes ao núcleo urbano; diante dos dois portos fluviais da cidade (o Porto di Ripa Grande e o Porto di Ripetta); ao transpor uma das três travessas que cortavam o Tevere na área densamente habitada - a ponte de Sant’Angelo

63 Desgraçadamente, com exceção de algumas poucas propriedades que se transformariam em espaços públicos - como, por exemplo, a Villa Borghese, parte da Villa Doria Pamphilj, a Villa Medici, os jardins do Pincio - a grande maioria das residências que constituíam o edênico cinturão verde da cidade desapareceriam em nome da ampliação da área residencial da capital, vendidas a preço de ouro pelas tradicionais famílias da nobreza local, que não hesitariam em se desfazer destes legados ancestrais ao final do século XIX, após a cidade assumir o título de capital do Reino da Itália. O resultado foi a perda daquela relação necessária da cidade com a natureza circundante e a inclusão de uma massa edificada formada por bairros ordenados, regulares, totalmente alheios à antiga configuração urbana, ausentes do núcleo que se encontraria logo abaixo, gerando a percepção de duas cidades independentes e desarticuladas. (INSOLERA, 2001, p. 58) 


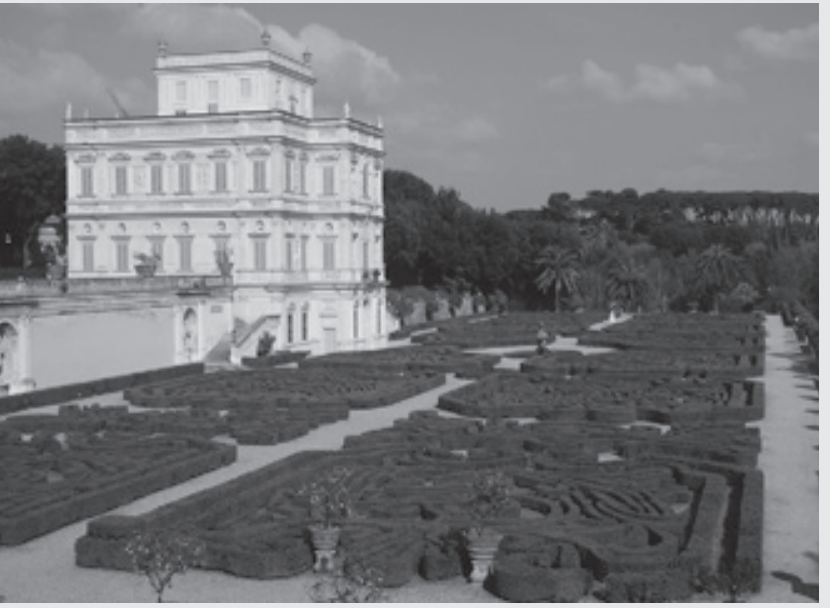

159. Imagem atual de uma das vilas que sobreviveram parcialmente à especulação - a Villa Doria Pamphilj. Fonte: Fotografia elaborada pelo autor (2007).

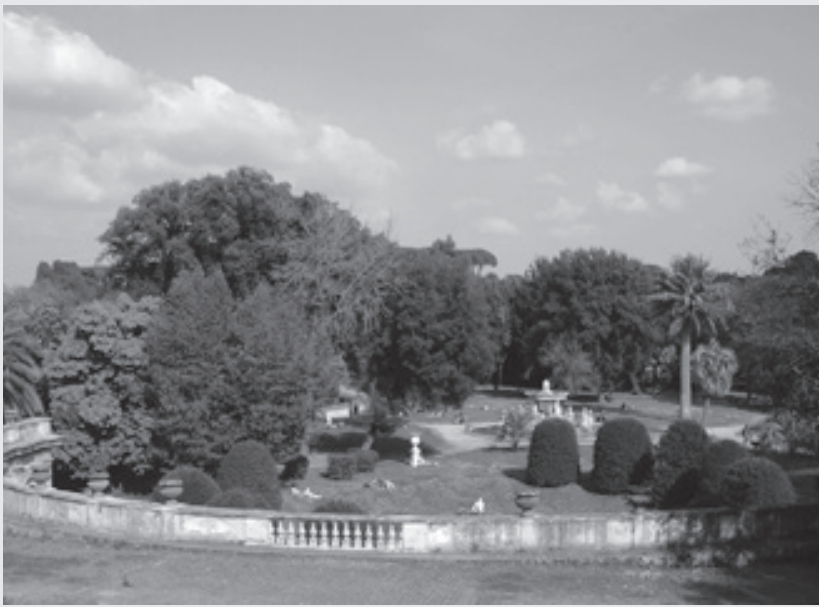

160. Jardins da Villa Doria Pamphilj.

Fonte: Fotografia elaborada pelo autor (2007)

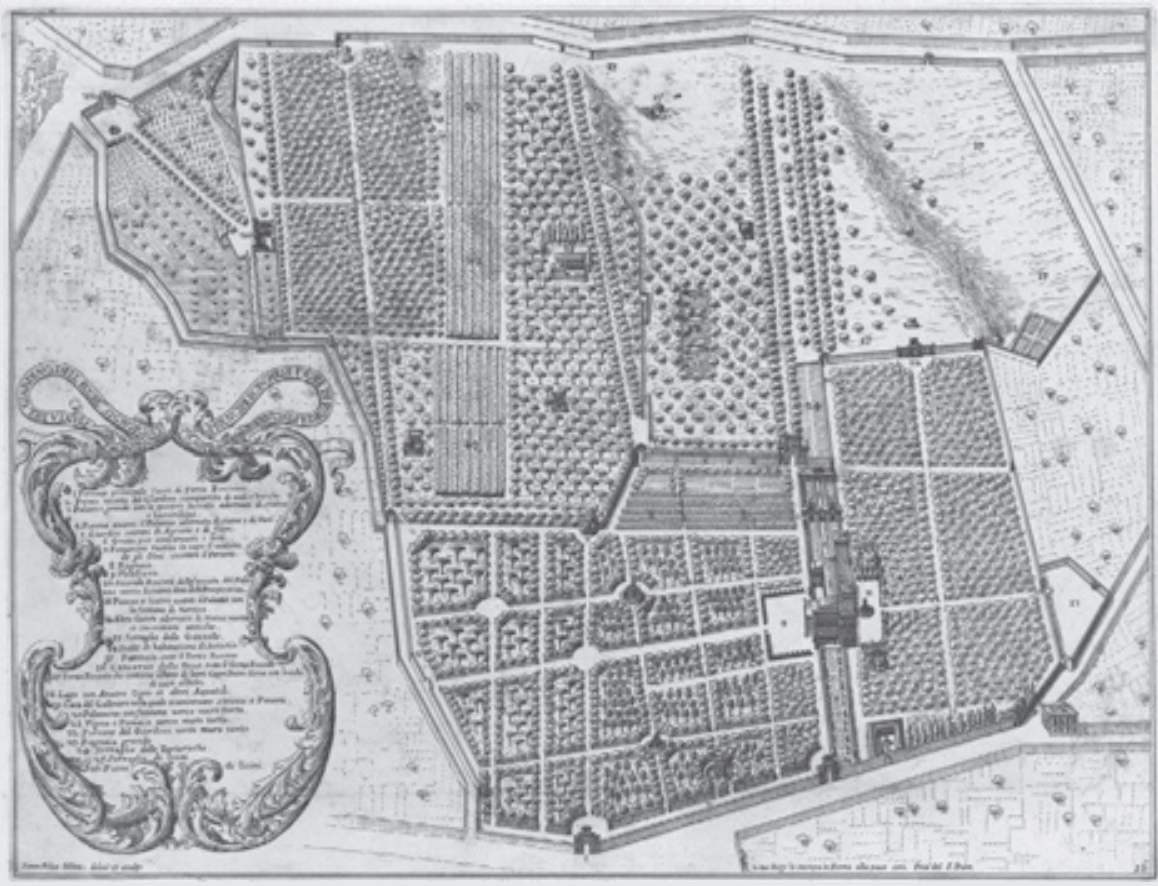

161. Planta axonomértica da Villa Borghese Pinciana, projetada por Flaminio Ponzio. Por Giovanni Battista Falda. Ville e giardini di Roma nelle incisioni di Giovanbattista Falda (1683). Fonte: Falda (1980, p. 59-60). 


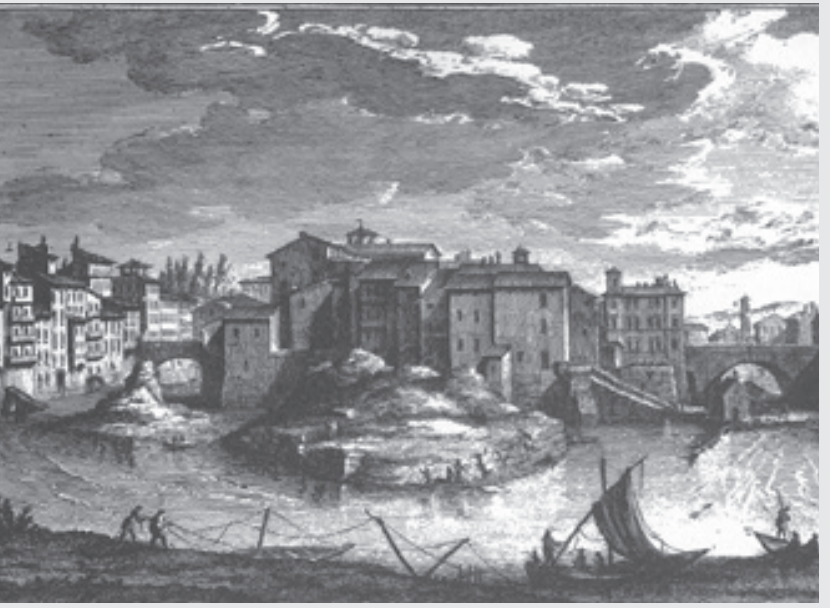

162. Isola Tiberina vista do ocidente. Reparar a ocupação das margens do Rio Tevere. Giuseppe Vasi, 1747. Fonte: Coen (2003, p. 145).

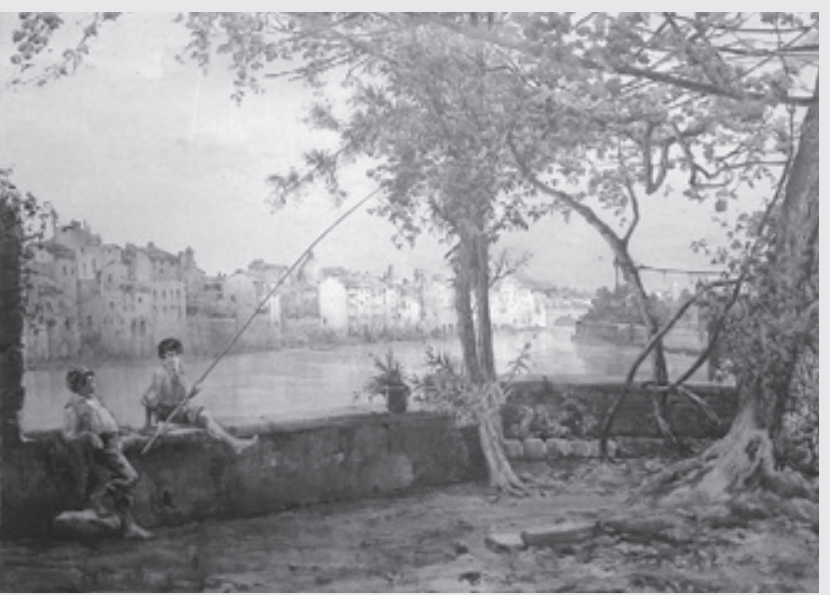

164. Aquarela de Ettore Roesler Franz revelando a ocupação da margem ocidental do Tevere a partir do Jardim da Farnesina. Fonte: Jannattoni (2003, p. 97).

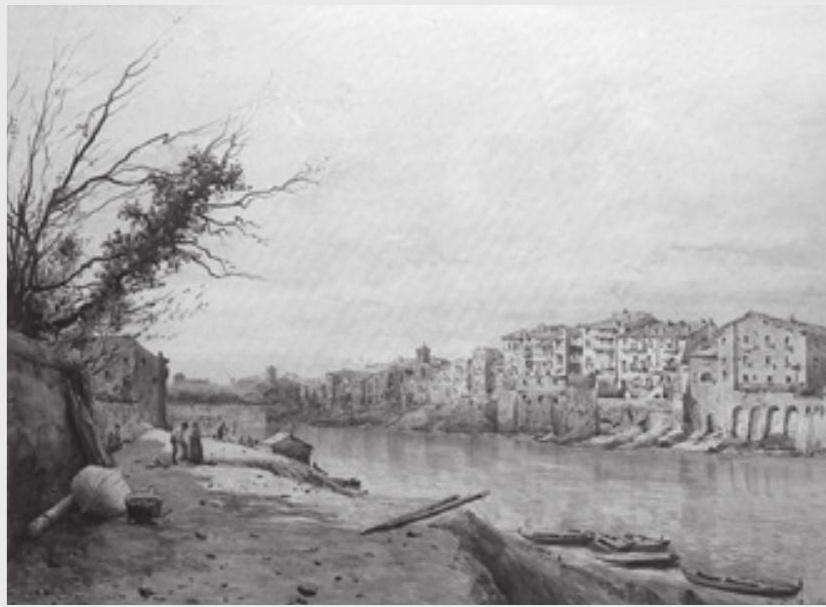

163. Aquarela do pintor italiano, de origem alemã, Ettore Roesler Franz (1845-1907), da série Roma Sparita, final do século XIX. Casas às margens do Tevere, ao fundo da Via della Lungara. Fonte: Jannattoni (2003, p. 83).

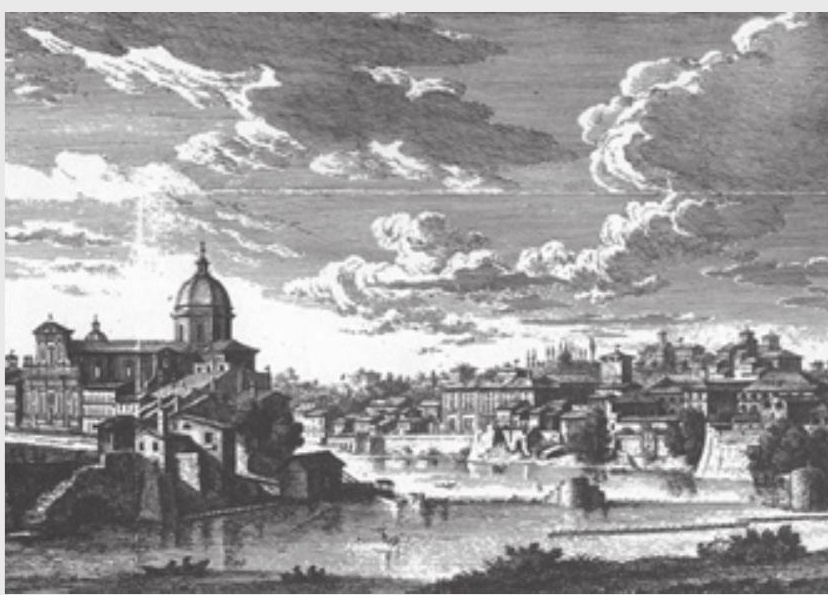

165. Vista do Rio Tevere - com destaque para a Igreja de San Giovanni dei Fiorentini, dando início a Via Giulia. Na outra margem, aparecem os fundos das edificações da Via della Lungara. Giuseppe Vasi, 1747. Fonte: Coen (2003, p. 141). 
(de origem romana imperial); a ponte Sisto (retificada no Quattrocento pelo Papa Sisto IV); e as pontes Cestio e Fabricio, que cruzavam a Isola Tiberina (ambas de origem romana republicana). Neste último caso, quando o transeunte deveria vencer o rio para irromper no outro lado da cidade, repentinamente sairia da massa urbana compacta da Roma barroca para cruzar uma das pontes, normalmente precedida de um pequeno largo, onde seriam descortinadas as imagens pitorescas do rio e das suas margens fortemente edificadas - trajetos que também contemplariam, dramaticamente, a passagem direta do denso e fechado emaranhado de vielas de um rione a outro intricado ambiente além-rio, ação que, além de promover a surpresa de capturar subitamente os panoramas abertos para o rio, daria início à revelação do burgo tradicional que se alcançaria à frente, após o cruzamento da ponte (Figuras I62-I65). ${ }^{64}$

Mas a apreciação dos mecanismos centrados na expectativa e na surpresa provenientes da relação da cidade com o seu rio poderiam ser multiplicados pelos inúmeros eventos barrocos que seriam dispersos por toda a urbe, particularmente no emaranhado dos apertados rioni que formariam as áreas mais populosas da cidade. Estes mecanismos serão analisados a seguir.

\section{A expressão do Barroco no denso emaranhado que comporia o tecido urbano da capital pontifícia}

Imaginemos sobrevoar a cidade com um balão aerostático que possa permanecer no ar por séculos e filmar o labirinto de estradas com um cinematógrafo ao ritmo de um fotograma por dia. Se pudéssemos

64 Toda esta rica trama dramática seria implacavelmente danificada pela contenção do rio e pela abertura dos lungotevere após Roma ser declarada capital italiana, em 1870, prejudicando a apreensão da unidade artística impressa na estrutura urbana da antiga capital pontifícia - além de alterar as relações sociais e econômicas provenientes da qualidade do rio como via de circulação de mercadorias e de sua importância como agente fornecedor de força motriz a baixo custo. Atualmente, o rio cria uma linha divisória clara entre os dois lados da cidade: os lungotevere, as avenidas de tráfego pesado abertas nas margens do curso d'água, normalmente se apresentam em cota mais elevada que o ambiente urbano contíguo, o que altera tragicamente as relações topográficas originais; as avenidas criam grandes barreiras de tráfego que tornam quase imperceptíveis os antigos percursos de transposição do Tevere. Os prédios de grandes dimensões, levantados nos lungotevere pela especulação imobiliária, as duas largas vias de tráfego, o leito do rio regularizado, dilatado e cavado profundamente através de seus imponentes arrimos de dezessete metros de altura, todo este complexo iria se apresentar como um evento monumental em escala não condizente à da cidade adjacente, episódio que dilaceraria o núcleo urbano não oferecendo qualquer solução de continuidade com o ambiente preexistente. 
efetuar uma tomada de $\mathrm{I} 420$, ano do retorno do papado, até I748, quando foi publicada a célebre planta de Gian Battista Nolli, as grandes vias mandadas traçar pelos pontífices apareceriam como talhos repentinos, perfeitamente diretos, cada corte realizado no arco de poucos segundos. Primeiramente veríamos a Via Alessandrina, desejada por Alessandro Vl, o Papa Borgia, rasgar o Burgo medieval de San Pietro - da Ponte de Sant'Angelo ao Portal do Palazzo Vaticano. Seguiriam as límpidas pausas de Via Giulia e de Via della Lungara, realizadas por Giulio II. Com um só rápido golpe, a Via del Consolato dei Fiorentini apontaria como a agulha de uma bússola ao ingresso de San Giovanni dei Fiorentini, e com outro golpe, Via dei Baullari teria seu percurso aberto até o Portal do Palazzo Farnese. Borgo Pio atravessaria os ainda verdejantes Prati até o grande portão de Bramante sobre o pátio do Belvedere, e, contemporaneamente, a Via Pia avançaria em linha reta do Palazzo do Quirinale à célebre porta citadina de Michelangelo. Enfim, em poucos segundos cinematográficos, veríamos as longas incisões dos eixos perspectivos de Sisto $V$ formarem uma estrela centrada na Basílica de Santa Maria Maggiore. Nestes súbitos instantes se poderia vislumbrar, corretamente, a imposição da vontade dos pontífices a uma cidade relutante e resistente.

Todavia, veríamos também o emaranhado que circunda as grandes estradas papais, denso e aparentemente informe, tomar forma como uma gigantesca flor que abre as suas pétalas em uma espécie de tomada acelerada. Grande parte do emaranhando assumiria gradativamente desenhos claros em volta de edifícios inicialmente pequenos, que acabariam por alcançar proporções gigantescas, como células que se desenvolvem de modo descontrolado no tecido urbano. Uma capela medieval poderia transformar-se em uma grande basílica contrarreformista no arco de poucos minutos de filmagem: uma fachada se acrescentaria como um raio, enquanto cresceria em todo o entorno, pátios e mais pátios, grandes estruturas que se sobreporiam pouco a pouco às casas menores. ${ }^{65}$ (CONNORS, 2005, p. VII-VIII, tradução nossa)

Não poderia existir uma melhor introdução aos complexos e diversos mecanismos de constituição dos inebriantes cenários barrocos que amplamente preencheriam, no Seicento e no Settecento, o âmago do aparentemente confuso

$65 \mathrm{O}$ ano de 1420, a que Joseph Connors se refere, foi a ano em que Ottone Colonna (1368-1431), o Papa Martino V - que dirigiu a igreja de 1417 até sua morte -, chegaria a Roma após ter passado um ano e meio viajando pela Itália ao voltar do Concílio de Constança (1414-1418), convocado para se pôr fim ao cisma papal do ocidente. 
emaranhado de vielas, becos e travessas que comporia a maior parte da Cidade Eterna - seu tecido medieval, a preexistência renascentista, bem como as imediações dos sítios onde despontariam as antigas ruínas da Roma clássica - do que as palavras proferidas pelo historiador americano da arte, da arquitetura e da cidade Joseph Connors (nascido em I945), retiradas do livro lançado em I989 e intitulado Alliance and enmity in Roman baroque urbanism. ${ }^{66}$ Estes mecanismos de reconfiguração, em pequena escala, do contexto paisagístico adjacente, fundados, prioritariamente, em intervenções arquitetônicas, seriam ações que, em termos quantitativos, e mesmo qualitativos, extrapolariam fatalmente os expressivos empreendimentos urbanísticos que imperariam no século XVI (Figura I66) - como foi visto em relação à conformação da Piazza del Popolo, que não assumiria sua dramaticidade barroca até sofrer as inclusões propriamente edilícias através da transferência do Obelisco Flaminio para o encontro dos eixos do tridente no centro da praça, mas principalmente por meio da construção das igrejas gêmeas que serviriam como portais cenográficos para a cidade.

Provavelmente, esta apropriação da arquitetura como o mais eficiente ingrediente utilizado na Roma barroca em prol da dramatização de seu cenário urbano remanescente seria a grande peculiaridade da capital pontifícia se confrontada à cidade de Paris, no que tange ao projeto de remodelação da paisagem citadina em direção aos preceitos básicos da cultura da época - na busca por artifícios visibilísticos que promovessem o controle das massas. Na capital francesa, muito mais rica e poderosa, o montante investido contemplaria, prioritariamente, empreendimentos urbanísticos de grande escala e mesmo as iniciativas arquitetônicas de alguma expressividade ficariam, quase sempre, ao encargo do império, se apresentando excepcionalmente dissolvidas na enorme extensão do núcleo edificado ${ }^{67}$ - ou então proporcionando poucos episódios megalômanos que habitariam, isoladamente, algumas áreas da cidade, sendo incapazes de alcançar qualquer interface com o envolvente burgo. Na Cidade Eterna, a reformulação no traçado seria muito mais vasta do que aquela que aconteceria em Paris - intervenções que tocariam, diretamente, o tecido preexistente, enquanto as da capital francesa ficariam restritas aos limites da cidade, ou mesmo constituídas fora dos

66 Editado pela primeira vez como um artigo em 1989. A versão em italiano, aqui contemplada, Alleanze e inimicizie: l'urbanistica di Roma barocca, foi lançada em 2005 e foi traduzida por Marco Cupellaro.

67 No século XVII Paris tinha quase o dobro da população de Roma. 


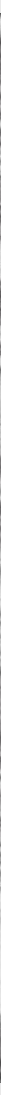

166. Detalhe da planta de Roma elaborada por Giovanni Battista Falda: destaque para a grande densidade presente na área central da cidade - no caso, na região da curva do Tevere - e também nas margens do rio.

Fonte: Site Roma ieri oggi. 
antigos cinturões de defesa. Contudo, para além da urbanística, as intervenções arquitetônicas pontuais seriam patrocinadas tanto pela iniciativa pontifícia, que comandaria aquelas obras que diriam respeito à esfera pública - ereção de fontes, obeliscos e monumentos escultóricos; sistematização dos portos fluviais; ordenação das praças mais suntuosas; alinhamento rigoroso das vias; edificação de imponentes edifícios públicos ou religiosos -, quanto pela iniciativa privada, que coordenaria quantitativamente um número significativamente maior de empreendimentos - se forem levados em consideração os palácios, igrejas e conventos que seriam construídos, ou mesmo recuperados, durante os 150 anos que se estenderiam a partir do início do Grand Siècle.

Ou seja, Roma não poderia se furtar, para a conformação de seu caráter barroco, de uma necessária conjunção entre a reformulação dos espaços monumentais, intervenções promovidas pelo governo dos papas, e as centenas de pequenos eventos dramáticos que povoariam todo o cenário da cidade, ações devidas aos já comentados grupos independentes de poder que constituiriam a capital pontifícia. A recuperação e ampliação de organismos religiosos preexistentes ou a construção de novas igrejas e conventos com suas fachadas e volumes barrocos voltados à cidade, bem como a criação de palácios, vilas e residências para as famílias abastadas, ou mesmo pequenas intervenções pontuais em edifícios preexistentes devidas a personagens comuns, seriam operações essenciais para a expressão da cultura barroca no espaço urbano, já que: "Em Roma, uma fachada ou um portão, um belvedere ou um ângulo protuberante parecem dotados do mágico poder de modelar o espaço urbano." (CONNORS, 2005, p. VII, tradução nossa)

Estas inserções não se fechariam, exclusivamente, nos domínios da arquitetura, mas poderiam contaminar o contexto adjacente; extrapolar o edifício e ocasionar significativas remodelações, em pequena escala, do espaço urbano. Logo, seria comum o estabelecimento de acordos entre entidades privadas e a esfera pública em prol da ordenação do cenário no qual aquele importante monumento religioso ou civil estaria assentado, ou aonde ele viria a ser construído - a regularização ou ampliação dos alinhamentos da praça em que a igreja, o convento, o palácio, figurariam como a estrutura mais imponente. Muitas vezes, a própria ordem religiosa, a família aristocrática ou mesmo a representação diplomática da nação que havia construído o edifício cederia terreno à municipalidade para o alargamento ou o redesenho do espaço público à frente, no recinto que 
envolveria o monumento - situação que seria favorável ao governo, mas também ao organismo privado que teria sua estrutura arquitetônica em maior destaque dentro do contexto da praça. Connors (2005, p. XII, tradução nossa) exemplificaria uma ocasião em que este mecanismo acontecera na Roma barroca:

[...] nas pesquisas efetuadas por mim no arquivo da Congregazione dell'Oratorio, em Santa Maria in Valicella, conhecida comumente como 'dei Filippini', me deparei com um importante documento sobre a história da Piazza della Chiesa Nuova. Se tratava de uma licença expedida por Mestres de ruas que consentia aos oratorianos alterar o alinhamento viário de um edifício assentado diante da sua fachada. Eles haviam adquirido tal edifício e se preparavam a demoli-lo e reconstruí-lo como um imóvel destinado ao aluguel. A licença lhes consentia de invadir solo público em troca de uma fração do seu terreno, a condição de que a superfície cedida por eles fosse maior que aquela adquirida. Definitivamente, uma troca assim era vantajosa tanto para os oratorianos como para a parte pública. A superfície do solo público aumentava, mas ao mesmo tempo uma ordem religiosa conquistava o direito de retificar o perímetro da própria praça. Os oratorianos se tornavam urbanistas em escala local.

Basta agora imaginar a multiplicação desta circunstância, relatada por Connors, pelo número inimaginável de expressivos monumentos barrocos, civis e religiosos, que preencheriam todos os rioni e os bairros da Cidade Eterna durante o Ancien Régime, para se poder vislumbrar a força de transformação que estes eventos ofereceriam para a imagem do núcleo urbano preexistente.

\section{Os persuasivos cenários fixos compostos pelas fachadas dos monumentos espalhadas por toda extensão da Roma barroca}

Não obstante, por mais esforços despendidos em prol da ordenação adequada da praça, do largo, ou mesmo do encaminhamento perspectivo que deveria se dirigir a um monumento arquitetônico qualquer, a lógica da construção cenográfica do espaço seria profundamente diversa daquela que viria a ser perseguida nas cinco places royales edificadas em Paris - modelo repetido em algumas outras praças regulares levantadas nas províncias francesas, bem como em parcos exemplos em diferentes nações do Ancien Régime. Em Roma, ao contrário, não haveria lugar 
para aquela preocupação obsessiva em conceber a praça como um organismo formado por um conjunto envolvente de fachadas absolutamente idênticas, fato que sugeriria, para os recintos parisienses, a ideia de que seriam compostos por um único palácio monumental disposto em volta da estátua do monarca assentada em seu vazio. Nos ambientes de destaque da "cidade santa", ao contrário, a apresentação do drama urbano estaria fundada, quase sempre, na presença de pelo menos um edifício dominante, estrutura que, frequentemente, estaria contraposta de forma eloquente a outros monumentos lançados na cavidade da praça - obeliscos, fontes, esculturas, estátuas.

Mesmo as poucas praças que seriam constituídas por uma arquitetura regular abertas desde o século XVI - como a maneirista Piazza del Campidoglio (iniciada em 1546), projetada pelo grande escultor, pintor e arquiteto italiano, Michelangelo Buonarroti (I475-I564), conformada por três edifícios administrativos, sendo os dois laterais idênticos (Palazzo dei Conservatori e Palazzo Nuovo); ou a minúscula e adorável Piazza di Sant'Ignazio, projetada por Filippo Raguzzini (I680-I77I) entre I727 e I728, que apresentaria um conjunto de prédios burgueses de mesma arquitetura, construídos de relance e projetados pelo mesmo arquiteto; ou a Piazza di San Pietro, iniciada em I656 por Bernini (I598-I680), com sua monumental colunata regular - apresentariam pelo menos um monumento de destaque: no caso do Campidoglio, o Palazzo Senatorio, ordenado no eixo da composição; na praça de Raguzzini, a preexistente Igreja de Sant'Ignazio; e em San Pietro, a grande basílica. Nas outras praças romanas, e mesmo em vias importantes, ou, simplesmente, em meio aos apertados burgos medievais ou renascentistas, o elemento que contribuiria para atribuir caráter dramático ao espaço - é sempre bom insistir - seria o próprio monumento, o que tornaria muito mais viável a difícil empresa calcada na transfiguração genérica da imagem da cidade se comparada ao que se perseguiria em Paris: seria muito mais fácil a construção de edifícios para as virtuais dramatizações de cada ambiente expressivo da cidade do que a ereção de todas as frontarias que deveriam envolver as grandiloquentes praças regulares patrocinadas pelos governos.

Neste sentido, a composição das fachadas dos monumentos adquiriria uma importância incondicional para a conformação da Roma barroca - bem como para a exibição do cenário dramático da maioria das cidades que buscariam a alteração de sua imagem segundo os preceitos oriundos da retórica e persuasiva cultura da época. Os monumentos, sejam civis ou religiosos, tenderiam a explici- 
tar uma independência fatal entre o espaço interior e o exterior, desenvolvendo uma disposição que já poderia ser sentida em algumas obras maneiristas - é só lembrar a desconexão entre o espaço interno, concebido e construído entre 1568 e I57I por Giacomo Barozzi da Vignola (I507-I573), para a Igreja de Il Gesù, e sua fachada, projetada por Giacomo della Porta (I532-I602), levantada a partir de I57I para "ornar" a acolhedora Piazza que se abria à frente. Na realidade, o envoltório exterior não seria mais compreendido como a casca contenedora do organismo arquitetônico, mas passaria a ser vislumbrado como parte integrante do contexto urbano - como um cenário fixo voltado para a grande plateia de indivíduos que percorreria o espaço urbano, colocando, em primeiro plano, o problema da composição da fachada para a remodelação da arquitetura da cidade. Segundo Portoghesi (I997, p. 8, tradução nossa):

Já a cultura maneirista, no tema da fachada compreendida como organismo autônomo não conectado com o interior, havia acentuado que a configuração externa do edifício deveria ser condicionada, mais do que pela coerência entre as duas partes da obra, pelo ambiente citadino - pela medida e pelo tom do espaço à frente.

Logo, os palácios urbanos, mesmo com a grande diversidade de soluções com que poderiam ser apresentados em uma praça ou em uma via linear, não seriam mais concebidos como blocos independentes, fechados em si mesmos como era pressuposto para a cultura renascentista. Pelo contrário, as fachadas expostas no seio da cidade, provenientes das longas mansões da nobreza romana ou dos edifícios vinculados às poderosas ordens religiosas, iriam adquirir uma importância ímpar como modeladoras dos vazios urbanos, parte integrante de um conjunto que definiria os muros de fechamento dos ambientes internos da cidade. O gregarismo e o alinhamento entre os edifícios definiriam os limites das praças, as perspectivas das ruas, as sinuosidades das vias e preparariam o caminho para se atingir os episódios monumentais. A largura das fachadas não estaria, consequentemente, mais atrelada a uma relação de proporção equilibrada com sua altura e profundidade. As frontarias dos palácios poderiam se estender ad infinitum, compondo o cenário urbano de preparação para as grandes surpresas barrocas (Figuras I67-I69). Argan (2004, p. 62, tradução nossa) complementaria:

Agora as fachadas não são mais o plano frontal de um volume fechado (o palácio), mas a superfície-limite de um espaço vazio e aberto: 

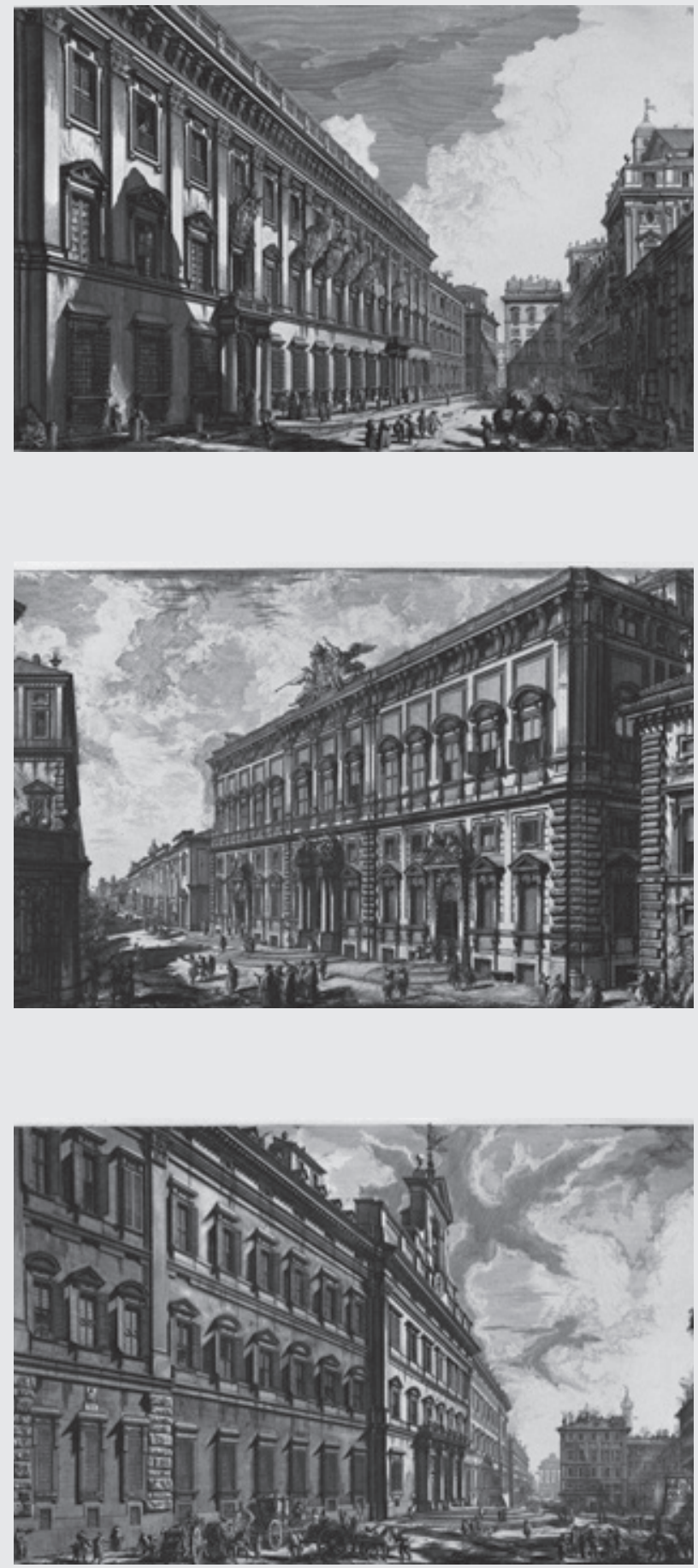

167. Veduta del Palazzo Odescalchi. Por Giambattista Piranesi. O Palazzo ChigiOdescalchi foi projetado por Gian Lorenzo Bernini (1598-1680) e finalizado em 1664. Fonte: Ficacci (2000, p. 710 ).
168. Veduta del Palazzo fabbricato sul Quirinale per le Segretarie de Brevi della Sacra Consulta. Por Piranesi. O Palazzo della Consulta, construído entre 1732-1733, foi projetado por Ferdinando Fuga (1699-1781). Fonte: Ficacci (2000, p. 709).
169. Veduta della Gran Curia Innocenziana, o Palazzo di Montecitorio. Por Piranesi. Vedute di Roma, publicadas em 1798. Projeto do palácio por Gian Lorenzo Bernini, mas alterado por Carlo Fontana (1634-1714). Fonte: Ficacci (2000, p. 715). 
também no campo da urbanística vale o princípio, que se tornará fundamental para a arquitetura, da definição do espaço por meio de limites marginais ao invés de defini-lo por massas e volumes plásticos. Assim, a fachada não é mais medida em relação ao volume plástico do edifício ao qual pertence; é uma superfície que pode ser ilimitadamente estendida [...], e cuja forma arquitetônica é definida pela sucessão rítmica das aberturas. O tecido urbano tende a se tornar regular, uniforme; mas nele os 'monumentos' colocam acentos que se referem aos motivos supremos, ideais, do correto e prosaico 'decoro' urbano.

Contudo, aqueles monumentos, citados por Argan, que mais se destacariam no âmago da Roma barroca, na grande maioria das vezes estariam atrelados a tipologias arquitetônicas vinculadas a usos religiosos, especialmente edifícios de culto - igrejas, capelas, oratórios, basílicas, catedrais -, fato que exigiria uma relação substancialmente mais complexa entre suas fachadas e o espaço urbano que as continha:

[...] sobretudo pela importância que o edifício religioso possui no conjunto urbano, por constituir sempre um elemento monumental em si mesmo, um núcleo de interesse público que corresponde frequentemente a uma praça, raramente está implantado em um alinhamento viário normal. (ARGAN, I973, p. 66, tradução nossa)

Com as revisitadas doutrinas religiosas comandadas pela Contrarreforma, alguns arquitetos do fim do século XVI e início do XVII, como Giacomo della Porta e Carlo Maderno (I556-I629), definiriam novos artifícios em prol da atribuição de uma proeminência fatal às fachadas eclesiásticas, procedimentos que estariam em perfeito acordo com os princípios doutrinários e persuasivos do Barroco - especialmente por estarem sendo praticados em uma cidade sagrada como Roma, a capital da civilização católica. A igreja, consequentemente, iria assumir um compromisso de propaganda que extrapolaria vastamente sua simples condição de espaço para a celebração do culto, alcançando uma dimensão cultural mais expressiva quando lançada como elemento cenográfico ao espaço abençoado da cidade, funcionando, prioritariamente, como instrumento de persuasão - convocando os fiéis para ingressarem em seus domínios.

Contudo, as inúmeras igrejas construídas a partir de finais do século XVI não poderiam usufruir da condição de isolamento comum às concepções ideais 
renascentistas - com algumas exceções parciais, como as igrejas gêmeas de Santa Maria dei Miracoli e Santa Maria di Montesanto, cujos volumes libertos poderiam ser apreciados na Piazza del Popolo, como foi debatido: a maioria dos edifícios estariam destinados a ocupar áreas reduzidas e sem um espaço amplo à frente para sua percepção. Os mestres do Barroco desenvolveriam, consequentemente, uma complexa pesquisa formal de moldagem plástica do frontispício, já que o monumento religioso deveria capturar, a qualquer custo, a atenção e o encanto do passante: interessaria como a frontaria seria percebida enquanto elemento inserido em um contexto preexistente de acordo com as visadas possíveis a serem direcionadas a ela - como o monumento, através do teatral cenário fixo da fachada, poderia se destacar e se dramatizar na praça, no alinhamento da via, no bairro medieval, pois nem sempre seria possível uma transformação significativa do entorno no qual viria a ser assentado. (CONNORS, 2005, p. XII)

Portanto, a fachada promoveria o instante mais efusivo no que concerne ao enredo teatral que se desenvolveria na vivência do espectador que caminhava pela cidade. Cada imagem que ela ofereceria ao transeunte - em escorço, elevação, em profundidade e mesmo oculta ou interrompida - definiria modos de fruição diversos e consequentemente demandaria articulações formais particulares, pois, segundo Argan (2004, p. I26, tradução nossa):

Inserida na parede de uma rua, a fachada da igreja se destaca dos edifícios vizinhos e serve de chamariz: convida a entrar. Somente por este motivo assume uma acentuação espacial e plástica mais marcada do que as fachadas civis, e, em geral, sugere dois movimentos: um em direção ao exterior, à via, e o outro em direção ao interior.

O artista barroco, deste modo, não ostentaria nenhum pudor em considerar a fachada como um elemento meramente cenográfico, voltado exclusivamente à dramatização do contexto urbano aberto à frente - dirigido à conquista do fiel para atraí-lo essencialmente ao espaço, completamente diverso, do interior do monumento. Algumas vezes esta teatralidade, este usufruto da frontaria como um simples cenário voltado à cidade, chegaria a extremos: no Oratorio dei Filippini, projetado pelo mais revolucionário arquiteto do século XVII, Franceso Borromini (I599-I667), e construído a partir de I637, a movimentada fachada côncava sequer coincidiria com o eixo dominante do edifício de culto - a porta principal do monumento daria acesso, como é de praxe, ao fundo da nave da 
igreja, só que transversalmente ao eixo do altar principal, que se desenvolveria longitudinalmente, à esquerda: uma total contrafação do esquema tradicional da arquitetura religiosa em nome da exposição do persuasivo frontispício à direção mais significativa em relação ao contexto imediato do monumento - o princípio propagandista de se voltar a fachada para o público na envolvente praça na qual o Oratorio se levantaria contíguo à grande estrutura maneirista da Igreja de Santa Maria in Vallicella (mais conhecida como Chiesa Nuova), não obstante o dano que esta atitude poderia causar para o usufruto prático da obra (Figuras I70-I73). ${ }^{68}$

Assim, para se alcançar a proeminência em relação ao contexto urbano à frente, e para conquistar o fiel com sua carga retórica, persuasiva, seu apelo aos domínios da imaginação e sua qualidade de organismo teatral voltado ao entretenimento do transeunte, as fachadas eclesiásticas romanas seguiriam, prioritariamente, dois caminhos. A primeira opção seria apreciada, em I855, na primeira edição do revolucionário livro do historiador, filósofo e crítico de arte suíço, Jacob Burckhardt (I8I8-I897), Der Cicerone - Eine Anleitung zum Genuss der Kunstwerke Italien: ${ }^{69}$

Com a fachada de Sant'Ignazio de Algardi e com aquela, plena de colunas, de Sant'Andrea della Valle do Rainaldi, ambas em Roma, a maneira mais robusta da fachada de San Pietro começa a colher seus frutos: um distender e um reentrar dos planos singulares, um alternar-se mais vigoroso dos elementos estruturais acompanhados dos correspondentes rompimentos das cornijas. (A fachada de Sant'lgnazio permanece uma das melhores desta categoria). A interessantíssima fachada de Santa Maria in Campitelli, de Rainaldi, apresenta sobre a parte inferior colunas e meias-colunas de quatro ordens sobre o mesmo eixo. Com particular evidência se revela o princípio pictórico do distender e reentrar dos muros da fachada; a variedade das linhas e o forte efeito de claro-escuro se tornam os fatores principais, em claro contraste com tudo aquilo que é arquitetura. (BURCKHARDT, I994, v. I, p. 405, tradução nossa)

68 A Chiesa Nuova seria construída por artistas menores do século XVI: Matteo da Città di Castello (15281598) levantaria seu interior desde 1575, e Fausto Rughesi terminaria sua fachada em 1606.

69 Aqui foi contemplada a edição de 1994, tradução para o italiano de Paolo Mingazzini e Frederico Pfister, denominada Il cicerone - Guida al godimento dell'arte in Italia. (BURCKHARDT, 1994) 


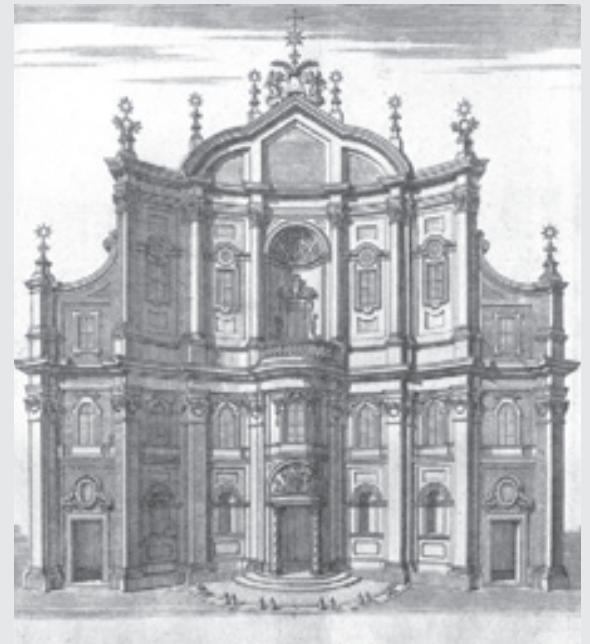

170. Desenho em perspectiva de uma das composições propostas para a fachada do Oratorio di San Filippo Neri, edifício projetado por Francesco Borromini (1599-1667) e construído entre 1637 e 1649 . Percebemse artifícios engenhosos, como a oposição entre a persuasiva e acolhedora fachada côncava e a pronunciada convexidade da parte inferior do eixo central - onde se abriria o suposto acesso principal ao edifício. O desenho foi retirado do livro do arquiteto publicado postumamente em 1725 e intitulado Opus Architectonicum. Fonte: Borromini (1993, tavola v).

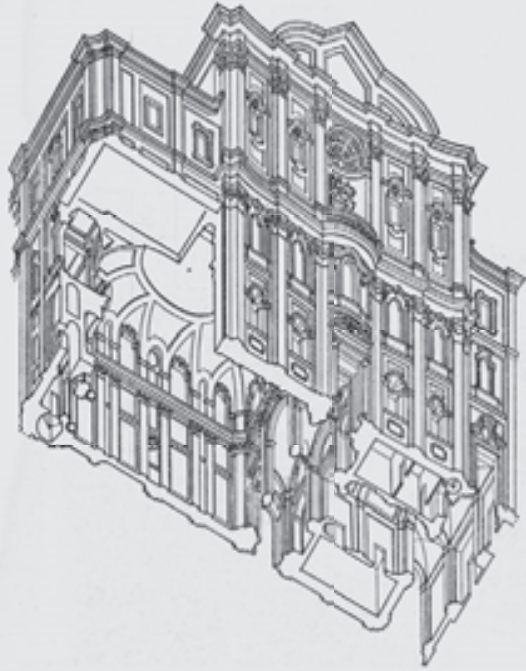

171. Axonométrica (por Paolo Portoghesi) do Oratorio dei Filippini, projetado por Borromini. Notar como a porta principal não coincide com o eixo do oratório. Fonte: Portoghesi (1997, p. 26).

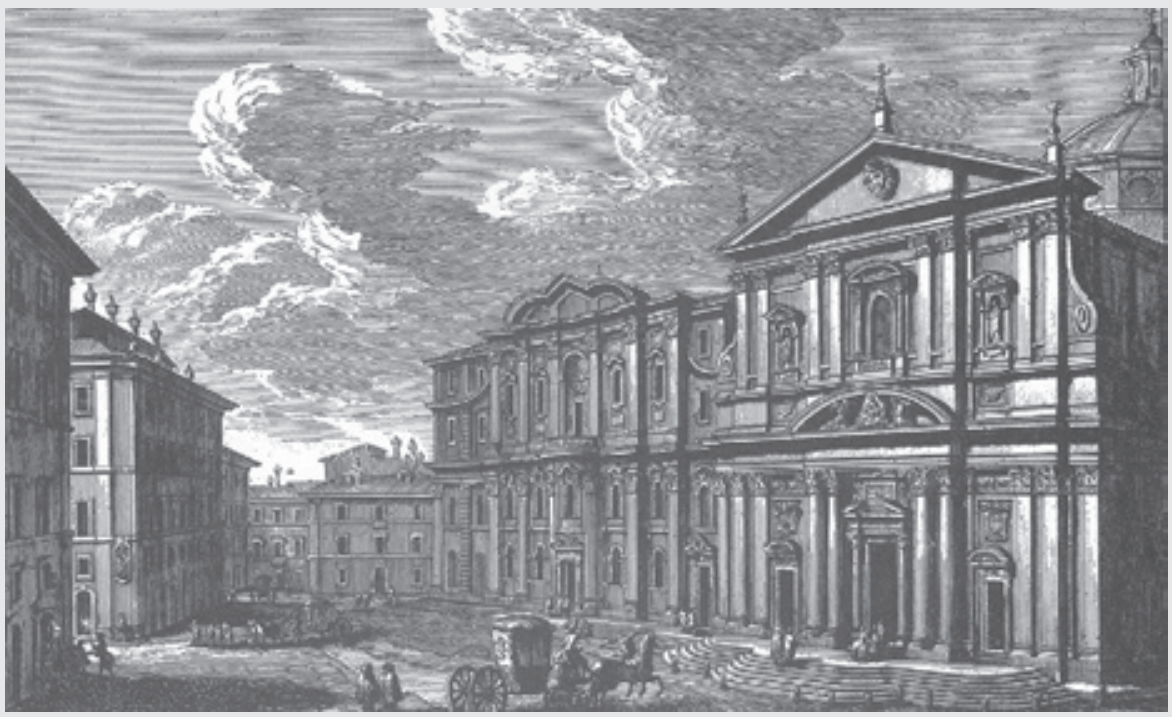

172. Oratorio di San Filippo Neri e a Igreja contígua de Santa Maria in Vallicella - também conhecida como Chiesa Nuova -, cuja fachada foi projetada por Fausto Rughesi e terminada em 1606. Gravura de Guiseppe Vasi, 1747. Fonte: Coen (2003, p. 199). 


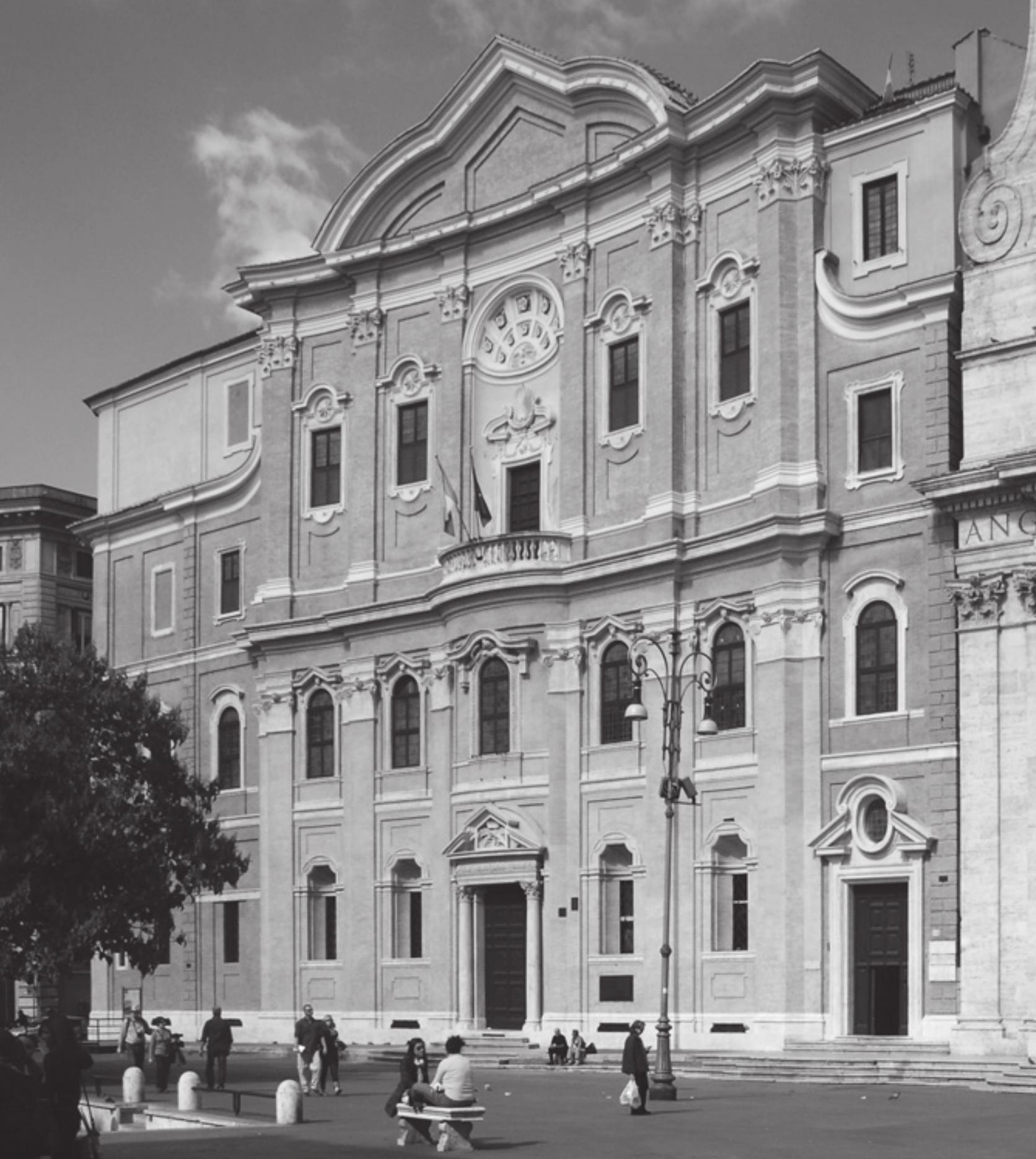

173. Fachada do Oratorio dei Filippini. Fonte: Fotografia elaborada pelo autor (2011). 
As típicas fachadas romanas, derivadas do modelo de Giacomo della Porta para Il Gesù (Figura 174) - frontarias muitas vezes assentadas em apertadas locações, agregadas e contíguas a outras edificações de caráter ordinário, ou ainda alinhadas com os próprios conventos e colégios vinculados àquela ordem religiosa - se apresentariam como robustas paredes fechadas, compostas por uma complicada e profusa modenatura formada pelos elementos reentrantes e salientes citados pelo crítico suíço: conjuntos de pilastras sobrepostas, meias-colunas, colunas de três quartos, colunas engastadas ou mesmo soltas; entablamentos (arquitraves, frisos, cornijas), frontões e tímpanos que se distenderiam e se recuariam para seguir o complexo e pitoresco jogo de claro e escuro gerado pelos seus apoios - a trama plástica agitada pelas ordens clássicas justapostas ao frontispício; os planos superiores e inferiores que avançariam ou recuariam para valorizar uma parte específica da fachada -, frequentemente, seu eixo central, com o objetivo de impelir, categoricamente, o transeunte a invadir o interior do templo (Figura 175).

Estas complexas articulações estariam, obviamente, relacionadas com as visadas principais que a implantação do edifício ofereceria ao espectador: a fachada de uma igreja exposta prioritariamente ao transeunte através de um vista frontal, seja um panorama imediato ou uma imagem em profundidade perspectiva, se mostraria mais atraente e persuasiva se sua composição privilegiasse um impulso mais direto aos planos centrais - uma ênfase ao ponto médio do cenográfico frontispício; já para uma imagem em escorço retirada em direção ao monumento, um desenho que propusesse um efeito de tridimensionalidade para a frontaria, que cadenciasse os elementos verticais através dos graves contrastes de luz e sombra conseguidos pelo uso de profusas reentrâncias e saliências impressas na configuração da modenatura da fachada, seria, provavelmente, mais atraente ao espectador; mas nada impediria que o monumento fosse tratado para ser apreendido em relação a estes dois tipos mais comuns de visadas - como as fachadas das igrejas de Santa Susana (Figura I76), concluída em i603 por Carlo Maderno; Sant'Ignazio, levantada entre i649 e I650 por Alessandro Algardi (I595I654); Sant'Andrea della Valle (Figura I77), construída por Carlo Rainaldi entre I655 e I665; também de Rainaldi, a dramática fachada da Igreja de Santa Maria in Campitelli - terminada em 1667 (Figura I78); Santi Vincenzo e Anastasio, obra de Martino Longhi, il Giovane (I602-I660), concluída em I650 (Figuras I79-I80); entre tantos outros frontispícios cenográficos espalhados pela cidade. 


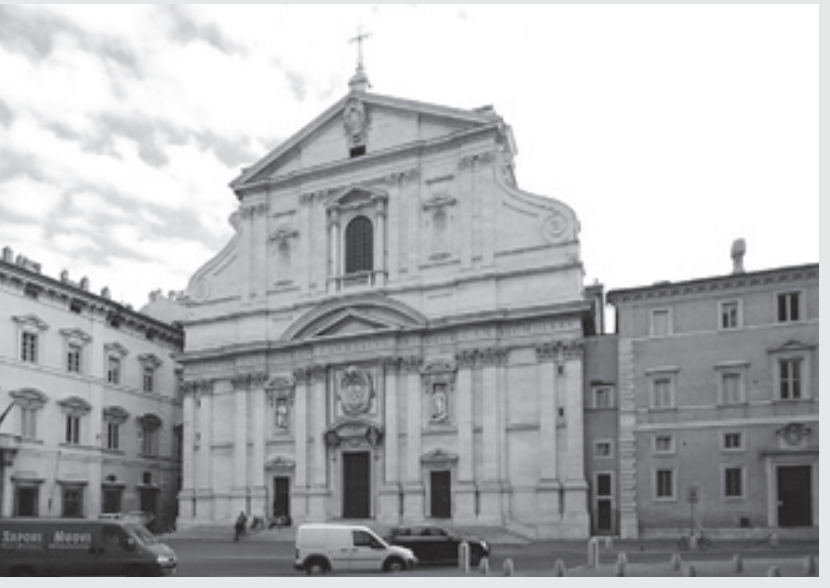

174. Frontispício da Igreja de II Gesù, fachada desenhada por Giacomo della Porta (1532-1602) em 1575. Segundo Wölfflin (1989), II Gesù seria um edifício barroco que se enquadraria, estilisticamente, na chamada "primeira fase do estilo pictórico". Hoje é considerado, paradoxalmente, uma das mais significativas criações da arquitetura maneirista. Ou seja, já no período maneirista os mestres da arquitetura desenvolveriam uma complexa pesquisa formal de moldagem plástica do frontispício dos templos, já que os monumentos religiosos deveriam capturar, a qualquer custo, a atenção e o encanto do passante. Fonte: Fotografia elaborada pelo autor (2011).

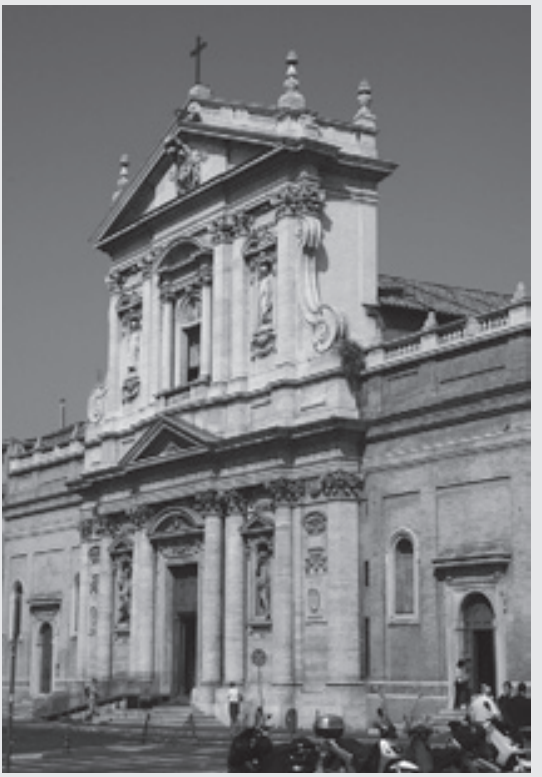

176. Fachada da Igreja de Santa Susana, em Roma. Fonte: Fotografia elaborada pelo autor (2007).

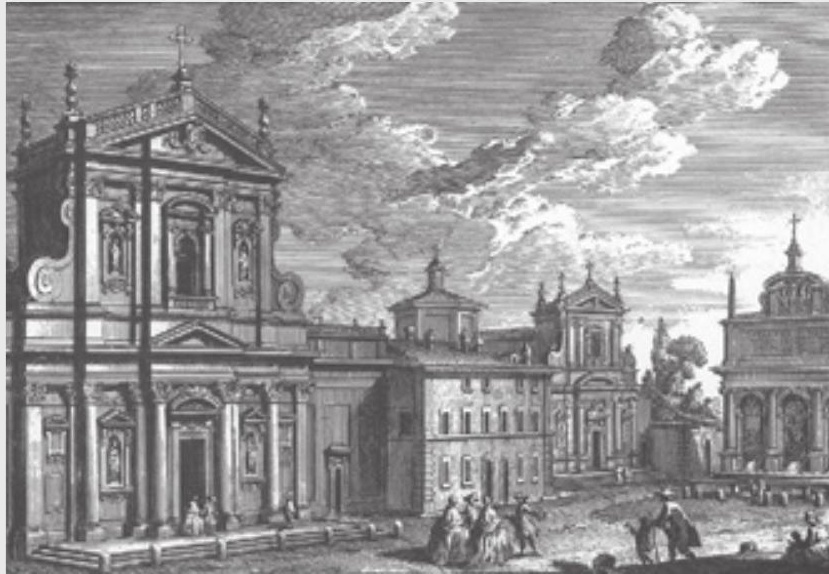

175. Vista de Giuseppe Vasi da Strada Pia, com

destaque para as fachadas da Igreja de Santa Susana, concluída em 1603 por Carlo Maderno (1556-1629), e da Igreja de Santa Maria della Vittoria, cuja frontaria foi projetada em 1626 por Giovanni Battista Soria (15811651) - a estrutura arquitetônica do templo já havia sido concebida e construída por Carlo Maderno. Os frontispícios das duas igrejas marcam a típica fachada do Maneirismo e do Barroco Primitivo romano. Fonte: Coen (2003, p. 193).

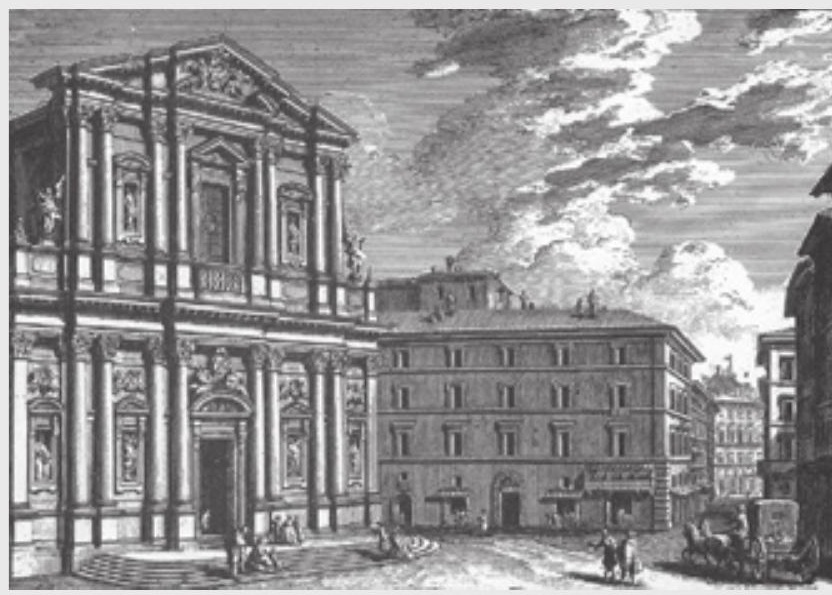

177. Vista de Giuseppe Vasi da fachada da Igreja de Sant'Andrea della Vale, construída por Carlo Rainaldi (1611-1691) entre 1655 e 1665. Fonte: Coen (2003, p. 196). 


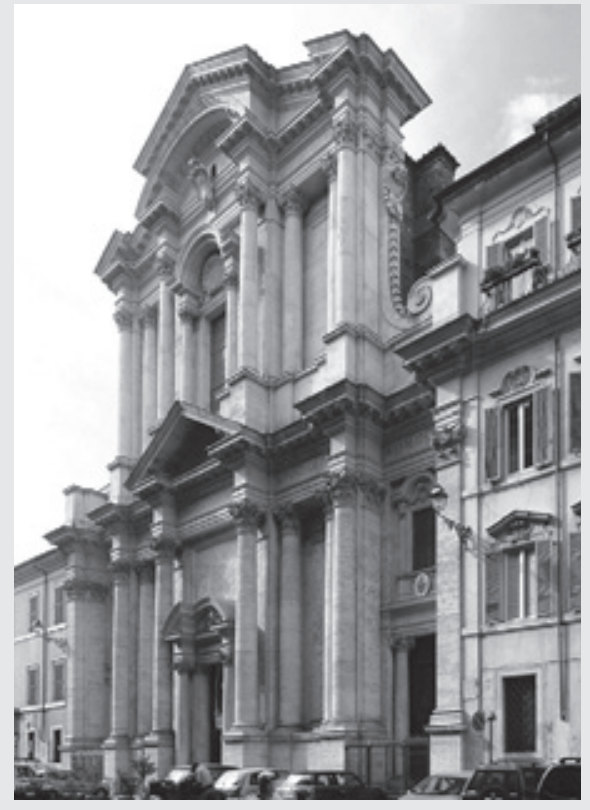

178. Fachada da Igreja de Santa Maria in Campitelli, projetada pelo arquiteto Carlo Rainaldi - terminada em 1667. As gradações de luz e sombra conseguidas através do lançamento dos elementos da modenatura clássica na fachada do edifício dariam a tonalidade pictórica do templo. No caso desta igreja, da segunda metade do século XVII, o arquiteto levaria estes princípios a extremos, libertando francamente parte das colunas da parede da fachada. Fonte: Fotografia elaborada pelo autor (2007).

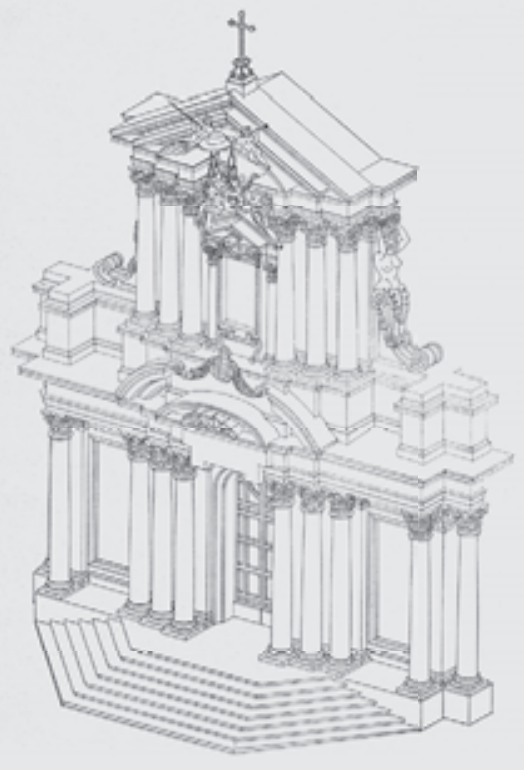

179. Axonométrica, por Portoghesi, da Igreja de Santi Vincenzo e Anastasio, revelando o forte caráter tridimensional do frontispício concebido por Martino Longhi, il Giovane. Fonte: Portoghesi (1997, p. 302).

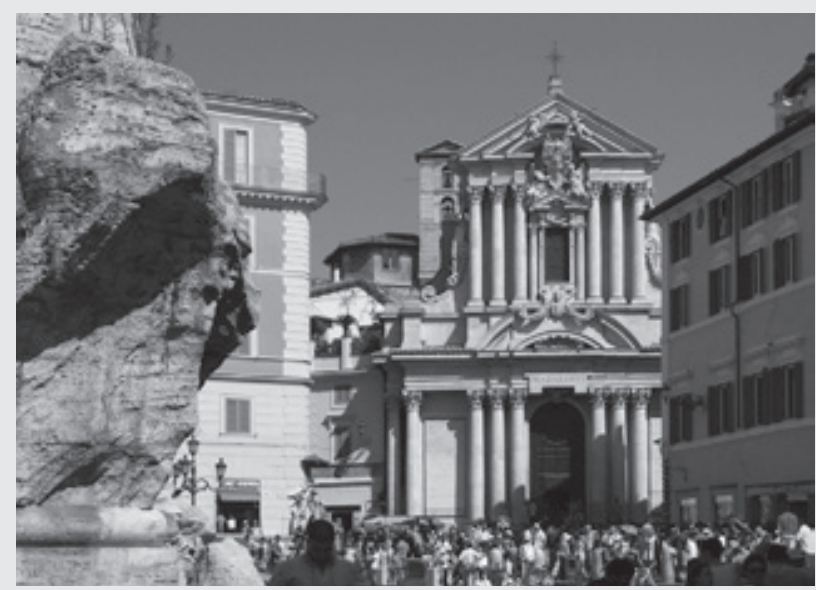

180. Fachada de Santi Vincenzo e Anastasio, obra de Martino Longhi, il Giovane (16021660), concluída em 1650. É impressionante a concentração das três colunas (a cada lado) justapostas em planos salientes - bem como de frontões e tímpanos interpenetrantes para marcar o eixo central e o acesso ao templo. Fonte: Fotografia elaborada pelo autor (2007). 
O outro tipo de fachada religiosa que apresentaria resultados profundamente expressivos na cidade de Roma seria aquele em que a frontaria estaria envolvida por um dinâmico jogo de curvaturas que teriam o poder de movimentar não só a frente do próprio edifício, mas também contaminar o cenário adjacente com a sua agitação - principalmente através do acolhimento envolvente produzido pelo "abraço" das paredes côncavas das fachadas, bem como a sugestiva expansão, para o espaço urbano, das superfícies que encerrariam o frontispício, dilatação provocada quando a igreja estivesse encerrada por formas convexas. Joseph Connors (2005, p. XV) afirmaria que estes expedientes, particularmente a oposição das formas côncavas com as convexas, seriam inclusive utilizados para oferecer, literalmente, a ilusão de que aquele organismo arquitetônico estaria invadindo o espaço urbano à frente, sem que isso efetivamente acontecesse - a solução encontrada para ampliar virtualmente o alinhamento do edifício em uma conjuntura em que a instituição religiosa não pudesse obter a permissão para alargar a construção para além de sua testada. ${ }^{\circ}$ Além destes fatos:

Pelo encurvamento da parede, o barroco alcançava ainda outra finalidade: como o conjunto de frontões, janelas, colunas etc. acompanham a curva, cria-se para o olhar uma impressão extremamente viva de movimento. $\mathrm{O}$ olho vê num mesmo momento formas de natureza semelhante, de ângulos diversos. O efeito é que colunas orientadas segundo eixos diferentes parecem torcer-se e girar continuamente. É como se de repente uma vertigem violenta tivesse se apoderado de todos os elementos. (WÖLFFLIN, I989, p. 77)

Esta violenta vertigem relatada pelo escritor, filósofo, historiador e crítico suíço, Heinrich Wölfflin (I864-I945), em seu precoce livro de I888, Renaissance un Barock - Eine untersuchung über Wesen und Entstehung des Barockstils, ${ }^{71}$ acompanharia diversos edifícios importantes da cidade de Roma, organismos religiosos em que os arquitetos contraporiam, abertamente, as formas côncavas às conve-

70 Connors (2005, p. XV, tradução nossa) exemplifica esta situação com o projeto de Borromini, de 1662 , para a elaboração de uma das fachadas para o jesuítico Collegio di Propaganda Fide: "Para o Collegio di Propaganda Fide, Borromini desenhou uma fachada que no curso da projetação parece escapar ao longo do edifício até se projetar sobre a linha perspéctica da contígua Via della Vite. Os mesmos efeitos que um barão medieval podia criar empregando a força bruta ou um Cardeal Farnese cedendo terreno à municipalidade, uma congregação da época barroca podia obter recorrendo à metáfora."

71 Renascença e Barroco. Estudo sobre a essência do estilo Barroco e a sua origem na Itália (WÖLFFLIN, 1989). Versão para o português de Mary Amazonas Leite de Barros e Antonio Steffen. 
xas: a fachada convexa de Santi Luca e Martina, levantada desde i634 por Pietro da Cortona (I596-I669) - com a forma ligeiramente expansiva do frontispício, emoldurada nos cantos por dois pequenos segmentos salientes de parede compostos por ordens sobrepostas de pilastras jônicas e compósitas; de Borromini, o Oratorio dei Filippini - monumento no qual o portal principal, em seu plano inferior, apresentaria uma expansiva forma convexa em grave contraste com a envolvente superfície côncava que deslocaria todo o resto da parede do frontispício; a fachada da Capela de San Carlo alle Quattro Fontane, também construída por Borromini em I667 - um complicado emaranhado de elementos curvos reentrantes e salientes que provocariam, mutuamente, a flexão do frontispício; Sant'Andrea al Quirinale, de Bernini - com seus envolventes muros laterais côncavos em contraste com seu corpo elíptico convexo -, igreja levantada entre I658 e I670 (Figuras I8I-I82); a pequena e esguia fachada de La Maddalena, concluída por Giuseppe Sardi (I680-I753) em I735 - claramente inspirada na conturbada obra do mestre lombardo, Francesco Borromini; a nova e oscilante frontaria convexa levantada em I743 para a Basílica de Santa Croce in Gerusalemme (Figura I83), obra de Domenico Gregorini (I692-I777) e Pietro Passalacqua (I690-I748); entre tantas outras fachadas curvilíneas do Barroco romano.

Para além disso, estas expressivas e independentes fachadas apresentariam uma relação profundamente complexa com o espaço interno do monumento. $\mathrm{Na}$ verdade, a casca externa do edifício guardaria um universo misterioso: o acesso ao seu âmago processar-se-ia como mais uma surpresa preparada para quem vivenciasse o grande espetáculo encenado na cidade barroca - uma experiência em que o limite do espaço real seria definitivamente rompido para se abrir a uma viagem fantástica, a uma experiência imaginativa singular, inesperada. A fachada, portanto, poria em comunicação o espaço interior com o exterior, invocando o transeunte a descobrir o que se esconderia dentro do invólucro. Para isso, direcionaria o olhar ao eixo principal de acesso do frontispício e movimentaria a superfície com reentrâncias e saliências, com curvas e contracurvas, de forma a propor, ilusionisticamente, uma instabilidade frente à abrupta separação entre os ambientes internos e externos - uma sensação de que o coração do monumento desejasse romper as paredes externas, que, por sua vez, tentariam conter esta força. O resultado da relação entre estes dois impulsos antitéticos apareceria na articulação complexa da fachada, na absorção diferenciada da luz promovida pelos diversos planos, perfis, nichos e, finalmente, na contraposição entre as projeções 


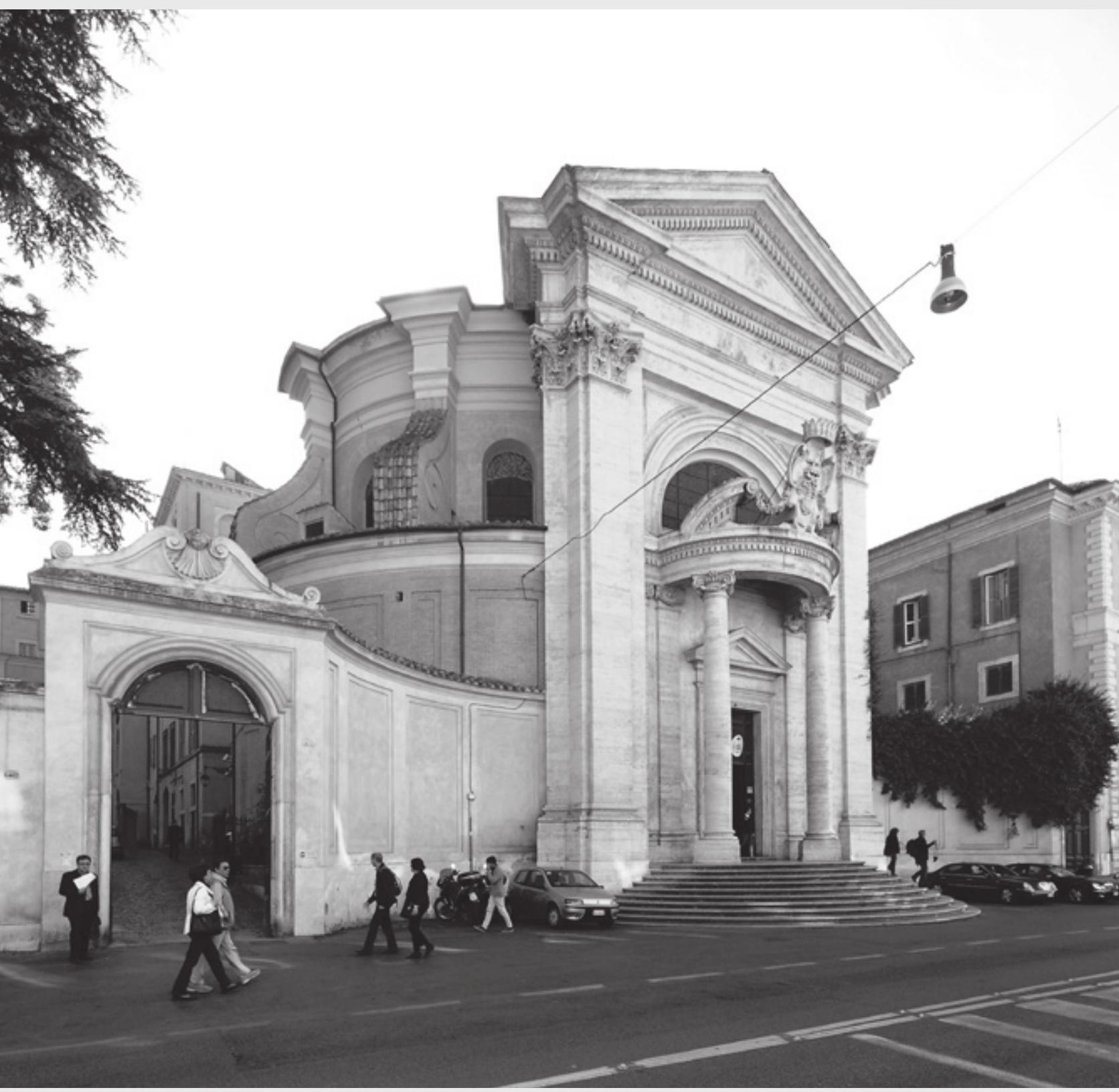

181. Fachada da Igreja de Sant'Andrea al Quirinale. Projetada por Gian Lorenzo Bernini e construída entre 1658 e 1670. Os muros côncavos da fachada produziriam uma forte sensação de acolhimento no recuo gerado na estreita Via del Quirinale (antiga Strada Pia) e atrairiam o fiel para seu espaço interno através da escadaria que invadiria, categoricamente, o espaço da via. Para além disso, a concavidade dos muros entraria em oposição com a convexidade da escadaria, com a poderosa fachada clássica e com a própria forma elíptica do edifício - revelada por detrás de toda a composição. Fonte: Fotografia elaborada pelo autor (2011). 


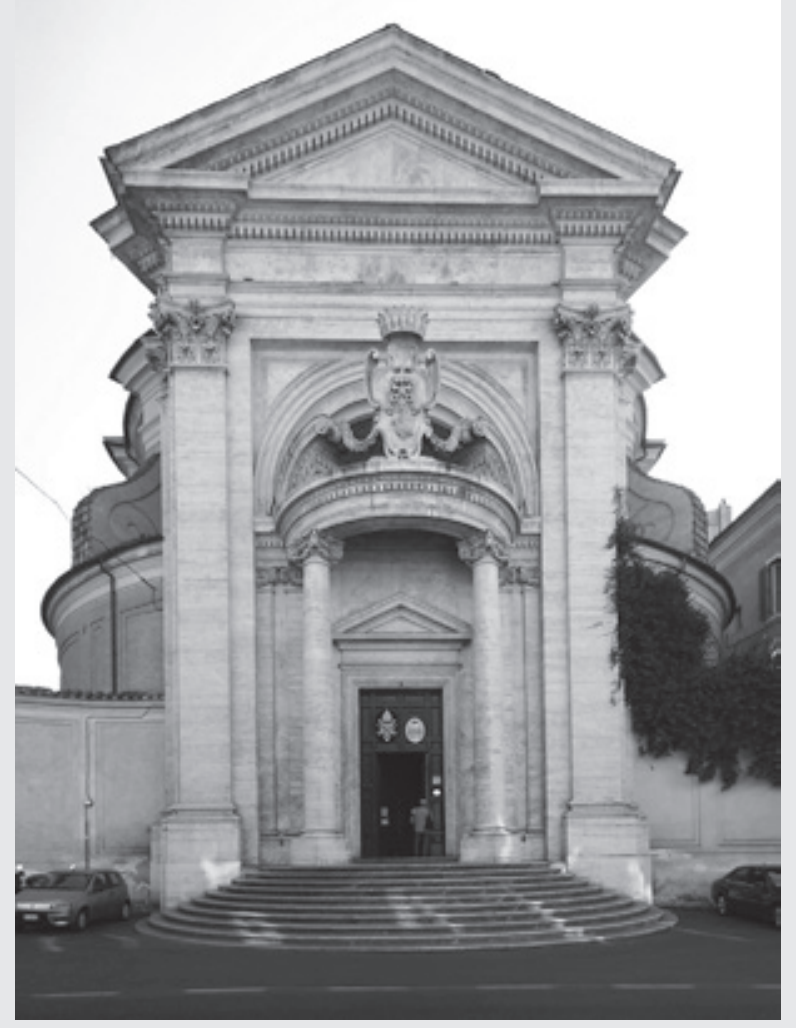

182. Vigoroso frontispício clássico da Igreja de Sant'Andrea al Quirinale, apresentando seu elaborado jogo persuasivo de concavidades e convexidades. Fonte: Fotografia elaborada pelo autor (2011).

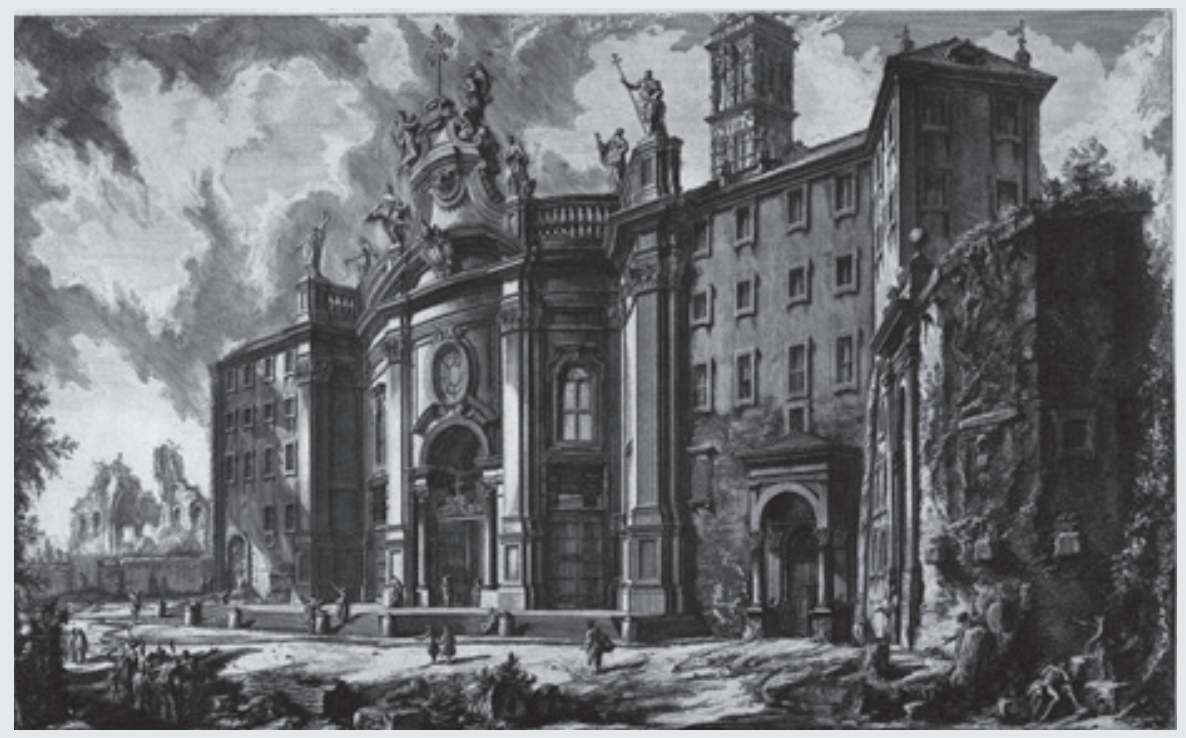

183. Veduta della Facciata della Basilica di S. Croce in Gerusalemme, obra de Domenico Gregorini (1692-1777) e Pietro Passalacqua (1690-1748) - 1743. Por Giambattista Piranesi. Fonte: Ficacci (2000, p. 708). 
côncavas e convexas, na sinuosidade geral da superfície - e revelaria, fundamentalmente, que o recinto interior das igrejas, mas também aquele dos palácios ou de qualquer outro edifício público, deveria ser compreendido como um espaço urbano, igual a uma rua ou a uma praça. Argan (2004, p. I3I, tradução nossa) concluiria:

Se adverte já que o espaço urbano não é mais apenas aquele das ruas e das praças: o espaço interno de uma igreja, ou do saguão, ou do pátio, ou da escadaria de um palácio não é menos urbanístico pelo fato de estar fechado ao invés de aberto. É também um espaço social; a vida da cidade circula também nestes espaços fechados. Portanto a fachada não é uma barreira, mas um diafragma; não fecha ou isola, mas põe em comunicação, por assim dizer, osmótica duas entidades espaciais, distintas em sua escala e intensidade luminosa, mas de igual interesse urbanístico e funcional. Visivelmente, este duplo impulso em direção ao exterior e ao interior se manifesta de dois modos, frequentemente combinados entre si: I) a alternância de corpos plásticos emergentes (colunas, pilastras, frontões, cornijas), nichos e reentrâncias prospectivas; 2) a flexão das superfícies, com curvaturas contrapostas, côncavas e convexas.

Após esta apreciação genérica do poder que as frontarias dos monumentos da Roma barroca assimilariam em transfigurar o espaço urbano, seria importante avaliar, brevemente, alguns dos mais significativos eventos arquitetônicos fundados na cidade, tanto pela iniciativa pública quanto por ações de particulares, análise calcada, essencialmente, no caráter morfológico e artístico dos organismos arquitetônicos, na sua interface com o contexto paisagístico preexistente ou em formação - uma pequena amostragem dos acontecimentos dramáticos que o espaço urbano passaria a acolher nos séculos XVII e XVIII.

\section{Piazza Navona e imediações}

Um dos elementos fundamentais da originalidade do plano sistino está no fato dele ter evitado ao máximo intervir no núcleo central da cidade - como usualmente haviam feito os seus predecessores operando aqueles dilaceramentos que teriam permitido substituir com novas vias retilíneas, as velhas vias tortuosas e irregulares. Ter concentrado as próprias intervenções em uma zona como aquela entre Santa Maria Maggiore, San Giovani e Piazza Venezia, escassamente habitada 
e privada de construções importantes, teve como resultado direto a criação de diretrizes para expansões múltiplas, com uma consequente disponibilidade de áreas edificáveis das mais diversas variedades, diminuindo a exigência de transformação do centro e tornando possível a conservação de grande parte do tecido viário medieval e a sua lenta transformação desde seu interior, através de um verdadeiro e próprio processo de substituição celular. (PORTOGHESI, I997, p. 43, tradução nossa)

As palavras proferidas pelo arquiteto Paolo Portoghesi, em seu vasto estudo sobre a Roma barroca, demonstrariam como Sisto V e Domenico Fontana não só impulsionariam a ocupação e o desenvolvimento urbano das áreas desoladas nas quais seriam implantadas seu novo sistema viário, mas também incentivariam a lenta transfiguração barroca da cidade. Ao não tocarem no núcleo central da urbe, o pontífice e seu arquiteto acabariam decretando, indiretamente, o lento processo de transformação da área densa dos rioni medievais e renascentistas, aquele gradativo mecanismo de "substituição celular" da massa edificada relatado por Portoghesi, através da inclusão ou recuperação pontual de monumentos e espaços públicos - ou seja, permitiriam o desabrochar cenográfico (CONNORS, 2005, p. VIII) do cerne da cidade preexistente por meio das intervenções barrocas setorizadas que o núcleo edificado receberia no Seicento e no Settecento, e das consequentes alterações urbanas de pequena escala que seriam agenciadas por todos os bairros, mutações que pouco esbarrariam no tecido tradicional (já que o plano de Sisto $V$ seria a última iniciativa urbanística de grande porte que a cidade sofreria nos próximos 150 anos).

Neste sentido, a teatral Piazza Navona - recinto aberto no Rione Parione e que viria a se configurar como o epicentro da Roma Barroca - seria um dos mais significativos eventos barrocos revelados na área central da cidade, um exuberante acontecimento dramático inserido no processo de transmutação que a massa urbana preexistente abrigaria. Para se alcançar o evento desde o ingresso à cidade pela Piazza del Popolo, o espectador deveria assumir o percurso da Via di Ripetta - a avenida do tridente que se abriria para o sentido oeste - e seguir toda a sua extensão perspectiva em direção ao coração de Roma. No encerramento do vasto logradouro linear - após mais de um quilômetro de percurso, quando a via já teria adquirido a denominação de Via della Scrofa -, o transeunte alcançaria as imediações da praça que acolheria a Igreja de San Luigi dei Francesi. Neste ponto da cidade, para se chegar à Piazza Navona, bastaria que o passante ingressasse em 
algumas das vielas que surgiriam à direita e caminhasse em direção a Parione, que brevemente irromperia na grande praça cruzando uma das curtas e estreitas travessas que lhe davam acesso.

A Piazza Navona seria, na verdade, fruto de um desenvolvimento morfológico e espacial que duraria mais de mil e seiscentos anos. Seria basicamente constituída pelo vazio resultante do assentamento de uma série de edifícios alinhados acima das fundações e das paredes remanescentes do antigo Stadio di Domiziano (também conhecido como Circus Agonalis), monumental estrutura arquitetônica construída por volta do ano 86 pelo Imperador Titus Flavius Domitianus (5I-96) - que governaria Roma de 8I até sua morte (Figura I84). A praça em si começaria a tomar forma apenas na segunda metade do Quattrocento, quando o mercado da ainda decadente cidade seria transferido do pé do morro do Campidoglio, abaixo da Igreja de Santa Maria in Aracoeli, para o ambiente desocupado acolhido pelas ruínas do ancestral estádio - vestígios arquitetônicos que começariam a apoiar as precárias construções sobrepostas às estruturas que antes recebiam as arquibancadas nas quais a plebe e a nobreza apreciavam os atletas. Pouco mais tarde, talvez pela sua grande dimensão e pela sua implantação privilegiada em relação aos burgos medievais e renascentistas, a praça também iria se transformar em uma das mais importantes locações dirigidas ao abrigo de festas populares e religiosas, eventos que mobilizavam quase toda a população em especais ocasiões. Finalmente, no último quartel do Cinquecento - quando já contaria com uma configuração morfológica condizente com a de hoje -, seriam edificadas, sob o patrocínio do Papa Gregório XIll, duas fontes nos extremos norte e sul da nova praça: amplamenta alteradas nos séculos subsequentes, foram concebidas por Giacomo della Porta, entre 1575 e I576, como amplas e polilobadas bacias que dariam apoio aos serviços do mercado, bem como para matar a sede dos animais que ali acorriam com suas cargas.

No que se refere à morfologia, o enclausurado espaço interno da Piazza Navona seguiria, precisamente, o desenho do estádio romano, apresentando uma dimensão de mais de 260 metros de comprimento longitudinal e pouco mais de 50 metros de largura (calcula-se que o estádio poderia acolher até 30.000 espectadores). Sua face norte, côncava, e seu lado sul, achatado, também seriam provenientes da forma do antigo edifício imperial. E não só o alinhamento das construções ordinárias, palácios, palacetes e igrejas - edifícios voltados para a cavidade interna da praça - coincidiria rigorosamente com os limites do campo 
esportivo, mas também a parte posterior destas estruturas estaria acomodada seguindo à risca a testada das paredes exteriores do estádio (Figura I85).

Apesar desta fascinante apropriação do design do edifício preexistente para a configuração da imensa praça, quando o espectador vencia o apertado e tortuoso tecido urbano que antecedia o ambiente e ingressava em seus domínios por uma das oito estreitas travessas que lhe dariam acesso - passagens que não retiravam em nada o caráter fechado do recinto -, o que mais o chamaria atenção seria, definitivamente, o conjunto dos cenográficos monumentos que despontariam em seu espaço. Estas obras-primas, concebidas pelos maiores artistas da época os arquirrivais Gian Lorenzo Bernini e Francesco Borromini -, seriam edificadas sob o patrocínio do Cardeal Giovanni Battista Pamphilj (I574-I655), que acabava de assumir o comando da Igreja como o Papa Innocenzo X (tendo governado a Santa Sé de i644 até sua morte).

Entre I648 e I65I, Bernini conceberia a espetacular Fontana dei Fiumi, levantada no centro da praça - fonte que acolheria o Obelisco Agonale, transferido das ruínas do Circo di Massenzio para o seu cume, em I649.72 Já em I653, o grande mestre remodelaria a fonte de Giacomo della Porta que marcava a zona meridional da praça, acrescentando à bacia preexistente uma dramática trama escultórica formada por diversas e dinâmicas figuras - o conjunto ficaria conhecido como Fontana del Moro.73 Borromini, por sua vez, entre I653 e I657, alteraria profundamente o projeto e complementaria a construção da Igreja de Sant'Agnese in Agone, iniciada por Girolamo Rainaldi (1570-I655) e seu filho Carlo Rainaldi grandiosa igreja idealizada como uma espécie de capela monumental contigua ao palácio de propriedade do Papa Giovanni Pamphilj, edificado desde I630 por Girolamo Rainaldi, mas também alterado por Borromini.

$\mathrm{Na}$ verdade, Innocenzo X remodelaria a Piazza Navona patrocinando as inserções de importantes monumentos em seus domínios, pois pretendia apresentá-la à população como uma espécie de antessala teatral para a sua moradia no Palazzo Pamphilj, demonstrando o vínculo do pontífice aos mecanismos culturais da época barroca (Figura I86).

72 Monumento confeccionado na época do Imperador Domiziano imitando os obeliscos egípcios trazidos para Roma - transferido para o Circo di Massenzio cerca de 150 anos depois, em $311 \mathrm{~d}$. C.

73 A terceira fonte, também construída por Giacomo della Porta, ocupando a área setentrional da praça, só seria adornada em finais do século XIX, mais precisamente em 1873. É conhecida hoje como Fontana del Nettuno. 


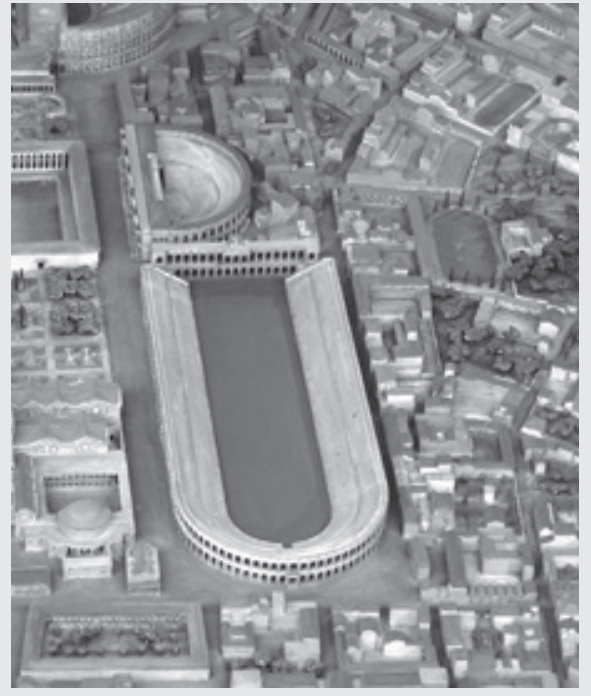

184. Detalhe da maquete da Roma antiga realizada a partir de 1937 pelo arqueólogo Italo Gismondi (18871974), conservada no Museo della Civiltà Romana, em Roma. Em destaque, o Circo Agonale. Fonte: Fotografia elaborada pelo autor (2007).

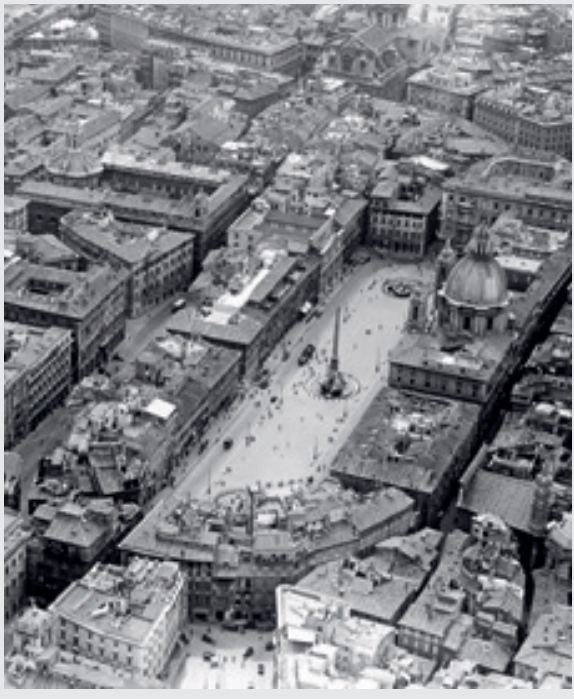

185. Fotografia de 1930 da aérea da região do Pantheon e da Piazza Navona. É interessante notar como tanto o vazio da praça como os quarteirões que a circulam seguem rigorosamente o desenho do antigo Circo Agonale. Em destaque, a Fontana del Moro (acima) e a Fontana del Nettuno (abaixo). Também em destaque, marcando o centro da praça, a Fontana dei Quattro Fiumi com seu obelisco - mas também a Igreja de Sant'Agnese com suas esbeltas torres e alta cúpula. Fonte: Site Roma ieri oggi.

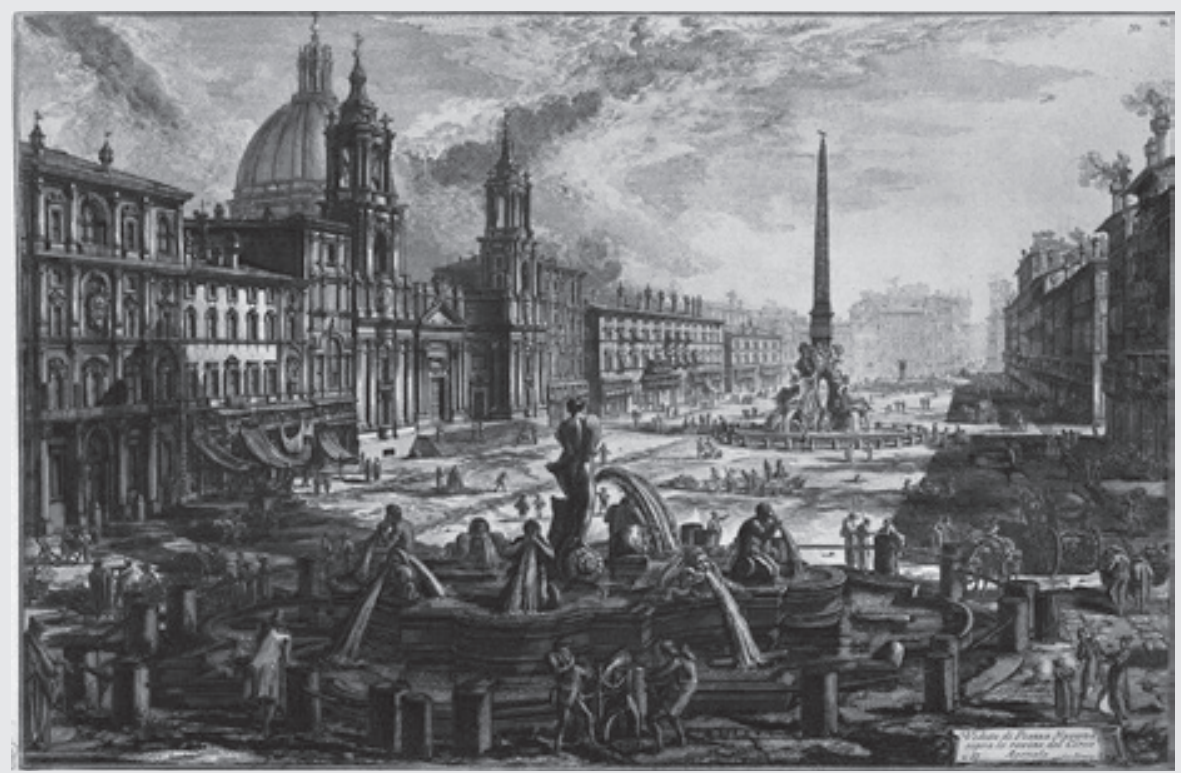

186. Veduta di Piazza Navona sopra le rovine del Circo Agonale. Por Giambattista Piranesi, Vedute di Roma, publicado em 1798. Vista da praça a partir do acesso sul. Fonte: Ficacci (2000, p. 690). 
Portanto, todos os monumentos lançados na praça - sejam as fontes, o obelisco, o palácio, ou a igreja - viriam a assumir, imediatamente, uma forte condição cenográfica e um caráter plenamente urbanístico. As duas fontes de Giacomo della Porta lançadas em seus extremos, independente da exuberante configuração escultórica que receberiam respectivamente nos séculos XVII e XIX, já contribuíam para ressaltar, sugestivamente, o desenho longilíneo do antigo estádio e, logo, o impulso direcional da piazza barroca. Na verdade, o comprimento da praça seria cinco vezes maior que a sua largura, oferecendo, naturalmente, uma axialidade marcada por um eixo dominante que se estenderia paralelo aos lados maiores da praça. Este eixo seria sublinhado pelas duas fontes locadas nos cantos da praça e coincidentes geometricamente com a linha imaginária longitudinal.

No entanto, mais importante para configuração artística e urbanística do espaço seria a ereção da outra fonte concebida por Bernini e implantada no centro geométrico do recinto, uma das obras mais espetaculares e inusitadas do escultor e arquiteto, mestre do barroco romano. O emérito historiador da arte alemão, Rudolf Wittkower (I90I-I97I), discorrendo sobre a Fontana dei Fiumi em sua monografia publicada em 1955 e intitulada Bernini. The sculptor of the roman baroque, afirmaria:

No centro da Piazza Navona se levanta a Fonte dos Quatro Rios, o maior e mais celebrado trabalho de Bernini neste campo, executada entre I648 e I65I. O desafio urbanístico deste empreendimento era extremamente complicado. Ele deveria erigir um monumento suficientemente grande para enfatizar definitivamente o centro da comprida praça sem prejudicar sua unidade; ao mesmo tempo, a fonte - não implantada axialmente em relação à fachada de Sant'Agnese - tinha que se ajustar à igreja barroca que havia sido apenas projetada, mas ainda não executada. Um recife 'natural', banhado por amplos mananciais, perfurado por aberturas nos pequenos e nos grandes eixos, coroado por uma gigantesca agulha egípcia: barreira e conexão, acompanhamento para os campanários e contraste; expansão e diversidade perto do solo, e na direção vertical, dureza, uniformidade e sutileza; fonte e monumento; improvisação e simbolismo de permanência supra-humana - estas aparentes contradições indicam a resposta engenhosa encontrada por Bernini a este problema. (WITTKOWER, 2002, p. I75, tradução nossa)

O monumento descrito por Wittkower, mesmo sendo um organismo fortemente enraizado, seria absolutamente leve e permeável, sensação conseguida 
pela presença de vastas aberturas perfuradas nas rochas. Esta transparência parcial do grande bloco inferior de mármore branco, grupo que imitava a presença de rochas naturais que se interpunham, acenderia o sentimento de que o pesado Obelisco Agonale flutuava no âmago da Piazza Navona. Além disso, a fonte se mostrava expansiva e dinâmica, justamente devido à presença dos informes recifes de pedra que se espraiavam no ponto médio da praça, bem como pelo movimento dos gigantes dispostos aos seus quatro lados - seres antropomórficos que representavam, com suas feições diversas, os quatro grandes rios do mundo. ${ }^{74}$ Contudo, contrariando o direcionamento longitudinal natural do recinto, a Fontana dei Quattro Fiumi marcaria, drasticamente, o centro do ambiente através do impulso vertical proveniente do esguio obelisco egípcio justaposto acima do conjunto escultórico, pairando no ponto médio da praça - rompendo, após séculos, a prioritária conformação axial do Stadio Domiziano. A força expressiva da criação de Bernini conseguiria, sem dúvida, impor um novo acolhimento centrípeto, nunca antes absorvido (Figuras I87-I90).

Todavia, este direcionamento centralizador não ficaria ao encargo exclusivo da linha vertical do obelisco, mas entraria em forte conexão com a lgreja de Sant'Agnese in Agone, construída, quase em frente, pelos Rainaldi - e logo alterada por Borromini. Os arquitetos dispunham de um terreno de grande testada para assentar seu edifício, mas não usufruíam de uma profundidade significativa devido ao exíguo comprimento longitudinal de cerca de 40 metros do terreno, dimensão derivada da largura da plateia do antigo estádio - além do fato de, por trás do edifício, passar a estreita Via di Santa Maria dell'Anima, rua alinhada com o que seria a alta parede externa do monumento da Roma imperial. Em função disto, os Rainaldi projetariam um templo de planta central com uma cúpula - que usualmente só cobriria o cruzeiro - ocupando quase toda a extensão longitudinal da construção, chegando a se configurar como a própria nave da igreja, praticamente tangenciando a fachada e os fundos do edifício.

Tirando proveito destas características, Borromini conceberia, a posteriori, uma extensa fachada, muito baixa, e pronunciadamente côncava, emoldurada aos dois lados por dinâmicos e leves campanários, que por sua vez enquadrariam, perspecticamente, a enorme e delgada cúpula. O domo apresentaria um alto tambor, uma esguia calota oblonga, e uma lanterna verticalizada, conjunto 


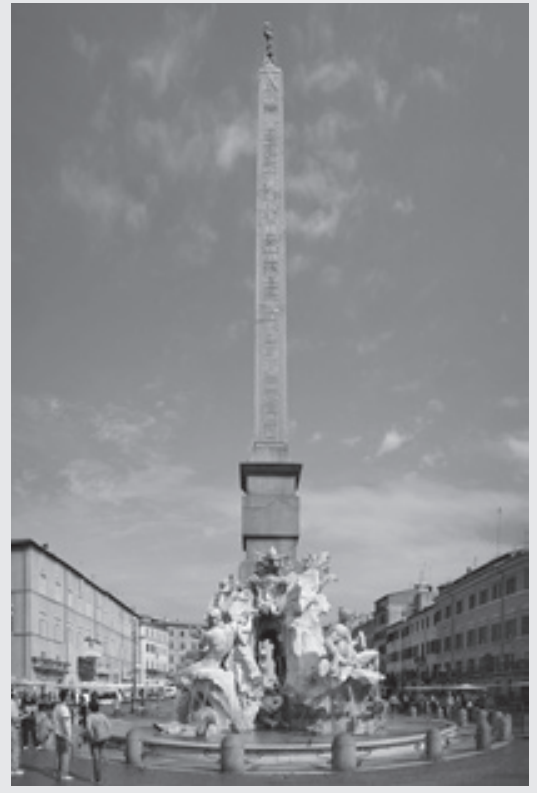

187. Fontana dei Quattro Fiumi com o Obelisco Agonale - peça que parece flutuar acima da fonte, acima do vão aberto em meio às rochas. $\mathrm{O}$ obelisco foi confeccionado por Titus Flavius Domitianus (51-96) imitando os obeliscos egípcios. Fonte: Fotografia elaborada por Ferras - Licença CC BY-SA 2.5 / Wikimedia Commons contributors.

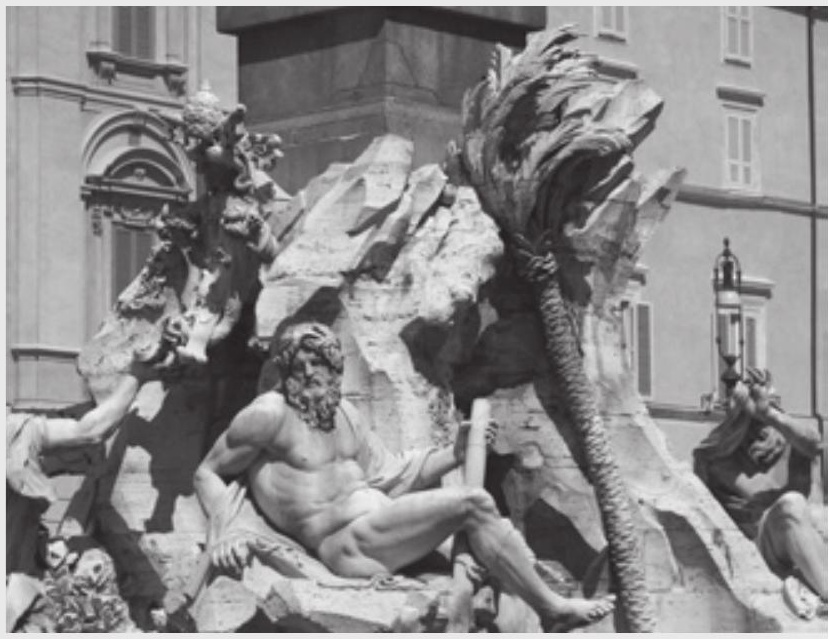

188. Fontana dei Quattro Fiumi. Representação do Rio Ganges. Fonte: Fotografia elaborada pelo autor (2007).

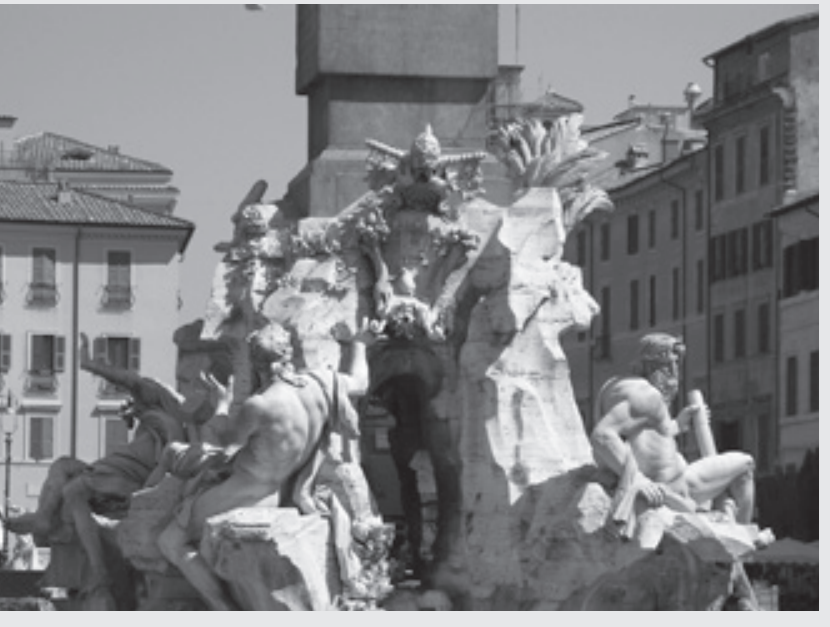

189. Fontana dei Fiumi. Representações do Rio de La Plata, do Rio Danúbio e do Rio Ganges. Destaque para o vão aberto em meio às rochas. Fonte: Fotografia elaborada pelo autor (2007).

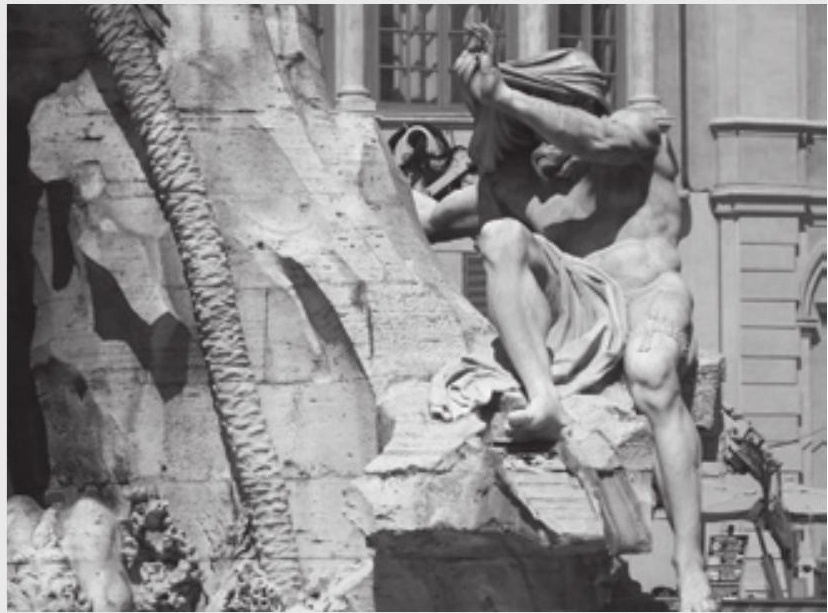

190. Fontana dei Fiumi. Representações do Rio Nilo. Fonte: Fotografia elaborada pelo autor (2007). 
que se voltaria plenamente aos domínios visuais da praça: não só por alcançar uma elevação extremamente significativa, superando em muito a altura das duas torres - elevação enfatizada pela baixa estatura da frente do edifício -, mas principalmente em função do tambor estar praticamente engastado na frontaria - invertendo a tendência contemporânea de esconder perspectivamente a cúpula pelo avanço da nave longitudinal e pelo alto frontispício. A concavidade da fachada, além de oferecer um sentimento de profundo acolhimento para aqueles que visitavam a praça, impelindo o espectador a ingressar no rico espaço interior da igreja, acabaria provocando uma fatal valorização da cúpula, integrando-a, decisivamente, ao vazio disposto à frente: o cavado frontispício ofereceria, virtualmente, a ideia de que o conjunto tambor-cúpula-lanterna estaria sendo simbolicamente arremessado para o espaço interno da praça, pois a concavidade da fachada recuaria ilusionisticamente o paramento frontal, enquanto o poderoso domo, enquadrado pelos campanários - que por sua vez produziriam um atraente contraponto vertical para a alta lanterna, bem como um contraste entre a sua forma vazada e o peso excessivo da cúpula -, se expandiria e se projetaria sugestivamente, buscando o vazio.

Não obstante, impressionaria ainda mais a relação que este grande edifício guardaria com a fonte projetada pelo arquirrival de Borromini assentada logo à frente. Nada seria mais lógico que os mestres, mesmo sendo inimigos mortais, promovessem uma sutil interface entre os dois monumentos em prol da ostentação da nova realidade persuasiva que celebraria o espaço central da praça como o ambiente mais importante do recinto, superando sua antiga direção dominante desenvolvida em profundidade. Contudo, aparentemente, os dois monumentos estariam em certa incompatibilidade compositiva, já que, como atestaria Wittkower, a fonte de Bernini não estaria implantada no alinhamento do eixo da fachada e da cúpula da Igreja de Sant'Agnese; pelo contrário, estaria deslocada frente ao portal de acesso ao templo (Figura I9I). É verdade que esta relação de entorse entre os dois monumentos revelaria imagens em escorço muito atraentes para aquele transeunte que, saindo do denso tecido medieval preexistente, alcançasse a fechada praça por uma das cinco travessas abertas nas suas faces menores: o espectador se depararia com a cenográfica imagem em profundidade perspéctica da praça, com a Fontana dei Fiumi e a Igreja de Santa Agnese apontando bem à frente, marcando os novos direcionamentos verticais e centrípetos, capturados em atraentes panoramas diagonais, em ricos escorços (Figuras I92-I93). Por outro 
lado, ao se aproximar do centro da praça, o passante poderia apreciar a fachada da igreja em perfeita elevação, sem a interrupção visual do conjunto da fonte.

Mas, a relação entre os dois monumentos não acabaria nestes últimos artifícios da retórica barroca: a vivência individual do espaço delataria que quando o espectador irrompesse no recinto, cruzando o único acesso que se abria diretamente para as duas obras - a Corsia Agonale, travessa rasgada na direção leste, em frente à fonte e à igreja -, se depararia, repentinamente, com uma poderosa imagem: o obelisco seria visto no eixo central da igreja de Borromini, pois, ao alcançar a praça, a viela imporia, subitamente, uma vista diagonal em direção à fachada do templo: panorama que seria interrompido pela estrutura da Fontana dei Fiumi, que se apresentaria ilusionisticamente no ponto médio da frontaria. Ou seja, a fonte e seu obelisco estariam locados na linha coincidente com o direcionamento oblíquo que ligaria, virtualmente, a abertura da Corsia Agonale ao eixo central do frontispício côncavo de Sant’Agnese in Agone (Figuras I94-I95).

Mais uma vez, o conceito dos "modos de visão" (ARGAN, I973, p. 79) comandaria a composição barroca: o que importava não era o que existia objetivamente, o desenho real do espaço, mas o que se via. Se a Fontana dei Fiumi estivesse, de fato, no eixo da fachada, o primeiro panorama que o transeunte que ingressasse na praça pela Corsia Agonale capturaria ao direcionar o olhar para a igreja seria a frustrante imagem do obelisco deslocado em relação ao eixo da fachada - em função da distorção perspectiva que seria gerada. Mas, devido à engenhosa trama concebida pelos dois mestres, o que se apreciaria no momento mais surpreendente da experimentação do cenário barroco seria a imagem inverossímil do alinhamento centralizado entre a fonte e a igreja. Porém, após o primeiro sentimento de êxtase proporcionado pela composição simétrica virtual marcada pelo contraponto gerado pelos impulsos verticais do obelisco, da cúpula e das torres, o transeunte passaria a descobrir outros aspectos da construção visibilística da praça, artifícios que poderiam se revelar extremamente complexos e igualmente fascinantes.

Assim, a Piazza Navona demonstraria toda a complexidade oriunda da transmutação barroca de uma importante região da cidade, uma dramática remodelação celular conseguida sem ao menos exigir uma mínima alteração urbanística da área - que, pelo contrário, seguiria ocupando regularmente, e inusitadamente, o espaço que antes acolhia o imenso estádio. Por outro lado, a implantação da praça, envolvida por um confuso, tortuoso e apertado tecido medieval, só aumentaria a sensação da ebriedade barroca dirigida ao espectador 


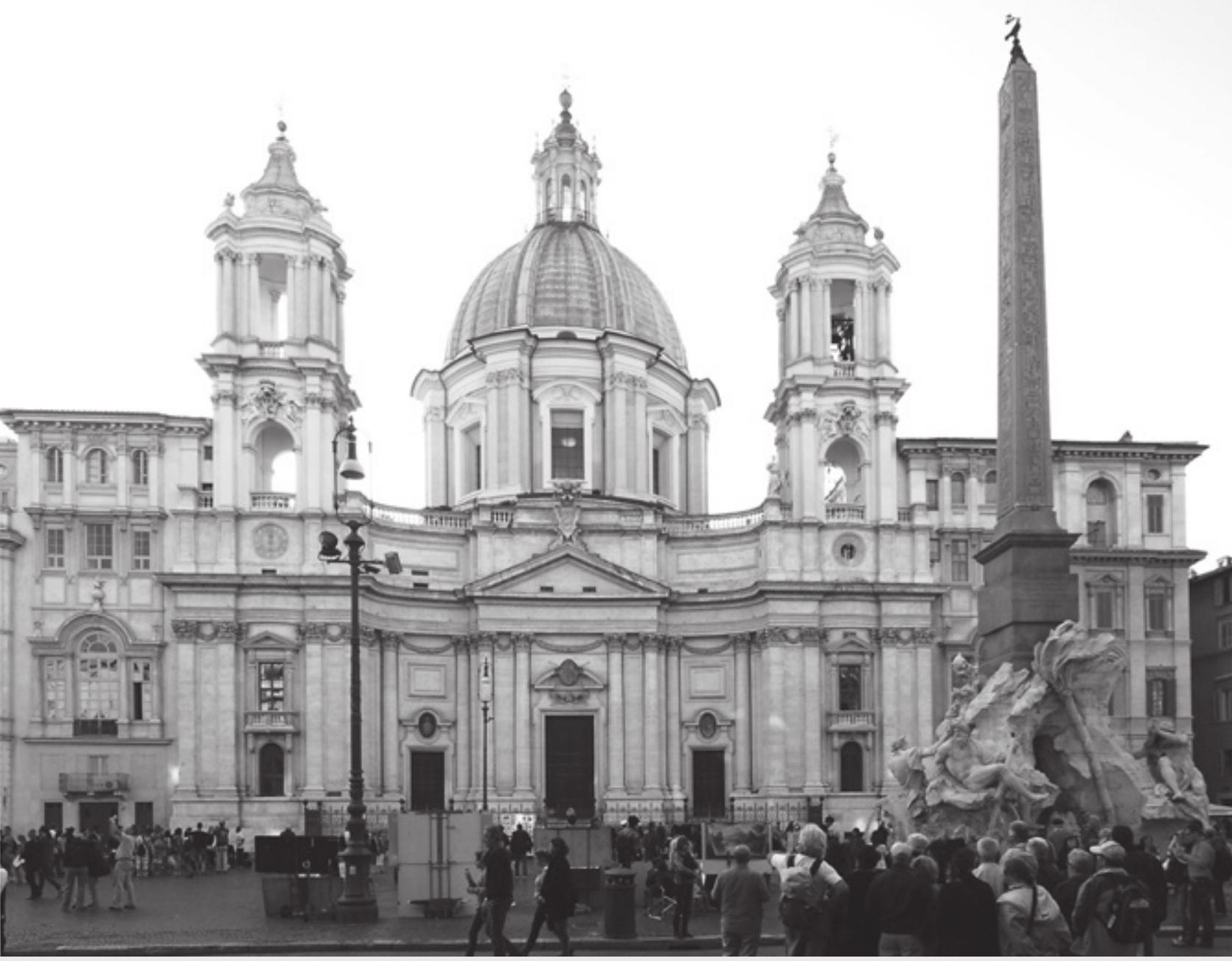

191. Igreja de Sant'Agnese in Agone e Fontana dei Quattro Fiumi - desalinhadas a partir do centro da praça. Fonte: Fotografia elaborada pelo autor (2011). 


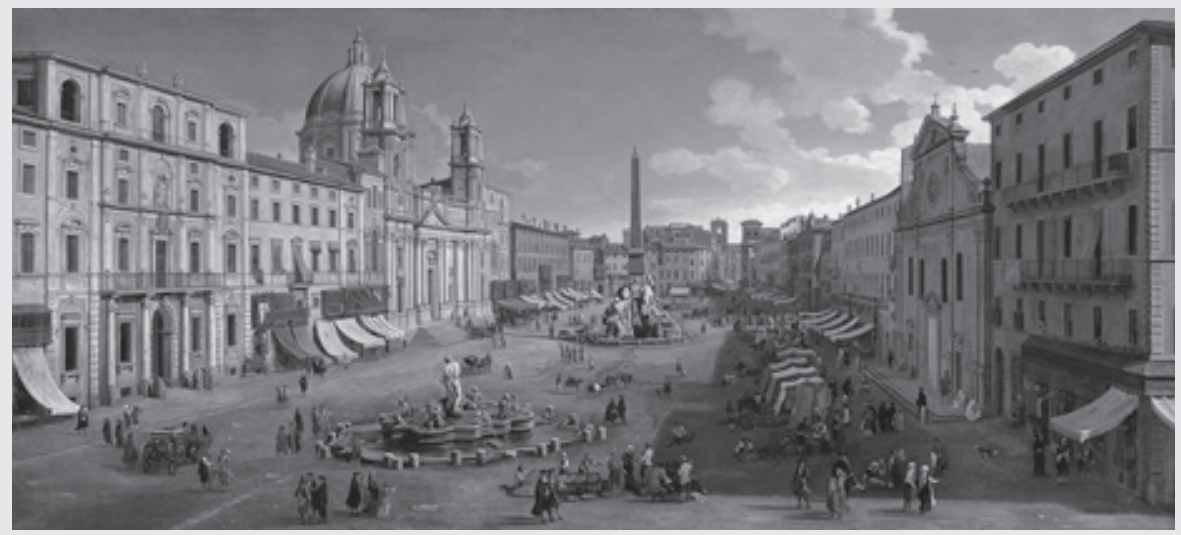

192. Vista, desde o lado sul, da Piazza Navona, em pintura a óleo de Caspar van Wittel (1652-1736). Em primeiro plano aparece a Fontana del Moro - em frente ao Palazzo Pamphilj -, seguida da Igreja de Sant"Agnese e da Fontana dei Quattro Fiumi. Fonte: Wikimedia Commons contributors.

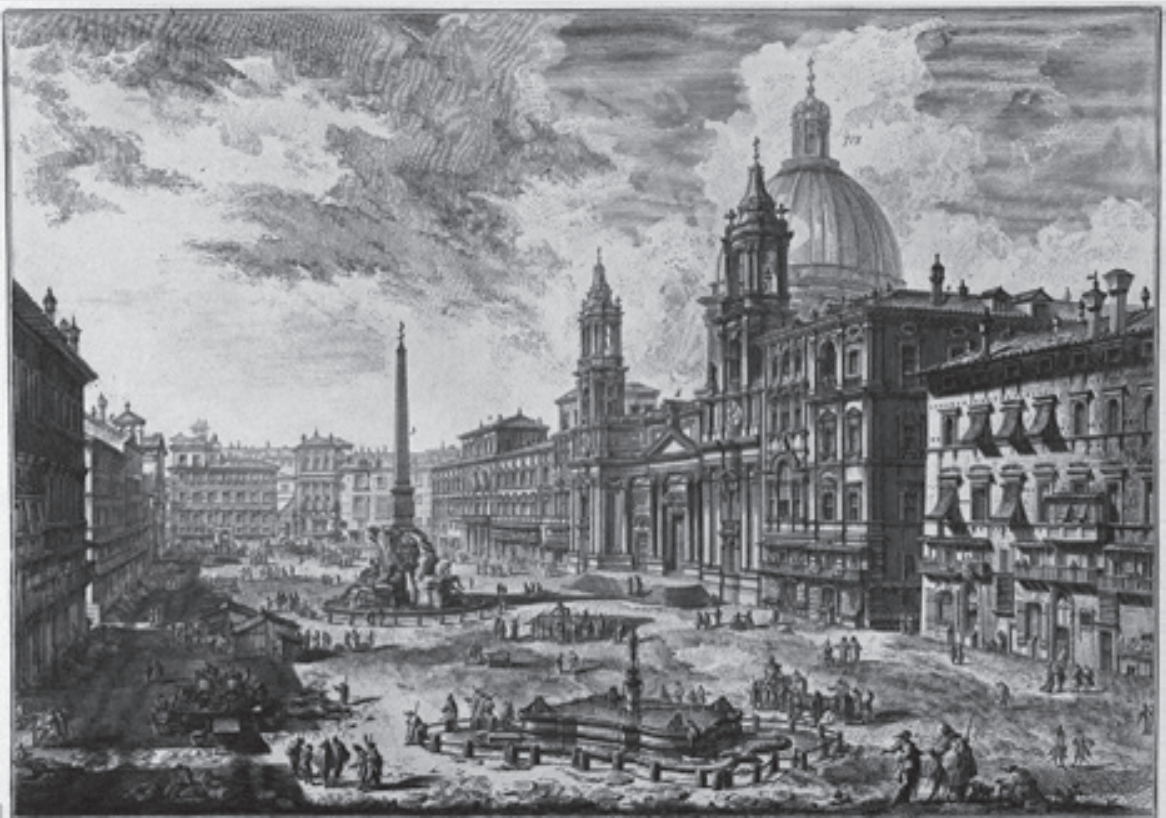

193. Veduta di Piazza Navona. Por Giambattista Piranesi, Vedute di Roma, publicadas em 1798. Vista da praça a partir de um dos acessos ao norte. Fonte: Ficacci (2000, p. 745). 
194. Detalhe da planta grande de Nolli, de 1748, mostrando a Piazza Navona. Marcado com uma linha escura, o eixo visual que busca a igreja desde a Corsia Agonale colocando a Fontana dei Quattro Fiumi no eixo perfeito de Sant'Agnese. Fonte: Elaborado pelo autor a partir da planta de Nolli. Disponível no site Roma ieri oggi.
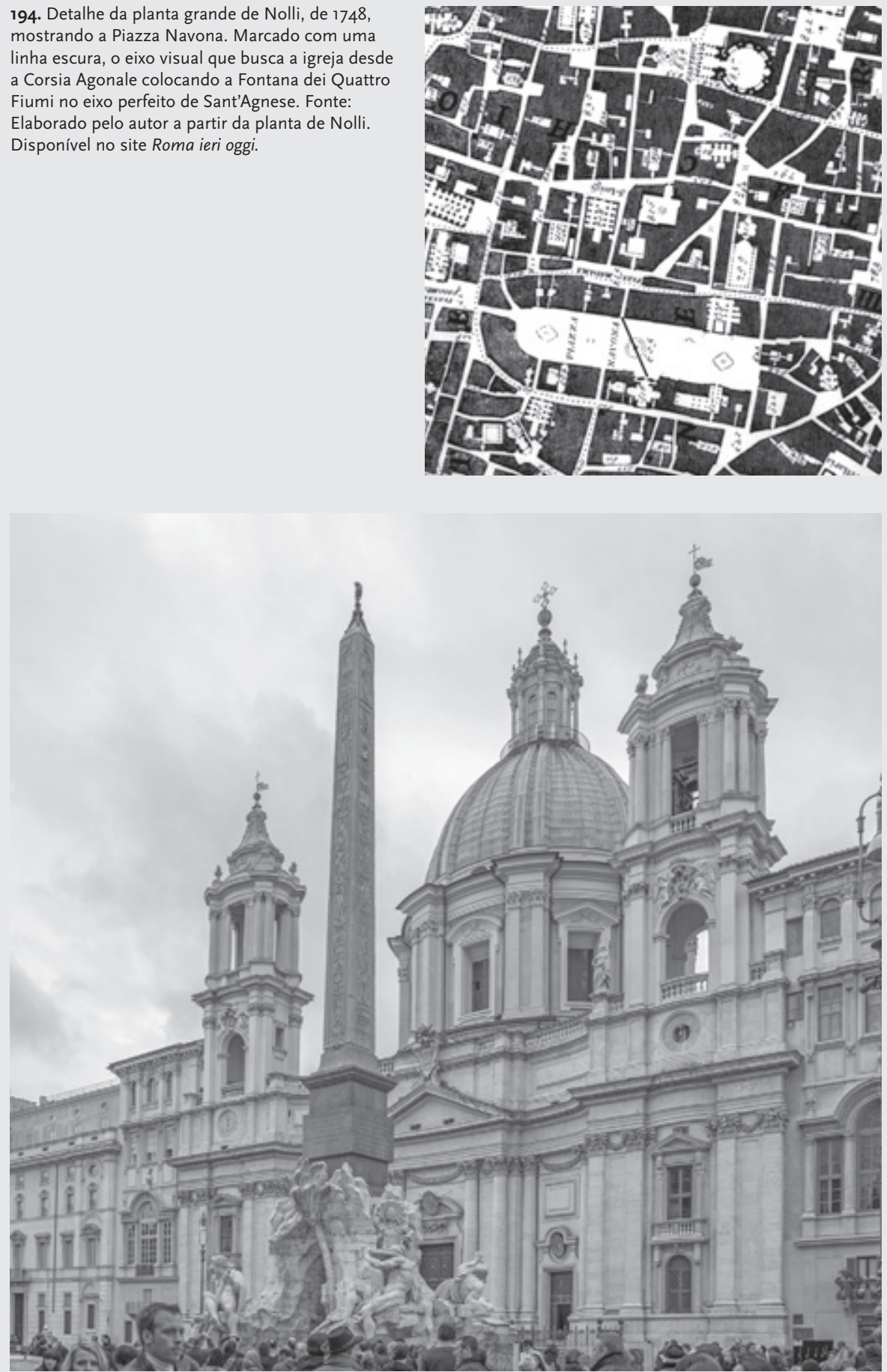

195. Vista da Fontana dei Quattro Fiumi e da Igreja de Sant'Agnese a partir do acesso leste à Piazza Navona, pela Corsia Agonale. Fonte: Fotografia elaborada por Bengt Nyman (2013) - Licença CC BY 2.0 / Wikimedia Commons contributors. 
que se surpreenderia enormemente ao se deparar com o inesperado vazio monumental e com seus cenográficos monumentos interligados por uma fascinante trama teatral.

Esta teatralidade também poderia ser capturada em outros tantos acontecimentos, intensamente expressivos, encenados no Rione Parione, como, por exemplo, a Igreja de Santa Maria della Pace, construída no Quattrocento, mas completamente alterada por Pietro da Cortona entre 1656 e i657, a mando do Papa Alessandro VII - monumento barroco que marcaria o hipotético encerramento das tortuosas artérias medievais da Via di Parione e da Via della Pace (Figura I96), ruas contíguas que se abriam nas proximidades da Piazza Navona. Wittkower (I993, p. 24I-242, tradução nossa), em seu livro Art and architecture in Italy: 1600 to 1750 , cuja primeira edição remontaria ao ano de I958, faria as seguintes colocações sobre o projeto de Cortona para a igreja e a praça que se dispunham à frente:

A nova fachada, colocada diante da igreja quatrocentista, juntamente com a sistematização da praça, é de importância muito maior que as transformações internas. Enquanto as praças com disposições regulares possuíam uma longa tradição na Itália, o projeto de Cortona inaugura um novo ponto de partida porque ele aplicou a experiência teatral ao plano regulador: a igreja se comporta como o palco cênico, a praça como a plateia, e as casas que a circundam como os camarotes. Um lógico corolário de tal concepção pode ser encontrado por quem se aproxima da praça por trás da igreja, pois deve atravessar espécies de portas de serviço, que, por sua vez, escondem as vielas do alcance visual da praça.

O piso superior convexo da fachada, pronunciadamente enquadrado por pilastras salientes, repete o motivo da fachada de Santi Martina e Luca. Mas, no projeto de Santa Maria della Pace este andar representa somente uma zona mediana entre o pórtico semicircular ousadamente distendido, e as grandes alas côncavas que circundam como braços a fachada em uma área muito mais distante dos espectadores. A ação recíproca de formas convexas e côncavas na mesma construção, já timidamente adotada na Villa Sacchetti di Cortona, é um típico tema do Barroco romano, que fascinou também Bernini e Borromini.

Logo, se percebe que a inspiração que o artista barroco absorveria para fomentar a intervenção concebida em prol da reconfiguração da pequenina igreja 


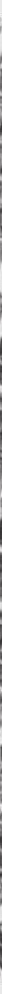

196. Detalhe do Mappa della città di Roma, confeccionado em 1676 pelo gravurista italiano Giovanni Battista Falda, com destaque para o emaranhado denso de ruelas no Rione Parione e no Rione Pigna. Dentro do círculo preto aparece a Igreja de Santa Maria della Pace. Fonte: Elaborado pelo autor a partir da planta de Falda. Disponível no site Roma ieri oggi. 
quatrocentista e da pracinha que se abria à frente estaria totalmente de acordo com a natureza do teatro, expediente tão caro à época: o meio mais imediato para conquistar as mentes e dirigir os indivíduos através do apelo à imaginação do espectador - a manipulação do transeunte por meio daquela euforia ilusória que a constituição dramática do espaço produziria. Contudo, seria impossível para uma pertinente apreciação do evento se furtar da fascinante relação que Pietro da Cortona saberia, coerentemente, trabalhar entre a igreja barroca e o sítio que habitava. Em nome da alteração celular do pequeno setor urbano no qual se apresentaria a igreja, Cortona acabaria preservando o sinuoso e apertado acesso pela Via di Parione e pela Via della Pace e só promoveria uma ampliação do exíguo largo onde se dispunha o monumento com a justificativa de permitir a manobra das carruagens que acorriam à igreja (BLUNT, 2004, p. I24) - praça que viria a alcançar, todavia, uma dimensão insignificante, com seu espaço geometricamente irregular contendo não mais de 30 metros de largura, por cerca de uns 15 metros de comprimento longitudinal (Figura I97).

Esta mínima, mas significativa, modificação da morfologia preexistente, viabilizada através de poucas e necessárias desapropriações, teria como aspecto mais expressivo o fato de o pintor-arquiteto ter ocultado as antigas fachadas irregulares dos edifícios remanescentes, ou daqueles parcialmente demolidos, através da sobreposição de cenários fixos, totalmente independentes, à frente das suas antigas estruturas - imponentes frontarias palacianas que se revelariam como autênticas scaenae frons implantadas em nome da monumentalização do espaço. As mais impressionantes destas falsas máscaras teatrais seriam aquelas radicalmente côncavas justapostas contíguas à igreja: panos cenográficos que encerrariam a praça, ocultando as duas vielas que se lançavam adjacentes à sua estrutura (a Via Arco della Pace e o Vicolo della Volpe). Não obstante, os sedutores e envolventes cenários que esconderiam a abertura das vielas não impediriam a sua passagem, já que Cortona as perfuraria com dois permeáveis portais, um a cada lado, permitindo o cruzamento do transeunte para a área do rione que se espalhava, confusamente, por detrás do templo - as "portas de serviço" as quais se referia Wittkower. Para além deste fato, a êxedra sugeriria uma virtual projeção da fachada convexa desenhada na terminação da nave da igreja - aplicada à frente do movimentado e contraído anteparo cenográfico côncavo - para o exíguo ambiente da praça, mais um mecanismo da persuasão barroca conquistado através da oposição curvilínea entre envolventes estruturas côncavas e expansivas 
formas convexas (Figura I98). Portoghesi (I997, p. 228-229) concluiria a apreciação do complexo da igreja debatendo a forte relação que o edifício guardaria com o contexto urbano adjacente:

A peremptória violência com a qual a estrutura de Santa Maria della Pace emerge no espaço da cidade, envolvendo com a sua presença o espaço circundante, é um fato arquitetônico que não cessa de surpreender - mesmo a quem captura estas imagens cotidianamente. De fato, é um dos pontos de Roma nos quais o programa barroco se revela com a mais direta comunicabilidade; e sendo condicionado pela multiplicidade e irregularidade do tecido urbano medieval, se expressa sistematicamente como um desejo de adesão à realidade, sentida em toda a sua contraditória vitalidade. $\mathrm{O}$ anteparo vibrante que é inserido ao fundo do canal da Via di Parione e da Via della Pace age sobre o espectador como um convite a participar de um drama de onde já se anuncia a intensidade e o encanto. E pouco a pouco, quem se aproxima, mesmo desiludido pelo revelar-se de um mecanismo cenográfico e ilusionístico, permanece hipnotizado pelo concretizar-se da imagem de uma matéria modelada com sutil sabedoria, bem como pelo acontecimento espacial que gradualmente se clarifica na experiência de quem se move naquela espécie de grande leque que, em torno do pórtico, se desenvolve minuciosamente. A relação entre o monumento e o ambiente adjacente, modificado pelo mesmo arquiteto, é tão persuasivo, é tão evidente a relação de recíproca necessidade, que se torna difícil pensar nas diversas limitações do programa reveladas na época da projetação.

O crítico italiano deixaria claro que a igreja, bem como a nova sistematização fake da praça, necessitariam, decisivamente, do tecido urbano medieval preexistente para se tornarem um absorvente acontecimento barroco. $\mathrm{O}$ transeunte que buscava a igreja - percorrendo as tortuosas vias que se dirigiam a ela -, até efetivamente irromper no exíguo espaço do largo, só poderia vislumbrar fragmentos do monumento revelados por uma reduzida greta enquadrada pelas últimas edificações da Via della Pace, uma nesga que iria se abrindo lentamente, desvelando, com a aproximação do espectador, o espectro visual da praça e a revelação do monumento. A trama cenográfica, contudo, só seria denunciada, em toda a sua expressão, pouco antes do ingresso ao recinto, quando o espectador se colocasse a menos de dez metros da igreja e conseguisse vislumbrar, finalmente, 
todo o campo visual da praça. A esta distância insignificante, a pequena fachada convexa avançaria poderosamente em direção ao passante e se tornaria grandiosa em sua relação de contrastante com a dramática êxedra côncava disposta ao fundo - puro teatro (Figuras 199-202).

Uma simples referência de escala poderia justificar a impressão que atribuiria à Santa Maria della Pace uma estatura colossal, apesar de sua pequena dimensão: a dez metros de distância, o limitado espectro visivo do transeunte criaria a sugestão de que qualquer edifício de razoável tamanho fosse um grande monumento - sentimento que estaria perdido se, por ventura, o arquiteto escolhesse rasgar um amplo eixo perspectivo direcionado à fachada do templo, assim como se houvesse proposto a abertura de uma grande praça para acolher o monumento. Por outro lado, a camuflagem dos dois becos que se irradiavam para além de Santa Maria della Pace, conseguida por meio da sugestão de que o passante, que prosseguia por estes caminhos, estaria simplesmente cruzando mais uma porta aberta na barreira condicionada pelo anteparo côncavo levantado ao fundo do recinto, seria um expediente fundamental: contribuiria para a geração do imprescindível acolhimento oferecido dentro do espaço contido da praça e também para dar a ilusão de que as paredes côncavas seriam o encerramento definitivo da meta a qual o espectador havia se submetido ao assumir o tortuoso percurso pelo emaranhado de vielas nas imediações da igreja (Figura 203).

Portanto, em Santa Maria della Pace poder-se-ia apreciar mais uma situação em que um edifício religioso promoveria, através do uso consciente do "efeito surpresa”, uma poderosa agitação teatral no âmago de um bairro medieval remanescente. Inusitado seria se esta animação fosse agenciada por construções burguesas comuns, como viria a acontecer na aprazível Piazza di Sant'Ignazio, uma pequenina praça construída para os jesuítas entre 1727 e I736, projetada pelo arquiteto napolitano Filippo Raguzzini (I680-I77I) - assentada não muito distante, no Rione Colonna.

Para alcançar o recinto desde e Piazza Navona, o espectador deveria atravessar a Corsia Agonale e buscar a direção leste, cruzando o adjacente e estreito Rione Sant'Eustachio, até chegar à Piazza della Rotonda, já no Rione Colonna. Não seria possível ignorar esta praça, pois ela se revelaria como um fascinante evento dramático disposto, surpreendentemente, a meio caminho: teria como destaque 
o gigantesco edifício clássico do Pantheon, ${ }^{75}$ que sofreria uma "restauração" em 1620 (atribuída a Bernini), ${ }^{76}$ quando seriam assentados os dois campanários acima da pronao do edifício - pequenas torres que logo ficariam conhecidas, ironicamente, como as orecchie d'asino do Pantheon (retiradas no século XIX); o caráter barroco da praça seria expresso, contudo, na interface entre o templo remodelado e a bela fontana disposta à frente, edificada por Giacomo della Porta em 1575 e sobreposta pelo Obelisco de Ramsés Il em I7II, por iniciativa do pontífice Clemente XI (I649-I72I). ${ }^{77}$ Na verdade, a fonte e seu delgado marco vertical se apresentariam como leves e elegantes contrapontos à colossal e maciça estrutura da rotunda, monumento que se agigantaria ainda mais em função da dimensão não muito extensa da piazza (Figura 204).

Continuando seu caminho em direção a Sant'Ignazio, o passante deveria ingressar à esquerda, quase adjacente ao pórtico do Pantheon, na atual Via del Seminario, e prossegui-la algumas dezenas de metros até alcançar a praça de Raguzzini. Enquanto o transeunte avançava pela suave curvatura da apertada e escura via, uma pequena faixa gradativamente se abriria revelando, em forte escorço, a irradiante fachada barroca da seiscentista Igreja de Sant'Ignazio (Figura 205), ainda aprisionada pelo exíguo campo visual oferecido. Quando finalmente o espectador irrompesse na praça, alcançando-a bem ao lado do grandioso frontispício da igreja jesuítica, o que despertaria sua imaginação não seria, contraditoriamente, a poderosa estrutura religiosa, e sim a efusiva agitação provocada pelos cinco edifícios burgueses construídos na primeira metade do Settecento: dois deles enquadrariam ortogonalmente os limites da fachada de Sant'Ignazio, enquanto os outros três, dispostos no fundo da praça, provocariam uma radical oscilação espacial por meio da contaminação plástica que o ambiente sofreria por influência das movimentadas frontarias côncavas das casas - frontarias que se sobreporiam e se interpenetrariam mutuamente.

É incrível como Raguzzini conseguiria compensar, com o design curvilíneo da pequena praça e das casas burguesas que a conformaria, o movimento

75 Templo construído pelo Imperador Adriano (76-138) entre os anos de 118 e 125, consagrado em 609 como a Igreja de Santa Maria ad Martyres pelo Papa Bonifácio IV - que dirigiria a Igreja entre 608 e 615 -, fato que teria decretado sua sobrevivência às pilhagens.

76 Autoria contestada, veementemente, pelo historiador da arte Tod A. Marder, em seu livro de 1998 , Bernini. And the art of architecture. (MARDER, 1998, p. 225)

Giovanni Francesco Albani governou o Vaticano de 1700 até 1721. 


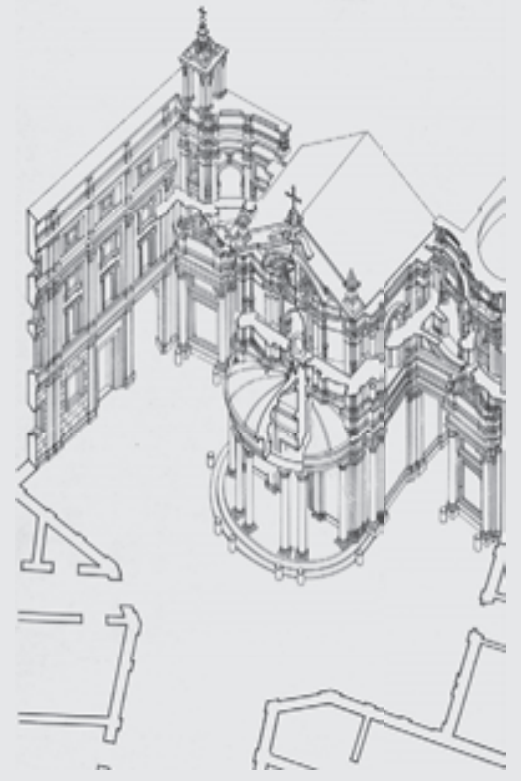

197. Axonométrica da estrutura cenográfica da nave, fachada e Praça de Santa Maria della Pace - por Paolo Portoghesi. Fonte: Portoghesi (1997, p. 253).

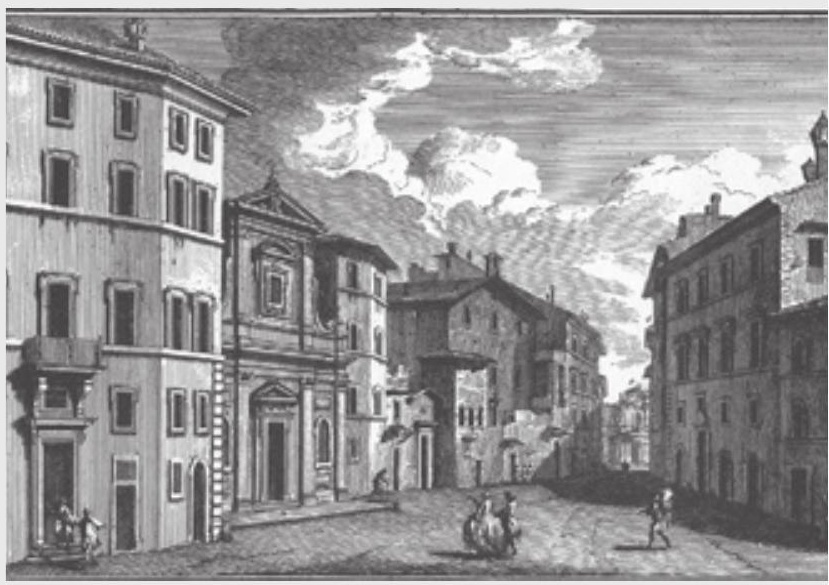

198. Vista de Giuseppe Vasi da Via di Parione, com destaque para a Igreja de San Tommaso in Parione, à esquerda. Percebe-se, ao final da via, a pequena fresta que se abre para a Igreja de Santa Maria della Pace. Fonte: Coen (2003, p. 168).

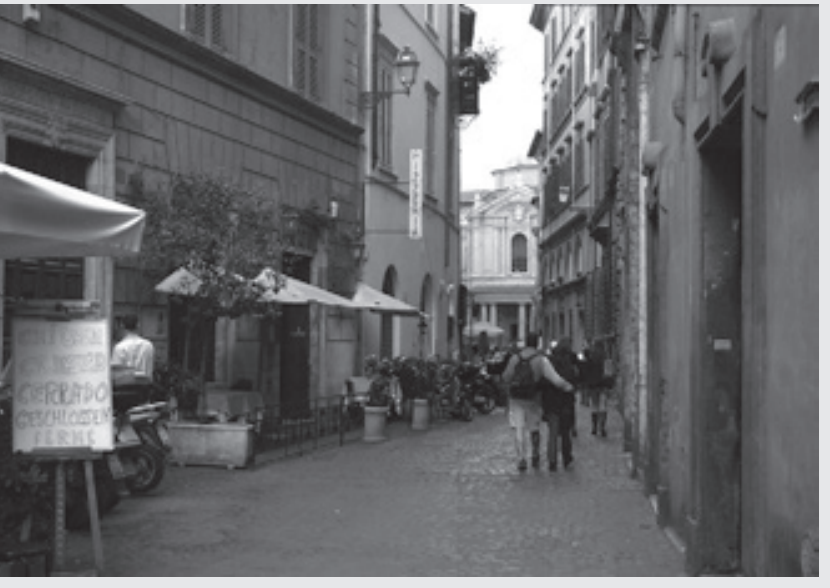

199. Via di Parione. A fresta em que se avista a Igreja de Santa Maria della Pace aumenta. Fonte: Fotografia elaborada pelo autor (2007).

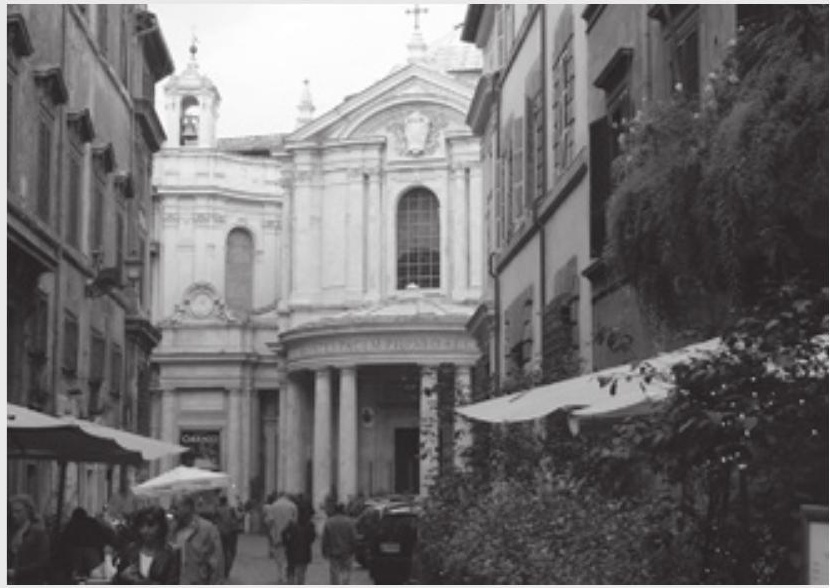

200. Cada vez mais se abre o enquadramento do campo de visão da igreja ao avançar na rua, agora denominada Via della Pace. Fonte: Fotografia elaborada pelo autor (2007). 


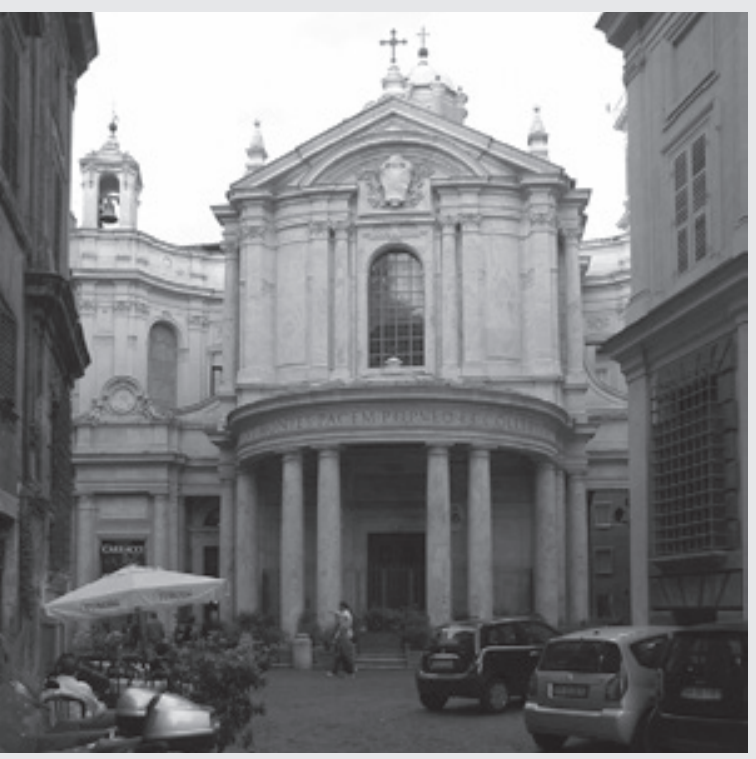

201. Muito próximo ao final da Via della Pace se pode ver todo o frontispício. Fonte: Fotografia elaborada pelo autor (2007).

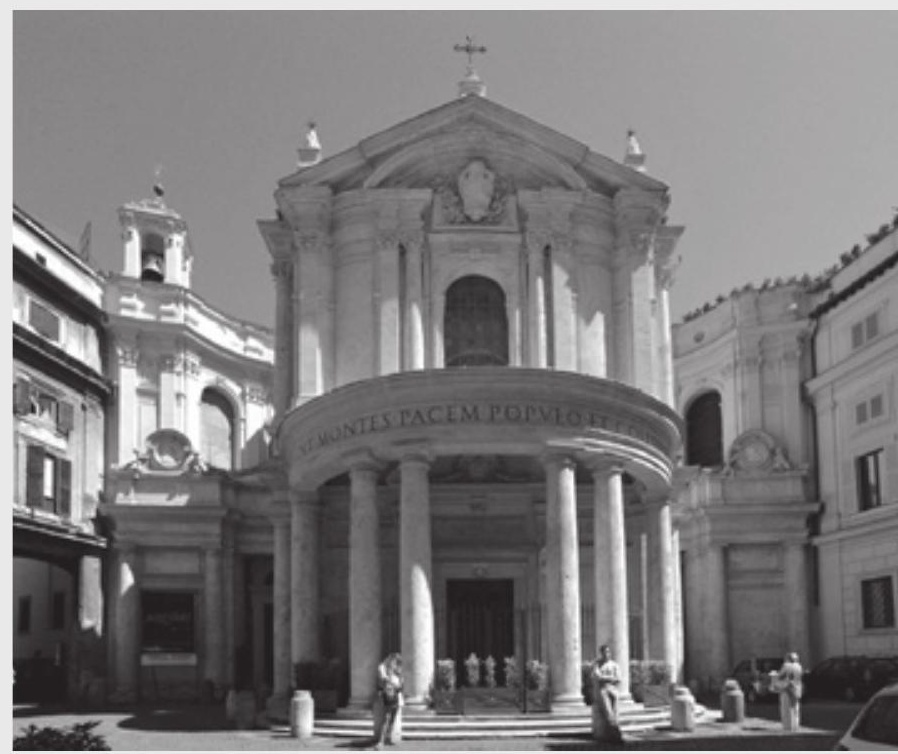

202. Ao alcançar a praça, toda a trama projetada por Pietro da Cortona se revela. Fonte: Fotografia elaborada por Gaspa (2006) - perspectiva corrigida pelo autor - Licença CC BY 2.0 / Wikimedia Commons contributors.

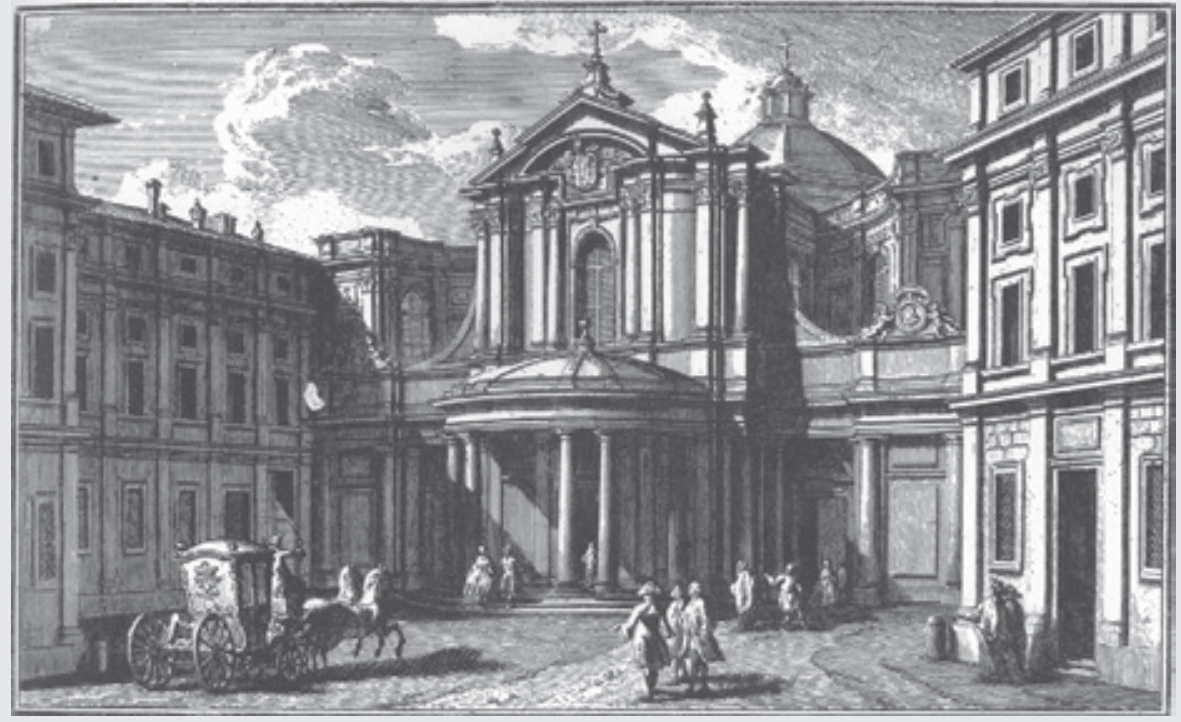

203. A praça cenográfica de Santa Maria della Pace em uma gravura de Giuseppe Vasi. Fonte: Coen (1996, p. 183). 


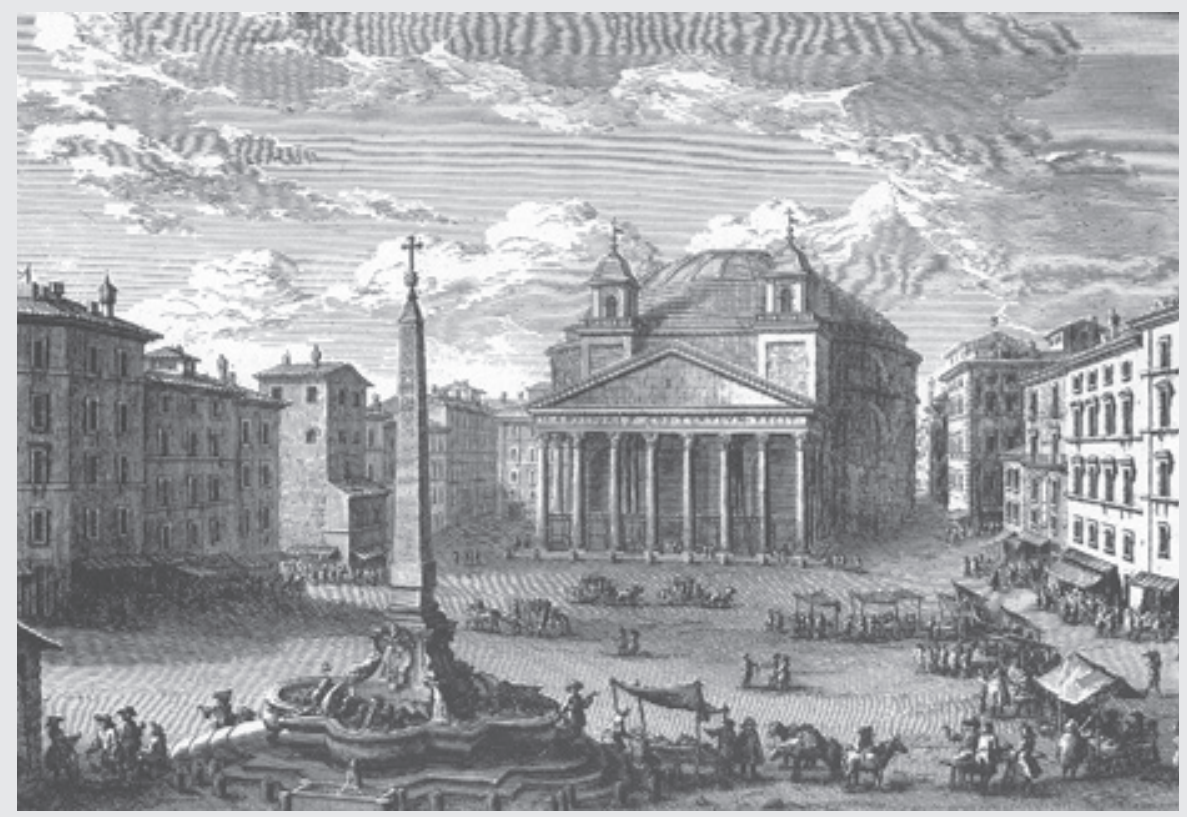

204. Giuseppe Vasi, 1747. Piazza della Rotonda. O Pantheon, a fonte e o obelisco. A primeira viela que se abre, à esquerda, dará acesso direto à Piazza di Sant'Ignazio. Fonte: Coen (1996, p. 67).

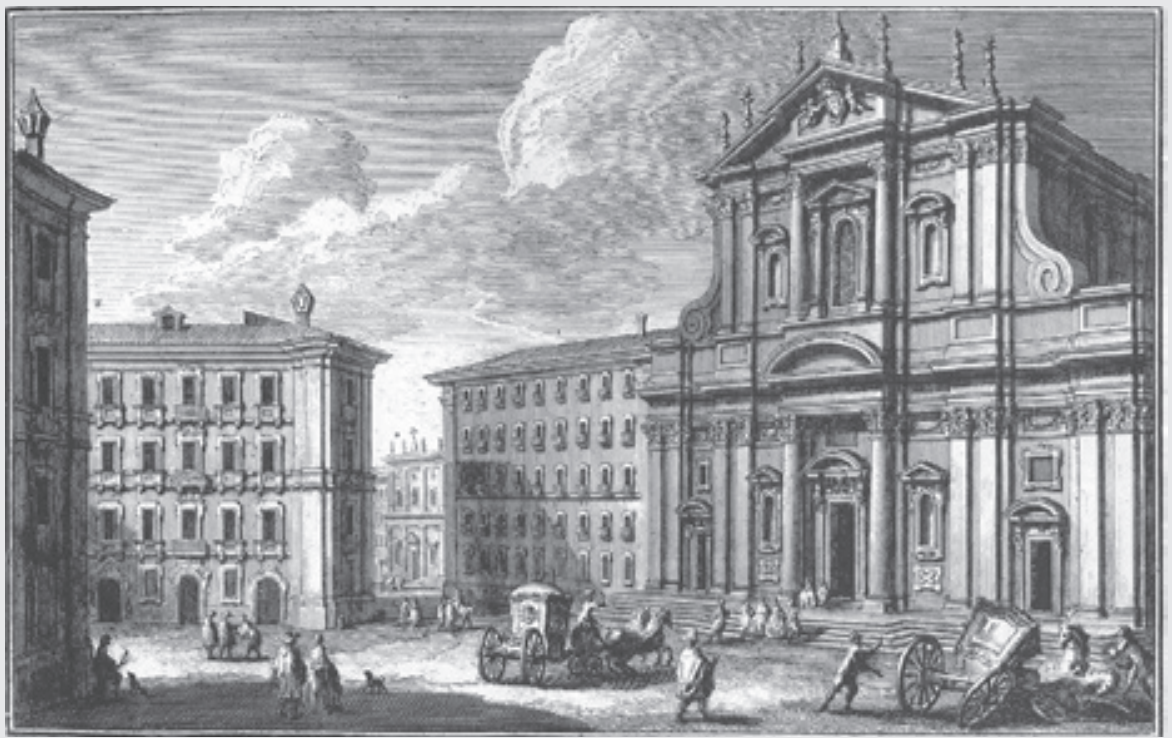

205. Igreja e Praça de Sant'Ignazio. A igreja foi projetada por Orazio Grassi (1583-1654), em 1627, e a fachada por Alessandro Algardi (1595-1654), entre 1649 e 1650. À frente da igreja está a praça de Filippo Raguzzini (1680-1771). Fonte: Coen (2003, p. 233). 
mais contido da fachada da igreja - frontispício que não teria sido levantado por Alessandro Algardi baseado na presença de curvas e contracurvas reentrantes e salientes, mas naquela composição tipicamente romana, com planos e perfis pronunciados, em altos e baixos relevos, formados por uma rica modenatura comandada pelas ordens clássicas (colunas, pilastras, entablamentos, áticos, frontões, tímpanos, molduras, nichos, pináculos). Em oposição, a intervenção de Raguzzini, fundada apenas na construção das edificações ordinárias que iriam encerrar a praça, deveria confiar toda a dinâmica agitação requerida pela cultura barroca - toda a cenografia teatral exigida em nome da conquista do espectador - à forma e ao volume dos edifícios, já que não poderia usufruir dos elementos derivados do repertório clássico. (CONNORS, 2005, p. I06) Seria uma completa inversão de valores em relação à concepção tradicional na qual o monumento seria o elemento a se destacar no espaço público - apesar de que a pequena dimensão da praça, bem como o contraste violento das formas côncavas com a fachada plana da igreja, não deixaria de favorecer a imposição dramática da monumental fachada barroca do templo jesuítico (Figuras 206-209).

Todas as intervenções pontuais debatidas revelariam que a tônica das obras estaria sempre relacionada à imposição ao espaço urbano de uma profusa teatralidade, situação que seria levada a extremos na mais famosa das fontes romanas: a Fontana di Trevi. Desenhada por Nicola Salvi (I697-I75I) e construída entre I732 e I762, no vizinho Rione Trevi, a fonte seria a parede terminal do Acqua Vergine, um dos poucos sistemas de captação e transporte de água construídos pelos antigos romanos a sempre funcionar (Figura 2IO). Locada nos fundos da Piazza di Trevi, a imponente fachada clássica que se assentava por detrás da fonte encerraria toda a extensão da face norte do recinto, sendo parte indissociável do conjunto monumental projetado por Salvi. O frontispício se revelaria, consequentemente, um anteparo meramente cenográfico para a fonte, que seria formada, por sua vez, por uma complexa e movimentada cena onde personagens mitológicos se espalhariam nas rochas e nos recifes esculpidos em travertino figuras que se apresentariam parcialmente imersas na água que, dinamicamente, jorrava, preenchendo a imensa bacia disposta à frente. Esta monumental estrutura não guardaria qualquer compromisso com os edifícios levantados por detrás, mas apenas com o espaço urbano, desvelando o exclusivo sentido teatral impresso na fachada. Para além destes fatos, a sensação de euforia e tensão gerada ao se irromper no espaço vazio da praça e se deparar com a colossal fonte - artifício 


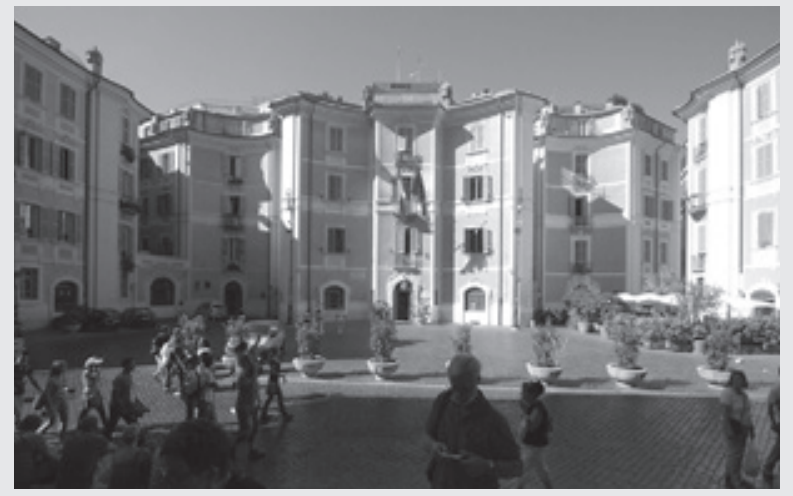

206. Casas burguesas da Piazza di Sant'Ignazio. Fonte: Fotografia elaborada pelo autor (2007)

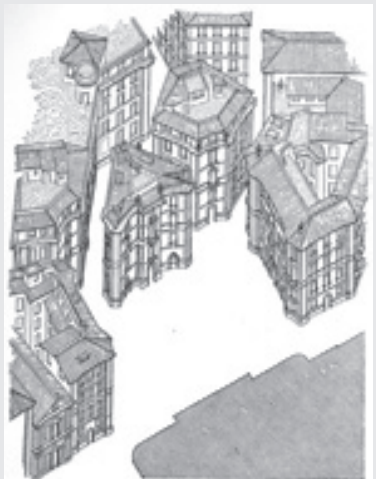

207. Perspectiva axonométrica da Piazza di Sant'lgnazio, por Paolo Portoghesi. Fonte: Portoghesi (1997, p. 400).

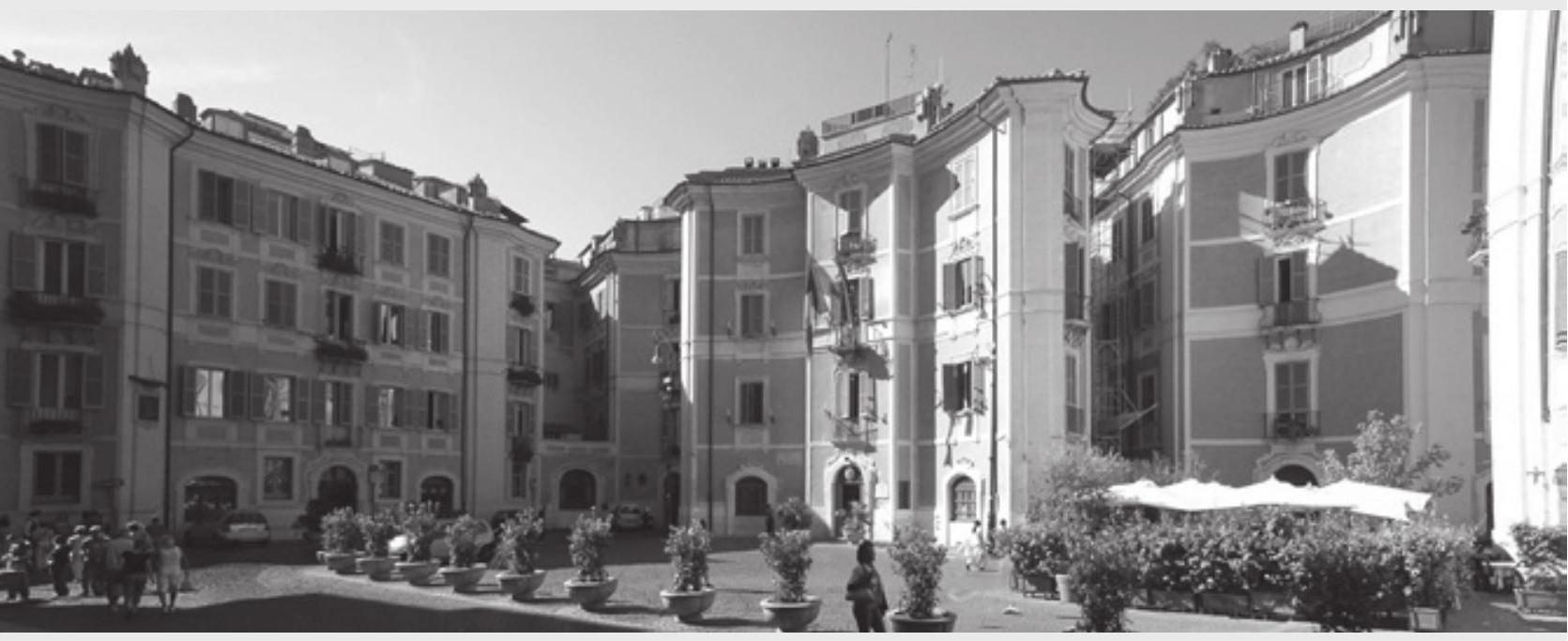

208. Piazza di Sant'Ignazio. Fonte: Fotografia elaborada pelo autor (2007).

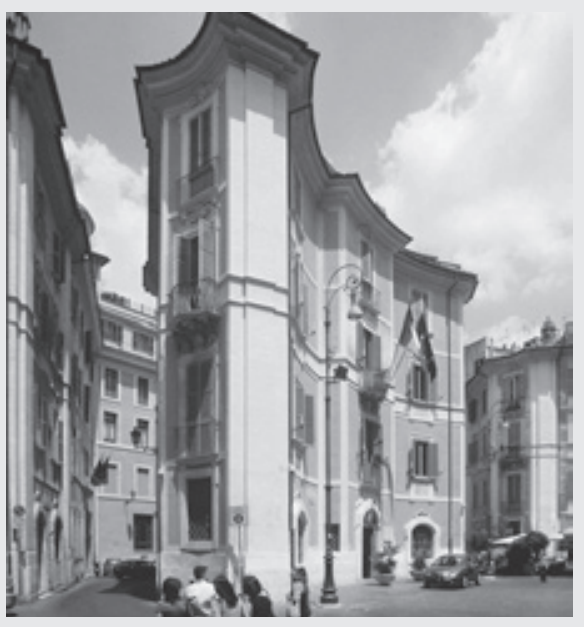

209. O design curvilíneo da pequena Piazza di Sant'Ignazio e das casas burguesas que a conformam, claramente contrastantes com a fachada da igreja. É uma inversão em relação à concepção tradicional onde o monumento deveria se destacar efetivamente no espaço público. Fonte: Fotografia elaborada pelo autor (2006). 
persuasivo multiplicado em sua profusão dramática pelo contraponto visual provocado pela frontaria cenográfica da igreja seiscentista de Santi Vincenzo e Anastasio, jogada, diagonalmente, em um inusitado chanfro perspectivo que lhe direcionava o olhar - seria imensamente favorecida pelo sentimento de espanto absorvido pelo transeunte que, caminhando pela tortuosa preexistência medieval, se depararia, subitamente, com a poderosa cena barroca.

Para além do "efeito surpresa" e do apelo cenográfico, a Fontana di Trevi, assim como as outras situações avaliadas, relatariam artifícios de transformação do ambiente preexistente da cidade alcançados por meio de mecanismos arquitetônicos fundados naquele lento processo de substituição celular do tecido urbano preexistente (Figuras 2II-2I2).

\section{Escadarias romanas no Settecento: dois eventos dramáticos no Campo Marzio}

A reocupação da seção norte da planície do Campo Marzio se iniciaria mesmo antes da abertura do tridente de vias que sairiam da Piazza del Popolo, na área que acolheria os restos da antiga Tumba de Augusto (63 a.C.-I4 d.C.), ${ }^{78}$ o primeiro imperador romano. Em meados do século XV, o chamado Augusteo - pilhado, arruinado, readaptado a inúmeros usos e funções - encontrar-se-ia isolado em um espaço pouco habitado, às margens do Tevere, área que era usada como o segundo porto de Roma ${ }^{79}$ e onde seria construída, no final do século, em substituição a uma antiga ermida, a atual Igreja de San Rocco (I499). Brevemente o tecido urbano iria se reconstituir com a demarcação, por iniciativa do Papa Sisto IV (I4I4-I484), ${ }^{80}$ de dois bairros oferecidos, respectivamente, à comunidade dos refugiados da Illiria ${ }^{81}$ - que edificariam a igreja e o hospital de San Girolamo - e à comunidade dos Lombardos - que levantariam, mais ao leste, na Via del Corso,

\footnotetext{
78 Gaius lulius Caesar Octavianus Augustus, imperador romano a partir 27 a.C.

79 O Porto di Ripetta, nome derivado de sua menor dimensão em relação ao outro porto da cidade, o Porto di Ripa Grande, localizado ao sul, do outro lado do rio.

8o Francesco della Rovere governou a Santa Sé de 1471 até sua morte.

81 Região mais ou menos coincidente com o que hoje seria a Albânia e parte da Croácia.
} 


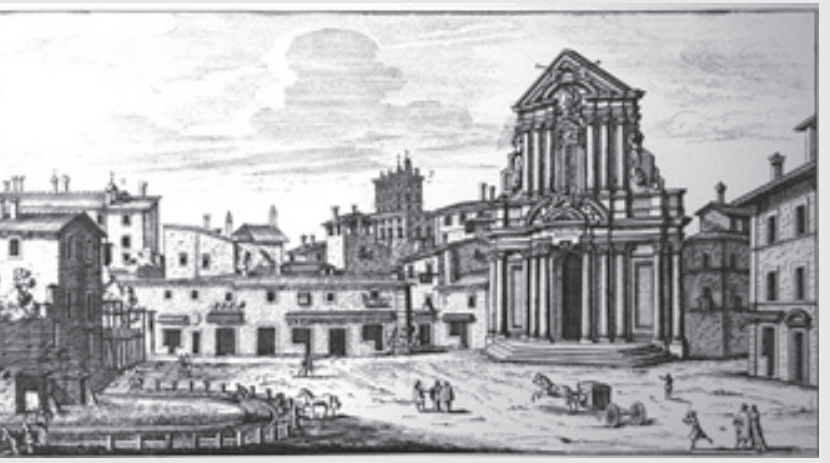

210. Chiesa di Santi Vincenzo e Anastasio alla Fontana di Trevi, de Padri Regiosi di S. Girolamo, Architettura di Martino Longhi, Il Giovane. Panorama da segunda metade do século XVII, elaborado por Giovanni Battista Falda, da imponente e dinâmica fachada da Igreja de Santi Vincenzo e Anastasio, bem como da antiga Fontana di Trevi (à esquerda), algumas décadas antes da intervenção do próximo século. Da série II nuovo teatro delle fabriche, et edificii, in prospettiva di Roma moderna - 1665. Fonte: Falda (1970, p. 19).

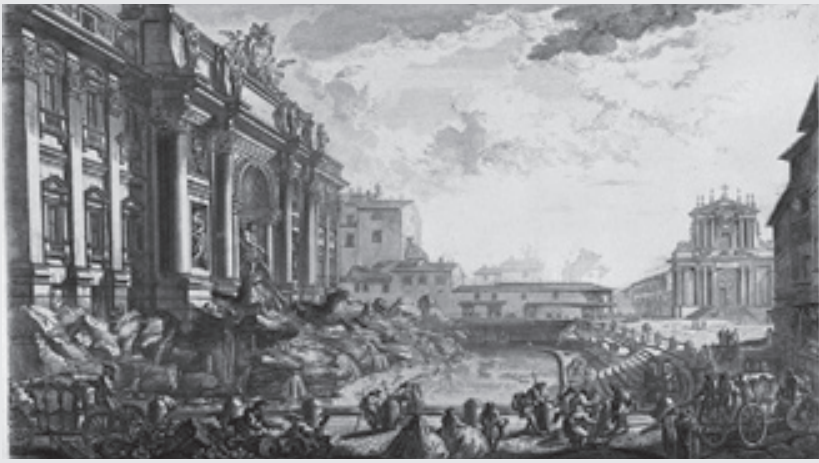

211. Veduta della vasta Fontana di Trevi anticamente detta l'Acqua Vergine. Gravura, por Giambattista Piranesi, da série Vedute di Roma, retirada do mesmo ângulo que a gravura anterior de Falda. Fonte: Ficacci (2000, p. 691).

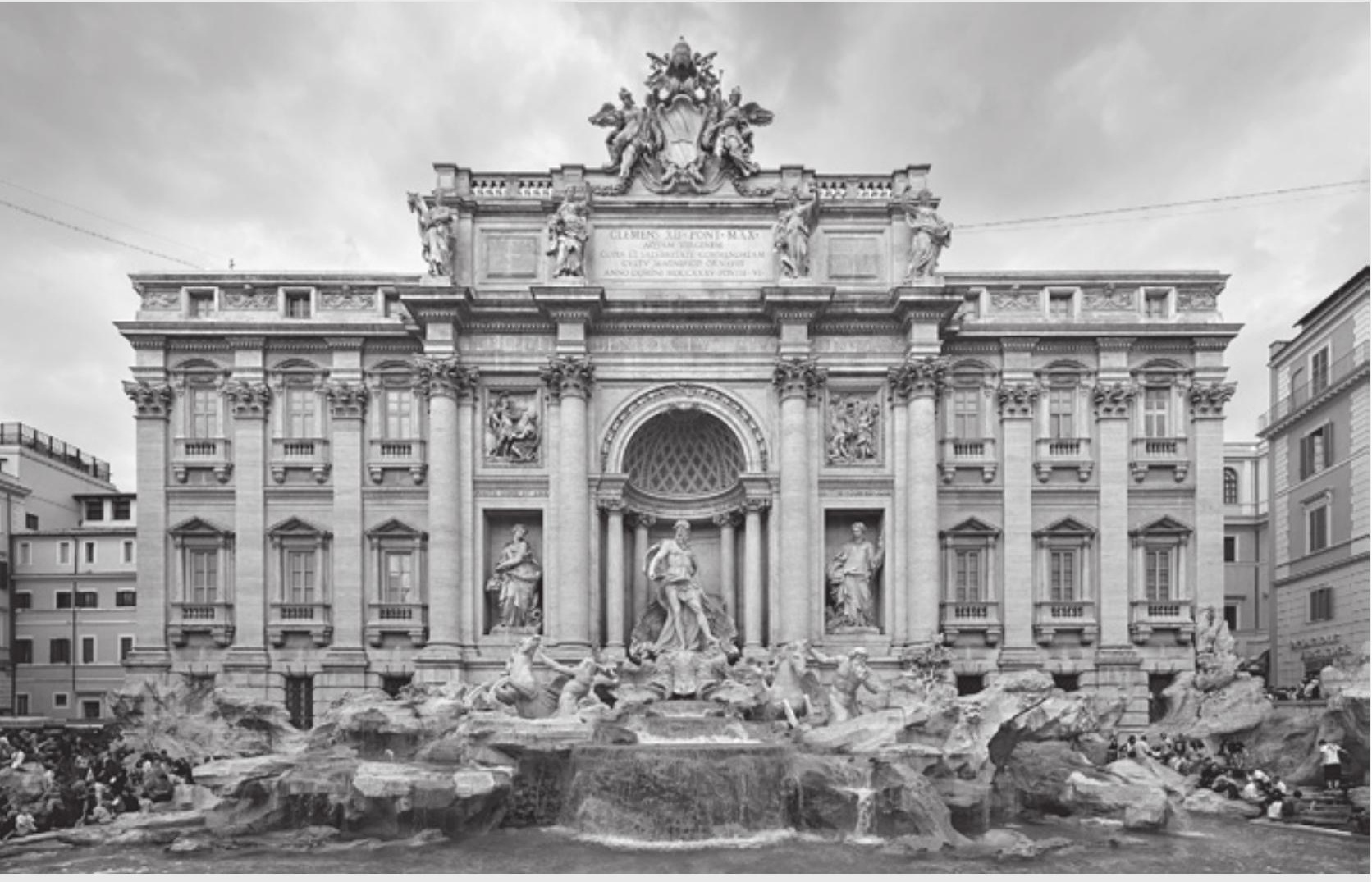

212. Fotografia recente da Fontana di Trevi. Notar a arquitetura cenográfica que envolve inúmeras esculturas e fontes de água, conjunto projetado por Nicola Salvi (1697-1751) e construído entre 1732 e 1762. Fonte: Fotografia elaborada por David Iliff - Licença CC BY-SA 3.0 / Wikimedia Commons contributors. 
a Igreja e o Hospital de Sant'Ambrogio, depois conhecidos como Sant'Ambrogio e San Carlo al Corso.

No Cinquecento, com o adensamento populacional dos dois bairros recémcriados, a Tumba de Augusto perderia gradativamente sua condição de ruína dispersa no tecido urbano, sendo incorporada à dinâmica mutante do caráter paisagístico da cidade. Logo, a área seria definitivamente ligada ao resto da mancha urbana e ao seu acesso norte com a abertura da Estrada Leonina (atual Via di Ripetta) e de sua ampliação até a área adjacente à Piazza Navona (atual Via della Scrofa). O grande eixo tangenciaria os quarteirões dos schiavoni da Illiria, bem como o Mausoléu de Augusto e o improvisado Porto di Ripetta (Figura 213).

Entretanto só no início do século XVIII a área da Tumba de Augusto passaria a fazer parte do processo, iniciado em finais do Cinquecento, de reinvenção cenográfica da capital pontífice, passando a abrigar um dos mais admiráveis acontecimentos barrocos da cidade. Em I704, por iniciativa do Papa Clemente XI, o arquiteto Alessandro Specchi (I668-I729) desenvolveria um projeto para a reestruturação do Porto di Ripetta, até então um simples vão aberto para o rio sem nenhum tratamento arquitetônico e urbanístico, no qual o atracamento das embarcações acontecia sobre a margem natural do Tevere. (INSOLERA, I996, p. 283) A obra de Specchi não só permitiria resolver de maneira eficiente o problema da descarga de mercadorias que vinham do Alto Lazio e da Úmbria, mas, principalmente, conseguiria transformar, plasticamente, o confuso bairro onde estava inserido o Augusteo em uma coerente e exuberante manifestação da cenografia barroca.

Promovendo um destaque para a típica fachada romana da Igreja de San Girolamo degli Schiavoni, inteiramente renovada por Martino Longhi, il Vecchio (I534-I59I), entre I588 e I599, Specchi criou uma pequena praça formada por um terraço oval cuja forma convexa se expandiria através de um arrimo em direção ao rio, sendo, ao mesmo tempo, ladeada por duas rampas contíguas e por escadarias côncavas que permitiriam o acesso do transeunte que chegava de barco e galgava da margem do rio para o platô mais acima. Desta forma, Specchi promoveria a conexão da preexistência natural, formada pelo Tevere e suas margens, com a irregular e confusa massa edificada, hierarquizando o espaço ao privilegiar a visão axial da igreja (para quem chegava pelo rio). Portoghesi (I997, p. 347-348, tradução nossa) resume: 
Specchi devia buscar reorganizar esta desordenada sequência de cenários através de um discurso orgânico, geometricamente determinado, e assim o fez estabelecendo antes de tudo uma gradação hierárquica entre os elementos alinhados e escolhendo a tímida fachada de Longhi como foco perspectivo e eixo de agregação para a simetria da escada; e uma vez que a ausência de uma vista axial privilegiada tornava precária a ligação entre o velho e o novo, acentuou a relação de influência da igreja através da forma oval que se projetava para o rio, criando um polo de expansão longitudinal ao longo da direção da Via della Scrofa. A grande praça oval, emergente em sua massa cilíndrica, articulada por uma simples parede de tijolos ritmada por molduras de travertino, é a forma geométrica geratriz que condiciona qualquer outro elemento da composição: a este volume cilíndrico se agregam duas rampas que conduzem ao desembarcadouro central, enquanto as grandes escadarias laterais partem dos extremos dos cortes retilíneos, se dobram em amplíssimas concavidades e então se unem suavemente à convexidade central da praça oval; nasce assim aquele modelo côncavo-convexo que de forma audaz translada para a escala urbanística o tema da onda contínua de San Carlino com o objetivo de estabelecer entre cidade e rio, entre água e pedra, uma relação de osmose, de recíproca influência, que exprime, além da negação do dado natural imediato, a sua síntese em um discurso puramente geométrico.

Logo, a zona do mausoléu do Imperador Augusto, com a reestruturação do Porto di Ripetta, passaria a emanar um forte apelo teatral, estrutura cenográfica que seria constituída, mais uma vez, pela radical agitação espacial oriunda da alternância de formas côncavas e convexas: nas alas laterais da escadaria, sua conformação linear emolduraria os contraídos impulsos gerados pelos desdobramentos côncavos da escada, que por sua vez, com seu design envolvente e acolhedor, assumiria uma drástica oposição frente ao pronunciado efeito expansivo promovido pela dilatadora forma convexa da área central da escadaria - pelas rampas, pelo arrimo, e pelo terraço aberto à frente da Igreja de San Girolamo (Figuras 214-2I5).

Para além deste efeito de sístole e diástole oferecido para quem apreciasse a margem oriental do Rio Tevere, outro fator diretamente relacionado à condição paisagística da área viria a contribuir para aumentar seu apelo persuasivo frente à capital barroca. $\mathrm{Na}$ área central da cidade, a mais significativa exceção à clausura da massa construída assentada gregariamante nas margens do Rio Tevere seria a 
fresta revelada pela fenda aberta pelo vão do Porto di Ripetta - já que o outro porto, Ripa Grande, se assentava em uma zona limítrofe, ainda pouco habitada. $\mathrm{Ou}$ seja, além de oferecer um acontecimento dinâmico de forte apelo retórico para quem chegava à cidade e ingressava pelo porto, bem como para o passante que descia as Vias di Ripetta ou Scrofa, o Porto di Ripetta também exibia a paisagem rasgada e expansiva do rio, raramente desvendada na massa edificada da cidade (Figura 216). ${ }^{82}$

Outra imponente e teatral escadaria seria construída, pouco tempo depois, entre 1723 e I726, no mesmo rione - mas em seu limite oposto, voltada para o oriente -, ligando a Piazza di Spagna à Igreja Trinità dei Monti, disposta na colina do Pincio. A Scalinata di Trinità dei Monti, desdenhada pelo arquiteto Francesco De Sanctis (I695-I740), se apresentaria como uma estrutura de caráter monumental que entraria em absoluta consonância com o contexto urbano adjacente - poder-se-ia até mesmo dizer que promoveria uma relação de interdependência fatal com toda a cidade, complementando, através de sua disposição dramática vinculada aos preceitos teatrais do Barroco, a moderna disposição urbanística quinhentista, o sistema viário que havia sido retificado pelos pontífices do século XVI. Na verdade, ela permitiria a ligação quase direta entre a Porta del Popolo e as basílicas de Santa Maria Maggiore, San Giovanni in Laterano e Santa Croce in Gerusalemme (assentadas a alguns quilômetros da Piazza del Popolo), pois conectaria a Via Babuino - o eixo oriental do tridente que rasgava a planície do Campo Marzio cruzando a Piazza di Spagna - com a Strada Felice - a longa avenida aberta por Sisto V nas colinas, artéria que, iniciando-se acima da Piazza di Spagna, uniria o largo à frente de Trinità dei Monti com as distantes basílicas. Além do mais, a escadaria também serviria para aproximar, simbolicamente, a igreja dos franceses e o Vaticano, já que da Piazza di Spagna afluiria a Via Condotti, artéria que cruzava linearmente todas as três avenidas do tridente do Campo Marzio, buscando, por um lado, as proximidades do Porto di Ripetta, e, por outro, a Ponte Sant'Angelo, travessa que daria acesso às vias que acorriam a San Pietro.

82 Infelizmente, poucos vestígios do Porto di Ripetta sobreviveram à construção dos muralhões do Tevere e à abertura das avenidas em suas margens - os famosos lungoteveri. O porto seria demolido entre $1870 \mathrm{e}$ 1880, eliminando a primorosa relação de conexão gradual entre rio e a trama urbana: o Lungotevere, assentado a 17 metros do leito do rio, passaria acima das cotas da Via della Scrofa e da Via di Ripetta e acima do nível do antigo porto, ocultando a visão que antes se abria para o Tevere e enterrando, parcialmente, as igrejas de San Rocco e de San Girolamo. 


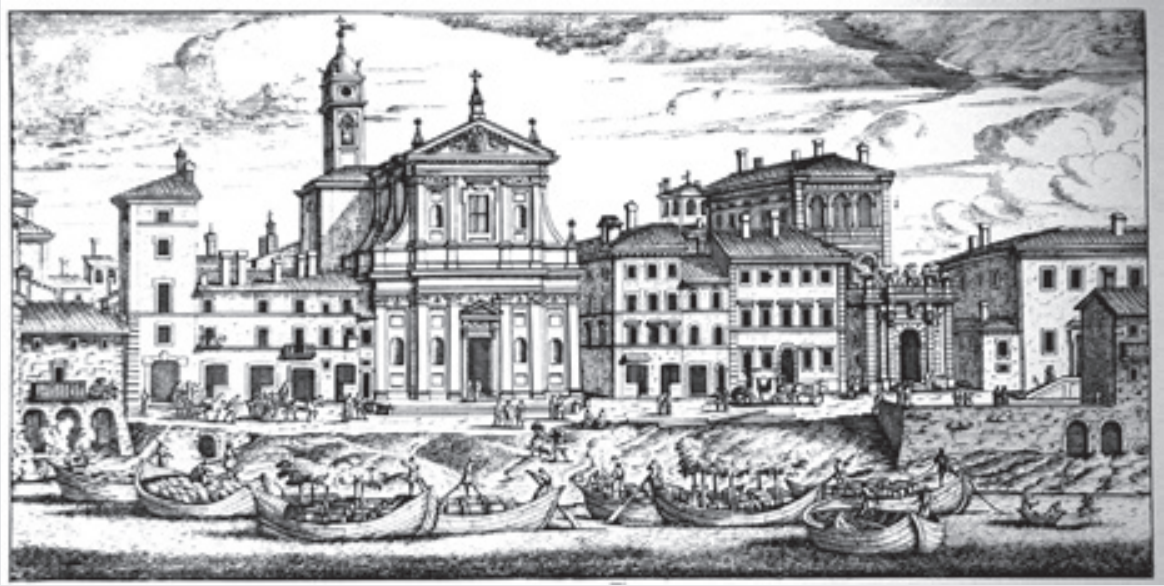

213. Chiesa di S. Girolamo della Natione de Schiavoni nella Regione di Campo Marzo a Ripetta. Imagem do antigo Porto di Ripetta antes da intervenção de sistematização promovida por Alessandro Specchi (1668-1729). Em destaque, a Igreja de San Girolamo degli Schiavoni - projetada por Martino Longhi, il Vecchio (1534-1591), entre 1588 e 1599 -, que viria a ser a protagonista da posterior intervenção. Giovanni Battista Falda, segunda metade do século XVII. Da série II nuovo teatro delle fabriche, et edificii, in prospettiva di Roma moderna - 1665. Fonte: Falda (1970, p. 51).

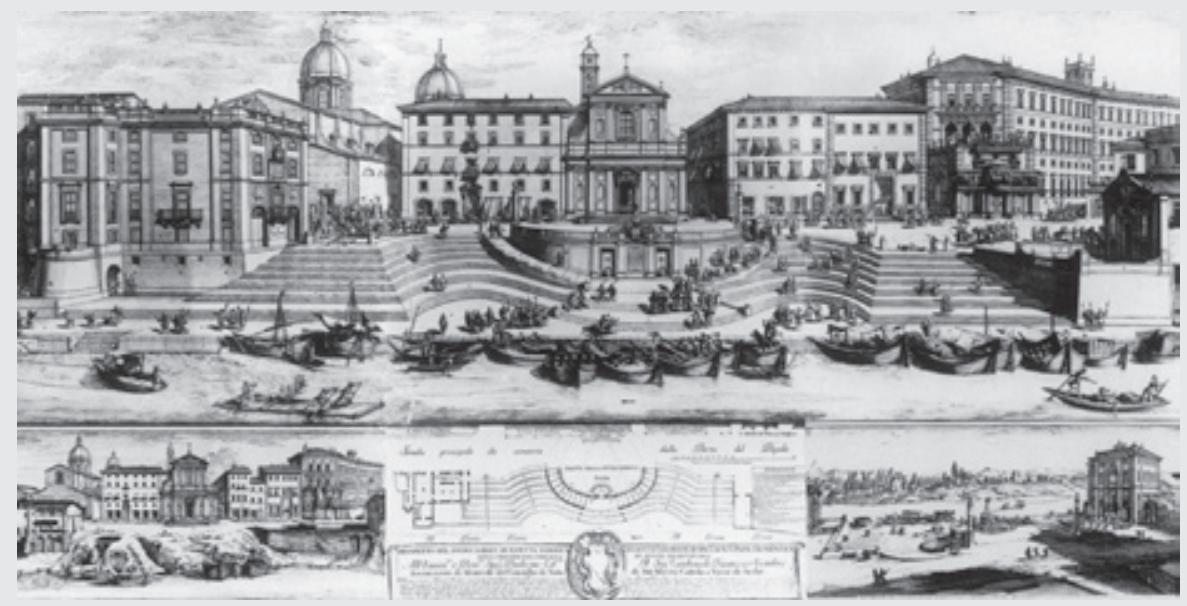

214. Porto e Dogana di Ripetta, Alessandro Specchi - 1705. A alfândega de Specchi é o edifico mais à esquerda. Notar o destaque dado à Igreja de San Girolamo degli Schiavoni. Ao fundo, a cúpula da Basílica de San Carlo al Corso. Fonte: Ponciroli (2007, p. 88). 


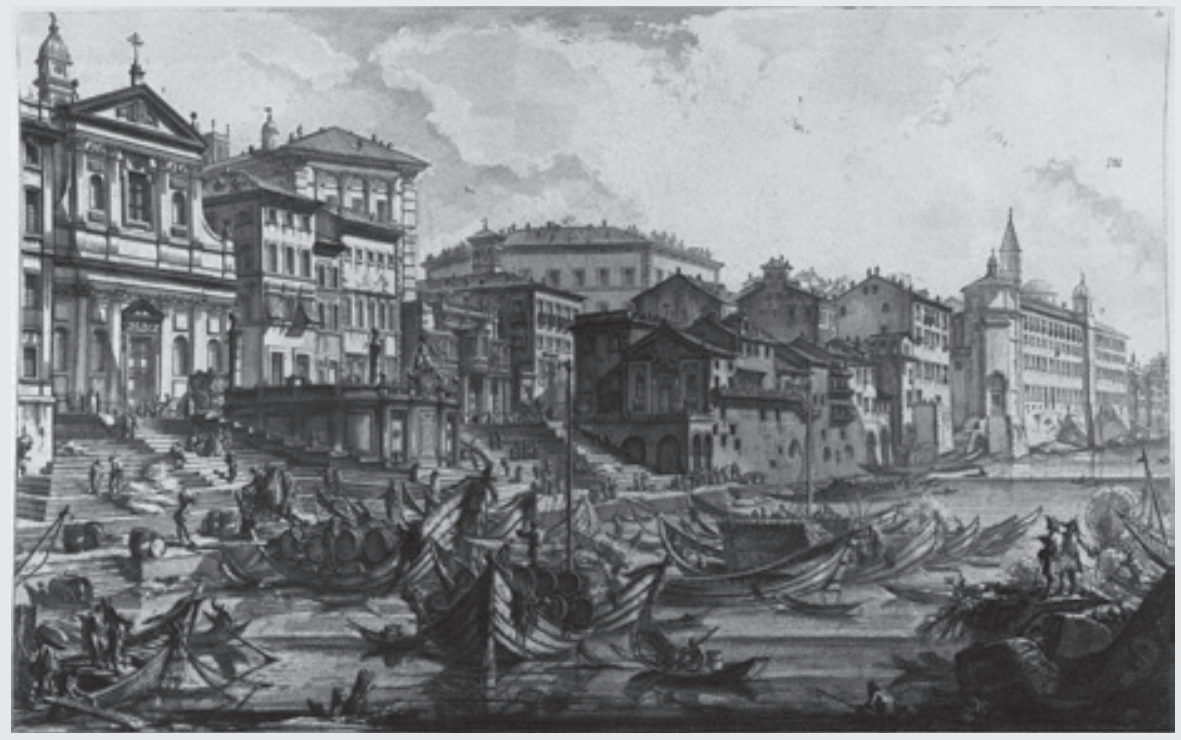

215. Veduta del Porto di Ripetta. Piranesi, 1749. Fonte: Ficacci (2000, p. 698)

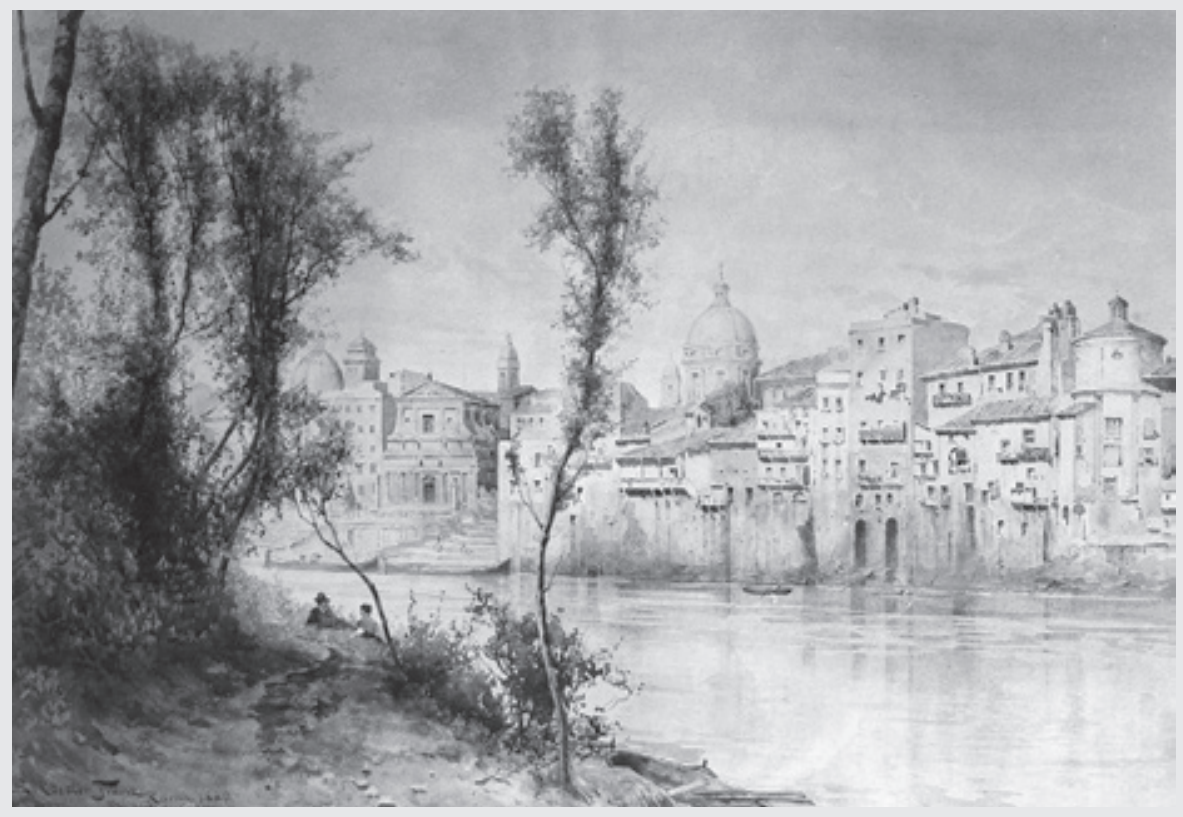

216. Uma janela aberta para o Porto di Ripetta, à esquerda, e a ocupação na margem oriental do Tevere (demolidos para a contenção do rio), vistos da então desabitada área do Prati di Castello. Aquarela de Ettore Roesler Franz, da série Roma Sparita, 1886. Fonte: Jannattoni (2003, p. 119). 
A escadaria também absorveria um grande significado político por unir duas áreas da cidade controladas por emissários das mais importantes nações católicas da época: a Piazza di Spagna, que devia seu nome à embaixada deste país, sediada na grande praça desde I622 (KIEVEN, 2006, p. 242), e Trinità dei Monti, que seria um dos templos construídos na Cidade Eterna por iniciativa dos franceses, estrutura comandada e protegida pelo poderoso império que dominava esta parte da colina do Pincio - igreja edificada em finais do século XV, mas alterada profundamente por Giacomo della Porta, em I575. Logo, a imponente ligação vertical proporia uma espécie de aliança entre as duas nações historicamente inimigas.

Apesar de também ser conhecida como Scalinata di Spagna, a obra-prima de Francesco De Sanctis viria a ser edificada através do patrocínio e do financiamento do governo francês, durante o reinado de Luís XV - após mais de um século e meio de especulações e debates sobre a solução mais adequada para a promoção de uma ligação entre os dois níveis da cidade, caminhos, até então, nutridos por improvisadas passagens abertas na encosta virgem (Figuras 217-2I9). Christian Norberg-Schulz (2000, p. 26, tradução nossa), em seu estudo datado de i972, intitulado Architettura Tardobarocca ${ }^{83}$ faria uma boa exposição crítica da escadaria:

A Escadaria da Piazza di Spagna foi construída para unir Via Babuino, a mais oriental das três artérias que irradiam na cidade a partir da Piazza del Popolo, com a Via Felice, a primeira grande estrada projetada por Sisto V. O seu ponto de interseção se cruza quase em ângulo reto com a Via Condotti, que marca o caminho para San Pietro e o Vaticano. Diversos projetos foram elaborados entre I7II e I720, inclusive por Alessandro Specchi, cujas ideias foram posteriormente assimiladas pelo arquiteto escolhido para a construção da escadaria, Francesco De Sanctis. A riquíssima e variada solução adotada por De Sanctis (I723-I726) é baseada em uma simples repetição aprofundada do tema central da Ripetta: um pronunciado volume, flanqueado por degraus convexos e um estreito patamar à frente. A parte superior apresenta o tema na sua forma básica; a parte inferior é constituída por uma articulada e animada variação. Logo, o pronunciado volume ao meio da escadaria está de alguma forma recuado, gerando um protegido e íntimo espaço entre os vãos laterais convexos, dentro dos quais avançam uma série de degraus côncavos - o então chamado 'teatro'. As duas partes são unidas por um complexo patamar e, ao longo

83 Edição original em italiano, com tradução de Michele Lo Buono. A publicação em inglês, Late Baroque and Rococo architecture, só seria lançada em 1979, sete anos depois. 


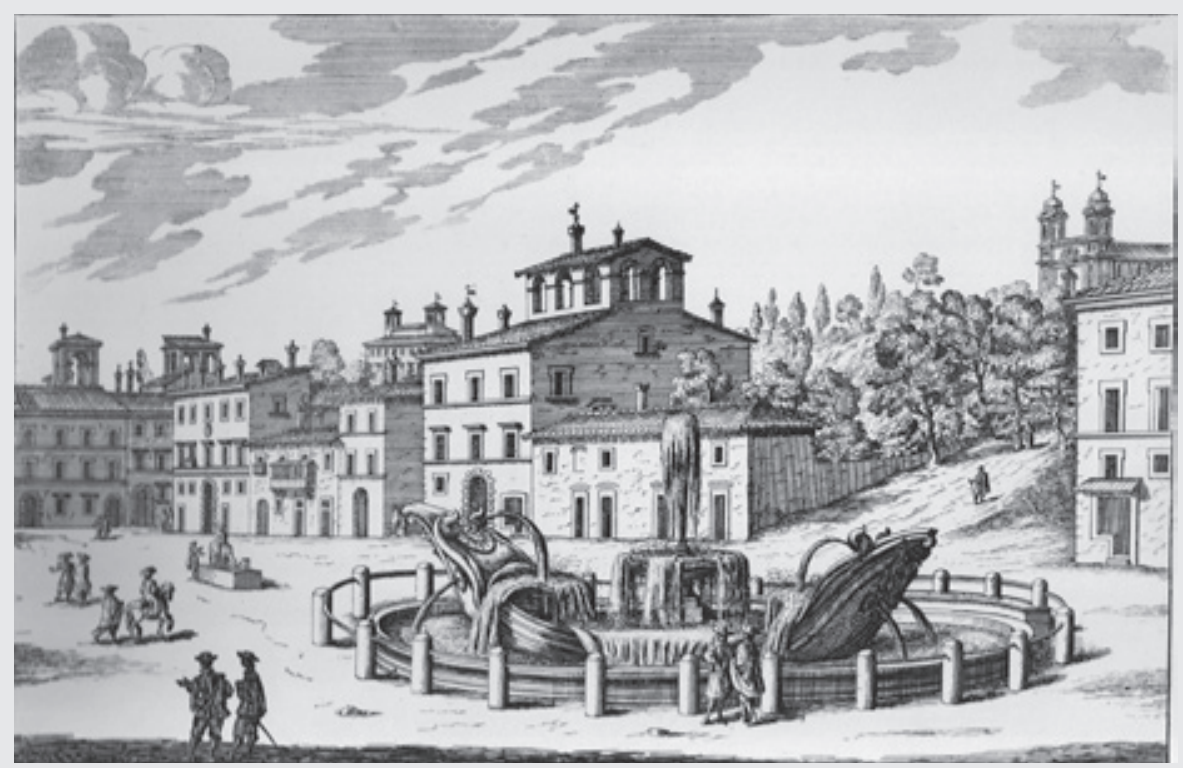

217. Fontana nella Piazza delle Trinità de Monti. Piazza di Spagna, na segunda metade do século XVII, por Giovanni Battista Falda, antes da construção da escadaria que a ligaria com a Igreja Trinità dei Monti (acima). Notar a Fontana della Barcaccia, concebida pelo pai de Gian Lorenzo Bernini, Pietro Bernini (1562- 1629), e terminada pelos dois em 1627. Da série II nuovo teatro delle fabriche, et edificii, in prospettiva di Roma moderna - 1665. Fonte: Falda (1970, p. 13).

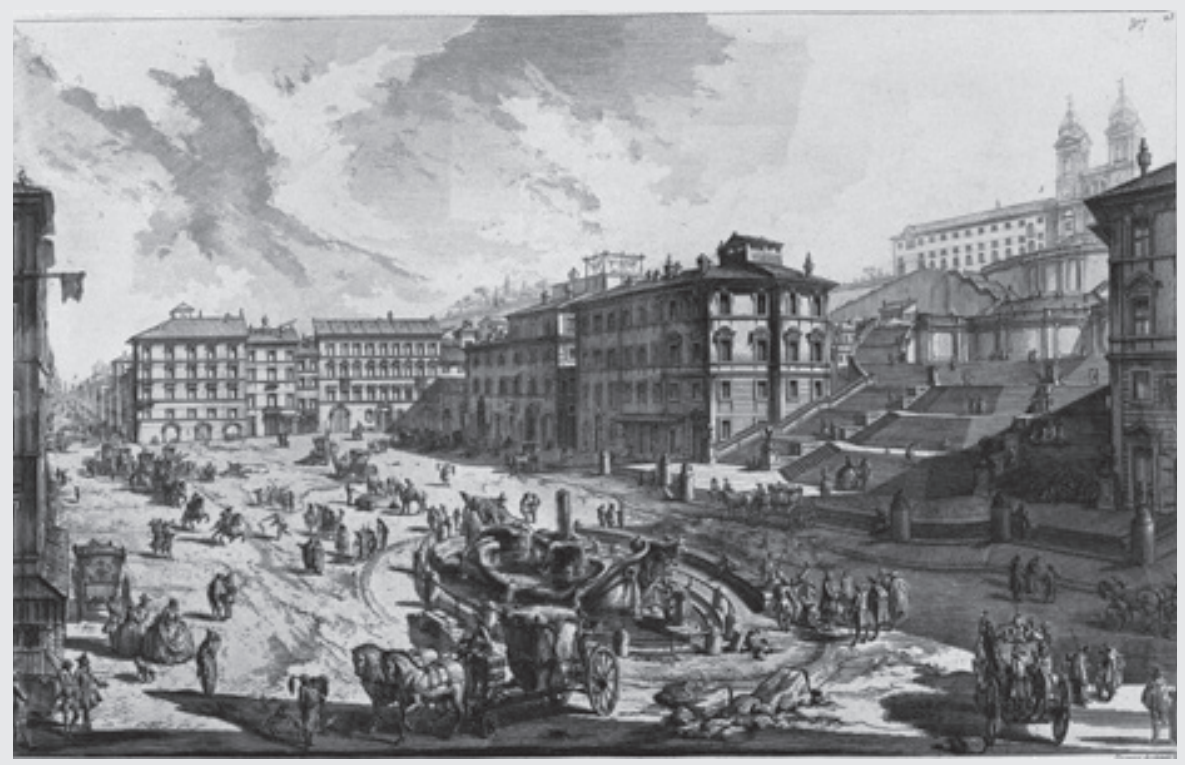

218. Veduta di Piazza di Spagna. Por Giambattista Piranesi, O panorama foi feito no mesmo ângulo da gravura anterior. Escadaria projetada por Francesco de Sanctis (1695-1740) e levantada a partir da década de 1720. Fonte: Ficacci (2000, p. 697). 
do perímetro, por um contínuo muro ondulado. Em sua forma total, a Scalinata di Spagna mostra uma rica interação entre movimentos de sístole e diástole criando um dinâmico equilíbrio que convida a um relaxante deleite, mais do que a uma rápida passagem. A composição é dominada pelo eixo da Igreja de Trinità dei Monti, na qual um obelisco figura, marcando o encontro das várias direções. A solução exprime com eficácia a passagem da retórica mais abstrata dos traçados axiais barrocos, à interpretação sensual de um problema concreto, característica do Settecento.

O obelisco a que se refere Norberg-Schulz só viria a ser assentado em sua atual posição, à frente da Igreja de Trinità dei Monti, em I789, quando acabaria complementando o espetáculo encenado neste setor da cidade ao marcar a meta final daqueles que galgavam os suaves degraus da Scalinata. Além do mais, a agulha vertical sublinharia o eixo longitudinal do complexo que, coincidente com a artéria linear da Via Condotti, passaria pela popular Fontana della Barcaccia $^{84} \mathrm{e}$ subiria a escadaria em direção ao obelisco e à igreja - além do que, o obelisco serviria como fuga perspectiva para aqueles que cruzavam a Via Felice, aberta dois séculos antes por Sisto $\mathrm{V}$.

Não obstante, desde o início da Via Condotti, nas proximidades do Porto di Ripetta, a estrutura já poderia ser avistada no ponto de fuga do eixo perspectivo, a uma distância de quase mil metros (Figura 220); com a aproximação, as longínquas imagens chapadas capturadas em perfeita elevação iriam aos poucos se distorcendo até explodirem em fortes projeções e contrações plástico-espaciais emanadas ao transeunte que alcançava o vazio da Piazza di Spagna. Ou seja, quando o espectador irrompia na praça pela Via Condotti, mas também pelos dois lados da Via Babuino (que ofereceriam oscilantes panoramas em escorço), ele poderia apreciar, plenamente, a estonteante movimentação curvilínea da escadaria que jorrava, como uma poderosa cascata, ao encontro do passante (Figuras 22I-222). Mais um inebriante acontecimento teatral da capital pontifícia, resumido pela historiadora da arte alemã, Elisabeth Kieven (nascida em I947), em seu ensaio, publicado em 2006, Piazza di Spagna: dalla Barcaccia alla Scalinata. ${ }^{85}$

\footnotetext{
84 Esculpida por Pietro Bernini (1562-1629) e pelo seu famoso filho, Gian Lorenzo, em 1627, a pedido do Papa Urbano VIII.

85 Artigo publicado no catálogo da exposição de 2006, Roma Barocca. Bernini, Borromini, Pietro da Cortona, mostra e livro organizados por Marcello Fagiolo e Paolo Portoghesi.
} 

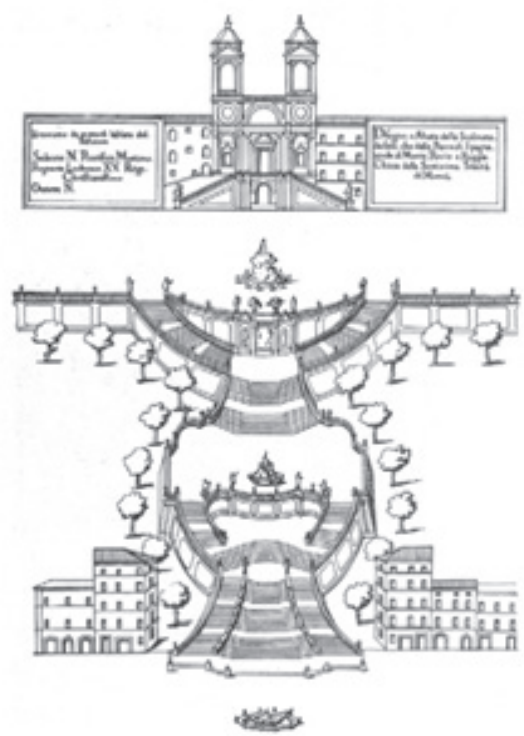

219. Desenho de Francesco de Sanctis, feito na década de 1720 , para a escadaria da Piazza di Spagna. Fonte: Portoghesi (1997, p. 360).

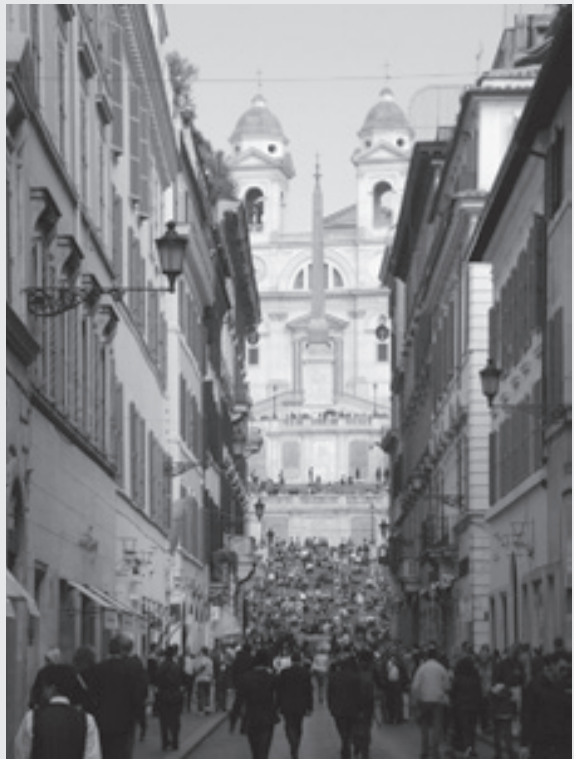

220. Panorama da retilínea Via dei Condotti (rua aberta no período romano e retificada por Paolo III na primeira metade do o século XVI). A Scalinata di Spagna aparece ao fundo, ao final do eixo perspectivo. Fonte: Fotografia elaborada pelo autor (2011)

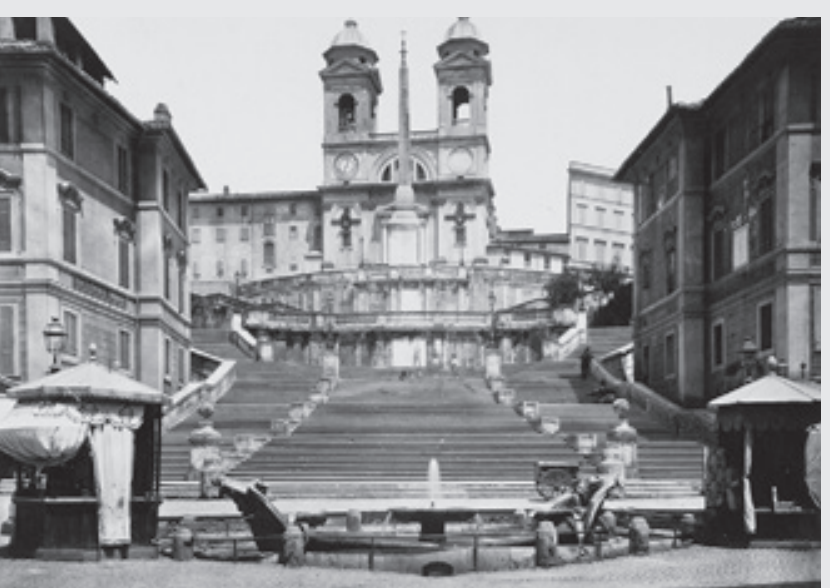

221. Fotografia de 1888 (autor anônimo) da Scalinata di Piazza di Spagna. Fonte: Wikimedia Commons contributors.

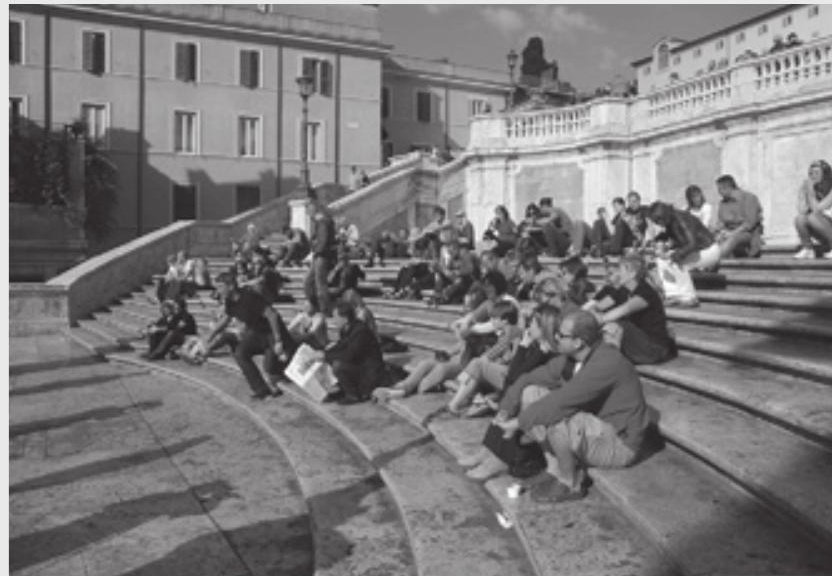

222. Detalhe de um dos setores côncavos da escadaria da Piazza di Spagna. Fonte: Fotografia elaborada pelo autor (2011). 
Alinhada com o eixo constituído pela Via Condotti e pela Barcaccia e flanqueada por duas testadas idênticas, a escadaria confere forma à praça e uma inconfundível qualidade urbanística. A superação do desnível torna-se um espetáculo festivo, os degraus saltam dinamicamente abaixo em direção à praça, onde a Barcaccia aparenta balançar-se na água. No alto, para além da praça, as torres de Santa Trinità dei Monti dominam o perfil da cidade. Esta praça é plena de movimento e, do seu modo, um cenário estável. (KIEVEN, 2006, p. 243, tradução nossa)

\section{A área dos antigos Fóruns: o trágico cenário da Roma antiga e o Barroco}

Como já foi dito, o centro da Roma antiga, tanto a republicana como a imperial, não coincidiria com o da cidade medieval, renascentista, nem com o da Roma barroca. Na verdade, as áreas remanescentes das praças monumentais, seja o Fórum Romano, ou mesmo os Fóruns Imperiais - edificados adjacentes e contíguos -, se transformariam em áreas periféricas da cidade com o decorrer do Medievo. Ainda no final da Idade Média, seriam trechos desolados fora da própria cidade, da aérea habitada (que terminaria no Campidoglio), vazios pontuados por algumas ruínas soterradas de edifícios romanos (basílicas, templos, arcos do triunfo, colunas, anfiteatros), encobertas pelos sedimentos que se depositariam no vale entre as Colinas do Campidoglio, do Palatino, do Esquilino e do Viminale, degradados e mutilados por séculos de pilhagem e pelos graves terremotos e inúmeras cheias que assaltariam o núcleo urbano por diversas vezes.

Em meados do Cinquecento, a zona arqueológica a nordeste, ao pé das encostas dos montes Quirinale e Viminale, área que guardava a herança dos Fóruns Imperiais através das ruínas dispersas de vestígios dos antigos edifícios encobertos, seria saneada com a reabertura da Cloaca Massima e loteada pelo Cardeal Alessandrino (I54I-I598) - após tê-la aterrado para viabilizar a implantação de novos quarteirões. O historiador Mario Sanfilippo (I993, p. III, tradução nossa), em seu livro intitulado La costruzione di una capitale: Roma I9II-I945, resumiria a história do bairro dos Pantani:

Na segunda metade do Cinquecento, a Cloaca Massima é restituída à sua função e é seca a zona dos Orti dei Pantani, sobre os restos dos Fóruns de Trajano, Augusto, Nerva. São sucedidos grandes trabalhos 
de aterramento (em certos pontos o transporte de terra supera os 3 metros) por impulso do Cardeal Michele Bonelli [...] conhecido como o Cardeal Alessandrino, do qual herdaram o nome duas das principais vias deste 'bairro': Via Alessandrina e Via Bonella. Depois a zona inteira é loteada entre 1585-1587 com uma implantação viária bastante regular, enquanto compatível com as ruínas das grandes obras imperiais. Em breve a zona é ocupada por numerosos habitantes modestos, porque é insalubre e pouco atraente aos grandes palácios nobiliários. Dentro do imenso Rione Monti se organiza este bairro dos Pantani [...], que rapidamente se liga àquele da Suburra, mesmo permanecendo distinto. Entre os séculos XVI e XVIII edifícios religiosos e construções civis ocultam quase todos os vestígios da Roma Antiga. Casebres, casas, palacetes, conventos, monastérios, priorados, conservatórios, hospícios, orfanatos, igrejas e superfetações de todo o tipo se apoiam, se sobrepõem, ocupam as grandes obras do passado.

O popular bairro dos Pantani revelaria uma interessante ocupação, onde edifícios barrocos e um casario denso se apoiariam e se sobreporiam aos restos dos monumentos da Roma imperial, ruínas muito danificadas pelo espólio que seria praticado desde o início da Idade Média. Os quarteirões se estenderiam até a base da Colina do Campidoglio e alcançariam a maior praça da zona, o Campo Vacino, o fascinante vazio que se abriria justamente onde antes se encontrava o monumental Fórum Romano.

É possível capturar, nas gravuras dos vedutiste dos séculos XVII e XVIII, como este espaço se configurava (Figura 223): uma praça desenvolvida longitudinalmente entre o Campidoglio e a mole arruinada do Colosseo, na qual uma ocupação edilícia formada por construções residenciais alinhadas dividiam o espaço com importantes igrejas - na base da Colina Capitolina, as Igrejas de San Giuseppe dei Falegnami (também conhecida como San Pietro in Carcere) e a fabulosa Igreja barroca de Santi Luca e Martina, projetada por Pietro da Cortona; logo à frente, com um aspecto exterior muito simples, aparecia a Igreja, de fundação medieval, de Sant'Adriano, templo cristão que então apresentava uma feição interna devido à restauração barroca (comandada por Martino Longhi, il Giovane) da antiga Cúria do Senado, edifício de origem romana construído por Júlio César (Ioo a.C. -44 a.C.) e reformado por Domiziano em 94 d.C.; após uma fileira de casas que definiam o limite nordeste do Campo Vacino surgia, também alinhada com as edificações civis, a inusitada Igreja de San Lorenzo in Miranda (Figura 224), dramático 
edifício barroco construído através da apropriação das estruturas preexistentes do Templo de Antonino e Faustina, principalmente a arruinada e parcialmente soterrada pronao de acesso ao templo, que passaria a servir como pórtico frontal da igreja; bem ao lado surgia o Templo de Rômulo, construção que também sofreu intervenção barroca e que passou a acolher o átrio de acesso à Basílica cristã de Santi Cosma e Damiano, mais uma interessante assimilação de antigos e deteriorados edifícios romanos para novos usos eclesiásticos; ao fundo se destacava, em elevação, a bela fachada palladiana da Igreja de Santa Francesca Romana; já ao lado sudoeste, em meio a um casario disperso e a algumas fortificações medievais e modernas, ao pé do Monte Palatino, despontava a Igreja barroca de Santa Maria Liberatrice, projetada por Onorio Longhi (I568-I6I9) e levantada em sobreposição à estrutura preexistente da Igreja paleocristã de Santa Maria Antiqua. (LOMBARDO, 2006)

Além do casario e das igrejas, a aparição dramática no vazio da praça de pedaços remanescentes e parcialmente enterrados de ruínas romanas - do Templo de Vespasiano; da Coluna Foca; do Templo de Castor e Polux, mais ao fundo; da Basílica de Constantino e do Arco de Tito; e a imagem distante das ruínas do Colosseo - gerava, em oposição às construções modernas, uma cenografia trágica que não poderia ser mais barroca. Algumas estruturas, como a pronao arruinada do Templo de Saturno, serviriam de apoio ao casario que se estenderia do Fórum em direção à Igreja de Santa Maria della Consolazione, gerando, mais uma vez, uma interessante e cenográfica sobreposição de épocas (Figuras 225-226).

Outros panoramas de dramático caráter barroco poderiam ser retirados na visão contígua entre a movimentada Igreja de Santi Luca e Martina, com sua fachada expansiva, e, logo à sua frente, a eloquente estrutura soterrada do Arco di Settimio Severo, mais um monumento antigo a "flutuar" em meio ao vazio do Campo Vacino. Os panoramas que expunham a oposição entre a forma íntegra e dinâmica da igreja de Pietro da Cortona - com a projeção convexa de sua fachada, bem como pela presença marcante da sua cúpula plenamente visível no espaço do antigo Fórum - e a imagem trágica da metade superior do arco do triunfo, aprisionado por séculos de abandono, só reforçariam os mecanismos da retórica barroca impressos na área, particularmente as tensões suscitadas por este insólito confronto entre organismos de épocas distintas e com diferentes níveis de conservação (Figuras 227-228). 
223. Veduta di Campo Vacino, de Giambattista Piranesi, da série Vedute di Roma. Elaborada em 1749. Nesta vista desponta, tragicamente, a praça com os importantes monumentos barrocos e as ruínas clássicas soterradas. A igreja que aparece à direita é a de Santa Maria Liberatrice - que sofreria um ripristino no período fascista perdendo sua feição barroca. Fonte: Ficacci (2000, p. 693).

224. Vista da Igreja de San Lorenzo in Miranda, que se apropriou da pronao do Templo de Antonino e Faustina. Piranesi, 1749. Fonte: Ficacci (2000, p. 702).

225. Vista do Campo Vaccino. Igreja de San Lorenzo, à esquerda, colunas de Castor e Pólux, à direita. Piranesi, 1749. Fonte: Ficacci (2000, p. 740).
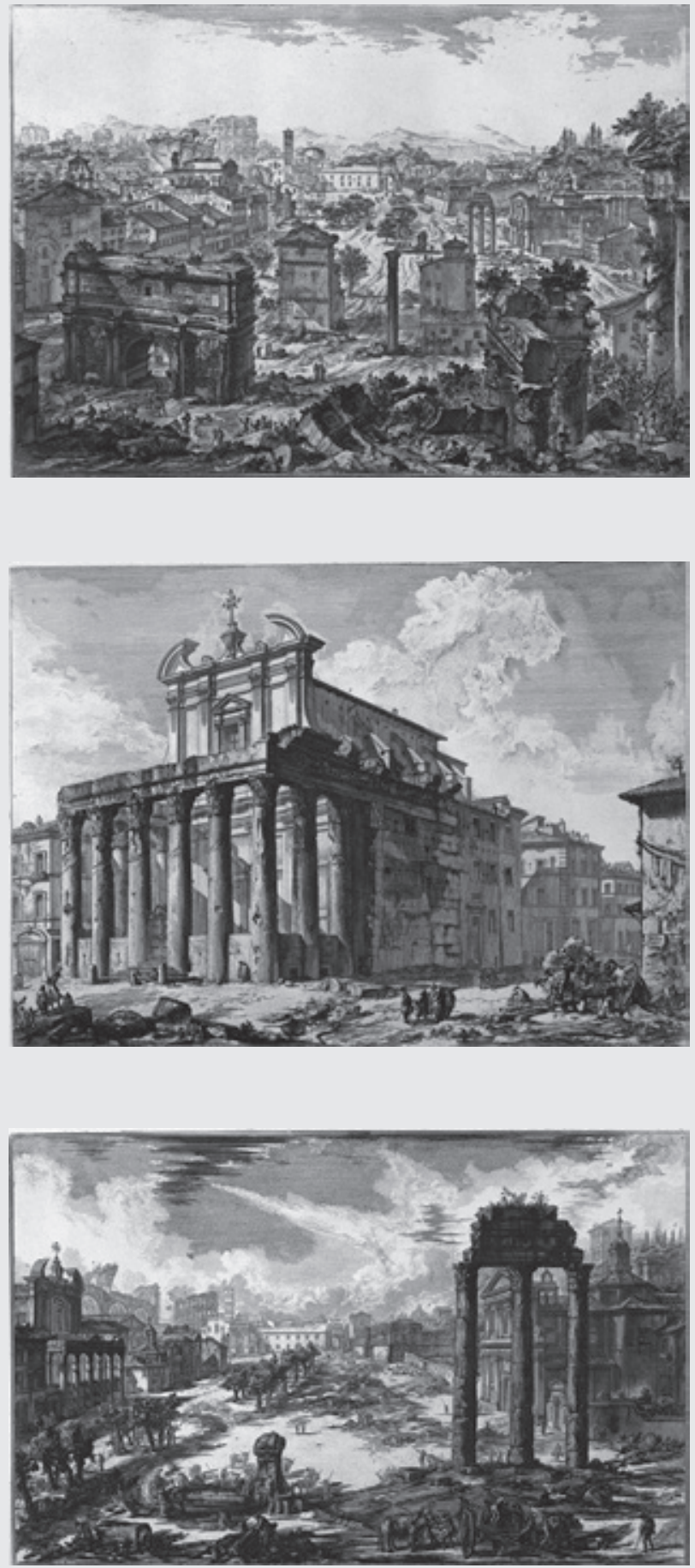

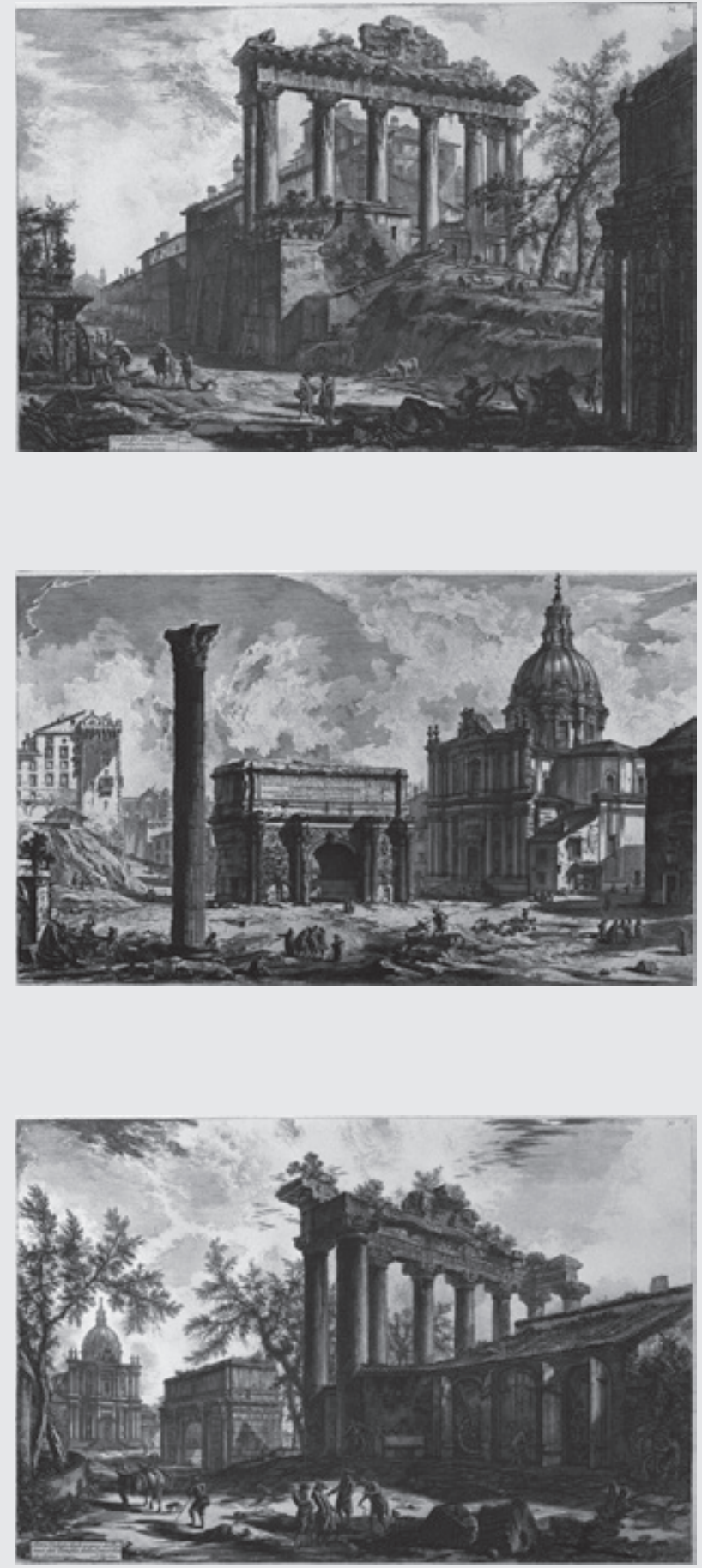

226. Veduta del Tempio detto della Concordia. Na verdade, é o Templo de Saturno. Piranesi, 1749. Ao fundo, após o casario, aparece a Igreja de Santa Maria della Consolazione. Fonte: Ficacci (2000, p. 745).

227. Arco de Settimio Severo soterrado e Igreja de Santi Luca e Martina. Piranesi, 1749. Fonte: Ficacci (2000, p. 704).

228. Imagem dramática das colunas do Templo de Saturno do Arco de Settimio Severo e da Igreja de Santi Luca e Martina. Piranesi, 1749. Fonte: Ficacci (2000, p. 746). 
Além disso, o Campo Vacino seria um verdadeiro respiro em relação aos densos e populares bairros dos Pantani e da Suburra, um vácuo que se abriria abaixo das imponentes Colinas do Campidoglio e do Palatino. O percurso assumido pelo passante através das ruas estreitas, rasgadas no século XVI, derrocaria em interessantes mecanismos de persuasão barroca nos quais, sem dúvida, seriam desvelados conflitos dramáticos devido à expectativa gerada no âmago dos quarteirões e na surpresa de irromper na praça. Nada da trama barroca deste fascinante ambiente revelado na Roma seiscentista sobreviveria aos arqueólogos e, num momento posterior, a Benito Mussolini (I883-I945). ${ }^{86}$

\section{O grande teatro do mundo: a Piazza di San Pietro, em Roma}

Esta apreciação da construção do caráter barroco da cidade de Roma só poderia ser finalizada com a análise do maior acontecimento dramático da cidade: o complexo de San Pietro, organismo no qual Bernini demonstraria os princípios essenciais da retórica persuasiva do Grand Siècle. Na Piazza di San Pietro o arquiteto buscaria sublinhar a condição da basílica enquanto sede da Igreja Católica através do uso de inúmeros artifícios dramáticos balizados pelos mecanismos compositivos oriundos das propriedades da percepção humana. $\mathrm{O}$ espaço estaria inserido, coerentemente, no processo de modernização da cidade, irrompendo em seu tecido urbano como a síntese de toda a pesquisa visual empreendida. Contudo, a concepção do grande arquiteto e escultor barroco não poderia ser compreendida desvinculada do processo de reconstrução da basílica vaticana, pois a sua estratégia de reformulação paisagística do espaço seria elaborada, justamente, em função do grandioso edifício dedicado a São Pedro que se postava logo à frente.

86 A praça barroca do Campo Vacino se transformaria no Parque do Fórum Romano, um desnível em meio à cidade, que, além das ruínas que já se sobressaíam, revelaria ao transeunte apenas fundações dos outros antigos edifícios do Fórum - com exceção de uma ou outra ruína levantada por anastilose. Pior sorte teria a área na qual antes se levantavam as estruturas dos Fóruns Imperiais, sobrepostos, desde o Cinquecento, pelo Bairro dos Pantani. Neste caso, as escavações iniciadas por Napoleão Bonaparte em princípios do século XIX acarretariam, inevitavelmente, em ações de destruição de partes inteiras do tecido urbano. Finalmente, entre as décadas de 1920 e 1930, por ordem de Mussolini, o bairro quinhentista seria totalmente arrasado por recomendação de seu mais influente arqueólogo, Antonio Muñoz (1884-1960), e com o apoio de quase todo o seu staff, destruído para dar lugar a parcas escavações e à imponente, e desolada, Via dell’Impero (atual Via dei Fori Imperiali). 
Sabe-se que desde o pontificado de Nicolò V (I397-I455), ${ }^{87}$ em meados do Quattrocento, já era contemplada a possibilidade de se restaurar a imensa igreja cristã primitiva construída pelo Imperador romano Constantinus (272-337) ${ }^{88}$ A mando do papa, o escultor e arquiteto Bernardo Rosselino (I409-I464) proporia a recuperação da forma basilical do templo preexistente (ARGAN, I986, p. I79) - igreja que havia sido edificada há mais de mil anos, entre os anos de 3I9 e 324, no local onde, tradicionalmente, se acreditava que o apóstolo de Jesus Cristo e primeiro bispo de Roma, São Pedro, teria sido sepultado. (COEN, I999, p. 28) Mas, em I506, o mestre da arquitetura renascentista Donato Bramante (I444-I5I4) proporia, para o Papa Giulio II (I443-I5I3), ${ }^{89}$ uma solução diversa: a reconstrução integral da igreja sob uma forma não basilical, em cruz grega. Após sua morte, outros tantos artistas alterariam, sem muito sucesso, o coerente design aditivo de Bramante - entre eles, o grande Raffaello Sanzio (I483-I520) e Antonio da Sangallo, o jovem (I453-I534).

Contudo, o projeto final seria elaborado, criteriosamente, por Michelangelo Buonarroti (I475-I564) depois de receber o convite do Papa Paolo III para assumir os encargos de San Pietro no inverno de I546-I547. (BENEVOLO, 2008, p. 305) A plasticidade contínua e tensa do organismo proposto pelo mestre toscano romperia definitivamente a composição serenamente aditiva de Bramante, impondo, apesar da preservação da tipologia de cruz grega, uma concepção ligada aos conflitos existenciais típicos do Maneirismo, principalmente a ideia da elevação da forma a um patamar de tensões e conflitos espirituais que não caberiam na condição de equilíbrio da proposta anterior. Por isso, seria concebido um corpo fechado e pesado, onde a tensão entre forças verticais e horizontais seria de fato radical. A concepção da cúpula monumental previa um grande elemento esférico, com um impulso vertical conduzido pelos pares de colunas do tambor cilíndrico e pelos pronunciados espigões que partiriam das ordens, elevando-se pela calota até o lanternim. Em função da grande dimensão do domo esférico, a cúpula se apresentaria visualmente achatada, com uma lanterna verdadeiramente monumental fazendo pressão para baixo. Esta composição ofereceria a ideia de que o

\footnotetext{
87 Tomaso Parentucelli, papa de 1447 até sua morte.

88 O imperador governaria desde sua vitória sobre Maxentius (278-312), em 312, até sua morte. Contudo, seria mais conhecido e celebrado pelo fato de, em 313, ter sancionado plena liberdade aos cultos cristãos no Édito de Milão, dando impulso a uma nova era que se consolidaria na Idade Média.

89 Giuliano della Rovere dirigiu a Santa Sé de 1503 até a sua morte.
} 
forte direcionamento vertical das colunas e dos espigões seria implacavelmente barrado pelo achatamento da cúpula e pelo imenso lanternim pousado em cima da calota, expondo um desconforto compositivo típico da cultura maneirista.

Apesar do grande cuidado que Michelangelo empreenderia para que o projeto fosse realizado em sua total integridade após a sua morte, o sucessor do artista na fábrica de San Pietro, o arquiteto Giacomo della Porta (1532-I602), o modificaria substancialmente quando, finalmente, conseguiria edificar a cúpula em finais do século XVI. O organismo resultante efetivaria a eliminação da composição tensa e contraditória anterior em prol da representação da calota esférica como o símbolo da retomada da estabilidade da Igreja após o Concílio de Trento, reafirmando seu papel como ponto de convergência para todo o universo católico. O artifício retórico desenvolvido estaria centrado, simplesmente, na diminuição do contraste entre os direcionamentos verticais e horizontais que causariam o esmagamento da cúpula na composição anterior. As seções dos espigões seriam suavizadas, substancialmente, amenizando o sentimento de elevação vertical em direção ao pesado lanternim. Por outro lado, a altura da cúpula externa seria elevada em oito metros, transformando-a em um volume levemente ogival, ao mesmo tempo em que a altura do lanternim seria diminuída, de forma significativa, em quase dois metros. Deste modo, a cúpula de San Pietro tornar-se-ia uma estrutura mais leve, perdendo o caráter de forma achatada e comprimida, resultante da proposta de Michelangelo, irrompendo no ambiente da cidade de Roma e de todo o mundo católico como o eixo simbólico da fé cristã (Figuras 229-23I). Estas constatações seriam fruto da exaustiva pesquisa enfrentada pelo já citado historiador da arte Rudolf Wittkower (I979, p. 522-523, tradução nossa) e seriam originalmente publicadas em 1933 no ensaio Zur Peterrkuppel Michelangelos, texto que ganharia uma versão ampliada em italiano na década de 6o do século passado. ${ }^{\circ \circ} \mathrm{O}$ crítico decretaria:

Totalmente de acordo com esta concepção problemática, Michelangelo concebeu uma cúpula hemisférica apertada, comprimida e absolutamente relacionada ao enfoque que dava a suas soluções. Porta deu à cúpula uma curva mais elegante, elevada e ascendente. Para conseguir esta mudança, teve que elevar os centros das cúpulas interior e

90 Aqui foi analisada a versão em espanhol, La cúpula de San Pedro de Miguel Angel, traduzida das versões em alemão e em italiano por Justo G. Beramendi e lançada em 1979 na coletânea Sobre la arquitetctura en la edad de Humanismo. 


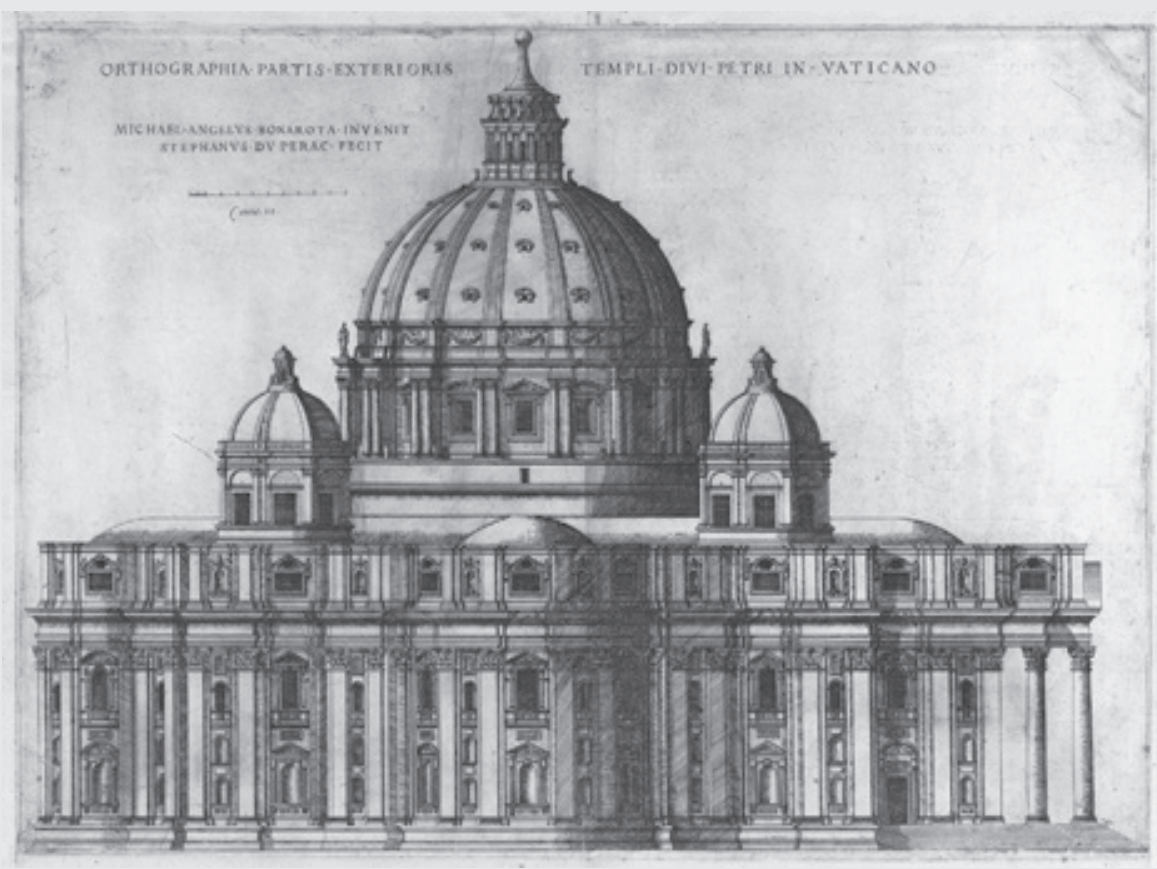

229. Uma das fachadas laterais projetadas por Michelangelo Buonarroti (1475-1564) para a Igreja de San Pietro. Por Étienne Duperác (1520-1607), publicado em 1569. Fonte: The Metropolitan Museum of Art.

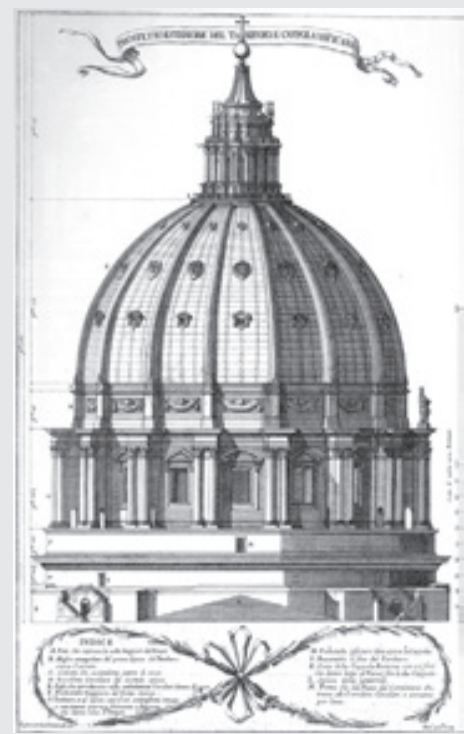

230. Elevação externa da Cúpula da Igreja de San Pietro tal como foi construída por Giacomo della Porta (1532-1602). Imagem retirada do livro de Carlo Fontana (1634-1714), publicado em 1694, II Tempio Vaticano e la sua origine, con gli edifici più cospicui antichi e moderni fatti dentro e fuori di esso, publicação que contou com desenhos de Alessandro Specchi. Compare a proporção entre a altura e o diâmetro da cúpula que foi edificada com a imagem anterior, onde aparece a estrutura segundo projeto de Michelangelo. Fonte: Fontana (2003, p. 221).

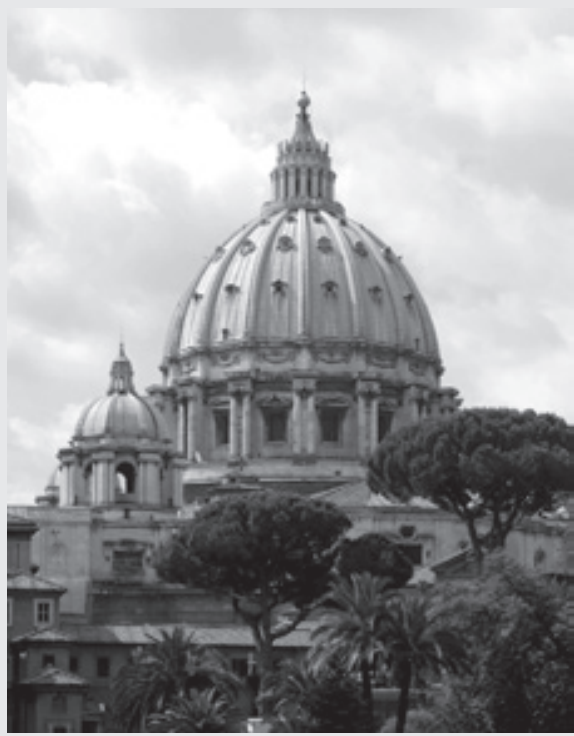

231. A cúpula de San Pietro, em Roma. Fonte: Fotografia elaborada por Myrabella - Licença CC BY-SA 3.0 \& GFDL / Wikimedia Commons contributors. 
exterior, a primeira aproximadamente uns 3,50 metros e a segunda ao redor de 4,6o metros, dando assim, como resultado, uma cúpula com uma pendência muito abrupta em sua parte inferior. Por outro lado, teve que situar os centros 4,0o metros além do eixo vertical, o que gera como resultado a elevada curva, tanto dentro como fora.

Podemos agora traduzir em cifras o aumento de altura introduzido por Porta na cúpula de Michelangelo. De acordo com meus próprios cálculos sobre a maquete, a cúpula de Michelangelo, desde a cornija do tambor, até o anel interior do ápice, deveria ter tido 21,79 metros de altura. Porta agregou a ela quase uma terceira parte e a cúpula exterior se eleva 8,08 metros acima da de Michelangelo. Ninguém pode negar que é uma cifra considerável.

A cúpula elevada de Porta reflete uma alteração nos valores estéticos e isto é ainda mais claro quando se considera a relação entre a cúpula e o lanternim. Porta diminuiu a altura da lanterna projetada por Michelangelo em I,83 metros.

Logo, no último quartel do Cinquecento, já um maneirista como Giacomo della Porta exporia, sob a influência direta da Contrarreforma, uma atitude de alto teor persuasivo no que diz respeito à construção da Basílica de San Pietro - se aproximando da retórica propagandista barroca. Todavia, estas não seriam as únicas modificações que o projeto de Michelangelo viria a sofrer com o passar dos anos. Em I607, o Papa Paolo V (I552-I62I) $)^{91}$ determinaria um aumento considerável da nave projetada por Michelangelo, ampliando e rompendo para sempre a cruz grega preexistente e gerando um edifício com uma nova estrutura em formato basilical, bem como promovendo a ereção de uma grande e larga fachada para a igreja, obviamente levantada bem mais à frente daquela prevista por Michelangelo - exigências fundadas, em parte, em uma simples questão funcional, para o templo poder congregar mais fiéis, mas também derivadas da má vontade que a Igreja contrarreformista guardava em relação às formas centralizadas, entendidas como pagãs. Estas alterações romperiam, definitivamente, o conceito inicial do mestre toscano que idealizava uma estrutura contínua para a igreja, desarticulando a massa escultórica pesada, tensa e fechada do organismo preexistente (Figuras 232-233).

91 Camillo Borghese governou a Igreja de 1605 até a sua morte. 
Por outro lado, estas obras, realizadas sob a coordenação do arquiteto Carlo Maderno (I556-I629), colocariam o templo em uma condição urbana mais explícita, contribuindo para projetá-lo ao tecido da cidade - bem como aproximaria a igreja um pouco mais do distante obelisco erigido por Domenico Fontana (I543I607), diminuindo em cerca de 90 metros (aproximadamente o comprimento da nave proposta) a distância original de mais de 270 metros entre o marco vertical assentado no eixo da igreja e o seu antigo frontispício. Em contrapartida, tragicamente a cúpula assumiria uma posição desfavorável por acabar perdendo grande parte de sua imponência para a fachada moderna, e por praticamente desaparecer, por efeito perspectivo, da visada imediata do frontispício - fato que levaria o arquiteto a ser criticado por todas as gerações que o sucederam (Figuras 234-235).

Felizmente, décadas mais tarde, Gian Lorenzo Bernini (I598-I680) iria propor uma admirável resolução barroca para o problema causado no início do século: o mestre napolitano promoveria o resgate da expressiva projeção da cúpula da basílica vaticana para a cidade de Roma - operação que seria alcançada por meio da junção de inúmeros artifícios visibilísticos e teatrais concebidos durante a construção da nova Piazza di San Pietro. O escultor, desde muito jovem, já estaria sendo responsável por importantíssimos encargos no Vaticano, especialmente após a posse de Urbano VIII (I568-I644) ${ }^{92}$ em I623 - obras maestras, como o gigantesco e agitado Baldaquino assentado abaixo da cúpula di San Pietro, um misto de escultura e arquitetura levantado dentro da grande basílica após o ano de i624. Com a morte de Maderno, em i629, Bernini ostentaria, definitivamente, o controle das obras da basílica, tendo, contudo, de esperar mais de três décadas para assumir, em I656, sua maior empreitada: o projeto e a construção da praça à frente do mais importante templo da civilização católica romana (Figura 236), trabalho desenvolvido a pedido do Pontífice Alessandro VII (I599-I667).93

Bernini aproveitaria as radicais modificações acionadas no início do século por Carlo Maderno para propor uma revalorização da cúpula de Michelangelo e jogá-la de vez a todo o ambiente citadino e, simbolicamente, para a totalidade do mundo cristão. A verdade infinita da fé católica se espalharia através deste autêntico teatro do mundo:

92 Maffeo Barberini foi papa de 1623 até a sua morte.

93 Fabio Chigi liderou a Santa Sé de 1655 até a sua morte. 


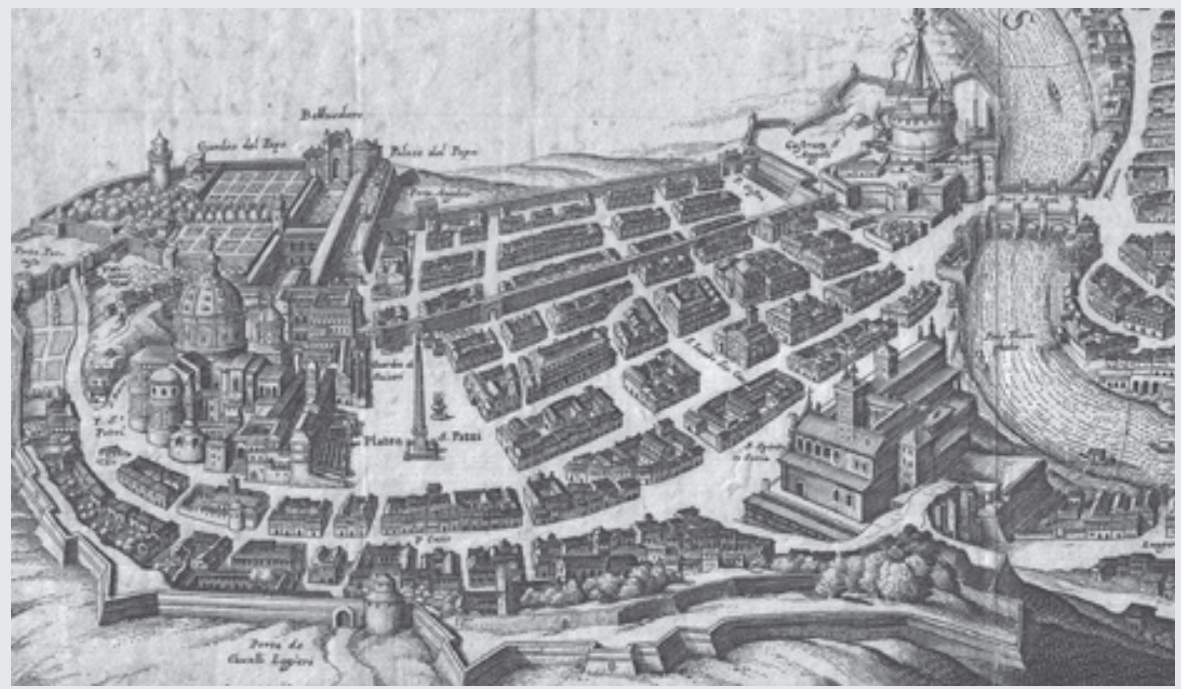

232. Detalhe da planta de 1593, do pintor e gravurista Antonio Tempesta (1555-1630), mostrando o Bairro dos Borghi e o complexo de San Pietro antes da edificação da nave e da fachada de Carlo Maderno (1556-1629) e da construção da Praça de Bernini. Fonte: Wikimedia Commons contributors.

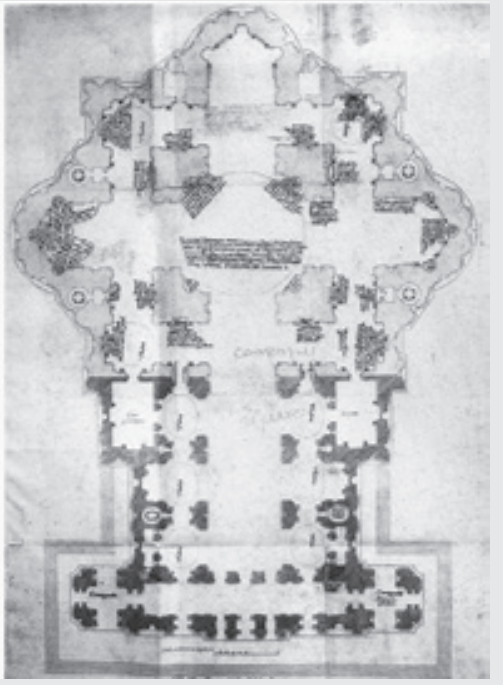

233. Planta da Basílica de San Pietro mostrando, em destaque, a nave projetada e construída por Carlo Maderno - traço escuro. Imagem retirada do livro de Carlo Fontana, II Tempio Vaticano e la sua origine, con gli edifici più cospicui antichi e moderni fatti dentro e fuori di esso. Fonte: Fontana (2003, p. CXCl).

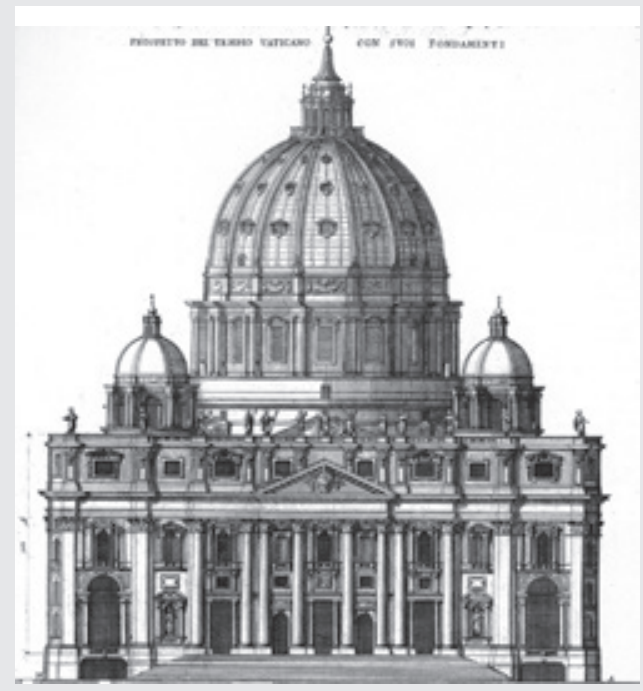

234. Elevação externa da Basílica de San Pietro, com destaque para a sua fachada principal, construída por Maderno, e para a cúpula projetada por Michelangelo e edificada por Giacomo della Porta após alterar o seu desenho, elevando a altura da estrutura. Imagem retirada do livro que Carlo Fontana escreveu sobre San Pietro - desenhos de Specchi. Fonte: Fontana (2003, p. 210). 


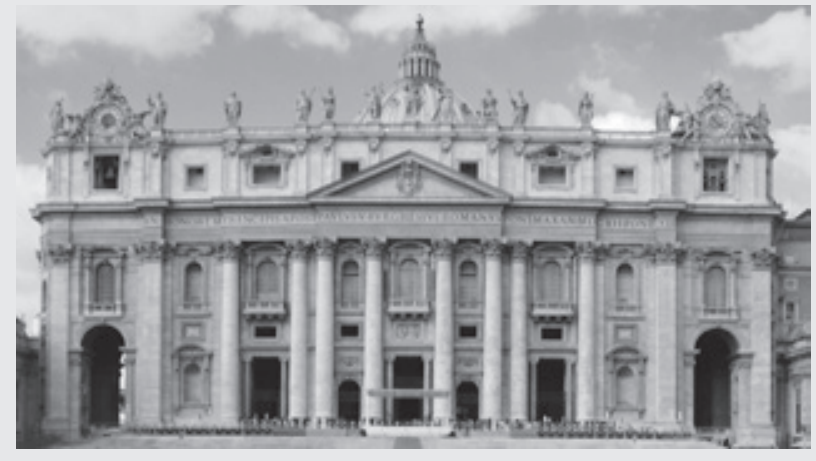

235. Panorama real da fachada principal de San Pietro, retirado a uma distância razoável do acesso à igreja. Percebe-se como, após a construção da imensa nave de Maderno e de sua monumental fachada, a cúpula desapareceu da visão do transeunte que se aproximava da basílica. Fonte: Fotografia elaborada pelo autor (2011).

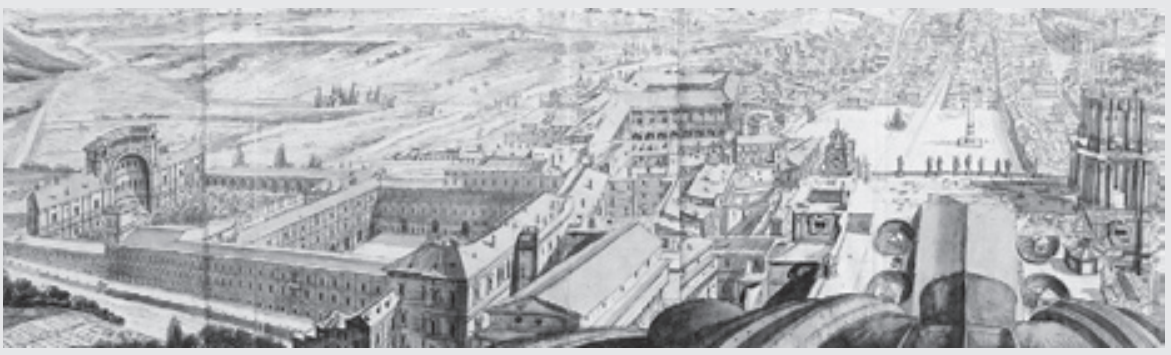

236. Panorama do Vaticano, feito em 1641, pelo arquiteto e gravurista francês Israël Silvestre (1621-1691), retirado a partir do lanternim da cúpula de San Pietro. Em destaque, a construção da torre sul projetada por Bernini e depois derrubada. Também em destaque a antiga sistematização da praça em frente à basílica, anterior à intervenção de Bernini. Fonte: Marder (1998, p. 73).

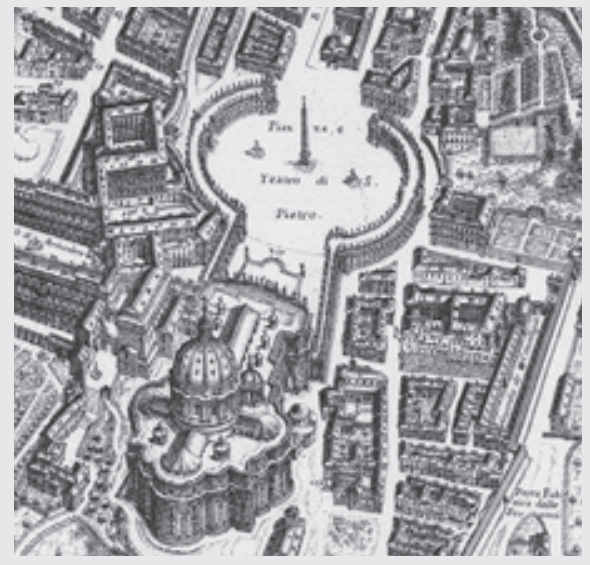

237. Detalhe do Mappa della città di Roma,

confeccionado em 1676 por Giovanni Battista Falda, onde aparece a então recém-edificada Piazza di San Pietro, projetada por Bernini em 1656. Fonte: Site Roma ieri oggi.

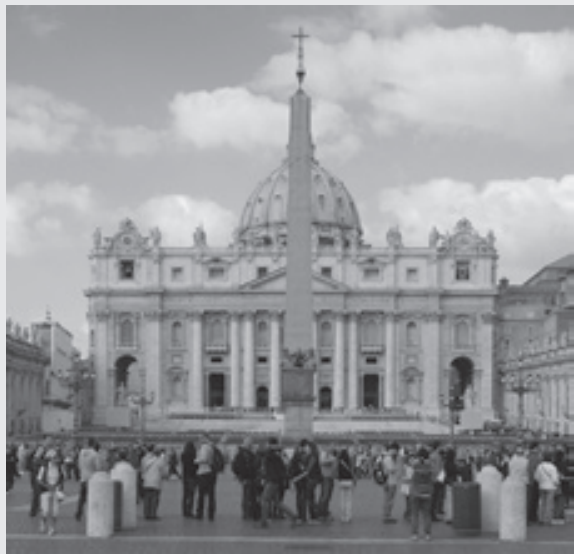

238. Fotografia tomada da entrada da atual Piazza di San Pietro. A recuada praça projetada por Gian Lorenzo Bernini recuperou a plena visão da calota da cúpula projetada por Michelangelo. Fonte: Fotografia elaborada pelo autor (2011). 
[...] pois, como dizia o próprio Bernini, as colunatas, símbolos dos braços da igreja que a tudo engloba, 'acolhem aos católicos para reforçar suas crenças, aos hereges para devolvê-los à igreja, e aos infiéis para iluminá-los com a autêntica fé.' Desta maneira a praça oblíqua se apresenta a nós como um auditório para todo o mundo. (WITTKOWER, I979, p. I6, tradução nossa)

As palavras do mestre do barroco romano, apresentadas por Wittkower no texto Palladio e Bernini, de 1966, ${ }^{94}$ demonstrariam a forma alegórica como o escultor pensava a configuração de sua piazza: a cúpula seria a cabeça de Deus; a nave, o seu corpo; e os limites construídos da praça, os braços de Deus acolhendo simbolicamente toda humanidade cristã - uma obra-prima da retórica persuasiva barroca (Figura 237).

Para conseguir esta irradiação centrífuga, a abertura da cúpula de Michelangelo para o espaço infinito da civilização católica, Bernini, primeiramente, deveria escolher uma locação adequada para o ambiente principal da praça, uma implantação que fosse o mais distante possível da fachada da basílica. Deste modo, concebendo o espaço tendo como ponto de referência o obelisco disposto há mais de 150 metros da igreja, resgataria, pelo menos, parte da vista da cúpula, perdida nas imediações do monumental frontispício desde as intervenções de Maderno (Figura 238).

Em segundo lugar, o arquiteto deveria recuperar a cúpula como eixo dominante da composição: sem dúvida, Bernini estava consciente de que para resgatar a condição hierarquicamente prioritária da cúpula em relação ao contexto edilício e urbano adjacente, precisaria desvalorizar a fachada de Maderno - que era o acontecimento arquitetônico mais suntuoso presente nas imediações do templo - para depois enfatizar o domo como o coroamento artístico e simbólico da cidade. Para isso, seria necessário colocar a frontaria "entre parênteses" (ARGAN, I986, p. 35I) - em segundo plano -, estratégia que Bernini perseguiria recusando a criação de uma praça circular que incentivaria a vista em elevação da fachada. Conceberia, pelo contrário, um imenso espaço elíptico recuado, com o diâmetro menor coincidindo com o eixo perpendicular ao ponto médio da fachada e tendo em seu centro o obelisco que Domenico Fontana deslocaria em 1586. Assim, os dois pontos principais da forma geométrica conseguida, os focos da

94 Versão em espanhol, Palladio y Bernini, traduzida por Justo G. Beramendi e lançada em 1979, na coletânea Sobre la arquitetctura en la edad de Humanismo. 
elipse, dispostos obliquamente à fachada, evitariam a valorização do eixo central e a frontaria ficaria submetida à visão em escorço, extremamente negativa em função de sua grande horizontalidade, além de ser gravemente interrompida, em algumas áreas laterais da praça, pelas finalizações dos braços elípticos (Figura 239). Por outro lado, a cúpula continuaria a ser vista em elevação perfeita por ser conformada por volumes cilíndricos e esféricos. Argan (I986, p. I8I-I82, tradução nossa), em seu livro L'architettura barocca in Italia, publicado pela primeira vez em 1957,95 detalharia e reforçaria estes mecanismos, além de explicitar como a fachada retomaria todo o seu prestígio após o transeunte vencer o espaço elíptico e ingressar no ambiente trapezoidal que antecederia a igreja:

Quanto à forma da colunata, o círculo teria sido a mais lógica, ainda que não a melhor. Já que existem dois pontos básicos - o centro da cúpula e o centro da colunata (indicado pelo obelisco que Domenico Fontana levantou em 1586) -, o diâmetro do círculo, ao passar pelo obelisco e prolongar-se idealmente até a cúpula, também teria que passar pelo eixo médio da fachada; e assim, esta teria reconquistado, no conjunto do monumento, esse valor de limite, de fundo de perspectiva que Bernini, pelo contrário, queria privá-la. Era preciso, pois, renunciar a uma solução axial; surge então a forma elíptica, que não tem um centro, e sim dois focos pelos quais passam dois eixos oblíquos. A cúpula é um cilindro coroado por uma forma esférica e, portanto, qualquer que seja o ponto de onde seja avistada, sempre tem a mesma forma; porém a fachada é um plano muito desenvolvido na largura, e uma visão mesmo que ligeiramente oblíqua é o suficiente para fazê-lo parecer em escorço. Enquanto aparece em escorço, esse plano fica comprometido pelo jogo da perspectiva ilusória, no deslizamento ótico dos planos laterais oblíquos: perde todo o valor como encerramento da perspectiva, se convertendo em um mero paramento decorativo; e a cúpula volta a ser o elemento soberano do monumento. Mas, assim que se supera a embocadura da colunata e a cúpula sai do campo visual, eis que a fachada, nobremente enquadrada nas duas alas que, agora, servem a valorizá-la, readquire todo o seu 'decoro': aliás, justamente em função da solução perspectiva derivada da praça capitolina, viria a ser realçado aquele caráter michelangesco, 'sublime', que Maderno teria tentando conferir-lhe. 
Outro fator que colaboraria, decisivamente, para a geração do alto teor persuasivo que a Piazza di San Pietro emanaria seria o mecanismo gerado na articulação da colunata presente nos limites do espaço elíptico, em sua interconexão com a cúpula. A colunata elíptica, aberta e permeável da praça seria inspirada, com segurança, na forma cilíndrica do tambor da cúpula de Michelangelo e nos pares de colunas que envolveriam sua massa pesada e densa. Mas, para o contexto desenvolvido embaixo, Bernini inverteria o seu sentido plástico: enquanto os pares de colunas da cúpula conformariam um volume fechado, comprimido em si mesmo, tenso e carregado, a colunata envolveria um espaço definitivamente aberto. Além de permeável, o ambiente apresentaria um caráter expansivo conseguido através do desenho centrífugo da forma elíptica, distendida transversalmente ao eixo longitudinal dominante da nave da igreja - projeção que lançaria, simbolicamente, o ambiente contido da Piazza para além dos vazios entre as colunas, se abrindo para toda a cidade, circunstância reforçada pelas marcas irradiadoras desenhadas no piso. Ilusionisticamente, era como se a cúpula e seu tambor fossem virtualmente projetados em direção ao espaço expansivo da praça, que, após absorver o organismo fechado e denso de Michelangelo, romperia a imensa força alegórica contida na grande massa contraída, arremessando-a para toda a capital e, consequentemente, para o espaço infinito do mundo católico (Figuras 240-24I).

Bernini também utilizaria o sentido multidirecional da projeção virtual das forças simbólicas que deveriam irradiar de San Pietro na interface buscada entre as colunas que compunham os braços côncavos da praça e a sua percepção em conjunto por parte do espectador que acorria ao espaço - um expediente cenográfico e ilusionístico que ofereceria um acontecimento de pura magia para o ambiente que envolveria o obelisco egípcio levantado em I586. Quando o fiel ingressava na acolhedora piazza e se colocava sobre um dos dois focos da elipse, e quando mirava para a colunata mais próxima ao ponto central de onde estaria direcionando seu olhar, o conjunto de colunas desvelado seria visto em elevação absoluta, não sendo permitida a percepção da existência das outras três colunas dóricas que se distenderiam radialmente, em profundidade, por detrás de cada um dos quarenta e quatro suportes alinhados com o lado côncavo da praça. ${ }^{96}$ As colunas que se levantariam para dentro das galerias formadas pelos braços curvos, bem como aquelas alinhadas com as faces exteriores, nos limites convexos

96 O complexo possuiria, ao todo, 352 colunas: oitenta e oito conjuntos de quatro ordens dóricas distendidas centrifugamente desde os dois centros da elipse -44 conjuntos contidos em cada braço côncavo da praça. 

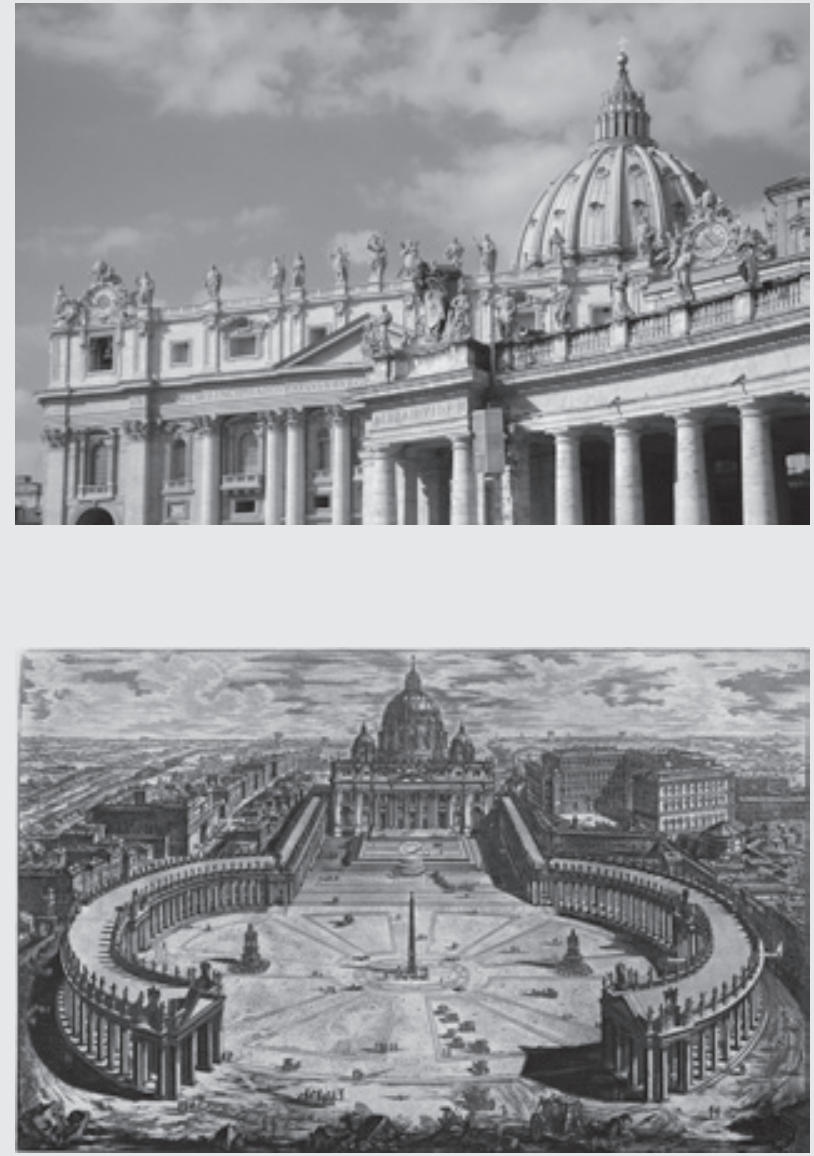

239. Vista da Piazza di San Pietro, em Roma, nas proximidades de um dos focos da elipse. Reparar o braço da colunata interrompendo a vista da fachada de Maderno. Fonte: Fotografia elaborada pelo autor (2011).
240. Veduta dell'insigne Basilica Vaticana coll'ampio Portico, $e$ Piazza adjacente. Por Piranesi, Vedute di Roma, publicado em 1798. Fonte: Ficacci $(2000$, p. 751).

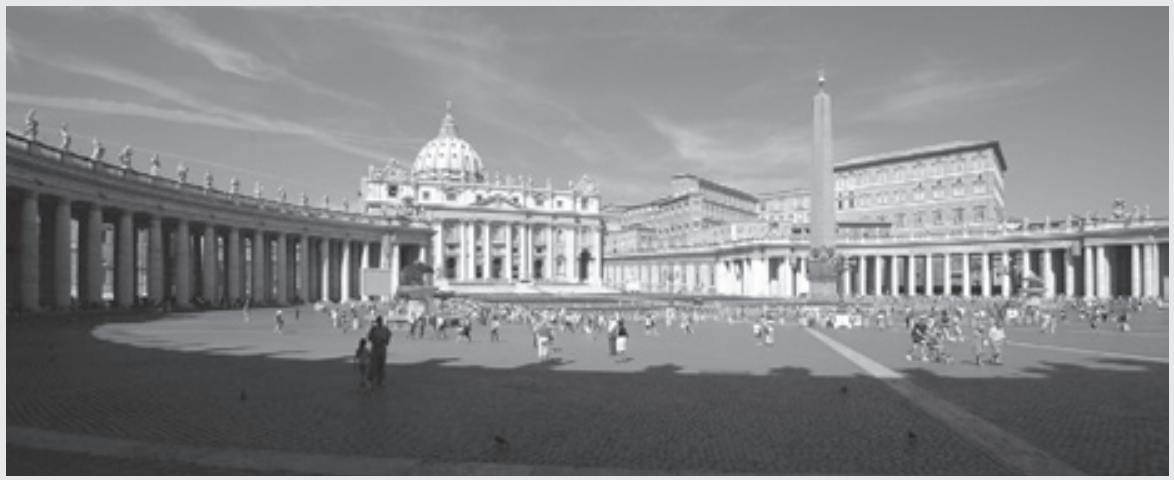

241. Piazza di San Pietro vista de sua entrada. As colunas do tambor da cúpula, quase invisíveis, são "refletidas" na colunata aberta e expansiva da praça. Fonte: Fotografia elaborada pelo autor (2007). 
entre o ambiente e a cidade, permaneceriam invisíveis nos panoramas retirados dos focos, já que seguiriam, cuidadosamente, as linhas de composição dos raios que partiriam dos centros da elipse (Figuras 242-243).

O resultado deste mecanismo de composição geométrica do espaço seria surpreendente, já que para o transeunte que eventualmente se postasse por cima de um dos dois focos da praça elíptica - pontos que até hoje figuram sutilmente no chão da grande praça - o engenhoso design da colunata permitiria a maior permeabilidade imaginável do espaço interior frente ao ambiente externo da cidade; a maior transparência possível da praça em relação ao espaço que se abria para além das colunas. $\mathrm{O}$ ato que levaria o espectador ao mais leve deslocamento traria consigo, contraditoriamente, imagens inverossímeis das colunas se multiplicando por trás daquelas alinhadas com o desenho côncavo da praça, comprometendo a anterior permeabilidade do espaço preexistente - até o ponto em que nada mais do espaço exterior seria capturado. O que seria aprendido, pelo contrário, seria a abertura gradativa de um leque infinito de colunas que encerrariam virtualmente a praça. Este fechamento incondicional do limite visual do espaço pela multiplicação ilimitada dos suportes poderia ser entendido como uma metáfora que atestava que as colunas representariam os pilares da fé católica se multiplicando infinitamente diante dos olhos do crente - mais uma vez, puro teatro (Figuras 244-245).

Finalmente, seria essencial frisar a complexa e necessária relação que a praça de Bernini guardaria frente ao cenário urbano preexistente, revelando a importância incondicional que o bairro dos Borghi ostentaria para a cidade de Roma, para o Vaticano e especialmente para a Piazza di San Pietro. Até o século XIX, esta densa área que se concentrava para além dos núcleos clássico, medieval, renascentista e barroco da cidade, sistematizada e fortificada, a partir de 852, pelo Pontífice Leone IV (papa de 847 a 855), se apresentaria como um ambiente relativamente independente em relação ao centro urbano e mesmo frente ao Rione vizinho de Trastevere. Seu sistema defensivo era autônomo e envolveria, basicamente, o Castel Sant'Angelo, o complexo do Vaticano e os quarteirões residenciais de origem medieval, justamente os Borghi; o conjunto da Praça e da Basílica de San Pietro se encontraria ao fundo do bairro, na extremidade ocidental da área habitada da cidade.

Logo, para o espectador alcançar a grande piazza desde os rioni mais importantes assentados na margem oposta do rio, seria necessário vencer a ponte de Sant'Angelo e cruzar toda a extensão dos Borghi. Já a ponte de Sant'Angelo 


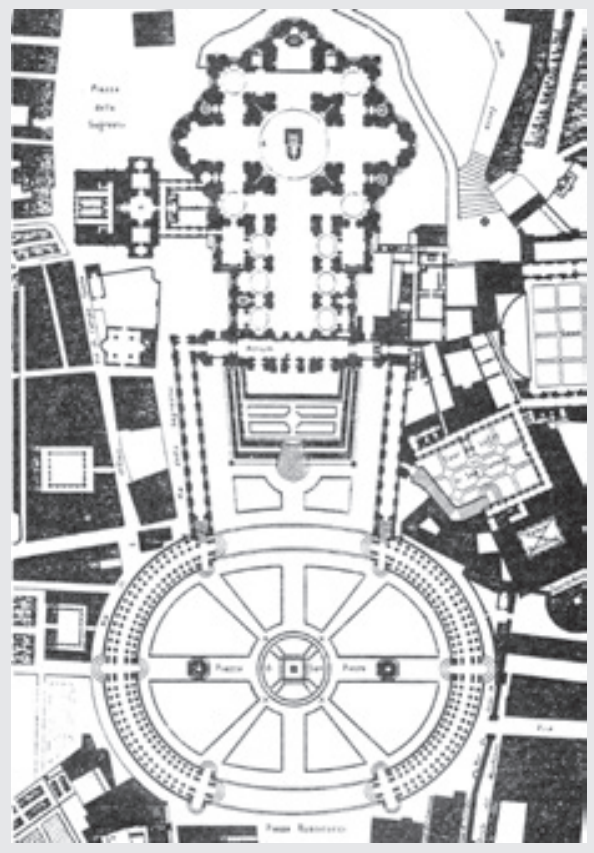

242. Plano da Piazza di San Pietro. Pelo arquiteto e gravurista francês, Paul-Marie Letarouilly (1755-1855). Publicado no século XIX. Fonte: Sitte (1992, p. 121).

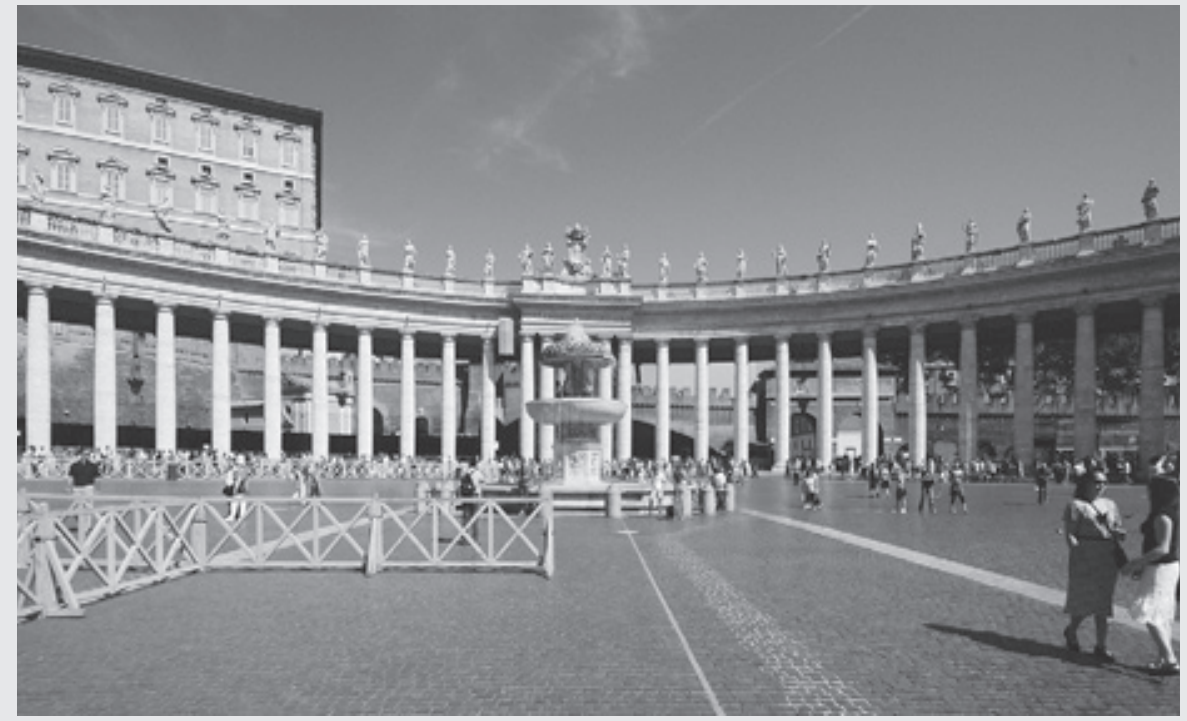

243. Colunata de San Pietro, toda permeável, vista de um dos focos da forma elíptica da praça. Fonte: Fotografia elaborada pelo autor (2007). 
244. Abertura do "leque" infinito de colunas a partir do deslocamento do transeunte em relação a um dos focos da elipse da Piazza di San Pietro. Fonte: Fotografia elaborada pelo autor (2011).

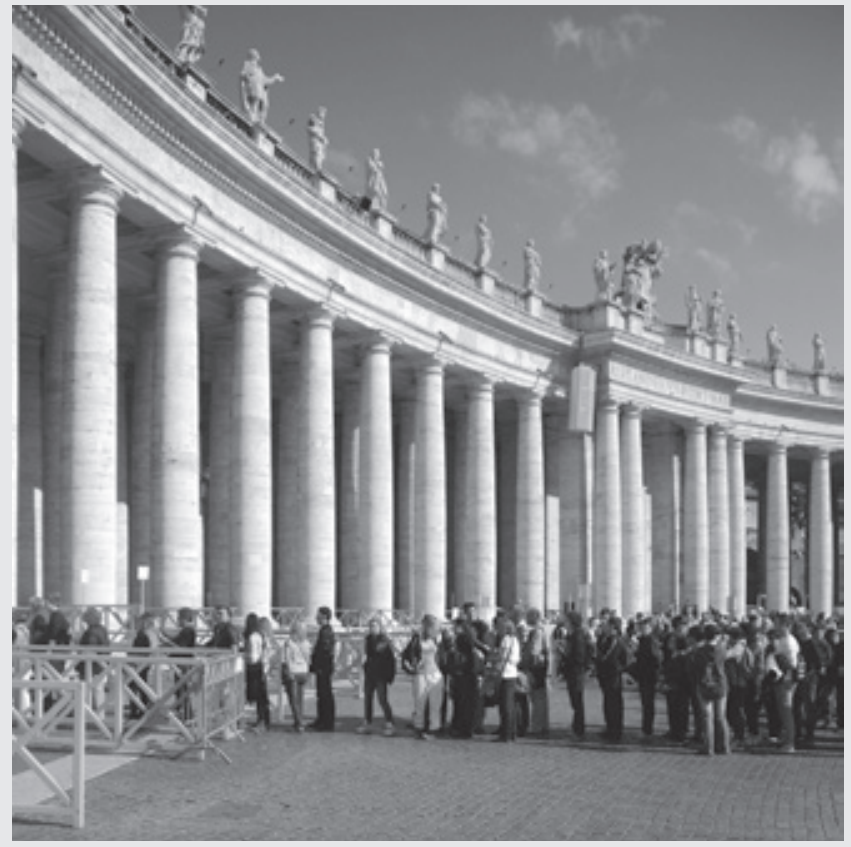

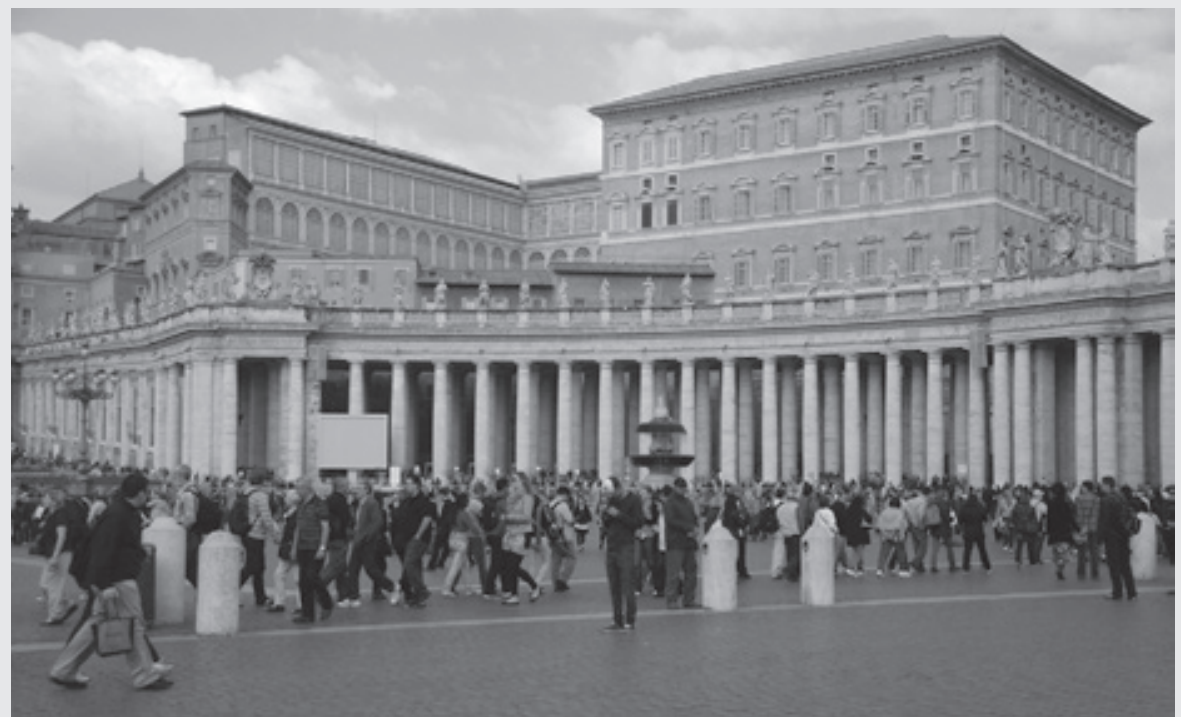

245. Detalhe de um dos lados da colunata da Piazza di San Pietro. Acima da colunata aparecem algumas estruturas do Palazzo Apostolico, no Vaticano. Fonte: Fotografia elaborada pelo autor (2011). 
- construída originalmente pelo Imperador Adriano (76-I38)97 no século Il e chamada então Pons Aelius - se apresentaria como um evento que se caracterizaria como uma massiva experiência barroca: atravessá-la certamente encantaria o espectador devido à imagem perspectiva que se abriria para o castelo homônimo, enquadramento forçado pelas esculturas dos anjos sequencialmente enfileirados, idealizados por Bernini, e assentados acima das balaustradas; também seduziria o passante a abertura da imagem distante, capturada à esquerda, no meio da travessa, da fachada (muito interrompida pela massa edificada dos Borghi) e da cúpula de San Pietro - o último panorama da basílica que seria revelado ao transeunte até, enfim, alcançar a praça.

Vencendo a ponte, o fruidor perderia quase todo o contato visual com a basílica ao ter que irromper no tecido denso dos Borghi. Não obstante, seriam abertos dois estreitos caminhos que poderiam dar acesso direto à Piazza di San Pietro: à esquerda, o Borgo Vecchio, via medieval praticamente retilínea, reordenada pelo Papa Nicolò V em meados do Quattrocento; e à direita, o fechado eixo perspectivo do Borgo Nuovo (antes, Via Alessandrina, depois, Via Recta), rua traçada por Alessandro VI para o jubileu de I500. (INSOLERA, I996, p. 24) Entre os dois caminhos assentava-se uma sequência surpreendente de estreitos quarteirões conhecidos como a spina dos Borghi (Figuras 246-248). O percurso pelos eixos alcançaria igrejas e palácios importantes - como a Igreja de Santa Maria Traspontina, na face norte do Borgo Nuovo; ou a pitoresca Piazza Scossacavalli, aberta em meio à spina, dominada pela Igreja de San Giacomo, bem como por importantes edifícios, como o Palazzo Torlonia (Figuras 249-252).

Finalmente, mais à frente, os dois eixos atingiriam, em lados opostos, a Piazza Rusticucci, um largo idealizado por Bernini e aberto imediatamente antes do ingresso à Piazza di San Pietro, ambiente que permitiria que fossem descortinados os panoramas que iriam ganhar todo o conjunto da basílica vaticana, assim como a apreensão integral da estrutura da cúpula - situação derivada da grande distância que o transeunte ainda guardaria frente à fachada de Maderno. Este dramático minuto de surpresa congregaria o momento em que a cúpula se reapresentaria ao instante em que a praça se revelaria pela primeira vez, em toda a sua complexidade, através das atraentes visadas oblíquas desejadas por Bernini - já que os dois eixos jamais apontariam para imagens frontais e chapadas

Publius Aelius Traianus Hadrianus foi imperador romano de 117 a 138. 
do complexo, despejando o transeunte nas extremidades laterais aos acessos à Piazza, através de eixos virtuais que buscariam as cercanias dos focos das elipses (Figura 253).

É exatamente neste ponto que seria possível compreender a mais intensa das motivações que levaria Bernini a conceber seu desenho: os percursos naturais que os maiores grupos de fiéis adotariam para alcançar San Pietro coincidiriam, certamente, com os trajetos diretos do Borgo Vecchio e do Borgo Nuovo, encaminhamentos que levariam o transeunte, imediatamente e naturalmente, a cada um dos focos da elipse transversal que formavam a praça - revelando que o mestre do barroco romano se apropriaria de modo incondicional da preexistência urbana para idealizar a sua maior obra. Argan (I986, p. I82, tradução nossa) complementaria:

Bernini, em consonância com esta solução biaxial, descartou a ideia de uma grande avenida retilínea de acesso à praça (que teria determinado uma perspectiva axial) e preferiu, ao contrário, conservar o duplo acesso através dos Borghi, que correspondia à duplicidade dos eixos visuais da colunata e proporcionava, a quem saísse destas ruas estreitas em direção ao espaço imenso da praça, essa 'surpresa' que é um dos aspectos característicos da urbanística do século XVII romano.

A conjunção da Piazza di San Pietro com os Borghi representaria a típica filiação da arte do século XVII ao apelo persuasivo e ao exercício da imaginação ilusionista. Efetivaria a consagração da autoridade histórica da basílica como eixo central do mundo católico através da presença, em uma única estrutura, de inúmeros artifícios de exaltação dramática: a surpresa - expressada no ato de atingir a Piazza Rusticucci e se deparar com a praça monumental após o longo percurso pelas ruas estreitas do bairro medieval; a alegoria - sugerida na forma do conjunto cúpula-basílica-praça como a representação da cabeça, corpo e braços de Deus acolhendo a toda humanidade; a dilatação - anunciada no reflexo da cúpula fechada, projetada no espaço aberto e expansivo da forma elíptica; o direcionamento infinito - conseguido no jogo mágico da formação do leque das colunas que modelariam o cenário; a desvalorização inicial, seguida da posterior valorização do frontispício, perseguidas no encaminhamento trapezoidal do último ambiente da praça. Segundo Portoghesi (I997, p. 8, tradução nossa), o que ofereceria o tempero para todas estas experiências seria o movimento do fruidor, pois a partir de seu deslocamento poderia ser desvelada, gradativamente, diante de seus olhos, toda a trama sugerida - como aconteceria no teatro: 
Bernini se preocupa com a eficácia das várias imagens que as suas estruturas produzem enquanto o espectador as observa movendo-se: mas não renuncia a indicar uma visada privilegiada que assume o objetivo de reabsorver sinteticamente os vários momentos da leitura. $\mathrm{Na}$ arquitetura acontece a mesma coisa: se raciocina e se projeta ainda em termos de eixos e percursos hierarquicamente distintos, mas a visão axial só tem o objetivo de conectar em uma unidade os tempos de uma narração contínua que se desenrola durante a completa estrutura do espaço, que quer ser indagada e vivida em cada mínimo particular.

Incrivelmente, após a morte de Bernini, inúmeros artistas, burocratas e governantes, não compreendendo a complexa trama desenhada pelo mestre, almejariam, inconsequentemente, eliminar a spina dos Borghi para abrir um grande e largo eixo perspectivo que permitisse a visão axial distante da igreja e de sua cúpula - começando pelo seu próprio aluno e parceiro, Carlo Fontana (I634I7I4). Mas, foi muito mais tarde, por ordem de Benito Mussolini (I883-I945), que o empreendimento seria tragicamente levado adiante com a constituição da Via della Conciliazione. O historiador Mario Sanfilippo (I993, p. I4I, tradução nossa) sintetizaria a iniciativa que arrasaria este importante pedaço da cidade que se desenvolvia nas proximidades do Vaticano há mais de mil anos:

No início dos anos 30, Attilio Spaccarelli dá início a um estudo para a demolição da 'spina dos Borghi'; em I934 se une a ele Marcello Piacentini. Conjuntamente (induzidos pelas altas hierarquias fascistas e vaticanas) colocam o seu projeto para a aprovação de Mussolini em 20 de junho de I936; em 28 de junho o apresentam a Pio IX, que o acolhe como obra de grande valor: na prática a demolição da 'spina dos Borghi' é filha legítima do Acordo de i929. [...] De fato não é abatida somente a spina entre Borgo Vecchio e Borgo Nuovo; são remanejados (especialmente nas fachadas), reconstruídos, realinhados, os edifícios sobre as testadas dos dois lados da nova via; outros edifícios são transportados e reconstruídos sobre novos alinhamentos na via della Conciliazione.

Assim, o percurso biaxial de acesso à Piazza di San Pietro, com todas as suas nuances e surpresas - igrejas, palácios, praças -, e com o seu encaminhamento adequado à praça, imediatamente em direção aos focos da elipse projetada por Bernini, seria jogado abaixo. Seriam perdidos todos os quarteirões ancestrais da 
spina, bem como as antigas Vias del Borgo Vecchio e del Borgo Nuovo - além de inúmeros palácios e edifícios históricos assentados nos alinhamentos que sobreviveriam na larga avenida, substituídos por construções fascistas nos dois lados da nova Via della Conciliazione. Só a demolição da "espinha", que demorou menos de um ano, expulsou quase 5.000 pessoas, desalojadas para povoar a periferia da cidade na década de I930. Após a guerra, os trabalhos continuariam - ainda com a coordenação do arquiteto Marcello Piacentini (I88I-I960). A nova via seria inaugurada em I950 com pompa e circunstância: com seus obtusos edifícios modernos, que preencheriam grande parte das duas faces da avenida; com a reformulada e fria Piazza Rusticucci (atualmente Piazza Pio XII); e com as luminárias colocadas por Piacentini no avançar da década de 1940 - conhecidas posteriormente como os "supositórios do papa" (Figura 254). Benevolo (2008, p. 558, tradução nossa) conclui:

A desastrosa iniciativa de abrir a Via della Conciliazione (I936-I950) eliminou em grande parte tanto a gradação dos efeitos ao longo do eixo longitudinal como o desequilíbrio entre as vistas axiais e angulares. Na realidade, introduziu uma vista distante onde a sucessão dos elementos escalonados em profundidade é aplainada em uma imagem bidimensional e a montagem berniniana resulta interrompida pelas construções laterais, deixando destacar-se livremente a composição michelangesca - cúpula e fachada - em sua forma abstrata original; sublinhou indevidamente o itinerário axial, reduzindo as colunatas a fundos secundários e o óvalo a uma esplanada viária; deu à Praça Rusticucci um caráter áulico e até conferiu aos novos palácios, com ridículo mimetismo, as mesmos marcações da colunata. E assim esta obra, síntese do Classicismo moderno, resumo de todo o ciclo de experiências que vão de Bramante e chegam até Bernini, foi mutilada, há pouco mais de 30 anos, com esta drástica determinação, apesar do grande aparato de estudos históricos e evocações retóricas que precederam e concorreram para este feito. 


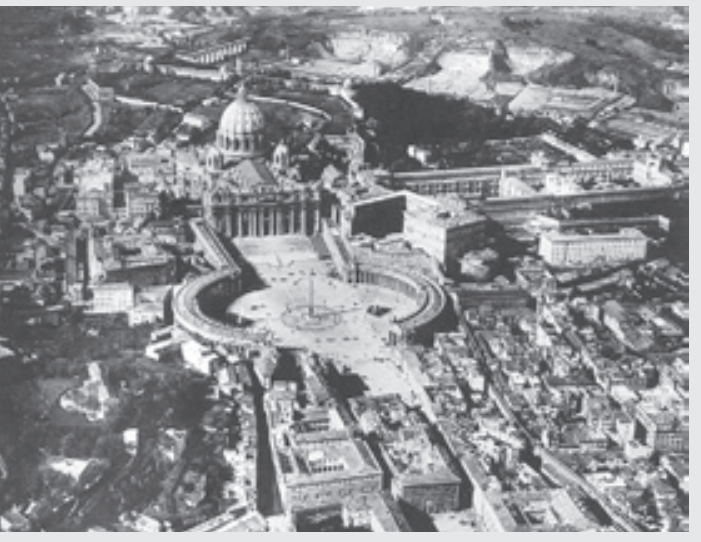

246. Fotografia aérea da Piazza di San Pietro em 1922, antes da abertura da Via della Conciliazione. Notar a Piazza Rusticucci, abaixo. Fonte: Marder (1998, p. 130).

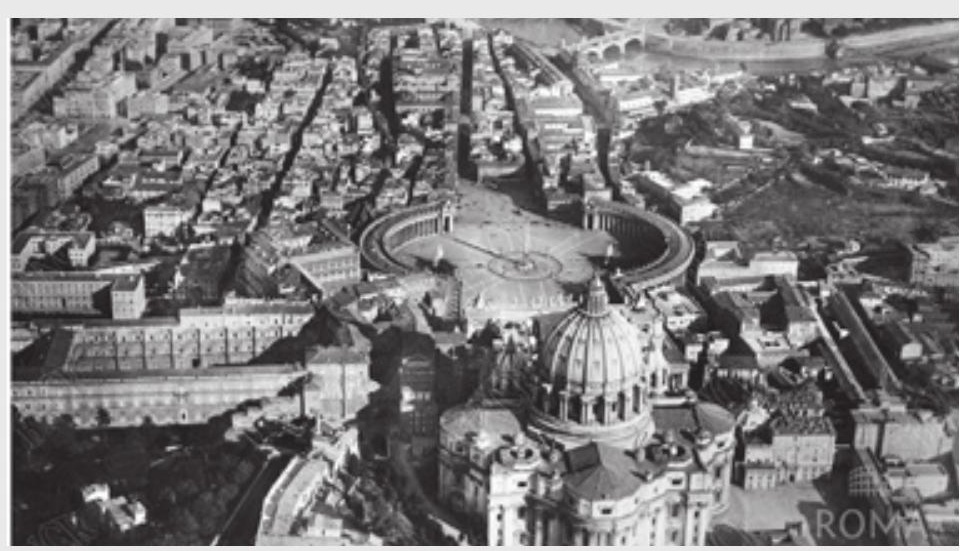

247. O complexo de San Pietro e a spina dos Borghi vistos em uma fotografia aérea de 1929. Notar a Via del Borgo Vecchio, à direita, e a Via del Borgo Nuovo, à esquerda. Fonte: Site Roma ieri oggi.

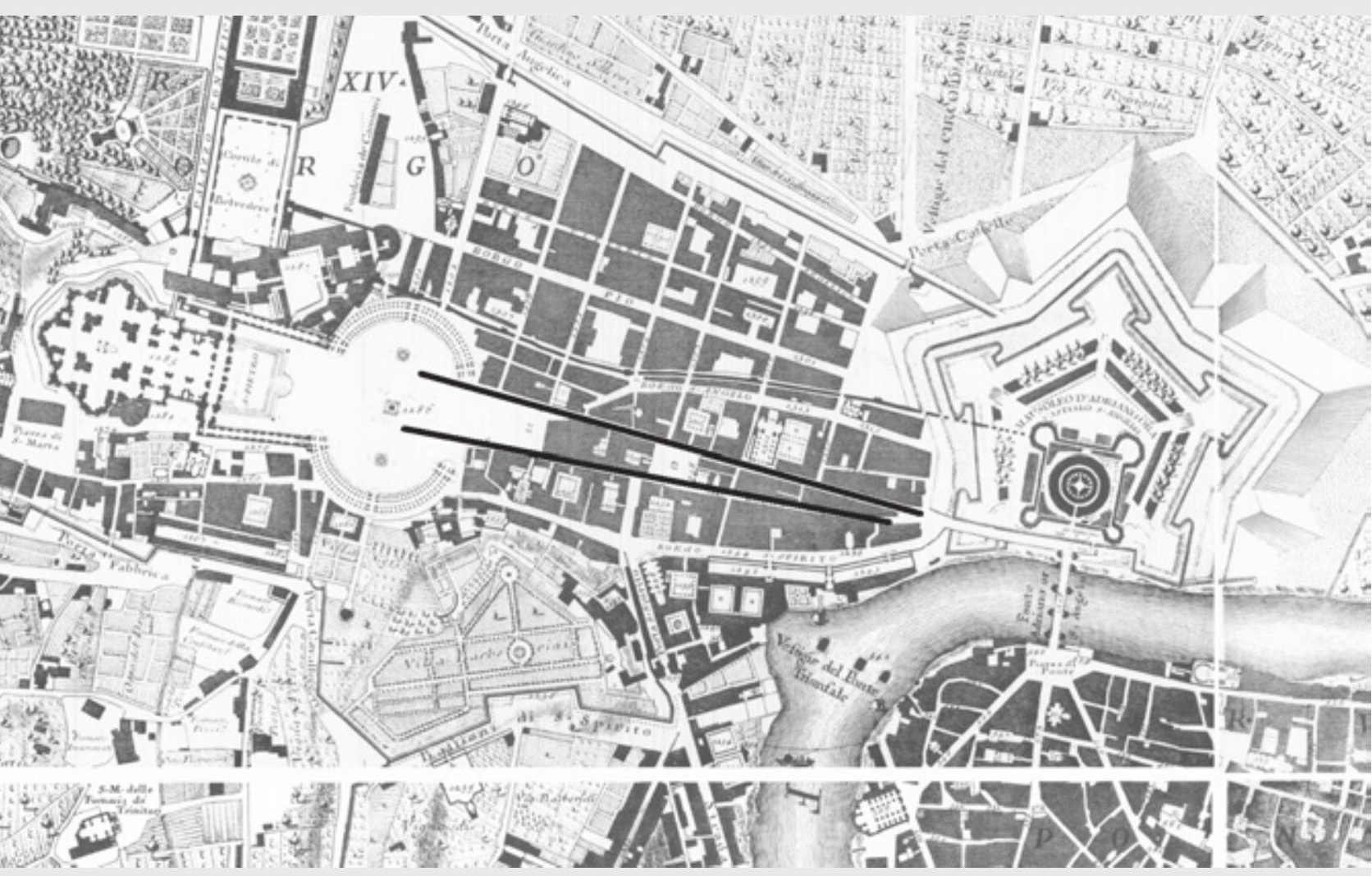

248. Detalhe da Planta de Nolli, de 1748, mostrando a região do Vaticano e dos Borghi. Estão marcados, com linhas escuras, os percursos possíveis - pela Via del Borgo Vecchio e pela Via del Borgo Nuovo - para se alcançar a Piazza di San Pietro a partir da travessia da Ponte di Sant'Angelo e da chegada à Piazza Pia - onde se abriam as duas ruas de acesso à grande praça. Fonte: Elaborado pelo autor a partir da planta de Nolli. Disponível no site Roma ieri oggi. 


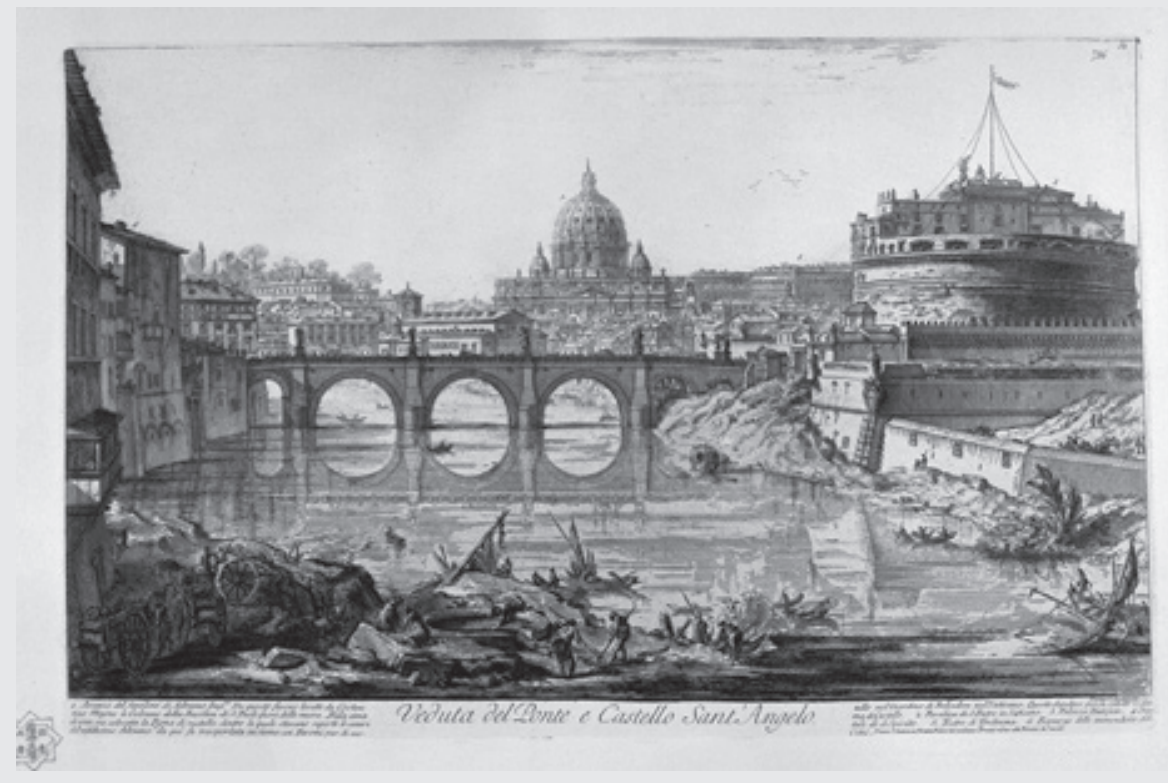

249. Veduta del Ponte e Castello Sant'Angelo. San Pietro ao fundo. Piranesi, 1749. Fonte: Ficacci (2000, p. 698).

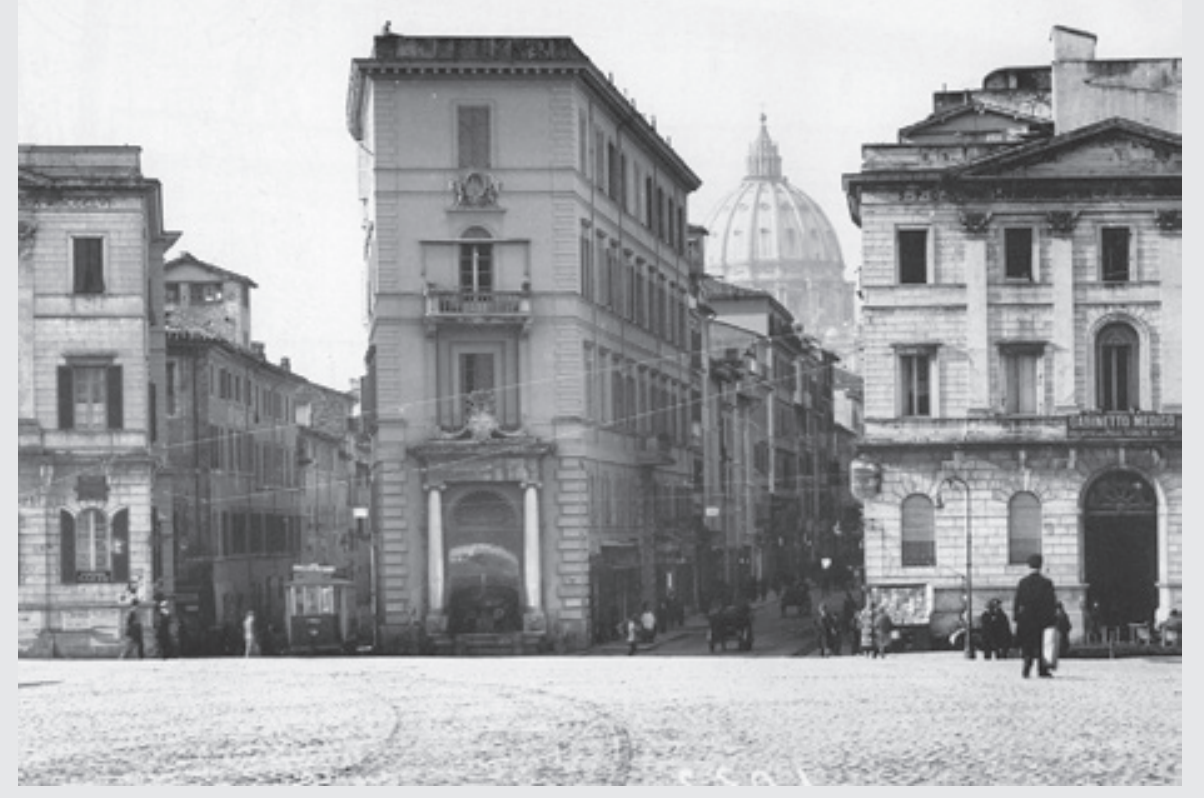

250. Piazza Pia, em 1900. Via del Borgo Vecchio, à esquerda, e Via del Borgo Nuovo, à direita. Ao meio, a spina del Borgo. Logo a imagem da cúpula desapareceria. Seria resgatada na Piazza Rusticucci. Fonte: Della Valle, Fondi e Sterpi (1997, p. 65). 


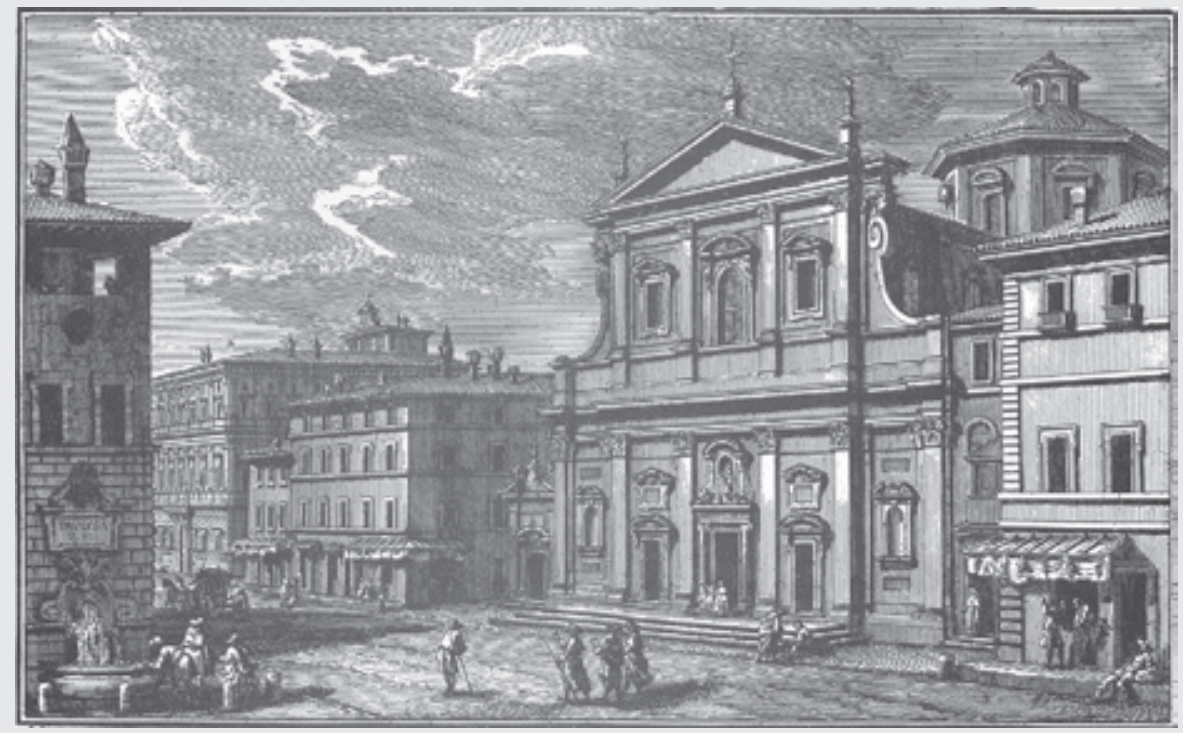

251. Igreja de Santa Maria in Transpontina, projetada por Ottaviano Mascherino (1536-1606), um dos acontecimentos dramáticos que se desvelavam no caminho para San Pietro - no caso, na Via del Borgo Nuovo. Hoje, sobrevivente das demolições e mutilações feitas para a abertura da Via della Conciliazione, se encontra desambientada na larga avenida. Giuseppe Vasi, 1747. Fonte: Coen (2003, p. 186).

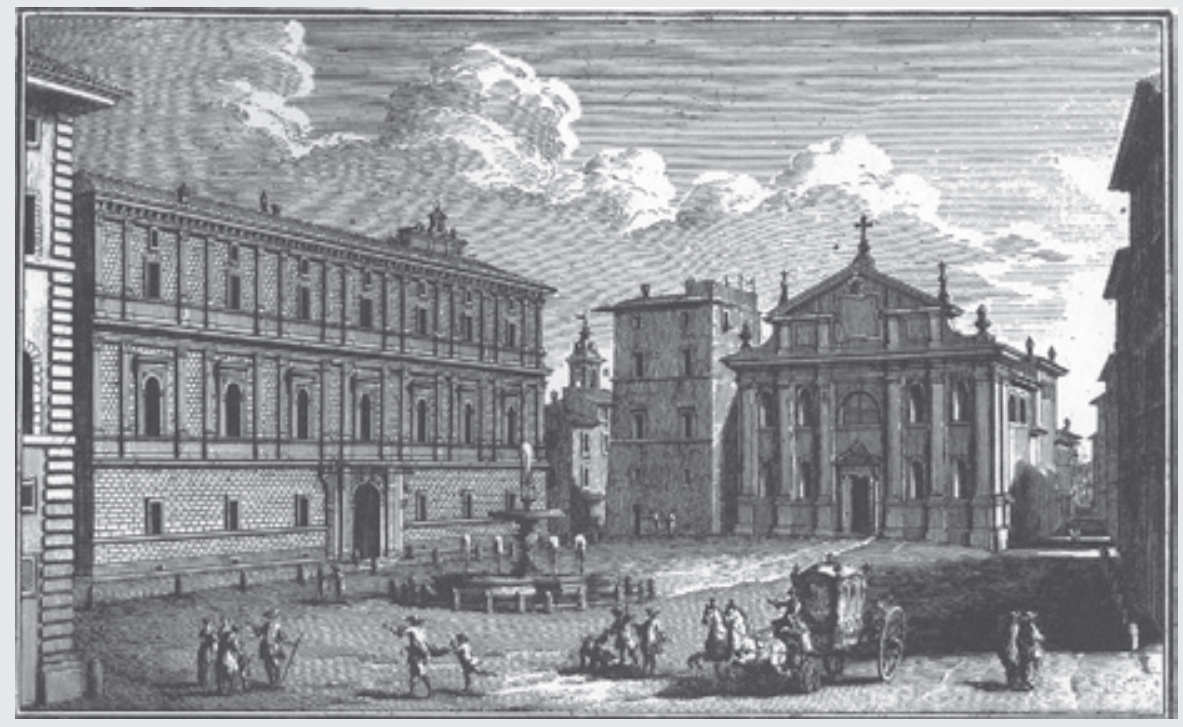

252. Praça e Igreja de Scossacavalli, desaparecidas. À esquerda, nota-se o Palazzo Torlonia, edifício do início do Cinquecento cujo projeto é atribuído a Donato Bramante (1444-1514). A praça era mais um evento cenográfico disposto a meio caminho entre as praças Pia e San Pietro. A Via della Conciliazione passou acima da antiga praça mas o Palazzo Torlonia sobreviveu desambientado na nova avenida. Giuseppe. Vasi, 1747. Fonte: Coen (2003, p. 178). 


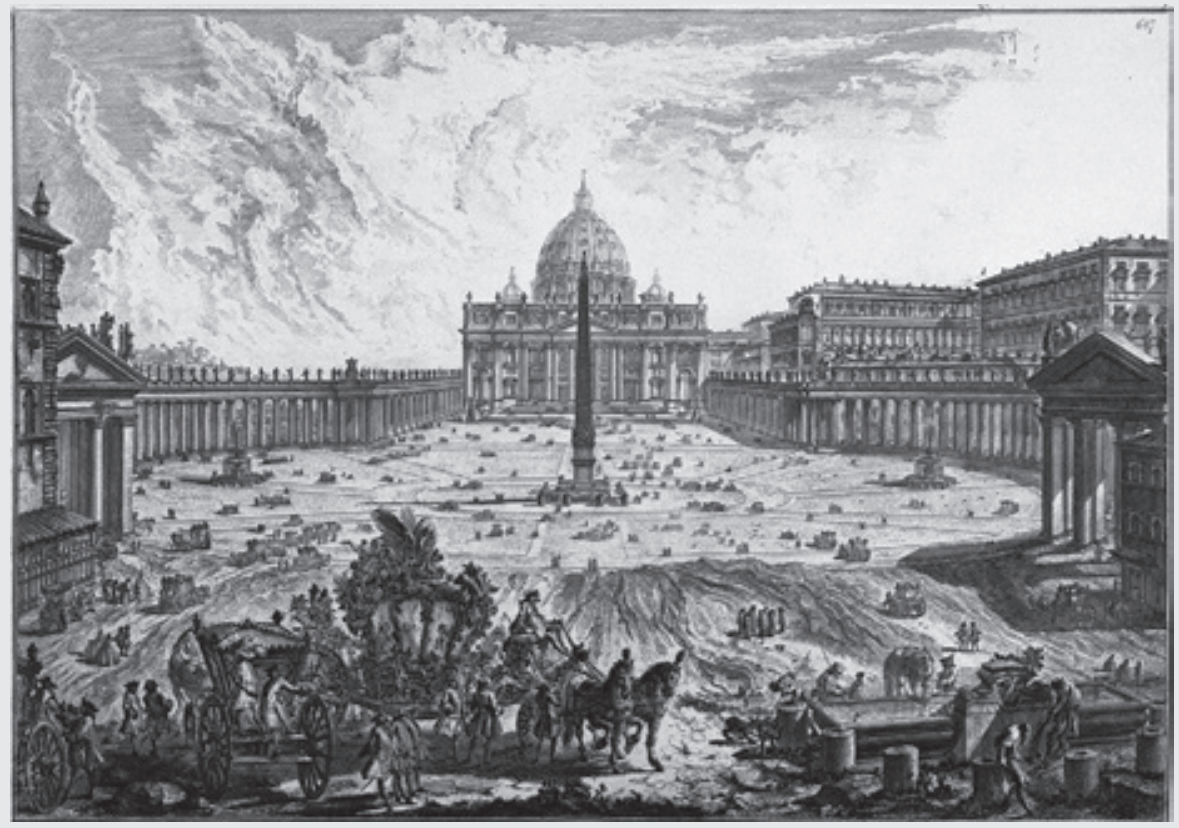

253. Veduta della gran Piazza e Basilica di San Pietro. Por Piranesi, Vedute di Roma. A Piazza di San Pietro se revela após o percurso dos Borghi e na chegada da Piazza Rusticucci, também aberta por Bernini. Fonte: Ficacci (2000, p. 740).

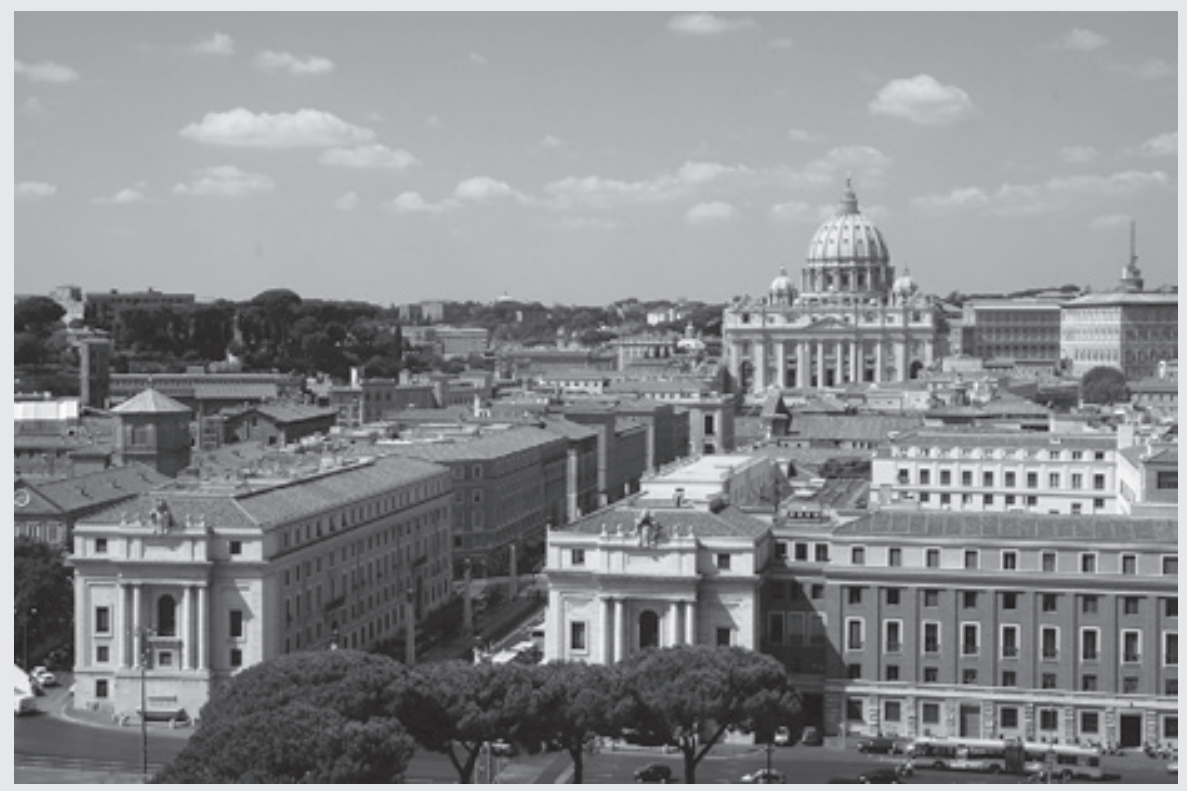

254. Fotografia tomada do Castel Sant'Angelo mostrando a Via della Conciliazione, com seus edifícios do racionalismo fascista - via aberta a partir da década de 1930 por Attilio Spaccarelli (1890-1975) e Marcello Piacentini (1881-1960), por ordem de Benito Mussolini (1883-1945). Fonte: Fotografia elaborada pelo autor (2007). 
SEGUNDA PARTE

\section{A cidade barroca na América Ibérica}

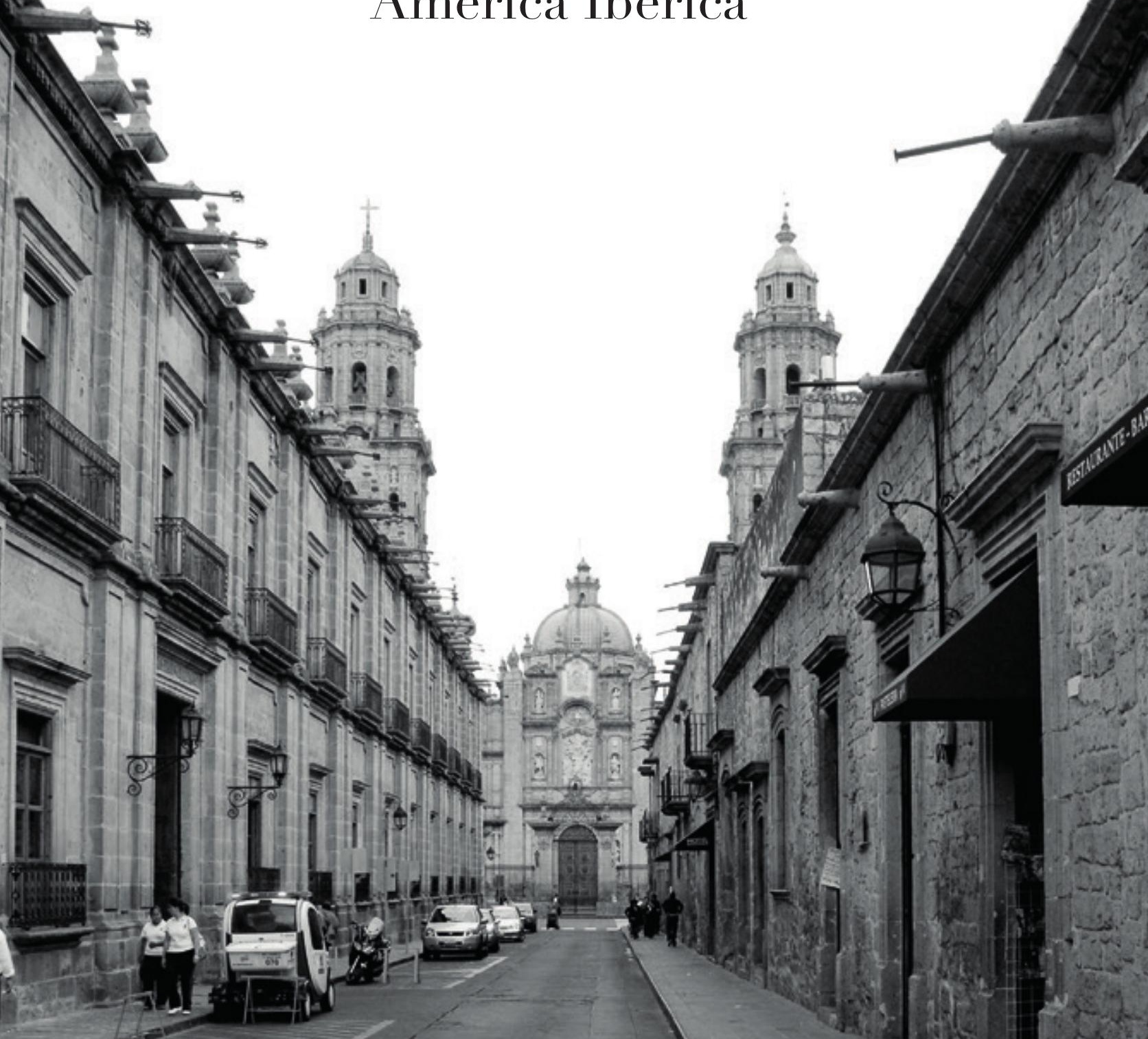




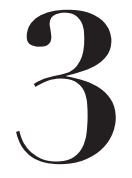

\title{
A CIDADE BARROCA SEM QUALQUER PLANIIFICAÇÃO: OURO PRETO
}

\author{
A experiência singular da Capitania das Minas Gerais constituiu, \\ pelas peculiaridades do condicionamento econômico e do processo \\ civilizador, um momento único da história cultural brasileira. E se o \\ ouro e o diamante - ou melhor, se a indústria da mineração foi, no \\ campo de economia, o fator material de cristalização e autonomia \\ da cultura montanhesa, o atavismo barroco preparou-lhe o suporte \\ espiritual, imprimindo à vida da sociedade mineradora os seus padrões \\ ético-religiosos e impondo às manifestações criativas os seus valores \\ e gostos estéticos. Sem essa unidade de conformação filosófica \\ jamais seria possível a sedimentação de uma cultura tão autêntica em \\ sua individualidade, fenômeno não de uma contingência histórico- \\ regional, mas de uma polarização de virtualidades étnicas da gente \\ colonizadora que aqui encontrariam condições excepcionais de \\ expansão e afirmação. (ÁVILA, 1980, p. 231-232)
}


As peculiaridades da formação histórica da sociedade mineira, que traz na diversidade cultural de seus centros urbanos um dos fatores mais significativos, têm no espírito barroco o elemento aglutinador e caracterizador - segundo o juízo decretado pelo poeta mineiro, Affonso Ávila (I928-20I2), no texto O primado do visual na cultura barroca mineira, inserido no livro de I980, O lúdico e as projeções do mundo barroco. É claro que este espírito não poderia deixar de estar presente na ambiência dos núcleos ligados ao extrativismo mineral e, particularmente, se fazer imponente no mais importante núcleo urbano vinculado ao ciclo do ouro: a antiga capital, Vila Rica.

Desta forma, o princípio fundamental que impulsiona a experiência artística desenvolvida na trama urbana de Ouro Preto, e que se identifica imediatamente com a alma barroca, é o conceito dos "modos de visão" elaborado por Giulio Carlo Argan (I973, p. 79). A busca das leis da imagem, a procura da sensibilização subjetiva do indivíduo em contraponto à articulação da estrutura objetiva da obra de arte são princípios comuns a todo o universo da arte setecentista mineira e, ao mesmo tempo, concepção prioritária em qualquer manifestação que se entenda como barroca.

O próprio Affonso Ávila discorreria sobre o conceito dos "modos de visão" ao assegurar como característica principal do Barroco nas Minas Gerais o que ele chamaria de "primado do visual" da cultura "montanhesa". (ÁVILA, I980, p. 232) Sem dúvida, este obsessivo interesse pela imagem que permearia o universo mineiro no século XVIII também envolveria, inevitavelmente, os outros princípios barrocos de imaginação e persuasão, formando um sistema indissociável; mesmo assim, o "primado do visual" apareceria como o elemento basilar, uma vez que, como diria Argan (I973, p. 79, tradução nossa):

\footnotetext{
Veja, então, o espaço; não é que exista um espaço com sua estrutura, com suas leis interiores; este espaço é um dado de visão, é uma imagem; o que interessa é que vocês estudem qual é a estrutura da imagem, quais são as leis interiores desta visão [...].
}

Este capítulo perseguirá exatamente as leis da visão, a estrutura da imagem retórica e persuasiva emanada pela cidade de Ouro Preto - entendida como uma unidade artística indivisível. Para alcançar a apreensão desta unidade figurativa será dada ênfase tanto à cidade contemplada genericamente - trabalhando a sua percepção artística em uma escala geográfica que "abrace" grande parte do 
ambiente envolvido pelo sítio natural -, como a apreciação do espaço citadino in loco, no contato do observador que caminha frente a frente com as diversas imagens do núcleo urbano.

Assim, será de primeira importância a análise dos monumentos que "costuram" as cenas mais dramáticas da paisagem ouro-pretana - sempre em simbiose com o cenário natural exuberante. Isto não quer dizer que se efetivará um rompimento com a ideia de promover a avaliação artística de todo o ambiente citadino, pois os monumentos têm uma participação na cidade que extrapola a sua simples inserção em algum ponto específico da malha urbana.

Estes valores formais contribuem para tornar os monumentos os organismos de maior permanência no desenvolvimento histórico da cidade, uma permanência que não depende, de modo algum, da função que absorvem originalmente. Igualmente, esta constância física e simbólica, não está relacionada com o seu uso atual, mas está ligada diretamente ao significado e à presença urbana da sua forma, que chega mesmo a modificar todo o caráter da cidade.

Por isso, a avaliação dos monumentos, principalmente a arquitetura das igrejas e a sua relação com o espaço urbano, absorve uma importância capital na análise da condição artística da cidade de Ouro Preto. Entretanto, para se entender a engenhosa armação cenográfica do núcleo urbano é necessário promover - como foi feito na análise da trama barroca da cidade de Roma - uma ruptura radical com o que até hoje a maioria dos críticos aceitaria como a essência do espaço urbano barroco (principalmente no contexto da história da arte brasileira), pois na antiga Vila Rica a resposta ao Barroco não se encontraria na regularidade do traçado, nos grandes eixos perspectivos, nas praças monumentais que seguem um desenho geométrico puro e bem definido. Pelo contrário, a qualificação artística do ambiente parte da espontaneidade explícita oriunda do processo de formação urbana da cidade. A partir do sítio natural aonde o assentamento urbano viria a se desenvolver, a cidade foi afirmando e elevando cada vez mais a sua condição barroca, atingindo o auge da expressividade dramática quando conclui, no início do século XIX, o cenário que ainda hoje é absorvido.

Assim, a imagem da capital das Minas vai-se tecendo agregada ao caminho inicial que une os vários povoados - a "estrada tronco" - em sua conjunção com a preexistência natural exuberante que envolve e conforma o sítio urbano. Nunca existirá um plano, nunca haverá uma intenção de formulação real do espaço urbano. Mas é claro que isto não importa: Ouro Preto consolida o seu apelo 
cenográfico no rápido processo de desenvolvimento, a partir da amarração das experiências monumentais pontuais - os largos e praças, as novas vias rasgadas a partir da década de I730, os palácios e principalmente as construções religiosas com a precária estrutura urbana inicial e com a paisagem natural.

Neste sentido, e por extensão, seria legítimo declarar a existência de cidades barrocas nos territórios conquistados e ocupados por portugueses nas Américas? Como os núcleos urbanos fundados pelos portugueses no Novo Mundo poderse-iam configurar como verdadeiras cidades barrocas se, frequentemente, seus planos urbanísticos nasceriam de processos espontâneos de crescimento e desenvolvimento urbano?

$\mathrm{Na}$ verdade, acredita-se que as ações que transfigurariam estas cidades em palcos nos quais seria encenado o drama barroco não se fundariam em intervenções propriamente urbanísticas. O espetáculo dramático encenado na cidade se daria através da amarração dos acontecimentos teatrais que transformariam o núcleo urbano em uma total e dramática experiência artística, dependendo, primordialmente, das intervenções pontuais que estaria recebendo gradativamente - e, particularmente, da costura destes eventos no espaço e no tempo da apreciação da cidade pelo espectador.

E a grande maioria dos acontecimentos cenográficos de tonalidade dramática dispersos pelos assentamentos luso-brasileiros estaria vinculada à massiva presença da arquitetura religiosa. Seria claramente perceptível, em qualquer contato com os ambientes preservados remanescentes da época da colonização portuguesa, como as igrejas, capelas, conventos, colégios, mosteiros dominariam a paisagem citadina: tanto no que se refere à sua inserção majestosa no sítio, como em relação à expressividade, muitas vezes fatal, de sua articulação formal.

Assim, almeja-se empreender uma análise que considere, conjuntamente, a arquitetura e a urbanística da antiga Vila Rica, capital da Capitania das Minas Gerais na época do Ciclo do Ouro. O escopo é, finalmente, alcançar um juízo crítico sobre a apreensão estética da paisagem do assentamento urbano, indagando sobre a presença de cenários dramáticos deflagrados pela antiga sede municipal - eventos barrocos comandados pela presença marcante dos organismos eclesiásticos -, para provar que é possível o desenvolvimento de uma cidade que poderia ser considerada barroca sem a existência de nenhum elemento de planificação derivado da chamada urbanística barroca. 


\section{O sítio natural no qual se assentaria a antiga Vila Rica}

A antiga Vila Rica se desenvolveu na calha do Vale do Ribeirão do Funil, limitada nos sentidos norte e sul por duas altas serras que correm paralelamente: a Serra de Ouro Preto e a Serra do Itacolomi (Figura 255). Estas serras verdes, ocupadas na sua maioria por vegetação rasteira, assumiriam uma escala efetivamente monumental em relação à área reduzida em que se elevam, servindo de limite visual, de moldura para grande parte do ambiente urbano. Este perfil radicalmente acidentado do sítio, contendo na sua parte mais baixa diversos córregos onde, no início da exploração mineral, o ouro brotava facilmente, seria comum a quase todos aglomerados urbanos do ciclo do ouro, como já percebia o jesuíta italiano André João Antonil (1649-1716), ${ }^{98}$ em sua obra publicada em I7II, Cultura e Opulência do Brasil por suas Drogas e Minas:

Primeiramente, em todas as minas que vi e em que assisti, notei que as terras são montuosas, com cerros e montes que se vão às nuvens, por cujos centros correndo ribeiros de bastante água, ou córregos mais pequenos, cercados todos de arvoredo grande e pequeno, em todos estes ribeiros pinta ouro com mais ou menos abundância. (ANTONIL, I982, p. I87-I88)

Porém, mesmo a topografia do vale que corre na direção leste-oeste não se apresenta de forma alguma suave, regular. Pelo contrário, na extensão ocupada pela cidade, três morros se elevam entre as duas serras: a oeste aparece o Morro das Cabeças, seguido pelo Morro de Santa Quitéria (Figura 256) e, finalmente, o Morro de Santa Efigênia, próximo ao extremo leste do aglomerado urbano. Estes acidentes geográficos vão impor inúmeras irregularidades no sistema viário, conformadas por íngremes ladeiras e por ruas tortuosas. Neste sentido, segundo atestaria o arquiteto e mestre da história da arquitetura colonial de Minas Gerais, Professor Sylvio de Vasconcellos (I9I6-I979), em sua primeira obra significativa, A arquitetura particular em Vila Rica, escrita em I95I para concorrer à cátedra de Arquitetura no Brasil da Universidade de Minas Gerais (publicada várias vezes com o título Vila Rica. Formação e desenvolvimento - residências):

98 Nascido em Lucca, na Toscana, como Giovanni Antonio Andreoni 


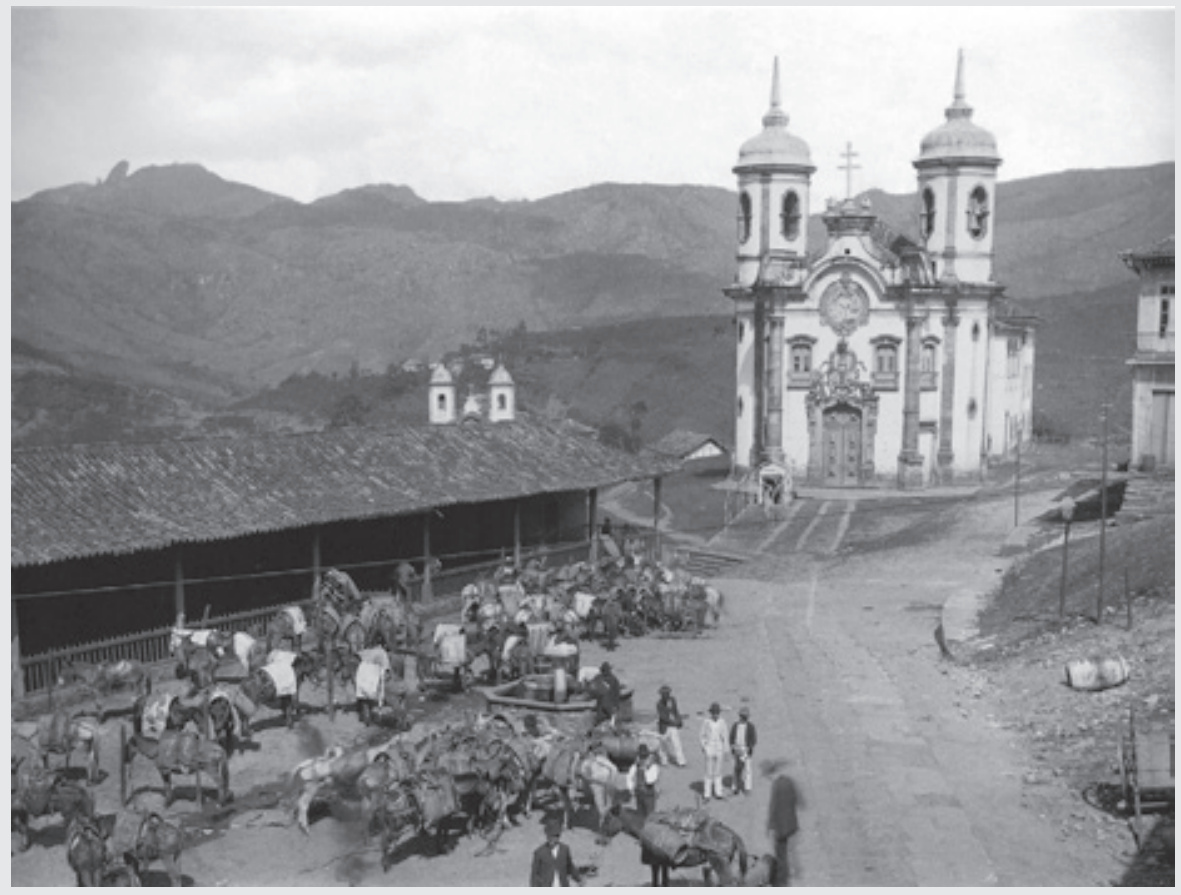

255. Ouro Preto. Igreja e Largo de São Francisco de Assis, em 188o, com destaque para o mercado de tropeiros. Ao fundo, a Serra e o Pico do Itacolomi como moldura da composição. Fonte: Ferrez (1997, p. 352).

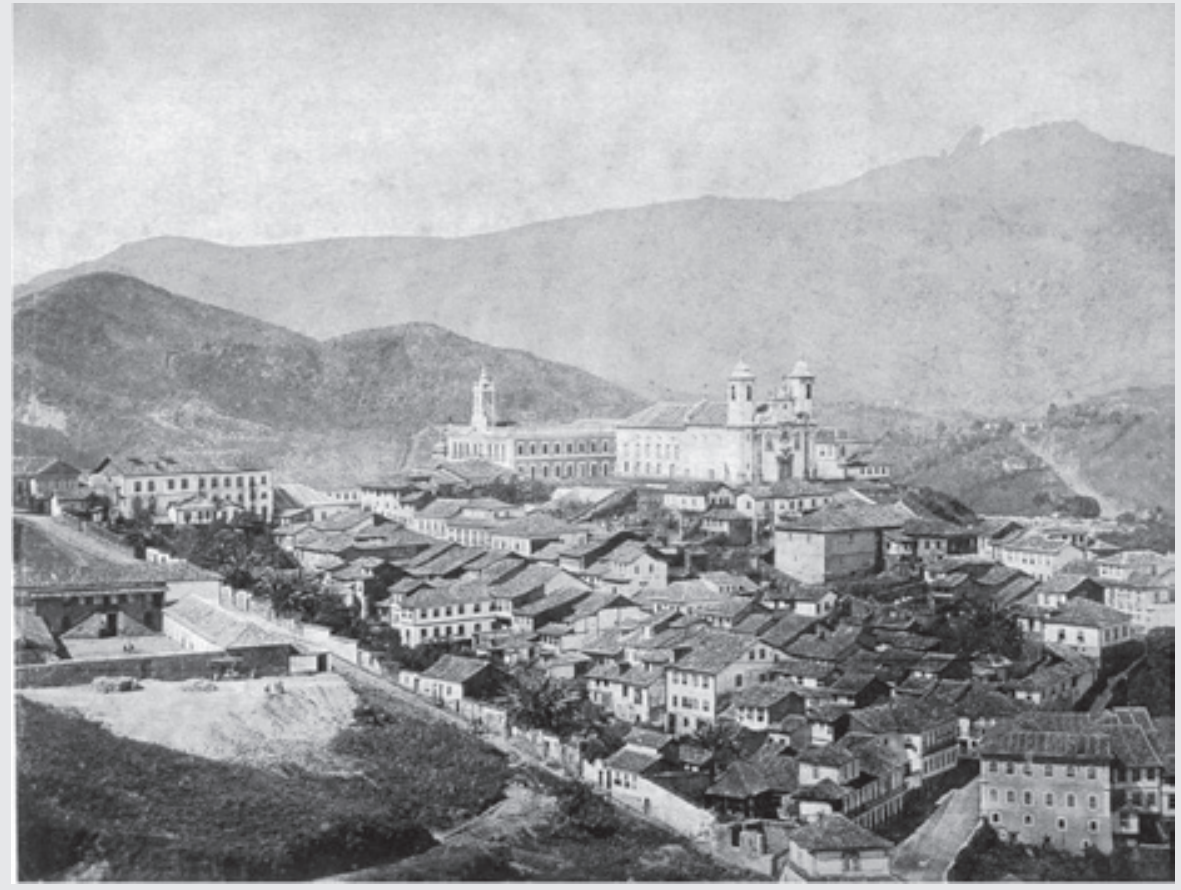

256. Vista panorâmica, de finais do século XIX, do Bairro do Pilar, com o Pico do Itacolomi, a Igreja de Nossa Senhora do Carmo e a Casa de Câmara e Cadeia ao fundo. Fonte: Acervo IFAC/UFOP. 
Convém frisar que o eixo longitudinal da povoação e as suas ruas mais importantes fazem-se no mesmo sentido do vale e da serra do Ouro Preto, vencendo, com inadequada valentia, as ondulações dos contrafortes que se antepõem à diretriz estabelecida, sem maior obediência, como seria de desejar-se, à topografia do lugar. (VASCONCELLOS, I977, p. 66)

Outros acidentes geográficos também contribuirão para esta diversidade orográfica que o sítio natural ajuda a criar. Entre o vale e a Serra do Itacolomi, algumas colinas servirão de contraponto vertical à concentração edificada. Assim, apesar do espigão da Serra do Itacolomi estar bem mais distante do núcleo urbano em relação à Serra de Ouro Preto, o Morro do Curral, o Morro do Cruzeiro, o Morro da Forca e o Alto da Cruz (que paira acima de Santa Efigênia), nascerão adjacentes à cidade, fechando ainda mais o vale. Por outro lado, a altitude mais elevada que atinge a Serra do Itacolomi contribuirá para que ela não fique totalmente encoberta por estes acidentes geográficos, sendo seu paredão visível de inúmeras partes da cidade (Figura 257).

\section{Considerações sobre a formação viária de Ouro Preto}

Como quase todos povoados, vilas e cidades nascidos da exploração mineral no século XVIII, o organismo urbano da antiga Vila Rica vai ser gerado a partir da conurbação de uma série de arraiais de extração aurífera, unidos entre si por um caminho direto - estrada que também se configura como a chegada e a partida da povoação. Porém, uma peculiaridade marcaria este processo em Ouro Preto: além dos arraiais espalhados pela via com suas respectivas capelas, duas freguesias balizarão o processo de conurbação, apontando o desenvolvimento posterior da povoação - a Freguesia de Nossa Senhora da Conceição de Antônio Dias e a Freguesia de Nossa Senhora do Pilar. Estas paróquias formarão os dois principais bairros da cidade, acolhendo os lados poucos solidários da antiga Vila Rica.

Logo, em Ouro Preto, o caminho que une os povoados e as duas freguesias vizinhas - e que corre tortuosamente no mesmo sentido do vale, vencendo os três altos morros que definem a topografia básica da cidade - será denominado por alguns autores como "estrada tronco". (VASCONCELLOS, I977) Cruzando os núcleos que surgem, na maioria das vezes, nas partes baixas do sítio, adjacentes 


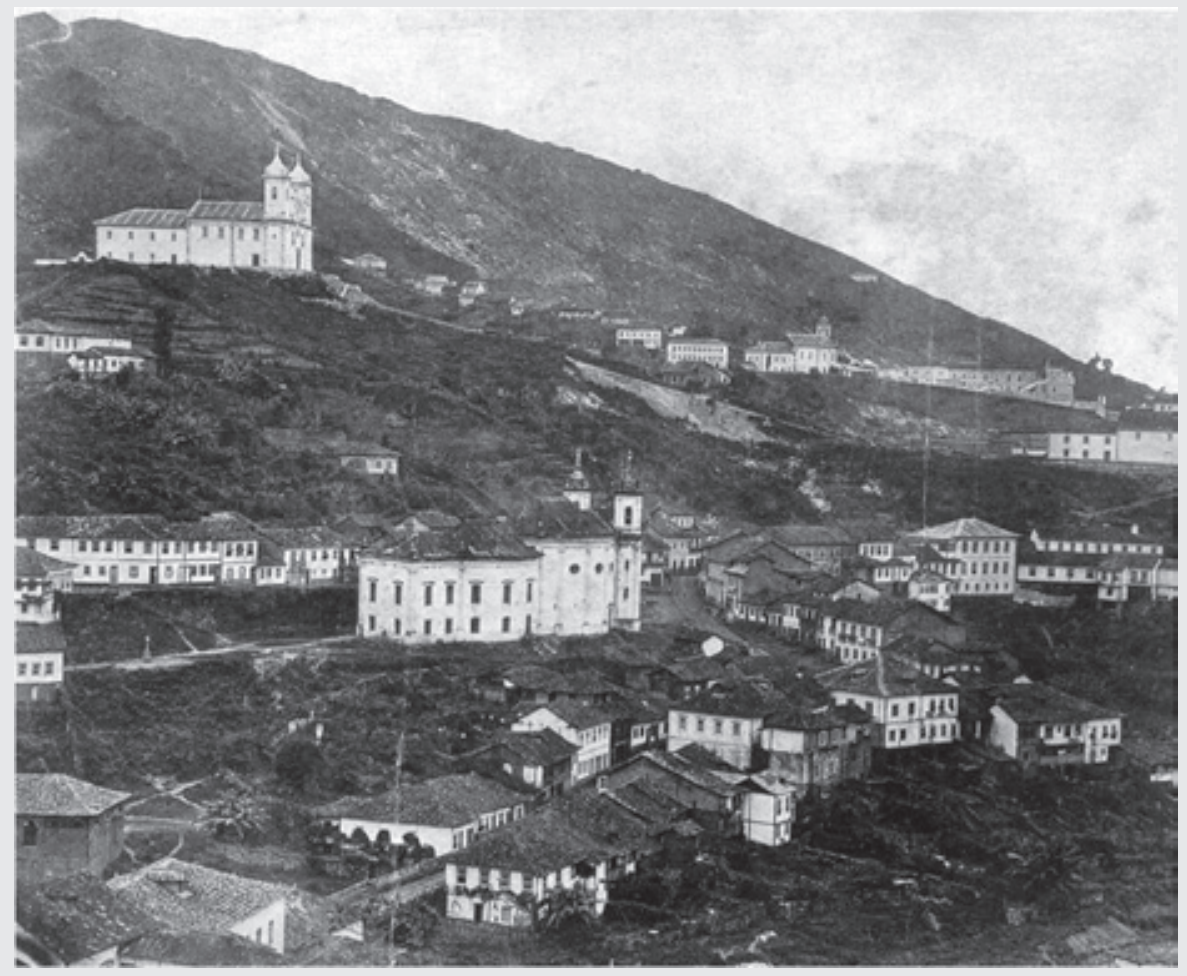

257. Panorama do Bairro do Rosário em 1875. Reparar a relação entre a mancha edificada, os monumentos livres de edificações e a paisagem natural. Em destaque, a Igreja de Nossa Senhora do Rosário (abaixo), a Igreja de São Francisco de Paula (acima) e a Igreja de São José (à direita). Fonte: Acervo IFAC/UFOP.

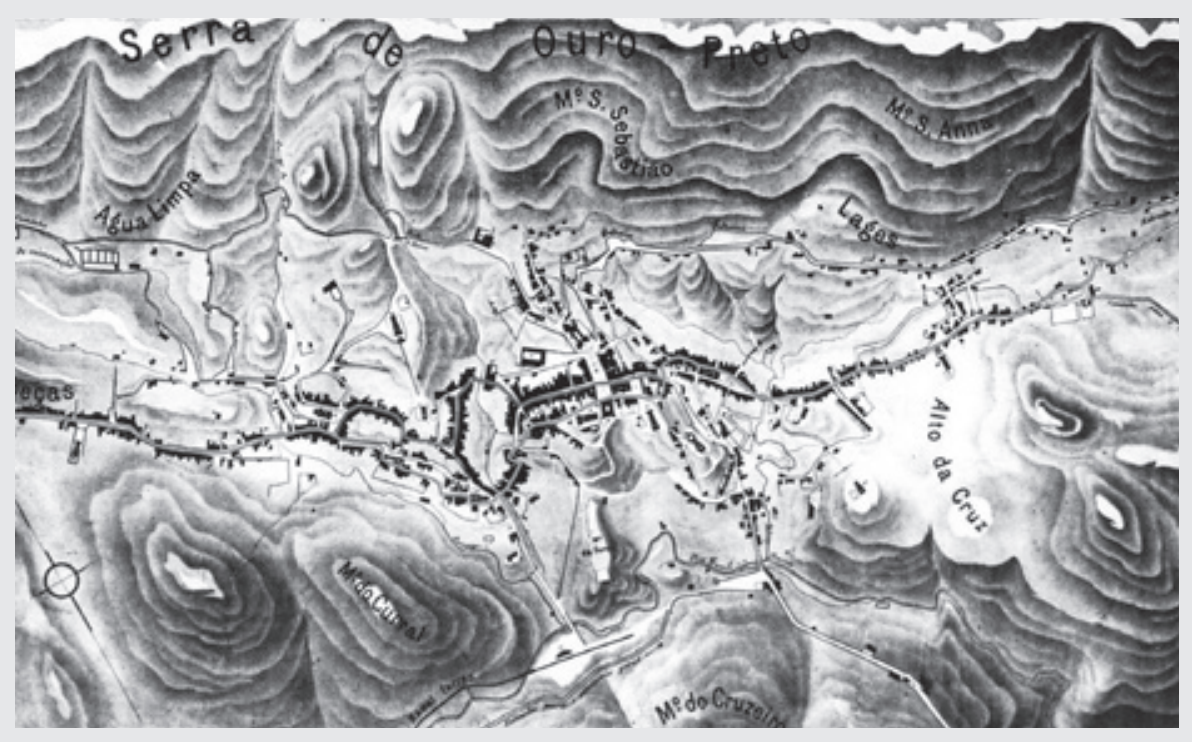

258. Planta da cidade de Ouro Preto de 1888. A mancha urbana desenvolvida entre a Serra de Ouro Preto e os Morros do Cruzeiro, do Curral, da Forca e o Alto da Cruz deflagram a morfologia linear que a cidade adquiriu em sua formação. Em destaque, o "caminho velho" e o "caminho novo" em cinza. Fonte: Elaborado pelo autor a partir da planta de 1888. MONUMENTA, IPHAN (2008, p. 4). 
às áreas onde inicialmente era extraído o ouro, a "estrada tronco" vai desenhar - no mapa da antiga Vila Rica - a morfologia longilínea típica dos núcleos urbanos de Minas Gerais. Segundo afirmaria Sylvio de Vasconcellos (LEFÈVRE; VASCONCELLOS, I968, p. 2), no livro Minas: cidades barrôcas, publicado em I968, em coautoria com a ilustradora, pintora e desenhista, Renée Lefèvre (I9IO-I996):

Vila Rica é uma rua contínua. Começa no Passa-dez; sobe para as Cabeças. Desce para o Rosário e Matriz de Nossa Senhora do Pilar, para elevar-se de novo até o Morro de Santa Quitéria, onde está a praça urbana principal. De novo mergulha para Antônio Dias, e sobe para o Alto da Cruz. Escorrega finalmente para o antigo Arraial do Padre Faria, e inflete para a cidade de Mariana. São três morros e dois vales que os separam.

Desta forma, quase sempre a estrada vai estar implantada à meia encosta, seguindo, na medida do possível, as curvas de nível - adquirindo, consequentemente, uma configuração bastante sinuosa (Figura 258). No caso de Ouro Preto, este caminho irregular vai chegar algumas vezes nas proximidades do vale, exatamente onde estão assentadas as mais antigas fundações religiosas - as Matrizes das Freguesias de Antônio Dias (Figura 259) e do Pilar (Figura 260), bem como a Igreja de Nossa Senhora do Rosário dos Brancos, do Bairro do Padre Faria. A primeira fundação da Igreja de Nossa Senhora do Rosário dos Pretos é também muito antiga e próxima a cursos d'água; seria substituída, na mesma locação, pelo templo que ainda hoje se eleva no lado ocidental da cidade.

Obviamente, este fato se deve à origem mineradora destes antigos arraiais, unidos em I7II a partir do ato de ereção da Vila Rica de Albuquerque. (LIMA JÚNIOR, I957, p. 68)

Próximo às matrizes, ladeiras muito íngremes vão dar prosseguimento à "estrada tronco" para atingir as três elevações que seguem o sentido longitudinal do vale. Duas destas ladeiras vão se encontrar no Morro de Santa Quitéria e as outras seguirão direções opostas: no sentido oeste, buscando o Bairro das Cabeças, ou no sentido leste, subindo a Ladeira do Vira e Saia para atingir o Morro de Santa Efigênia (Figura 26I) - descendo depois em direção ao Padre Faria. Porém, com o tempo, outras vias mais bem estruturadas serão abertas em locais menos acidentados, superando em muito a importância da primitiva "estrada tronco". Este processo se inicia após I720, quando a antiga Vila Rica é escolhida para abrigar o 
governo geral da recém-criada Capitania das Minas Gerais. A partir de então, o aglomerado disforme vai cedendo lugar a um núcleo urbano que construirá aos poucos seu aspecto imponente que o caracterizará em finais do século XVIII, quando entra em processo de decadência pelo esgotamento das jazidas mineradoras.

Assim, o novo caminho irá surgir um pouco mais acima, também à meia encosta, após a descida do Morro das Cabeças, no Largo do Rosário. A partir de então, o "caminho novo" segue paralelo à antiga "estrada tronco" até subir o Morro de Santa Quitéria (Figuras 262-266). Atravessando o cume do morro que se configurará posteriormente como a praça principal da cidade, a rua desce em direção à Freguesia de Antônio Dias, onde reencontra o "caminho velho" antes de galgar o Morro de Santa Efigênia. Este "caminho novo" terá um percurso mais direto que o anterior, não atingindo, em nenhum momento, o fundo do vale onde estão assentadas as matrizes - determinando, inevitavelmente, um maior adensamento na área central e afirmando a grande importância que o Morro de Santa Quitéria viria a assumir.

Na verdade, o Morro de Santa Quitéria permanecerá desocupado até a década de I740, rasgado apenas pelo ramal do "caminho velho" que cruzava a área desolada, servindo a colina como elemento sistemático de separação entre as Freguesias do Pilar e de Antônio Dias. O "caminho novo", bem como a construção, a partir de I74I, do imponente Palácio dos Governadores, trará o incentivo para ocupação desta área central da vila que logo se conformaria como o centro cívico de Ouro Preto. Na década de I780, o largo firma-se definitivamente como a principal praça da cidade, quando será construída - no lado oposto ao do palácio do governo - a nova Casa de Câmara e Cadeia da Vila Rica.

Fica claro que o desenvolvimento urbano de Ouro Preto se faz a partir de várias ações não planejadas, mas que seguem diversos padrões de ocupação comuns à maioria dos núcleos mineradores. Segundo Sylvio de Vasconcellos, este sistema de implantação seria específico das Minas Gerais e dos assentamentos de formação espontânea. Promovendo um confronto entre a forma de ocupação por anéis concêntricos, derivada das tradições medievais portuguesas - e europeias no geral - e o processo de desenvolvimento urbano em Minas Gerais, Vasconcellos (I968, p. 85) afirmaria, no livro Mineiridade: ensaio de caracterização, publicado em I968:

A configuração urbana mineira é longilínea, de meia encosta ou de cumeada, segmento de linha que é a estrada, voltada para dentro. A portuguesa é nucleada, concêntrica, centrífuga, tendendo para a 


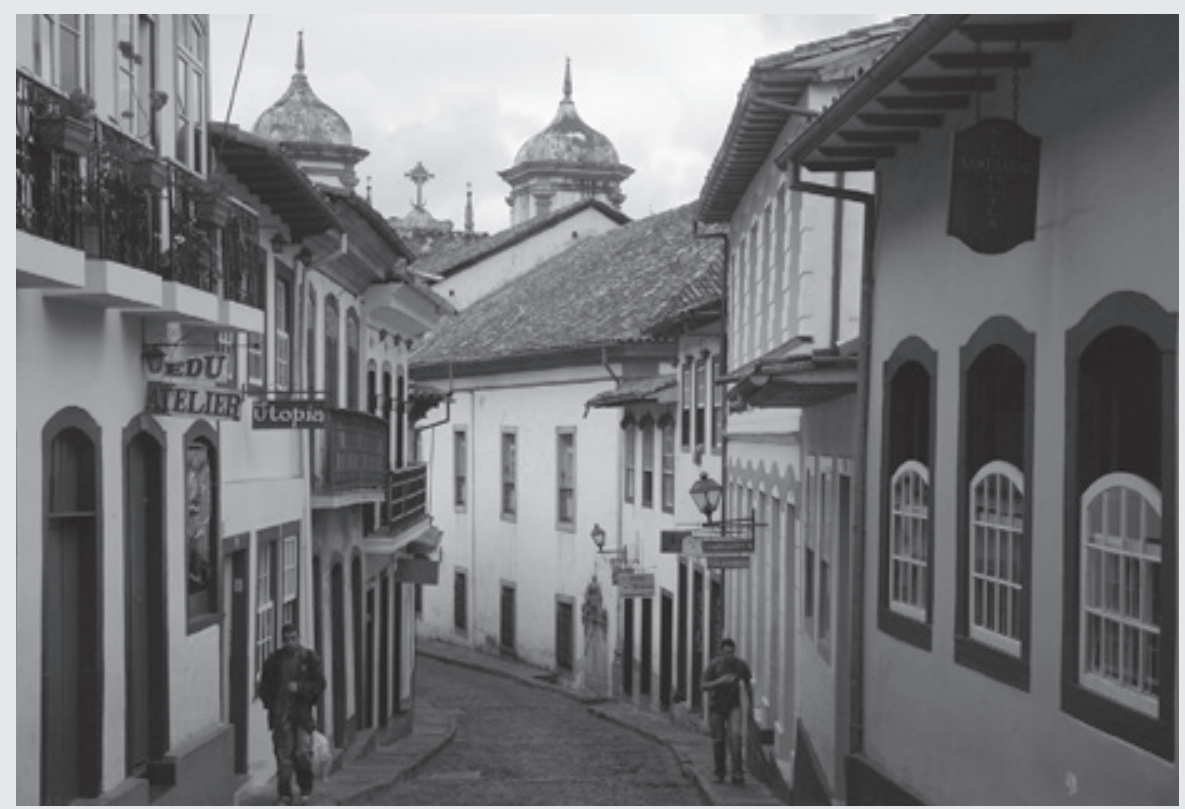

259. Trecho da "estrada tronco" que passa pela Freguesia de Antônio Dias, com destaque para a Igreja Matriz de Nossa Senhora da Conceição. Fonte: Fotografia elaborada pelo autor (2008).

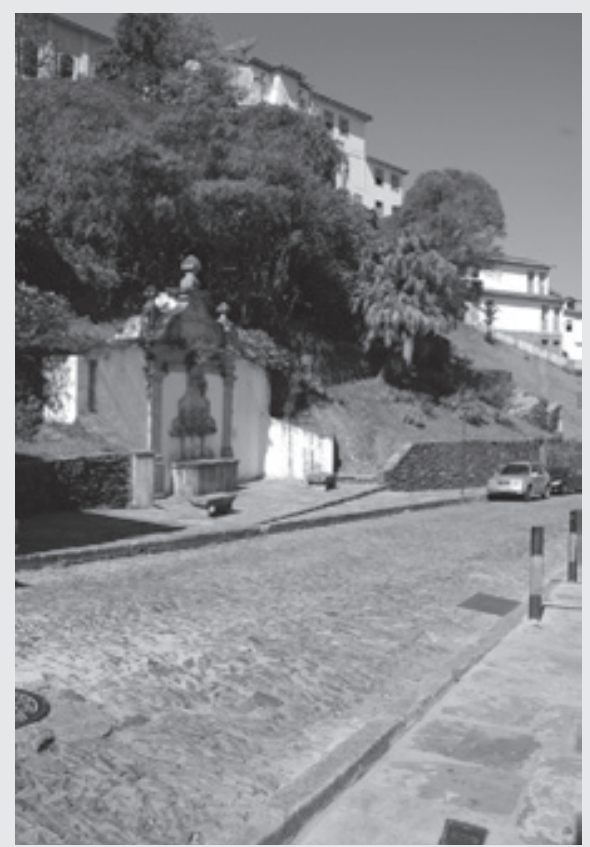

26o. À esquerda, Chafariz do Bonfim, em um dos ramais da "estrada tronco", na Freguesia do Pilar, próximo à matriz de mesmo nome. Fonte: Fotografia elaborada pelo autor (2008).

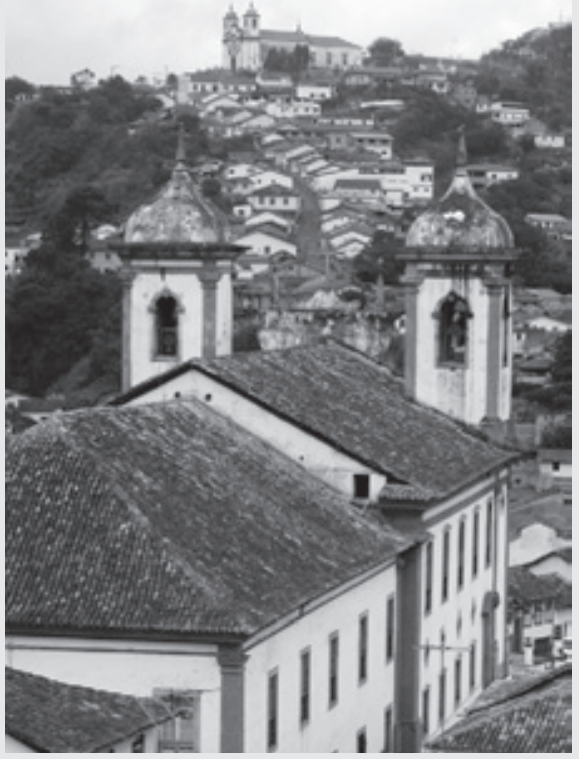

261. A direita, Morro, Igreja e Ladeira de Santa Efigênia ("caminho velho"). Abaixo, a Igreja Matriz de Nossa Senhora da Conceição de Antônio Dias, também lançada na "estrada tronco". Um dos poucos panoramas onde é possível confirmar o desenho linear da ocupação urbana. Fonte: Fotografia elaborada pelo autor (2008) 


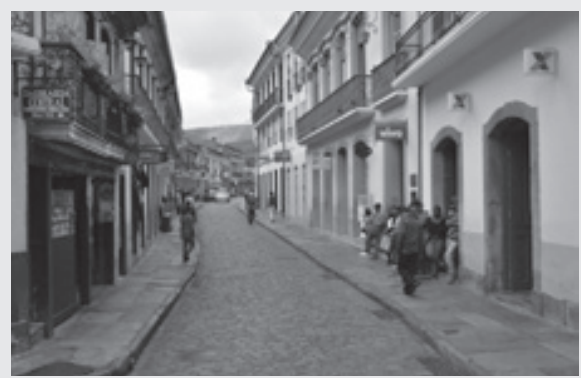

262. Trecho do "caminho novo" na Freguesia do Pilar. A atual Rua São José. Fonte: Fotografia elaborada pelo autor (2017).

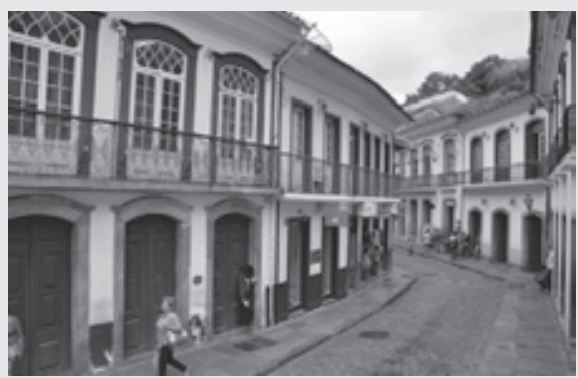

263. Trecho do "caminho novo" na Freguesia do Pilar. A Rua São José. Fonte: Fotografia elaborada pelo autor (2017).

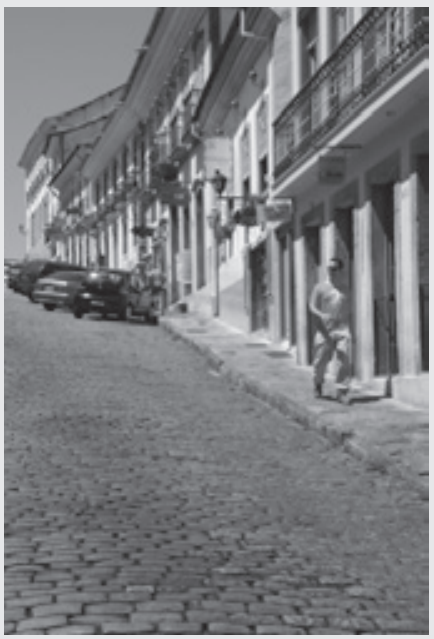

264. Trecho do "caminho novo". A Rua Direita (atual Conde de Bobadela). Fonte: Fotografia elaborada pelo autor (2008).

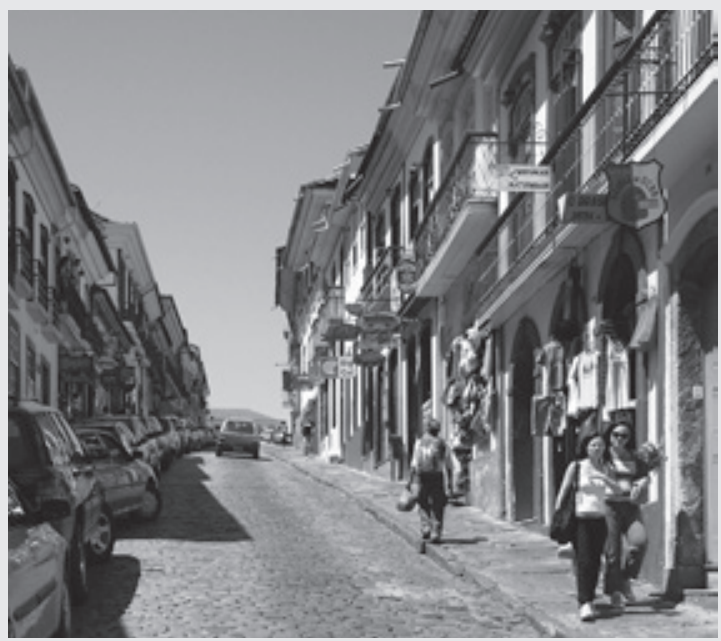

265. Trecho do "caminho novo" na Freguesia do Pilar. A Rua Direita (atual Conde de Bobadela). Acima, alcança a Praça Tiradentes. Fonte: Fotografia elaborada pelo autor (2008).
266. A Rua Direita. Fonte: Fotografia elaborada pelo autor (2008)

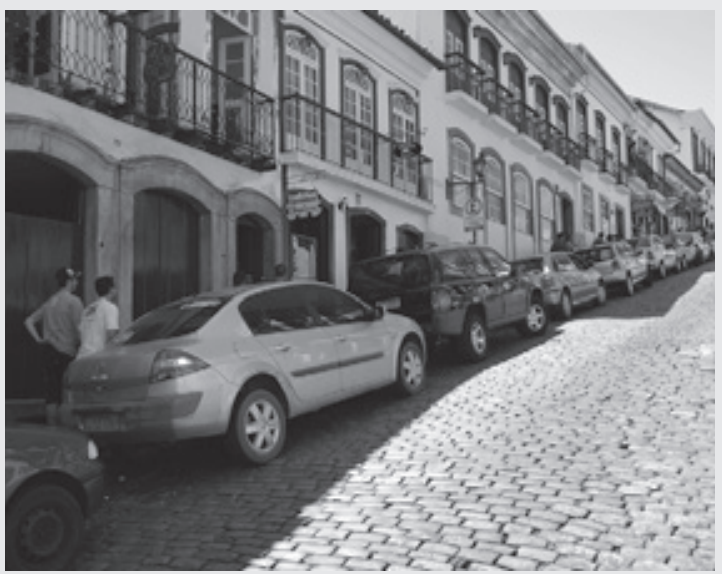


ampliação periférica de densidade decrescente. O crescimento da primeira se faz por paralelismo à rua-tronco ou por prolongamento de suas extremidades. Da segunda, por radiação e círculos concêntricos. Ou em semicírculos quando o mar ou outro obstáculo estabelece diametrais limites.

A cidade "nucleada" tradicional possuiria uma malha edificada muito mais concentrada, sobrando menos espaço para a interação da arquitetura com o sítio. Já a cidade linear mineira estaria mais aberta para as possibilidades da conjugação da massa construída com o ambiente natural preexistente, principalmente em sítio acidentado, irregular. Mas a questão é bem mais complexa do que possa parecer a princípio. Um dos motivos da alta densidade da cidade portuguesa, e também de cidades brasileiras do litoral, como Salvador, por exemplo, está relacionado à necessidade do núcleo urbano se apertar entre os seus limites de proteção: acidentes naturais, como a falha geológica da primeira capital do Brasil, ou barreiras edificadas, como as muralhas que vão cercar as cidades lusas. Em Minas não vão existir muralhas, não sendo o espaço das cidades circunscrito por necessidade de defesa. Mesmo assim, as povoações vão apresentar um elevado índice de ocupação. A diferença é que esta ocupação não é relativa à área espalhada pela mancha urbana, mas uma densidade apegada à configuração linear que a cidade adquire, oriunda da necessidade imperativa de aproveitar a única direção que normalmente define o espaço urbano:

\footnotetext{
Nas urbanizações lusitanas e brasileiras junto ao mar, as construções se apertam umas às outras, em consequência da exiguidade das áreas que lhes são reservadas no interior, das fortificações ou de delimitações favoráveis à defesa. Nas mineiras também as construções se amontoam, se interpenetram, multiplicam-se para o alto e para os fundos, escoram-se mutuamente, mas por outras razões: só há uma rua disponível que importa aproveitar ao máximo. Fazem-se mínimas as testadas, comprimindo as frentes rueiras das moradias. (VASCONCELLOS, I968, p. 89)
}

No caso de Ouro Preto, esta alta densidade concentra-se, principalmente, no "caminho novo", por ser mais adequado à ocupação humana e por adquirir grande status ao fazer parte das obras de infraestrutura que a vila vem a sofrer a partir da década de I720. Isto não quer dizer que a antiga "estrada tronco" tenha 
sido abandonada. Nas áreas mais distantes, como as Cabeças e Santa Efigênia, onde só existe uma via, a densidade vai crescendo gradativamente com o avanço do século XIX. Nas outras áreas, paralelas ao caminho novo, a ocupação sempre será alta onde a topografia permitir.

\section{A arquitetura religiosa e a paisagem urbana de Ouro Preto}

Em Ouro Preto, o meio físico em que a cidade se assenta define, irremediavelmente, as fronteiras visuais e simbólicas que encerram a apreciação do espaço urbano. $\mathrm{Na}$ realidade, a natureza ciclópica característica do lugar se concentra em uma área muito reduzida; assim, em função da proximidade com que interage a parte edificada com os acidentes geográficos, o núcleo urbano fica contido entre as serras e os morros que se elevam por toda parte, dando a nítida impressão de que o espaço está comprimido entre poderosas barreiras. E é verdade, pois a cidade nunca vence as fronteiras da Serra de Ouro Preto e dos Morros do Curral, do Alto da Cruz e do Cruzeiro. Porém, dentro destes limites que o relevo impõe ao núcleo urbano, as colinas, montanhas e serras da antiga capital das Minas promovem uma variedade realmente inusitada de cenários naturais, sendo esta diversidade plenamente absorvida dentro do aglomerado urbano. Ou seja, além de moldura e limite visual, a montanha enriquece a gama de cenas das mais diversas qualidades que despontam no circuito fechado das vias mais importantes da cidade.

Contudo, antes de estar à frente das cenas monumentais que se desenvolvem em volta dos caminhos que cortam a antiga Vila Rica, o transeunte se depara com uma série de panoramas que antecipam o persuasivo jogo de imagens que vai se abrindo aos olhos ao penetrar na cidade. Estas imagens não são capturadas apenas nos acessos ao núcleo urbano e nas elevações que acolhem a cidade, mas também nos próprios caminhos internos - já que as constantes ladeiras da antiga Vila Rica permitem, na sua ação de descida, a abertura de diversas paisagens atraentes.

O mais interessante é que estes panoramas fazem uma apresentação prévia dos principais personagens do drama encenado no âmago da Ouro Preto barroca: os monumentos religiosos já se mostram em situações de alto teor cenográfico nas vistas abertas nas estradas que passam nos arredores da cidade. É o primeiro ato da peça barroca que irrompe na antiga Vila Rica: a posição destes edifícios no 
cume dos morros, com a moldura verde das serras atrás e a grande luminosidade do céu de Ouro Preto, ao fundo, oferece muitas das imagens mais dramáticas. É como se o morro funcionasse como o suporte - como a peanha onde se colocaria a imagem sagrada composta pela igreja com as suas altas torres. Por outro lado, as montanhas verdes dispostas por detrás dos monumentos religiosos assumem um contraste exuberante com a verticalidade das torres e com as paredes brancas caiadas que envolvem o templo - contraste enfatizado pela suavidade dos contornos orográficos, característica comum ao relevo das Minas Gerais (Figuras 267-269).

Por outro lado, no cenário de Ouro Preto os monumentos religiosos não se propõem a uma simples presença nas vistas capturadas dos mais diversos pontos da malha urbana irregular. Pelo contrário, as igrejas rompem a massa amorfa da mancha edificada distribuída pelo sítio natural, dando legibilidade e dramaticidade às imagens que são derramadas no ambiente. Nos panoramas mais importantes se apresentam em grande número e se mostram plenamente, isoladas de qualquer construção que pudesse obstruir a sua visão, exibindo o seu corpo alvo, movimentado, frequentemente, por curvas (Figura 270).

É neste contexto que é deflagrada a mais importante regra do jogo persuasivo de Ouro Preto: após se apresentarem nos acessos à cidade, as igrejas desaparecem do campo de visão do observador, tornando-se impossível prever a experiência a ser assimilada no reencontro com os monumentos. Na realidade, devido ao acidentado percurso que o espectador precisa assumir e também em função da sinuosidade geral do traçado, é impossível até mesmo prever o trajeto necessário para alcançar os edifícios. Portanto, após o observador assumir o percurso para a descoberta da cidade, inesperadamente um templo pode vencer a densidade da área construída e reaparecer, integralmente ou em parte, pairando sobre um morro acima da calha fechada das vias, ou visível em algum panorama aberto nos caminhos internos da cidade. No entanto, só pelo acaso que o caminhante, finalmente, consegue absorver uma imagem aproximada da igreja e, consequentemente, tomar um trajeto simples para chegar ao seu largo, situação que se configura como um momento de surpresa, após períodos de desorientação e tensão. E a reaparição do monumento gera, no contato direto com a sua frontaria e com o seu adro, uma experiência de alto teor dramático que muitas vezes chega a superar as cenas anteriores, capturadas nos grandes panoramas e nos caminhos internos da cidade. 


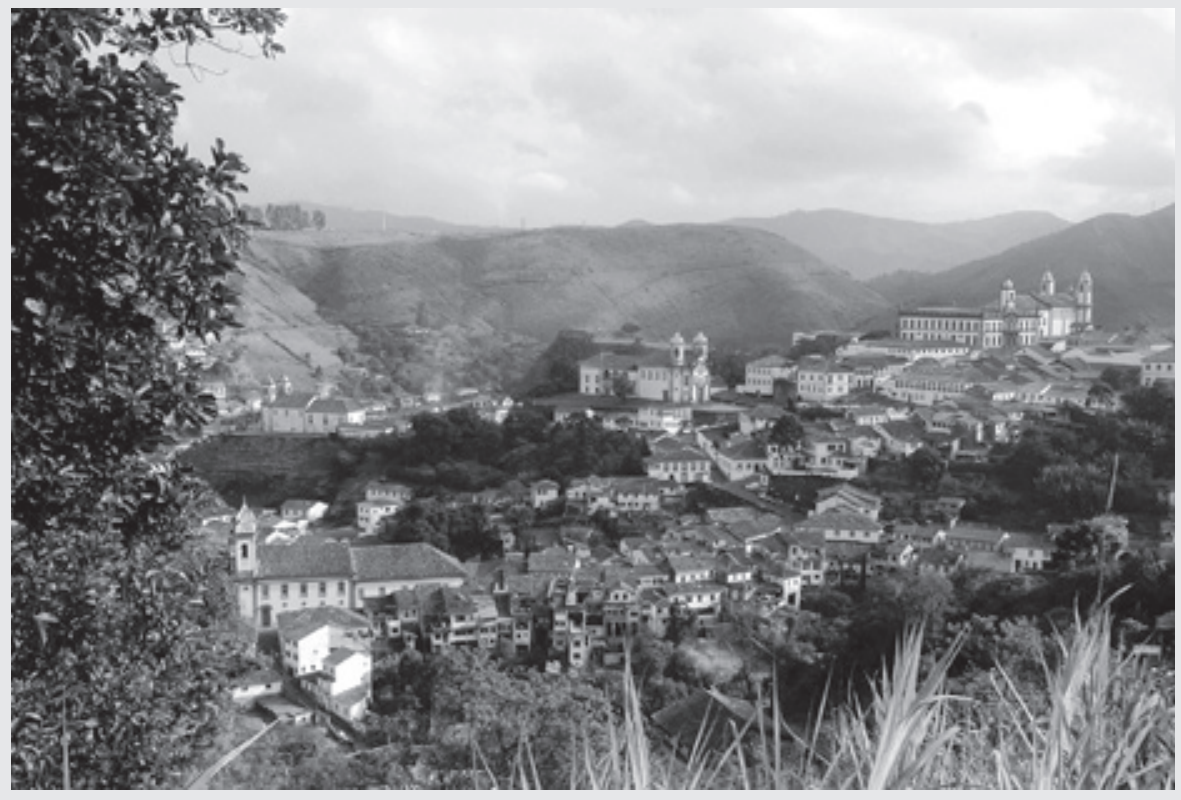

267. Vista da Freguesia de Antônio Dias a partir do Caminho das Lajes. Em destaque, da esquerda para a direita: a Matriz de Nossa Senhora da Conceição; a Igreja das Mercês de Baixo; a Igreja de São Francisco de Assis; a Casa de Câmara e Cadeia; a Igreja de Nossa Senhora do Carmo. Fonte: Fotografia elaborada pelo autor (2008).

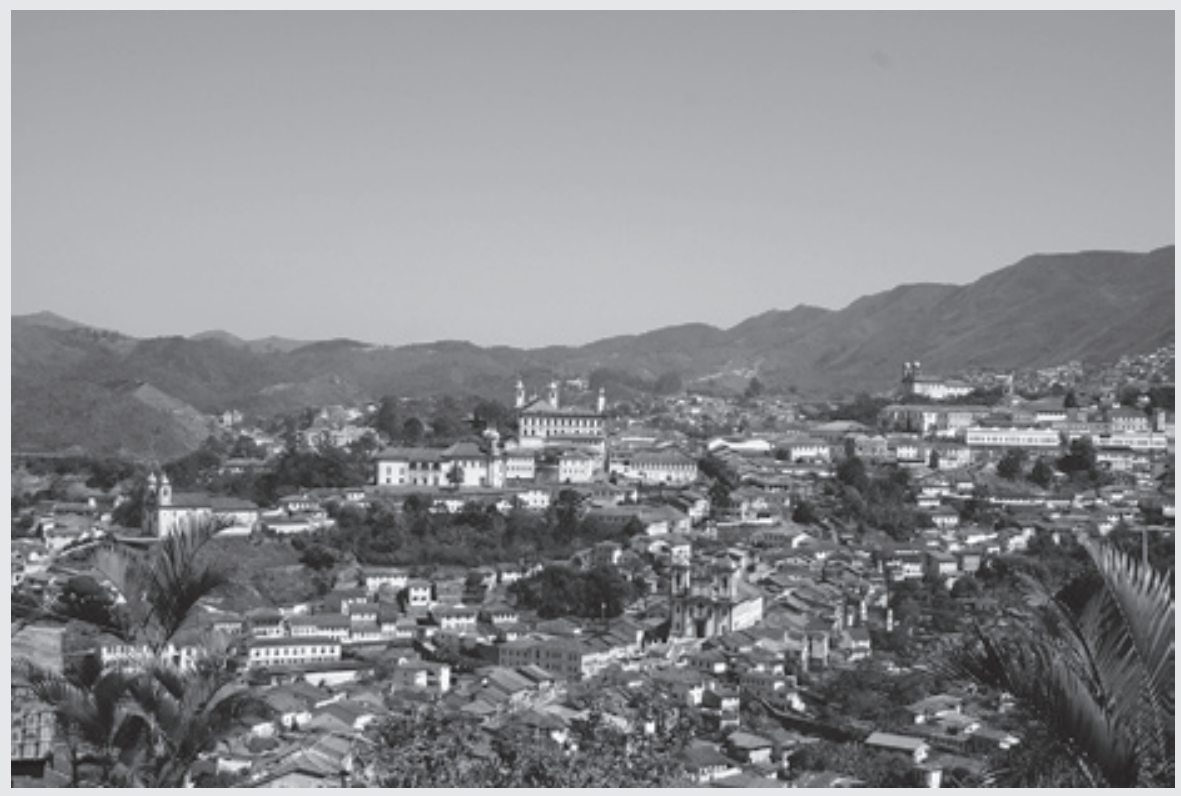

268. Vista panorâmica do Morro de Santa Quitéria, do lado da Freguesia de Antônio Dias - retirada das proximidades da Igreja de Santa Efigênia. É possível ver, diluídas na encosta do bairro, da esquerda para a direita: as Igrejas das Mercês de Baixo, São Francisco de Assis e a Igreja Matriz de Antônio Dias. Ainda é possível vislumbrar acima, já na Freguesia do Pilar, as torres da Igreja da Ordem Terceira do Carmo e, bem distante, todo o corpo alvo da Igreja de São Francisco de Paula. Ao fundo, a Serra de Ouro Preto emoldura a composição. Fonte: Fotografia elaborada pelo autor (2008). 


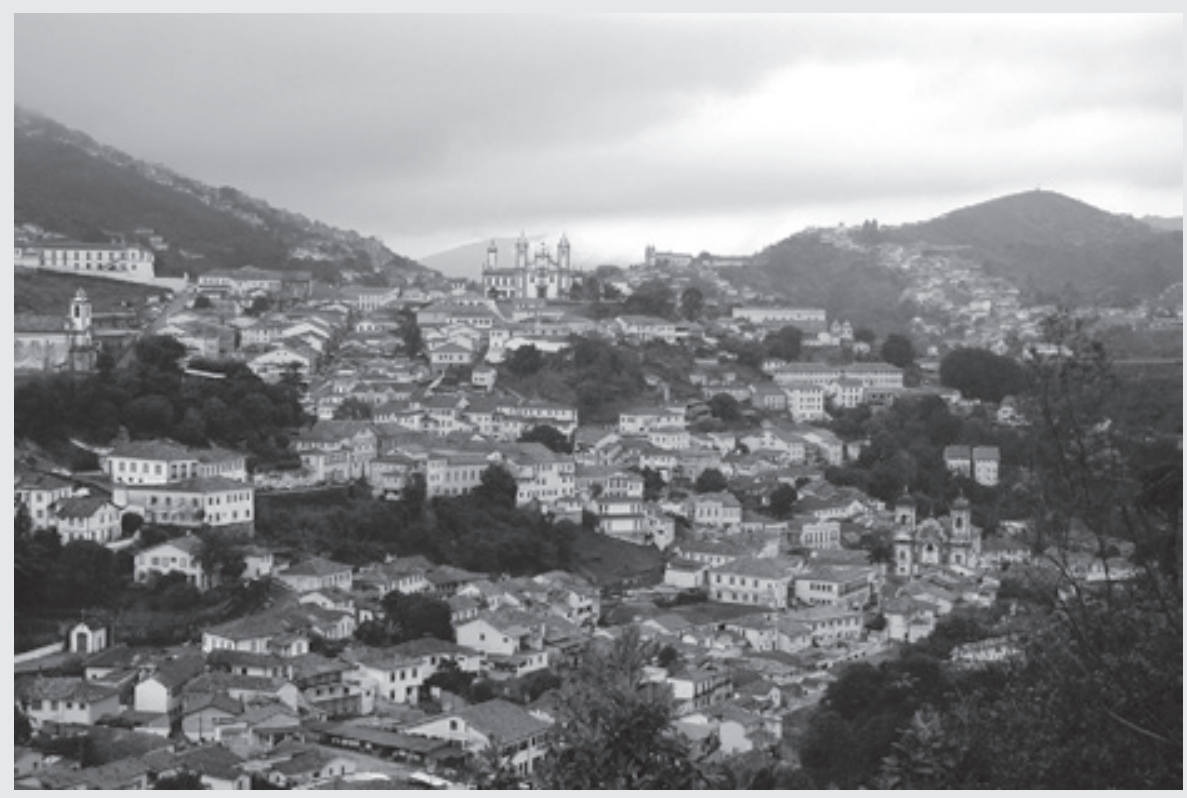

269. Panorama da Paróquia do Pilar, retirada do Morro do Curral, nas adjacências do Morro das Cabeças. Destaque para a Igreja Matriz de Nossa Senhora do Pilar, abaixo, e para a Igreja de Nossa Senhora do Carmo, acima. Fonte: Fotografia elaborada pelo autor (2008).

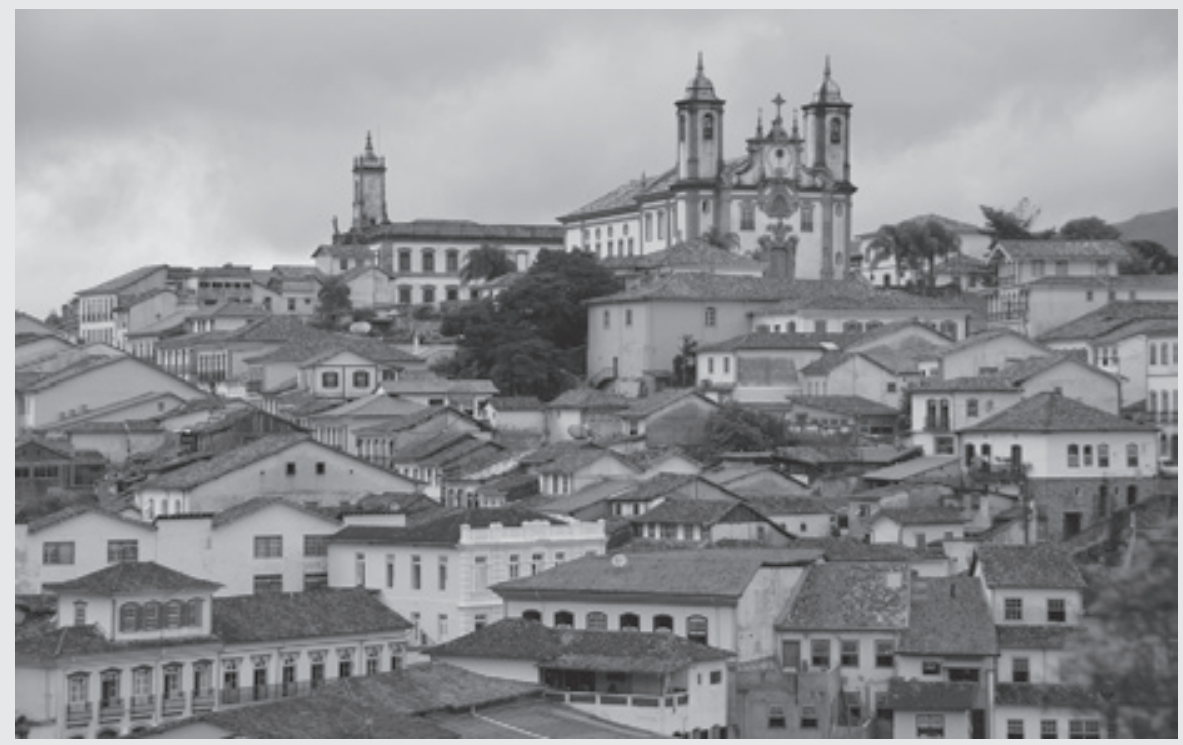

270. Panorama retirado do belvedere da Secretaria de Planejamento da Prefeitura de Ouro Preto, onde se vislumbra o Morro de Santa Quitéria, com destaque para a Igreja de Nossa Senhora do Carmo e a Casa de Câmara e Cadeia. Em destaque surge, em diagonal, o casario da Rua Direita, a mais imponente da cidade. Fonte: Fotografia elaborada pelo autor (2017). 
A análise subsequente da experiência adquirida na descoberta dos quatro mais importantes organismos religiosos da Ouro Preto colonial - a Igreja de Nossa Senhora do Rosário dos Pretos, a Igreja Matriz de Nossa Senhora do Pilar, a Igreja da Ordem Terceira de Nossa Senhora do Carmo e a Igreja da Ordem Terceira de São Francisco de Assis - ilustrará, de modo muito transparente, os mecanismos que foram discutidos até aqui e que concorrem para a construção cenográfica do espaço urbano.

\section{A Igreja de Nossa Senhora do Rosário dos Pretos e sua contribuição para a constituição do cenário barroco de Ouro Preto}

Próximo à extremidade ocidental da cidade, ao percorrer o caminho que teria dado origem à antiga Vila Rica através da conurbação de um vasto número de arraiais e freguesias ligados à extração aurífera (a "estrada tronco"), é possível avistar a Igreja de Nossa Senhora do Rosário - capela da irmandade dos negros, reconstruída na década de I750, projetada pelo bacharel e arquiteto português, Antônio Pereira de Souza Calheiros, seguindo um modelo inovador adotado também para a lgreja de São Pedro dos Clérigos, em Mariana. Na ladeira, ela aponta no campo de visão conjugada com as elevações distantes da Matriz de Nossa Senhora do Pilar e da Igreja de Nossa Senhora do Carmo. Neste panorama é possível vislumbrar - além das fachadas principais dos dois templos, desimpedidas e em perfeita elevação - a distante elevação lateral da Igreja de São José, voltada para a Serra do Itacolomi, e a imagem da parte posterior da Capela do Rosário. Os quatro edifícios também se destacam por assumirem cotas diferenciadas, com as suas torres marcando apontamentos verticais contrastantes com os suaves contornos topográficos dos morros vizinhos.

Descendo a ladeira, a Matriz do Pilar e a Igreja do Carmo desaparecem do campo de visão, mas começa a se definir a imagem de outra obra: a lgreja de São Francisco de Paula. Este imponente edifício, construído a partir de I804 - o mais novo e um dos mais elevados de Ouro Preto -, só se torna plenamente visível nas proximidades da Ponte do Caquende, trecho que marca o fim da ladeira que encerra o antigo e distante Arraial das Cabeças e o início do Bairro do Rosário. Contudo, é a Igreja dos Pretos que se mostra mais sedutora ao transeunte no confronto com os outros templos apreciados na descida, mesmo estando em uma posição desfavorável, mais próxima ao vale e de costas para o acesso principal à cidade. 
Na realidade, a Igreja do Rosário dos Pretos anima este trecho da "estrada tronco" não pela implantação, mas principalmente pela arquitetura arrojada. Mais do que qualquer outro edifício do Brasil colonial, destaca-se excepcionalmente em função da complexa volumetria. Seu arrojado jogo de volumes curvilíneos exporia uma filiação incondicional à movimentada disposição sinuosa de algumas manifestações edilícias desenvolvidas na Itália e na Europa Central. Não obstante, a igreja iria subverter o esquema compositivo contemporâneo que jogava o interesse da irradiação e da interpenetração espacial para o ambiente interno do edifício - sistema em evidência, sobretudo, na arquitetura produzida na Boêmia e no sul da Alemanha, onde seriam quase exauridas as possibilidades de modelagem espacial dos monumentos: no Rosário, o empenho estaria voltado para a disposição da volumetria exterior, na qual os muros convexos invadiriam, virtualmente, o espaço da cidade, expandindo-se por todos os lados.

A igreja é composta, basicamente, por duas elipses que se interpenetram: o volume maior e mais alto contém a nave e o menor acolhe a capela-mor. A sacristia disposta ao fundo, por sua vez, é de planta retangular, fechada por um telhado em três águas. Os outros corpos tridimensionais usam coberturas em duas águas em forma de quilha de navio invertido, com a cumeeira desenhando uma pronunciada curva convexa proveniente do rico trabalho de carpintaria que fecha os dois espaços ovalados. Ou seja, também o telhado contribui para o efeito expansivo geral que os volumes elípticos promovem em relação ao espaço exterior.

Mas não são só estes elementos que irão participar do intenso processo de interconexão volumétrica. À frente da nave, duas torres cilíndricas cobertas por bulbos em forma de sino tangenciam a massa elíptica, definindo o enquadramento da fachada principal. Estes campanários, por sua vez, invadem o espaço de outra massa curva que nasce a partir de um sugerido movimento centrífugo que parte da nave principal, formando o volume convexo do frontispício que se coloca diante de toda a composição (Figura 27I). Desta maneira, em todas as visadas que o fruidor pode capturar é sempre inevitável a absorção da força dinâmica das curvas que se mesclam abruptamente, sem a intermediação de superfícies côncavas, como se existisse uma pressão interna querendo explodir, mas inibida por estar amarrada por algumas linhas de força presentes na volumetria exterior do edifício. Estas linhas, que abafam a ação que impulsiona o sentimento de dilatação da forma, se encontram na interseção da nave com a capela-mor, na junção da capela-mor com a sacristia - que na sua conformação ortogonal estática ser- 
ve como pano de fundo e elemento de contraste à diástole radical dos outros volumes -, mas também na tangência das torres (os contrapontos verticais da composição) com a nave e na interpenetração dos torreões cilíndricos no corpo convexo da frontaria (Figura 272).

É óbvio que esta concentração intensa de curvaturas expansivas diminui o efeito surpresa da descoberta do ambiente interior - até então ocultado, nas primeiras matrizes mineiras, pelo singelo invólucro de taipa ou adobe. De fato, seguindo o caminho inverso, a articulação interior do Rosário é verdadeiramente espartana, exibindo pouco interesse artístico, sendo uma consequência meramente formal da arquitetura exterior - mas não tendo nem a mínima parte da sua expressividade. Todo o interesse é transferido para o ambiente externo através do desejo de expandir a magia cenográfica dos espaços interiores reluzentes das igrejas mais antigas para toda a cidade, contaminando o panorama aberto pelo movimento oscilatório do edifício.

Felizmente, a articulação da superfície do edifício não se sobrepõe à já complicadíssima trama volumétrica. Os corpos principais possuem uma simples modenatura de estuque formada por cunhais, cornijas e pilastras toscanas, o que preserva um destaque inevitável à fachada principal, toda marcada por uma poderosa cantaria de quartzito. Mesmo assim, o frontispício ganharia um desenho rígido, fruto de uma intervenção de finais do século XVIII, negando o tipo de frontaria que se fazia por esta época e que expunha uma nova tipologia arquitetônica que iria reinar na fase final do período barroco nas Minas Gerais. A frontaria convexa, projetada perspectivamente para o adro pelas torres cilíndricas recuadas, está dividida em três tramos isolados por ordens toscanas colossais que sustentam um entablamento contínuo, encimado por um complicado frontão curvilíneo trilobado. No pavimento inferior, a igreja é aberta ao adro por três vãos em arco pleno de acesso a uma galilé - e, acima destes vãos, janelas rasgadas por inteiro aparecem na altura do coro. O resultado é elegante e vigoroso, mas enquanto tratamento de superfície não deixaria de ser simples e estático, não entrando em competição com a dinâmica incomum do jogo volumétrico da igreja.

Contudo, sem a preparação do terreno no qual o edifício viria a se assentar, não seria possível a evidência de todo este jogo volumétrico nas inúmeras imagens absorvidas nos mais diversos caminhos que cortariam a cidade. Para isso, seria inevitável a construção de um elevado platô que receberia a igreja e formaria o seu adro, pois o sítio possuía uma significativa declividade em relação às faces 

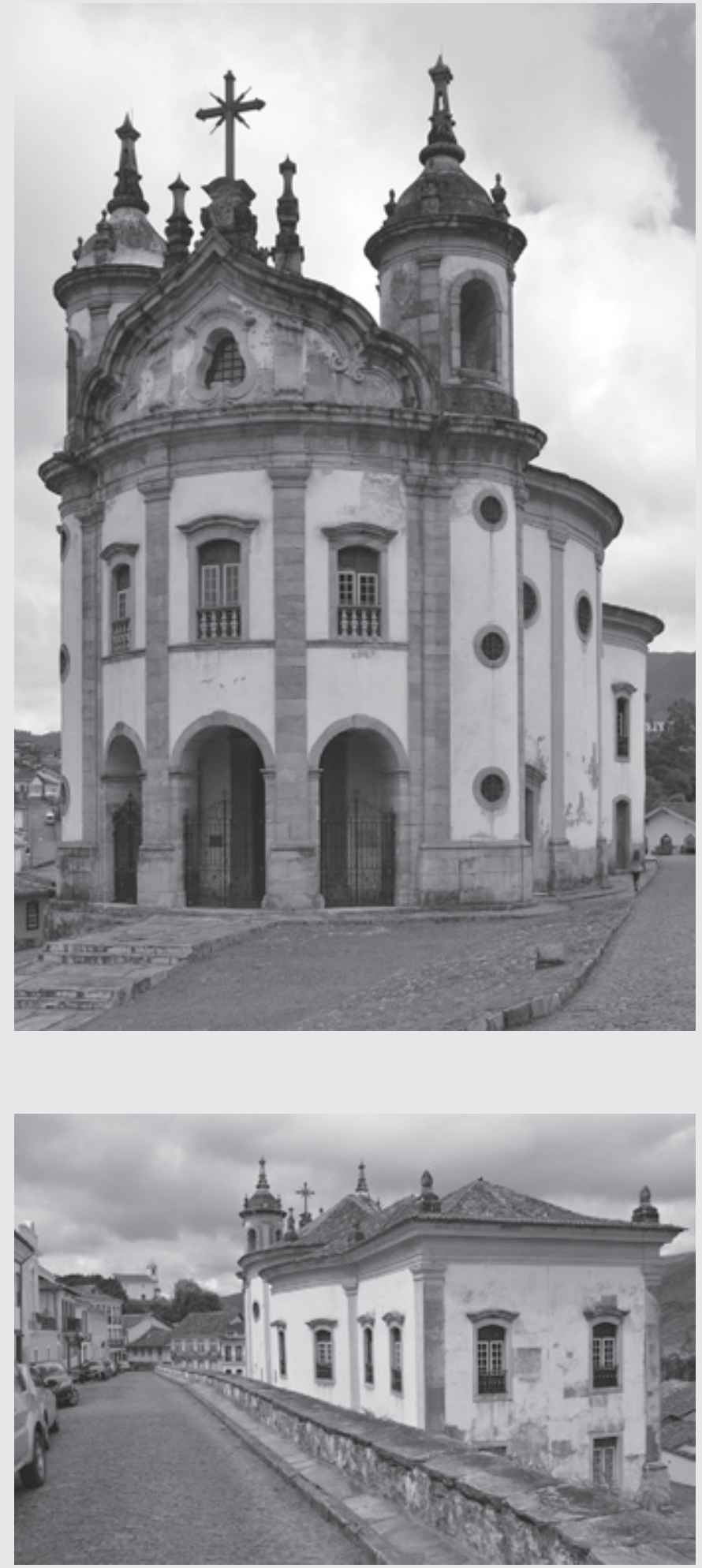

271. Igreja de Nossa

Senhora do Rosário dos

Pretos vista de frente e em escorço. Fonte: Fotografia elaborada pelo autor (2017).

272. Igreja do Rosário dos Pretos, vista de trás e em escorço. Fonte: Fotografia elaborada pelo autor (2017). 
laterais do edifício. Desta maneira, a Igreja da Irmandade dos Pretos assume uma posição proeminente que contribui para a sua exposição majestosa, oferecendo a imagem sedutora das suas quatro fachadas desimpedidas.

Assim, ao descer o Morro das Cabeças e atingir a ponte que atravessa o córrego do Caquende, é aberto um panorama onde se vislumbra a lgreja do Rosário pairando sobre o conjunto de sobrados que acompanha as sinuosidades da via abaixo. Acima do muro branco de contenção que fecha a face oposta da praça onde se assenta o templo, outro aglomerado de sobrados contíguos atua como pano de fundo à sensualidade e à dinâmica dos movimentos interpenetrantes e expansivos do volume posterior do edifício. Enriquecendo mais ainda este quadro, a lgreja de São Francisco de Paula, voltada para o sentido sul, se sobrepõe a toda paisagem coroando a composição aberta na ponte. Curiosamente, enquanto tratamento exterior, este templo apresenta uma arquitetura dura e ortogonal, contrastando com a oscilação contínua do Rosário. Na verdade, a dimensão grandiosa da construção, a implantação sublime e o imponente escorço frontal a que está submetido, autoriza a ausência de uma articulação arquitetônica mais movimentada.

Dando continuidade ao "caminho velho", após a travessia do córrego do Caquende, a imagem das duas igrejas vai se apagando gradativamente, em consequência da redução do campo de visão, limitado pelo estreito corredor sinuoso de sobrados que conforma o próximo trecho da rua. Na verdade, logo que se vence a ponte, São Francisco de Paula desaparece por completo, mas ainda se guarda a imagem posterior das torres e do arremate do corpo da Igreja de Nossa Senhora do Rosário, que aos poucos se desvanece. Por alguns momentos, consequentemente, é guardada a expectativa da redescoberta destes monumentos que despontam em uma situação cenográfica completamente diversa, na súbita abertura do Largo do Rosário: reaparecem as torres de São Francisco de Paula acima do fechamento oposto da praça, enquanto a Igreja do Rosário aponta logo à frente, à esquerda, com a imagem de parte de seu corpo interrompido, em função do efeito perspectivo, pelo aterro que acolhe o adro do edifício. Desta maneira, é exigido o movimento do transeunte, que deve subir o largo para apreciar integralmente o templo.

Para quem chega pelo "caminho velho", o Largo do Rosário configura-se como uma ladeira bem larga, em aclive significativo, que afunila para cima na direção nordeste, onde nasce o "caminho novo". O seu perímetro irregular apresenta quase todos os contornos limitados por paredões de sobrados que encerram o es- 
paço, dando uma ideia de recolhimento e intimidade. A única exceção é a face noroeste, que é fechada por um pequeno aglomerado de casarões somente na sua parte baixa, abrindo-se mais acima para o espaço desafogado que recebe a Igreja do Rosário - área que amplia irregularmente a extensão lateral do espaço (Figura 273).

Para além da visão posterior da igreja, tomada na chegada da cidade para quem desce o antigo Arraial das Cabeças, bem como na descoberta do largo após estre trecho baixo do "caminho velho", será no encerramento do chamado "caminho novo" - trecho mais imponente do núcleo central (como já foi analisado), que marca, cronologicamente, a segunda ocupação viária da cidade - que serão oferecidas as imagens mais surpreendentes da igreja, principalmente para o transeunte que marcha na direção oposta, no sentido leste-oeste. Neste trajeto, o percurso é definido por um longo trecho plano, que corta a abrupta encosta da Serra de Ouro Preto, assumindo uma inevitável conformação sinuosa.

Em função do status que esta via absorve a partir de meados do século XVIII, ela acaba acolhendo muitos dos mais importantes sobrados da antiga Vila Rica, todos alinhados com a rua e unidos entre si pela implantação gregária tradicional. Deste modo, o casario forma um estreito corredor sinuoso, a céu aberto, cadenciado pela modenatura dos edifícios, onde vários eventos - como, por exemplo, a aparição constante da Igreja de São Francisco de Paula e da Capela de São José, ou a abertura de diversos panoramas ao lado da parte em declive da encosta animarão o percurso e contribuirão para oferecer o tom dramático à experiência barroca de se percorrer o "caminho novo".

Contudo, estas cenas pontuais não antecipam a surpreendente descoberta da Igreja do Rosário dos Pretos, efetivada na finalização da atual Rua Getúlio Vargas: em um dos trechos mais sinuosos do "caminho novo", o transeunte finalmente avista, em uma greta aberta pela curvatura de uma das faces da rua, a imagem interrompida do templo, que anuncia a sua presença logo à frente, onde se abre o Largo do Rosário. Bastam mais alguns passos para o caminhante se deparar com a estrutura do edifício exposta ao nível do observador e enviesada, denunciando toda a complexidade de sua volumetria - que invade, virtualmente, com o seu movimento expansivo, o espaço à frente do adro.

A diástole formada pelos elementos convexos que se sucedem na fachada lateral do edifício (torre, nave, capela-mor) assume um duro contraste com o arrimo retilíneo e branco que demarca o beco que passa adjacente ao templo. Este confronto entre a imagem dinâmica do escorço da igreja e a moldura alva do muro 
acaba valorizando ainda mais a inusitada agitação do edifício, acrescentando, à visão lateral, um movimento em profundidade - movimento perspectivo que é reforçado pela rua assentada acima do arrimo; via que, em função do direcionamento proposto pelos sobrados contíguos e alinhados incorpora a mesma conformação retilínea da parede abaixo.

Curiosamente, a dilatação a que está submetido o frontispício convexo, apertado pelos dois campanários cilíndricos, sobre certo aspecto não incentiva o ingresso ao interior do templo que, como já foi discutido anteriormente, não assume praticamente nenhum interesse plástico. Na verdade, a expressividade inédita do volume da igreja inibe a articulação da cavidade interna, que não entra em competição com a presença marcante do templo em relação à cidade (Figura 274).

Portanto, é significativa a maneira como a Igreja de Nossa Senhora do Rosário dos Pretos absorve interesse tanto em sua visão imediata como nos panoramas mais comuns em que ela normalmente protagoniza, principalmente aqueles que apresentam o edifício na sua parte posterior. É claro que este poderoso jogo de escorços dramáticos é sublinhado pelo efeito surpresa, derivado das constantes aparições do monumento nas inflexões que o transeunte assume na cidade, e na sua descoberta inusitada no percurso final do "caminho novo".

\section{Espaço exterior x espaço interior: a Matriz de Nossa Senhora do Pilar de Ouro Preto}

Ao atravessar a parte baixa do Largo do Rosário e tomar o caminho que se dirige à Igreja Matriz de Nossa Senhora do Pilar, antes mesmo de descer o primeiro segmento da ladeira, um belo cenário se revela: ainda na cerrada praça é possível vislumbrar a imagem do caminho tortuoso que parte do largo e segue para as torres já visíveis da Igreja do Pilar; ao fundo, fechando a composição, o panorama é delimitado pelos morros do Cruzeiro e do Alto da Cruz, e como marco referencial distante aparece o Pico do Itacolomi (Figura 275). Esta imagem antecipa o percurso idílico que vai permear a maior parte da experimentação do caminho que busca a matriz. O trajeto se desenrola a partir de um poético movimento sinuoso oriundo da via irregular rasgada na abruta encosta que marca a parte mais baixa da vertente norte da Serra de Ouro Preto (Figura 276). A alta declividade da montanha torna proibitiva a ocupação da maior parte do flanco esquerdo da 

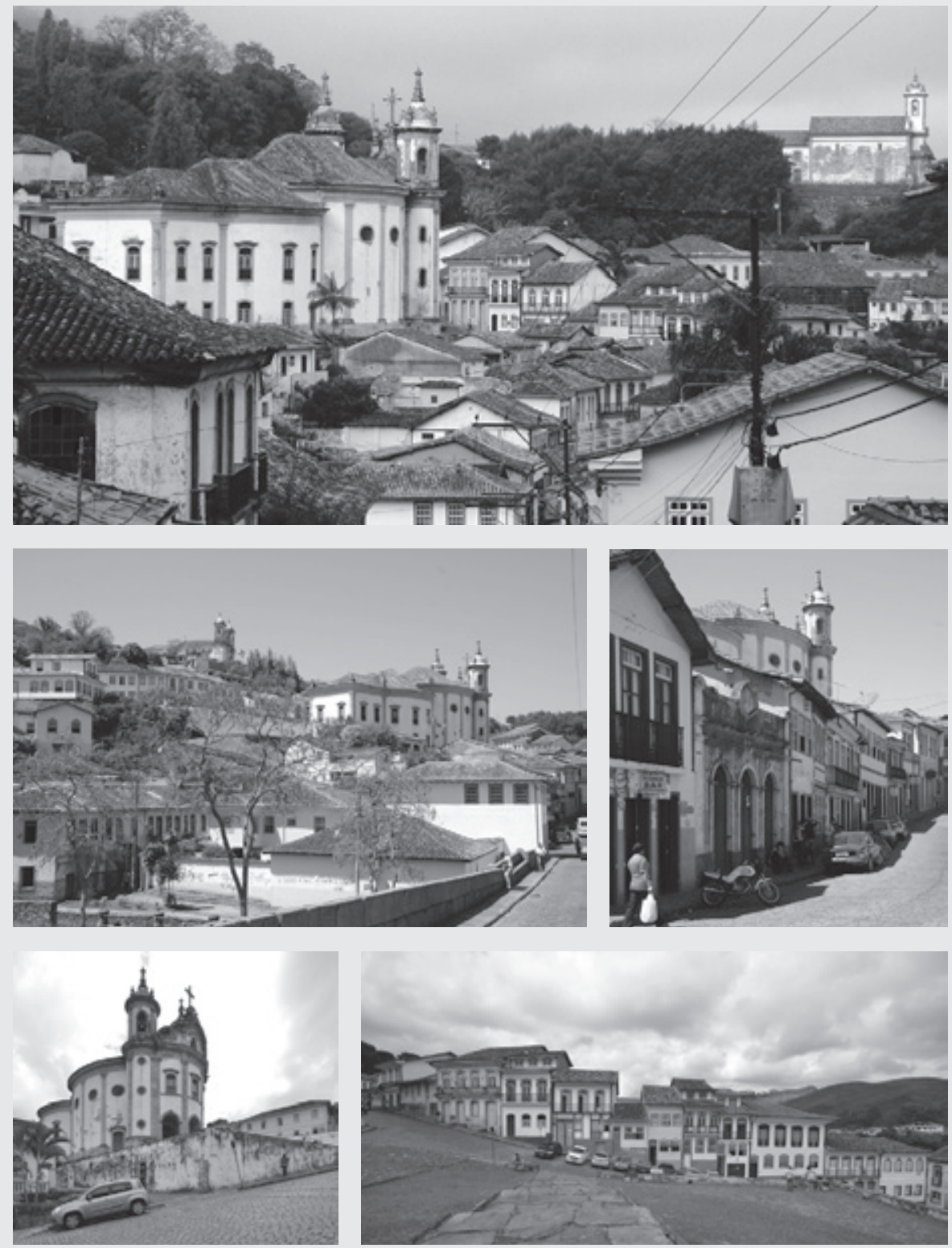

273. Percurso do "caminho velho", assumido a partir do acesso ocidental à cidade - pelo Bairro das Cabeças -, no qual se retiram diversos panoramas onde despontam expressivas imagens da Igreja de Nossa Senhora do Rosário dos Pretos vista em sua parte posterior. A penúltima imagem marca a chegada ao Largo do Rosário e a última, logo abaixo, revela a sequência de casarões dispostos em frente ao adro da igreja - a leste. Fonte: Fotografias elaboradas pelo autor. As três primeiras imagens são de 2008. As duas últimas são de 2017. 

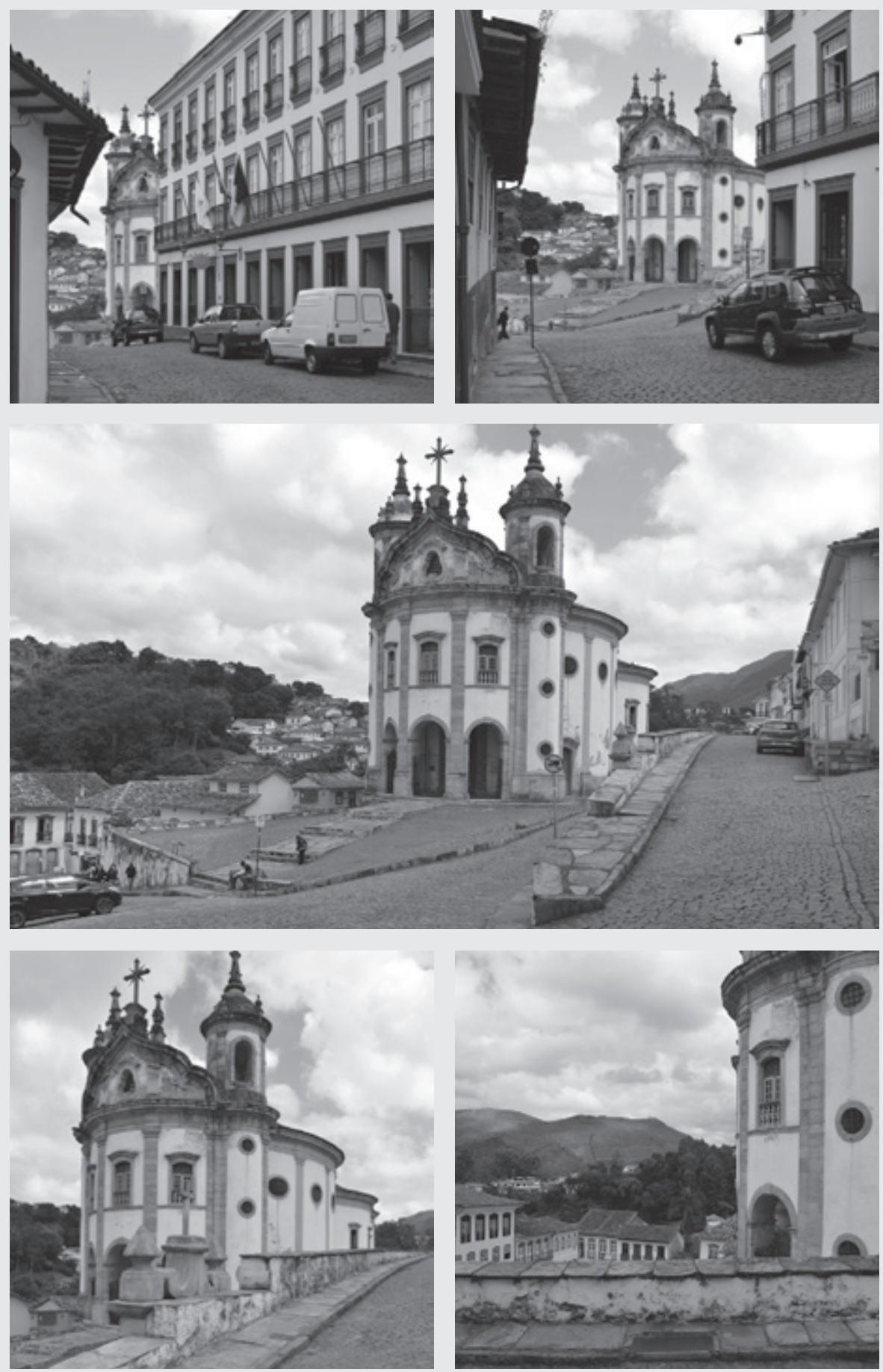

274. Sequência de imagens retiradas do "caminho novo" - para quem percorre a direção oeste -, trajeto que se encerra justamente no Largo do Rosário. As imagens assinalam a aproximação da Igreja do Rosário dos Pretos se anunciando, inicialmente, em uma pequena fresta aberta entre os últimos casarões do "caminho novo"; o panorama vai se abrindo até a chegada ao Largo do Rosário; as duas últimas marcam o trajeto do caminhante, à direita, para além do largo. Fonte: Fotografias elaboradas pelo autor (2017). 
via, permitindo a visão frequente da massa verde da vegetação que preenche a ribanceira em contraste com o fundo irregular da parte posterior dos casarões que conformam o "caminho novo" - que passa bem acima. Ao lado direito, a grande declividade da encosta também impede, principalmente no início do trajeto, o assentamento edilício, obrigando as edificações a se posicionarem um pouco abaixo.

Mais à frente abre-se, à direita, a rua que irá se configurar como a chegada à Igreja do Pilar. A matriz é vista não muito distante, em cota um pouco mais baixa, com a parte superior da fachada principal e as torres despontando acima do casario que, por outro lado, esconde a superfície inferior do frontispício (Figura 277). Ao contrário do que possa parecer a princípio, esta irregularidade do traçado, ao invés de prejudicar a apreciação da igreja, acaba valorizando o processo de sua descoberta - ao tornar menos óbvia e imediata a sua experimentação. De fato, é muito atraente a forma como a perspectiva ondulante direcionada ao Pilar vai ser gerada a partir do próprio desenho da via e reforçada pelo gregarismo entre as construções civis alinhadas nos dois lados da rua. Este trajeto incentiva a marcha do transeunte em busca da matriz, pois a sua revelação plena só é concluída após a última curva, quando se atinge o largo que se abre abruptamente e irregularmente à igreja (Figura 278).

Reinaugurada em I733, com as grandes festividades do Triunfo Eucarístico (ÁVILA, I984, p. 8), a Matriz de Nossa Senhora do Pilar irá romper a paisagem idílica que se vislumbra neste trecho da "estrada tronco". É certo que o atual frontispício seria fruto pretensioso de uma série de reformas que a igreja sofreria a partir do segundo quartel do século XIX - ações que decretariam a substituição da singela fachada anterior pela atual, de composição não muito elegante. $\mathrm{Na}$ verdade, a antiga frontaria deveria seguir a conformação tradicional aplicada nas elevações principais das igrejas paroquiais mineras - tipologia básica resumida pelo historiador da arte francês, Germain Bazin (I90I-I990), no estudo L'architecture religieuse baroque au Brésil, editado pela primeira vez em I955 e só traduzido para o português em $1983 .{ }^{99}$

O corpo central, arrematado por um frontão triangular, se equilibra entre duas torres de elevação moderada, estas acabadas por um pavilhão de madeira coberto de telhas. As vigas angulares se perfilam em

99 Aqui foi contemplada justamente a edição brasileira de 1983, A arquitetura religiosa barroca no Brasil, traduzida por Glória Lúcia Nunes. 


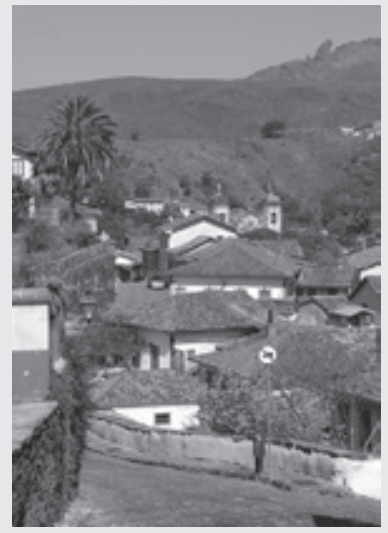

275. As torres da Matriz do Pilar surgem após o Largo do Rosário, na direção do "caminho velho" (atual Rua Deodoro da Fonseca), com o Pico do Itacolomi ao fundo. Fonte: Fotografia elaborada pelo autor (2008).

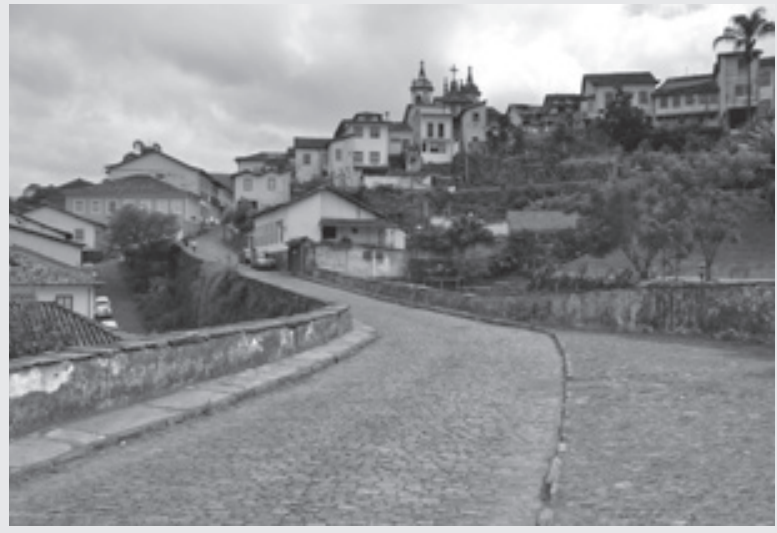

276. Imagem do fundo das residências do Largo do Rosário capturada do "caminho velho", com destaque para as torres da Igreja de Nossa Senhora do Rosário dos Pretos. Este é o percurso que se deve enfrentar (na direção contrária) para se alcançar a Matriz de Nossa Senhora do Pilar a partir do Largo do Rosário. Fonte: Fotografia elaborada pelo autor (2017).

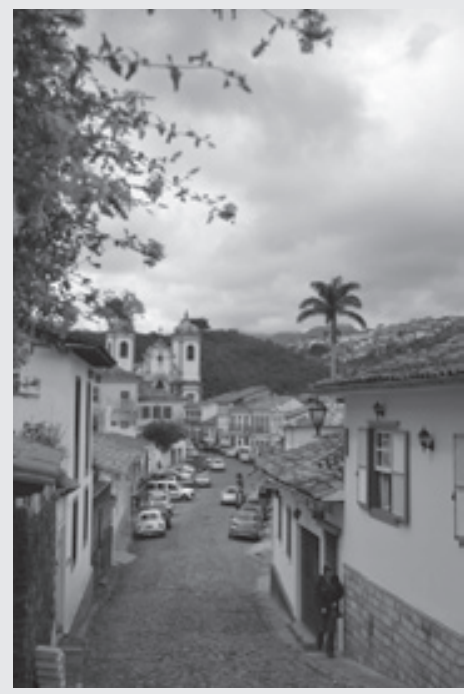

277. A Matriz do Pilar revela-se interrompida, a partir da perspectiva tortuosa retirada da Rua Conselheiro Santana ("caminho velho"), que dá acesso a ela. Fonte: Fotografia elaborada pelo autor (2017).

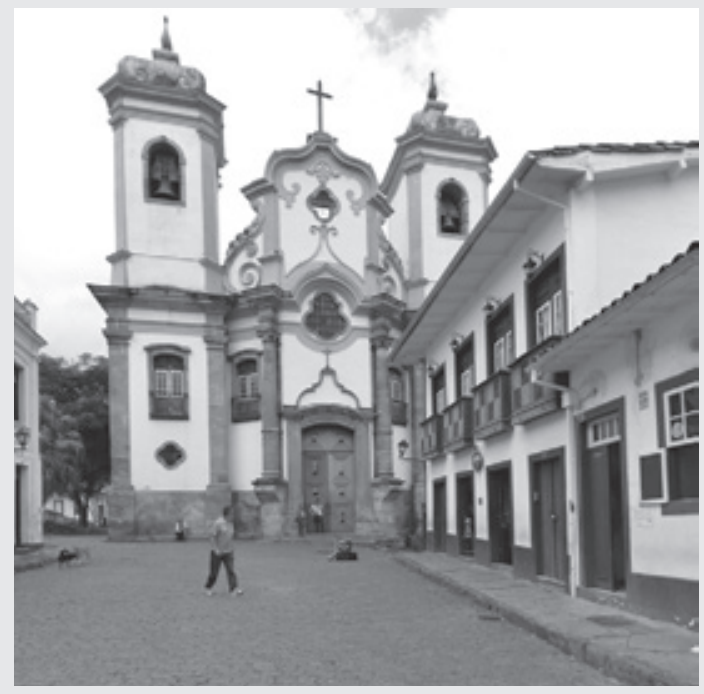

278. O Largo e a Matriz de Nossa Senhora do Pilar - com a sua fachada oitocentista interrompida pela sequência de sobrados do largo. Fonte: Fotografia elaborada pelo autor (2017). 
pilastras toscanas: o corpo da fachada está selado por uma única porta, encimada por duas ou três janelas que iluminam o coro. As arquitraves se desenvolvem em diversos ressaltos, a fim de formar uma cornija saliente, que se torna necessária para afastar da base das paredes de taipa a água que escorre; isso leva o arquiteto a definir acentuadamente à maneira da arquitrave antiga a horizontalidade dos elementos, apoiados em elegantes pilastras; dessa forma está bem expressa a estática do monumento. [...] Esses monumentos nunca são muito elevados, pois sua altura é limitada pela dimensão máxima dos esteios de madeira do primeiro andar da fachada. (BAZIN, I983, v. I, p. I98)

A articulação anterior - muito grosseira e rígida - não atrapalhava, minimamente, a constituição do cenário barroco desvelado neste trecho da antiga Vila Rica; pelo contrário, reforçava substancialmente o dramático enredo teatral - de um modo que ainda se pode apreciar nas Matrizes de Santo Amaro de Brumal, Santo Antônio de Santa Bárbara, Nossa Senhora da Conceição de Sabará, Nossa Senhora do Rosário de Santa Rita Durão, na Catedral da Sé de Mariana, entre outras. Promovendo um destaque mais reduzido em relação à arquitetura civil que compunha o cenário urbano - seja pela dimensão menor que a fachada atingia, seja pelo uso dos mesmos materiais e das mesmas soluções construtivas dos edifícios ordinários -, quem avistava o templo e se deparava com a sua dureza e simplicidade flagrantes não poderia antecipar a inebriante experiência que seria descortinada em seu espaço interior: ao irromper na Igreja do Pilar e vencer por um dos lados o pórtico para-vento, o espectador se depara com uma hipnótica e escura nave elíptica, toda ornada pelo sistema da talha dourada, e com uma pronunciada capela-mor que recupera o eixo longitudinal dominante da composição.

Na nave da Matriz de Nossa Senhora do Pilar, o virtuoso trabalho de carpintaria constrói um cenário teatral onde a fantasia barroca se faz presente no processo de absorção de um ambiente que parece muito maior do que realmente é. Para isso, a área elíptica do decágono alongado cresce no sentido vertical, em direção ao forro artesoado: as dez pilastras colossais de sustentação da cornija do teto não sobem niveladas ao solo, mas inclinam-se na direção posterior à elipse. Deste modo, na maior extensão transversal da nave, na altura do forro, a armação de madeira chega mesmo a tangenciar as paredes estruturais do edifício, deixando as passagens dos corredores laterais que dão acesso aos púlpitos e à sacristia - bem como às tribunas no pavimento superior - estranguladas, configurando-se 
como espaços residuais que aparecem entre as paredes inclinadas do biombo de madeira e o muro exterior. Na realidade, estes ambientes de uso restrito, sem qualquer acabamento arquitetônico e nenhuma articulação plástica, lembram o espaço de circulação que se encontra atrás do cenário móvel de uma peça de teatro. A diferença é que, no caso da Igreja do Pilar, esta armação cenográfica é fixa e a peça que se desenvolve entre as duas paredes côncavas que se abrem para a nave tem como protagonistas não os atores, mas todos que participam dos serviços religiosos desenvolvidos em seu interior.

Logo, o primeiro sentimento que se retira ao adentrar o edifício é o acolhimento impulsionado pela forma ovalada contrastiva - sensação reforçada pelo conjunto das ordens compósitas radiais que acompanham a curvatura do espaço da nave e rodeiam o ambiente elíptico. Estas pilastras falsas de madeira vencem dois pisos e sustentam o pesado forro da igreja - expondo, no pavimento inferior, os vãos preenchidos pelos altares laterais, e, na altura das tribunas, os vãos totalmente livres. Desta maneira, a imagem emanada pelo espaço elíptico envolvente lembra um teatro barroco, com parte da plateia disposta nas galerias superiores e a outra parte distribuída no piso inferior da nave - todos os espectadores apreciando a encenação religiosa simulada no palco principal, apresentada pelo sacerdote no vazio profundo da capela-mor (Figura 279).

É exatamente o presbitério que vai romper o impulso centralizador do espaço interior, sugerindo um direcionamento longitudinal que já era insipiente na própria forma ovalada. Como foco principal do espetáculo, o suntuoso espaço retangular está todo ornado por uma profusa talha dourada, desde o arco do cruzeiro até o altar principal. Contudo, esta decoração efusiva não é privilégio do presbitério, mas também se encontra pontualmente na nave, nos seis altares laterais e nos dois púlpitos que, inusitadamente, estão fixados acima das duas pilastras centrais da elipse. Os outros elementos da modenatura arquitetônica as dez ordens de pilastras colossais, a cornija e o próprio forro - não deixam de oferecer este sentimento hipnótico, pois são tratados com o mesmo revestimento dourado irradiante (Figura 280). Por outro lado, a reduzida luz natural, que atinge a nave e a capela-mor indiretamente pelas tribunas, reforça o efeito dramático ao deixar o ambiente na penumbra, dificultando substancialmente a sua apreensão objetiva. Todos estes fatores contribuem para a percepção de um interior mais virtual do que material, onde é impossível separar plasticamente a estrutura arquitetônica dos trabalhos de talha e de pintura. 


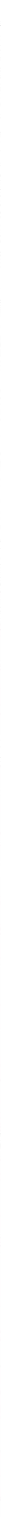

279. Nave elíptica cenográfica e interior dourado reluzente da Igreja Matriz de Nossa Senhora do Pilar, uma grande surpresa para quem percorre o bucólico percurso revelado acima. Fonte: Fotografia elaborada pelo autor (2008). 

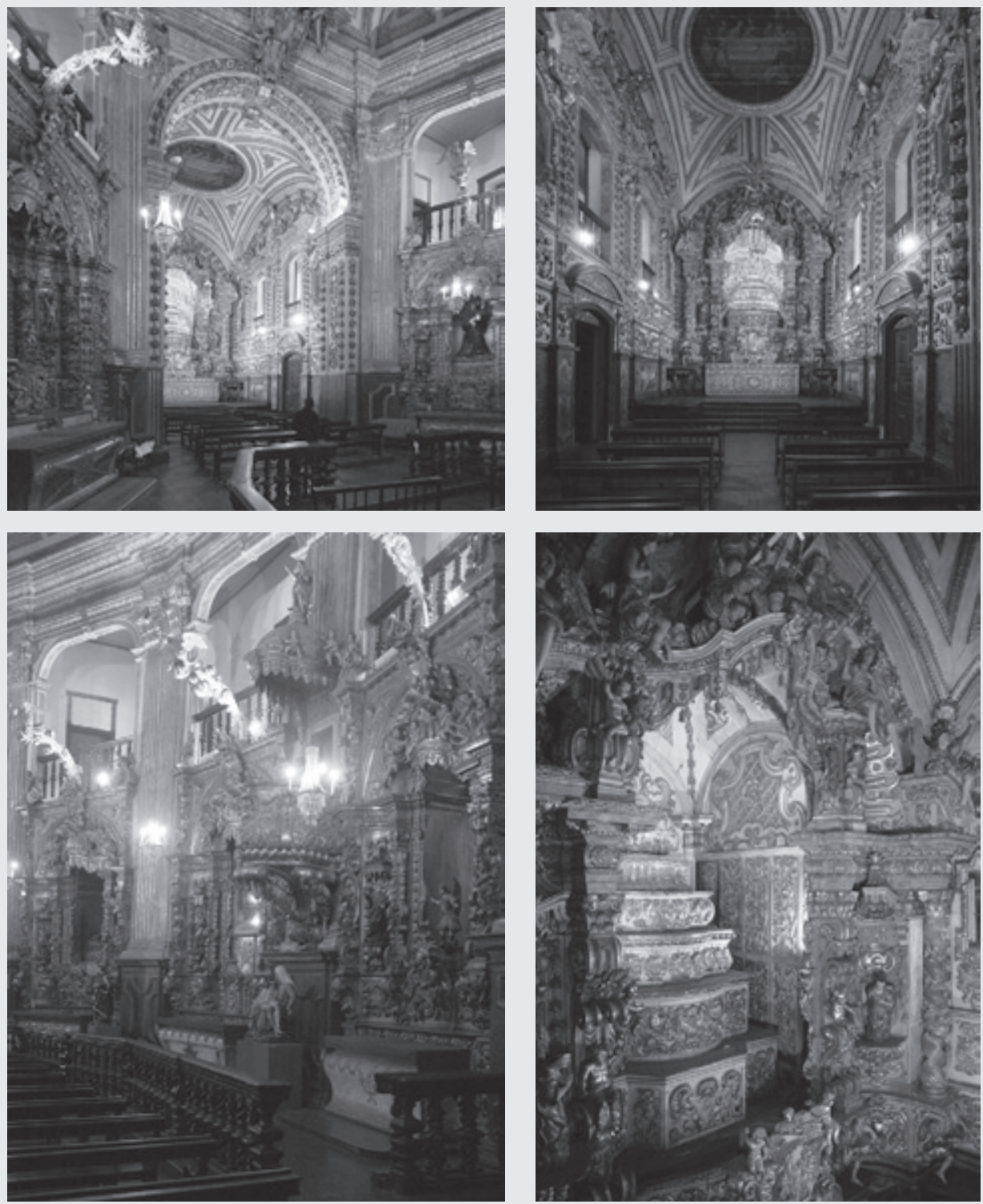

280. Panoramas do interior hipnótico da Igreja Matriz de Nossa Senhora do Pilar, de Ouro Preto. As imagens da esquerda foram retiradas da nave da igreja; as da direita, de sua capela-mor. Fonte: Fotografia elaborada pelo autor (2008). 
Este espetáculo que a Matriz do Pilar guarda em seu espaço interior não pode ser encarado a partir de uma leitura isolada do edifício, mas expõe um grande aparato dramático que anima o contexto exterior da igreja e, por extensão, a apreensão barroca de toda a cidade de Ouro Preto. Mesmo hoje, tendo diminuído o efeito surpresa de irromper na nave em função da ereção da afetada e desengonçada fachada oitocentista, ainda é chocante a descoberta inesperada do ambiente reluzente e misterioso da igreja. O contraste entre o invólucro despojado e o interior ilusório deflagra simbolicamente, como diria Argan (2004, p. I28-I29), a passagem do espaço real da cidade para o espaço imaginário sagrado das igrejas. Por isso, o suave percurso idílico cheio de eventos pitorescos que o transeunte assume após a travessia do Largo do Rosário pode ser encarado como uma preparação para a inesperada descoberta do interior dramático da Igreja Matriz de Nossa Senhora do Pilar. O trajeto, na sua sinuosidade flagrante, age como um crescente na formulação da expectativa de se deparar com a experiência cenográfica do espaço imaginário escondido pelo invólucro da matriz, reforçando ainda mais o seu caráter barroco em função da elevação do efeito surpresa. Rodrigo Bastos (2013, p. I7I), em seu livro, editado em 2013, A maravilhosa fábrica das virtudes: o decoro na arquitetura religiosa de Vila Rica, Minas Gerais (I7III822), acrescenta:

A Igreja do Pilar se destacava dentre as mais por suas circunstâncias, Matriz da cabeça das povoações da capitania, mas também, e em congruente proporção a isso, pela condição espetacular do theatrum sacrum de sua arquitetura [...]. A perfeição do templo atingiu efeitos de maravilha, conveniência, estilo e ornato os mais elevados, encerrando com eficácia as finalidades persuasivas da retórica arquitetônica dos Setecentos. A refulgência material do ornato ativava efeitos e afetos capazes de representar e dar a ver, amplificada pela pintura e douramentos preciosos, a própria luminosidade divina, ali participada como integração modelada pelo próprio sacramento da Eucaristia. Assim, o caráter adequado da pompa e do esplendor, a maravilha e o aparato da beleza representavam, proporcionalmente, a legitimidade absoluta do bem divino e da Igreja Católica, analogia essencial à política tridentina portuguesa de propaganda e expansões espirituais e territoriais da fé católica. 


\section{A Igreja da Ordem Terceira de Nossa Senhora do Carmo e a sua relação com a trama barroca de Ouro Preto}

A partir da Matriz de Nossa Senhora do Pilar inicia-se a experiência da descoberta de outro importante evento barroco: a Igreja da Ordem Terceira de Nossa Senhora do Carmo - construída a partir década de I76o. Deixando o interior teatral da sede paroquial, é necessário retomar a direção oposta ao "caminho velho", contornando o volume do templo, para depois galgar o Morro de Santa Quitéria. Por trás da matriz, um panorama de grande qualidade plástica se abre: desponta no cenário a imagem distante da Igreja do Carmo, sobreposta ao conjunto de edificações que marca a subida da Ladeira do Pilar.

$\mathrm{Na}$ realidade, o que se vê pouco antes de atingir a Ponte de Ouro Preto, que define o início da Rua do Pilar, é um interessante jogo de panoramas que relaciona o casario à igreja: apesar de ter sido aberta em uma encosta de alta pendência, a via se encontra ocupada em seus dois lados por casas e sobrados geminados, definindo uma calha fechada e muito sinuosa; esta sinuosidade produz, inicialmente, uma suave inflexão à esquerda, o que expõe as elevações do casario locado na face oposta da rua, até desaparecerem do campo de visão em função da curvatura da estrada; por outro lado, a Igreja do Carmo paira acima de toda a composição, oferecendo uma imagem enviesada em 45 graus, proporcionando um atraente panorama que revela o frontispício e parte de uma das fachadas laterais do edifício. O cenário gerado deflagra, consequentemente, um contraponto entre o direcionamento da ladeira que busca o templo e a imagem do edifício voltada ao sentido perpendicular à subida da rua, convidando o transeunte a desvendar o mistério que guarda o acesso enigmático à igreja. A expectativa de descobrir a basílica é aumentada pelo fato de ela desaparecer por completo do limite visual logo que o fruidor começa a subir a ladeira, após vencer a Ponte de Ouro Preto.

Bem mais acima, uma extenuante ladeira alcança, finalmente, a Igreja da Ordem Terceira do Carmo - via que se direciona linearmente ao adro e à elevação principal do templo, solução pouco comum em Ouro Preto. Porém, nunca é possível retirar, no percurso da ladeira, uma visão integral da frontaria do Carmo, pois, através do efeito perspectivo, a imagem do frontispício é sempre vista com a sua parte inferior interrompida, situação que não vai mudar até que o observador comece a galgar a grande escadaria do elevado terrapleno da igreja (Figura 28I). 
Esta imagem obstruída poderia parecer um pouco frustrante, principalmente em se tratando de uma das mais interessantes fachadas barrocas de toda Minas Gerais, obra do mestre Antônio Francisco Lisboa - o Aleijadinho (1738I8I4). Na verdade, esta circunstância faz parte de um mesmo jogo dramático que envolve a cidade de Ouro Preto, e que se traduz, muitas vezes, nas aparições sucessivas dos principais monumentos nas mais diversas cenas barrocas; a estas aparições segue-se a perda inevitável da sua referência visual e do seu sentido geográfico, criando um sentimento de tensão que vai durar até o ressurgimento imprevisto destes acontecimentos dramáticos pontuais. Ou seja, a visão obstruída convida o transeunte a subir o adro para buscar a imagem integral do pano cenográfico constituído pelo frontispício, porque ele só é revelado em toda a sua imponência e graça ao final da longa escadaria. Assim, o templo promove uma surpreendente trama persuasiva que atira imagens aprazíveis da igreja para fora do alcance do fruidor, convidando-o a buscar a sua mole no emaranhado confuso das vias do núcleo urbano; quando ela finalmente se torna acessível, exigirá a aproximação sistemática do transeunte para poder ser desvendada integralmente. Neste momento, o cenário que se revela é, sem dúvida, monumental, devido à dimensão considerável do frontispício e, principalmente, à distância de poucos metros com que a fachada interage com o transeunte.

A necessidade de se deslocar para apreender toda a dramaticidade do evento é também fatal em outro importante contato com o edifício - na experiência que se retira ao irromper na Praça Tiradentes por um dos ramais do "caminho novo”. Ao se voltar para o lado sul da praça, após a subida da imponente e marcial Rua Direita (mais um significativo trecho do "caminho novo"), é deflagrada a imagem grandiosa da estrutura da Casa de Câmara e Cadeia de Ouro Preto, com a sua torre central marcando o seu eixo dominante; porém, esta condição de destaque é imediatamente ameaçada pelo corpo adjacente da Irmandade do Carmo - que expõe sua parte posterior, obstruída pelo casario que direciona o olhar para o Paço Municipal. A posição desfavorável da igreja contribui, desta forma, para convidar o observador a se aproximar - a subir a pequena escadaria que atinge seu adro por trás e se dirigir à fachada principal para apreciar o eloquente frontispício (Figura 282).

No contato frente a frente com a frontaria é encerrada a intensa busca pelo acesso à igreja, sendo inaugurada sua apreciação in loco, que acaba gerando um impulso virtual direcionado ao eixo central do frontispício. Para suscitar 

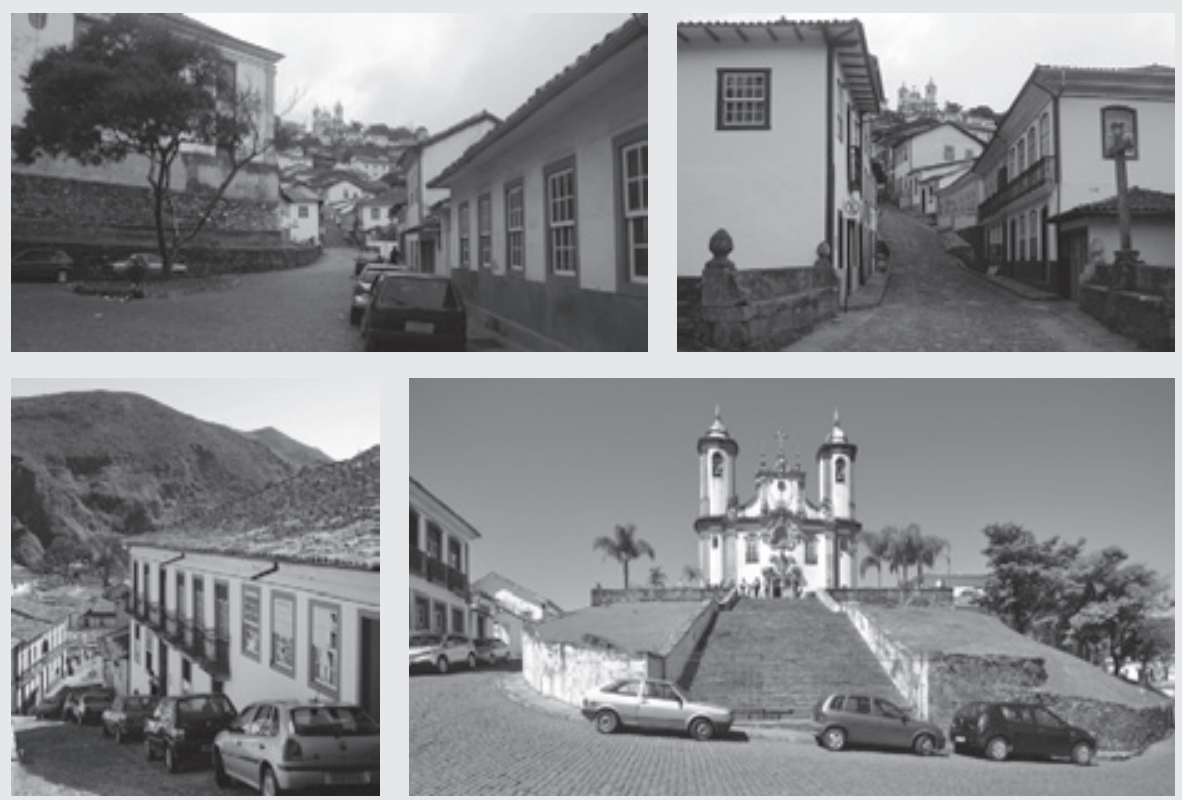

281. Sequência de imagens do percurso da "estrada tronco" buscando a Igreja da Ordem Terceira de Nossa Senhora do Carmo a partir do contorno da parte lateral e posterior da Matriz do Pilar. Por trás da matriz, a Igreja do Carmo se anuncia pairando no Morro de Santa Quitéria. O transeunte sobe a Ladeira do Pilar até alcançar a imagem da igreja interrompida pelo seu adro na Rua Coronel Alves. Fonte: Fotografias elaboradas pelo autor. As três primeiras são de 2008 e a última é de 2014.
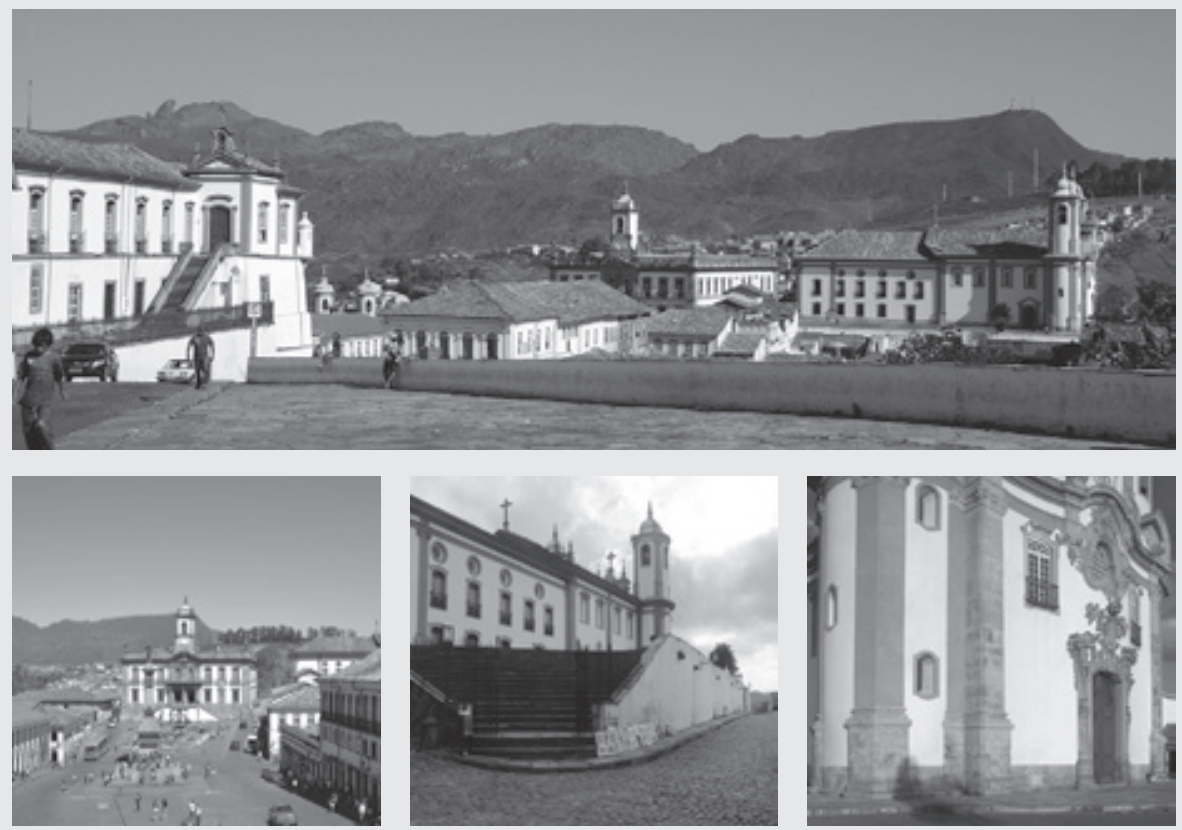

282. Buscando a Igreja do Carmo a partir da atual Praça Tiradentes (no Morro de Santa Quitéria). A primeira imagem destaca o atual acesso à praça, com o Palácio dos Governadores à esquerda, o Pico do Itacolomi acima, as torres distantes da Igreja de São Francisco de Assis (também à esquerda), a Casa de Câmara e Cadeia à frente e a fachada lateral da Igreja do Carmo à direita; a segunda imagem expõe a chegada à praça com destaque para a imagem interrompida da igreja, à direita, ao lado da Casa de Câmara e Cadeia; as duas últimas imagens revelam a chegada do transeunte ao adro da Igreja do Carmo - primeiro diante da fachada lateral e, depois, do frontispício da igreja. Fonte: Fotografias elaboradas pelo autor. A segunda imagem é de 2014, as outras são de 2008. 


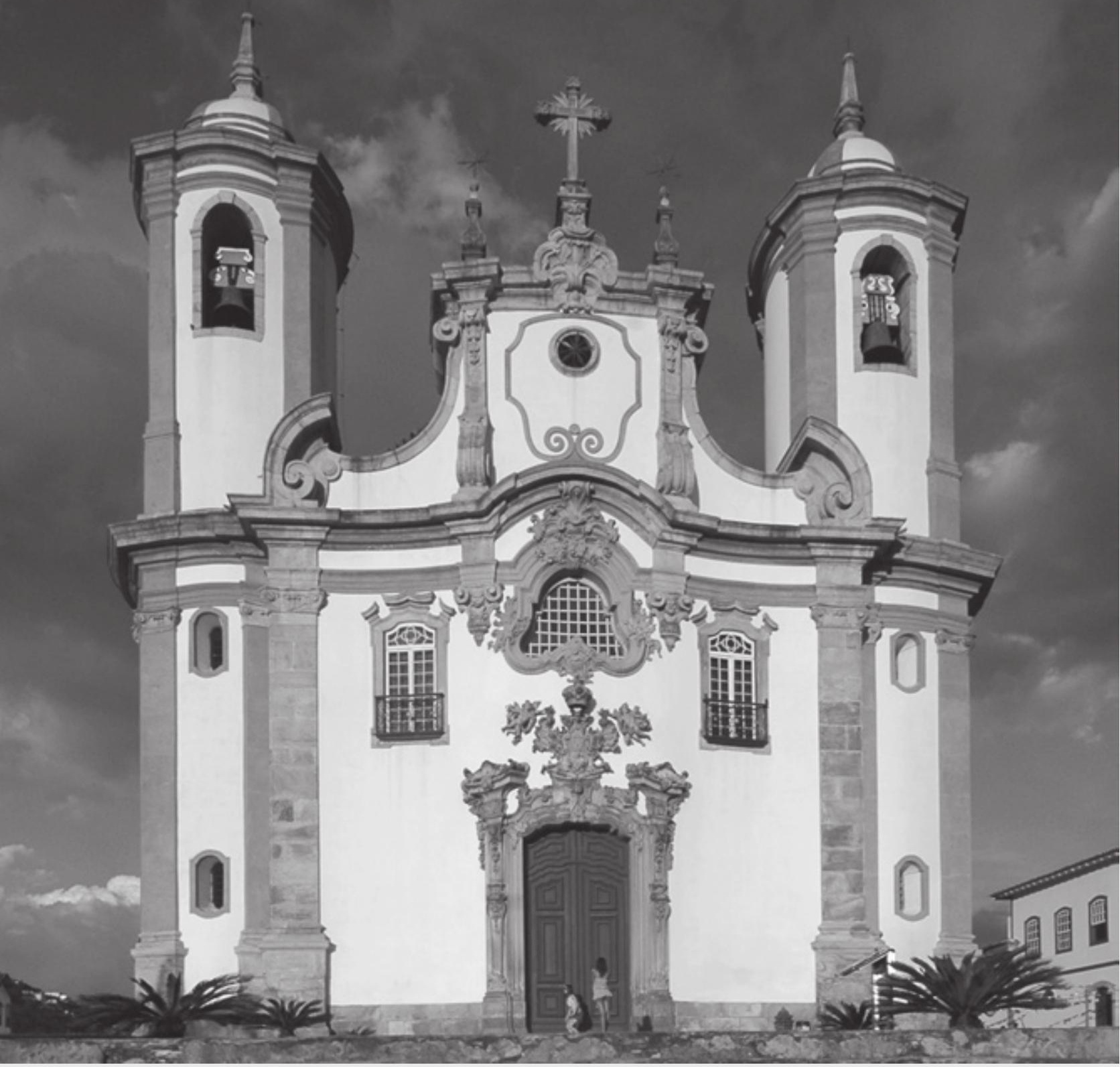

283. Fachada principal da Igreja da Ordem Terceira de Nossa Senhora do Carmo. Fonte: Fotografia elaborada pelo autor (2008). 
esta atração, que impele o transeunte a ganhar o espaço interior da nave, a lgreja do Carmo expressa sua retórica refinada apropriando-se de artifícios profundamente expressivos. As torres bojudas - que se colocam independentes em relação ao corpo da igreja, tangentes à parede exterior da nave - não são perfeitamente cilíndricas, como no Rosário, mas apresentam as quatro faces abauladas para melhor receber o enquadramento de pilastras sobrepostas. O frontispício, por sua vez, emoldurado pelas esguias torres, se projeta virtualmente para o espaço do adro, pois sua parte central é encurvada para frente, desenhando uma suave linha sinuosa que destaca o organismo composto pela portada e pelo óculo. E não é por acaso, pois este conjunto é o grande protagonista da visada imediata da frontaria, apresentando uma simbiose extremamente requintada e dramática entre a portada esculpida e o óculo: recusando a forma circular tradicional, o vão de iluminação do coro, aberto no eixo da fachada, ganha um desenho complexo em forma de "boca de peixe", além de romper a cornija que marca a linha inferior do frontão. Desta forma, o movimentado óculo incorpora a dinâmica incomparável das esculturas concebidas pelo Aleijadinho para as ombreiras e para a sobreverga da porta - todo o conjunto assumindo uma unidade fatal e uma prioridade hierárquica na imagem aproximada da frontaria (Figura 283).

\section{A Igreja da Ordem Terceira de São Francisco de Assis de Ouro Preto}

A Igreja de São Francisco de Assis - projetada pelo Aleijadinho e construída a partir da década de I76o - poderia ser considerada não só a obra-prima do Barroco em Ouro Preto, como também a síntese conclusiva de todo o período nas Minas Gerais, uma das realizações mais significativas do Barroco no cenário mundial. O edifício é um exemplo legítimo da última fase do Barroco no território minerador, fase em que os esforços de ruptura com a tradição construtiva portuguesa, manifestados desde as primeiras obras levantadas na região, atingem o ápice, o maior patamar de maturidade. Na verdade, o templo possui todos os elementos que a tipologia eclesiástica, proclamada em território colonial, apresenta. Porém, as formas vão sendo radicalmente desconstruídas, definindo uma nova linguagem plástica sem precedentes, de alto grau de dramaticidade. Apesar de apresentar uma volumetria extremamente atraente, a lgreja de São Francisco não assume a agitação expansiva deflagrada pela estrutura pujante e bombeada da 
sede da Irmandade do Rosário dos Pretos. Mesmo assim, segundo decretariam os Professores André Dangelo e Vanessa Brasileiro (2008, p. II8-II9), no livro lançado em 2008, O Aleijadinho arquiteto e outros ensaios:

Consideramos que o ponto de partida para a concepção desse polêmico projeto certamente foi a influência exercida sobre Antônio Francisco Lisboa pelos valores da planimetria da arquitetura barroca, utilizados anteriormente, com excelente resultado, na Igreja do Rosário, em Ouro Preto, de I753, e São Pedro dos Cléricos, em Mariana. Se voltarmos ao projeto de São Francisco de Ouro Preto, podemos verificar que a idéia das torres redondas e o bombeamento do frontispício são releituras de soluções que já tinham sido experimentadas naquele primeiro projeto do Doutor Antônio Pereira de Souza Calheiros. Dentro deste contexto, é preciso compreender a importância desses dois edifícios para a construção da segunda fase da obra arquitetônica do Aleijadinho, que aparece bastante influenciada pelos cânones do repertório do Barroco italiano, sob a influência dos modelos de Borromini e Pozzo.

O tratamento plástico derivado da interpenetração dos três grandes organismos que formam o "partido" do templo - a nave, a capela-mor e a sacristia -, juntamente com a presença marcante das duas torres cilíndricas e do frontispício proeminente, proporcionam, para o espaço urbano de Ouro Preto, um acontecimento de forte apelo cenográfico. Contudo, enquanto na Igreja dos Negros - que também possui os três volumes bem definidos - o caráter volumétrico é elástico, orgânico, exaltado, no edifício franciscano é elegante, solene, requintado.

Inicialmente, o jogo de massas é oferecido na diferente dimensão e no sistema de cobertura que cada volume adquire: o volume da nave é mais estreito, porém mais alto que a capela-mor, recebendo uma cobertura proeminente em quatro águas, com a cumeeira desenvolvida no sentido longitudinal do edifício; o invólucro posterior, que contém a sacristia e o consistório, é bem curto, mas atinge a mesma altura da nave, recebendo um telhado em quatro águas articulado no sentido oposto, transversal ao eixo principal da igreja - solução raríssima, talvez inédita em toda a arquitetura barroca no Brasil; finalmente, o organismo central apresenta uma cobertura baixa, em duas águas, que literalmente penetra nos volumes da nave e da sacristia, avançando pelos caimentos dos telhados de quatro águas que se voltam para este organismo plástico que acolhe a capela-mor - espaço que adquire a mesma largura da sacristia, possuindo corredores laterais 
de circulação e, acima destes, galerias abertas para o exterior, o que confere um ar de leveza ao volume, solução contrastante com os outros organismos plásticos, muito cerrados (Figura 284).

As qualidades formais do projeto de São Francisco podem ser notadas de maneira mais fácil para o leigo principalmente quando olhamos a igreja de perfil. Nesse plano, vê-se mais ainda o esforço que o arquiteto teve para dispor de maneira diferenciada as partes volumétricas do edifício de forma que elas tivessem identidade formal própria, mas também um sentido de unidade. Para a construção desse efeito, foi preciso, principalmente, tirar partido da utilização da inversão e diferenciação de leituras das linhas das cumeeiras, como também do estudo cuidadoso da inserção volumétrica entre os telhados. A complexidade dessa elaboração dos planos de telhado, preferindo o arquiteto trabalhar com mais beirais e tacaniças, utilizando a empena tradicional somente na frente do edifício e de maneira também inédita e complexa, torna essa solução de cobertura definitivamente mais um elemento que rompe com as tradições portuguesa e brasileira. [...] Neste sentido, temos, pela primeira vez dentro da tradição da cultura arquitetônica luso-brasileira, um edifício que aparece tratado por inteiro, arquitetonicamente falando, e não mais como uma edificação de volumetria tradicional, onde o frontispício era modernizado com aplicações escultóricas de ordem apenas ornamental. (DANGELO; BRASILEIRO, 2008, p. I25-I26)

Mesmo com esse apuro volumétrico, que envolveria todo o corpo da igreja, a elegante trama formada, é bem verdade, por superfícies planas - ao contrário da dinâmica incomparável da Igreja do Rosário dos Pretos -, se justifica como uma preparação mais sóbria para o evento prioritário da composição: a fachada principal. Não é fácil encontrar na história da arquitetura uma solução para a frontaria que absorva um caráter tridimensional tão intenso como no caso da Igreja de São Francisco de Assis de Ouro Preto - trama volumétrica expressa principalmente na relação dos campanários cilíndricos com o frontispício. De fato, várias são as igrejas em Minas Gerais que romperam com o esquema tradicional da arquitetura colonial, onde as torres estavam presas ao corpo da nave pelos corredores laterais que delas partiam. Quando são eliminados os corredores laterais, os campanários passam a assumir uma independência fatal em relação ao organismo da nave, podendo se modelar em formas complexas, como acontece 
na configuração cilíndrica típica da arquitetura mineira da segunda metade do século XVIIl: Igrejas do Rosário dos Pretos e Ordem Terceira do Carmo de Ouro Preto; Ordens Terceiras do Carmo e de São Francisco de Assis de São João del Rei; Ordem Terceira do Carmo de Mariana; Matriz de São João Batista de Barão de Cocais, entre outras menos conhecidas. Mas em nenhum outro templo as torres assumem uma posição de destaque comparável à de São Francisco de Assis na antiga Vila Rica.

Na realidade, os campanários do templo franciscano aparecem recuados em relação à fachada. Mas, ao contrário dos torreões da Igreja do Rosário dos Pretos e da irmandade rival de Nossa Senhora do Carmo, colocados tangentes às paredes exteriores da nave, em São Francisco as torres invadem abertamente o espaço interior; o ponto central da forma cilíndrica coincide com os eixos dos muros que fecham o edifício em suas faces laterais. Por outro lado, segmentos de paredes côncavas partem adjacentes às linhas que marcam, em elevação, o eixo central dos torreões cilíndricos, fazendo a união entre os volumes recuados dos campanários e o frontispício plano colocado mais à frente. Para receber as superfícies cavadas que partem das torres são engastadas, diagonalmente à fachada, duas elegantes colunas jônicas que, por sua vez, fazem o enquadramento dinâmico da parede do frontispício.

Todo este mecanismo compositivo é articulado para dar a impressão virtual de que as torres de São Francisco de Assis assumem, a partir da superfície plana da fachada, um movimento rotatório ao rolarem para a parte posterior da frontaria. Deste modo, é possível explicar as curvaturas côncavas e convexas celebradas pelas paredes que unem a elevação principal do templo aos volumes cilíndricos dos campanários, bem como a invasão do espaço interior do edifício por parte dos torreões. Confirmando ainda mais esta oscilação giratória, os campanários não estão emoldurados pela marcação da arquitetura, como acontece na Igreja de Nossa Senhora do Carmo de Ouro Preto; pelo contrário, as pilastras aparecem no eixo central das torres, jogando para a visão em escorço os vãos dos sinos, que olham diagonalmente para fora da igreja. É claro que este fato reforça o movimento giratório dos torreões, pois gera a impressão de que a sua imagem foi capturada em um instante desta rotação e que a agitação prosseguirá. Nada poderia ser mais barroco...

Além disso, o movimento rotatório que as torres recuadas apresentam contribui para promover uma participação urbana mais ativa para a Igreja de São 
Francisco de Assis. Este mecanismo projeta sistematicamente o frontispício para o espaço do adro, pois a proeminência da parte central da fachada vai ocultar, em parte, a imagem dos dois organismos verticais, ampliando a noção de que a frontaria avança à frente do corpo da igreja. Mesmo quando o transeunte busca o abarcamento visual incondicional das torres, se deslocando para um dos lados do edifício, é impossível a sua percepção conjunta: quanto mais um campanário se expõe plenamente e revela seu complexo movimento de contração e expansão, menos o observador consegue visualizar a outra torre, exigindo a sua movimentação para a apreensão da face oposta do edifício - sendo obrigado a contemplar, mais uma vez, a proeminente fachada principal (Figura 285).

Por outro lado, quando analisados nos desenhos projetivos da fachada principal, os campanários revelam uma dimensão exagerada, pesada e grosseira, ao serem confrontados com as proporções delicadas do frontispício. Porém, este peso exagerado dos torreões nunca é declarado ao transeunte, já que, nas imagens aproximadas retiradas da igreja, as torres recuadas se apresentam virtualmente menores por efeito perspectivo, harmonizando-se perfeitamente à elegância da fachada (Figuras 286-287).

Este fato confirma o conceito barroco da proeminência da imagem sobre o desenho, já que não interessaria a concepção objetiva do edifício, e sim a percepção das imagens que dele são emanadas. Ou seja, mais uma vez, é delatada a importância fatal do plano central da frontaria, que afirmará a sua notoriedade na complexa e dinâmica articulação, composição analisada pelo crítico de arte e jornalista, Lourival Gomes Machado (I9I7-I967), no ensaio Viagem a Ouro Preto, publicado na coletânea de i969, Barroco mineiro:

Estamos, pois, diante de uma porção do templo que já exige uma definição larga, pois se é uma projeção da frontaria, não é toda a frontaria, e, embora pareça constituir um desenvolvimento da entrada, sobrepassa notoriamente os limites de um simples pórtico. Limitam-na duas grandes colunas de pedra arenosa e rosada, que sobem para desenharem, por sobre os capitéis, sempre em pedra, duas asas poderosas que, prenunciando um grande frontão, no entanto, logo se interrompem. O verdadeiro frontão nasce, na verdade, do interior desses elementos e, esbatendo seu triângulo estrutural em curvas vagarosas, encaracola-se em volutas e coroa-se pelo poderoso supedâneo da cruz de Lorena ladeada por duas esferas flamejantes. A linha inferior do frontão, que coincidiria com a cornija vinda do teto da nave, atravessando as torres 


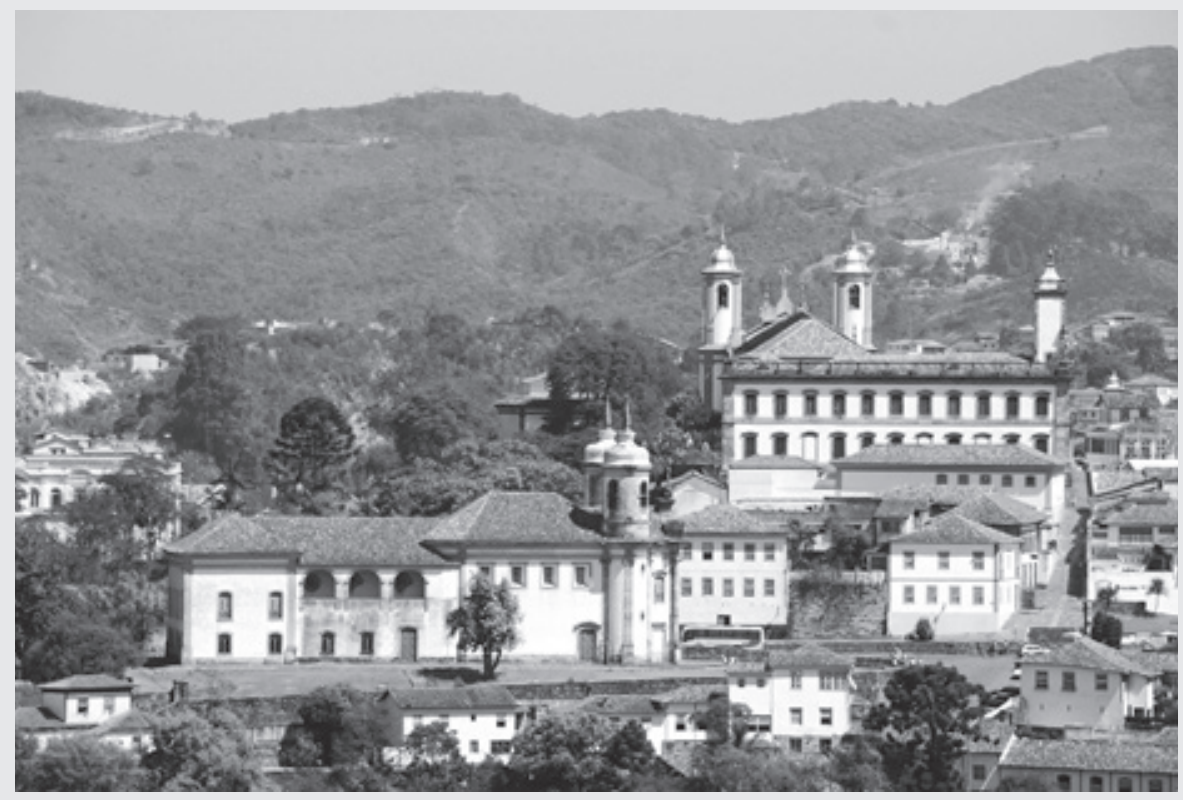

284. Fotografia em zoom feita do Alto da Cruz (Morro de Santa Efigênia), com destaque para a Igreja de São Francisco (à esquerda), para a Casa de Câmara e Cadeia e para as torres da Igreja do Carmo de Ouro Preto.

É possível apreciar a inusitada volumetria anunciada pelo jogo dos caimentos dos telhados que fecham a nave, a capela-mor e o consistório da Igreja de São Francisco de Assis. Fonte: Fotografia elaborada pelo autor (2008).

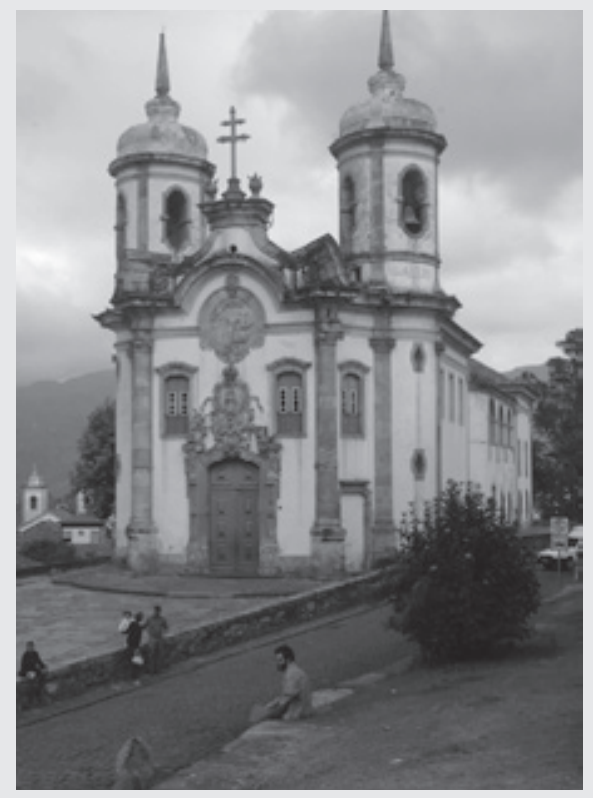

285. Adro e Igreja da Ordem Terceira de São Francisco de Assis, em Ouro Preto. Fonte: Fotografia elaborada pelo autor (2008). 


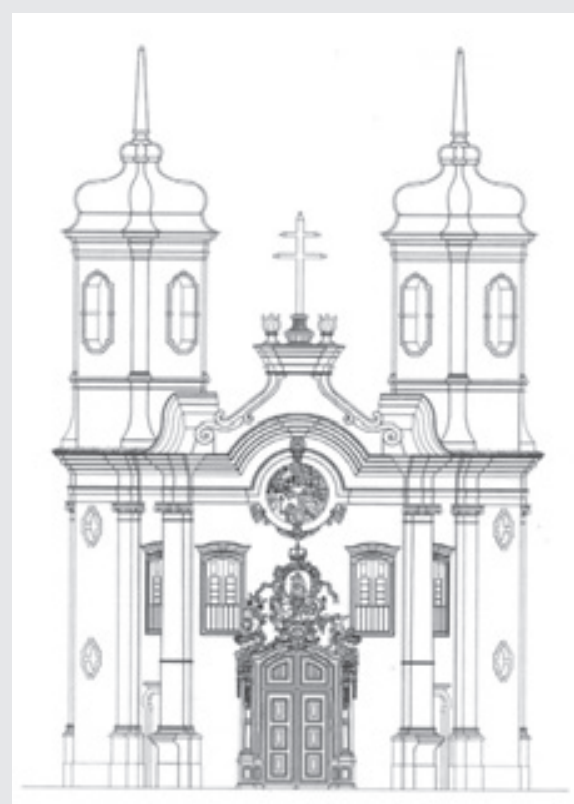

286. Desenho da elevação principal da Igreja de São Francisco de Assis, em Ouro Preto. Fonte: Dangelo e Brasileiro (2008, p. 329).

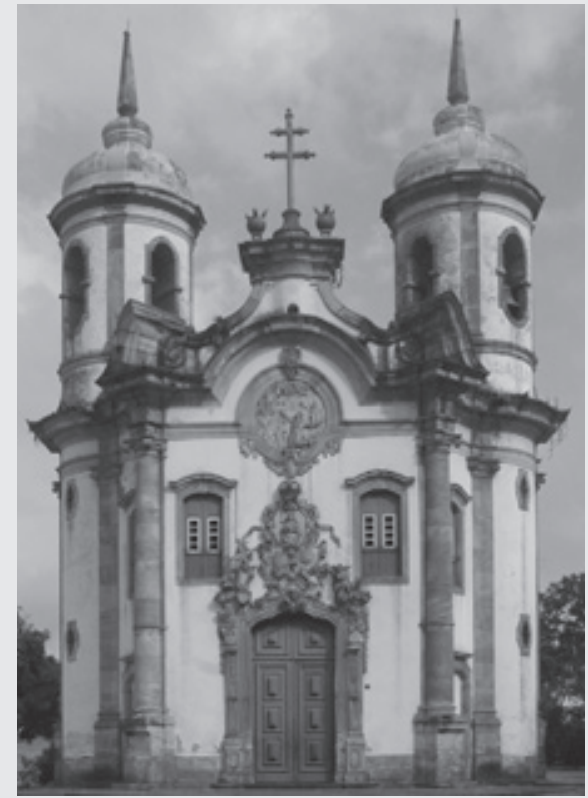

287. Frontispício da Igreja de São Francisco de Assis, em Ouro Preto. Comparar com a imagem anterior. Fonte: Fotografia elaborada pelo autor (2008).

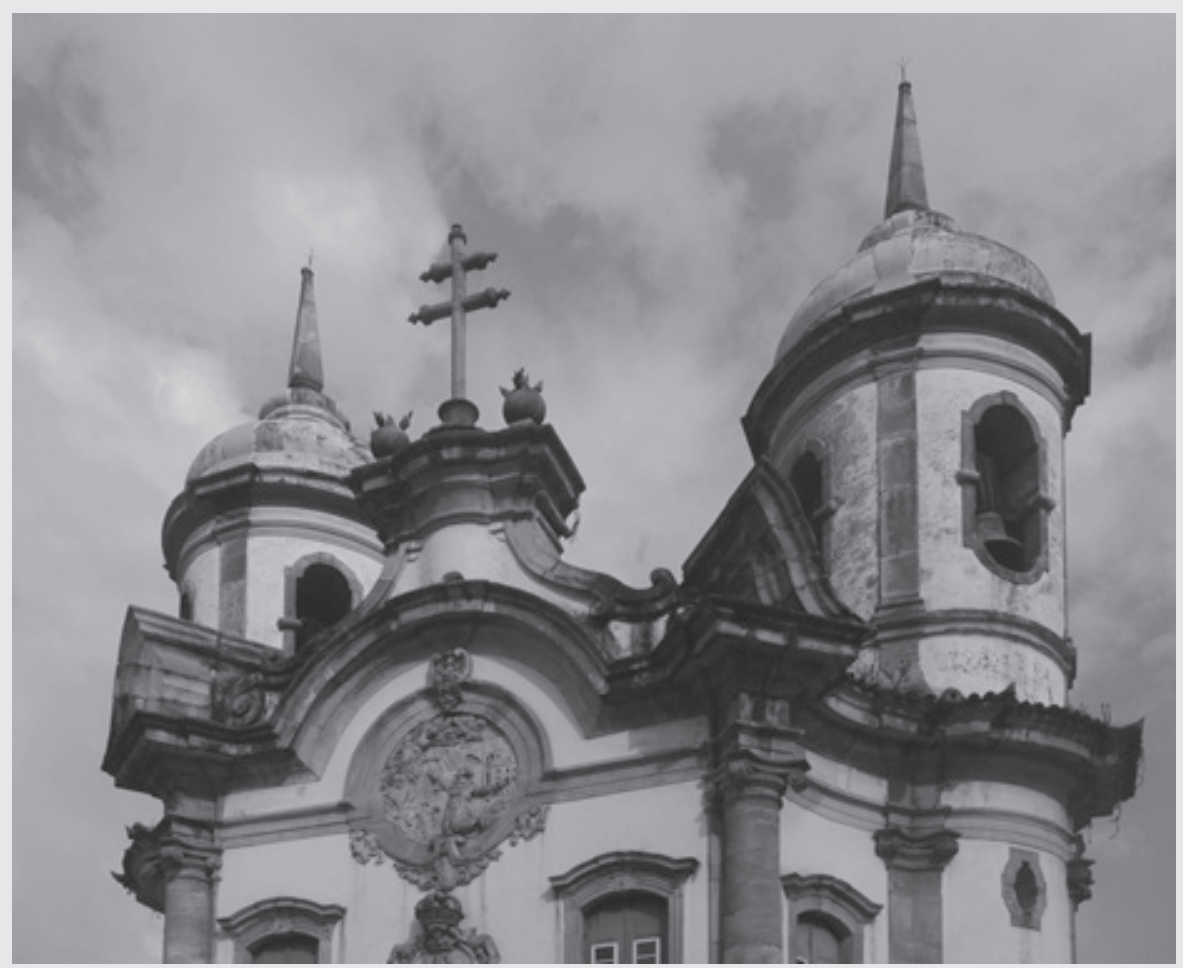

288. Torres e frontão da Igreja da Ordem Terceira de São Francisco de Assis, em Ouro Preto. Fonte: Fotografia elaborada pelo autor (2008). 


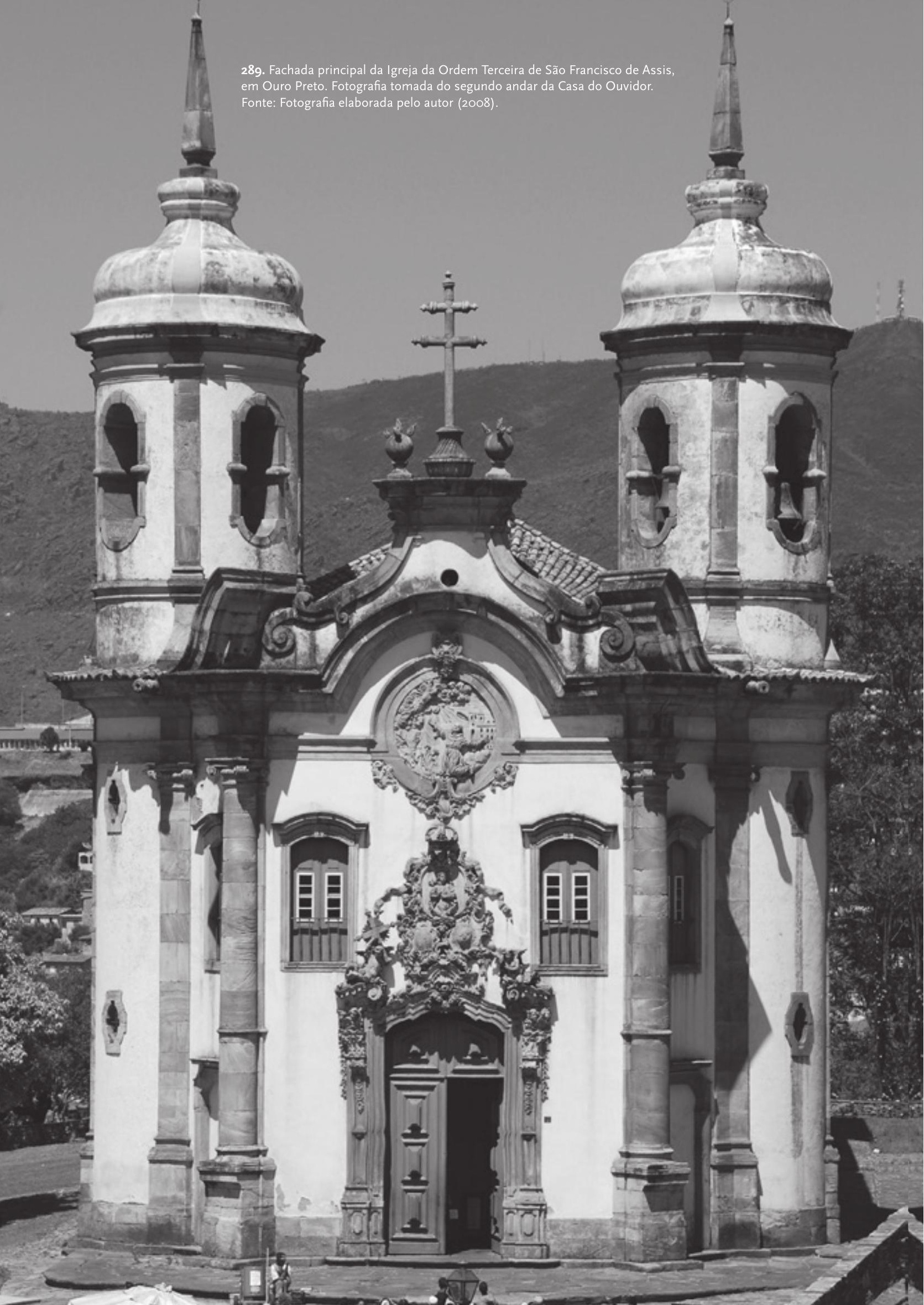


e alinhando-se pêlos capitéis das colunas fronteiras, suspende-se num semicírculo que acaba de desfazer a configuração habitual do acabamento em triângulo. O recurso é conhecido, sendo freqüente onde há olho-de-boi, um nicho ou um medalhão, mas aqui a sugestão duma linha livre é mais acentuada e mistura-se, portanto, à norma barroca. Também o aprisionamento do verdadeiro frontão dentro de dois prenúncios de um inexistente frontão maior é conhecido, mas agora adquire nova beleza por colocar-se o elemento figurado em uma linha de orientação diversa da do verdadeiro - um a 45, outro a 90 graus em relação ao eixo longitudinal, o primeiro no plano do lance intermediário e o segundo na linha da fachada. (MACHADO, I973, p. 2I3-2I4)

Além da disposição dos elementos propriamente arquitetônicos na articulação do frontispício, impressiona a maneira como os trabalhos de escultura invadem o espaço da portada, atingindo o medalhão em alto relevo que fecha o óculo. Consequentemente, a integração entre arquitetura e escultura é total no plano central da frontaria; além disso, as torres recuadas e a complexa volumetria do edifício não podem ser entendidas desassociadas da fachada principal, gerando um organismo coeso, onde o frontispício é hierarquicamente o elemento prioritário (Figuras 288-289).

Toda esta trama altamente expressiva e dramática é oferecida para o transeunte que cruza os caminhos que atingem a cidade de Ouro Preto ou que a circulam. Assim, para quem galga o Morro de Santa Quitéria, ao lado da Matriz de Nossa Senhora da Conceição, buscando a praça principal da cidade, ao aproximar-se do Chafariz de Antônio Dias, já percebe uma das torres cilíndricas de São Francisco de Assis brotando por cima da fonte. O impulso imediato é prosseguir o caminho que, a cada passo, revela um pouco mais do edifício, que lentamente expõe - em um panorama enviesado muito expressivo - a outra torre, o frontão e parte do frontispício.

Chegando ao chafariz, o transeunte pode dar prosseguimento ao percurso da antiga estrada, ou escolher, à direita, a subida íngreme que marca o "caminho novo".

O observador que escolhe prosseguir o andamento sinuoso do "caminho velho", cada vez mais vai absorvendo a imagem enviesada do templo que, pairando por sobre um conjunto de sobrados, aumenta gradativamente de dimensão. Não é possível apreciar nenhum dos organismos plásticos que formam a sua volumetria tradicional, escondidos pelo casario; em compensação, o proeminente 
jogo tridimensional da fachada, que atira virtualmente a frontaria para frente, é revelado em toda a sua expressividade. Chegando mais próximo da igreja, será o muro de arrimo em pedra aparente, que segura o aterro que acolhe o Adro de São Francisco de Assis, que interromperá perspectivamente a imagem da parte inferior do edifício. Portanto, na finalização da rua, o transeunte deverá rodear a contenção para, finalmente, mais acima, apreciar toda a beleza do edifício, ao ingressar em seu adro (Figura 290).

Por outro lado, assumindo a subida pelo "caminho novo", logo a igreja desaparece por completo no corredor solene de sobrados, sua imagem só sendo resgatada bem acima, na abertura, à esquerda, do Largo de São Francisco de Assis - ambiente que tem como limite norte uma das faces da Rua do Ouvidor (o trecho do "caminho novo" aberto na Freguesia de Nossa Senhora da Conceição de Antônio Dias). Ou seja, mais uma vez o encaminhamento cenográfico elimina o panorama do monumento para investir na sua reaparição súbita, surpreendente.

Mas, certamente, a experiência mais significativa da descoberta da igreja é assimilada na descida da Rua do Ouvidor, a partir do largo principal da cidade. Logo ao sair da Praça Tiradentes e assumir o trecho do "caminho novo" que se dirige à freguesia de Antônio Dias já é possível vislumbrar o panorama distante de outro monumento religioso: a lgreja de Santa Efigênia, elevada sobre o morro de mesmo nome, com a imagem da estrada sinuosa que busca o templo em destaque. Esta visada prenderá a atenção do espectador até a abertura repentina, à direita, do largo que acolhe a Igreja de São Francisco de Assis, expondo toda a estrutura do edifício em uma imagem relativamente distante - vista remota se comparada ao curto alcance visual característico da apreciação localizada dos monumentos de Ouro Preto. O inebriante panorama que se abre é emoldurado tragicamente pelo espigão da Serra do Itacolomi, que fecha o limite visual ao fundo da igreja. $\mathrm{Na}$ verdade, a imagem revelada, quando se irrompe no largo, é admirável, principalmente pelo contraste entre as proporções elegantes, a verticalidade, o frontispício projetado, a alvura do templo, e a irregularidade horizontal da serra verde que passa atrás, animada pelo Pico do Itacolomi - que provoca um contraponto vertical com os torreões poderosos de São Francisco (Figura 29I). 

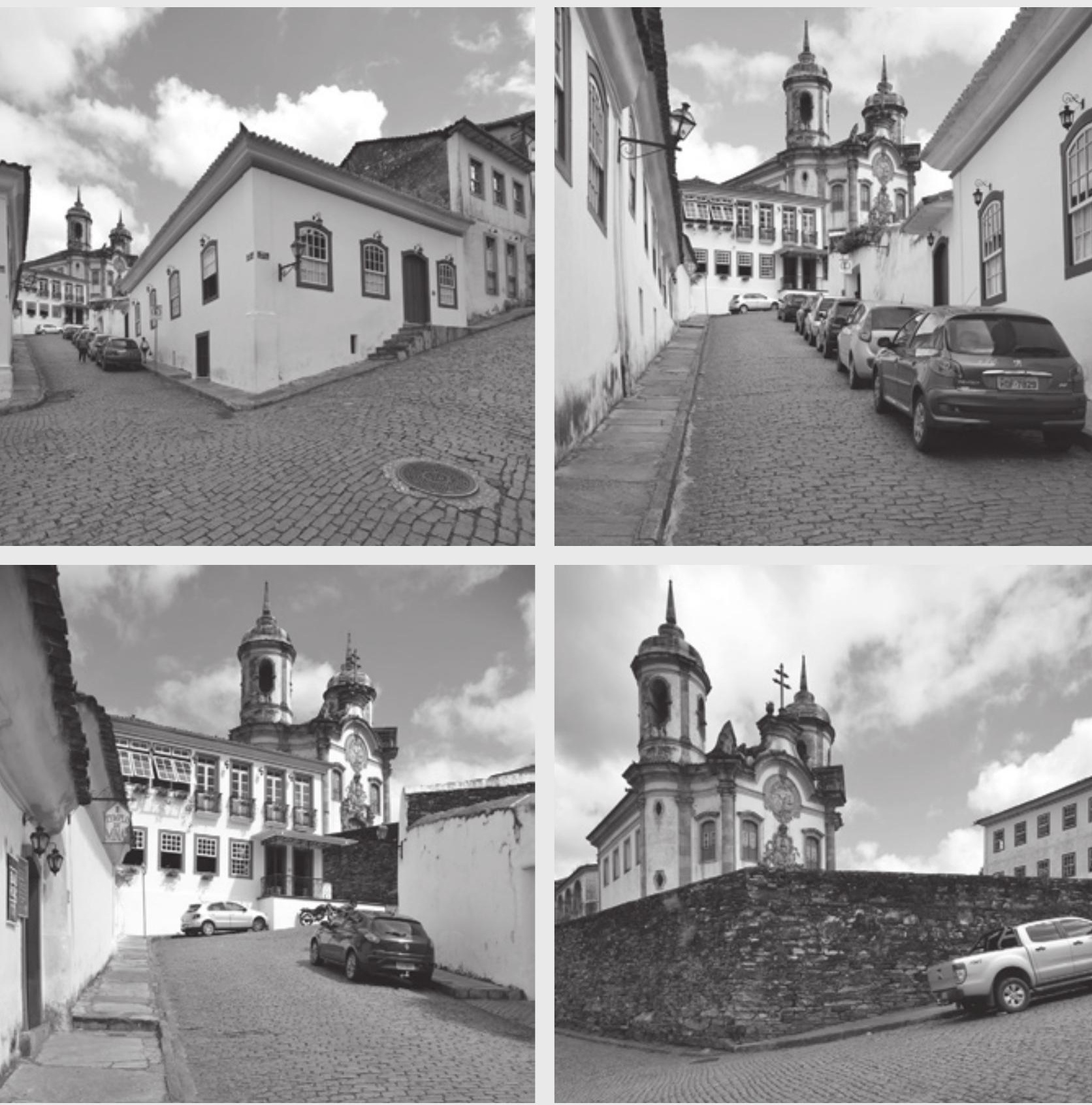

290. O percurso para a Igreja da Ordem Terceira de São Francisco de Assis, de Ouro Preto - trajeto no qual o templo é capturado em diversas vistas a partir do trajeto assumido para quem sobe o "caminho velho", vindo da Matriz de Nossa Senhora da Conceição de Antônio Dias. É possível perceber como o caráter tridimensional da fachada principal, com suas torres cilíndricas torcidas para trás da fachada, provoca a projeção do frontispício para o adro da igreja. Fonte: Fotografias elaboradas pelo autor (2017). 

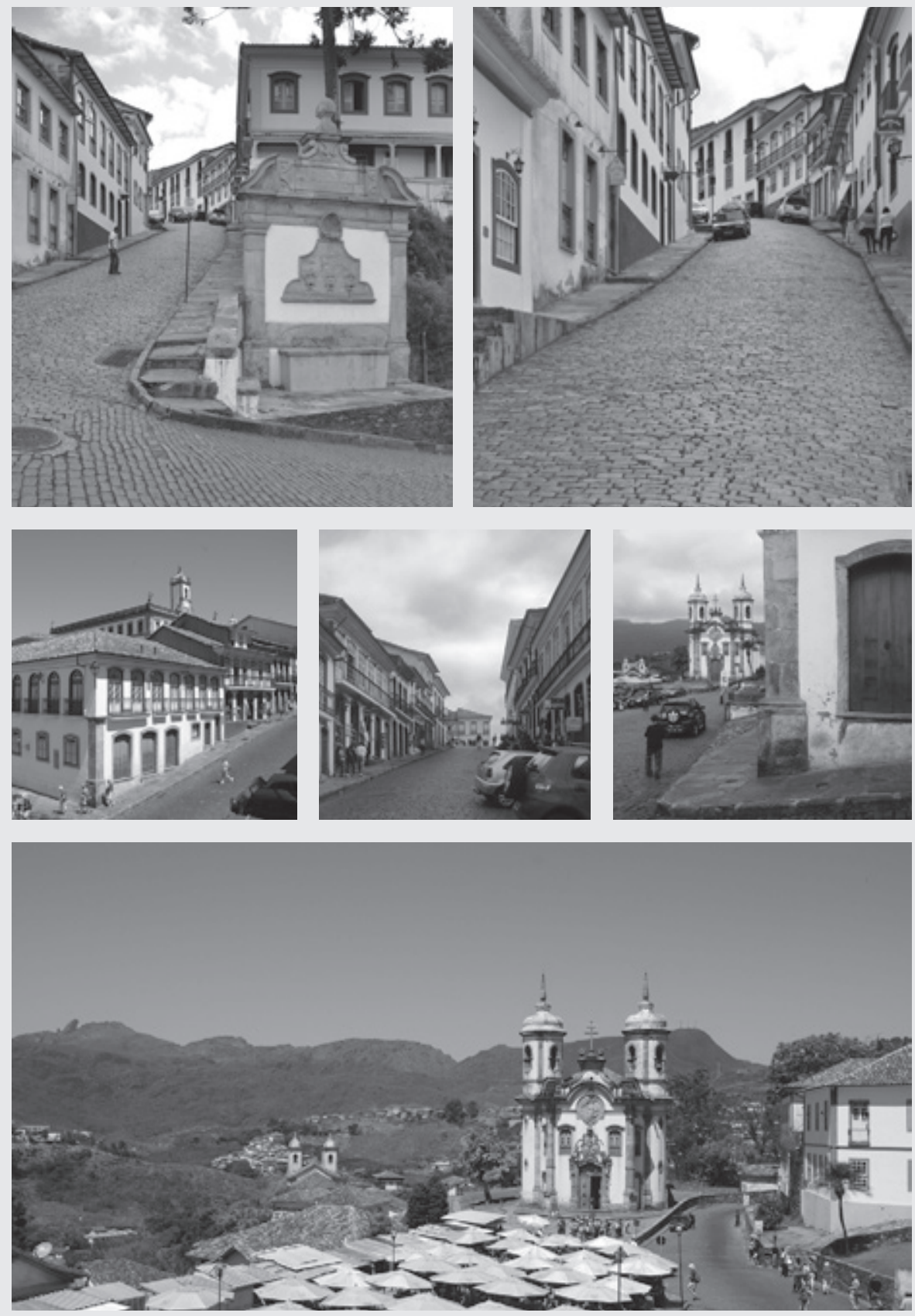

291. Percursos para a Igreja da Ordem Terceira de São Francisco de Assis, de Ouro Preto, retirados da Freguesia de Antônio Dias, subindo o "caminho novo" (Rua do Ouvidor), a partir de seu surgimento diante do Chafariz de Antônio Dias (duas primeiras imagens), ou descendo o mesmo caminho a partir da Praça Tiradentes (as duas imagens subsequentes). Os dois últimos panoramas marcam a chegada ao largo da igreja ao descer o "caminho novo". Fonte: Fotografias elaboradas pelo autor. As duas primeiras imagens são de 2017 e as outras são de 2008. 


\section{A Praça Tiradentes}

Paradoxalmente, a trama barroca da antiga Vila Rica apresenta um ambiente central e conclusivo não comandado, em termos cenográficos, por organismos religiosos: o largo conhecido, atualmente, como Praça Tiradentes. Ele aparece como um dos elementos prioritários na trama revelada: no ponto médio do aglomerado urbano configura-se como centro administrativo, social e político da cidade. Para a apreensão do cenário barroco da antiga Vila Rica interessa esta condição de centralidade expressa no âmago do núcleo citadino, situação derivada de fatores muito mais complexos do que o seu simples posicionamento geográfico - decididamente no ponto médio do linear aglomerado urbano.

$\mathrm{Na}$ verdade, até o presente momento, pareceria que só os edifícios religiosos absorveriam, individualmente, algum destaque na paisagem de Ouro Preto. Seriam pouquíssimas as construções civis e oficiais possuidoras de alguma evidência. A princípio, este número reduzido de edifícios nunca assumiria uma importância comparável às igrejas se considerarmos a sua relação paisagística com o ambiente citadino. Contudo, contrariando esta tendência, os focos de maior interesse da Praça Tiradentes são monumentos oficiais - o Palácio dos Governadores, a sede política da Capitania das Minas Gerais; a Casa de Câmara e Cadeia, centro administrativo e punitivo da vila -, monumentos que se aproximam das construções religiosas como eventos prioritários na trama dramática.

Para absorver todo este destaque, a posição que os edifícios adotam não poderia ser mais significativa: colocando-se frente a frente, na grande praça, ocupam integralmente os dois lados menores do estreito e alongado retângulo irregular que conforma o ambiente. Reforçando o alto teor persuasivo e dramático deflagrado na relação do vasto largo com o amplo volume dos edifícios, uma cuidadosa implantação os colocará mais ainda em evidência: topograficamente, a superfície do largo afunda em direção ao centro, na área onde cruza o "caminho novo" para ligar a Freguesia do Pilar com a de Antônio Dias; desta forma, as estruturas distantes do Palácio dos Governadores e da Casa de Câmara e Cadeia assumem uma posição proeminente, em cota mais elevada, revelando toda imponência dos dois edifícios. Concluindo o direcionamento visual promovido às duas faces memores da praça, os monumentos são absorvidos, mais uma vez, em contraste com o fundo verde das Serras do Itacolomi e de Ouro Preto, que servem de moldura ao cenário exposto. 
A praça é assim transformada em um grande aparato retórico e persuasivo de ostentação do poder oficial da coroa portuguesa; o sentimento de fausto e de esplendor emanado desenvolve um ar de sobriedade palaciana que singulariza este espaço em relação ao resto do núcleo urbano - voltado, inevitavelmente, a uma atmosfera mais espiritualizada -, anunciando a Praça Tiradentes como o centro legítimo da cidade. Mas o caráter de centralidade que se absorve no imponente platô estabelece outra propriedade, talvez mais importante, ao se definir como o elo de união entre os dois lados rivais de Ouro Preto.

Na verdade, no processo de formação da cidade, o Morro de Santa Quitéria vai adquirir, naturalmente, a condição de barreira de separação entre as freguesias que dividem o espaço urbano. Além disso, as duas paróquias vão afirmar espacialmente a sua autonomia na própria implantação das suas estruturas administrativas mais importantes: as matrizes. Isoladas em seus domínios, as igrejas apresentam-se voltadas para os acessos dos viajantes, no sentido oposto ao núcleo central da vila, de costas uma para a outra. É como se as sedes das freguesias não reconhecessem o ajuntamento proposto pela criação da Vila Rica em I7II, buscando sempre reforçar a independência inevitável - a rivalidade confessada. Por outro lado, esta independência historicamente declarada entre os lados do Pilar e de Antônio Dias será incentivada ainda mais pela condição geográfica do sítio natural, que não permite se obter de um bairro quase nenhuma imagem do outro.

Por isso, a Praça Tiradentes entra no processo geral de apreensão artística da cidade ao coligar coerentemente as suas duas metades: quando se marcha em direção à praça central, subindo os percursos solenes do "caminho novo", que, na verdade, fazem parte da mesma celebração do poder oficial imposta pelo Palácio dos Governadores e pelo Paço Municipal, ao tomar a descida para o outro lado da antiga vila - após o ingresso surpreendente no largo -, a segunda parte do mistério que oculta o sobe e desce de Ouro Preto começa finalmente a ser desvendada; mais uma etapa imprevisível do drama barroco oculto pela malha urbana pode ser aos poucos exposta.

Deste modo, a praça atua como ligação entre as duas freguesias geneticamente e geograficamente isoladas, promovendo, mais uma vez, a apreensão do espaço como elemento central da cidade: conclui metade da encenação dramática desenvolvida no núcleo urbano e, em grande triunfo, inaugura a fruição do último ato da peça representada na Ouro Preto barroca. O grandioso evento exibido no ambiente incomparavelmente amplo da praça não pertence nem à 


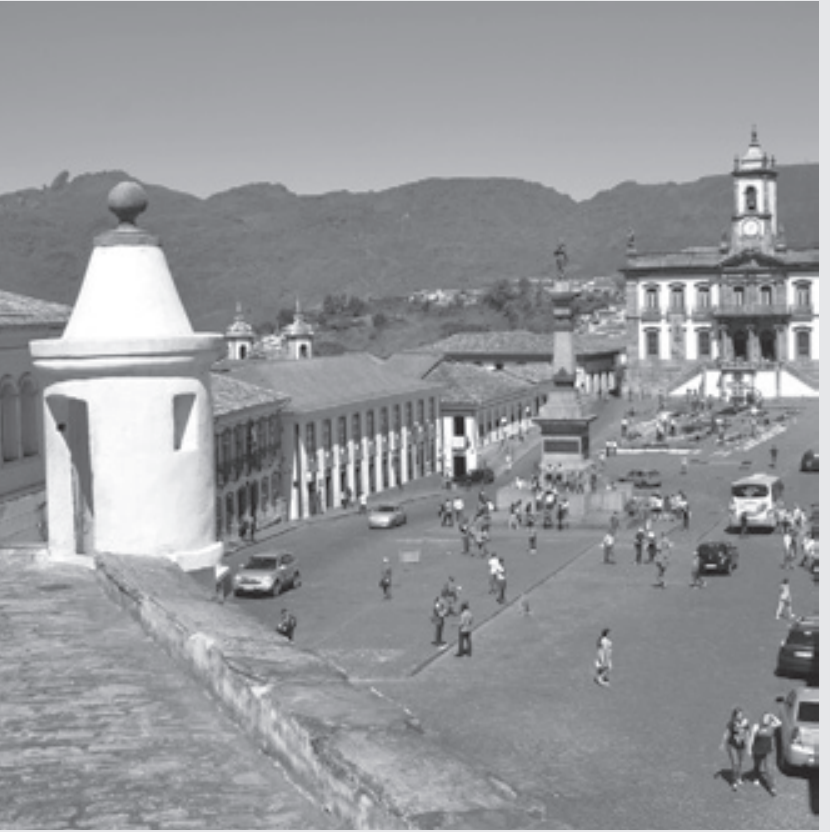

292. Panorama da Praça Tiradentes retirado do terraço do Palácio dos Governadores, com destaque para a Casa de Câmara e Cadeia e para o Pico do Itacolomi. Fonte: Fotografia elaborada pelo autor (2014).

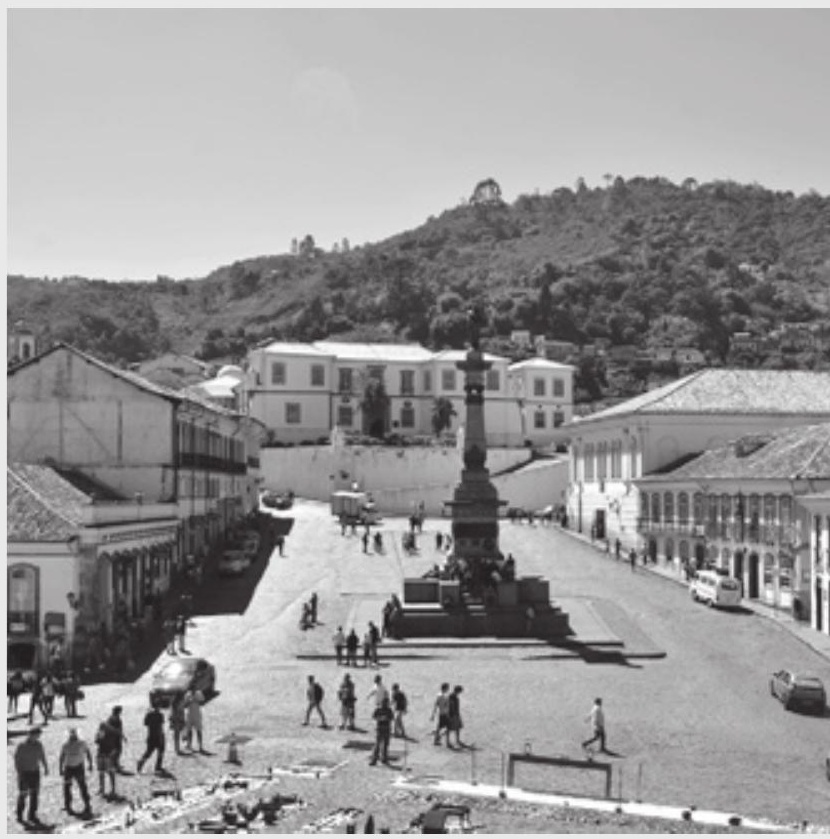

293. A atual Praça Tiradentes, com destaque para o Palácio dos Governadores. Fonte: Fotografia elaborada pelo autor (2014).

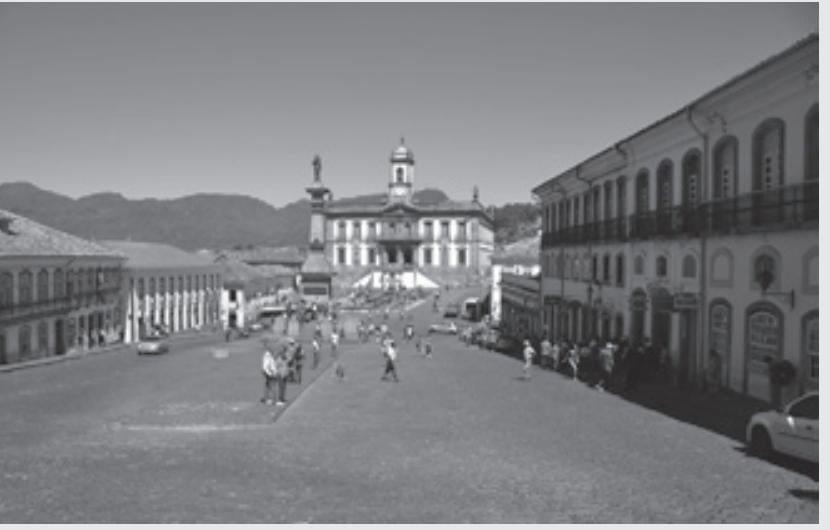

294. A atual Praça Tiradentes, com destaque para a Casa de Câmara e Cadeia (hoje, Museu da Inconfidência). Fonte: Fotografia elaborada pelo autor (2014).

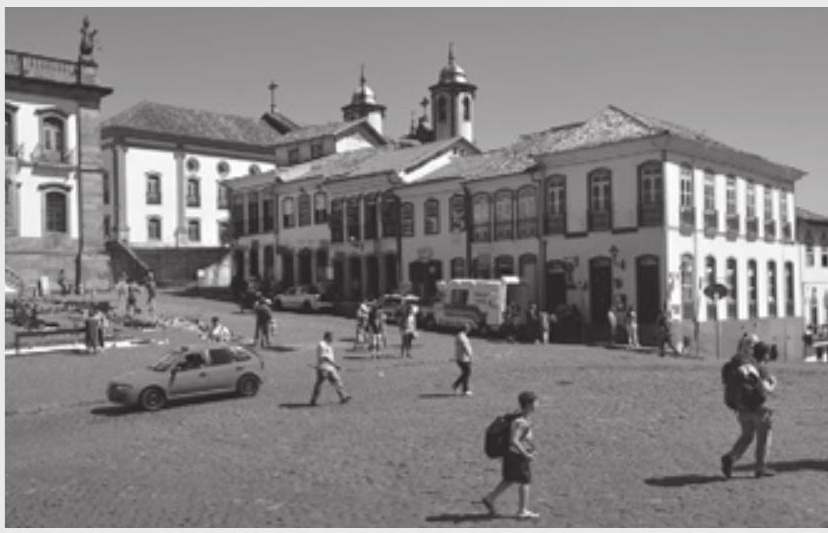

295. Detalhe do casario da atual Praça Tiradentes. Fonte: Fotografia elaborada pelo autor (2014). 
Freguesia de Antônio Dias nem à do Pilar, mas atua como o intervalo imponente e extenuante que une irremediavelmente os dois capítulos, as duas metades da capital barroca (Figuras 292-295).

\title{
A Ouro Preto barroca
}

\begin{abstract}
Uma vez que não se trata mais de realizar formas que possuam um valor absoluto e eterno, mas de agir sobre o ânimo das pessoas, se admite que são vários os modos de se exprimir e de persuadir: delineiam-se por isso diversas tendências que, não correspondendo mais a diversos esquemas de interpretação da realidade, mas somente a diversas atitudes e modos de ser e comunicar, podem facilmente combinar-se e entrelaçar-se. (ARGAN, I994, v. 3, p. 223, tradução nossa)
\end{abstract}

As palavras de Argan servem para reforçar a hipótese que atesta que a experiência artística que se retira da paisagem urbana de Ouro Preto, especialmente em sua interface com os organismos religiosos fundados no período colonial, é plenamente barroca. No núcleo citadino são despejadas uma série de imagens derivadas de eventos dramáticos sucessivos, que na sua amarração através da memória de tudo o que se apreendeu, proporcionam um único acontecimento cenográfico: a grande encenação teatral da antiga Vila Rica, vivida em cada traço íntimo do núcleo citadino. O esforço profundo de comunicação e a convincente retórica proposta pelas imagens oferecidas ao transeunte despertam a sua imaginação e apoiam a apreciação de um cenário que não é desvelado objetivamente, mas que preenche a mente com experiências fantásticas. E esta sensação de maravilha (ARGAN, 2004) não está subordinada à suposta intenção que antecipa os eventos, ao esquema de formulação das cenas na maioria das vezes oriundas de acontecimentos rigorosamente espontâneos; mas fundamenta-se na pura percepção visibilística da encenação dramática.

Assim, a duração da peça teatral, o desenvolvimento de seu enredo, estão inevitavelmente ligados ao espectador; a trama se desenrola a partir da maneira como o passante se apropria do ambiente citadino: o acesso que irrompe na cidade, os percursos que escolhe, as visadas que aprecia na sua jornada. Assim, é eliminada a possibilidade de se buscar o seu caráter barroco através dos efeitos da fuga perspectiva, tendência muito comum na crítica atual à configuração urbana 
colonial. Na verdade, o direcionamento perspéctico tradicional, derivado das leis formuladas no Renascimento, é uma solução que pode até existir em um determinado contexto, mas nada mais é do que uma entre tantas outras possibilidades de articulação cenográfica de que o cenário barroco se apropria para conseguir a necessária riqueza de acontecimentos que vão ativar a imaginação do transeunte.

Por outro lado, quando se procura buscar uma coerência entre o caráter artístico da cidade e o seu desenvolvimento urbano, os problemas não deixam de aparecer. Em relação à Praça Tiradentes, por exemplo, a sua própria gênese desautoriza este processo, ao servir como afirmação da diferença entre o esquema lusitano de crescimento urbano e aquele típico da região mineradora. A cidade portuguesa e muitos assentamentos brasileiros do litoral se formam a partir de um crescimento centrífugo: de um pequeno núcleo central mais antigo, a cidade se expande por anéis concêntricos; assim, quanto mais distante do centro, mais recente é a ocupação. Em Ouro Preto acontece exatamente o contrário: em seu desenvolvimento, o Morro de Santa Quitéria, que se configura geograficamente como o centro da povoação, é o último dos grandes espaços da antiga Vila Rica a ser ocupado e a adquirir a atual feição monumental que ostenta. Por isso, Ouro Preto passa por um desenvolvimento mais próximo ao crescimento centrípeto, da periferia para o núcleo da vila. Mesmo assim, a Praça Tiradentes não deixa de ser o ponto médio legítimo da antiga capital das Minas, referência fundamental para a condição da cidade barroca.

Logo, é bom frisar: não existem soluções plásticas predefinidas, e sim o arranjo de imagens que se inter-relacionam sequencialmente para criar um universo comunicativo muito superior à esfera objetiva que se afirma usualmente para a organização do espaço urbano do período barroco: no caso de Ouro Preto, um organismo que suscita um intenso apelo persuasivo, convite a um confronto fatal - mas extremamente atraente - entre as igrejas, as montanhas, as construções oficiais e a massa construída; entre as duas freguesias rivais; entre o poder laico e o poder religioso; entre a natureza selvagem e o mundo civilizado. 


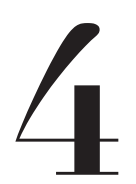

\title{
ARQUITETURA E CIDADE NA AMÉRICA HISPÂNICA: A CONFIGURAÇÃO DO CENÁRIO BARROCO DA CUSCO COLONIAL
}

\author{
Dentro desse fluxo de saber, graças a ele, surgirão essas cidades \\ ideais da grande expansão americana. Serão governadas por uma \\ razão ordenadora que é revelada em uma ordem social hierárquica \\ transposta a uma ordem distributiva geométrica. Não é a sociedade, \\ mas sua forma organizada que é transposta; e não a cidade, mas sua \\ forma distributiva. [...] Não vincula, pois, sociedade e cidade, e sim \\ suas respectivas formas, que são percebidas como equivalentes, \\ permitindo que leiamos a sociedade ao ler o plano de uma cidade. Para \\ que esta conversão fosse possível, era indispensável que se transitasse \\ através de um projeto racional prévio, que foi o que ampliou e, à sua \\ vez, tornou indispensável a ordem dos signos, reclamando-se a maior \\ liberdade operacional de que se fosse capaz. (RAMA, 2002, p. 4, \\ tradução nossa)
}


Quando se analisa a conformação dos núcleos urbanos fundados pelos espanhóis nas Îndias Ocidentais durante o período colonial fica latente o impressionante processo de desenvolvimento de uma tipologia regular de cidade: uma tendência de ordenação referente ao plano gerador dos assentamentos humanos criados e algumas vezes sobrepostos a antigos aglomerados pré-colombianos - que teria sido repetida inúmeras vezes, nas mais diversas regiões do vastíssimo território sob o domínio da metrópole peninsular. Este processo seria fruto de um projeto de urbanização territorial aparentemente inédito, especialmente ao se considerar a monumental extensão das terras ocupadas e conquistadas nas Américas por súditos da coroa espanhola, bem como o inigualável número de organismos urbanos levantados em um período tão curto de tempo: só no século XVI, mais de 200 cidades teriam sido fundadas no Caribe, na Mesoamérica, na América Central e nas áreas não lusitanas da parte meridional do grande continente (especialmente em torno da Cordilheira dos Andes e nas imediações do Rio da Prata). Segundo atestariam os arquitetos e críticos espanhóis, Fernando Chueca Goitia (I9II-2004) e Leopoldo Torres Balbás (I888-I960), juízo proferido na introdução da publicação de 195I, Planos de ciudades Iberoamericanas y Filipinas, não houve na história da humanidade uma ação tão extensa e rápida de urbanização comandada por uma única nação, por um único governo:

A obra de criação urbana, realizada entre os séculos XVI e XIX, foi enorme. Nenhum outro povo levou a cabo, neste aspecto, nada que sequer de longe possa ser comparado a esta iniciativa. No continente recém descoberto pouquíssimas vezes foi aproveitada alguma cidade pré-colombiana; a imensa maioria dos núcleos urbanos foram de nova fundação. No transcurso da história os povos conquistadores sempre se instalaram nas cidades que tomavam. Na América hispânica tiveram que partir do zero e criar totalmente, sobre terras, na maioria das vezes, sem cultivo, cidades que surgiram como por arte da magia em lugares despovoados. O crescimento de muitas foi rapidíssimo, sublinhando o acerto de sua implantação. (CHUECA GOITIA; TORRES BALBÁS, I98I, p. VII, tradução nossa)

Para isso, segundo afirmaria o Professor Alberto Nicolini (2005, p. 29) - no artigo publicado em 2005, La ciudad hispanoamericana, medieval, renacentista y americana -, desde Santo Domingo (a primeira cidade fundada nas Américas 
pelos espanhóis), ${ }^{\text {100 }}$ o delineamento regular dos núcleos urbanos aspiraria, gradativamente, a um esquema cada vez mais rigoroso, culminando na realização de um modelo que apresentaria uma organização absolutamente cartesiana: a cidade projetada de forma quadrangular, com quarteirões e plaza mayor quadrados, assim como lotes urbanos também quadrangulares - fruto da divisão das quadras em quatro solares de idênticas dimensões (Figuras 296-308).

Não obstante, um lento e gradativo processo de ocupação e desenvolvimento viria a ocorrer nas cidades coloniais hispano-americanas após a sua fundação, em todo território. Em alguns assentamentos, estrategicamente implantados, o espaço urbano se consolidaria de maneira um pouco mais célere; e em outros, menos significativos e prósperos, de forma muito vagarosa. $\mathrm{O}$ ato de criação, bem como o delineamento prévio dos núcleos urbanos do Novo Mundo, particularmente aqueles projetados através de um design que tenderia à regularidade - aqueles concebidos por meio de uma traza que fosse efetivamente ordenadora -, seria o primeiro instante que marcaria o intricado processo de constituição da estrutura e da paisagem das cidades.

Indubitavelmente, o desenho elaborado com antecedência à implantação do organismo urbano propriamente dito viria a ser uma ocasião de enorme gravidade para a definição do cenário que se estabeleceria na vivência do ambiente citadino - já que, como diria o arquiteto e crítico italiano Aldo Rossi (I93I-I997), em seu clássico livro de I966, L'architettura della città, o plano não seria apenas um dos mais eficientes organismos estruturadores da cidade, mas, especialmente, um dos elementos que apresentariam maior disposição em permanecer inalterado no futuro desenvolvimento do ambiente urbano:

As persistências são detectáveis através dos monumentos, os sinais físicos do passado, mas também através da persistência dos traçados e do plano. Este último ponto é a descoberta mais importante de Poëte: as cidades permanecem sobre seus eixos de desenvolvimento, mantêm a posição dos seus traçados, crescem segundo a direção e com o significado de fatos mais antigos, muitas vezes remotos, do que os fatos atuais. Às vezes, esses fatos permanecem idênticos, são dotados de uma vitalidade contínua, às vezes se extinguem; resta, então a permanência

100 Fundada em 1496 e transladada para o sítio atual em 1502, mais do que a primeira cidade levantada pelos conquistadores no Novo Mundo, Santo Domingo é o primeiro assentamento europeu no continente recém-descoberto. 
da forma, dos sinais físicos, do locus. A permanência mais significante é dada, pois, pelas ruas e pelo plano; o plano permanece sob níveis diversos, diferencia-se nas atribuições, muitas vezes se deforma, mas, substancialmente, não se desloca. (ROSSI, 2006, p. 56, tradução nossa)

Transferindo para o caso americano o juízo proferido por Rossi a respeito da teoria das persistências, elaborada pelo urbanista francês Marcel Poëte (I866I950), e considerando que as mais importantes urbes além-mar já teriam sido fundadas e delineadas no decorrer do século XVI, seria possível supor que a tra$z a$ das cidades coloniais sofreria pouca, ou nenhuma transformação, no período que coincidiria com a eclosão do espírito barroco. Por outro lado, mesmo os novos assentamentos criados nas próximas centúrias, assim como aqueles núcleos urbanos que, nos seiscentos e nos setecentos, por diversos motivos - invasões, enchentes, terremotos -, sofreriam traslados e seriam refundados, quase sempre apresentariam uma estrutura urbanística e um design derivados da prática consolidada no primeiro grande século de colonização. Mais do que isso, estas cidades seriam projetadas seguindo, categoricamente, os procedimentos consagrados no século XVI, não oferecendo, praticamente, nenhuma inovação enquanto experiência urbanística. Ou seja, em relação ao modelo regular dos núcleos hispano-americanos - referente à tradição da urbanística ordenadora praticada nas Índias Ocidentais, herdeira de diversas experiências teóricas e práticas ligadas ao mundo clássico, à Idade Média e à cultura do Renascimento -, todos os mais significativos parâmetros de assentamento urbano já estariam definidos antes da irrupção da estética barroca. Logo, causaria estranheza a tese de alguns críticos da urbanização colonial que defenderiam a filiação do desenho das cidades ao que poderia ser compreendido como urbanística barroca. ${ }^{\text {Ior }}$

$\mathrm{Na}$ verdade, estes pesquisadores vislumbrariam uma suposta condição barroca impressa na tradição do planejamento de núcleos urbanos em forma de grelha, juízo que estaria vinculado tanto ao fato das urbes acolherem uma concepção projetual dada a priori como em função de sua regularidade se relacionar com a estética promovida pela arte do século XVII. Por conseguinte, segundo as

101 Sobre o rebatimento do sentido de ordem perseguido na América hispânica no desenho das cidades, diria o escritor uruguaio Angel Rama (1926-1983), em seu último livro datado de 1984, La ciudad letrada: "O resultado na América Latina foi o desenho em tabuleiro de damas, que reproduziu (com ou sem plano à vista) as cidades barrocas e que se prolongou até praticamente nossos dias." (RAMA, 1998, p. 20, tradução nossa) 


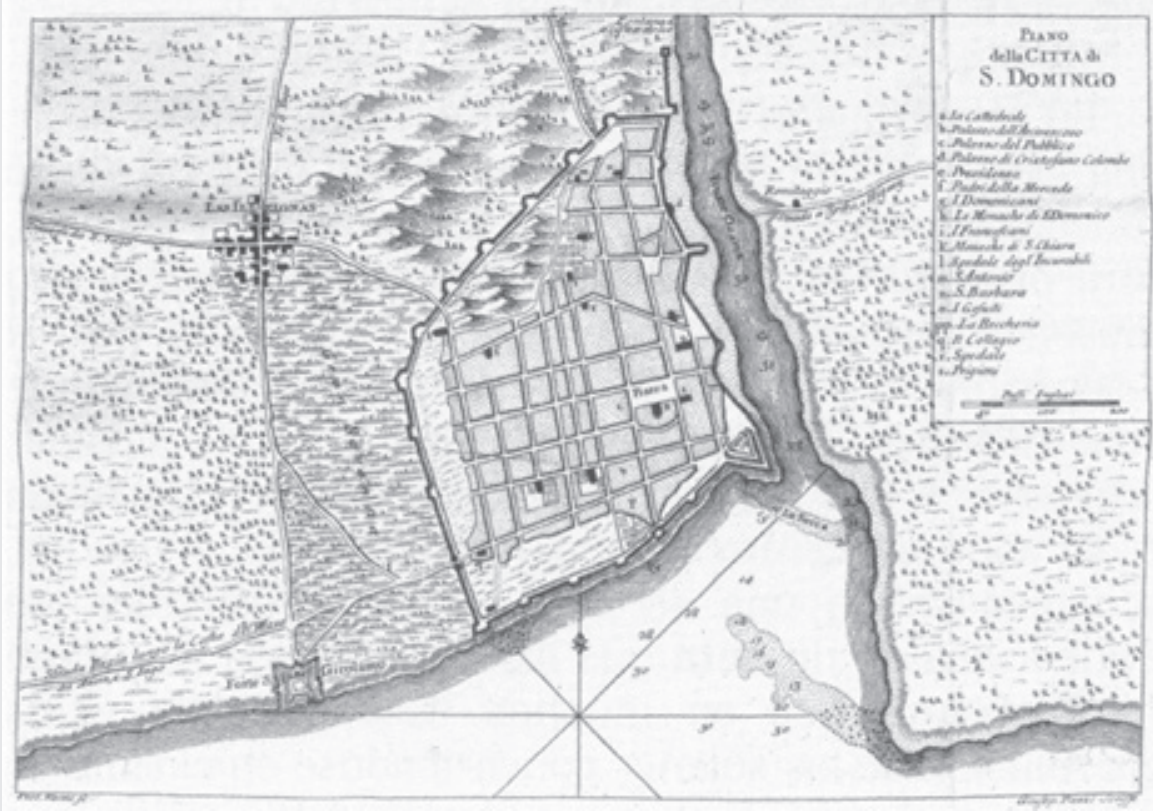

296. Plano de Santo Domingo, retirado do Atlas /l Gazzettiere Americano, contenente un distinto ragguaglio di tutte le parti del Nuovo Mondo, publicado em Livorno, em 1763. Percebe-se a linearidade das ruas da capital de La Espaniola, mas também a diversidade dos ângulos com que se encontram e a diferença do tamanho dos quarteirões. Sua estruturação viária marcaria, segundo Nicolini, o primeiro estágio de racionalização do desenho das cidades hispano-americanas. Fonte: Ortiz Crespo (2007, p. 69).

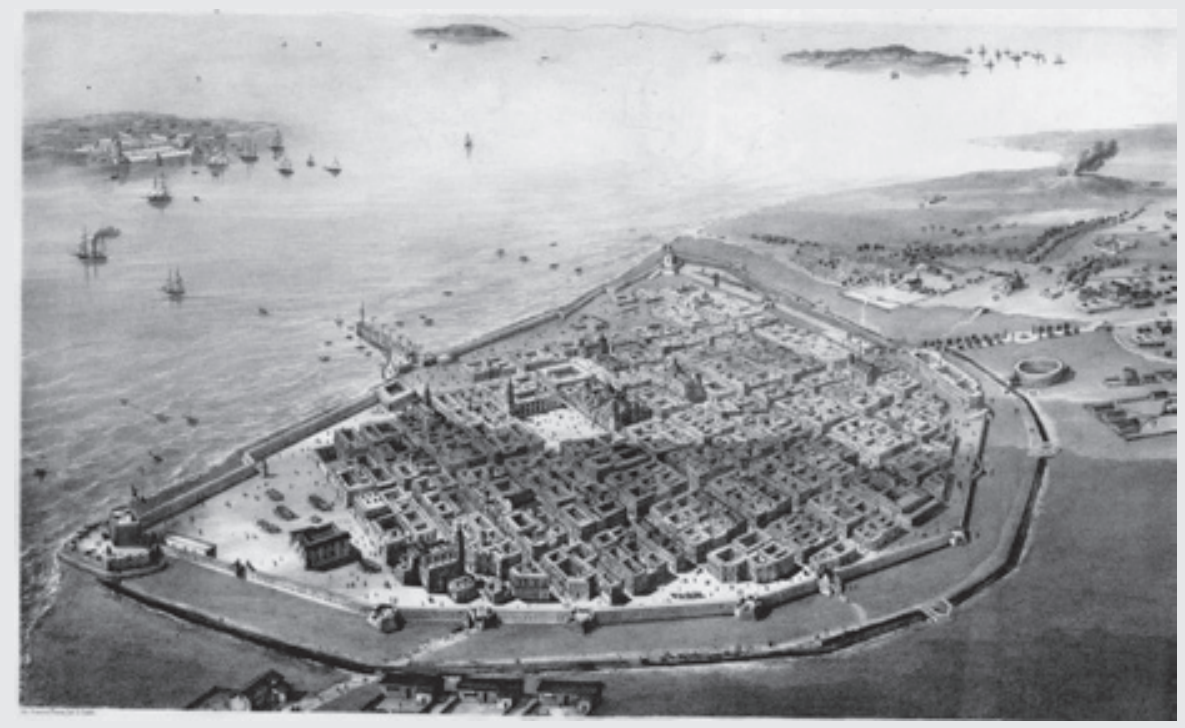

297. Litografia feita em 1846 , de um balão aerostático, pelo desenhista e pintor mexicano Casimiro Castro (1826-1889), mostrando a cidade de Veracruz, fundada em 1519. Ainda se nota o sentido regular de seu ordenado desenho urbano. O plano de Veracruz estaria enquadrado no segundo estágio de racionalização do desenho das cidades hispano-americanas, segundo a classificação de Nicolini. Fonte: University of Texas Libraries. 


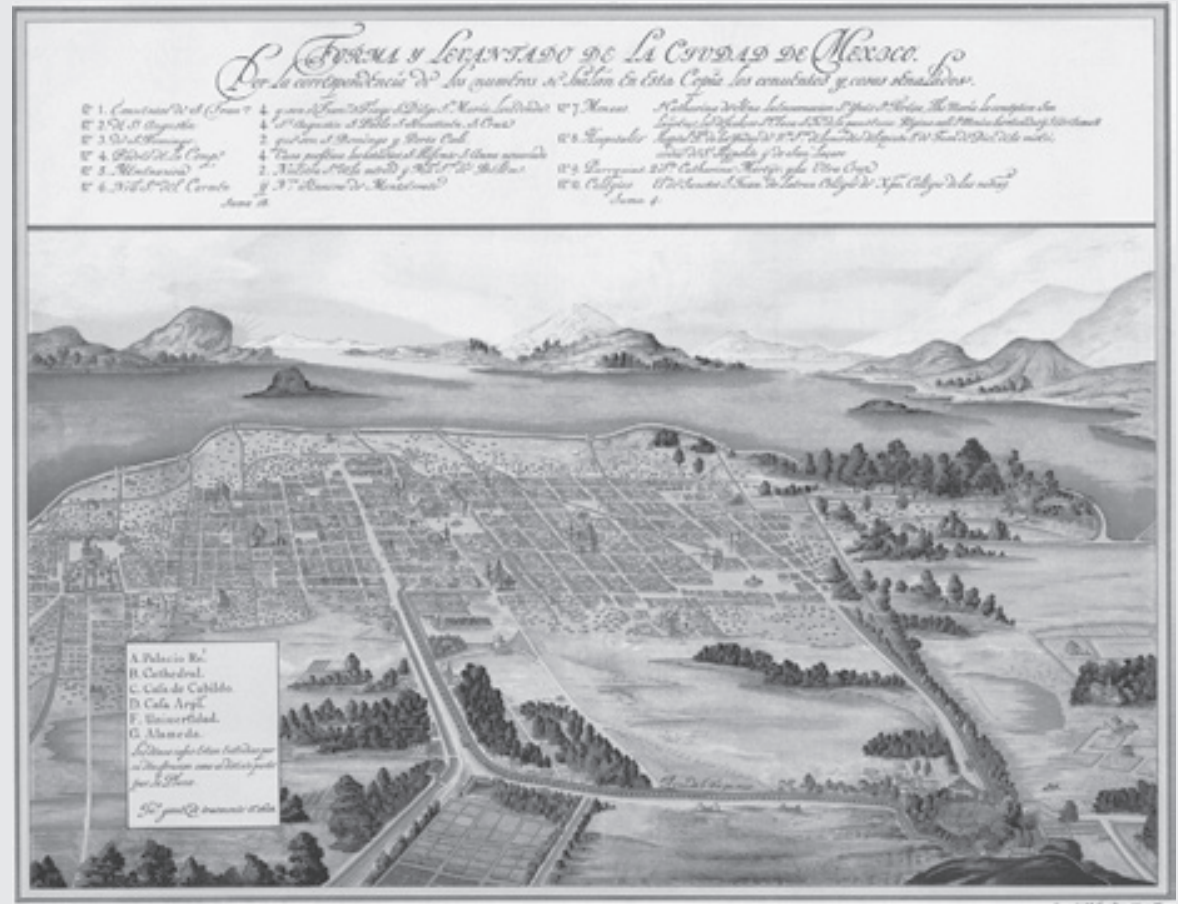

298. Imagem em voo de pássaro da Cidade do México em 1628, feita pelo arquiteto hispano-mexicano Juan Gómez de Trasmonte (morto em 1647), que teria sido o mestre maior da construção da Catedral - de 1635 até sua morte. Sua estruturação viária marcaria o terceiro estágio de racionalização do desenho das cidades hispano-americanas - segundo Nicolini. Fonte: University of Texas Libraries.

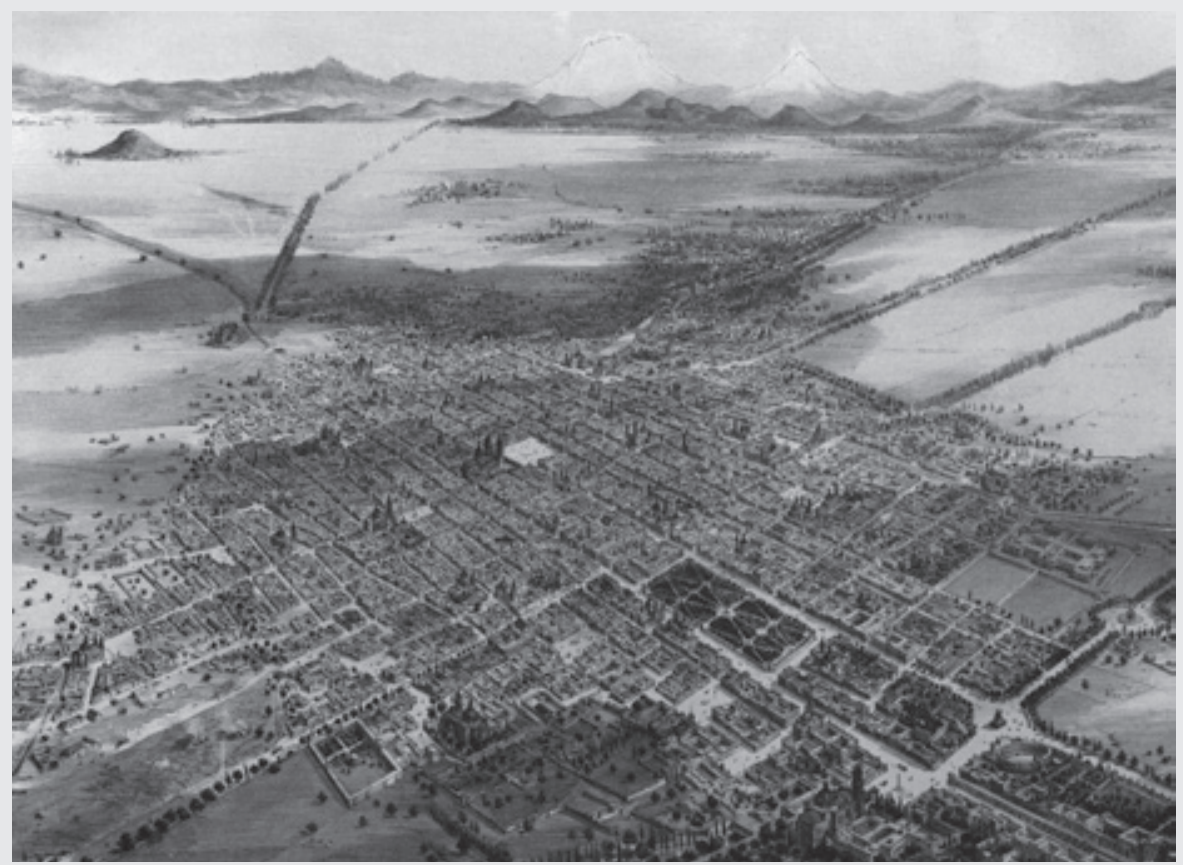

299. Vista panorâmica da Cidade do México no século XIX feita a partir de um balão aerostático. Por Casimiro Castro - litografia publicada em 1869 em México e sus arredores. Fonte: Blog Barrio de Tultenco. 


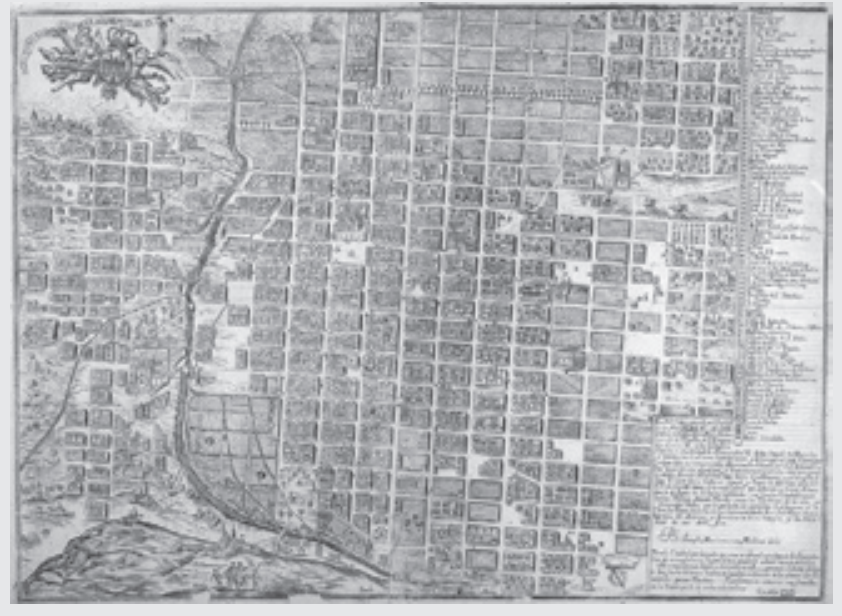

300. Plano de Puebla de 1754, elaborado por Joseph Marianus, mostrando os quarteirões retangulares ainda desocupados em meados do século XVIII, nas proximidades da Plaza Mayor. Terceiro estágio de racionalização do desenho das cidades hispanoamericanas. Fonte: Allende Carrera (2006, p. 109).

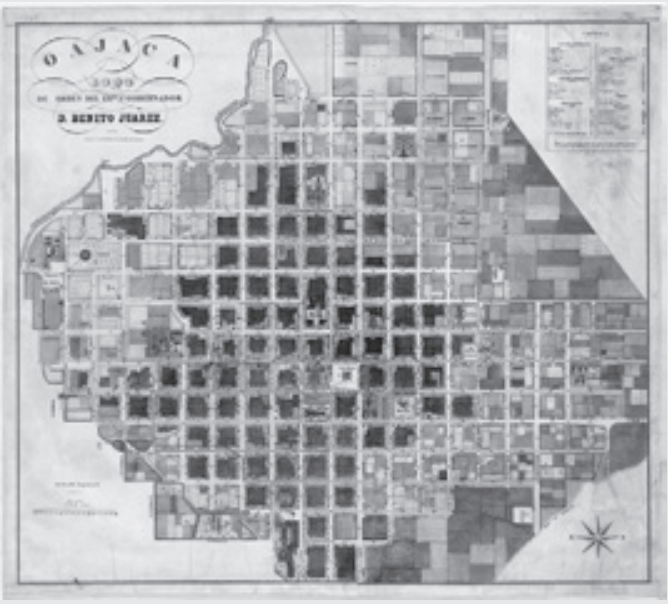

301. Plano de Oaxaca de 1843. A planta revelaria que ainda no século XIX grande parte da quadrícula regular implantada a partir de 1521 estaria desocupada, lançada na zona rural fronteiriça. Sua estruturação viária estaria enquadrada, segundo a classificação elaborada por Nicolini, no quarto estágio de racionalização do desenho das cidades hispano-americanas. Fonte: University of Texas Libraries.

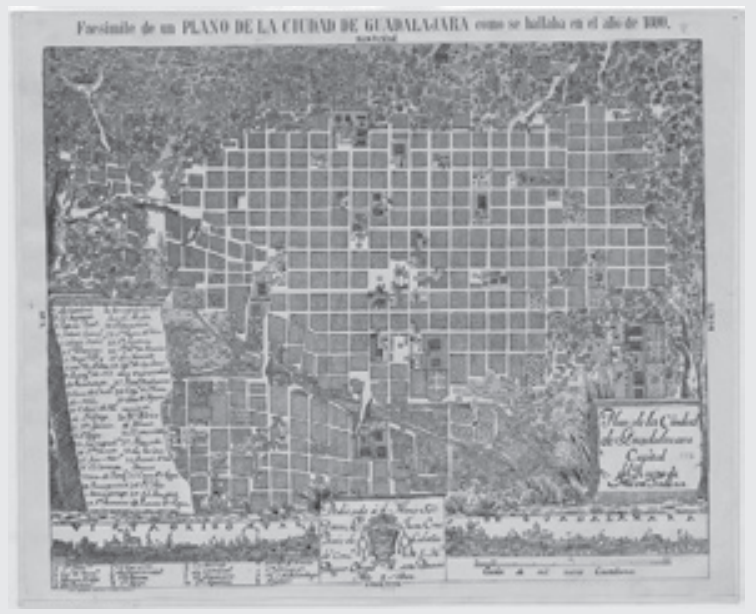

302. Plan de la Ciudad de Guadalaxara Capital del Reyno de Nueva Galicia. Confeccionado no ano de 1800. A cidade de Guadalajara, capital do atual estado de Jalisco, no México, seria criada, oficialmente, em 1542 - no quarto sítio que ocuparia. Sua primeira locação remontaria à fundação original da cidade, em 1530. Quarto estágio de racionalização do desenho das cidades hispano-americanas. Fonte: University of Texas Libraries.

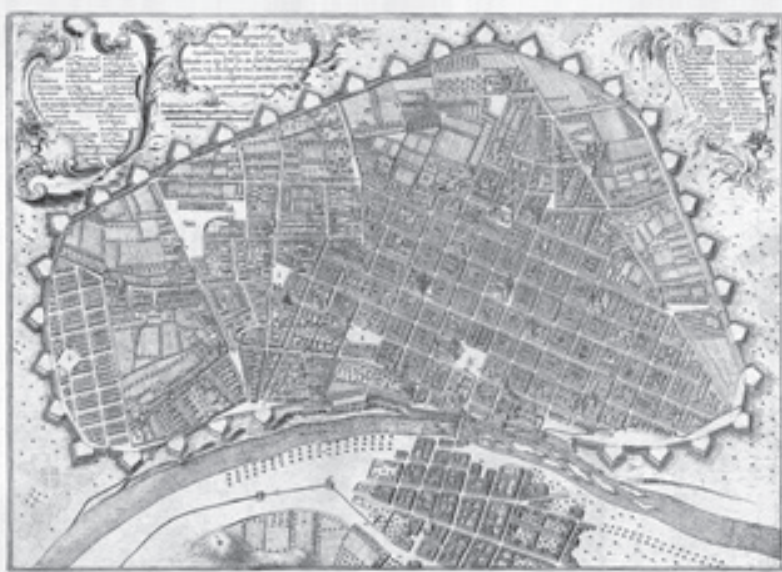

303. Plano Scenographico, de la Ciudad de los Reyes, o Lima Capital de los Reynos de Peru, por Jorge Juan (1713-1773) e Antonio de Ulloa (1716-1795), 1748. Lima, capital do Vice-Reinado do Peru, foi fundada em 1535. As fortificações foram feitas a posteriori, entre de $1684 \mathrm{e}$ 1687. Quinto estágio de racionalização do desenho das cidades hispano-americanas, segundo Alberto Nicolini. Fonte: Blog Arqueologia Colonial (2012). 


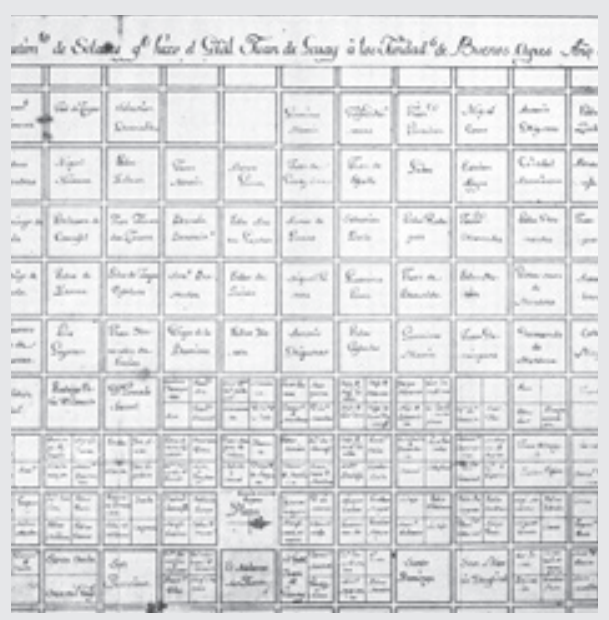

304. Plano de 1583 da segunda fundação de Buenos Aires, que remonta ao ano de 1580 , por iniciativa do conquistador Juan de Garay (1528-1583). Fonte: Guidoni e Marino (1982, p. 371).

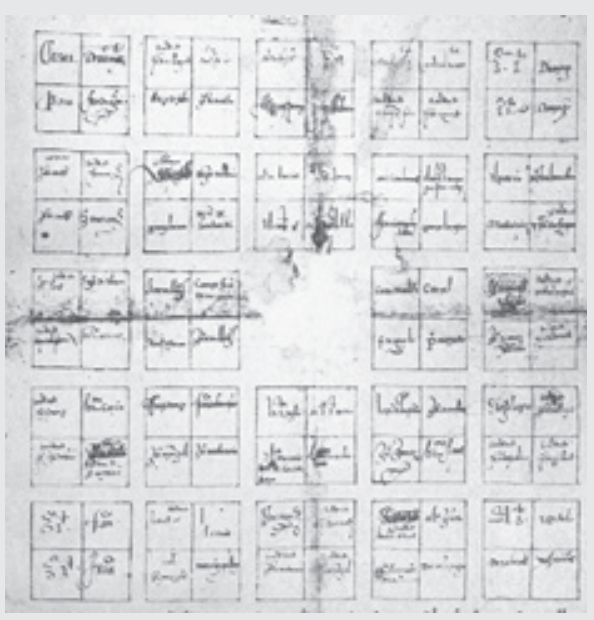

305. Plano de fundação da cidade de Mendoza, na atual Argentina, confeccionado em 1561. O tabuleiro de damas (damero) perfeitamente quadrangular era dividido em 25 quadras, cada uma com quatro imensos solares quadrados - e a Plaza Mayor era formada pela supressão da quadra central. Sexto e último estágio de racionalização do desenho das cidades hispanoamericanas, segundo Nicolini. Fonte: Guidoni e Marino (1982, p. 375).

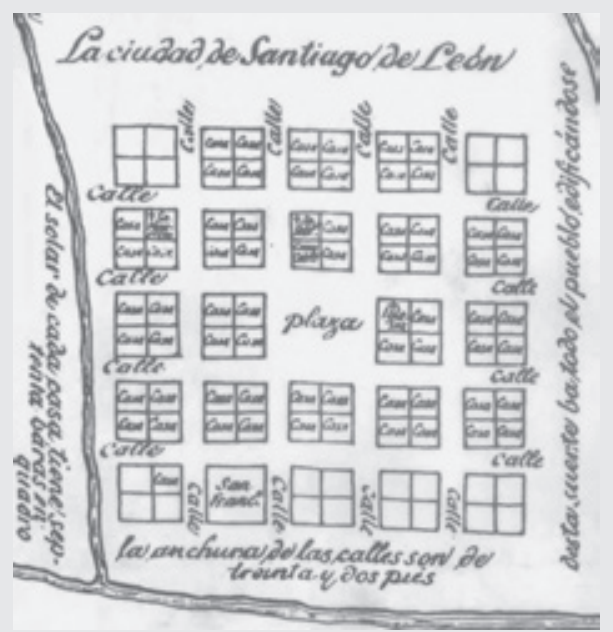

306. Detalhe do plano de fundação de Santiago de León de Caracas, 1567 . Sexto e último estágio de racionalização do desenho das cidades hispano-americanas. Fonte: CEHOPU (1989, p. 122).

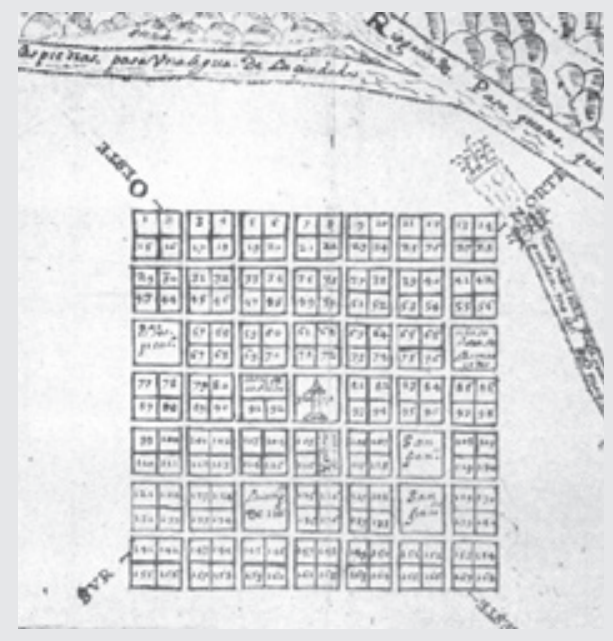

307. Fragmento do plano de fundação de 1668 da cidade de Talavera de Madrid, na Argentina. Tabuleiro de damas com 49 quadras. Sexto e último estágio de racionalização do desenho das cidades hispano-americanas. Fonte: Chueca Goitia e Torres Balbás (1981, p. 19). 


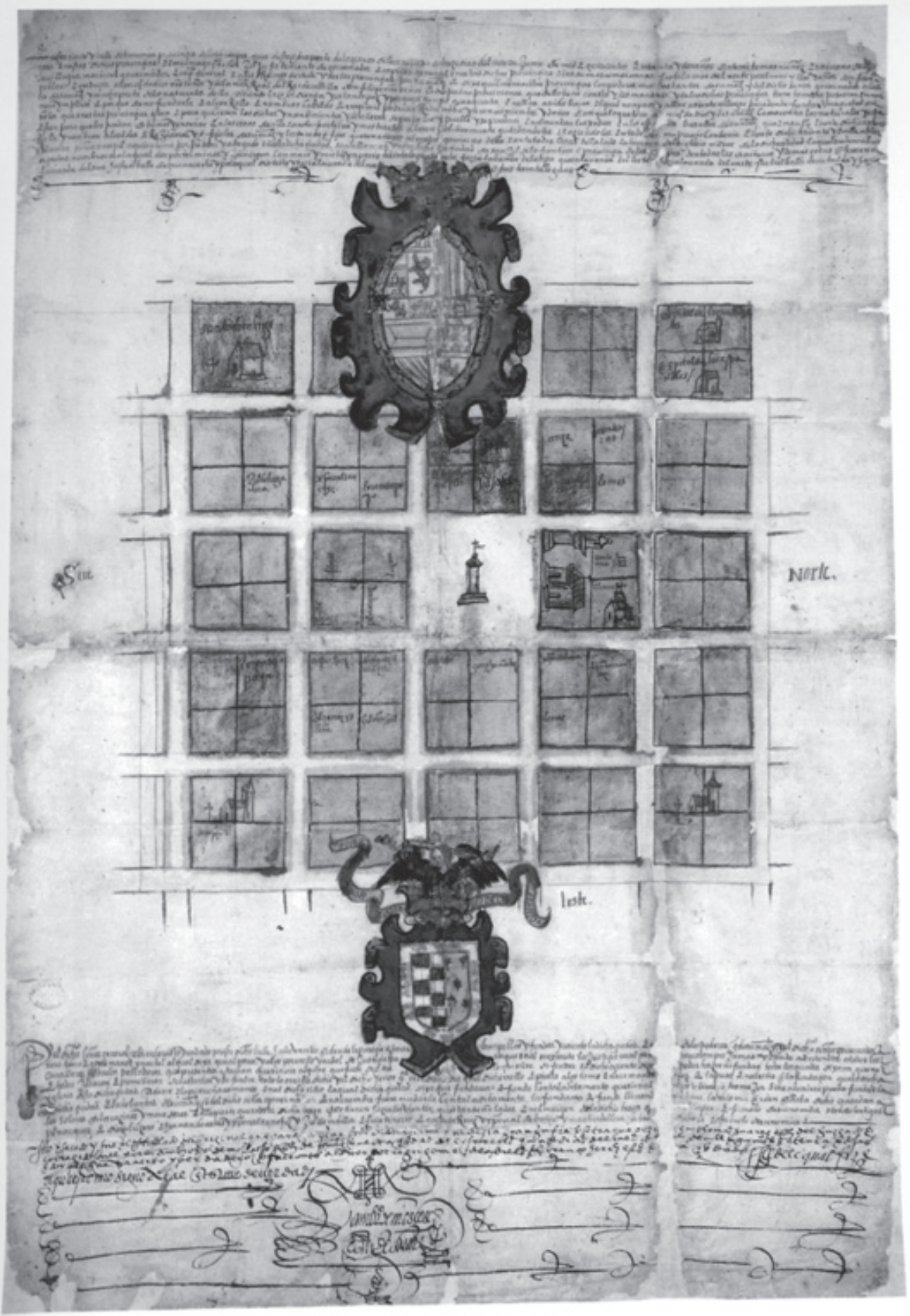

308. Plano de la fundación de San Juan de la Frontera, de la ciudad del Reyno de Chile - atualmente na Argentina. Plano assinado em 1562. Sexto e último estágio de racionalização do desenho das cidades hispano-americanas o damero. Fonte: Van Doesburg (2007, v. 1, p. 75). 
arquitetas argentinas Daniela Moreno e Ana Lía Chiarello, ${ }^{\mathrm{I0}}$ o império espanhol teria promovido uma antecipação das ações que caracterizariam a urbanística barroca europeia dos séculos XVII e XVIII ao implantar, em toda extensão das Índias Ocidentais, cidades desenhadas em forma de tabuleiro de damas, com praça central monumental. Tomando de empréstimo o discurso desenvolvido pelo crítico norueguês Christian Norberg-Schulz (I979) acerca do espaço urbano barroco, as autoras afirmariam que:

Sobre uma estrutura urbana de base renascentista, ruas paralelas que se cruzam para formar blocos quadrados ou retangulares e praças centrais, os conceitos de centralidade, continuidade e extensão, próprios da cidade barroca, estavam presentes na gênese mesma do espaço urbano americano. (MORENO; CHIARELLO, 20oIb, v. 2, p. I273, tradução nossa).

Desta forma, ainda no século XVI, os núcleos coloniais teriam atingindo níveis artísticos grandiosos, quiçá superiores aos das cidades europeias do período subsequente, pois alcançariam a planificação e a regularidade totais - princípios geneticamente ligados ao Velho Mundo, mas raramente expressos na Europa, já que suas cenográficas cidades barrocas seriam quase que, invariavelmente, produtos de transformações setoriais promovidas em assentamentos urbanos preexistentes e historicamente consolidados. Portanto:

A materialização de uma cidade barroca a partir do zero não foi comum na Europa do século XVII, mas sim transformar uma cidade existente em outra barroca. Frente a isto, as cidades hispano-americanas foram concebidas e materializadas como um projeto urbano total, assim que o pensar a cidade enquanto projeto unitário esteve implícito no urbanismo colonizador desde sua origem. Além disso, para conseguir a transformação barroca, a Europa apelaria para a construção de ruas retas, a construção de ruas regulares e a criação de novos bairros em grelha. Em grande parte das cidades americanas a malha urbana reticular, as ruas retas e praças regulares estiveram presentes tanto

102 As autoras argentinas expõem seu juízo sobre a urbanística barroca hispano-americana em duas versões do texto Rasgos barrocos en la génesis de los espacios públicos americanos - versões com conteúdos curiosamente diversos: o texto resumido publicado em 2001 nas Preactas del III Congreso Internacional del Barroco Iberoamericano; e o ensaio completo inserido na coletânea Barroco Iberoamericano: territorio, arte, espacio y sociedad, publicação que reuniria os trabalhos apresentados no citado congresso acontecido em Sevilha no ano de 2001. 
em sua morfogênese como no seu posterior desenvolvimento e crescimento. (MORENO; CHIARELLO, 2ooIa, p. II2-II3, tradução nossa)

Entretanto, fazendo oposição ao que afirmariam Moreno e Chiarello, para além do problema da antecipação cronológica da constituição do modelo da cidade virreinal nas Índias Ocidentais em relação ao despertar da poética barroca, se fosse promovida uma interface entre o caráter estrutural e paisagístico dos assentamentos hispano-americanos e a prática da urbanística dita barroca, verificar-se-ia que não haveria muitos pontos de concordância. Pelo contrário, tornar-se-ia latente o fato de que as características mais importantes da cidade regular colonial, invariavelmente estabelecidas na primeira metade da centúria, revelar-se-iam por demais distantes daquilo que seria identificado pela crítica moderna, de forma incipiente, como "urbanística barroca". Se não bastasse, seria possível até mesmo assegurar que o caráter dos rarefeitos núcleos urbanos quinhentistas, com traçado em tabuleiro de damas, apresentaria a tendência contrária: uma disposição em coibir a expressão da teatralidade, do impulso persuasivo, bem como da miragem que a cidade barroca deveria provocar no transeunte.

Artifícios dramáticos, como as grandes e ininterruptas avenidas retilíneas; os epidérmicos cenários teatrais das praças reais e das vias de arquitetura contínua e uniforme; os longos e marcados eixos perspectivos que, geralmente, apresentariam um determinado point de vue assinalado por um poderoso monumento escultórico ou arquitetônico; os tridentes e os poliviuns que, comumente, se encontrariam em um ponto nodal distinguido pela presença de uma fonte, de um obelisco, de uma estátua do governante, de um símbolo religioso, sempre levantados no setor mais proeminente de uma monumental praça que acolheria o leque de vias; nenhum destes mecanismos urbanísticos de sedução e de direção das massas figuraria nos assentamentos coloniais durante o século XVI. Do mesmo modo, os estratagemas lançados pela urbanística barroca não seriam percebidos, ou mesmo implantados, nas cidades novas ou preexistentes nos séculos subsequentes, pelo menos no decorrer da dominação espanhola - devido àquele esforço de permanência que os planos decretariam para as urbes com o passar dos anos, fenômeno citado por Rossi (2006, p. 56) e exposto no início deste capítulo.

É verdade que a organização do sistema viário dos assentamentos conformados por uma grelha contínua que poderia ser estendida ad infinitum acabaria gerando longas vias retilíneas. Todavia, a ausência de uma hierarquia dimensional 
entre os inúmeros eixos que se cruzariam em ângulos retos, já que as ruas possuiriam sempre a mesma largura, eliminaria o destaque essencial que, nas cidades europeias, as vastas avenidas abertas no período barroco absorveriam. Na mesma direção, o baixo gabarito das edificações civis, aliado à parca ocupação dos quarteirões e das testadas dos imensos solares, testadas nas quais seriam deixadas, no alinhamento das vias, amplas áreas desocupadas - vazias, ou fechadas por simples muros -, todos estes fatores, coligados à largura sempre significativa das ruas e à constante interrupção dos eixos viários pelos inevitáveis cruzamentos que se sucederiam em um obsessivo ritmo regular, contribuiriam para inibir o impulso necessário àquele fluxo perspectivo tão peculiar nas artérias rasgadas no período barroco (Figuras 309-316).

Como consequência, na América espanhola, a racional e burocrática cidade quinhentista atuaria, paradoxalmente, contra o Barroco - uma das teses defendidas neste livro. Mais ainda, atuaria, frequentemente, em oposição a qualquer ação vinculada à constituição estética e paisagística do ambiente urbano tridimensional. Seria uma legítima antecipação de um dos mecanismos mais utilizados pelo esquema funcional e pragmático despertado na disciplina do "urbanismo": uma das primeiras realizações consistentes relativas à ideia de uma planificação urbana que deveria antecipar propositivamente um novo tipo de cidade; tipo que demandaria algum tempo para se consolidar devido ao lento processo de ocupação, de adensamento do núcleo urbano - ações implantadas muitos séculos antes do "urbanismo" se estabelecer como disciplina independente nos anos I80o. Nesta direção, ao discutir a formação e o caráter dos núcleos urbanos hispano-americanos na centúria subsequente à descoberta das Américas, Leonardo Benevolo (2006, v. 3, p. I07, tradução nossa) - no volume de seu livro Storia della Città dedicado à cidade moderna, publicado pela primeira vez em I975 - diria:

Aquilo que se estabelece no momento de fundar uma cidade não é um organismo em três dimensões, mas uma traza (um plano regulador de duas dimensões, como em Ferrara). De fato, não se prevê a construção de edifícios em curto prazo, e mais ou menos contemporaneamente, como no Medievo; conferem-se os lotes edificáveis, sobre os quais os proprietários irão construir como e quando o desejarem. Nas cidades americanas, o desenho das ruas e das praças é por vezes inutilmente grandioso, ao passo que os edifícios são baixos e modestos (as casas são, quase sempre, de um andar). 


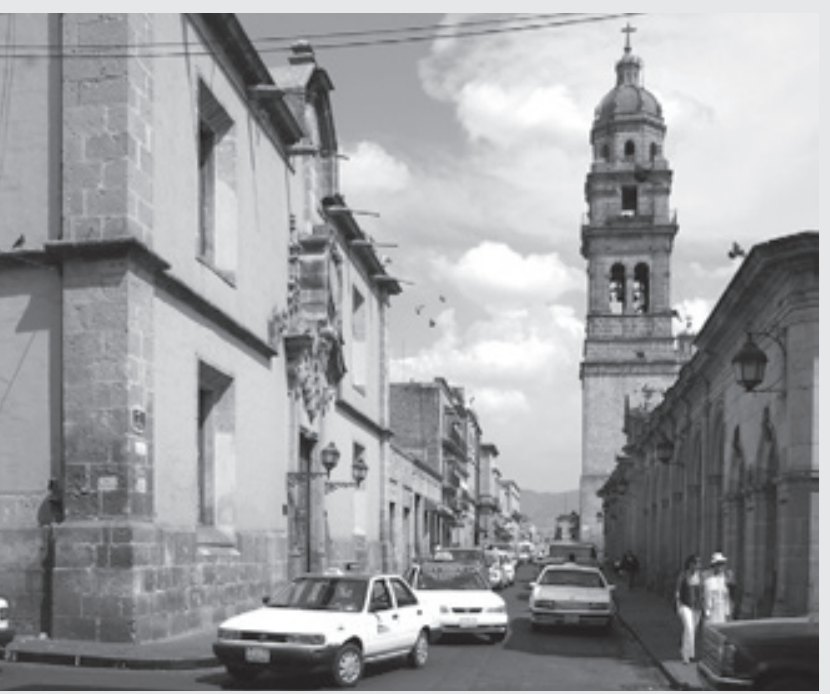

309. Uma rua do centro histórico de Morelia, com as fachadas das edificações agregadas e alinhadas com as vias, gerando o típico encaminhamento perspectivo que se perderia no infinito. À direita, adjacente à via e animando a fuga em profundidade, apareceria a torre da igreja do antigo Convento de San Agustín. Fonte: Fotografia elaborada pelo autor (2009)

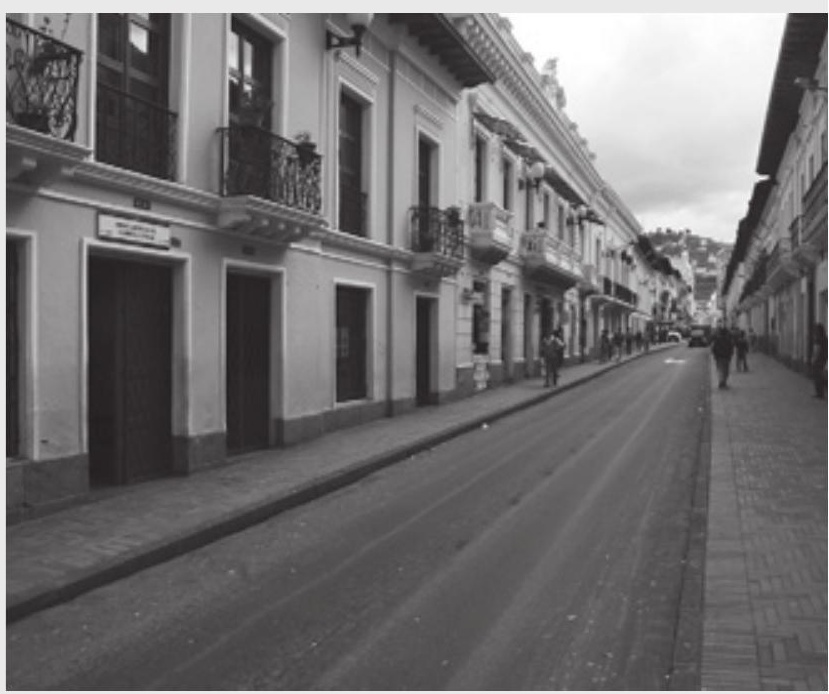

310. Fuga perspectiva capturada em uma das mais importantes vias do centro histórico de Quito, no Equador - cidade que receberia uma traza flexível, de relativa regularidade. Na ocasião da fundação da cidade, em 1534, as manzanas seriam dividias em oito solares e não seriam ocupadas em sua totalidade. Nos próximos séculos mais subdivisões decretariam o adensamento dos quarteirões e das testadas dos lotes. Fonte: Fotografia elaborada pelo autor (2007)

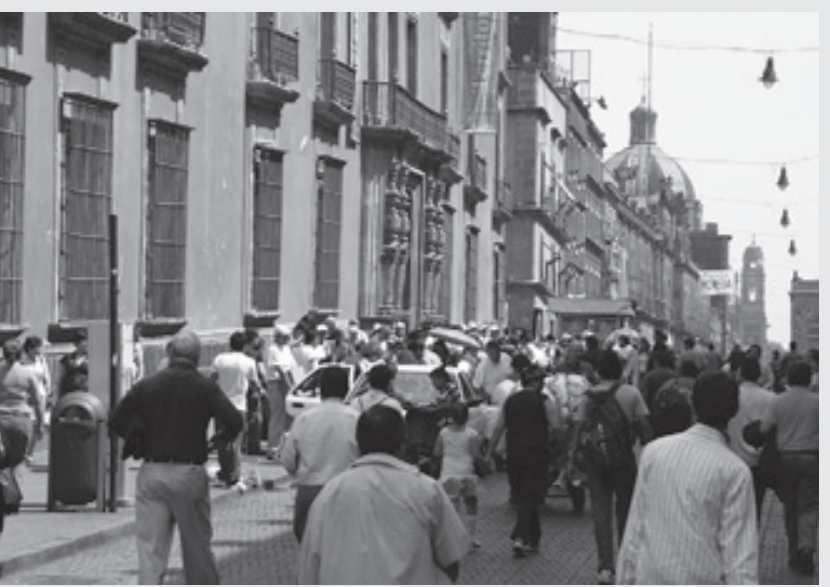

311. Uma das ruas mais importantes do centro histórico da Cidade do México: a Calle Moneda, em fotografia retirada a partir da Plaza Mayor (El Zócalo), nas proximidades da grande Catedral. Fonte: Fotografia elaborada pelo autor (2009).

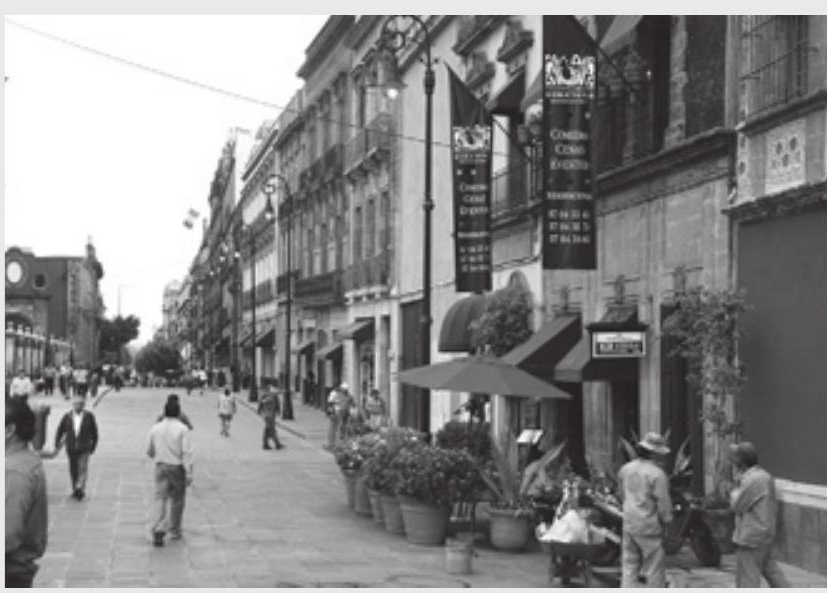

312. A atual Calle Tacuba, antiga Calzada México-Tacuba uma das quatro vias que comunicavam a capital do império asteca, México-Tenochtitlan (então situada em uma ilha do Lago Texcoco), com os povoados adjacentes, para além do lago. A Calzada México-Tacuba foi aproveitada (como todas as outras três) no plano que Alonso García Bravo (14901561) faria para a Cidade do México, após Tenochtitlan ser conquistada por Hernán Cortés (1485-1547), em 1521. Nessa imagem a rua aparece ao fundo da catedral - com a feição que adquiriu no período colonial. Fonte: Fotografia elaborada pelo autor (2009). 


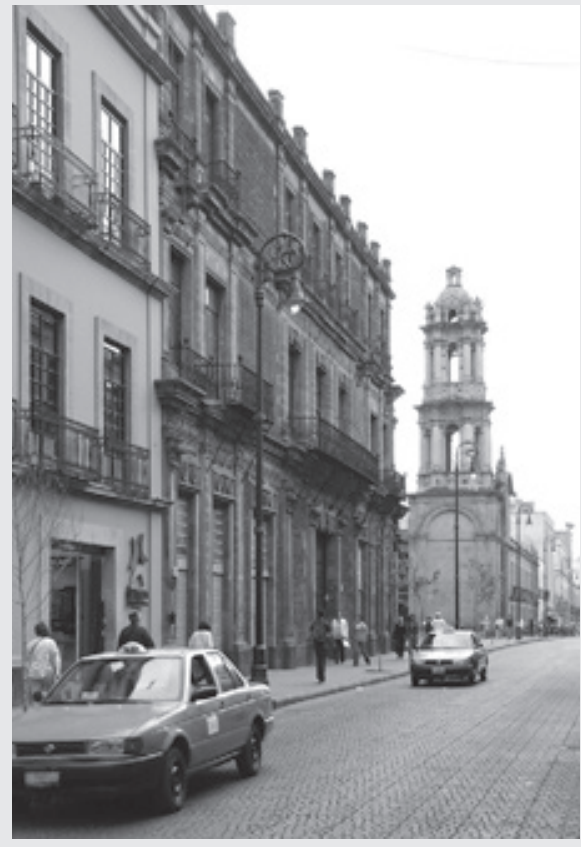

313. Rua República de El Salvador, no centro histórico da capital mexicana, com destaque para a torre do complexo do Oratório de San Felipe Neri, edificada no século XVIII. Fonte: Fotografia elaborada pelo autor (2009).

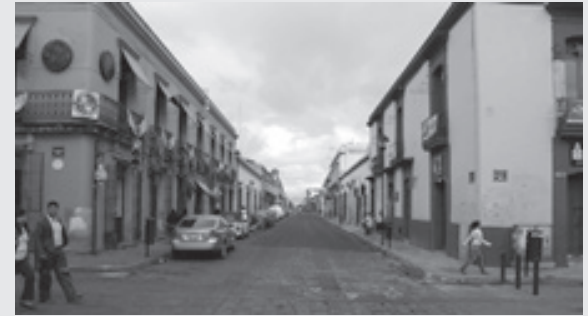

314. Trecho da Calle de Mariano Matamoros, em

Oaxaca, México. Fonte: Fotografia elaborada pelo autor (2009).

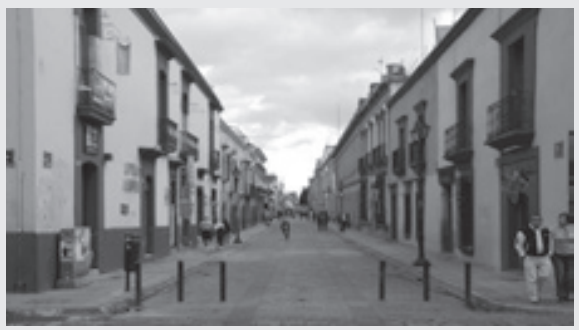

315. Trecho da Calle Macedonio Alcalá, em Oaxaca - em direção à Plaza Mayor. Fonte: Fotografia elaborada pelo autor (2009).

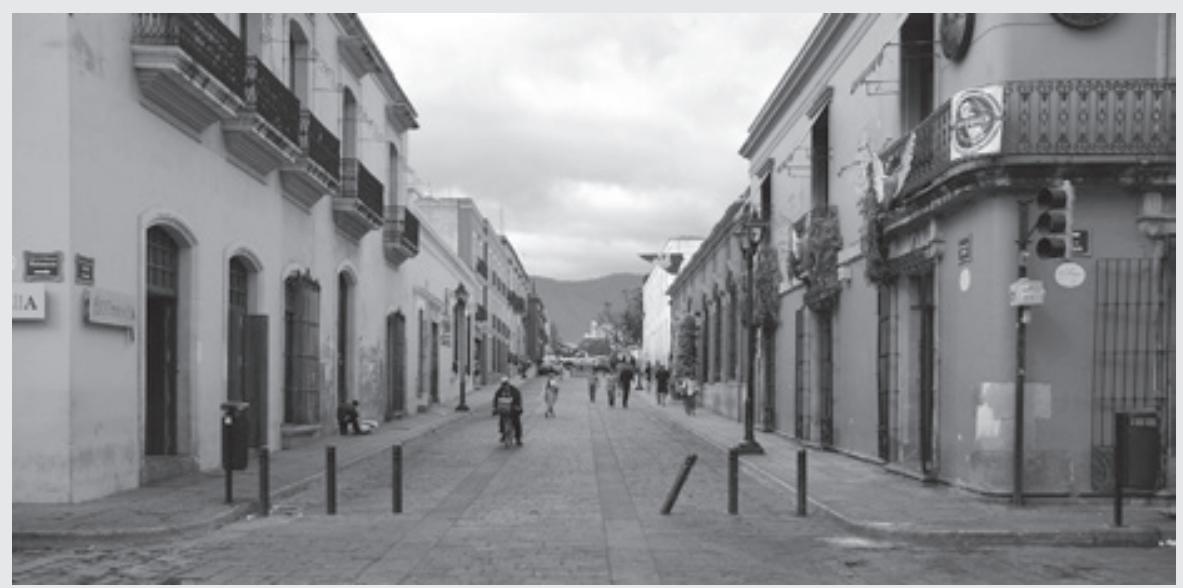

316. Trecho da Calle Macedonio Alcalá, em Oaxaca - direção contrária à Plaza Mayor. Fonte: Fotografia elaborada pelo autor (2009). 
Por outro lado, a quadrícula apresentaria uma tendência natural à monotonia que, obviamente, não combinaria com o inebriante jogo persuasivo e dramático apregoado pelas imagens frenéticas lançadas no espaço urbano, situação característica da poética urbana barroca. Não haveria lugar para os triviuns ou poliviuns, nem mesmo para os virtuais fechamentos, por monumentos destacados, dos pontos de fuga gerados nas vias pelos encaminhamentos retilíneos em profundidade - já pouco marcados pela aridez da ocupação de seus flancos por raros edifícios de baixa estatura. Na verdade, a concepção burocrática do plano somente preveria o cruzamento regular dos logradouros e a diluição da rua no vazio dos limites da cidade, em sua fronteira com a área rural - a não ser nos casos das cidades portuárias que, frequentemente, contariam com um sistema de fortificações encerrando bruscamente o encaminhamento das artérias que cruzariam as urbes.

Logo, muitas das iniciativas seiscentistas e setecentistas voltadas ao universo da urbanística - assim como grande parte das ações ligadas aos domínios da arquitetura e que tocariam a paisagem urbana -, quando versadas na aplicação para o espaço urbano do espírito inebriante do Barroco, operariam em forte confronto e oposição ao modelo de cidade regular consolidado no século XVI; seriam iniciativas que agiriam, parodoxalmente, contra a quadrícula.

Neste sentido, haveria uma tendência, expressa nos assentamentos que receberiam uma configuração viária mais aprisionada, cujos planos estariam diretamente atrelados ao modelo mais racional de traza das cidades hispanoamericanas, a se prestarem de maneira mais tímida às renovações cenográficas da paisagem urbana. Ao se comparar as cidades configuradas como um perfeito e imaculado tabuleiro de xadrez, com os assentamentos virreinales delineados a partir de diagramas viários menos rígidos, seria possível constatar que os últimos, indubitavelmente, aceitariam melhor as intervenções que atuariam contra a quadrícula; consequentemente, estariam mais bem preparados para se transformarem em cenográficas cidades barrocas (Figura 317).

Para a cidade em forma de grelha, pequenas concessões à severidade da malha ortogonal, cujas ruas, praças e quarteirões contariam, usualmente, com as mesmas dimensões, poderiam ser suficientes para suscitar expedientes que auxiliassem a aparição de acontecimentos dramáticos pontuados na paisagem urbana, eventos que atuariam em prol da constituição de um cenário de alto teor barroco. 
Uma rua contígua à plaza mayor, aberta com uma largura ligeiramente superior às das outras vias, poderia transformar-se em um evento de enorme destaque no seio da cidade: com o tempo e com a nova distribuição fundiária dos solares, a antiga via poderia acolher, prontamente, uma sequência ininterrupta de imponentes casarões e de palácios institucionais dos dois lados de cada segmento de rua, tornando-se a poderosa e monumental avenida senhorial do núcleo urbano, assim como seu mais importante eixo de circulação - processo automático que favoreceria a configuração hierárquica da cidade e que revelaria os objetivos da coroa espanhola de expressar, no ambiente urbano, a retórica e a persuasão barrocas (Figuras 318-324).

$\mathrm{Na}$ mesma direção, os núcleos urbanos que possuiriam geneticamente um traçado mais flexível, mesmo seguindo a tradição viária da grelha, aceitariam mais naturalmente o aparecimento de frontarias e portadas de templos, conventos e palácios que atravancariam as ruas originalmente diretas, gerando - na conclusão em profundidade do eixo - aquele desejado encerramento perspectivo característico da urbanística barroca. No que se refere, especificamente, à arquitetura religiosa, sabe-se que muitos complexos arquitetônicos alcançariam dimensões colossais ainda no século XVI, chegando a cobrir, no âmago das cidades, uma área equivalente a duas ou mais quadras do núcleo urbano regular, invadindo diversos segmentos das longas ruas, que até então figurariam diretas e contínuas. Em consequência, a grande extensão de terra utilizada para o assentamento de certas catedrais, assim como o imenso espaço destinado às cercas de determinados conventos e monastérios, acabariam, inevitavelmente, provocando singulares enquadramentos perspectivos que despontariam na finalização de algumas vias, eixos que, segundo o plano original, deveriam se estender ininterruptamente até os limites da mancha urbana edificada, mas que agora seriam detidos ao atingirem perpendicularmente os imensos conjuntos religiosos. Seriam situações de alto teor cenográfico em que o ponto de fuga ficaria emoldurado por uma trabalhada portada barroca, pela presença de altas torres e campanários, ou mesmo pelo aparecimento de um elaborado frontispício, efusivamente ornamentado (Figuras 325-332).

Logo, como arremate das discussões abertas acerca da cidade barroca seria pertinente a apreciação da configuração artística de um expressivo assentamento hispano-americano em prol da experimentação dos artifícios de transfiguração do ambiente citadino - particularmente, o papel da arquitetura como elemento gerador do espaço urbano barroco. Ou seja, a ideia residiria na busca pela interface 


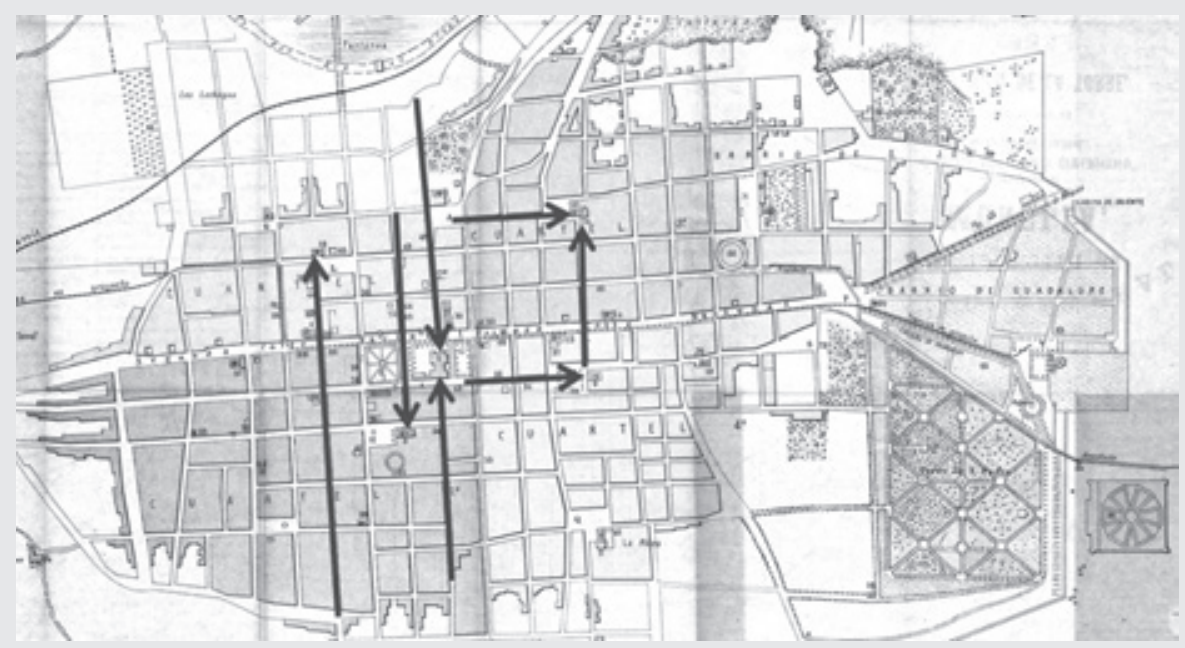

317. Planta da antiga Valladolid de Michoacán, atual Morelia (1883). O ordenado desenho reticular da cidade estabelecido por Antonio de Godoy e pelo alarife Juan Ponce - não apresentaria a rigidez dos últimos estágios de desenvolvimento da quadrícula hispano-americana, sendo discretamente adaptado à topografia e abrindo caminho para o desenvolvimento de interessantes e raríssimas manifestações que se assemelhariam àquilo que seria estabelecido pela chamada urbanística barroca. Cruzando o centro da cidade, apresentar-se-ia a Calle Real (a via mais larga que corta a cidade da esquerda para a direita - oeste a leste). Para além disso, as setas escuras pontuariam alguns dos diversos enquadramentos perspectivos que a cidade gradativamente receberia emoldurando - em perfeita elevação - fachadas e portadas de edifícios eclesiásticos. Fonte: Elaboração do autor a partir do Plano de 1883. Disponível no site Espejel.

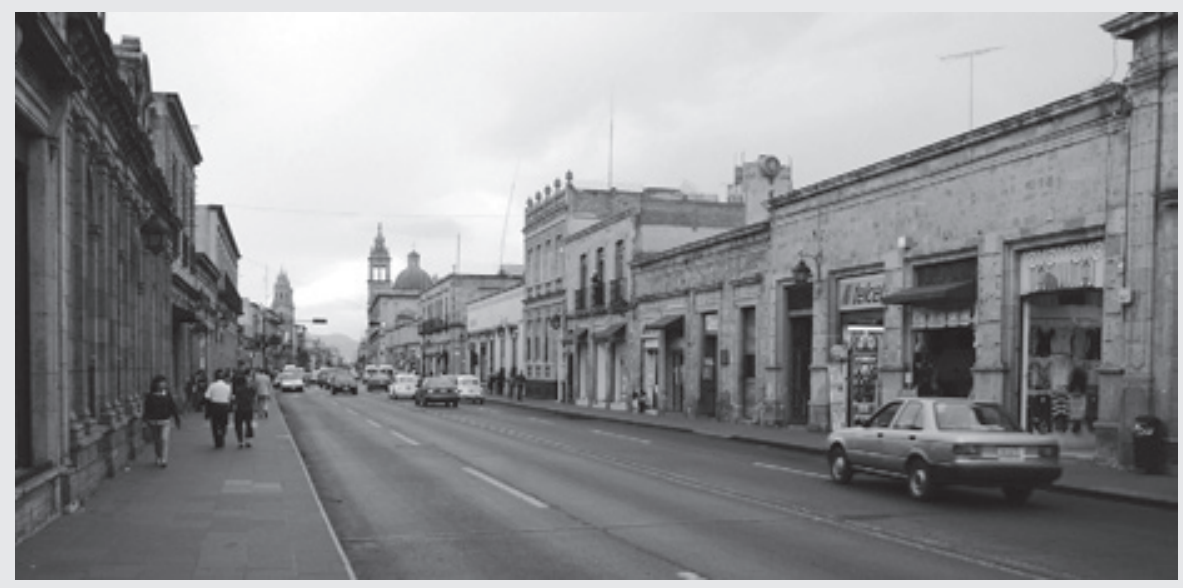

318. Imagem da Calle Real de Morelia, a via principal da cidade, em sua porção oriental. Cruzaria todo o núcleo colonial com uma extensão de quase dois quilômetros e uma largura média de cerca de doze metros - muito superior à das outras ruas que correriam paralelas ou perpendiculares -, colocando-se, hierarquicamente, como a principal artéria da cidade. Para além disso, conformaria um dos lados da imensa Plaza Mayor e acolheria uma série de monumentos oficiais e religiosos. Nesta imagem percebe-se, à direita, a torre do Templo de las Monjas e, à esquerda, os campanários da Catedral. Fonte: Fotografia elaborada pelo autor (2009). 


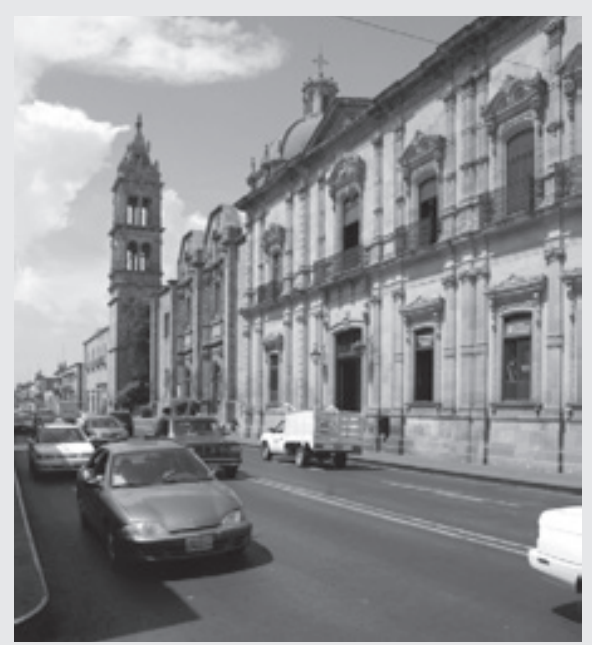

319. Templo de las Monjas, construído a partir de 1721, alinhado lateralmente com a Calle Real. Fonte: Fotografia elaborada pelo autor (2009).

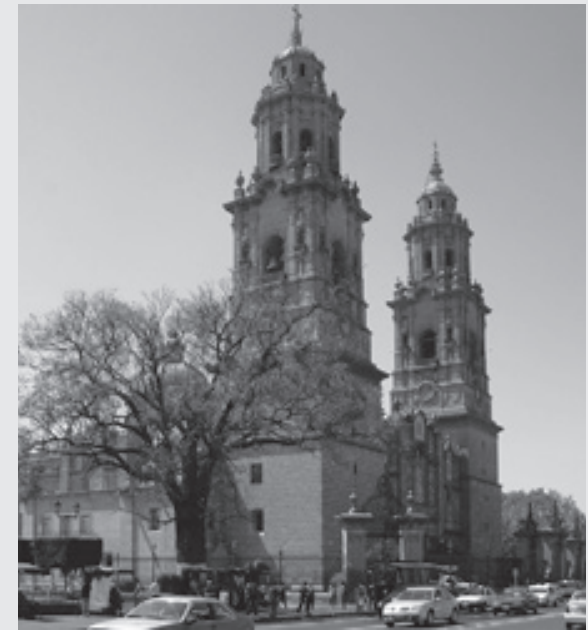

320. Grandiosa Catedral de Valladolid de Michoacán (Morelia), com sua fachada voltada à Calle Real. Edificada a partir de 1660 com projeto de Vicenzo Baroccio de la Escayola. Fonte: Fotografia elaborada pelo autor (2009).

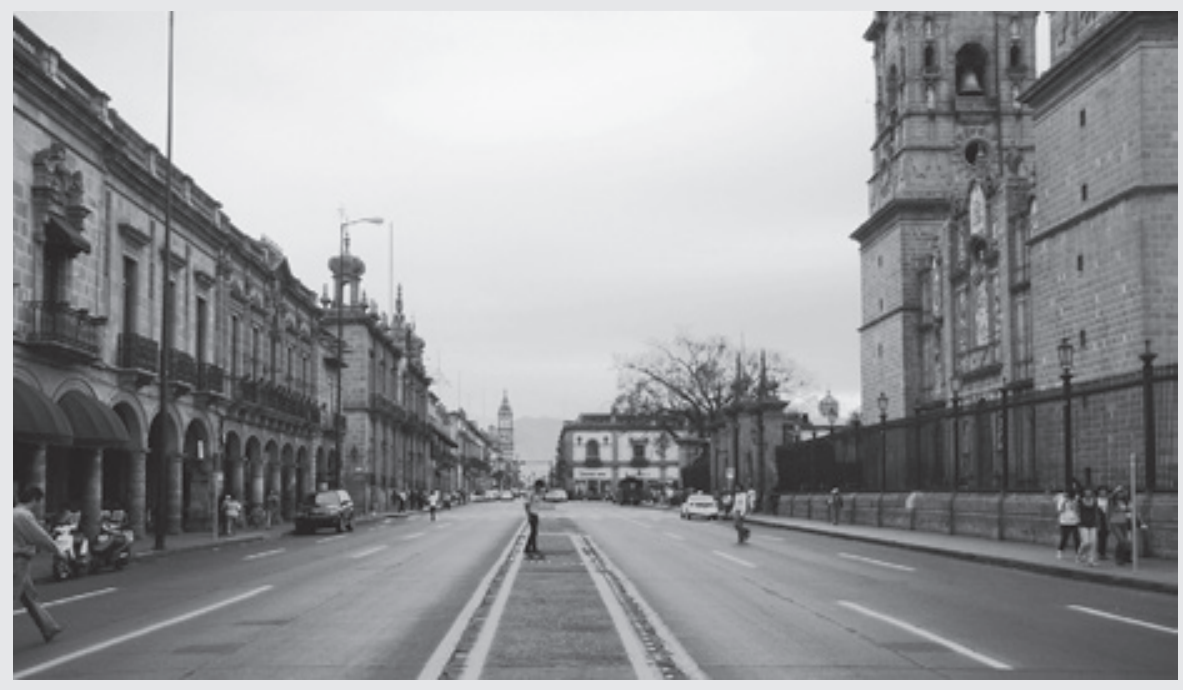

321. Calle Real em sua porção central, onde é mais larga - mais de dezesseis metros -, conformando um dos lados da Plaza Mayor. Em primeiro plano, à direita, a fachada barroca da Catedral; à esquerda, à frente do edifício com soportales, o Palácio do Governo (antigo seminário); e, ao fundo, a torre do Templo de las Monjas. Fonte: Fotografia elaborada pelo autor (2009). 


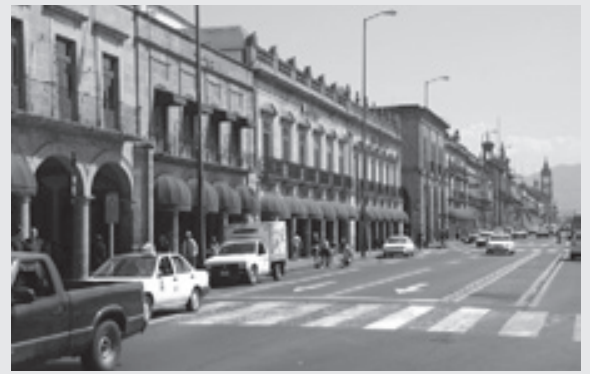

322. Um dos lados em longa fuga perspectiva da Calle Real de Valladolid de Michoacán. Fonte: Fotografia elaborada pelo autor (2009).

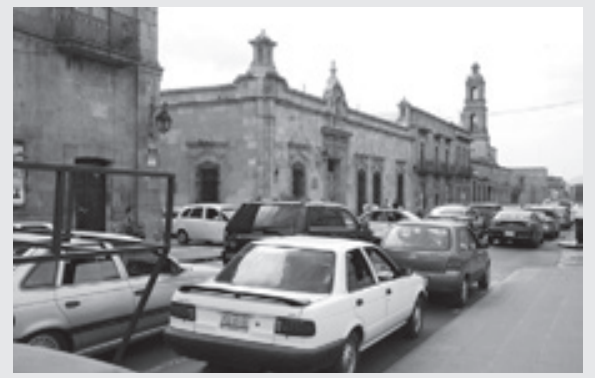

324. Torre do Templo de la Merced - construído a partir de inícios do século XVII, mas com o grosso da obra se estendendo até a próxima centúria. A igreja marcaria mais um edifício religioso levantado de costados para a Calle Real - que aqui é contemplada em seu segmento ocidental. Fonte: Fotografia elaborada pelo autor (2009).

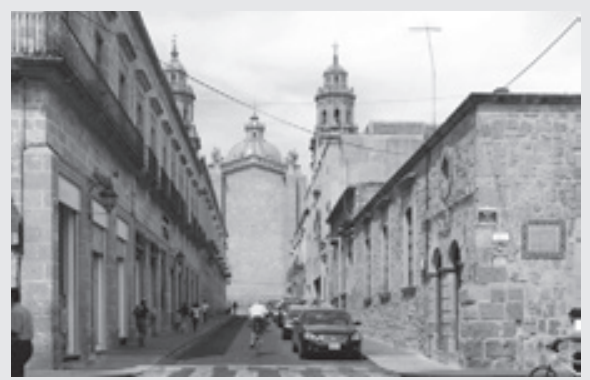

326. Fuga perspectiva para o fundo desnudo da Catedral de Morelia. Contudo, não deixaria de ser atraente o panorama em profundidade das torres e da cúpula em contraponto com a nudez da fachada posterior da igreja. Fonte: Fotografia elaborada pelo autor (2009).

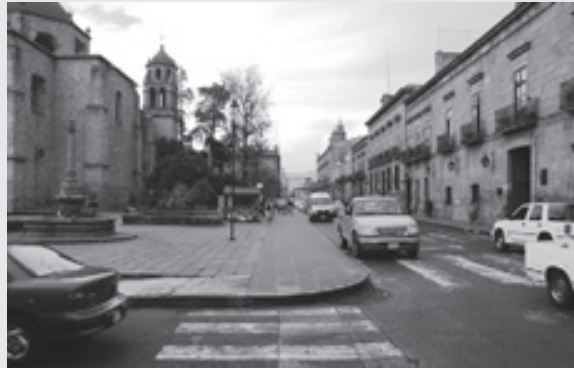

323. Antiga igreja jesuítica do Colégio de San Francisco Xavier - hoje Biblioteca Pública Universitária -, levantada a partir do ano de 1580 com sua fachada lateral voltada para a Calle Real de Morelia. Fonte: Fotografia elaborada pelo autor (2009).

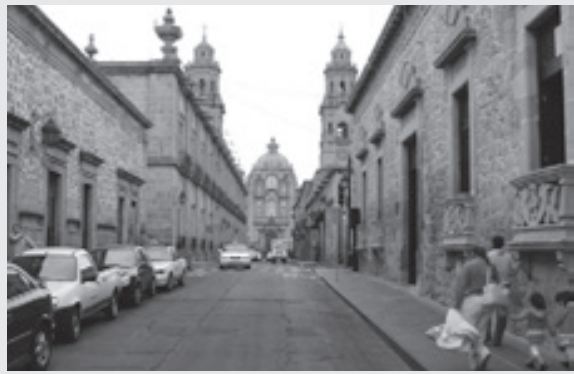

325. Via em encaminhamento perspectivo cujo ponto de fuga estaria marcado pela frontaria barroca da Catedral de Morelia. É muito interessante o contraponto entre o frontispício integralmente exposto e as torres parcialmente ocultas, apresentando apenas seus arremates acima das edificações que compõem os dois lados da via. Fonte: Fotografia elaborada pelo autor (2009).

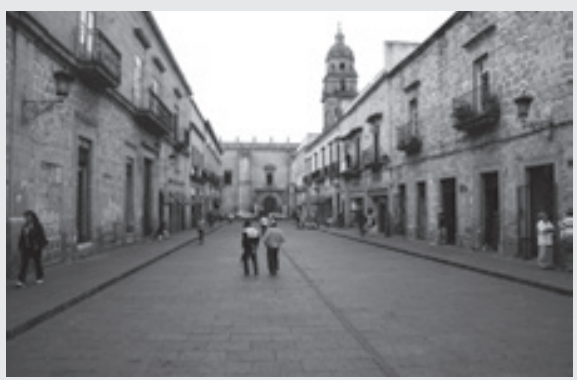

327. Perspectiva capturada desde o lado meridional da Plaza Mayor direcionado à portada de uma das fachadas laterais da igreja do antigo convento quinhentista de San Agustín. Fonte: Fotografia elaborada pelo autor (2009). 


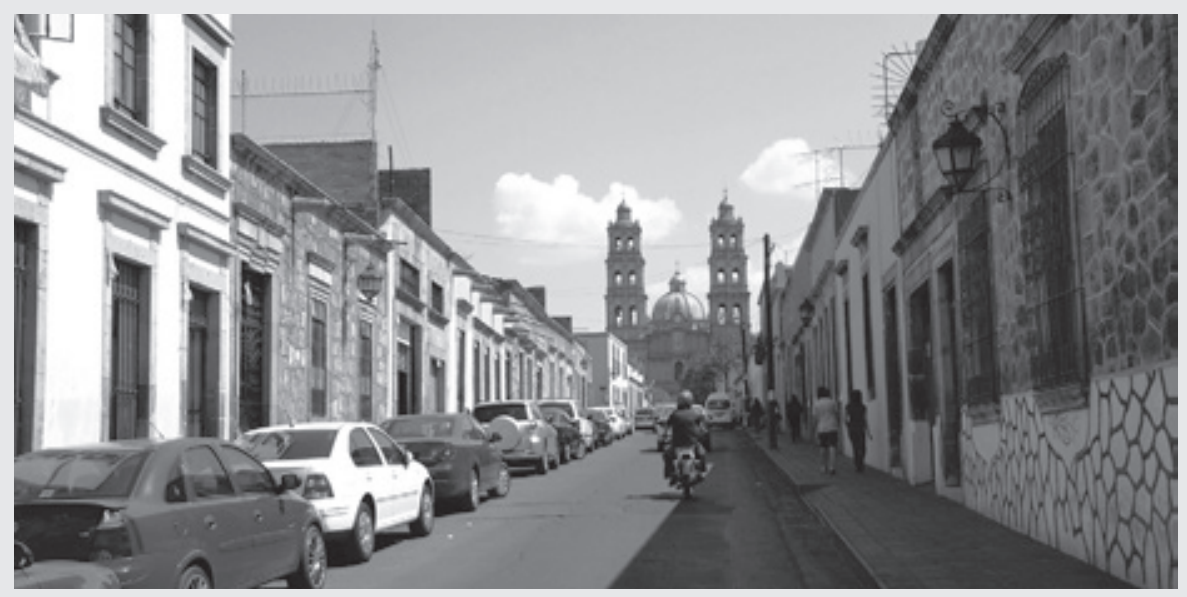

328. Perspectiva voltada à fachada setecentista do Templo de San José. Fonte: Fotografia elaborada pelo autor (2009).

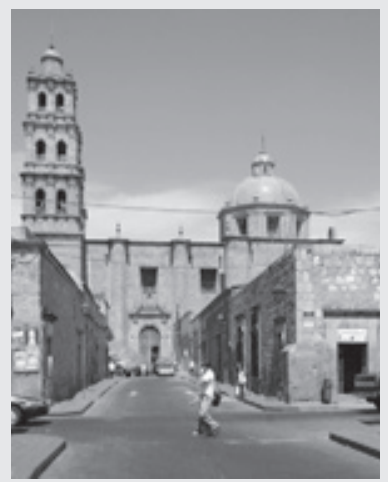

329. Encaminhamento em profundidade para a fachada lateral de San José. Fonte: Fotografia elaborada pelo autor (2009).

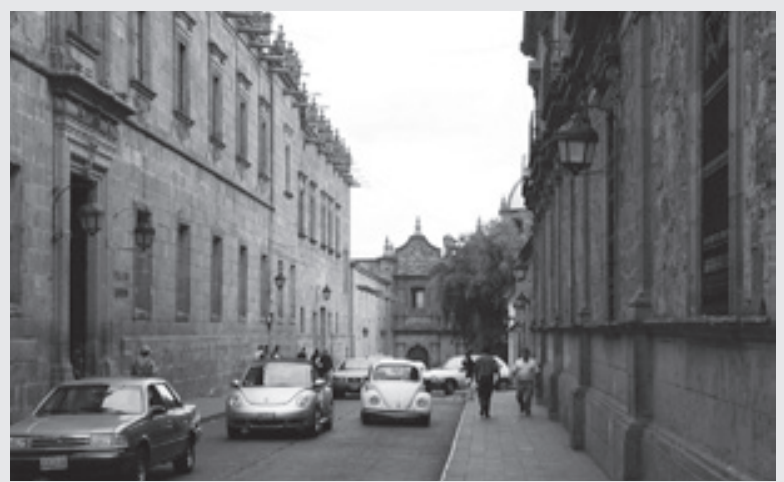

330. Perspectiva direcionada à fachada barroca do Templo de las Rosas. Fonte: Fotografia elaborada pelo autor (2009).

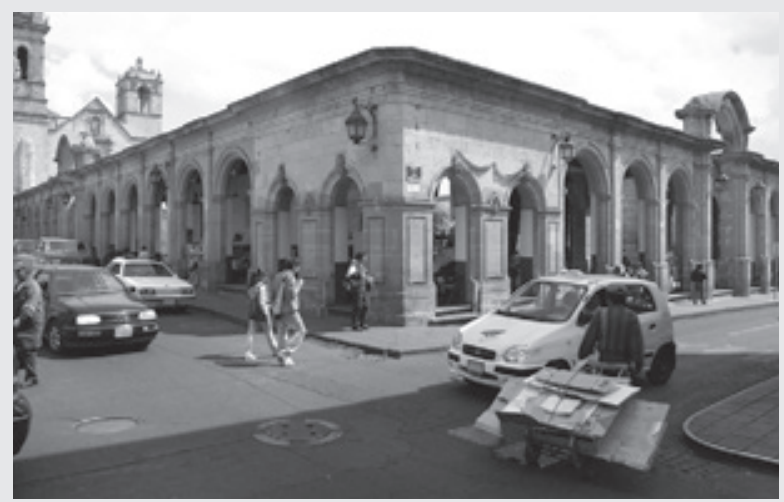

331. Galerias porticadas que envolvem o adro da Igreja e Convento de San Agustín, em Morelia. Ao fundo, as torres da igreja. Fonte: Fotografia elaborada pelo autor (2009).

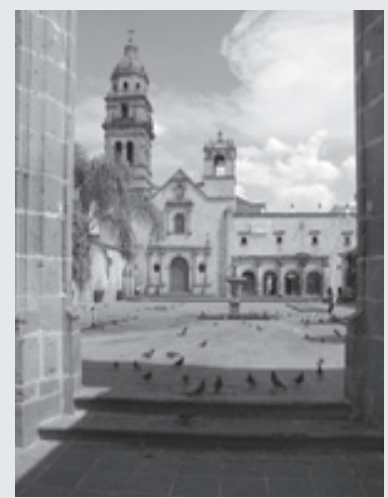

332. O Adro e a Igreja de San

Agustín, em Morelia, vistos do arco principal das galerias porticadas que envolvem o grande espaço. Fonte: Fotografia elaborada pelo autor (2009). 
entre as construções civis, institucionais e, principalmente, aquelas de cunho religioso e os panoramas persuasivos e teatrais emanados no núcleo urbano.

Consequentemente, a avaliação da configuração visiva da Cusco colonial - cidade pré-hispânica do sul peruano, refundada em I534, pelo conquistador da região andina, Francisco Pizarro (I476-I54I) - poderia servir ao julgamento crítico das possibilidades de uma cidade de colonização espanhola se transformar em uma inebriante experiência barroca: devido, sobretudo, à presença marcante da dramática arquitetura componente.

Referindo-se às categorias de análise elaboradas pelo emérito pesquisador argentino da cidade e do urbanismo, Professor Jorge Enrique Hardoy (I926-I993) - categorias que versariam sobre os tipos de cidade estabelecidos nas Índias Ocidentais $^{103}$-, a traza de Cusco não estaria vinculada ao rígido modelo clásico, segundo as acepções do investigador argentino, e sim ao conhecido modelo regular, esquema que acolheria os assentamentos virreinales de conformação viária mais flexível; traza que poderia nascer mais bem adaptada ao sítio e à topografia. (HARDOY, I983, p. 320-32I) Não obstante, o modelo regular teria, como pressuposto, a presença de certo sentido de ordenação; um desenho composto por vias retilíneas que, frequentemente, poderiam se cruzar em ângulos retos. Já, segundo declararia o arquiteto, teórico, crítico, historiador da arquitetura e pesquisador argentino, Ramón Gutiérrez (nascido em i939) - em seu extenso estudo Arquitectura y Urbanismo en Iberoamérica, cuja primeira edição seria publicada em I983 -, o plano de Cusco deveria estar vinculado ao chamado modelo semirregular e, mais especificamente, à classe especial de ciudades superpuestas a assentamentos preexistentes - como a Cidade do México, Cholula, Quito entre tantas outras povoações da Mesoamérica e dos Andes. (GUTIÉRREZ, I997, p. 82-83)

Para além do indiscutível e complexo processo de "transculturação" derivado da impositiva sobreposição física e cultural espanhola frente ao cenário indígena da cidade, o motivo principal que permearia a escolha de Cusco para apreciação de sua configuração visiva proviria do fato da cidade ter passado, em I650, por um grande terremoto que destruiria quase todos os monumentos arquitetônicos de vulto - o que obrigaria a rápida reconstrução dos edifícios mais significativos, obras reerguidas sob a inspiração plástico-compositiva do Barroco.

103 Conceito exposto, pela primeira vez, no texto de 1968, El modelo clásico de la ciudad colonial hispanoamericana. 


\section{A Cusco Inca}

A cidade pré-colombiana de Cusco teria nascido por volta do ano I200 da Era Cristã (CASTILLO VENERO, I983, p. 47), fundada, segundo a lenda, pelo primeiro Chefe de Estado inca, Manco Cápac. Na próxima centúria, se tornaria a capital de Tawantinsuyu - como era conhecido o poderoso império -, sendo levantada a 3400 metros de altitude, nos Andes Centrais, no ponto de encontro dos quatro grandes suyus (regiões) que dividiriam a longa extensão do domínio inca, cada um se desdobrando em direção a um dos pontos cardeais. ${ }^{\text {I04 }}$

Pela tradição, Pachacútec (I438-I47I), o governante que teria ampliado as parcas possessões incas para o monumental império andino de mais de 4000 quilômetros de extensão linear - desde a atual Colômbia, até a Argentina e o Chile -, seria o responsável pela reconstrução do centro nobiliário da cidade através de um eficiente plano racional (HARDOY, I999, p. 380), área urbana que contaria com as funções religiosas e administrativas da capital e que acolheria as residências dos nobres.

A cidade ganharia um desenho viário que, mesmo considerando adequadamente a topografia e os cursos d'água do vale dos Rios Huatanay e Tullumayo, apresentaria um ordenado traçado de caráter semirregular. Em sua investigação publicada em 2004, El espacio urbano en el Cusco colonial: uso y organización de las estructuras simbólicas, a arquiteta argentina Graciela María Viñuales (nascida em I940) delataria as características gerais da implantação do núcleo incaico:

A própria cidade pré-hispânica de Cusco não era o que hoje chamaríamos uma quadrícula, mas poderia reconhecer-se nela o uso de ruas retas e quadras retangulares, acomodadas - mais que implantadas sobre um terreno com fortes declives e cruzado por três cursos d'água. (VIÑUALES, 2004, p. i6, tradução nossa)

No centro da cidade se abriria a monumental Praça de Huacaypata, com uma dimensão de aproximadamente 150 por 450 metros, distribuída em um espaço que tenderia à forma de um retângulo. Este amplo vazio urbano, cercado de

104 Hardoy (1999, p. 353, tradução nossa), em seu livro de 1962, Ciudades Precolombinas, fruto da tese de doutorado defendida na Universidade de Harvard, nos Estados Unidos, nomearia as quatro províncias do império inca: "Tawantisuyu estava dividida em quatro províncias ou partes, chamadas 'suyu', com sua capital Cusco em seu centro; a província do sul se denominava Collasuyu, a do leste Antisuyu, a do norte Chinchaysuyu e a do oeste Cuntisuyu." 
construções rarefeitas e de pequena estatura, seria cruzado pelo Rio Huatanay determinando diferenciações simbólicas e de uso entre os dois grandes ambientes resultantes: a porção nordeste seria destinada a cerimônias religiosas e atos políticos; a face sudoeste estaria voltada ao lazer. Por outro lado, do mesmo modo que ocorreria na divisão política do imenso território inca, Cusco seria repartida em quatro setores principais que representariam os quatro suyus do império, bairros alcançados desde Huacaypata por importantes vias - estradas que, ao fim do núcleo urbano, seguiriam, simbolicamente, para as regiões de Tawantinsuyu através de quatro caminhos imperiais. (VIÑUALES, 2004, p. I6)

\section{A fundação da Cusco espanhola sobre os alicerces do núcleo pré-hispânico}

Esta imponente e bem desenhada cidade, cabeça do império inca, seria conquistada por Francisco Pizarro (I476 -I54I) em novembro de I533; em 23 de março do próximo ano, por iniciativa do conquistador espanhol, contaria com uma nova fundação: desta vez uma povoação levantada sob o signo da cruz e da espada; sob o domínio da Igreja católica e do rei da Espanha. Apesar do desejo incondicional dos invasores europeus de apagarem as marcas do passado indígena impressas na cidade preexistente - desígnio que teria levado Pizarro a levantar o novo assentamento acima dos vestígios da antiga cultura -, os espanhóis acabariam reconhecendo a qualidade urbanística do núcleo nativo, já que, após a destruição da cidade, aproveitariam grande parte do sistema viário e da infraestrutura preexistentes.

Ou seja, mesmo sendo redelineada de modo parcialmente regular, ainda hoje seria possível perceber inúmeras vias de traçado pré-hispânico nas proximidades da Plaza de Armas - onde se encontraria o núcleo cerimonial, administrativo e aristocrático da cidade configurada por Pachacútec. Na verdade, as grossas paredes de alvenaria inca - compostas por pedras de diversas dimensões, regularmente aparelhadas e sem argamassa - acomodariam longos muros que alcançariam até os dois metros de altura: muros que estariam distribuídos por toda a cidade colonial, revelando parte do traçado remanescente da antiga capital de Tawantinsuyu - situação que não deixaria de expor trágicos e dramáticos panoramas perspectivos nas ruas coloniais. Na verdade, inúmeras construções 
hispânicas seriam edificadas aproveitando os alicerces e as paredes exteriores das casas incas; sobrados que, alinhados nas testadas dos logradouros preexistentes, apontariam - mesmo entre as artérias virreinales de caráter mais significativo a ocupação de muitas vias abertas no período pré-colombiano (Figuras 333-334). Viñuales (2004, p. I8, tradução nossa) acrescentaria:

Os espanhóis se encontram, então, com uma cidade que tinha alguns alinhamentos que atendiam bem a seus planos, e outros que resultavam difíceis. Por um lado, esta certa regularidade do traçado se encaixava com a ideia das fundações que então eram levadas adiante. A própria existência de uma praça onde existiam locais simbólicos importantes e até mesmo a presença de cursos d'água. Mas a amplitude do espaço central as tornou inacessíveis e por isto decidiu-se pela subdivisão, o que foi feito em etapas, mais ou menos rápidas, mas que continuou durante mais de cinquenta anos.

Portanto, na Cusco colonial, o elemento central da nova cidade viria a ser, como era usual na planificação e no desenvolvimento dos assentamentos hispânicos, a Plaza de Armas, imenso espaço vazio com o formato de um retângulo quase regular, desenvolvido, longitudinalmente, no sentido noroeste-sudeste. Apesar de sua dimensão grandiosa, o mais importante recinto público do núcleo hispânico nasceria da fragmentação do ambiente precedente ocupado pela Praça Huacaypata (Figuras 335-336). Seria o principal espaço religioso e cerimonial da cidade colonial, separado da outra face, remanescente do extenso vazio da antiga praça inca, por construções porticadas levantadas acima do Rio Huatanay (Figura 337). O lado sudoeste de Huacaypata, por sua vez, seria preenchido por outras duas praças e pelas construções que as separariam. El Regocijo seria a praça na qual se estabeleceria o cabildo e onde aconteceriam a maioria dos eventos e festas: tais como representações teatrais, corrida de toros, celebrações civis - ambiente que também seria conhecido pela remota alcunha quechua de Cusipata, denominação dada a este setor na antiga esplanada inca (Figura 338). A Praça de San Francisco, por sua vez, seria o átrio contíguo ao imponente convento franciscano e que viria a acumular as funções de adro religioso e de mercado indígena a céu aberto - o tradicional tianguez hispano-americano (Figura 339).

A diversidade, complexidade e extensão das praças coloniais e dos quarteirões que as separariam poderiam dar uma ideia do tamanho incomensurável de Huacaypata e da dimensão, frequentemente grandiosa, dos espaços abertos 


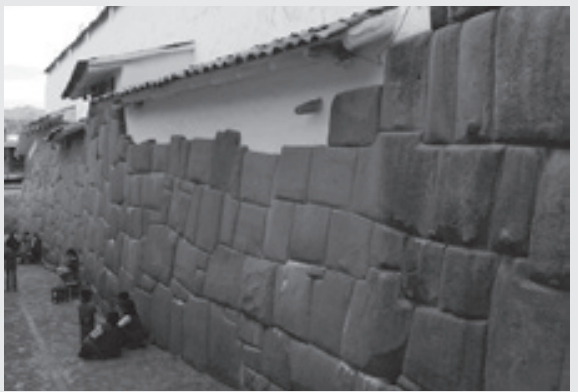

333. Casarões coloniais cusqueños construídos acima de alicerces e de muros incas remanescentes. Fonte: Fotografia elaborada pelo autor (2007)

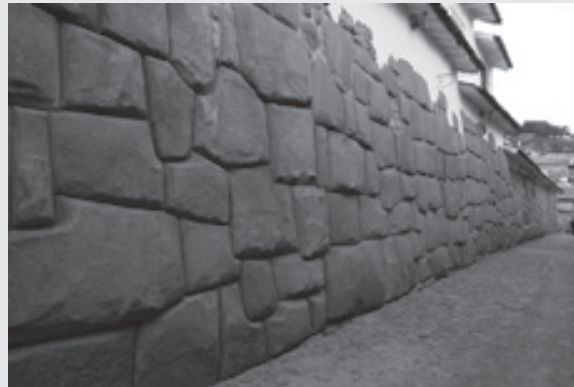

334. Casarões coloniais cusqueños construídos acima de alicerces e de muros incas remanescentes. Fonte: Fotografia elaborada pelo autor (2007).

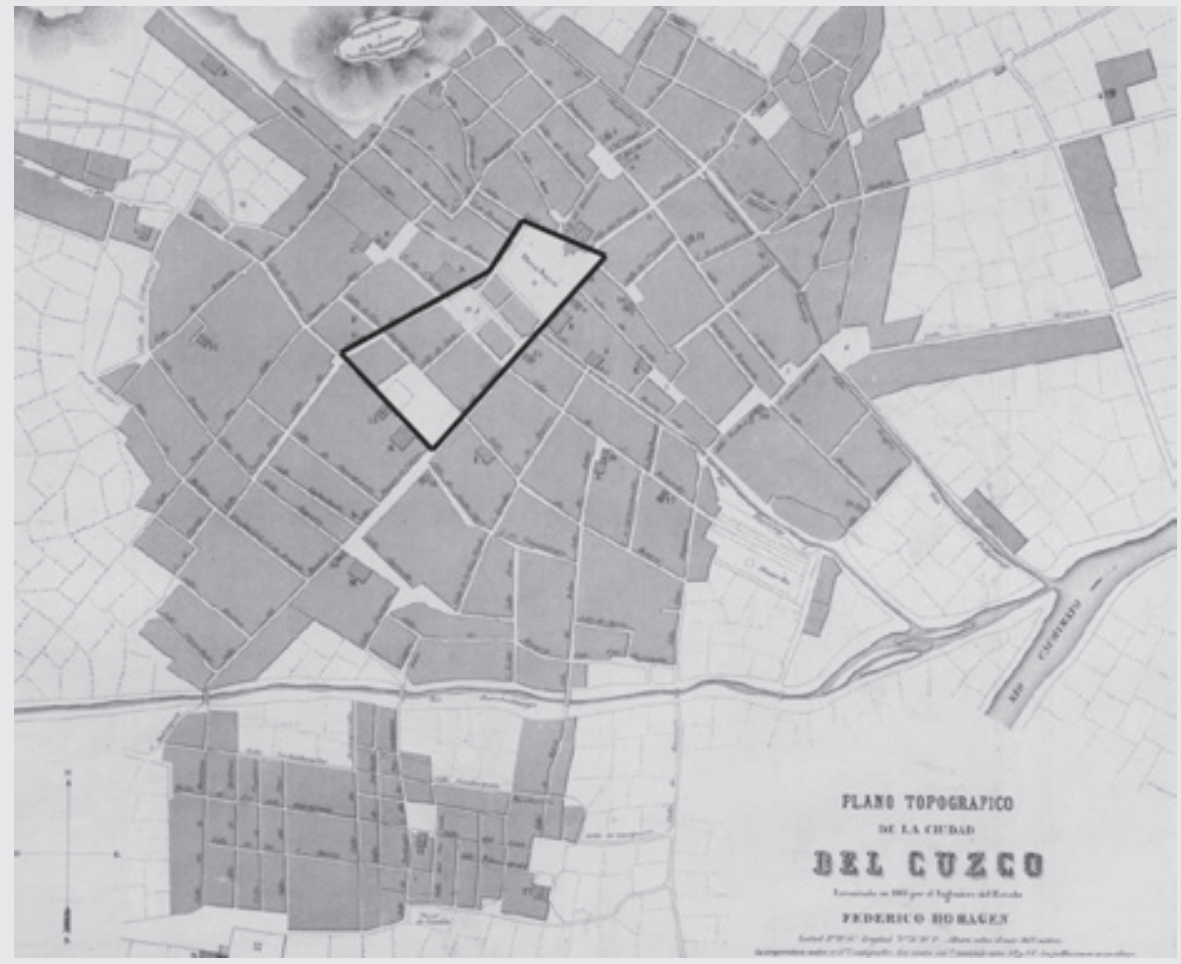

335. Plano Topográfico de la Ciudad del Cusco de 1861. Em destaque - envolvido com traços escuros -, o antigo contorno da imensa Praça de Huacaypata. A esplanada seria fragmentada pelos espanhóis e dividida em três grandes recintos: a Plaza de Armas, acima; a Plaza El Regocijo, ao meio; e a Plaza de San Francisco, abaixo. Fonte: Elaboração do autor a partir do plano de 1861. Disponível no site David Rumsey Historical Map Collection. 


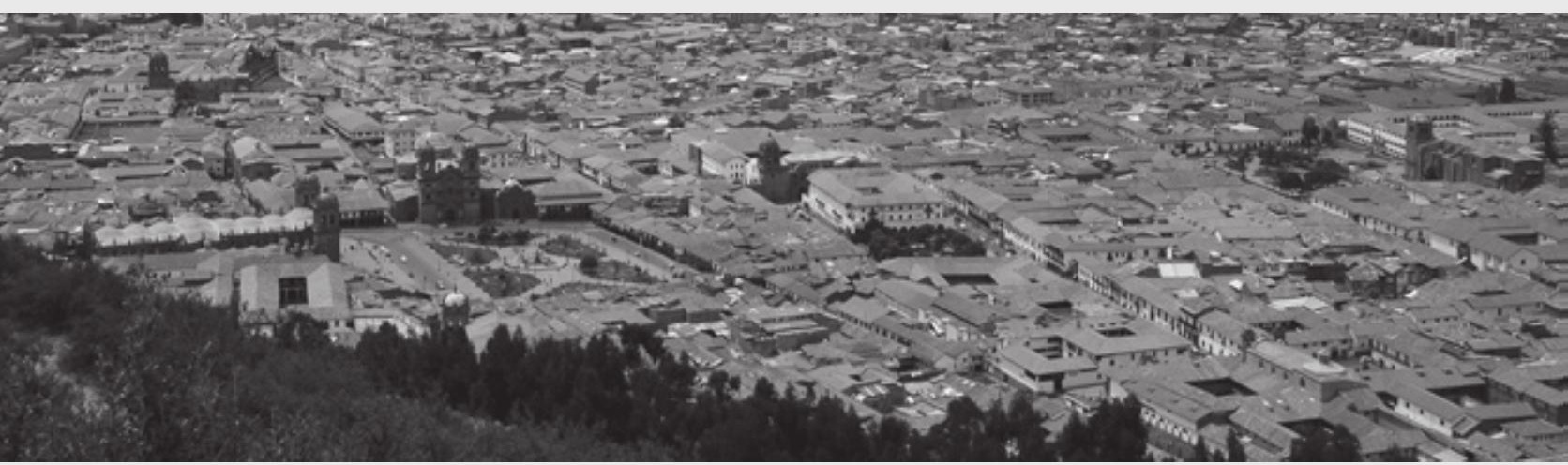

336. Fotografia de Cusco retirada da colina na qual se assenta a fortaleza inca de Sacsayhuamán. Reparar os vazios das três praças hispânicas, da esquerda para a direita, sequencialmente: a Plaza de Armas, a Plaza El Regocijo e a Plaza de San Francisco - ambientes que ocupariam, separadamente, a antiga Esplanada inca de Huacaypata. Fonte: Fotografia elaborada pelo autor (2007).

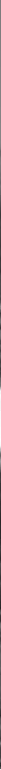

337. Casarões com galerias porticadas na Plaza de Armas de Cusco. Fonte: Fotografia elaborada pelo autor (2007). 


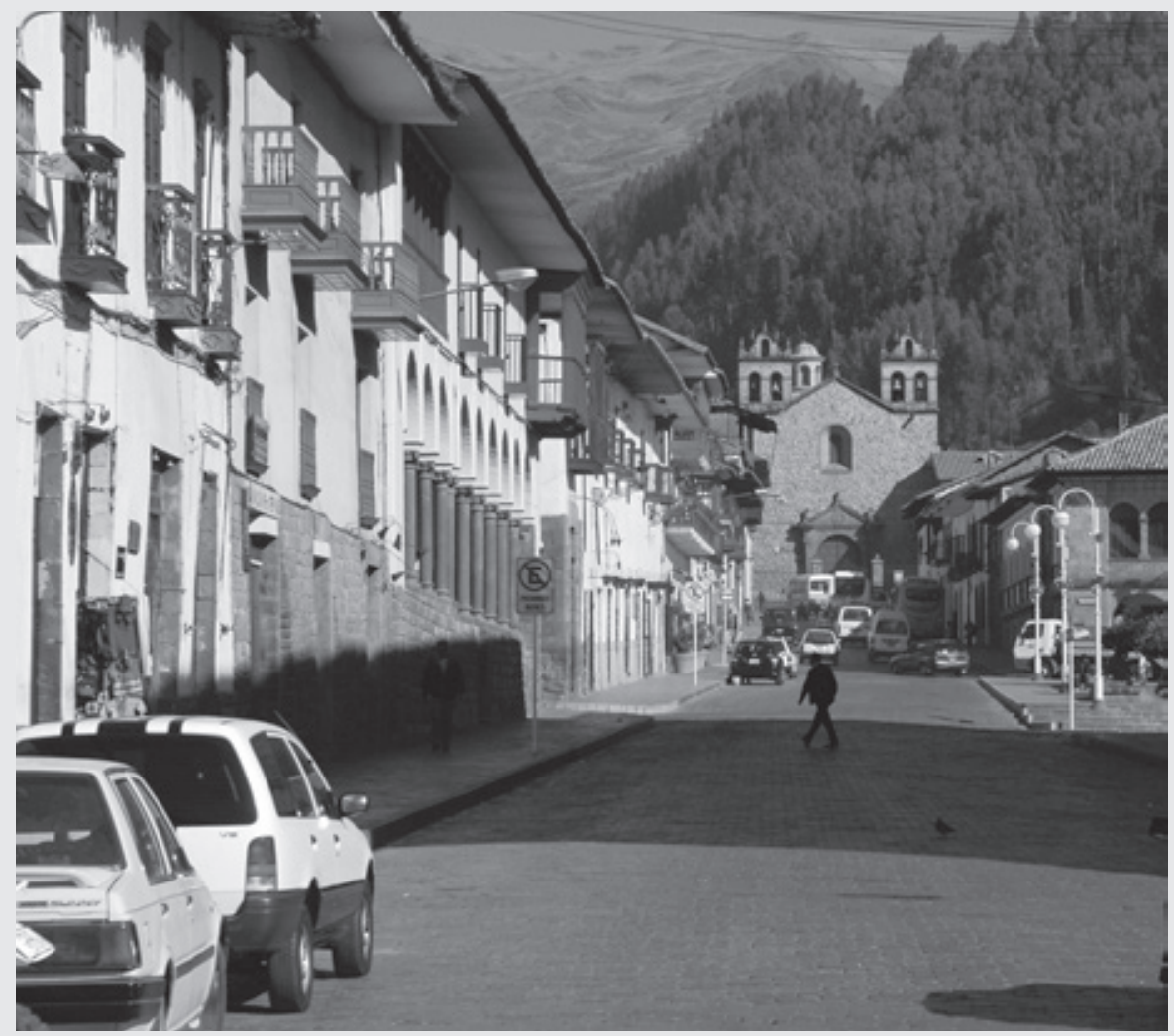

338. Casarões que ocupam um dos lados da Plaza El Regocijo. Ao fundo, em perspectiva, a Igreja de Santa Teresa. Fonte: Fotografia elaborada pelo autor (2007).

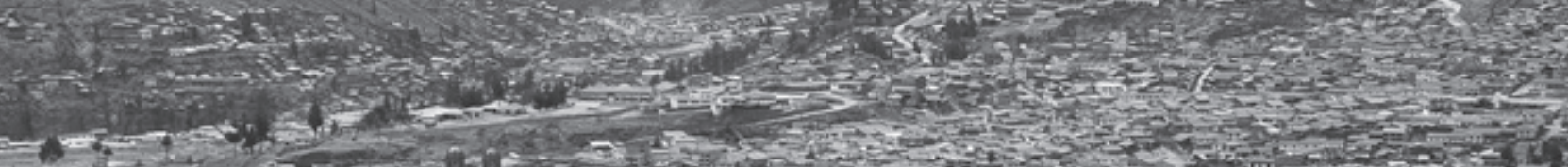

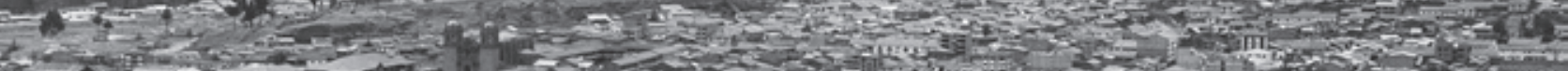
(4.6.

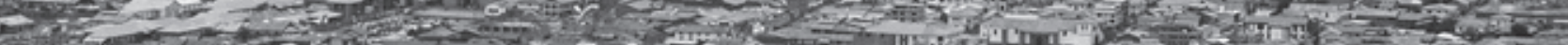

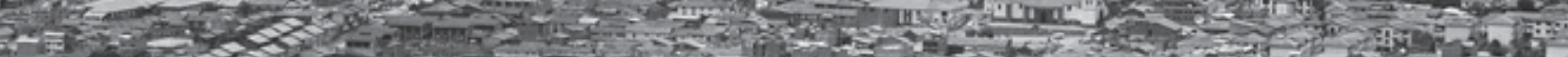

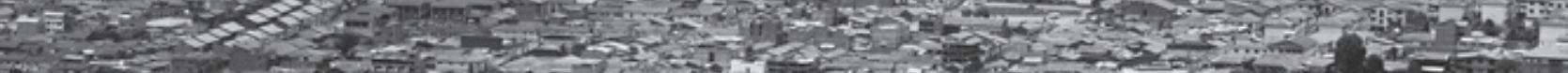

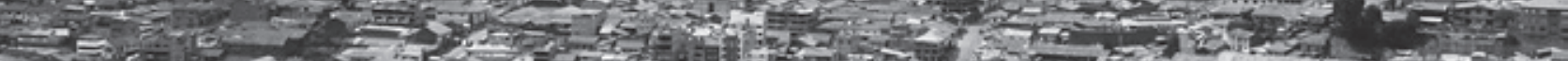

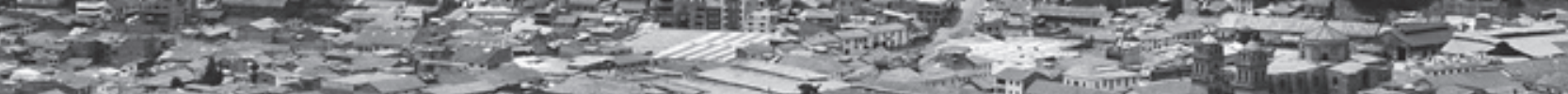

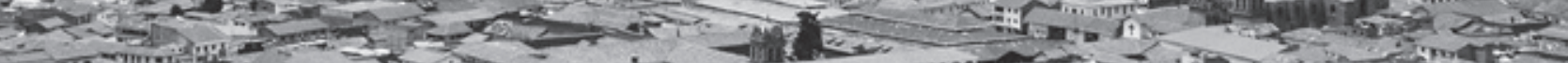

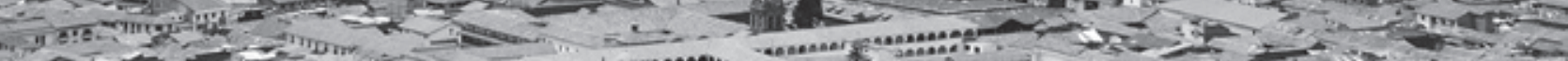

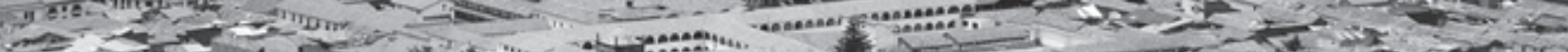

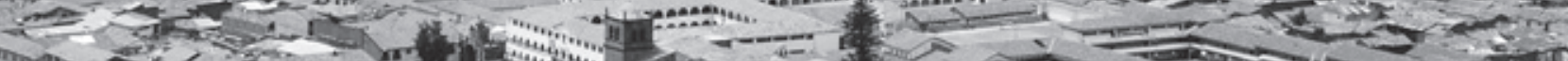

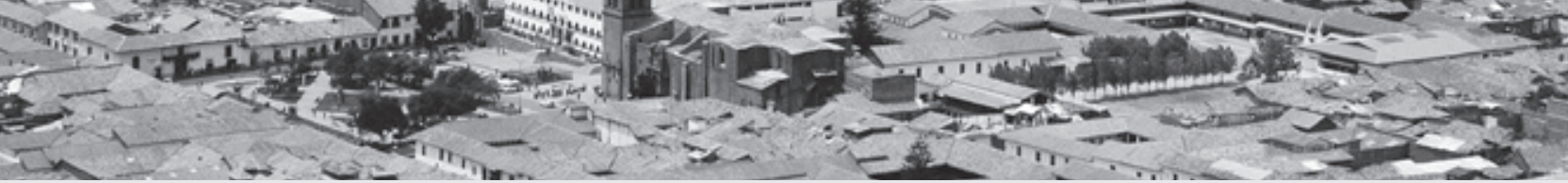

339. Fotografia panorâmica feita da colina onde se encontra a fortaleza inca de Sacsayhuamán, com destaque para a Praça e Igreja de San Francisco. Fonte: Fotografia elaborada pelo autor (2007). 
que preencheriam as cidades pré-colombianas. Por outro lado, a especialização funcional de cada um dos três recintos urbanos coincidiria, em parte, com a hierarquia simbólica da praça remanescente: coincidiriam os espaços destinados aos ritos religiosos na cidade inca e no núcleo colonial, bem como aqueles dedicados ao lazer e às festas.

\section{A Plaza de Armas como estrutura cenográfica barroca}

Contudo, o cenário dramático da Plaza de Armas de Cusco não seria constituído, unicamente, pela sua condição como fragmento espacial da antiga Huacaypata, e sim pela presença marcante de pelo menos duas estruturas arquitetônicas singulares: a Catedral e a Igreja da Companhia de Jesus. Neste sentido, para apoiar a análise da configuração artística do núcleo urbano, seria interessante considerar o papel exercido por estas igrejas como elementos hierarquicamente privilegiados dispostos no âmago da cidade, na praça que recolheria as maiores atenções por parte dos espectadores. A estrutura monumental da Catedral e o majestoso templo jesuítico iriam pontuar, distintamente, a experiência da descoberta do ambiente citadino com seus vastos frontispícios que acomodariam verdadeiros retábulos barrocos esculpidos em pedra.

Assim, em um dos lados mais extensos da Plaza de Armas, na sua face nordeste, seria edificada a Catedral de Cusco. Levantada acima das ruínas do ancestral palácio do governante inca Viracocha (I380-I448), o oitavo monarca de Tawantinsuyu (BAYÓN, I974, p. 7I), marcaria duas tendências essenciais da arquitetura e da urbanística hispano-americanas: por um lado, a sobreposição de uma importante estrutura arquitetônica virreinal frente a um significativo monumento pré-colombiano, simbolizando o sepultamento dos valores culturais preexistentes e a ascensão de uma nova ordem - a imposição do cristianismo católico; por outro lado, a tradição colonial de se assentar a mole da principal construção eclesiástica da cidade na Plaza Mayor.

Apesar da exigência de sua criação ter sido cunhada já no ano de 1538 pelo primeiro bispo de Cusco, o frei dominicano Vicente Valverde (I498-I54I), a estrutura arquitetônica monumental da Catedral começaria a ser erguida somente em I560, seguindo projeto do venerável Francisco Becerra (1545-I605), arquiteto espanhol em exercício na Nova Espanha e no Peru - os dois vice-reinados que até 
o século XVIII dividiriam o território das Îndias Ocidentais. ${ }^{105} \mathrm{O}$ hábil construtor - que seria também responsável pelos riscos das sedes episcopais de Puebla e de Lima, bem como pelos projetos dos conventos dominicanos do México e de Quito e da clausura de Santo Agostinho da mesma cidade - provaria a qualidade técnica de seu trabalho e daqueles que o sucederiam durante o terremoto de I650: a Catedral de Cusco seria um dos únicos edifícios religiosos a escapar do colapso -, apesar de ainda estar em construção nesta ocasião, sendo consagrada alguns anos depois do sismo, em I654. (BUSCHIAZZO, I944, p. 95-97)

A implantação da larga fachada - que encerraria uma parte significativa da face nordeste da praça, nas proximidades do vértice que marcaria o encontro com o lado sudeste - voltada de frente para o grande vazio que se abriria diante do templo, tendo seu eixo principal cruzando perpendicularmente a testada da igreja, seria clara exceção entre as primeiras matrizes e catedrais alçadas nas cidades virreinales. Segundo os estudos de Nicolini (2005, p. 232), as plazas mayores contariam, comumente, com estruturas religiosas ajustadas de lado para o ambiente liberto das praças, ocupando toda a extensão de um dos flancos que encerrariam os vastos recintos abertos - deixando, quando muito, um pequeno respiro à frente da igreja (todavia, fora dos domínios da plaza). Ou seja, a opção de Becerra por erguer a Catedral com sua monumental frontaria direcionada imediatamente ao espectador que acorreria a Plaza de Armas favoreceria a constituição, a posteriori, de um dramático cenário perspectivo barroco (Figuras 340-343).

Contribuindo para sua exaltação cenográfica, apresentaria outras duas pequenas igrejas adossadas à sua fachada principal, recuadas em relação à sua dilatada fachada em sinal de respeito à Catedral - devido à sua condição hierarquicamente inferior diante do grande templo. A mais antiga, El Triunfo, seria a igreja que acolheria a cadeira do bispo até a consagração da atual Catedral, mais de IOo anos após a fundação do primitivo templo. Já na década de 1530, a igreja seria levantada acima das ruínas do Palácio inca de Sunturhuasi, ao lado direito da fachada principal da igreja maior, em um dos limites da face nordeste da praça (Figura 344). No outro costado seria construída, a partir de I723, a Capela de Jesús y María (Figura 345), complementando o conjunto volumétrico, de alto teor cenográfico, composto pelos organismos religiosos deste flanco da Plaza de Armas.

105 Nos setecentos seriam criados o Vice-Reinado de Nova Granada (1717), com sede em Santa Fé de Bogotá, cidade fundada em 1538, e o Vice-Reinado do Rio da Prata (1777), com sede em Buenos Aires, núcleo criado em 1536. 
A estrutura maneirista da igreja, por sua vez, formada por uma massa poderosa e sólida, surgiria como um dos eloquentes e grandiosos volumes que romperiam o conjunto formado pelas galerias porticadas, sobrepostas por casarões com balcões, que envolveriam o ambiente da Plaza de Armas. Sua fachada principal seria emoldurada por duas torres barrocas, de acanhada estatura, achatadas e pesadas - solução frequente na composição da arquitetura eclesiástica em muitos territórios das Índias Ocidentais, especialmente na área andina, que sofreria constantemente com trágicos terremotos. ${ }^{106}$ A largura incomum da frontaria provocaria a sensação de que o volume da igreja invadiria o ambiente à frente dilatando-se, simbolicamente, para toda área da praça principal da cidade. Este sentido de diástole oferecido pela projeção perspéctica do edifício diante da praça e pela expansão transversal do frontispício para além de sua larga testada - direcionamentos virtuais que buscariam preencher o vazio urbano seria favorecido pela implantação do templo, que se colocaria à frente das duas capelas agregadas às suas fachadas laterais. Na verdade, as igrejas lançadas aos costados da Catedral, subordinadas simbolicamente e plasticamente a ela, reforçariam o sentido ilusório da projeção perspectiva da sua frontaria e de parte de sua nave para o espaço aberto à frente - efeito provocado pelo avanço virtual da fachada diante dos templos retrocedidos. Fernando Chueca Goitia (I980, v. I, p. I93, tradução nossa) comentaria - no artigo de 1980, El Barroco hispánico y sus invariantes $^{\mathrm{IO} 7}$ - a consequência plástico-compositiva desta tendência hispano-americana de agregar outros organismos religiosos à fachada das igrejas maiores (Figura 346):

O agrupamento de igrejas, uma grande e dominante e outra ou outras pequenas, é muito frequente na América e fértil para a promoção dos jogos volumétricos e espaciais do maior encanto arquitetônico. Não há catedral que não tenha um sacrário anexo, concebido como uma igreja menor satélite. No caso da Catedral de Cusco o tema se duplica

106 Sobre os campanários da Catedral, o arquiteto argentino e historiador da arte, Professor Mario José Buschiazzo (1902-1970), diria, em seu livro de 1944, Estudios de arquitectura colonial hispano americana: "As torres são posteriores ao famoso terremoto, razão pela qual foram feitas de escassa altura temendo novas sacudidas, desproporção que, embora claramente visível na silhueta do edifício, contribui, por outro lado, para acentuar a impressão desafiante de grandes massas horizontais que são a característica do soberbo templo." (BUSCHIAZZO, 1944, p. 99, tradução nossa)

107 Texto publicado nas Atas do Simposio internazionale sul Barocco Latino Americano, evento que aconteceu em Roma no ano de 1980. 

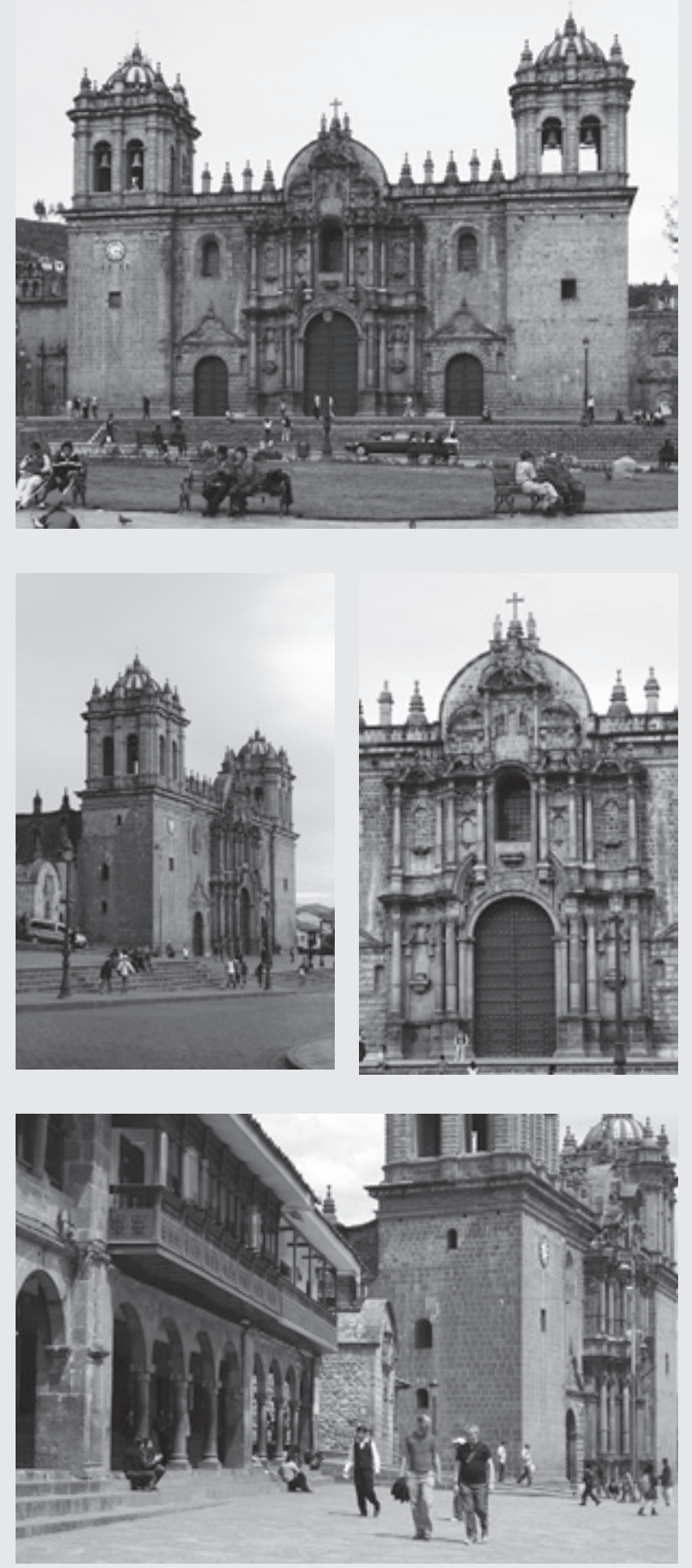

340. A Catedral na Plaza de Armas de Cusco. Fonte: Fotografia elaborada pelo autor (2007).

341. À esquerda, a Catedral, sede episcopal de Cusco, em imagem em escorço. Fonte: Fotografia elaborada pelo autor (2007).

342. A direita, frontispício barroco da Catedral de Cusco. Fonte: Fotografia elaborada pelo autor (2007).
343. Casarões com soportales do lado nordeste da Plaza de Armas e a Catedral de Cusco. Fonte: Fotografia elaborada pelo autor (2007). 


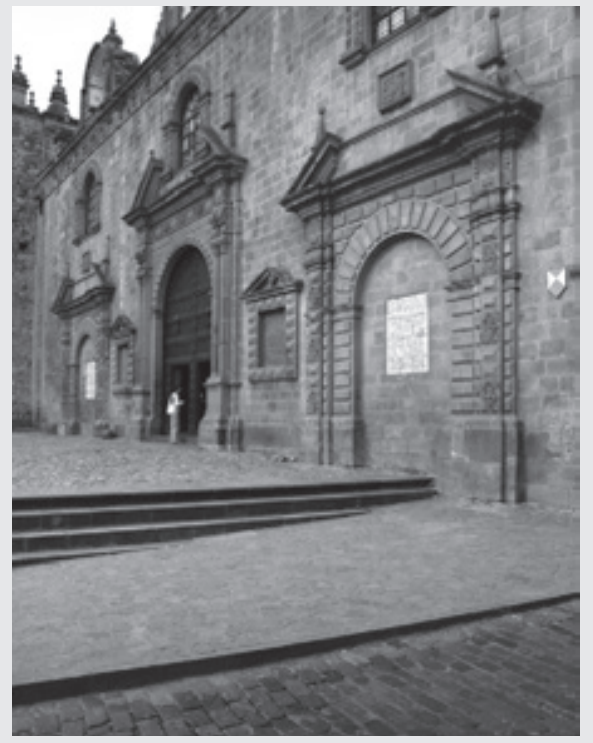

344. Igreja El Triunfo, ao lado direito da Catedral de Cusco. Fonte: Fotografia elaborada pelo autor (2007).

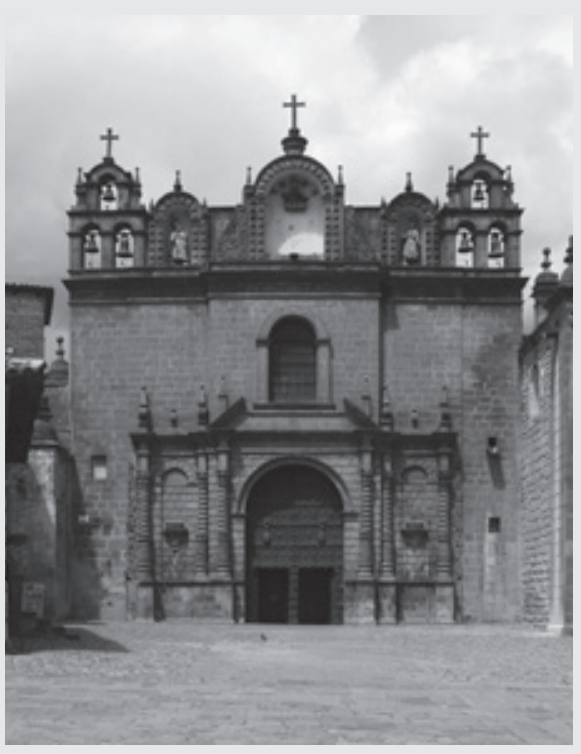

345. Capela de Jesús y María, ao lado esquerdo da Catedral. Fonte: Fotografia elaborada pelo autor (2007).

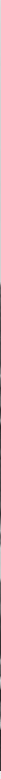

346. Sede episcopal de Cusco e a antiga Igreja de El Triunfo, à direita. Fonte: Fotografia elaborada pelo autor (2007). 
e o corpo da igreja principal se vê acompanhado por dois templos satélites, de Jesus e Maria, e do Triunfo. As fachadas das duas igrejas satélites ficam retraídas com respeito à principal e se constituem em espaços em esquadro dos mais sugestivos. O movimento dos conjuntos assim obtido, ressaltado, por sua vez, por torres e cúpulas, é uma fonte de contrastes arquitetônicos cheios de intencionalidade plástica.

lgualmente expressivo seria o dinâmico frontispício da Catedral. Após o terremoto de meados do século XVII, a frontaria apareceria coberta por uma intrincada e agitada composição barroca formada por elementos de relevo derivados do repertório clássico greco-romano: colunas da ordem coríntia, arquitraves, frisos, cornijas, frontões curvilíneos - uma rica modenatura arquitetônica que avançaria e recuaria à frente da superfície das rugosas paredes da fachada. Deste modo, o conjunto decorativo conformaria um retábulo de pedra exposto diante da praça, uma complexa máquina cenográfica barroca que entraria em grave contraste com a sobriedade, a densidade e a assepsia do restante da fachada, bem como com a poderosa massa das torres comprimidas. Esta profusão de elementos arquitetônicos sobrepostos revelaria a típica relação "figura-fundo" dos edifícios hispano-americanos - o confronto entre a ornamentação aplicada e as superfícies estéreis que marcariam os corpos construtivos. Chueca Goitia (I984, v. 8, p. 25-26, tradução nossa), no livro que discorreria sobre o Barroco na América hispânica, em Portugal e no Brasil, na coleção Historia de la arquitectura occidental (publicada a partir de 1974), faria uma boa síntese descritiva da fachada da Catedral de Cusco:

A fachada da Catedral de Cusco é muito harmoniosa em sua simplicidade. Forma um retângulo muito longo com duas torres baixas nas extremidades. Em seu centro, a grande portada é de um período posterior (I65I-I657) e do mais típico barroco cusqueño. É, curiosamente, muito delicada, em contraste com a severidade e o vigor da Catedral. É organizada em duas alas, com as colunas muito esbeltas e livres, o que lhe dá uma grande ligeireza. A porta, em arco, rompe o entablamento de primeira ordem e sua cornija se abre em dois ramos quase verticais (solução muito peruana). A janela central volta a romper o outro entablamento que vai estar se movendo com sutileza rococó.

Contudo, a Catedral teria que dividir a atenção com o mais expressivo monumento do Barroco cusqueño: o conjunto de La Compañía - complexo levantado logo após a chegada dos jesuítas à cidade, em I57I, mas totalmente reconstruído, 
oitenta anos depois, devido ao arruinamento causado pelo sismo de $1650 .{ }^{108} \mathrm{~A}$ igreja e o colégio seriam erguidos em um dos lados menores da Plaza de Armas, acima das ruínas do Palácio inca de Amuracancha (BAYÓN, I974, p. 74), residência de Huyana Cápac, décimo segundo imperador inca (que teria reinado de I493 a I525).

Esta copresença das duas estruturas arquitetônicas religiosas mais suntuosas da cidade disputando espaço na Plaza Mayor não iria se filiar ao modus operandi praticado pelos conquistadores; e Cusco, talvez, venha a ser o único exemplar significativo de núcleo urbano virreinal onde despontaria esta concorrência acirrada pela atenção do transeunte na praça principal. Os invasores peninsulares e a própria cúria municipal buscariam evitar que qualquer organismo arquitetônico religioso de caráter expressivo disputasse o interesse, na Plaza de Armas, com a Catedral - e na antiga capital inca não seria diferente, já que o Cabildo Eclesiástico teria feito grave oposição à construção da igreja dos jesuítas na praça, sob a alegação de que não se deveria erigir edifício de semelhante porte nas proximidades da Sede. (BUSCHIAZZO, I944, p. Ioo) Outras importantes cidades hispano-americanas, como Arequipa ou Oaxaca, também contariam com as Igrejas de La Compañía assentadas no alcance visual das praças; mas, nestes casos, elas apareceriam no encontro de duas das artérias que conformariam vértices dos recintos quadrangulares, nas esquinas opostas às Catedrais - logo, fora dos domínios das plazas; direcionadas visualmente a elas pelas nesgas abertas nos cruzamentos das vias.

Reforçando ainda mais a disputa pela comoção do espectador na praça central, La Compañía apresentaria, do mesmo modo que a Catedral, sua inebriante frontaria barroca voltada diretamente à plaza, assim como contaria com duas capelas unidas aos seus flancos - menos recuadas em relação à fachada principal do que no caso da sede episcopal. A estreita Igreja de Lourdes apareceria à esquerda do templo jesuítico; a Capela de San Ignacio despontaria do outro lado, junto à área na qual seria levantado o colégio da ordem. Esta pequena igreja, particularmente, apresentaria uma rica e entalhada fachada barroca recoberta por formas estereométricas que lembrariam "pontas de diamantes", superando, em expressividade, as elevações frontais dos templos adossados à Catedral.

Mas nada que pudesse se comparar ao tratamento da verticalizada fachada da igreja jesuítica que viria a dominar, visualmente, a Plaza de Armas após a segunda metade do século XVII - para o desgosto dos canônicos da sede episcopal -, uma

108 Segundo Ramón Gutiérrez (1997, p. 160), reedificado entre 1651 e 1668. 
solução arquitetônica muito arrojada, se for levado em consideração o risco constante de desmoronamento que uma estrutura tão elevada sofreria naquela região sujeita a fortes abalos sísmicos. O decorativo frontispício de pedra se destacaria, por contraste "figura-fundo", diante das duas torres nas quais estaria enquadrado - organismos profundamente expressivos, mas de articulação mais simples que o maquinário barroco da portada central (Figuras 347-349). No livro de 1974, Sociedad y arquitectura sudamericana: una lectura polémica, o historiador da arte argentino, Damián Bayón (I915-I995), faria uma excelente descrição da fachada:

\begin{abstract}
A fachada da Companhia de Cusco é uma página brilhante. O corpo central da fachada principal articula-se com o conjunto, guardando, na realidade, uma suprema independência. Trata-se de um grande 'gesto' vertical talhado em pedra, um grande relevo - dentro do planimetria dominante - que possui vida e significado próprios. À sua maneira pode-se dizer que também usa a superposição de ordens, mas as colunas aneladas se 'afogam', literalmente, na proliferação geral e o olho só as descobre na análise e não à primeira vista. Esta é a sua vantagem e não seu inconveniente: o fragmento - verdadeiro morceau de bravure - imediatamente atrai a atenção até do mais distraído dos espectadores. É harmônico, ascensional: repetidas curvas se alçam, sucessivas, desde o arco rebaixado da porta, se tornando cada vez mais empinadas e peremptórias, como um tema musical, até culminar no ressalto de sombra trilobada que arrasta, em seu 'terremoto de formas', o entablamento, apesar de toda afirmação horizontal. (BAYÓN, I974, p. 85, tradução nossa)
\end{abstract}

Portanto, a Catedral, em sintonia com sua implantação em um dos lados maiores da praça, direcionada a um espaço bem mais largo do que comprido, constituiria a dominante horizontal da esplanada; já a Igreja de La Compañía, erigida diante do longilíneo eixo noroeste-sudeste que interceptaria um dos lados menores do grande recinto aberto, marcaria a componente vertical. O conjunto da Catedral se apresentaria como um monumental acontecimento arquitetônico que se expandiria lateralmente e perspectivamente para o espaço da Plaza Mayor, provocando um virtual alargamento de sua fachada-retábulo. O santuário dos jesuítas, por sua vez, desvelaria um dinâmico altar-mor de pedra, aprisionado e contraído pelas elegantes e graves estruturas volumétricas constituídas pelos altos campanários. A relação entre as massas edificadas das torres jesuíticas e o 


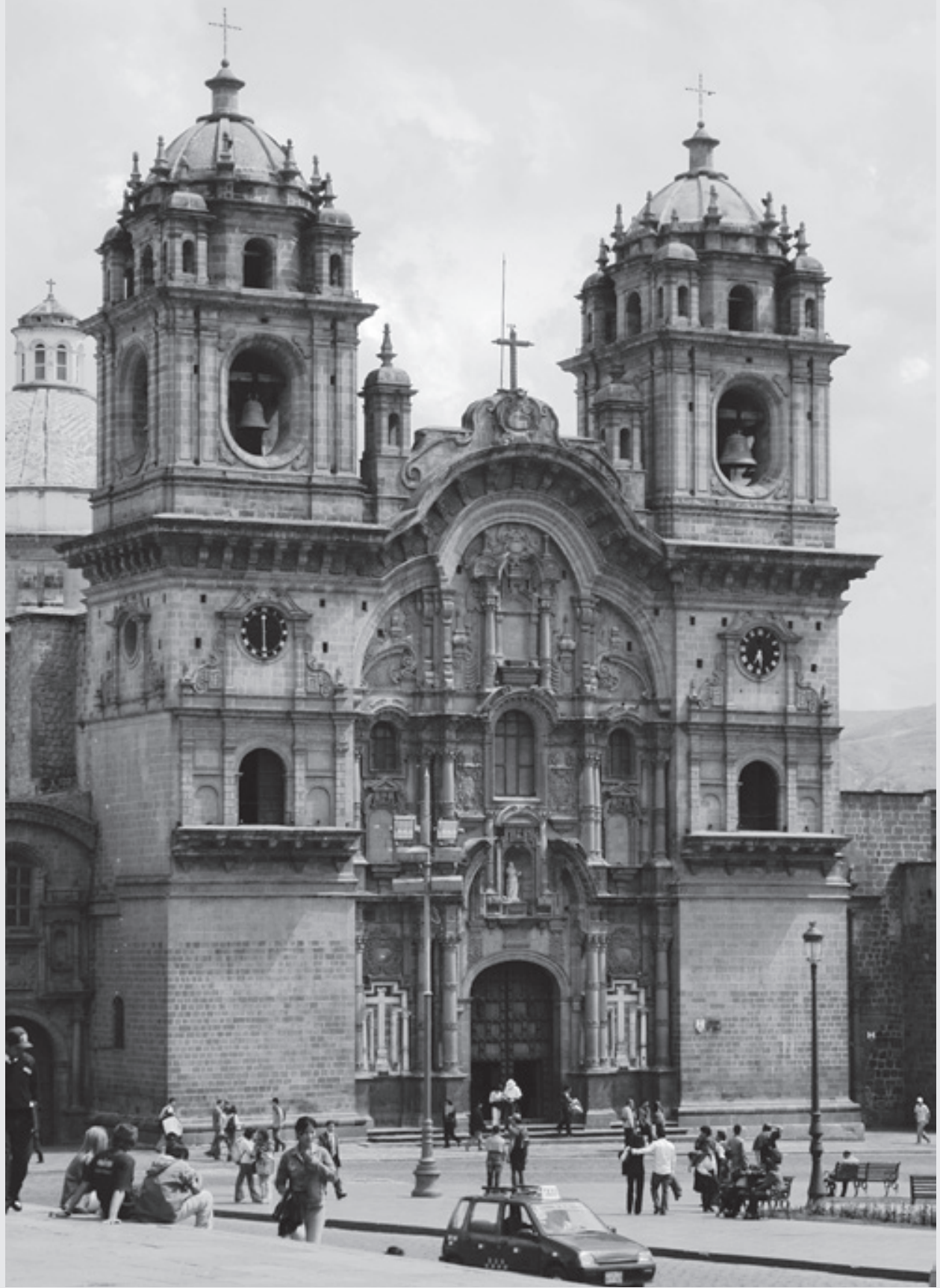

347. Igreja de La Compañia, em Cusco, apresentando sua fachada-retábulo. Fonte: Fotografia elaborada pelo autor (2007). 


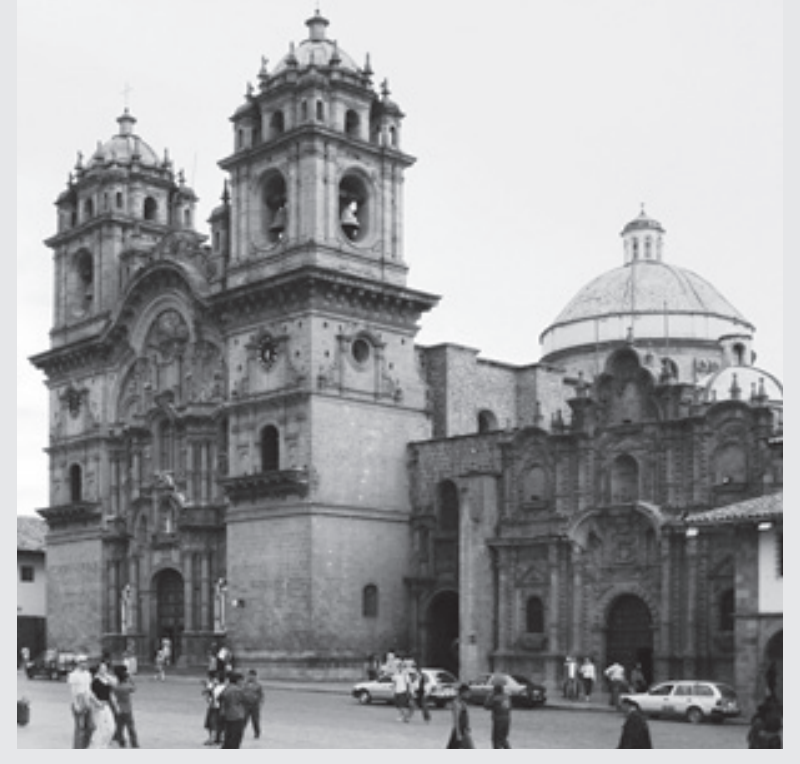

348. Igreja de La Compañia, com a Capela de Santo Ignacio agregada ao seu lado direito. Fonte: Fotografia elaborada pelo autor (2007).

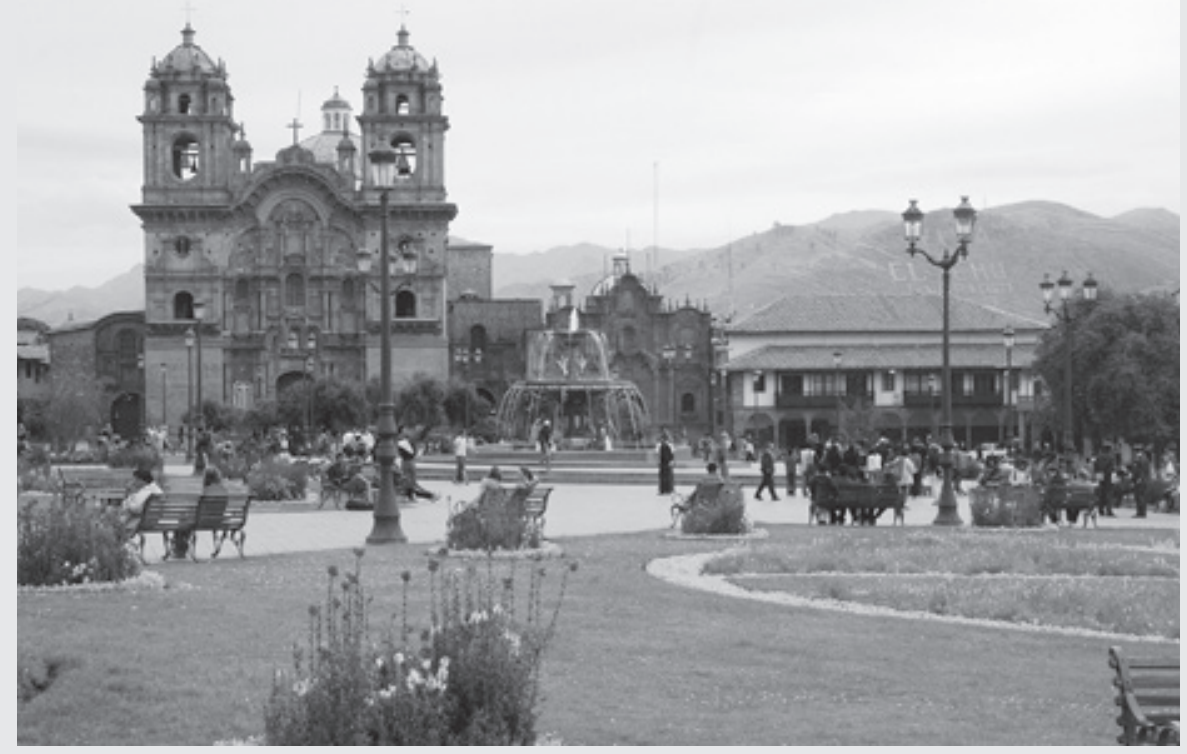

349. Nave a céu aberto da Plaza de Armas de Cusco, tendo como altar-mor a fachada-retábulo da igreja dos jesuítas. Fonte: Fotografia elaborada pelo autor (2007). 
frontispício tridimensional profusamente ornamentado, "acoplado" à superfície, produziria um sentimento de estrangulamento do núcleo central da fachada, sensação que levaria à ilusão de que o saliente retábulo barroco petrificado - armado sob o céu azul da Cusco colonial e voltado ao principal espaço do núcleo urbano - se desprenderia da frontaria planimétrica e também se projetaria idealmente à praça.

Não obstante, o efeito barroco mais significativo, retirado da experimentação dramática arrebatadora da Plaza de Armas, estaria fundado no convincente discurso retórico instigado pela concentração em conjunto - e não isoladamente - das ações cenográficas promovidas pelas duas estruturas religiosas adversárias: edifícios que imperariam majestosamente sem a ameaçadora presença de outros eloquentes complexos arquitetônicos de caráter institucional - como seria o costume nas plazas mayores das cidades hispano-americanas, que, usualmente, acolheriam a catedral ou igreja matriz, bem como o palácio municipal ou a sede do governo regional. Em Cusco, o cabildo contaria com sua própria praça demarcada na Cusipata, um dos fragmentos da antiga Huacaypata.

Contudo, o persuasivo evento barroco não seria expresso, unicamente, pela agitação suscitada na percepção contígua da imagem dos templos, panoramas que revelariam o poderoso contraponto da horizontalidade oferecida pela Catedral com a verticalidade proporcionada por La Compañía, mas também, notadamente, na justaposição dos espaços livres adjacentes às duas igrejas: o expansivo átrio dominado pela sede episcopal e a virtual nave, aberta à praça, disposta à frente do templo jesuítico - nave a céu aberto, encerrada pelo movimentado retábulo de pedra, enquadrado pela frontaria da igreja. O professor da Universidad Mayor de Chile, Romolo Trebbi del Trevigiano (200I, v. 2, p. II69, tradução nossa), proporia, no ensaio El atrio y su fachada como expresión espacial, formal y decorativa en la arquitectura ibero-americana: siglos $X V I-X V I I,{ }^{\mathrm{rog}}$ uma interpretação da relação entre estes dois organismos religiosos e a Plaza de Armas de Cusco, ao discutir a importância dos átrios das igrejas na América espanhola e da relação destes espaços, ao mesmo tempo públicos e privados, com as fachadas dos templos:

Muito interessante é o caso de Cusco, em que a praça principal, resultado da redução da precedente cancha Inca, tem duas igrejas que

109 Publicado em 2001, em Sevilha, na já citada coletânia Barroco Iberoamericano: territorio, arte, espacio y sociedad. 
disputam o espaço: a Catedral e a Companhia; a primeira de finais do século XVI, a segunda do século XVII.

Mas será a Companhia a que, com sua fachada-retábulo de estilo barroco, presidirá a praça-igreja como uma grandiosa nave aberta segundo os novos conceitos urbanísticos, enquanto que a Catedral, com seu grande átrio, sem muros que o limitem, e com a austeridade de seus volumes, rememora as soluções do século XVI. A praça é cercada por amplos portais que formam uma galeria contínua quebrada apenas pelos volumes grandes e imponentes das duas igrejas posicionadas em ângulo, para além dos edifícios anexos.

Em ocasiões de festas religiosas, durante o período colonial, os altares da Catedral eram deslocados para os lados da praça, as galerias eram cobertas com panos e cortinas e se armavam arcos triunfais no trajeto das procissões, enquanto as duas fachadas eclesiásticas se faziam de retábulos principais revivendo a função das capelas abertas dos índios.

O cerne da Plaza de Armas, portanto, revelaria uma fatal interpenetração dos dois adros religiosos que, à frente das igrejas principais e de seus retábulos exteriores, invadiriam e romperiam o vazio da praça através de um intenso e dinâmico movimento de dilatação. A longilínea nave jesuítica, rodeada pelos soportales das edificações civis, se justaporia ao átrio transversal da Catedral que, por sua vez, ocuparia o espaço da Plaza Mayor (Figuras 350-354).

Assim, a concentração destas duas estruturas ligadas ao poder espiritual, dispostas em um dos cantos do amplo espaço aberto, apoiaria um confronto dramático que, indubitavelmente, só favoreceria a intensificação do caráter barroco no núcleo urbano. O sentido de "maravilha" revelado na coexistência dos virtuais átrios - espaços ligados, simbolicamente, aos organismos religiosos - animaria a retórica barroca encenada no vazio da praça através de mais um esquema de sobreposição espacial lançado no retalho da remanescente esplanada inca.

\section{A "Via Sacra" como eixo dominante da Cusco barroca}

Para além do inebriante evento dramático conformado pela Plaza de Armas, a cidade abrigaria outros acontecimentos que animariam os panoramas capturados pelos espectadores, manifestações teatrais que contribuiriam para transformar a cidade em uma incondicional experiência barroca. Um destes acontecimentos 


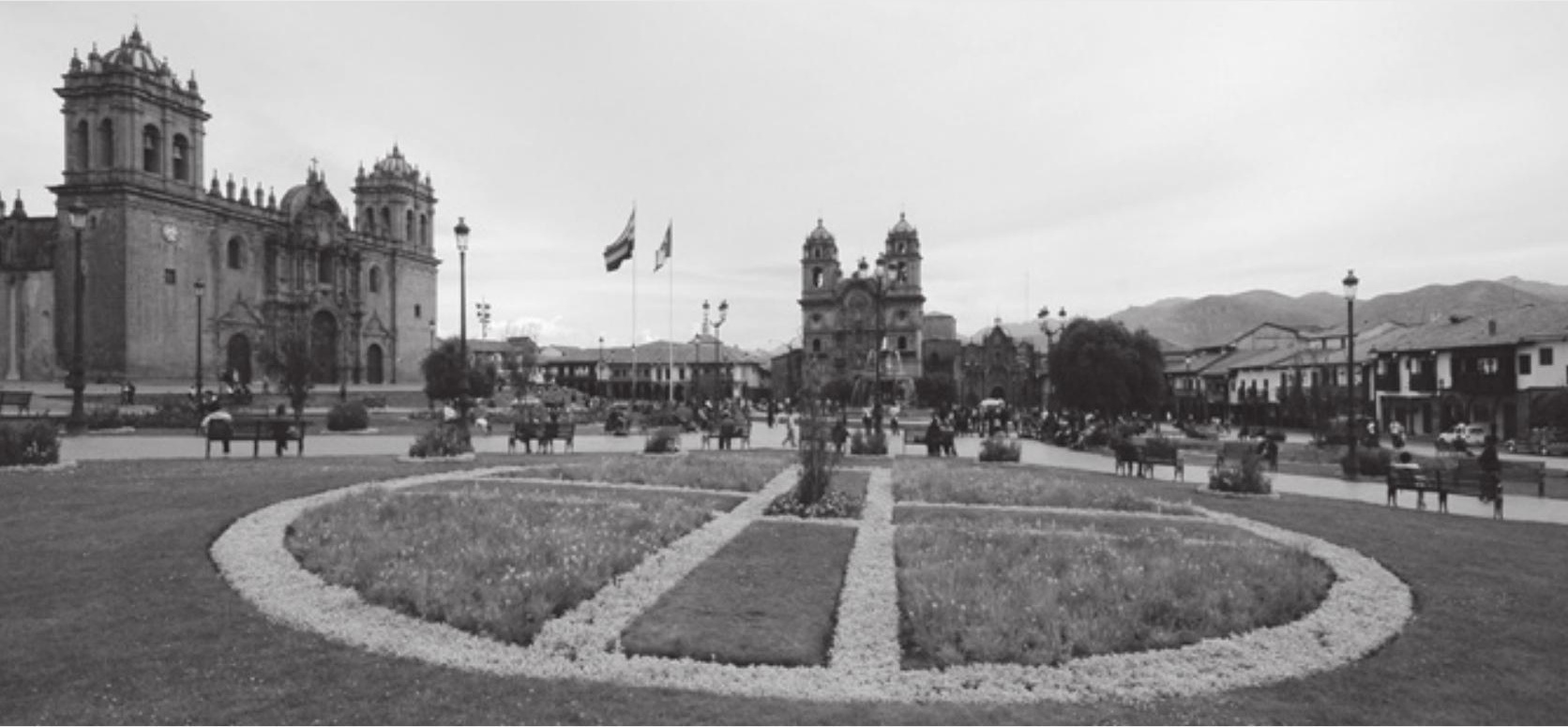

350. A sede episcopal de Cusco, à esquerda, e a Igreja de La Compañia, ao centro. Fonte: Fotografia elaborada pelo autor (2007).

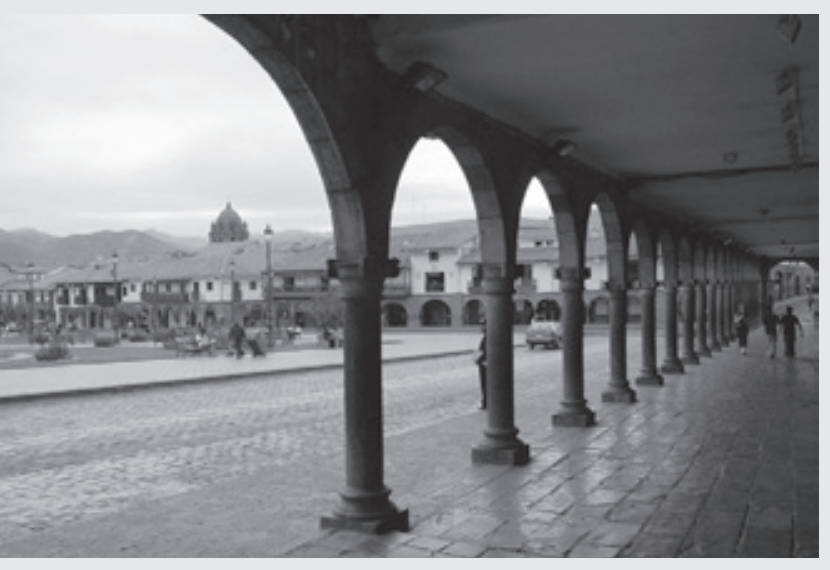

351. Edifícios com galerias porticadas da Plaza de Armas de Cusco. O espaço seria animado, dramaticamente, pela Catedral e pela igreja dos jesuítas. Fonte: Fotografia elaborada pelo autor (2007).

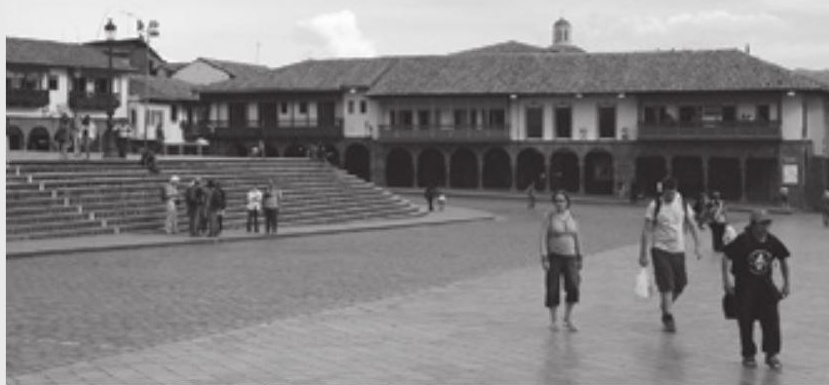

352. Plaza de Armas de Cusco, com destaque para as escadarias da Catedral. Fonte: Fotografia elaborada pelo autor (2007). 


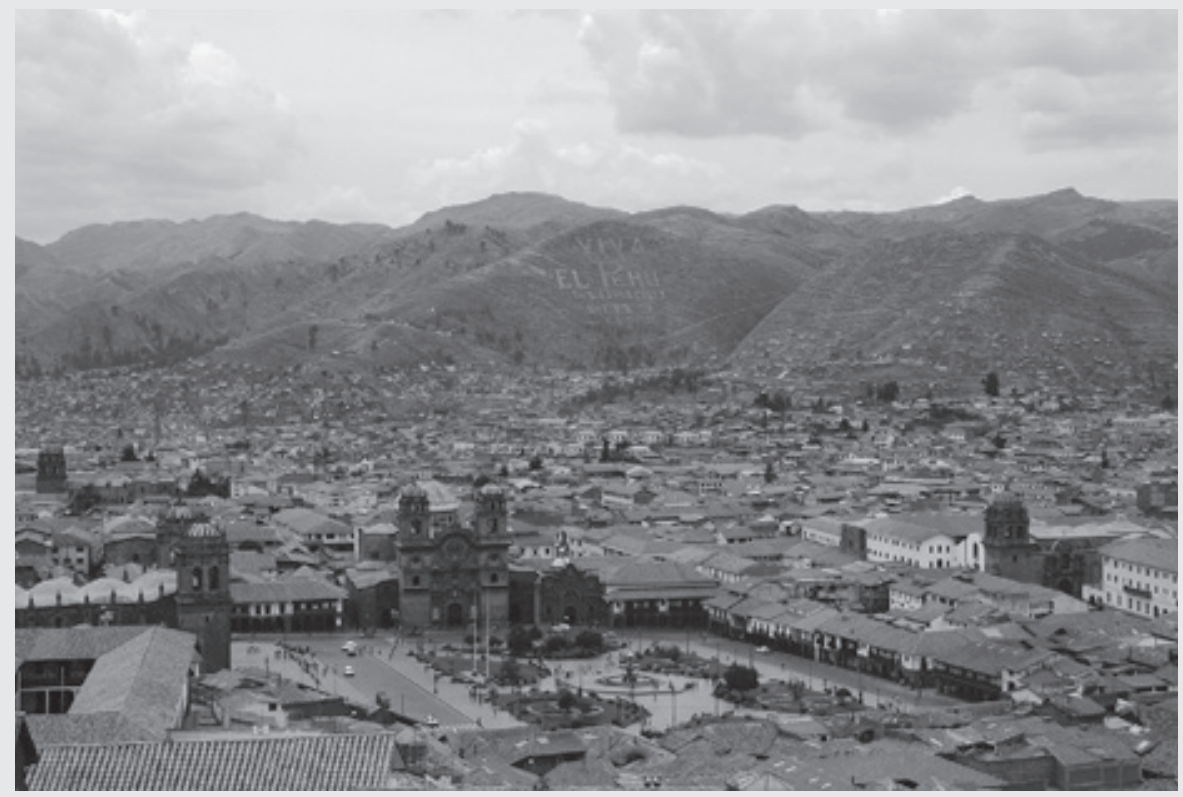

353. Fotografia feita da colina onde se encontra a Igreja de San Cristóbal, mostrando a Plaza de Armas de Cusco com suas duas igrejas. Percebe-se a conformação cenográfica do espaço se configurando como uma nave a céu aberto voltada para a fachada-retábulo da Igreja de La Compañia. Fonte: Fotografia elaborada pelo autor (2007).

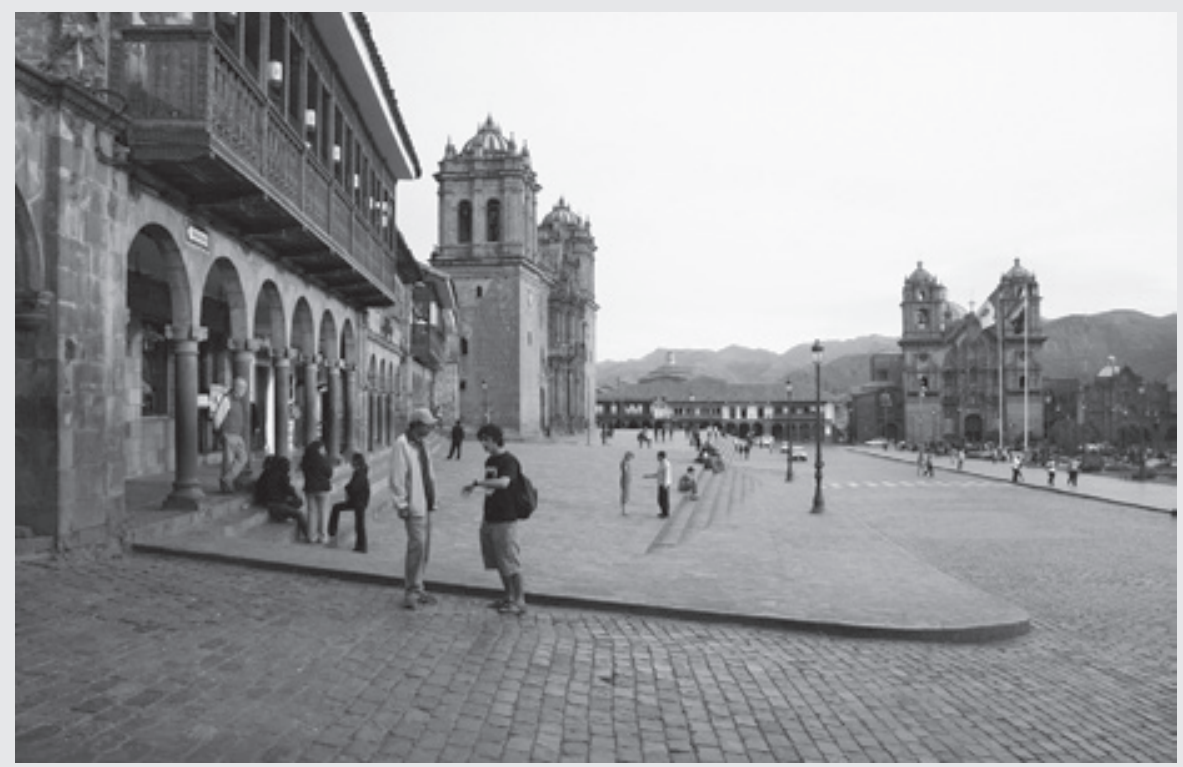

354. Sede Episcopal de Cusco - à esquerda - dividindo espaço, na Plaza de Armas, com a Igreja de La Compañia à direita. Fonte: Fotografia elaborada pelo autor (2007). 
estaria relacionado, diretamente, à praça principal e participaria dos processos de sobreposição e interpenetração física, simbólica e espacial que dominariam grande parte da configuração morfológica e artística do ambiente citadino. Seria um evento modelado pela mais importante artéria do núcleo colonial; uma estrada inca preexistente, remanescente da reorientação do traçado urbano após a nova fundação da cidade; eixo que marcaria dois dos caminhos voltados para os quatro suyus do império pré-hispânico - no caso, a estrada para Antisuyu, na aproximada direção leste (de fato, mais para nordeste) e o caminho ocidental para Cuntisuyu (que cruzaria a cidade vindo da direção sudoeste).

Segundo Graciela Viñuales (2004, p. 13), a preservação desta e de outras importantes vias pré-hispânicas estaria vinculada ao fato de as mais relevantes composições arquitetônicas e as mais proeminentes áreas cerimoniais da Cusco incaica terem sido, invariavelmente, sobrepostas pelas moles de conventos, monastérios, igrejas, hospitais, colégios, palácios - imponentes complexos arquitetônicos levantados na cidade colonial. De fato, seriam ações que indicariam a manutenção física dos lugares que abrigariam as estruturas simbólicas do antigo núcleo urbano pré-colombiano - estruturas, porém, totalmente ressignificadas no contexto da nova povoação cristã. Por outro lado, esta rua privilegiada cruzaria muitos dos mais admiráveis recintos sagrados do assentamento hispânico - como a Plaza de Armas e a Plaza de San Francisco; também receberia, sequencialmente, a maioria dos organismos eclesiásticos cusqueños de certa relevância, edifícios que substituiriam as tradicionais huacas ${ }^{\text {II }}$ indígenas. Por isso, este eixo organizador do espaço da cidade ganharia a denominação, por parte da pesquisadora argentina, de "Via Sacra".

Já foi dito que o centro nobiliário do núcleo urbano pré-hispânico conteria, tradicionalmente, para além da grande Esplanada de Huacaypata, as mais importantes áreas cerimoniais da cidade e as residências das famílias reais e da nobreza incaica. A grande massa da população viveria no entorno do núcleo de

110 Neste caso, o termo quéchua huaca indica os lugares sagrados da cultura inca.

111 "Porque além de consolidar a centralidade da praça, afirma-se a proeminência das antigas huacas e sítios cerimoniais que na colônia definem renovados usos e significados. Mas com esse marco volta-se a dar significado aos antigos eixos, entre os quais se sobressai o leste-oeste, que se transforma de maneira quase natural na 'Via Sacra' da cidade. As intervenções dos primeiros anos da conquista vão trabalhar em tal sentido, mas a configuração desta rota sagrada continuará ratificando-se ao longo dos séculos, quando uma ou outra vez se coloquem ou recondicionem edifícios e monumentos em toda a sua extensão." (VIÑUALES, 2004, p. 13-14, tradução nossa) 
poder, dispersa pelas áreas adjacentes e nas encostas e morros um pouco mais distantes. Com a chegada dos espanhóis, toda a população nativa da área central e de suas cercanias imediatas seria expulsa para dar lugar às moradias levantadas para os peninsulares, além dos palácios institucionais, igrejas, conventos para homens e monastérios femininos, estruturas arquitetônicas voltadas à população dominante. Os aborígenes seriam obrigados a se deslocarem para os bairros periféricos, povoando ainda mais as áreas de encostas e os morros - o que levaria o governo da metrópole a constituir diversas paróquias para índios, assim como edificar suas respectivas igrejas. (VIÑUALES, 2004, p. 136)

$\mathrm{Na}$ encosta a nordeste da Plaza de Armas seria erguida, provavelmente no início do século XVII, a Igreja de San Blas, templo que dominaria a paróquia de mesmo nome - uma das cinco primeiras a serem criadas para os nativos. Poderse-ia dizer que o inebriante interior da capela - formado por altares dourados ultraornamentados e por um suntuoso e movimentado púlpito, equipamentos lançados na nave e no presbitério, em contraste fatal com as paredes brancas desnudas de adobe e com o exterior de caráter essencialmente simples - marcaria o início (ou o encerramento) do eixo de mais de um quilômetro de extensão da "Via Sacra" (Figura 355). A antiga estrada inca passaria, na verdade, adjacente à estrutura de San Blas e de sua praça e desceria, em um percurso não muito linear, em direção à Plaza de Armas - disposta a cerca de quinhentos metros de distância.

Um pouco abaixo, a uma quadra da praça principal, a via passaria pelo Palácio Arzobispal, casarão que pertenceria aos Marqueses de San Juan de Buenavista, construído sobre as ruínas do palácio do governador inca, Roca - que reinaria, aproximadamente, de 1350 a I380. Sem dúvida, seria muito rica a experiência do transeunte que galgasse a encosta em direção a San Blas e se deparasse com a esquina na qual este edifício seria levantado, erguido sobre complexos muros incas preexistentes. O vértice do casarão contaria com um balcão quadrangular, justaposto a uma espécie de torreão ligeiramente saliente, um mirante lançado na esquina da "Via Sacra" com a atual Calle Herrajes - elemento arquitetônico sublinhado pelo telhado em balanço que cobriria toda extensão do organismo de madeira que avançaria sobre a rua desde o segundo piso do palácio. Um pouco à frente surgiria a imponente portada de pedra que distinguiria o acesso ao edifício - estrutura pujante, capturada através da visão em escorço devido à sua implantação angulosa, oriunda do deslocamento provocado pela portada ao se desalinhar do limite da testada. A interface entre o balcão, a cobertura proeminente, 


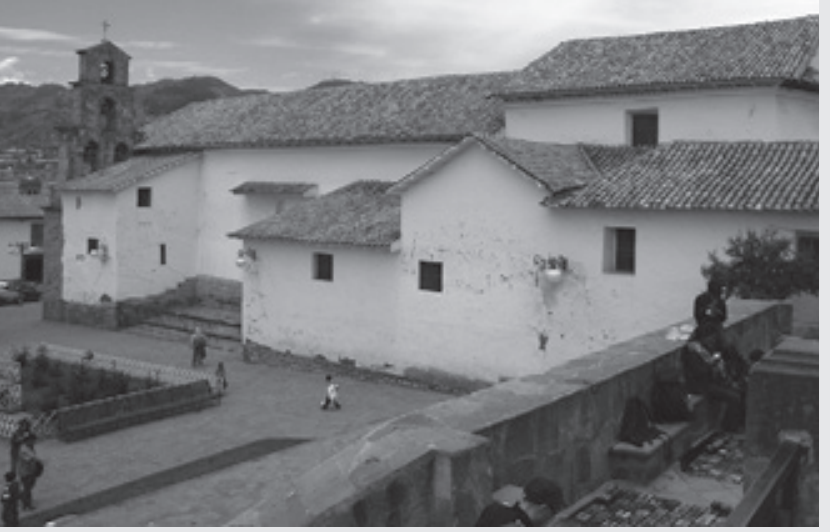

355. Igreja e Praça da comunidade indígena de San Blas, em Cusco. Fonte: Fotografia elaborada pelo autor (2007).

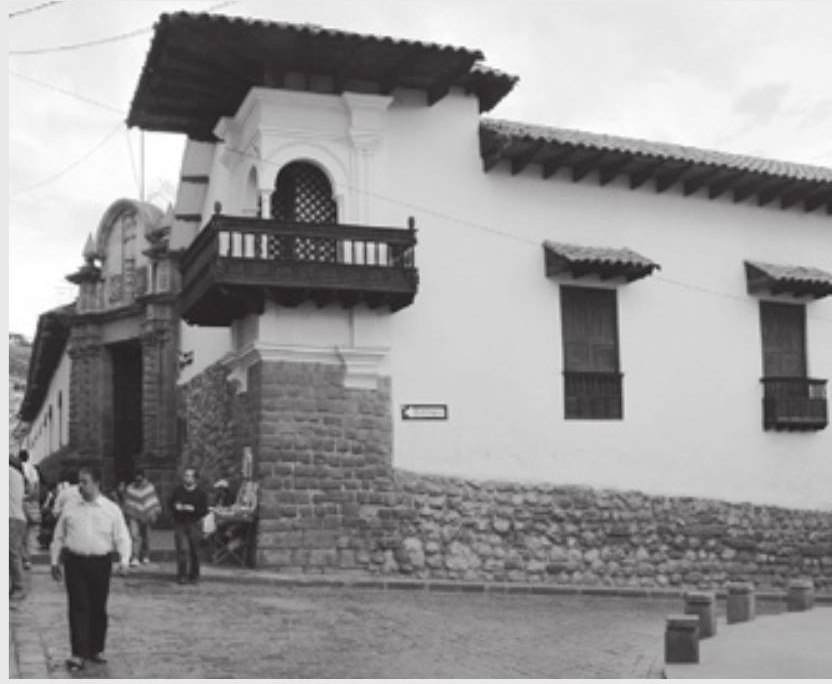

356. Palacio Arzobispal de Cusco. Fonte: Fotografia elaborada pelo autor (2007).

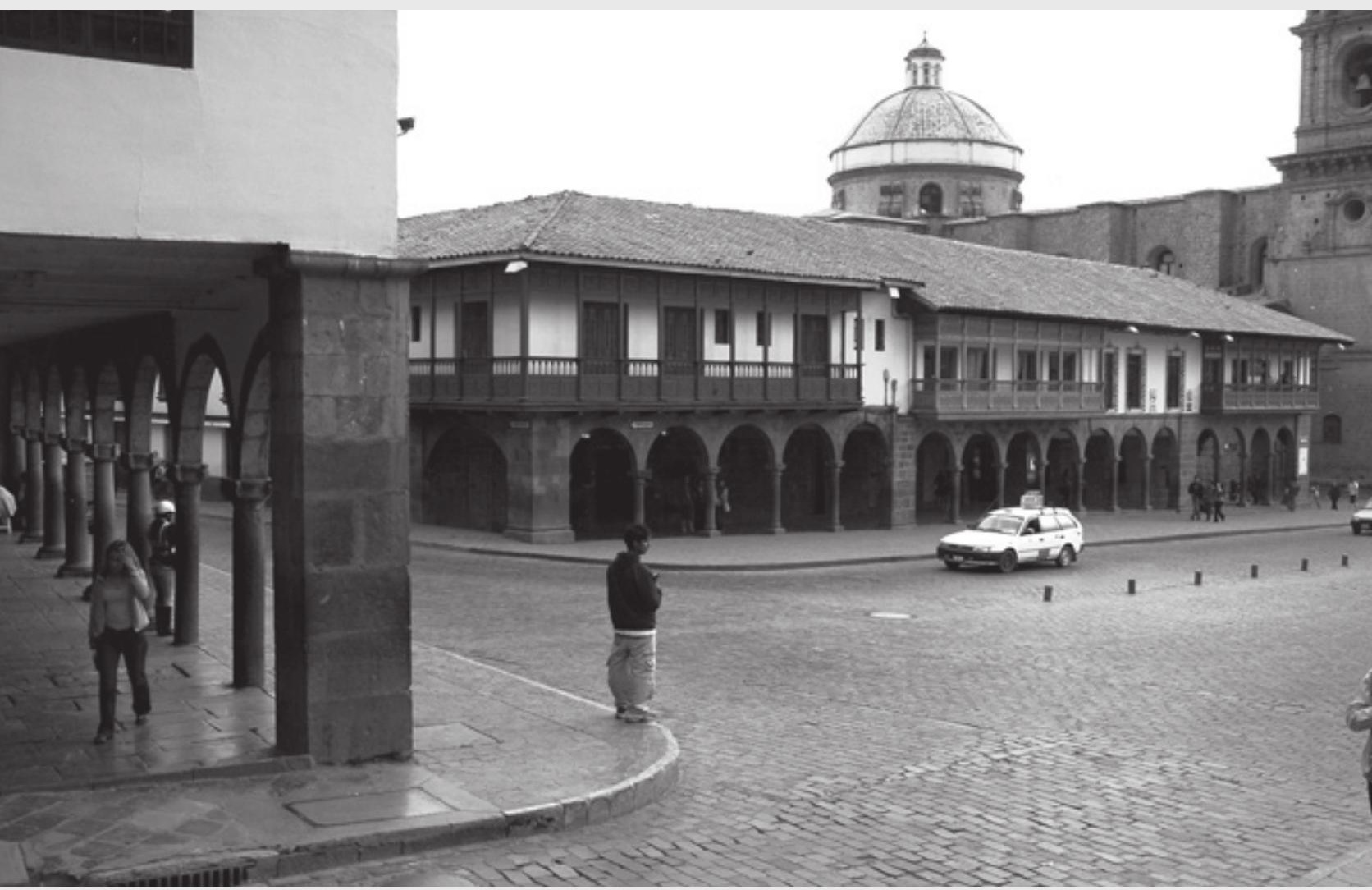

357. A chegada à Plaza de Armas com a "Via Sacra" desalinhada - para o transeunte que vem do Bairro de San Blas. Fonte: Fotografia elaborada pelo autor (2007). 
a portada e os embasamentos de pedra que sustentariam as paredes brancas de adobe - alguns remanescentes da construção inca preexistente, outros, fruto de pilhagem de diversas obras pré-hispânicas - desvelaria uma inusitada experiência arquitetônica voltada para o cruzamento das ruas (Figura 356). Mas a cidade de Cusco, como a maioria dos núcleos urbanos coloniais das Índias Ocidentais, aproveitaria, constantemente, as portadas e os balcões dos edifícios civis e oficiais como elementos de agitação cenográfica do ambiente urbano.

Mais alguns passos e o espectador irromperia na Plaza de Armas e se depararia com os panoramas que revelariam toda a trama barroca discutida anteriormente. Este instante especial seria comandado por um sentimento de "maravilha" proporcionado pelo "efeito surpresa": a descoberta, repentina, do mais importante evento cenográfico da cidade - situação completamente incomum para os núcleos hispano-americanos de desenho clássico, regular e mesmo semirregular, nos quais a abertura de um acontecimento dramático imprevisto raramente ocorreria. O mecanismo que geraria a impressão da "surpresa" residiria no fato da "Via Sacra" nascer muito estreita na altura do Bairro de San Blas e alcançar a praça principal ainda com uma largura modesta, o que limitaria o campo de visão do espectador até ele ingressar na praça após passar pelo costado da Capela de El Triunfo - que aparece à direita, na conclusão deste trecho do antigo caminho pré-hispânico. Além disso, apesar da via cruzar a Plaza Mayor acompanhando um dos lados menores da grande esplanada, justamente aquela face na qual seria levantada La Compañía, ela chegaria um pouco desalinhada em relação ao seu lado sudeste - cerca de 20 metros (Figura 357); só depois seguiria seu flanco, unidirecionalmente, até a conclusão final do eixo perspectivo, na altura da lgreja de San Pedro, 700 metros adiante (Figura 358).

Deste modo, após ter avistado as torres elevadas da igreja jesuítica nas proximidades da Capela de San Blas, ao iniciar a descida do eixo sagrado, o transeunte perderia o contato visual com o templo e só o resgataria pouco antes de alcançar o deslocado acesso à praça: situação que ofereceria ao passante uma imagem muito mais atraente da igreja, destacando-se o volume e, especialmente, seu frontispício - lançados em grave escorço para a visão do espectador que se aproximasse. Se a via chegasse na esplanada flanqueando perfeitamente o lado sudeste da Plaza de Armas, sua fachada principal estaria, neste momento, pouco chamativa, vista em intenso delineamento lateral. 


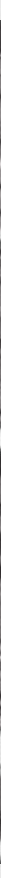

358. Fotografia feita do Bairro de San Blas revelando a trama dramática da "Via Sacra". Vislumbram-se,

sequencialmente: a Catedral; as torres e a fachada da Igreja de La Compañia; o campanário único de La Merced; mais distante, a torre de Santa Clara; e, fechando o encaminhamento perspectivo, San Pedro, com suas duas torres e fachada-retábulo. Fonte: Fotografia elaborada pelo autor (2007).

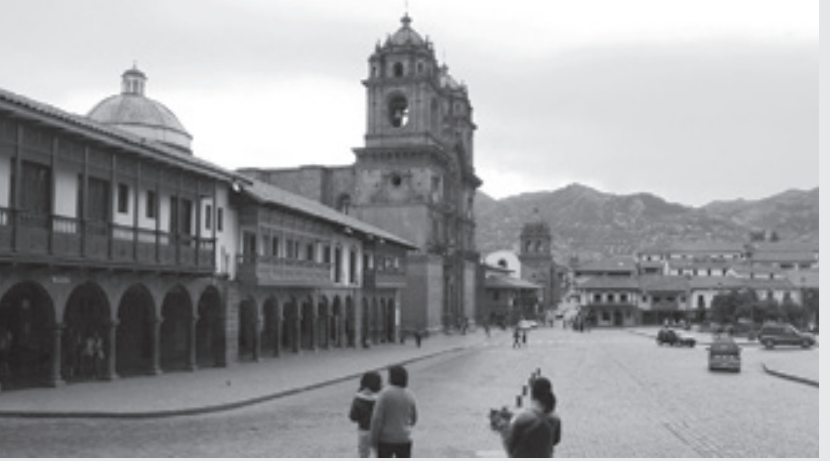

359. O eixo retilíneo da "Via Sacra" visto a partir da Plaza de Armas - que se abre à direita. É possível apreciar, em escorço, as torres e a fachada de La Compañia, além dos campanários de La Merced e de Santa Clara. Fonte: Fotografia elaborada pelo autor (2007).

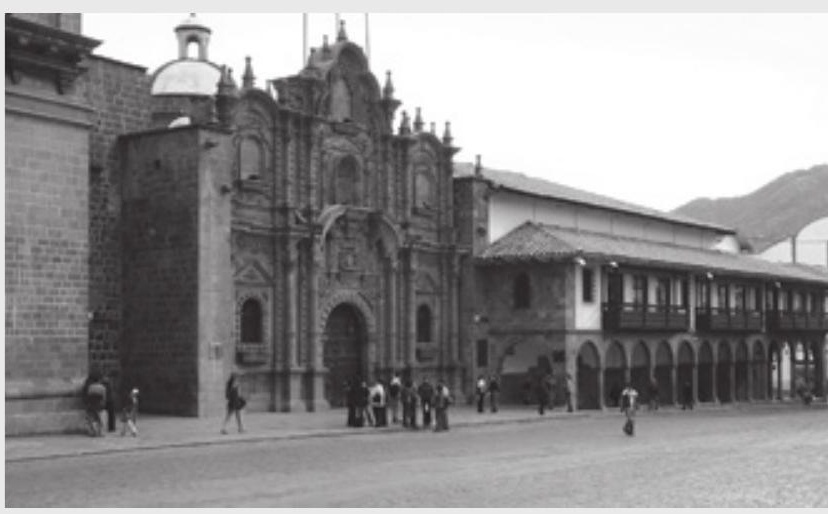

36o. Capela de Santo Ignacio e a continuação da "Via Sacra" no alinhamento dos casarões porticados. Fonte: Fotografia elaborada pelo autor (2007). 
Após a igreja dos jesuítas, a via seguiria absolutamente retilínea, perseguindo o ponto de fuga que encerraria o eixo dramático. No setor mais baixo da Plaza Mayor, o passante poderia avistar, no poderoso encaminhamento em profundidade, para além dos campanários da Compañía, outras diversas torres de igrejas que seriam assentadas na via. Os torreões achatados de La Merced e de Santa Clara, lançados no eixo da "Via Sacra", seriam imediatamente capturadas pelo olhar, alinhados em fuga perspectiva com as duas torres dos jesuítas. No entanto, um pouco mais à frente, o par de campanários de San Pedro se apresentaria conjuntamente ao transeunte (Figuras 359-36I).

Assim, dando prosseguimento ao trajeto, vencendo o ambiente da Plaza de Armas, a estrada ganharia, a noroeste, um pequeno alargamento que acompanharia toda a extensão de uma das fachadas laterais da Igreja do Convento de La Merced, implantada na face oposta da via, logo após a grande mole do colégio jesuítico (Figura 362). A estrutura monástica seria fundada em 537 e construída em uma huaca que marcaria a casa de uma coya, ou princesa inca. (VIÑUALES, 2004, p. 94) Não obstante, o convento masculino e a igreja seriam praticamente reconstruídos após o terremoto de meados do século XVII. Seguindo a tradição "mudéjar" (NICOLINI, 2005, p. 32), a igreja estaria assentada de costados para a pequena praça à frente e nem sequer exporia a fachada voltada para o eixo longitudinal do templo (geralmente a mais importante) - por estar oculta por um muro e por um portão alinhados com a rua. A sóbria fachada lateral só teria, como elementos de destaque, a portada principal, que daria acesso transversal ao seu interior, e o arremate superior da pesadíssima e achatada torre, organismos que receberiam um tratamento decorativo mais complexo. Deste modo, o frontispício, marcado pela portada em uníssono com o andar elevado do campanário, criaria um interessante contraponto diagonal frente à assepsia e rugosidade da frontaria. Também seria significativa a inusitada presença de uma capela aberta de índios diluída no conjunto decorativo da portada - nicho implantado acima do acesso ao templo, incorporado à sóbria composição barroca (Figura 363). Esta capilla abierta teria como finalidade permitir que os ofícios fossem executados para as pessoas que trabalhassem no comércio e nas oficinas abaixo. Graciela Viñuales (2004, p. I92, tradução nossa) relataria:

Também se instalaram em Cusipata muitas tendas de comércio, algumas delas coladas aos muros da lgreja de la Merced, algumas das quais persistiram até I990, aproximadamente. Tal função comercial levaria 


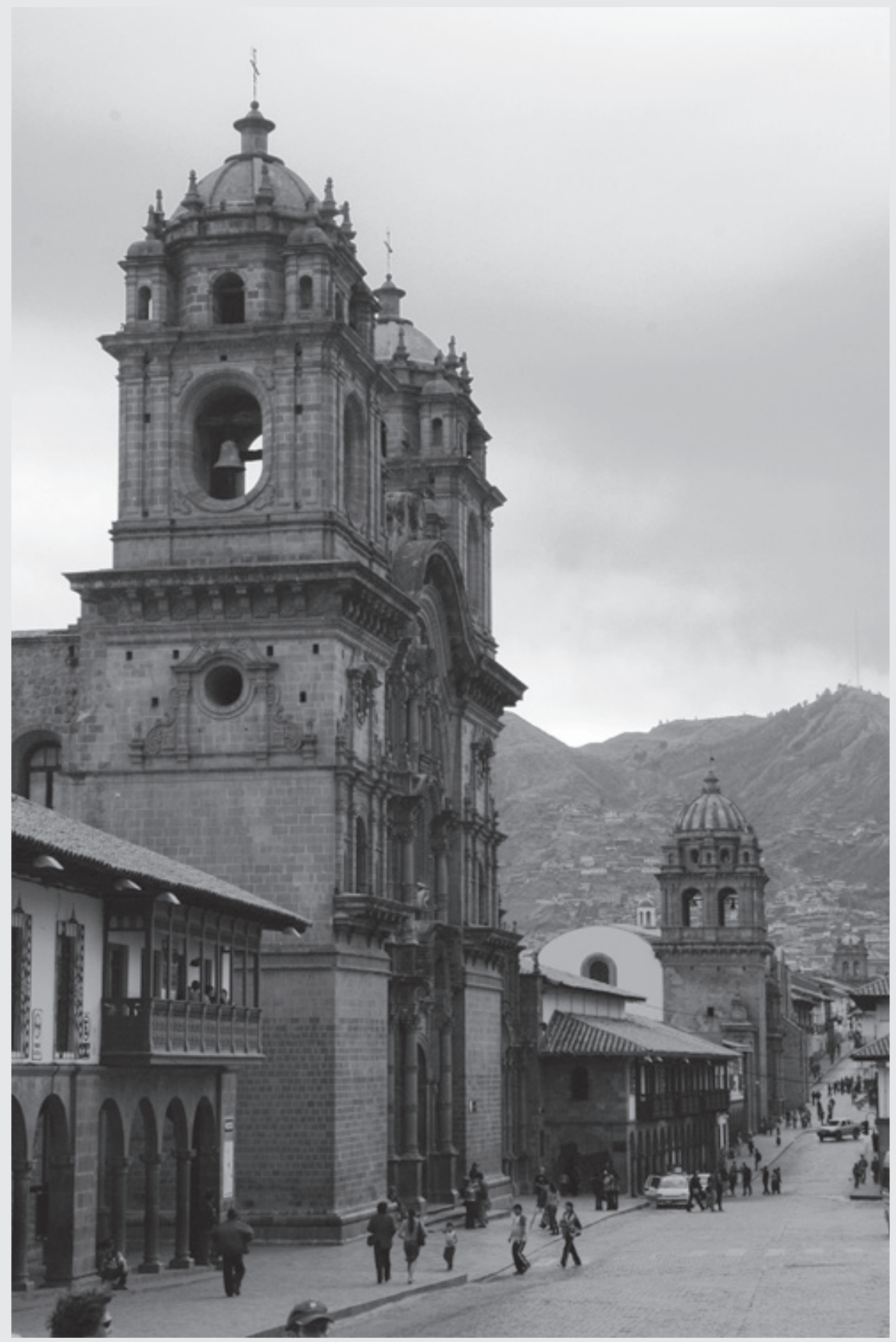

361. O eixo retilíneo da "Via Sacra". É possível apreciar as torres e a fachada de La Compañia, além dos campanários de La Merced e de Santa Clara. Fonte: Fotografia elaborada pelo autor (2007). 


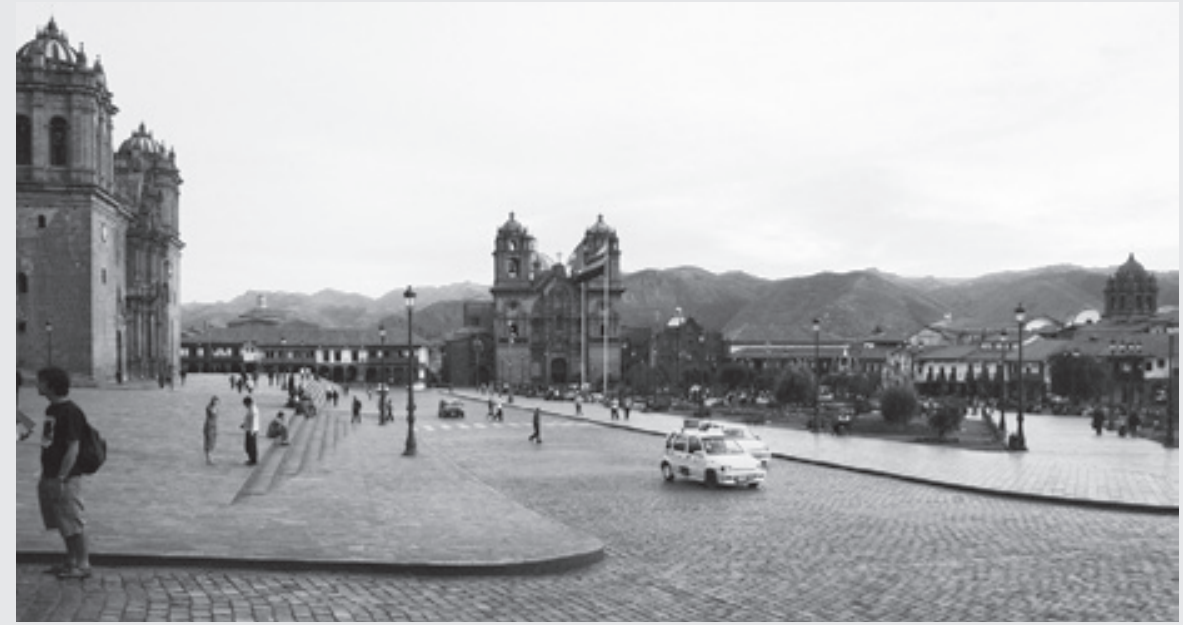

362. Plaza de Armas com suas duas igrejas. À direita é possível perceber a torre do Templo de La Merced, que se assenta alinhada com a "Via Sacra" - que passa ao fundo, adjacente à La Compañia. Fonte: Fotografia elaborada pelo autor (2007).

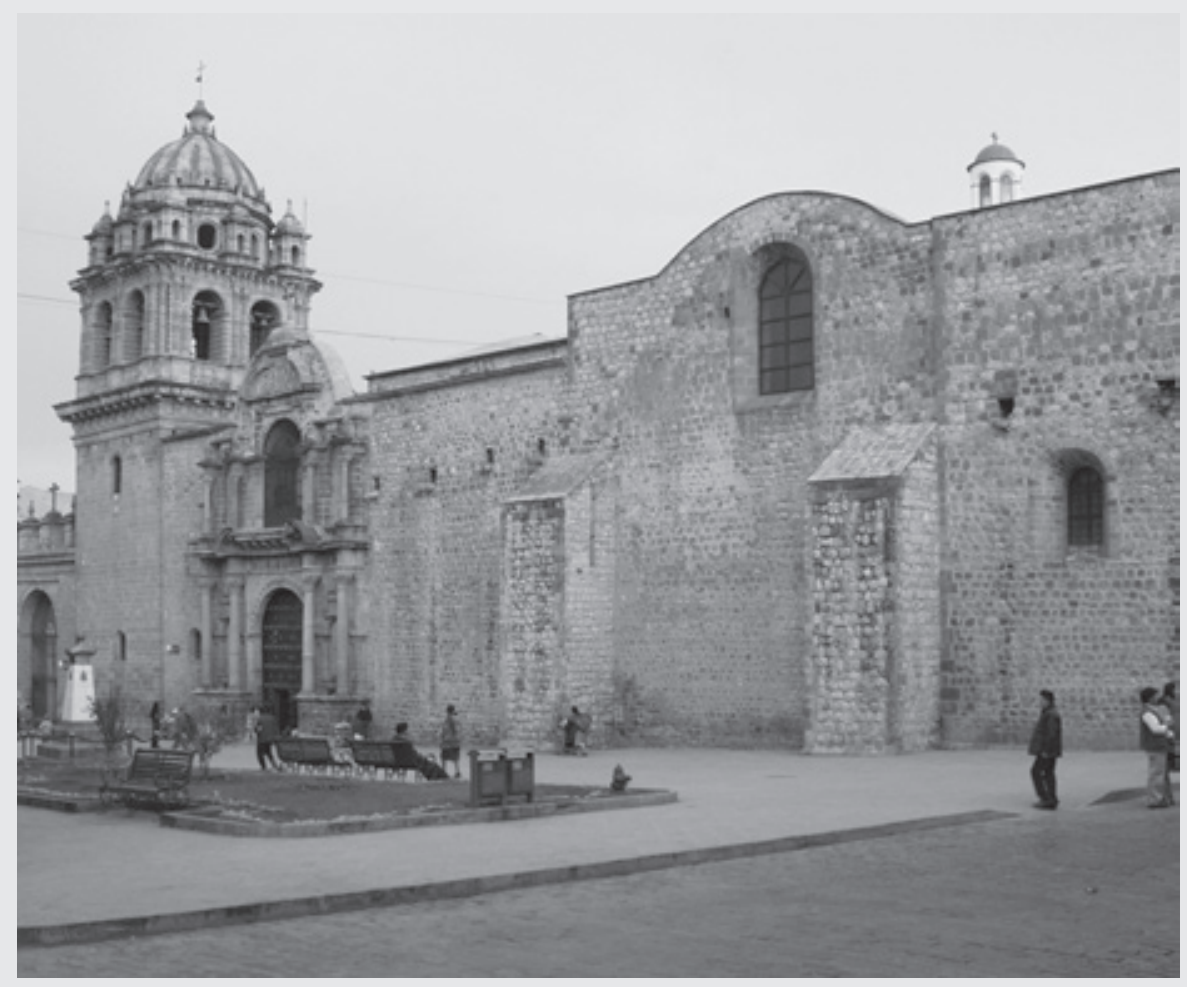

363. La Merced, voltada de costados para a sua praça e para a "Via Sacra". Percebe-se a contraposição da torre com a vultosa portada. Fonte: Fotografia elaborada pelo autor (2007). 
a instalar uma capela aberta nesta igreja, o que permitia participar da missa aqueles que ali trabalhavam, sem necessidade de abandonar o local nem mercadorias.

Por outro lado, a praça na qual se levantaria a Igreja de La Merced seria um fragmento da antiga Plaza del Regocijo, separada do recinto da municipalidade por um quarteirão construído algum tempo após a divisão da esplanada de Huacaypata - quadra que receberia, a partir de finais do século XVII, a Casa de Moneda de Cusco, substituída, na década de 1930, por uma monumental construção neocolonial. Não obstante, este quarteirão permitiria que se abrisse, à direita, ao final do pequeno largo de La Merced, um encaminhamento perspectivo de mais de 300 metros. Flanqueando a Casa de Moneda, passando adjacente à face sudoeste da Plaza del Regocijo e por seu cabildo, e prosseguindo por outro longo trecho de rua, a fuga visual estaria emoldurada, em profundidade, pela sóbria e distante fachada da Igreja do Convento de Monjas de Santa Teresa (Figura 364). Seria outra situação atípica para o modelo consagrado de traza em damero (tabuleiro de damas) hispano-americano: as cidades que contariam rigidamente com este desenho nunca apresentariam um monumento postado na conclusão dos pontos de fuga gerados, perspectivamente, pelas linhas paralelas lançadas nas vias retilíneas - ruas que se cruzariam ortogonalmente e em intervalos regulares. Na cidade racional desenhada através de um plano que preveria uma estrutura viária conformando uma perfeita grelha, as linhas de fuga se perderiam, de fato, no vazio.

Persistindo na "Via Sacra" (Figura 365) e vencendo mais um seguimento de rua, seria aberto, à direita, o último retalho da antiga esplanada inca: a enorme Plaza de San Francisco, recinto dominado pela igreja sede do convento que daria nome ao espaço, ambiente no qual também se estabeleceria o tianguez - como já foi comentado. O convento, que ganharia dimensões bem significativas, seria construído, a partir de I538, acima das ruínas de outra huaca pré-hispânica: a cancha de Ccasana. ${ }^{\text {II2 }}$ (BUSCHIAZZO, I944, p. I02) A igreja maior, levantada adjacente à face sudoeste da praça, no vértice oposto em relação à "Via Sacra" - que cruzaria bem abaixo, flanqueando o lado sudeste -, não contaria com um tratamento plástico expressivo, para além de sua dimensão grandiosa e de sua implantação ao fundo do recinto, em uma área um pouco mais elevada. Porém, assentada na antiga plataforma inca, seria um organismo arquitetônico que ex-

112 Cancha seria uma palavra de origem quechua que significaria, grosso modo, "Recinto". 


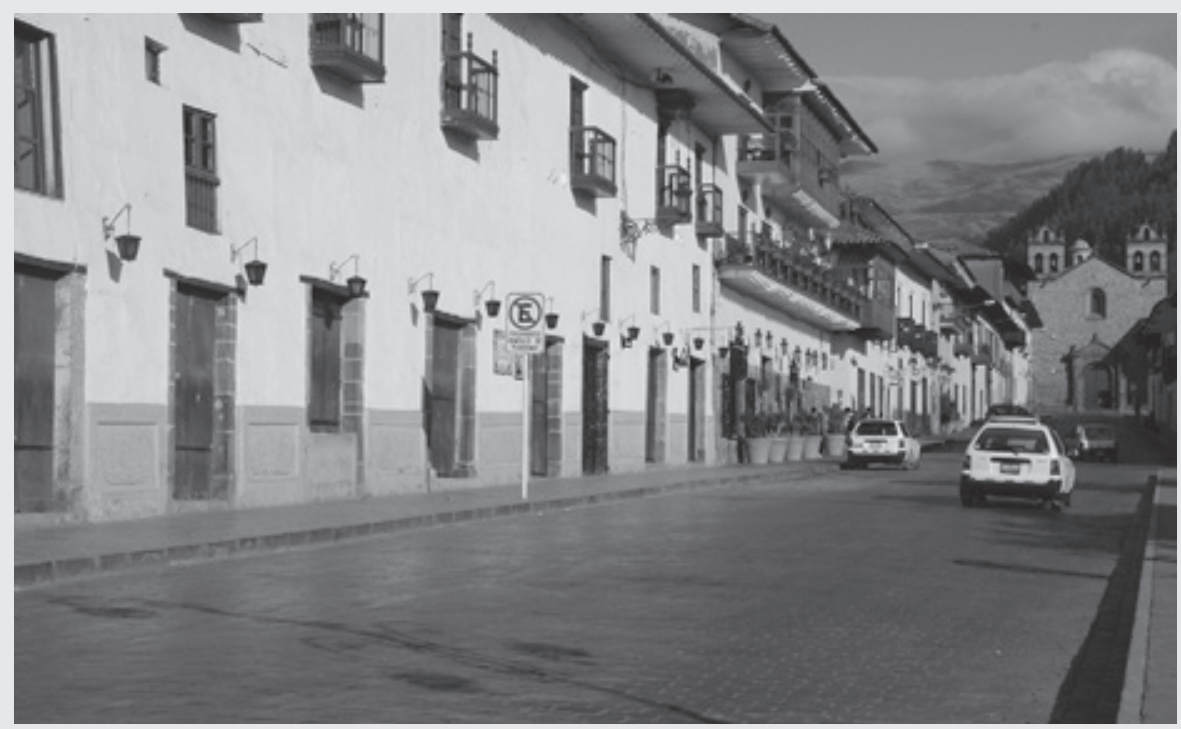

364. Fuga perspectiva - retirada entre a Plaza de La Merced e a Plaza El Regocijo - voltada para a fachada principal da Igreja do Convento de Monjas de Santa Teresa. Fonte: Fotografia elaborada pelo autor (2007).

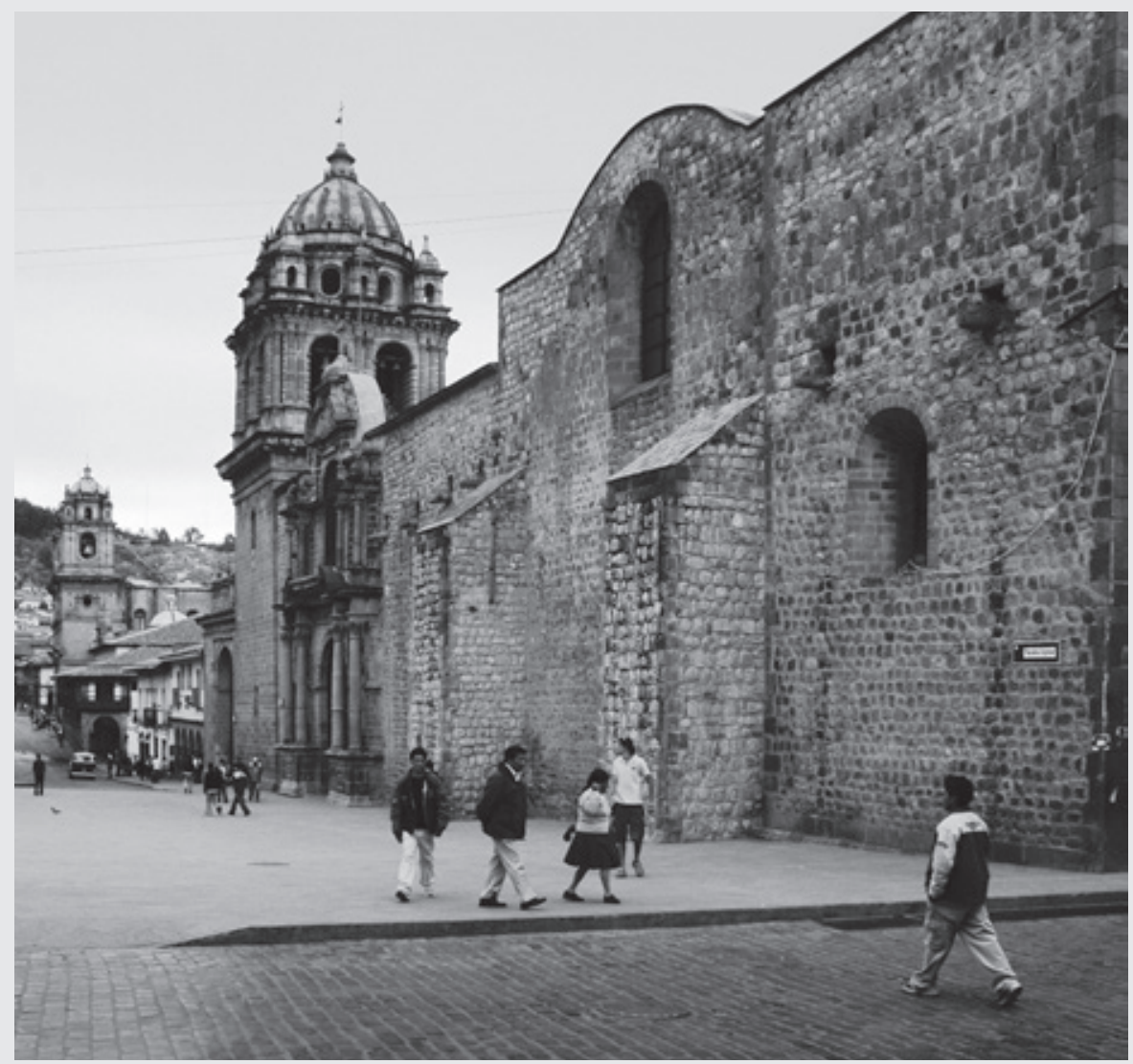

365. Perspectiva retirada da "Via Sacra", voltada na direção oposta à analisada até o momento - buscando a Plaza de Armas e o Bairro de San Blas. Destacam-se a Igreja de La Merced e, mais à frente, as torres de La Compañia. A esquerda se abriria o encaminhamento em profundidade que derrocaria na distante fachada de Santa Teresa. Fonte: Fotografia elaborada pelo autor (2007). 
poria mais do que a superfície de uma de suas fachadas, como era de costume: apresentaria sua poderosa massa edificada em escorço, oferecendo a visão da sua imponente volumetria que dominaria o recinto - demarcando, de forma diferenciada, mais um rito católico vinculado ao eixo sagrado (Figura 366).

Logo após, alinhado com a terminação do lado sudoeste da praça franciscana, surgiria um organismo arquitetônico republicano edificado em I835: o Arco de Santa Clara - um arco do triunfo de três fórnices, com uma abertura central mais ampla, que passaria por cima da artéria de veículos, e outras menores, que se sobreporiam às passagens para os perdestes. Apesar de ter sido levantado após o período barroco, pelo seu tratamento e materiais construtivos - a mesma pedra andesita que constituiria a base de toda arquitetura religiosa -, e por sublinhar a fuga perspectiva que se desenvolveria desde a Plaza de Armas, o arco não perturbaria a intensidade do evento dramático encenado na via; pelo contrário, acabaria favorecendo-o (Figuras 367-368).

Sua denominação estaria vinculada ao fato de estar muito próximo ao Monastério de Santa Clara, que surgiria no campo visual logo após o transeunte passar abaixo de um de seus fórnices. O complexo religioso feminino teria sido fundado na década de I550, na zona de Amarucata, um tradicional bairro da nobreza inca. (VIÑUALES, 2004, p. I20) Juntamente com a Catedral, seriam as únicas estruturas arquitetônicas religiosas de vulto que teriam escapado com poucos danos do sismo de I650 (Figura 369). A implantação da igreja maior se daria segundo o modelo tradicional - seguido também por La Merced e San Francisco -, de costado para o logradouro, do mesmo lado sudeste que as estruturas jesuíticas e mercedárias. Contudo, sua fachada lateral, a única exposta à cidade, estaria ligeiramente recuada em relação à "Via Sacra", definindo um pequeno átrio encerrado por um gradil levantado na testada do lote. Como destaque, a pesada fachada só apresentaria as sóbrias portadas e a larga e achatada torre: campanário erguido à frente, lançado acoplado ao plano da grande frontaria, com uma largura equivalente à do átrio - ou seja, sobressalente e alinhado com a via e encerrando a extensão linear do pequeno recinto aberto.

Porém, o que mais despertaria a atenção na imagem que se capturava da fachada e do campanário de Santa Clara seria sua interface com o panorama perspectivo do edifício religioso que encerraria os eventos barrocos do eixo sagrado (Figura 370): a Igreja da paróquia de índios de San Pedro - templo que originalmente faria parte de um hospital para os nativos, fundado em 1565. 


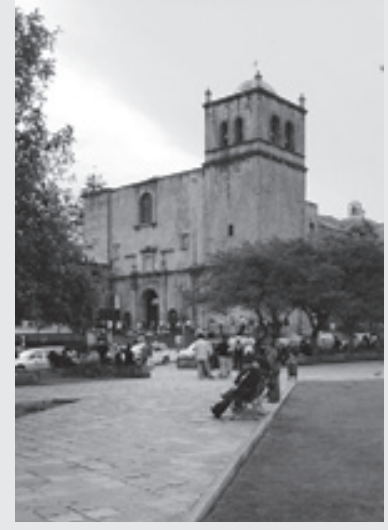

366. Praça e Igreja do Convento de San Francisco, contíguas à "Via Sacra". Vindo da Plaza de Armas, o ambiente remanescente da antiga Praça inca de Huacaypata apareceria à direita, logo após o transeunte vencer o pequeno vazio da Plaza de La Merced. Fonte: Fotografia elaborada pelo autor (2007).

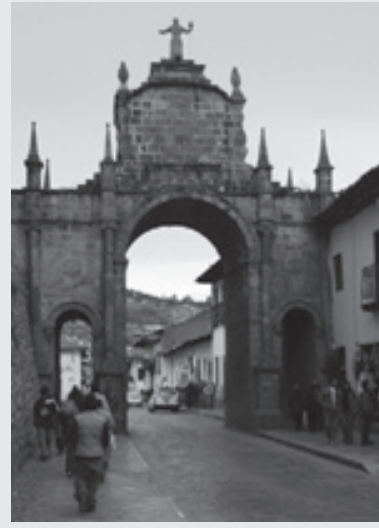

367. Arco de Santa Clara, aberto acima da "Via Sacra", vendo, em perspectiva, o percurso que busca a Plaza de Armas. Fonte: Fotografia elaborada pelo autor (2007).

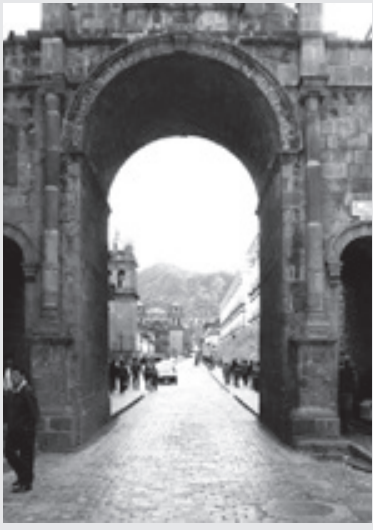

368. Arco de Santa Clara, aberto acima da "Via Sacra", vendo, em perspectiva, a direção contrária, que busca a Igreja de San Pedro. Fonte: Fotografia elaborada pelo autor (2007)

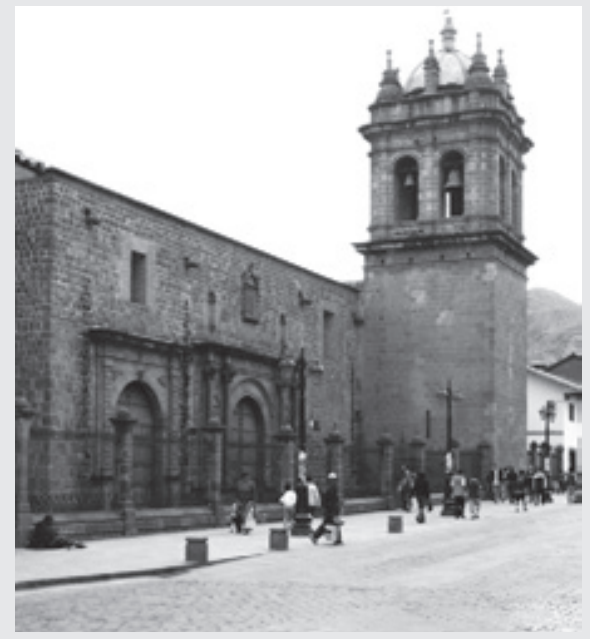

369. Igreja do Convento de Santa Clara, com sua fachada lateral voltada à "Via Sacra". Fonte: Fotografia elaborada pelo autor (2007).

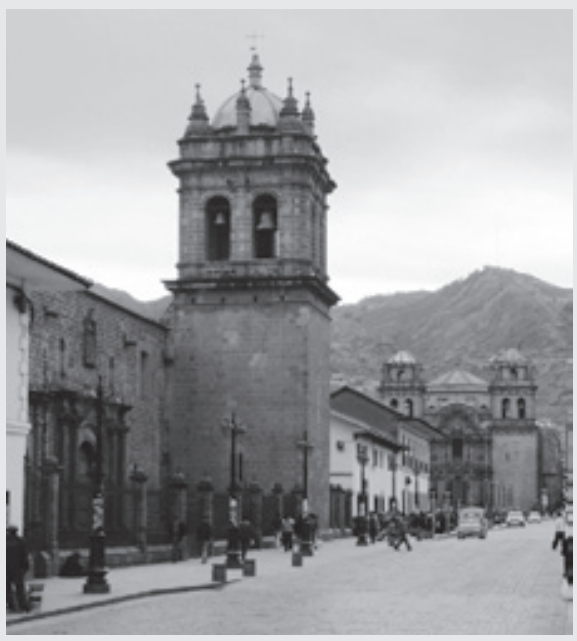

37o. Finalização do encaminhamento perspectivo da "Via Sacra". A animação se deve, cenograficamente, ao campanário de Santa Clara e à fachada de San Pedro, frontaria que emoldura, parcialmente, a fuga em profundidade. Fonte: Fotografia elaborada pelo autor (2007). 


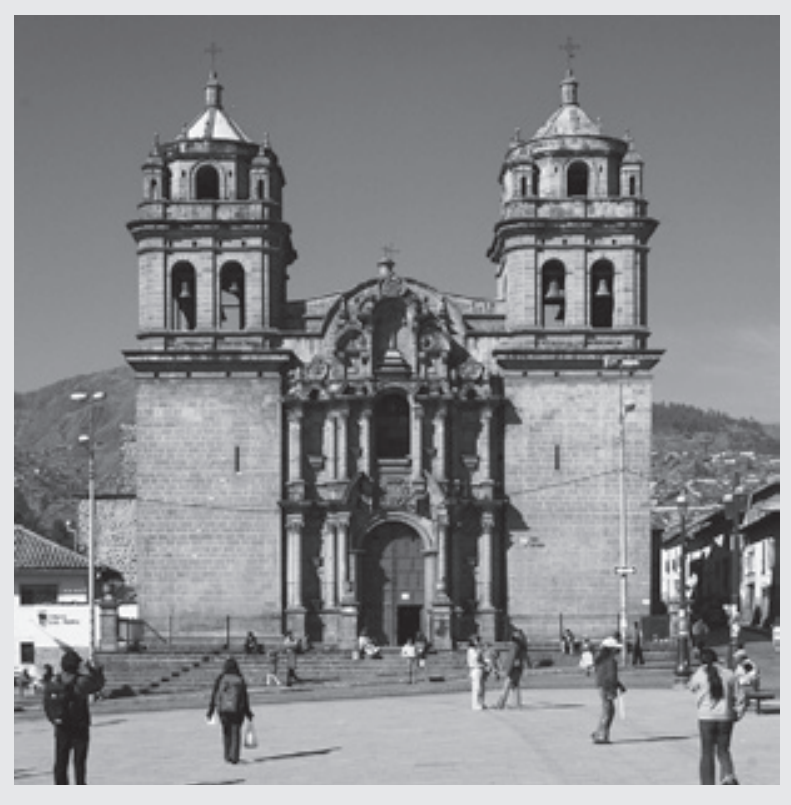

371. Fachada da Igreja de San Pedro, em Cusco - a perfeita conclusão do evento dramático da "Via Sacra". Fonte: Fotografia elaborada pelo autor (2007).

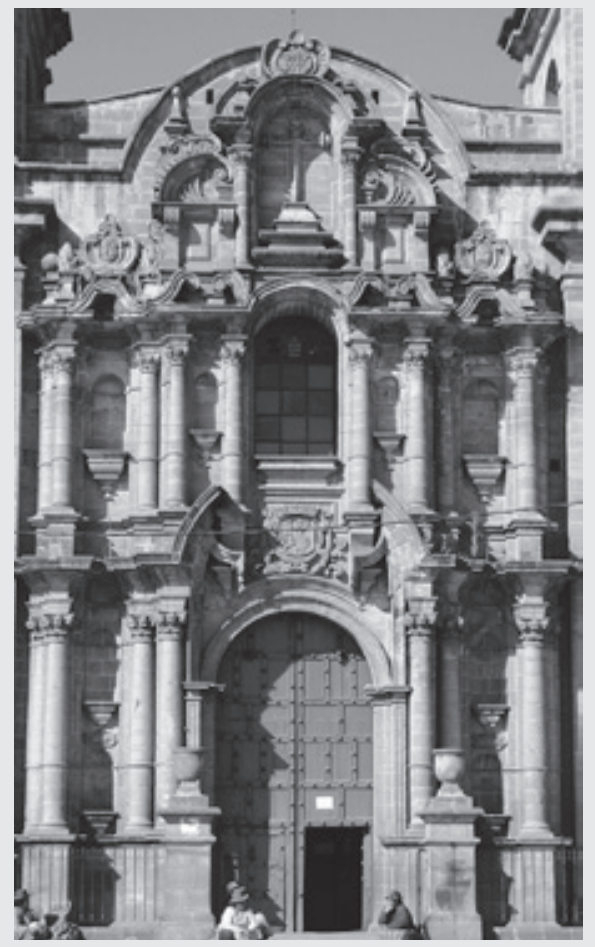

372. Fachada-retábulo da Igreja de San Pedro. Fonte: Fotografia elaborada pelo autor (2007).

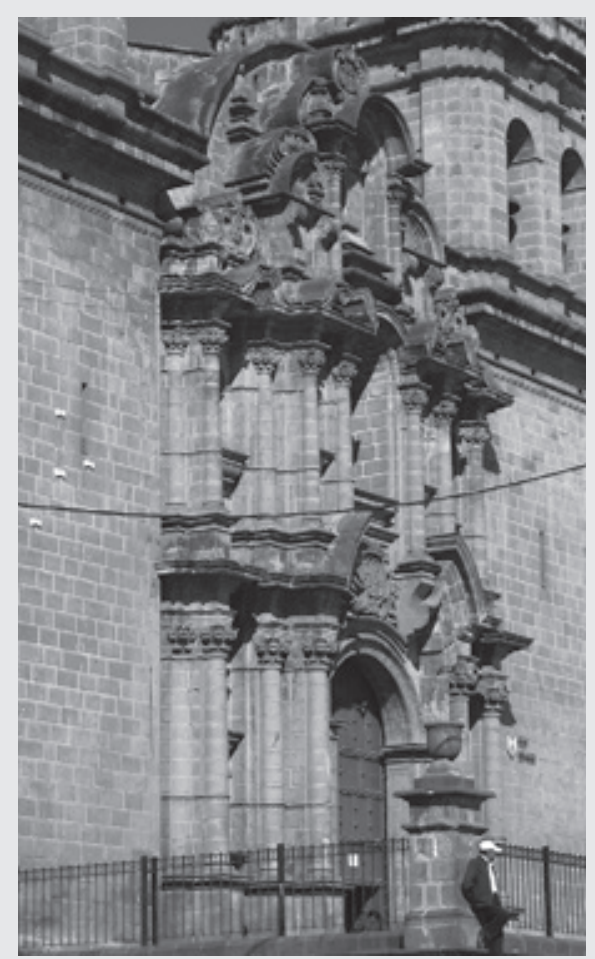

373. Detalhe da fachada-retábulo da Igreja de San Pedro. Fonte: Fotografia elaborada pelo autor (2007). 
A igreja, construída por um mestre indígena a partir de I688 - utilizando-se, ainda, de pedras provenientes das muralhas incas do Monte Picchu (BUSCHIAZZO, I944, p. I07) - seria implantada, mais uma vez, na face sudeste da rua, no vértice do quarteirão que estaria voltado à praça que se abriria à frente. Para o espectador, as elegantes torres da igreja, bem como sua frontaria barroca, já poderiam ser vistas, parcialmente, em contraposição ao pesado campanário de Santa Clara, após a travessia do arco triunfal republicano. E devido à existência do recuo, conformado pela praça aberta entre o mosteiro e a sede da paróquia, sua expressiva imagem perspectiva iria se abrindo, gradativamente, até se apresentar, integralmente, ao transeunte e em perfeita elevação - desvelando seu rico frontispício barroco lançado à frente da superfície da fachada: mais um inebriante retábulo de pedra, embutido entre duas torres, que seguiria o modelo de La Compañía (como também aconteceria nas igrejas paroquiais de San Sebastián e Belén).

O altar-mor, aberto perspectivamente à "Via Sacra”, visto nas proximidades da finalização do eixo, seria a conclusão ideal deste caminho que, após alcançar a Plaza de Armas, sempre revelaria panoramas nos quais torres, portadas e frontispícios de igrejas se sucederiam perspectivamente (Figuras 37I-373). É claro que, se o percurso fosse feito na direção oposta, outros efeitos cenográficos despontariam - e alguns se anulariam. Assim, a "Via Sacra" nasceria em uma igreja para índios, passaria pela arquitetura religiosa monumental da classe dominante e se concluiria, de forma pertinente, em outra paróquia indígena - independe do sentido do percurso assumido pelo passante.

\section{O papel da arquitetura religiosa como elemento estruturador da cenografia barroca na cidade de Cusco}

A apreciação desenvolvida até o momento, fundada na elaboração de um juízo sobre a constituição da cenografia barroca da cidade através da avaliação da interface entre a arquitetura de caráter monumental lançada nos domínios dos dois mais importantes elementos constituintes do espaço urbano da Cusco colonial, deixaria claro que o principal artifício de transfiguração dramática do ambiente da antiga capital inca seria a presença marcante dos edifícios religiosos. A Catedral, as igrejas, capelas, hospitais, colégios, bem como as poderosas estruturas monásticas, masculinas e femininas, contaminariam a cidade e provocariam 
a sua virtual transformação em um organismo integralmente barroco. Seriam monumentos que, com sua estrutura mais complexa e imponente, e, frequentemente, com sua rica decoração aplicada, entrariam em contraste fatal com o delineamento urbano semirregular, especialmente com a dramática massa homogênea da arquitetura ordinária apresentada ao espectador: casarões formados pelos embasamentos dos muros incas de andesita, justapostos por paredes de adobe caiadas e telhados cerâmicos.

Contribuindo para potencializar a narrativa dramática destes episódios barrocos, todos os conjuntos religiosos discutidos marcariam um processo de reorientação simbólica dos mais importantes sítios sagrados da cidade pré-colombiana, ação que se estenderia para outros setores do espaço urbano. Neste sentido, nada seria mais adequado do que a cancha escolhida para abrigar o Convento de Santa Calina. Levantada a poucos passos da Plaza Mayor, ao lado da quadra na qual seria construída a Igreja de La Compañía, quase contígua à praça central e à "Via Sacra", a clausura das monjas se sobreporia às ruínas de Acllahuasi, a Casa das Virgens Escolhidas, configurando mais um importante espaço ligado ao culto católico, lançado acima de uma huaca inca preexistente. (VIÑUALES, 2004, p. I8)

Ou seja, a construção da expressividade barroca cusqueña - espetáculo visual que atingiria a configuração cenográfica do núcleo urbano estruturado com hábeis artifícios de propaganda e pregação religiosa - viria contaminar o espaço da cidade, bem como sua miscigenada população, após o terremoto ocorrido em I650. Contudo, esta inebriante experiência barroca não poderia ser compreendida como uma realidade cultural deflagrada apenas nos séculos XVII e XVIII; sua estrutura simbólica acometeria acontecimentos ancestrais vinculados à cidade inca e atrelados à reorientação quinhentista do espaço urbano e das huacas pré-hispânicas. Para Viñuales (2004, p. I95, tradução nossa):

As estruturas simbólicas parecem ter existido com bastante anterioridade e se consolidado um pouco antes da chegada do século XVIII. Mas o interessante é ver que a etapa barroca de Cusco - que, em princípio, podemos dar-lhe uma extensão que supera mais de uma centúria - teve momentos peculiares em sua concepção dos espaços e da participação na vida pública. Ainda hoje pode-se ler o sentido barroco na cidade, nos seus edifícios religiosos e na vida e nos costumes dos seus habitantes. Este é o resultado de influências diversas e diferentes 
situações que ocorreram ao longo da história, e não uma transição fe-

chada e estagnada como tende a pensar-se.

Neste sentido, a mais trágica e notória situação de sobreposição aconteceria com a construção do Convento e da Igreja de Santo Domingo acima dos muros e alicerces do principal santuário da Cusco pré-hispânica: o célebre Coricancha, ou Templo del Sol - monumento que contaria com inúmeras riquezas descritas pelos cronistas que relatariam a conquista encabeçada por Francisco Pizarro. (ROMERO, 2008, p. 52) O conjunto dominicano seria fundado em I534, no mesmo ano da criação da cidade espanhola, aproveitando, efetivamente, grande parte da estrutura remanescente do ancestral santuário. E seriam, justamente, os muros incas de andesita que sobreviveriam ao sismo de I650, quando grande parte da estrutura conventual seria arruinada. Segundo Ramón Gutiérrez (I997, p. 258, tradução nossa), o complexo arquitetônico "[...] por fim, não só respeitou as construções existentes, mas procurou sobrepor o presbitério sobre a plataforma da parede curva."

Até recentemente, esta significativa justaposição do presbitério de Santo Domingo acima da plataforma encurvada dos fundos de Coricanhca poderia ser vislumbrada do vale do Rio Huatanay; após a canalização do curso d'água, neste setor da cidade, estes panoramas ainda seriam capturados desde a moderna Avenida del Sol, que passaria abaixo, por sobre o antigo rio (Figura 374). Não obstante, da Plaza de Armas se alcançaria, facilmente, a Igreja de Santo Domingo, caminhando pela Calle Loreto, uma estreita via remanescente da capital inca que cruzaria a Plaza Mayor na direção sudeste, em ângulo reto com a "Via Sacra". Esta tradicional viela, que conectaria a Esplanada de Huacaypata diretamente ao Templo del Sol, acabaria acolhendo, de um lado, uma das fachadas laterais do complexo de La Compañía, e, do outro, uma das faces do Convento das Monjas de Santa Catalina. Pouco depois, a rua pré-hispânica alcançaria o largo onde se assentaria a Igreja de Santo Domingo, abrindo-se para um dos panoramas que melhor apresentariam o templo: a imagem em escorço da parte posterior de sua fachada lateral - que estaria, seguindo a tradição, de costados para a praça. Esta imagem destacaria, em primeiro plano, o presbitério e o belvedere curvo pré-hispânico, para, depois, sequencialmente, apontar para a sóbria portada lateral e para a densa e achatada torre - organismo arquitetônico que teria, como elemento mais proeminente, o intricado arremate decorativo do campanário, articulação que entraria em forte oposição ao caráter rústico da pesada massa muraria da igreja (Figura 375). 


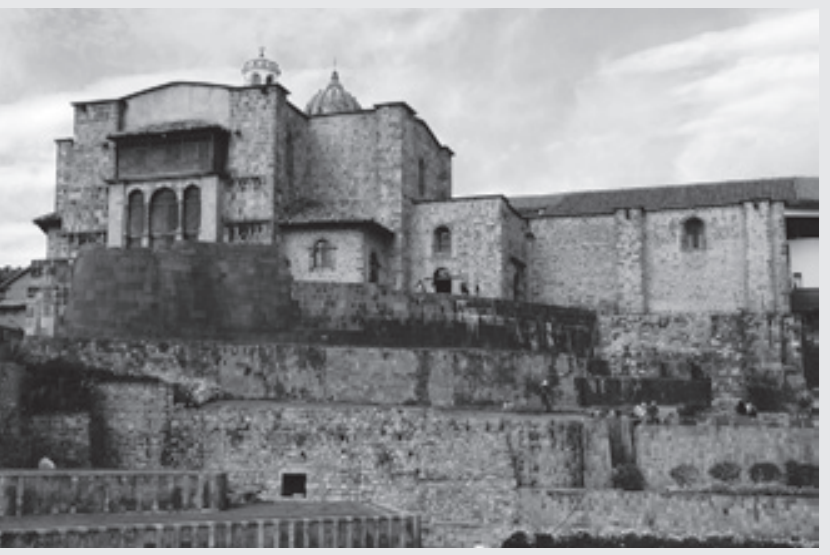

374. Dramática imagem da face posterior da Igreja do Convento de Santo Domingo, em Cusco, desvelando a justaposição do presbitério do edifício católico acima da plataforma encurvada dos

fundos do Templo de Coricancha. Fonte: Fotografia elaborada pelo autor (2007).

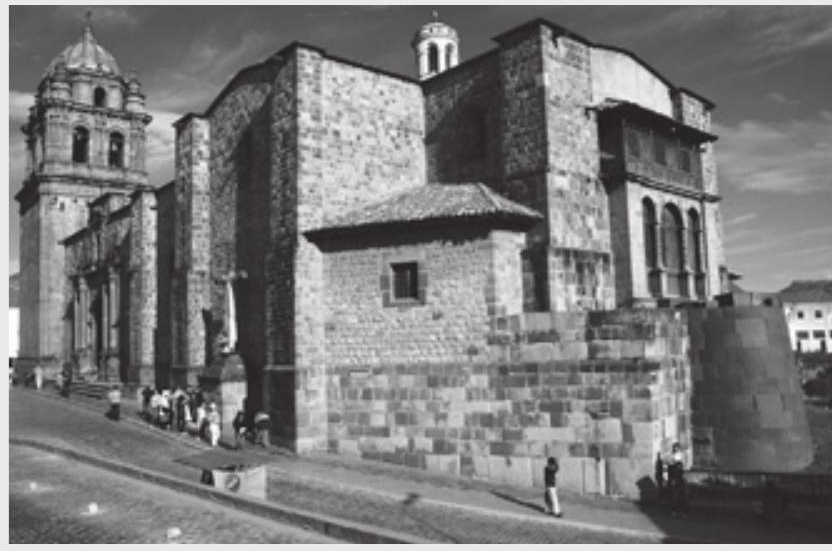

375. Fachada lateral do Templo de Santo Domingo. Destaque para o ornado campanário, para a sóbria portada e para a plataforma inca sobreposta pelo presbitério da igreja dominicana. Fonte: Fotografia elaborada pelo autor (2007).

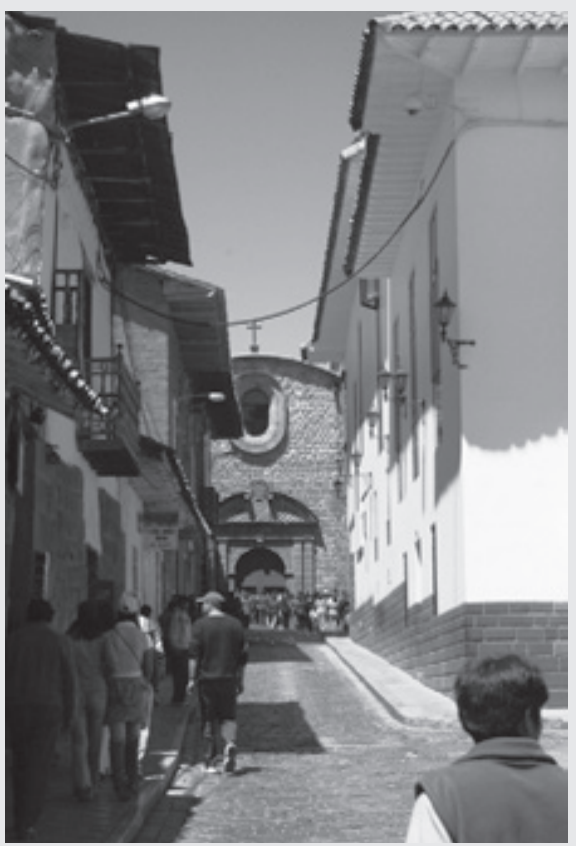

377. Encaminhamento perspectivo para a fachada de Santo Domingo. Fonte: Fotografia elaborada pelo autor (2007).
376. Frontispício de Santo Domingo.

Fonte: Fotografia elaborada pelo autor (2007). 
Apesar de o templo estar voltado de lado para praça, mais à frente seria revelada sua fachada principal por meio de um recuo que o largo sofreria para se abrir ao eixo longitudinal dominante - uma frontaria simples, que contribuiria ainda mais para a oposição "figura-fundo", marcada pelo confronto entre a torre e o corpo sólido do edifício (Figura 376). Para além disso, uma pequena travessa, rasgada à frente da fachada, viria emoldurar a portada frontal da igreja - e sublinhar seu eixo longilíneo dominante - com um intenso movimento de fuga perspectiva, rompendo, mais uma vez, a usual impossibilidade da constituição deste expediente barroco nas cidades quadriculares hispano-americanas (Figura 377).

\section{A arquitetura religiosa e as vistas panorâmicas da cidade de Cusco}

Até o presente momento, a expressão da dramaticidade, deflagrada pela cidade andina, foi analisada através do percurso assumido pelo passante que caminhava pelas vias internas do núcleo urbano, trajeto que revelaria, progressivamente, os importantes acontecimentos cenográficos que acabariam contagiando todo o ambiente citadino com sua teatralidade barroca. Contudo, a cidade também poderia ser vislumbrada dos morros e encostas que envolveriam o vale dos Rios Huatanay e Tullumayo (Figura 378) - entre outros vales e cursos d'água que cruzariam a região -, sítios geralmente ocupados por bairros indígenas caracterizados pela presença significativa de expressivas igrejas paroquiais: as Paróquias de San Cristóbal e Santa Ana, com suas igrejas assentadas na encosta abaixo da Fortaleza de Sacsayhuamán - monumental fortificação inca de onde, igualmente, panoramas inebriantes da cidade colonial poderiam ser capturados; a Igreja de Belén, levantada mais distante, na franja entre os Rios Chunchulmayo e Huancaro; o Bairro, assim como o já comentado Templo de San Blas, na encosta a nordeste da Plaza de Armas, em uma das pontas da "Via Sacra". (VIÑUALES, 2004, p. 137)

Ou seja, galgando estes elevados assentamentos, áreas que seriam frequentadas, prioritariamente, pelas comunidades indígenas, as vistas dominantes que se abririam ao transeunte destacariam, indubitavelmente, os organismos religiosos. Na verdade, a paisagem anunciada das encostas e morros desvelaria uma grande massa de telhados cerâmicos alaranjados distribuídos, homogeneamente, através de uma virtual trama de linhas dominantes ortogonais que produziria 


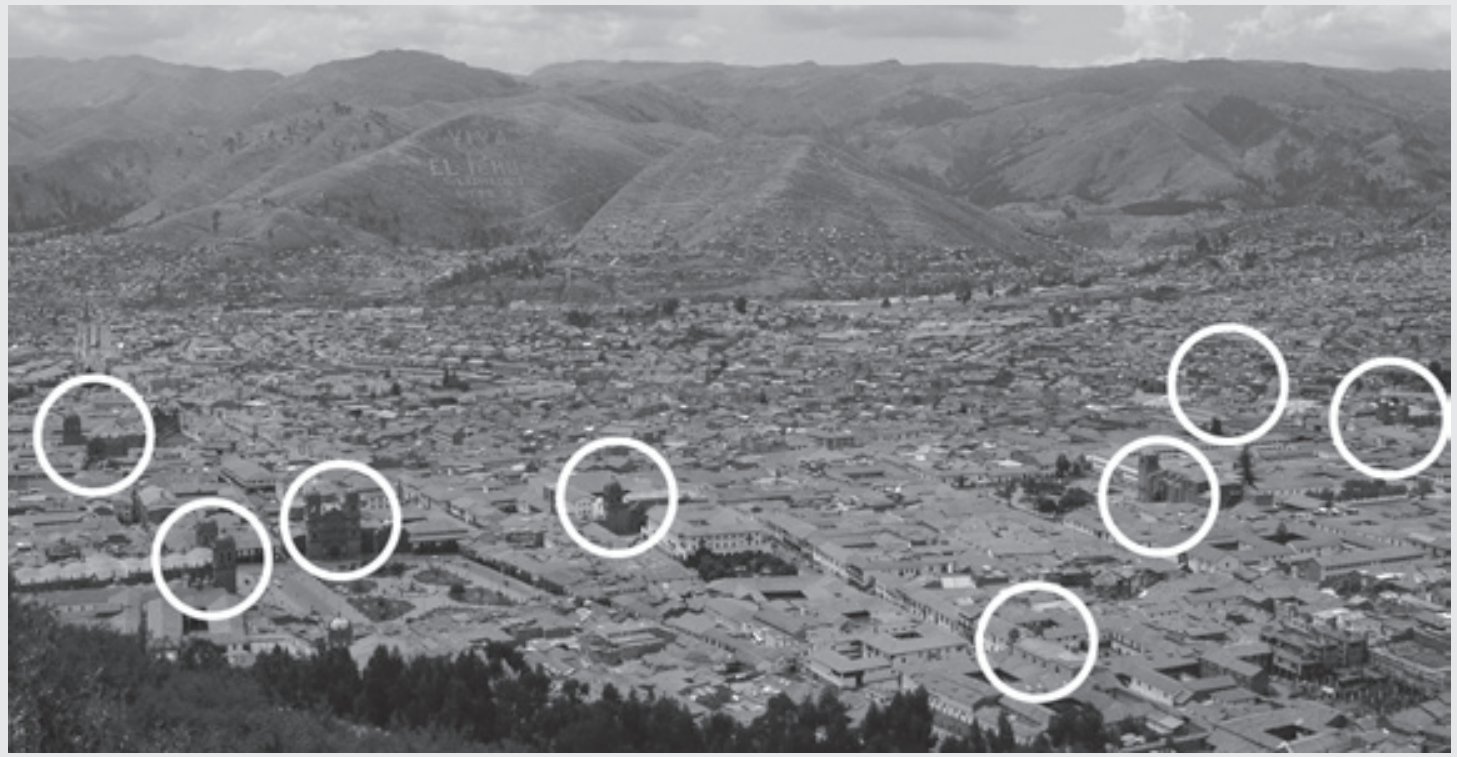

378. Foto de Cusco retirada da Colina de Sacsayhuamán. As principais igrejas estão assinaladas em branco. Da esquerda para a direita: Santo Domingo, a única fora do alcance visual da "Via Sacra"; a Catedral; La Compañia; La Merced; Santa Tersa; San Francisco; Santa Clara; San Pedro - sem contar os pequenos templos contíguos à sede episcopal e à igreja dos jesuítas. Fonte: Fotografia elaborada pelo autor (2007).

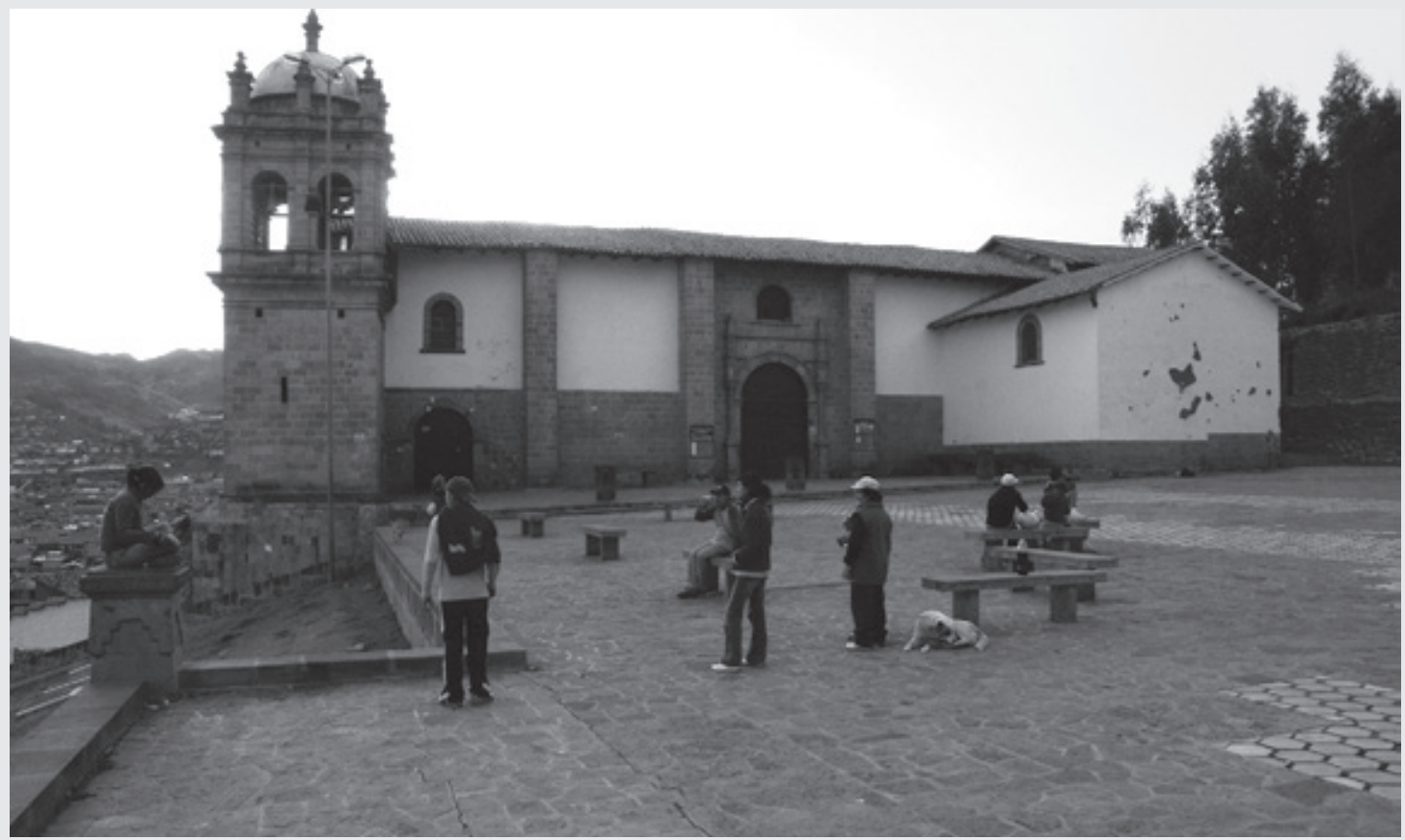

379. A igreja paroquial disposta na Colina de San Cristóbal. Fonte: Fotografia elaborada pelo autor (2007). 
uma falsa impressão de regularidade - impressão que superaria, ilusionisticamente, o baixo teor de ordenação racional do traçado da cidade. Deste modo, dilacerando a suposta grelha ortogonal, formada por uma superfície plana de coberturas alaranjadas que se espalhariam pelos vales, as torres das igrejas e os frontispícios conformados em pedra andesita, bem como as cúpulas mais claras de tijolo, despontariam como "figuras" sobre o "fundo" homogêneo dos telhados.

Discorrendo, especificamente, sobre as calotas hemisféricas assentadas acima das proeminentes construções católicas, ao contrário do modus operandi praticado no Velho Mundo, onde apenas uma grande cúpula - construída acima de um tambor cilíndrico e coroada por uma verticalizada lanterna - se destacaria sobre o telhado de duas ou mais águas que protegeria o edifício religioso, na América hispânica seria comum a apresentação - para o exterior da igreja - da complexa trama de abóbadas que encerraria as naves, as capelas laterais e o presbitério do monumento. De fato, esta tradição (também corriqueira em algumas regiões da Espanha) seria desenvolvida devido à reiterada ausência de telhados nas igrejas e catedrais hispano-americanas, prática construtiva que deixaria suas complexas abóbadas de tijolo - formadas quase sempre por casquetes de cúpulas justapostos sequencialmente - descobertas e expostas à cidade, criando interessantíssimos efeitos volumétricos determinados pela interpenetração de inúmeras estruturas sinuosas e onduladas.

Assim, o espectador que subisse em direção à Paróquia de San Cristóbal (Figuras 379-380), em algumas áreas do Bairro de San Blas (Figuras 38I-386), ou que galgasse a Fortaleza de Sacsayhuamán (Figura 387) avistaria pelo menos vinte e seis calotas hemisféricas distribuídas acima da Catedral de Cusco, sem contar com aquelas cúpulas que fechariam as Igrejas de El Triunfo e de Jesús y María e das outras ondulações referentes às abóbadas de La Compañía, Merced, San Pedro, Santo Domingo (Figura 388)... Este dinâmico jogo de formas onduladas seria potencializado pelos arremates cupuliformes das grossas torres, o que levaria Fernando Chueca Goitia (1980, p. I96) a denominar este massivo agrupamento de suaves cúpulas distribuídas pelas coberturas dos edifícios virreinales de arquitectura-montículo.

Logo, seriam capturadas das encostas, invariavelmente, cenas dramáticas nas quais se destacariam: a nave e o átrio a céu aberto formados pala Plaza de Armas e suas igrejas dominantes - suas cúpulas, campanários e frontispícios (especialmente o retábulo exterior da igreja dos jesuítas); a sequência das torres dos 


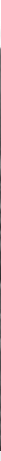

380: Fotografia panorâmica retirada do morro no qual se assenta a Igreja de San Cristóbal. Em destaque, as três praças principais da cidade, bem como as torres e cúpulas de algumas das mais importantes igrejas. Fonte: Fotografia elaborada pelo autor (2007)

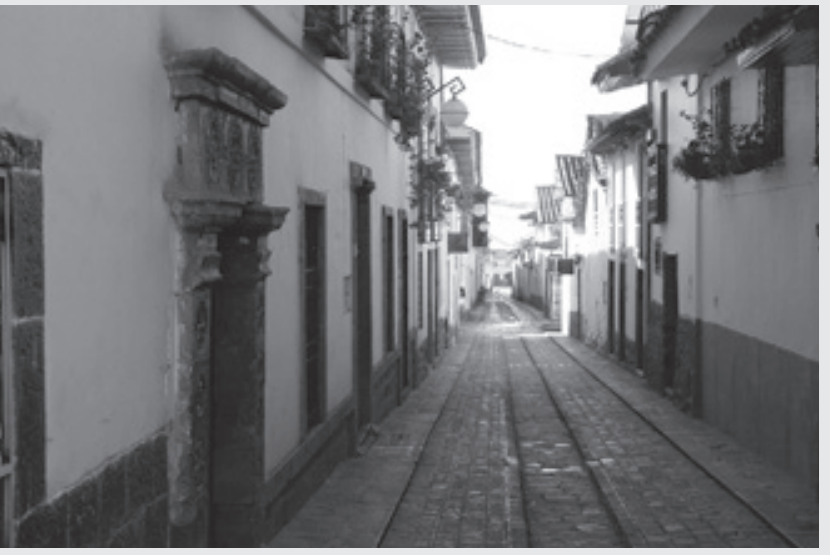

381: Uma rua do elevado Bairro de San Blas. Fonte: Fotografia elaborada pelo autor (2007)

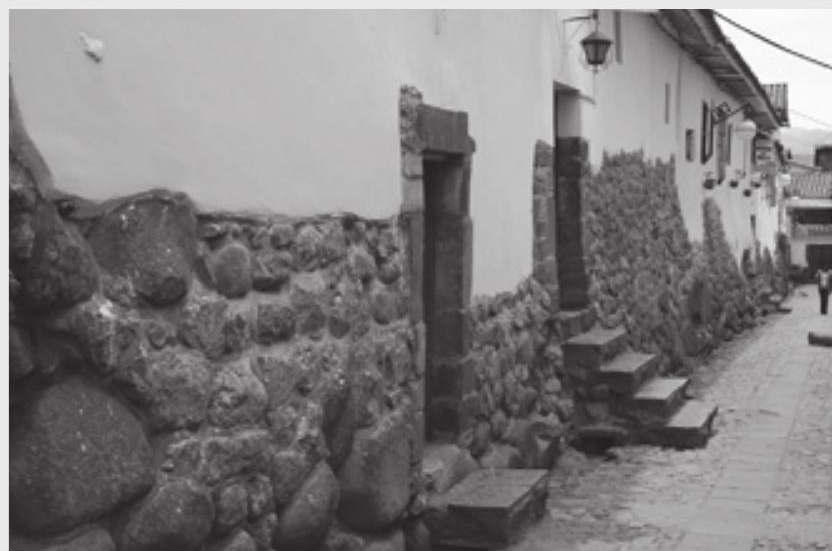

382: Rua do Bairro de San Blas. Fonte: Fotografia elaborada pelo autor (2007) 


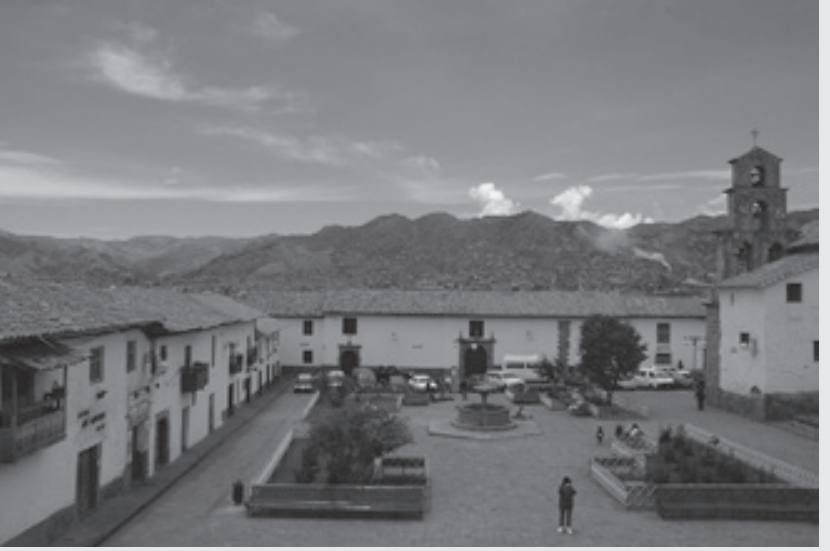

383. Praça da igreja paroquial do Bairro de San Blas. Fonte: Fotografia elaborada pelo autor (2007).

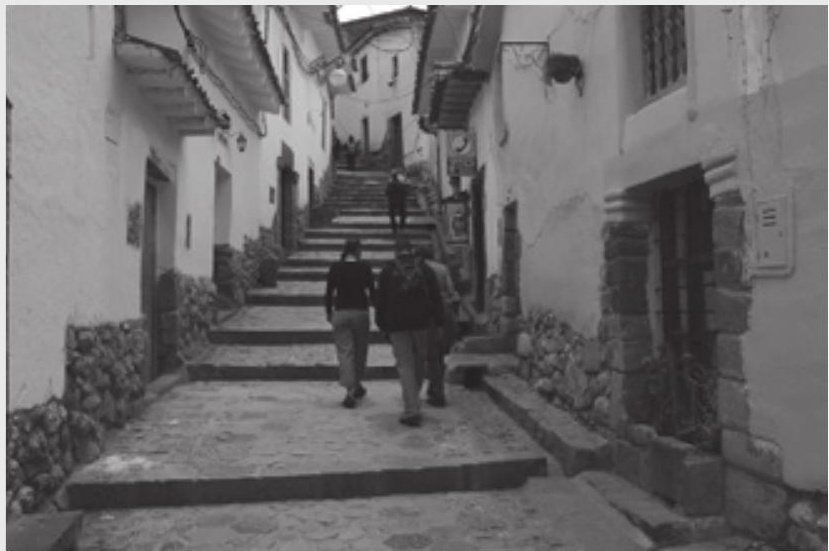

384. Subindo em direção ao Bairro de San Blas. Fonte: Fotografia elaborada pelo autor (2007).

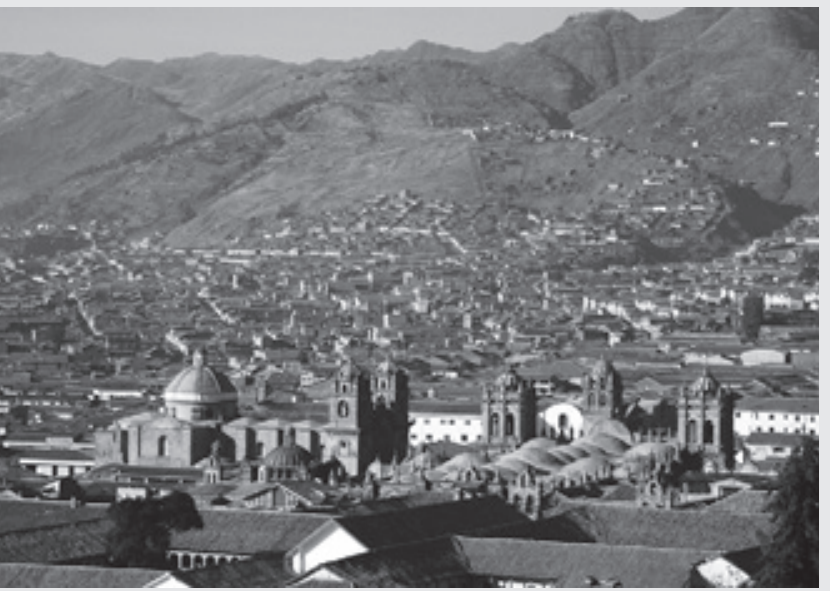

386. As calotas das cúpulas e as torres da Catedral e de La Compañia vistas do Bairro de San Blas. Fonte: Fotografia elaborada pelo autor (2007).

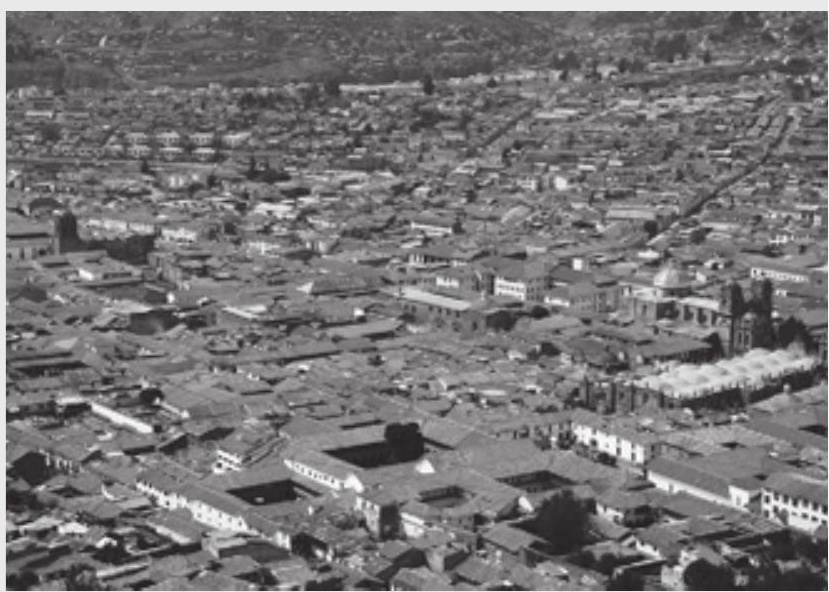

385. Fotografia retirada do Bairro de San Blas. A esquerda, desponta a Igreja e o Convento de Santo Domingo; à direita, as cúpulas e torres da Catedral e de La Compañia. Os organismos religiosos aparecem em contraposição ao fundo homogêneo da massa de telhados que cobrem as edificações civis da cidade. Fonte: Fotografia elaborada pelo autor (2007) 


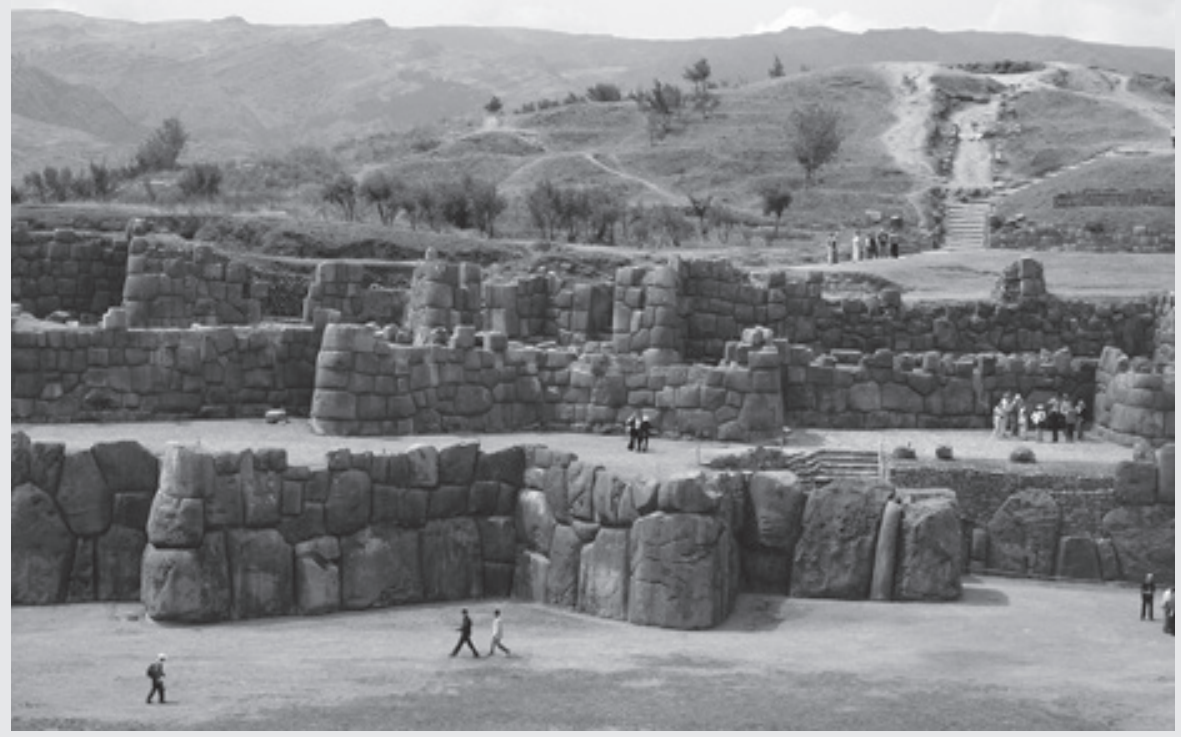

387. Fortaleza inca de Sacsayhuamán, disposta acima da cidade de Cusco. Na colina, à frente, despontaria uma das mais dramáticas vistas da cidade. Fonte: Fotografia elaborada pelo autor (2007).

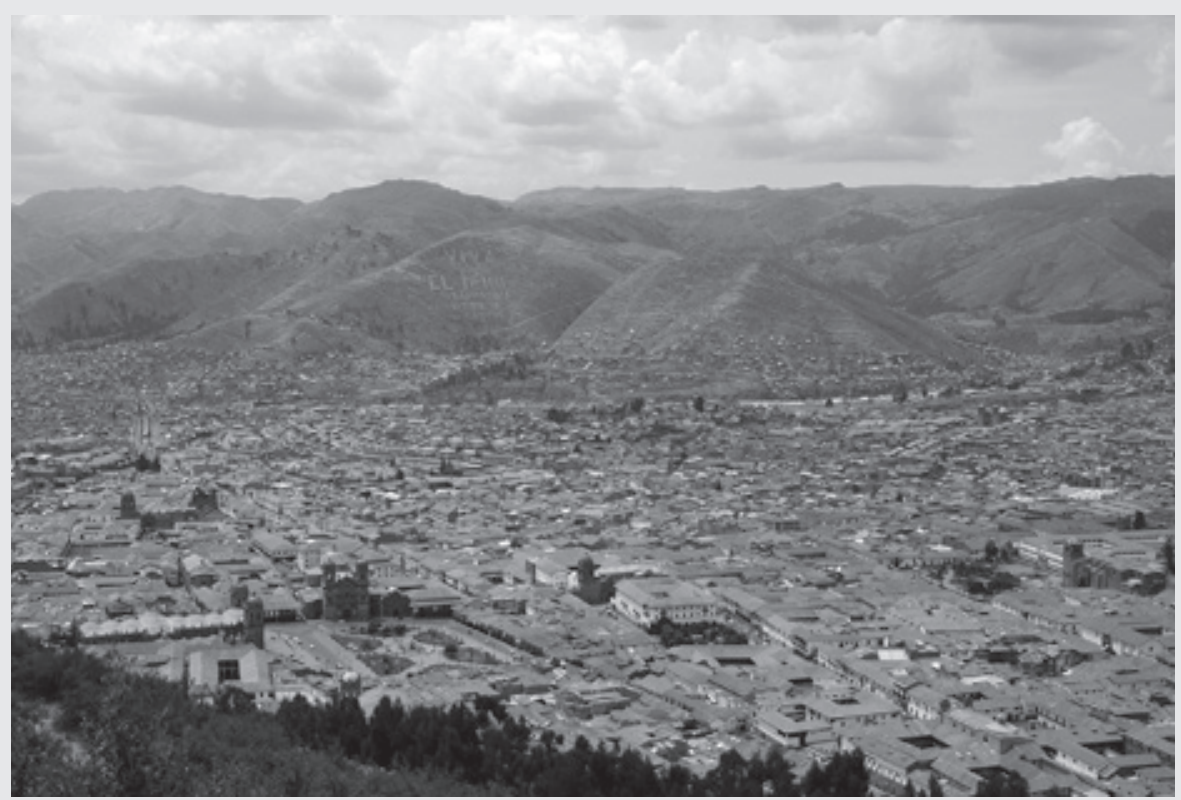

388. Panorama de Cusco retirado da fortaleza inca de Sacsayhuamán. As torres e cúpulas dos organismos religiosos dilacerariam, dramaticamente, a massa construtiva regular - supostamente ortogonal - dos telhados da cidade. Fonte: Fotografia elaborada pelo autor (2007). 
templos alinhados, que conformariam a fuga perspectiva da "Via Sacra", além do encaminhado perpendicular que buscaria o Convento de Santo Domingo; mas também os outros organismos religiosos lançados por toda extensão da cidade; e as igrejas à cavaleiro das elevações que envolveriam o vale coberto pelos telhados das construções coloniais ordinárias. Desta forma, a paisagem apreendida do núcleo privilegiado, que se espalharia abaixo, ofereceria ao transeunte uma síntese imediata de toda trama cenográfica que se poderia vivenciar ao se caminhar pelas ruas do assentamento urbano.

Como os nativos seriam os espectadores que, comumente, trafegariam pelas encostas de onde se abririam os panoramas distantes da cidade - já que habitariam as áreas altas ao redor do vale central -, ficaria claro que a Cusco colonial cumpriria seu papel como centro regional de propagação da devoção religiosa. De cima, os descendentes daquele povo que teria edificado o grandioso império inca se sentiriam subjugados pela nova ordem política e religiosa que, impositivamente, teria se instaurado - um comando espiritual capturado na imponente presença das estruturas religiosas que apontariam por toda cidade. Deste modo, não restaria alternativas à massa indígena se não a aceitação satisfatória da crença cristã - cumprindo o objetivo lançado pela trama persuasiva da cidade barroca.

Não sendo escolhida para acolher a poderosa capital do Vice-Reinado do Peru - posto assumido pela cidade de Lima, fundada por Pizarro em I535, em uma localização estratégica, a poucos quilômetros do Oceano Pacífico -, a pujança artística e arquitetônica da cidade de Cusco, transfigurada segundo o signo do Barroco após o terremoto de 1650 , só poderia ser compreendida pela importância que a cidade assumiria como núcleo estratégico de divulgação e consolidação da fé católica (Figura 389). Assim: "Cusco é uma Ville d'art a mais de três mil metros de altitude, na solidão de um vale dos Andes. Em uma área pequena se sucedem os monumentos, prova eloquente do que devia ser este centro no que concerne à vida religiosa." (CHUECA GOITIA, I984, p. 27, tradução nossa)

\section{Contra a quadrícula: a arquitetura como artifício de dramatização da rígida grelha hispano-americana}

Como conclusão, poderia ser dito que sob inúmeros aspectos, o centro regional andino romperia, gravemente, com o esquema tradicional aplicado para as 


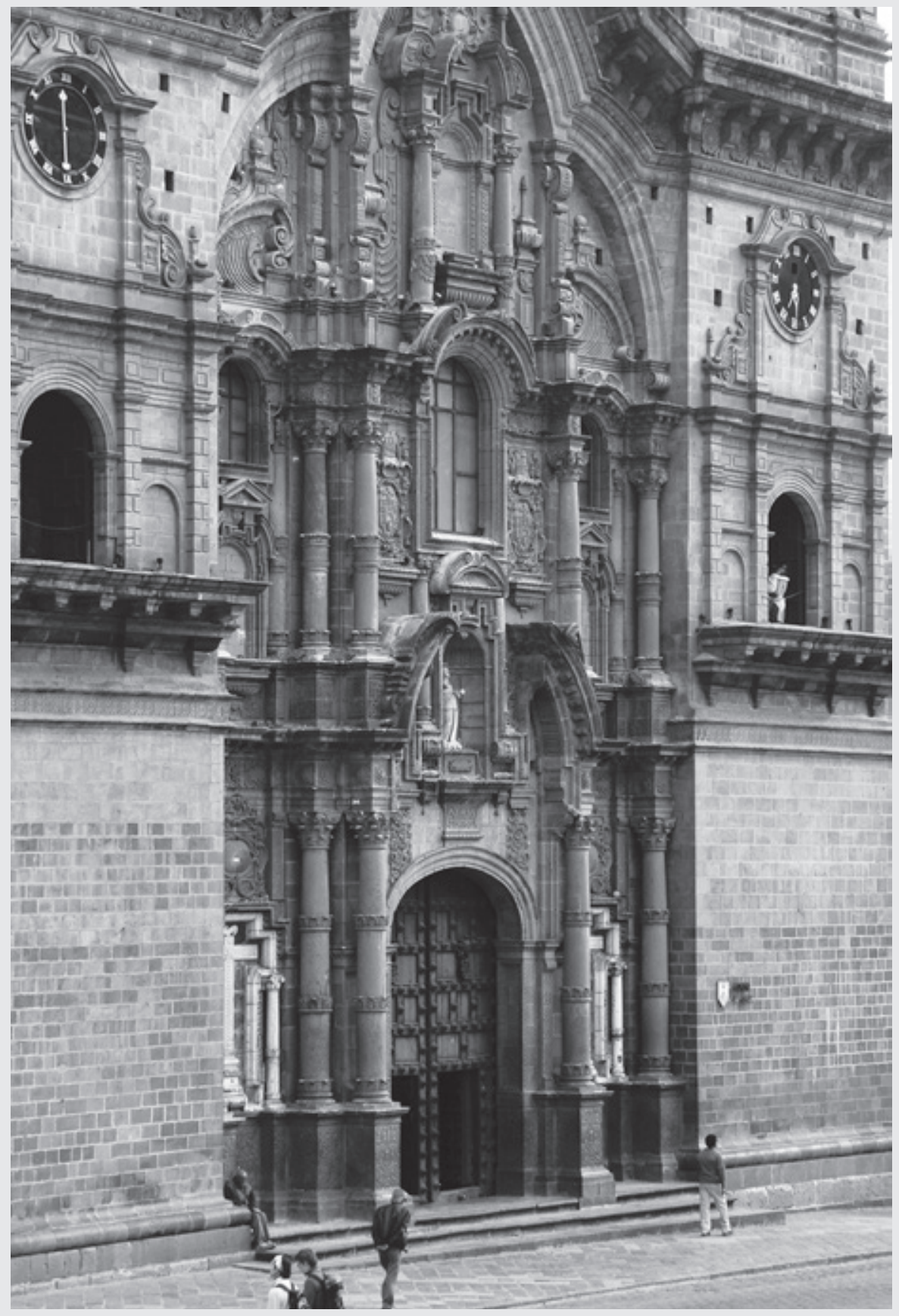

389. Fachada-retábulo da Igreja de La Compañia, em Cusco, uma das obras-primas da arquitetura hispanoamericana. Fonte: Fotografia elaborada pelo autor (2007). 
povoações coloniais de caráter racionalizado e ordenado - mesmo reconhecendo que a cidade apresentaria uma estrutura viária de caráter semirregular.

Assim, a traza de Cusco não se desenharia como um somatório de "manzanas" de iguais dimensões, retangulares ou quadrangulares, que se distribuiriam através de uma malha rigidamente ortogonal, esboçada pelas interseções das ruas que, por sua vez, apresentariam a mesma largura. Na verdade, no máximo, seria possível encontrar vias retilíneas que raramente se cruzariam em ângulos retos e que, amiúde, seriam interrompidas durante o percurso - situação pouco frequente para as cidades que seguiriam o modelo regular de traçado viário e inexistente para aquelas que acolheriam o design aprisionado do modelo clásico (HARDOY, I983, p. 320-32I) e, consequentemente, a configuração em forma de damero.

Contudo, este expediente cusqueño, que admitiria que algumas ruas diretas se concluíssem no meio das testadas de outros quarteirões - artifícios derivados, quase sempre, do traçado nativo preexistente -, acabaria contribuindo para a geração de enquadramentos perspectivos que emoldurariam as fachadas e as portadas de alguns monumentos. Esta solução, entendida como um dos mais importantes estratagemas da urbanística barroca, nem sempre teria nascido nos séculos XVII e XVIII, remontando, frequentemente, à própria fundação quinhentista de conventos, monastérios e igrejas. Porém, nas próximas centúrias, a fuga em profundidade dos eixos perspectivos ganharia força com o remodelamento das fachadas - após o sismo de I650.

Por outro lado, o lançamento da mole da Catedral, com sua fachada principal aberta adjacente ao eixo longitudinal dominante e, consequentemente, voltada de frente para a Plaza de Armas - estratagema que favoreceria a apresentação dramática do templo no mais importante ambiente da cidade -, seria, igualmente, uma solução que agiria contra o esquema tradicional praticado pela urbanística virreinal. Segundo os procedimentos usuais, as igrejas maiores deveriam estar assentadas de lado, de costados para o vasto recinto vazio da Plaza Mayor, ocupando, racionalmente, toda a testada de uma das suas faces. (NICOLINI, 2005, p. 32)

A cavidade interna da praça principal, por sua vez, deveria contar, pela tradição da quadrícula, com uma planta quadrangular. Seria um eficiente e lógico recurso vinculado ao esforço prático de fundação daquelas inúmeras cidades em que a praça seria o ambiente resultante da elementar supressão de uma quadra central. No caso de Cusco, a Plaza de Armas contaria com uma planta sugestivamente 
retangular, alongada no sentido em que seria erguida a Igreja de La Compañía, produzindo o efeito de que o recinto agiria como uma nave a céu aberto cuja terminação estaria emoldurada pela fachada-retábulo do templo jesuítico. Este seria outro artifício totalmente contrário ao esquema tradicional por provocar o enfrentamento da Catedral com um dos mais importantes organismos religiosos da cidade, diminuindo, teoricamente, seu autoridade no núcleo central. Segundo o legado deixado pela urbanística regular praticada nas Índias Ocidentais, a sede episcopal deveria reinar absoluta, mesmo dividindo espaço com os edifícios rasantes dos palácios de governo e com o tianguez (o mercado indígena).

Ou seja, a tradicional cidade hispano-americana concentraria as mais importantes estruturas oficiais, cívicas, comerciais e seculares na Plaza Mayor o que geraria o típico caráter centrípeto encontrado nos assentamentos virreinales. No entanto, contraditoriamente, em Cusco despontaria uma fatal descentralização das atividades e dos organismos arquitetônicos que comumente habitariam, em uníssono, a praça principal - já que o cabildo e o mercado indígena contariam com suas próprias praças, derivadas da fragmentação da antiga esplanada inca de Huacaypata.

Seria possível apreender outros recursos transgressores na configuração cenográfica do núcleo urbano levantado nas altitudes andinas, expedientes que sempre acabariam sublinhando o drama barroco encenado no âmago da cidade e desvelado nas vistas capturadas nas encostas e nos morros: assim, a presença de uma artéria hierarquicamente destacada, como seria o caso da "Via Sacra", negaria a homogeneidade marcante do traçado em grelha das cidades em damero das Índias Ocidentais; do mesmo modo, o processo de aproveitamento de partes significativas da estrutura viária semirregular do núcleo pré-hispânico - ruas retificadas que não apresentariam uma largura uniforme e que poderiam contar com brandas sinuosidades - acabaria provocando, em alguns casos, sentimentos de tensão, expectativa e, em consequência, a geração de situações de "surpresa" para o espectador que caminhasse pela cidade, circunstâncias, obviamente, inexistentes em um assentamento levantado a partir de um plano duramente cartesiano.

Ou seja, a configuração barroca da cidade de Cusco estaria - quase que invariavelmente - atrelada à corrupção do que viriam a ser os modelos consagrados de assentamentos racionais e ordenadores da América hispânica.

Porém, deve-se ter o cuidado para que esta análise não ofereça a ideia de que, quanto mais errática fosse a cidade, mais barroca ela seria - não era assim tão 
simples. Na verdade, foi visto que a Cusco colonial não se configuraria como um assentamento de delineamento essencialmente irregular - nem mesmo antes da conquista espanhola. Inclusive, os fascinantes panoramas, capturados a certa distância, do alto dos morros e encostas da cidade, ofereceriam vistas de um espaço urbano virtualmente mais racionalizado do que seria em sua realidade física e em seu desenho - e para o Barroco importariam os "modos de visão", o que sensibilizaria o espectador através da apreensão subjetiva do olhar; a aparência, e não a conformação real dos objetos. (ARGAN, I973, p. 79)

Por outro lado, pujantes cidades virreinales de padrão absolutamente irregular, como os núcleos mineradores de Guanajuato (I548) e de Taxco (I529), no México, não aproveitariam o desenho sinuoso e imprevisível de suas vias, bem como sua topografia acidentada, para a produção de efeitos teatrais ligados à poética barroca. Esta seria uma diferença substancial entre a cidade orgânica hispano-americana e os núcleos urbanos de formação espontânea do Brasil colonial - povoações que, repetidamente, constituiriam cenários de alto teor dramático se valendo, exatamente, da sua falta de ordenação: como foi visto em relação à estonteante configuração artística de Vila Rica, núcleo minerador no qual as irregularidades da estrutura viária seriam artifícios essenciais para a produção do "efeito surpresa", estratagema que contribuiria, substancialmente, para a edificação da paisagem barroca da capital da antiga Capitania das Minas Gerais.

Não obstante, é preciso dizer que, para além das inúmeras corrupções do esquema habitual da urbanística colonial praticadas em Cusco - que, sem dúvida, favoreceriam a constituição do enredo barroco encenado na cidade andina, assim como em diversos outros núcleos urbanos que não apresentariam uma estruturação viária tão estacionária como o tabuleiro de xadrez -, o artifício que mais impulsionaria a transfiguração barroca da cidade nos séculos XVII e XVIII seria a arquitetura; especialmente aqueles edifícios religiosos que promoveriam o ato de sacralização de todo espaço urbano através da encenação barroca oferecida ao passante, convidado a caminhar por suas vias e a conhecer seus panoramas distantes ao trafegar pelas encostas. Neste aspecto, a conformação da cidade barroca hispano-americana se aproxima daquela luso-brasileira.

Assim, na introdução desse capítulo, outra cidade - Morelia, no México seria analisada através da inclusão de mais de uma dezena de imagens ilustrativas e de suas respectivas legendas - figuras que reforçariam a afirmativa que colocaria a arquitetura religiosa como o maior agente da dramatização e transformação do 
espaço urbano preexistente em prol da exaltação de um agitado espírito barroco. Estas imagens revelariam a possibilidade de dilaceração da estrutura aprisionada da cidade regular hispano-americana através da inserção de alguns expedientes urbanísticos atrelados à chamada Grand Manner, mas, especialmente, devido à presença de uma expressiva e teatral arquitetura monumental, contraposta ao "fundo" estéril da massa edificada do tecido urbano.

É interessante como a configuração mais flexível do traçado urbano da antiga Valladolid de Michoacán possibilitaria a construção de múltiplos expedientes caros à urbanística barroca: a presença de um eixo dominante que deveria cruzar a cidade - a Calle Real; os encaminhamentos perspectivos direcionados em profundidade a específicos points de vues, emoldurados por fachadas ou portadas de igrejas. Neste sentido, seria significativo o fato da arquitetura monumental, componente da cidade de Morelia prescindir de um caráter espetaculoso, preferindo uma composição mais sóbria, apesar de absolutamente imponente, grandiosa. Provavelmente, a cidade hispano-americana que mais se apropriaria das soluções urbanísticas vinculadas às intervenções praticadas no Ancien Régime não necessitaria tanto de uma arquitetura de grande expressão cenográfica para provocar a virtual transformação de seu ambiente em prol da persuasiva exaltação do poder da coroa espanhola e da Igreja Católica.

Se em Morelia a arquitetura barroca seria mais contida, em outras cidades hispano-americanas os edifícios singulares apresentariam, a partir do século XVII, uma trama compositiva barroca calcada, notadamente, na presença de uma decoração efusiva aplicada nas fachadas e portadas dos monumentos. Frequentemente, a transfiguração do espaço cartesiano de cidades como Arequipa, Lima, Oaxaca, conseguida através da reorientação cenográfica da paisagem urbana, exigiria a presença desta dramática arquitetura com suas fachadas-retábulo e suas portadas decorativas - lançadas como cenários teatrais fixos por todo o assentamento. Mesmo o mais importante núcleo urbano colonial, a Cidade do México, capital do Vice-Reinado da Nova Espanha, constituiria seu enredo barroco através da presença de monumentos que despontariam como "figuras" na trama viária regular desenhada pelo alarife espanhol Alonso García Bravo (I490-I56I), após a fundação do núcleo colonial em I52I - traza incrivelmente bem adaptada ao antigo plano da cidade asteca de Tenochtitlán (Figuras 390-39I).

Neste sentido, cidades com um traçado rigorosamente racionalizado, que seguiriam o tradicional esquema distributivo que conformaria a grelha estendida 


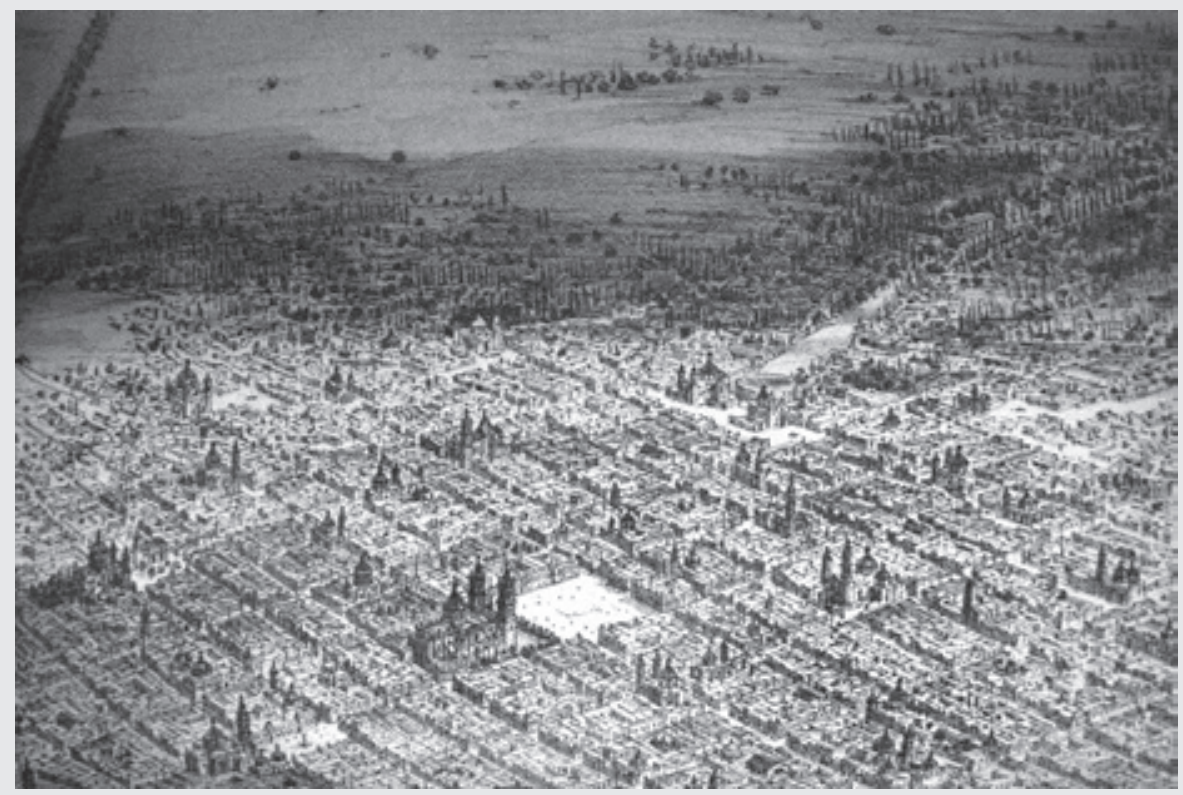

39o. Detalhe da vista panorâmica da Cidade do México - confeccionada por Casimiro Castro (1826-1889) -,

litografia publicada em 1869 em México y sus arredores. Nela vislumbra-se a imensa Catedral assentada no colossal vazio da Plaza de Armas, assim como a grande quantidade de igrejas, com suas torres e cúpulas, despontando como "figuras" no "fundo" regular da massa edificada distribuída pela grelha ortogonal do núcleo urbano. Imagem retirada do estofado de uma poltrona oitocentista pertencente ao acervo do Museo de la Ciudad de México. Fonte: Fotografia elaborada pelo autor (2009).

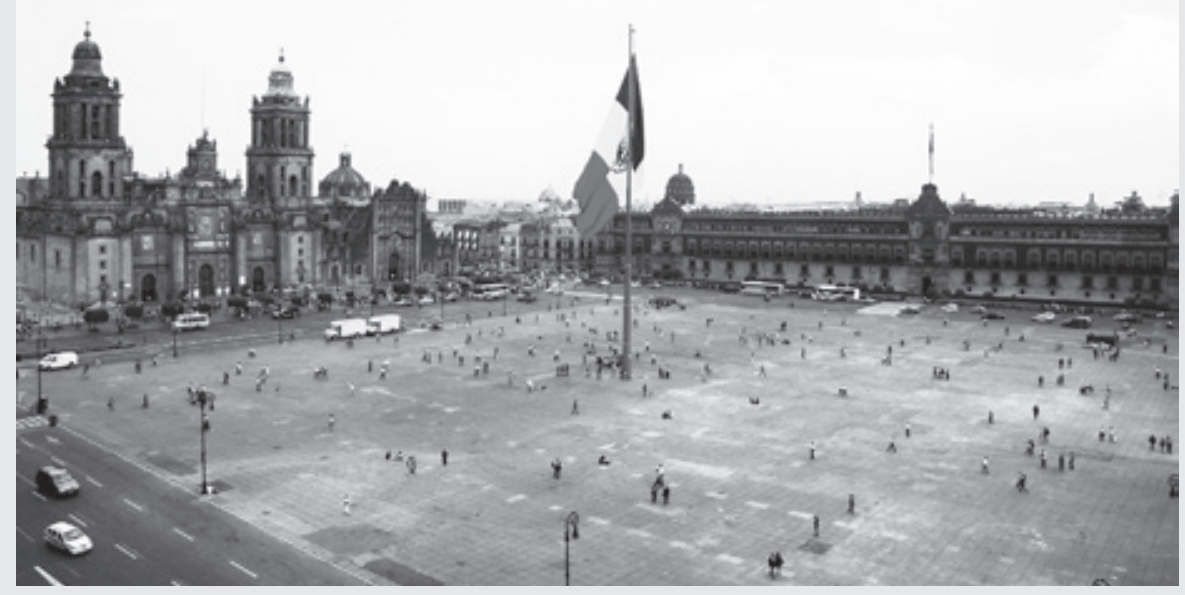

391. El Zócalo - a Plaza Mayor da Cidade do México - e sua colossal Catedral voltada de frente para a praça. Imagem retirada do terraço do Gran Hotel. Fonte: Fotografia elaborada pelo autor (2009). 
desde a plaza mayor - núcleos urbanos alheios a qualquer expediente vinculado à urbanística barroca, ou distantes de atos transgressores que viessem perverter a quadrícula regular - poderiam ser corrompidas através da contaminação de seu espaço por uma arquitetura barroca que virtualmente agisse contra a grelha regular: edifícios prioritariamente religiosos, que agenciariam as mais significativas experiências cenográficas através do exercício do contraponto "figura-fundo" com a massa edificada e com a armação viária ortogonal. Catedrais, igrejas, capelas, torres, cúpulas, portadas, fachadas-retábulo que balizariam, sequencialmente, grandes eventos dramáticos que transformariam - na dimensão temporal do percurso do espectador - a ação de se conhecer e vivenciar a cidade através de uma fatal experiência barroca (Figuras 392-399). 


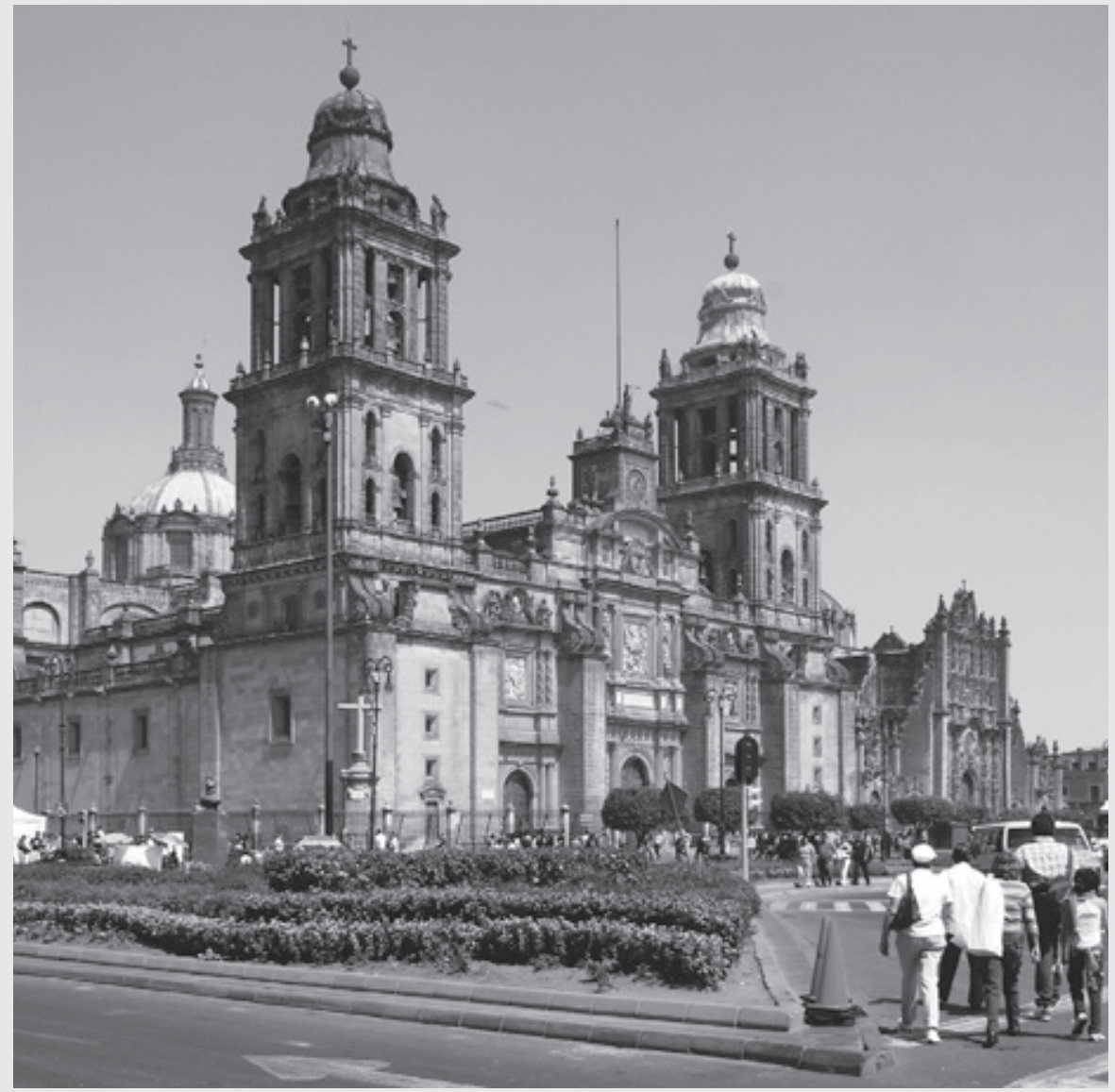

392. Grandiosa mole da Catedral Metropolitana do México lançada no vazio do Zócalo, flanqueada por uma das fachadas-retábulo churrigueresca do Sagrario. O edifício da Catedral - que se voltaria de frente à praça - seria iniciado em 1563 segundo projeto do arquiteto espanhol Claudio de Arciniega (1527-1593). O Sagrario seria projetado pelo mestre espanhol, radicado no México, Lorenzo Rodríguez (1704-1774) e construído na segunda metade do século. Fonte: Fotografia elaborada pelo autor (2009). 


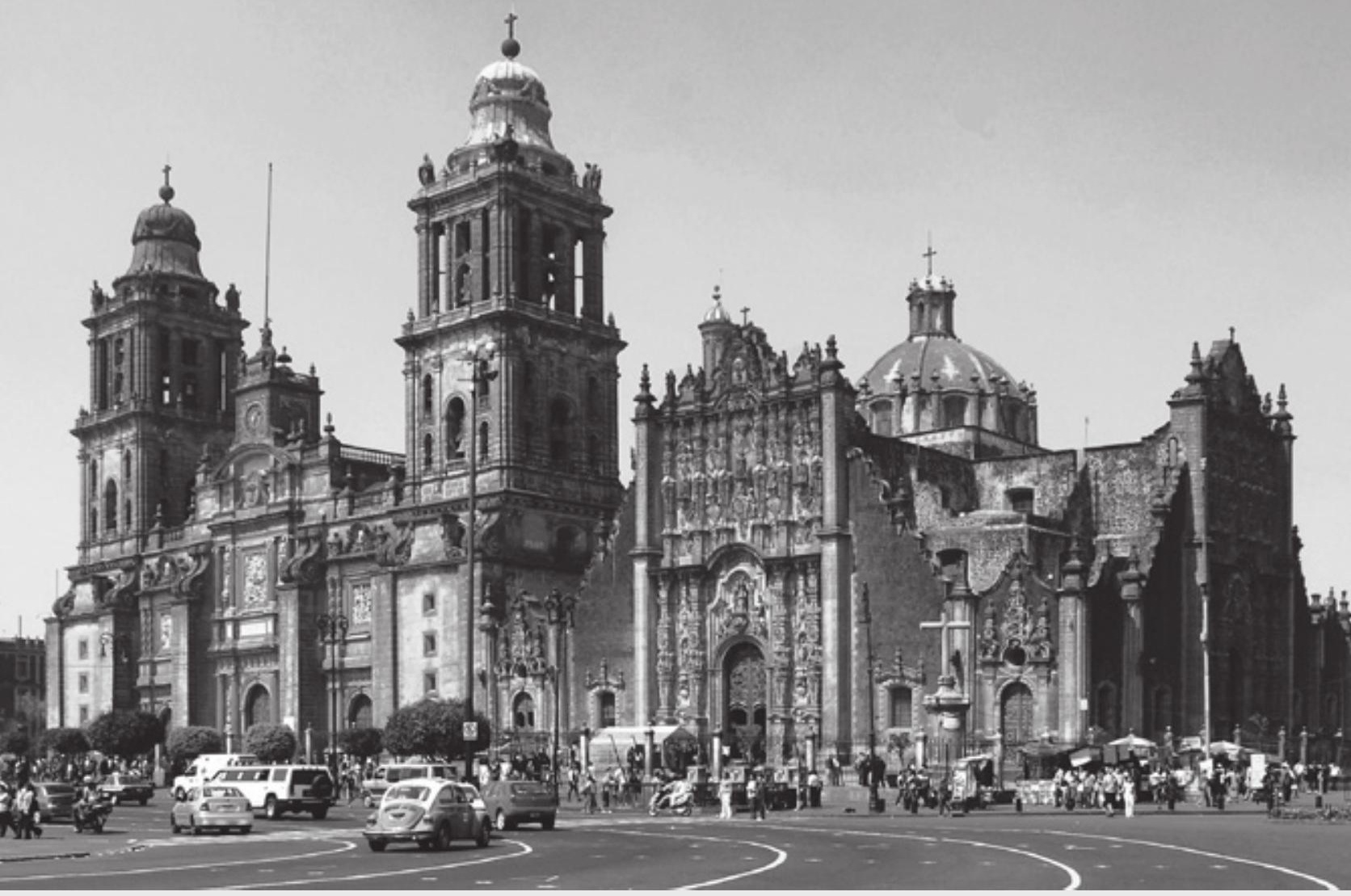

393. El Sagrario de México e a Catedral. Notar as fachadas-retábulos do Sagrario, bem como suas exuberantes portadas voltadas para El Zócalo. Fonte: Fotografia elaborada pelo autor (2009). 


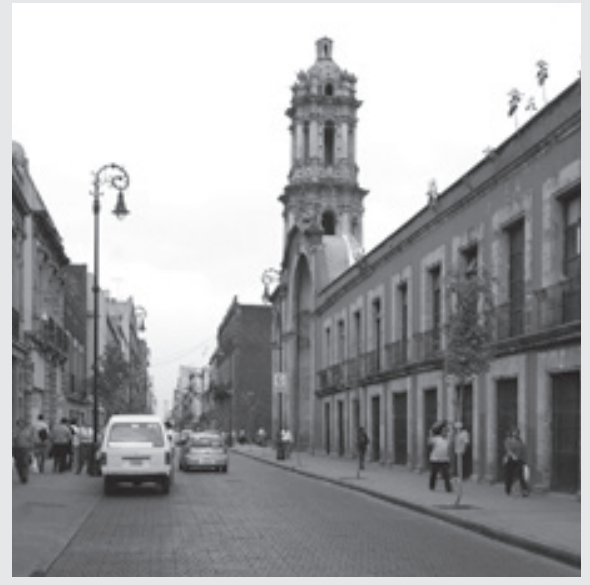

394. Perspectiva da Calle República de El Salvador, no centro histórico da capital mexicana, com destaque para a torre do complexo do Oratório de San Felipe Neri, edificada na segunda metade do século XVIII. Fonte: Fotografia elaborada pelo autor (2009).

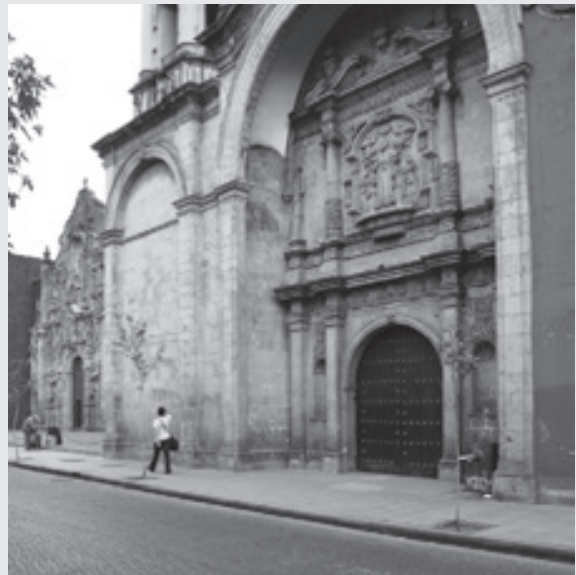

395. A direita, aparece a fachada alinhada com a via e flanqueada pela torre do Oratório de San Felipe Neri; à esquerda, a outra fachada, recuada em relação à via, do mesmo complexo eclesiástico. Fonte: Fotografia elaborada pelo autor (2009).

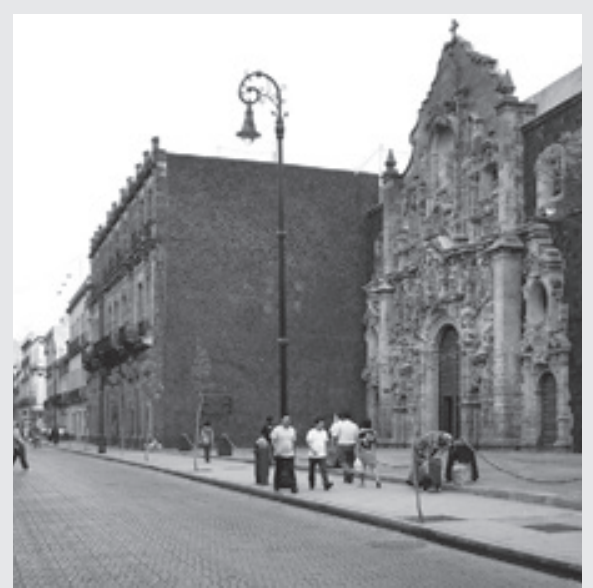

396. Recuada fachada-retábulo churrigueresca do Oratório de San Felipe Neri, na Cidade do México - projetada em 1751 pelo arquiteto Ildefonso Iniesta Bejarano y Durán (1716-1781). Este conjunto proporcionaria um dos mais interessantes jogos cenográficos lançados na rígida grelha ortogonal do núcleo urbano. Fonte: Fotografia elaborada pelo autor (2009).

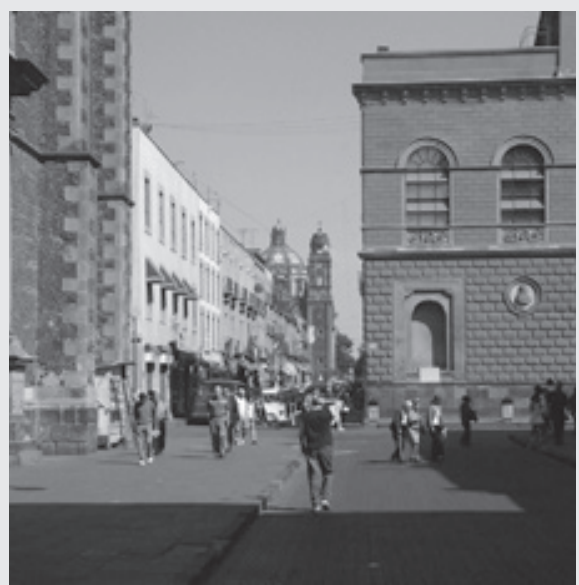

397. A Calle Moneda, na Cidade do México. Ao fundo, a Igreja de la Santísima Trinidad busca se destacar em uma esquina da grelha regular. Fonte: Fotografia elaborada pelo autor (2009). 
398 Fachada-retábulo de estilo churrigueresco projetada, em 1755 , por Lorenzo Rodríguez, para a Igreja de la Santísima Trinidad, na Cidade do México. Fonte: Fotografia elaborada pelo autor (2009).

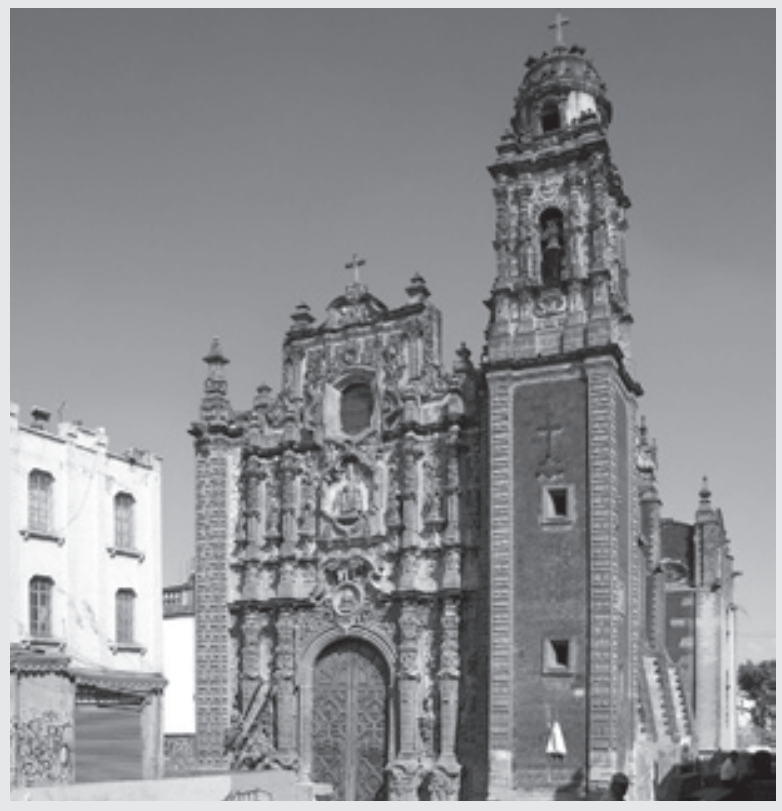

399. Detalhe da fachada-retábulo da Igreja de la Santísima Trinidad, na Cidade do México. Fonte: Fotografia elaborada pelo autor (2009).

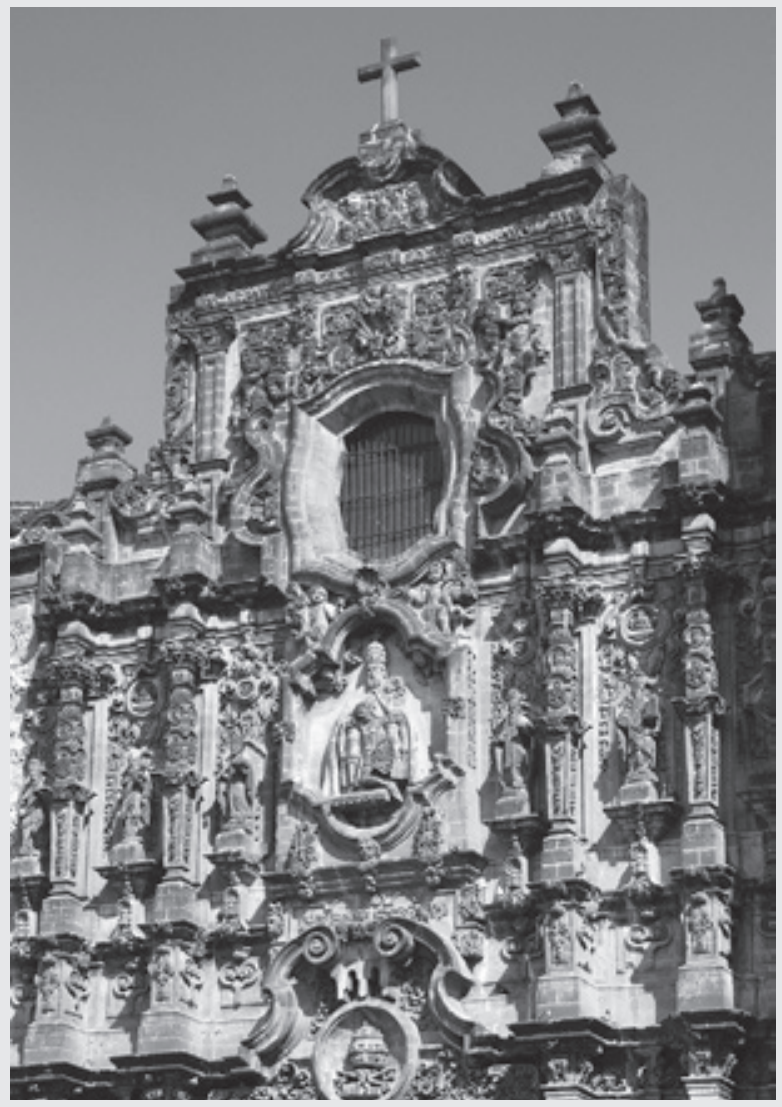




\section{CONSIDERAÇÕES FINAIS}

O século XVII marcaria um período de transição que forneceria os subsídios para a caracterização do fenômeno barroco. No Quattrocento, ao início da Idade do Humanismo, a natureza e a história, ligadas diretamente à revisão da herança clássica greco-romana, assumiriam o papel de comandantes dos desígnios da produção artística através de ações que buscariam promover uma arte fundamentada em uma visão idealizada da natureza - perfeita, ordenada e bela; já no Cinquecento, seguiriam governando o interesse do artista quando a transgressão da ordem - o Antinaturalismo e o Anticlassicismo - acabaria conduzindo os rumos ditados pelo cenário cultural europeu. Contrariando esta tendência, o homem barroco revelaria certo desprezo frente às polêmicas suscitadas sobre a essência do universo: seja a imagem positiva que o Renascimento conferiu às supostas leis eternas do cosmos, seja a noção de seu colapso vislumbrada pelos maneiristas, o artista do Seicento não nutriria uma real preocupação com a natureza.

A mudança de enfoque, no que se refere à produção artística, começaria a ser desenhada em finais do século XVI, quando a fusão entre ciência e arte pregada pela Renascença, e base para grande parte dos dramas maneiristas, seria rompida definitivamente - os problemas oriundos da interpretação do mundo afastar-se -iam do império da arte e se voltariam, exclusivamente, para a experimentação científica e para a filosofia. Este fato revelaria que os artistas não buscariam mais o domínio do real, a experiência sensível ou inteligível do mundo. Como consequência, a verdade não importaria senão como referência para a sua superação; a técnica artística não estaria mais a serviço da representação correta da natureza, mas da ampliação das barreiras do possível, assumindo, deste modo, o alcance ilimitado da imaginação humana.

Para além do comando da "maravilha", da fantasia, enfim, do envolvimento da imaginação, a arte barroca também apresentaria uma relação íntima e inevitável com outro princípio essencial: a elaboração de um discurso de qualidade altamente retórica com o objetivo de perseguir a meta final da persuasão. As motivações que impulsionariam o exercício da persuasão estariam vinculadas à construção de estratégias de propaganda empreendidas pela Igreja e pelos governos autoritários, em crise constante em função do colapso econômico, político, 
mas principalmente devido às revoltas sociais que se desenhavam na esfera das sociedades seiscentistas - um panorama conturbado que se estenderia à próxima centúria. Por meio do artifício da imaginação e da fantasia, logo da dramatização e da teatralização das expressões visibilísticas, os artistas, comprometidos com as monumentais estruturas de poder, construiriam um sedutor discurso de alto teor retórico que revelaria, simbolicamente, o caráter grandioso da Igreja e dos impérios absolutistas, dirigindo as massas a um comportamento adequado de apoio e subordinação aos governos.

A persuasão, portanto, proveria da necessidade de elaborar um enérgico mecanismo de divulgação e de exposição do poder inigualável emanado pelas estruturas políticas e religiosas que povoariam o cenário seiscentista e setecentista: uma estratégia de representação que fosse acessível a todos, desde os mais humildes aos mais sábios. Assim, o esforço profundo de comunicação e a convincente retórica proposta pelas imagens oferecidas ao fruidor nas mais distintas manifestações artísticas despertariam a sua imaginação e apoiariam a apreciação de um cenário que não poderia ser desvelado objetivamente, mas que preencheria a mente com experiências fantásticas - e só o poder arrebatador da fantasia e da imaginação seria capaz de confirmar a estrutura sobrenatural da Igreja e do Estado.

A arte, consequentemente, acabaria se transformando no mais poderoso baluarte do projeto de propaganda barroca, absorvendo uma estrutura profundamente cativante para a sedução do fruidor. E para atiçar as mentes dos indivíduos com suas ilusórias e inebriantes imagens, bem como para conquistá-lo com sua mensagem retórica, as manifestações artísticas ofereceriam uma experiência que se aproximaria da estrutura de um teatro. Ou seja, para seduzir os espectadores o Barroco apelaria a um conteúdo formal que produziria efeitos compositivos de teor absolutamente cenográfico, logo fatalmente teatral - conteúdo fundado, integralmente, nos princípios da imaginação e da persuasão.

Fica claro que a análise que aqui se propõe se sustenta em uma pesquisa cuja temática estaria indissociavelmente relacionada a estas discussões que afetariam a caracterização do fenômeno Barroco. E nesta direção, tem como fundamento essencial a averiguação da hipótese que atestaria que o Barroco teria alcançado a configuração visiva das cidades. Ou seja, investiga o problema que indagaria se a poética barroca - com seu apelo à imaginação, à fantasia, à ebriedade, à "maravilha", com seu uso incondicional de artifícios retóricos voltados a conquistar e 
persuadir as massas, dirigindo-as ao apoio incondicional às estruturas de poder estabelecidas na Europa e nas colônias além-mar - poderia comandar o desenho de novas cidades planificadas, bem como promover transformações em muitos núcleos preexistentes, organismos urbanos que passariam a exaltar, genericamente, um panorama cenográfico de grande expressão barroca.

Neste sentido buscou-se, peremptoriamente, construir uma avaliação crítica sobre a formação histórica da chamada "urbanística barroca" - a prática quinhentista, seiscentista e setecentista de intervenção, em larga escala, sobre o organismo citadino. Este fenômeno, apesar de não chegar a atingir a enorme complexidade que seria cobrada, décadas mais tarde, para o exercício da moderna disciplina do urbanismo, alcançaria a experimentação de procedimentos que ultrapassariam o simples desenho de novas áreas e equipamentos para a cidade, envolvendo problemas ligados à especulação imobiliária, desapropriações, controle estatal das intervenções, infraestrutura, espaços verdes, salubridade, defesa etc.

Não obstante, praticamente todos os planos debatidos estariam vinculados a ações dos governos absolutistas pensadas em nome da transformação cenográfica de setores de cidades preexistentes, principalmente a remodelação de pequenas áreas centrais, bem como de ambientes limítrofes dos núcleos urbanos, seja nas capitais das nações modernas ou nas sedes administrativas das províncias - como aconteceria em Paris ou em Nancy. Também seria comum, apesar de menos frequente, a criação de completas estruturas urbanas cujo objetivo máximo seria promover a exaltação das figuras dos reis, príncipes e duques, através de ousados empreendimentos de fundação de núcleos urbanos de ostensivo caráter áulico - como Versailles e Karlsruhe. Mas, como toda intervenção urbanística, as iniciativas das nações totalitárias de reordenação das cidades acabariam pressupondo um desenvolvimento posterior das cidades comandado, especialmente, por processos bidimensionais de planificação, fato que não poderia garantir a alteração significativa do caráter visibilístico da paisagem urbana - por ser a imagem da cidade compreendida, genericamente, como um organismo tridimensional.

Portanto, apesar do usual objetivo de constituir um espetáculo adequado à celebração da onipresença e do poder sobrenatural do monarca, escopo vinculado às ações de remodelação e criação de cidades em prol da grandiloquência e do esplendor que glorificariam o governante - procedimentos herdados, francamente, da ideia de um Classicismo barroco revisitado -, na maioria das vezes 
as intervenções urbanísticas não seriam capazes de compor, isoladamente, uma cidade que se poderia dizer barroca, mas apenas o estabelecimento de episódios barrocos espalhados pelo núcleo urbano.

É o que aconteceria com a Paris do Ancien Régime, cidade na qual o exercício da urbanística, mesmo gerando acontecimentos fabulosos calcados na dramatização barroca, como as places royales, não conseguiria alcançar uma alteração cenográfica global de sua paisagem urbana. Isto se daria pelo fato das intervenções - ao não perseguirem uma relação mais direta entre a arquitetura, o monumento e sua interação com o tecido preexistente - não chegarem a extrapolar os mecanismos da planificação e desenho urbano; por não ter-se buscado um investimento global que reconheceria a força dramática que modernos e expressivos edifícios, espalhados por todo o organismo urbano, poderiam assumir em prol da contaminação, com sua carga teatral, de toda a massa edificada da cidade - como aconteceria na Roma barroca. É certo que algumas estruturas arquitetônicas megalômanas seriam edificadas na capital francesa durante o Seicento -, mas prosseguiriam sendo situações ímpares. Além do mais, estas construções, frequentemente, estariam assentadas em áreas isoladas e desocupadas dos limites do centro urbano, não interagindo, imediatamente, com o apertado burgo preexistente - como seria o caso do complexo do Hôtel des Invalides e sua monumental igreja, grandiosos monumentos levantados a certa distância do núcleo central da Paris do século XVII.

Neste sentido, partindo-se exclusivamente da urbanística, somente as cidades formadas ex novo, particularmente aquelas concebidas com o objetivo de servir de morada à nobreza e à realeza, seriam capazes de coordenar a apreensão de um cenário genericamente barroco - levando-se em conta que a preservação de seu caráter exigiria certa manutenção da escala original do empreendimento. Contudo, mesmo para um assentamento rigorosamente planificado, como Karlsruhe, o próprio design bidimensional de grande escala, concebido para compor o núcleo urbano e garantir seu crescimento regular, não seria tão apreensível após a sua implantação - após a construção e o desenvolvimento do núcleo citadino. Na nova capital de Baden, o sedutor direcionamento radial das vias, que comporiam as principais artérias da urbe, seria dificilmente compreendido in loco: primeiramente, com exceção do eixo central do palácio do Margrave, que seria deixado livre, os jardins à frente da grande estrutura do monumento não acompanhariam a projeção radial das vias que acorreriam ao torreão postado 
por detrás da residência principesca, dificultando, ou mesmo impossibilitando, a descoberta deste jogo cenográfico irradiante - especialmente depois que os canteiros, que originalmente continham vegetação rasteira, seriam povoados com árvores frondosas, situação que se preserva até os dias de hoje; em segundo lugar, o fato da torre de caça que acolhe o polivium estar assentada atrás do palácio exigiria um esforço imenso de abstração para o seu entendimento como centro da irradiação axial do leque de vias que ordenavam a cidade - vias que só partiriam, por outro lado, a 400 metros do palácio, contribuindo ainda mais para dificultar a apreciação da trama persuasiva proposta. Desta forma, a racionalidade clássica do enredo barroco de Karlsruhe, claramente visível no desenho, seria dificilmente percebida na experimentação direta da cidade.

Finalmente, e essa é a principal hipótese defendida nesse livro, na grande maioria das vezes, para se conseguir alterar o caráter visibilístico da paisagem urbana, os procedimentos não poderiam se esgotar apenas nos mecanismos de intervenção propriamente urbanísticos, mas exigiriam outros estratagemas ligados, principalmente, à concepção de construções espalhadas por toda a cidade, monumentos imersos sabiamente na grande massa da arquitetura ordinária - na sua interface com o ambiente preexistente, mas também na relação com o sistema viário, com os acidentes naturais, com outros monumentos. Ou seja, para a cidade impressionar, para elevar a extremos os objetivos exigidos pela cultura barroca de controle e direção das massas, as intervenções deveriam extrapolar o universo urbanístico, não prescindindo de forma alguma da arquitetura - especialmente do monumento como elemento de destaque no núcleo edificado.

Por isso, aqui se rejeita, sistematicamente, o tradicional julgamento crítico que só reconheceria expressão estética em uma obra de arte que teria sido fruto de uma totalidade controlada e previamente idealizada - situação que, na cidade, só poderia estar relacionada à confecção do plano urbanístico, expressão do desejo consciente de se administrar, integralmente, a implantação e o desenvolvimento do artefato urbano. Pelo contrário, acredita-se que, para cada categoria artística sempre exista um mecanismo específico voltado à apreciação do objeto acabado - e não de seu processo de idealização. No caso da arquitetura, assim como, em uma escala bem mais ampla, para a própria cidade, a sua valoração artística deveria estar, necessariamente, vinculada ao ativo percurso escolhido pelo espectador para a experimentação de seus espaços componentes - o trajeto do transeunte pelos ambientes internos e externos conformadores dos edifícios, bem como pelo 
movimento do espectador pelas ruas, avenidas, largos, praças, mirantes, belvederes, que coordenariam a estruturação do espaço urbano. Logo, a forma singular, possível e especial de leitura artística da cidade só poderia realizar-se no ato de caminhar e vivenciar, na dimensão espaço-temporal, o ambiente urbano.

Ou seja, para o reconhecimento da unidade figurativa das povoações não bastaria a sua apreciação através de um juízo crítico que as contemplasse genericamente - diante de uma percepção que envolvesse uma escala geográfica abraçando todos os ambientes conformados pelas suas tramas viárias, bem como pelos cinturões naturais que envolveriam seus limites máximos; seria, de fato, imperativo o julgamento do espaço citadino in loco, no contato direto do observador que se moveria à frente das diversas imagens capturadas pela cidade, ou que vivenciasse seus distantes panoramas -, se assim o fosse permitido.

A apreciação abstrata do desenho bidimensional dos assentamentos revelaria aportes importantíssimos vinculados às intenções subjacentes aos agentes que teriam participado do ato de planificação da cidade, além de influenciar, diretamente, o desenvolvimento, a posteriori, da "cidade real" que surgiria através de seu design prévio. Mas, esta análise não poderia ser confundida com uma avaliação fundamentalmente artística, pois simplesmente não contemplaria a cidade em sua materialidade física, não alcançando a apreensão visual do núcleo urbano. Deste modo, a efetiva qualificação estética só seria possível a partir do contato direto do observador com os espaços componentes da cidade - ou, pelo menos, com a memória visual de sua estrutura visibilística perdida, através da reconstrução virtual de sua trama cenográfica.

Por sua vez, da mesma forma que em outras manifestações artísticas alguns elementos proeminentes se destacariam, abertamente, no tecido figurativo da obra, absorvendo grande parte de seu teor expressivo em contraposição a um "fundo" regular mais estéril - é só pensar no protagonismo exercido pela representação da Madona em uma pintura de Raffaello Sanzio em seu contraste com a paisagem exuberante colocada na retaguarda -, a cidade também apresentaria seus momentos especiais de expressão. A avaliação da configuração dos núcleos urbanos como conformadores de uma plena unidade artística não partiria, assim, do pressuposto de que toda a sua trama morfológica tivesse que emanar uma incondicional qualificação estética; seria absolutamente viável que poucas cenas, ou mesmo um único acontecimento inebriante (a cúpula da Catedral de Florença, por exemplo), fossem o suficiente para transformar a percepção do assentamen- 
to e oferecer a possibilidade de se alcançar uma valoração artística plena para a cidade - o que colocaria a arquitetura como elemento essencial na constituição do caráter artístico do núcleo urbano, sempre em conexão direta com os espaços urbanos especiais nos quais seria lançada.

Não seria arbitrário afirmar que as grandes avenidas retilíneas, os bulevares, as alamedas, os eixos perspectivos, as praças regulares, os vazios urbanos monumentais, o trivium e o polivium constituiriam, efetivamente, soluções características da urbanística praticada no Grand Siècle, bem como na próxima centúria - como professariam muitos dos historiadores das cidades que enfrentariam o difícil tema da urbanística praticada nos séculos XVI, XVII e XVIII. Não obstante, esta constatação tornar-se-ia mais realista e eficiente - no que se refere à avaliação da existência de cidades que se poderiam dizer barrocas - se fosse considerada a diferença entre a prática da urbanística barroca e a ideia contida na constituição de um cenário urbano armado segundo os preceitos da poética barroca, noção que estaria interligada ao conceito maior e mais complexo de cidade barroca.

Ampliando o que foi discutido anteriormente, o conceito de cidade barroca estaria, indissociavelmente, vinculado à apreensão artística do núcleo urbano; ou seja, seria oriundo da valoração estética de sua paisagem, da apreciação do cenário revelado a quem vivenciasse seus domínios. Deste modo, a atribuição de uma condição barroca à cidade não poderia, simplesmente, derivar da análise bidimensional de seu desenho, da tipologia das intervenções que teriam rasgado o núcleo urbano com grandes artérias e monumentais praças. Mesmo admitindo que algumas cidades poderiam ter sofrido verdadeiras renovações morfológicas ligadas à prática da urbanística barroca, não seria consequência imediata elas alcançarem uma conformação cenográfica que poderia receber esta denominação - a herança da Grand Manner (KOSTOF, I99I, p. 240) para o século XIX demonstraria isso: seria a base morfológica para as mais importantes intervenções urbanas dos oitocentos, como demonstraria Mumford (I989, p. 409). Mas nenhuma destas iniciativas chegaria a produzir um ambiente urbano no qual seria possível apreender uma conformação cenográfica e uma paisagem que poderiam ser ditas barrocas.

$\mathrm{Na}$ verdade, a cidade barroca seria o resultado da conjunção destas iniciativas urbanísticas com o que se poderia chamar de "arquitetura da cidade"; arquitetura que povoaria todos os setores dos aglomerados urbanos, desde as áreas que iriam ser privilegiadas com as intervenções viárias regulares, até os re- 
cônditos interiores dos bairros medievais. Por isso, não só a típica via linear de circulação, mas também as ruas tortuosas, irregulares, estreitas e apertadas, derivadas das formações urbanas preexistentes, de processos espontâneos de criação ou crescimento de cidades, poderiam colaborar para o desenvolvimento do espetáculo encenado na cidade - e particularmente para a elevação de um importante artifício da cenografia barroca: o "efeito surpresa". Joseph Connors (2005, p. VIXII, tradução nossa), discorrendo sobre o método de investigação elaborado para fomentar sua pesquisa publicada no livro Alleanze e inimicizie: L'urbanistica di Roma barocca - método que contemplaria a avaliação do poder de transformação fundado na relação dos monumentos jogados nos bairros medievais da capital pontifícia em sua interface com as vielas, os becos, o tortuoso e irracional traçado - , reconheceria:

Pela primeira vez era possível mirar a cidade que víamos nas fotografias aéreas ou na planta de Nolli como um organismo vivo em lento, mas constante, movimento, que mudava sua forma a cada pontificado. Contudo, o culto das vias lineares e o acento sobre a racionalidade vitruviana como princípio diretor da urbanística renascentista tendiam a ignorar os confusos becos e as praças menores do emaranhado apertado medieval. Eu pretendia dar uma explicação, de algum modo, àquele surpreendente fenômeno que todos os visitantes estrangeiros constatam quando, depois de terem girado ao longo do intrincado labirinto de vielas, alcançando um ângulo, descobrem, improvisadamente, uma grandiosa fachada dominante. Estava convencido que surpresa, desequilíbrio, dissonância e desalinhamento - vistos habitualmente como características do Medievo - fossem princípios altamente modernos. Até mesmo um possante ângulo que se projetasse brutalmente no tecido urbano podia representar não tanto um elemento medieval, quanto, ao contrário, uma criação intencional do design renascentista e barroco. Se tratava substancialmente de traçar, da melhor maneira, as modificações no emaranhado e de interpretar a sua relevância.

O "efeito surpresa", consequentemente, se fundamentaria na alternância de imagens estéreis e confusas com as grandes cenas que se revelariam, subitamente, ao alcance visual do fruidor, especialmente a abertura das inesperadas imagens dos inebriantes monumentos da arquitetura barroca que apareceriam, repentinamente, envolvidos no denso tecido preexistente - igrejas, palácios, fontes, jardins. Às vezes, um lento processo de preparação poderia promover um "crescente" na 
aparição destes importantes acontecimentos dramáticos; outras vezes, estas situações despontariam imediatamente, após experiências suaves, quase idílicas, aumentando o deslumbramento e a admiração da descoberta.

Assim, em Roma, a transformação da cidade em um núcleo urbano moderno e efusivamente barroco, entre os séculos XVI e XVIII, se daria através do contraste entre a nova ordem viária proposta pelos pontífices, o "fundo" preexistente - denso e apertado - dos pitorescos bairros medievais, a paisagem circundante e a construção e restauração celular de praças e monumentos - acontecimentos que despontariam como "figuras" no tecido urbano. As intervenções edilícias seiscentistas e setecentistas, como pontos de referências em relação às novas vias, ao tecido medieval e ao sítio natural, dariam o tom da transformação barroca da nova imagem da cidade.

Portanto, desde o acesso pela Porta del Popolo, o transeunte passaria a ser espectador de um grande teatro que se revelaria, progressivamente, ao caminhar pelos eixos quinhentistas ou pela tortuosa preexistência medieval. Após longa preparação, ou mesmo inesperadamente, o fruidor seria surpreendido por qualquer cena especial que se abriria ao olhar. Estas cenas iriam se repetindo em outros pontos da malha urbana a partir de eventos diferenciados, impondo uma enorme riqueza de imagens a serem absorvidas pelo indivíduo, imagens que ficariam impressas na mente do fruidor. A memória derivada da amarração dos sentimentos de maravilha, ebriedade, fantasia, surpresa, capturados nos panoramas emanados pelos diversos acontecimentos expressivos - apreendidos através da cenografia cativante que jorraria pelo núcleo urbano, se desvelando, paulatinamente, aos olhos de quem caminhava pela capital pontífice - seria o mecanismo que levaria o espectador a absorver uma real e total experiência barroca; é o que autorizaria a afirmação de que Roma seria uma cidade barroca, contrariando o comentado juízo proferido por Cesare de Seta (I978, p. 57) e apresentado na introdução deste livro.

O núcleo urbano se configuraria, por conseguinte, a partir de uma técnica especial de produção da arte e da arquitetura que reuniria os princípios básicos de persuasão e imaginação acionados em nome dos fundamentos ideológicos do Ancien Régime - particularmente a necessidade de promover estratagemas teatrais para a conquista e direção das massas naqueles momentos de aberta crise que marcariam os séculos barrocos; artifícios derivados da necessidade de exaltação da cidade de Roma como capital legítima do mundo católico - expressos através da aliança entre a herança clássica representada pelas avenidas regulares rasgadas 
desde finais do século $\mathrm{XV}$, com o exercício da imaginação anunciado no acúmulo de imagens fantásticas dispersas, de forma imprevista, por todo o núcleo urbano.

Mumford lamentaria a perda desta relação de contraste entre as estruturas urbanísticas regulares e retilíneas e o animado pano de fundo tortuoso, denso e congestionado que as rodeava, situação na qual a arquitetura e a urbanística se encontrariam em total aliança. Quando o planejamento barroco passou a ser apenas impulsionado pelo aspecto burocrático da Grand Manner, pela imponência, regularidade, ordenação, a cidade perderia sua expressividade, que era a essência de seu espírito - e provavelmente estes núcleos urbanos não poderiam ser chamados de barrocos:

\begin{abstract}
Algo desse espírito perdurou nas melhores obras do período barroco: particularmente nas fontes esculpidas e nas praças de Bernini em Roma. Mas aqueles trechos de beleza e ordem se valorizam significativamente pelo congestionamento contrastante que os rodeia. Tão logo a ordem barroca se tornou propagada, uniforme e absoluta, quando nem o contraste nem a evasão eram possíveis, sua fraqueza se revelou. A clarificação cedeu lugar à arregimentação, a vastidão ao vazio, a grandeza à grandiosidade. A voz solitária do planejador podia ser amplificada muitas vezes; porém não poderia nunca tomar o lugar de todos os cantores de um coro cívico, cada qual com a sua própria parte, embora seguindo uma partitura em contraponto. (MUMFORD, I989, p. 350, tradução nossa)
\end{abstract}

Muitas das cidades dos séculos XVII e XVIII - aquelas que receberiam significativas inserções e transformações, mas não recairiam no planejamento burocrático que relataria Mumford - acabariam se transformando em um dos sustentáculos do projeto de propaganda barroca, absorvendo uma estrutura francamente dramática para a sedução do transeunte. Porém, a cenografia imposta pela cidade barroca atuaria de forma diferenciada de uma peça de teatro: na encenação teatral, o espectador permaneceria parado enquanto tudo se moveria à sua frente; no espaço urbano o espetáculo seria imóvel, exigindo a circulação do fruidor para a revelação dos acontecimentos dramáticos, antecedidos por momentos de expectativa e espera - toda a estrutura visibilística do organismo urbano concorrendo para despertar o poder insuperável da imaginação.

Assim, nas mais importantes cidades do período barroco, não seriam, isoladamente, os eixos perspectivos, as praças regulares, o trivium, o polivium que 
proporcionariam a nova qualificação artística para a cidade. O que transformaria a cidade em um organismo sinceramente barroco seriam os recursos retóricos dramáticos que, através do trabalho das imagens surpreendentes derramadas no espaço urbano, sensibilizariam os que participavam da encenação barroca - os cidadãos comuns. A duração da peça teatral e o desenvolvimento de seu enredo estariam inevitavelmente ligados ao espectador: a trama se desenrolaria a partir da maneira como o passante se apropriaria do ambiente citadino - o acesso em que irromperia na cidade, os percursos que escolheria, as visadas que apreciaria na sua jornada.

O que poderia oferecer a condição barroca aos espaços urbanos, finalmente, seria a absorção do espírito geral de dramaticidade formulado no período: o problema consistiria na elaboração de um ambiente que revelasse um discurso convincente - retórica, persuasão - e um desejo de demonstrar o afastamento em direção ao sentido de imitação da realidade objetiva, buscando a geração de um jogo de imagens que provocasse, virtualmente, o rompimento das barreiras do possível - a expressão da maravilha, a imaginação, com a consequente conquista do súdito e do fiel em nome do apoio às grandes estruturas de poder barrocas naquela fase histórica de grande crise e colapso social. (MARAVALL, 2007)

É por isso que as resoluções formais utilizadas para alcançar este esforço de representação, no fundo, de teor decisivamente abstrato, acabariam se manifestando através de ações categoricamente distintas em cada contexto no qual o Barroco viria a ser absorvido. Já na sua origem, na cidade de Roma, seria possível encontrar poéticas tão diversas e até mesmo opostas, como aquelas praticadas pelos arquirrivais Bernini e Borromini - ambas absolutamente barrocas, comandadas pelo mesmo espírito inebriante do Grand Siècle. Da mesma forma, seria possível perceber, na pequena amostragem de intervenções avaliadas - das centenas de eventos barrocos dispersos na Cidade Eterna -, a incrível variação dos temas caros ao Barroco nas diversas inserções urbanas, desde simples justaposições de novas fachadas cenográficas para monumentos preexistentes ou modernos, até a transmutação dramática de sítios arqueológicos.

Ou seja, poder-se-ia dizer que estaria confirmada a hipótese inicial: seria ratificada a suposição que asseguraria a existência de cidades que, em seu desenvolvimento urbano nos séculos XVII e XVIIl, alcançariam a constituição de um cenário que se poderia dizer barroco. Contudo, é preciso que fique claro que esta condição artística não seria genérica; na verdade, atingiria uma minoria de 
assentamentos que, pelos mais diversos motivos, seriam contaminados com o inebriante espírito dramático e teatral do período.

Neste ponto, a pesquisa desenvolvida se abriria para outra linha de investigação conexa, complementar - coincidente com a segunda parte do livro. Provada a existência da cidade barroca, se voltaria à segunda hipótese investigada neste trabalho, proposição que afirmaria a possibilidade de sua expressão nos territórios conquistados e ocupados pelos portugueses e espanhóis nas Américas. Contudo, esta afirmativa esbarraria em graves problemas.

No caso luso-brasileiro, e mais especificamente de seu núcleo mais pujante enquanto expressão dramática - a antiga Vila Rica -, fica claro que a não absorção dos pressupostos da urbanística praticada no período, em prol de um assentamento urbano que mais naturalmente se moldasse à complexa topografia local, só favoreceria a construção da trama barroca. No caso de Ouro Preto, a construção artística do espaço seguirá um caminho próprio, mas gerando um ambiente não menos barroco.

A mineração no vale do córrego do Tripuí começa por volta de I698, logo após a descoberta do ouro nas montanhas até então pouco acessíveis do sudeste brasileiro. Imediatamente inicia-se o rápido povoamento do vale entre as serras de Ouro Preto e do Itacolomi - aglomerado urbano que atinge o status de vila já em I7II. A paisagem exuberante já oferecia uma condição de excepcionalidade para o ambiente onde se assentava o que viria a ser um dos mais importantes núcleos do Brasil no século XVIII, sendo difícil imaginar uma topografia menos adequada para a ereção racional de uma cidade - contudo, mais significativa no que se refere à organização dramática do espaço.

A partir da década de I720, quando a Capitania das Minas Gerais é desmembrada da de São Paulo, o tosco aglomerado disforme - então capital da zona mineradora - vai cedendo lugar a um assentamento que construirá aos poucos seu aspecto imponente que o caracterizará em finais do século XVIIl, quando entra em processo de decadência pelo esgotamento das jazidas mineradoras. Portanto, a imagem da capital das Minas vai se definindo a partir da "estrada tronco" e da preexistência natural exuberante.

A construção ótica da experiência teatral barroca se dará no processo de rápido desenvolvimento, através da amarração dos acontecimentos monumentais pontuais (os largos, praças, as novas ruas, os palácios e, principalmente, a cons- 
trução das igrejas), com a precária estrutura urbana inicial e a paisagem natural. Segundo Ávila (1980, p. I99):

Com efeito, é o comprazimento dos olhos que se busca sempre, seja no aproveitamento das singularidades topográficas, no risco ousado da arquitetura, na elegância das fachadas, no ornato caprichoso das portadas, na decoração interior das igrejas.

Assim, todas as iniciativas edilícias efetivadas na cidade no seu período de prosperidade econômica e no início de sua decadência concorrerão para afirmar, efetivamente, o caráter cenográfico, a comovente articulação barroca da Ouro Preto colonial.

E, da mesma forma que na cidade de Roma, o aparelho dramático que gera a fruição da imagem emanada pela cidade é em grande parte fundamentado na descoberta gradativa e inesperada dos grandes acontecimentos teatrais. Porém, no caso da antiga Vila Rica, são as condições topográficas do sítio natural que, prioritariamente, vão gerar este mecanismo dramático, estando os grandes eventos escondidos pela fatal irregularidade viária e pelas barreiras provocadas pelo acidentado perfil orográfico. Nada é óbvio e direto, mas todas as situações possuem uma imprevista "resolução" teatral grandiosa.

Neste sentido, é plenamente legítima a atribuição de uma condição barroca à antiga Vila Rica, pois imperará sempre, em seu processo de desenvolviento urbano, o espírito de transformação visibilística do espaço, a busca sistemática do "primado do visual" (ÁVILA, I980): nos panoramas constantemente oferecidos, ou no trajeto extenuante que se vence pelos caminhos do núcleo urbano, as montanhas e os monumentos se afirmam como os elementos hierarquicamente prioritários na composição figurativa do espaço, oferecendo experiências francamente teatrais que se moldam ao percurso assumido pelo observador. A amarração, na memória do passante, das diversas imagens recolhidas, promove o sentido de unidade artística necessário para legitimar a cidade de Ouro Preto como um único fenômeno integralmente barroco. Ou seja, o espaço urbano prescinde dos artifícios da urbanística barroca, pois, como diria Lourival Gomes Machado (I973, p. I88-I89), a cidade já nasceu barroca:

Que adiantaria, nessa paisagem, uma escadaria barroca, longa e espalhada, em vários lances, seguindo eixos divergentes? De que valeriam, nesse 
panorama, jogos d'água que alternassem lagos ovalados e cachoeirinhas espumejantes? Degraus, curvas e rampas há em todas as ruas de Ouro Preto e os córregos e ribeirões espadanam águas fervilhantes sob cada ponte e debaixo das janelas de cada sobradão. A cidade já nasceu barroca.

Para o caso hispano-americano, mais complexo e difícil, não haveria como desconsiderar a força expressiva que o desenho planimétrico da cidade regular guardaria para a configuração paisagística do típico ambiente urbano colonial. Suas características morfológicas essenciais estariam conectadas a uma série de experiências práticas e teóricas vinculadas à herança clássica greco-romana, bem como atreladas a diversas iniciativas promovidas pela cultura urbanística da Idade Média, mas também coerentes com o contemporâneo sentimento racionalista praticado pela recente concepção ideológica renascentista. Neste sentido, o modelo ordenador viria a se estabelecer e a se consolidar - através de inúmeras influências ancestrais e coevas - em pleno século XVI, contaminando, praticamente, toda ação urbanística de vulto praticada nas primeiras décadas das conquistas, criando um padrão tipológico que seria insistentemente repetido, com poucas alterações, inclusive nas duas próximas centúrias.

Contudo, fica claro que a consagrada traza racionalizada e repetitiva hispano-americana não apresentaria nenhuma conexão com o teatral e espalhafatoso espírito barroco, espírito que emergiria ao final do século XVI e que alcançaria as Índias Ocidentais apenas no XVII. Por isso, o americanista alemão, Erwin Walter Palm (I9I0-I988), simplificando enormemente o problema da urbanística barroca, se indagaria:

Existe na América hispânica uma urbanística barroca, tal como se apresenta na Europa Ocidental? Quer dizer, existe uma planificação que se serve de grandes eixos para dirigir a atenção em direção a um ponto de referência, a um point de vue? Diríamos que não. (PALM, I980, v. I, p. 2I7) II3 $^{13}$

Não obstante, foi visto, através da avaliação do desenvolvimento da configuração cenográfica da cidade colonial de Cusco, como um núcleo urbano hispano-americano poderia, nos séculos XVII e XVIII, se transfigurar visibilisti-

113 Citação retirada do artigo ¿Urbanismo barroco en América Latina?, publicado em 1980, nos Anais do Simposio Internazionale sul Barocco Latino Americano, evento acontecido na cidade de Roma no mesmo ano. 
camente para alcançar uma condição artística decisivamente barroca. Não seria ao acaso que se escolheria a antiga capital do império inca como objeto de estudo voltado à experimentação daqueles artifícios barrocos identificados na primeira parte desta investigação - apontados como as mais célebres estratégias praticadas no período com o escopo de promover a teatralização do espaço urbano. $\mathrm{Na}$ verdade, a conformação física da cidade - fruto de um complicado processo de sobreposição do assentamento espanhol fundado por Pizarro acima das ruínas do núcleo nobiliário desenhado pelo Imperador inca Pachacútec - acabaria confirmando uma das hipóteses investigadas na segunda parte do livro: proposição que asseveraria que os assentamentos virreinales poderiam, eventualmente, constituir-se como cidades barrocas se a composição de sua paisagem urbana agisse contra a quadrícula, contra o modelo rígido de estruturação do plano viário consagrado nas Índias Ocidentais, no século XVI. 


\section{FONTES}

FIGURA FONTE

$10 \quad$ Wikimedia Commons contributors. 'File:Salzburg panorama.jpg', Wikimedia Commons, the free media repository, 20 December 2015, 14:47 UTC. Available in: <https://commons.wikimedia.org/w/index. php?title=File:Salzburg_panorama.jpg\&oldid=182361638>

$11 \quad$ Wikimedia Commons contributors. 'File:Saint Petersburg 1776 map LOC g7064s ctoo 1468. jpg', Wikimedia Commons, the free media repository, 30 October 2015, 17:51 UTC. Available in: <https:// commons.wikimedia.org/w/index.php?title=File:Saint_Petersburg_1776_map_LOC_g70645_ cto01468.jpg\&oldid=177409397>

13 Wikimedia Commons contributors. 'File:Piazza SS Annunziata Firenze Apr 2008.jpg', Wikimedia Commons, the free media repository, 6 March 2015, 22:36 UTC. Available in: <https:// commons.wikimedia.org/w/index.php?title=File:Piazza_SS_Annunziata_Firenze_Apr_2008. jpg\&oldid=152324397>

14 Wikimedia Commons contributors. ‘File:Piazza Ducale stitch 2 Vigevano.jpg', Wikimedia Commons, 28 November 2016, 08:36 UTC. Available in: <https://commons.wikimedia.org/w/index. php?title=File:Piazza_Ducale_stitch_2_Vigevano.jpg\&oldid=222608494>

15 Contributori di Wikipedia. 'Città ideale (dipinto)', Wikipedia, L'enciclopedia libera, 13 marzo 2017, 14:35 UTC. Disponibile in: <//it.wikipedia.org/w/index.php?title=Citt\%C $3 \%$ Ao_ideale_ (dipinto)\&oldid=86498531>

16 Wikimedia Commons contributors. 'File:Cupola santamariadelfiore.jpg', Wikimedia Commons, the free media repository, 6 April 2015, 19:41 UTC. Available in: <https://commons.wikimedia.org/w/index. php?title=File:Cupola_santamariadelfiore.jpg\&oldid=156132641>

17 Wikimedia Commons contributors. ‘File:Fratelli Alinari Duomo Firenze c186os.jpg', Wikimedia Commons, 14 November 2016, 16:29 UTC. Available in: <https://commons.wikimedia.org/w/index. php?title=File:Fratelli_Alinari_Duomo_Firenze_c186os.jpg\&oldid=213950864>

Wikimedia Commons contributors, 'File:Firenze, pianta della catena.jpg', Wikimedia Commons, the free media repository, 7 February 2015, 13:04 UTC. Available in: <https://commons.wikimedia.org/w/ index.php?title=File:Firenze,_pianta_della_catena.jpg\&oldid=149284834>

Wikimedia Commons contributors. ‘File:Santa Maria del Fiore from Palazzo Vecchio.JPG', Wikimedia Commons, the free media repository, 27 November 2016, 19:23 UTC. Available in: <https:// commons.wikimedia.org/w/index.php?title=File:Santa_Maria_del_Fiore_from_Palazzo_Vecchio. JPG\&oldid=221743655>

Wikimedia Commons contributors. 'File:Palmanova16oo.jpg', Wikimedia Commons, the free media repository, 30 October 2015, 21:06 UTC. Available in: <https://commons.wikimedia.org/w/index. php?title=File:Palmanova160o.jpg\&oldid=177428829>

Wikimedia Commons contributors. 'File:Teatro olimpico, scena 13.JPG', Wikimedia Commons, 19 November 2015, 21:09 UTC. Available in: <https://commons.wikimedia.org/w/index. php?title=File:Teatro_olimpico,_scena_13.JPG\&oldid=179626487>

Wikimedia Commons contributors. “File:Dupérac, Étienne - Gardens at Villa d’Este - 1560-1575. jpg." Wikimedia Commons, the free media repository. 25 Sep 2017, 17:54 UTC. Available in: <https:// commons.wikimedia.org/w/index.php?title=File:Dup\%C $3 \%$ Agrac,_\% $3 \% 8$ tienne_-_Gardens_at_ Villa_d\%27Este_-_1560-1575.jpg\&oldid=259767745>.

Wikimedia Commons contributors. 'File:Villa d'Este fountain and pools.jpg', Wikimedia Commons, the free media repository, 31 May 2017, 07:20 UTC. Available in: <https://commons.wikimedia.org/w/ index.php?title=File:Villa_d\%27Este_fountain_and_pools.jpg\&oldid=246127677> 
Wikimedia Commons contributors. 'File:Pierre-Denis Martin - View of the Château de Fontainebleau - Google Art Project.jpg', Wikimedia Commons, the free media repository, 8 August 2013, 07:57 UTC. Available in: <https://commons.wikimedia.org/w/index.php?title=File:Pierre-Denis_Martin_-_View_ of_the_Ch\%C3\%A2teau_de_Fontainebleau_-_Google_Art_Project.jpg\&oldid=101493485>

Wikimedia Commons contributors. 'File:Fontainebleau with gardens.jpg', Wikimedia Commons, the free media repository, 31 December 2014, 23:45 UTC. Available in: <https://commons.wikimedia. org/w/index.php?title=File:Fontainebleau_with_gardens.jpg\&oldid $=144894466>$

Wikimedia Commons contributors. 'File:Covent garden c1720.jpg', Wikimedia Commons, the free media repository, 25 November 2016, 06:57 UTC. Available in: <https://commons.wikimedia.org/w/index. php?title=File:Covent_garden_c1720.jpg\&oldid=219137164>

Wikimedia Commons contributors. 'Alexey Zubov', Wikimedia Commons, 2 October 2015, 23:46 UTC Available in: <https://www.wikiart.org/en/alexey-zubov/view-of-the-summer-gardens-from-theneva-river-1717?utm_source=returned\&utm_medium =referral\&utm_campaign=referral>

Wikimedia Commons contributors. 'File:Noack, Alfred (1833-1895) - n. 3026 - Genova Via Nuova. jpg', Wikimedia Commons, the free media repository, 15 January 2015, 07:32 UTC. Available in: <https:// commons.wikimedia.org/w/index.php?title=File:Noack,_Alfred_(1833-1895)_-_n._3026_-_Genova_ Via_Nuova.jpg\&oldid=146571493>

Wikimedia Commons contributors. 'File:Nevsky prospect in 180o.jpg', Wikimedia Commons, the free media repository, 15 April 2017, 14:26 UTC. Available in: <https://commons.wikimedia.org/w/index. php?title=File:Nevsky_prospect_in_180o.jpg\&oldid=240878117>

Wikimedia Commons contributors, 'File:Durand - View of Nevsky Prospekt near the Politseisky Bridge 1839.jpg', Wikimedia Commons, the free media repository, 21 April 2016, 15:16 UTC. Available in: $<$ https://commons.wikimedia.org/w/index.php?title=File:Durand_-_View_of_Nevsky_Prospekt_ near_the_Politseisky_Bridge_1839.jpg\&oldid=194034934>

Wikimedia Commons contributors. 'File:Via Po Torino.jpg', Wikimedia Commons, the free media repository, 3 December 2012, 02:41 UTC. Available in: <https://commons.wikimedia.org/w/index. php?title=File:Via_Po_Torino.jpg\&oldid=84149270>

Wikimedia Commons contributors. 'File:Turin piazza san carlo 2009.JPG', Wikimedia Commons, the free media repository, 23 April 2015, 10:52 UTC. Available in: <https://commons.wikimedia.org/w/ index.php?title=File:Turin_piazza_san_carlo_2009.JPG\&oldid=158487623>

Yale University, Cushing/Whitney Medical Library. Available in: <https://archive.org/ details/39002086316958.med.yale.edu>

Wikimedia Commons contributors. 'File:Assembly Rooms and The Circus from a balloon-geograph2042508-by-Roger-Beale.jpg', Wikimedia Commons, 16 April 2017, 02:01 UTC. Available in: <https:// commons.wikimedia.org/w/index.php?title=File:Assembly_Rooms_and_The_Circus_from_a_ balloon-geograph-2042508-by-Roger-Beale.jpg\&oldid=240920824>

Wikimedia Commons contributors. 'File:Royal.crescent.aerial.bath.arp.jpg', Wikimedia Commons, the free media repository, 19 April 2017, 15:0o UTC. Available in: <https://commons.wikimedia.org/w/ index.php?title=File:Royal.crescent.aerial.bath.arp.jpg\&oldid=241369542>

Wikimedia Commons contributors. 'File:Royal Crescent - geograph.org.uk - 1624923.jpg', Wikimedia Commons, the free media repository, 8 April 2015, 17:20 UTC. Available in: <https://commons. wikimedia.org/w/index.php?title=File:Royal_Crescent_-_geograph.org.uk_-_1624923. jpg\&oldid $=156401689>$

Wikimedia Commons contributors. 'File:Nymphenburg, de Geer, um 1730.jpg', Wikimedia Commons, the free media repository, 11 March 2017, 18:42 UTC. Available in: <https://commons.wikimedia.org/w/ index.php?title=File:Nymphenburg,_de_Geer,_um_1730.jpg\&oldid=236784424>

Wikimedia Commons contributors. 'Vue aérienne du domaine de Versailles par ToucanWings Creative Commons By Sa 3.0 - 082.jpg', Wikimedia Commons, the free media repository, 19 August 2013, 20:59:45 UTC. Available in: <https://commons.wikimedia.org/wiki/File:Vue_a\%C3\%Agrienne_ du_domaine_de_Versailles_par_ToucanWings_-_Creative_Commons_By_Sa_3.0_-_082.jpg> 
$51 \quad$ Wikimedia Commons contributors. 'File:Plan de Turgot.jpg', Wikimedia Commons, the free media repository, 14 October 2015, 17:32 UTC. Available in: <https://commons.wikimedia.org/w/index. php?title=File:Plan_de_Turgot.jpg\&oldid=175684336>

52 Musée national du château de Pau / Jean-Yves Chermeux. La place Dauphine construite dans la ville de Paris durant le règne d'Henri le Grand, gravure par Claude Chastillon. Musée national du château de Pau, Inv. P. 1345. Disponible en: < http://www.henriiv.culture.fr/fr/uc/o2_01_04?version=accessible>. Site Nicolas Le Floch. Disponible en: <http://www.nicolaslefloch.fr/Lieux/placeDauphine.html>

57 Wikimedia Commons contributors. 'File:Charleville-Mézières, Place Ducale -- 2017 -- 4864 jpg', Wikimedia Commons, , 28 March 2017, 17:12 UTC. Available in: <https://commons.wikimedia. org/w/index.php?title=File:Charleville-M\%C3\%Agzi\%C3\%A8res,_Place_Ducale_--_2017_--_4864. jpg\&oldid $=238870817>$

58 Wikimedia Commons contributors. 'File:Charleville place ducale.jpg', Wikimedia Commons, the free media repository, 12 July 2014, 04:03 UTC. Available in: <https://commons.wikimedia.org/w/index. php?title=File:Charleville_place_ducale.jpg\&oldid=128758731>

Wikimedia Commons contributors. 'File:Plan de Turgot.jpg', Wikimedia Commons, the free media repository, 14 October 2015, 17:32 UTC. Available in: <https://commons.wikimedia.org/w/index. php?title=File:Plan_de_Turgot.jpg\&oldid $=175684336>$

Musée national du château de Pau / Jean-Yves Chermeux. The Place Royale (Claude Chastillon, Dessins des Pompes et magnificiences du caroussel faict en la place royalle de Paris, les V, VI, VII of April 1612, engraving). Musée national du château de Pau, Inv. P. 1344 Disponible en: <http://www.henriiv.culture.fr/en/uc/o2_01_04?version=mobile>

$61 \quad$ Wikimedia Commons contributors. 'File:Einzug des Alvise Mocenigo in Paris 1709.jpg', Wikimedia Commons, the free media repository, 22 March 2017, 04:12 UTC. Available in: <https:// commons.wikimedia.org/w/index.php?title=File:Einzug_des_Alvise_Mocenigo_in_Paris_1709. jpg\&oldid $=238113521>$

63 Wikimedia Commons contributors. 'File:PlacedeFrance.jpg', Wikimedia Commons, the free media repository, 26 April 2009, 12:45 UTC. Available in: <https://commons.wikimedia.org/wiki/ File:PlacedeFrance.jpg>

64 Wikimedia Commons contributors. 'File:Plan de Turgot.jpg', Wikimedia Commons, the free media repository, 14 October 2015, 17:32 UTC. Available in: <https://commons.wikimedia.org/w/index. php?title=File:Plan_de_Turgot.jpg\&oldid $=175684336>$

65 https://upload.wikimedia.org/wikipedia/commons/d/d1/Turgot_map_Paris_KU_14.jpg

66 Wikimedia Commons contributors. 'File:P1120256 Paris ler et II place des Victoires rwk.JPG', Wikimedia Commons, , 17 November 2016, 20:14 UTC. Available in: <https://commons.wikimedia.org/w/index. php?title=File:P1120256_Paris_ler_et_II_place_des_Victoires_rwk.JPG\&oldid=215010398>

Wikimedia Commons contributors. 'File:Plan de Turgot.jpg', Wikimedia Commons, the free media repository, 14 October 2015, 17:32 UTC. Available in: <https://commons.wikimedia.org/w/index. php?title=File:Plan_de_Turgot.jpg\&oldid=175684336>

69 Biblioteca Nacional da França. Disponível em: <http://gallica.bnf.fr/ark:/12148/btv1b69487604>

70 Wikimedia Commons contributors. 'File:Place Vendome, Paris, France, ca. 1890-1900.jpg', Wikimedia Commons, the free media repository, 26 May 2014, 18:31 UTC. Available in: <https://commons. wikimedia.org/w/index.php?title=File:Place_Vendome,_Paris,_France,_ca._1890-1900. jpg\&oldid $=124987404>$ Commons, , 15 January 2015, 21:11 UTC. Available in: <https://commons.wikimedia.org/w/index. php?title=File:Place_Louis_XV_-_Projet_de_Gabriel.JPG\&oldid=146643043> html> 
73 Wikimedia Commons contributors. 'File:Paris Place de la concorde et Champs-Elysees 19Jh. jpg', Wikimedia Commons, the free media repository, 11 March 2017, 19:18 UTC. Available in: <https:// commons.wikimedia.org/w/index.php?title=File:Paris_Place_de_la_concorde_et_ChampsElysees_19Jh.jpg\&oldid=236787672>

Wikimedia Commons contributors. ‘File:Le Jardin des Plantes 2 - Paul Legrand.jpg', Wikimedia Commons, the free media repository, 14 March 2017, 20:54 UTC. Available in: <https:// commons.wikimedia.org/w/index.php?title=File:Le_Jardin_des_Plantes_2_-_Paul_Legrand. jpg\&oldid $=237150026>$

Wikimedia Commons contributors. 'File:Plan de Turgot.jpg', Wikimedia Commons, the free media repository, 14 October 2015, 17:32 UTC. Available in: <https://commons.wikimedia.org/w/index. php?title=File:Plan_de_Turgot.jpg\&oldid $=175684336>$

Wikimedia Commons contributors. 'File:Plan de Turgot.jpg', Wikimedia Commons, the free media repository, 14 October 2015, 17:32 UTC. Available in: <https://commons.wikimedia.org/w/index. php?title=File:Plan_de_Turgot.jpg\&oldid=175684336>

Wikimedia Commons contributors. 'File:Vue des Champs Elysées, ca. 1853-70.jpg', Wikimedia Commons, the free media repository, 11 March 2017, 17:23 UTC. Available in: <https://commons. wikimedia.org/w/index.php?title=File:Vue_des_Champs_Elys\%C_\%Ages,_ca._1853\%E2\%80\%9370. jpg\&oldid $=236773065>$

Wikimedia Commons contributors. 'File:Paris moderne. Les Tuileries, le Louvre, et la rue de Rivoli, vue prise du Jardin des Tuileries 2.jpg', Wikimedia Commons, the free media repository, 31 January 2017, 17:36 UTC. Available in: <https://commons.wikimedia.org/w/index.php?title=File:Paris_ moderne._Les_Tuileries,_le_Louvre,_et_la_rue_de_Rivoli,_vue_prise_du_Jardin_des_Tuileries_2. jpg\&oldid $=231794390>$

Wikimedia Commons contributors. 'File:Plan de Turgot.jpg', Wikimedia Commons, the free media repository, 14 October 2015, 17:32 UTC. Available in: <https://commons.wikimedia.org/w/index. php?title=File:Plan_de_Turgot.jpg\&oldid=175684336>

$81 \quad$ Wikimedia Commons contributors. 'File:Plan de Turgot.jpg', Wikimedia Commons, the free media repository, 14 October 2015, 17:32 UTC. Available in: <https://commons.wikimedia.org/w/index. php?title=File:Plan_de_Turgot.jpg\&oldid=175684336>

83 David Rumsey Historical Map Collection. Disponível em: <http://www.davidrumsey.com/luna/ servlet/detail/RUMSEY 8 1 292520 90064115:View--Veue-en-Perspective-de-I-Elev>.

Wikimedia Commons contributors. 'Hôtel des Invalides from the Eiffel Tower, September 7, 2013. jpg' Wikimedia Commons, the free media repository, 7 September 2013, 18:43 UTC. Available in: <https://commons.wikimedia.org/wiki/File:H\%C3\%B4tel_des_Invalides_from_the_Eiffel_Tower, September_7,_2013.jpg>

Wikimedia Commons contributors. 'File:Veue et perspective du Chasteau de Vaux-le-Vicomte du costé de l'entrée - INHA.jpg', Wikimedia Commons, the free media repository, 2 May 2015, 01:03 UTC. Available in: <https://commons.wikimedia.org/w/index.php?title=File:Veue_et_ perspective_du_Chasteau_de_Vaux-le-Vicomte_du_cost\%C3\%A9_de_l\%27entr\%C3\%Age_-_INHA. jpg\&oldid=159402995>

Wikimedia Commons contributors. 'File:Kasteel van Vaux-le-Vicomte - Maincy o6.jpg', Wikimedia Commons, the free media repository, 31 January 2015, 19:26 UTC. Available in: <https:// commons.wikimedia.org/w/index.php?title=File:Kasteel_van_Vaux-le-Vicomte_-_Maincy_o6. jpg\&oldid=148587155>

Wikimedia Commons contributors. 'File:Chateau de Versailles 1668 Pierre Patel.jpg', Wikimedia Commons, the free media repository, 25 June 2017, 19:03 UTC. Available in: <https:// commons.wikimedia.org/w/index.php?title=File:Chateau_de_Versailles_1668_Pierre_Patel. jpg\&oldid=249168995>

Wikimedia Commons contributors. 'File:Etching of the Palace of Versailles in circa 1680 by Adam Perelle.png', Wikimedia Commons, the free media repository, 25 November 2016, 21:24 UTC. Available in: <https://commons.wikimedia.org/w/index.php?title=File:Etching_of_the_Palace_of_Versailles_ in_circa_1680_by_Adam_Perelle.png\&oldid=219566440> 
98 Wikimedia Commons contributors. 'File:Versailles by Pierre-Denis Martin.jpg', Wikimedia Commons, the free media repository, 25 June 2017, 19:03 UTC. Available in:< https://en.wikipedia.org/w/index. php?title=File:Versailles_by_Pierre-Denis_Martin.jpg\&oldid=502475872>

$100 \quad$ Wikimedia Commons contributors. 'File:Israel Silvestre, Château de Versailles seen from the forecourt, 1682.jpg', Wikimedia Commons, the free media repository, 14 March 2017, 20:43 UTC. Available in: <https://commons.wikimedia.org/w/index.php?title=File:Israel_Silvestre, Ch\%C3\%A2teau_de_Versailles_seen_from_the_forecourt,_1682.jpg\&oldid=237148437> - Creative Commons By Sa 3.0 - 073.jpg', Wikimedia Commons, the free media repository, 20 December 2015, 19:27 UTC. Available in: <https://commons.wikimedia.org/w/index. php?title=File:Vue_a\%C3\%Agrienne_du_domaine_de_Versailles_par_ToucanWings_-_Creative_ Commons_By_Sa_3.0_-_073.jpg\&oldid=182378464>

Wikimedia Commons contributors. 'File:Versailles chateau.jpg', Wikimedia Commons, the free media repository, 23 February 2015, 23:06 UTC. Available in: <https://commons.wikimedia.org/w/index. php?title=File:Versailles_chateau.jpg\&oldid=150828351>

Wikimedia Commons contributors. 'File:Karlsruhe Bodenehr 1721 koloriert.jpg', Wikimedia Commons, the free media repository, 18 April 2016, 11:28 UTC. Available in: <https://commons.wikimedia.org/w/ index.php?title=File:Karlsruhe_Bodenehr_1721_koloriert.jpg\&oldid=193613543>

Vikidia contributors, 'Nancy', Vikidia, , 29 décembre 2016, 23:09 UTC. Available in: <https://fr.vikidia. org/w/index.php?title=Nancy\&oldid=925979>

Biblioteca Nacional da França. Disponível em: <http://gallica.bnf.fr/ark:/12148/btvıb8442713t/ f1.zoom.r=plan+nancy.langFR>

Le Journal de Durival, Biblioteca de Nancy. Disponível em: <http://www.journaldedurival.fr/images/ illustrations/B543956101_TS21_COLLIN_0017.jpg>

Getty Search Gateway. Veue de la Place Royal de Nancy du côté de l'Arc de Triomphe. Disponibile en: $<$ http://search.getty.edu/gateway/search?q=\&cat=type\&types=\%22Prints $\% 22 \&$ rows $=20 \&$ crt $=$ $d \& d i r=s \& d s p=0 \&$ ing $=0 \& p g=6>$

Académie de Nancy-Metz: http://www4.ac-nancy-metz.fr/junior-actu-88/junior_actu_20/img/ placecarriere2.jpg

Biblioteca Nacional da França. Disponível em: <http://gallica.bnf.fr/ark:/12148/btv1b6949195k\#>

Wikimedia Commons contributors, 'File:1652 Merian Panoramic View or Map of Rome, Italy Geographicus - Roma-merian-1642.jpg', Wikimedia Commons, the free media repository, 25 August 2016, 11:39 UTC, <https://commons.wikimedia.org/w/index.php?title=File:1652_Merian_Panoramic_ View_or_Map_of_Rome,_Italy_-_Geographicus_-_Roma-merian-1642.jpg\&oldid=204770468> [accessed 27 July 2017

Site Roma ieri oggi. Disponível em: <https://www.romaierioggi.it/mappa-della-citta-di-roma-g-bfalda- $1676 />$

Wikimedia Commons contributors. 'File:Roma Piazza del Popolo BW 1.JPG', Wikimedia Commons, the free media repository, 6 April 2015, 16:03 UTC. Available in: <https://commons.wikimedia.org/w/ index.php?title=File:Roma_Piazza_del_Popolo_BW_1.JPG\&oldid=156111529>

Wikimedia Commons contributors. 'File:Hendrik Frans van Lint - Roma - Piazza del Popolo WGA13057.jpg', Wikimedia Commons, the free media repository, 13 November 2016, o8:23 UTC. Available in: <https://commons.wikimedia.org/w/index.php?title=File:Hendrik_Frans_van_Lint_-Roma_-_Piazza_del_Popolo_-_WGA13057.jpg\&oldid=213558156>

Site Roma ieri oggi. Disponível em: <https://www.romaierioggi.it/mappa-della-citta-di-roma-g-bfalda-1676/>

Site Roma ieri oggi. Disponível em: <https://www.romaierioggi.it/mappa-della-citta-di-roma-g-bfalda-1676/> 


\begin{tabular}{|c|c|}
\hline FICURA & FONTE \\
\hline 185 & Site Roma ieri oggi. Disponível em: <https://www.romaierioggi.it/piazza-navona-193o-ca/> \\
\hline 187 & $\begin{array}{l}\text { Wikimedia Commons contributors, 'File:Vierstroemebrunnen Piazza Navona Rom.jpg', Wikimedia } \\
\text { Commons, the free media repository, } 17 \text { December 2014, } 20: 23 \text { UTC. Available in: <https:// } \\
\text { commons.wikimedia.org/w/index.php?title=File:Vierstroemebrunnen_Piazza_Navona_Rom. } \\
\text { jpg\&oldid=143087443> }\end{array}$ \\
\hline 192 & $\begin{array}{l}\text { Wikimedia Commons contributors. 'File:Caspar van Wittel - Piazza Navona, Rome - Google Art } \\
\text { Project.jpg', Wikimedia Commons, the free media repository, } 22 \text { September 2016, } 15: 56 \text { UTC. Available } \\
\text { in: <https://commons.wikimedia.org/w/index.php?title=File:Caspar_van_Wittel_-_Piazza_Navona,_ } \\
\text { Rome_-_Google_Art_Project.jpg\&oldid=207462828> }\end{array}$ \\
\hline 194 & $\begin{array}{l}\text { Site Roma ieri oggi. Disponível em: <https://www.romaierioggi.it/la-nuova-topografia-di-roma- } \\
\text { nolli-1748/> }\end{array}$ \\
\hline 195 & $\begin{array}{l}\text { Wikimedia Commons contributors. ‘File:Piazza Navona } 0945 \text { 2013.jpg’, Wikimedia Commons, the free } \\
\text { media repository, } 14 \text { March 2013, 23:01 UTC. Available in: }<\text { https://commons.wikimedia.org/w/index. } \\
\text { php?title=File:Piazza_Navona_0945_2013.jpg\&oldid=92593830> }\end{array}$ \\
\hline 196 & $\begin{array}{l}\text { Site Roma ieri oggi. Disponível em: <https://www.romaierioggi.it/mappa-della-citta-di-roma-g-b- } \\
\text { falda-1676/> }\end{array}$ \\
\hline 202 & $\begin{array}{l}\text { Wikimedia Commons contributors. 'File:Ponte- Chiesa di S.Maria della Pace.jpg', Wikimedia Commons, } \\
\text { the free media repository, } 1 \text { May 2015, } 15: 15 \text { UTC. Available in: }<\text { https://commons.wikimedia.org/w/ } \\
\text { index.php?title=File:Ponte-_Chiesa_di_S.Maria_della_Pace.jpg\&oldid=159346191> }\end{array}$ \\
\hline 212 & $\begin{array}{l}\text { Wikimedia Commons contributors. 'File:Trevi Fountain, Rome, Italy } 2 \text { - May 2007.jpg', Wikimedia } \\
\text { Commons, the free media repository, } 1 \text { February 2017, } 10: 06 \text { UTC. Available in: <https:// } \\
\text { commons.wikimedia.org/w/index.php?title=File:Trevi_Fountain,_Rome,_Italy_2_-_May_2007. } \\
\text { jpg\&oldid=231904755> }\end{array}$ \\
\hline
\end{tabular}

221 Wikimedia Commons contributors. 'File:Spanska trappan - Hallwylska museet - 107515.tif', Wikimedia Commons, the free media repository, 16 March 2017, 20:29 UTC. Available in: <https://commons. wikimedia.org/w/index.php?title=File:Spanska_trappan_-_Hallwylska_museet_-_107515. tif\&oldid=237348906>

229 The Metropolitan Museum of Art. Available in: <http://www.metmuseum.org/art/collection/ search/403640>

231 Wikimedia Commons contributors. 'File:Basilique Saint-Pierre Vatican dome.jpg', Wikimedia Commons, 22 April 2017, 14:36 UTC. Available in: <https://commons.wikimedia.org/w/index. php?title=File:Basilique_Saint-Pierre_Vatican_dome.jpg\&oldid=241692297>

232 Wikimedia Commons contributors. 'File:1652 Merian Panoramic View or Map of Rome, Italy Geographicus - Roma-merian-1642.jpg', Wikimedia Commons, the free media repository, 25 August 2016, 11:39 UTC. Available in: <https://commons.wikimedia.org/w/index.php?title=File:1652 Merian_Panoramic_View_or_Map_of_Rome,_Italy_-_Geographicus_-_Roma-merian-1642. jpg\&oldid=204770468>

237 Site Roma ieri oggi. Disponível em: <https://www.romaierioggi.it/mappa-della-citta-di-roma-g-bfalda-1676/>

247 Site Roma ieri oggi. Disponível em: <https://www.romaierioggi.it/san-pietro-e-dintorni-1929/>

248 Site Roma ieri oggi. Disponível em: <https://www.romaierioggi.it/la-nuova-topografia-di-romanolli-1748/>

297 Cortesia das University of Texas Libraries, da University of Texas em Austin. Disponível em: <http:// www.lib.utexas.edu/benson/historicmaps/maps17.html>

298 Cortesia das University of Texas Libraries, da University of Texas em Austin. Disponível em: <https:// www.lib.utexas.edu/benson/historicmaps/maps14.html>

299 Blog Barrio de Tultenco. Disponível em: <http://barriodetultenco.blogspot.com/2009/og/la-ciudadde-mexico.html> 
301 Cortesia das University of Texas Libraries, da University of Texas em Austin. Disponível em: <http:// www.lib.utexas.edu/benson/historicmaps/maps2o.html>

302 Cortesia das University of Texas Libraries, da University of Texas em Austin. Disponível em: <http:// www.lib.utexas.edu/benson/historicmaps/maps5.html>

303 Blog Arqueologia Colonial (2012). Disponível em: <http://arqueologiacolonial.blogspot.com. $\mathrm{br} / 2012 / 01 /$ planos-antiguos-de-la-ciudad-de-lima.html> Espejel. Plano o Mapa de la Nobilissima Ciudad de Valladolid de Michoacan, 1794. Disponibile em: <http://www.espejel.com/planos/Morelia_1883_Bosquejo_Historico_Juan_de_la_Torre.jpg>

David Rumsey Historical Map Collection. Disponível em: <http://www.davidrumsey.com/luna/ servlet/detail/RUMSEY 8 1 20598 580002:Plano-topografico,-Ciudad-del-Cuzco> 


\section{REFERÊNCIAS}

ALBERTI, Leon Battista. Dedica a Filippo Brunelleschi. In: ARGAN, Giulio carlo. Storia dell'arte italiana. Milano: Rizzoli, I994. v. 2, p. 343.

ALBERTI, Leon Battista. L'Arquitetura. De Re Aedificatoria. Testo latino e traduzione a cura di Giovanni Orlandi. Introduzione e note di Paolo Portoghesi. Milano: Polifilo, I966. 2. v. ALLENDE CARRERA, Arnulfo. Puebla. Y el Paseo de San Francisco. Madrid: Turner, 2006.

ANTONIL, André João. Cultura e opulência no Brasil. Belo Horizonte: Ed. Itatiaia; São Paulo: EDUSP, 1982.

ARGAN, Giulio Carlo. El concepto del espacio arquitectónico desde el barroco a nuestros días. Buenos Aires: Nueva Visión, I973.

ARGAN, Giulio Carlo. Immagine e persuasione. Milano: Feltrinelli, I986.

ARGAN, Giulio Carlo. L'Europa delle capitali. Milano: Skira, 2004.

ARGAN, Giulio Carlo. Storia dell'arte come storia della città. Roma: Riuniti, I984.

ARGAN, Giulio Carlo. Storia dell'arte italiana. Milano: Rizzoli, I994. 3 v.

ÁVILA, Affonso. Iniciação ao barroco mineiro. São Paulo: Nobel, I984.

ÁVILA, Affonso. O lúdico e as projeções do mundo barroco. São Paulo: Perspectiva, I980.

BAETA, Rodrigo Espinha. Teoria do Barroco. Salvador: EDUFBA, PPGAU, 2012.

BARDET, Gaston. L'urbanisme. Paris: Presses Universitaires de France, I967.

BASTOS, Rodrigo. A maravilhosa fábrica das virtudes: o decoro na arquitetura religiosa de Vila Rica, Minas Gerais (I7II-I822). São Paulo: EDUSP, FAPESP, 2013.

BAYÓN, Damián. Sociedad y arquitectura sudamericana: una lectura polémica. Barcelona: Gustavo Gili, I974.

BAZIN, Germain. A arquitetura religiosa barroca no Brasil. Rio de janeiro: Ed. Record, I983. $2 \mathrm{v}$.

BENEVOLO, Leonardo. La cattura dell'infinito. Roma: Leterza, I99I.

BENEVOLO, Leonardo. La città nella storia dell'europa. Roma: Laterza, 2007. 
BENEVOLO, Leonardo. Storia della città. La città moderna. Roma: Laterza, v. 3, 2006. BENEVOLO, Leonardo. Storia dell'architettura del Rinascimento. Roma: Laterza, 2008. BLUNT, Anthony. Alla scoperta di Roma barocca. Un'introduzione breve ma intensa ai fasti dell'architettura e dell'arte del Seicento a Roma e ai suoi tre maggiori esponenti: Bernini, Borromini, Pietro da Cortona. Roma: Newton \& Comptom, 2004.

BORROMINI, Francesco. Opus Architectonicum. Roma: De Rubeis Editore, I993. BURCKHARDT, Jacob. Il cicerone. Guida al godimento dell'arte in Italia. Milano: Biblioteca Universali Rizzoli, I994. 2 v.

BUSCHIAZZO, Mario. Estudios de arquitectura colonial hispano americana. Buenos Aires: Editorial Guillermo Kraft, I944.

CALABI, Donatella. Storia della città. L’età moderna. Venezia: Marsilio Editori, 200 I. CASTILlO VENERO, Carlos. Cuzco: patrones de asentamientos. Lima: Colegio de arquitectos del Perú, I983.

CEHOPU. La ciudad hispanoamericana. El sueño de un orden. Madrid: CEHOPU, I989. COBBAN, Alfred. A history of modern France. Volume One: Old Régime and Revolution: I7I5-I799. London: Penguin Books, I990.

COEN, Paolo. Le magnificenze di Roma nelle incisioni di Giuseppe Vasi. Un affascinante viaggio settecentesco dalle Mura Aureliane fino alle maestose ville patrizie, attraverso rovine, le basiliche e le più belle piazze della Città Eterna. Roma: Newton \& Compton Editori, I996.

COEN, Paolo. Le sette chiese. Le basiliche giubilari romane. Roma: Newton \& Compton, I999.

CONNORS, Joseph. Alleanze e inimicizie. l'urbanistica di Roma barocca. Roma: Laterza, 2005.

CHANTELOU. Paul Fréart de. Journal du voyage en France du Cavalier Bernin. New York: Burt Franklin Reprints, I972.

CHOAY, Françoise. Espacements. L'évolution de l'espace urbain en France. Milano: Skira Editore, 2003.

CHUECA GOITIA, Fernando. Breve historia del urbanismo. Madrid: Alianza Editorial, I986. 
CHUECA GOITIA, Fernando. El Barroco hispánico y sus invariantes. In: MINARDI, Vittorio (Org.). Simposio internazionale sul Barocco Latino Americano. Atti. Roma: Istituto Italo-Latino Americano, I980. p. I89-200. v. I.

CHUECA GOITIA, Fernando. Historia de la arquitectura occidental VIII. Barroco en Hispanoamérica, Portugal y Brasil. Madrid: Dossat, I984.

CHUECA GOITIA, Fernando; TORRES BALBÁS, Leopoldo. Planos de ciudades Iberoamericanas y Filipinas. Madrid: Instituto de Estudios de Administración Local, I98I. DANGELO, André Guilherme Dornelles; BRASILEIRO, Vanessa Borges. O Aleijadinho arquiteto e outros ensaios. Belo Horizonte: Escola de Arquitetura da UFMG, 2008.

DE SETA, Cesare. La città europea: Origini, sviluppo e crisi della civiltà urbana in età moderna e contemporanea. Milano: Il Saggiatore, 20 Io.

DE SETA, Cesare. Sulla presunta 'città barocca' In: BLUNT, Anthony; DE SETA, Cesare. Architettura e città barocca. Napoli: Guida Editori, I978.

DELLA VALLE, Adriana; FONDI, Daniella; STERPI, Claudio. Il passeto e il suo borgo nelle immagini del passato (I875-I939). Roma: Edizioni Kappa, I997.

FAGIOLO, Marcello (Org). La festa a Roma. Roma: Umberto Allemandi \& C., I997.

FALDA, Giovanni Battista. Vedute di Roma. Roma: Danesi, Signorelli Editore, I970.

FALDA, Giovanni Battista. Ville e giardine di Roma. Milano: Il Polifilo, I980.

FERREZ, Gilberto. Fotografia no Brasil e um de seus mais dedicados servidores: Marc Ferrez (I843-I923). Revista do Patrimônio Histórico e Artístico Nacional, Rio de Janeiro, n. 26, 1997 .

FICACCI, Luigi. Piranesi. The complete etchings. Köln: Taschen, 2000.

FONTANA, Carlo. Il Tempio Vaticano I694. A cura di Giovanna Curcio. Milano: Electa, 2003.

FONTANA, Domenico. Della trasportatione dell'obelisco vaticano et delle fabriche di nostro signore Papa Sisto V fatte dal Cavallier Domenico Fontana architetto di Sua Santità. Roma: Natal Bonifacio da Sibennico, I590.

FRUTAZ, Pietro Amato. Piante di Roma. Roma: Istituto di Studi Romani, I962. 3 v. GIEDION, Sigfried. Espaço, tempo e arquitetura: o desenvolvimento de uma nova tradição. São Paulo: Martins Fontes, 2004. 
GUIDONI, Enrico; MARINO, Angela. Storia dell'urbanistica. Il Cinquecento. Roma: Laterza, I982.

GUIDONI, Enrico; MARINO, Angela. Storia dell'urbanistica. Il Seicento. Roma: Laterza, I979.

GUTIÉRREZ, Ramón. Arquitectura y Urbanismo en Iberoamérica. Madrid: Ediciones Cátedra, I997.

HARDOY, Jorge Enrique. Ciudades precolombinas. Buenos Aires: Ediciones Infinito, I999. HARDOY, Jorge enrique. La forma de las ciudades coloniales en la América española. In: SOLANO, Francisco. Estudios sobre la ciudad iberoamericana. Madrid: Consejo Superior de Investigaciones Científicas Instituto "Gonzalo Fernández de Oviedo", I983. p. 315-344. HOLANDA, Aurélio Buarque. Novo Dicionário Eletrônico Aurélio versão 5.o. Curitiba: Ed. Positivo, 2004.

INSOLERA, Italo. Roma moderna. Torino: Giulo Einaldi Editore, 20oI.

INSOLERA, Italo. Roma. Immagini e realtà dal X al XX secolo. Roma: Laterza, I996.

INSOLERA, Italo; PEREGO, Francesco. Storia moderna dei Fori Romano. Roma: Laterza, I999.

JANNATTONI, Livio. Roma Sparita negli acquerelli di Ettore Roesler Franz. Roma: Newton \& Compton Editori, 2003.

KIEVEN, Elisabeth. Piazza di Spagna: dalla Barcaccia alla Scalinata. In: FAGIOLO, Marcello; PORTOGHESI, Paolo. Roma Barocca. Bernini, Borromini, Pietro da Cortona. Milano: Electa, 2006.

KOENIGSBERGER, Helmut Georg; MOSSE, George Lachmann. Europe in the Sixteenth Century. Longman: Hong Kong, I975.

KOSTOF, Spiro. The city shaped. Urban patterns and meaning through history. London: Thames \& Hudson, I99I.

LAVEDAN, Pierre. Histoire de l'urbanisme. Renaissance et temps moderns. Paris: Henri Laurens Éditeur, I94I.

LAVEDAN, Pierre. Nouvelle histoire de Paris. Histoire de l'urbanisme à Paris. Paris: Association pour la publication d'une Histoire de Paris, I975.

LEFÈVRE, Renée; VASCONCELLOS, Sylvio de. Minas: cidades barrôcas. São Paulo: Companhia Editora Nacional, I968. 
LIMA JÚNIOR, Augusto de. Vila Rica do Ouro Preto: síntese histórica e descritiva. [S.n.]:

Edição do Autor, 1957.

LOMBARDO, Alberto. Vedute del Foro Romano. Roma: Palombi \& Partner, 2006.

MACHADO, Lourival Gomes. Barroco mineiro. São Paulo: Perspectiva, I973.

MARAVALL, José Antonio. La cultura del Barroco. Barcelona: Editorial Ariel, 2007.

MARDER, Tod. A. Bernini. And the art of architecture. New York: Abbeville Press

Publishers, 1998.

MÍNGUEZ, Víctor; RODRÍGUEZ, Inmaculada. Las ciudades del absolutismo. Arte, urbanismo y magnificencia en Europa y América durante los siglos XV-XVIII. Castelló de la Plana: Publicaciones de la Universitat Jaume I, 2006.

MONCLÚS, Francisco Javier. OYÓN, José Luis. Elementos de composición urbana. Barcelona: Ediciones UPC, I998.

MONUMENTA, IPHAN. Ouro Preto. Minas Gerais. Imagens. Brasília: IPHAN, Programa Monumenta, 2008.

MORENO, Daniela; CHIARELLO, Ana Lía. Rasgos barrocos en la génesis de los espacios públicos americanos. In: CONGRESO INTERNACIONAL DEL BARROCO IBEROAMERICANO, 3., 20oI. Sevilla. Preactas... Sevilla: Departamento de Humanidades, Universidad Pablo de Olavide, 2oora. p. IIo-II4.

MORENO, Daniela; CHIARELLO, Ana Lía. Rasgos barrocos en la génesis de los espacios públicos americanos. In: ARANDA, Ana María et al. Barroco Iberoamericano: territorio, arte, espacio y sociedad. Sevilla: Ediciones Giralda, 20oIb. v. 2, p. 1273-I286.

MORRIS, Anthony Edwin James. History of urban form. Before the Industrial Revolution. New York: A Halsted Press Book, I979.

MUMFORD, Lewis. The city in history. Its origins, its transformations, and its prospects. San Diego: A Harvest Book, Harcourt, I989.

NICOLINI, Alberto. La ciudad hispanoamericana, medieval, renacentista y americana. Atrio. Revista de Historia del Arte, Sevilla, n. Io-II, p. 27-36, 2005.

NORBERG-SCHULZ, Christian. Architettura Tardobarocca. Milano: Electa, 2000.

NORBERG-SCHULZ, Christian. Arquitettura barocca. Milano: Electa, I979.

NORBERG-SCHULZ, Christian. Il Significato nella architettura occidentale. Milano:

Electa, I974. 
ORTIZ CRESPO, Affonso. Damero. Quito: FONSAL, Fondo de Salvamento del Patrimonio Cultural de Quito, 2007.

PALM, Erwin Walter. ¿Urbanismo barroco en América Latina? In: MINARDI, Vittorio (Org.). Simposio internazionale sul Barocco Latino Americano. Atti. Roma: Istituto ItaloLatino Americano, v. I, p. 217-220, I980.

PONCIROLI, Virginia (org). Richard Meier - Il museo dell'Ara Pacis. Milano: Electa, 2007. PORTOGHESI, Paolo. Roma barocca. Roma: Laterza, I997.

RAMA, Angel. La ciudad letrada. Montevideo: Arca, I998.

ROMERO, José Luis. Latinoamérica: la ciudad y las ideas. Buenos Aires: Siglo XXI Editores Argentina, 2007.

ROSSI, Aldo. L'architettura della città. Torino: Città Studi Edizioni, 2006.

SANFILIPPO, Mario. I rioni e i quartieri nella storia di Roma. In: CARPANETO, Giorgio et al. La grande guida dei rioni di Roma. Roma: Newton \& Compton Editoti, 2004. p. 7-35. SANFILIPPO, Mario. La construzione di una Capitale: Roma I9II-I945. Milano: Silvana Editoriale, I993.

SICA, Paolo. Storia dell'urbanistica. Il Settecento. Roma: Laterza, 1992.

SITTE, Camillo. A Construção das cidades segundo seus princípios artísticos. São Paulo: Ática, I992.

TAPIÈ, Victor-Lucien. Boroque et classicisme. Paris: Librairie Générale Française, I980.

TAPIÈ, Victor-Lucien. Le Baroque. Paris: Presses Universitaires de France, I96I.

TITI, Filippo. Descrizione delle pitture, sculture e architetture esposte al pubblico in Roma. Roma: Stamperia Marco Pagliarini, I763.

TREBBI DEL TREVIGIANO, Romolo. El atrio y su fachada como expresión espacial, formal y decorativa en la arquitectura ibero-americana: siglos XVI-XVII. In: ARANDA, Ana María et al. Barroco Iberoamericano: territorio, arte, espacio y sociedad. Sevilla: Ediciones Giralda, 200I. v. 2, p. I085-IIoo.

VAN DOESBURG, Sebastián. 475 años de la fundación de Oaxaca. Oaxaca: Ayuntamiento de la Ciudad de Oaxaca, 2007. 2 v.

VASARI, Giorgio. Le vite de' piú eccellenti architetti, pittori et scultori italiani, da Cimabue, insino a' tempi nostri. Torino: Einaldi Tascabili, I986. 2. v. 
VASCONCELLOS, Sylvio de. Mineiridade: ensaio de caracterização. Belo Horizonte: Imprensa Oficial, I968.

VASCONCELLOS, Sylvio de. Vila Rica: formação e desenvolvimento - Residências. São Paulo: Perspectiva, I977.

VIÑUALES, Graciela María. El espacio urbano en el Cusco colonial: uso y organización de las estructuras simbólicas. Lima: Epígrafe Editores: CEDODAL, 2004.

WITTKOWER, Rudolf. Art and architecture in Italy: I60o to I750. New Haven: London: Yale University Press, 1993.

WITTKOWER, Rudolf. Bernini. The sculptor of the roman baroque. London: Phaidon, 2002.

WITTKOWER, Rudolf. Sobre la arquitectura en la edad del humanismo. Barcelona: Gustavo Gili, I979.

WÖLFFLIN, Heinrich. Renascença e Barroco: estudo sobre a essência do estilo Barroco e a sua origem na Itália. São Paulo: Perspectiva, 1989. 
Este livro foi publicado no formato 17 x $24 \mathrm{~cm}$ utilizando as fontes Calluna e Scala Sans Miolo em papel Off-Set $90 \mathrm{~g} / \mathrm{m}^{2}$

Capa em Cartão Triplex $350 \mathrm{~g} / \mathrm{m}^{2}$

Impresso na Gráfica Santa Marta, na Paraíba 